\title{
USO DE AGREGADOS RECICLADOS DE CONCRETO EM BLOCOS DE ALVENARIA ESTRUTURAL
}

\author{
Alexandre Marques Buttler
}

Tese apresentada à Escola de Engenharia de São Carlos, da Universidade de São Paulo, como parte dos requisitos para obtenção do título de Doutor em Engenharia de Estruturas.

Orientador: Márcio Roberto Silva Corrêa

São Carlos

2007 
AUTORIZO A REPRODUÇÃO E DIVULGAÇÃO TOTAL OU PARCIAL DESTE TRABALHO, POR QUALQUER MEIO CONVENCIONAL OU ELETRÔNICO, PARA FINS DE ESTUDO E PESQUISA, DESDE QUE CITADA A FONTE.

Ficha catalográfica preparada pela Seção de Tratamento da Informação do Serviço de Biblioteca - EESC/USP

Buttler, Alexandre Marques

B988u

Uso de agregados reciclados de concreto em blocos de alvenaria estrutural / Alexandre Marques Buttler ; orientador Márcio Roberto Silva Corrêa. -- Săo Carlos, 2007.

Tese (Doutorado-Programa de Pós-Graduação e Área de concentraçăo em Engenharia de Estruturas) -- Escola de Engenharia de São Carlos da Universidade de São Paulo, 2007 .

1. Agregados reciclados de concreto. 2. Blocos estruturais com agregados reciclados de concreto. 3. Elementos compostos por unidades com agregados reciclados. 4. Propriedades físicas e mecânicas. I. Título 
Candidato: Engenheiro ALEXANDRE MARQUES BUTTLER

Tese defendida e julgada em 13/06/2007 perante a Comissão Julgadora:

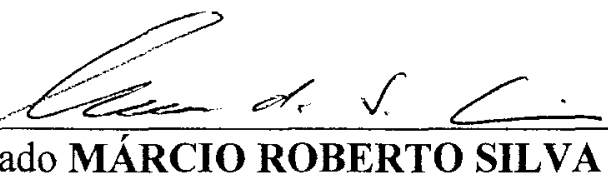

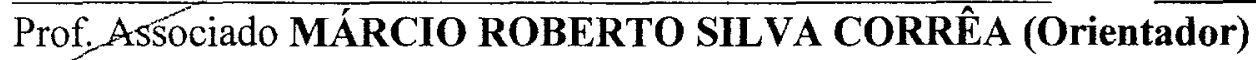

(Escola de Engenharia de São Carlos/USP)

KMace

Prof. Dr. LUIZ SERGIO FRANCO

(Escola Politécnica/USP)

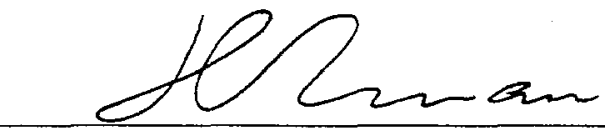

Prof. Dr. HUMBERTO RAMOS ROMAN

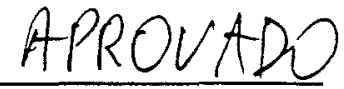

(Universidade Federal de Santa Catarina/UFSC)
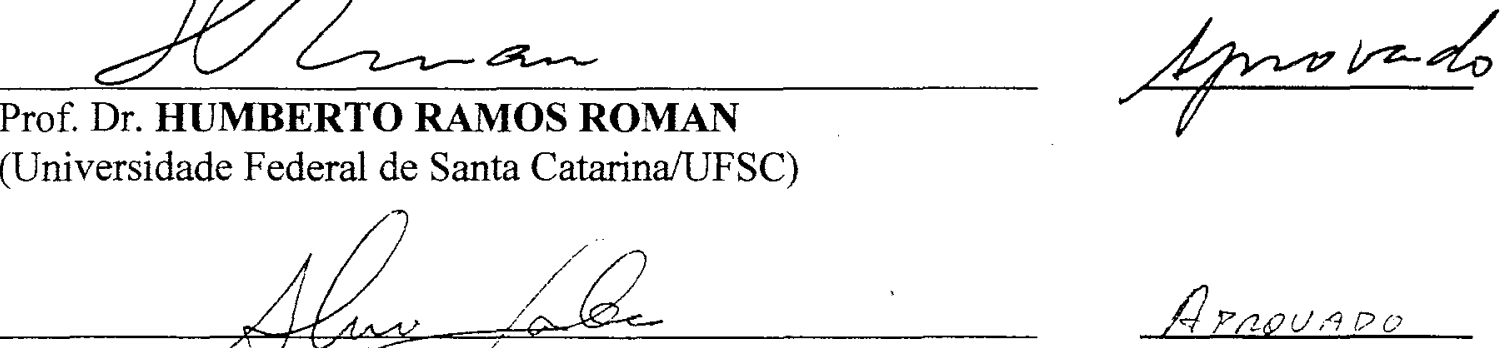

Prof. Dr. ALMiR SALES

APROUADO

(Universidade Federal de São Carlos/UFSCar)

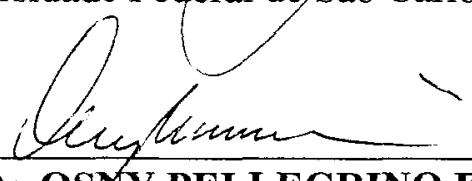

Prof. Dr. OSNY PELLEGRINO FERREIRA

(Escola de Engenharia de São Carlos/USP)
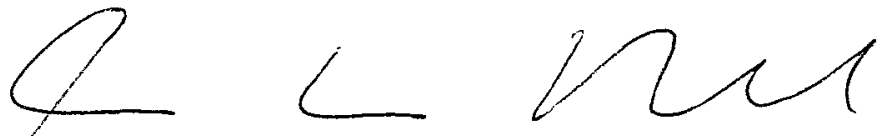

Prof. Ass øciado MARCIO ANTONIO RAMALHO

Coordenador do Programa de Pós-Graduação em

Engenharia Civil (Engenharia de Estruturas)

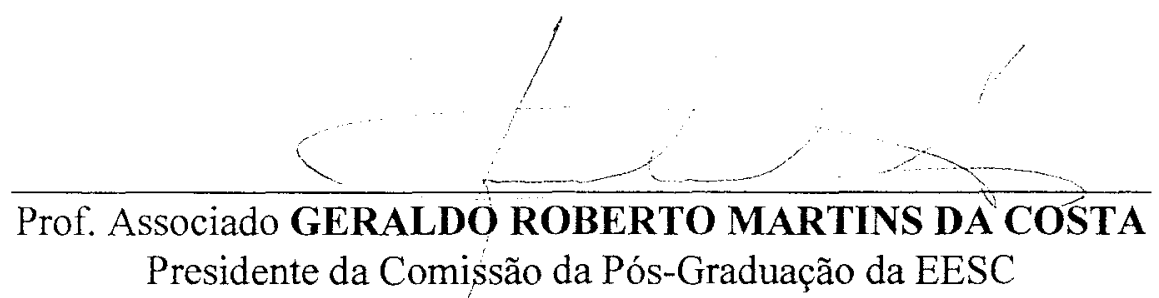


Aos meus pais e minha esposa; dedico este trabalho. 
A Deus, que esteve ao meu lado, protegendo-me e guiando-me em todos os momento da vida.

Aos meus pais, Félix Buttler e Maria Amália Marques Buttler, grandes incentivadores da minha carreira acadêmica, retribuo todo o amor, companheirismo e confiança que foram fundamentais para o meu desenvolvimento pessoal e profissional. Que Deus lhes dê saúde, proteção e muitos anos de vida.

A minha esposa, Eliandra, por ser acima de tudo minha grande companheira, sempre me apoiando nas decisões difíceis, pelas palavras de incentivo, pela confiança no meu potencial. Agradeço a Deus por você existir na minha vida.

A Olivardo (sogro) e Maria José (sogra), pelo apoio, incentivo e hospitalidade. Que Deus Ihes proteja e conceda muita saúde.

A Elisângela (cunhada), Fábio (cunhado) e Maria Luísa (minha querida sobrinha), agradeço o apoio, incentivo e os momentos que passamos juntos.

Ao Prof. Márcio Corrêa, orientador e grande amigo, agradeço por sua valiosa orientação e pelas contribuições durante o desenvolvimento do trabalho.

Aos professores Almir Sales, Luís Sérgio Franco, Humberto Ramos Roman e Osny Pellegrino Ferreira, obrigado pelas sugestões durante o exame de defesa.

Ao grande amigo Danilo Mascarenha Prado, que dividiu comigo grande parte das tarefas deste árduo trabalho. Obrigado por tudo e que Deus ilumine seu caminho.

A todos os funcionários do laboratório, que foram verdadeiros companheiros durante os quase três anos de atividades no laboratório. Agradeço a todos indistintamente, Luís Vareda, Mário, Amauri, Mauri, Fabiano, Valdir, Romeu e Caio.

A todos os funcionários da secretaria do Departamento de Estruturas pelas valiosas colaborações.

A todos os colegas de pós-graduação, em especial, a Alexandre Freitas, Caio Nogueira, George, Daniel, Fernanda, Sérgio, André e Júlio pela amizade sincera e pelos momentos de descontração que compartilhamos. 


\section{CRÉDITOS}

A elaboração deste trabalho foi possível em função do apoio de instituições e empresas, por meio de sugestões e apoio técnico-financeiro. Dessa maneira, são dignos de crédito:

- CAPES - Coordenadoria de Aperfeiçoamento de Pessoal de Ensino Superior

Pela concessão de bolsa de estudos.

- FAPESP - Fundação de Amparo à Pesquisa do Estado de São Paulo

Pelo auxílio à pesquisa correspondente ao processo 2004/05141-2

- Tatu Pré-Moldados Ltda.

Por meio do Engenheiro Rogério Durante e dos funcionários de laboratório Ederval e Willian. 


\section{SUMÁRIO}

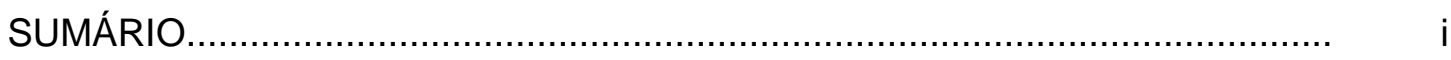

ÍNDICE DE FIGURAS.................................................................... viii

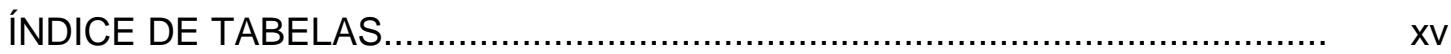

LISTA DE SÍMBOLOS E ABREVIAÇÕES.................................................... xxvii

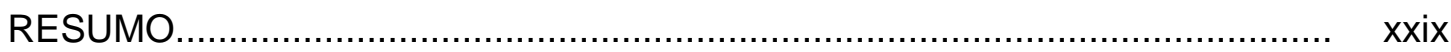

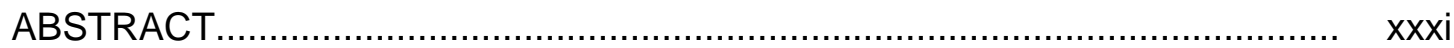

CAPÍTULO 1. INTRODUÇÃO..................................................................... 1

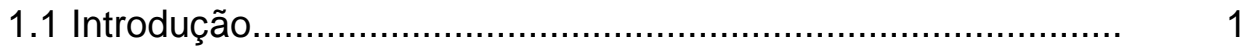

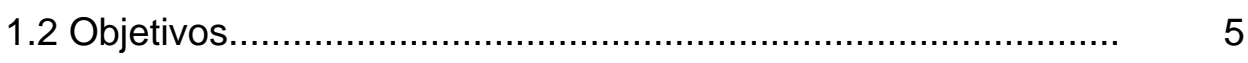

1.3 Justificativas..................................................................... 6

1.4 Metodologia ................................................................. 11

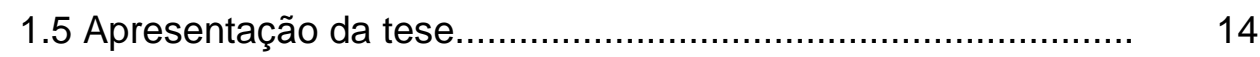

CAPÍTULO 2. RESÍDUOS DE CONCRETO................................................ 17

2.1 Diferenças entre os resíduos de concreto e resíduos de construção e demolição............................................................... 17

2.2 Fontes de geração de resíduos de concreto............................ 19

2.2.1 Etapas de construção e demolições............................... 19

2.2.2 Usinas de concreto pré-misturado e fábricas de prémoldados........................................................................... 22

2.2.3 Pavimentos de concreto e obras de arte........................ $\quad 25$

2.3 Estimativas de geração e reciclagem de resíduos.................... 27

2.3.1 Panorama mundial..................................................... 27

2.3.2 Situação brasileira...................................................... $\quad 30$

2.4 Deposição de resíduos........................................................ $\quad 32$

2.5 Unidades de reciclagem................................................. 39

2.6 Experiências e campos de aplicação para os agregados reciclados................................................................. 44

2.7 Recomendações normativas e legislações.............................. 52

2.8 Conclusões do capítulo........................................................ 60

CAPÍTULO 3. UNIDADES DE ALVENARIA............................................... 61

3.1 Blocos de concreto............................................................ 61

3.1.1 Histórico......................................................................... 61

3.1.2 Produção de blocos de concreto................................... 62

3.1.3 Metodologias de dosagem.......................................... 64 
3.1.3.1 Método da Besser Company............................. 64

3.1.3.2 Método da ABCP............................................ 66

3.1.3.3 Método de dosagem do menor volume de vazios $\quad 67$

3.1.3.4 Método IPT/EPUSP............................................ 68

3.1.3.5 Método de dosagem da composição granulométrica............................................................ 69

3.1.3.6 Método de dosagem da Columbia ...................... $\quad 70$

3.1.3.7 Procedimento proposto por Maia (2002).............. 73

3.1.3.8 Procedimento proposto por Frasson Júnior (2000) 73

3.1.3.9 Procedimento utilizado por Souza (2002)............ 75

3.1.3.10 Procedimento proposto por Barbosa (2004)...... 75

3.1.4 Blocos de concreto com agregados reciclados................ $\quad 76$

3.2 Conclusões do capítulo.......................................................... 87

CAPÍTULO 4. RETRAÇÃO POR SECAGEM.............................................. 89

$4.1 \mathrm{O}$ fenômeno da retração........................................................... 89

4.2 Classificação dos tipos de retração......................................... 90

4.3 Retração por secagem........................................................ 92

4.4 Fatores que influenciam a retração por secagem...................... 93

4.5 Retração em elementos de concreto....................................... 97

4.5.1 CPs produzidos com agregados reciclados de concreto.. $\quad 97$

4.5.2 Blocos de concreto....................................................... 99

4.5.3 Alvenaria de blocos de concreto..................................... 101

4.5.4 Recomendações construtivas......................................... 103

4.6 Conclusões do capítulo........................................................... 109

CAPÍTULO 5. CARACTERIZAÇÃO DOS MATERIAIS................................. 110

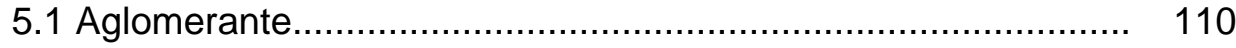

5.2 Aditivo.................................................................... 111

5.3 Agregados................................................................... 111

5.3.1 Primeiro processamento ............................................ 115

5.3.2 Segundo processamento........................................ 118

5.3.2.1 Representatividade das frações graúda e miúda.. 119

5.3.2.2 Granulometria............................................... 121

5.3.2.3 Massa específica e absorção de agregado.......... 125

5.3.2.3.1 Procedimento da Norma Brasileira....... 125

5.3.2.3.2 Procedimento proposto por Leite (2001) 133 
5.3.2.3.3 Procedimento proposto por Dias e Agopyan (2004)........................................... 135

5.3.2.4 Massa unitária (estado solto e compactado)........ 144

5.3.2.5 Índice de forma de agregado............................. 146

5.3.2.6 Abrasão Los Angeles....................................... 149

5.3.2.7 Quantidade de argamassa aderida.................... 152

5.4 Conclusões do capítulo.......................................................... 153

CAPÍTULO 6. METODOLOGIA EXPERIMENTAL....................................... 156

6.1 Descrição das etapas.......................................................... 156

6.1.1 Primeira etapa ....................................................... 159

6.1 .2 Segunda etapa.................................................. 174

6.1.3 Terceira etapa....................................................... 181

6.1.3.1 Escolha dos agregados reciclados..................... 181

6.1.3.2 Diretrizes Básicas............................................ 183

6.1.3.3 Investigações preliminares (cura térmica e procedimento de mistura)............................................ 185

6.1.3.4 Avaliação das propriedades dos CPs para diferentes classes de resistência.................................... 194

6.1.3.4.1 Grupos avaliados............................. 195

6.1.3.4.1.1 Grupos $4,5 \ldots \ldots \ldots \ldots \ldots \ldots \ldots . .196$

6.1.3.4.1.2 Grupo 8,0 ........................ 196

6.1.3.4.1.3 Grupo 12,0..................... 197

6.1.3.4.2 Propriedades físicas............................ 198

6.1.3.4.2.1 Grupo $4,5 \ldots \ldots \ldots \ldots \ldots \ldots \ldots \ldots . . . . . . . . . . .198$

6.1.3.4.2.2 Grupo 8,0 ....................... 199

6.1.3.4.2.3 Grupo $12,0 \ldots \ldots \ldots \ldots \ldots \ldots \ldots . . .200$

6.1.3.4.2.4 Análise dos resultados propriedades físicas.......................... 201

6.1.3.4.3 Propriedades mecânicas..................... 214

6.1.3.4.3.1. Grupo 4,5....................... 214

6.1.3.4.3.2. Grupo 8,0...................... 215

6.1.3.4.3.3 Grupo 12,0....................... 216

6.1.3.4.3.4. Análise dos resultados propriedades mecânicas................... 217 
6.1.3.4.3.5. Estimativa da resistência dos blocos através da correlação com os CPs..................................... 228

6.2 Conclusões do capítulo....................................................... 230

\section{CAPÍTULO 7. UNIDADES DE ALVENARIA COM AGREGADOS}

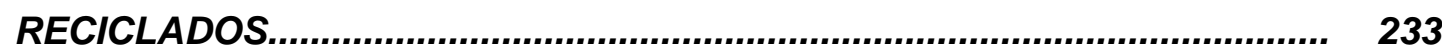

7.1 Descrição das propriedades físicas avaliadas.......................... 233

7.1.1 Análise dimensional................................................... 233

7.1.2 Absorção de água e área líquida.................................. 234

7.1.3 Massa específica e índice de vazios............................. 234

7.1.4 Taxa de absorção inicial (IRA) ................................... 235

7.1 .5 Absorção capilar.................................................... 235

7.2 Descrição das propriedades mecânicas avaliadas................... 237

7.2.1 Resistência à compressão ........................................ 237

7.2.1.1 Blocos de concreto......................................... 237

7.2.1.2 Meios-Blocos de concreto................................ 237

7.2.2 Resistência à tração indireta.......................................... 237

7.2 .3 Módulos de deformação............................................ 238

7.3 Blocos de concreto com agregados reciclados....................... 238

7.3.1 Produção dos blocos de concreto............................... 238

7.3.2 Grupos avaliados................................................. 247

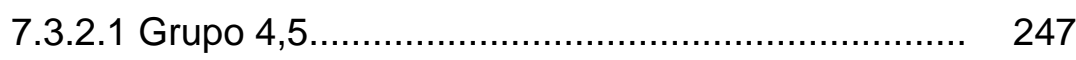

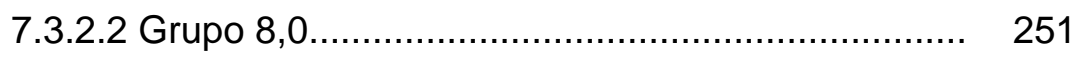

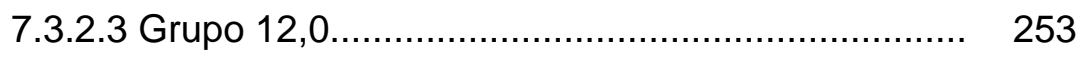

7.3.3 Propriedades Físicas................................................. 256

7.3.3.1 Análise dimensional....................................... 256

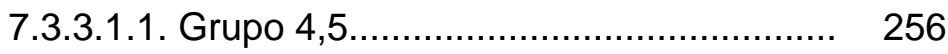

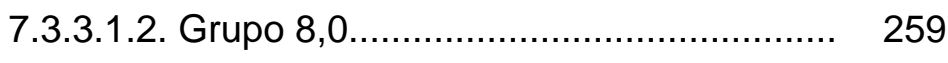

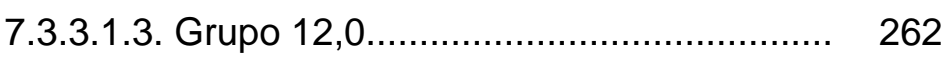

7.3.3.2 Absorção de água e área líquida........................ 265

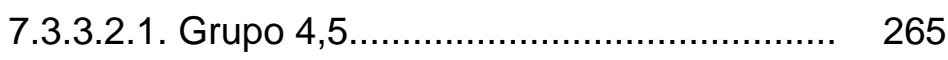

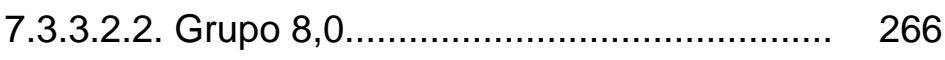

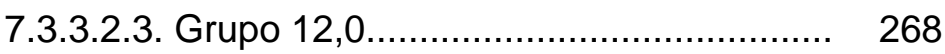

7.3.3.2.4. Análise dos resultados - absorção de água e área líquida.......................................... 269 
7.3.3.3 Massa específica e índice de vazios......

271

7.3.3.3.1. Grupo 4,5 271

7.3.3.3.2. Grupo 8,0 . 272

7.3.3.3.3. Grupo 12,0 272

7.3.3.3.4. Análise dos resultados - massa específica e índice de vazios.......................... 273

7.3.3.4 Taxa de absorção inicial.................................... 276

7.3.3.4.1. Grupo 4,5........................................ 276

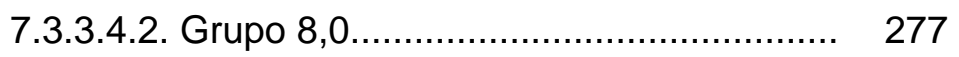

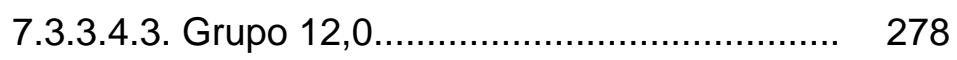

7.3.3.4.4. Análise dos resultados - taxa de absorção inicial.............................................. 279

7.3.3.5 Absorção Capilar............................................... 280

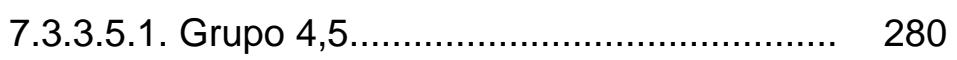

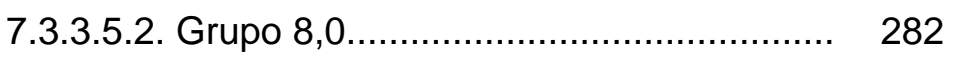

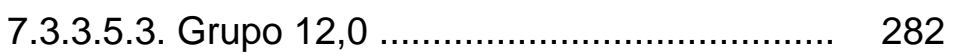

7.3.3.5.4. Análise dos resultados - absorção por capilaridade.............................................. 283

7.3.4 Propriedades mecânicas................................................ 285

7.3.4.1 Resistência à compressão............................... 285

7.3.4.1.1 Grupo 4,5...................................... 285

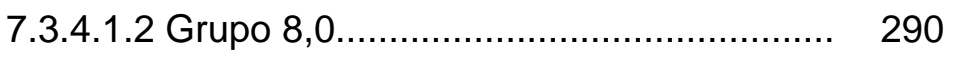

7.3.4.1.3 Grupo 12,0..................................... 296

7.3.4.1.4 Análise dos resultados - resistência à compressão............................................... 302

7.3.4.2 Resistência à tração indireta............................... 304

7.3.4.2.1 Grupo 4,5.................................... 304

7.3.4.2.2 Grupo 8,0................................. 305

7.3.4.2.3 Grupo 12,0..................................... 306

7.3.4.2.4 Análise dos resultados - resistência à tração indireta.............................................. 306

7.3.4.3 Módulo de deformação .................................... 308

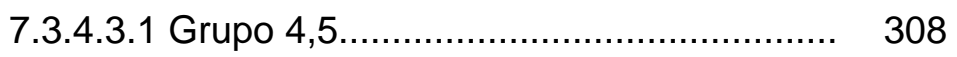

7.3.4.3.2 Grupo 8,0.......................................... 311

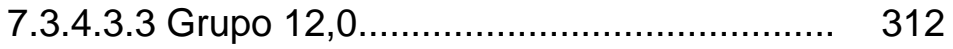


7.3.4.3.4. Análise dos resultados - módulo de deformação.................................................. 314

7.3.5. Análise de viabilidade econômica............................... 315

7.4 Meios-Blocos de concreto com agregados reciclados............. 327

7.4.1 Produção das unidades............................................ 328

7.4.2 Características dos traços........................................ 332

7.4.3 Propriedades Físicas................................................ 336

7.4.3.1 Absorção de água e área líquida........................ 336

7.4.3.2 Massa específica e índice de vazios................... 340

7.4.3.3 Taxa de absorção inicial .................................. 343

7.4.4 Propriedades Mecânicas.......................................... 344

7.4.4.1 Resistência à compressão................................. 344

7.4.4.2 Módulo de deformação..................................... 346

7.5 Conclusões do capítulo....................................................... 348

CAPÍTULO 8. CARACTERIZAÇÃO DA ALVENARIA................................ 351

8.1 Argamassa................................................................. 351

8.1.1 Características dos materiais..................................... 351

8.1.2 Escolha do traço de argamassa................................. 352

8.1.3 Propriedades avaliadas........................................... 355

8.2 Prismas..................................................................... 356

8.2.1 Definição dos prismas produzidos................................. 356

8.2.2 Propriedades avaliadas e instrumentação adotada......... 357

8.3 Miniparedes................................................................ 358

8.3.1 Definição das miniparedes produzidas......................... 359

8.3.2 Propriedades avaliadas e instrumentação adotada......... 360

8.4 Resultados e análises - Prismas......................................... 362

8.4.1 Características das argamassas................................ 362

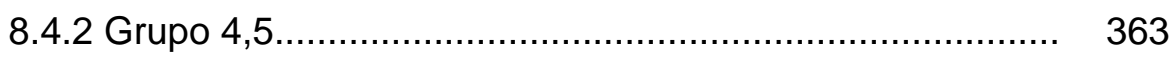

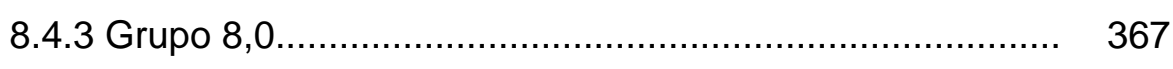

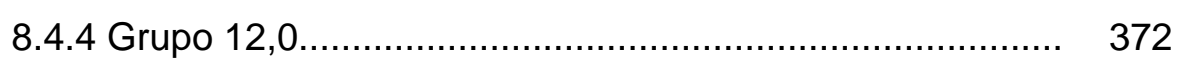

8.4.5 Análise dos resultados obtidos - Prismas..................... 378

8.5 Resultados e análises - Miniparedes................................. 381

8.5.1 Características das argamassas............................... 381

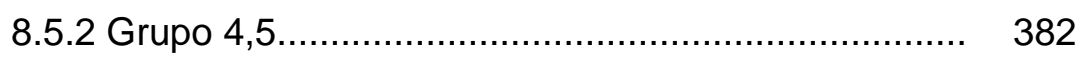

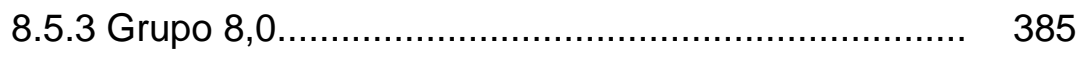

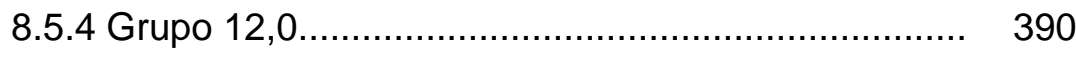


8.5.5 Análise dos resultados obtidos - Miniparedes. 394

8.6 Conclusões do capítulo....................................................... 395

CAPÍTULO 9. RETRAÇÃO POR SECAGEM.............................................. 397

9.1 Programa experimental................................................. 397

9.1.1 Blocos de concreto - retração.................................... 397

9.1.1.1 Traços avaliados........................................... 397

9.1.1.2 Procedimento de ensaio.................................. 398

9.1.2 Miniparedes - Retração................................................ 405

9.1.2.1. Argamassa utilizada........................................ 405

9.1.2.2. Procedimentos adotados para execução das miniparedes de retração.......................................... 405

9.1.2.3. Definição das miniparedes .............................. 409

9.2 Resultados e análises - Blocos de concreto......................... 410

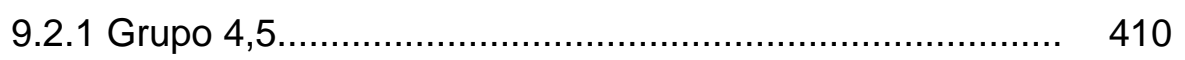

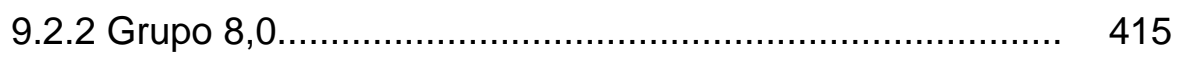

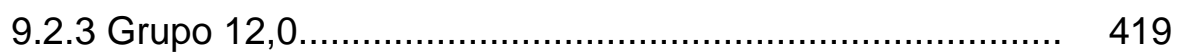

9.2.4 Avaliação global dos resultados obtidos......................... 423

9.3 Resultados e análises - Miniparedes..................................... 425

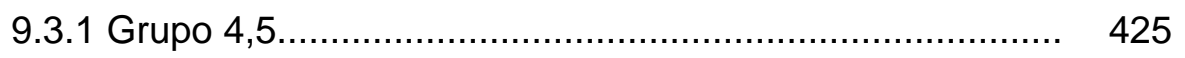

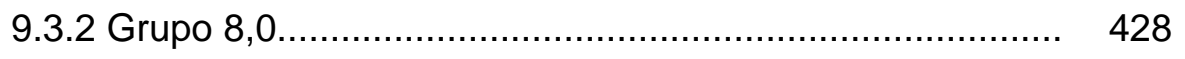

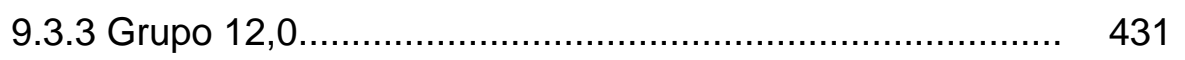

9.3.4 Avaliação global dos resultados obtidos - Miniparedes... 435

9.3.5 Estimativa da distância entre juntas de controle............. 436

9.4 Conclusões do capítulo................................................... 438

CAPÍTULO 10. CONCLUSÕES................................................................ 440

10.1 Principais conclusões........................................................ 440

10.2 Sugestões para futuras pesquisas.................................. 443

CAPÍTULO 11. REFERÊNCIAS BIBLIOGRÁFICAS................................... 444

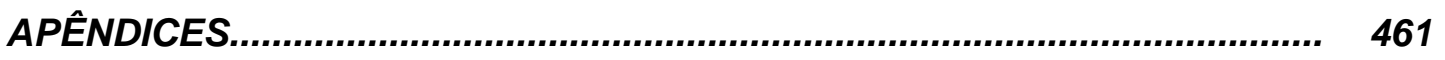

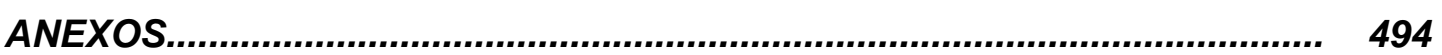




\section{ÍNDICE DE FIGURAS}

Figura 1.1 Abordagem metodológica da primeira etapa experimental ............ 11

Figura 1.2 Abordagem metodológica da segunda etapa experimental.............. 12

Figura 1.3 Abordagem metodológica da terceira etapa experimental.............. 13

Figura 1.4 Abordagem metodológica da quarta etapa experimental................ 14

Figura 2.1 Resíduos de concreto produzidos em uma fábrica de prémoldados (foto do autor)....................................................... 23

Figura 2.2 Resíduos gerados no processo de vibro-prensagem dos blocos (foto do autor) ...................................................................... 24

Figura 2.3 Resíduos de concreto produzidos entre os silos e o misturador (foto do autor).

Figura 2.4 Demolição de viaduto na rodovia Washington Luís (km 235) (foto do autor).

Figura 2.5 Deposição irregular de resíduos na cidade de São Carlos (foto do autor).

Figura 2.6 Usina de reciclagem de São Carlos (foto do autor)......

Figura 2.7 Unidades em operação no local da usina de reciclagem (foto do autor).

Figura 2.8

Resíduos de concreto (foto do autor).

Figura 2.9

Alguns tipos de agregados reciclados produzidos pela usina (foto do autor)

Figura 2.10 Casas construídas com blocos de agregados reciclados (foto do autor).

Figura 2.11 Equipamentos utilizados para a produção dos blocos de concreto (foto do autor).

Figura 2.12 Unidades produzidas pela fábrica de artefatos de cimento (foto do autor)

Figura 2.13 Detalhes da fábrica de blocos e do protótipo de casa popular (fonte: Racional Engenharia, 2003)...

Figura 2.14 Processamento dos resíduos de concreto no canteiro de obras (foto do autor).

Figura 2.15 Estoque de agregados reciclados (brita 1 e brita 2) (foto do autor).

Figura 2.16 Elementos produzidos utilizando agregados reciclados (foto do autor) 
Figura 3.1 Resistência à compressão dos blocos em função do tipo de vibroprensa (fonte: Adaptado de Albuquerque, 2005)....

Figura 3.2 Relação entre módulo de finura (M.F.) e resistência à compressão em corpos-de-prova (fonte: Frasson Júnior, 2000).....

Figura 3.3 Equipamento utilizado no ensaio para a determinação da coesão das misturas (fonte: Frasson Júnior, 2000).

Figura 3.4 Unidades de vedação produzidas pelo pesquisador (fonte: Albuquerque, 2005

Figura 4.1 Juntas de movimentação entre elementos de alvenaria (fonte: Vilató e Franco, 1998).

Figura 4.2 Juntas de movimentação entre elementos de alvenaria (fonte: conforme citado na figura).

Figura 5.1 Resíduos avaliados no trabalho (foto do autor).

Figura 5.3 Britador de mandíbulas utilizado para o processamento dos resíduos.

Figura 5.4

Agregados reciclados de concreto (fração graúda).

Figura 5.5 Ensaios para caracterização dos agregados (segundo processamento).

Figura 5.6 Curvas granulométricas dos agregados graúdos.

Figura 5.7 Composição granulométrica dos agregados miúdos reciclados e dos agregados naturais.

Figura 5.8 Resultados relativos para a propriedade de massa específica.......

Figura 5.9 Relação entre as propriedades de massa específica seca e absorção de água.

Figura 5.10 Ensaio de massa específica pelo Frasco de Chapman................... 132

Figura 5.11 Taxa de absorção média dos agregados durante os 120 primeiros minutos.

Figura 5.12 Velocidade de secagem x conteúdo de umidade, Brown et al. (1965 apud Dias; Agopyan, 2004) ${ }^{1}$ 
Figura 5.18 Comparação dos métodos para avaliação da absorção

Figura 5.19 Relação entre as propriedades de massa específica seca e absorção de água, conforme procedimento de Dias e Agopyan (2004)

Figura 5.20 Número de angulosidade para os agregados miúdos

Figura 5.21

Relação massa unitária/massa específica para os agregados graúdos

Figura 5.22 Relação massa unitária/massa específica para os agregados analisados.

Figura 5.23

Abrasão Los Angeles

Figura 5.24

Ensaio de Abrasão Los Angeles (agregados GRb e GRt).

Figura 5.25

Argamassa aderida aos agregados reciclados.

Figura 5.26

Fluxograma simplicado para caracterização dos materiais

Figura 6.1

Curva do menor volume de vazios das composições

Figura 6.2

Processo de mistura manual

Figura 6.3

Moldagem dos corpos-de-prova e manutenção na cura úmida por sete dias

Figura 6.4 Textura superficial dos CPs de diferentes composições: a) 50\% de pedrisco; b) 40\% de pedrisco; c) $30 \%$ de pedrisco.

Figura 6.5 Equipamento utilizado para a determinação da coesão das misturas (FRASSON JUNIOR, 2000).

Figura 6.6 Retirada das amostras de concreto para a produção dos corposde-prova.

Figura 6.7

Produção dos corpos-de-prova no laboratório da fábrica.

Figura 6.8

Processo de cura térmica aplicada aos blocos e respectivos corpos-de-prova.

Figura 6.9 Resultados relativos (CPs/blocos) para as propriedades avaliadas

Figura 6.10

Procedimento de mistura (Tam et al., 2005)

Resultados relativos para a propriedade de coesão.

Figura 6.12 Resultados relativos para a propriedade de massa específica seca

Figura 6.13

Resultados relativos para a propriedade de absorção de água...... 
Figura 6.16 Resultados relativos para a propriedade de resistência à tração...

Figura 6.17 Resultados relativos para a propriedade de módulo de deformação..........................................................................

Figura 6.18 Fluxograma contendo as principais etapas da produção e caracterização das propriedades dos CPs.................................. 232

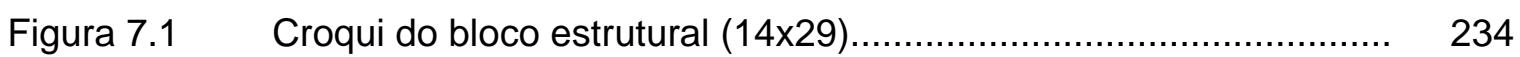

Figura 7.2 Silos para estoque dos agregados........................................... 240

Figura 7.3 Baias para estoque dos agregados.............................................. 240

Figura 7.4 Vibro-prensa utilizada para a produção dos blocos de concreto.....

Figura 7.5 Definição da quantidade de material em função de uma volta da esteira de dosagem.

Figura 7.6 Fluxograma do processo de dosagem/transporte dos agregados dos silos até o misturador.

Figura 7.7 Detalhes do misturador mecânico......

Figura 7.8 Correia transportadora situada entre o misturador e a vibroprensa.

Figura 7.9 Regulagem dos tempos de alimentação, vibração e compactação da vibro-prensa.................................................................. 245

Figura 7.10 Carro de transporte dos blocos............................................... 245

Figura 7.11 Retirada dos blocos da câmara de cura térmica........................... 246

Figura 7.12 Estocagem dos blocos no pátio da fábrica.................................. 246

Figura 7.13 Transporte/estocagem dos blocos.............................................. 247

Figura 7.14 Produção das unidades do traço B4,5-RMB-33\%......................... 249

Figura 7.15 Paredes longitudinais das unidades da classe 4,5...................... 250

Figura 7.16 Presença dos agregados reciclados no traço B4,5-RGV-100\%..... 250

Figura 7.17 Paredes das unidades da classe 8,0............................................. 253

Figura 7.18 Defeitos na face inferior de algumas unidades dos traços B12,0REF, B12,0-RGV-100\% e B12,0-RGV-50\%............................. 255

Figura 7.19 Paredes das unidades do Grupo 12,0...................................... 256

Figura $7.20 \quad$ Blocos do Grupo 4,5......................................................... 258

Figura 7.21 Textura áspera das unidades com agregados miúdos reciclados comparativamente às unidades de referência................................ 258

Figura 7.22 Textura das unidades com agregados graúdos reciclados comparativamente as unidades de referência................................ $\quad 259$

Figura $7.23 \quad$ Unidades do Grupo 8,0............................................................. 261 
Figura 7.24 Textura das unidades de referência e das unidades com

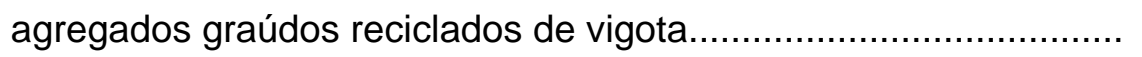

Figura 7.25 Textura das unidades de referência e das unidades com agregados reciclados de vigota/bloco..................................... 262

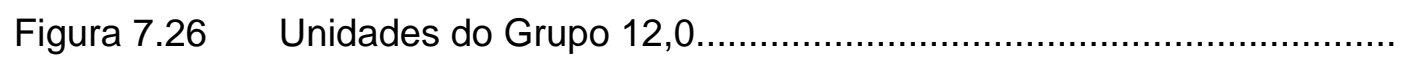

Figura 7.27 Textura das unidades de referência e com agregados reciclados de vigota

Figura 7.28 Textura das unidades de referência e com agregados reciclados de bloco.

Figura 7.29 Fissuras e cantos quebrados nas unidades com agregados miúdos reciclados.

Figura 7.30 Fissuras e cantos quebrados em algumas unidades do traço B8,0-RMB-33\% ocasionadas pela falta de coesão e pela umidade excessiva da mistura.

Figura 7.31 Silos para estoque dos agregados.

Figura 7.32

Vibro-prensa utilizada para a produção dos meios-blocos.

Figura 7.33 Separação dos agregados reciclados para a produção dos meiosblocos

Figura 7.34 Detalhes do misturador mecânico utilizado na produção dos meios-blocos

Figura 7.35

Equipamentos utilizados na produção dos blocos

Figura 7.36

Painel de ajuste dos tempos de produção

Figura 7.37

Produção dos meio-blocos.

Figura 7.38

Processo de cura dos meio-blocos.

Figura 7.39

Estocagem dos meio-blocos no Laboratório de

Estruturas.

Figura 7.40

Mistura deficiente dos materiais (MB4,5-REF)

Figura 7.41

Croqui dos meio-blocos produzidos.

Figura 7.42 Fluxograma contendo as principais etapas da produção e caracterização das propriedades dos blocos......

Figura 8.1

Curva granulométrica da areia utilizada.

Figura 8.2 Posicionamento dos extensômetros removíveis no ensaio de prismas.

Figura 8.3 Posicionamento dos extensômetros removíveis no ensaio de miniparedes. 
Figura 8.5 Configuração típica dos ensaios de miniparedes.

362

Figura 8.6 Ruptura típica dos prismas do Grupo 4,5................................ 367

Figura 8.7 Ruptura típica dos prismas do Grupo 8,0................................. 372

Figura 8.8 Ruptura típica dos prismas do Grupo 12,0............................... 376

Figura 8.9 Ruptura típica dos prismas do Grupo 12,0 (PR 12,0 - RGB -50\% e PR 12,0 - RMV - 33\%).

Figura 8.10 Fissuração vertical dos blocos provocada pelo esmagamento da argamassa.

377

Figura 8.11 Ruptura típica das miniparedes do grupo 4,5 ............................. 385

Figura 8.12 Ruptura típica das miniparedes do grupo 8,0.............................. 389

Figura 8.13 Ruptura típica das miniparedes do grupo 12,0............................ 393

Figura 9.1 Aparelho digital Mitutoyo e barra padrão de aço invar................... 400

Figura 9.2 Balança de precisão de 0,1 ..................................................... 400

Figura 9.3 Equipamento utilizado para o corte dos blocos de concreto............ 401

Figura $9.4 \quad$ Corpos-de-prova de blocos (prismas)........................................... 401

Figura 9.5 Procedimento de leitura adotado para os corpos-de-prova de blocos......................................................................... 401

Figura 9.6 Corpos-de-prova de blocos dispostos em tanque com água........... 402

Figura 9.7 Câmara climatizada com controle de umidade e temperatura........ 402

Figura 9.8 Prismas de blocos em diferentes estágios do ensaio de retração... 403

Figura $9.9 \quad$ Layout da câmara climatizada......................................................... 403

Figura 9.10 Equipamentos de refrigeração, aquecimento, desumidificação e umidificação existentes na câmara climatizada.............................. 404

Figura 9.11 Sistema de controle e quadro analógico....................................... 404

Figura 9.12 Mistura manual da argamassa..................................................... 406

Figura 9.13 Execução das miniparedes de retração............................................ 406

Figura 9.14 Disposição das bases de apoio....................................................... 407

Figura 9.15 Miniparedes de retração........................................................... 408

Figura 9.16 Miniparedes do grupo 8,0 dispostas na câmara úmida.................. 408

Figura 9.17 Miniparedes do grupo 8,0 dispostas na câmara climatizada........... 409

Figura 9.18 Evolução da retração por secagem para os corpos-de-prova do grupo 4,5 .

Figura 9.19 Umidade das unidades $\mathrm{x}$ retração por secagem para os corposde-prova de referência e agregados reciclados de vigota Grupo 4,5 . 
Figura 9.20 Umidade das unidades $x$ retração por secagem para os corposde-prova de referência e agregados reciclados de bloco Grupo 4,5 .

Figura 9.21 Evolução da retração por secagem para os corpos-de-prova do Grupo 8,0

Figura 9.22 Umidade das unidades $x$ retração por secagem para os corposde-prova de referência e agregados reciclados de vigota Grupo 8,0 .

Figura 9.23 Umidade das unidades $\mathrm{x}$ retração por secagem para os corposde-prova de referência e agregados reciclados de bloco Grupo 8,0 .

Figura 9.24 Evolução da retração por secagem para os corpos-de-prova do Grupo 12,0

Figura 9.25 Umidade das unidades $\mathrm{x}$ retração por secagem para os corposde-prova de referência e agregados reciclados de vigota Grupo 12,0 .

Figura 9.26 Umidade das unidades $\mathrm{x}$ retração por secagem para os corposde-prova de referência e agregados reciclados de bloco Grupo 12,0 .

Figura 9.27 Evolução da retração por secagem para as miniparedes do Grupo 4,5 .

Figura 9.28 Interpolação dos resultados de retração das miniparedes do Grupo 4,5

Figura 9.29 Evolução da retração por secagem para as miniparedes do Grupo 8,0 .

Figura 9.30 Interpolação dos resultados de retração das miniparedes do Grupo 8,0.

Figura 9.31 Evolução da retração por secagem para as miniparedes do Grupo 12,0 .

Figura 9.32 Interpolação dos resultados de retração das miniparedes do Grupo 12,0 


\section{ÍNDICE DE TABELAS}

Tabela 2.1 Pavimentos de concreto reciclados para utilização como agregados.

Tabela 2.2 Geração, reciclagem e aplicação dos resíduos de construção e demolição.

Tabela 2.3 Geração de resíduos de construção e demolição.

Tabela 2.4 Instalações de reciclagem em alguns municípios brasileiros...

Tabela 2.5 Características do traço utilizado para a produção das unidades.....

Tabela 2.6 Classificação dos agregados reciclados de acordo com a densidade e composição e exigências para os concretos com agregados reciclados.

Tabela 2.7 Classe dos agregados reciclados de concreto e campos de aplicação.

Tabela 2.8 Composições e campos de aplicação para os agregados reciclados.

Tabela 2.9 Exigências para os agregados reciclados.

Tabela 2.10 Limites de resistência para a utilização de concretos reciclados segundo diferentes códigos normativos.

Tabela 2.11 Coeficientes de correção para os concretos reciclados segundo diferentes códigos normativos

Tabela 2.12 Exigências para os agregados reciclados destinados a produção de concreto não-estrutural.

Tabela 2.13 Exigências para os agregados reciclados em aplicações estruturais.

Tabela 3.1 Porcentagens retidas acumuladas desejáveis na produção de blocos de concreto

Tabela 3.2 Relação cimento/agregado sugeridos para a produção de blocos de concreto na máquina Montana MBX 975.

Tabela 3.3 Valores sugeridos para $\left(k_{n t} \cdot s\right)$ em função do controle da produção..

Tabela 3.4 Valores limites para que a mistura seja de granulometria densa.......

Tabela 3.5 Composições granulométricas recomendadas para a produção de blocos de concreto. 
Tabela 3.6 Correlação da resistência à compressão de blocos e corpos-deprova......

Tabela 3.7 Pesquisas que correlacionaram a resistência à compressão de blocos e CPs.

Tabela 3.8 Composições de cada traço e resultados de resistência à compressão.

Tabela 3.9 Dosagens utilizadas na produção de blocos de concreto e principais resultados.

Tabela 3.10 Dosagem selecionada para a produção dos blocos de concreto......

Tabela 3.11 Resultados das propriedades físicas e mecânicas para os blocos reciclados.

Tabela 3.12 Composições dos agregados reciclados 82

Tabela 3.13 Dosagens utilizadas na produção dos blocos. 82

Tabela 3.14 Resultados das propriedades físicas e mecânicas......

Tabela 3.15 Características dos traços utilizados para a produção dos blocos....

Tabela 3.16 Resultados das propriedades físicas e mecânicas.

Tabela 3.17 Custos de insumos para a moldagem de blocos com agregados naturais e com agregados reciclados para uma mesma classe de resistência.

Tabela 3.18 Propriedades físicas dos agregados reciclados.

Tabela 3.19 Caracterização das propriedades físicas dos agregados reciclados.

Tabela 4.1 Efeito da composição da pasta de cimento com agregados de dolomita de diversas granulometrias.

Tabela 4.2 Influência do plano de cura na retração por secagem.

Tabela 4.3 Retração de concretos em função da umidade relativa do ar............. 96

Tabela 4.4 Características dos concretos com agregados reciclados.

Tabela 4.5 Retração por secagem para blocos de concreto e pisos de pavimentação..

Tabela 4.6 Umidade máxima do bloco em função da umidade relativa anual....

Tabela 4.7 Valores de retração para alvenarias de blocos de concreto curados a vapor

Tabela 4.8 Coeficientes de atrito da alvenaria com sua respectiva base.

Tabela 4.9 Valores do coeficiente de deformação unitária por retração na alvenaria $(\mathrm{mm} / \mathrm{m})$. 
Tabela 4.10 Espaçamento máximo das juntas verticais de controle em alvenarias de blocos de concreto.............................................. 106

Tabela 5.1 Propriedades físicas e químicas do aglomerante empregado.......... 110

Tabela 5.2 Agregados utilizados na pesquisa................................................... 111

Tabela 5.3 Ensaios de caracterização dos agregados (primeiro processamento).

Tabela 5.4 Propriedades físicas dos agregados reciclados (primeiro processamento).

Tabela 5.5 Ensaios para caracterização dos agregados (segundo processamento).

Tabela 5.6 Distribuição das frações granulométricas para cada um dos agregados reciclados.

Tabela 5.7 Composições granulométricas dos agregados graúdos.

Tabela 5.8 Composições granulométricas dos agregados miúdos (referência). 122

Tabela 5.9 Composições granulométricas dos agregados miúdos reciclados.... 123

Tabela 5.10 Porcentagens de materiais passantes na peneira $0,075 \mathrm{~mm}$ para os agregados graúdos e miúdos reciclados.

125

Tabela 5.11 Absorção de água e índice de vazios...

Tabela 5.12 Massa específica dos agregados graúdos.

Tabela 5.13 Massa específica dos agregados miúdos conforme NBR 9776 (1987)

Tabela 5.14 Taxa de absorção média dos agregados, em função do tempo de ensaio, pelo procedimento proposto por Leite (2001).

Tabela 5.15 Absorção dos agregados graúdos utilizando-se o procedimento de Dias e Agopyan (2004).

Tabela 5.16 Resultados da absorção para os métodos avaliados comparandose com os valores da NBR 9937 (1987)......

Tabela 5.17 Absorção dos agregados miúdos conforme procedimento de Dias e Agopyan (2004)

Tabela 5.18 Massa específica e índice de vazios para os agregados graúdos....

Tabela 5.19 Massa unitária dos agregados graúdos.

Tabela 5.20 Massa unitária para os agregados miúdos.

Tabela 6.1 Resultados de massa unitária e volume de vazios para cada uma das composições avaliadas...

Tabela 6.2 Ensaios referentes ao concreto fresco e endurecido...... 
Tabela 6.4 Resultados das propriedades físicas para o traço 1:18.

Tabela 6.5 Avaliação da influência das composições adotadas para o traço 1:18 nas propriedades físicas dos corpos-de-prova.

Tabela 6.6 Resultados das propriedades mecânicas para o traço 1:18.

Tabela 6.7 Avaliação da influência das composições adotadas para o traço 1:18 nas propriedades mecânicas dos corpos-de-prova.

Tabela 6.8 Traços avaliados para verificar a influência de algumas substituições na mistura.

Tabela 6.9 Propriedades físicas e mecânicas para os traços $2 b \times 5$ e $3 b \times 6 \ldots$

Tabela 6.10 Teste "t de Student" para verificar a influência da porcentagem de pó de pedra e areia nas propriedades físicas e mecânicas.

Tabela 6.11 Características dos traços produzidos para avaliar a influência da energia de adensamento.

Tabela 6.12 Propriedades físicas e mecânicas dos traços produzidos para avaliar a influência da energia de adensamento.

Tabela 6.13 Teste ANOVA e "t de student" para verificar a influência da energia de adensamento nas propriedades físicas e mecânicas dos CPs....

Tabela 6.14 Parâmetros para a produção dos blocos...

Tabela 6.15 Nomenclatura adotada para os blocos de concreto e respectivos corpos-de-prova.

Tabela 6.16 Dosagens utilizadas para a produção dos CPs e blocos de concreto.

Tabela 6.17 Propriedades físicas dos blocos e respectivos corpos-de-prova (3,0MPa e 4,5MPa).

Tabela 6.18 Propriedades físicas dos blocos e respectivos corpos-de-prova (6,0MPa e 8,0MPa).

Tabela 6.19 Propriedades mecânicas dos blocos e respectivos corpos-deprova......

Tabela 6.20 Dosagem utilizada para verificação da influência do tipo de cura nas propriedades dos CPs.

Tabela 6.21 Resultados das propriedades para os CPs submetidos à cura térmica e cura úmida

Tabela 6.22 Teste ANOVA para verificar a influência do tipo de cura adotada e da idade nas propriedades físicas e mecânicas dos CPs

Tabela 6.23 Características dos traços para a verificação da influência do tipo de mistura nas propriedades dos CPs. 
Tabela 6.24 Resultados para os CPs de referência (REF) considerando-se os

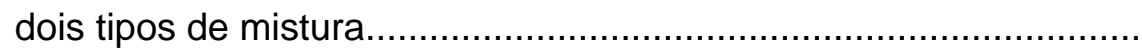

Tabela 6.25 Resultados para os CPs com agregados reciclados de vigota (RGV-100\%) considerando-se os dois tipos de mistura.

Tabela 6.26 Teste ANOVA para verificar a influência do procedimento de mistura e idade nas propriedades físicas e mecânicas dos CPs......

Tabela 6.27 Terminologias adotadas para as dosagens...................................... 195

Tabela 6.28 Dosagens do Grupo 4,5.............................................................. 196

Tabela 6.29 Dosagens do Grupo 8,0................................................................ 197

Tabela 6.30 Dosagens do Grupo 12,0.......................................................... 198

Tabela 6.31 Propriedades físicas dos CPs do Grupo 4,5............................... 199

Tabela 6.32 Propriedades físicas dos CPs do Grupo 8,0................................. 200

Tabela 6.33 Propriedades físicas dos CPs do Grupo 12,0................................ 201

Tabela 6.34 Teste ANOVA para as propriedades físicas dos corpos-de-prova.... 203

Tabela 6.35 Propriedades mecânicas dos CPs do Grupo 4,5.......................... 215

Tabela 6.36 Propriedades mecânicas dos CPs do Grupo 8,0............................. 216

Tabela 6.37 Propriedades mecânicas dos CPs do Grupo 12,0.......................... 217

Tabela 6.38 Teste ANOVA para as propriedades mecânicas dos corpos-de-

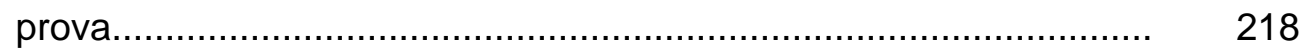

Tabela 6.39 Estimativa da resistência dos blocos, na área bruta, em função dos resultados dos corpos-de-prova................................................... 229

Tabela 7.1 Terminologias e características de cada uma das dosagens............ 239

Tabela 7.2 Dados técnicos da vibro-prensa (Fonte: www.piorotti.com.br)........... 241

Tabela 7.3 Quantidades de materiais em função de uma volta da esteira de dosagem.

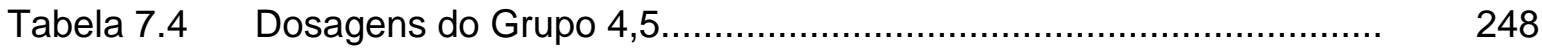

Tabela 7.5 Características das dosagens do Grupo 4,5................................ 248

Tabela 7.6 Dosagens do Grupo 8,0..................................................... 251

Tabela 7.7 Características das dosagens do Grupo 8,0.............................. 252

Tabela $7.8 \quad$ Terminologia adotada para o Grupo 12,0..................................... 254

Tabela 7.9 Características dos traços do Grupo 12,0.................................... 254

Tabela 7.10 Análise dimensional das unidades do Grupo 4,5.......................... 257

Tabela 7.11 Análise dimensional das unidades do Grupo 8,0.......................... 260

Tabela 7.12 Análise dimensional das unidades do Grupo 12,0.......................... 263

Tabela 7.13 Absorção de água e valores de massa seca para as unidades do Grupo 4,5....... 
Tabela 7.14 Área líquida e relação entre área líquida e bruta para as unidades do Grupo 4,5.

Tabela 7.15 Absorção de água e valores de massa seca para as unidades do Grupo 8,0

Tabela 7.16 Área líquida e relação entre área líquida e bruta para as unidades do Grupo 8,0......

Tabela 7.17 Absorção de água e valores de massa seca para as unidades do Grupo 12,0

Tabela 7.18 Área líquida e relação entre área líquida e bruta para as unidades do Grupo 12,0 ......

Tabela 7.19 Teste ANOVA para valores de absorção de água e área líquida dos blocos de concreto.

Tabela 7.20 Massa específica seca e saturada superfície seca para as unidades do Grupo 4,5.

Tabela 7.21 Índice de vazios para as unidades do Grupo 4,5.

Tabela 7.22 Massa específica seca e saturada superfície seca para as unidades do Grupo 8,0.

Tabela 7.23 Índice de vazios para as unidades do Grupo 8,0.......

Tabela 7.24 Massa específica seca e saturada superfície seca para as

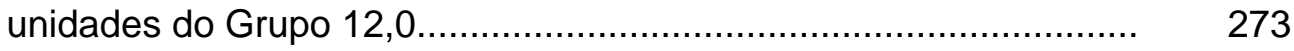

Tabela 7.25 Índice de vazios para as unidades do Grupo 12,0.

Tabela 7.26 Teste ANOVA para valores de massa específica e índice de vazios

Tabela 7.27 Dosagens que apresentaram valores de absorção e índice de vazios significativamente diferentes (5\% de significância)............... 275

Tabela 7.28 Taxa de absorção inicial para os blocos de concreto do Grupo 4,5..

Tabela 7.29 Taxa de absorção inicial para os blocos de concreto do Grupo 8,0..

Tabela 7.30 Taxa de absorção inicial para as unidades do Grupo 12,0................

Tabela 7.31 Teste ANOVA para valores de IRA.

Tabela 7.32 Absorção capilar para os blocos de concreto do Grupo 4,5.

Tabela 7.33 Absorção capilar para os blocos de concreto do Grupo 8,0.....

Tabela 7.34 Absorção capilar para os blocos de concreto do Grupo 12,0............

Tabela 7.35 Teste ANOVA para valores de absorção por capilaridade.

Tabela 7.36 Resistência à compressão das unidades de alvenaria do Grupo 4,5 aos sete dias 
Tabela 7.37 Coeficientes de correlação considerando os resultados dos CPs e dos blocos aos sete dias - Grupo 4,5......

Tabela 7.38 Resistência à compressão das unidades de alvenaria do Grupo 4,5 aos vinte e oito dias.

Tabela 7.39 Coeficientes de correlação considerando os resultados dos CPs e dos blocos aos vinte e oito dias - Grupo 4,5.

Tabela 7.40 Resultados de resistência à compressão para idades superiores a cem dias.

Tabela 7.41 Resistência à compressão das unidades aos sete dias - Grupo 8,0 .

Tabela 7.42 Coeficientes de correlação considerando os resultados dos CPs e dos blocos aos sete dias - Grupo 8,0.

Tabela 7.43 Resistência à compressão das unidades aos vinte e oito dias Grupo 8,0......

Tabela 7.44 Coeficientes de correlação considerando os resultados dos CPs e dos blocos aos vinte e oito dias - Grupo 8,0.

Tabela 7.45 Resistência à compressão das unidades para idades superiores a cem dias - Grupo 8,0.

Tabela 7.46 Resistência à compressão das unidades aos sete dias - Grupo 12,0

Tabela 7.47 Resistências reais das unidades do Grupo 12,0 e os valores previstos através da correlação com os corpos-de-prova cilíndricos aos sete dias.

Tabela 7.48 Resistência à compressão das unidades aos vinte e oito dias Grupo 12,0 ......

Tabela 7.49 Coeficientes de correlação considerando os resultados dos CPs e dos blocos aos vinte e oito dias - Grupo 12,0.....

Tabela 7.50 Resistência à compressão das unidades para idades superiores a

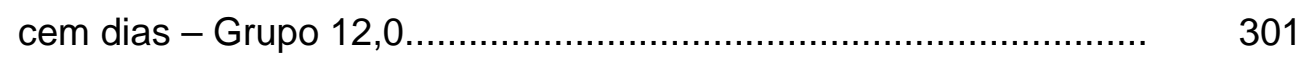

Tabela 7.51 Teste ANOVA para valores de resistência à compressão................ 302

Tabela 7.52 Resultados de resistência à tração indireta - Grupo 4,5................ 304

Tabela 7.53 Resultados de resistência à tração indireta - Grupo 8,0................. 305

Tabela 7.54 Resultados de resistência à tração indireta - Grupo 12,0............... 306

Tabela 7.55 Teste ANOVA para valores de resistência à tração indireta.............. 307

Tabela 7.56 Dosagens que apresentaram valores ligeiramente maiores de resistência à tração. 
Tabela 7.57 Módulo de deformação dos blocos - Grupo 4,5.

Tabela 7.58 Relação entre o módulo de deformação e a resistência à compressão das unidades do Grupo 4,5.

Tabela 7.59 Módulo de elasticidade e relação entre módulo/resistência considerando as prescrições do ACl 318-89 (1995) para as unidades do Grupo 4,5.

Tabela 7.60 Módulo de deformação dos blocos - Grupo 8,0

Tabela 7.61 Relação entre o módulo de deformação e a resistência à compressão das unidades do Grupo 8,0.......

Tabela 7.62 Módulo de elasticidade e relação entre módulo/resistência considerando as prescrições do ACl 318-89 (1995)........................ 312

Tabela 7.63 Módulo de deformação dos blocos - Grupo 12,0............................

Tabela 7.64 Relação entre o módulo de deformação e a resistência à compressão das unidades do Grupo 12,0

Tabela 7.65 Módulo de elasticidade e relação entre módulo/resistência considerando as prescrições do $\mathrm{ACl}$ 318-89 (1995) para as unidades do grupo 12,0

Tabela 7.66 Teste ANOVA para valores de módulo de deformação.

Tabela 7.67 Valores de insumos, frete e preço de comercialização das unidades.

Tabela 7.68 Valores de comercialização do agregado reciclado de concreto e para deposição dos resíduos em aterros de RCD.

Tabela 7.69 Resultados do Grupo 4,5 considerando-se a Hipótese A

Resultados do Grupo 8,0 considerando-se a Hipótese A.

Tabela 7.71 Resultados do Grupo 12,0 considerando-se a Hipótese A

Tabela 7.72 Resultados do Grupo 4,5 considerando-se a Hipótese B

Tabela 7.73 Resultados do Grupo 8,0 considerando-se a Hipótese B

Tabela 7.74 Resultados do Grupo 12,0 considerando-se a Hipótese B........

Tabela 7.75 Acréscimo no custo dos insumos e comercialização das unidades quando os resíduos são depositados em aterros (Grupo 4,5)......... 323

Tabela 7.76 Resultados do Grupo 4,5 considerando-se a Hipótese C................. 324

Tabela 7.77 Resultados do Grupo 8,0 considerando-se a Hipótese C................ 325

Tabela 7.78 Resultados do Grupo 12,0 considerando-se a Hipótese C.............. 325

Tabela 7.79 Análise de viabilidade econômica da Hipótese A considerando-se fábricas de pré-moldados com diferentes escalas de produção....... 
Tabela 7.80 Quantidades de materiais em função de uma volta da esteira de dosagem.

Tabela 7.81 Terminologia e características gerais das dosagens utilizadas para a produção dos meio-blocos..

Tabela 7.82 Dosagens para a produção dos meios-blocos - Grupo 4,5. 334

Tabela 7.83

Dosagens para a produção dos meios-blocos - Grupo 8,0. 335

Tabela 7.84 Dosagens para a produção dos meios-blocos - Grupo 12,0.

Tabela 7.85 Absorção de água e valores de massa seca (em estufa) para os três grupos avaliados $(4,5 ; 8,0 ; 12,0)$

Tabela 7.86 Teste ANOVA para valores de absorção dos meios-blocos.......

Tabela 7.87 Área líquida e relação entre área líquida e área bruta para os meios-blocos dos três grupos avaliados $(4,5 ; 8,0 ; 12,0)$......

Tabela 7.88 Teste ANOVA para valores de área líquida dos meios-blocos.......... 340

Tabela 7.89 Massa específica seca e saturada superfície seca para os meiosblocos dos três grupos avaliados.

Tabela 7.90 Teste ANOVA para valores de massa específica dos meios-blocos 341

Tabela 7.91 Índice de vazios para os meios-blocos dos três grupos avaliados...

Tabela 7.92 Teste ANOVA para valores de índice de vazios dos meios-blocos..

Tabela 7.93 Taxa de absorção inicial para as unidades dos três grupos avaliados.

Tabela 7.94 Teste ANOVA para valores de IRA dos meios-blocos.....

Tabela 7.95 Resistência à compressão aos sete dias para os meios-blocos dos três grupos avaliados.

Tabela 7.96 Teste ANOVA para valores de resistência à compressão.

Tabela 7.97 Módulo de deformação para as unidades dos três grupos avaliados

Tabela 7.98 Teste ANOVA para valores de módulo de deformação.

Tabela 8.1 Massa específica e massa unitária dos componentes da argamassa.......

Tabela 8.2 Composição granulométrica do agregado miúdo natural................... 352

Tabela 8.3 Traços de argamassa especificados pela BS 5628: Part 1. ............ 353

Tabela 8.4 Características das argamassas utilizadas no estudo de traço........ 353

Tabela 8.5 Propriedades físicas e mecânicas das argamassas avaliadas...

Tabela 8.6 Relação entre a resistência da argamassa e a resistência dos blocos obtidos experimentalmente...

Tabela 8.7 Ensaios referentes à argamassa fresca e endurecida. 
Tabela 8.8 Terminologia adotada para os prismas

Tabela 8.9 Terminologia adotada para as miniparedes.

Tabela 8.10 Características das argamassas utilizadas para o assentamento das unidades.

Tabela 8.11 Terminologia adotada para o Grupo 4,5

Tabela 8.12 Valores de resistência à compressão dos prismas e das unidades do Grupo 4,5

Tabela 8.13 Resultados de módulo de deformação dos prismas do Grupo 4,5...

Tabela 8.14 Resultados das propriedades físicas e mecânicas dos CPs de argamassa do Grupo 4,5......

Tabela 8.15 Terminologia adotada para o Grupo 8,0.

Tabela 8.16 Valores de resistência à compressão dos prismas e das unidades do Grupo 8,0

Tabela 8.17 Resultados de módulo de deformação dos prismas do Grupo 8,0...

Tabela 8.18 Resultados das propriedades físicas e mecânicas do CPs de argamassa do Grupo 8,0.

Tabela 8.19 Terminologia adotada para o Grupo 12,0.

Tabela 8.20 Valores de resistência à compressão dos prismas e das unidades pertencentes ao Grupo 12,0.

Tabela 8.21 Resultados de módulo de deformação dos prismas do Grupo 12,0.

Tabela 8.22 Resultados das propriedades físicas e mecânicas do CPs de argamassa do Grupo 12,0.

Tabela 8.23 Teste ANOVA para as propriedades de resistência à compressão (prismas, blocos e argamassas) e módulo de deformação dos prismas.

Tabela 8.24 Teste ANOVA para as propriedades de resistência à compressão (prismas, blocos e argamassas) e módulo de deformação dos prismas (Grupos 8,0 e 12,0)

Tabela 8.25 Características das argamassas utilizadas para o assentamento e capeamento das unidades.

Tabela 8.26 Terminologia adotada para as miniparedes do Grupo 4,5.

Tabela 8.27 Valores de resistência à compressão e módulo de deformação das miniparedes do Grupo 4,5. 
Tabela 8.28 Fatores de eficiência, razão entre o módulo e resistência e relação entre o módulo de deformação dos diferentes elementos - Grupo 4,5

Tabela 8.29 Resultados das propriedades físicas e mecânicas do CPs de argamassa das miniparedes do grupo 4,5

Tabela 8.30 Terminologia adotada para as miniparedes do Grupo 8,0.....

Tabela 8.31 Valores de resistência à compressão e módulo de deformação das miniparedes do Grupo 8,0.

Tabela 8.32 Fatores de eficiência, razão entre o módulo e resistência e relação entre o módulo dos diferentes elementos para as miniparedes do Grupo 8,0

Tabela 8.33 Resultados das propriedades físicas e mecânicas do CPs de argamassa das miniparedes do grupo 8,0

Tabela 8.34 Terminologia adotada para as miniparedes do Grupo 12,0. 390

Tabela 8.35 Valores de resistência à compressão e módulo de deformação das miniparedes do Grupo 12,0

Tabela 8.36 Fatores de eficiência, razão entre o módulo e resistência e relação entre o módulo dos diferentes elementos para as miniparedes do Grupo 12,0 ......

Tabela 8.37 Resultados das propriedades físicas e mecânicas do CPs de argamassa das miniparedes do Grupo 12,0.

Tabela 8.38 Teste ANOVA para as propriedades de resistência à compressão (miniparedes, blocos e argamassas) e módulo de deformação das miniparedes.

Tabela 8.39 Teste ANOVA para verificar a influência das diferentes classes de resistência $(4,5 ; 8,0 ; 12,0)$ e elementos (prismas e miniparedes) sobre a propriedade de resistência à compressão.

Tabela 9.1 Terminologias e características de cada dosagem.

Tabela 9.2 Argamassa utilizada para a execução das miniparedes de retração.

Tabela 9.3 Terminologias adotadas para as miniparedes.

Tabela 9.4 Dosagens do Grupo 4,5.

Tabela 9.5 Valores de retração por secagem para os corpos-de-prova do Grupo 4,5...... 
Tabela 9.7 Valores de retração por secagem para os corpos-de-prova do Grupo 8,0

Tabela 9.8 Dosagens do Grupo 12,0......

Tabela 9.9 Valores de retração por secagem para os corpos-de-prova do Grupo 12,0 .

Tabela 9.10 Teste ANOVA para a propriedade de retração por secagem.

Tabela 9.11 Miniparedes do Grupo 4,5.

Tabela 9.12 Valores de retração por secagem para as miniparedes do Grupo 4,5

Tabela 9.13 Previsão dos valores de retração das miniparedes do Grupo 4,5.... 428

Tabela 9.14 Miniparedes do Grupo 8,0.

Tabela 9.15 Valores de retração por secagem para as miniparedes do Grupo 8,0

Tabela 9.16 Previsão dos valores de retração das miniparedes do Grupo 8,0.....

Tabela 9.17 Miniparedes do Grupo 12,0......

Tabela 9.18 Valores de retração por secagem para as miniparedes do Grupo 12,0 .

Tabela 9.19 Previsão dos valores de retração das miniparedes do Grupo 12,0...

Tabela 9.20 Teste ANOVA para a propriedade de retração por secagem (miniparedes).

Tabela 9.21 Coeficientes de retração da alvenaria (Grupos 4,5; 8,0 e 12,0) para dois e dez anos 


\section{LISTA DE ABREVIATURAS E SÍMBOLOS}

\begin{tabular}{|c|c|}
\hline $\mathrm{ABCl}$ & Associação Brasileira da Construção Industrializada \\
\hline ABCP & Associação Brasileira de Cimento Portland \\
\hline ABESC & Associação Brasileira das Empresas de Serviços de Concretagem \\
\hline $\mathrm{ACl}$ & American Concrete Institute \\
\hline ANOVA & Análise de Variância \\
\hline AS & Australian Standard \\
\hline ASCE & American Society of Civil Engineers \\
\hline ASTM & American Society for Testing and Materials \\
\hline BS & British Standard \\
\hline COMASP & Comitê de Meio Ambiente, Segurança e Produtividade do Sinduscon \\
\hline CONAMA & Conselho Nacional do Meio ambiente \\
\hline DIN & Deutsche Institut für Normung \\
\hline DNER & Departamento de Estradas de Rodagem \\
\hline EESC & Escola de Engenharia de São Carlos \\
\hline EPUSP & Escola Politécnica da Universidade de São Paulo \\
\hline FHWA & Federal Highway Administration \\
\hline IPT & Instituto de Pesquisas Tecnológicas \\
\hline ISO & International Organization for Standardization \\
\hline MBT & Master Builder Technologies \\
\hline NBR & Norma Brasileira \\
\hline PBPQ-H & Programa Brasileiro de Produtividade e Qualidade no Hábitat \\
\hline PROHAB & Secretaria Municipal de Desenvolvimento Sustentável, Ciência e \\
\hline & Tecnologia e Progresso Habitação de São Carlos \\
\hline RILEM & $\begin{array}{l}\text { International Union of Laboratories and Experts in Construction Materials, } \\
\text { Systems and Structures }\end{array}$ \\
\hline SINDUSCON & Sindicato da Indústria da Construção Civil \\
\hline TMS & The Masonry Society \\
\hline URPV's & Unidades de recebimento de pequenos volumes \\
\hline$A b_{s s d}$ & Absorção na condição saturada superfície seca \\
\hline$A_{\text {bruta }}$ & Área bruta \\
\hline $\mathrm{ARb}$ & Agregados reciclados de blocos \\
\hline ARpb & Agregados reciclados de resíduos da produção dos blocos \\
\hline ARpp & Agregados reciclados de pisos de pavimentação \\
\hline ARt & Agregados reciclados de telha \\
\hline
\end{tabular}


ARv Agregados reciclados de vigotas

ARvf Agregados reciclados de vigotas com barra de aço

ARvp Agregados reciclados de resíduos da vibro-prensa

C.V. Coeficiente de variação

$\mathrm{C}_{\text {un. }} \quad$ Coeficiente de uniformidade

D.Máx. Dimensão máxima característica

$f_{b k} \quad$ Resistência característica à compressão das unidades de alvenaria

$\mathrm{f}_{\mathrm{bm}} \quad$ Resistência média à compressão das unidades de alvenaria

$\mathrm{f}_{\mathrm{c}} \quad$ Resistência à compressão dos corpos-de-prova

$\mathrm{f}_{\mathrm{cm}} \quad$ Resistência média à compressão dos corpos-de-prova

IRA Taxa de absorção inicial

M.F. Módulo de finura

$\mathrm{RC} \quad$ Agregado reciclado de resíduos de concreto

RCD Agregado reciclado de resíduos de construção e demolição

$Y_{s} \quad$ Massa específica seca

$Y_{\text {ssd }} \quad$ Massa específica saturada superfície seca

$\mathrm{S}_{\mathrm{d}} \quad$ Desvio Padrão

$\mathrm{E}_{\mathrm{b}} \quad$ Módulo de elasticidade na área líquida

$f_{\text {prisma }} \quad$ Resistência à compressão dos prismas

$\mathrm{f}_{\mathrm{arg}} \quad$ Resistência à compressão das argamassas

$\mathrm{f}_{\text {miniparede }} \quad$ Resistência à compressão das miniparedes

$V_{\text {vazios }} \quad$ Volume de vazios

$V_{\text {rec }} \quad$ Volume do recipiente

$\varepsilon_{\mathrm{t}} \quad$ Deformação por retração

s Espaçamento entre juntas

$\mathrm{w}_{\mathrm{j}} \quad$ Espessura das juntas

$\mathrm{e}_{\mathrm{j}} \quad$ Extensividade do selante

$k_{m} \quad$ Coeficiente de retração da alvenaria ou de retração dos blocos

$\mathrm{k}_{\mathrm{t}} \quad$ Coeficiente de dilatação térmica

T Temperatura

U Umidade

$\Delta \mathrm{T} \quad$ Variação térmica 
BUTTLER, A. M. Uso de agregados reciclados de concreto em blocos de alvenaria estrutural. 2007. Tese (Doutorado) - Escola de Engenharia de São Carlos, Universidade de São Paulo, São Carlos, 2007.

A pesquisa teve como objetivo principal avaliar a incorporação de agregados reciclados de concreto em blocos estruturais de concreto para três classes de resistência (4,5 MPa, 8,0 MPa e 12,0 MPa). O estudo foi desenvolvido basicamente em quatro etapas. A primeira etapa consistiu na análise das propriedades físicas de agregados miúdos e graúdos reciclados de concreto originários de uma fábrica de pré-moldados. Na segunda etapa, foram analisadas as propriedades físicas e mecânicas de corpos-de-prova cilíndricos produzidos com concreto de consistência seca utilizando-se dois tipos de agregados reciclados previamente avaliados. O objetivo foi definir um intervalo de correlação entre a resistência à compressão de corpos-de-prova e blocos, verificar preliminarmente a influência dos agregados reciclados sobre as propriedades físicas e mecânicas e determinar os traços para a próxima etapa. Para a terceira etapa, foi avaliada a viabilidade técnica da produção de blocos com agregados reciclados através da análise de propriedades físicas e mecânicas, sendo também avaliada a viabilidade econômica pela proposição de algumas alternativas para reciclagem. De maneira geral, independentemente do grupo de resistência avaliado, todas as unidades com agregados graúdos reciclados cumpriram os requisitos estabelecidos; já para o estudo econômico, todas as hipóteses atestaram a viabilidade da produção de unidades com agregados reciclados com custos de produção e comercialização inferiores aos das unidades comumente produzidas. Finalmente, a quarta etapa, consistiu na avaliação da retração por secagem em miniparedes, resistência à compressão e módulo de deformação de elementos (prismas e miniparedes) produzidos com as unidades da etapa anterior. Em função dos resultados obtidos, pode-se afirmar que apenas a propriedade de retração por secagem foi afetada pelas unidades com agregados reciclados; nesse caso, a redução da distância entre juntas de controle foi considerada uma medida suficiente para minimizar os efeitos da retração por secagem.

Palavras-chave: agregados reciclados de concreto; blocos estruturais com agregados reciclados de concreto; elementos compostos por unidades com agregados reciclados; propriedades físicas e mecânicas. 
BUTTLER, A. M. Use of recycled concrete aggregates in blocks of structural masonry. 2007. Ph.D. Thesis. School of Engineering of São Carlos, University of São Paulo, São Carlos, 2007.

The main goal of the present research project was the evaluation of recycled concrete aggregates incorporation in structural concrete blocks of three different levels of compressive strength (4,5 MPa, 8,0 MPa and 12,0 MPa). The study was developed in four stages. The first stage analyzed the physical properties of fine and coarse concrete aggregates derived from a precast concrete plant. In the second stage, physical and mechanical properties of dry consistency concrete cylindrical specimens were analyzed using two types of recycled aggregates. The aim was to define a correlation interval between the compressive strength of cylindrical specimens and concrete blocks, verify the influence of recycled aggregates on the physical and mechanical properties, and determine the better compositions to be used in the next stage. The third stage involved the technical viability of producing concrete blocks, and also the economic viability of some recycling alternatives. As a whole, independently of the strength class, the recycled coarse aggregate blocks fulfilled the required specifications; additionally the economic hypotheses confirmed the viability of producing recycled aggregate units with both production and market costs lower than those of the conventional units. Finally, the fourth stage dealt with the drying shrinkage of mini-walls, the compressive strength and the elasticity modulus of elements (prisms and mini-walls) built with units defined in the former stage. Based on the obtained results, the study showed that only the drying shrinkage property was affected by the recycled aggregates units; the reduction of the distance between two adjacent control joints was an adequate procedure to minimize the effects of the drying shrinkage in this case.

Key-words: recycled concrete aggregates; structural blocks produced with recycled concrete aggregates; elements composed with recycled concrete aggregates; physical and mechanical properties. 


\subsection{INTRODUÇÃO}

A indústria da construção civil constitui-se numa grande fonte geradora de resíduos. Estatísticas indicam que o volume de resíduos de construção e demolição (RCD) representa cerca de $60 \%$ do volume total de sólidos gerados nas cidades brasileiras. O Brasil, felizmente, encontra-se em posição de vanguarda quando comparado a outros países da América Latina; a Resolução $N^{0} 307$ do CONAMA (BRASIL, 2002) e as normas técnicas que entraram em vigor em 2004 tratando da questão dos RCD, são os primeiros indícios de mudanças com relação a esta questão.

Em vários países, tais como, Holanda, Inglaterra, Bélgica, Dinamarca, Japão e Hong Kong existem regulamentações e decretos que tratam do gerenciamento e deposição dos resíduos de construção, com a aplicação de severas taxas sobre os resíduos que são depositados no meio ambiente. Na Inglaterra, por exemplo, o governo cobra pelos resíduos que são gerados nas obras e impõe elevadas taxas para a exploração de agregados naturais visando incentivar o reaproveitamento de materiais reciclados. Na Holanda, país que pode ser considerado como exemplar na questão de reaproveitamento de RCD, a forma encontrada pelo governo para coibir o desperdício e promover a reciclagem, atingindo níveis superiores a $80 \%$, foi aumentar em cerca de cinco vezes as taxas para deposição dos resíduos no meio ambiente; acrescenta-se a isso, a enorme pressão da própria sociedade contra a utilização de áreas para a deposição de resíduos e exploração de recursos naturais. No Brasil, a Resolução $N^{0} 307$ do CONAMA (BRASIL, 2002), em vigor desde 2 de janeiro de 2003, é uma das primeiras medidas em âmbito federal com a missão de disciplinar a destinação dos resíduos de construção. As prefeituras, segundo essa resolução, deverão elaborar planos de gerenciamento de resíduos com regras para reciclagem e deposição final, contando com um prazo de 18 meses para a implementação desses planos e, o mesmo tempo, para cessar a deposição dos resíduos de construção em aterros de resíduos domiciliares e em áreas denominadas de "bota-fora". As construtoras, por sua vez, terão que elaborar projetos de gerenciamento de resíduos da construção civil, 
com prazo de 24 meses para incluí-los nos projetos de obras a serem submetidos à aprovação das prefeituras. Loturco (2004) cita que a partir dessa resolução, o Brasil entrou para um seleto grupo de países que se preocupam com a destinação dos resíduos, sendo que não existem propostas semelhantes em toda a América Latina. As alterações exigidas pela Resolução 307 estão sendo feitas, segundo Pinto (2004), seguindo novas normas técnicas. As normas técnicas NBRs 15112 a 15114, publicadas em 2004, e preparadas pelos comitês CB02 e CB18 da Associação Brasileira de Normas Técnicas fornecem diretrizes para o projeto, implantação e operação de áreas de transbordo, triagem e aterros de resíduos de construção civil e volumosos. As outras normas NBR 15115 (2004) e NBR 15116 (2004) estabelecem procedimentos e requisitos para execução de camadas de pavimentação, aplicação em pavimentação e preparo de concreto sem função estrutural utilizando agregados reciclados de resíduos sólidos da construção civil.

Com relação à geração de $\mathrm{RCD}$, no Brasil, algumas estimativas indicam valores da ordem de 230 a $660 \mathrm{~kg} / \mathrm{hab}$.ano (PINTO, 1999) e outras apontam para valores próximos a 68,5 Mt/ano (ANGULO, 2002). Segundo John (2004), o volume de RCD produzido na cidade de São Paulo chega a 500 kg/hab.ano, sendo que a porcentagem efetivamente reciclada é da ordem de 10\%. Este índice pode ser considerado ínfimo quando comparado com alguns países europeus, tais como, Alemanha, Bélgica e Holanda, onde o volume reciclado, em relação ao total produzido, supera o índice de $80 \%$. Provavelmente, a ineficácia do poder público, a falta de conscientização da população, o reduzido investimento público/privado em novas instalações de reciclagem, a relativa abundância de recursos naturais e a falta de conhecimento sobre o comportamento do material reciclado podem justificar as baixas taxas de reciclagem comparativamente a outros países.

Entretanto, essa relativa abundância de recursos naturais já pode ser questionada. Segundo Valverde (2003), a disponibilidade de matérias primas naturais dentro ou em torno dos grandes aglomerados urbanos do país vem declinando em virtude de planejamento inadequado, problemas ambientais, zoneamento restritivo e usos competitivos do solo. A possibilidade de exploração desses recursos está tornando-se relativamente limitada, tornando-se incertas as perspectivas de suprimento futuro. Até o presente momento, o preço relativamente baixo destes insumos deveu-se ao fácil acesso às reservas e as pequenas distâncias de transporte; mas as restrições estão progressivamente maiores, tanto para a obtenção de novas licenças como para garantir a atividade das minerações existentes. A perspectiva mundial também é preocupante; de acordo com Mattos e Wagner (1999), entre 1970 e 1995, o consumo de matérias primas cresceu de 5,7 bilhões de toneladas para 9,5 bilhões de toneladas. A conseqüência desse fato é a diminuição da reserva de muitos 
recursos naturais, especialmente nas grandes cidades aonde já é necessário extrair algumas dessas matérias primas a distâncias cada vez maiores, encarecendo o custo final para o consumidor.

A deterioração ambiental provocada pela deposição incorreta dos resíduos e pela exploração desenfreada dos recursos naturais também merece destaque. Cavalcanti (2004) cita que a deposição dos resíduos de construção, de maneira descontrolada, acarreta uma série de custos ambientais. Além desses custos, segundo a pesquisadora, podem ser incluídos os custos referentes ao gerenciamento da deposição clandestina, e o não aproveitamento desses resíduos que poderiam ser reciclados e utilizados em obras públicas.

Apesar da publicação de novas normas técnicas e da resolução do Resolução $N^{0} 307$ do CONAMA (BRASIL, 2002), o potencial de reciclagem pode ser considerado ínfimo perante a geração diária de RCD. No Brasil, existem apenas 18 instalações de reciclagem com escala de produção pequena (menor que 100 t/dia de resíduos processados); já na Alemanha, conforme Müller (2006), são cerca de 1600 plantas fixas de reciclagem e 3313 plantas móveis de reciclagem que processaram, em 2005, 59 Mt de RCD. Considerando-se a escala de produção das instalações de reciclagem em funcionamento no país e a taxa média de geração de $445 \mathrm{~kg} / \mathrm{hab}$.ano de RCD, chega-se a conclusão que o país precisaria de, no mínimo, 2300 usinas para processar o volume gerado diariamente.

No Brasil, a experiência com reciclagem de RCD tem se restringido principalmente à iniciativa pública de algumas prefeituras, tais como, São Paulo, Santo André, Londrina, Belo Horizonte, São José dos Campos, São Carlos, Ribeirão Preto, etc. No caso de alguns países europeus, como a Holanda, as atividades de pesquisa e desenvolvimento na área de reciclagem transformaram-se em excelente negócio para um grande número de empresas privadas (JOHN, 2000). Por outro lado, também podem ser citadas algumas iniciativas recentes do setor privado brasileiro que merecem destaque na área de reciclagem. A Racional Engenharia adotou um sistema inédito de gestão ambiental no setor da construção civil, que, em menos de dois anos, já teve resultados expressivos. A construtora, dentro desta filosofia, reciclou o entulho gerado pela demolição de um edifício para a fabricação de blocos de concreto destinados a casas populares. A Construtora Setin assessorada pela empresa Obra Limpa, reciclaram cerca de $12000 \mathrm{~m}^{3}$ de concreto proveniente de um piso industrial de uma antiga indústria para a produção de blocos estruturais, lajes e outras peças pré-moldadas. 
Uma das grandes dificuldades encontradas para a utilização de RCD como agregado reciclado refere-se a grande heterogeneidade do material. A variabilidade na composição pode ser considerada um fator limitante na utilização desses agregados em concretos estruturais. Ângulo e John (2004) atestaram a variabilidade dos agregados de RCD obtidos em uma usina de reciclagem; os coeficientes de variação situaram-se entre 5\% e $87 \%$ para as propriedades físicas analisadas impossibilitando o uso desses agregados em concretos estruturais. A separação das diferentes frações presentes nos RCD também pode ser considerada um fator limitante, uma vez que não há um método adequado e eficiente para essa separação. Essa constatação fica clara quando se observa que mesmo em países considerados exemplares com relação à gestão de resíduos, apenas 1\% do mercado das empresas de demolição empregam a demolição seletiva com a finalidade de separar a fração representada pelo concreto das demais fases.

A fração representada pelo concreto dos RCD, desde que corretamente separada, apresenta um dos maiores potenciais de utilização como agregado reciclado. Algumas fontes geradoras potenciais de resíduos de concreto são: as fábricas de pré-moldados e blocos, usinas de concreto pré-misturado e pavimentos rodoviários. A grande potencialidade na utilização dessa fração pode ser atribuída à possibilidade de conhecimento das suas propriedades físicas e mecânicas e o menor grau de contaminação por outros tipos de rejeitos, especialmente quando se tratam de resíduos de concreto $(\mathrm{RC})$ oriundos de usinas de concreto e fábricas de pré-moldados.

No caso de uma fábrica de pré-moldados e blocos, os RC são basicamente provenientes de elementos rejeitados pelo controle de qualidade, final de linhas de produção e sobras de concreto fresco ao término do processo. As usinas de concreto pré-misturado são outra fonte de RC, sendo que grande parte destes são gerados pelo retorno de sobras de concreto dos caminhões betoneira, bombas de lançamento de concreto, lavagem dos caminhões e instalações da central. Estimativas da Associação Brasileira das Empresas de Serviço de Concretagem (2001), para a região metropolitana de São Paulo, apontam para um volume de 3500 a $7000 \mathrm{~m}^{3}$ de concreto residual gerados mensalmente nas centrais dosadoras. No Japão, a reciclagem de RCD representa 57\% do volume total produzido, sendo que aproximadamente $73 \%$ desse volume são constituídos por RC provenientes da demolição de estruturas e pavimentos de concreto (NOGUCHI e TAMURA, 2001).

Há inúmeras pesquisas acadêmicas que analisaram as propriedades dos agregados reciclados de concreto e dos concretos produzidos com esses agregados, podendo ser citados os trabalhos de Ajdukiewicz e Kliszczewicz (2002), Barra e Vázquez (1998), De Vries (1993), Frondistou-Yannas (1977), Hansen e Narud (1983), Katz (2002), Soroushian e 
Tavakoli (1996), Gonçalves (2000) e Buttler (2003), sendo que os dois últimos mencionados foram desenvolvidos no Departamento de Engenharia de Estruturas - SET/EESC/USP. Com relação às unidades de alvenaria produzidas com materiais reciclados, podem ser citados Pimienta e Delmotte (1998); Souza et al. (2002), Fonseca (2002), Albuquerque (2005), Farias et al. (2005) e Patto e Oliveira (2006), embora nenhum deles tenham empregado exclusivamente reciclados de concreto. Apenas Poon et al. (2002) analisaram a aplicação de reciclados de concreto na produção de unidades de alvenaria maciça. De maneira geral, os resultados obtidos pelos pesquisadores foram satisfatórios, mas entendese que as propriedades avaliadas por esses pesquisadores não foram em número suficiente para comprovar a viabilidade técnica e econômica desses novos elementos produzidos com agregados reciclados, além de não possuírem as características próprias dos elementos fabricados no Brasil. Diante deste fato e, em virtude do surgimento de resoluções disciplinando a deposição e a utilização de resíduos e o grande déficit habitacional brasileiro, torna-se importante o desenvolvimento de pesquisas voltadas para a produção de unidades de alvenaria que empreguem exclusivamente agregados reciclados de concreto.

\subsection{OBJETIVOS}

Esta tese tem como objetivo principal avaliar a incorporação de agregados reciclados de concreto nas propriedades físicas e mecânicas de unidades e elementos de alvenaria estrutural comparando-os com unidades e elementos produzidos com agregados naturais. Além disso, este trabalho estabelece os seguintes objetivos específicos:

- Desenvolvimento de trabalho teórico-experimental amplo que forneça subsídios para o avanço do conhecimento sobre a utilização dos agregados reciclados de concreto na produção de unidades de alvenaria e monitoramento do desempenho ao longo do tempo destes elementos.

- Estabelecimento de critérios para a dosagem de concretos para blocos estruturais utilizando agregados reciclados de concreto e o entendimento das variáveis envolvidas no processo produtivo, tendo em conta as particularidades quanto à consistência seca do concreto para blocos e o emprego de agregados reciclados que exigem considerações especiais.

- Produção de blocos estruturais de concreto ( $f_{b k}>4,5 \mathrm{MPa}$ ) com a utilização de reciclados aferindo-se o potencial do material; incluem-se aqui os blocos de maior 
resistência, necessários para a aplicação em edifícios de múltiplos andares, que usualmente exigem maior consumo de cimento, potencializando os problemas relacionados à retração por secagem.

- Proposta de solução de problemas que possam ocorrer na produção desses elementos, baseando-se no conhecimento científico existente. Especial atenção será dada à absorção de água, a taxa de absorção inicial da unidade e a retração por secagem da unidade e da alvenaria.

- Caracterização das propriedades físicas de agregados reciclados de concreto representativos de uma fábrica de elementos pré-moldados e, principalmente, as propriedades das unidades de alvenaria estrutural produzidas com alguns desses agregados, verificando o cumprimento incondicional às normas técnicas pertinentes;

- Avaliação econômica da produção de blocos com agregados reciclados considerando-se diversas variáveis intervenientes, tais como, reciclagem dos resíduos na própria unidade de produção e compra dos resíduos em usinas de reciclagem.

- Estudo comparativo do desempenho de prismas de três blocos e miniparedes constituídas por unidades com agregados reciclados e agregados naturais.

\subsection{JUSTIFICATIVAS}

A primeira justificativa refere-se à originalidade do tema proposto; a grande maioria dos trabalhos consultados trata apenas da utilização de agregados reciclados de RCD para a produção de unidades de alvenaria com propriedades diferentes daqueles que seriam fabricados exclusivamente com agregados reciclados de $R C$, uma vez que os $R C$ apresentam maior qualidade e homogeneidade comparativamente aos RCD.

De Pauw (1980, apud SOUZA, 2001)루 ; Pollet et al. (1997), Pimienta et al. (1998), Fonseca (2002), Souza et al. (2002), Albuquerque (2005) e Farias et al. (2005) avaliaram a incorporação de agregados de RCD na produção de blocos de concreto. Conforme comentado anteriormente, a heterogeneidade dos agregados de RCD dificulta seu emprego em aplicações estruturais; dentre os trabalhos citados, apenas Pimienta et al. (1998) e 
Fonseca (2002) obtiveram êxito na produção de blocos estruturais de concreto utilizando-se a fração graúda composta por agregados reciclados.

A composição heterogênea e a presença de algumas frações indesejáveis nos RCD dificultam a produção de artefatos com esses agregados; de acordo com Souza (2001), elementos como vidro, papel, metais, gipsita e matéria orgânica, geralmente presentes nos $R C D$, podem influenciar negativamente as propriedades de trabalhabilidade, pega e endurecimento, resistência e durabilidade dos concretos. Souza et al. (2002) relatam que os agregados de RCD exercem influência significativa nas propriedades dos blocos, uma vez que para as séries com substituições de 30\% e 50\% de RCD (fração graúda e miúda), os resultados individuais de absorção e resistência não ficaram de acordo com as especificações normativas para alvenaria de vedação. Farias et al. (2005) produziram blocos de concreto e prismas com agregados reciclados de RCD. Os resíduos foram provenientes da demolição de uma residência, sendo compostos predominantemente por material cerâmico e pequenas frações de argamassa e concreto; os traços utilizados na produção dos blocos foram os seguintes: 1:6; 1:7; 1:8; 1:10,6 e 1:13. Com relação aos resultados, na propriedade de absorção de água, todas as unidades apresentaram valores de absorção superiores a 12\%; já para a resistência à compressão aos 28 dias, apenas as unidades do traço 1:6 obtiveram valores de resistência superiores a 3,0 MPa; para as unidades dos demais traços, os valores situaram-se entre 1,5 MPa e 2,8 MPa.

A produção, em larga escala, de elementos de concreto com agregados de RCD também fica comprometida, uma vez que os resíduos processados em unidades de reciclagem apresentam variações diárias significativas quanto à sua composição (fração cerâmica, concreto, argamassa, etc). Angulo e John (2004) avaliaram agregados graúdos de $R C D$, provenientes de uma central de reciclagem e coletados em diferentes dias, quanto à composição de fases e a conseqüência da variabilidade sobre algumas propriedades físicas. De maneira geral, o estudo indicou que existe uma grande variabilidade na composição dos agregados reciclados quando coletados em diferentes dias e, conseqüentemente, nas propriedades analisadas com coeficientes de variação entre $5 \%$ e $87 \%$. A variabilidade impediu o uso desses agregados em concretos estruturais, sendo que apenas $50 \%$ das amostras atenderam as exigências relativas às propriedades de absorção de água, massa específica e materiais pulverulentos.

No caso de resíduos de concreto gerados, por exemplo, em uma fábrica de prémoldados, a homogeneidade do material beneficiado fica assegurada, uma vez que as

\footnotetext{
${ }^{1}$ DE PAUW (1980). Recyclage dês decombres d'une ville sinistree. CSTC Revue, n.4, p.12-28, dez.
} 
variações diárias na composição desse material podem ser consideradas desprezíveis, desde que o processamento concomitante de RC de qualidades distintas provenientes de diferentes linhas de produção seja evitado. Dessa forma, desde que sejam respeitadas essas considerações, a produção, em larga escala, de elementos com agregados reciclados de concreto torna-se viável. No presente trabalho, uma das etapas refere-se à avaliação criteriosa das propriedades físicas de agregados reciclados oriundos de diferentes qualidades de resíduos de concreto, os quais serão processados separadamente. Segundo Hansen e Boegh (1985), Tavakoli e Soroushian (1996) e Kikuchi et al. (1998), apesar da maior homogeneidade do agregado reciclado de RC, comparativamente ao agregado de $\mathrm{RCD}$, as características do resíduo de concreto devem ser avaliadas cuidadosamente, uma vez que a sua composição afetará as propriedades dos agregados reciclados de concreto e do concreto produzido com esses agregados.

Uma outra justificativa que pode ser enumerada refere-se ao fato que na grande maioria dos trabalhos consultados foram produzidos blocos de concreto não-estruturais, Souza et al. (2002), Albuquerque (2005), Farias et al. (2005) e Patto e Oliveira (2006). No presente trabalho, um dos propósitos, desde que sejam asseguradas as condições citadas no parágrafo anterior, é a produção de blocos estruturais ( $f_{b k}=4,5 ; 8,0 ; 12,0 \mathrm{MPa}$ ) com a incorporação de diferentes qualidades de resíduos de concreto e posterior avaliação das propriedades físicas e mecânicas dessas unidades. Além disso, visando garantir a qualidade das unidades com agregados reciclados e a reprodução da metodologia proposta, as unidades recicladas serão avaliadas comparativamente às unidades produzidas com agregados naturais.

Outra razão para o desenvolvimento da presente tese deve-se ao fato de que em alguns trabalhos, apesar do relativo sucesso na produção de blocos com agregados reciclados, para elevadas taxas de substituições de agregados naturais por reciclados, inúmeras propriedades físicas e mecânicas, tais como, absorção de água e resistência à compressão não atenderam aos requisitos normativos. Diante disso, neste trabalho, pretende-se produzir unidades, com taxas de substituições parciais de agregados naturais por reciclados, que atendam irrestritamente às especificações normativas e recomendações existentes na literatura. Além disso, até o presente momento, nenhum trabalho foi conclusivo, no que diz respeito à utilização de agregados reciclados de concreto para a produção de unidades de alvenaria. Na grande maioria desses estudos não foram contemplados todos os ensaios necessários para a caracterização das propriedades físicas e mecânicas das unidades, bem como o desempenho de prismas e miniparedes fundamentais para a compreensão do comportamento da alvenaria; além de não terem 
atendido às peculiaridades de produção no Brasil, tais como, Poon et al. (2002), De Pauw (1980 apud SOUZA, 2001) ${ }^{1}$ e Pimienta et al. (1998), sendo que os dois últimos utilizaram agregados reciclados de RCD. Nesse sentido, o presente trabalho avaliará uma grande gama de propriedades, visando caracterizar o comportamento físico e mecânico das unidades, prismas e miniparedes e, dessa forma, substanciar o emprego das unidades com agregados reciclados indicando campos de aplicação e possíveis restrições.

Também se deve salientar que a maior absorção dos concretos com agregados reciclados devido à argamassa que se encontra aderida ao agregado, conforme Buttler (2003) pode ocasionar, para o caso dos blocos de concreto, maiores valores para o índice de absorção inicial (IRA) e para a taxa de absorção capilar (absorptividade). Segundo Gallegos (1989), caso o IRA da unidade seja elevado, a argamassa tenderá a ser deformar e endurecer mais rapidamente, devido à transferência de água para a unidade. A conseqüência desse fato é a redução do contato com a face da unidade superior, gerando uma adesão pobre e incompleta com baixa resistência e permeável à água e hidratação incompleta da argamassa; por outro lado, segundo Nepomuceno (2005), a absorção capilar é um dos mecanismos de transporte que mais afeta a durabilidade das edificações, especialmente àquelas expostas à chuva e sujeitas a ciclos de umedecimento e secagem. Nesse sentido, a tese avaliará essas duas propriedades que estão intimamente ligadas com a durabilidade e o desempenho dos elementos produzidos com unidades com agregados reciclados.

A retração por secagem será avaliada detalhadamente nesta tese, conforme recomendado nas conclusões de Fonseca (2002) e Souza et al. (2002). A retração na alvenaria, quando restringida, pode ocasionar o surgimento de fissuras, as quais são as principais responsáveis pelo surgimento de patologias ocasionadas pelo ingresso de água; de acordo com Buttler (2003), para concretos com agregados graúdos reciclados oriundos de concreto de resistência média de $50 \mathrm{MPa}$, os valores de retração por secagem foram de 1,5 a 2,0 vezes o valor obtido para o concreto com agregados naturais. Diante disso, pretende-se avaliar a retração de blocos e miniparedes de diferentes classes de resistência com agregados reciclados comparando-as com similares produzidas com agregados naturais e com as especificações normativas existentes. Entende-se que o cumprimento aos valores prescritos para a retração por secagem, conjuntamente com os limites recomendados para as propriedades de absorção de água, taxa de absorção inicial e absorção capilar, sejam requisitos indispensáveis para a aprovação do desempenho das unidades com agregados reciclados. Na literatura pesquisada, apenas Poon et al. (2002), 
para blocos maciços de concreto reciclado, avaliaram a retração por secagem e obtiveram resultados até $30 \%$ superiores comparativamente às unidades com agregados naturais.

Após a análise da viabilidade técnica, a presente tese pretende avaliar a viabilidade econômica da produção de blocos com agregados reciclados de concreto considerando-se diferentes alternativas, tais como, a reciclagem do resíduo na própria fábrica de prémoldados e a reciclagem do resíduo ou a compra desse material diretamente em usinas de reciclagem.

Outro ponto importante que fundamenta este trabalho se refere às novas políticas de reciclagem do país. Como já exposto no item introdutório, a Resolução $N^{0} 307$ do CONAMA (BRASIL, 2002), que entrou em vigor em janeiro de 2003, tenta disciplinar a gestão dos RCD com o estabelecimento de diretrizes, critérios e procedimentos, visando minimizar o seu impacto. Com isso, espera-se que haja uma conscientização e mudança de atitude de toda a sociedade brasileira com relação a esta questão; provavelmente, esta tarefa seja árdua no início, a exemplo do que ocorreu em vários países como Holanda e Inglaterra, que só conseguiram êxito quando estabeleceram multas para quem fosse flagrado depositando resíduos em locais inadequados. Na realidade, a resolução é uma das primeiras medidas do Estado com relação a essa problemática e que, felizmente, já está sendo bem sucedida em seus propósitos diante das iniciativas da Racional Engenharia e da Construtora Setin. Acrescenta-se a isso, a publicação de Normas Técnicas pela ABNT, em 2004, tratando da aplicação de agregados reciclados de RCD para dosagens não-estruturais e a Lei 12300 (2006) que instituiu a política estadual de resíduos sólidos do estado de São Paulo.

Finalmente, a última justificativa se refere à racionalização da construção promovida pela alvenaria estrutural com blocos de concreto. Além de ser uma tecnologia ecologicamente correta com o emprego de agregados reciclados de concreto, a alvenaria estrutural promove uma redução do custo final da edificação, através da eliminação de fôrmas e cimbramentos e redução do consumo de armaduras.

Diante das justificativas apresentadas, torna-se necessária a quantificação de todos os intervenientes presentes na produção de unidades de alvenaria estrutural com o emprego de agregados reciclados e, principalmente, o estabelecimento de séries exaustivas de ensaios que contemplem todas as propriedades físicas e mecânicas das unidades e dos elementos produzidos. Então, desta maneira, haverá subsídios para promover um consenso na comunidade científica, no que diz respeito ao emprego de agregados reciclados de concreto na produção de unidades de alvenaria estrutural. 


\subsection{METODOLOGIA}

A abordagem metodológica da tese é dividida em quatro etapas. A $1^{\mathrm{a}}$ etapa consiste na análise das propriedades físicas dos agregados reciclados de concreto, Figura 1.1.

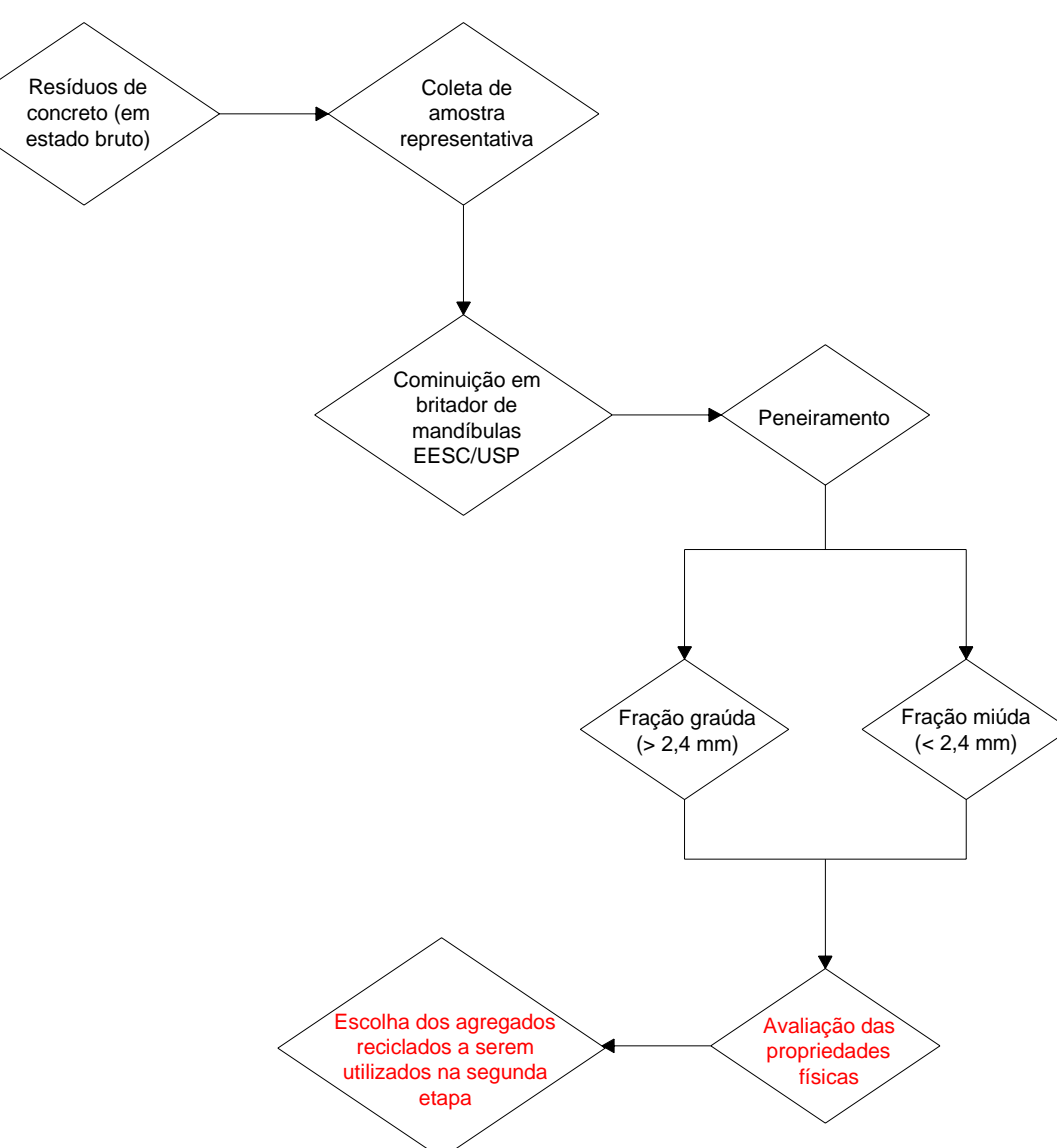

Figura 1.1 - Abordagem metodológica da primeira etapa experimental.

A $2^{\mathrm{a}}$ etapa consiste na análise das propriedades físicas e mecânicas de corpos-deprova cilíndricos utilizando-se agregados reciclados selecionados na $1^{a}$ etapa, Figura 1.2. 


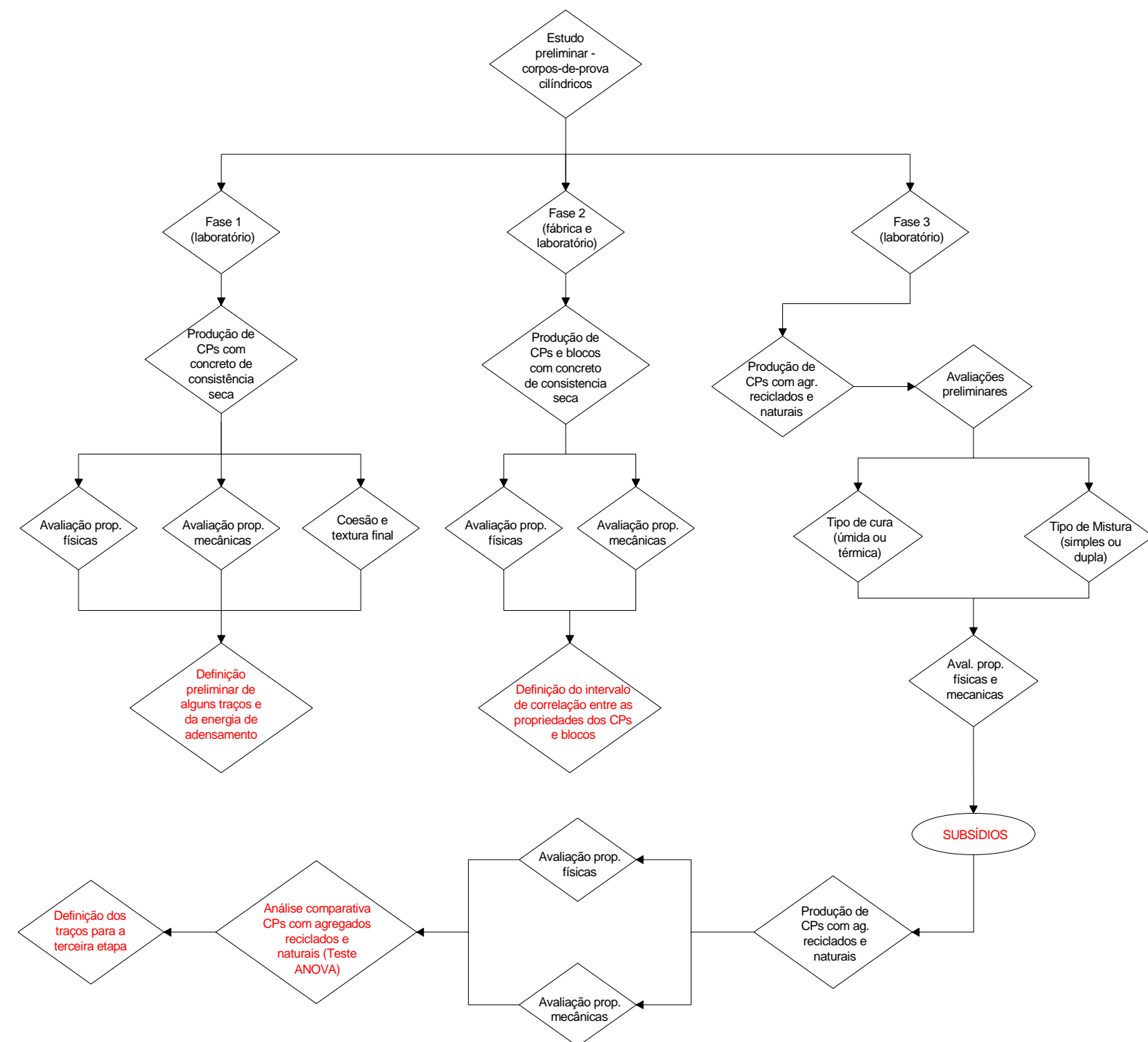

Figura 1.2 - Abordagem metodológica da segunda etapa experimental.

A $3^{\mathrm{a}}$ etapa consiste na análise das propriedades físicas e mecânicas de unidades de alvenaria utilizando-se os traços definidos na $2^{\mathrm{a}}$ etapa. Nesta etapa, também é realizado o estudo de viabilidade econômica. 


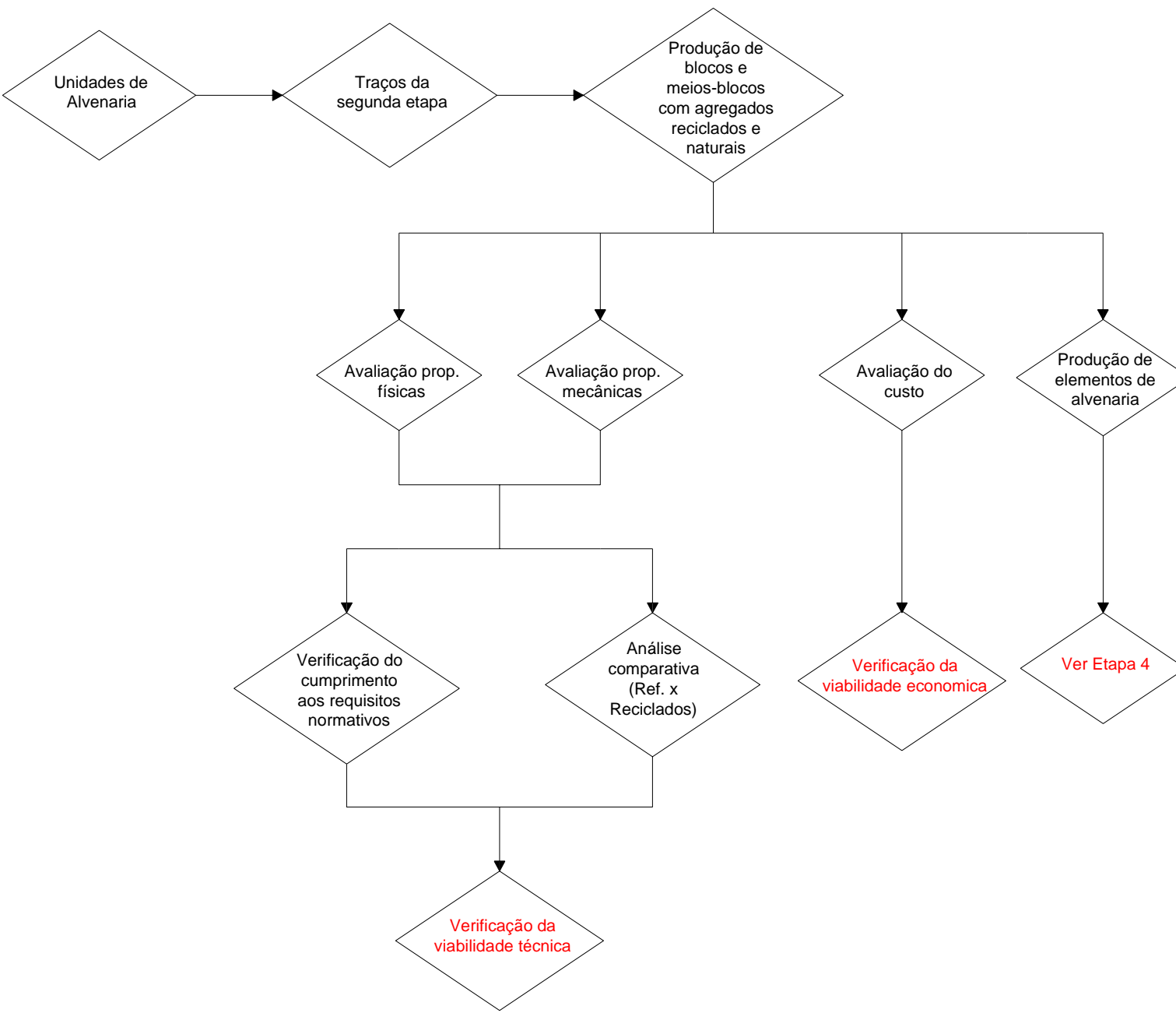

Figura 1.3 - Abordagem metodológica da terceira etapa experimental.

A $4^{\mathrm{a}}$ etapa consiste na avaliação das propriedades mecânicas de elementos representativos (prismas e miniparedes) produzidos com as unidades da $3^{\mathrm{a}}$ etapa e, por último, a avaliação da retração por secagem em miniparedes. 


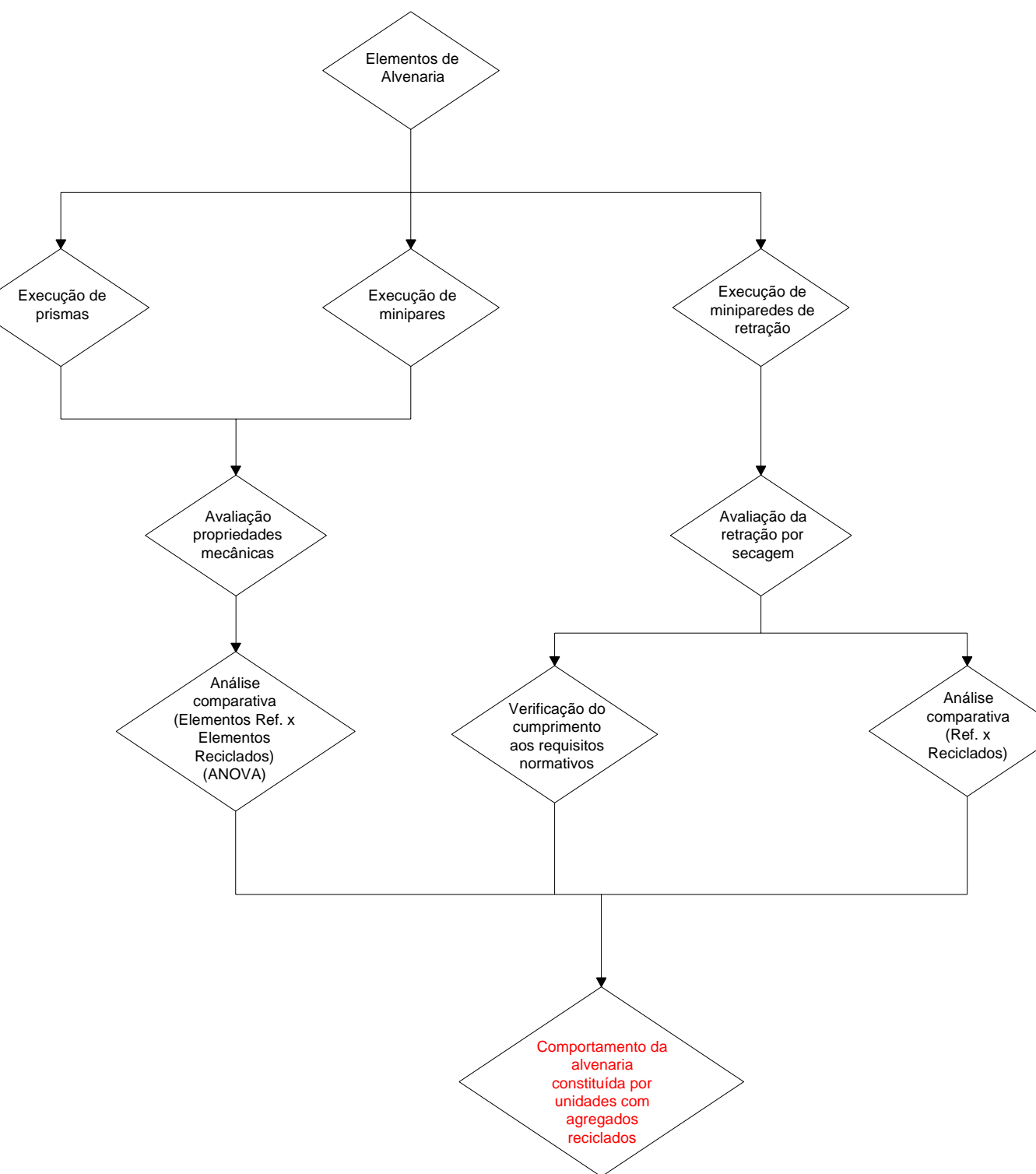

Figura 1.4 - Abordagem metodológica da quarta etapa experimental.

\subsection{APRESENTAÇÃO DA TESE}

A seguir, apresentam-se a ordem e os conteúdos dos capítulos que constituem esta tese:

No Capítulo 2, são apresentados alguns aspectos relacionados à reciclagem de resíduos de concreto e sua diferenciação em relação aos resíduos de construção e demolição; fontes e estimativas de geração, deposição dos resíduos, experiência práticas 
tratando do emprego de materiais reciclados e exposição de algumas recomendações normativas e decretos.

No Capítulo 3, são apresentados alguns aspectos referentes à produção de blocos de concreto, as principais metodologias de dosagem existentes e revisão de trabalhos que produziram blocos com agregados reciclados.

No Capítulo 4, são apresentados alguns conceitos sobre o fenômeno da retração, conceituação da retração por secagem, a retração em concretos com agregados reciclados, blocos de concreto e alvenaria e algumas recomendações construtivas relacionadas às juntas de movimentação.

No Capítulo 5, são caracterizadas as propriedades físicas dos agregados naturais e agregados reciclados de concreto, bem como do aglomerante empregado. Todos os ensaios são descritos previamente, os resultados são, então, apresentados e, posteriormente, analisados e comparados aos obtidos por outros pesquisadores.

No Capítulo 6, são analisados diversos parâmetros que influem nas propriedades físicas e mecânicas das unidades de alvenaria mediante a correlação com corpos-de-prova cilíndricos de características similares aos blocos. A incorporação de agregados reciclados de concreto, em porcentagens crescentes de substituição, é avaliada em comparação com exemplares produzidos com agregados naturais e com as recomendações normativas existentes. Os resultados são comparados mediante a utilização dos testes $t$ de Student $e$ Análise de Variância.

No Capítulo 7, são descritos os ensaios referentes às propriedades físicas e mecânicas, apresentados os resultados e as análises para as unidades de alvenaria estrutural (bloco e meio-bloco) produzidas com agregados reciclados e naturais. Neste capítulo, também é apresentado o estudo de viabilidade econômica. Os resultados são comparados mediante a utilização dos testes t de Student e Análise de Variância.

No Capítulo 8, são descritos os procedimentos e equipamentos utilizados na caracterização da alvenaria. Neste item, são apresentados os resultados e respectivas análises dos ensaios de argamassa, prismas de três blocos e miniparedes. Os resultados são comparados mediante a utilização do teste ANOVA.

No Capítulo 9, são apresentados os resultados de retração das unidades de alvenaria e miniparedes. Em função da retração dos elementos, é apresentada uma previsão da distância entre juntas de controle. Os resultados das unidades e elementos com 
agregados reciclados são analisados comparativamente às unidades e elementos produzidos com agregados naturais e com os limites normativos.

No Capítulo 10, são apresentadas as conclusões do trabalho e sugestões para trabalhos futuros.

No Capítulo 11, é apresentada a bibliografia utilizada para o desenvolvimento da presente tese.

Nos Apêndices são apresentados alguns detalhes dos ensaios realizados com 0 objetivo de complementar a argumentação.

Nos Anexos são apresentadas algumas formulações que servem de fundamentação para assuntos abordados na tese. 
A importância deste capítulo na tese refere-se ao fato que tanto na metodologia experimental para a produção dos corpos-de-prova cilíndricos como na fabricação dos blocos de concreto foram empregados agregados reciclados originários de resíduos de concreto de uma fábrica de pré-moldados. Nesse sentido, é oportuno listar no presente capítulo as principais diferenças entre esses resíduos $(R C)$ e os resíduos de construção e demolição (RCD), as principais fontes de geração de resíduos de concreto, as estimativas referentes à geração e reciclagem, as principais medidas setoriais visando à correta gestão desse resíduo e os problemas decorrentes da sua deposição inadequada, algumas aplicações envolvendo resíduos de concreto e as principais recomendações normativas tratando da utilização de agregados reciclados.

\subsection{DIFERENÇAS ENTRE OS RESÍDUOS DE CONCRETO E OS RESÍDUOS DE CONSTRUÇÃO E DEMOLIÇÃO}

Como o presente trabalho trata especificamente da reciclagem de resíduos de concreto, torna-se interessante listar as principais diferenças entre esses resíduos e os resíduos de construção e demolição (RCD).

Conforme Angulo (2005), a definição de RCD inclui todo e qualquer resíduo proveniente das atividades de construção, sejam eles de novas construções, reformas, demolições, obras de arte e limpeza de terrenos com presença de solos ou vegetação. Por outro lado, segundo Buttler (2003), os resíduos de concreto (RC) incluem preponderantemente rejeitos oriundos da demolição de estruturas de concreto, resíduos de usinas de concreto pré-misturado, fábricas de elementos pré-moldados e pavimentos de concreto.

Com relação à composição desses resíduos, pode-se dizer que a fração representada pelo concreto geralmente está presente na composição mineral do RCD 
oriundo das atividades da construção e demolição, além da presença de outros materiais, tais como, argamassas, blocos, tijolos, telhas, solos, gesso, etc. As diferentes frações presentes no RCD são responsáveis pela heterogeneidade do agregado reciclado e, conforme Angulo (2005), essas frações variam para cada canteiro de obras. Essas características dos resíduos de construção e demolição dificultam sua reciclagem e aplicação do agregado reciclado para a produção de concreto e elementos pré-moldados. Dessa maneira, grande parte do agregado reciclado de RCD ou agregado reciclado misto ainda é empregada em aplicações de baixo valor agregado, tais como, bases e sub-bases de pavimentos, obras de contenção e aterros (ALAEJOS et al., 2004; ANGULO et al., 2004). A separação do concreto, notadamente de maior qualidade, das demais fases do RCD ainda é extremamente onerosa e de difícil reprodutibilidade por se tratar de um processo de separação visual; por isso, diversos pesquisadores estão investigando processos de separação do RCD por via densitária (ANGULO, 2005; JUNGMANN; QUINDT, 1998).

Os resíduos de concreto originários de atividades da construção civil e demolições, desde que corretamente separados, e os oriundos de fábricas e usinas de concreto são caracterizados geralmente pela sua homogeneidade e pela possibilidade de conhecimento das propriedades mecânicas do resíduo. Além disso, segundo Buttler et $\mathrm{al}^{2}$, para os resíduos de usinas de concreto pré-misturado e fábricas de pré-moldados, o processo de reciclagem pode ser considerado simplificado e realizado no próprio local de geração, uma vez que tais resíduos são constituídos basicamente de elementos rejeitados pelo controle de qualidade, sobras de concreto fresco e unidades danificadas durante o transporte e estocagem (em fase de elaboração) ${ }^{2}$. Essas características dos resíduos de concreto facilitam seu emprego em aplicações de alto valor agregado, tais como, produção de concreto estrutural e elementos pré-moldados (DOLARA et al., 1998; ETXEBERRIA et al., 2006; POON et al., 2002; POON et al., 2006; SANTOS et al., 2004; TERANISHI et al., 1998).

As normas e especificações existentes são menos restritivas quando do emprego de agregados reciclados de concreto, comparativamente aos agregados reciclados de RCD, permitindo o emprego desses agregados para concretos de até $60 \mathrm{MPa}$ (BS 8500: Part 2, 2002; RILEM RECOMMENDATION, 2004); já outras normas, tais como, a revisão do código espanhol citada por Alaejos et al. (2004) e o texto normativo brasileiro citado por Oliveira et

${ }^{2}$ BUTTLER, A. M.; CORRÊA, M. R. S.; PRADO, D. M.; RAMALHO, M. A. Avaliação das propriedades de agregados reciclados de concreto gerados em uma fábrica de pré-moldados. A ser publicado pela Revista de Ciência e Tecnologia de Materiais de Construção Civil, 2006. 
al. (2004), que estão em fase de elaboração, permitirão apenas o emprego de agregados reciclados oriundos de resíduos de concreto para a produção de concreto estrutural.

\subsection{FONTES DE GERAÇÃO DE RESÍDUOS DE CONCRETO}

Neste item, serão contempladas as principais fontes geradoras de resíduos de concreto. Para algumas das fontes de geração, o procedimento de separação da fase concreto das demais fases presentes nos resíduos de construção e demolição (RCD) é dificultada pela ausência de uma tecnologia eficiente de separação e pela elevada morosidade dos processos de segregação existentes.

\subsubsection{ETAPAS DE CONSTRUÇÃO E DEMOLIÇÕES}

As etapas de construção, demolições e reformas de edificações constituem-se possivelmente nas principais fontes geradoras de resíduos de concreto. Nesse contexto, uma das maiores dificuldades relacionadas à reciclagem desses resíduos refere-se à separação eficiente da fração representada pelos resíduos de concreto das demais fases presentes nos RCD (argamassa, cerâmica, madeira, plástico, etc), com o objetivo de atender as especificações normativas de agregados para a produção de concreto estrutural, as quais geralmente tratam do emprego de resíduos de concreto. Considerando-se os resíduos gerados em obras, geralmente é feita à segregação seletiva desses materiais separando-se a fração não mineral (madeira, plástico, metal, etc) da fração mineral (concreto, argamassa, cerâmica, etc), fato esse que já ocorre com algumas construtoras da cidade de São Paulo (LOTURCO, 2004). Segundo Angulo (2005), o processo de triagem dos resíduos reduz os custos de deposição e facilita a reciclagem, já que certos tipos de materiais podem ser reciclados por processos distintos. De acordo com Valtercir (2006), a prefeitura de São Paulo dispõe de sete áreas de transbordo e triagem que recebem um volume diário de 1,2 × $10^{3} \mathrm{t}$ de RCD. Nesses locais, ocorre principalmente a separação da fração não-mineral do RCD (plástico, papéis, madeiras, metais, etc), sendo a fração mineral encaminhada posteriormente para aterros de RCD ou usinas de reciclagem (informação verbal) ${ }^{3}$.

\footnotetext{
${ }^{3}$ Informação verbal fornecida pelo funcionário Valtercir da Prefeitura Municipal de São Paulo, em 2006
} 
Com relação aos resíduos gerados durante a etapa de construção, Jadovski (2005) cita alguns fatores que contribuem para a geração de RCD nessa fase: a qualidade inferior dos materiais e componentes de construção disponíveis no mercado, a indefinição e detalhamento insuficiente nos projetos, a mão de obra não qualificada e ausência de procedimentos operacionais e mecanismos de controle de execução e inspeção; segundo John e Agopyan (2000), as perdas também podem ficar incorporadas nas construções na forma de componentes com dimensões superiores às projetadas. Pinto (1997) estima que $50 \%$ dos RCD são gerados pelas atividades de canteiro de obras. Na Alemanha e Europa Ocidental, 33\% dos resíduos são produzidos nas etapas de construção (BOSSINK; BROUWERS, 1996); já nos Estados Unidos essa parcela cai para apenas 8\%. Um estudo coordenado pela Financiadora de Estudos e Projetos (1998) avaliou a questão do desperdício de materiais nos canteiros de obras, sendo que um dos itens de estudo foi à análise do índice de perdas de concreto dosado em central para a execução da superestrutura. Os resultados mostraram que, entre as obras analisadas, o índice médio de perdas para esse material foi igual a $9 \%$.

Com relação aos resíduos gerados em demolições e reformas, Campos (2006) cita que, no Brasil, 59\% dos RCD são provenientes de demolições e reformas. Nos Estados Unidos, 92\% dos resíduos gerados são representados por rejeitos oriundos da demolição e reforma de edificações (KIBERT et al.; 2000). Na Europa Ocidental e Alemanha, dois terços dos RCD são provenientes de reformas e demolições (BOSSINK; BROUWERS, 1996).

John e Agopyan (2000) citam que a redução da geração do resíduo de demolição depende dos seguintes fatores: prolongamento da vida útil dos edifícios e seus componentes, incentivo para que os proprietários realizem modernizações e não demolições e o investimento em técnicas que permitam a reutilização dos componentes. Dentre essas técnicas, Kibert e Chini (2000) citam o processo de desconstrução controlada que permite uma série de vantagens comparativamente à demolição convencional. As principais vantagens referem-se ao maior reaproveitamento dos componentes da edificação, facilidade na reciclagem dos resíduos gerados, redução da energia necessária para o reprocessamento e remanufaturamento dos materiais. Apesar disso, os autores reconhecem que os desafios para a implantação da demolição controlada ainda são representativos; as principais dificuldades citadas pelos autores são enumeradas a seguir: a) as edificações existentes e seus componentes não foram projetados para a execução de uma demolição controlada; b) inexistência de ferramentas adequadas; c) os custos de deposição dos resíduos de demolição são relativamente baixos; d) a demolição controlada exige maior planejamento e tempo para a sua execução; e) os códigos de edificações existentes 
geralmente não tratam da questão de reutilização de componentes; f) os benefícios econômicos e ambientais ainda não foram totalmente estabelecidos.

Na Austrália, entre 50\% a 80\% dos resíduos oriundos de demolições residenciais são recuperados e reaproveitados posteriormente (CROWTHER, 2000). Na Alemanha, alguns estudos de caso mostraram que a técnica de demolição controlada permitiu uma taxa de recuperação dos materiais de até 95\% (SCHULTMANN; RENTZ, 2000). Na Holanda, segundo Van Dijk et al. (2000), o conceito de edificações "desmontáveis" foi introduzido pelo professor Reinhardt, em 1976, baseado na utilização de conexões parafusadas em sistemas de concreto pré-moldado. Após 20 anos, apesar da criação de um comitê para desenvolvimento desse sistema, menos de $1 \%$ das edificações utilizam esse conceito.

Considerando-se os resíduos gerados nas etapas de construção, demolição e reformas, Jadovski (2005) cita, com base em diversos trabalhos, que a composição dos resíduos varia de acordo com a fase da obra e com o tipo de obra. Pela consulta de diversos trabalhos, o pesquisador estima que a fração representada pelos resíduos de concreto, no Brasil, pode representar de 7\% a 21\% do RCD. Na Alemanha, segundo Schultmann e Rentz (2000), 25\% do RCD é composto por resíduos de concreto; na Austrália, 75\% do RCD é composto por resíduos de concreto e alvenaria (CROWTHER, 2000). Müller (2006) estima que, na Europa, os RCD sejam constituídos predominantemente de resíduos de alvenaria (42\% a 92\%), concreto (2\% a 39\%), asfalto (6\% a 21\%) e resíduos mistos de construção e demolição (2\% a 11\%).

Alguns casos emblemáticos de demolição de edificações merecem ser destacadas, como por exemplo, a demolição do estádio, Rose Garden Arena, na cidade de Portland Estados Unidos, aonde $45 \times 10^{3} \mathrm{t}$ de concreto foram recicladas resultando em uma receita de $R \$ 400 \times 10^{3}$. De acordo com Soutsos et al. (2005), em Liverpool, entre 2001 e 2006, espera-se a demolição de 56 edifícios. Uma dessas torres produziu $15 \times 10^{3}$ t de RCD, sendo que grande parte desses resíduos processados foram utilizados como agregados para bases e sub-bases de rodovias. Com relação ao Brasil, Fontes (2003) cita a Construtora Setin que demoliu e reciclou um piso de concreto de uma antiga indústria, na cidade de Guarulhos - São Paulo, para a construção de um condomínio de casas. Os agregados reciclados foram utilizados na produção de blocos, concretos e lajes prémoldadas. A Racional Engenharia (2003) instalou uma central de reciclagem de entulho, em Guaratiba (RJ), para receber o material extraído da demolição de um edifício localizado no centro do Rio de Janeiro. O agregado de RCD foi empregado na produção de um milhão de blocos de concreto, além de ladrilhos, argamassa para assentamento e revestimento. 


\subsubsection{USINAS DE CONCRETO PRÉ-MISTURADO E FÁBRICAS DE PRÉ- MOLDADOS}

Em fábricas de pré-moldados, o concreto desperdiçado é proveniente de elementos rejeitados pelo controle de qualidade, final de linhas de produção e sobras de concreto ao final do processo. Outra fonte de resíduos de concreto são as usinas de concreto prémisturado; o concreto desperdiçado nessas centrais pode ser atribuído a diversas fontes, seja pelo retorno de sobras de concreto nos caminhões betoneira, bombas de concreto ou pela lavagem dos caminhões e instalações da central dosadora. O processamento desses resíduos pode ser realizado em plantas de reciclagem de primeira geração, citadas por $\mathrm{ACl}$ 555-R01 (2002), uma vez que a presença de contaminantes pode ser considerada desprezível. Essas plantas de reciclagem são constituídas essencialmente de um alimentador vibratório, britador primário/secundário e um peneirador vibratório.

Van Acker (1996) cita uma companhia situada em Lier/Bélgica, especializada na produção de elementos estruturais pré-moldados (Partek Ergon), que recicla o concreto desperdiçado na sua linha de produção. Os resíduos de concreto são estocados em uma grande área e, uma vez por ano ou a cada dois anos, uma unidade de reciclagem móvel processa esses resíduos. Em 1995, o volume de resíduos de concreto ficou em torno de $7,42 \times 10^{3}$ t. Segundo o autor, o custo de processamento do resíduo de concreto é equivalente ao custo do agregado natural; entretanto, os maiores benefícios da reciclagem advém da economia com as taxas de deposição desses resíduos em aterros e o transporte até esses locais.

No Brasil, informações obtidas em fábricas de pré-moldados de pequeno porte indicam um volume de resíduos em torno de $0,2 \mathrm{~m}^{3} / \mathrm{dia}$, representando $2 \%$ da produção total. Em uma fábrica de grande porte do interior paulista, o volume de resíduos gerados pode chegar a $7 \mathrm{~m}^{3} / \mathrm{dia}$, contabilizando 160 3/mês de resíduos de concreto, representando $1 \%$ da produção total. Desse total, aproximadamente $30 \mathrm{~m}^{3}$ seriam representados por blocos de concreto rejeitados pelo controle de qualidade e $12 \mathrm{~m}^{3}$ por rejeitos de vigotas e painéis de laje pré-moldados, Figura 2.1. 


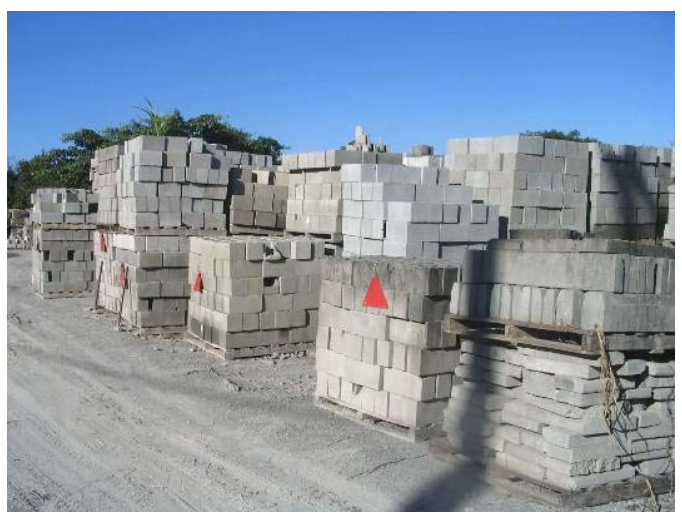

a) blocos de concreto rejeitados pelo controle de qualidade

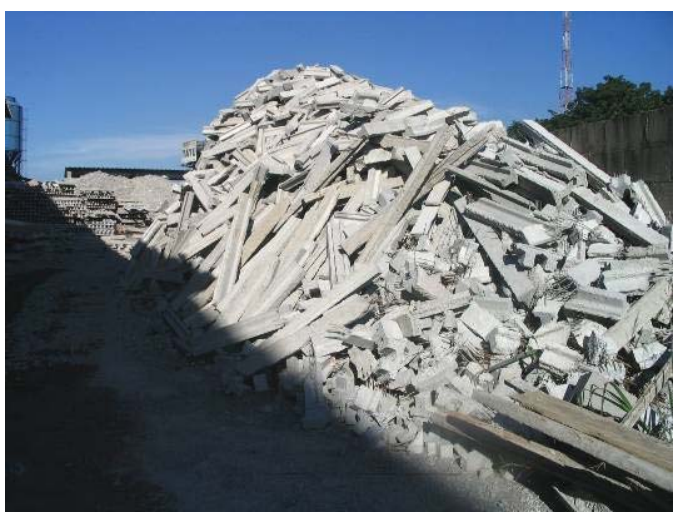

b) resíduos de vigotas oriundas do final das linhas de produção

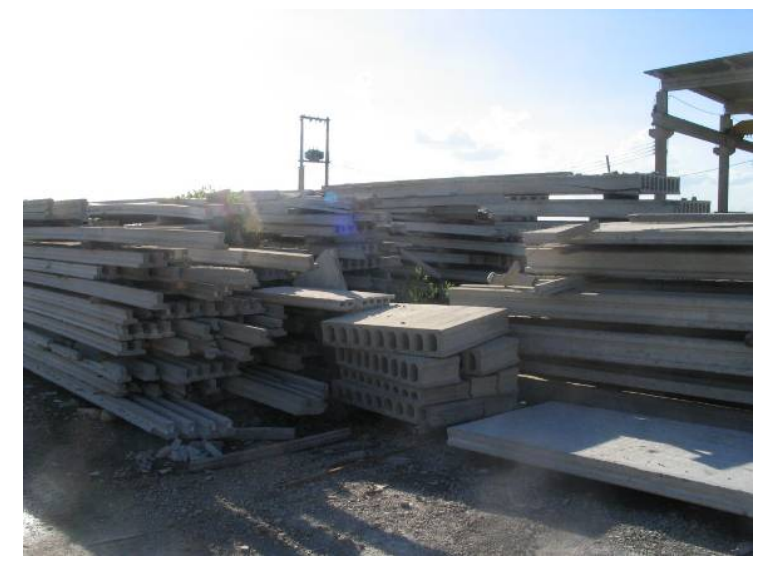

c) resíduos de painéis de lajes pré-moldadas

Figura 2.1 - Resíduos de concreto produzidos em uma fábrica de pré-moldados (foto do autor).

$\mathrm{Na}$ visita a essa fábrica, foi constatada que uma grande parcela dos resíduos de concreto é constituída por sobras de concreto ao final do processo de produção; especialmente, na fabricação de blocos, ocorre um desperdício considerável de material após a vibração e prensagem nas vibro-prensas, Figura 2.2. Outra parcela de resíduos é constituída por materiais desperdiçados no transporte entre os silos e o misturador, Figura 2.3. 


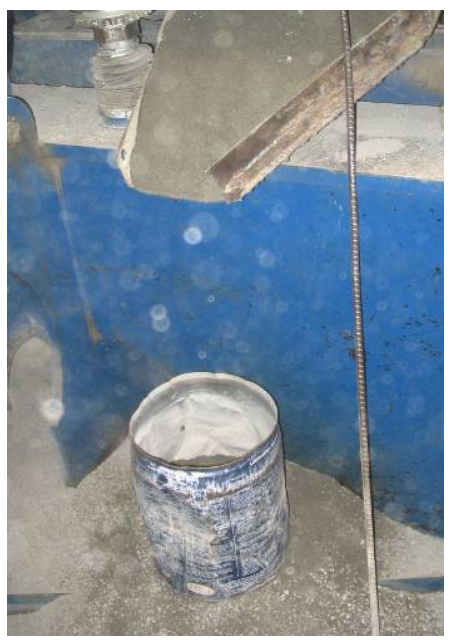

a) resíduos gerados no processo de vibroprensagem dos blocos

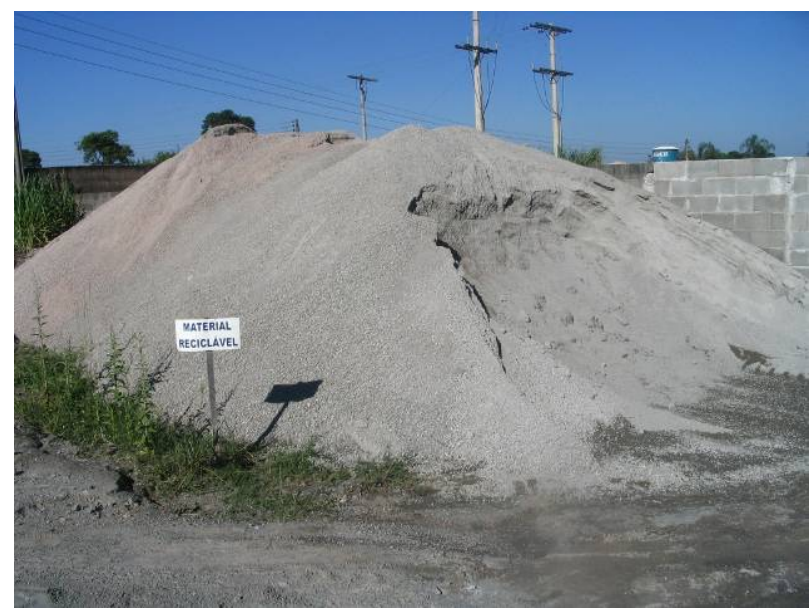

b) resíduos estocados no pátio da fábrica

Figura 2.2 - Resíduos gerados no processo de vibro-prensagem dos blocos (foto do autor).
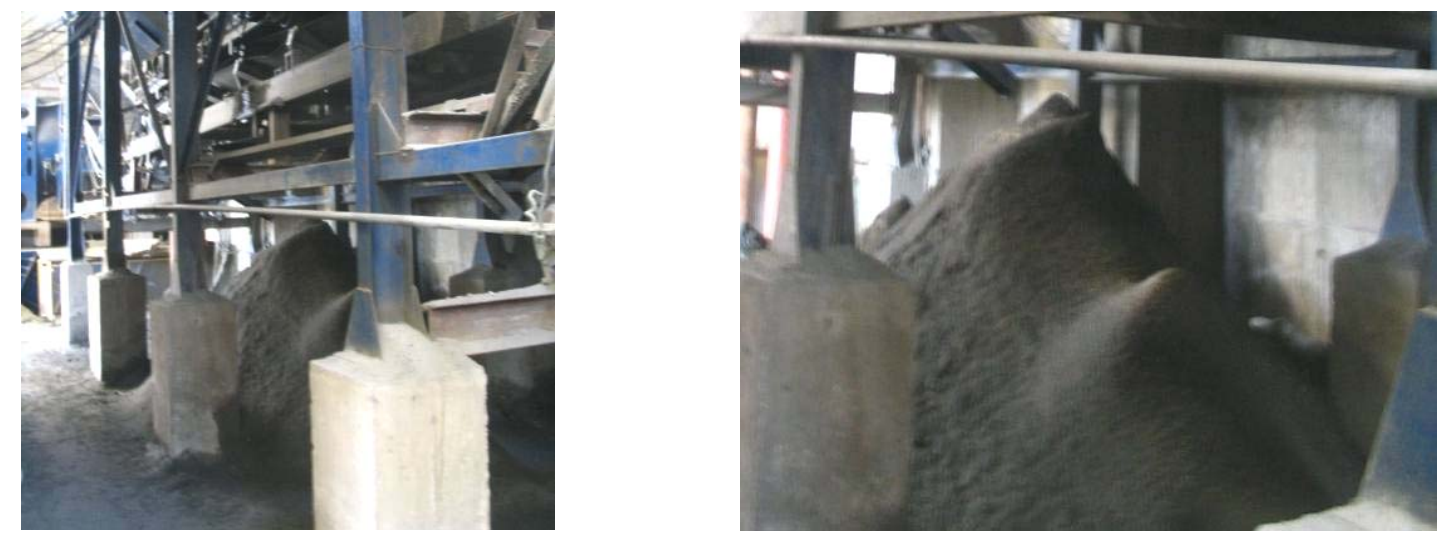

Figura 2.3 - Resíduos de concreto produzidos entre os silos e o misturador (foto do autor).

Com relação ao desperdício nas usinas de concreto pré-misturado, Okawa et al. (2000) citam que as usinas de concreto pré-misturado no Japão produzem cerca de $180 \mathrm{x}$ $10^{6} \mathrm{~m}^{3}$ /ano de concreto e perdem $1 \%$ a $2 \%$ desse volume. Segundo Rezende (2000), na Alemanha, o setor de usinas de concreto pré-misturado estima que são desperdiçados de $1 \%$ a $4 \%$ da produção total de concreto.

Algumas estimativas fornecidas pela Associação Brasileira das Empresas de Serviços de Concretagem (2006), para a região metropolitana de São Paulo, apontam para um volume de $3,5 \times 10^{3} \mathrm{~m}^{3}$ a $7,0 \times 10^{3} \mathrm{~m}^{3}$ de resíduos de concreto gerados mensalmente nas centrais dosadoras. No Brasil, o setor de centrais dosadoras é composto por cerca de 
130 empresas com aproximadamente 600 centrais, dosando um volume anual de 9,5 x $10^{6}$ $\mathrm{m}^{3}$ de concreto; estimando um índice médio de perdas de $4 \%$, chega-se a um desperdício anual de $380 \times 10^{3} \mathrm{~m}^{3}$ de concreto. Segundo Costa et al. (2004), algumas concreteiras brasileiras já estão preocupadas com o destino das sobras de concreto e, nesse sentido, estão investindo em equipamentos e tecnologias com o objetivo de reaproveitar e reciclar esses resíduos.

\subsubsection{PAVIMENTOS DE CONCRETO E OBRAS DE ARTE}

Com relação à reciclagem de pavimentos de concreto, os Estados Unidos encontrase em posição de vanguarda, comparativamente a outros países, uma vez que investem consideravelmente em tecnologia e normalização visando à aplicação dos agregados reciclados em bases e sub-bases de rodovias. Segundo a Associated General Contractors (2001), entre 1994 e 1996, a utilização de agregados reciclados de concreto aumentou cerca de $170 \%$, sendo que cerca de $320 \mathrm{Km}$ de pavimentos de concretos foram reciclados anualmente nesse período. Segundo Mehta e Monteiro (1994), o "Michigan State Department of Transportation", executou a maior reciclagem de pavimento de concreto. Em 1983, a rodovia "Interstate 94", uma das mais antigas e de maior tráfego do estado de Michigan, tornou-se a primeira grande freeway dos Estados Unidos a reciclar concreto. Um trecho deteriorado de $9 \mathrm{~km}$ de extensão de pavimento de concreto foi britado e o material processado foi usado como agregado na construção de um novo pavimento.

A Organisation for Economic Co-Operation and Development (1997) fornece algumas estatísticas com relação à reciclagem de pavimentos de concreto, em alguns países integrantes dessa comunidade, Tabela 2.1.

Tabela 2.1 - Pavimentos de concreto reciclados para utilização como agregados.

\begin{tabular}{cccccccc}
\hline & Austrália & Áustria & Bélgica & Canadá & Dinamarca & Finlândia \\
\hline Reciclagem (\%) & 5 & 80 & 100 & 90 & 0 & 0 \\
\hline & França & Japão & Holanda & Suécia & Reino Unido & $\begin{array}{c}\text { Estados } \\
\text { Unidos }\end{array}$ \\
\hline Reciclagem (\%) & - & 70 & 100 & 0 & 75 & - & \\
\hline
\end{tabular}

(fonte: Organisation for Economic Co-Operation and Development, 1997)

De acordo com Winston (2001), um dos maiores projetos de reciclagem está ocorrendo nos Estados Unidos, na cidade de Denver; trata-se do processamento de $4 \times 10^{6}$ $\mathrm{m}^{2}$ de pavimentos de concreto do antigo aeroporto da cidade para serem comercializados como agregados reciclados, totalizando cerca de $6 \times 10^{6} \mathrm{t}$ de agregados de excelente qualidade. A remoção total desse pavimento será concluída em julho de 2005 e a deposição 
final somente em 2009. O Departamento de Rodovias do Colorado já utilizou $41 \times 10^{3} \mathrm{t}$ desses agregados reciclados obtendo resultados favoráveis.

Segundo o Federal Highway Administration (2004), o Departamento de Transportes do Texas utiliza agregados reciclados, há pelo menos 10 anos, em pavimentos de concreto e como base de ruas. Desde 1983, o Departamento de Transportes de Michigan, utiliza agregados reciclados de concreto como base para rodovias; atualmente, o emprego de reciclados na rodovia US-41 acarretou uma economia de cerca de $\mathrm{R} \$ 300 \times 10^{3}$. Um estudo elaborado pelo FHWA, indica que 38 estados americanos utilizam agregados reciclados de concreto como base para rodovias, sendo que apenas 11 estados empregam esses agregados para produção de concreto (PORTLAND CEMENT ASSOCIATION, 2005).

Ajdukiewicz e Kliszczewicz (2002) citam que nos países do Leste Europeu está ocorrendo um programa intensivo de modernização e reconstrução de rodovias e obras de arte desde o início da década de 90. Devido a isso, está sendo gerada uma grande quantidade de resíduos provenientes de estruturas de concreto armado e protendido os quais, depois de reciclados, apresentarão um grande potencial para serem utilizados como agregados. No Brasil, particularmente no Estado de São Paulo, também está ocorrendo um programa de modernização e adequação ao tráfego das obras de arte existentes. Um desses exemplos está ocorrendo na Rodovia Washington Luís na cidade de São Carlos (km 235), Figura 2.4. Os resíduos de concretos oriundos da demolição do viaduto foram encaminhados até a usina de reciclagem do município para serem reciclados.
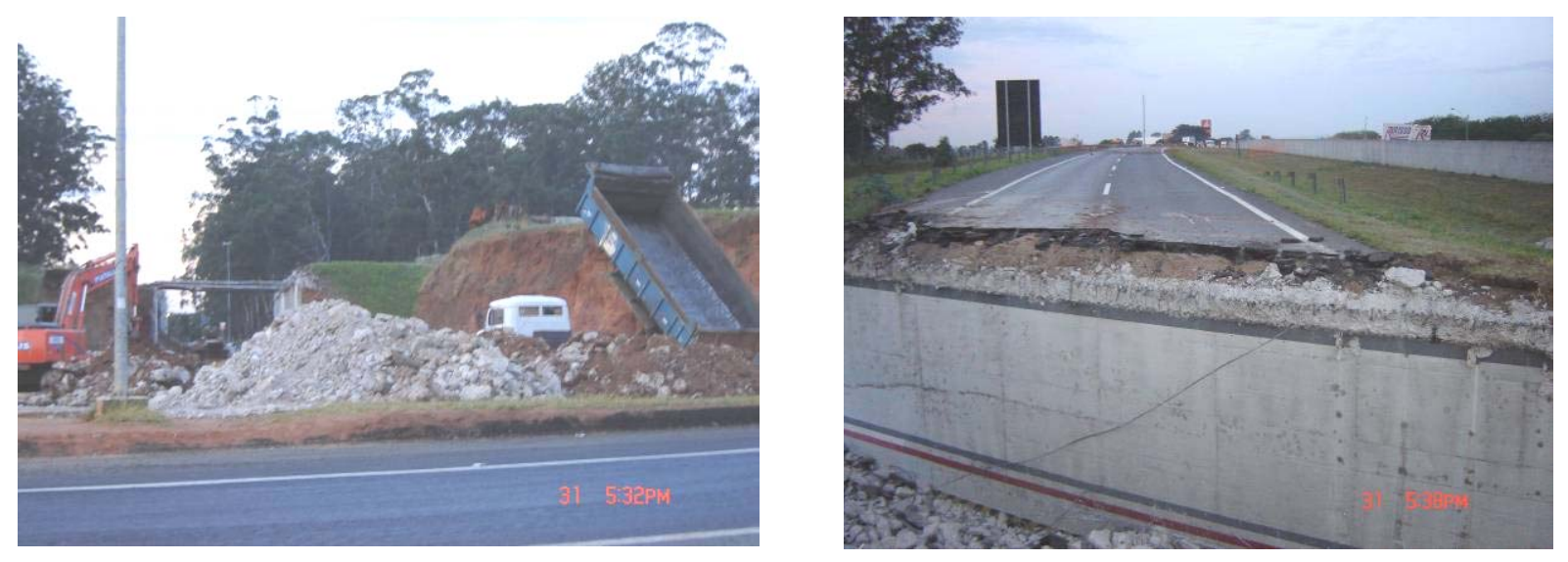

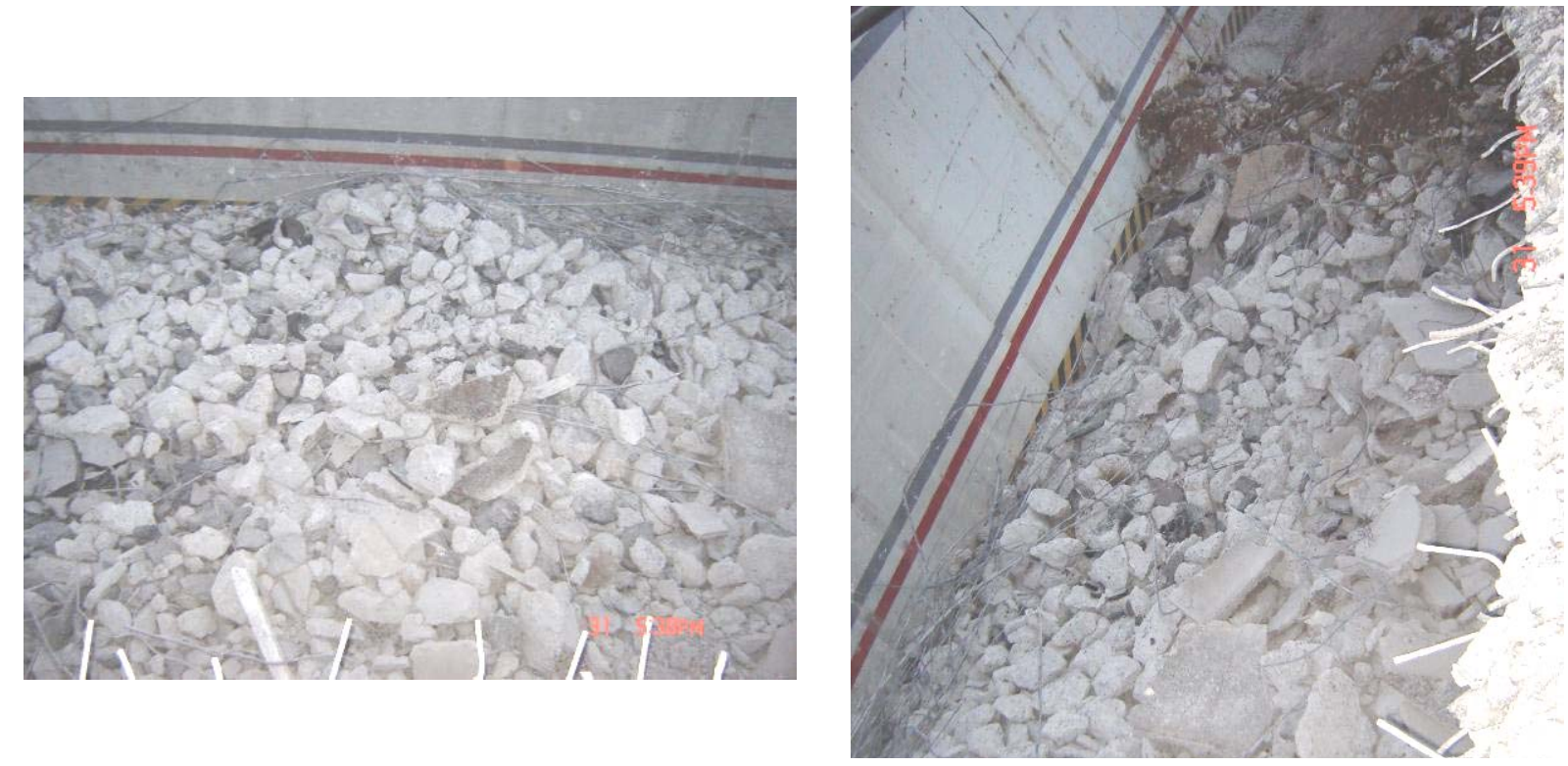

Figura 2.4 - Demolição de viaduto na rodovia Washington Luís (km 235) (foto do autor).

\subsection{ESTIMATIVAS DA GERAÇÃO E RECICLAGEM DE RESÍDUOS}

Neste item, serão apresentadas algumas estimativas da geração e reciclagem de RCD e, quando existentes, da geração e porcentagem reciclada de resíduos de concreto. Os países que apresentam uma elevada porcentagem de resíduos efetivamente reciclados, tais como, Holanda, Dinamarca e Alemanha possuem uma política ambiental austera e leis rigorosas que punem a deposição irregular de resíduos e, por outro lado, premiam as iniciativas que visam o reaproveitamento e reciclagem desses materiais.

Inicialmente, será exposto um panorama mundial com relação à questão de geração e reciclagem de resíduos e, posteriormente, será apresentada a situação brasileira.

\subsubsection{PANORAMA MUNDIAL}

A primeira aplicação significativa de agregados reciclados ocorreu após a $2^{\circ}$ Guerra Mundial, na reconstrução das cidades européias, que tiveram seus edifícios demolidos e o 
entulho resultante, foi britado para produção de agregados visando atender à demanda de consumo da época (LEVY; HELENE, 2002; PARK, 1999).

Mehta (2002) cita que são geradas mundialmente $900 \times 10^{6}$ t/ano de RCD; sendo que grande parte desse volume de resíduos não é reciclado devido à existência de regulamentações normativas restritivas que impedem a utilização de materiais reciclados. Adjukiewicz e Kliszczewicz (1996, apud LEVY, 2001) ${ }^{4}$ citam que, durante a década de 90, o total de resíduos de concreto produzidos no mundo já suplantava a marca de $1 \times 10^{9} \mathrm{t}$. Hansen (1985) estima que são geradas na Comunidade Européia, Estados Unidos e Japão cerca de $50 \times 10^{6}$ t, $60 \times 10^{6}$ t e $12 \times 10^{6}$ t de resíduos de concreto, respectivamente.

Na União Européia, a quantidade de resíduos de construção é estimada em cerca de $170 \times 10^{6}$ t/ano; sendo que desse total, $41 \%$ é representado por resíduos de concreto, 40\% de rejeitos de alvenaria, $12 \%$ de resíduos de asfalto e o restante por resíduos de cerâmicas e azulejos (VAN ACKER, 1996). Dados mais recentes indicam um volume total de $216 \times 10^{6}$ t/ano (MARCIANO JR, 2000). Segundo Oikonomou (2005) e Van Acker (1996), na União Européia, são geradas cerca de $500 \mathrm{Kg}$ de RCD/habitante/ano. Na União Européia, apesar de existirem países com elevadas taxas de reciclagem (superiores a 80\%), há nações que reciclam menos de $20 \%$ dos resíduos gerados, tais como, Espanha, Irlanda, Itália e Noruega. Alaejos et al. (2004) apresentam alguns dados tratando da geração, reciclagem e aplicação de RCD em alguns países europeus, Tabela 2.2.

\footnotetext{
${ }^{4}$ AJDUKIEWICZ, B. A.; KLISZCZEWICZ, T. A. Properties of structural concretewith rubble aggregate from demolition of RC/PC structures. In: CONCRETE IN THE SERVICE OF MANKIND INTERNATIONAL CONFERENCE CONCRETE FOR ENVIRONMENT ENHANCEMENT AND PROTECTION, 1996, Dundee - Escócia. Proceedings... Grã Bretanha: Ravindra \& Thomas, 1996. p. 115 a 120.
} 
Tabela 2.2 - Geração, reciclagem e aplicação dos resíduos de construção e demolição.

\begin{tabular}{ccccc}
\hline País & $\begin{array}{c}\text { Produção anual } \\
\left(\mathbf{x} \mathbf{1 0}^{6} \mathbf{t}\right)\end{array}$ & $\begin{array}{c}\text { Porcentagem } \\
\text { reciclada }\end{array}$ & \multicolumn{2}{c}{ Aplicação da porcentagem reciclada } \\
\hline Bélgica & $7,0(1990)$ & $87 \%$ & $\begin{array}{c}\text { Agregados para } \\
\text { concreto: } 19,5 \%\end{array}$ & Estradas: $80,5 \%$ \\
\hline França & $24,0(1990)$ & $15 \%$ & $\begin{array}{c}\text { Agregados para } \\
\text { concreto: } 10 \%\end{array}$ & $\begin{array}{c}\text { Estradas: } 54,5 \% \\
\text { Contenções e aterros: } \\
35,5 \%\end{array}$ \\
\hline Reino Unido & $30,0(1999)$ & $45 \%$ & $\begin{array}{c}\text { Agregados para } \\
\text { concreto: } 4,5 \%\end{array}$ & $\begin{array}{c}\text { Estradas: } 20 \% \\
\text { Espontençose aterros: } \\
75,5 \%\end{array}$ \\
\hline Espanha & $38,5(2003)$ & $10 \%$ & $\begin{array}{c}\text { Bases e sub-bases de } \\
\text { rodovias: } 30 \%\end{array}$ & Base de solos: $35 \%$ \\
\hline
\end{tabular}

(fonte: adaptada de Alaejos et al., 2004)

Na Noruega, a disponibilidade de recursos naturais e a abundância de locais para a deposição dos resíduos são fatores que justificam as baixas taxas de reciclagem que estão situadas entre 10\% a 20\% (PETKOVIC et al., 2004). Para contornar essa situação, a Administradora Pública de Estradas da Noruega iniciou, em 2002, um projeto com o intuito de promover a utilização de materiais reciclados.

O Ministério do Meio ambiente Espanhol, em 2001, segundo Alaejos et al. (2004), publicou um Plano Nacional de Resíduos com o objetivo de alcançar, em cinco anos, aproximadamente $25 \%$ de reciclagem de RCD e redução de $10 \%$ na geração desses resíduos. Com essas medidas, o governo espanhol espera atingir taxas de reciclagem próximas à média da Comunidade Européia (28\%).

Nos Estados Unidos, Alemanha e Hong Kong, segundo Müller (2006), são geradas $450 \mathrm{~kg} / \mathrm{hab}$.ano (30 hab/km²), $900 \mathrm{~kg} / \mathrm{hab}$.ano (333 hab/km²) e $1700 \mathrm{~kg} / \mathrm{hab}$.ano (6126 $\mathrm{hab} / \mathrm{km}^{2}$ ) de RCD, respectivamente. Segundo a pesquisadora, a densidade populacional influencia significativamente na quantidade de resíduos gerados. De acordo com Crowther (2000), na Austrália, são geradas $14 \times 10^{6}$ t/ano de resíduos, sendo que $16 \%$ a 40\% desse total são compostos por resíduos de construção e demolição. Desse montante, a parcela composta por resíduos de alvenaria e concreto representa 75\%. Além disso, o autor estima que $70 \%$ a $80 \%$ dos resíduos de concreto são reciclados para serem utilizados em bases de rodovias.

De acordo com a Organisation for Economic Co-Operation and Development (1997), alguns países, tais como, Bélgica, Dinamarca, Japão e Holanda convivem com uma grande cobrança da sociedade contra a utilização de áreas para a deposição de resíduos e a exploração de recursos naturais; por esse motivo, o reaproveitamento e a reciclagem de resíduos estão ocupando um local de destaque na agenda política desses países. Conforme Vazquez (2005), a Holanda é líder absoluta na reciclagem de RCD (mais de 90\% dos 
resíduos são reciclados); a Bélgica está logo a seguir com $87 \%$ dos resíduos reciclados, empregando esse montante da seguinte maneira: $70 \%$ dos resíduos destinam-se para rodovias e o restante, aproximadamente 17\%, para a produção de concreto. Na Espanha, a quantidade de resíduos de concreto gerado é estimada em 7,7 x 10 RCD) (VAZQUEZ, 2005). Em Portugal, segundo Ruivo e Veiga (2004), apenas 5\% dos RCD são reciclados.

Segundo Poon et al. (2004b), em Hong Kong, são geradas diariamente cerca de 37 x $10^{3}$ t de RCD, representando aproximadamente quatro vezes o volume de sólidos urbanos. Bossink e Brouwers (1996) citam, baseando-se em diversos trabalhos, o percentual de RCD sobre o total de lixo gerado em vários países: Holanda - 26\%, Austrália de $20 \%$ a 30\%, Estados Unidos de 20\% a 29\%, Alemanha - 19\% e Finlândia de 13\% a 15\%.

No Japão, de acordo com Marciano Jr (2000), são consumidas aproximadamente $400 \times 10^{6}$ t/ano de concreto com a respectiva geração de $36 \times 10^{6}$ t/ano de resíduos de concreto. Esse volume de resíduos gerados é destinado majoritariamente na produção de agregados para sub-base de estradas, sendo que uma pequena parcela é destinada para os aterros. Nesse país há um sério problema com relação à exaustão das reservas de agregados naturais e a falta de aterros para a destinação correta dos resíduos. Noguchi e Tamura (2001) citam que a reciclagem de RCD alcança 57\% do volume total produzido; sendo que aproximadamente $73 \%$ desse total são representados pelos resíduos de concreto oriundos da demolição de estruturas e pavimentos rodoviários.

Nos Estados Unidos, segundo a Environmental Council of Concrete Organizations (1997), 23\% a 33\% dos resíduos sólidos produzidos são compostos por RCD; de acordo com Lauritzen (2004), nesse país, a quantidade de resíduos de construção e demolição gerados está entre $250 \times 10^{6}$ t/ano a $300 \times 10^{6}$ t/ano (dados de 2002), sendo que $20 \%$ a $30 \%$ do total são reciclados (dados de 1996).

\subsubsection{SITUAÇÃO BRASILEIRA}

No Brasil, algumas estimativas indicam um volume total de resíduos de construção e demolição gerados da ordem de 0,55 t/hab.ano; por outro lado, Angulo (2005) estima a geração de RCD em $68,5 \times 10^{6}$ t/ano, representando $30 \%$ do consumo de agregados naturais. $O$ volume de entulho gerado na cidade de São Paulo chega a 0,50 t/hab.ano, sendo que a reciclagem processa apenas $10 \%$ do total gerado.

Oliveira et al. (2004) cita alguns dados referentes à geração de resíduos em algumas cidades brasileiras, Tabela 2.3 . 
Tabela 2.3 - Geração de resíduos de construção e demolição.

\begin{tabular}{|c|c|c|c|}
\hline Cidades & População (x 106) & $\begin{array}{c}\text { Geração de resíduos (x } \\
10^{3} \mathrm{t} \text { /dia) }\end{array}$ & Resíduos/hab./dia (kg) \\
\hline São Paulo & 10,0 & 10,86 & 1,08 \\
\hline Porto Alegre & 1,20 & 0,35 & 0,29 \\
\hline Salvador & 2,20 & 1,70 & 0,77 \\
\hline Ribeirão Preto & 0,46 & 1,04 & 2,26 \\
\hline São José do Rio Preto & 0,32 & 0,69 & 2,14 \\
\hline Jundiaí & 0,29 & 0,71 & 2,45 \\
\hline Santo André & 0,63 & 1,01 & 1,60 \\
\hline Belo Horizonte & 2,01 & 1,20 & 0,60 \\
\hline Vitória da Conquista & 0,24 & 0,31 & 1,29 \\
\hline São José dos Campos & 0,50 & 0,70 & 1,40 \\
\hline Guaratinguetá & 0,10 & 0,06 & 0,60 \\
\hline Taubaté & 0,23 & 0,23 & 1,00 \\
\hline Ubatuba & 0,06 & 0,05 & 0,82 \\
\hline Caçapava & 0,07 & 0,05 & 0,77 \\
\hline Pindamonhangaba & 0,12 & 0,07 & 0,55 \\
\hline Tremembé & 0,03 & 0,01 & 0,27 \\
\hline
\end{tabular}

(fonte: Oliveira et al., 2004)

A Prefeitura Municipal de São Paulo recolhe $11 \times 10^{3}$ t/dia de resíduos, sendo esse volume distribuído da seguinte forma: resíduos domiciliares $\left(8,8 \times 10^{3} \mathrm{t}\right)$, resíduos inertes $\left(2,1 \times 10^{3}\right.$ t) e resíduos de saúde (89 t). Os transportadores de RCD (caçambeiros) são responsáveis pela coleta de $60 \%$ dos resíduos inertes gerados $\left(3,15 \times 10^{3}\right.$ t) (DE MELLO, 2006).

No Brasil, Campos (2006) cita que $61 \%$ do total de resíduos gerados são representados pelos resíduos de construção e demolição e $28 \%$ pelos resíduos domiciliares. Desse volume, $59 \%$ são originários de reformas, $20 \%$ e $21 \%$ originários da construção de residências e prédios, respectivamente. Jadovski (2005) cita, baseando-se em diversos trabalhos, que a quantidade de RCD, em várias cidades brasileiras, varia entre $51 \%$ e $68 \%$ em relação ao total de resíduos em aterros públicos. Segundo o pesquisador, a elevada taxa de geração de RCD pode ser atribuída ao baixo nível de desenvolvimento tecnológico da indústria da construção civil brasileira.

Em 1998, a cidade de Belo Horizonte gerava $1,2 \times 10^{3} \mathrm{t} / \mathrm{dia}\left(1,0 \times 10^{3} \mathrm{~m}^{3} / \mathrm{dia}\right) \mathrm{de}$ $R C D$, que eram despejados em 134 pontos clandestinos e 15 locais oficializados para aterro desse tipo de resíduo. Como outras cidades brasileiras, Belo Horizonte vem perdendo seus aterros sanitários gradativamente, por simples esgotamento: dos doze que existiam em 1993, sobraram apenas sete em 1995 (CAVALCANTI, 2004). A geração de resíduos de construção e demolição, em São Carlos - SP, é estimada em cerca de 400 t/dia, contra 140 t/dia de lixo doméstico. De acordo com Julião (2004), a usina de reciclagem do município, tem capacidade para processar 160 t/dia de material. Essa usina processará apenas 40\% 
do total de resíduos produzidos, dessa forma a prefeitura tentará buscar novos parceiros na iniciativa privada para o estabelecimento de novas usinas de reciclagem.

\subsection{DEPOSIÇÃO DOS RESÍDUOS}

Os resíduos de concreto e os RCD são geralmente depositados indiscriminadamente em vales, margens de rios, a céu aberto, em terrenos baldios, em vias públicas ou em aterros desprovidos de qualquer tratamento específico. Apesar da Resolução $\mathrm{N}^{0} 307$ do CONAMA (BRASIL, 2002) e de algumas iniciativas setoriais proibirem a deposição irregular de resíduos, essa ainda é uma prática freqüente em inúmeras cidades brasileiras. Segundo Ângulo (2005), as deposições ilegais de resíduos ocorrem em função dos custos e distâncias que envolvem o transporte desses materiais. De acordo com Pinto (2004), o entulho por ser considerado uma material não-deteriorável, que teoricamente não oferece risco de contaminação, sua gestão tem sido sistematicamente marginal. Na cidade de São Carlos, apesar da existência de uma usina de reciclagem municipal, são observados vários pontos de descarga irregular; inclusive, na própria rua de acesso à usina de reciclagem, Figura 2.5.
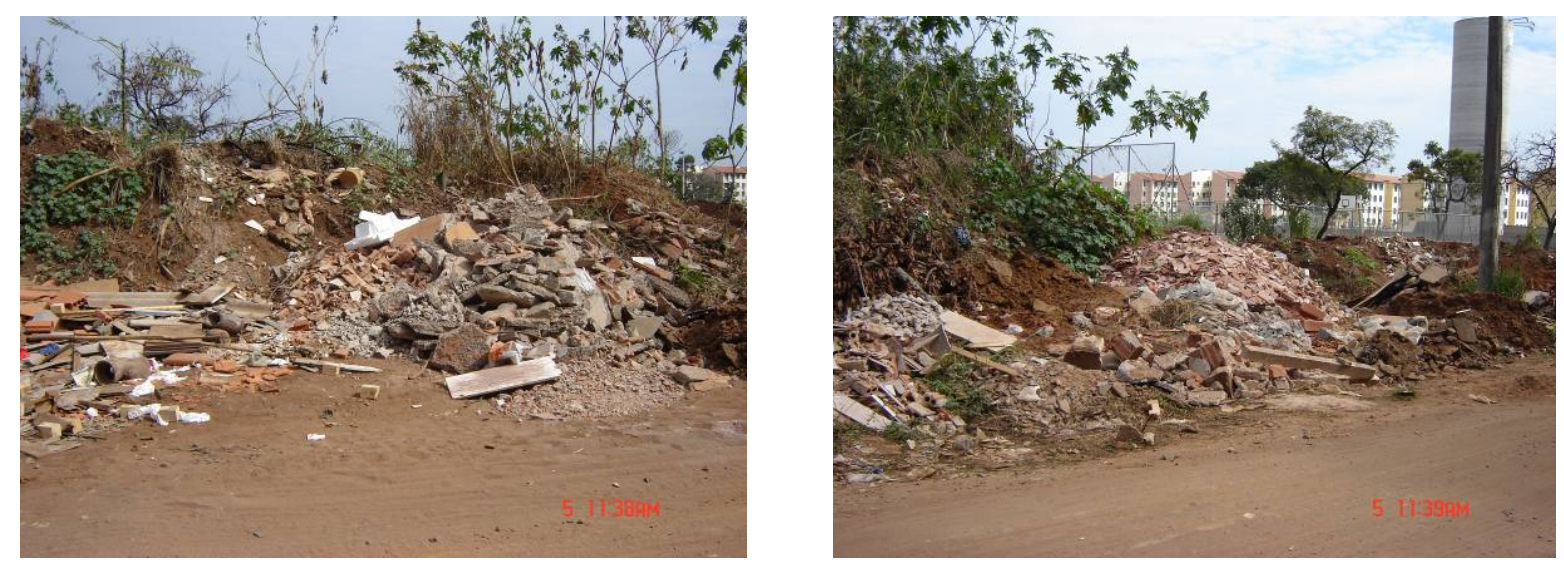

Figura 2.5 - Deposição irregular de resíduos na cidade de São Carlos (foto do autor).

A deposição dos RCD e RC, de forma descontrolada, acarreta uma série de custos ambientais. Além disso, há os custos referentes ao gerenciamento da deposição clandestina e o não reaproveitamento desses resíduos que poderiam ser reciclados e utilizados em obras públicas (CAVALCANTI, 2004). A prefeitura de São José dos Campos, conforme 
Cavalcanti (2004), gasta $\mathrm{R} \$ 3 \times 10^{6}$ /ano para o gerenciamento das 700 t/dia de entulho; a cidade tem atualmente 150 áreas de deposição clandestina; sendo que oficialmente, existem apenas três pontos de bota-fora para deposição controlada desses resíduos. De acordo com Schneider (2003), na cidade de São Paulo, mais de $20 \%$ dos RCD são depositados ilegamente em ruas, avenidas, margens de córregos e viadutos, gerando um custo, segundo Angulo (2005), de R $45 \times 10^{6}$ /ano para coleta e deposição desse resíduo em aterros. Em São Paulo, há cerca de 500 pontos de descarga irregular de RCD e apenas um aterro de inertes (VIVEIROS, 2004). Uma das soluções seria a implantação de novas unidades de reciclagem, pois, atualmente, na região metropolitana existem apenas três estações de reciclagem que processam menos de 5\% do RCD produzido diariamente. De acordo com Cavalcanti (2004), a reciclagem de RCD, além de eliminar um problema, produziria soluções para outras demandas importantes, tais como, a geração de materiais de baixo custo e de boa qualidade.

A deposição dos resíduos em aterros pode ser considerada uma solução viável, uma vez que esses materiais são considerados inertes pela NBR 10004 (1987); entretanto, segundo diversos pesquisadores a classificação normativa pode ser questionada. Angulo (2005) cita que componentes orgânicos presentes no RCD, tais como, plásticos, tintas, óleos, asfaltos e madeiras podem contaminar aterros ou colocar em risco a saúde das pessoas. Segundo Ruivo e Veiga (2004), a construção de uma edificação pode produzir até $20 \mathrm{~kg}$ de resíduos químicos ou perigosos que podem contaminar os outros materiais presentes no RCD. Um exemplo marcante da presença de toxinas em resíduos de concreto ocorreu na Noruega; em 1999, foram produzidas $1,15 \times 10^{6}$ t de resíduos de concreto e alvenaria com a presença de cerca de $1,50 \times 10^{3}$ t de bifenila policlorada que era adicionada como um aditivo selador. Atualmente, diretrizes norueguesas proíbem a reciclagem de resíduos de concreto que contenham esse aditivo, uma vez que não há procedimentos especiais para o tratamento dessa toxina. Esse aditivo é considerado uma das toxinas mais prejudiciais ao meio ambiente e pode ser responsável pelo aumento do risco de câncer e de distúrbios hormonais em seres humanos e animais (WARMER BULLETIN, 2001). O problema da dispersão e diluição de contaminantes dentro de materiais de construção não está na fase de uso dos materiais, mas sim ao final da vida útil aonde poderá ser gerado um resíduo de demolição mais contaminado que os resíduos tradicionais (JOHN; ANGULO, 2003).

Com relação à vantagem ambiental de um processo de reciclagem, há necessidade de se avaliar o risco ambiental da reciclagem de RCD para a produção de argamassas e concretos, mesmo que seja constatada a viabilidade do ponto de vista 
tecnológico e econômico (ANGULO et al., 2001). Segundo Cincotto (1988 apud JADOVSKI, $2005)^{5}$ um resíduo para ser utilizado não pode ser potencialmente nocivo durante a fase de construção e uso da edificação. A utilização de testes de lixiviação permite a análise dos riscos de contaminação ambiental pela interação da água com produtos contendo resíduos (JOHN; ANGULO, 2003). Oliveira e Assis (2002) avaliaram o risco de contaminação ambiental para concretos com agregados reciclados de concreto; de acordo com os pesquisadores, esses concretos, quando submetidos à ação de chuva ácida, apresentaram maior facilidade de lixiviação, especialmente para os concretos produzidos com resíduos concretos mais antigos, podendo causar danos ao meio ambiente e riscos à saúde pública.

Com relação à gestão dos resíduos, no Brasil, as esperanças renascem com a publicação da Resolução $N^{0} 307$ do CONAMA (BRASIL, 2002) e de normas relacionadas com o gerenciamento e reaproveitamento do RCD (NBR 15112 a NBR 15116). De acordo com a Resolução $N^{0} 307$ do CONAMA (BRASIL, 2002), os resíduos de construção e demolição (fração mineral) e os resíduos de concreto são classificados como sendo da Classe A e, portanto, são passíveis de serem reutilizáveis ou recicláveis como agregados. Essa resolução, que já está em vigor, impõe obrigatoriedades tanto para os municípios como para as os grandes geradores (construtoras). Os municípios deverão elaborar Programas Municipais de Gerenciamento de Resíduos de Construção Civil e os grandes geradores terão que desenvolver Projetos de Gerenciamento de Resíduos da Construção Civil. Para a empresa Obra Limpa (2005), que presta assessoria para diversas empresas engajadas na questão ambiental, a apresentação dos Projetos de Gerenciamento de Resíduos da Construção pelas construtoras, conforme a Resolução $N^{0} 307$ do CONAMA (BRASIL, 2002), representará um avanço significativo sob dois aspectos fundamentais: a) responsabilidade na geração: geradores passam a assumir o controle sobre o fluxo dos resíduos; b) possibilidade de redução na geração: o acompanhamento durante a execução da obra permitirá redução de custos decorrentes do maior controle sobre a geração de cada resíduo.

Com relação aos Programas Municipais de Gerenciamento de Resíduos de Construção Civil, na cidade de São Paulo, por exemplo, foi implementado o Plano Municipal de Gestão Sustentável de Entulho que tem como principais objetivos (DE MELLO, 2006): a)

${ }^{5}$ CINCOTTO, M. A. Utilização de sub-produtos e resíduos na indústria da construção civil. In: TECNOLOGIA DE EDIFICAÇÕES. São Paulo: PINI/IPT, 1988. p. 71-74. 
cumprir à Resolução $N^{0} 307$ do CONAMA; b) estabelecer as bases para a gestão privada de resíduos que têm origem privada; c) exigir os Projetos de Gerenciamento de Resíduos para obras que requeiram o alvará municipal; d) consolidar a "cadeia de responsabilidades" geradores de resíduos declarando sua responsabilidade, os transportadores deverão ser exclusivamente os cadastrados e deposição dos resíduos apenas em áreas licenciadas; e) interromper as ações em bota-foras e incentivar às áreas de triagem e reciclagem; e) utilizar o "poder de compra" da administração municipal para incentivar o uso de agregados reciclados em serviços que já estejam normatizados pela ABNT.

Alguns casos da aplicação bem-sucedida da Resolução $\mathrm{N}^{0} 307$ do CONAMA (BRASIL, 2002) podem ser citados, como por exemplo, em São Paulo, onde os pequenos geradores (até $1 \mathrm{~m}^{3} / \mathrm{dia}$ ) dispõem de seis EcoPontos (DE MELLO, 2006) para a entrega voluntária de materiais inservíveis (RCD, móveis velhos, podas de árvores e objetos volumosos), no entanto, de acordo com Jadovski (2005), está prevista a implantação de 90 áreas de Ecopontos; já em Belo Horizonte, de acordo com Da Fonseca (2006), a Prefeitura disponibiliza aos pequenos geradores (até $2 \mathrm{~m}^{3} / \mathrm{dia}$ ) 22 locais denominados URPV's (unidades de recebimento de pequenos volumes) para a recepção de RCD e resíduos volumosos (informação verbal) ${ }^{6}$; em Salvador, pelo Projeto de Gestão Diferenciada do Entulho foram implantados seis Postos de Descarga de Entulho com previsão de ampliação para 22 pontos de coleta. Na cidade de São Carlos, segundo Fagury (2006), está para ser votado na câmara municipal, o Plano de Gestão e Gerenciamento de Resíduos de Construção e Demolição; segundo esse plano, serão criados oito a doze pontos de entrega de materiais inservíveis que funcionarão em sistema de cooperativa. O material previamente separado será levado até a usina de reciclagem, que está em funcionamento desde janeiro de 2006, para reciclagem da fração mineral e triagem dos resíduos da Classe B (informação verbal) ${ }^{7}$.

Em São Paulo, os grandes geradores (> $2 \mathrm{~m}^{3} / \mathrm{dia}$ ) devem contratar empresas especializadas em serviços de coleta e transporte de RCD que transportarão esses resíduos até as áreas de transbordo e triagem; atualmente, a cidade dispõe de nove áreas privadas de transbordo e triagem de resíduos com capacidade de recepção de até $6,75 \times 10^{3} \mathrm{t} / \mathrm{dia}$ de resíduos e duas áreas municipais de transbordo de inertes (Vila Leopoldina e Itatinga). Com

\footnotetext{
${ }^{6}$ Informação verbal fornecida pela Eng. Laís Bertola da Fonseca da Usina de Reciclagem de Estoril da cidade de Belo Horizonte, em 2006.

7 Informação verbal fornecida pelo Eng. Samir Fagury da Prohab (Secretaria Municipal de Desenvolvimento Sustentável, Ciência e Tecnologia e Progresso Habitação de São Carlos), em 2006.
} 
relação aos aterros, a cidade dispõe de cinco áreas privadas com capacidade de recepção de $9,38 \times 10^{3} \mathrm{t} /$ dia de resíduos e um aterro municipal de inertes (Parelheiros) (DE MELLO, 2006); em Belo Horizonte, segundo Da Fonseca (2006), na rodovia BR 040, há um aterro de inertes que recebe também resíduos domiciliares (Central de Tratamento de Resíduos Sólidos); nesse local, a taxa de deposição de $R C D$ é de $R \$ 5,00 / \mathrm{m}^{3}$ e $R \$ 16,00 /$ para resíduos domiciliares. Dependendo da qualidade do RCD (avaliado por meio de inspeção visual) o resíduo pode ser destinado à reciclagem, em uma usina de reciclagem que funciona no próprio aterro, sem a cobrança da taxa de deposição (informação verbal) ${ }^{6}$.

Em decorrência da Resolução N ${ }^{0} 307$ do CONAMA (BRASIL, 2002), algumas outras iniciativas merecem ser destacadas:

- A Resolução n41, da Secretaria Estadual de Meio Ambiente do Estado de São Paulo, publicada em 17 de outubro de 2002. Trata-se do primeiro instrumento estadual, em decorrência da Resolução N ${ }^{0} 307$ do CONAMA (BRASIL, 2002), sobre a questão dos resíduos de construção. Essa Resolução proíbe a operação de botaforas no Estado, define procedimentos para o licenciamento de Aterros de Resíduos da Construção Civil e fornece prazos para o enquadramento das áreas existentes.

- Em São Paulo, a Lei $n^{0}$ 12.300, sancionada em 16 de março de 2006, que institui a Política Estadual de Resíduos Sólidos e define princípios e diretrizes (em processo de regulamentação) (DEPARTAMENTO DE MEIO AMBIENTE, 2006).

- A publicação pela Caixa Econômica Federal de uma linha específica de financiamento destinada a apoiar entidades privadas que, em parceria com os municípios, promovam a implantação de usinas de reciclagem. Esse financiamento está sujeito ao atendimento de alguns requisitos prescritos pela Resolução $N^{0} 307$ do CONAMA (PINTO, 2004);

- O relatório preliminar da Política Nacional de Resíduos Sólidos, elaborada pelo então Deputado Federal Emerson Kapaz, que considera os resíduos da construção civil como resíduos especiais que necessitam de gerenciamento específico, em razão de sua tipologia e/ou quantidade (DEGANI, 2003).

- A criação do Comitê de Meio Ambiente, Segurança e Produtividade do Sinduscon SP, em janeiro de 2003, que contou com um grupo piloto de construtoras para a criação de um programa, nos canteiros de obras, visando aperfeiçoar a logística da obra, a organização, segregação e acondicionamento dos resíduos bem como sua correta deposição, mediante o credenciamento de empresas de remoção. Outra 
iniciativa do COMASP que merece destaque é a criação de grupos de trabalho para o desenvolvimento de soluções práticas objetivando o reuso, reciclagem e correta destinação dos resíduos (CAMPOS, 2006; DEGANI, 2003);

Segundo Obra Limpa (2005), os resultados estão sendo muito favoráveis para as construtoras da capital paulista que implantaram um programa de gestão de resíduos com a coleta seletiva e a destinação compromissada. Dentre as principais vantagens destaca-se: a) destinação mais adequada aos resíduos gerados com conseqüente redução direta da geração através da adoção de técnicas racionalizadas de execução dos serviços; b) redução do custo global de destinação dos resíduos das obras em até 25\%; c) agilidade no atendimento aos requisitos presentes nos programas de qualidade, tais como, o Programa Brasileiro de Produtividade e Qualidade no Hábitat (PBPQ-H), Qualihab e ISO14000, entre outros. De acordo com Campos (2006), uma comparação realizada entre dois edifícios de alto padrão, sendo que em um deles não foi adotado o programa de gestão de resíduos, mostrou que a adoção do sistema de gestão de resíduos representou uma redução de 43\% no volume total de resíduos e diminuição de $40 \%$ no custo total da destinação.

Com relação ao panorama internacional, Schneider (2003) cita que os países membros da Organização para Cooperação e Desenvolvimento Econômico implantaram medidas para atenuar o impacto das atividades da construção civil a partir da década de 70 . Nos anos 80, em razão da escassez de áreas apropriadas para a deposição de resíduos na Europa, a redução na geração e a reciclagem de resíduos tornaram-se diretrizes básicas de diversas políticas públicas. Em vários países, existem regulamentações que proíbem e punem severamente os responsáveis pela deposição de resíduos no meio ambiente. De acordo com a Organisation for Economic Co-Operation and Development (1997), em países como a Bélgica, Dinamarca, Japão e Holanda, a sociedade exerce uma grande pressão contra a utilização de áreas para a deposição de resíduos e a exploração desenfreada de recursos naturais; por esse motivo, o reaproveitamento e a reciclagem de resíduos estão ocupando um local de destaque na agenda política desses países. Na Holanda, aproximadamente $90 \%$ dos resíduos são reciclados devido à existência de regulamentações rígidas que punem os responsáveis pela deposição incorreta desses materiais no meio ambiente.

Em 1978, foi publicada pelo governo holandês uma regulamentação com relação aos $\mathrm{RCD}$, tendo como finalidade reduzir a poluição do meio ambiente através da diminuição do volume desses materiais e, quando isto não for possível, promover a reciclagem. A solução encontrada pelas autoridades holandesas para coibir o desperdício e promover a reciclagem dos materiais foi aumentar em cerca de cinco vezes as taxas para deposição desses 
materiais em aterros. Nesse país, de acordo com De Vries (1993), desde 1984, há várias recomendações tratando do uso de agregados reciclados de concreto e alvenaria. De acordo com Schneider (2003), na Holanda, foi aprovado, em 1999, um decreto que determina limites para a quantidade máxima de substâncias perigosas contidas nos materiais de construção.

Na Dinamarca, a taxação de matéria-prima natural é de $10 \%$ em decorrência da sua escassez. Segundo Schneider (2003), nesse país, o aumento da taxa de deposição de RCD em aterros elevou significativamente as taxas de reciclagem de resíduos. No ano da introdução da taxa, o valor cobrado era de cinco Euros por tonelada e, atualmente, é de aproximadamente 50 Euros. Desde a introdução da taxa foi verificado um crescimento significativo da média de reciclagem, que passou de 25\%, em 1990, para 90\% em 1999. O pesquisador cita que em vários países europeus, tais como, Inglaterra, República Checa, Itália e França, a redução da geração de resíduos é alcançada por meio de instrumentos econômicos (taxação de aterros). De acordo com Coelho (2001), na Dinamarca, existem mineradoras que vendem tanto o agregado primário quanto o reciclado para seus clientes, sendo que o preço de venda dos agregados naturais é $50 \%$ superior aos agregados reciclados de concreto.

No Japão, em vigor desde 2002, há uma política que prevê a triagem dos resíduos na obra e posterior entrega em unidades de reciclagem. A triagem dos resíduos no próprio local de geração é um dos instrumentos que visam facilitar o reaproveitamento dos resíduos. Schneider (2003) cita que no Japão e em mais sete países europeus a triagem dos resíduos é um procedimento obrigatório. O pesquisador cita que em alguns países europeus é necessária a apresentação de documentação contendo detalhes de como os resíduos serão gerenciados. Na Suécia, por exemplo, o plano de gestão deve vir acompanhado da documentação para a demolição da edificação o qual deve ser aprovado previamente pelas autoridades. Em alguns países existem subsídios para unidades de reciclagem; na Inglaterra, por exemplo, há subsídios para a compra de equipamentos para reciclagem, já na Bélgica o governo investe em companhias de reciclagem que processam os RCD.

Segundo Van Acker (1996), as regulamentações ambientais estão tornando-se mais restritivas em quase todos os países europeus. No Reino Unido, a cobrança de taxas sobre a deposição de resíduos de concreto incentivou as usinas de concreto pré-misturado a diminuir substancialmente a quantidade de resíduos gerados (SEALEY et al., 2001). De acordo com a Associação Brasileira das Empresas de Serviços de Concretagem (2001), as empresas filiadas à entidade estão formulando programas de gestão ambiental com as 
seguintes metas: promover a reutilização de sobras de concreto, controlar a emissão de particulados, efluentes líquidos e a deposição de resíduos sólidos.

Outro fato preocupante é a exploração desenfreada de recursos naturais. De acordo com Mattos e Wagner (1999), entre 1970 e 1995, o consumo de materiais no mundo cresceu de 5,7 bilhões de toneladas para 9,5 bilhões de toneladas. Segundo Ciocchi (2003), países como Holanda, Bélgica e Dinamarca, que reciclam mais de $90 \%$ dos RCD, precisam importar areia e até mesmo resíduos devido à escassez de recursos minerais. Além disso, as restrições ambientais encarecem ou inibem os processos extrativos minerais, bem como a deposição final dos resíduos gerados por construções e reformas (BUTTLER, 2003). Nos Estados Unidos, apesar da disponibilidade de agregados primários; as distâncias de transporte são geralmente significativas, aliadas à escassez de áreas apropriadas para deposição dos resíduos ou seu alto valor (COELHO, 2001).

Felizmente, o Brasil ainda pode ser considerado um país com razoáveis reservas de agregados naturais. Entretanto, segundo Valverde (2003), mesmo havendo recurso mineral disponível, muitas vezes esse não pode ser extraído devido a restrições a sua exploração. $\mathrm{Na}$ cidade do Rio de Janeiro, por exemplo, acima de determinada cota é proibida a extração de rocha, restringindo tanto o nível de produção quanto a vida útil das pedreiras em operação, além de impedir a abertura de novas pedreiras. De acordo com o autor, apesar da produção de agregados, no Brasil, atenderem satisfatoriamente a demanda nacional; a disponibilidade desses recursos, especialmente aqueles localizados dentro ou no entorno dos grandes aglomerados urbanos do país vem declinando em virtude de inadequado planejamento, problemas ambientais, zoneamento restritivo e usos competitivos do solo. A possibilidade de exploração desses recursos está sendo limitada cada vez mais; tornandose aleatórias as perspectivas de garantia de suprimento futuro. As restrições são cada vez maiores, seja para a obtenção de novas licenças, seja para garantir a atividade das minerações existentes.

\subsection{UNIDADES DE RECICLAGEM}

Com relação às unidades de reciclagem existentes no Brasil, pode-se dizer que o déficit de instalações de reciclagem é considerável. No país, existem apenas 18 instalações de reciclagem com escala de produção pequena (menor que 100 t/dia de resíduos processados). De acordo com Buttler et al., considerando-se a escala de produção das usinas de reciclagem em funcionamento no país e a taxa média de geração de 445 
kg/hab.ano de RCD, chega-se a conclusão que o país precisaria de, no mínimo, 2300 usinas para processar o volume gerado diariamente (em fase de elaboração) ${ }^{2}$. Na Alemanha, conforme Müller (2006), são cerca de 1600 plantas fixas de reciclagem e 3313 plantas móveis de reciclagem que processaram, em 2005, $59 \times 10^{6}$ t de RCD, sendo que 55\% desse total foram processados pelas plantas móveis.

Levy (2001) cita alguns dados com relação às usinas instaladas e a serem implantadas em alguns municípios brasileiros, Tabela 2.4 .

Tabela 2.4 - Instalações de reciclagem em alguns municípios brasileiros.

\begin{tabular}{cc}
\hline Município & Instalação de reciclagem \\
\hline Salvador & Primeiro projeto concluído \\
\hline Brasília & Duas instalações de reciclagem com capacidade nominal para 240 t/dia \\
\hline Belo Horizonte & $\begin{array}{c}\text { Estoril - capacidade de 120 t/dia (1994) } \\
\text { Pampulha - cap. de } 240 \text { t/dia (1996) } \\
\text { BR 040 - cap. de } 380 \text { t/dia (2004) }\end{array}$ \\
\hline Ribeirão Preto & Cap. 240 t/dia, está desativada \\
\hline São José dos Campos & Cap. 240 t/dia - parada \\
\hline São José do Rio Preto (JADOVSKI, & em implantação \\
\hline 2005) & Cap. 800 t/dia, totalmente reformulada \\
\hline São Paulo & Cap. 120 t, em fase de implantação \\
\hline Guarulhos & Cap. 120 t, em fase de implantação \\
\hline Ribeirão Pires & desenvolvimento \\
\hline Diadema & Não existe, apesar de que uma políca de resíduos encontra-se em \\
\hline Santo André & Não existe, mas uma política de resíduos já está definida \\
\hline Vinhedo & Cap. 52 t/dia, sendo a pioneira na comercialização de material \\
Piracicaba & Cap. 170 t/dia, totalmente reformada; 25\% dos resíduos são reciclados \\
\hline Campinas & Cap. 80t/hora, em implantação \\
\hline Londrina & Cap. 160 t/dia \\
\hline São Carlos (JULIÃO, 2004) & Cap. 100 t/dia, encontra-se parada \\
\hline
\end{tabular}

(fonte: adaptada de Levy, 2001)

Segundo Da Fonseca (2006), na usina de reciclagem de Estoril, situada na cidade de Belo Horizonte, são processadas 240 t/dia de RCD. Os agregados oriundos de resíduos cerâmicos são utilizados pela prefeitura em sub-base de vias, enchimento de valas e aterros e também são comercializados a razão de $\mathrm{R} \$ 8,50 / \mathrm{m}^{3}$; já os agregados oriundos de resíduos de concreto (materiais cimentícios) são utilizados por uma cooperativa constituída por ex-moradores de rua para a produção de blocos não-estruturais de concreto (30000 blocos/mês). Os blocos são produzidos na própria usina de reciclagem e comercializados a razão de $\mathrm{R} \$$ 0,80 (19 cm x $19 \mathrm{~cm} \times 39 \mathrm{~cm}), \mathrm{R} \$ 0,65(14 \mathrm{~cm} \times 19 \mathrm{~cm} \times 39 \mathrm{~cm})$ e $\mathrm{R} \$ 0,50(9$

${ }^{2}$ BUTTLER, A. M.; CORRÊA, M. R. S.; PRADO, D. M.; RAMALHO, M. A. Avaliação das propriedades de agregados reciclados de concreto gerados em uma fábrica de pré-moldados. A ser publicado pela Revista de Ciência e Tecnologia de Materiais de Construção Civil, 2006. 
$\mathrm{cm} \times 19 \mathrm{~cm} \times 39 \mathrm{~cm}$ ). A renda proveniente da venda dos blocos é distribuída entre os exmoradores de rua (informação verbal) ${ }^{6}$. Segundo Jadovski (2005), em Belo Horizonte, desde que foram implantadas as usinas de reciclagem, a quantidade de RCD reciclado subiu de 16 x $10^{3} \mathrm{t}$ (1996) para $116 \times 10^{3} \mathrm{t}$ (2003); no entanto, apenas $15 \%$ dos resíduos gerados na cidade são reciclados (PINTO, 2004). Na usina de reciclagem de Piracicaba, que recicla 120 $\mathrm{m}^{3} /$ dia de RCD, também está instalada uma fábrica de blocos que utiliza os agregados reciclados para a produção diária de 2000 blocos não-estruturais (JADOVSKI, 2005).

Na cidade de São Carlos, a Secretaria de Progresso e Habitação de São Carlos (PROHAB) conjuntamente com a Secretaria Municipal de Desenvolvimento Sustentável, Ciência e Tecnologia implantou uma usina de reciclagem de RCD com capacidade de processamento de 160 t/dia, Figura 2.6. A operação dessa usina foi autorizada pela Cetesb no início de 2006; anteriormente, em setembro e outubro de 2005, a Cetesb já havia concedido as licenças prévia e de instalação, respectivamente.

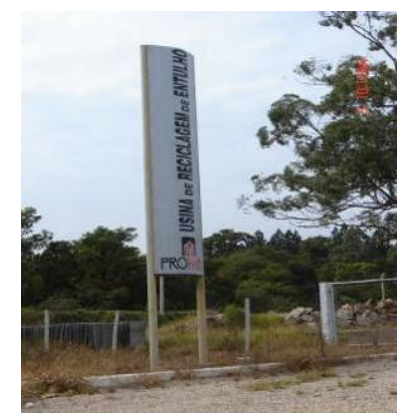

a) entrada da usina

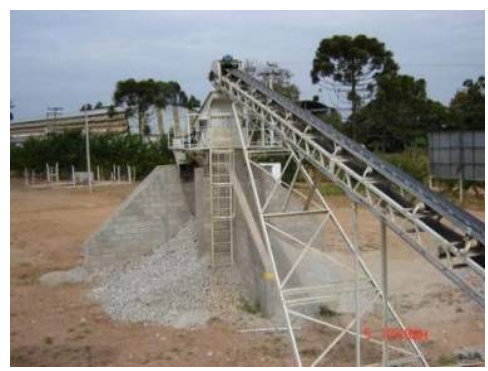

d) correia transportadora

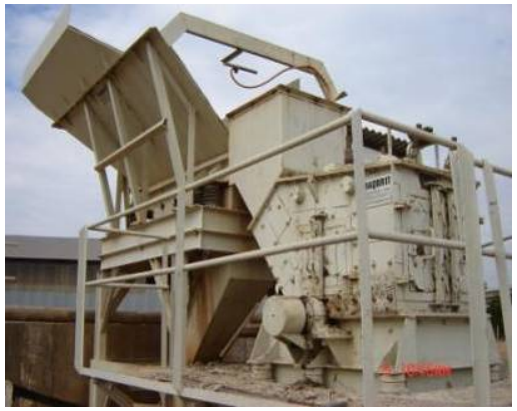

b) alimentador vibratório e britador de martelos

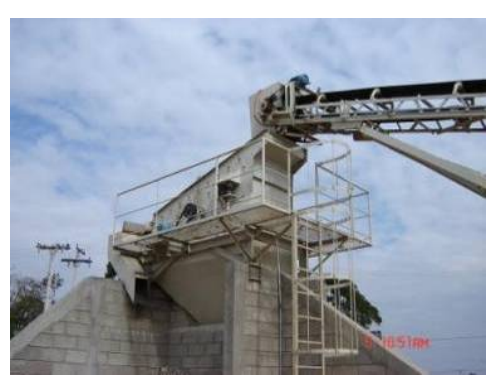

e) peneirador vibratório

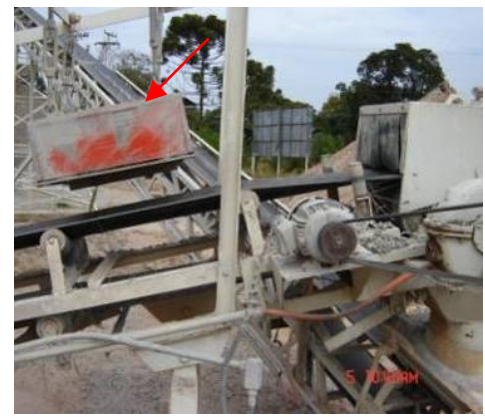

c) separador magnético

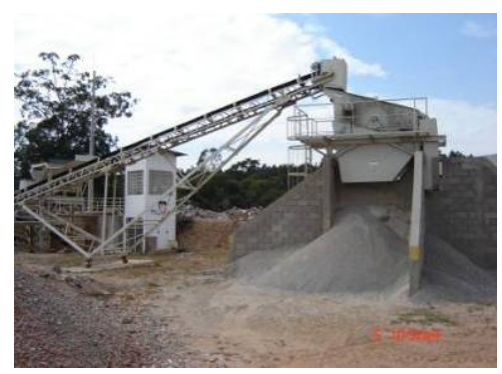

f) material separado em diferentes granulometrias

Figura 2.6 - Usina de reciclagem de São Carlos (foto do autor).

\footnotetext{
${ }^{6}$ Informação verbal fornecida pela Eng. Laís Bertola da Fonseca da Usina de Reciclagem de Estoril da cidade de Belo Horizonte, em 2006.
} 
Segundo Fagury (2006), no local da usina estão em operação: a central de triagem de resíduos da classe $B$ (papel, plástico, vidro, madeira, etc) e a fábrica de artefatos de cimento (blocos de concreto), Figura 2.7. Nesses locais, estão trabalhando 12 detentos da penitenciária de Itirapina como parte de um programa de ressocialização. Além de receber pelo trabalho desenvolvido, a pena é reduzida em um dia para cada três dias trabalhados (informação verbal) ${ }^{7}$.

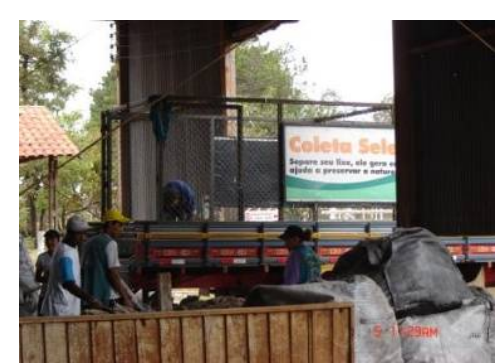

a) coleta seletiva de resíduos

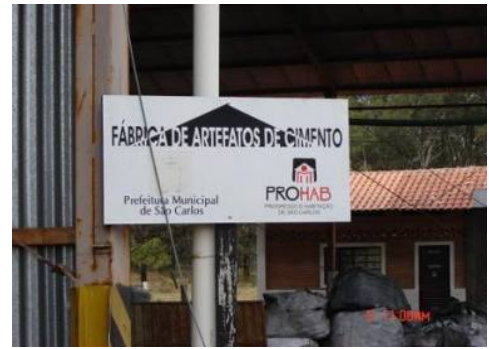

b) fábrica de artefatos de cimento

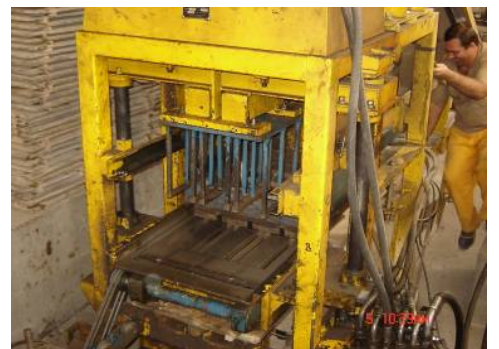

c) vibro-prensa para produção

Figura 2.7 - Unidades em operação no local da usina de reciclagem (foto do autor).

De acordo com Fagury (2006), a usina entrou em funcionamento no início de 2005 com a finalidade de reduzir a deposição irregular de RCD na cidade e produzir artefatos de cimento para habitações sociais. Atualmente, a PROHAB tem várias parcerias com empresas do setor de coleta de resíduos, recebendo em média 20 caçambas diárias. A triagem do material é realizada na própria usina, Figura 2.8. Os agregados reciclados de concreto são utilizados para a fabricação de blocos de concreto e os agregados reciclados de cerâmica são empregados para pavimentação de vias rurais, Figura 2.9. O preço de venda do material reciclado é estimado em $\mathrm{R} \$ 5,00 / \mathrm{m}^{3}$ (agregado reciclado cerâmico - bica corrida) e $\mathrm{R} \$ 15,00 / \mathrm{m}^{3}$ (agregado reciclado de concreto - fração cinza) (informação verbal) ${ }^{7}$.

7 Informação verbal fornecida pelo Eng. Samir Fagury da Prohab (Secretaria Municipal de Desenvolvimento Sustentável, Ciência e Tecnologia e Progresso Habitação de São Carlos), em 2006. 

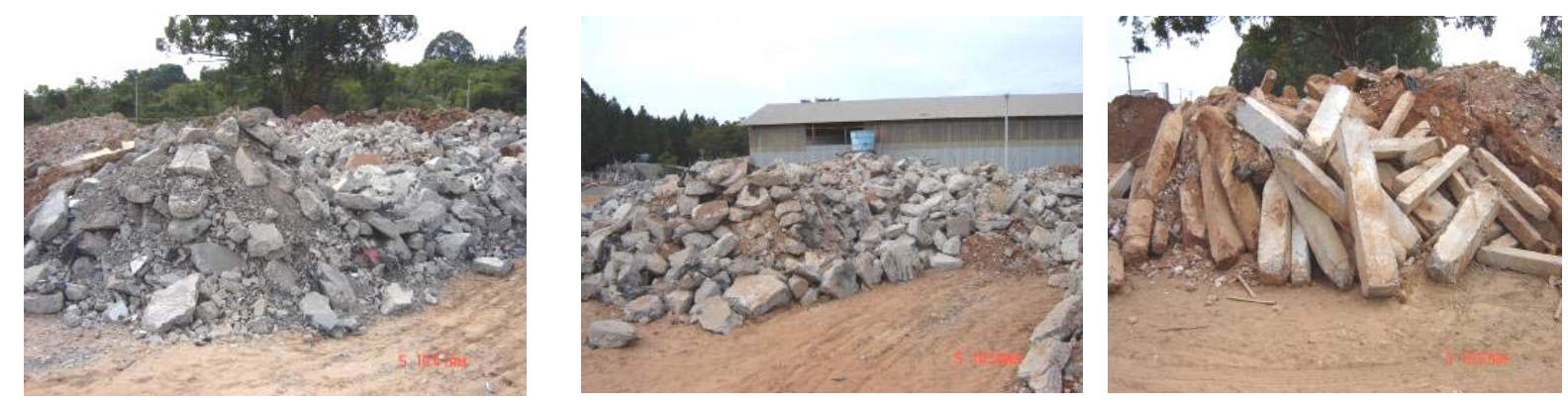

Figura 2.8 - Resíduos de concreto (foto do autor).

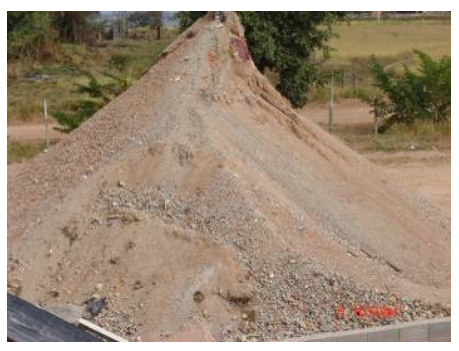

a) agregados reciclados de cerâmica (bica corrida)

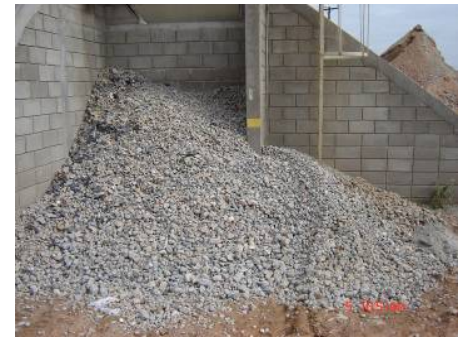

b) agregados reciclados de concreto (brita 3)

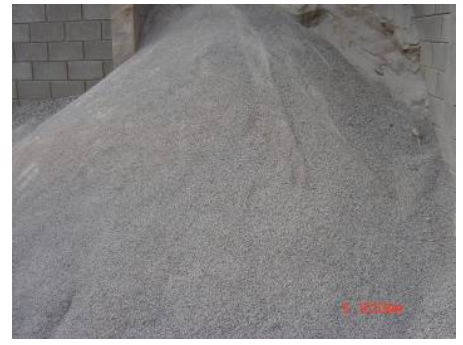

c) agregados reciclados de concreto (areia reciclada)

Figura 2.9 - Alguns tipos de agregados reciclados produzidos pela usina (foto do autor).

Segundo Fagury (2003) a fábrica de artefatos de cimento está produzindo blocos de concreto, com o emprego de agregados reciclados de concreto, para o projeto Moradia Solidária. Esse programa foi criado para garantir o direito à habitação para famílias que não tem condições de adquirir financiamento para a aquisição da casa própria. Destinado às famílias com renda de 1 a 3 salários mínimos, o projeto prevê a construção de 224 unidades que serão construídas sob a forma de mutirão (informação verbal) ${ }^{7}$.

De acordo com a Urbem (2006), na cidade de São Bernardo do Campo, está em operação, desde janeiro de 2005, uma usina de reciclagem que processa 50t/h de resíduos de concreto. Os agregados reciclados de concreto são comercializados a razão de $R \$$ 25,00/m³. A empresa não processa resíduos cerâmicos e resíduos mistos (cerâmico +

7 Informação verbal fornecida pelo Eng. Samir Fagury da Prohab (Secretaria Municipal de Desenvolvimento Sustentável, Ciência e Tecnologia e Progresso Habitação de São Carlos), em 2006. 
concreto) devido à dificuldade de aceitação pelo mercado. Os principais consumidores dos agregados reciclados são: empresas de pavimentação, fábricas de artefatos de concreto, administração pública (prefeitura de São Bernardo $-4,8 \times 10^{3} \mathrm{~m}^{3}$ de brita corrida e prefeitura de Mauá - 4,0 × $10^{3} \mathrm{~m}^{3}$ ) e construtoras.

\subsection{EXPERIÊNCIAS E CAMPOS DE APLICAÇÃO PARA OS AGREGADOS RECICLADOS}

Neste item serão apresentadas algumas experiências práticas envolvendo a utilização de agregados reciclados de concreto na produção de pavimentos de concreto, artefatos de concreto, etc. As aplicações destinadas à produção de artefatos de concreto são denominadas de alto valor e, segundo Angulo e John (2004), devem ser desenvolvidas, em detrimento daquelas relacionadas com a aplicação em bases e sub-bases de rodovias, com o intuito de permitir a valorização do produto e o interesse de empresas privadas. Conforme Angulo et al. (2004) mesmo em países europeus com elevadas taxas de reciclagem, os agregados reciclados continuam sendo absorvidos em grande parte pelas atividades de pavimentação; essa prática denomina-se "downcycling", isto é, produtos com materiais reciclados empregados em condições de menor qualidade e valor agregado. No Reino Unido, segundo SOUTSOS et al. (2005), embora existam campos potenciais para aplicação dos resíduos, os materiais reciclados são normalmente empregados em aplicações de baixo valor, tais como, sub-bases para rodovias, aterros, etc; apenas $4 \%$ dos materiais reciclados são utilizados em aplicações de alto valor agregado.

As experiências internacionais envolvendo a utilização de agregados reciclados são enumeradas a seguir. Apesar do desempenho satisfatório de grande parte dos elementos produzidos com agregados reciclados, Levy (2001) cita que, na Bélgica, ocorreram problemas sérios com duas pontes que empregaram concretos com agregados reciclados; essas obras de arte tiveram que ser demolidas devido a reações álcali-agregados.

Grübl e Nealen (1998) citam a utilização de agregados reciclados de concreto (> $2 \mathrm{~mm}$ ) para produção de concreto usinado bombeado; esse concreto foi empregado na construção de um edifício de escritórios com áreas de estacionamento, Vilbeler Weg, em Darmstadt, Alemanha. Os aspectos relacionados à tecnologia do concreto, logística e controle de qualidade ficaram sob a responsabilidade da Darmstadt University of Technology. Para a utilização do concreto com agregados reciclados foi necessário obter a aprovação das autoridades competentes; para isso foram estabelecidos ensaios, de acordo 
com o Código Alemão - DIN 1045, para avaliar as propriedades do concreto no estado fresco e endurecido. Esses resultados permitiram a aplicação do concreto reciclado, em classes de resistência de até $35 \mathrm{MPa}$. Os primeiros elementos estruturais foram produzidos no final de 1997. O edifício foi concluído em fevereiro de 1998, utilizando $480 \mathrm{~m}^{3}$ de concreto com agregados reciclados.

Teranishi et al. (1998) produziram painéis pré-moldados, em escala real, com dimensões de $6,75 \times 3,00 \mathrm{~m}^{2}$ e abertura central de $1,70 \times 1,25 \mathrm{~m}^{2}$. Para os painéis fabricados com concretos reciclados, a taxa de substituição dos agregados graúdos naturais por agregados graúdos reciclados chegou a $30 \%$ e, para os agregados miúdos naturais, a taxa de substituição foi de até $15 \%$. Após três meses da fabricação desses elementos foram observadas as condições de fissuração; para os painéis contendo agregados reciclados foi observado um número maior de fissuras à medida do aumento da porcentagem de agregados reciclados na mistura; como solução para essa tendência, os autores recomendaram ajustes na dosagem da mistura ou na concepção do projeto (colocação de barras adicionais nos painéis).

Segundo Levy (2001), na Comunidade Européia, a partir de 1998, foram executadas inúmeras obras utilizando concretos com agregados reciclados, de concreto, de alvenaria, assim como da mistura de ambos. Na Holanda podem ser enumeradas às seguintes obras em concreto com agregados reciclados:

- A laje submersa da Hidrovia de Haandrick, em 1998, com um volume de concreto igual a $2000 \mathrm{~m}^{3}$.

- O $2^{\circ}$ viaduto na Rodovia RW-32, em 1990, aonde todos os componentes da estrutura foram produzidos com concreto reciclado, em porcentagens de substituição de $20 \%$ a $80 \%$, totalizando um volume de $11 \times 10^{3} \mathrm{~m}^{3}$.

- A construção de um empreendimento residencial, entre 1997 e 1998, com 272 unidades de médio-padrão. O projeto foi desenvolvido para demonstrar a viabilidade de substituição de $100 \%$ dos agregados naturais por reciclados e servir de suporte para a publicação de normas específicas para concretos reciclados. Nesse empreendimento, foram empregados painéis pré-moldados de concretos que atenderam as exigências dos órgãos competentes com relação ao isolamento acústico.

$\mathrm{Na}$ Inglaterra, também podem ser citadas algumas obras em concretos com agregados reciclados, Levy (2001): 
- O Edifício do meio ambiente, em 1996, que empregou concreto usinado com agregados reciclados. Nessa obra, o volume de concreto foi estimado em cerca de $1500 \mathrm{~m}^{3}$; para as fundações utilizou-se um concreto $\mathrm{C} 25$, nas lajes e pilares foi empregado um concreto C35.

- O piso de alta resistência do Laboratório de Cardinton $\left(500 \mathrm{~m}^{2}\right)$, em 1996, construído para analisar o efeito causado pela substituição, em massa, de $20 \%$ dos agregados naturais por reciclados de concreto e alvenaria de baixa qualidade. A evolução da resistência à compressão do piso com agregados reciclados foi similar ao piso com agregados naturais.

De acordo com Levy (2001), A Eclusa de Berendrecht, para ampliação do Porto de Antuérpia, pode ser considerada uma das maiores obras em concreto com agregados reciclados. Os agregados reciclados, em um total de $80 \times 10^{3} \mathrm{~m}^{3}$, foram provenientes da demolição das antigas paredes da eclusa de Zandvliet. Esse empreendimento, executado entre 1987 e 1989, demonstrou a viabilidade da produção de concretos reciclados de até 35 MPa e retração por secagem menor que $150 \mu \mathrm{m} / \mathrm{m}$. O sucesso no reaproveitamento dos resíduos de demolição deveu-se aos seguintes fatores: a) caracterização detalhada dos resíduos; b) otimização da instalação para processamento dos resíduos; c) desenvolvimento do sistema de controle e qualidade.

Levy (2001) cita grandes peças de concreto, que foram utilizadas como elementos decorativos, para adornar a área de exposição do Federal Gardenig Exhibition, em Magdeburg, Alemanha. Essas peças foram fabricadas com agregados reciclados oriundos de resíduos de concreto, alvenaria de blocos cerâmicos e da combinação de ambos.

Krezel e Mcmanus (2000) produziram barreiras acústicas com concretos utilizando agregados reciclados. As barreiras apresentaram excelente desempenho acústico; em um trecho de três quilômetros, com altura média de $2,5 \mathrm{~m}$, foram empregados $1 \times 10^{3} \mathrm{t}$ de agregados graúdos reciclados.

No Brasil, a utilização de materiais reciclados para a produção de artefatos de concreto resume-se as iniciativas de algumas prefeituras e construtoras que adotaram as prescrições da Resolução $\mathrm{N}^{0} 307$ do CONAMA (BRASIL, 2002) e implantaram programas de gestão de resíduos nas obras. Com relação às prefeituras, a cidade de São Paulo, em 2003, erigiu um alojamento utilizando $4 \times 10^{3}$ blocos de concreto com agregados reciclados (COELHO, 2001). Após cinco anos, foi verificado o excelente comportamento dos blocos comparativamente às unidades convencionais, sendo que o custo desses blocos foi $70 \%$ 
inferior àqueles produzidos com agregados naturais. $\mathrm{Na}$ cidade de Belo Horizonte, os agregados reciclados oriundos de resíduos de concreto (materiais cimentícios) são utilizados por uma cooperativa constituída por ex-moradores de rua para a produção de blocos não-estruturais de concreto (30000 blocos/mês). Os blocos são produzidos na própria usina de reciclagem e comercializados a razão de $\mathrm{R} \$ 0,80(19 \mathrm{~cm} \times 19 \mathrm{~cm} \times 39 \mathrm{~cm})$, $\mathrm{R} \$$ 0,65 (14 cm x $19 \mathrm{~cm} \times 39 \mathrm{~cm})$ e $\mathrm{R} \$ 0,50\left(9 \mathrm{~cm} \times 19 \mathrm{~cm} \times 39 \mathrm{~cm}\right.$ ) (informação verbal) ${ }^{6}$. Segundo Jadovski (2005), na usina de reciclagem de Piracicaba, que recicla $120 \mathrm{~m}^{3} / \mathrm{dia}$ de $R C D$, também está instalada uma fábrica de blocos que utiliza os agregados reciclados para a produção diária de $2 \times 10^{3}$ blocos não-estruturais. Na cidade de São Carlos, no local da usina de reciclagem, está em funcionamento uma fábrica de artefatos de cimento que produz blocos não-estruturais de concreto, com a utilização de agregados reciclados de concreto, para o projeto Moradia Solidária. Esse programa foi criado para garantir o direito à habitação para famílias que não tem condições de adquirir financiamento para a aquisição da casa própria. Destinado às famílias com renda de 1 a 3 salários mínimos, o projeto prevê a construção de 224 unidades que serão construídas sob a forma de mutirão. Cada moradia possui $54 \mathrm{~m}^{2}$ e são utilizados $1,8 \times 10^{3}$ blocos para sua construção, Figura 2.10.
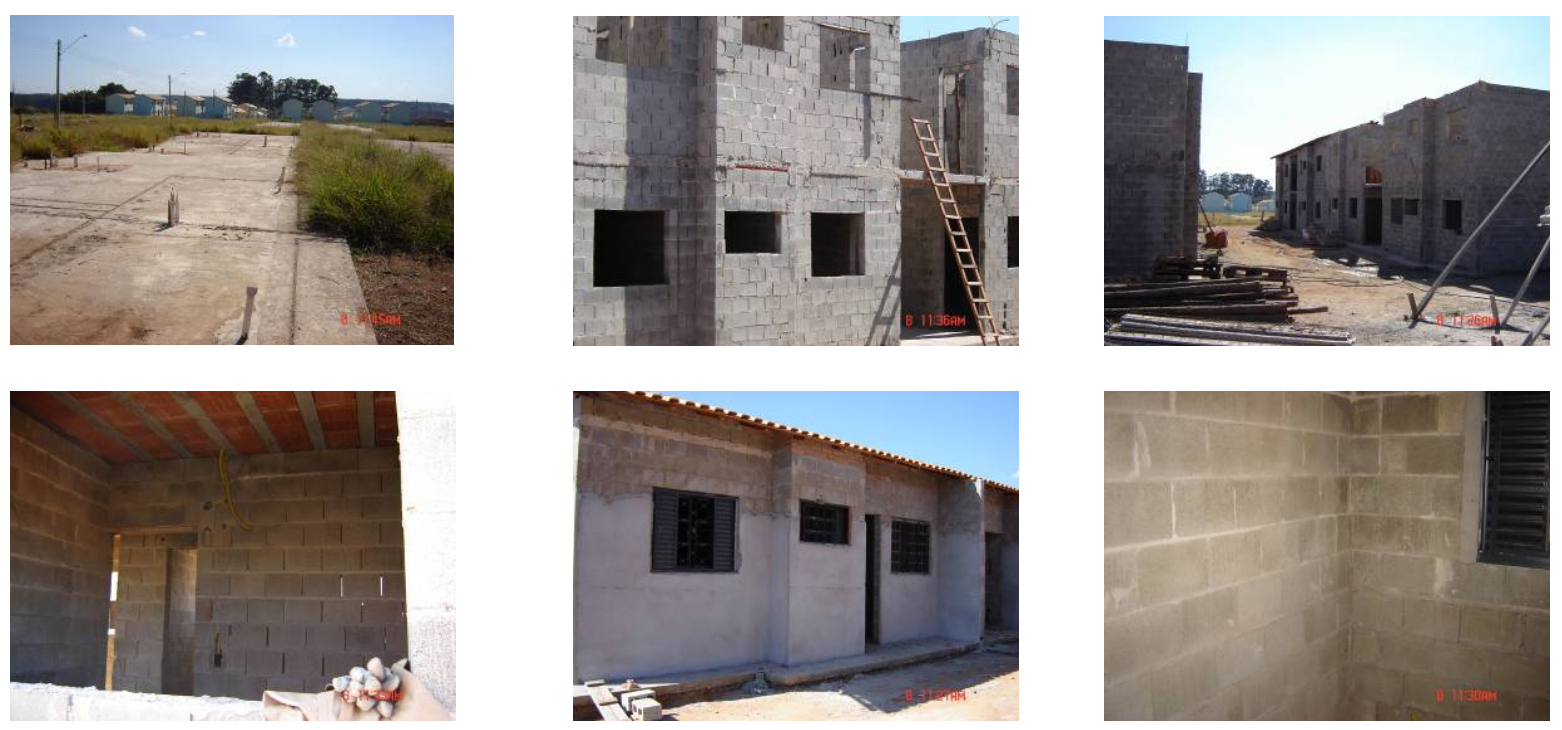

Figura 2.10 - Casas construídas com blocos de agregados reciclados (foto do autor).

\footnotetext{
6 Informação verbal fornecida pela Eng. Laís Bertola da Fonseca da Usina de Reciclagem de Estoril da cidade de Belo Horizonte, em 2006.
} 
Segundo informações de Fagury (2006), a fábrica de artefatos pode produzir até 3100 unidades/dia. Para a produção dos blocos de concreto está sendo utilizada uma vibroprensa automática da marca Vibramaq e um misturador mecânico de eixo horizontal, Figura 2.11 (informação verbal) ${ }^{7}$.
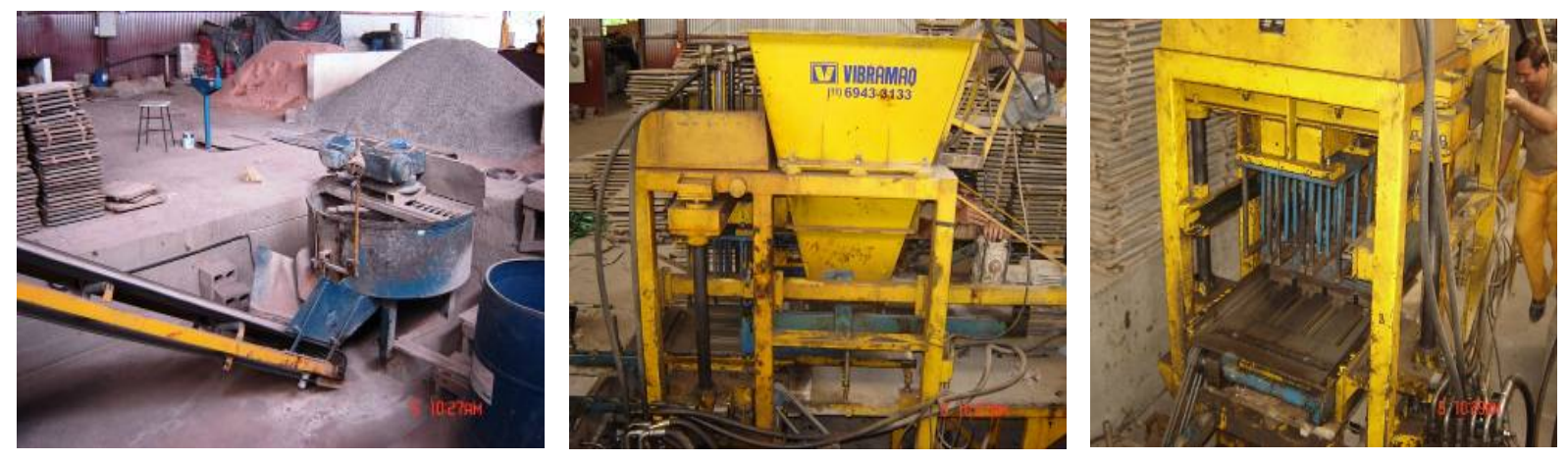

Figura 2.11 - Equipamentos utilizados para a produção de blocos de concreto (foto do autor).

As unidades comumente produzidas são: blocos (14 x $19 \times 29)$, meio-blocos (14 x 19 $x$ 14) e canaletas. Após a produção, todas as unidades são submetidas a um processo de cura úmida por aspersão durante um período de três a sete dias. Na Tabela 2.5, encontra-se uma estimativa do traço utilizado para a produção dessas unidades.

Tabela 2.5 - Características do traço utilizado para a produção das unidades.

\begin{tabular}{ccccccc}
\hline \multicolumn{2}{c}{ Consumo de materiais $\mathbf{( k g / \mathbf { m } ^ { 3 } )}$} & & $\begin{array}{c}\text { \% da fração } \\
\text { reciclada }\end{array}$ & $\begin{array}{c}\text { \% da } \\
\text { fração } \\
\text { natural }\end{array}$ \\
\hline \multirow{2}{*}{ cimento } & Areia natural & $\begin{array}{c}\text { Areia } \\
\text { reciclada }\end{array}$ & $\begin{array}{c}\text { Agregado } \\
\text { graúdo } \\
\text { reciclado }\end{array}$ & $\begin{array}{c}\text { Areia } \\
\text { reciclada }\end{array}$ & graúda & $\begin{array}{c}\text { Areia } \\
\text { natural }\end{array}$ \\
\hline 155 & 660 & 705 & 1015 & 29,6 & 42,7 & 27,7 \\
\hline
\end{tabular}

O consumo de agregados reciclados em relação ao total de agregados é de aproximadamente $70 \%$. A resistência média à compressão das unidades, aos 28 dias, varia normalmente de 3,0 MPa a 4,0 MPa. Até o presente momento, não foram feitos ensaios relativos às propriedades físicas dessas unidades, tais como, absorção de água, índice de

7 Informação verbal fornecida pelo Eng. Samir Fagury da Prohab (Secretaria Municipal de Desenvolvimento Sustentável, Ciência e Tecnologia e Progresso Habitação de São Carlos), em 2006. 
vazios, IRA, retração por secagem, etc. Na Figura 2.12, podem ser observadas algumas unidades produzidas pela fábrica.

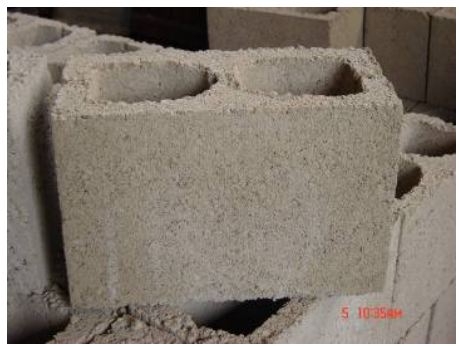

a) blocos $(14 \times 19 \times 29)$

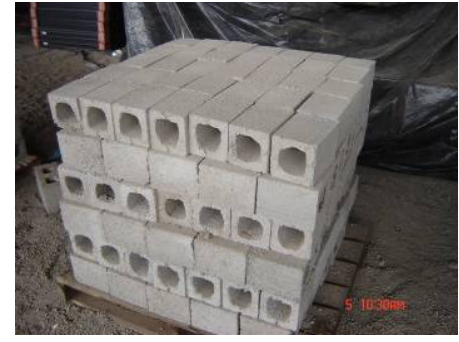

b) meio-bloco $(14 \times 19 \times 14)$

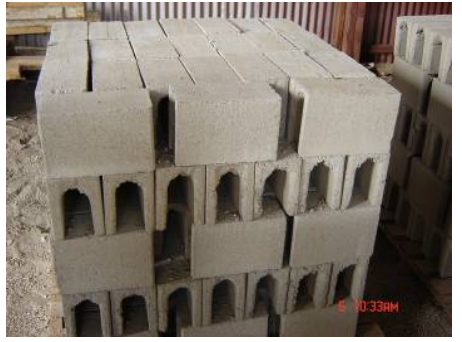

b) blocos-canaleta $(14 \times 19 \times 29)$

Figura 2.12 - Unidades produzidas pela fábrica de artefatos de cimento (foto do autor).

Com relação às construtoras, um exemplo emblemático da utilização de agregados reciclados foi dado pela Racional Engenharia (2003). A construtora empregou os agregados reciclados, advindos da demolição parcial de um edifício no Rio de Janeiro, para a fabricação de blocos de concreto com a finalidade de se edificar casas populares. O volume estimado foi de aproximadamente $5 \times 10^{3} \mathrm{~m}^{3}$ provenientes de resíduos de contrapiso, concreto e alvenaria. Para reciclar esses resíduos, a construtora alugou um terreno, no Distrito de Campo Grande e comprou equipamentos de reciclagem para realizar a britagem dos resíduos e utilizar o material para a produção dos blocos de concreto. O investimento foi de $\mathrm{R} \$ 400 \times 10^{3}$ e o local de processamento do material situava-se a cerca de $60 \mathrm{Km}$ do empreendimento; o custo do material reciclado foi cerca de $10 \%$ a $15 \%$ menor do que o agregado natural.

Os agregados reciclados geraram cerca de $600 \times 10^{3}$ blocos de concreto, suficientes para a construção de 600 casas populares. O material foi doado às secretarias de Habitação do Estado e do Município do Rio de Janeiro, além da Secretaria Municipal de Urbanização. De acordo com a Racional Engenharia (2003), os maiores benefícios com a implantação dessas medidas são de caráter ambiental, como, por exemplo, a preservação de uma jazida de pedra ou areia e, principalmente, a redução drástica da deposição de RCD em locais inadequados. Na central de reciclagem, a Racional Engenharia (2003) construiu um protótipo de casa popular com os blocos reciclados, Figura 2.13. 

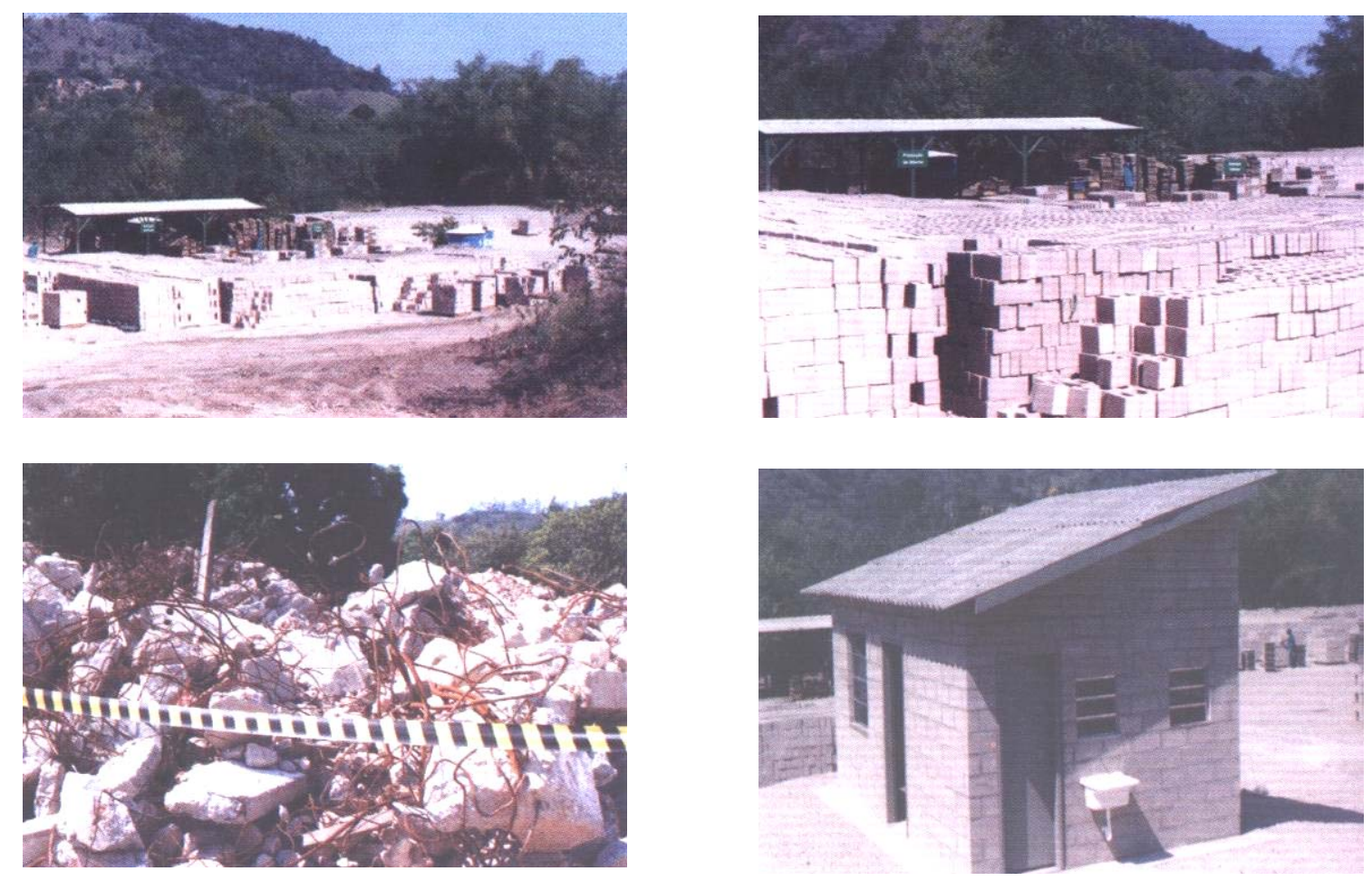

Figura 2.13 - Detalhes da fábrica de blocos e do protótipo de casa popular (fonte: Racional Engenharia, 2003).

A Construtora Setin, assessorada pela empresa Obra Limpa, reciclaram cerca de 40 $x 10^{3} \mathrm{~m}^{2}$ de um piso de concreto com $40 \mathrm{~cm}$ de espessura, que constituía o pátio de um antiga fábrica de equipamentos rodoviários. O volume de resíduo bruto foi estimado em $16 \mathrm{x}$ $10^{3} \mathrm{~m}^{3}$. Esse material está sendo utilizado na obra de um condomínio de alto padrão de 346 casas, em Guarulhos, Região Metropolitana de São Paulo. A construtora implantou um sistema de reciclagem de primeira geração visando o processamento dos resíduos e sua separação em diferentes granulometrias, Figura 2.14. 

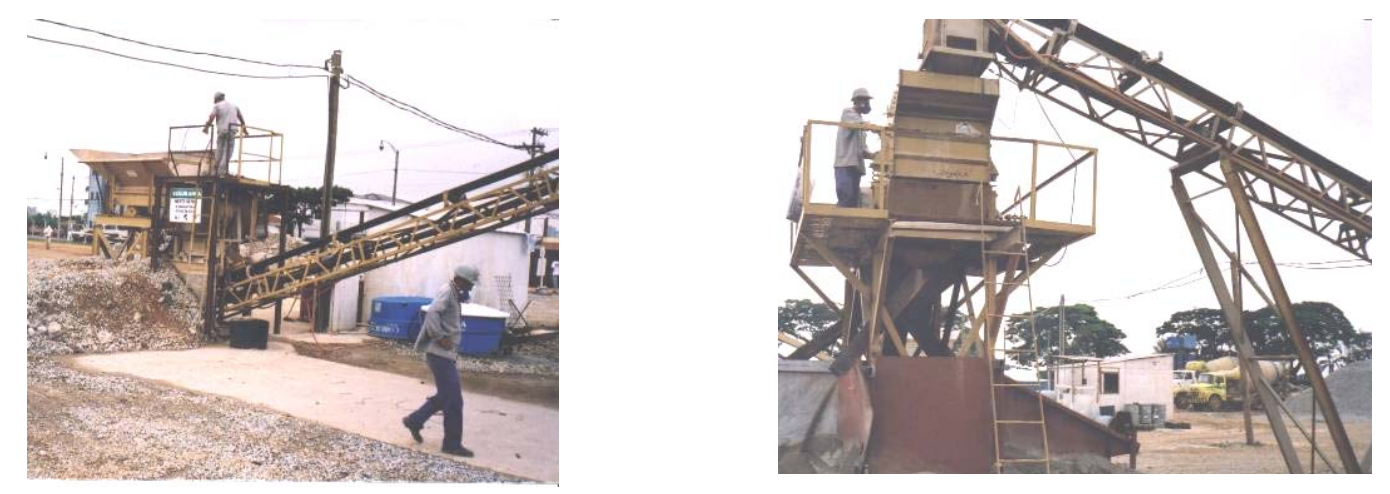

Figura 2.14 - Processamento dos resíduos de concreto no canteiro de obras (foto do autor).

Os agregados reciclados foram separados em cinco diferentes granulometrias: fração retida na peneira $25 \mathrm{~mm}$, utilizados para produção de concreto e base de pavimentação; $19 \mathrm{~mm}$, utilizados na produção de concreto; 9,5 mm, produção de concreto e blocos; 4,8 mm e frações inferiores, produção de concreto e blocos, Figura 2.15. Os materiais reciclados foram utilizados na produção de painéis pré-moldados, lajes prémoldadas, blocos de concreto e base de pavimentação, Figura 2.16.
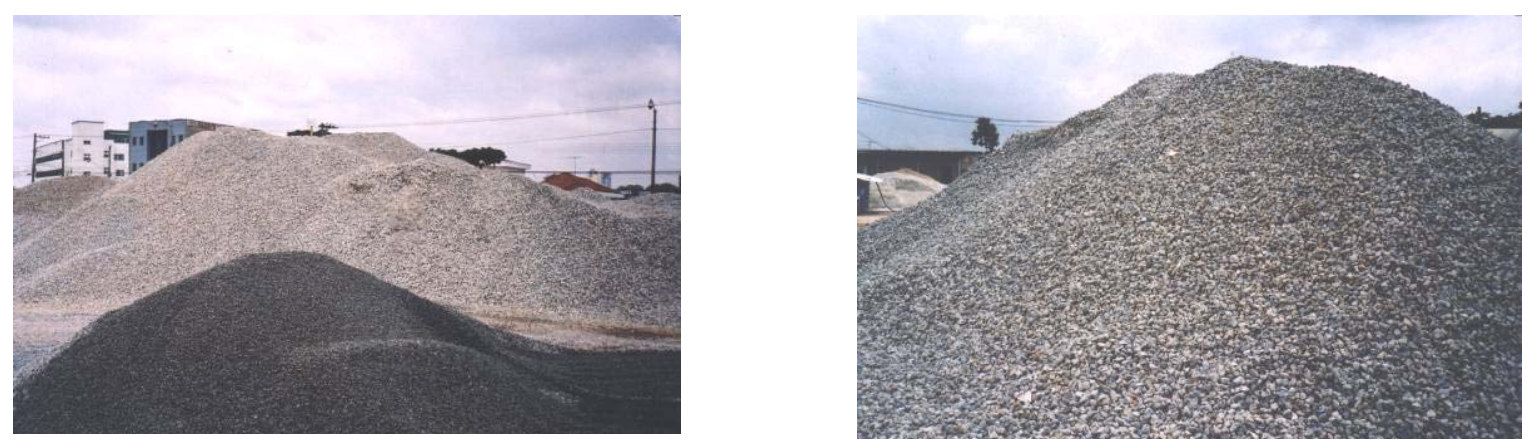

Figura 2.15 - Estoque de agregados reciclados (brita 1 e brita 2) (foto do autor). 


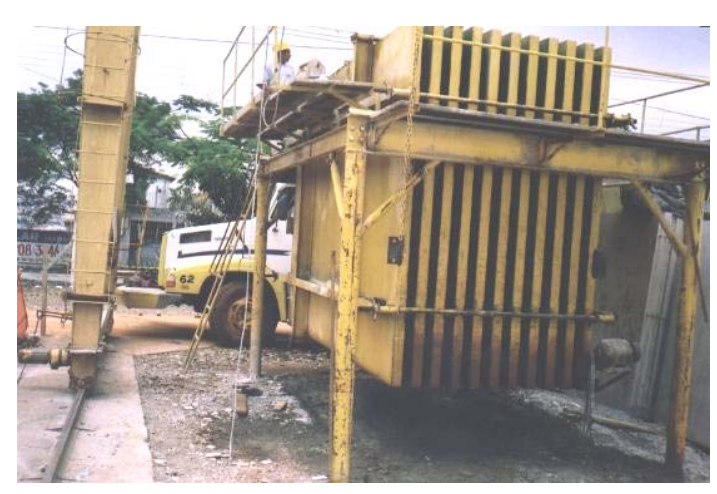

a) fôrmas metálicas para os painéis

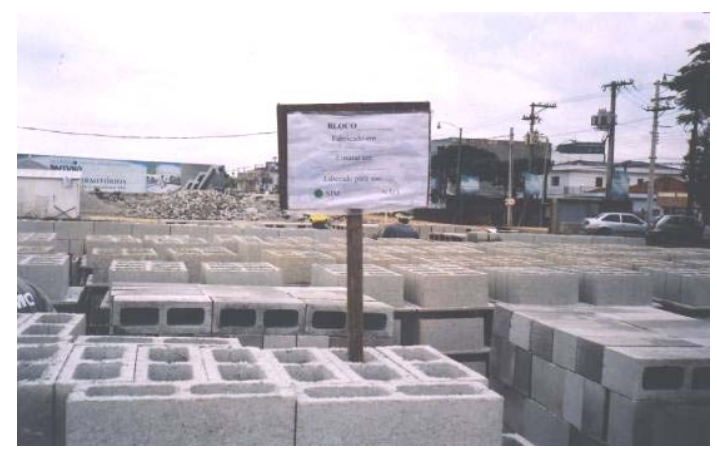

c) blocos não-estruturais de concreto

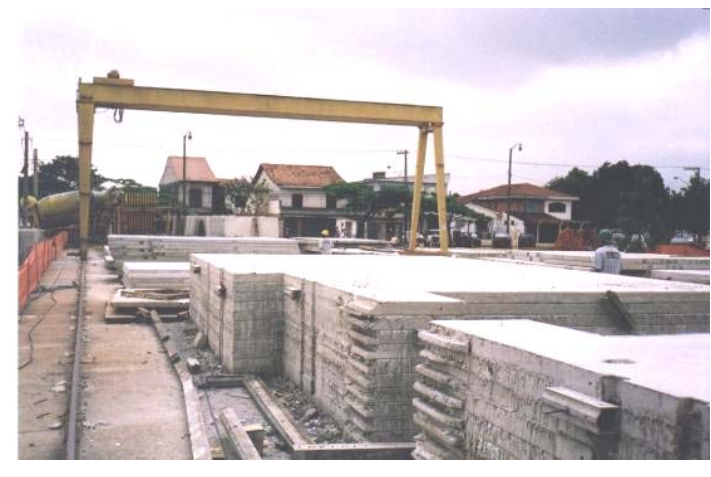

b) lajes pré-moldadas

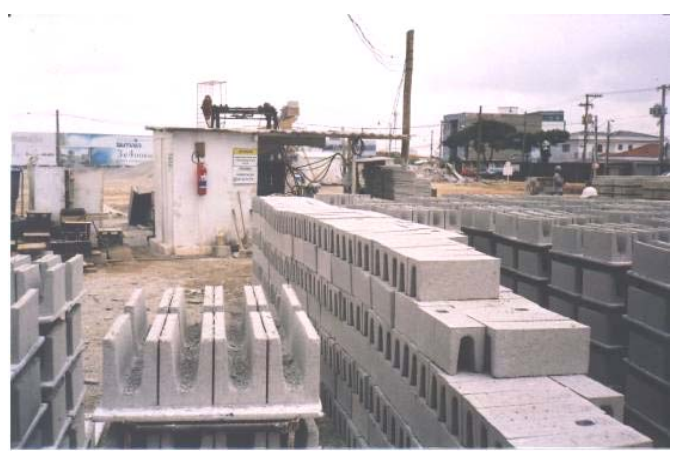

d) blocos canaletas

Figura 2.16 - Elementos produzidos utilizando agregados reciclados (foto do autor).

Os blocos não-estruturais foram avaliados quanto às propriedades de resistência à compressão e absorção de água. Os resultados mostraram que essas propriedades mantiveram-se dentro dos limites especificados pelas normas específicas.

\subsection{RECOMENDAÇÕES NORMATIVAS E LEGISLAÇÕES}

Neste tópico são apresentadas algumas recomendações normativas, decretos e legislações referentes à utilização de agregados reciclados. A adoção de critérios e diretrizes visa disciplinar o emprego desses materiais, garantindo sua correta aplicação e desempenho satisfatório. Conforme Buttler et al. (2005), o Brasil, felizmente, encontra-se em posição de vanguarda quando comparado a outros países da América Latina, devido à publicação da Resolução $\mathrm{N}^{0} 307$ do CONAMA (BRASIL, 2002) e a entrada em vigor de normas técnicas tratando do gerenciamento e utilização de RCD. 
De acordo com Glavind e Haugaard (1998), a Associação Dinamarquesa de Concreto publicou algumas recomendações envolvendo agregados reciclados de concreto; tais recomendações fornecem informações a respeito de esferas de aplicação, terminologias, classificação dos agregados reciclados e regras para o emprego dos materiais reciclados. Segundo essas recomendações, os agregados reciclados são divididos em duas classes: Classe GP1 - massa específica superior a $2200 \mathrm{~kg} / \mathrm{m}^{3}$, composto basicamente por resíduos de concreto e pequenas quantidade de resíduos de alvenaria; Classe GP2 - massa específica superior a $1800 \mathrm{~kg} / \mathrm{m}^{3}$, composto por resíduos de concreto e alvenaria ou somente alvenaria. Com relação aos campos de aplicação, os agregados pertencentes à classe GP1 podem ser utilizados para concreto armado ou simples, em ambientes pertencentes à classe passiva ou moderada, para classes de resistência de até $40 \mathrm{MPa}$; já os agregados da classe GP2 podem ser empregados em concreto armado ou simples, em ambientes pertencentes à classe passiva, com resistências de até $20 \mathrm{MPa}$. A Rilem Recommendation (1994) classifica os agregados reciclados em função da massa específica e composição e prescreve exigências para os concretos com esses agregados reciclados, Tabela 2.6 .

Tabela 2.6 - Classificação dos agregados reciclados de acordo com a densidade e composição e exigências para os concretos com agregados reciclados.

\begin{tabular}{|c|c|c|c|c|}
\hline & & Tipo I & Tipo II & Tipo III \\
\hline \multirow[b]{2}{*}{ Agregados } & Massa específica seca $\left(\mathrm{kg} / \mathrm{m}^{3}\right)$ & $\geq 1500$ & $\geq 2000$ & $\geq 2400$ \\
\hline & Composição & $\begin{array}{c}\text { Agregados } \\
\text { oriundos de } \\
\text { resíduos de } \\
\text { alvenaria }\end{array}$ & $\begin{array}{c}\text { Agregados } \\
\text { oriundos de } \\
\text { resíduos de } \\
\text { concreto }\end{array}$ & $\begin{array}{l}\text { Mistura de } \\
\text { agregados } \\
\text { naturais e } \\
\text { reciclados }\end{array}$ \\
\hline \multirow{2}{*}{ Concretos } & $\begin{array}{c}\text { Fração }>4 \mathrm{~mm} \\
\text { Fração miúda reciclada }<4 \mathrm{~mm}\end{array}$ & \multicolumn{3}{|c|}{$\begin{array}{c}\text { Até } 100 \% \\
\text { Não é recomendada }\end{array}$} \\
\hline & Classe máxima de resistência & C16/20 & C50/60 & $\begin{array}{l}\text { Sem limite } \\
\text { superior }\end{array}$ \\
\hline
\end{tabular}

(fonte: Rilem Recommendation, 1994)

No estudo de Tomosawa e Noguchi (2000, apud TAM et al., 2005) ${ }^{8}$ é proposta uma classificação para os agregados reciclados de concreto, bem como possíveis aplicações para esses materiais. Essa classificação baseia-se na absorção dos agregados reciclados; geralmente, valores elevados de absorção indicam grande quantidade de argamassa aderida que conduzem a uma diminuição da resistência e durabilidade, aumento das

${ }^{8}$ TOMOSAWA, F; NOGUCHI, T. New technology for the recycling of concrete - japanese experience. Concrete Technology for a Sustainable Development in the $21^{\text {st }}$ Century, Londres: E \& F Spon, 2000. p. 274-287. 
deformações e retração do concreto. $\mathrm{Na}$ Tabela 2.7, são enumerados alguns pontos fundamentais dessa classificação.

Tabela 2.7 - Classe dos agregados reciclados de concreto e campos de aplicação.

\begin{tabular}{|c|c|c|c|c|}
\hline $\begin{array}{l}\text { Classe dos agregados } \\
\text { reciclados }\end{array}$ & Agregado Graúdo & Agregado Miúdo & $\begin{array}{c}\text { Resistência } \\
\text { recomendada (MPa) }\end{array}$ & $\begin{array}{l}\text { Campos de } \\
\text { aplicação }\end{array}$ \\
\hline $\mathrm{C} 1$ & $\begin{array}{l}\text { Agregado reciclado tipo C1 - } \\
\text { Absorção } \leq 3,0 \%\end{array}$ & $\begin{array}{l}\text { Agregado miúdo } \\
\text { natural }\end{array}$ & 18 a 24 & $\begin{array}{c}\text { Concreto simples ou } \\
\text { armado, paredes de } \\
\text { contenção, infra- } \\
\text { estrutura de pontes, } \\
\text { etc }\end{array}$ \\
\hline $\mathrm{C} 2$ & $\begin{array}{l}\text { Agregado reciclado tipo C2 - } \\
\text { Absorção } \leq 5,0 \%\end{array}$ & $\begin{array}{c}\text { Natural ou reciclado } \\
\text { tipo F1 - Absorção } \leq \\
5,0 \%\end{array}$ & 16 a 18 & $\begin{array}{l}\text { Concreto simples, } \\
\text { unidades de } \\
\text { alvenaria, bases de } \\
\text { rodovias, dispositivos } \\
\text { de drenagem, etc }\end{array}$ \\
\hline $\mathrm{C} 3$ & $\begin{array}{c}\text { Agregado reciclado tipo C3 - } \\
\text { Absorção } \leq 7,0 \%\end{array}$ & $\begin{array}{c}\text { Ag. miúdo reciclado } \\
\text { tipo F2 - Absorção } \leq \\
10,0 \%\end{array}$ & $\leq 16$ & $\begin{array}{c}\text { Radiers, } \\
\text { enchimentos, } \\
\text { nivelamentos, etc }\end{array}$ \\
\hline
\end{tabular}

(fonte: Adaptado de Tomosawa e Noguchi (2000, apud TAM et al., 2005))

A norma DIN 4226-100 (2002, apud MÜLLER, 2006) ${ }^{9}$ classifica os agregados reciclados de acordo com a sua composição, estabelece exigências quanto as propriedades físicas e fixa limites de substituições para elementos interiores e exteriores de concreto armado, Tabela 2.8 .

${ }^{9}$ DEUTSCHE INSTITUT FÜR NORMUNG (DIN). DIN 4226-100: aggregates for mortar and concrete part 100: recycled aggregates. Germany, 2002. 
Tabela 2.8 - Composições e campos de aplicação para os agregados reciclados.

\begin{tabular}{|c|c|c|c|c|c|c|c|c|c|c|c|c|}
\hline \multirow{3}{*}{$\begin{array}{l}\text { Tipo de } \\
\text { agregado }\end{array}$} & \multicolumn{6}{|c|}{ Composição(\%) } & \multirow{3}{*}{$\begin{array}{l}\text { Quant. } \\
\text { máxima } \\
\text { de } \\
\text { cloretos } \\
\text { solúveis } \\
\% \text { em } \\
\text { massa }\end{array}$} & \multirow{3}{*}{$\begin{array}{c}\text { Massa } \\
\text { especí- } \\
\text { fica } \\
\text { mínima } \\
\text { dos } \\
\text { agre- } \\
\text { gados } \\
\left(\mathrm{kg} / \mathrm{m}^{3}\right)\end{array}$} & \multirow{3}{*}{$\begin{array}{c}\text { Máxima } \\
\text { absor- } \\
\text { ção de } \\
\text { água, } \\
\text { \% em } \\
\text { massa }\end{array}$} & \multicolumn{3}{|c|}{$\begin{array}{c}\text { Quantidade máxima } \\
\text { de agregados } \\
\text { graúdos reciclados, \% } \\
\text { do total de agregados }\end{array}$} \\
\hline & \multirow{2}{*}{$\begin{array}{c}\text { Concre- } \\
\text { to, } \\
\text { agre- } \\
\text { gado } \\
\text { natural } \\
\end{array}$} & \multirow{2}{*}{ Tijolo } & \multirow{2}{*}{$\begin{array}{c}\text { Pedra } \\
\text { calcá- } \\
\text { rea }\end{array}$} & \multirow{2}{*}{$\begin{array}{l}\text { Outros } \\
\text { minerais } \\
\text { constitu- } \\
\text { intes }^{1}\end{array}$} & \multirow{2}{*}{$\begin{array}{l}\text { Asfal- } \\
\text { to }\end{array}$} & \multirow{2}{*}{$\begin{array}{l}\text { Conta- } \\
\text { minan- } \\
\text { tes }^{2}\end{array}$} & & & & \multicolumn{2}{|c|}{$\begin{array}{l}\text { Concreto } \\
\text { armado }\end{array}$} & \multirow{2}{*}{$\begin{array}{l}\text { Aterros } \\
\text { ou } \\
\text { material } \\
\text { de sub- } \\
\text { base }^{3} \\
\end{array}$} \\
\hline & & & & & & & & & & $\begin{array}{l}\text { el. } \\
\text { Int. }\end{array}$ & $\begin{array}{l}\text { el. } \\
\text { Ext. }\end{array}$ & \\
\hline $\begin{array}{l}1 \text { - agregado } \\
\text { de concreto }\end{array}$ & $\geq 90$ & & 10 & $\leq 2$ & $\leq 1$ & $\leq 0,2$ & 0,4 & 2000 & 10 & 50 & 40 & 100 \\
\hline $\begin{array}{l}2 \text { - agregado } \\
\text { de RCD }\end{array}$ & $\geq 70$ & & 30 & $\leq 3$ & $\leq 1$ & $\leq 0,5$ & 0,4 & 2000 & 15 & 40 & - & 100 \\
\hline $\begin{array}{l}3 \text { - agregado } \\
\text { de alvenaria }\end{array}$ & $\geq 20$ & $\geq 80$ & $\leq 5$ & $\leq 5$ & $\leq 1$ & $\leq 0,5$ & 0,4 & 1800 & 20 & 40 & - & 100 \\
\hline $\begin{array}{l}4 \text { - mistura de } \\
\text { agregados }\end{array}$ & & $\geq 80$ & & $\leq 20$ & & $\leq 1,0$ & 0,4 & 1500 & - & - & - & 100 \\
\hline
\end{tabular}

(fonte: DIN 4226-100 (2002, apud Müller, 2006))

As prescrições do Comitê Alemão para Concreto Armado, segundo Müller (2006), recomendam que as propriedades dos concretos com agregados reciclados sejam similares às propriedades dos concretos com agregados naturais. Além disso, são feitas as seguintes exigências: a) apenas a fração graúda (> $2 \mathrm{~mm}$ ) dos agregados reciclados tipo 1 e 2 pode ser utilizada na produção de concreto estrutural; b) classe máxima de resistência permitida: C30/37; c) os agregados reciclados não podem ser utilizados na produção de concreto leve e protendido; d) a aplicação dos elementos de concreto deve ser feita em ambiente seco ou com baixa umidade; e) as taxas de substituições de agregados naturais por reciclados devem ser diminuídas à medida do aumento da agressividade do ambiente; f) os agregados devem ser produzidos à partir de resíduos com dimensão superior a $3 \mathrm{~mm}$ para evitar a contaminação por materiais finos e leves. Com relação ao controle de qualidade durante o processamento dos resíduos e produção do concreto reciclado recomenda-se: a) inspeção visual; b) avaliação semanal da massa específica e absorção de água do agregado reciclado; c) avaliação da massa específica e ar incorporado do concreto fresco.

$\mathrm{Na}$ Espanha, em novembro de 2002, foi criada uma equipe de trabalho visando revisar as regulamentações normativas de concreto estrutural com a inclusão de materiais reciclados. Segundo Alaejos et al. (2004), na revisão desse código normativo deverão ser incluídas algumas limitações para a utilização de agregados reciclados em concretos estruturais. Os principais pontos são transcritos abaixo: 
- A utilização de agregados reciclados será permitida apenas para os concretos massa e armado, sendo vedado o emprego desses agregados para a produção de concreto protendido;

- Apenas será permitida a utilização de agregados reciclados oriundos de resíduos de concreto; excluindo tipos especiais de concreto, tais como, concreto com agregados leves, concreto reforçado com fibras e concreto produzido com cimentos aluminosos. Nessas recomendações, de acordo com Alaejos et al. (2004), certamente serão incluídos tópicos relacionados à resistência mínima do resíduo de concreto visando garantir a qualidade dos agregados reciclados.

- Como regra geral, apenas a fração graúda reciclada poderá ser utilizada para a produção de concretos estruturais, para níveis de substituição, em massa, de até $20 \%$. Esse limite garante que o concreto reciclado possua propriedades similares ao concreto produzido com agregados naturais.

- O emprego de concreto reciclado, em ambientes agressivos, só será permitido com a adoção de algumas precauções, tais como, estabelecimento de testes complementares, elevação do consumo de cimento e redução da relação água/cimento na mistura.

Os agregados reciclados deverão cumprir as exigências da Tabela 2.9 para 0 emprego em concretos estruturais, conforme as Instruções para Concreto Estrutural (EHE).

Tabela 2.9 - Exigências para os agregados reciclados.

\begin{tabular}{cc}
\hline Propriedade & Limites \\
\hline Quantidade de finos & $\leq 1$ \\
\hline Coeficiente de forma & $\geq 0,2$ \\
\hline Absorção (\%) & $\leq 7$ \\
\hline Perda de massa por Abrasão (\%) & $\leq 40$ \\
\hline Cloretos solúveis em água (\%) & $\leq 1$ \\
\hline Partículas leves (\%) & $\leq 1$ \\
\hline
\end{tabular}

(fonte: adaptada de ALAEJOS et al., 2004)

Segundo Alaejos et al. (2004), o concreto com agregados reciclados somente poderá ser produzido em usinas de concreto pré-misturado; tais locais deverão ser equipados com os seguintes dispositivos:

a) silos independentes para os agregados reciclados; 
b) quando as misturas são produzidas com agregados reciclados saturados, os estoques de agregados reciclados deverão ser providos de sistemas apropriados, tais como, sprinklers que permitirão a manutenção das condições de umidade próximas a condição de saturado superfície seca.

c) O equipamento de mistura deverá possuir velocidade e tempo de mistura ajustado para prevenir a geração de finos provenientes da argamassa aderida ao agregado reciclado.

Na Tabela 2.10, são expostas as recomendações de alguns códigos normativos com relação aos limites de resistência para a aplicação de concretos com agregados reciclados (ALAEJOS et al., 2004).

Tabela 2.10 - Limites de resistência para a utilização de concretos reciclados segundo diferentes códigos normativos.

\begin{tabular}{ccc}
\hline País/Código & $\begin{array}{c}\text { Categoria de resistência (MPa) - } \\
\text { concreto com 100\% de agregados } \\
\text { graúdos reciclados }\end{array}$ & $\begin{array}{c}\text { Categoria de resistência (MPa) - } \\
\text { concreto com 20\% de agregados } \\
\text { graúdos reciclados }\end{array}$ \\
\hline Rilem & 50 & sem limite \\
\hline Hong Kong & 20 & $25-30$ \\
\hline Bélgica & 30 & - \\
\hline Holanda & 45 (corpo-de-prova cúbico) & sem limite \\
\hline Reino Unido & 40 & sem limite \\
\hline Japão (obras civis) & 24 & - \\
\hline Austrália (aplicações não- \\
estruturais)
\end{tabular}

(fonte: adaptada de ALAEJOS et al., 2004)

*Agregado tipo II - agregados graúdos provenientes totalmente de resíduos de concreto

Com relação às propriedades de deformabilidade do concreto, na Tabela 2.11 são apresentados alguns coeficientes de correção quando do emprego de concretos com agregados graúdos reciclados. Esses coeficientes multiplicariam os valores das propriedades obtidas para concretos similares produzidos com agregados naturais (ALAEJOS et al., 2004). 
Tabela 2.11 - Coeficientes de correção para os concretos reciclados segundo diferentes códigos normativos.

\begin{tabular}{|c|c|c|c|c|c|c|}
\hline \multirow[b]{3}{*}{ País/Código } & \multicolumn{6}{|c|}{ Coeficientes de correção para os concretos reciclados } \\
\hline & \multicolumn{2}{|c|}{ Módulo de deformação } & \multicolumn{2}{|c|}{ Retração } & \multicolumn{2}{|c|}{ Fluência } \\
\hline & $\begin{array}{l}100 \% \text { de } \\
\text { agregados } \\
\text { graúdos } \\
\text { reciclados }\end{array}$ & $\begin{array}{l}20 \% \text { de } \\
\text { agregados } \\
\text { graúdos } \\
\text { reciclados }\end{array}$ & $\begin{array}{l}100 \% \text { de } \\
\text { agregados } \\
\text { graúdos } \\
\text { reciclados }\end{array}$ & $\begin{array}{l}20 \% \text { de } \\
\text { agregados } \\
\text { graúdos } \\
\text { reciclados }\end{array}$ & $\begin{array}{l}100 \% \text { de } \\
\text { agregados } \\
\text { graúdos } \\
\text { reciclados }\end{array}$ & $\begin{array}{l}20 \% \text { de } \\
\text { agregados } \\
\text { graúdos } \\
\text { reciclados }\end{array}$ \\
\hline Bélgica & 0,80 & - & 1,50 & 1,00 & 1,25 & 1,00 \\
\hline Holanda & & & $1,35-1,55$ & 1,00 & $1,25-1,45$ & 1,00 \\
\hline Rilem & 0,80 & 1,00 & 1,50 & 1,00 & 1,25 & 1,00 \\
\hline
\end{tabular}

(fonte: adaptada de ALAEJOS et al., 2004)

No Brasil, A NBR 15116 (2004), recentemente publicada, permite o emprego de agregados reciclados de resíduos de construção e demolição em pavimentos e preparação de concreto sem função estrutural nas classes de resistência à compressão C10 e C15.

A NBR 15116 (2004) classifica os agregados reciclados em dois tipos: a) RCA (agregado reciclado de concreto) - agregados reciclados obtidos do beneficiamento de resíduos da Classe $\mathrm{A}$, constituídos de uma fração graúda mínima de 90\%, em massa, de fragmentos compostos por cimento Portland e rochas; b) MRA (agregado reciclado misturado) - agregados reciclados obtidos do beneficiamento de resíduos da Classe $A$, constituídos de uma fração graúda, em massa, inferior a 90\% de fragmentos compostos por cimento Portland e rochas. Para o preparo de concreto reciclado sem função estrutural deve ser realizada a pré-saturação do agregado reciclado, considerando-se valores próximos a $80 \%$ da absorção total do agregado. As principais exigências para os agregados reciclados destinados a produção de concreto sem função estrutural são apresentados na Tabela 2.12. 
Tabela 2.12 - Exigências para os agregados reciclados destinados a produção de concreto não-estrutural.

\begin{tabular}{|c|c|c|c|c|c|c|c|}
\hline \multirow{3}{*}{\multicolumn{2}{|c|}{ Propriedades }} & \multicolumn{4}{|c|}{ Agregado Reciclado - Classe A } & \multicolumn{2}{|c|}{ Normas } \\
\hline & & \multicolumn{2}{|c|}{ RCA } & \multicolumn{2}{|c|}{ MRA } & \multirow{2}{*}{$\begin{array}{l}\text { Agregado } \\
\text { graúdo }\end{array}$} & \multirow{2}{*}{$\begin{array}{l}\text { Agregado } \\
\text { miúdo }\end{array}$} \\
\hline & & miúdo & graúdo & miúdo & graúdo & & \\
\hline \multicolumn{2}{|c|}{$\begin{array}{l}\text { Proporção de fragmentos compostos por } \\
\text { cimento e rochas }\end{array}$} & - & $\geq 90 \%$ & - & $\leq 90 \%$ & - & Anexo B \\
\hline \multicolumn{2}{|c|}{ Absorção (\%) } & $\leq 12 \%$ & $\leq 7 \%$ & $\leq 17 \%$ & $\leq 12 \%$ & $\begin{array}{c}\text { NBR NM } \\
30\end{array}$ & $\begin{array}{c}\text { NBR NM } \\
53\end{array}$ \\
\hline \multirow{5}{*}{$\begin{array}{c}\text { Contaminantes (proporção } \\
\text { máxima em relação a } \\
\text { massa de agregado } \\
\text { reciclado) }\end{array}$} & Cloretos & \multicolumn{4}{|c|}{$\leq 1 \%$} & \multicolumn{2}{|c|}{ NBR 9917} \\
\hline & Sulfatos & \multicolumn{4}{|c|}{$\leq 1 \%$} & \multicolumn{2}{|c|}{ NBR 9917} \\
\hline & $\begin{array}{c}\text { Materiais não- } \\
\text { minerais* }\end{array}$ & \multicolumn{4}{|c|}{$\leq 2 \%$} & Anexo A & Anexo B \\
\hline & $\begin{array}{l}\text { Partículas de } \\
\text { argila }\end{array}$ & \multicolumn{4}{|c|}{$\leq 2 \%$} & \multicolumn{2}{|c|}{ NBR 7218} \\
\hline & $\begin{array}{c}\text { Máxima } \\
\text { proporção de } \\
\text { contaminantes }\end{array}$ & \multicolumn{4}{|c|}{$\leq 3 \%$} & \multicolumn{2}{|c|}{-} \\
\hline \multicolumn{2}{|c|}{ Materiais passando na peneira $0,075 \mathrm{~mm}$} & $\leq 15 \%$ & $\leq 10 \%$ & $\leq 20 \%$ & $\leq 10 \%$ & \multicolumn{2}{|c|}{ NBR NM 46} \\
\hline
\end{tabular}

* madeira, plástico, betume, vidro e materiais carbonizados

(fonte: NBR 15116, 2004)

Oliveira et al. (2004) cita que está em fase de elaboração o texto-base normativo para a aplicação de agregados reciclados de concreto na produção de concretos estruturais. $\mathrm{Na}$ Tabela 2.13, encontram-se algumas exigências para utilização de reciclados na produção de concretos estruturais.

Tabela 2.13 - Exigências para os agregados reciclados em aplicações estruturais.

\begin{tabular}{cc}
\hline \% Máxima de agregados reciclados & $20 \%$ \\
\hline Resistência à compressão média limite aos 28 das & $40 \mathrm{MPa}$ \\
\hline Absorção máxima do agregado reciclado & $7 \%$ \\
\hline Agregado graúdo & $12 \%$ \\
\hline Agregado miúdo & $2300 \mathrm{~kg} / \mathrm{m}^{3}$ \\
\hline Massa específica do agregado reciclado - RCA & \\
\hline Massa específica mínima do agregado reciclado & \\
\hline $\begin{array}{c}\text { Proporção máxima de contaminantes relacionadas à massa } \\
\text { de agregado reciclado }\end{array}$ & $1 \%$ \\
\hline Materiais carbonáceos & $0,35 \%$ \\
\hline Cloretos & $1 \%$ \\
\hline Sulfatos & $1 \%$ \\
\hline Betuminosos & $0,5 \%$ \\
\hline Materiais não-minerais & $0 \%$ \\
\hline Solo e plantas & \\
\hline O somatório dos contaminantes não deve ser maior que $2 \%$ \\
\hline
\end{tabular}

(fonte: Oliveira et al., 2004) 


\subsection{CONCLUSÕES DO CAPÍTULO}

Conforme exposto neste capítulo, os resíduos de concreto (RC) podem ser reciclados por processos simplificados devido à sua maior homogeneidade comparativamente aos $\mathrm{RCD}$, principalmente em se tratando de resíduos de fábricas de prémoldados e usinas de concreto pré-misturado. Para os resíduos oriundos de atividades de construção e demolição, a separação da fase concreto das demais frações é complicada e onerosa devido aos processos de separação comumente empregados. Nesse sentido, é vital que sejam desenvolvidos processos mais eficientes de segregação nos canteiros de obras, novos métodos de separação (via densitária) e eventuais adequações nos projetos visando maximizar o reaproveitamento e reciclagem dos materiais.

A Resolução $N^{0} 307$ do CONAMA (BRASIL, 2002) e outras iniciativas setoriais são instrumentos valiosos para a gestão adequada dos RC e RCD visando minimizar os seus impactos ambientais e econômicos. Desta maneira, a parceria entre os setores público e privado é fundamental para o sucesso no gerenciamento dos resíduos nas cidades brasileiras, uma vez que, de maneira geral, é necessária a implantação de pontos de coleta para os pequenos geradores, criação de áreas (aterros) para a correta deposição dos resíduos e implantação de unidades de reciclagem.

A publicação de novas normas técnicas tratando de resíduos (NBR 15112 a NBR 15116) e o texto-base normativo para aplicações estruturais deverá encorajar o emprego de materiais reciclados em aplicações de maior valor agregado e em mercados mais competitivos. Dentre essas aplicações, a produção de elementos pré-moldados, principalmente blocos de concreto, surge como uma alternativa para absorver o volume de resíduos gerados. Essa opção é particularmente interessante para fábricas de artefatos de concreto que podem reciclar os resíduos de concreto no seu próprio local de geração, garantindo-se a qualidade e homogeneidade do material, para então introduzi-los novamente no processo produtivo. Conforme apresentado no capítulo, podem ser citadas inúmeras aplicações bem-sucedidas do emprego de agregados reciclados de concreto para produção de concreto e elementos pré-moldados. 
Neste capítulo, inicialmente, são apresentados os principais conceitos referentes à produção de blocos de concreto, as principais metodologias de dosagem de blocos de concreto com agregados naturais e reciclados e, finalmente, a revisão de vários trabalhos que avaliaram blocos de concreto com agregados reciclados de RCD e resíduos de concreto (RC). O objetivo principal deste capítulo é fornecer subsídios para a compreensão da metodologia adotada e discussão dos resultados presentes nos capítulos 6 e 7 .

\subsection{BLOCOS DE CONCRETO}

\subsubsection{HISTÓRICO}

De acordo com Medeiros (1993), os blocos de concreto surgiram nos Estados Unidos no final do século XIX. Em 1905, o governo norte-americano adotou o bloco de concreto para construção de hospitais, armazéns, depósitos e quartéis nas obras do Canal do Panamá e nas Filipinas, Lefer (1976 apud MEDEIROS, 1993) ${ }^{10}$. Os blocos de concreto chegaram ao Brasil na década de 50, quando se importou dos Estados Unidos uma máquina para produção desses componentes. Em 1966, foi instalada em São Paulo a primeira fábrica de blocos de concreto de alvenaria estrutural; entretanto, somente na década de 70 esses blocos consolidaram-se no mercado brasileiro, principalmente devido à divulgação das primeiras obras de alvenaria armada em blocos de concreto.

\footnotetext{
${ }^{10}$ LEFER, H. What's new on the old block. Progressive Architecture. v.12, p.82-88, 1976.
} 


\subsubsection{PRODUÇÃO DE BLOCOS DE CONCRETO}

Atualmente, no Brasil, grande parte das fábricas não possui um controle rigoroso sobre o processo produtivo que confira qualidade e segurança para as unidades produzidas. São poucas as fábricas que possuem o selo de qualidade da Associação Brasileira de Cimento Portland (ABCP). De acordo com Frasson Júnior (2000), as metodologias de dosagem existentes são bastante deficientes e dependem fundamentalmente de testes em fábrica.

Os concretos de consistência seca, empregados na produção de blocos, possuem características de um concreto levemente umedecido, sendo necessária a utilização de máquinas que conferem compacidade à mistura para retirada do ar aprisionado. Segundo Frasson Júnior (2000), a qualidade do maquinário e a do processo produtivo são fundamentais para o alcance da resistência e da qualidade desejadas. A resistência dos blocos é proporcional à energia de compactação utilizada na vibração, sendo a eficiência da vibro-prensa a responsável direta pela qualidade final das unidades produzidas. Na Figura 3.1, pode ser observada a influência do tipo de equipamento utilizado na moldagem sobre a resistência à compressão dos blocos (ALBUQUERQUE, 2005).

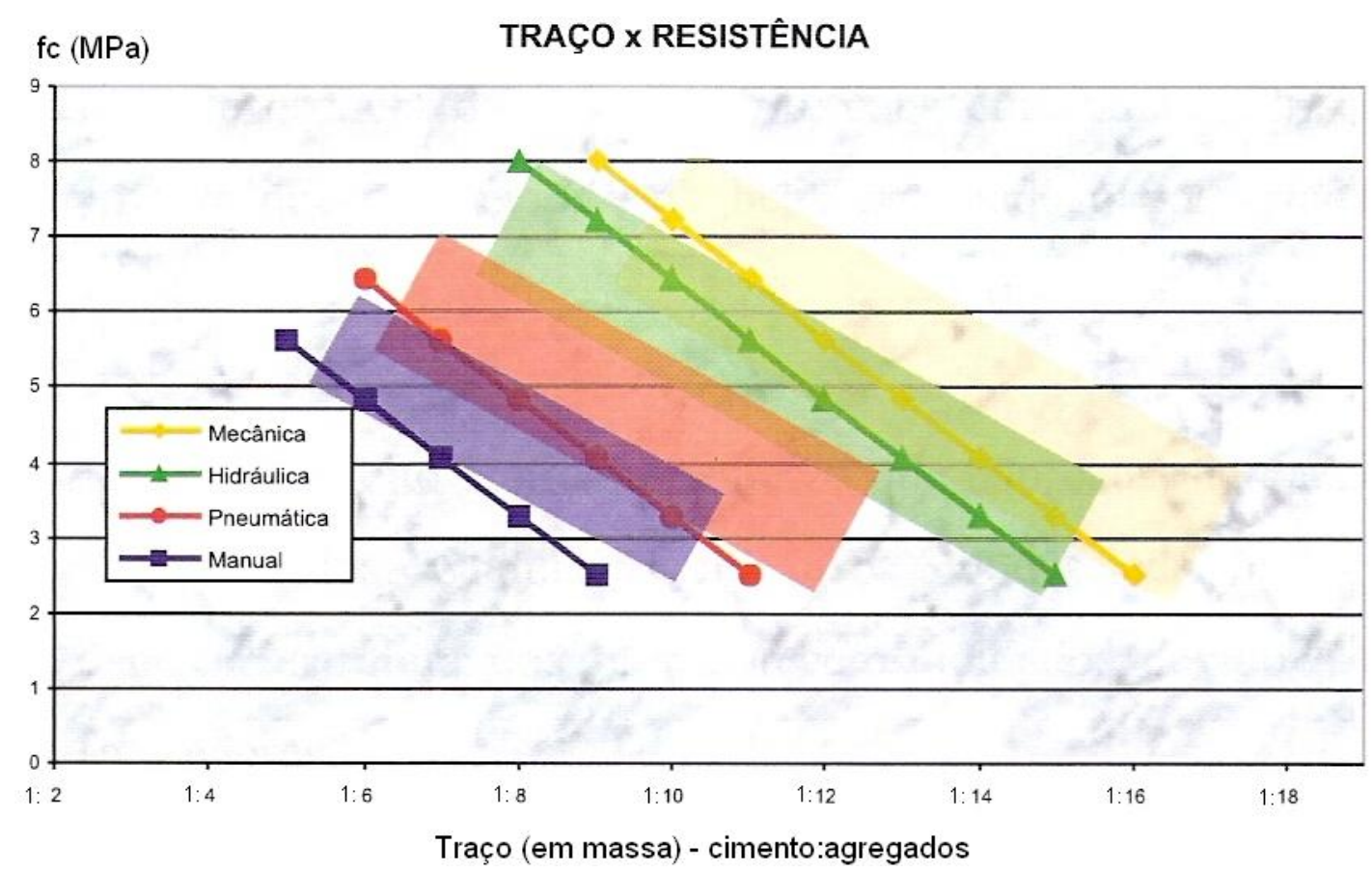

Figura 3.1 - Resistência à compressão dos blocos em função do tipo de vibro-prensa (fonte:

Adaptado de Albuquerque, 2005). 
A umidade alcançada na produção das unidades deve ser a maior possível (6\% a $8 \%$ ), para que as unidades não se esboroem (TANGO, 1994). De acordo com Frasson Junior (2000), para os concretos secos não é válida a Lei de Abrams. Nesse caso, quanto mais água puder ser incorporada à mistura, para uma determinada quantidade de cimento, maior será a resistência e compacidade e maior será a plasticidade que facilitará a prensagem do material nas fôrmas da máquina; entretanto, frisa que se essa quantidade for excessiva, poderão ocorrer problemas de desforma e deformações indesejáveis nas peças durante o transporte. Conforme Tango (1987), a principal fonte de variabilidade no ato do proporcionamento é a variação da umidade dos agregados, sendo que esse fato afeta a compacidade da mistura e a resistência à compressão.

Usualmente, para a fabricação de blocos, são utilizados cimento Portland de alta resistência inicial, agregado miúdo (areia natural/artificial e/ou pó-de-pedra), agregado graúdo (pedrisco) e aditivo plastificante. A utilização do cimento de alta resistência inicial é recomendada, pois acelera a desmoldagem do material. A NBR 6136 (1994) limita a zona de graduação zero para os agregados graúdos na produção dos blocos, uma vez que o agregado não pode possuir grãos com diâmetro superior à metade da espessura da menor parede do bloco. Medeiros (1993) recomenda a utilização de areia de rio, pois se apresenta lavada desde a origem; por outro lado, condena o emprego de resíduos de britagem, denominados de pó-de-pedra. De acordo com o pesquisador, geralmente, tais materiais apresentam grande quantidade de finos com a presença de grãos angulosos de textura áspera; esses agregados geram uma mistura de baixa plasticidade e que exigem uma maior quantidade de água de amassamento. Frasson Júnior (2000) relata que o pó-de-pedra é um material que deve ser avaliado cuidadosamente devido à variação de módulo de finura e à fração passante na peneira de 0,30 mm. O emprego de pó-de-pedra ou areia fina, em maiores porcentagens, é recomendado para traços com baixo consumo de cimento; nesse caso, os finos presentes nesses materiais melhoram a coesão e a textura superficial do bloco.

De acordo com Albuquerque (2005), o emprego de agregados de RCD na produção de blocos de concreto depende fundamentalmente da qualidade dos agregados; entretanto, o RCD, na maioria das vezes, é descartado sem uma prévia separação e, geralmente, encontra-se misturado ao lixo orgânico e a outros tipos de materiais indesejados (substâncias tóxicas ou deletérias), fato esse que dificulta a sua caracterização e utilização. Por outro lado, Poon et al. (2002) citam que a incorporação de agregados reciclados não acarreta um aumento significativo da retração por secagem e fluência das unidades, uma 
vez que, comumente na produção de blocos de concreto, a quantidade de água utilizada na mistura e o consumo de cimento são relativamente baixos.

\subsubsection{METODOLOGIAS DE DOSAGEM}

De acordo com Medeiros (1993), os blocos de concreto devem cumprir os seguintes requisitos: a) coesão no estado fresco; b) máxima compacidade; c) resistência mecânica compatível; d) textura superficial. A composição ideal entre os agregados é um dos primeiros passos para a dosagem dos concretos secos. Esse procedimento baseia-se na formulação de uma mistura com um mínimo de vazios possíveis, visando alcançar as maiores massas unitárias. A busca por um menor volume de vazios visa encontrar uma proporção entre agregados que resulte em uma mistura mais compacta por ter relação direta com a resistência à compressão; além disso, quanto maior a umidade da mistura, para cada teor de cimento, maiores serão as resistências alcançadas; entretanto, caso essa quantidade seja excessiva, poderão ocorrer problemas na desforma (FRASSON JÚNIOR, 2000).

Furnas (1997) cita que a relação pasta/agregado do concreto seco deve ser otimizada, considerando-se o índice de vazios do agregado miúdo, para que se obtenha uma coesão e trabalhabilidade suficientes para uma dada compactação. A relação ideal entre pasta e agregado garante o preenchimento dos vazios do agregado miúdo pela pasta. Nesse procedimento, também deve ser considerado os vazios do agregado graúdo que deverá ser preenchido pela argamassa.

Nos próximos itens serão descritas as principais metodologias de dosagem para concreto seco existentes na literatura. Posteriormente, serão apresentados alguns trabalhos que correlacionaram às propriedades dos blocos através de corpos-de-prova cilíndricos e, finalmente, pesquisas que avaliaram as propriedades das unidades pela extração de CPs do próprio bloco.

\subsubsection{Método da Besser Company}

O método adotado pela Besser Company, fabricante americana de máquinas vibroprensas, baseia-se no ajuste de traço pela granulometria final das misturas, mais especificamente seu módulo de finura. Esse método, que foi muito utilizado pela empresa Encol, inicia-se com uma proporção pré-estabelecida: 40\% de pedrisco e $60 \%$ de areia média, em massa, variando-se essas porcentagens de acordo com a análise granulométrica 
dos materiais. Caso haja deficiência na granulometria (falta de finos), pode-se usar um terceiro material, como por exemplo, uma areia fina, na tentativa de ajustar o módulo de finura final da mistura, que deve ficar entre 3,60 e 3,75. As expressões utilizadas são as seguintes:

$$
X=100 .\left(\frac{A-B}{A-C}\right) \quad(3.1) \quad Y=100-X
$$

onde:

$X=$ porcentagem de agregado miúdo

$\mathrm{Y}=$ porcentagem de agregado graúdo

$A=M . F$. do agregado graúdo

B = M.F. do agregado combinado (graúdo + miúdo)

C $=$ M.F. do agregado miúdo

Para se obter uma granulometria adequada para os blocos de concreto seria desejável que a mistura possuísse uma graduação conforme a Tabela 3.1.

Tabela 3.1 - Porcentagens retidas acumuladas desejáveis na produção de blocos de concreto.

\begin{tabular}{|c|c|c|c|}
\hline Peneiras (mm) & Grupo & Categoria & \% Retida acumulada \\
\hline $\begin{array}{l}4,8 \\
2,4\end{array}$ & 1 & Grosso & $40 \%$ do material \\
\hline 1,2 & & & \\
\hline $\begin{array}{l}0,6 \\
0,3 \\
\end{array}$ & 2 & Médio & $45 \%$ do material \\
\hline $\begin{array}{c}0,15 \\
\text { fundo } \\
\end{array}$ & 3 & Fino & $15 \%$ do material \\
\hline
\end{tabular}

(fonte: Frasson Júnior, 2000)

Segundo Frasson Júnior (2000) há necessidade de agregados com as granulometrias desejadas para utilização deste método. Caso não haja disponibilidade desses agregados, faz-se necessário uma adequação com um terceiro tipo de material para que se enquadre nas faixas granulométricas. Dentre as desvantagens desse método, pode ser citada a não consideração do cimento como material fino que melhoraria a compacidade da mistura.

A partir da análise das proporções mais adequadas de agregados, deve-se executar a produção de traços-piloto a fim de testar a resistência dos blocos. O Manual Poli-Encol (1991) cita traços e ajustes, utilizando-se a máquina Montana MBX 975, para alcançar as resistências desejadas durante os testes. Segundo esse manual, a mistura deve possuir de $6,0 \%$ a $7,5 \%$ de umidade, dependendo do uso de aditivos. A relação cimento/agregado 
depende da resistência à compressão pretendida para os blocos. O manual recomenda as seguintes relações considerando-se um coeficiente de variação igual a 15\%, Tabela 3.2.

Tabela 3.2 - Relação cimento/agregado sugeridos para a produção de blocos de concreto na máquina Montana MBX 975.

\begin{tabular}{c|c|c|c|c}
\hline & \multicolumn{4}{|c}{ Resistência à compressão (MPa) } \\
\cline { 2 - 5 } & $\mathbf{4 , 5}$ & $\mathbf{6 , 0}$ & $\mathbf{8 , 0}$ & $\mathbf{9 , 0}$ \\
\hline $\begin{array}{c}\text { Relação cimento:agregado } \\
\text { (em massa) }\end{array}$ & $1: 9$ a $1: 12$ & $1: 8$ a $1: 10$ & $1: 7$ a $1: 9$ & $1: 6$ a $1: 8$ \\
\hline
\end{tabular}

(fonte: Manual Poli-Encol, 1991)

\subsubsection{2.. Método da $A B C P$}

O método sugerido pela Associação Brasileira de Cimento Portland - ABCP e desenvolvido por FERREIRA (1990) baseia-se na determinação de proporções entre areia e pedrisco que resultem na máxima compacidade da mistura e, conseqüentemente, na maior resistência. O método consiste na comparação de massas que cabem em um recipiente padronizado e de volume conhecido. O procedimento é descrito nos itens subseqüentes:

a) secagem dos agregados - areia e pedrisco.

b) os agregados são previamente misturados e colocados em um recipiente com quadro (colarinho) metálico já adaptado $(40 \mathrm{~cm} \times 40 \mathrm{~cm})$ e de volume conhecido. Procede-se o adensamento, retira-se o quadro, rasa-se e pesa-se. A composição de maior massa será a ideal indicando a máxima compacidade possível.

c) caso haja mais de dois agregados, determina-se a composição com os dois mais graúdos e depois a composição desses agregados com o miúdo.

De acordo com Frasson Júnior (2000), o método ABCP não leva em consideração a granulometria nem as características particulares do agregado, o que resulta, muitas vezes, no alcance de misturas compactas, mas pouco coesivas. Outra deficiência apontada se refere à não inclusão do cimento nos estudos de composição, uma vez que esse material fino é extremamente importante na redução do volume de vazios e, principalmente, na coesão das misturas. A metodologia, segundo Frasson Júnior (2000), também é falha quando se utiliza um terceiro agregado para suprir a necessidade de finos da mistura. Em traços já dosados, quando se utilizou areia fina nas misturas, foram obtidos resultados que conduziam a um consumo excessivo desse agregado para o menor volume de vazios com conseqüente redução da resistência mecânica dos blocos (alta superfície específica do material demandando quantidades elevadas de água e pasta de cimento). 


\subsubsection{Método de dosagem do menor volume de vazios}

O Método de Dosagem do Menor Volume de Vazios para misturas secas é baseado no ensaio de massa unitária do agregado, consistindo da comparação de misturas de areia e pedrisco, que cabem em um recipiente padronizado, de volume conhecido (RODRIGUES, 1995). Para se efetuar o ensaio deve-se respeitar o seguinte procedimento:

- Secagem prévia dos agregados.

- Produção de misturas homogeneizadas contendo quantidades variáveis dos dois componentes $(30 \%, 40 \%, 50 \%, 60 \%, 70 \%$ e $80 \%$ de massa de areia em relação à massa total do agregado).

- Lançamento das diferentes misturas no recipiente cilíndrico, em três camadas iguais, compactando cada uma com 25 golpes da haste, com a ponta arredondada voltada para baixo. Compactada a última camada e rasado o material excedente, pesa-se o recipiente cheio.

Com base nesses dados, traça-se uma curva para determinar o ponto ótimo da mistura, onde a proporção de agregado obtém o menor volume de vazios. A determinação do volume de vazios é dada pela expressão (3.3):

$$
V_{\text {vazios }}=\frac{\left[V_{\text {rec }}-\left(\frac{\%_{\text {areia }} \times M}{100 \times d_{\text {areia }}}+\frac{\%_{\text {pedrisco }} \times M}{100 \times d_{\text {pedrisco }}}\right)\right]}{V_{\text {rec }}} \times 100
$$

onde:

d - massa específica dos agregados

M - massa da composição necessária

$\mathrm{V}_{\text {rec }}$ - volume do recipiente

\% - proporção dos materiais na composição

A relação entre as massas de agregado e cimento, segundo RODRIGUES (1995), depende, principalmente, do equipamento de moldagem, sendo essa relação baixa quando a energia de adensamento for pequena, indicando alto consumo de cimento. Caso contrário, quando há disponibilidade de um equipamento capaz de fornecer energia de adensamento elevada, a relação entre as massas de agregado e cimento é maior conduzindo a um menor consumo de cimento por unidade. Além disso, as máquinas com graus de compactação 
elevados são capazes de produzir unidades que cumpram com outros requisitos normativos, tais como absorção, textura e retração (FRASSON JÚNIOR, 2000).

\subsubsection{Método IPT/EPUSP}

Segundo Tango (1994) para cada traço de concreto, a compacidade da mistura fresca é função do equipamento, do procedimento de moldagem e do teor de água/materiais secos. Para cada traço de concreto há um teor ótimo de água/materiais secos ( $\left.\mathrm{H}_{\text {ót }}\right)$ que corresponde à massa unitária máxima.

O método proposto baseia-se nas seguintes premissas:

1. Ajuste dos agregados - recomenda-se utilizar agregados com $D_{\text {máx }}$ inferior à metade da menor espessura de parede dos blocos. Para a definição das proporções entre agregados graúdos e miúdos deve-se escolher aquela que proporcione a maior massa unitária.

2. Estabelecimento da resistência média visada ou resistência de dosagem - que será função da resistência característica requerida e do desvio padrão da produção (3.4).

$$
f_{b d, j}=f_{b k, j}+k_{n t} \cdot s
$$

onde:

$f_{b d, j}$ : resistência média visada ou resistência de dosagem

$f_{b k, j}$ : resistência característica requerida

$\mathrm{k}_{\mathrm{nt}} \mathrm{s}$ : desvio padrão da produção

$\mathrm{Na}$ Tabela 3.3, são fornecidos os valores do produto $\mathrm{k}_{\mathrm{nt}} \mathrm{s}$ em função do controle da produção e da resistência requerida para os blocos.

Tabela 3.3 - Valores sugeridos para $\left(\mathrm{k}_{\mathrm{n}} \cdot \mathrm{S}\right)$ em função do controle da produção.

\begin{tabular}{|c|c|c|c|c|c|c|}
\hline \multirow{2}{*}{$\begin{array}{c}\text { Conceito de } \\
\text { controle }\end{array}$} & \multicolumn{6}{|c|}{$\left(\mathrm{k}_{\mathrm{nt}} \cdot \mathrm{s}\right)(\mathrm{MPa})$, para $\mathrm{f}_{\mathrm{bk}}:$} \\
\hline & $>10 \mathrm{Mpa}$ & $9 \mathrm{Mpa}$ & $8 \mathrm{Mpa}$ & $7 \mathrm{Mpa}$ & $6 \mathrm{Mpa}$ & 4,5 MPa \\
\hline Rigoroso & 3,5 & 3,2 & 2,8 & 2,4 & 2,1 & 1,6 \\
\hline Razoável & 4,5 & 4,2 & 3,8 & 3,4 & 3,1 & 2,6 \\
\hline
\end{tabular}

3. Estimativa dos teores agregado/cimento $(m)$ - definição de pelo menos três traços de concreto, denominados de "rico", "médio" e "pobre". O objetivo é que a resistência 
média visada, na idade de interesse, esteja dentro do campo de variação das resistências obtidas com os traços avaliados.

4. Determinação da proporção de argamassa e da umidade ótima do traço médio produzir blocos de concreto variando-se o teor de argamassa e escolher por aquela que apresentar no estado fresco as seguintes características: bom aspecto superficial dos blocos, massa unitária mais elevada e trabalhabilidade. A quantidade de água deve ser a maior possível, suficiente para que os blocos não esboroem. Normalmente, segundo Tango (1994), a umidade ótima é a que permite moldar uma pelota de concreto nas palmas das mãos, sem que esta se esboroe (falta de água) ou suje excessivamente as mãos (excesso de água).

5. Produção das misturas experimentais.

\subsubsection{Método de dosagem da composição granulométrica}

O Método de Dosagem da Composição Granulométrica é baseada na metodologia adotada pelo Departamento Nacional de Estradas de Rodagem (1996 apud SILVEIRA et al., $2004)^{11}$. Segundo essa metodologia, a mistura final deve apresentar uma granulometria densa, isto é, com o máximo de empacotamento dos grãos da mistura. Para o cálculo das curvas limites relacionadas à granulometria densa da mistura é utilizada a equação (3.5):

$$
P R=100-100 \times\left(\frac{d}{D}\right)^{n}
$$

onde:

PR: porcentagem, em massa, que fica retida na peneira de diâmetro 'd'

D: diâmetro máximo

d: diâmetro da peneira desejada

$\mathrm{n}$ : constante

A mistura pode ser considerada de granulometria densa quando sua curva granulométrica se enquadrar entre as curvas de " $n=0,35$ " e "n=0,55". A equação é denominada de Füller quando "n=0,50". Na Tabela 3.4, são apresentados os valores limites para que a mistura seja de granulometria densa (SILVEIRA et al., 2004).

11 DEPARTAMENTO NACIONAL DE ESTRADAS DE RODAGEM - DNER. Manual de pavimentação. $2^{\circ}$ edição. Rio de Janeiro: Departamento Nacional de Estradas de Rodagem, 1996. $320 p$. 
Tabela 3.4 - Valores limites para que a mistura seja de granulometria densa.

\begin{tabular}{cccc}
\hline Peneiras $(\mathbf{m m})$ & $\begin{array}{c}\text { Curva limite inferior } \\
(\mathbf{n}=\mathbf{0}, \mathbf{3 5})\end{array}$ & $\begin{array}{c}\text { Curva limite superior } \\
(\mathbf{n}=\mathbf{0 , 5 5})\end{array}$ & $\begin{array}{c}\text { Curva de Füller } \\
(\mathbf{n}=\mathbf{0 , 5 0})\end{array}$ \\
\hline 9,50 & 0,00 & 0,00 & 0,00 \\
\hline 6,35 & 13,15 & 19,87 & 18,24 \\
\hline 4,80 & 21,25 & 31,30 & 28,92 \\
\hline 2,40 & 38,22 & 53,08 & 49,74 \\
\hline 1,20 & 51,53 & 67,95 & 64,46 \\
\hline 0,60 & 61,97 & 78,11 & 74,87 \\
\hline 0,30 & 70,16 & 85,05 & 82,23 \\
\hline 0,15 & 76,59 & 89,79 & 87,43 \\
\hline fundo & 100,00 & 100,00 & 100,00 \\
\hline
\end{tabular}

(fonte: Silveira et al., 2004)

\subsubsection{Método de dosagem da Columbia}

O método sugerido pela Columbia, fabricante norte-americana de vibro-prensas, considera as características dos agregados e de que maneira estes influenciam na produção, nas características dos blocos e na mistura. A seguir serão apresentados, conforme essa metodologia, os fatores que influenciam na escolha dos agregados e as proporções consideradas ideais para produção de artefatos de concreto (FRASSON JÚNIOR, 2000):

a) Resistência à compressão: a granulometria dos agregados influi de maneira decisiva no consumo de cimento das misturas para uma dada resistência.

b) Textura: dependerá, em grande parte, da granulometria dos agregados. Agregados mais grosseiros tenderão a produzir blocos de textura mais grossa e agregados finos (miúdos) produzirão blocos de textura mais lisa.

c) Porosidade: depende da granulometria dos agregados, sendo que essa característica está ligada a resistência à compressão, isolamento térmico e acústico.

d) Trabalhabilidade: a trabalhabilidade das misturas é influenciada pela granulometria, características da superfície e formato dos agregados.

e) Disponibilidade: a disponibilidade e homogeneidade dos agregados miúdos e graúdos são fundamentais para o controle do processo de produção e qualidade final dos artefatos.

Com relação à granulometria dos agregados, a combinação de agregados graúdos e miúdos deve possuir o total passante na peneira $9,5 \mathrm{~mm}$ e $20 \%$ a $30 \%$ do total retido na 
4,8mm. O conceito de módulo de finura ótimo para cada tipo de mistura foi introduzido por Wilk (1947 apud FRASSON JÚNIOR, 2000) ${ }^{12}$, a partir de ensaios com corpos-de-prova cilíndricos utilizando concreto de consistência seca. Em seus ensaios, a proporção de pedrisco e areia grossa foi mantida constante enquanto que a quantidade de areia fina foi variada para compor misturas de M.F. de 3,02 a 4,30. O aumento do M.F. de 3,02 para 3,88 acarretou um aumento de $137 \%$ na resistência à compressão; já para valores de M.F. superiores a 3,88, ocorreu um decréscimo da resistência, Figura 3.2.

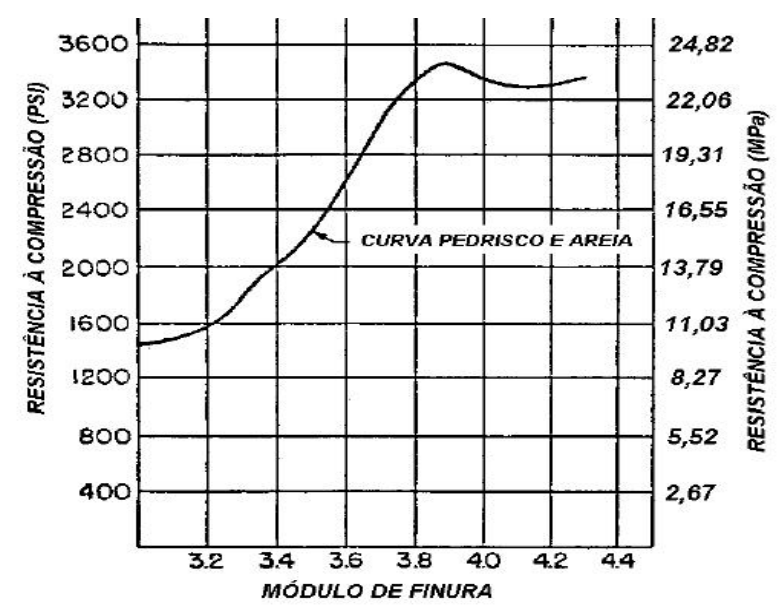

Figura 3.2 - Relação entre módulo de finura (M.F.) e resistência à compressão em corposde-prova (fonte: Frasson Júnior, 2000).

O autor recomenda que a quantidade mínima de finos seja de $12 \%$ a $15 \%$, em volume, passantes na peneira 0,3 $\mathrm{mm}$, com relação a mistura total (incluindo o cimento). Essa quantidade de finos produzirá misturas com boa trabalhabilidade, facilidade de compactação e coesão; por outro lado, porcentagens menores aumentarão a porosidade, absorção, permeabilidade e diminuirão a estabilidade do bloco verde; já percentagens maiores poderão afetar a resistência mecânica dos blocos. De acordo com Leite (2001), para dosagens envolvendo agregados reciclados, os limites devem ser especificados em volume, uma vez que o agregado reciclado apresenta massa específica inferior à do agregado natural. Desta maneira, se ocorresse substituição da massa de agregado natural por agregado reciclado, o volume de argamassa do material reciclado seria maior,

${ }^{12}$ WILK, B. Influence of grading on strength of concrete. Rock Products, p. 169-170, fev. 1947. 
necessitando de maior quantidade de água e cimento para produzir misturas equivalentes à mistura de referência, em consistência e resistência mecânica.

$\mathrm{Na}$ Tabela 3.5, são apresentadas as porcentagens retidas acumuladas e as texturas recomendadas para a produção de blocos de concreto.

Tabela 3.5 - Composições granulométricas recomendadas para a produção de blocos de concreto.

\begin{tabular}{cccc}
\hline Peneira $(\mathbf{m m})$ & \multicolumn{2}{c}{ Porcentagem retida acumulada por volume para várias texturas de blocos } \\
\hline & Fina & Média & Grossa \\
\hline 9,5 & 0 & 0 & 0 \\
\hline 4,8 & 21 & 25 & 30 \\
\hline 2,4 & 36 & 40 & 50 \\
\hline 1,2 & 51 & 55 & 67 \\
\hline 0,6 & 66 & 70 & 81 \\
\hline 0,3 & 82 & 85 & 91 \\
\hline 0,15 & 94 & 95 & 98 \\
\hline M.F. & 3,50 & 3,70 & 4,17
\end{tabular}

(fonte: Frasson Júnior, 2000)

A próxima etapa da metodologia refere-se à produção de concretos que variem a porcentagem de agregados graúdos, entre $25 \%$ e $55 \%$, do total de agregados, e distintas proporções de cimento (1:6 a 1:11). Normalmente, a máxima resistência, para um dado consumo de cimento, é obtida para porcentagens de até $40 \%$ de agregados graúdos na mistura. Por outro lado, misturas com grande quantidade de finos e elevada superfície específica necessitarão de grande quantidade de pasta de cimento.

Segundo a metodologia, caso ocorra deficiência de finos na mistura, os blocos apresentarão falhas na sua superfície e possibilidade de quebras durante o transporte. Nesse caso, o problema pode ser corrigido das seguintes maneiras: aumento das proporções de agregado miúdo, utilização de pó-de-pedra, incorporadores de ar, entre outros.

Nos próximos itens, serão descritos resumidamente alguns trabalhos que buscaram correlacionar as propriedades dos blocos através de corpos-de-prova cilíndricos. Os ensaios com corpos-de-prova cilíndricos possibilitam a avaliação de inúmeras variáveis intervenientes no processo de produção de blocos com extrema facilidade e reprodutibilidade; caso contrário, o processo tradicional de produção de diversos traços de blocos para a avaliação das propriedades físicas e mecânicas seria extremamente dispendioso e praticamente inviável. 


\subsubsection{Procedimento proposto por Maia (2002)}

Maia et al. (2002) buscaram correlacionar pela massa específica do concreto no estado fresco, as propriedades de corpos-de-prova cilíndricos $(10 \mathrm{~cm} \times 20 \mathrm{~cm})$ com correspondentes blocos de concreto. O processo foi dividido em duas etapas. Inicialmente, os corpos-de-prova foram preenchidos em três camadas de espessuras praticamente iguais e mais uma camada suplementar, sendo que cada camada era previamente compactada com auxílio de um peso de massa igual a $4,0 \mathrm{~kg}$, aplicando-se um número distinto de golpes em cada camada visando assegurar a regularidade, distribuição do material em camadas e manter o mesmo grau de compactação. A segunda etapa consistia na colocação de um disco de aço sobre a última camada e aplicação de uma carga de 0,67 kN/min até atingir 90 kN. O intuito da adoção desse procedimento foi obter valores de massa específica no estado fresco que fossem próximos daqueles alcançados no processo de fabricação dos blocos; permitindo, dessa maneira, correlacionar as resistências dos corpos-de-prova com as resistências dos blocos. Os pesquisadores concluíram que os CPs apresentaram resultados superiores de resistência à compressão quando comparados aos blocos, devido a influência da geometria dos blocos.

\subsubsection{Procedimento proposto por Frasson Júnior (2000)}

Frasson Júnior (2000) avaliou inúmeras variáveis fundamentais para o alcance de resistências e características especificadas para os blocos, tais como, resistência à compressão, coesão e textura das misturas. Dentro desse propósito, foram avaliadas as misturas e proporções mais adequadas para blocos de concreto através do emprego de corpos-de-prova cilíndricos $(5 \mathrm{~cm} \times 10 \mathrm{~cm})$. Com a moldagem e testes desses corpos-deprova, foi possível obter valores de resistência, coesão e avaliação visual da textura.

Pelo ensaio de coesão proposto pelo pesquisador, foi avaliada a resistência à desagregação relativa à compressão diametral de corpos-de-prova recém-moldados, Figura 3.3. 


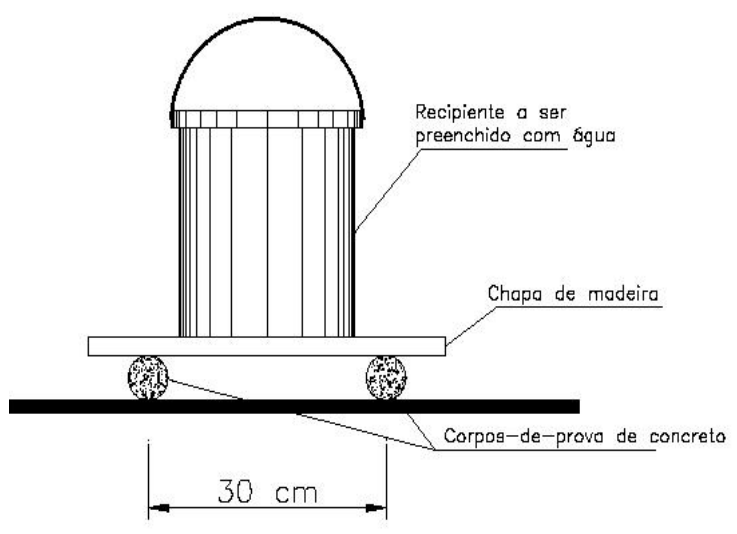

Figura 3.3 - Equipamento utilizado no ensaio para a determinação da coesão das misturas (fonte: Frasson Júnior, 2000).

De acordo com Frasson Júnior (2000), esse ensaio possibilita a modificação da proporção das misturas de modo a adequar a coesão para produção de blocos de concreto. De acordo com o pesquisador, valores de coesão superiores a 6,0 kg significam que as misturas são apropriadas para a produção de blocos de concreto. O programa experimental do pesquisador resumiu-se em duas etapas que são descritas conjuntamente com seus resultados:

- $1^{a}$ etapa, em fábrica, à medida da produção dos blocos, retirava-se uma amostra de concreto e moldavam-se os corpos-de-prova, que posteriormente eram colocados na cura térmica, juntamente com os blocos de sua série. Para garantir que os corposde-prova tivessem a mesma massa específica dos blocos, os blocos recémmoldados eram pesados e seu volume determinado para o cálculo da massa específica que serviria de parâmetro para os corpos-de-prova. Os resultados indicaram que a proporção entre a resistência dos corpos-de-prova e blocos, para os traços e geometrias testados, situou-se em torno de $80 \%$.

- $2^{a}$ etapa, em laboratório, com o objetivo de avaliar o comportamento dos traços, granulometrias, agregados e umidades distintas. Nessa etapa, variou-se a umidade e a massa específica dos corpos-de-prova e verificou-se, na ruptura do material, se realmente esses parâmetros, juntamente com a distribuição granulométrica dos diferentes traços influenciaram na resistência mecânica. Os resultados mais significativos obtidos pelo autor foram os seguintes: a) elevação da massa específica - à medida que as misturas íam tendo seu módulo de finura diminuído e o consumo de cimento aumentado, o volume de vazios diminuiu, tornando as misturas mais compactas e densas; b) as misturas pouco coesivas apresentaram menor massa específica, menor consumo de cimento e módulo de finura superiores; de maneira 
geral, eram misturas contendo poucos finos e também pouco compactas; c) a umidade da mistura foi diretamente proporcional a massa específica dos corpos-deprova; o aumento da umidade da mistura acarretou elevação da trabalhabilidade e aumento da massa incorporada nos corpos-de-prova.

\subsubsection{Procedimento utilizado por Souza (2002)}

Souza et al. (2002) investigaram a incorporação de agregados reciclados de RCD na produção de blocos de concreto. A definição dos parâmetros de mistura e avaliação das propriedades foi realizado em corpos-de-prova cilíndricos $(10 \mathrm{~cm} \times 20 \mathrm{~cm})$ moldados em uma mesa vibratória em condições de adensamento similares a da vibro-prensa utilizada na moldagem dos blocos de concreto. Posteriormente, com as séries que apresentaram os melhores resultados, foram produzidos blocos de concreto, sendo avaliadas às propriedades de massa específica, absorção de água e resistência à compressão. Como considerações finais, os autores citam a influência dos agregados reciclados nas propriedades dos blocos; para substituições de 30\% a 50\% de agregados reciclados (graúdo + miúdo), em relação à quantidade total de materiais, os resultados de resistência à compressão e absorção de água não estiveram em acordo com as recomendações normativas para blocos de vedação; já para a série, com substituição de $40 \%$ do material natural por agregado graúdo reciclado, os resultados apresentaram-se dentro dos limites especificados.

\subsubsection{Procedimento proposto por Barbosa (2004)}

Barbosa (2004) cita a necessidade de uma maior padronização dos corpos-de-prova para que se encontre uma adequada correlação com os blocos de concreto. Em relação ao processo de adensamento, relata a importância do pleno conhecimento da técnica com o objetivo de obter uma energia de adensamento próxima daquela que os blocos são submetidos na vibro-prensagem. Diante disso, o pesquisador produziu corpos-de-prova e blocos de concreto, com concreto plástico de consistência usual, em três níveis de resistência, em condições semelhantes de moldagem e adensamento. A finalidade principal foi correlacionar às propriedades mecânicas dos corpos-de-prova com as obtidas em ensaios de blocos isolados.

Os resultados mostraram que os valores de resistência à compressão obtidos em corpos-de-prova $10 \mathrm{~cm} \times 20 \mathrm{~cm}$ e $15 \mathrm{~cm} \times 30 \mathrm{~cm}$ foram os que mais se aproximaram da resistência à compressão do bloco de concreto, em relação à sua área líquida. Os corposde-prova $5 \mathrm{~cm} \times 10 \mathrm{~cm}$ apresentaram valores de resistência e módulo de elasticidade superiores aos obtidos pelos blocos de concreto, Tabela 3.6. 
Tabela 3.6 - Correlação da resistência à compressão de blocos e corpos-de-prova.

\begin{tabular}{|c|c|c|c|}
\hline Corpo-de-prova & Dimensões & Bloco & $\begin{array}{l}\text { Relação corpo-de- } \\
\text { prova/bloco }\end{array}$ \\
\hline \multirow{3}{*}{$\begin{array}{l}\text { Moldados com concreto } \\
\text { plástico }\end{array}$} & $5 \times 10 \mathrm{~cm}$ & \multirow{3}{*}{$\begin{array}{l}\text { Concreto } \\
14 \times 19 \times 39\end{array}$} & $1,13-1,31$ \\
\hline & $10 \times 20 \mathrm{~cm}$ & & $1,03-1,16$ \\
\hline & $15 \times 30 \mathrm{~cm}$ & & $0,92-1,03$ \\
\hline
\end{tabular}

(fonte: Barbosa, 2004)

A justificativa para as diferentes relações entre a resistência do corpo-de-prova e bloco deveu-se basicamente a geometria do corpo-de-prova. Para as unidades com menor relação altura-espessura foram obtidos os maiores valores de resistência, devido ao maior confinamento exercido pelas placas de ensaio sobre o elemento. Segundo Barbosa (2004), quanto menor a altura dos CPs, maior será a resistência obtida em função das menores dimensões e, consequentemente, menor será a probabilidade da presença de falhas no concreto.

Finalmente, serão apresentados na Tabela 3.7, resultados de pesquisas que buscaram correlacionar às propriedades dos blocos através da extração de corpos-de-prova das paredes do bloco.

Tabela 3.7 - Pesquisas que correlacionaram a resistência à compressão de blocos e CPs.

\begin{tabular}{|c|c|c|c|c|}
\hline Pesquisador & Corpo-de-prova & Dimensões & Bloco & $\begin{array}{l}\text { Relação } \\
\text { CP/bloco }\end{array}$ \\
\hline $\begin{array}{c}\text { Becica e Harris (1983 } \\
\text { apud BARBOSA, } \\
2004)^{13}\end{array}$ & $\begin{array}{c}\text { Prismáticos extraídos } \\
\text { do bloco }\end{array}$ & $\begin{array}{c}1: 1 \text { a } 2: 1 \\
\text { (altura:largura) }\end{array}$ & $\begin{array}{c}\text { Vazado de } \\
\text { concreto } \\
(20 \times 20 \times 39 \mathrm{~cm})\end{array}$ & 1,22 \\
\hline \multirow{2}{*}{ Ganzerli et al. (2003) } & $\begin{array}{c}\text { Prismáticos extraídos } \\
\text { do topo do bloco }\end{array}$ & \multirow{2}{*}{$\begin{array}{c}1: 2: 4 \\
\text { (altura:espessura: } \\
\text { comprimento) }\end{array}$} & \multirow{2}{*}{$\begin{array}{c}\text { Vazado de } \\
\text { concreto } \\
(20 \times 20 \times 39 \mathrm{~cm})\end{array}$} & 1,41 \\
\hline & $\begin{array}{c}\text { Prismáticos extraídos } \\
\text { da base do bloco }\end{array}$ & & & 1,12 \\
\hline \multirow{2}{*}{ Marzahn (2003) } & \multirow{2}{*}{$\begin{array}{l}\text { Cilíndricos extraídos do } \\
\text { bloco }\end{array}$} & \multirow{2}{*}{$10 \times 20 \mathrm{~cm}$} & $\begin{array}{c}\text { Maciço, sílico } \\
\text { calcário } \\
\text { 23,8x24×50 cm } \\
\end{array}$ & $0,61-0,66$ \\
\hline & & & $\begin{array}{l}\text { Maciço, concreto } \\
\text { auto-clavado } \\
20 \times 24 \times 50 \mathrm{~cm}\end{array}$ & $0,86-0,95$ \\
\hline
\end{tabular}

(fonte: conforme citado na Tabela)

\subsubsection{BLOCOS DE CONCRETO COM AGREGADOS RECICLADOS}

Recentemente, alguns pesquisadores avaliaram a incorporação de agregados reciclados de RCD e resíduos de concreto na produção de blocos de concreto, De Pauw

${ }^{13}$ BECICA, I. J.; HARRIS, H. G. Behavior of hollow concrete masonry prisms under axial load and bending. The Masonry Society Journal, v. 2., n. 2, p. T1-T26, jan. - jun. 1983. 
(1980 apud SOUZA, 2001)1; Pollet et al. (1997), Pimienta et al. (1998), Souza et al. (2002), Fonseca (2002), Poon et al. (2002), Albuquerque (2005), Farias et al. (2005), Soutsos et al. (2005) e Patto e Oliveira (2006). Apesar de tratar-se de uma iniciativa ecologicamente correta e que está em sintonia com as novas legislações ambientais e códigos normativos, o uso de materiais reciclados exige diversos cuidados, principalmente com relação à composição do próprio agregado reciclado que pode apresentar contaminantes e substâncias deletérias ao emprego da fração miúda do agregado reciclado. Acrescenta-se a isso, o fato que a elevada porcentagem de agregados reciclados na mistura pode conduzir a um aumento significativo da absorção de água, diminuição da coesão e aumento da retração por secagem das unidades.

De Pauw (1980 apud SOUZA, 2001) $)^{1}$ avaliou a substituição de agregados naturais por agregados reciclados de RCD na produção de blocos de concreto. Para todas as composições, foi mantida uma determinada porcentagem de agregado miúdo natural; a quantidade de água foi definida visualmente pela experiência do operador de moldagem. Os resultados bem como as composições de cada traço encontram-se na Tabela 3.8.

Tabela 3.8 - Composições de cada traço e resultados de resistência à compressão.

\begin{tabular}{|c|c|c|c|c|c|c|}
\hline \multirow{3}{*}{ Séries } & \multicolumn{5}{|c|}{ Consumo estimado de materiais $\left(\mathrm{kg} / \mathrm{m}^{3}\right)$} & \multirow{3}{*}{$\begin{array}{c}\text { Resistência à } \\
\text { compressão }-\mathrm{f}_{\mathrm{c} 28} \\
\text { (MPa) }\end{array}$} \\
\hline & \multirow{2}{*}{ Cimento } & \multirow{2}{*}{$\begin{array}{l}\text { Areia } \\
\text { Natural }\end{array}$} & \multirow{2}{*}{$\begin{array}{l}\text { Agregado } \\
\text { graúdo } \\
\text { natural }\end{array}$} & \multicolumn{2}{|c|}{$\begin{array}{l}\text { Agregados } \\
\text { reciclados }\end{array}$} & \\
\hline & & & & $\begin{array}{l}0-25 \\
(\mathrm{~mm})\end{array}$ & $\begin{array}{c}3-12 \\
(\mathrm{~mm})\end{array}$ & \\
\hline Referência & 265 & 530 & 1590 & - & - & 3,7 \\
\hline 1 & 245 & 730 & - & 1220 & - & 2,2 \\
\hline 2 & 315 & 630 & - & 1260 & - & 3,3 \\
\hline 3 & 211 & 845 & - & 845 & - & 2,9 \\
\hline 4 & 190 & 570 & - & - & 1145 & 4,1 \\
\hline 5 & 210 & 630 & - & - & 1050 & 7,0 \\
\hline 6 & 211 & 845 & - & - & 845 & 2,1 \\
\hline
\end{tabular}

(fonte: Adaptado de De Pauw, 1980)

Segundo o pesquisador, para as substituições com agregados graúdos e miúdos reciclados, observou-se uma redução na resistência que variou entre 10\% e 40\% comparativamente à dosagem de referência; já para as dosagens com apenas a fração

\footnotetext{
${ }^{1}$ DE PAUW (1980). Recyclage dês decombres d'une ville sinistree. CSTC Revue, n.4, p.12-28, dez.
} 
graúda reciclada, foi notado um ligeiro aumento nos valores de resistência em relação à composição de referência.

Pollet et al. (1997) produziram blocos vazados de concreto $(19 \mathrm{~cm} \times 19 \mathrm{~cm} \times 39 \mathrm{~cm})$, em duas diferentes fábricas, utilizando, separadamente, agregados reciclados de concreto e agregados reciclados de alvenaria cerâmica. Essas fábricas diferenciavam-se entre si apenas pela energia de vibração utilizada na produção das unidades.

Segundo os autores, para os blocos produzidos sob uma menor energia de vibração, nenhuma das dosagens apresentou valores de absorção inferiores ao recomendado pela NBN B21-001 (1998) que fixa em 8\% o índice de absorção. Apesar disso, os pesquisadores salientam que a produção de blocos de concreto com agregados reciclados é possível, desde que sejam tomadas algumas precauções quanto ao uso dessas unidades em paredes externas ou subsolos.

Pimienta et al. (1998) produziram blocos vazados de concreto $(20 \mathrm{~cm} \times 20 \mathrm{~cm} \times 50$ $\mathrm{cm})$ com agregados graúdos reciclados de RCD. As propriedades avaliadas foram: resistência à compressão, massa específica, variação dimensional, absorção capilar e resistência à compressão de paredes. Em estudo preliminar, os autores verificaram que a utilização da fração graúda e miúda reciclada poderia acarretar uma redução de até $50 \%$ na resistência à compressão e um aumento de 2,5 vezes na retração por secagem. Os pesquisadores estabeleceram cinco dosagens com agregados reciclados variando-se apenas o consumo de cimento, Tabela 3.9. Nesta Tabela, também são apresentados os principais resultados obtidos. 
Tabela 3.9 - Dosagens utilizadas na produção de blocos de concreto e principais resultados.

\begin{tabular}{|c|c|c|c|c|c|c|}
\hline & \multicolumn{6}{|c|}{ Dosagens } \\
\hline & Ref & Rec - A & Rec- B & Rec - C & Red - D & Rec - E \\
\hline Consumo de cimento $\left(\mathrm{kg} / \mathrm{m}^{3}\right)$ & 107,5 & $\begin{array}{c}125 \\
(+11 \%)^{a}\end{array}$ & $\begin{array}{c}130 \\
(+14,5 \%)^{\mathrm{a}}\end{array}$ & $\begin{array}{c}135 \\
(+17,7 \%)^{\mathrm{a}}\end{array}$ & $\begin{array}{c}140 \\
(+20,9 \%)^{a} \\
\end{array}$ & $\begin{array}{c}145 \\
(+24,2 \%)^{a} \\
\end{array}$ \\
\hline $\begin{array}{l}\text { Agregado miúdo natural - kg (0- } \\
6 \mathrm{~mm})\end{array}$ & - & $\begin{array}{c}597 \\
(70 \%)^{b}\end{array}$ & $\begin{array}{c}595 \\
(70 \%)^{b}\end{array}$ & $\begin{array}{l}593,5 \\
(70 \%)^{b}\end{array}$ & $\begin{array}{c}592 \\
(70 \%)^{b}\end{array}$ & $\begin{array}{l}590,5 \\
(70 \%)^{\mathrm{b}}\end{array}$ \\
\hline $\begin{array}{l}\text { Agregado graúdo reciclado - } \mathrm{kg} \\
(6-12 \mathrm{~mm})\end{array}$ & - & $\begin{array}{c}261 \\
(30 \%)^{b}\end{array}$ & $\begin{array}{c}260 \\
(30 \%)^{b}\end{array}$ & $\begin{array}{l}259,5 \\
(30 \%)^{b}\end{array}$ & $\begin{array}{c}259 \\
(30 \%)^{b}\end{array}$ & $\begin{array}{c}258 \\
(30 \%)^{b}\end{array}$ \\
\hline Agregado Natural (0-12mm) & 873 & - & - & - & - & - \\
\hline Água (I) & 65 & 73 & 74 & 74 & 74 & 74,5 \\
\hline Teor de umidade (\%) & $7,0 \%$ & $7,9 \%$ & $8,0 \%$ & $8,0 \%$ & $8,0 \%$ & $8,0 \%$ \\
\hline $\begin{array}{l}\text { Resistência à compressão - } 21 \\
\text { dias (MPa) }\end{array}$ & 5,44 & $\begin{array}{c}5,52 \\
(+1,4 \%)^{c}\end{array}$ & $\begin{array}{c}5,36 \\
(-1,5 \%)^{c}\end{array}$ & $\begin{array}{c}5,73 \\
(+5,3 \%)^{c}\end{array}$ & $\begin{array}{c}6,15 \\
(+13 \%)^{c}\end{array}$ & $\begin{array}{c}7,50 \\
(+37 \%)^{c}\end{array}$ \\
\hline Massa específica $\left(\mathrm{kg} / \mathrm{m}^{3}\right)$ & 2150 & 2050 & - & - & - & - \\
\hline Variação dimensional $(\mathrm{mm} / \mathrm{m})$ & - & $0,42^{d}$ & - & - & - & - \\
\hline Capilaridade & 11,27 & 9,31 & - & - & - & - \\
\hline $\begin{array}{c}\text { Resistência das paredes (1m x } \\
1 \mathrm{~m})->150 \mathrm{~d}(\mathrm{MPa})\end{array}$ & 4,0 & 3,8 & - & - & - & - \\
\hline $\begin{array}{l}\text { Módulo de deformação - >150d } \\
(\mathrm{MPa})\end{array}$ & 6800 & 6110 & - & - & - & - \\
\hline
\end{tabular}

(fonte: Adaptado de Pimienta et al., 1998)

De maneira geral, os pesquisadores citam que a utilização de agregados graúdos reciclados na produção de blocos de concreto é uma alternativa viável, desde que ocorra um pequeno aumento no consumo de cimento (610\%) para que as propriedades das unidades com agregados reciclados sejam equiparadas às apresentadas pelos blocos com agregados naturais.

Souza et al. (2002) avaliaram a utilização de agregados de RCD na produção de blocos de concreto. Inicialmente, pelo emprego de CPs $(10 \times 20) \mathrm{cm}$ moldados em mesa vibratória, foram definidos os parâmetros de mistura para os materiais convencionais. Posteriormente, estabeleceram-se faixas granulométricas, com o objetivo de ajustar a granulometria dos agregados reciclados. Finalmente, foram produzidos blocos de concreto $(9 \times 19 \times 39) \mathrm{cm}$ para os materiais convencionais e para as diversas composições com agregados de RCD. As propriedades avaliadas foram: umidade da moldagem, massa específica, absorção de água e resistência à compressão.

Segundo os pesquisadores, com relação aos corpos-de-prova, para as composições com 70\% e 60\% de RCD, foi observada uma influência significativa dos agregados nas propriedades avaliadas; principalmente, na redução dos valores de massa específica e resistência à compressão e aumento considerável da absorção de água. Para as 
composições próximas de $30 \%$ de RCD, os resultados foram satisfatórios, sem grandes alterações em relação aos resultados de referência.

Em relação aos blocos de concreto, novamente foi observada uma influência significativa dos agregados de RCD nas propriedades das unidades; para as séries com $30 \%$ e 50\% de agregado reciclado na mistura, sem a adição de agregado miúdo natural, grande parte dos resultados de resistência e absorção não esteve de acordo com a NBR 7173 (1982) para alvenaria de vedação. Por outro lado, considerando-se apenas a fração graúda reciclada, para uma taxa de substituição de 40\%, em relação ao total de agregados, os resultados obtidos estiveram em concordância com a NBR 7173 (1982). A partir desses resultados, os pesquisadores apontam para as potencialidades de uso dos agregados de RCD na produção de blocos de concreto, entretanto, alertam para o emprego da fração miúda $(<2,4 \mathrm{~mm})$ na fabricação dessas unidades.

Fonseca (2002) avaliou as propriedades físicas e mecânicas de blocos de concreto com função estrutural. Tais unidades foram produzidas utilizando-se a fração miúda natural (< 2,4 mm) e a fração graúda provenientes de RCD da usina de reciclagem de Ribeirão Preto - SP. Posteriormente, foram avaliadas as propriedades mecânicas de miniparedes produzidas com esses blocos, variando-se o tipo de argamassa de assentamento e o tipo de revestimento (argamassa convencional e argamassa reciclada).

O pesquisador avaliou também a natureza da composição dos resíduos de $R C D$, os resultados foram os seguintes: argamassa $(40,6 \%)$, concreto $(12,5 \%)$, cerâmica polida $(3,5 \%)$, cerâmica $(22,2 \%)$, brita $(20,3 \%)$ e outros $(0,8 \%)$. No estudo experimental, o pesquisador, através da produção de CPs $(10 \times 20) \mathrm{cm}$, avaliou a resistência à compressão de inúmeras composições com agregados de RCD. De posse desses resultados, procedeuse a fabricação de blocos piloto de concreto que foram avaliados quanto às propriedades de resistência à compressão, aparência superficial e absorção de água e verificação do cumprimento aos requisitos da NBR 6136 (1994). Com base nos resultados obtidos, o pesquisador selecionou a seguinte dosagem para a produção dos blocos de concreto, Tabela 3.10. 
Tabela 3.10 - Dosagem selecionada para a produção dos blocos de concreto.

\begin{tabular}{|c|c|c|c|c|c|c|c|}
\hline \multicolumn{6}{|c|}{ Consumo teórico de materiais $\left(\mathrm{kg} / \mathrm{m}^{3}\right)$} & \multirow{4}{*}{$\begin{array}{l}\text { Relação } \\
\text { Agregado: } \\
\text { cimento }\end{array}$} & \multirow{4}{*}{$\begin{array}{c}\text { Teor de } \\
\text { umidade } \\
(\%)\end{array}$} \\
\hline \multirow{3}{*}{ Cimento } & \multicolumn{4}{|c|}{ Agregados } & \multirow{3}{*}{ Água } & & \\
\hline & $\mathrm{Na}$ & & Reci & ados & & & \\
\hline & $<1,20$ & $1,2-2,4$ & $2,4-4,8$ & $4,8-9,5$ & & & \\
\hline \multirow{2}{*}{210} & 137 & 776 & 374 & 457 & \multirow{2}{*}{179} & \multirow{2}{*}{$1: 8,31$} & \multirow{2}{*}{9,16} \\
\hline & \multicolumn{2}{|c|}{$52,4 \%$} & \multicolumn{2}{|c|}{$47,6 \%$} & & & \\
\hline
\end{tabular}

(fonte: adaptado de Fonseca, 2002)

Os resultados das propriedades físicas e mecânicas dos blocos de concreto com agregados reciclados de RCD são apresentados na Tabela 3.11.

Tabela 3.11 - Resultados das propriedades físicas e mecânicas para os blocos reciclados.

\begin{tabular}{|c|c|c|c|c|c|}
\hline Unidades & Idade & $\mathrm{f}_{\mathrm{bm}}(\mathrm{MPa})$ & $\mathrm{f}_{\mathrm{bk}}(\mathrm{MPa})$ & $\begin{array}{c}\text { Absorção } \\
(\%)\end{array}$ & $\gamma_{\mathrm{s}}\left(\mathrm{g} / \mathrm{cm}^{3}\right)$ \\
\hline \multirow{2}{*}{$39 \times 14 \times 19$} & 7 & 9,87 & 7,0 & \multirow{2}{*}{8,1} & \multirow{2}{*}{1,99} \\
\hline & 28 & 11,22 & 8,5 & & \\
\hline \multirow{2}{*}{$19 \times 14 \times 19$} & 7 & 10,43 & 8,5 & \multirow{2}{*}{8,9} & \multirow{2}{*}{1,97} \\
\hline & 28 & 14,87 & 9,5 & & \\
\hline
\end{tabular}

(fonte: adaptado de Fonseca, 2002)

As principais conclusões a que o pesquisador chegou são enumeradas a seguir: a) os agregados reciclados apresentaram elevada absorção de água oriunda da argamassa aderida ao agregado e a presença da fração cerâmica; b) os blocos produzidos com agregados reciclados apresentaram uma resistência característica aos 28 dias ( $f_{b k}$ ) igual a $8,5 \mathrm{MPa}$, para um consumo de cimento de $210 \mathrm{~kg} / \mathrm{m}^{3}$. Segundo o pesquisador, o processo de cura adotado (cura úmida) foi fundamental para impedir a elevada perda de água, garantindo, dessa maneira, a hidratação das partículas de cimento nas primeiras idades, fato esse que ocasionou uma resistência aos 7 dias muito próxima daquela aos 28 dias; c) os valores de absorção situaram-se em torno de $8,5 \%$, portanto abaixo do valor de $10 \%$ prescrito pela NBR 12118 (1991).

Poon et al. (2002) produziram blocos maciços de concreto $(22,5 \mathrm{~cm} \times 10,5 \mathrm{~cm} \times 7,5$ $\mathrm{cm}$ ) utilizando agregados reciclados de RCD e agregados reciclados de concreto. Os agregados reciclados apresentavam as seguintes composições porcentuais, Tabela 3.12. 
Tabela 3.12 - Composições dos agregados reciclados.

\begin{tabular}{ccc}
\hline \multirow{2}{*}{ Material } & \multicolumn{3}{c}{ Agregado Reciclado } \\
\cline { 2 - 3 } & $\mathrm{RCD}$ & $\mathrm{RC}$ (Resíduos de concreto) \\
\hline Concreto & 77,7 & 99,8 \\
\hline Rochas naturais & 21,8 & 0 \\
\hline Tijolos de barro & 0,2 & 0 \\
\hline Outras impurezas & 0,3 & 0,2 \\
\hline
\end{tabular}

(fonte: Poon et al., 2002)

As unidades foram produzidas mediante a aplicação de uma força de compactação de $600 \mathrm{kN}$ por um período de um minuto. Após isso, as unidades foram curadas em temperatura ambiente durante 28 dias. As dosagens utilizadas na produção dos blocos apresentavam as seguintes características, Tabela 3.13.

Tabela 3.13 - Dosagens utilizadas na produção dos blocos.

\begin{tabular}{|c|c|c|c|c|c|}
\hline \multirow[b]{2}{*}{ Dosagem } & \multicolumn{5}{|c|}{ Consumo de materiais $(\mathrm{kg})$} \\
\hline & Cimento & $\begin{array}{c}\text { Cinza } \\
\text { volante }\end{array}$ & $\begin{array}{c}\text { Agregado } \\
\text { natural }^{\mathrm{b}}\end{array}$ & $\begin{array}{l}\text { Agregado } \\
\text { reciclado }\end{array}$ & Água \\
\hline Referência & \multirow{6}{*}{200} & \multirow{6}{*}{50} & 3200 & 0 & 85 \\
\hline $\mathrm{RC}-25 \%$ & & & 2400 & 800 & $90(5,9 \%)^{\mathrm{a}}$ \\
\hline $\mathrm{RC}-50 \%$ & & & 1600 & 1600 & $98(15,3 \%)^{a}$ \\
\hline $\mathrm{RC}-75 \%$ & & & 800 & 2400 & $110(29,4 \%)^{\mathrm{a}}$ \\
\hline RC - $-100 \%$ & & & 0 & 3200 & $122(43,5 \%)^{\mathrm{a}}$ \\
\hline RCD - 100\% & & & 0 & 3200 & $122(43,5 \%)^{\mathrm{a}}$ \\
\hline
\end{tabular}

${ }^{a}$ Acréscimo percentual da quantidade de água em relação à dosagem de referência

b proporção de agregados: agregados miúdos (45\%) e agregados graúdos (55\%)

(fonte: adaptado de Poon et al., 2002)

As propriedades avaliadas foram: resistência à compressão, resistência à flexão, retração por secagem e massa específica. Os resultados para as propriedades físicas e mecânicas são apresentados na Tabela 3.14. 
Tabela 3.14 - Resultados das propriedades físicas e mecânicas.

\begin{tabular}{ccccc}
\hline Unidades & $\begin{array}{c}\text { Resistência à } \\
\text { compressão } \\
(\mathrm{MPa})^{\mathrm{a}}\end{array}$ & $\begin{array}{c}\text { Resistência à } \\
\text { flexão }(\mathrm{MPa})\end{array}$ & $\begin{array}{c}\text { Retração por } \\
\text { secagem }(\%)^{\mathrm{b}}\end{array}$ & $\begin{array}{c}\text { Massa } \\
\text { específica } \\
\left(\mathrm{kg} / \mathrm{m}^{3}\right)\end{array}$ \\
\hline Referência & 16,2 & 1,76 & 0,040 & 2210 \\
\hline $\mathrm{RC}-25 \%$ & $15,9(-1,9 \%)^{\mathrm{c}}$ & $1,80(+2,3 \%)^{\mathrm{c}}$ & $0,042(+5,0 \%)^{\mathrm{c}}$ & $2195(-0,7 \%)^{\mathrm{c}}$ \\
\hline $\mathrm{RC}-50 \%$ & $16,7(+3,0 \%)^{\mathrm{c}}$ & $1,87(+6,3 \%)^{\mathrm{c}}$ & $0,044(+10 \%)^{\mathrm{c}}$ & $2150(-2,7 \%)^{\mathrm{c}}$ \\
\hline $\mathrm{RC}-75 \%$ & $15,0(-7,4 \%)^{\mathrm{c}}$ & $1,95(+10,8 \%)^{\mathrm{c}}$ & $0,046(+15 \%)^{\mathrm{c}}$ & $2120(-4,1 \%)^{\mathrm{c}}$ \\
\hline $\mathrm{RC}-100 \%$ & $11,8(-27,2 \%)^{\mathrm{c}}$ & $1,99(+13,1 \%)^{\mathrm{c}}$ & $0,052(+30 \%)^{\mathrm{c}}$ & $2060(-6,8 \%)^{\mathrm{c}}$ \\
\hline $\mathrm{RCC}-100 \%$ & $11,4(-29,6 \%)^{\mathrm{c}}$ & $1,94(+10,2 \%)^{\mathrm{c}}$ & $0,051(+28 \%)^{\mathrm{c}}$ & $2054(-7,1 \%)^{\mathrm{c}}$ \\
\hline
\end{tabular}

BS 6717 (1993)

b BS 6073 (1981). Exemplares dispostos na água por pelo menos quatro dias e, posteriormente, colocados em uma sala à temperatura de $55^{\circ} \mathrm{C}$ durante 14 dias.

${ }^{c}$ Resultados em relação às unidades de referência

(fonte: adaptado de Poon et al., 2002)

Considerando-se os resultados obtidos, os pesquisadores estabeleceram os seguintes comentários: a) todas as unidades cumpriram com os requisitos da BS 6073 (1981), que prescreve valores de resistência à compressão < 7,0MPa, resistência à flexão < 0,65MPa e retração por secagem [ $0,06 \%$; b) para substituições elevadas de agregados naturais por reciclados (> 50\%) observou-se um decréscimo da resistência à compressão e ligeiro aumento da retração por secagem; já para a resistência à flexão, os maiores valores foram obtidos com a elevação da porcentagem de agregado reciclado.

Albuquerque (2005) avaliou o emprego de agregados reciclados mistos de RCD na produção de blocos de concreto. Os resíduos foram provenientes de obras de saneamento e reformas de edificações da cidade de Londrina. Estes resíduos foram processados em um britador de mandíbulas e moinho de martelos, sendo separados em diferentes frações granulométricas. Os agregados graúdos reciclados (fração $>2,4 \mathrm{~mm}$ ) eram constituídos pelas seguintes frações: cerâmica $(10,65 \%)$, fração cimentícia $(48,36 \%)$ e rocha $(39,58 \%)$.

Para a produção dos blocos, o pesquisador utilizou a metodologia do IPT adaptada para blocos de concreto. A escolha da graduação da curva granulométrica para a produção das unidades foi realizada de duas maneiras: a) compacidade aparente da mistura combinação de cada parcela granulométrica buscando a maior compacidade aparente da mistura; b) adequação das parcelas granulométricas de modo a obter um módulo de finura igual a 3,70. No entanto, após a produção de CPs no laboratório, foi observado que a combinação de agregados conforme a curva de melhor compacidade mostrava-se inviável devido à falta de materiais finos. 
O pesquisador produziu unidades de vedação utilizando três traços (1:7; 1:9 e 1:11), com substituição total da fração natural (graúda e miúda) pela fração reciclada. As características dos traços produzidos encontram-se na Tabela 3.15.

Tabela 3.15 - Características dos traços utilizados para a produção dos blocos.

\begin{tabular}{cccc}
\hline & \multicolumn{3}{c}{ Traço } \\
\cline { 2 - 4 } & $\mathbf{1 : 7 , 0 0}$ & $\mathbf{1 : 9 , 0 0}$ & $\mathbf{1 : 1 1 , 0 0}$ \\
\hline Agregado Miúdo $(<2,4 \mathrm{~mm})$ & 4,20 & 5,40 & 6,60 \\
\hline Agregado Graúdo & 2,80 & 3,60 & 4,40 \\
\hline Relação água/cimento & 1,88 & 1,11 & 1,21 \\
\hline Proporção de argamassa $(\alpha)$ & 0,65 & 0,64 & 0,63 \\
\hline Umidade (\%) & 11 & 11 & 10 \\
\hline \multirow{2}{*}{ Tempos de produção } & $\begin{array}{c}\text { Alimentador de gaveta }=4,2 \mathrm{~s} ; \text { Vibrador da gaveta }=3,1 \mathrm{~s} ; \\
\text { Prensa do molde }=8,0 \mathrm{~s} ; \text { Vibrador }=2,5 \mathrm{~s} ; \text { Parada do } \\
\end{array}$ & \multicolumn{2}{c}{ vibrador = 3,5s e Desforma = 2,0s } \\
\hline
\end{tabular}

(fonte: Adaptado de Albuquerque, 2005)

Os agregados reciclados foram previamente saturados. Conforme o pesquisador, a facilidade de moldagem e a aparência dos blocos produzidos com agregados reciclados agradaram os profissionais envolvidos na produção. Na Figura 3.4, encontram-se algumas das unidades produzidas.
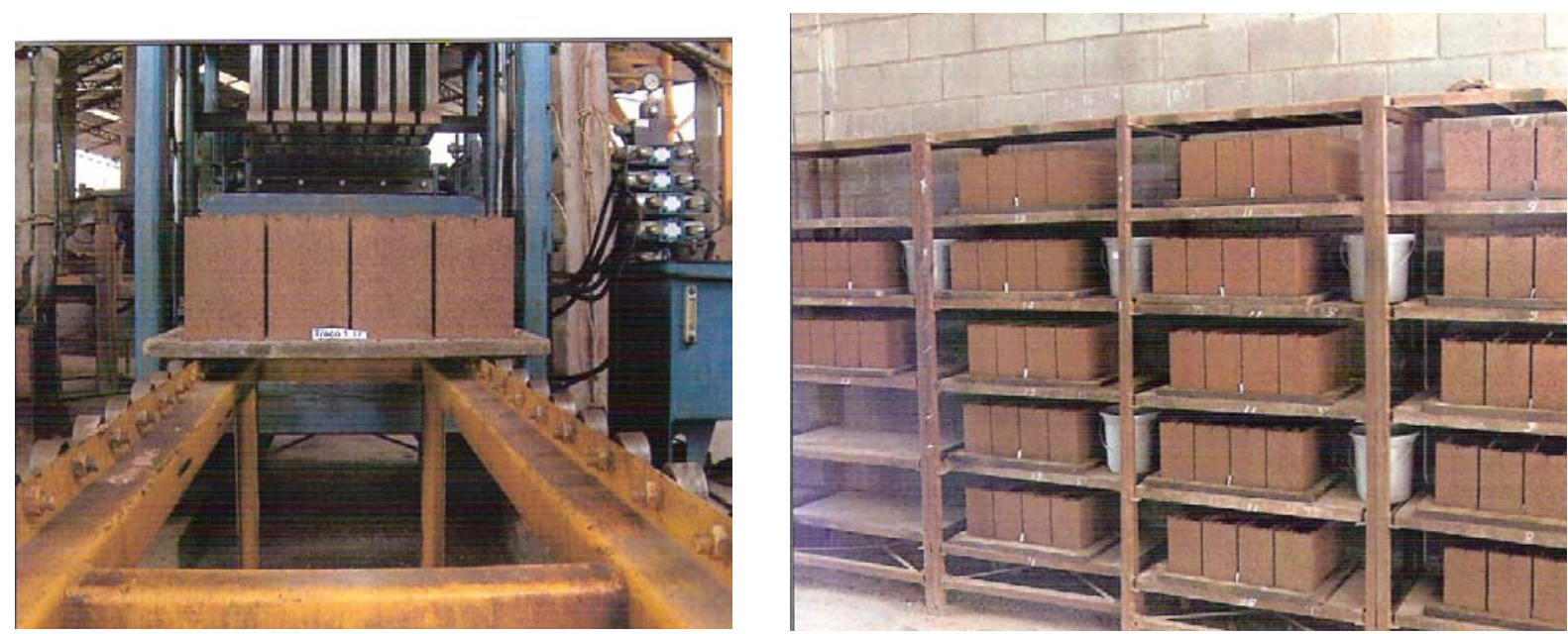

Figura 3.4 - Unidades de vedação produzidas pelo pesquisador (fonte: Albuquerque, 2005). 
Após a produção, os blocos de concreto foram armazenados em prateleiras de aço e protegidos com lona. A cura ocorreu à temperatura ambiente que variou entre $20^{\circ} \mathrm{C}$ e $35^{\circ} \mathrm{C}$. Os resultados obtidos são apresentados na Tabela 3.16.

Tabela 3.16 - Resultados das propriedades físicas e mecânicas.

\begin{tabular}{|c|c|c|c|c|}
\hline & & \multirow{2}{*}{ Absorção (\%) } & \multicolumn{2}{|c|}{ Resistência à compressão (MPa) } \\
\hline & & & $\mathrm{fc}_{7}$ & $\mathrm{fc}_{30}$ \\
\hline \multirow{3}{*}{ Traço 1:7 } & Média & 14,1 & 4,37 & 4,70 \\
\hline & $S_{d}$ & - & 0,15 & 0,20 \\
\hline & C. V. & - & 3,50 & 4,26 \\
\hline \multirow{3}{*}{ Traço 1:9 } & Média & 13,7 & 3,43 & 3,40 \\
\hline & $S_{d}$ & - & 0,15 & 0,10 \\
\hline & C. V. & - & 4,45 & 2,94 \\
\hline \multirow{3}{*}{ Traço 1:11 } & Média & 14,1 & 2,20 & 2,37 \\
\hline & $S_{d}$ & - & 0,00 & 0,06 \\
\hline & C. V. & - & 0,00 & 2,44 \\
\hline
\end{tabular}

(fonte: Adaptado de Albuquerque, 2005)

Apesar dos valores elevados de absorção, o pesquisador avalia que para a utilização de blocos de concreto que não se destinam a execução de alvenarias expostas a intempéries ou umidade, os ensaios de absorção podem ser dispensados. Na Tabela 3.17, encontra-se um estudo de viabilidade econômica para a produção de blocos de concreto com agregados reciclados (ALBUQUERQUE, 2005).

Tabela 3.17 - Custos de insumos para a moldagem de blocos com agregados naturais e com agregados reciclados para uma mesma classe de resistência.

\begin{tabular}{|c|c|c|c|c|}
\hline & & & $\begin{array}{c}\text { Bloco com agregados } \\
\text { naturais }\end{array}$ & $\begin{array}{c}\text { Bloco com } \\
\text { agregados } \\
\text { reciclados mistos }\end{array}$ \\
\hline & & & $1: 16$ & $1: 9$ \\
\hline \multirow{15}{*}{ Insumo } & \multirow{3}{*}{ Areia } & Consumo $\left(\mathrm{m}^{3}\right)$ & 0,00370 & - \\
\hline & & $\mathrm{R} \$ / \mathrm{m}^{3}$ & 40,00 & - \\
\hline & & Custo parcial & 0,15 & - \\
\hline & \multirow{3}{*}{ Pedrisco } & Consumo $\left(\mathrm{m}^{3}\right)$ & 0,00200 & - \\
\hline & & $\mathrm{R} \$ / \mathrm{m}^{3}$ & 20,00 & - \\
\hline & & Custo parcial & 0,04 & - \\
\hline & \multirow{3}{*}{ Pó-de-pedra } & Consumo $\left(\mathrm{m}^{3}\right)$ & 0,00075 & - \\
\hline & & $\mathrm{R} \$ / \mathrm{m}^{3}$ & 20,00 & - \\
\hline & & Custo parcial & 0,02 & - \\
\hline & Agregado & Consumo $\left(\mathrm{m}^{3}\right)$ & - & 0,0073 \\
\hline & \multirow{2}{*}{$\begin{array}{l}\text { Reciclado } \\
\text { misto }\end{array}$} & $\mathrm{R} \$ / \mathrm{m}^{3}$ & - & 10,00 \\
\hline & & Custo parcial & - & 0,07 \\
\hline & \multirow{3}{*}{ Cimento } & Consumo $\left(\mathrm{m}^{3}\right)$ & 0,66 & 1,02 \\
\hline & & $\mathrm{R} \$ / \mathrm{kg}$ & 0,33 & 0,33 \\
\hline & & Custo parcial & 0,22 & 0,34 \\
\hline \multicolumn{3}{|c|}{ Custo total (R\$) } & 0,42 & 0,41 \\
\hline
\end{tabular}


A utilização de agregados reciclados, em substituição à fração natural, não acarretou uma diminuição significativa dos custos de insumos (cerca de 2,5\%), uma vez que houve um aumento significativo no consumo de cimento (55\%) comparativamente aos blocos tradicionais.

Farias et al. (2005) produziram blocos de concreto e prismas com agregados reciclados de RCD. Os resíduos foram provenientes da demolição de uma residência, sendo compostos predominantemente por material cerâmico e pequenas frações de argamassa e concreto. Na Tabela 3.18, são apresentados os resultados referentes às propriedades físicas dos agregados reciclados.

Tabela 3.18 - Propriedades físicas dos agregados reciclados.

\begin{tabular}{ccc}
\hline & Resultado & Procedimento \\
\hline Dimensão máxima característica & $4,8 \mathrm{~mm}$ & NBR 7217 \\
\cline { 1 - 2 } Módulo de Finura & 2,44 & \\
\hline Massa específica & $2,56 \mathrm{~g} / \mathrm{cm}^{3}$ & NBR NM 52 \\
\hline Absorção de água & $9,5 \%$ & LEITE (2001) \\
\hline
\end{tabular}

(fonte: Farias et al., 2005)

Para a produção dos blocos de concreto foi utilizado cimento Portland CP-II-F32 e agregados reciclados (fração miúda e graúda). Em virtude da elevada absorção dos agregados reciclados, foi realizado a pré-saturação dos agregados. Os traços utilizados na produção dos blocos foram os seguintes: 1:6; 1:7; 1:8; 1:10,6 e 1:13.

Os blocos reciclados foram constantemente molhados e cobertos por uma lona plástica para a conservação da umidade. Após sete e vinte e oito dias de cura, os blocos foram transportados para o laboratório. Com relação aos resultados, para a propriedade de absorção de água, todas as unidades apresentaram valores de absorção superiores a 12\%. Com relação aos resultados de resistência à compressão aos 28 dias, apenas as unidades do traço 1:6 obtiveram valores de resistência superiores a 3,0 $\mathrm{MPa}$; para as unidades dos demais traços, os valores situaram-se entre 1,5 MPa e 2,8 MPa.

Soutsos et al. (2005) produziram blocos maciços de concreto com agregados reciclados de resíduos de alvenaria cerâmica. Uma das maiores dificuldades encontradas foi correlacionar às propriedades dos blocos produzidos no laboratório com os produzidos na fábrica, especialmente às propriedades de resistência à compressão, massa específica seca e saturada superfície seca.

Os resultados indicaram um efeito adverso, quando da incorporação de agregados reciclados de alvenaria cerâmica, para níveis de substituição superiores a 20\%. Para uma 
resistência de $7 \mathrm{MPa}$, foi necessário um acréscimo de $70 \mathrm{~kg} / \mathrm{m}^{3}$ de cimento quando se utilizou a fração graúda reciclada comparativamente à dosagem de referência. Segundo os pesquisadores, a elevação no consumo de cimento pode acarretar um aumento entre $10 \% \mathrm{e}$ $15 \%$ no custo da unidade. Para substituições de até $20 \%$, a resistência à compressão das unidades com agregados reciclados foi similar às unidades com agregados naturais. Segundo Soutsos et al. (2005), a superfície irregular dos agregados reciclados demanda um consumo maior de cimento para promover o preenchimento dos vazios existentes na matriz.

Patto e Oliveira (2006) produziram unidades de alvenaria com agregados reciclados de resíduos de concreto oriundos de obras civis. As propriedades físicas dos agregados reciclados são apresentadas na Tabela 3.19.

Tabela 3.19 - Caracterização das propriedades físicas dos agregados reciclados.

\begin{tabular}{ccc}
\hline Propriedades & $\begin{array}{c}\text { Agregado miúdo } \\
\text { reciclado }\end{array}$ & $\begin{array}{c}\text { Agregado graúdo } \\
\text { reciclado }\end{array}$ \\
\hline Módulo de Finura & 2,63 & 6,14 \\
\hline Dimensão máxima $(\mathrm{mm})$ & 4,80 & 12,7 \\
\hline Massa unitária $\left(\mathrm{g} / \mathrm{cm}^{3}\right)$ & 1,52 & 1,01 \\
\hline $\mathrm{d}_{\mathrm{s}}\left(\mathrm{g} / \mathrm{cm}^{3}\right)$ & 2,62 & 2,04 \\
\hline $\mathrm{d}_{\mathrm{ssd}}\left(\mathrm{g} / \mathrm{cm}^{3}\right)$ & - & 2,20 \\
\hline $\mathrm{Absorção}(\%)$ & - & 8,09 \\
\hline
\end{tabular}

(fonte: Patto e Oliveira, 2006)

Segundo os pesquisadores, as unidades produzidas com agregados miúdos e graúdos reciclados obtiveram valores de resistência à compressão em torno de 3,25 MPa, no entanto, os valores de absorção foram iguais a $16,2 \%$, sendo maiores do que o recomendado pela NBR 7173 (1982).

\subsection{CONCLUSÕES DO CAPÍTULO}

Conforme visto no presente capítulo, o concreto de consistência seca utilizado para a produção de blocos de concreto apresenta inúmeras particularidades e diferenças em relação ao concreto plástico, principalmente, em relação ao teor de umidade da mistura que deve ser elevado, entretanto, se esta quantidade for excessiva, podem ocorrer problemas de desforma e deformações indesejáveis nas peças durante o transporte. A composição adequada dos agregados na mistura, o tipo de cura utilizada e a escolha do equipamento de vibro-prensagem são fundamentais para que sejam garantidas a textura (aparência visual), a coesão e a resistência especificadas. Além disso, a cura térmica desempenha um papel 
importante não só para a elevação da resistência como também para reduzir as deformações originárias da retração por secagem.

Com relação às metodologias de dosagem, destacam-se aquelas que correlacionam as propriedades dos blocos através de exemplares de menores dimensões, tais como, corpos-de-prova cilíndricos. A vantagem desses métodos está na possibilidade da avaliação de inúmeras variáveis, principalmente em se tratando de dosagens com agregados reciclados, utilizando-se quantidade reduzida de material e em tempo relativamente curto; por outro lado, a existência de diferentes tipos de vibro-prensas, com distintas energias de vibração e adensamento, exige que o processo de produção dos CPs cilíndricos seja reavaliado e readaptado continuamente para que o intervalo de correlação permaneça válido.

Considerando-se os trabalhos que avaliaram as propriedades de blocos com agregados reciclados, pode-se dizer que há uma redução da resistência à compressão e aumento da absorção de água proporcional à taxa de substituição de agregado natural por reciclado. Apesar disso, para a comprovação da viabilidade técnica, ainda faltam ensaios que atestem o desempenho de elementos produzidos com blocos reciclados e estudos mais aprofundados voltados para a análise da viabilidade econômica da produção dessas unidades. 
Neste capítulo, inicialmente, são caracterizados o fenômeno e os tipos de retração, a conceituação da retração por secagem e os principais fatores influentes e, posteriormente, é apresentada a retração em elementos de concreto, principalmente em unidades e elementos de alvenaria com a inclusão de recomendações construtivas tratando de juntas de movimentação. O objetivo deste capítulo é fornecer subsídios para a análise dos resultados de retração por secagem em unidades e elementos de alvenaria presentes no capítulo 9.

\subsection{O FENÔMENO DA RETRAÇÃO}

O efeito físico da retração está associado a uma deformação na estrutura da pasta de cimento decorrente da interação de diversos fenômenos. Cada um desses fenômenos contribui para a deformação total externa do compósito de cimento. A retração total é resultado de vários tipos de retração que podem ocorrer concomitantemente (BASTOS e CINCOTTO, 2000).

A perda de água da pasta de cimento é a principal responsável pela retração. Além disso, em compósitos à base de cimento há outros tipos de retração: retração térmica, retração por carbonatação (reação do dióxido de carbono do ar com compostos da pasta de cimento hidratada), retração por hidratação do cimento e retração autógena (BASTOS e CINCOTTO, 2000). Para blocos de concreto, uma parte da retração, considerada irreversível, ocorre após a fabricação dos blocos e está relacionada às reações internas da pasta de cimento; já a outra parte da retração é reversível e está associada à variação higroscópica do ambiente (BARBOSA, 2005). 


\subsection{CLASSIFICAÇÃO DOS TIPOS DE RETRAÇÃO}

Segundo Bastos e Cincotto (2000), a retração tem diferentes naturezas e ocorre em diferentes fases do endurecimento do compósito de cimento. Esse fato conduz à classificação da retração quanto ao estado físico da mistura, à natureza, ao grau de restrição e à sua permanência.

\section{1) Estado físico da mistura}

- Retração plástica

A retração ocorre por perda de água da pasta, argamassa ou concreto no estado fresco. A retração inicia-se antes da pega do cimento, quando as partes sólidas da mistura podem se movimentar e a diminuição de volume do sistema é igual ao volume de água retirado na secagem. Nessa etapa, pode haver fissuração se a quantidade de água perdida for maior do que a água que se eleva à superfície por efeito da exsudação.

- Retração no estado endurecido

Essa retração ocorre na pasta, argamassa ou concreto após a pega do cimento. A retração total depende diretamente do grau de dificuldade encontrado para a remoção da água e das propriedades mecânicas do compósito. A retração no estado endurecido depende fundamentalmente de como a água está ligada às partes sólidas da pasta e a dimensão do local de saída da água.

\section{2) Natureza do fenômeno}

- Retração por perda de água ou retração por secagem

A retração por secagem pode ocorrer na pasta, argamassa ou concreto no estado fresco ou endurecido.

- Retração por Hidratação ou Retração Química

Na hidratação do cimento, o volume total dos hidratos é inferior ao volume absoluto inicial (soma dos volumes absolutos da água e do cimento anidro). Esse fenômeno foi descoberto por Le Chatelier e é chamado de "Contração de Le Chatelier" sendo da ordem de $10 \%$ do volume inicial da pasta. No entanto, o volume da contração não implica em diminuição similar do volume aparente do compósito, uma vez que a estrutura da pasta endurecida também contém vazios. 
- Retração Autógena ou Endógena

Essa retração ocorre em um sistema fechado, sem trocas de umidade com o meio externo, sendo verificada no interior de uma massa volumosa de concreto ou em corpos-deprova protegidos da troca de água com o meio. O processo ocorre com o consumo de água dos capilares que hidrata a fração anidra do cimento. Neville (1997) cita que a retração autógena é relativamente pequena e, para efeitos práticos, não precisa ser diferenciada da retração por secagem.

- Retração por Carbonatação

Essa retração ocorre quando o $\mathrm{CO}_{2}$ do ar reage com os compostos hidratados do cimento (BASTOS e CINCOTTO, 2000 e NEVILLE, 1997). A carbonatação provoca, simultaneamente, aumento de massa e diminuição do volume na pasta de cimento endurecida. A retração por carbonatação é causada por dois mecanismos: a perda de água na reação química de carbonatação e a dissolução do $\mathrm{Ca}(\mathrm{OH})_{2}$ em zonas onde ele está sob tensão.

- Retração Térmica

A retração térmica pode ocorrer de duas maneiras diferentes: a) após o pico de evolução da temperatura por acúmulo de calor de hidratação; b) após o aquecimento por exposição a uma fonte de calor externa;

Segundo Mehta e Monteiro (1994), a retração térmica acontece, principalmente, em grandes massas de concreto, onde o esfriamento à temperatura ambiente pode levar à fissuração.

\section{3) Grau de Restrição}

- Retração Livre

É a retração em pasta, argamassa ou concreto caracterizada pela liberdade do elemento se retrair, pois não se encontra aderido a uma base porosa ou outro elemento estrutural.

- Retração Restringida ou Impedida

Nesse tipo de retração, a peça não está livre para se mover, resultando em uma deformação nula. A restrição provoca o aparecimento de tensões de tração no material, podendo ocorrer fissuração dependendo da sua combinação com a resistência à tração e o 
módulo de deformação da argamassa ou do concreto. Segundo Barbosa et al. (2004), a retração em alvenarias de blocos de concreto é caracterizada pelo surgimento de tensões de tração devido à restrição provocada pelo intertravamento das faces laterais da parede com outro painel de alvenaria ou pelo travamento inferior e superior provido pelos pisos. Nesse caso, a fissuração pode ocorrer quando as tensões de tração são maiores que a resistência à tração. O emprego de argamassas de baixo módulo de deformação minimiza as tensões de retração da alvenaria, permitindo que as próprias juntas absorvam as deformações de retração.

\section{4) Permanência do Fenômeno}

Segundo Bastos e Cincotto (2000), essa classificação relaciona-se com os ciclos de molhagem e secagem dos compósitos à base de cimento. Esse fato conduz a classificação da retração quanto à sua reversibilidade.

- Retração reversível: Parcela da retração recuperada com a molhagem da pasta de cimento a após secagem. No caso de unidades de alvenaria, essa retração está associada, principalmente, à variação de umidade do ambiente.

- Retração irreversível ou permanente: Parcela da retração que permanece em ciclos de molhagem e secagem. Grande parte da retração irreversível ocorre na primeira secagem, sendo que esta irreversibilidade é causada pela ligação entre as partículas sólidas. Para blocos de concreto, a retração irreversível ocorre nas primeiras idades, sendo menor para unidades submetidas à cura térmica (BARBOSA, 2005).

\subsection{RETRAÇÃO POR SECAGEM}

A retração por secagem pode ocorrer no estado plástico ou no estado endurecido. Segundo Neville (1997), a retração plástica ocorre pela perda de água da superfície do concreto, sendo influenciada pela temperatura, pela umidade relativa e pela velocidade do vento. Segundo Bastos e Cincotto (2000), essa retração pode ser reduzida pelo ajuste da dosagem para evitar a exsudação, proteção da peça contra a evaporação e pelo uso de aditivos retentores de água.

A retração no estado endurecido ocorre na pasta de cimento saturada que não permanece dimensionalmente estável quando exposta a uma condição de umidade que está 
abaixo da sua saturação (FURNAS, 1997). A magnitude da retração na pasta endurecida depende de onde ocorre a saída de água.

O processo de secagem inicia-se com a perda de água livre retida nas grandes cavidades. Essa água livre não está ligada à estrutura dos produtos hidratados por ligações físico-químicas fortes e, portanto, a sua perda não é acompanhada de retração significativa. Dessa maneira, uma pasta saturada ou um bloco de concreto expostos a uma umidade relativa inferior a $100 \%$, perderão uma quantidade considerável de água evaporável sem que haja uma retração intensa (MEHTA e MONTEIRO, 1994; DRYSDALE e KHATTAB, 1995).

Posteriormente, quando grande parte da água livre for removida, qualquer perda adicional de água resulta em retração considerável. Esse fenômeno é atribuído principalmente à perda de água adsorvida e da água retida em pequenos capilares. $\mathrm{A}$ água adsorvida, quando confinada em espaços estreitos entre duas superfícies sólidas, causa pressão de desligamento; a remoção dessa água adsorvida reduz a pressão de desligamento e causa a retração do sistema (MEHTA e MONTEIRO, 1994; NEVILLE, 1997). Para condições severas de secagem, a água interlamelar, presente na forma de um filme monomolecular de água entre as camadas da estrutura do silicato de cálcio hidratado (C-S$\mathrm{H}$ ), também pode ser removida. Para a água presente em pequenos capilares (5 a $50 \mathrm{~nm}$ ), sua remoção induz o aparecimento de tensões de compressão sobre as paredes sólidas do poro capilar ocasionando a retração do sistema (MEHTA e MONTEIRO, 1994; BASTOS e CINCOTTO, 2000). Finalmente, a água quimicamente combinada, que é parte integrante da estrutura de vários produtos hidratados do cimento, somente é perdida para temperaturas acima de $100^{\circ}$ (MEHTA e MONTEIRO, 1994; BASTOS e CINCOTTO, 2000).

\subsection{FATORES QUE INFLUENCIAM A RETRAÇÃO POR SECAGEM}

Inúmeros fatores podem influenciar a retração por secagem, tais como, as condições ambientais, tipo litológico dos agregados, dimensão máxima característica, propriedades físicas do agregado, proporções de material (principalmente a quantidade de água), microfissuras (interface pasta/agregado), cura do concreto e outros (FURNAS, 1997).

Segundo Mehta e Monteiro (1994), a retração por secagem é influenciada principalmente pelo módulo de deformação do agregado; já a influência de outras características do agregado é considerada indireta. A influência do módulo de deformação 
do agregado foi confirmada na pesquisa de Troxell et al. (1958 apud MEHTA e MONTEIRO, $1994)^{14}$ sobre fluência e retração do concreto. Segundo esses pesquisadores, a retração por secagem aumentou 2,5 vezes quando um agregado com alto módulo de deformação foi substituído por outro com baixo módulo de deformação. De acordo com Neville (1997), os agregados leves resultam em retração maior, principalmente, devido ao seu menor módulo de deformação, sendo que agregados leves com grande quantidade de partículas menores que $0,075 \mathrm{~mm}$ apresentam retração ainda mais elevada, pois os finos resultam em teores de vazios maiores.

Segundo Furnas (1997), a capacidade das partículas de agregado em restringir as deformações da pasta de cimento depende de vários fatores importantes: a) extensibilidade relativa da pasta e a compressibilidade do agregado (módulo de deformação); b) ligação ou contato entre a pasta e o agregado; c) contração da pasta no estado fresco; d) grau de fissuração da pasta de cimento; e) variação de volume das partículas de agregado devida à secagem. De acordo com Neville (1997), os agregados sujeitos à retração apresentam normalmente valores elevados de absorção.

O efeito da dimensão do agregado na retração por secagem foi avaliado por Furnas (1997). A relação água/cimento foi mantida igual a 0,40 e a dosagem foi de 1:1, Tabela 4.1 .

Tabela 4.1 - Efeito da composição da pasta de cimento com agregados de dolomita de diversas granulometrias.

\begin{tabular}{|c|c|c|c|c|c|c|c|}
\hline \multirow{2}{*}{$\begin{array}{l}\text { Tamanho do } \\
\text { agregado }\end{array}$} & \multicolumn{7}{|c|}{ Faixa Granulométrica (mm) } \\
\hline & $\begin{array}{l}\text { Pasta de } \\
\text { cimento }\end{array}$ & $0,3-0,6$ & $\begin{array}{c}0,6- \\
1,2 \\
\end{array}$ & $\begin{array}{c}1,2- \\
2,4 \\
\end{array}$ & $\begin{array}{c}2,4- \\
4,8 \\
\end{array}$ & $\begin{array}{c}4,8- \\
9,5\end{array}$ & $\begin{array}{c}9,5- \\
19 \\
\end{array}$ \\
\hline $\begin{array}{c}\text { Retração em um ano } \\
\left(\times 10^{-6}\right)\end{array}$ & 2710 & 1190 & 1240 & 1220 & 1160 & 940 & 690 \\
\hline
\end{tabular}

(fonte: Furnas, 1997)

A utilização de menos água de amassamento reduz substancialmente a retração; por outro lado, um aumento no volume de água do concreto não eleva somente a relação água/cimento, mas também reduz o volume de agregado, aumentando, conseqüentemente, a retração do concreto. Para uma dada relação água/cimento, ocorre aumento da retração por secagem e da fluência com a elevação do consumo de cimento (MEHTA e MONTEIRO, 1994 e FURNAS, 1997).

\footnotetext{
${ }^{14}$ TROXELL, G. E.; RAPHAEL, J. M.; DAVIS, R. E. Proceedings ASTM. v. 58, p. 1101-1120, 1958.
} 
Com relação à distribuição dos agregados graúdos no interior do concreto, Aïtcin (2000) cita que os agregados não se distribuem uniformemente na massa de concreto; o concreto próximo à superfície é mais rico em argamassa devido ao chamado "efeito parede". Como conseqüência, a superfície do concreto apresenta uma maior retração resultando em fissuras mais abertas do que no interior da massa de concreto.

De acordo com Neville (1997), a cura do concreto é necessária para se obter o mais alto grau de hidratação possível, a maior resistência e a menor permeabilidade. A cura é realizada basicamente para hidratar o cimento presente na mistura e para minimizar a retração. Caso a cura seja interrompida, a relação água/cimento, a quantidade e o tipo dos agregados determinam a retração final do concreto (AїTCIN, 2000). Segundo Aïtcin (2000), dentre os meios existentes para diminuir a durabilidade de uma estrutura de concreto armado está a eliminação da cura do concreto, isto é, para qualquer que seja a relação água/cimento utilizada, o concreto se retrairá e desenvolverá tantas fissuras quanto possível. A influência da duração da cura úmida na retração por secagem foi avaliada por Furnas (1997). Na Tabela 4.2, pode-se observar a influência do plano de cura na retração por secagem de concretos com agregados convencionais.

Tabela 4.2 - Influência do plano de cura na retração por secagem.

\begin{tabular}{|c|c|c|c|c|c|c|c|c|}
\hline \multirow{2}{*}{$\begin{array}{l}\text { Agregado/ } \\
\text { Dmáx }\end{array}$} & \multirow{2}{*}{$\begin{array}{c}\text { Plano de } \\
\text { Cura } \\
\text { (dias) }^{*}\end{array}$} & \multirow{2}{*}{$\begin{array}{c}\text { Relação } \\
\text { a/c }\end{array}$} & \multicolumn{6}{|c|}{$\begin{array}{c}\text { Retração }\left(\times 10^{-6}\right) \\
\text { Idade (dias) }\end{array}$} \\
\hline & & & 14 & 28 & 90 & 180 & 360 & 500 \\
\hline \multirow{2}{*}{$\begin{array}{c}\text { Quartzito } \\
19 \mathrm{~mm}\end{array}$} & 28 & \multirow{2}{*}{0,592} & - & -55 & 55 & 158 & 250 & 308 \\
\hline & 14 & & -23 & -15 & 40 & 200 & 310 & 445 \\
\hline
\end{tabular}

Mehta e Monteiro (1994) citam que a umidade relativa de $100 \%$, admite-se que a retração por secagem seja zero, aumentando-se para $200 \times 10^{-6}$ a umidade relativa de $80 \%$ e $400 \times 10^{-6}$ a umidade relativa de $45 \%$. A magnitude da retração será função da umidade relativa do local onde o elemento de concreto estará exposto, Tabela 4.3. 
Tabela 4.3 - Retração de concretos em função da umidade relativa do ar.

\begin{tabular}{cc}
\hline Umidade $-\cup_{\mathrm{r}}(\%)$ & Retração total $\bigcup_{\mathrm{r}}(\mathrm{x}) /$ Ret. total $\mathrm{U}_{50 \%}$ \\
\hline 100 & 0 \\
\hline 95 & 0,38 \\
\hline 90 & 0,56 \\
\hline 85 & 0,66 \\
\hline 80 & 0,77 \\
\hline 75 & 0,82 \\
\hline 70 & 0,85 \\
\hline 65 & 0,90 \\
\hline 60 & 0,94 \\
\hline 55 & 0,97 \\
\hline 50 & 1,00 \\
\hline
\end{tabular}

(fonte: Thomaz, 1989)

Segundo Neville (1997), as propriedades do cimento têm pequena influência sobre a retração do concreto, exceto no caso dos cimentos com deficiência de gesso. Furnas (1997) cita que, em geral, cimentos mais finos, pozolânicos ou com adição de escória aumentam a retração, mas o efeito é influenciado pelo tipo de agregado.

Segundo Mehta e Monteiro (1994), as adições e aditivos para o concreto tais como cloreto de cálcio, escória granulada e pozolanas aumentam o volume de poros finos no produto de hidratação do cimento e, consequentemente, elevam a retração por secagem. Aditivos redutores de água e retardadores de pega também levam a um refinamento dos poros.

A geometria do elemento de concreto influencia na retração por secagem. Para umidade relativa constante, tanto o tamanho quanto à forma da peça de concreto determinam a magnitude da retração por secagem, uma vez que a taxa de remoção de água é controlada pelo comprimento do caminho percorrido pela água que está sendo expelida durante a retração por secagem (MEHTA e MONTEIRO, 1994). A retração diminui com o aumento das dimensões, sendo também função da relação volume/área da peça (FURNAS, 1997). 


\subsection{RETRAÇÃO EM ELEMENTOS DE CONCRETO}

\subsubsection{CPS PRODUZIDOS COM AGREGADOS RECICLADOS DE CONCRETO}

As propriedades dos agregados reciclados de resíduos de concreto são influenciadas pela presença da argamassa do concreto original aderida à superfície dos mesmos. Esta camada de argamassa é responsável pela elevada absorção, porosidade e redução da rigidez do concreto reciclado em comparação com o concreto com agregados naturais e, consequentemente, pelo aumento significativo da retração por secagem.

Para uma dada trabalhabilidade, a elevação da relação água/cimento para concretos reciclados, quando comparados com concretos com agregados naturais, acaba sendo fundamental no aumento da retração por secagem. Neville (1997) relata que a retração é função da relação água/cimento, pois essa relação determina a quantidade de água evaporável na pasta de cimento e a velocidade com que a água pode se deslocar para a superfície do concreto. Segundo Carlson (1938 apud FURNAS, 1997) ${ }^{15}$, um acréscimo de $1 \%$ na água de amassamento gera um aumento de $2 \%$ na retração.

Segundo Neville (1997), os agregados leves apresentam maiores deformações por retração, principalmente devido ao seu menor módulo de deformação. Vazquez e Barra (2002) citam que a retração por secagem procede-se, inicialmente, pela perda de água livre localizada nos macro capilares $(>0,03 \mu \mathrm{m})$, fato esse que não provoca variações dimensionais no concreto; já quando é introduzido o agregado reciclado na mistura, ocorre um aumento no raio desses capilares, contudo o volume desses poros mantém-se praticamente similar quando comparado ao concreto com agregados naturais. Nos concretos reciclados, o volume total de micro poros $(<0,03 \mu \mathrm{m})$ aumenta gradativamente com a elevação da taxa de substituição de agregados naturais por reciclados e, consequentemente, eleva-se a retração por secagem.

Hansen (1985) cita que, devido a grande quantidade de argamassa aderida à superfície do agregado reciclado, a retração por secagem do concreto reciclado é maior do que a retração do concreto com agregados naturais. Esse aumento situa-se entre 40 e $80 \%$, sendo que os maiores valores são encontrados quando é utilizada a fração miúda e a 
graúda reciclada. Hansen e Boegh (1985) avaliaram o módulo de deformação e a retração por secagem de concretos com agregados graúdos reciclados de concreto. Foi observado um aumento de 40 a $60 \%$ da retração por secagem para o concreto reciclado comparativamente ao concreto com agregados naturais.

Em seu estudo, Ravindrarajah et al. (1987) cita que a retração por secagem dos concretos com agregados graúdos reciclados foi $55 \%$ maior em comparação à retração do concreto com agregados naturais. Para concretos com agregados graúdos e miúdos reciclados, a retração por secagem foi duas vezes o valor da retração para o concreto com agregados naturais. Teranishi et al. (1998) estabeleceram várias dosagens para concretos com agregados graúdos reciclados. Os resultados evidenciaram que a retração por secagem de concretos com agregados graúdos reciclados foi cerca de 30\% maior para concretos com relação água/cimento igual a 0,6, 25\% superior para relação água/cimento igual a 0,5 e cerca de $17 \%$ maior para concretos com relação água/cimento igual a 0,4 comparando-se com a retração de concretos com agregados naturais de características similares.

Sagoe-Crentsil et al. (1998) estudaram a retração por secagem de concretos com agregados graúdos reciclados. Para concretos reciclados produzidos com cimento com adição de escória de alto forno, a retração foi $35 \%$ maior se comparado com o concreto de referência. Buttler e Machado (2004) avaliaram a retração por secagem de concretos com agregados graúdos reciclados cujos agregados foram oriundos de um concreto de resistência média, aos 28 dias, de 44,5 $\mathrm{MPa}$. Os concretos produzidos com agregados reciclados apresentavam as seguintes características, Tabela 4.4.

${ }^{15}$ CARLSON, R. W. Drying shrinkage of concrete as concrete as affected by many factors. ASTM Proceedings, Philadelphia, p. 419-440, 1938. 
Tabela 4.4 - Características dos concretos com agregados reciclados.

\begin{tabular}{cccccccc}
\hline & \multicolumn{7}{c}{ Consumo teórico de materiais $\left(\mathrm{kg} / \mathrm{m}^{3}\right)$} \\
\cline { 2 - 8 } Dosagem & Cimento & $\begin{array}{c}\text { Agreg. } \\
\text { Graúdo } \\
\text { natural }\end{array}$ & $\begin{array}{c}\text { Agreg. } \\
\text { Graúdo } \\
\text { Reciclado }\end{array}$ & $\begin{array}{c}\text { Agregado } \\
\text { miúdo } \\
\text { natural }\end{array}$ & Água & $\begin{array}{c}\text { Slump } \\
(\mathrm{mm})\end{array}$ & $\begin{array}{c}\text { Teor de } \\
\text { argamassa } \\
(\%)\end{array}$ \\
\hline Ref & 475 & 1140 & - & 665 & 195 & 60 & 50 \\
\hline CR1 $^{*}$ & 441 & - & 1058 & 617 & 198 & 50 & 50 \\
\hline CR7 $^{*}$ & 430 & - & 1032 & 602 & 206 & 70 & 50 \\
\hline CR28 $^{*}$ & 438 & - & 1051 & 613 & 197 & 50 & 50 \\
\hline
\end{tabular}

${ }^{*}$ Os agregados reciclados foram obtidos de resíduos de concretos com diferentes idades (1, 7 e 28 dias)

(fonte: Buttler e Machado, 2004)

Os exemplares foram mantidos durante sete dias em cura úmida, para então serem dispostos em câmara climatizada $\left(T=31,2^{\circ} \mathrm{C} ; \mathrm{U}=54,2 \%\right)$. Após seis meses de ensaio, os prismas produzidos com agregados reciclados apresentaram valores de retração entre $55 \%$ e $80 \%$ superiores à retração do concreto com agregados naturais. Para a avaliação da retração de concretos com agregados graúdos reciclados, a Rilem Recommendation (1994) recomenda a multiplicação da retração do concreto com agregados naturais pelo coeficiente 1,50. A norma BS 8500: part 2 (2002) prescreve que concretos com agregados graúdos reciclados devem satisfazer o limite de $0,075 \%$ para a retração por secagem.

\subsubsection{BLOCOS DE CONCRETO}

Usualmente, conforme Barbosa (2005), a retração por secagem em blocos de concreto é avaliada sob condições extremas de saturação em água e secagem em estufa, conforme as recomendações da NBR 12117 (1991) e ASTM C426 (1999). A seguir, são apresentados alguns estudos relativos à retração por secagem em blocos de concreto que provavelmente seguiram essas recomendações normativas.

Segundo Medeiros (1993) a retração por secagem de blocos de concreto é, em geral, muito elevada nas primeiras idades. Diante disso, para que um determinado lote seja liberado para utilização, deve ser respeitado um limite mínimo de três dias para unidades curadas a vapor e 14 dias para blocos submetidos à cura ambiente. De acordo com a NBR 8798 (1985), esse período mínimo deve ser de 21 dias para que os efeitos da retração hidráulica inicial e irreversível sejam evitados. Barbosa (2005) cita um período mínimo de 21 dias para a utilização de blocos produzidos por pequenos fabricantes (sem cura a vapor), um período mínimo de 7 dias para blocos de resistência até 8,0 MPa e um período mínimo de 14 dias para blocos de resistência superior a 8,0 MPa, sendo que ambos produzidos sob rigoroso controle e submetidos à cura a vapor. 
Kalousek (1955) cita que a retração de blocos produzidos com agregados leves pode ser até $70 \%$ superior à retração de blocos produzidos com agregados convencionais. Drysdale et al. (1994) estimam a retração por secagem de blocos de concreto em $330 \pm 140$ $\mu \mathrm{m} / \mathrm{m}$, sendo esse valor dependente do método empregado para a fabricação das unidades e dos agregados utilizados. Pimienta et al. (1998) produziram blocos com agregados de RCD utilizando apenas à fração graúda reciclada $(6 / 12 \mathrm{~mm})$; segundo os pesquisadores, a variação dimensional dos blocos, quando submetidos a um período de 21 dias de secagem $\left(\mathrm{t}=33^{\circ} \mathrm{C}\right)$ e 4 dias de imersão na água, foi de 0,42 mm/m. A NF P 14-301 (1983) prescreve um valor máximo de $0,45 \mathrm{~mm} / \mathrm{m}$.

Poon et al. (2002) avaliaram a retração por secagem de blocos de concreto maciços e pisos de pavimentação fabricados com agregados reciclados de concreto (fração graúda e miúda). Os resultados podem ser encontrados na Tabela 4.5.

Tabela 4.5 - Retração por secagem para blocos de concreto e pisos de pavimentação.

\begin{tabular}{ccccccc}
\hline & \multicolumn{6}{c}{ Retração por Secagem (\%) } \\
\cline { 2 - 7 } Dosagem & $\begin{array}{c}\text { Blocos de } \\
\text { Concreto }\end{array}$ & $\begin{array}{c}\text { Relação } \\
\text { rec/ref }\end{array}$ & $\begin{array}{c}\text { Pisos de } \\
\text { pavim. s/ } \\
\text { cinza } \\
\text { volante }\end{array}$ & $\begin{array}{c}\text { Relação } \\
\text { rec/ref }\end{array}$ & $\begin{array}{c}\text { Pisos de } \\
\text { pavim. } \\
\text { c/cinza } \\
\text { volante }\end{array}$ & $\begin{array}{c}\text { Relação } \\
\text { rec/ref }\end{array}$ \\
\hline Referência & 0,040 & 1,00 & 0,027 & 1,00 & 0,026 & 1,00 \\
\hline $25 \%$ de reciclados & 0,042 & 1,05 & - & - & 0,026 & 1,00 \\
\hline $50 \%$ de reciclados & 0,044 & 1,10 & 0,030 & 1,11 & 0,029 & 1,12 \\
\hline $75 \%$ de reciclados & 0,046 & 1,15 & - & - & 0,034 & 1,31 \\
\hline $100 \%$ de reciclados & 0,052 & 1,30 & 0,038 & 1,41 & 0,036 & 1,38 \\
\hline
\end{tabular}

(fonte: Poon et al., 2002)

De maneira geral, segundo os pesquisadores, as dosagens que empregaram $100 \%$ de reciclados (graúdo e miúdo) apresentaram uma retração aproximadamente $35 \%$ superior à obtida para os blocos de referência. Apesar disso, todas as unidades cumpriram com os requisitos da BS 6073 (1981), que prescreve valores de retração por secagem inferiores a $0,060 \%$.

De acordo com Drysdale e Khattab (1995), que avaliaram 24 fábricas de blocos de concreto em Ontário, grande parte da retração por secagem ocorre em estágios avançados de secagem. Partindo-se da condição saturada, usualmente, é necessário remover mais da metade da água presente na unidade para que ocorra uma retração significativa. A NBR 6136 (1994) prescreve a umidade máxima do bloco no momento do assentamento em função da umidade relativa do ambiente visando limitar a retração por secagem, Tabela 4.6. 
Tabela 4.6 - Umidade máxima do bloco em função da umidade relativa.

\begin{tabular}{cccc}
\hline \multirow{2}{*}{$\begin{array}{c}\text { Retração linear } \\
(\mathrm{mm} / \mathrm{m})\end{array}$} & \multicolumn{3}{c}{ Umidade máxima do bloco no momento do assentamento $(\%)$} \\
\cline { 2 - 4 } & Úmido $(\mathrm{Hr}>75 \%)$ & Médio $(50 \%<\mathrm{Hr}<75 \%)$ & Seco $(\mathrm{Hr}<50 \%)$ \\
\hline$<0,30$ & 45 & 40 & 35 \\
\hline $0,30-0,45$ & 40 & 35 & 30 \\
\hline 0,45 a 0,65 & 35 & 30 & 25 \\
\hline
\end{tabular}

(fonte: NBR 6136, 1994)

Barbosa (2005) avaliou a retração por secagem de blocos de concreto de diferentes resistências, tipos de cura e procedimentos de produção. O pesquisador teceu as seguintes considerações: a) os diferentes tipos de cura (natural, úmida e vapor) não interferiram de maneira significativa nos resultados de retração; b) os blocos de maior resistência apresentaram maior retração; c) o porte da fábrica, o processo e controle de produção influenciaram significativamente na retração; os maiores valores de retração foram obtidos para as fábricas de pequeno porte que possuíam baixo controle de produção, equipamentos menores e cura úmida; d) os blocos com retração por secagem acima de 0,065\% devem ser rejeitados.

\subsubsection{ALVENARIA DE BLOCOS DE CONCRETO}

O estudo da retração em alvenaria de blocos iniciou-se na década de 1920. Allan (1930) concluiu que o emprego de blocos secos ao ar (26 dias de cura) reduziu a retração da alvenaria em até $35 \%$ quando comparada com unidades utilizadas na condição saturada.

A qualidade dos blocos, a qualidade da argamassa de assentamento e o grau de restrição imposto à parede exercem grande influência na retração final da alvenaria. Conforme Abrams (1995), a seleção de uma correta argamassa pode reduzir consideravelmente as tensões originárias da retração em paredes de alvenaria. A probabilidade da ocorrência de fissuras pode ser reduzida com a seleção de argamassas de baixo módulo de deformação.

Os valores de retração livre para alvenarias de blocos de concreto podem ser encontrados na Tabela 4.7 (DRYSDALE et al., 1994). 
Tabela 4.7 - Valores de retração para alvenarias de blocos de concreto curados a vapor.

\begin{tabular}{cc}
\hline Tipo de agregado & Retração $(\boldsymbol{\mu m} / \mathbf{m})$ \\
\hline Cascalho e areia & 230 \\
\hline Escória expandida & 340 \\
\hline Xisto expandido & 310 \\
\hline
\end{tabular}

(fonte: Drysdale et al., 1994)

Os valores de retração são inferiores para as alvenarias que apresentam restrições à movimentação. Essas restrições ocorrem devido ao atrito da alvenaria com sua própria base e por armaduras dispostas nas juntas horizontais. Nesse caso, os valores de retração situam-se entre $15 \%$ e $50 \%$ do valor da retração livre dos blocos de concreto, sendo função da condição de umidade dos próprios blocos no momento assentamento. Taneja et al. (1986 apud BARBOSA, 2005) ${ }^{16}$ propõem as seguintes equações para estimar a deformação por retração da alvenaria de blocos de concreto e argamassas dos traços (1:0:3 e 1:0,5:4,5):

$$
\begin{gathered}
\varepsilon_{t}=[23,188 \cdot \ln (t)+23,882] \cdot 10^{-6} \text { para } \mathrm{t} \leq 10 \text { dias } \\
\varepsilon_{t}=[139,22 \cdot \ln (t)-228,64] \cdot 10^{-6} \text { para } 10<\mathrm{t} \leq 200 \text { dias } \\
\varepsilon_{t}=510.10^{-6} \text { para } \mathrm{t}>200 \text { dias }
\end{gathered}
$$

Conforme Drysdale et al. (1994), as deformações provocadas pela retração são menores na base da alvenaria devido à aderência ou atrito com a estrutura de suporte. Os coeficientes de atrito sugeridos pelo pesquisador encontram-se na Tabela 4.8.

Tabela 4.8 - Coeficientes de atrito da alvenaria com sua respectiva base.

\begin{tabular}{cc}
\hline Superfícies & Coeficientes de atrito \\
\hline Alvenaria - Alvenaria & 0,65 \\
\hline Alvenaria - Madeira & 0,55 \\
\hline Alvenaria - Concreto & 0,70 \\
\hline Alvenaria - Aço & 0,40 \\
\hline Alvenaria - Solo seco & 0,65 \\
\hline Alvenaria - Solo úmido & 0,30
\end{tabular}

(fonte: Drysdale et al., 1994)

${ }^{16}$ TANEJA, R.; SHRIVE, N.; HUIZER, A. Loss of prestress in post-tensioned hollow masonry walls. In: ADVANCES IN ANALYSIS OF STRUCTURAL MASONRY, 1., 1986, New Orleans. Proceedings... Estados Unidos: Structural Division of the Association of Civil Engineers, 1986. p. 76-83. 
Barbosa et al. (2004) apresentam alguns valores do coeficiente de retração em alvenarias de blocos de concreto recomendadas por algumas normas internacionais para serem adotadas em projeto, Tabela 4.9. Esses valores são usualmente a favor da segurança e em condições ambientalmente desfavoráveis.

Tabela 4.9 - Valores do coeficiente de deformação unitária por retração na alvenaria.

\begin{tabular}{cc}
\hline Referência & Retração (mm/m) \\
\hline AS 3700 (1998) & $-0,7$ \\
\hline ACl 530 (1999) / ASCE 5 (1999) / TMS 402 (1999) & $-0,65$ \\
\hline BS 5628: part 2 (1995) & $-0,5$ \\
\hline ABCl (1990) & $-0,2$ a -0,6
\end{tabular}

(fonte: Barbosa et al., 2004)

Barbosa (2005) avaliou a retração por secagem de alvenarias de blocos de concreto de diferentes resistências, tipos de cura e procedimentos de produção. O pesquisador estabeleceu as seguintes considerações: a) as paredes executadas com blocos de cura a vapor apresentaram os menores valores de retração; b) a retração foi afetada para paredes executadas com blocos de diferentes idades, isto é, os valores de retração das paredes com blocos mais jovens ( 5 dias) foram superiores aos valores das paredes com blocos de idades mais avançadas (19 dias); c) recomenda-se adotar o valor de $0,5 \mathrm{~mm} / \mathrm{m}$ para a retração de alvenarias de blocos produzidos com cura a vapor e $0,6 \mathrm{~mm} / \mathrm{m}$ no caso da inexistência de cura a vapor.

\subsubsection{RECOMENDAÇÕES CONSTRUTIVAS}

Segundo Vilató e Franco (1998), no projeto de edifícios de alvenaria estrutural, a definição correta de juntas de movimentação entre os elementos de alvenaria ou entre a alvenaria e os demais elementos da estrutura são medidas essenciais para evitar futuros problemas patológicos. As juntas de movimentação têm por função limitar as dimensões do painel de alvenaria a fim de que não ocorram elevadas concentrações de tensões em razão de suas deformações intrínsecas. Na Figura 4.1, podem ser observados alguns exemplos de juntas de movimentação entre elementos de alvenaria. 


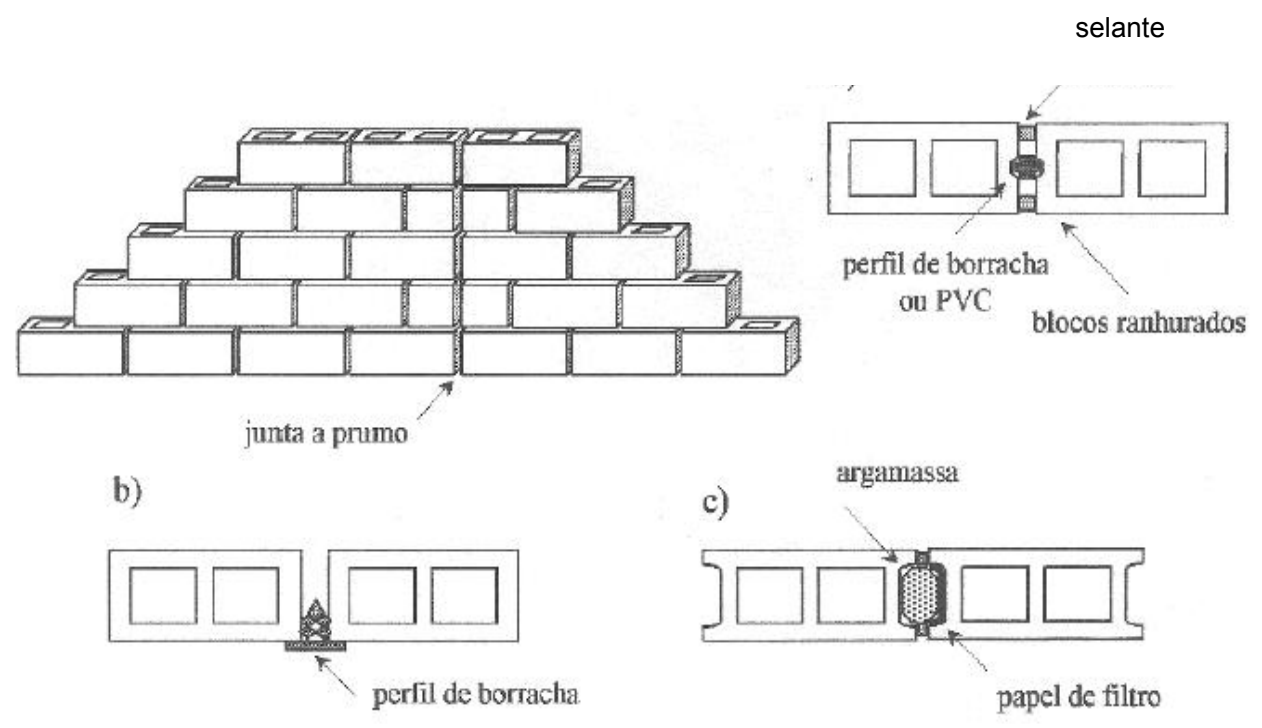

Figura 4.1 - Juntas de movimentação entre elementos de alvenaria (fonte: Vilató e Franco, 1998).

Segundo Drysdale et al. (1994), na alvenaria podem ser utilizados três tipos de juntas de movimentação: a) juntas de controle: empregadas para acomodar a retração da alvenaria de blocos de concreto; b) juntas de expansão: usualmente utilizadas para acomodar a expansão da alvenaria de tijolos cerâmicos; c) juntas de construção: utilizadas para acomodar possíveis movimentações diferenciais entre a alvenaria e os elementos adjacentes.

De acordo com Vilató e Franco (1998), a retração reversível ocorre comumente na alvenaria de blocos de concreto. A distância entre juntas de controle deve ser tal que a deformação longitudinal da parede não seja maior que sua capacidade de deformação. $O$ National Concrete Masonry Association (2003a apud BARBOSA, 2005) ${ }^{17}$ recomenda que devam ser previstas juntas de movimentação nos seguintes pontos: a) em mudanças de altura e largura das paredes; b) sob lajes que se apóiam em alvenarias; c) nas laterais de aberturas (apenas em um lado quando as aberturas forem menores que 1,80 $\mathrm{m}$ e nos dois lados nos outros casos). Grimm (1997) cita algumas medidas para minimizar o surgimento de fissuras em alvenarias de blocos de concreto: a) limitação da relação comprimento/altura das paredes; b) limitação da distância horizontal entre juntas de controle; c) colocação de juntas com armadura; d) disposição de juntas de controle nos pontos de concentração de tensões; e) controle do índice de umidade das unidades no momento do assentamento; f) instalação de juntas de deslizamento.

17 NATIONAL CONCRETE MASONRY ASSOCIATION. Control joints for concrete masonry walls alternative engineering method. TEK 10-3, 2003a. 
O Texto Base da Nova NBR 10837 (2007) cita que as juntas de movimentação devem ser dispostas com a finalidade de prevenir o aparecimento de fissuras provocadas por variações de temperatura e variação brusca de carregamento vertical, altura ou espessura da parede. A Norma prescreve que para painéis de alvenaria contidos em um único plano e na ausência de uma avaliação precisa das condições do painel, devem ser dispostas juntas verticais que não ultrapasse o menor dos seguintes valores: a) 2,5 vezes a altura da parede; b) 7,5 m. Para paredes executadas com blocos não curados a vapor, os limites anteriores devem ser reduzidos em $20 \%$. O código normativo também prescreve a disposição de armaduras horizontais nas paredes com taxa mínima de 0,07\% relativa à área da seção transversal vertical da parede.

O Código BS 5628: part 3 (1978) recomenda a definição de juntas de controle a cada 6,0 m, no entanto, esse código adverte o risco de fissuração quando o comprimento do painel exceder duas vezes sua altura; além disso, em paredes externas contendo aberturas é necessário definir juntas com maior freqüência ou reforçar a alvenaria acima e abaixo da abertura. O código ACI/ASCE (1995) é mais geral nas suas recomendações, referindo-se apenas à necessidade de se localizar as juntas nas aberturas com um espaçamento menor que $7 \mathrm{~m}$ ou três vezes à altura da parede. O National Concrete Masonry Association (2003a apud BARBOSA, 2005) ${ }^{16}$ cita que, para paredes sem aberturas, as juntas de controle são utilizadas para dividir uma parede em uma série de painéis isolados, sendo que o afastamento máximo dessas juntas é de, no máximo, $7,6 \mathrm{~m}$ ou 1,5 vezes a altura; além disso, deve-se dispor uma taxa de armadura mínima na alvenaria igual a 0,07\% considerando-se a área líquida dos blocos. De acordo com Barbosa (2005), essa taxa de armadura pode ser obtida com 2 barras de $4,2 \mathrm{~mm}$ dispostas nas juntas horizontais a cada $80 \mathrm{~cm}$ ou uma canaleta armada com 1 barra de $10 \mathrm{~mm}$ a cada 2,20 m.

No convênio Epusp-Encol (1988 apud VILATÓ e FRANCO, 1998) ${ }^{18}$, que avaliou alvenarias de vedação, foram definidos espaçamentos de $12 \mathrm{~m}$ e $9 \mathrm{~m}$ para juntas de controle em paredes de blocos de concreto sem e com aberturas, respectivamente. De acordo com Grimm (1997), para alvenarias externas de blocos de concreto, as juntas de controle devem ser espaçadas a cada $5,5 \mathrm{~m}$ em regiões com umidade entre $50 \%$ e $75 \%$; já para paredes internas essa distância pode ser aumentada em até $25 \%$. Para regiões com

${ }^{18}$ EPUSP-ENCOL. Recomendações para construção de paredes de vedação em alvenaria. São Paulo: EPUSP-PCC, Escola Politécnica da Universidade de São Paulo, 1988. (Relatório técnico CPqDCC/LPC $n^{0}$ 20.013). 
índices de umidade inferiores a $50 \%$, as distâncias citadas anteriormente devem ser reduzidas de 1,8 m; já para regiões com umidades médias superiores a $75 \%$, as juntas de controle podem ser afastadas de 1,8 m em relação aos valores iniciais. Segundo Drysdale et al. (1994), o espaçamento máximo horizontal para as juntas de controle verticais é determinada pelos seguintes fatores: a) umidade relativa média do local; b) tipo e a qualidade dos blocos de concreto; c) espaçamento vertical entre as juntas horizontais armadas; d) condições de exposição. Na Tabela 4.10, são sugeridos espaçamentos entre as juntas de controle baseando-se nesses quatro critérios. De acordo com Barbosa (2005), quando não são previstas juntas de controle, recomenda-se elevar a taxa de armadura para no mínimo $0,2 \%$ da área correspondente às paredes longitudinais das unidades, isto é, para blocos de $14 \mathrm{~cm}$ de largura, essa taxa pode ser obtida com 2 barras de 3,2 $\mathrm{mm}$ a cada fiada ou canaletas com uma barra de $12,5 \mathrm{~mm}$ a cada 1,2 $\mathrm{m}$. Segundo o National Concrete Masonry Association (2003b apud BARBOSA, 2005) ${ }^{19}$, essa taxa de armadura é calculada para que a armadura existente tenha ainda um comportamento elástico, para uma abertura máxima de fissura de $0,5 \mathrm{~mm}$.

Tabela 4.10 - Espaçamento máximo das juntas verticais de controle em alvenarias de blocos de concreto.

\begin{tabular}{|c|c|c|c|c|}
\hline \multirow[b]{2}{*}{$\begin{array}{l}\text { Umidade relativa } \\
\text { média anual }\end{array}$} & \multirow[b]{2}{*}{$\begin{array}{l}\text { Localização da } \\
\text { alvenaria }\end{array}$} & \multirow{2}{*}{$\begin{array}{c}\text { Espaçamento vertical } \\
\text { entre as juntas } \\
\text { horizontais armadas } \\
(\mathrm{m})\end{array}$} & \multicolumn{2}{|c|}{ Tipologia das unidades, ASTM C90 } \\
\hline & & & $\begin{array}{c}\text { umidade } \\
\text { controlada (I) }\end{array}$ & $\begin{array}{l}\text { sem controle da } \\
\text { umidade (II) }\end{array}$ \\
\hline \multirow{6}{*}{ Inferior a $50 \%$} & \multirow{3}{*}{ Externa } & - & 3,60 & 1,80 \\
\hline & & 0,40 & 5,45 & 3,00 \\
\hline & & 0,20 & 7,30 & 4,25 \\
\hline & \multirow{3}{*}{ Interna } & - & 5,00 & 2,70 \\
\hline & & 0,40 & 7,30 & 4,25 \\
\hline & & 0,20 & 9,60 & 5,75 \\
\hline \multirow{6}{*}{ Entre $50 \%$ e $75 \%$} & \multirow{3}{*}{ Externa } & - & 5,45 & 3,65 \\
\hline & & 0,40 & 7,30 & 4,85 \\
\hline & & 0,20 & 9,10 & 6,05 \\
\hline & \multirow{3}{*}{ Interna } & - & 6,85 & 4,55 \\
\hline & & 0,40 & 9,10 & 6,10 \\
\hline & & 0,20 & 11,45 & 7,60 \\
\hline \multirow{6}{*}{ Maior que $75 \%$} & \multirow{3}{*}{ Externa } & - & 7,30 & 5,45 \\
\hline & & 0,40 & 9,10 & 6,70 \\
\hline & & 0,20 & 10,95 & 7,90 \\
\hline & \multirow{3}{*}{ Interna } & - & 8,65 & 6,40 \\
\hline & & 0,40 & 10,95 & 7,90 \\
\hline & & 0,20 & 13,25 & 9,40 \\
\hline
\end{tabular}

* a NBR 6136 (1994) aceita somente blocos do Tipo I, limitando a umidade do bloco e quanto o mesmo poderá retrair

(fonte: Drysdale et al., 1994)

\footnotetext{
${ }^{19}$ NATIONAL CONCRETE MASONRY ASSOCIATION. Control joints for concrete masonry walls empirical method. TEK 10-2B., 2003b.
} 
Grimm (1993) cita uma equação (4.4) para a previsão do espaçamento de juntas verticais em função do coeficiente de retração da alvenaria, entretanto, nessa expressão não é considerada a umidade relativa do ambiente e a taxa de armadura pré-existente.

$$
s=\frac{\left(w_{j} \cdot e_{j}\right)}{\left(k_{m}+k_{t} \cdot \Delta T\right)}
$$

$\mathrm{s}=$ espaçamento entre juntas, em $\mathrm{mm}$

$\mathrm{w}_{\mathrm{j}}=$ espessura da junta, em $\mathrm{mm}$

$e_{j}=$ extensividade do selante, em \%

$\mathrm{k}_{\mathrm{m}}=$ coeficiente de retração da alvenaria $(\mathrm{mm} / \mathrm{m}$ ) ou de retração dos blocos (que deverá ser reduzido em virtude das condições de restrição e da presença de armaduras na alvenaria) $\mathrm{k}_{\mathrm{t}}=$ coeficiente de dilatação térmica, podendo ser admitido igual a $8,1.10^{-6} \mathrm{~mm} / \mathrm{mm} /{ }^{\circ} \mathrm{C}$ (BARBOSA, 2005)

$\Delta \mathrm{T}=$ variação térmica $\left({ }^{\circ} \mathrm{C}\right)$

Uma alternativa para aumentar a distância das juntas de movimentação é o não preenchimento das juntas verticais entre componentes com o intuito de distribuir mais uniformemente as deformações internas do painel de alvenaria (VILATÓ e FRANCO, 1998). De acordo com Melhado et al. (1995 apud VILATÓ e FRANCO, 1998) ${ }^{20}$, que estudaram alvenarias de vedação, o não preenchimento das juntas verticais promoveu um espaçamento maior das juntas de movimentação, um a dois metros maiores comparativamente a paredes com juntas preenchidas.

Nas juntas de movimentação, segundo Vilató e Franco (1998), geralmente, são empregadas resinas e compostos químicos com o intuito de acomodar os movimentos de retração e expansão sem que sejam introduzidos esforços adicionais nos elementos. De acordo com a BS 5628: part 3 (1978), a largura da junta $(\mathrm{mm})$ deve ser $30 \%$ maior que a distância entre juntas $(m)$ e, para que seja assegurada s aderência entre alvenaria e selante, o selante deve cobrir uma profundidade de pelo menos $10 \mathrm{~mm}$. Epusp-Encol (1988 apud VILATÓ e FRANCO, 1998) ${ }^{17}$ recomenda uma espessura de junta entre 10 e $15 \mathrm{~mm}$ e uma profundidade de aplicação do selante entre 50\% e 100\% da espessura da junta; além disso, prescreve que para alvenarias de fachada seja empregado um filete de mástique (acrílico ou

\footnotetext{
${ }^{20}$ MELHADO, S. B.; BARROS, M. S. B.; SOUZA, A. L. R. Diretrizes para elaboração do projeto de alvenaria de vedação. São Paulo: EPUSP-PCC, Escola Politécnica da Universidade de São Paulo, 1995. (Relatório técnico CPqDCC n ${ }^{0}$ 20.085-EP/SC-1).
} 
poliuretânico) na face exterior. Na Figura 4.2, são apresentadas, segundo diversos autores, algumas alternativas para a execução das juntas de movimentação entre elementos de alvenaria.

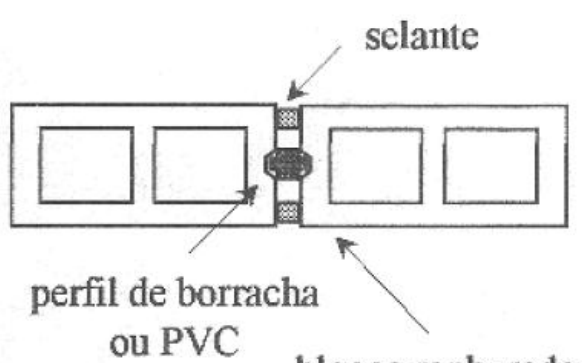

blocos ranhurados

a) ACI/ASCE (1995)

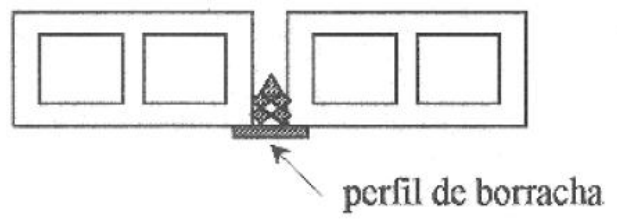

c) Poli-Encol (1991 apud VILATÓ e FRANCO, 1998) ${ }^{21}$

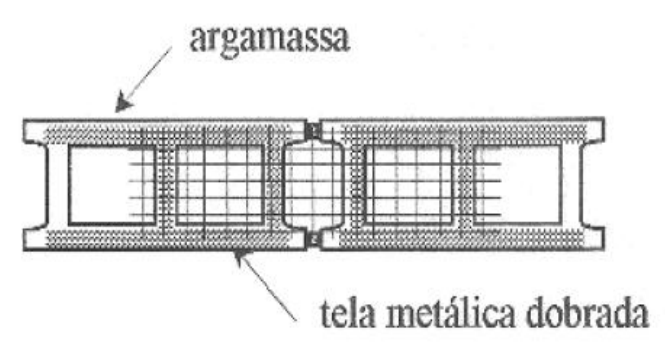

e) Vilató e Franco (1998)

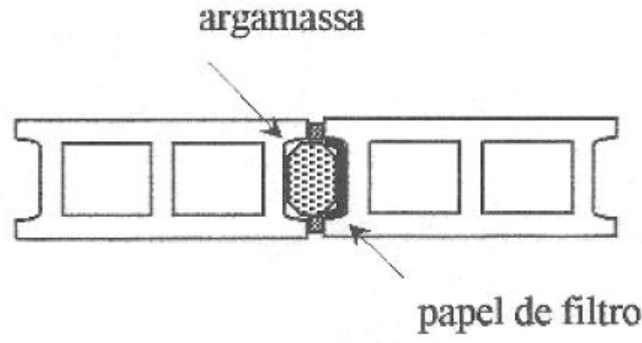

b) ACI/ASCE (1995)

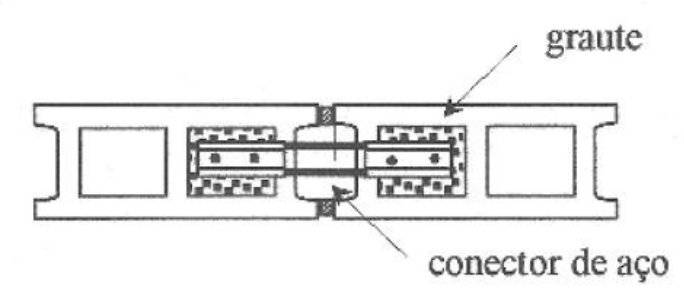

d) Catani e Heights (1988 apud VILATÓ e FRANCO, 1998) $)^{22}$

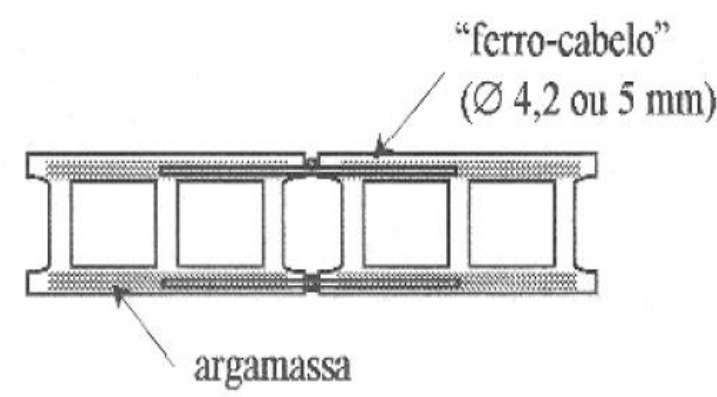

f) Vilató e Franco (1998)

Figura 4.2 - Juntas de movimentação entre elementos de alvenaria (fonte: conforme citado na Figura).

Segundo Vilató e Franco (1998), as alternativas "e" e "f" da Figura 4.2 são as mais comumente empregadas devido à simplicidade do conector e a facilidade de execução. 


\subsection{CONCLUSÕES DO CAPÍTULO}

Conforme apresentado no capítulo, a retração é um fenômeno que ocorre basicamente pela perda da água adsorvida presente em pequenos capilares do compósito de cimento, sendo comumente classificada quanto ao seu estado físico, natureza do fenômeno, grau de restrição e permanência.

Dentre os principais fatores que influenciam a retração em elementos de concreto podem ser citados: a relação água/cimento, o módulo de deformação do agregado e o tipo e duração da cura. Para unidades com agregados reciclados, os valores de retração são maiores, devido à redução do módulo de deformação do agregado provocado pela argamassa porosa que se encontra aderida à sua superfície; por outro lado, a implantação da cura térmica e um controle mais rigoroso do processo de produção são medidas que podem reduzir a retração dessas unidades.

Para alvenarias de blocos de concreto, a implantação de juntas de controle, o controle da umidade das unidades no momento do assentamento, a disposição de armaduras nas juntas horizontais e a utilização de argamassas com menor módulo de deformação são medidas que podem reduzir as tensões oriundas da retração e, consequentemente, evitar o surgimento de fissuras e patologias; principalmente, no caso de alvenarias compostas por unidades com agregados reciclados.

projeto. São Paulo: EPUSP-PCC, Escola Politécnica da Universidade de São Paulo, 1991. (Relatório técnico R5-25/91).

${ }^{22}$ CATANI, M. L.; HEIGHTS, A. Where do you need joints? Masonry Construction, oct. 1988. 
Os ensaios de caracterização dos agregados naturais e agregados reciclados foram realizados no Laboratório de Estruturas do Departamento de Estruturas e no Laboratório do Departamento de Transportes, ambos da EESC-USP. Todos os insumos necessários para a pesquisa foram obtidos por intermédio da Tatu Pré-Moldados (fabricante de elementos prémoldados) e são comumente utilizados para a produção de peças pré-moldadas. A caracterização dos agregados reciclados e naturais visa também substanciar as próximas etapas do estudo que são a produção de corpos-de-prova e blocos estruturais de concreto com esses agregados.

\subsection{AGLOMERANTE}

O aglomerante utilizado na pesquisa foi o cimento CP $\vee$ ARI PLUS, usualmente utilizado para a produção de elementos pré-moldados que exigem elevada resistência em baixas idades. O relatório técnico contendo a análise química e física desse cimento, referente aos meses de fevereiro a abril de 2005, está apresentado na Tabela 5.1.

Tabela 5.1 - Propriedades físicas e químicas do aglomerante empregado.

\begin{tabular}{|c|c|c|c|c|c|c|c|c|c|c|c|c|c|}
\hline & \multicolumn{8}{|c|}{ Propriedades físicas } & \multicolumn{5}{|c|}{ Propriedades químicas } \\
\hline & \multirow{2}{*}{$\begin{array}{l}\text { pen. } \\
325 \\
(\%) \\
\text { NBR } \\
9202\end{array}$} & \multirow{2}{*}{$\begin{array}{c}\text { Blaine } \\
\left(\mathrm{cm}^{2} / \mathrm{g}\right) \\
\text { NBR } \\
7224\end{array}$} & \multicolumn{2}{|c|}{$\begin{array}{l}\text { Tempo de } \\
\text { pega (min) } \\
\text { NBR } 11581\end{array}$} & \multicolumn{4}{|c|}{$\begin{array}{c}\text { Resistência à } \\
\text { compressão (MPa) } \\
\text { NBR } 7215\end{array}$} & \multirow{2}{*}{$\begin{array}{l}\mathrm{CO}_{2} \\
(\%)\end{array}$} & \multirow{2}{*}{$\begin{array}{c}\text { Perda } \\
\text { ao fogo } \\
500^{\circ} \mathrm{C} \\
(\%)\end{array}$} & \multirow{2}{*}{$\begin{array}{c}\text { Perda } \\
\text { ao } \\
\text { fogo } \\
1000^{\circ} \\
\text { C } \\
(\%)\end{array}$} & \multirow{2}{*}{$\begin{array}{l}\text { Res. } \\
\text { Inso- } \\
\text { lúvel } \\
(\%)\end{array}$} & \multirow{2}{*}{$\begin{array}{l}\mathrm{SO}_{3} \\
(\%)\end{array}$} \\
\hline & & & Ínício & Final & $1 \mathrm{dia}$ & $\begin{array}{c}3 \\
\text { dias }\end{array}$ & $\begin{array}{c}7 \\
\text { dias }\end{array}$ & $\begin{array}{c}28 \\
\text { dias }\end{array}$ & & & & & \\
\hline Média & 1,2 & 4716 & 149 & 202 & 28,0 & 43,0 & 46,9 & 55,1 & 1,15 & 0,65 & 3,11 & 0,29 & 2,68 \\
\hline Mín & 0,8 & 4563 & 120 & 185 & 26,0 & 40,7 & 44,6 & 53,2 & 0,67 & 0,39 & 2,54 & 0,20 & 2,57 \\
\hline Máx & 1,6 & 4936 & 176 & 225 & 29,2 & 45,6 & 51,6 & 67,8 & 1,66 & 0,89 & 3,78 & 0,39 & 2,80 \\
\hline D.Pad & 0,2 & 60 & 11 & 12 & 0,84 & 1,22 & 1,62 & 1,54 & 0,36 & 0,19 & 0,30 & 0,05 & 0,07 \\
\hline $\begin{array}{l}\text { C.V. } \\
(\%)\end{array}$ & 17 & 2 & 8 & 6 & 3 & 3 & 3 & 3 & 31,2 & 28,9 & 12,2 & 20,4 & 2,7 \\
\hline
\end{tabular}

(fonte: Diniz Filho, 2005) 


\subsection{ADITIVO}

O aditivo empregado para a produção dos concretos e blocos foi um aditivo plastificante - Rheomix 610 da MBT (Master Builder Technologies). Trata-se de um aditivo com base química saponácea, cor laranja claro e densidade de 1,03 0,02 $\mathrm{g} / \mathrm{cm}^{3}$. Esse produto é recomendado para a fabricação de blocos e concretos de consistência seca, pois reduz a água de amassamento, melhora a resistência mecânica e a textura dos blocos.

\subsection{AGREGADOS}

Os agregados utilizados na presente pesquisa são apresentados na Tabela 5.2.

Tabela 5.2 - Agregados utilizados na pesquisa.

\begin{tabular}{cc}
\hline Designação & Agregado \\
\hline Agregado miúdo natural & Areia natural quartzoza - Itaporanga \\
\hline Agregado miúdo natural & Areia natural quartzoza - Tietz \\
\hline Agregado miúdo & Pó-de-pedra - origem basáltica \\
\hline Agregado graúdo & Pedrisco - origem basáltica \\
\hline Agregados graúdos reciclados & Originários de diferentes resíduos de concreto \\
\hline Agregados miúdos reciclados & Originários de diferentes resíduos de concreto \\
\hline
\end{tabular}

Os resíduos de concreto foram coletados em uma fábrica de pré-moldados de grande porte com o objetivo de englobar a maior parte dos artefatos comumente produzidos para o mercado consumidor (blocos de concreto, telhas de concreto e vigotas prémoldadas), sendo também coletados resíduos produzidos durante o próprio processo de fabricação das peças, Figura 5.1.

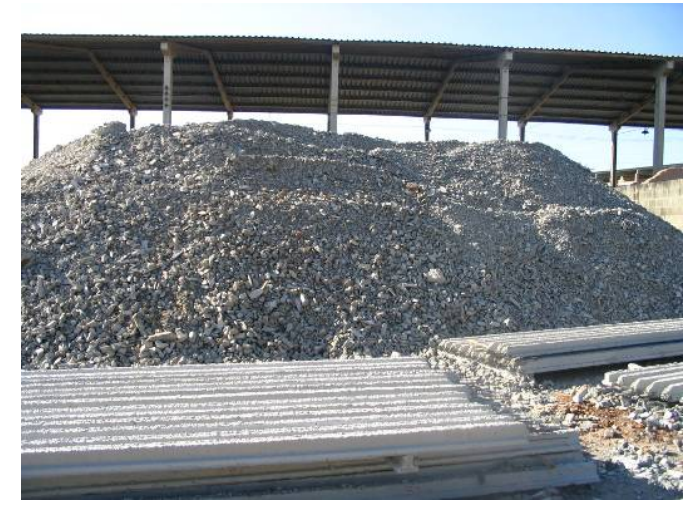

a) resíduos de vigotas $\left(\mathrm{f}_{\mathrm{c}}=35 \mathrm{MPa}\right)-\mathrm{Rv}$ e Rvf

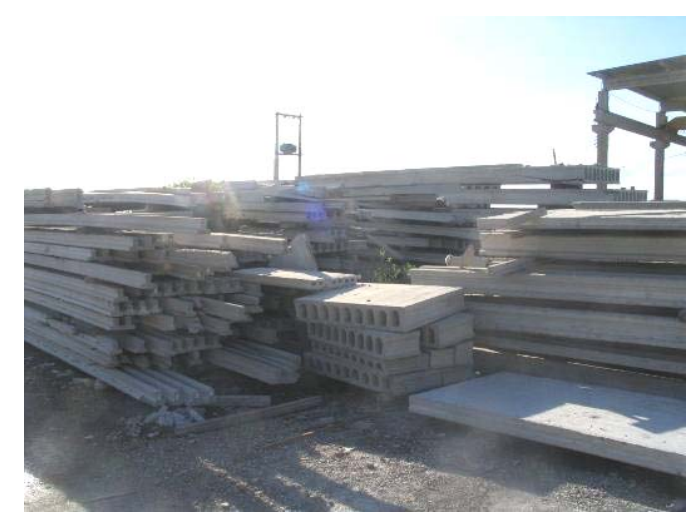

b) resíduos de painéis pré-moldados 


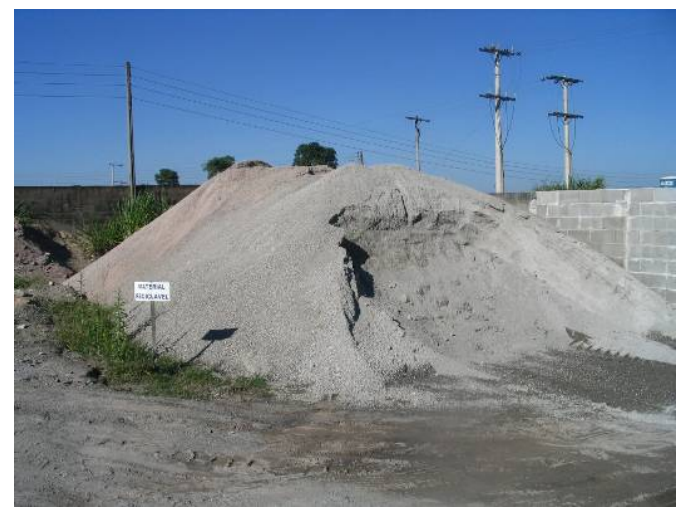

c) resíduos gerados na etapa final de produção dos blocos (Rvp)

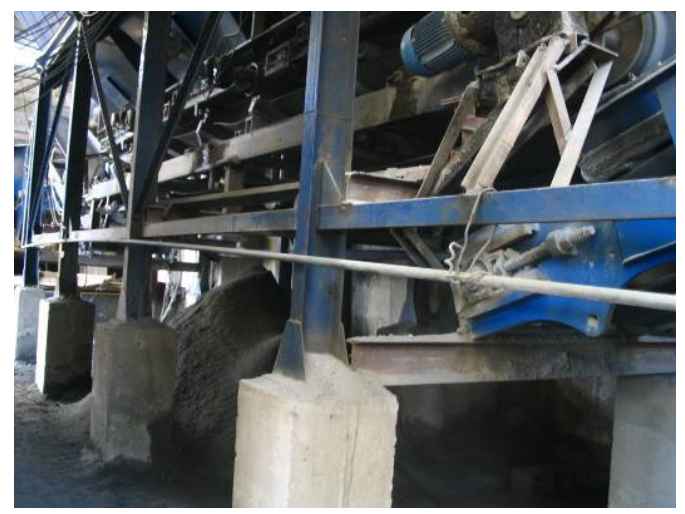

e) resíduos gerados durante a produção dos blocos $(\mathrm{Rpb})$

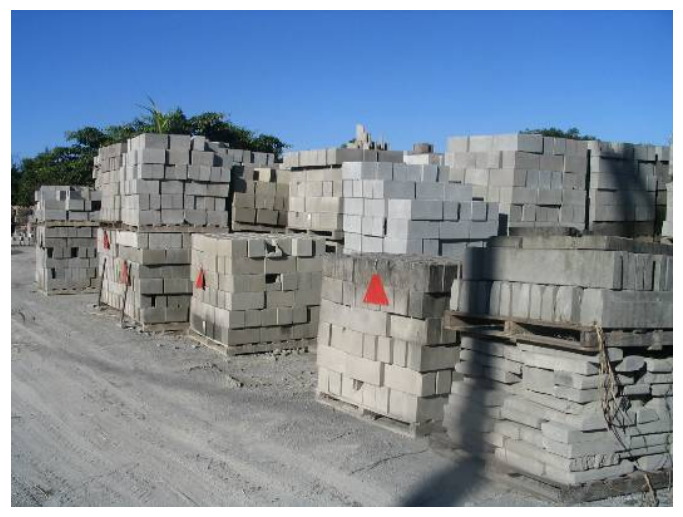

d) resíduos de blocos de concreto $(\mathrm{Rb})$

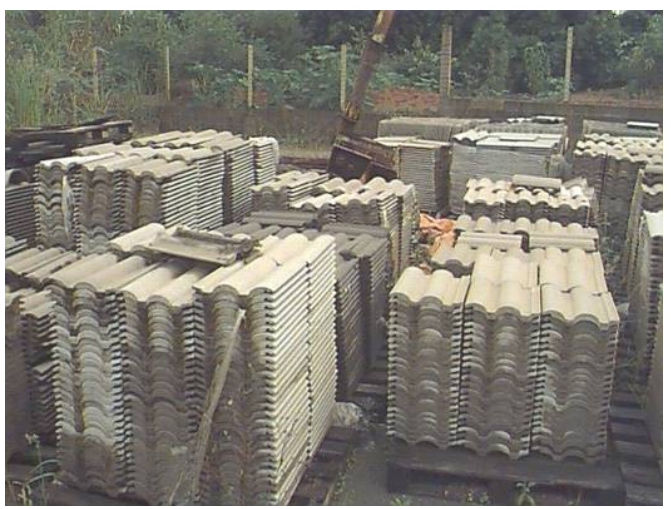

f) resíduos de telhas de concreto $(\mathrm{Rt})$

Figura 5.1 - Resíduos avaliados no trabalho (foto do autor).

Além dos resíduos mencionados, foram analisados, em uma primeira etapa, os resíduos oriundos de pisos de pavimentação de concreto, denominados Rpp. A classificação para cada tipo de resíduo de concreto, conforme Figura 5.1, foi estabelecida da seguinte maneira:

1 - Resíduos de vigotas de concreto: resíduos oriundos de concretos de média resistência $\left(\mathrm{f}_{\mathrm{c}}=35 \mathrm{MPa}\right)$, elevado consumo de cimento, boa qualidade, porcentagem de contaminantes inferior a 1\% (pequenas lascas de madeira). Os resíduos de vigotas constituídos por pequenos pedaços de concreto e que são produzidos durante o processo de concretagem e desforma foram denominados de Rv; já os resíduos constituídos por pedaços de vigotas com pequenas barras de aço e que são gerados na liberação da protensão, início e final das pistas de produção foram denominados de Rvf. A estimativa de geração desses resíduos é de aproximadamente $15 \mathrm{~m}^{3} / \mathrm{mês}$. 
2 - Resíduos de painéis pré-moldados: resíduos de características similares aos resíduos de vigotas, média resistência, elevado consumo de cimento e boa qualidade. Esses resíduos não foram analisados pela presente pesquisa, uma vez que a produção desses elementos iniciou-se no ano de 2006. A estimativa de geração desses resíduos é de aproximadamente $2 \mathrm{~m}^{3} / \mathrm{mês}$.

3 - Resíduos gerados na etapa final de produção dos blocos: resíduos oriundos de concretos de baixa resistência (10 a $25 \mathrm{MPa}$ ), baixo consumo de cimento, elevado consumo de pó-de-pedra, boa qualidade (fração graúda), porcentagem de contaminantes desprezível. Esses resíduos são produzidos durante o processo de vibro-prensagem do maquinário responsável pela fabricação dos blocos; são constituídos basicamente de materiais miúdos (cerca de 70\%) e podem ser reaproveitados sem a necessidade de processamento em uma planta de reciclagem. Nesta pesquisa foram denominados de Rvp - resíduos produzidos durante a vibro-prensagem dos blocos;

4 - Resíduos de blocos de concreto: resíduos oriundos de concretos de baixa resistência (10 a $25 \mathrm{MPa}$ ), baixo consumo de cimento, elevado consumo de pó-de-pedra, baixa qualidade e porcentagem de contaminantes desprezível. Esses resíduos são constituídos por blocos de concreto rejeitados pelo controle de qualidade e unidades danificadas durante o transporte e estocagem. A estimativa da geração desses resíduos é de aproximadamente $60 \mathrm{~m}^{3} / \mathrm{mês}$. Foram denominados de $\mathrm{Rb}$ - resíduos de blocos;

5 - Resíduos gerados durante a produção dos blocos: resíduos oriundos de concretos de baixa resistência (10 a $25 \mathrm{MPa}$ ), baixo consumo de cimento, elevado consumo de pó-depedra, boa qualidade (fração graúda) e porcentagem de contaminantes desprezível. Esses resíduos são produzidos durante as etapas de produção dos blocos (descarga dos silos de agregados, transporte nas correias transportadoras e mistura dos materiais); são constituídos basicamente de materiais miúdos (cerca de $70 \%$ ) e podem ser reaproveitados sem a necessidade de processamento em uma planta de reciclagem. Nesta pesquisa foram denominados de $\mathrm{Rpb}$ - resíduos gerados na produção dos blocos;

6 - Resíduos de telhas de concreto: resíduos oriundos de concretos de média resistência ( $f_{c}$ = $35 \mathrm{MPa}$ ), elevado consumo de cimento elevado teor de argamassa, baixo consumo de agregados graúdos, boa qualidade e porcentagem de contaminantes desprezível. Os resíduos de telhas (Rt) são constituídos basicamente por elementos rejeitados pelo controle de qualidade e danificados durante o processo de transporte e armazenamento. A estimativa de geração desses resíduos é de aproximadamente $1 \mathrm{~m}^{3} / \mathrm{mês}$. 
Os resíduos de concreto mencionados foram recebidos em estado bruto, conforme Figura 5.2. Esses materiais foram processados em um britador de mandíbulas, pertencente ao Departamento de Geotecnia; tal equipamento possuía uma boca de alimentação de $20 \mathrm{x}$ $10 \mathrm{~cm}^{2}$ com controle de abertura da mandíbula, Figura 5.3.
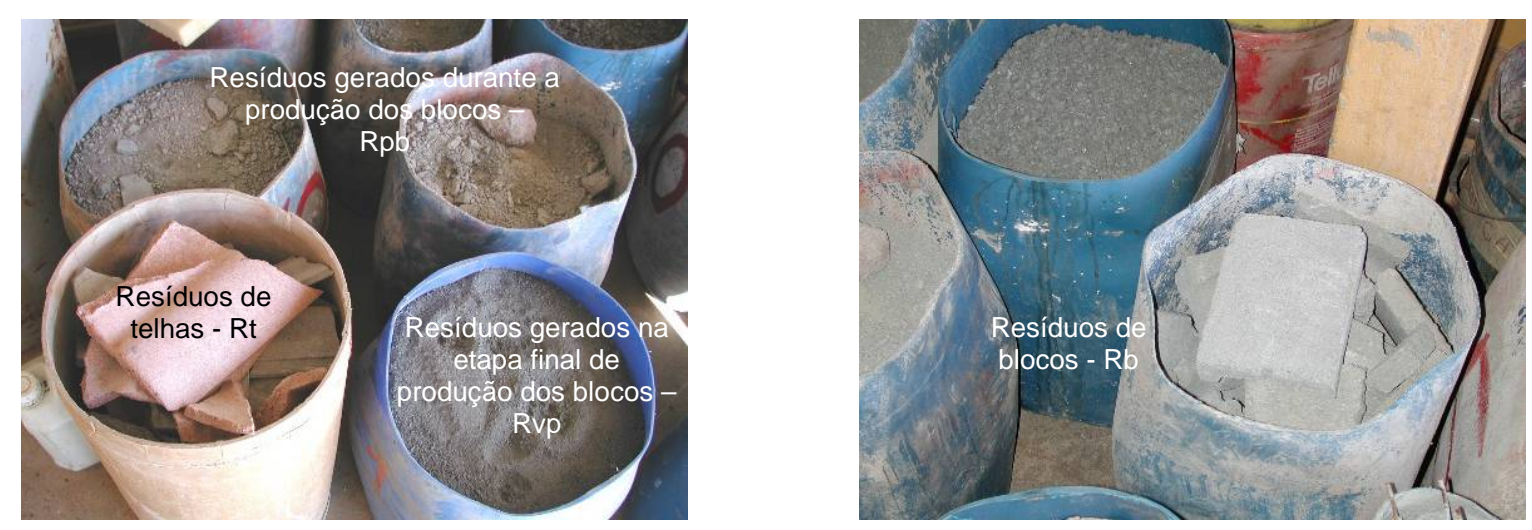

Figura 5.2 - Resíduos de concreto no estado bruto.
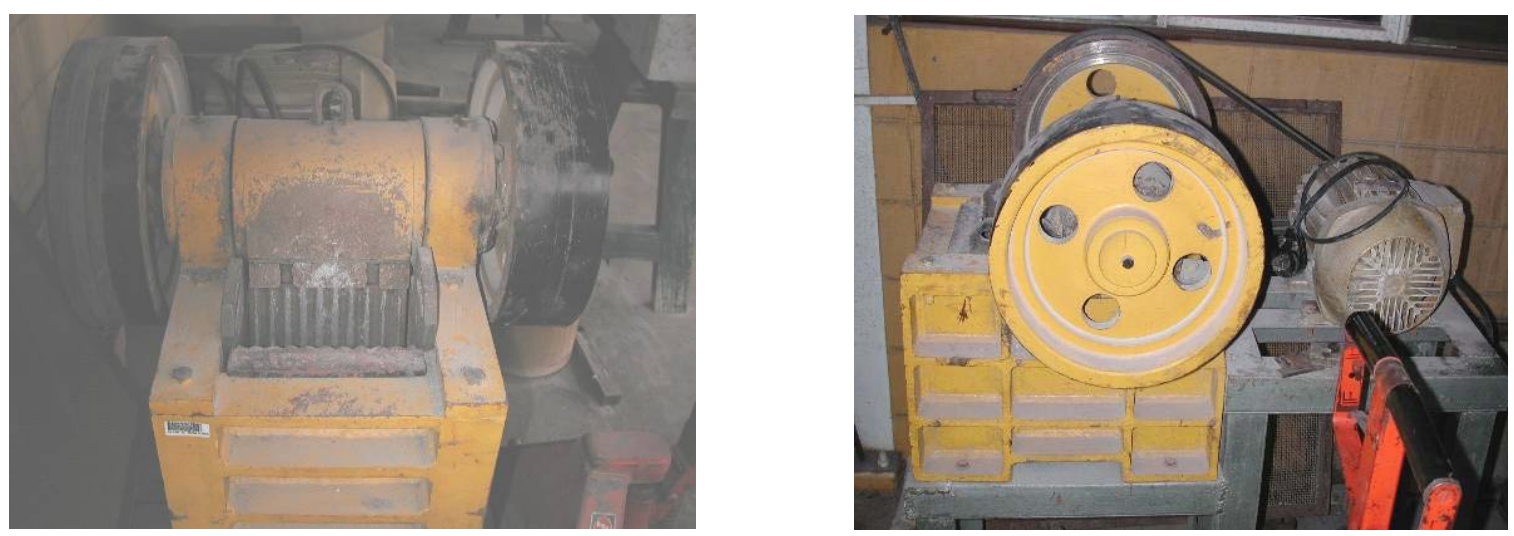

Figura 5.3 - Britador de mandíbulas utilizado para o processamento dos resíduos.

Após a britagem do material, os agregados reciclados foram separados em duas frações distintas: > 4,8 mm (graúda) e $<$ 4,8 mm (miúda) e estocados em sacos devidamente etiquetados. No primeiro processamento, foram avaliadas algumas propriedades físicas dos sete agregados graúdos reciclados, Tabela 5.3. Em função da não adequação do material graúdo reciclado à granulometria de brita 0 (empregada na produção dos blocos), os resultados e as análises serão apresentados resumidamente. Por outro lado, para o segundo processamento dos materiais reciclados, os ensaios de caracterização, a apresentação e a análise dos resultados serão discutidos detalhadamente. 
Tabela 5.3 - Ensaios de caracterização dos agregados (primeiro processamento).

\begin{tabular}{cl}
\hline Propriedade & Referência \\
\hline Composição granulométrica dos agregados & NBR 7217 (1987) \\
\hline Massa específica e absorção de agregado graúdo & NBR 9937 (1987) \\
\hline Massa unitária de agregados em estado solto & NBR 7251 (1982) \\
\hline Massa unitária de agregados em estado compactado seco & NBR 7810 (1983) \\
\hline Teor de material pulverulento & NBR 7219 (1987) \\
\hline
\end{tabular}

\subsubsection{PRIMEIRO PROCESSAMENTO}

Os ensaios de caracterização dos materiais foram realizados seguindo-se as recomendações das Normas Brasileiras, no Laboratório de Estruturas do Departamento de Engenharia de Estruturas. Na Figura 5.4, podem ser observados os agregados reciclados (fração graúda) após a britagem e o peneiramento.

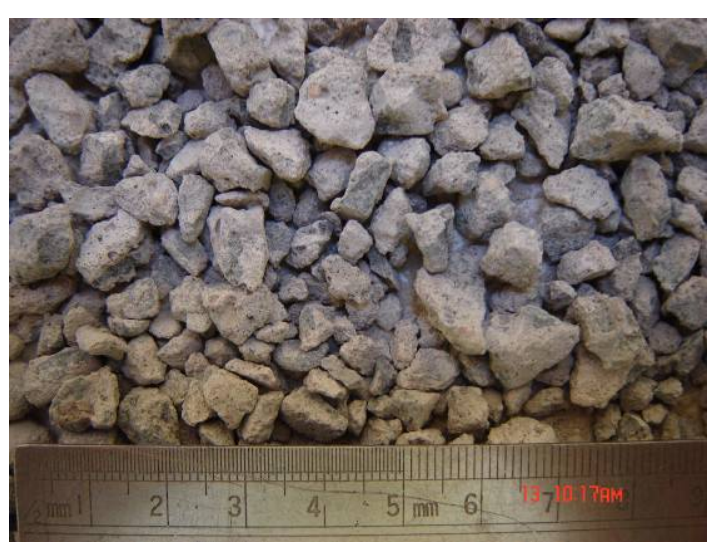

ARv - agregado reciclado de vigota

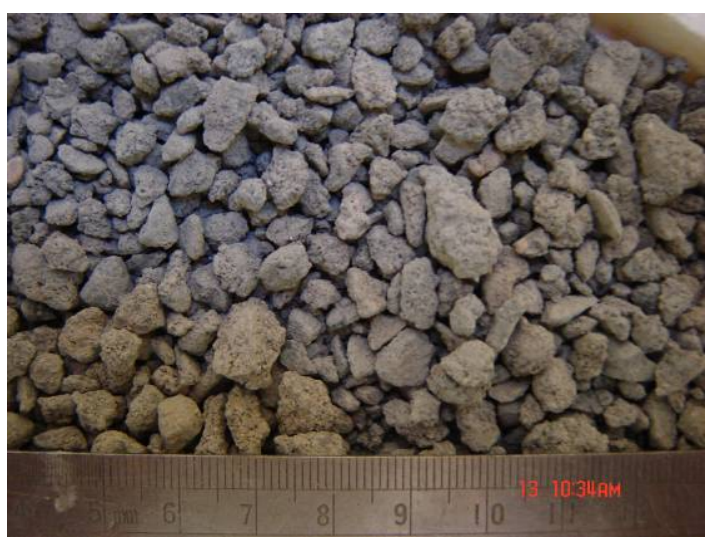

$\mathrm{ARb}$ - agregado reciclado de bloco

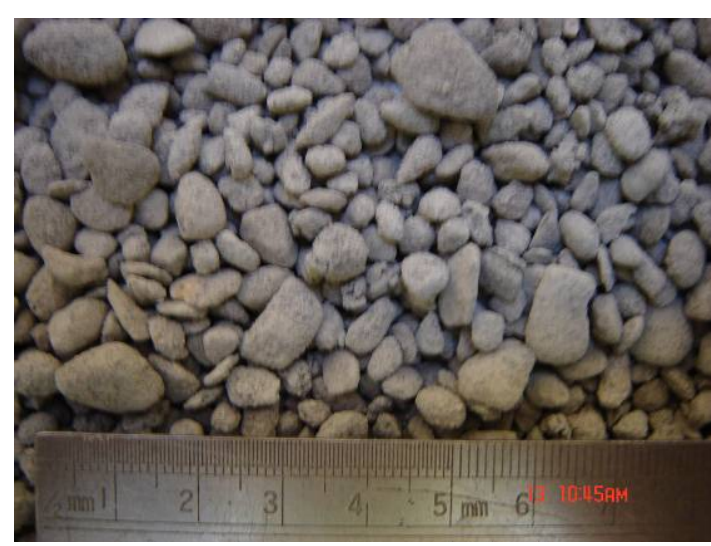

ARvp - agregado reciclado de resíduos gerados durante a etapa de vibro-prensagem dos blocos

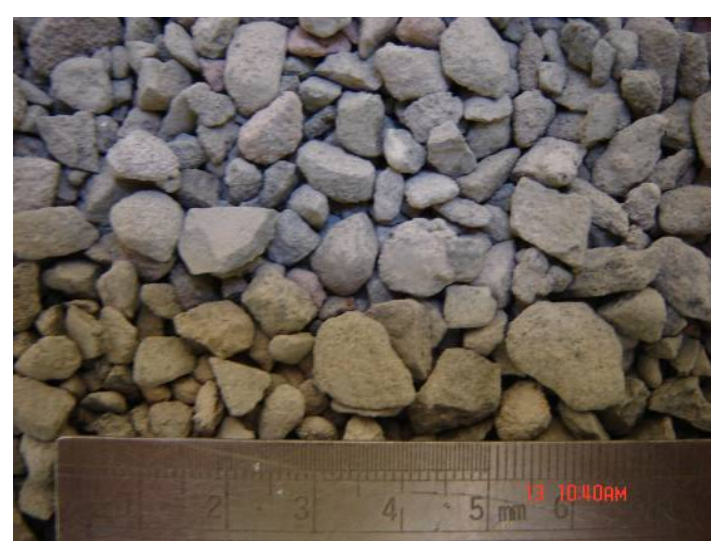

ARpb - agregado reciclado de resíduos gerados durante a produção dos blocos 


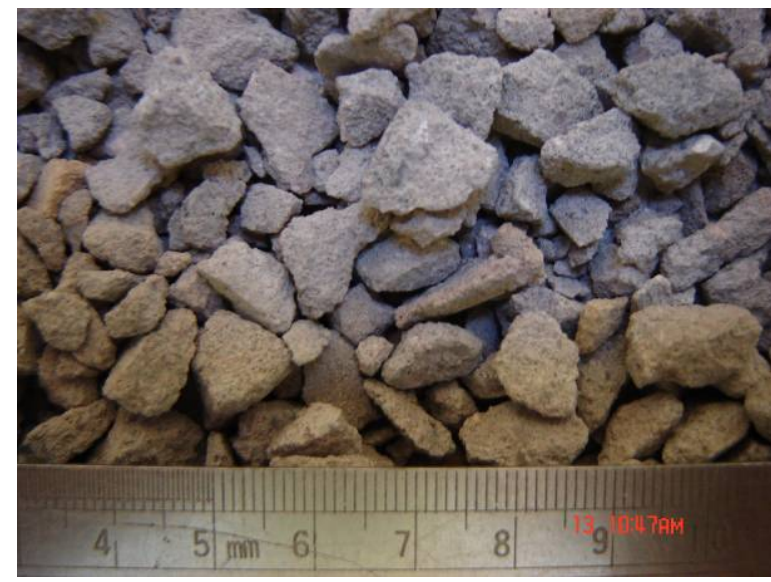

ARt - agregado reciclado de telha

Figura 5.4 - Agregados reciclados de concreto (fração graúda).

Após a realização da análise visual, foi notada uma grande quantidade de argamassa aderida aos agregados reciclados ARv e ARt e a fragilidade do agregado ARb. Conforme relatado anteriormente, serão apresentados os resultados gerais dessa primeira etapa de processamento. As propriedades físicas dos agregados reciclados encontram-se na Tabela 5.4.

Tabela 5.4 - Propriedades físicas dos agregados reciclados (primeiro processamento).

\begin{tabular}{|c|c|c|c|c|c|c|c|}
\hline & ARv & ARvf & ARvp & ARb & ARpb & ARt & ARpp \\
\hline $\begin{array}{c}\text { Representatividade } \\
\text { da fração graúda - }>4,8 \mathrm{~mm}(\%)\end{array}$ & 75,2 & 70,2 & 11,1 & 42,4 & 22,0 & 74,2 & 63,5 \\
\hline & GRv & GRvf & GRvp & GRb & GRpb & GRt & GRpp \\
\hline $\begin{array}{l}\text { Dimensão máxima característica } \\
(\mathrm{mm})\end{array}$ & 19,0 & 19,0 & 9,5 & 12,5 & 12,5 & 19,0 & 19,0 \\
\hline Módulo de Finura & 6,43 & 6,53 & 5,94 & 6,04 & 6,06 & 6,50 & 6,36 \\
\hline Classificação & - & - & Brita 0 & - & - & - & - \\
\hline $\begin{array}{l}\text { Massa unitária estado solto } \\
\left(\mathrm{kg} / \mathrm{dm}^{3}\right)\end{array}$ & 1,21 & 1,18 & 1,39 & 1,18 & 1,29 & 1,15 & 1,18 \\
\hline $\begin{array}{l}\text { Massa unitária estado compactado } \\
\left(\mathrm{kg} / \mathrm{dm}^{3}\right)\end{array}$ & 1,35 & 1,35 & 1,56 & 1,37 & 1,47 & 1,29 & 1,33 \\
\hline Massa específica seca $\left(\mathrm{kg} / \mathrm{dm}^{3}\right)$ & 2,332 & 2,348 & 2,684 & 2,382 & 2,438 & 2,239 & 2,319 \\
\hline Massa específica saturada $\left(\mathrm{kg} / \mathrm{dm}^{3}\right)$ & 2,440 & 2,456 & 2,748 & 2,503 & 2,549 & 2,364 & 2,427 \\
\hline Índice de Vazios (\%) & 10,75 & 10,76 & 6,38 & 12,10 & 11,09 & 12,48 & 10,78 \\
\hline \multicolumn{8}{|l|}{ Absorção de água (\%) } \\
\hline $10^{\prime}$ & 4,26 & 4,14 & 2,27 & 4,84 & 4,24 & 4,80 & 4,31 \\
\hline 30 & 4,33 & 4,21 & 2,31 & 4,97 & 4,30 & 5,13 & 4,38 \\
\hline $24 \mathrm{~h}$ & 4,61 & 4,58 & 2,38 & 5,08 & 4,55 & 5,57 & 4,55 \\
\hline Teor de materiais pulverulentos (\%) & - & - & 0,46 & 1,18 & 1,61 & - & - \\
\hline \multicolumn{8}{|c|}{$\begin{array}{l}\text { ARv - agregado reciclado de vigota; GRv - agregado graúdo reciclado de vigota }(>4,8 \mathrm{~mm}) \\
\text { ARvf - agregado reciclado de vigota com barras de aço; GRvf - agregado graúdo reciclado de vigota com barras de aço (> } \\
4,8 \mathrm{~mm}) \\
\text { ARvp - agregado reciclado de resíduos da vibro-prensagem dos blocos; GRvp - agregado graúdo reciclado de resíduos da } \\
\text { vibro-prensagem dos blocos ( }>4,8 \mathrm{~mm}) \\
\text { ARb - agregado reciclado de bloco de concreto; GRb - agregado graúdo reciclado de bloco de concreto }(>4,8 \mathrm{~mm}) \\
\mathbf{A R p b} \text { - agregado reciclado de resíduos da produção dos blocos; GRvp - agregado graúdo reciclado de resíduos da produção } \\
\text { dos blocos (> 4,8mm) } \\
\text { ARt - agregado reciclado de telha de concreto; GRt - agregado graúdo reciclado de telha de concreto } \\
\text { ARpp - agregado reciclado de paver; GRpp - agregado graúdo reciclado de paver }\end{array}$} \\
\hline
\end{tabular}


Analisando-se os resultados dessa etapa são feitos os seguintes comentários:

- Com relação à representatividade da fração graúda, nota-se que os resíduos ARv, ARvf, ARt e ARpp apresentaram valores similares em ordem de grandeza (63\% a 75\%). A prevalência da fração graúda em relação à miúda pode ser explicada pela maior resistência e o maior consumo de cimento empregado na produção desses elementos. Para os agregados oriundos de resíduos de blocos (ARb) foi observada uma prevalência da fração miúda, provavelmente, devido ao menor consumo de cimento dessas unidades, sua menor resistência e o consumo elevado de pó-depedra. Para os demais materiais (ARvp e ARpb), o processamento no britador é opcional, uma vez que esses resíduos são constituídos preponderantemente por frações miúdas (<4,8 mm).

- O menor módulo de finura do agregado GRb, quando comparado aos demais agregados, pode ser justificado pela baixa resistência do resíduo de bloco.

- A maior massa unitária no estado solto e compactada dos agregados GRvp e GRpb pode ser atribuída ao fato que esses materiais apresentaram, comparativamente aos demais agregados, uma distribuição granulométrica mais uniforme e menor quantidade de argamassa aderida.

- Com relação à massa específica seca e saturada superfície seca, o agregado GRt apresentou os menores valores quando comparado com os demais agregados. Esse fato deve-se à grande quantidade de argamassa aderida ao agregado e as próprias características do resíduo (baixo consumo de agregado graúdo por $\mathrm{m}^{3}$ ).

- Para as propriedades de absorção de água e índice de vazios, os resultados foram similares para a grande maioria dos agregados analisados. Os agregados GRb e GRt apresentaram os maiores valores para essas propriedades, motivados pela baixa qualidade e elevada quantidade de argamassa aderida, respectivamente. Apesar disso, os valores mantiveram-se dentro dos limites impostos por algumas recomendações internacionais.

- O teor de materiais pulverulentos manteve-se dentro dos limites recomendados pela NBR 7219 (1989).

O primeiro processamento permitiu definir algumas diretrizes fundamentais para a continuidade da pesquisa. Nos próximos itens são enumerados alguns desses parâmetros: 
- O primeiro deles refere-se aos tipos de resíduos a serem analisados. A partir dos resultados obtidos, pode-se notar a similaridade nas propriedades físicas dos agregados ARv, ARvf e ARpp; nesse sentido, e em função da geração mais representativa do resíduo ARv na presente fábrica, no segundo processamento, são estudados apenas resíduos de vigotas sem barras de aço (ARv).

- No segundo processamento, em função da granulometria obtida no primeiro processamento, é realizado um ajuste na abertura da mandíbula do britador para o processamento dos resíduos Rv, Rvp, Rpb e Rt. Para o processamento dos resíduos oriundos de blocos de concreto $\mathrm{Rb}$ não é realizado o ajuste da mandíbula em razão da menor resistência do material.

- No primeiro processamento, já foi notada uma dificuldade na definição da condição saturada superfície seca para a determinação da absorção dos agregados reciclados. Em razão disso e do menor módulo de finura dos agregados no segundo processamento, são propostas metodologias para a determinação da absorção e massa específica dos agregados reciclados baseadas nos trabalhos de Leite (2001) e Dias e Agopyan (2004).

- A resistência à abrasão e a quantidade de argamassa aderida são avaliadas mediante o ensaio de abrasão Los Angeles e pela metodologia citada por Bazuco (1999), respectivamente.

- Todos os resultados obtidos para os agregados reciclados são comparados com similares obtidos para os agregados de referência comumente utilizados para a produção de elementos pré-moldados.

\subsubsection{SEGUNDO PROCESSAMENTO}

No segundo processamento, a abertura da mandíbula do britador foi ajustada com a finalidade de adequar a granulometria do material processado para a graduação de brita 0 , que normalmente é empregada para a produção de blocos de concreto. Esse ajuste foi realizado com a colocação de chapas de aço na parte posterior da mandíbula visando diminuir sua abertura, Figura 5.5. Para o processamento dos resíduos de blocos, oriundo de um resíduo de concreto de menor resistência, foi mantido o ajuste estabelecido no primeiro processamento. 

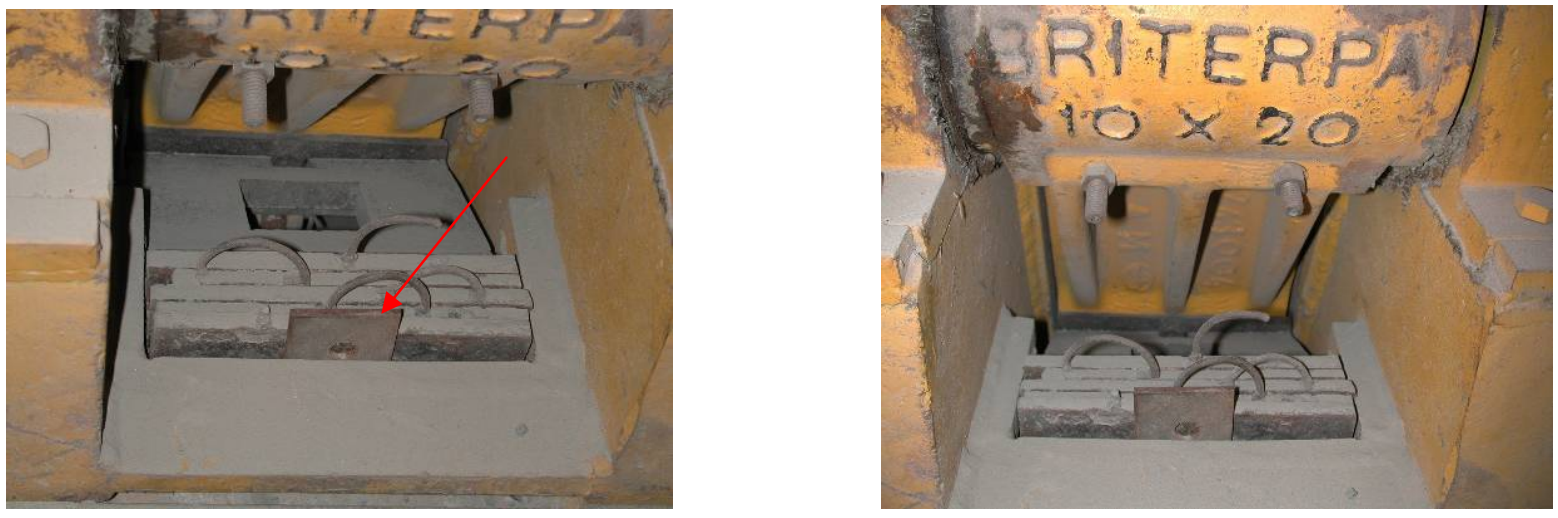

Figura 5.5 - Ajuste realizado na mandíbula do britador para a produção de brita 0.

Os ensaios para a caracterização das propriedades físicas dos agregados são encontrados na Tabela 5.5.

Tabela 5.5 - Ensaios para caracterização dos agregados (segundo processamento).

\begin{tabular}{cc}
\hline \multicolumn{1}{c}{ Propriedade } & Referência \\
\hline Composição granulométrica dos agregados & NBR 7217 (1987) \\
\hline Massa específica e absorção de agregado graúdo & NBR 9937 (1987) \\
\hline Absorção de agregado miúdo e graúdo & Dias e Agopyan (2004) e Leite (2001) \\
\hline Massa específica de agregado miúdo - Frasco de Chapman & NBR 9776 (1987) \\
\hline Massa unitária de agregados em estado solto & NBR 7251 (1982) \\
\hline Massa unitária de agregados em estado compactado seco & NBR 7810 (1983) \\
\hline Índice de forma de agregado & Liborio (2003) e Neville (1997) \\
\hline Abrasão Los Angeles & NBR 6465 (1984) \\
\hline Quantidade de argamassa aderida ao agregado reciclado & Hansen (1985) e Bazuco (1999)
\end{tabular}

Os agregados miúdos reciclados $(<2,4 \mathrm{~mm})$ também foram avaliados quanto às suas propriedades físicas, uma vez que serão empregados nas próximas etapas da pesquisa visando à produção de corpos-de-prova e blocos de concreto. Apesar disso, muitos pesquisadores, tais como, Hansen (1985); Van Acker (1996); Di Niro et al. (1998); SagoeCrentsil et al. (1998); Park (1999) e Works Bureau Technical Circular (2002) não recomendam o emprego da fração miúda reciclada, devido sua elevada absorção e grande variabilidade. Por outro lado, Van Loo (1998) cita a atividade pozolânica dos agregados miúdos reciclados $(<0,15 \mathrm{~mm}$ ) quando submetidos a um processo de tratamento térmico; segundo o pesquisador, esses agregados podem ser utilizados, em substituição ao cimento, sem prejuízo da resistência, para taxas de substituição de até $25 \%$.

\subsubsection{Representatividade das frações graúda e miúda}

Após a britagem dos resíduos, os agregados foram separados em duas granulometrias distintas (graúda $>2,4 \mathrm{~mm}$ e miúda $<2,4 \mathrm{~mm}$ ). A distribuição das frações granulométricas para cada um dos resíduos encontra-se na Tabela 5.6. 
Tabela 5.6 - Distribuição das frações granulométricas para cada um dos agregados reciclados.

\begin{tabular}{cccccc}
\hline \multirow{2}{*}{ Frações $(\mathbf{m m})$} & \multicolumn{5}{c}{ Retidos acumulados (\%) } \\
\cline { 2 - 6 } & ARv & ARb & ARpb & ARvp & ARt \\
\hline$<12,5$ & $0,0 \%$ & $0,1 \%$ & $0,0 \%$ & $0,0 \%$ & $0,1 \%$ \\
\hline $12,5-9,5$ & $1,7 \%$ & $1,6 \%$ & $0,1 \%$ & $0,0 \%$ & $2,0 \%$ \\
\hline $9,5-6,3$ & $37,9 \%$ & $26,5 \%$ & $11,4 \%$ & $4,6 \%$ & $41,5 \%$ \\
\hline $6,3-4,8$ & $57,0 \%$ & $39,3 \%$ & $21,7 \%$ & $12,8 \%$ & $57,0 \%$ \\
\hline $4,8-2,4$ & $75,2 \%$ & $59,5 \%$ & $37,4 \%$ & $38,7 \%$ & $72,7 \%$ \\
\hline $2,4-1,2$ & $82,5 \%$ & $72,6 \%$ & $49,7 \%$ & $58,5 \%$ & $79,8 \%$ \\
\hline $1,2-0,6$ & $87,8 \%$ & $82,5 \%$ & $62,5 \%$ & $75,1 \%$ & $85,9 \%$ \\
\hline $0,6-0,3$ & $93,3 \%$ & $92,5 \%$ & $79,0 \%$ & $89,1 \%$ & $93,0 \%$ \\
\hline $0,3-0,15$ & $96,7 \%$ & $97,6 \%$ & $91,0 \%$ & $97,1 \%$ & $96,9 \%$ \\
\hline$<0,15$ & $100,0 \%$ & $100,0 \%$ & $100,0 \%$ & $100,0 \%$ & $100,0 \%$ \\
\hline
\end{tabular}

Pela Tabela 5.6, nota-se que a fração graúda (> 2,4 mm), para os agregados ARpb e ARvp, apresentou valores similares em ordem de grandeza (38\%). A pequena representatividade da fração graúda, em relação aos demais resíduos, deve-se ao fato que esses materiais já são constituídos, antes do processo de britagem, de grande quantidade de materiais miúdos. Por outro lado, para os agregados ARv e ARt, foram obtidas as maiores porcentagens para essa fração $(\approx 75 \%)$, comparativamente ao agregado ARb (apesar da regulagem da mandíbula do britador), provavelmente devido a maior resistência do resíduo de vigota e telha e a fragilidade do resíduo de bloco. Outros pesquisadores não notaram a influência da resistência/qualidade do resíduo de concreto sobre a distribuição granulométrica; Hansen e Narud (1983) obtiveram para resíduos de concretos, produzidos no laboratório, e que apresentavam consumo de cimento de 410, 215 e $138 \mathrm{~kg} / \mathrm{m}^{3}$, valores de $81 \%$, 83\% e 78\%, respectivamente para as frações retidas acumuladas na peneira de malha 4,8 mm; já Ravindrarajah et al. (1987) obtiveram valores de 77\%, 74\% e 73\% para resíduos de concreto com resistência à compressão de 37, 30 e $22 \mathrm{MPa}$, respectivamente. Por outro lado, a menor abertura da mandíbula do britador utilizada na pesquisa reduziu a quantidade de materiais retidos na peneira de malha $4,8 \mathrm{~mm}, 57 \%$ para os resíduos ARv e ARt e 40\% para o resíduo ARb, comparativamente aos valores próximos a $80 \%$ obtidos por Hansen e Narud (1983) e Ravindrarajah et al. (1987). Buttler (2003) utilizando uma abertura da mandíbula maior para o mesmo britador de mandíbulas, obteve valores próximos a $70 \%$ (fração > 4,8 mm) para resíduos de concreto de 50 MPa. 


\subsubsection{Granulometria}

A composição granulométrica dos agregados foi determinada de acordo com a NBR 7217 (1987). A granulometria pode ser considerada como a propriedade de um agregado de maior aplicação na prática, principalmente para a determinação do módulo de finura (M.F.), da dimensão máxima característica e da curva granulométrica utilizadas na dosagem do concreto. Os equipamentos utilizados nesse ensaio são apresentados no Apêndice A.

Os resultados obtidos para os agregados graúdos naturais e reciclados encontramse na Tabela 5.7 e Figura 5.6.

Tabela 5.7 - Composições granulométricas dos agregados graúdos.

\begin{tabular}{|c|c|c|c|c|c|c|c|c|c|c|c|c|}
\hline \multirow{2}{*}{$\begin{array}{c}\text { Peneira } \\
(\mathrm{mm})\end{array}$} & \multicolumn{2}{|c|}{$\begin{array}{c}\text { Pedrisco } \\
\text { (basalto) - } \\
\text { Gref }\end{array}$} & \multicolumn{2}{|c|}{ GRv } & \multicolumn{2}{|c|}{ GRvp } & \multicolumn{2}{|c|}{$\mathbf{G R} \mathbf{b}$} & \multicolumn{2}{|c|}{ GRpb } & \multicolumn{2}{|c|}{ GRt } \\
\hline & $\begin{array}{c}\% \\
\text { ret. }\end{array}$ & $\begin{array}{c}\% \\
\text { acum. }\end{array}$ & $\begin{array}{c}\% \\
\text { ret. }\end{array}$ & $\begin{array}{c}\% \\
\text { acum. }\end{array}$ & $\begin{array}{c}\% \\
\text { ret. }\end{array}$ & $\begin{array}{c}\% \\
\text { acum. }\end{array}$ & $\begin{array}{c}\% \\
\text { ret. }\end{array}$ & $\begin{array}{c}\% \\
\text { acum. }\end{array}$ & $\begin{array}{c}\% \\
\text { ret. }\end{array}$ & $\begin{array}{c}\% \\
\text { acum. }\end{array}$ & $\begin{array}{c}\% \\
\text { ret. }\end{array}$ & $\begin{array}{c}\% \\
\text { acum. }\end{array}$ \\
\hline 12,5 & 0 & 0 & 0 & 0 & 0 & 0 & 0 & 0 & 0 & 0 & 0 & 0 \\
\hline 9,5 & 0 & 0 & 2 & 2 & 0 & 0 & 3 & 3 & 0 & 0 & 3 & 3 \\
\hline 6,3 & 24 & 24 & 50 & 53 & 13 & 13 & 44 & 47 & 33 & 33 & 56 & 59 \\
\hline 4,8 & 37 & 61 & 27 & 79 & 24 & 38 & 23 & 69 & 30 & 63 & 22 & 80 \\
\hline 2,4 & 35 & 95 & 20 & 99 & 61 & 99 & 28 & 97 & 35 & 98 & 19 & 99 \\
\hline \multirow[t]{4}{*}{ fundo } & 5 & 100 & 1 & 100 & 1 & 100 & 3 & 100 & 2 & 100 & 1 & 100 \\
\hline & \multicolumn{2}{|c|}{ D.Máx= } & \multicolumn{2}{|c|}{ D.Máx= } & \multicolumn{2}{|c|}{ D.Máx= } & \multicolumn{2}{|c|}{ D.Máx= } & \multicolumn{2}{|c|}{ D.Máx= } & \multicolumn{2}{|c|}{ D.Máx= } \\
\hline & \multicolumn{2}{|c|}{ M.Fin. $=5,56$} & \multicolumn{2}{|c|}{ M.Fin. $=5,81$} & \multicolumn{2}{|c|}{ M.Fin. $=5,37$} & \multicolumn{2}{|c|}{ M.Fin. $=5,69$} & \multicolumn{2}{|c|}{ M.Fin. $=5,62$} & \multicolumn{2}{|c|}{ M.Fin. $=5,83$} \\
\hline & \multicolumn{2}{|c|}{-} & \multicolumn{2}{|c|}{ Brita 0} & \multicolumn{2}{|c|}{-} & \multicolumn{2}{|c|}{-} & \multicolumn{2}{|c|}{-} & \multicolumn{2}{|c|}{ Brita 0} \\
\hline
\end{tabular}

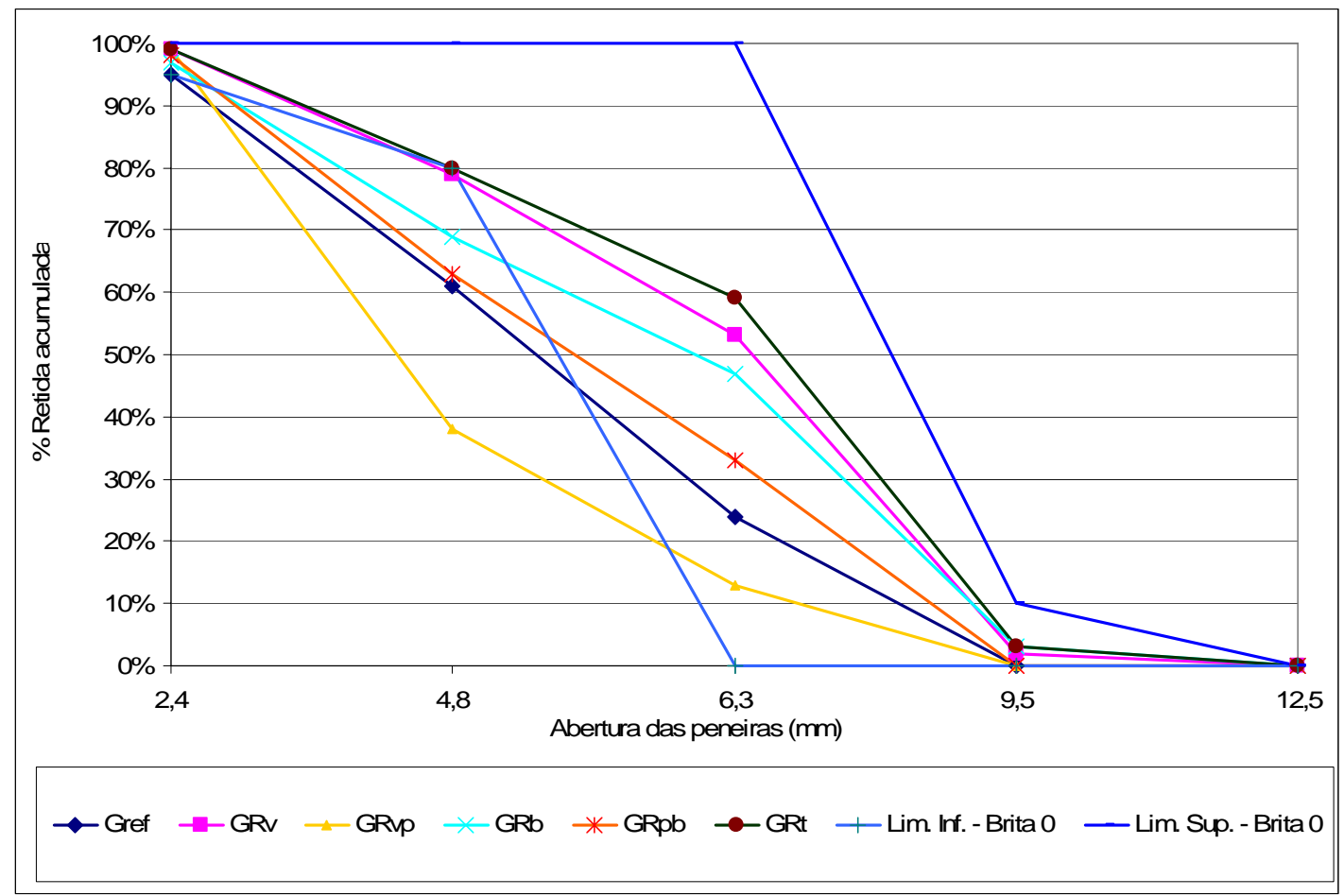

Figura 5.6 - Curvas granulométricas dos agregados graúdos. 
De maneira geral, os agregados reciclados apresentaram um módulo de finura maior quando comparado com o do agregado natural. Segundo Sagoe-Crentsil et al. (1998), a granulometria do agregado reciclado depende do processo de britagem utilizado.

Analisando-se as composições granulométricas dos agregados reciclados, nota-se que os agregados reciclados de bloco (GRb), comparativamente aos agregados GRv e GRt, apresentaram menor módulo de finura devido à menor resistência do agregado e concentração significativa de partículas menores que 4,8 mm (cerca de 30\%). A diminuição do módulo de finura do agregado indica a maior quantidade de finos; a presença desses finos eleva a superfície específica do material gerando, consequentemente, um aumento na demanda de água pelo agregado. Para os agregados reciclados GRvp e GRpb ocorreu uma diminuição do módulo de finura, quando comparado com os demais agregados, não se enquadrando na classificação de brita 0, conforme NBR 7217 (1987). Os agregados GRpb apresentaram uma distribuição granulométrica similar à obtida para o agregado natural (pedrisco); já para os agregados GRvp, notou-se uma grande concentração de partículas menores que 4,8 $\mathrm{mm}$ (cerca de 62\%). Na realidade, o procedimento de britagem para esses resíduos pode ser opcional, uma vez que há grande concentração de partículas miúdas (< $2,4 \mathrm{~mm})$.

As composições granulométricas dos agregados miúdos naturais (referência) encontram-se na Tabela 5.8.

Tabela 5.8 - Composições granulométricas dos agregados miúdos (referência).

\begin{tabular}{|c|c|c|c|c|c|c|}
\hline \multirow{2}{*}{ Peneira (mm) } & \multicolumn{2}{|c|}{ Pó-de-pedra (Basalto) } & \multicolumn{2}{|c|}{ Areia Tietz } & \multicolumn{2}{|c|}{ Areia Itaporanga } \\
\hline & $\%$ ret. & $\%$ acum. & $\%$ ret. & $\%$ acum. & $\%$ ret. & $\%$ acum. \\
\hline 4,8 & 1 & 1 & 1 & 1 & 0 & 0 \\
\hline 2,4 & 16 & 17 & 2 & 4 & 1 & 1 \\
\hline 1,2 & 21 & 38 & 4 & 8 & 4 & 5 \\
\hline 0,6 & 19 & 57 & 8 & 16 & 13 & 18 \\
\hline 0,3 & 15 & 72 & 66 & 82 & 60 & 79 \\
\hline 0,15 & 12 & 83 & 15 & 97 & 16 & 94 \\
\hline \multirow[t]{4}{*}{ Fundo } & 17 & 100 & 3 & 100 & 6 & 100 \\
\hline & \multicolumn{2}{|c|}{ D.Máx= 4,8 mm } & \multicolumn{2}{|c|}{ D.Máx= 2,4 mm } & \multicolumn{2}{|c|}{ D.Máx= 1,2 mm } \\
\hline & \multicolumn{2}{|c|}{ M.Fin. $=2,68$} & \multicolumn{2}{|c|}{ M.Fin. $=2,08$} & \multicolumn{2}{|c|}{ M.Fin. $=1,98$} \\
\hline & \multicolumn{2}{|c|}{-} & \multicolumn{2}{|c|}{ Zona 1 (muito fina) } & \multicolumn{2}{|c|}{ Zona 1 (muito fina) } \\
\hline
\end{tabular}

Como nota-se pela Tabela 5.8, o pó-de-pedra (basalto) possui uma grande quantidade de finos (<0,30 mm), em torno de $28 \%$. A utilização desse insumo é necessária, principalmente para melhorar a coesão e textura superficial dos blocos de vedação. A Besser Company (2006) recomenda que para a produção de blocos, a porcentagem de material passante na peneira $0,30 \mathrm{~mm}$, represente aproximadamente $15 \%$ do total de material; por outro lado, uma quantidade excessiva dessa fração (> 20\%), pode afetar negativamente a resistência mecânica dos blocos. É consenso entre os fabricantes de 
blocos de que pequenas porcentagens de finos acarretam um aumento da porosidade, absorção e permeabilidade e diminuem a estabilidade do bloco recém-moldado.

As areias avaliadas apresentaram menores valores de módulo de finura, quando comparadas com o pó-de-pedra e, portanto, foram classificadas como areias muito finas. A quantidade de finos também pode ser considerada representativa (20\%) para esses agregados e, conforme já relatado, esses finos auxiliarão na coesão e na textura superficial dos blocos. Na definição dos traços para a produção dos blocos, deverá haver um equilíbrio entre o consumo de pó-de-pedra e areia; caso ocorra um consumo elevado de pó-de-pedra haverá um aumento da coesão da mistura, mas, por outro lado, poderá ocorrer uma elevação da absorção de água pelo bloco.

A análise granulométrica do material reciclado encontra-se na Tabela 5.9.

Tabela 5.9 - Composições granulométricas dos agregados miúdos reciclados.

\begin{tabular}{|c|c|c|c|c|c|c|c|c|c|c|}
\hline \multirow{2}{*}{$\begin{array}{c}\text { Peneira } \\
(\mathrm{mm})\end{array}$} & \multicolumn{2}{|c|}{ MRv } & \multicolumn{2}{|c|}{ MRvp } & \multicolumn{2}{|c|}{ MRb } & \multicolumn{2}{|c|}{ MRpb } & \multicolumn{2}{|r|}{ MRt } \\
\hline & $\begin{array}{c}\% \\
\text { ret. }\end{array}$ & $\begin{array}{c}\% \\
\text { acum. }\end{array}$ & $\%$ ret. & $\begin{array}{c}\% \\
\text { acum. }\end{array}$ & $\%$ ret. & $\begin{array}{c}\% \\
\text { acum. }\end{array}$ & $\%$ ret. & $\begin{array}{c}\% \\
\text { acum. }\end{array}$ & $\begin{array}{c}\% \\
\text { ret. }\end{array}$ & $\%$ acum. \\
\hline 4,80 & 0 & 0 & 0 & 0 & 0 & 0 & 0 & 0 & 0 & 0 \\
\hline 2,40 & 13 & 13 & 8 & 8 & 10 & 10 & 6 & 6 & 8 & 8 \\
\hline 1,20 & 26 & 38 & 30 & 38 & 29 & 39 & 18 & 24 & 24 & 32 \\
\hline 0,60 & 19 & 57 & 25 & 63 & 22 & 61 & 19 & 43 & 21 & 53 \\
\hline 0,30 & 19 & 77 & 21 & 84 & 22 & 83 & 25 & 68 & 24 & 76 \\
\hline 0,15 & 12 & 88 & 12 & 96 & 12 & 95 & 18 & 86 & 13 & 89 \\
\hline \multirow[t]{4}{*}{ fundo } & 12 & 100 & 4 & 100 & 5 & 100 & 14 & 100 & 11 & 100 \\
\hline & \multicolumn{2}{|c|}{ D.Máx.: 4,8 mm } & \multicolumn{2}{|c|}{ D.Máx.: 4,8 mm } & \multicolumn{2}{|c|}{ D.Máx.: 4,8 mm } & \multicolumn{2}{|c|}{ D.Máx.: 4,8 mm } & \multicolumn{2}{|c|}{ D.Máx.: 4,8 mm } \\
\hline & \multicolumn{2}{|c|}{ Mód. Fin.: 2,73 } & \multicolumn{2}{|c|}{ Mód. Fin.: 2,88 } & \multicolumn{2}{|c|}{ Mód. Fin.: 2,89 } & \multicolumn{2}{|c|}{ Mód. Fin.: 2,28 } & \multicolumn{2}{|c|}{ Mód. Fin.: 2,58 } \\
\hline & \multicolumn{2}{|c|}{$\begin{array}{c}\text { Classif: zona } 3 \\
\text { (média) }\end{array}$} & \multicolumn{2}{|c|}{$\begin{array}{c}\text { Classif: zona } 3 \\
\text { (m édia) }\end{array}$} & \multicolumn{2}{|c|}{$\begin{array}{l}\text { Classif: zona } 3 \\
\text { (média) }\end{array}$} & \multicolumn{2}{|c|}{$\begin{array}{c}\text { Classif: zona } 3 \\
\text { (média) }\end{array}$} & \multicolumn{2}{|c|}{$\begin{array}{c}\text { Classif: zona } 3 \\
\text { (média) }\end{array}$} \\
\hline
\end{tabular}

Conforme a Tabela 5.9, os agregados miúdos reciclados não apresentaram diferenças significativas entre si com relação à composição granulométrica. O agregado miúdo MRb, proveniente de resíduos de blocos, apresentou maior módulo de finura, comparativamente aos demais agregados, devido à maior abertura da mandíbula do britador utilizada para processar esse material. Considerando-se o coeficiente de uniformidade $\left(C_{u n}\right)$, citado em Bortoluzzo (2000), os agregados miúdos reciclados foram classificados como sendo de granulometria muito uniforme; com exceção dos agregados MRv e MRt, que foram designados como sendo de uniformidade média.

Na Figura 5.7, são apresentadas as composições granulométricas dos materiais naturais e reciclados. 


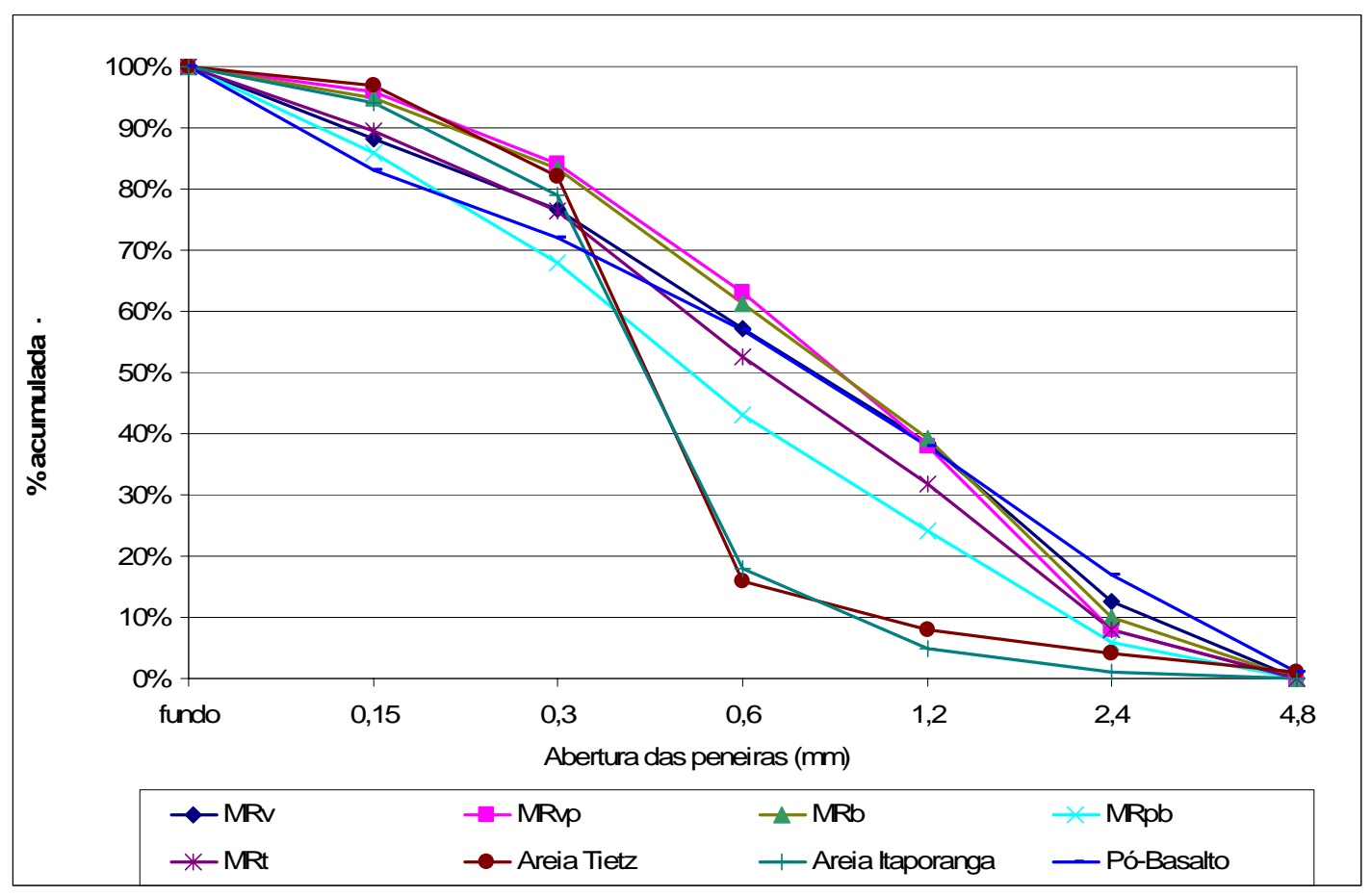

Figura 5.7 - Composição granulométrica dos agregados miúdos reciclados e dos agregados naturais.

Como se nota pela Figura 5.7, os agregados miúdos reciclados possuem uma dimensão de partículas maior quando comparada com os agregados naturais (Areia Tietz e Itaporanga). Esse fato deve-se às características do britador utilizado, abertura da sua mandíbula e o tipo de resíduo processado; por outro lado, a distribuição granulométrica dos agregados reciclados e do pó-de-pedra pode ser considerada semelhante. Para os agregados reciclados, notou-se uma grande porcentagem de partículas retidas na peneira de malha 1,2 mm (em torno de 25\%); já para os agregados miúdos naturais (areia Tietz e Itaporanga), a porcentagem retida mais significativa ocorreu na peneira 0,3 $\mathrm{mm}$ (cerca de 63\%). Um fato interessante e importante na distribuição granulométrica, que novamente pode ser observado, foi a similaridade na porcentagem de materiais finos passantes na peneira $0,3 \mathrm{~mm}$, em torno de $20 \%$, tanto para os materiais naturais como para os reciclados, exceção essa feita para o pó-de-pedra. Essa quantidade de finos contribuirá para melhorar a textura superficial e a coesão das unidades de alvenaria; por outro lado, a NBR 15116 (2004) prescreve limites para a porcentagem de finos passantes na peneira 0,075 $\mathrm{mm}$. Os resultados para as porcentagens passantes nessa peneira são apresentados na Tabela 5.10 . 
Tabela 5.10 - Porcentagens de materiais passantes na peneira $0,075 \mathrm{~mm}$ para os agregados graúdos e miúdos reciclados.

\begin{tabular}{cccccc}
\hline Agregados & $\mathrm{Rv}$ & $\mathrm{Rb}$ & $\mathrm{Rpb}$ & $\mathrm{Rvp}$ & $\mathrm{Rt}$ \\
\hline graúdos & $0,35 \%$ & $0,50 \%$ & $0,59 \%$ & $0,44 \%$ & $0,28 \%$ \\
\hline miúdos & $7,28 \%$ & $2,47 \%$ & $6,35 \%$ & $1,62 \%$ & $7,01 \%$ \\
\hline
\end{tabular}

Considerando-se a norma NBR 15116 (2004), observa-se que todos os agregados reciclados cumpriram os requisitos estabelecidos para a fração passante na peneira 0,075 $\mathrm{mm}$. Segundo essa norma, as frações devem ser menores que 10\% e 15\%, em relação à massa total de agregados, para os agregados graúdos e miúdos, respectivamente. Por outro lado, a ASTM C-33 (2003), para concretos sujeitos à abrasão, recomenda para a fração passante na peneira $0,075 \mathrm{~mm}$, porcentagens inferiores a 1,5\% e 5,0\% para os agregados graúdos e miúdos, respectivamente e o limite de 7\% para a fração miúda considerando-se outros tipos de concreto. A revisão do código normativo espanhol de concreto estrutural estabelece para agregados graúdos reciclados um limite de 1\% para a quantidade de finos passantes na peneira 0,075 mm. Diante dessas recomendações, observa-se que apenas o agregado MRv apresentou uma porcentagem passante ligeiramente superior ao recomendado pela ASTM C-33 (2003). Hansen (1985) cita alguns trabalhos que obtiveram, em função das características do resíduo de concreto, valores entre 0,3\% e 0,5\% para os agregados graúdos e entre $4,1 \%$ e $6,6 \%$ para os agregados miúdos. Para resíduos compostos exclusivamente de argamassa, o valor referente à parcela passante na peneira 0,075 mm foi de 9,1\%. Em função da qualidade do resíduo de concreto, Hansen e Narud (1983) obtiveram para agregados miúdos valores entre 0,8\% e 3,5\% para a fração passante na peneira $0,075 \mathrm{~mm}$.

\subsubsection{Massa específica e absorção de agregado}

Inicialmente, é apresentado o procedimento preconizado pela Norma Brasileira e, em virtude das suas limitações, são expostos dois procedimentos citados por Leite (2001) e Dias e Agopyan (2004). Os resultados são apresentados e analisados comparativamente entre si.

\subsection{Procedimento da Norma Brasileira}

\section{A) Agregados Graúdos}

A massa específica, a absorção de água e o índice de vazios do agregado graúdo foram determinados de acordo com a NBR 9937 (1987). A massa específica é a razão entre 
a massa do agregado e o seu volume, sendo empregada principalmente para transformação do traço em massa para volume absoluto e cálculo do consumo de cimento. Conforme Aïtcin (2000), a massa específica saturada superfície seca de um agregado expressa quão mais denso do que a água é um agregado nessas condições. Para os agregados reciclados, a argamassa aderida ao agregado e, consequentemente, sua maior porosidade reduzirão a massa específica quando comparada com o agregado natural. Na realização desse ensaio bem como o de absorção dos agregados reciclados, de acordo com o procedimento da norma brasileira, foram encontradas algumas dificuldades devido à possibilidade de desagregação das partículas, fato esse que não permitiu a obtenção de valores confiáveis. Além disso, conforme Leite (2001), a porosidade e a fragilidade do agregado reciclado dificultam a sua secagem superficial sem desagregá-lo, podendo ainda ocorrer à retirada de água dos poros internos mais superficiais durante o processo de secagem mascarando, por conseqüência, os resultados a serem obtidos.

Com o monitoramento da absorção de água, procura-se determinar o total de poros permeáveis nos agregados; já o índice de vazios relaciona o volume de poros permeáveis com o volume total. O estado saturado superfície seca é um importante parâmetro para calcular ou expressar a composição de um determinado concreto, pois estabelece uma diferenciação clara entre os dois tipos de água tipicamente encontradas em um agregado. Caso o teor de água de um agregado seja inferior àquele no seu estado saturado superfície seca, o agregado absorverá água da mistura e, conseqüentemente, ocorrerá um aumento na velocidade de perda de abatimento do concreto. Por outro lado, quando o teor de água é superior àquele no seu estado saturado superfície seca, o agregado introduzirá água na mistura, Aïtcin (2000). Em misturas com maior consumo de cimento, a determinação da absorção inicial do agregado (10 a 30 minutos) torna-se importante em relação à absorção total, pois, nesses casos, a absorção de água pelo agregado torna-se mais lenta ou cessa completamente devido ao cobrimento das partículas de agregado pela pasta de cimento (NEVILLE, 1997). Alguns autores recomendam a pré-saturação dos agregados reciclados para evitar a perda de trabalhabilidade da mistura; entretanto, essa questão ainda pode ser considerada controversa, Poon et al. (2004b), De Brito et al. (2004), Barra e Vazquez (1996).

Os principais equipamentos utilizados para a realização desses ensaios foram: balança da marca Metter Toledo adaptada para determinar massas aparentes, cesto de malha de arame e Estufa da marca Quimis. Os ensaios foram realizados para pelo menos duas amostras do mesmo agregado. Os resultados utilizando o procedimento da NBR 9937 (1987), para as propriedades de absorção de água e índice de vazios, são apresentados na Tabela 5.11. 
Tabela 5.11 - Absorção de água e índice de vazios.

\begin{tabular}{ccccc}
\hline & Índice de Vazios (\%) & \multicolumn{3}{c}{ Absorção de água (\%) } \\
\cline { 3 - 5 } & & $\mathbf{1 0}$ minutos & $\mathbf{3 0}$ minutos & $\mathbf{2 4}$ horas \\
\hline \multirow{2}{*}{ Ag. referência (pedrisco) } & 2,02 & - & - & 0,73 \\
\hline GRv & 9,47 & 3,64 & 3,73 & 4,00 \\
\hline GRvp & 8,70 & - & 3,16 & 3,48 \\
\hline GRb & 10,64 & - & 4,34 & 4,45 \\
\hline GRpb & 8,90 & - & 3,27 & 3,57 \\
\hline GRt & 9,91 & 3,56 & 3,81 & 4,45 \\
\hline
\end{tabular}

Analisando-se os resultados, observa-se que nos primeiros dez minutos, cerca de 85\% da água total foi absorvida pelos agregados GRv e GRt. Esse fato condiciona a uma grande perda de trabalhabilidade do concreto no estado fresco. Para resolver esse problema, alguns pesquisadores recomendam a previsão dessa quantidade de água a ser adicionada na mistura ou também a pré-saturação do agregado. Ensaios conduzidos por De Brito et al. (2004), demonstraram que, para agregados reciclados de concreto, após 30 minutos de contato com água, aproximadamente $75 \%$ da água é absorvida em relação ao período total de ensaio (24 horas). Nas conclusões, os autores citam que a condição de saturação dos agregados (seca ou saturada) não afeta as propriedades dos concretos; recomendando-se, portanto, a utilização de agregados reciclados na condição secos ao ar. Por outro lado, Poon et al. (2004b) citam que a utilização de agregados na condição présaturada, em relação aos agregados secos ao ar, acarreta uma redução na resistência à compressão. A movimentação da água presente no agregado, em direção a matriz de cimento, aumenta a relação água/cimento na vizinhança das partículas de agregados, sendo então a responsável pela queda de resistência.

O agregado reciclado $\mathrm{GRb}$, nos primeiros minutos, apresentou uma absorção elevada, possivelmente devido à existência de grande quantidade de poros permeáveis interconectados; já no período entre 30 minutos e 24 horas, a quantidade de água absorvida foi muito pequena em relação ao total absorvido, apenas 2,5\%. Com relação aos agregados reciclados GRvp e GRpb, o procedimento prescrito pela NBR 9937 (1987) não permitiu a obtenção de valores confiáveis devido ao menor módulo de finura desses agregados e a dificuldade encontrada para atingir a condição saturada superfície seca, fato esse que também foi observado para os demais agregados. Outro problema observado refere-se à tendência de desagregação das partículas de agregados reciclados durante o ensaio com conseqüente perda de material. Dias e Agopyan (2004) citam que o método prescrito pela NBR 9937 (1987) para a determinação da absorção de agregados graúdos reciclados (> $12,5 \mathrm{~mm}$ ) fornece resultados representativos, pois, nesse processo, é possível secar as partículas de agregado com um pano, caracterizando o estado saturado superfície seca. No 
entanto, quando se trata de determinar a absorção de agregados que contenham partículas menores, situação do presente estudo, ou partículas que podem desagregar-se com o processo, o método normativo não permite a obtenção de valores confiáveis.

Com relação às prescrições normativas, todos os resultados de absorção dos agregados graúdos reciclados estiveram dentro dos limites recomendados. A norma alemã DIN 4226-100 (2002) estabelece o limite igual a 10\% para a absorção máxima do agregado reciclado. A NBR 15116 (2004) permite o emprego de agregados graúdos reciclados de concreto para a produção de concreto sem função estrutural desde que a absorção desses agregados seja inferior a 7\%. As recomendações citadas por Tam et al. (2005) podem ser consideradas mais rígidas, uma vez que permite a produção de concreto simples com agregados graúdos reciclados, desde que a absorção desse agregado seja inferior a 5\%. Algumas recomendações citadas por Hansen (1985) não recomendam o emprego de agregados reciclados para a produção de concretos, quando a absorção da fração graúda for superior a 7\% e maior que 13\% para a fração miúda.

Buttler (2003), que avaliou agregados reciclados oriundos de resíduos de concreto de média resistência, obteve valores médios de absorção em torno de $6 \%$, sendo que, nos primeiros dez minutos, $88 \%$ da água total já haviam sido absorvidas pelos agregados reciclados. Padmini et al. (2002) concluíram que a resistência do resíduo de concreto tem pequena influência sobre a absorção de água dos reciclados; normalmente, pode ocorrer um ligeiro aumento da absorção quando se eleva a resistência do concreto, possivelmente devido a maior quantidade de argamassa aderida ao agregado.

A presença de argamassa aderida aos agregados reciclados foi a responsável pela redução da massa específica quando comparados aos agregados naturais. Os resultados para a propriedade de massa específica encontram-se na Tabela 5.12. 
Tabela 5.12 - Massa específica dos agregados graúdos.

\begin{tabular}{|c|c|c|c|c|c|c|}
\hline \multirow[b]{2}{*}{ Propriedade } & \multicolumn{3}{|c|}{ Massa específica seca $\left(\gamma_{s}\right)$} & \multicolumn{3}{|c|}{ Massa específica saturada ( $\left.\gamma_{\text {sss }}\right)$} \\
\hline & $\begin{array}{c}\text { Valor } \\
\left(\mathrm{kg} / \mathrm{dm}^{3}\right)\end{array}$ & $\begin{array}{c}\mathrm{S}_{\mathrm{d}}\left(\mathrm{kg} / \mathrm{dm}^{3}\right) \\
\text { C.V }(\%)\end{array}$ & $\begin{array}{l}\text { Relação } \\
\text { rec/refer. }\end{array}$ & $\begin{array}{c}\text { Valor } \\
\left(\mathrm{kg} / \mathrm{dm}^{3}\right)\end{array}$ & $\begin{array}{c}S_{d} \\
\left(\mathrm{~kg} / \mathrm{dm}^{3}\right) \\
\text { C.V }(\%)\end{array}$ & $\begin{array}{c}\text { Relação } \\
\text { rec/ref. }\end{array}$ \\
\hline Ag. referência (pedrisco) & 2,756 & $\begin{array}{c}0,004 \\
0,13 \%\end{array}$ & 1,00 & 2,776 & $\begin{array}{c}0,006 \\
0,23 \%\end{array}$ & 1,00 \\
\hline GRv & 2,367 & $\begin{array}{c}0,004 \\
0,18 \% \\
\end{array}$ & 0,86 & 2,461 & $\begin{array}{c}0,011 \\
0,46 \% \\
\end{array}$ & 0,89 \\
\hline GRvp & 2,499 & - & 0,91 & 2,586 & - & 0,93 \\
\hline $\mathrm{GRb}$ & 2,391 & $\begin{array}{c}0,010 \\
0,42 \% \\
\end{array}$ & 0,87 & 2,497 & $\begin{array}{c}0,015 \\
0,61 \% \\
\end{array}$ & 0,90 \\
\hline GRpb & 2,514 & $\begin{array}{c}0,028 \\
1,12 \% \\
\end{array}$ & 0,90 & 2,596 & $\begin{array}{c}0,018 \\
0,69 \% \\
\end{array}$ & 0,93 \\
\hline GRt & 2,230 & $\begin{array}{c}0,003 \\
0,13 \%\end{array}$ & 0,81 & 2,329 & $\begin{array}{c}0,001 \\
0,05 \%\end{array}$ & 0,84 \\
\hline
\end{tabular}

Analisando-se os resultados da Tabela 5.12, nota-se que, para os agregados reciclados GRvp e GRpb, foram obtidos os maiores valores, comparativamente aos demais agregados reciclados. Para o agregado reciclado GRt, originário de resíduos de telha, foram obtidos os menores valores para essa propriedade devido à grande quantidade de argamassa aderida ao agregado e as próprias características do resíduo (elevado consumo de argamassa por volume). Os valores de massa específica dos agregados reciclados foram similares aos obtidos no primeiro processamento, quando comparados com o agregado de referência (pedrisco), significando que, provavelmente, não houve influência significativa do tamanho das partículas sobre essas propriedades. Para a massa específica saturada superfície seca, a relação entre os resultados (reciclado/referência) apresentou um pequeno aumento, em relação a massa específica seca, motivado pela maior absorção dos agregados reciclados e pela dificuldade na determinação da condição saturada superfície seca.

Para ilustrar o comportamento dos resultados obtidos para a propriedade de massa específica, foi elaborado um gráfico relacionando os valores obtidos para os diferentes agregados estudados (Figura 5.8). No eixo das abscissas estão indicados os agregados, enquanto nas ordenadas procurou-se expressar cada valor obtido com relação ao agregado de referência (pedrisco). 


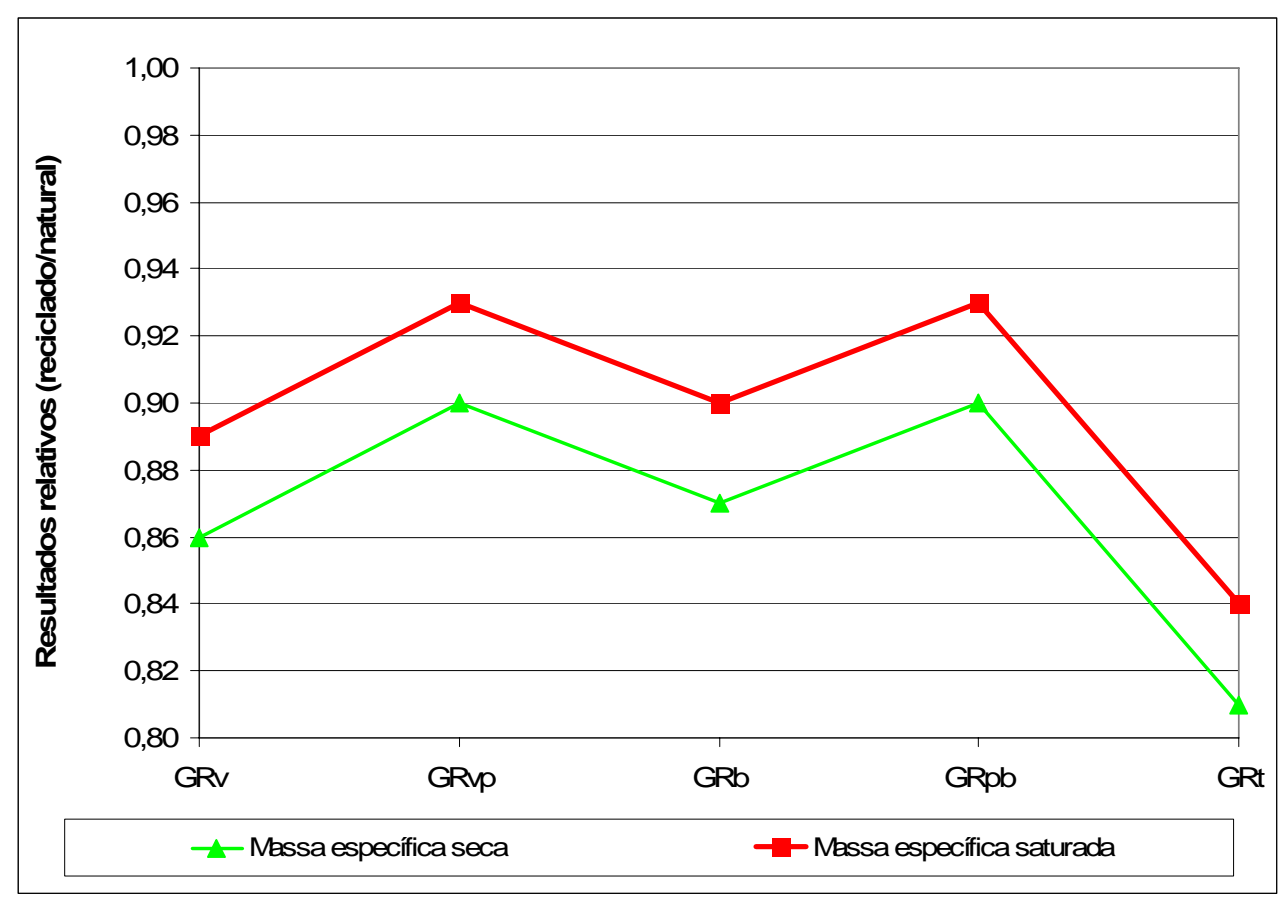

Figura 5.8 - Resultados relativos para a propriedade de massa específica.

Hansen e Narud (1983) investigaram a influência da resistência do resíduo de concreto e do tamanho das partículas do agregado na massa específica do agregado graúdo reciclado. Em suas análises, citam que o tamanho das partículas influenciou no valor da massa específica; mas por outro lado, não notaram nenhuma influência da resistência do concreto original nessa propriedade. Na presente pesquisa, o tamanho das partículas não teve uma influência significativa na massa específica seca e saturada superfície seca.

Gómez-Soberon (2002) cita que para agregados reciclados há um aumento da massa específica diretamente proporcional ao tamanho das partículas. Além disso, as diferenças entre a massa específica seca e saturada superfície seca são maiores para os agregados reciclados quando comparadas com o agregado natural. Na presente pesquisa, em função da maior absorção do material reciclado, essa diferença também foi observada.

Padmini et al. (2002) pesquisaram a influência da resistência do concreto original e da dimensão das partículas nas propriedades físicas dos agregados reciclados. Notaram que há um pequeno aumento na massa específica (5\%), à medida que foi elevada a dimensão da partícula (10 mm para $40 \mathrm{~mm}$ ); já para a resistência do concreto original, observaram uma diminuição de $3 \%$ na massa específica, quando foi elevada a resistência de $35 \mathrm{MPa}$ para $56 \mathrm{MPa}$. Estabelecendo-se uma análise comparativa com os resultados obtidos para o agregado natural, os pesquisadores encontraram uma redução média de aproximadamente $12 \%$ na massa específica do agregado reciclado. Na presente pesquisa, 
também foi notada uma diminuição da massa específica, aproximadamente $5 \%$, quando foi comparado um resíduo de média resistência ( $R v$ - $35 \mathrm{MPa}$ ) com um resíduo de baixa resistência (Rb - $10 \mathrm{MPa}$ a $25 \mathrm{MPa})$.

$\mathrm{Na}$ Figura 5.9, pode ser observada a relação entre as propriedades de massa específica e absorção de água, sendo que as hipóteses levantadas para explicação dos resultados de massa específica são corroboradas pelos resultados de absorção.

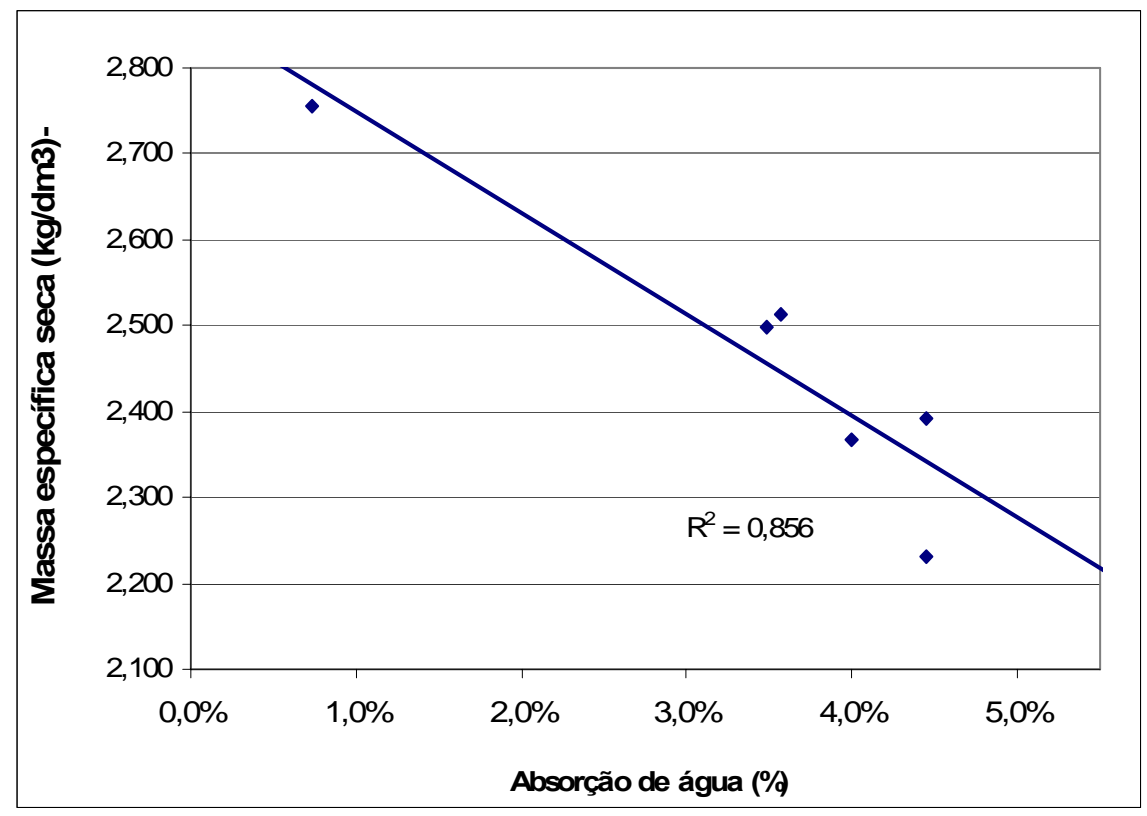

Figura 5.9 - Relação entre as propriedades de massa específica seca e absorção de água.

B) Agregados Miúdos

A massa específica para os agregados miúdos foi avaliada utilizando-se o Frasco de Chapman, conforme NBR 9776 (1987), para duas determinações. Nesse ensaio foram encontradas algumas dificuldades relacionadas à formação de espuma superficial provocadas pela presença de finos (Figura 5.10), e também pelo fato do material não se encontrar na condição saturada superfície seca. A colocação de material seco no frasco, principalmente os agregados reciclados, ocasionou uma imprecisão nas leituras devido à elevada absorção do material. Um método alternativo, baseado nas prescrições de Leite (2001), para a determinação da massa específica e índice de vazios dos materiais miúdos reciclados foi proposto, mas os resultados preliminares não foram satisfatórios, em função da perda de material fino e do aprisionamento de bolhas de ar.

Segundo Dias (2004), a condição saturada superfície seca só poderia ser obtida para a fração graúda, desde que os agregados pudessem ser secados com uma toalha, por 
exemplo. Para o agregado miúdo, de acordo com a ASTM C128 (1988), o estado saturado superfície seca é determinado quando um pequeno tronco de cone truncado não consegue manter a forma devido às forças de capilaridade entre as partículas úmidas. Entretanto, esse ensaio não foi realizado para os agregados reciclados, em virtude dos finos formarem uma pasta e, ainda caso esses finos fossem retirados, o desmoronamento do tronco-cônico talvez não ocorresse em virtude do formato lamelar dos grãos.
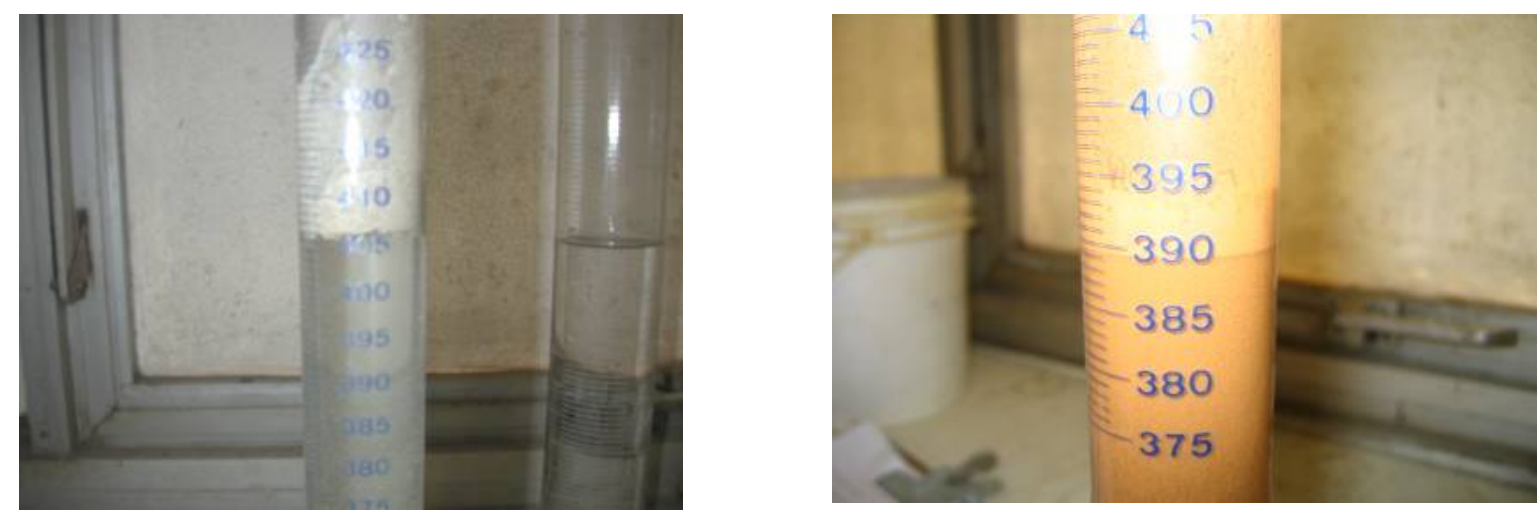

Figura 5.10 - Ensaio de massa específica pelo Frasco de Chapman.

Os resultados de massa específica utilizando-se o procedimento da NBR 9776 (1987) são apresentados na Tabela 5.13.

Tabela 5.13 - Massa específica dos agregados miúdos conforme NBR 9776 (1987).

\begin{tabular}{ccccc}
\hline \multirow{2}{*}{ Propriedade } & Valor & $\mathbf{S}_{\mathbf{d}} \mathbf{( k g / \mathbf { d m } ^ { \mathbf { 3 } } \text { ) }}$ & $\begin{array}{c}\text { Coef. Variação } \\
\text { (\%) }\end{array}$ & $\begin{array}{c}\text { Relação rec/ref. } \\
\text { (pó) }\end{array}$ \\
\cline { 2 - 5 } & 2,625 & 0,010 & 0,37 & - \\
\hline Areia Tietz & 2,625 & 0,010 & 0,37 & - \\
\hline Areia Itaporanga & 2,874 & 0,000 & 0,00 & 1,00 \\
\hline Pó-de-pedra (Basalto) & 2,479 & 0,030 & 1,27 & 0,86 \\
\hline MRv & 2,618 & 0,019 & 0,74 & 0,91 \\
\hline MRvp & 2,653 & 0,010 & 0,38 & 0,92 \\
\hline MRb & 2,649 & 0,015 & 0,56 & 0,92 \\
\hline MRt & 2,392 & 0,016 & 0,68 & 0,83 \\
\hline
\end{tabular}

Analisando-se os resultados da Tabela 5.13, observa-se que para os agregados reciclados MRvp e MRpb foram obtidos os maiores valores, comparativamente aos demais agregados reciclados, devido à recuperação quase que completa do agregado natural após o processamento e a pequena quantidade de argamassa aderida aos agregados; já para o agregado reciclado $\mathrm{MRb}$, os maiores valores de massa específica podem ser explicados pela própria composição do resíduo de bloco (elevado consumo de pó-de-pedra, de $40 \%$ a $50 \%$ do total de insumos). Para os agregados reciclados MRv e MRt, originários de resíduos 
de vigota e telha, foram obtidos os menores valores para essa propriedade, redução média de 15\% em relação ao pó-de-pedra, devido à grande quantidade de argamassa aderida ao agregado reciclado.

\subsection{Procedimento proposto por Leite (2001)}

Devido à possibilidade de desagregação das partículas de agregados reciclados, quando do emprego das prescrições da NBR 9937 (1987), foi utilizado um procedimento adaptado de Leite (2001) para a determinação da absorção de água dos agregados graúdos reciclados. Nesse procedimento, foi utilizada a seguinte aparelhagem: balança da marca Metter Toledo adaptada para determinar massas aparentes e um cilindro revestido com tela metálica (malha 2,0 $\mathrm{mm}$ ) para facilitar a retirada do ar aprisionado sob o conjunto.

Para os agregados miúdos reciclados, o procedimento proposto pela pesquisadora foi avaliado, mas os resultados não foram satisfatórios. O dispositivo utilizado, composto por duas peneiras de malha $0,15 \mathrm{~mm}$ e $0,075 \mathrm{~mm}$, dificultou a retirada do ar aprisionado entre as partículas de agregados reciclados e, como conseqüência, da agitação do dispositivo para a retirada do ar aprisionado também ocorreu a perda de material fino. Para os agregados graúdos reciclados, inicialmente, esses foram lavados sobre a peneira $2,4 \mathrm{~mm}$ visando a retirada de materiais pulverulentos aderidos à superfície e depois foram mantidos na estufa por 24 horas; posteriormente, a amostra foi disposta em um cilindro revestido com tela metálica, em água, à temperatura ambiente, sendo executada leituras em intervalos prédeterminados. Após 24 horas de ensaio, a amostra foi colocada na estufa até a estabilidade de massa, obtendo-se a massa seca. A taxa de absorção final dos agregados foi determinada como sendo a média entre os resultados da taxa de absorção do material seco e a taxa de absorção do material submerso, conforme prescrições de Leite (2001).

Devido à elevada absorção inicial do agregado reciclado GRb, o ensaio proposto por Leite (2001) não se mostrou adequado a esse tipo de resíduo, ocorrendo uma distorção no valor da primeira leitura, não representando a condição inicial de material seco. Deve-se ressaltar que os valores de absorção utilizando-se a metodologia proposta pela pesquisadora foram relativamente inferiores aos obtidos utilizando as prescrições da norma, devido provavelmente à dificuldade encontrada para a realização da primeira leitura, isto é, a determinação da massa do material no instante zero de imersão em água. Os resultados são expressos na Tabela 5.14 e Figura 5.11, referindo-se a duas determinações. 
Tabela 5.14 - Taxa de absorção média dos agregados, em função do tempo de ensaio, pelo procedimento proposto por Leite (2001).

\begin{tabular}{|c|c|c|c|c|c|}
\hline & \multicolumn{5}{|c|}{ Agregados graúdos } \\
\hline & Pedrisco & GRv & GRvp & GRpb & GRt \\
\hline Ab.10' & $\begin{array}{c}25,5 / 100 \% \\
\mathbf{0 , 1 3} \%\end{array}$ & $\begin{array}{c}64,6 / 100 \% \\
\mathbf{2 , 4 1} \%\end{array}$ & $\begin{array}{c}51,6 / 100 \% \\
\mathbf{0 , 8 9 \%}\end{array}$ & $\begin{array}{c}53,2 / 100 \% \\
1,04 \%\end{array}$ & $\begin{array}{c}56,7 / 100 \% \\
2,39 \%\end{array}$ \\
\hline Ab. 30' & $\begin{array}{c}30,5 / 100 \% \\
\mathbf{0 , 1 6 \%}\end{array}$ & $\begin{array}{c}72,0 / 100 \% \\
\mathbf{2 , 6 8} \%\end{array}$ & $\begin{array}{c}60,5 / 100 \% \\
\mathbf{1 , 0 0 \%}\end{array}$ & $\begin{array}{c}65,6 / 100 \% \\
\mathbf{1 , 2 8 \%}\end{array}$ & $\begin{array}{c}67,3 / 100 \% \\
\mathbf{2 , 8 3} \%\end{array}$ \\
\hline$A b^{\prime} 1 \mathrm{~h}$ & $\begin{array}{c}43,3 / 100 \% \\
\mathbf{0 , 2 2} \% \\
\end{array}$ & $\begin{array}{c}76,3 / 100 \% \\
\mathbf{2 , 8 4} \% \\
\end{array}$ & $\begin{array}{c}69,7 / 100 \% \\
\mathbf{1 , 0 9 \%} \\
\end{array}$ & $\begin{array}{c}71,6 / 100 \% \\
1,40 \%\end{array}$ & $\begin{array}{c}72,4 / 100 \% \\
\mathbf{3 , 0 5 \%}\end{array}$ \\
\hline$A b^{\prime} 2 h$ & $\begin{array}{c}57,4 / 100 \% \\
\mathbf{0 , 3 0 \%}\end{array}$ & $\begin{array}{c}81,0 / 100 \% \\
\mathbf{3 , 0 1} \%\end{array}$ & $\begin{array}{c}75,2 / 100 \% \\
1,19 \%\end{array}$ & $\begin{array}{c}79,2 / 100 \% \\
1,55 \%\end{array}$ & $\begin{array}{c}77,4 / 100 \% \\
\mathbf{3 , 2 6} \%\end{array}$ \\
\hline Ab' média final & $\begin{array}{c}100 / 100 \% \\
\mathbf{0 , 5 1} \% \\
\end{array}$ & $\begin{array}{c}100 / 100 \% \\
\mathbf{3 , 7 2} \% \\
\end{array}$ & $\begin{array}{c}100 / 100 \% \\
\mathbf{1 , 4 3} \%\end{array}$ & $\begin{array}{c}100 / 100 \% \\
1,96 \%\end{array}$ & $\begin{array}{c}100 / 100 \% \\
\mathbf{4 , 2 1} \%\end{array}$ \\
\hline $\mathrm{S}_{\mathrm{d}}$ & $0,05 \%$ & $0,11 \%$ & $0,25 \%$ & $0,51 \%$ & $0,59 \%$ \\
\hline Coef. Variação (\%) & $10,29 \%$ & $2,85 \%$ & $17,72 \%$ & $25,91 \%$ & $14,07 \%$ \\
\hline Ab final - NBR 9937 & $0,73 \%$ & $4,00 \%$ & $3,48 \%$ & $3,57 \%$ & $4,55 \%$ \\
\hline
\end{tabular}

Segundo Leite (2001) a utilização da média entre os valores de absorção do material seco e absorção do material submerso fornece uma boa aproximação do valor real de absorção; fato esse que foi confirmado para os agregados reciclados GRv e GRt. Para esses agregados, foi observada uma diminuição de aproximadamente sete porcento no valor da absorção quando comparada com o resultado obtido utilizando-se as prescrições da NBR 9937 (1987). Entretanto, para os demais agregados, a utilização do procedimento prescrito pela pesquisadora não forneceu valores confiáveis devido possivelmente à dificuldade de mensuração do valor inicial de absorção, subestimando, portanto, os valores finais de absorção. Na determinação da absorção dos agregados GRvp e GRpb, ocorreu uma redução de aproximadamente $58 \%$ e $45 \%$, respectivamente quando comparado com o procedimento normativo. Para o agregado de referência (pedrisco), essa redução foi de cerca 30\% quando comparado com o valor obtido pela NBR 9937 (1987).

Outros pesquisadores chegaram a conclusões similares; Dias e Agopyan (2004) citam que o método proposto pela pesquisadora não se mostrou adequado, devido à dificuldade de se obterem leituras confiáveis, em virtude do aprisionamento de bolhas de ar sob o conjunto e pela lavagem do material fino. Acrescenta-se a isso, a rápida absorção de água que ocorre ao se imergir o conjunto, com conseqüente distorção do valor da primeira leitura, não representando a condição inicial de material seco. Por outro lado, o procedimento proposto pela pesquisadora permitiu avaliar, com certa precisão, a dinâmica de absorção dos agregados ao longo do tempo de ensaio, Figura 5.11. 


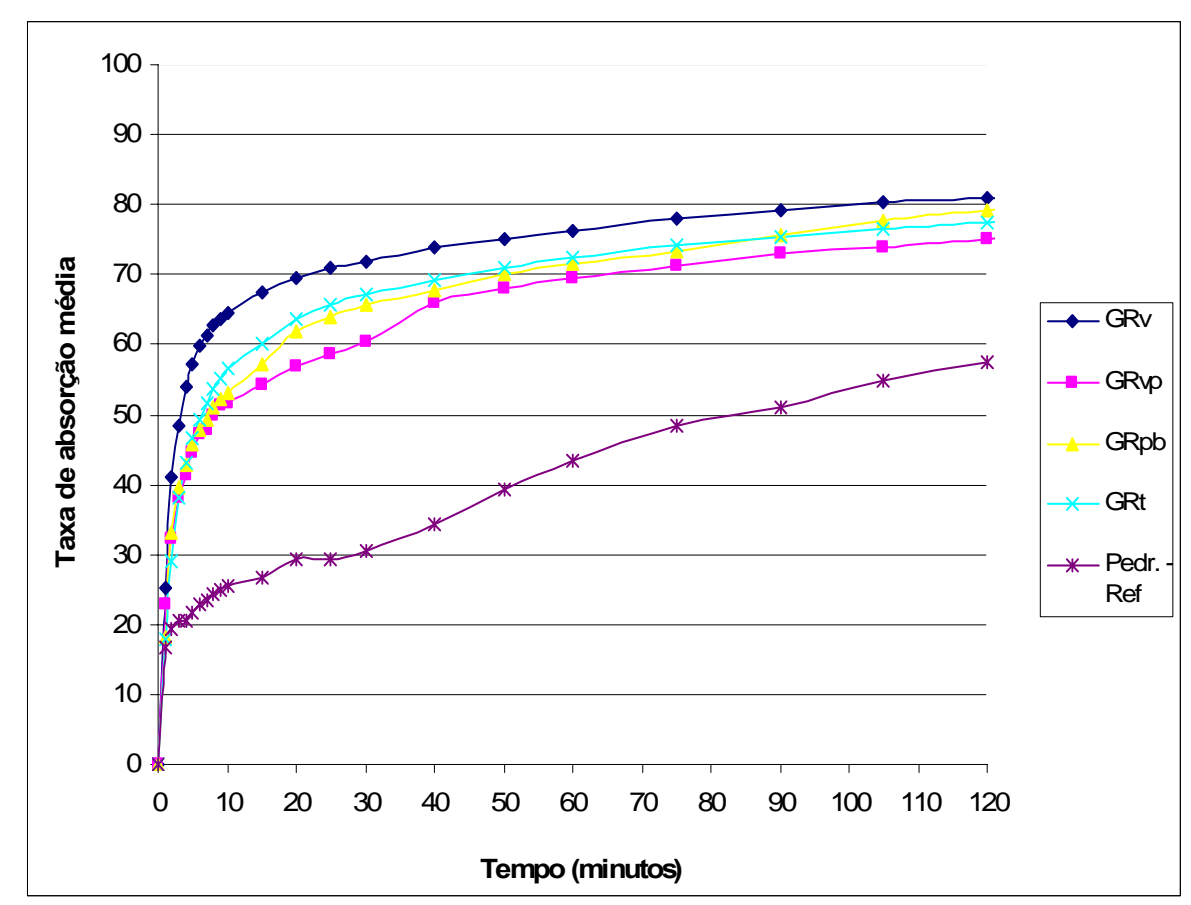

Figura 5.11 - Taxa de absorção média dos agregados durante os 120 primeiros minutos.

Analisando-se a Figura 5.11, observa-se que entre os 10 e 30 minutos iniciais, os agregados reciclados apresentaram um elevado potencial de absorção, aproximadamente $50 \%$ a $70 \%$ do total de água absorvida ao final das 24 horas; já para o pedrisco, até os trinta primeiros minutos, apenas $30 \%$ do total de água havia sido absorvido pelo agregado. A elevada absorção dos agregados reciclados ocasiona uma perda considerável da trabalhabilidade da mistura fresca; conforme já discutido anteriormente, o procedimento mais correto é adicionar essa quantidade de água absorvida diretamente na mistura, cerca de 50\% a 70\% da absorção final do agregado, evitando-se utilizar o agregado na condição pré-saturada. Segundo alguns autores, o procedimento de pré-saturação é de difícil mensuração, principalmente em escala industrial e, além disso, pode ocasionar prejuízo nas propriedades mecânicas do concreto (POON et al, 2004b). De Brito et al. (2004) citam que a condição de saturação dos agregados (seca e saturada) não influi nas propriedades dos concretos, entretanto, recomendam a utilização de agregados reciclados na condição seca ao ar.

\subsection{Procedimento proposto por Dias e Agopyan (2004)}

Dias e Agopyan (2004) citam que o método proposto por Leite (2001) não se mostrou adequado ao agregado reciclado de telha devido à dificuldade de se obter leituras confiáveis, em virtude do aprisionamento de bolhas de ar sob o conjunto e pela lavagem do material fino. Dias e Agopyan (2004) propõe uma metodologia baseada em ensaios de 
secagem do agregado reciclado saturado, com medida da perda de água com o tempo decorrido, para a determinação da absorção na condição saturada superfície seca $\left(A b_{s s d}\right)$. Uma das grandes vantagens desse ensaio é a determinação da absorção na condição saturada superfície seca de agregados miúdos reciclados, uma vez que a proposição da ASTM C128 (1988) para a absorção de agregados miúdos é de difícil execução. Essa metodologia baseia-se em estudos realizados por Brown et al. (1965 apud Dias; Agopyan, $2004)^{23}$. Segundo os primeiros autores, a velocidade de secagem de um sólido caracterizase por distintos períodos à medida que a umidade do sólido se reduz, Figura 5.12.

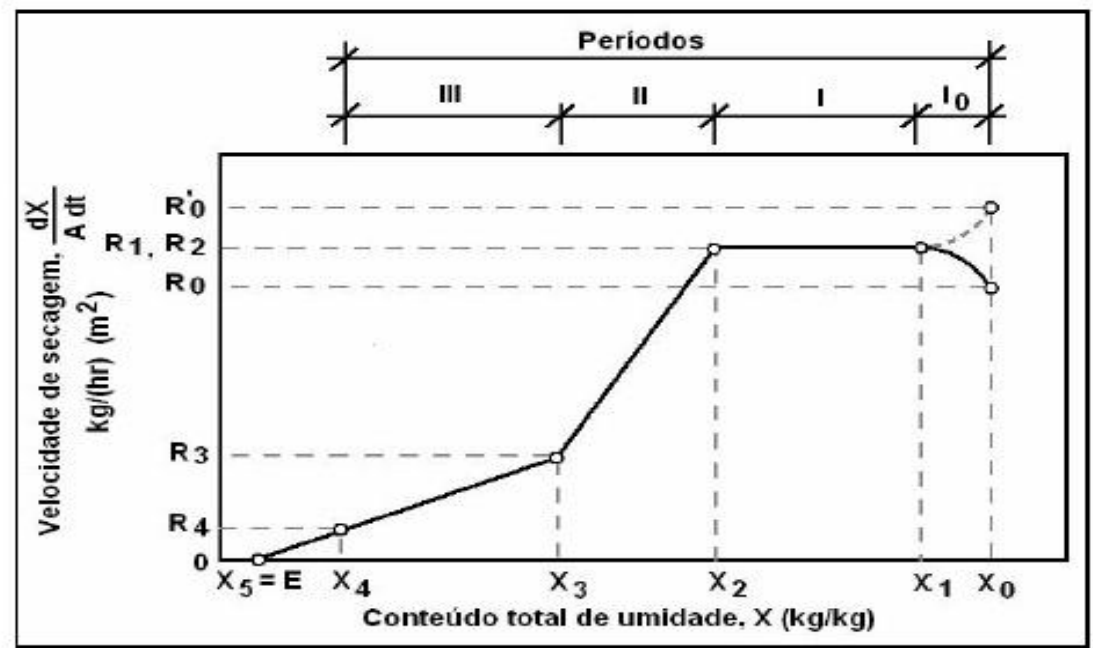

Figura 5.12 - Velocidade de secagem x conteúdo de umidade, Brown et al. (1965 apud Dias; Agopyan, 2004) $)^{23}$.

O período $I_{0}$ de secagem (vide Figura 5.12) é relativamente curto e caracteriza-se pela diminuição ou pelo aumento da velocidade de secagem. É um período essencialmente instável, dependente da temperatura inicial do material. O período I, representa a primeira etapa de secagem; nesse período a velocidade de secagem é praticamente constante, e fica bem caracterizado, quando se utiliza um recipiente isolado, pois a temperatura na superfície e no interior do sólido também é constante. Segundo Dias (2004), com o prosseguimento da secagem ocorre uma substituição da água presente no sólido pelo ar através de canais mais largos que estão em conexão com os poros da superfície. A superfície molhada do sólido pode ser considerada como uma superfície de água livre, cuja velocidade de secagem é praticamente constante, com pequenas variações provocadas pelas características do material e das condições de secagem.

\footnotetext{
${ }^{23}$ BROWN, G. G. et al. Operaciones básicas de la ingeniería química. Barcelona: Editora Marin S. A, 1965.
} 
O final desse período é caracterizado pela diminuição da velocidade de secagem. No período II, segundo Dias e Agopyan (2004), a velocidade de secagem é decrescente, pois ocorre uma diminuição da quantidade de água evaporada por unidade de tempo (a superfície de evaporação de desloca para as camadas interiores do sólido úmido). O período III, nem sempre se diferencia claramente do anterior, sendo também decrescente. De acordo com Brown et al. (1965 apud Dias; Agopyan, 2004) ${ }^{23}$, prosseguindo-se com a secagem, chega-se a um momento em que a velocidade de secagem é zero, o que caracteriza o conteúdo mínimo de umidade, ou seja, a umidade de equilíbrio com o meio. A condição saturada superfície seca do sólido é representada pela transição entre os períodos I e II. O procedimento de ensaio utilizado pode ser encontrado no Apêndice B.

Com os dados obtidos, foram construídos gráficos relacionando a velocidade de secagem do material, na ordenada, com o índice de umidade na abscissa. Os resultados para os agregados reciclados (fração graúda e miúda) utilizando-se o procedimento citado por Dias e Agopyan (2004) são apresentados nos próximos gráficos.

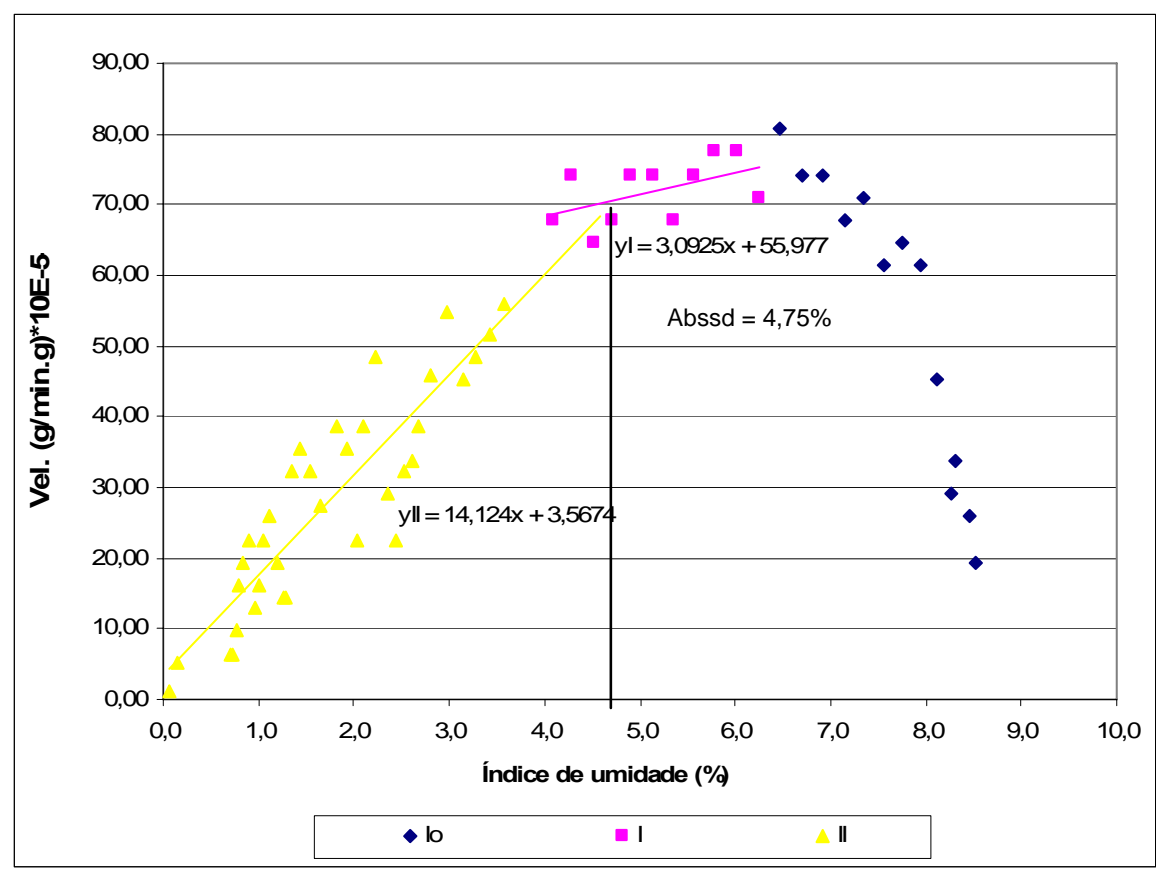

Figura 5.13 - Velocidade de secagem x conteúdo de umidade (GRv).

Analisando-se a Figura 5.13, podem ser observadas as diferentes fases de secagem do material; período $\mathrm{I}_{0}$ (duração de 40 minutos), período I (duração de 30 minutos) caracterizado pela velocidade constante de secagem do material, e período II com decréscimo da velocidade de secagem. Diferentemente do proposto por Dias e Agopyan (2004), as curvas de regressão polinomial não apresentaram resultados satisfatórios, superestimando a condição saturada superfície seca do material, possivelmente devido à 
condição de umidade inicial do agregado reciclado (próxima a 10\%). O fenômeno de secagem do material fica corretamente representado quando cada período é tratado de forma independente, conforme se observa no gráfico da Figura 5.13. O valor da absorção na condição saturada superfície seca foi obtida na intersecção das duas retas de regressão referentes aos períodos I e II. Para o agregado reciclado GRv, o valor da absorção na condição saturada superfície seca, considerando-se duas determinações, foi de 4,63\%; aproximadamente 15\% superior ao valor obtido através das prescrições da NBR 9937 (1987).

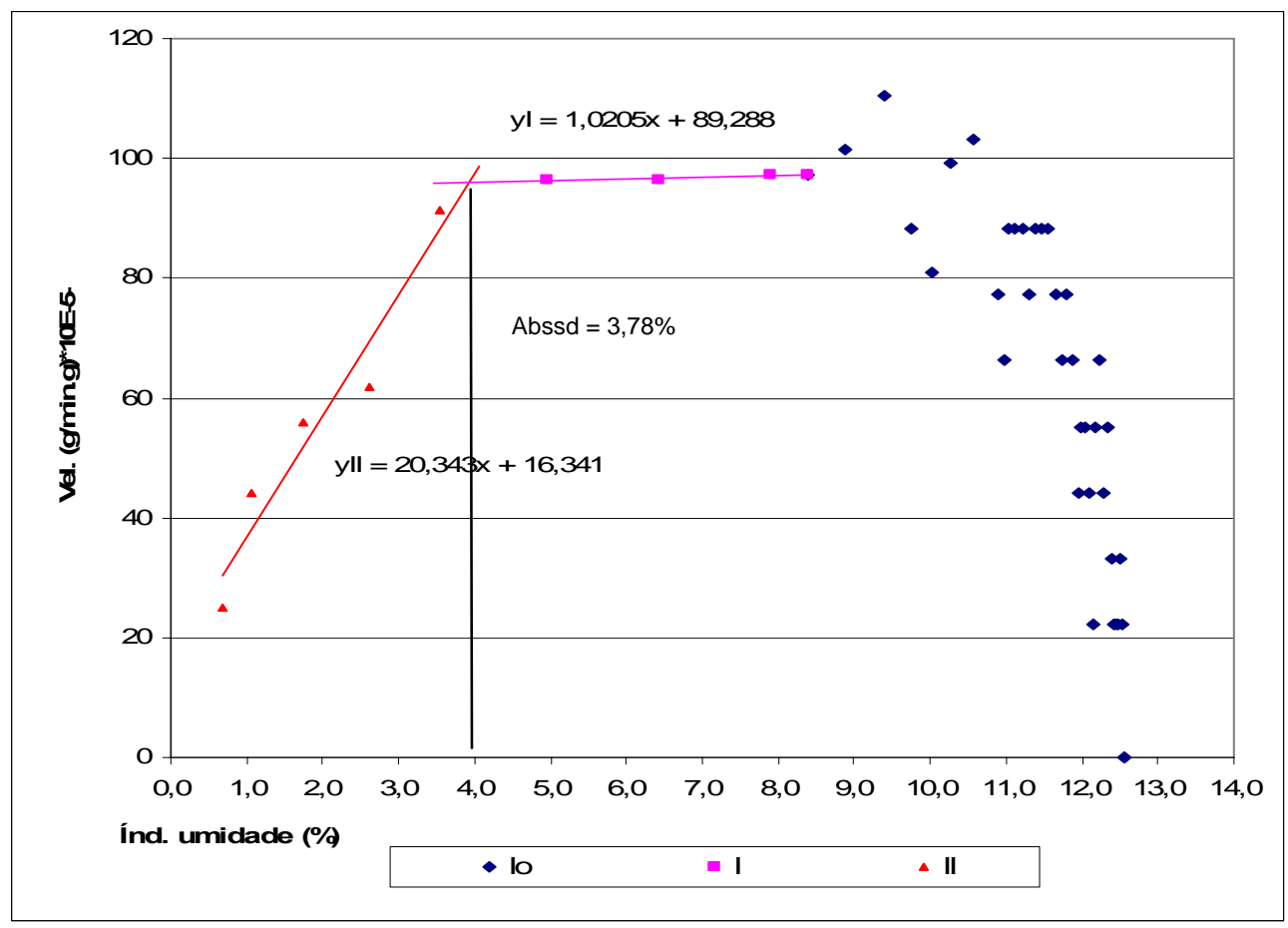

Figura 5.14 - Velocidade de secagem x conteúdo de umidade (GRvp).

Analisando-se a Figura 5.14, nota-se que o número de dados experimentais deveria ser maior, uma vez que o período I (velocidade constante de secagem) foi definido por apenas quatro pontos. Não obstante isso, a ordem de grandeza do resultado $(3,78 \%)$ foi próximo ao valor obtido utilizando-se as recomendações da NBR 9937 (1987), isto é, aproximadamente 8,5\% superior para apenas uma determinação. 


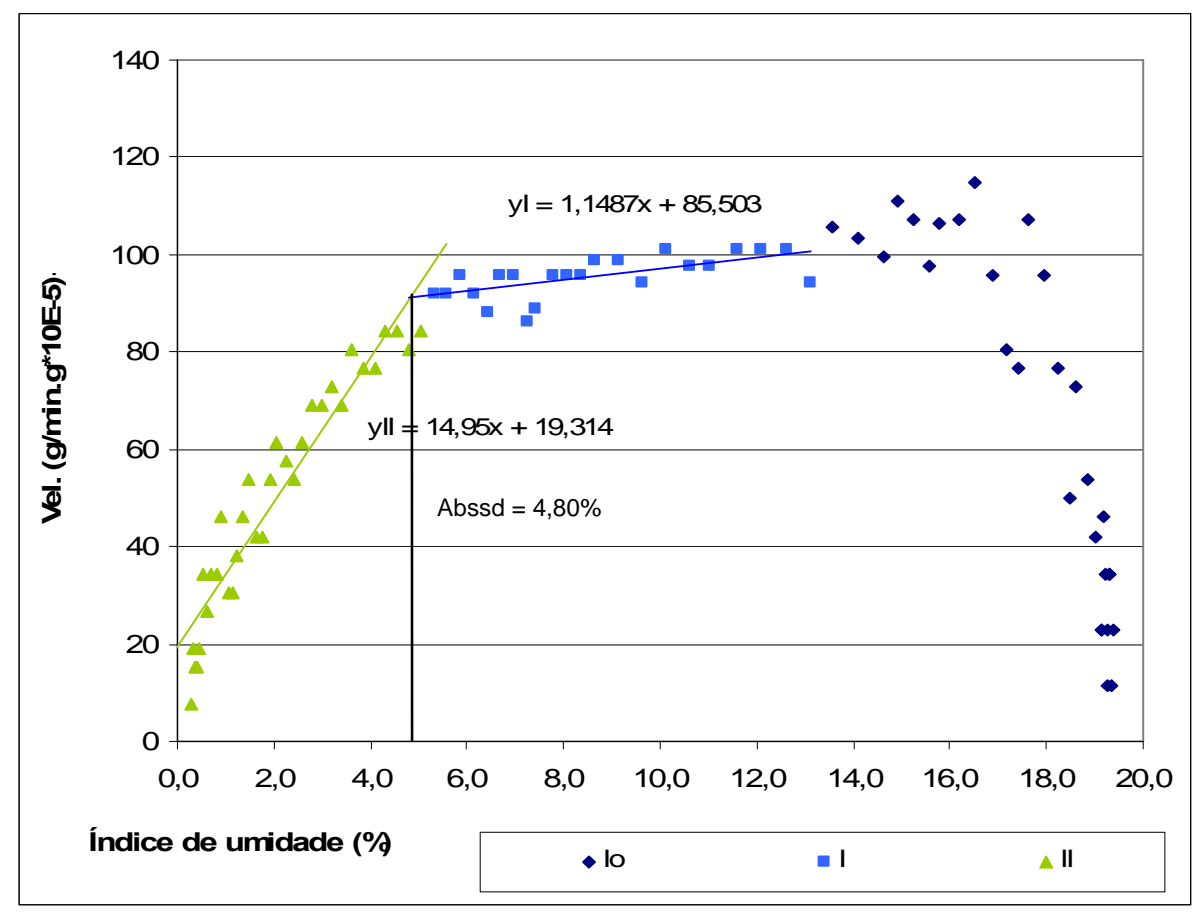

Figura 5.15 - Velocidade de secagem x conteúdo de umidade (GRb).

Analisando-se a Figura 5.15, observa-se que o período I foi relativamente extenso, pois o material foi disposto em uma condição de umidade muito superior ao estado saturado superfície seca, umidade próxima de $20 \%$, com a formação de um filme d'água sob a superfície do material. Para materiais porosos, com absorção não superior a 10\%, torna-se interessante a colocação do material em uma condição de umidade superior a sua condição saturada superfície seca, pois dessa maneira permite-se visualizar mais claramente a etapa de secagem I e a transição para a etapa II; ponto esse que é considerado fundamental para a determinação da absorção do material. A desvantagem desse processo é o prolongamento da secagem do material até a identificação precisa de cada fase. Para o agregado reciclado GRb, o valor da absorção na condição saturada superfície seca, para duas determinações, foi de 4,85\%; aproximadamente $9 \%$ superior ao valor encontrado utilizando-se as prescrições da NBR 9937 (1987). 


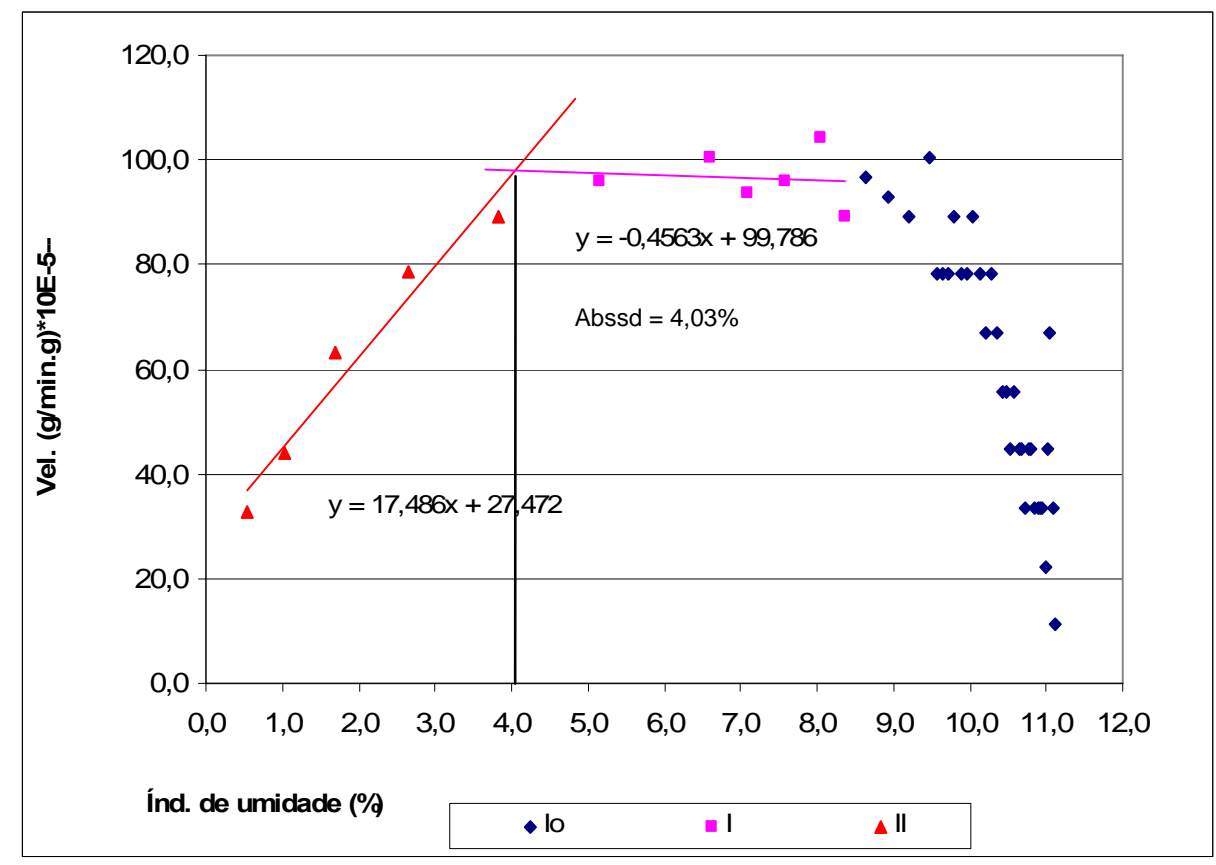

Figura 5.16 - Velocidade de secagem x conteúdo de umidade (GRpb).

Analisando-se a Figura 5.16, podem ser observadas as diferentes fases de secagem do agregado GRpb; período Io (duração de 40 minutos) e período I (duração de 35 minutos). A absorção através desse método foi aproximadamente 13\% superior ao valor encontrado seguindo as recomendações da NBR 9937 (1987). Uma das desvantagens do método refere-se à impossibilidade de mensuração da dinâmica de absorção do agregado reciclado ao longo do tempo.

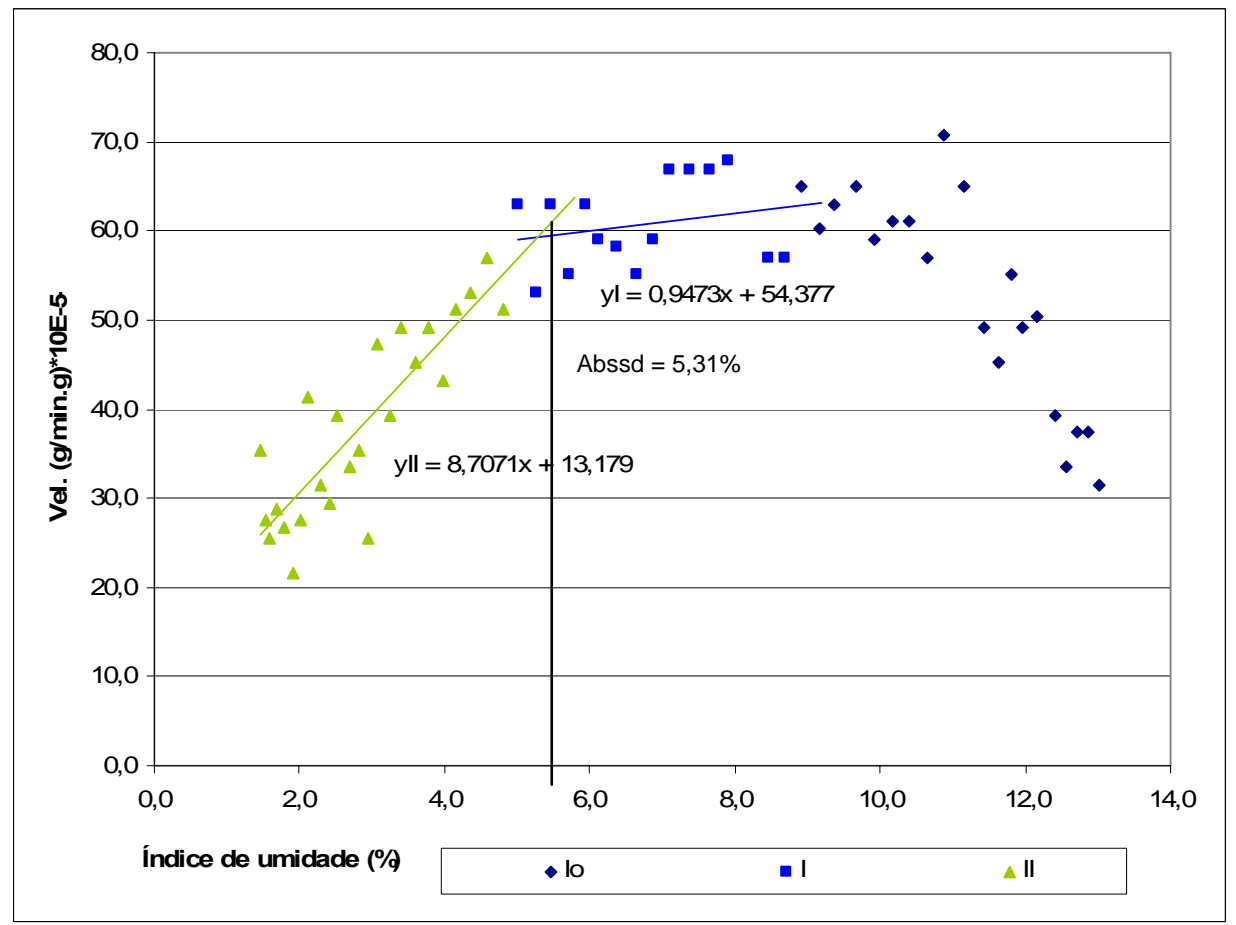

Figura 5.17 - Velocidade de secagem x conteúdo de umidade (GRt). 
Analisando-se a Figura 5.17, podem ser observadas as diferentes fases de secagem do agregado GRpb; período I (duração de 80 minutos) e período I (duração de 65 minutos). A absorção, para duas determinações, utilizando-se o procedimento citado por Dias e Agopyan (2004) foi aproximadamente $17 \%$ superior ao valor encontrado seguindo as recomendações da NBR 9937 (1987). Os resultados de absorção para os agregados graúdos reciclados são sumarizados na Tabela 5.15.

Tabela 5.15 - Absorção dos agregados graúdos utilizando-se o procedimento de Dias e Agopyan (2004).

\begin{tabular}{cccccc}
\hline & \multicolumn{5}{c}{ Agregados graúdos } \\
\cline { 2 - 6 } & GRv & GRvp* & GRb & GRpb* $^{*}$ & GRt \\
\hline $\begin{array}{c}\text { Absorção na condição } \\
\text { saturada superfície seca (\%) }\end{array}$ & 4,63 & 3,78 & 4,85 & \multirow{2}{*}{4,03} & 5,22 \\
\hline S $_{d}(\%)$ & 0,18 & - & 0,07 & - & 0,13 \\
\hline C. Variação (\%) & 3,82 & - & 1,46 & - & 2,44 \\
\hline
\end{tabular}

* uma determinação

$\mathrm{Na}$ Tabela 5.16, são reunidos os resultados de absorção de água utilizando-se os três métodos citados: NBR 9937 (1987) e os procedimentos prescritos por Leite (2001) e Dias e Agopyan (2004).

Tabela 5.16 - Resultados da absorção para os métodos avaliados comparando-se com os valores da NBR 9937 (1987).

\begin{tabular}{cccccc}
\hline & \multicolumn{5}{c}{ Absorção (\%) - agregados reciclados } \\
\cline { 2 - 6 } & GRv & GRvp & GRb & GRpb & GRt \\
\hline NBR 9937 & 4,00 & 3,48 & 4,45 & 3,57 & 4,45 \\
\hline LEITE (2001) & $3,72(-7,0 \%)$ & $1,43(-59 \%)$ & $*$ & $1,96(-45 \%)$ & $4,21(-5,4 \%)$ \\
\hline DIAS \& AGOPYAN (2004) & $4,63(+15,8 \%)$ & $3,78(+8,6 \%)$ & $4,85(+9,0 \%)$ & $4,03(+12,9 \%)$ & $5,22(+17,3 \%)$ \\
\hline
\end{tabular}

* Valor não foi mensurado devido à dificuldade de obtenção da primeira leitura

Estabelecendo-se uma análise geral dos métodos avaliados, pode-se concluir que a metodologia proposta por Dias e Agopyan (2004) forneceu um indicativo mais preciso da absorção na condição saturada superfície seca para os agregados reciclados, pois não ocorreu manuseamento do material (probabilidade de desagregação das partículas) e perda de material fino; uma das desvantagens do método referiu-se à impossibilidade de se conhecer a dinâmica de absorção dos agregados reciclados. Os métodos propostos pela NBR 9937 (1987) e por Leite (2001), para os agregados reciclados avaliados, não permitiram a obtenção de valores confiáveis devido à possibilidade de desagregação e perda de material, aprisionamento de bolhas de ar sob o conjunto e lavagem de material fino; apesar disso, o procedimento de Leite (2001) permitiu avaliar, com razoável precisão, a dinâmica de absorção dos agregados reciclados ao longo do tempo. Para facilitar a 
compreensão dos resultados, os valores de absorção para os três métodos são apresentados na Figura 5.18.

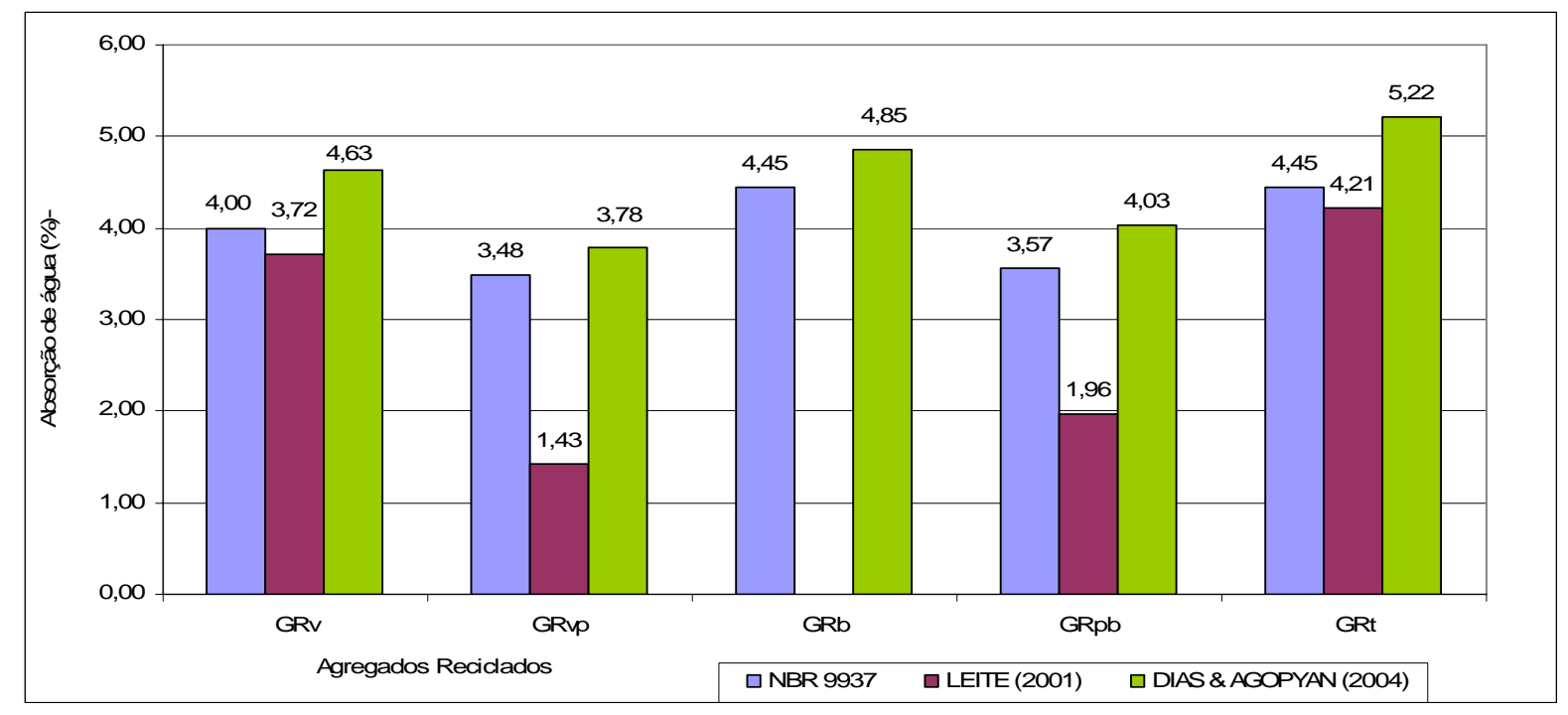

Figura 5.18 - Comparação dos métodos para avaliação da absorção.

A absorção na condição saturada superfície seca para os agregados miúdos foi avaliada conforme o método proposto por Dias e Agopyan (2004), seguindo-se o mesmo procedimento empregado para os agregados graúdos. Os resultados para os agregados miúdos são expressos na Tabela 5.17.

Tabela 5.17 - Absorção dos agregados miúdos conforme procedimento de Dias e Agopyan (2004).

\begin{tabular}{cccccccc}
\hline & \multicolumn{7}{c}{ Agregados Miúdos } \\
\cline { 2 - 8 } & $\begin{array}{c}\text { Areia } \\
\text { Itaporanga }\end{array}$ & $\begin{array}{c}\text { Pó-de- } \\
\text { pedra }\end{array}$ & MRv & MRvp & MRb & MRpb & MRt \\
\hline $\begin{array}{c}\text { Umidade } \\
\text { Inicial do material (\%) }\end{array}$ & 15,30 & 16,08 & 34,85 & 36,95 & 26,91 & 24,16 & 34,75 \\
\hline Período lo (min.) & 32 & 32 & 60 & 69 & 68 & 75 & 84 \\
\hline $\begin{array}{c}\text { Período I } \\
\text { (min.) }\end{array}$ & 68 & 88 & 228 & 169 & 138 & 117 & 196 \\
\hline Absorção (\%) & 3,02 & 2,32 & 9,15 & 6,47 & 6,05 & 5,99 & 10,62 \\
\hline
\end{tabular}

Analisando-se a Tabela 5.17, pode-se notar a elevada absorção dos agregados miúdos reciclados comparativamente aos agregados de referência; especialmente, os agregados MRv e MRt (três vezes superior ao pó-de-pedra) devido à elevada quantidade de argamassa aderida a esses agregados. A argamassa aderida é a principal responsável pela elevação da quantidade de poros permeáveis e aumento da absorção de água dos agregados reciclados; alguns pesquisadores citam que para agregados graúdos reciclados com partículas entre 16-32 mm, o volume de argamassa aderida está entre 25 e 35\%; já para partículas entre 8-16 mm, o volume de argamassa aderida é de aproximadamente 
40\%; e para partículas entre 4-8 mm, o volume chega a 60\%. O agregado MRv apresentou um valor de absorção aproximadamente $97 \%$ superior ao agregado GRv, ocasionado pela grande quantidade de argamassa aderida e a presença de finos.

Os agregados MRvp, MRb, e MRpb apresentaram os menores valores de absorção, comparativamente aos demais agregados reciclados, devido a menor quantidade de argamassa aderida as partículas de agregado. No caso do agregado MRb, o valor encontrado para a absorção corrobora o resultado obtido para a propriedade de massa específica. Segundo a NBR 15116 (2004), os agregados miúdos reciclados podem ser utilizados para a produção de concreto não-estrutural desde que a absorção seja inferior a 12\%; já segundo Tam et al. (2005), para a produção de concreto simples, unidades de alvenaria e bases de rodovias, a absorção do agregado miúdo reciclado deve ser menor que $5 \%$. Os agregados miúdos reciclados analisados cumpriram apenas com os requisitos de absorção da NBR 15116 (2004).

Para a determinação da massa específica e do índice de vazios dos agregados graúdos, utilizou-se um procedimento citado por Dias e Agopyan (2004). Por este ensaio foi possível obter, com razoável precisão, as propriedades físicas de massa específica seca, massa específica saturada superfície seca e índice de vazios. Os resultados são apresentados na Tabela 5.18 juntamente com os valores obtidos através das prescrições da NBR 9937 (1987).

Tabela 5.18 - Massa específica e índice de vazios para os agregados graúdos.

\begin{tabular}{|c|c|c|c|c|c|c|c|c|c|}
\hline & \multicolumn{3}{|c|}{$\begin{array}{c}\text { Massa específica seca } \\
\left(\mathrm{kg} / \mathrm{dm}^{3}\right)\end{array}$} & \multicolumn{3}{|c|}{$\begin{array}{c}\text { Massa específica } \\
\text { saturada superfície seca } \\
\left(\mathrm{kg} / \mathrm{dm}^{3}\right)\end{array}$} & \multicolumn{3}{|c|}{ Índice de vazios (\%) } \\
\hline & Valor & $\begin{array}{c}\text { Desvio } \\
\text { padrão } \\
\left(\mathrm{kg} / \mathrm{dm}^{3}\right)\end{array}$ & $\begin{array}{l}\text { Coef. } \\
\text { Var. } \\
(\%)\end{array}$ & Valor & $\begin{array}{l}\text { Desvio } \\
\text { padrão } \\
\left(\mathrm{kg} / \mathrm{dm}^{3}\right)\end{array}$ & $\begin{array}{l}\text { Coef. } \\
\text { Var. } \\
(\%)\end{array}$ & Valor & $\begin{array}{c}\text { Desvio } \\
\text { padrão } \\
\left(\mathrm{kg} / \mathrm{dm}^{3}\right)\end{array}$ & $\begin{array}{l}\text { Coef. } \\
\text { Var. } \\
(\%)\end{array}$ \\
\hline G R v & $\begin{array}{c}2,436 \\
2,367 \text { * }\end{array}$ & 0,043 & 1,75 & $\begin{array}{c}2,584 \\
2,461^{*}\end{array}$ & 0,044 & 1,75 & $\begin{array}{l}11,28 \\
9,47^{*}\end{array}$ & 0,20 & 1,75 \\
\hline$G R \vee p$ & $\begin{array}{c}2,686 \\
2,499 *\end{array}$ & 0,048 & 1,79 & $\begin{array}{c}2,787 \\
2,586^{*}\end{array}$ & 0,050 & 1,79 & $\begin{array}{l}10,15 \\
8,70 *\end{array}$ & 0,18 & 1,79 \\
\hline G R b & $\begin{array}{c}2,482 \\
2,391 *\end{array}$ & 0,012 & 0,49 & $\begin{array}{c}2,602 \\
2,497^{*}\end{array}$ & 0,013 & 0,49 & $\begin{array}{c}12,04 \\
10,64 *\end{array}$ & 0,06 & 0,49 \\
\hline G R pb & $\begin{array}{c}2,566 \\
2,514^{*}\end{array}$ & 0,014 & 0,53 & $\begin{array}{c}2,670 \\
2,596^{*}\end{array}$ & 0,014 & 0,53 & $\begin{array}{l}10,35 \\
8,90^{*}\end{array}$ & 0,05 & 0,53 \\
\hline G R t & $\begin{array}{c}2,228 \\
2,230^{*}\end{array}$ & 0,006 & 0,25 & $\begin{array}{c}2,344 \\
2,329 *\end{array}$ & 0,006 & 0,25 & $\begin{array}{l}11,63 \\
9,91^{*}\end{array}$ & 0,03 & 0,25 \\
\hline
\end{tabular}

* valores obtidos através das prescrições da NBR 9937 (1987)

Comparando-se os valores obtidos para as propriedades, nota-se que os resultados advindos das recomendações de Dias e Agopyan (2004) foram razoavelmente superiores aos obtidos através das prescrições da NBR 9937 (1987), com exceção do agregado GRt. As razões para essas diferenças podem ser devidas aos seguintes fatores: a) a 
subestimação da condição saturada superfície seca, através da recomendação normativa, com conseqüente redução do volume de poros permeáveis do agregado; b) a desagregação das partículas de agregado e perda de material durante a execução do ensaio normativo; c) o ensaio normativo provavelmente não é muito adequado para materiais frágeis e que apresentem menores módulos de finura; d) probabilidade de aprisionamento de ar entre as partículas de agregado na determinação da massa imersa, fato esse que pode ocorrer em qualquer um dos ensaios.

A relação entre a massa específica seca e a absorção dos agregados, conforme procedimento citado por Dias e Agopyan (2004), são apresentados na Figura 5.19.

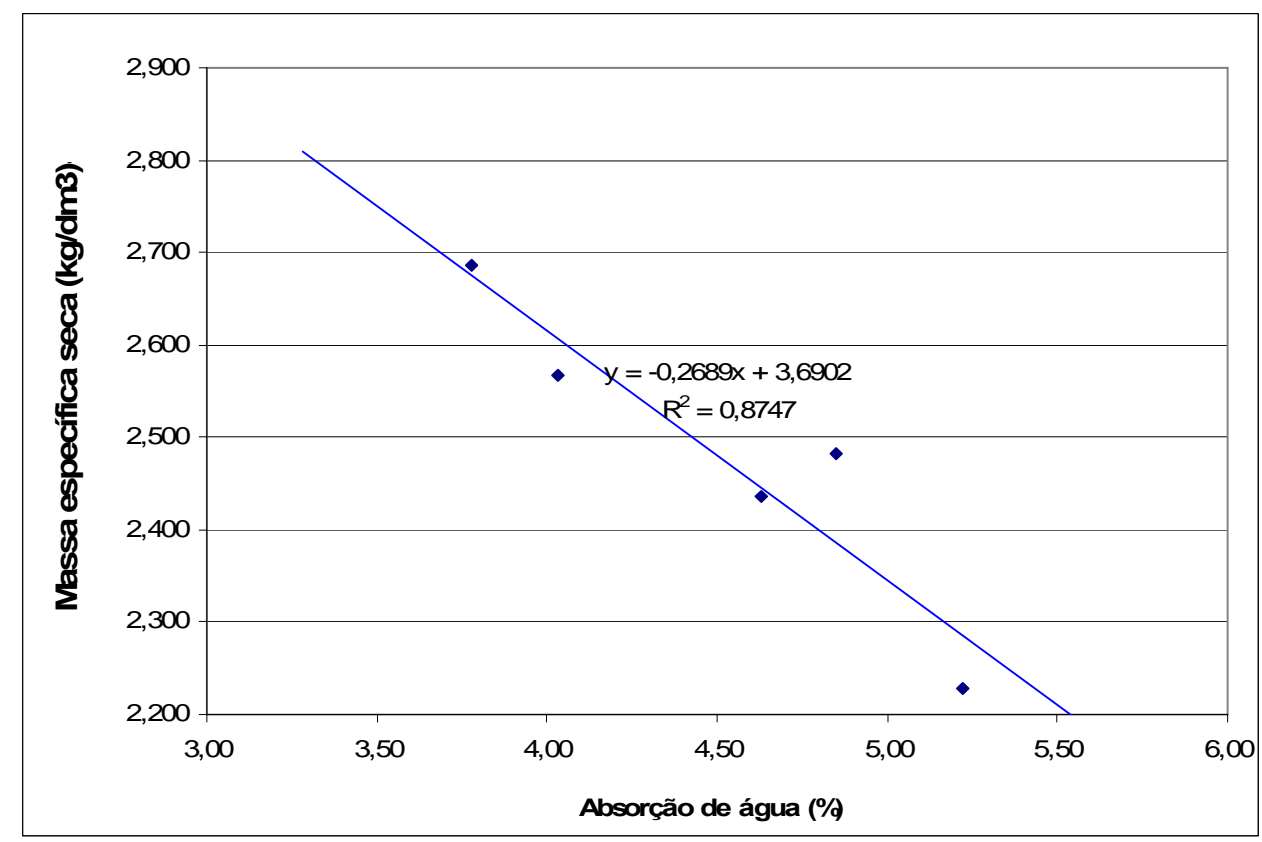

Figura 5.19 - Relação entre as propriedades de massa específica seca e absorção de água, conforme procedimento de Dias e Agopyan (2004).

\subsubsection{Massa unitária (estado solto e compactado)}

As massas unitárias dos agregados (estado solto e compactado) foram determinadas utilizando-se as prescrições das NBR 7251 (1982) e NBR 7810 (1983). A massa unitária em estado solto de um agregado refere-se à relação entre a massa do agregado e seu volume, sem compactar. A massa unitária compactada de um agregado pode ser definida como sendo a relação entre sua massa e seu volume compactado, considerando-se os vazios entre os agregados. Seu emprego destina-se principalmente para escolha da mistura de agregados que seja mais compacta e, consequentemente, com menor índice de vazios para produção de concretos. Segundo Neville (1997), a massa unitária depende da distribuição de tamanho e forma das partículas, isto é, partículas de um mesmo tamanho podem ser adensadas até um determinado limite, mas caso partículas menores sejam incorporadas, 
preenchendo os vazios existentes entre as partículas maiores, haverá um aumento significativo da massa unitária do material adensado. Para os materiais reciclados, ocorre uma diminuição da massa unitária, comparativamente ao agregado de referência, em razão da argamassa aderida as partículas de agregado. Os resultados para os agregados graúdos são apresentados na Tabela 5.19.

Tabela 5.19 - Massa unitária dos agregados graúdos.

\begin{tabular}{|c|c|c|c|c|c|c|c|c|}
\hline & \multicolumn{4}{|c|}{ Massa unitária estado solto } & \multicolumn{4}{|c|}{ Massa unitária estado compactado } \\
\hline & $\begin{array}{c}\text { Valor } \\
\left(\mathrm{kg}^{2} / \mathrm{dm}^{3}\right)\end{array}$ & 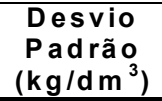 & $\begin{array}{c}\text { Coef. } \\
\text { Variação } \\
(\%)\end{array}$ & $\begin{array}{c}\text { Relação } \\
\text { rec/nat }\end{array}$ & $\begin{array}{c}\text { Valor } \\
\left(\mathrm{kg}^{3} \mathrm{dm}^{3}\right)\end{array}$ & $\begin{array}{c}\text { Desvio } \\
\text { Padrão } \\
\left({\left.\mathrm{kg} / \mathrm{d} \mathrm{m}{ }^{3}\right)}\right.\end{array}$ & $\begin{array}{c}\text { Coef. } \\
\text { Variação } \\
(\%)\end{array}$ & $\begin{array}{l}\text { Relação } \\
\mathrm{rec} / \mathrm{n} \text { at }\end{array}$ \\
\hline $\begin{array}{c}\text { Agreg. } \\
\text { Ref. }\end{array}$ & 1,393 & 0,0046 & 0,33 & 1,00 & 1,548 & 0,0096 & 0,62 & 1,00 \\
\hline G R v & 1,250 & 0,0019 & 0,15 & 0,90 & 1,320 & 0,0120 & 0,91 & 0,85 \\
\hline GRvp & 1,301 & 0,0049 & 0,38 & 0,93 & 1,452 & 0,0150 & 1,04 & 0,94 \\
\hline GR b & 1,180 & 0,0026 & 0,22 & 0,85 & 1,374 & 0,0273 & 1,99 & 0,89 \\
\hline GRpb & 1,281 & 0,0045 & 0,35 & 0,92 & 1,432 & 0,0186 & 1,30 & 0,93 \\
\hline G R t & 1,134 & 0,0026 & 0,23 & 0,81 & 1,238 & 0,0120 & 0,97 & 0,80 \\
\hline
\end{tabular}

Analisando-se a Tabela 5.19, nota-se que a relação entre as massas unitárias no estado solto para os agregados reciclados e para o material natural ficou com o valor médio de 0,85; com exceção dos agregados reciclados GRvp e GRpb que obtiveram uma relação próxima a 0,93. Para esses últimos agregados, que foram processados no britador (procedimento opcional) e separados pelo peneiramento, pode-se observar uma recuperação quase que completa do agregado natural (pedrisco) e, com isso, os valores de massa unitária desses agregados ficaram próximas daquele obtido para o agregado de referência. Com relação à massa unitária no estado compactado, os resultados mantiveram o mesmo comportamento da massa unitária no estado solto; pode-se notar que os agregados reciclados com melhor distribuição granulométrica, isto é, maior empacotamento de partículas, alcançaram os maiores valores para essa propriedade. Com relação ao agregado reciclado GRb, o processo de compactação de cada camada realizado durante o ensaio provocou a desagregação das partículas devido à fragilidade do agregado gerando, consequentemente, uma grande quantidade de finos que ocasionaram um aumento expressivo da massa unitária no estado compactado.

Buttler (2003) notou que a relação entre as massas unitárias no estado solto para os agregados reciclados e para o agregado natural ficou com o valor médio de 0,85; para a massa unitária no estado compactado, essa relação foi de 0,86 . Os agregados reciclados foram provenientes de um resíduo de média resistência ( $\left.f_{\mathrm{cm}}=50 \mathrm{MPa}\right)$

Na Tabela 5.20 encontram-se os resultados para os agregados miúdos. 
Tabela 5.20 - Massa unitária para os agregados miúdos.

\begin{tabular}{|c|c|c|c|c|c|c|c|c|}
\hline & \multicolumn{4}{|c|}{ Massa unitária estado solto } & \multirow{2}{*}{$\begin{array}{c}\text { Massa } \\
\begin{array}{c}\text { Valor } \\
\left(\mathrm{kg}^{3} / \mathrm{dm}^{3}\right)\end{array}\end{array}$} & \multicolumn{3}{|c|}{ unitária estado compactado } \\
\hline & $\begin{array}{c}\text { Valor } \\
\left(\mathrm{kg} / \mathrm{dm}^{3}\right)\end{array}$ & $\begin{array}{c}\text { Desvio } \\
\text { Padrão } \\
\left(\mathrm{kg} / \mathrm{d} \mathrm{m}{ }^{3}\right)\end{array}$ & $\begin{array}{c}\text { Coef. } \\
\text { Variação } \\
(\%)\end{array}$ & $\begin{array}{c}\text { Re lação } \\
\text { rec/pó }\end{array}$ & & $\begin{array}{c}\text { Desvio } \\
\text { Padrão } \\
\left(\mathrm{kg} / \mathrm{dm}^{3}\right)\end{array}$ & $\begin{array}{c}\text { Coef. } \\
\text { Variação } \\
(\%)\end{array}$ & $\begin{array}{c}\text { Re lação } \\
\text { rec/pó }\end{array}$ \\
\hline $\begin{array}{l}\text { Areia } \\
\text { Tietz }\end{array}$ & 1,573 & 0,0035 & 0,22 & - & 1,692 & 0,0016 & 0,09 & - \\
\hline $\begin{array}{l}\text { Areia } \\
\text { Itapor. }\end{array}$ & 1,605 & 0,0044 & 0,27 & - & 1,754 & 0,0040 & 0,23 & - \\
\hline $\begin{array}{l}\text { Pó de } \\
\text { pedra }\end{array}$ & 1,646 & 0,0064 & 0,39 & 1,00 & 1,981 & 0,0110 & 0,55 & 1,00 \\
\hline M R v & 1,270 & 0,0172 & 1,35 & 0,77 & 1,495 & 0,0153 & 1,02 & 0,75 \\
\hline$M R \vee p$ & 1,420 & 0,0023 & 0,16 & 0,86 & 1,577 & 0,0175 & 1,11 & 0,80 \\
\hline M R b & 1,323 & 0,0111 & 0,84 & 0,80 & 1,540 & 0,0179 & 1,16 & 0,78 \\
\hline M R pb & 1,533 & 0,0120 & 0,78 & 0,93 & 1,746 & 0,0021 & 0,12 & 0,88 \\
\hline M R t & 1,254 & 0,0048 & 0,38 & 0,76 & 1,524 & 0,0209 & 1,37 & 0,77 \\
\hline
\end{tabular}

Com relação à massa unitária no estado solto e compactado, os agregados reciclados apresentaram uma redução média de 18\%, em comparação ao material natural (pó-de-pedra). Devido o menor módulo de finura do agregado (M.F = 2,58) e a grande quantidade de argamassa aderida, que se desprendeu após o processo de compactação, o agregado reciclado MRt apresentou um aumento expressivo, cerca de 24\%, da massa unitária no estado compactado em relação à massa unitária no estado solto. Por outro lado, para o agregado reciclado MRpb foram obtidos os maiores valores de massa unitária (estado solto e compactado), comparativamente aos demais agregados reciclados, devido o menor módulo de finura do material $(2,28)$ e a grande quantidade de finos $(32 \%)$. O pó-depedra, comparativamente aos demais agregados naturais, apresentou massa unitária compactada aproximadamente $15 \%$ superior devido sua grande quantidade de finos (28\%) e melhor distribuição granulométrica. Na produção de blocos, a utilização do pó-de-pedra confere maior coesão à mistura, principalmente para as dosagens com baixo consumo de cimento. Segundo Dal Molin (2005), o pó-de-pedra pode ser considerado um fíller; sua função se resume a um efeito físico de empacotamento granulométrico e ação como pontos de nucleação para a hidratação dos grãos de cimento.

\subsubsection{5. Índice de forma de agregado}

Devido à dimensão máxima característica dos agregados graúdos analisados, o ensaio prescrito pela NBR 7809 (1983) não foi realizado. A BS 812: Parte 1 (1975 apud LIBORIO, 2003, p.12) ${ }^{24}$, em suas prescrições, define o conceito de angulosidade de um agregado. Segundo essa norma, o número de angulosidade é definido subtraindo-se de 67, a porcentagem de volume de sólidos em um recipiente preenchido com agregados segundo

${ }^{24}$ BRITISH STANDARD. BS 812: Part 1 - Aggregate silt, clay and dust content of fine and coarse aggregate. 1975 
um procedimento estabelecido, conforme preconizado pela NBR 7810 (1983). O número 67 representa a porcentagem de volume do sólido do agregado mais arredondado, de modo que o número de angulosidade mede a porcentagem de vazios a mais daquele agregado arredondado. Quanto maior o número, mais anguloso é o agregado, sendo que esse número situa-se entre 0 e 11 . Conforme Libório (2003), realizando-se o proporcionamento entre dois agregados, um arredondado e outro alongado, verifica-se que o teor de vazios diminui à medida que se aumenta a quantidade de material arredondado. Para a realização desse ensaio foram utilizadas duas propriedades dos agregados; a massa unitária no estado compactado, conforme a NBR 7810 (1983), e a massa específica de agregados, segundo NBR 9776 (1987) e NBR 9937 (1987), respectivamente. O procedimento citado foi empregado para os agregados graúdos, mas os resultados não foram satisfatórios, pois todos os números de angulosidade ficaram próximos ou ultrapassaram o limite (11). Caso esse método fosse utilizado, todos os agregados graúdos seriam classificados como angulosos. Os resultados para os agregados miúdos encontram-se na Figura 5.20.

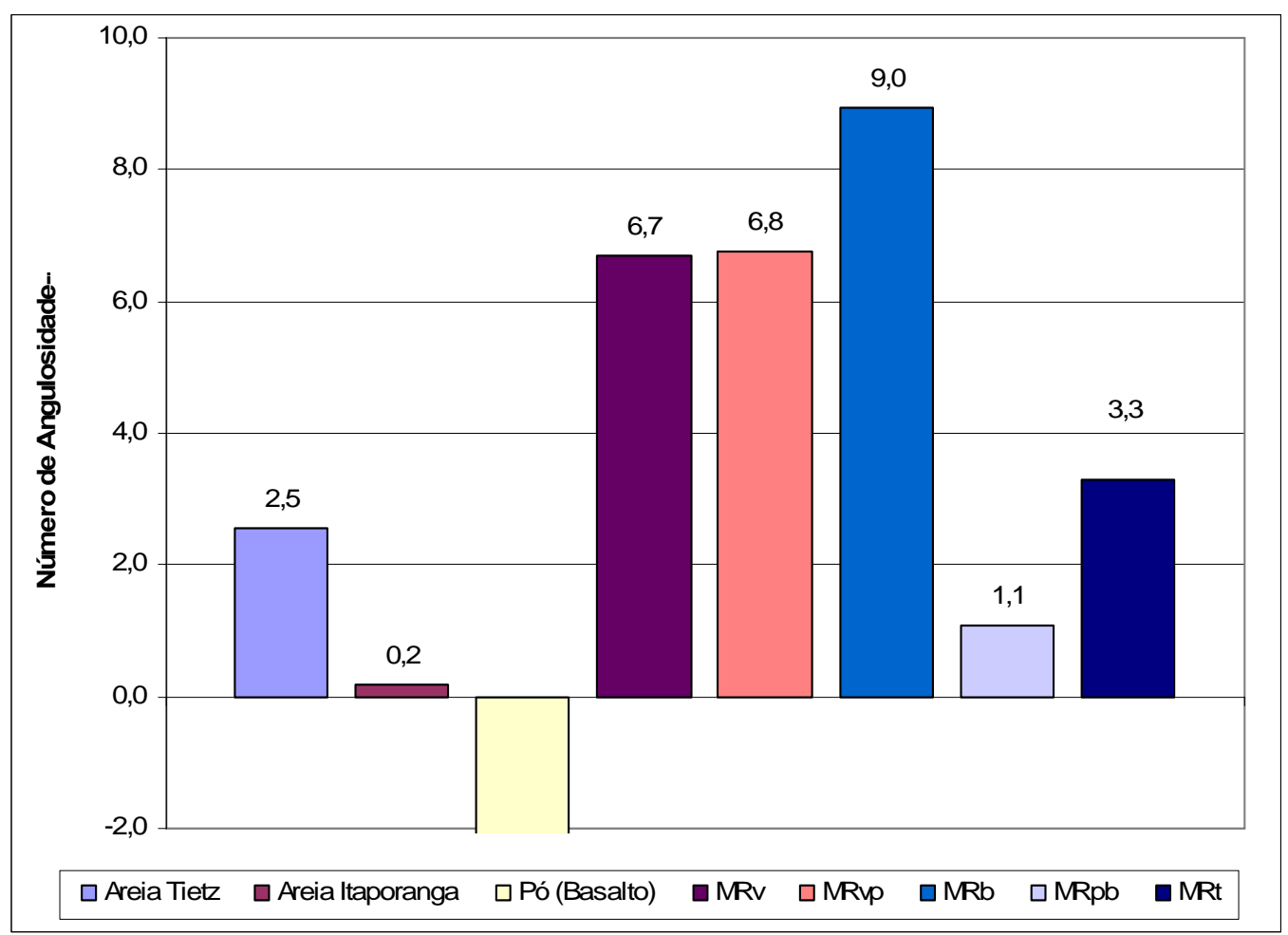

Figura 5.20 - Número de angulosidade para os agregados miúdos.

Analisando-se a Figura 5.20, nota-se que o procedimento preconizado pela BS 812: Parte 1 (1975 apud LIBORIO, 2003, p.12) ${ }^{24}$ não forneceu resultados satisfatórios para o póde-pedra. Provavelmente, a grande quantidade de finos $(<0,30 \mathrm{~mm})$ e a presença de material pulverulento (aproximadamente 18\%) comprometeram a validade do ensaio. Os agregados reciclados MRpb e MRt, que apresentaram menor módulo de finura e grande 
quantidade de finos (cerca de 28\%), em relação aos demais agregados reciclados, obtiveram um número de angulosidade situado entre 1,0 e 3,5; fato esse que permitiu classificá-los como ligeiramente arredondados. Por outro lado, devido à pequena quantidade de finos e o maior módulo de finura, os agregados reciclados MRv, MRvp e MRb apresentaram um número de angulosidade superior a 6,0; devido a isso, esses agregados foram classificados como angulosos. A presença de agregados angulosos na mistura provoca a necessidade de aumento da água de amassamento para uma determinada consistência.

Devido os resultados não satisfatórios obtidos para os agregados graúdos, foi utilizado outro procedimento para avaliar o formato dos agregados, extraído de Neville (1997). Segundo o autor, se os agregados forem constituídos integralmente de partículas esféricas, todas do mesmo tamanho, a arrumação mais compacta é atingida quando os seus centros se situarem nos centros de tetraedros imaginários. A massa unitária compactada será, nessa idealização, $74 \%$ da massa específica do material. Na arrumação mais aberta, quando as esferas se situam nos vértices de cubos imaginários, a massa unitária representará apenas $52 \%$ da massa específica do sólido. Os resultados para os agregados graúdos utilizando-se esse procedimento são apresentados na Figura 5.21.

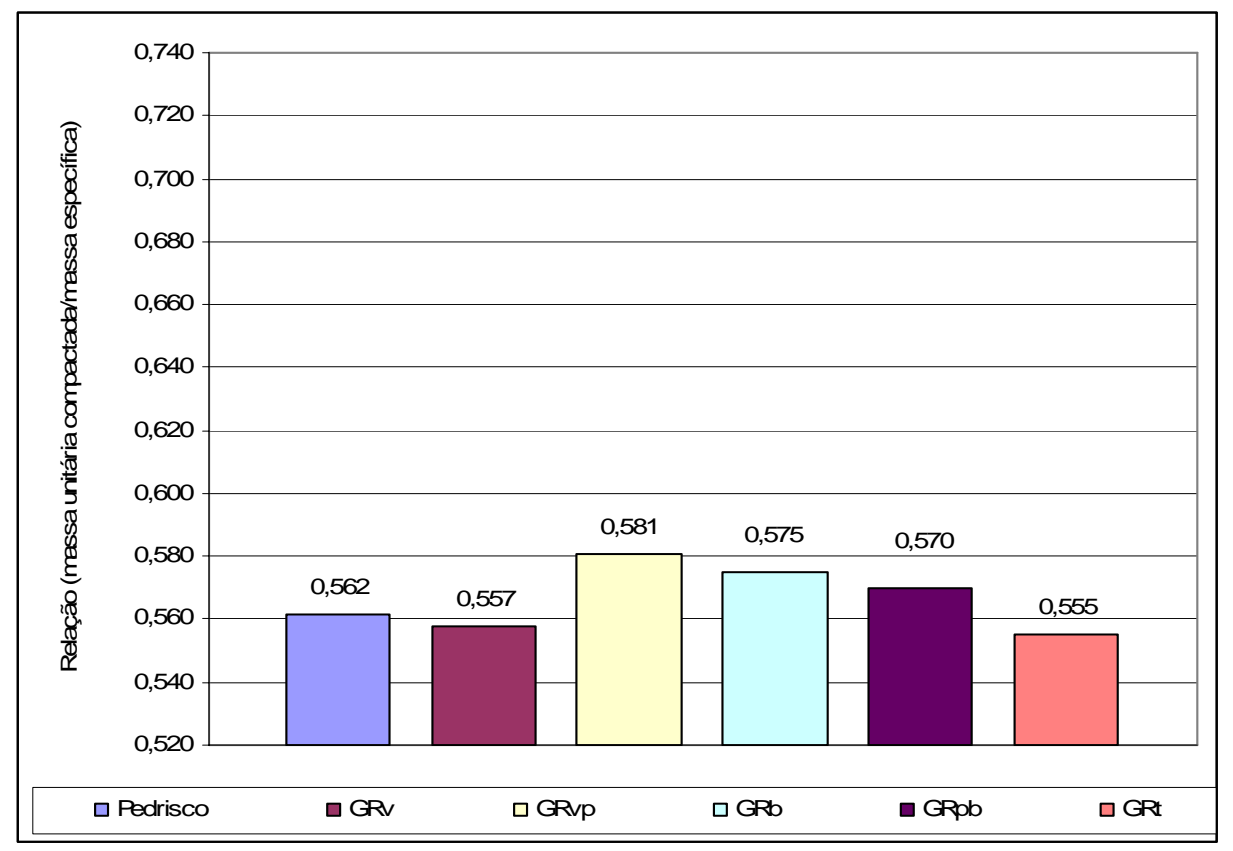

Figura 5.21 - Relação massa unitária/massa específica para os agregados graúdos.

Analisando-se a Figura 5.21, observa-se que todos os agregados graúdos analisados apresentaram uma relação entre massa unitária e massa específica inferior a 0,60. A classificação mais correta para esses agregados é seu enquadramento como materiais 
angulosos corroborando os resultados advindos do procedimento da BS 812: Parte 1 (1975 apud LIBORIO, 2003, p.12) ${ }^{24}$. Na Figura 5.22, são expostos os resultados para os agregados miúdos.

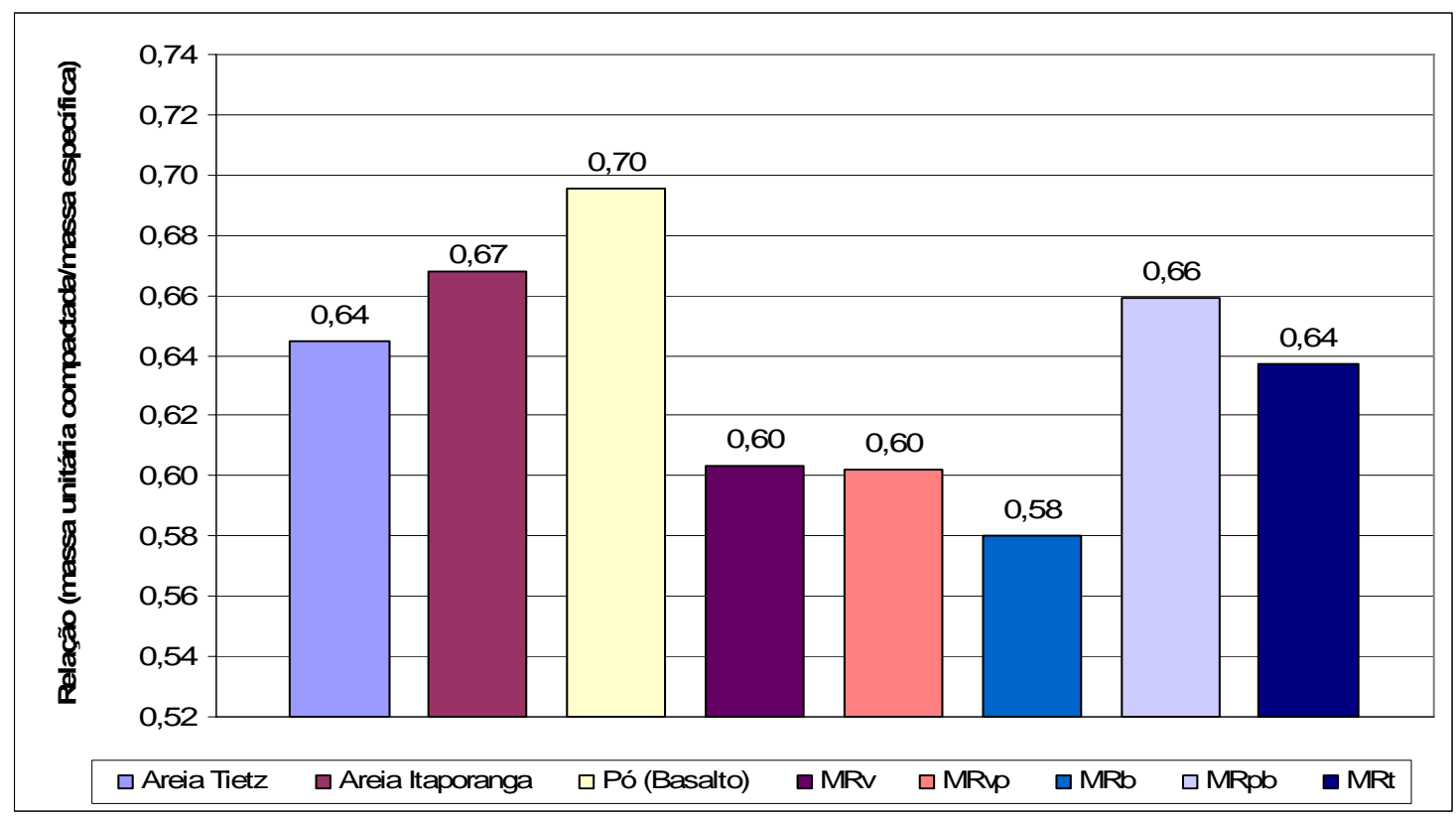

Figura 5.22 - Relação entre massa unitária e massa específica para os agregados analisados.

Analisando-se a Figura 5.22, observa-se que os agregados miúdos, tais como, as areias Itaporanga e Tietz, pó-de-pedra e os agregados reciclados MRpb e MRt, com relações entre massa unitária e massa específica superiores a 0,64 , podem ser classificados como ligeiramente arredondados. Para os demais agregados (MRv, MRvp e MRb) que apresentaram relações massa específica/unitária inferiores a 0,60, a classificação mais correta é o enquadramento desses materiais como agregados angulosos. De maneira geral, esses resultados corroboram os resultados obtidos pelo procedimento da BS 812: Parte 1 (1975 apud LIBORIO, 2003, p.12) ${ }^{24}$.

\subsubsection{Abrasão Los Angeles}

O ensaio de abrasão Los Angeles, segundo Neville (1997), apresenta boa correlação não só com a resistência do agregado ao desgaste no concreto, mas também com a resistência do concreto à compressão e à tração na flexão. Conforme Dias (2004), esse ensaio quantifica o índice de qualidade de um agregado, sendo parte de especificações nacionais e internacionais para materiais de base e sub-base de pavimentos rodoviários. No Apêndice $C$ encontra-se a descrição do ensaio bem como dos equipamentos utilizados. Os resultados são apresentados na Figura 5.23. 


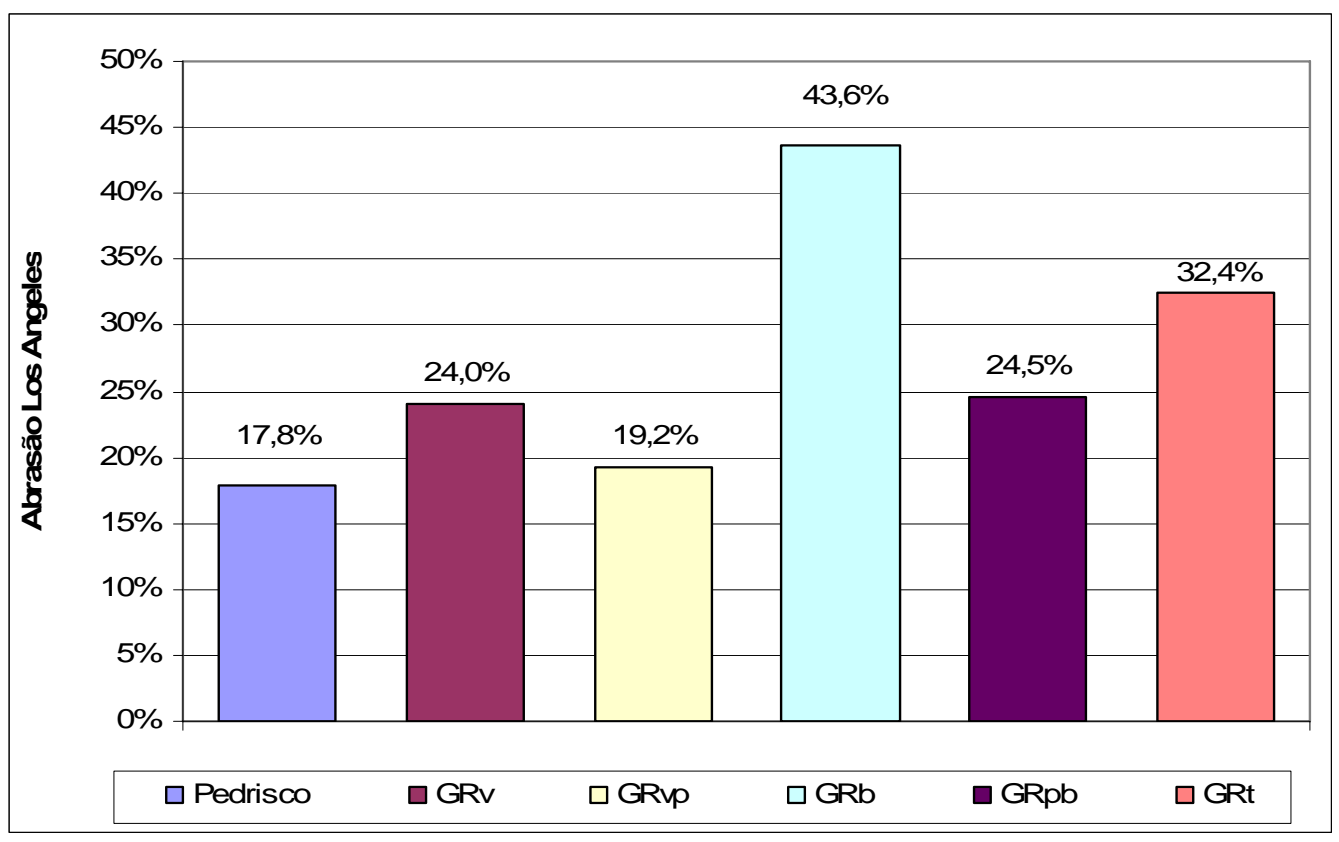

Figura 5.23 - Abrasão Los Angeles.

Analisando-se os resultados, observa-se que os agregados graúdos reciclados GRv, GRvp e GRpb obtiveram resultados de perda de massa por abrasão muito próximas daquela obtida para o agregado natural (pedrisco). O agregado GRvp, oriundo de materiais desperdiçados durante a vibro-prensagem dos blocos, obteve a menor perda de massa quando comparado com os demais reciclados, um aumento de apenas oito porcento quando comparado ao pedrisco. Para os agregados reciclados GRv e GRpb, esta perda de massa representou um aumento de 35\% em relação ao valor de abrasão do agregado natural. A reduzida perda de massa por abrasão do agregado GRv, em relação aos agregados GRb e GRt, pode ser explicada pela elevada resistência do resíduo de concreto de vigota. Por outro lado, os agregados reciclados GRb e GRt obtiveram os maiores valores de perda de massa por abrasão, um aumento de $144 \%$ e $82 \%$ quando comparado ao pedrisco. Esses resultados podem ser explicados pelas seguintes razões: a) a grande quantidade de argamassa aderida ao agregado reciclado GRt que no processo de abrasão e atrito acabam desprendendo-se do agregado gerando, consequentemente, uma grande quantidade de finos; b) a baixa resistência do agregado reciclado GRb originário de resíduos de blocos $\left(\mathrm{f}_{\mathrm{c}}=\right.$ $5 \mathrm{MPa}$ a $20 \mathrm{MPa}$ ) e o baixo consumo de cimento empregado na produção desses artefatos. Na Figura 5.24 podem ser observados os agregados reciclados GRb e GRt após o ensaio de abrasão Los Angeles. 


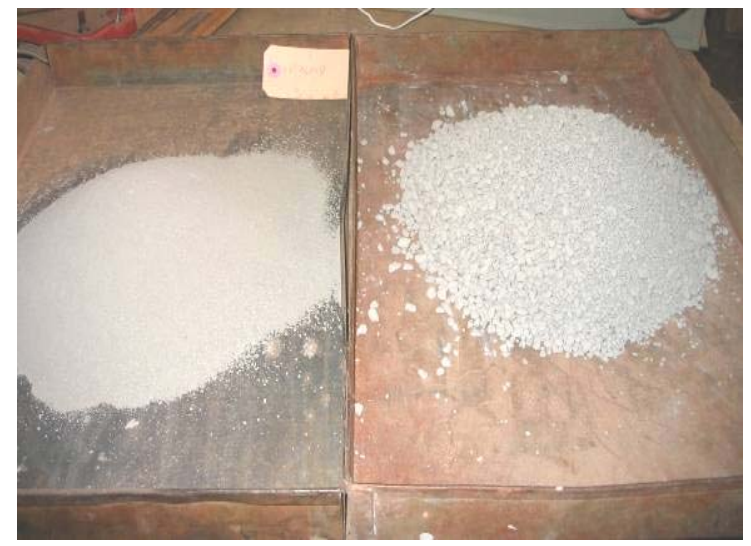

a) agregado reciclado GRb

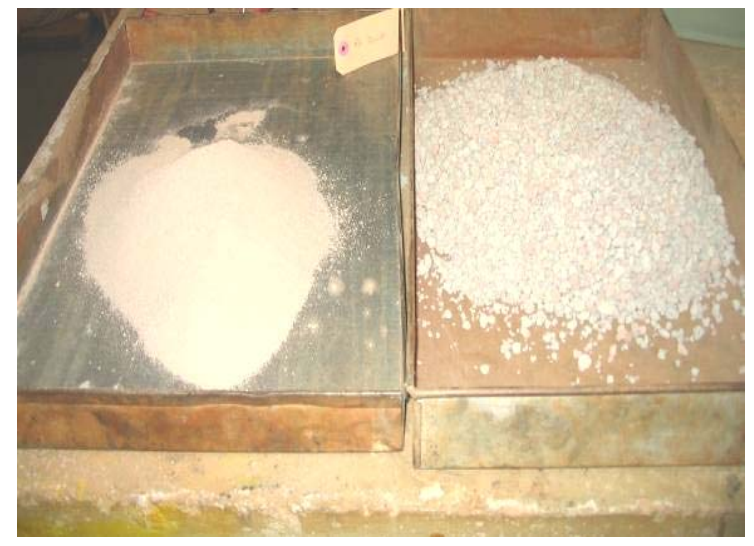

b) agregado reciclado GRt

Figura 5.24 - Ensaio de Abrasão Los Angeles (agregados GRb e GRt).

Para os agregados da Figura 5.24, a bandeja à esquerda representa o material passante na peneira $1,7 \mathrm{~mm}$, e a outra bandeja o material retido nesta peneira. $\mathrm{O}$ material passante representa a perda de massa por abrasão que é comprovadamente significativa para esses dois materiais.

De acordo com a ASTM C-33 (2003), os agregados podem ser utilizados para produção de concreto desde que os valores de perda de massa por abrasão não ultrapassem 50\%, sendo que para pavimentação esse limite é reduzido para 40\%. Dessa forma, pode-se concluir que os agregados reciclados analisados encontram-se aptos para produção de artefatos de concreto.

Buttler (2003) avaliou agregados reciclados provenientes de um concreto de média resistência (50MPa); os valores de perda de massa por abrasão situaram-se em torno de $30 \%$. Bazuco (1999) encontrou valores de perda de massa por abrasão em torno de $42 \%$ para agregados reciclados oriundos de concretos de resistência média de $16 \mathrm{MPa}$. Hansen e Narud (1983) obtiveram valores de perda de massa por abrasão igual a 22,4\% e 41,4\%, para agregados reciclados oriundos de concretos de alta e baixa resistência, respectivamente. Yoshikane (1985 apud Hansen, 1985, p. 215) ${ }^{25}$ encontrou valores de perda de massa por abrasão entre 20,1\% e 28,7\% para agregados reciclados provenientes de resíduos de concreto de $40 \mathrm{MPa}$ e $16 \mathrm{MPa}$, respectivamente.

25 YOSHIKANE, T. Present status of recycling waste cement concrete in Japan. Private communication from Touru Yoshikane, Director, Research Laboratory, Taiyu Kensetsu, Japan, 1985. 


\subsubsection{Quantidade de argamassa aderida}

A argamassa aderida ao agregado reciclado acarreta um aumento da absorção de água pelo agregado, diminuição da massa específica e redução da trabalhabilidade do concreto. O procedimento de ensaio utilizado encontra-se no Apêndice D. Os resultados para os agregados graúdos reciclados são apresentados na Figura 5.25.

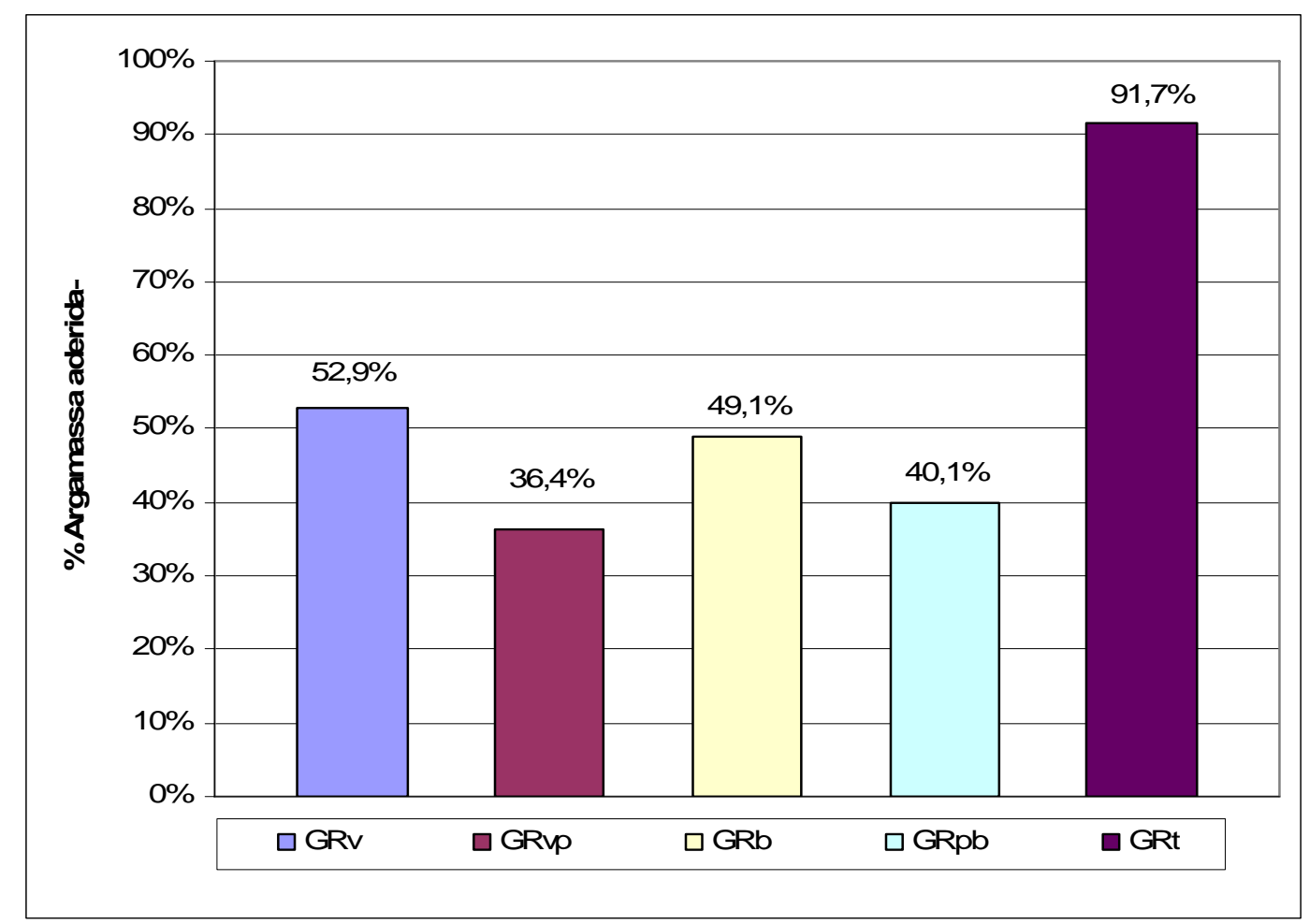

Figura 5.25 - Argamassa aderida aos agregados reciclados.

Analisando-se a Figura 5.25, nota-se que os agregados reciclados GRvp e GRpb apresentaram, em relação aos demais agregados, as menores porcentagens de argamassa aderida. Esse fato justifica os menores valores de absorção e índice de vazios e os maiores valores de massa específica e unitária obtidos anteriormente para esses dois agregados. Os agregados GRv e GRb apresentam valores próximos com relação a quantidade de argamassa aderida (aproximadamente 50\%) e, consequentemente, para as demais propriedades avaliadas anteriormente (massa específica, índice de vazios e absorção de água). O agregado GRt, oriundo de um resíduo de média resistência e baixo consumo de agregado graúdo, obteve uma porcentagem de argamassa aderida próxima a 92\%; essa elevada porcentagem justifica várias propriedades físicas obtidas para esse agregado, tais como, grande quantidade de finos, baixa massa específica e unitária, elevada absorção e índice de vazios. 
De acordo com Hansen e Narud (1983), a percentagem em volume de argamassa aderida para os agregados reciclados pode variar de 30\%, para frações granulométricas entre $16 \mathrm{~mm}$ e $32 \mathrm{~mm}$, a valores superiores a $60 \%$ para frações entre $4 \mathrm{~mm}$ e $8 \mathrm{~mm}$. A presença de grande quantidade de argamassa aderida ao agregado afeta negativamente as propriedades de deformabilidade do concreto, tais como, módulo de deformação, retração por secagem e fluência; além da durabilidade do concreto frente aos agentes físicos e químicos.

\subsection{CONCLUSÕES DO CAPÍTULO}

Com relação aos resultados obtidos são estabelecidas as seguintes conclusões:

- Com relação à composição granulométrica, a distribuição das frações granulométricas foi influenciada pela abertura da mandíbula do equipamento de britagem e pelas características dos resíduos de concreto, principalmente quando foram comparados os resíduos de vigota e telha com os resíduos de bloco. Apesar disso, todos os agregados cumpriram as determinações da ASTM C-33 (2003) e da NBR 15116 (2003) com relação à quantidade máxima de finos passantes na peneira $0,075 \mathrm{~mm}$.

- Com relação à absorção de água, todos os agregados graúdos reciclados apresentaram valores de absorção inferiores aos prescritos pelos códigos normativos. O procedimento da NBR 9937 (1987) conduziu a uma subestimação dos valores de absorção; provavelmente, a tendência à desagregação das partículas durante o processo de secagem e o aprisionamento de bolhas de ar sob o conjunto foram responsáveis por esse comportamento. O método de Leite (2001), apesar de possibilitar a avaliação da dinâmica de absorção dos agregados ao longo do tempo, não forneceu valores finais de absorção confiáveis devido à dificuldade de mensuração da primeira leitura (valor inicial de absorção). Dentre os métodos, o procedimento de Dias e Agopyan (2004) mostrou-se o mais adequado para a determinação da absorção dos agregados reciclados. Para os agregados miúdos, apesar do cumprimento aos requisitos da NBR 15116 (2004), nenhum dos agregados apresentou valores de absorção inferiores aos prescritos por Tam et al. (2005) para a produção de concreto simples e blocos de concreto. Dessa maneira, pode-se aferir que a utilização de agregados miúdos reciclados de concreto, independentemente de sua qualidade e origem, deve ser 
recomendada para pequenas porcentagens ou até mesmo ser evitada para que sejam reduzidos os problemas decorrentes da diminuição de resistência e durabilidade, aumento da retração por secagem e deformações.

- A massa específica dos agregados graúdos reciclados foi influenciada pela argamassa porosa que se encontra aderida à superfície dos agregados; uma redução de $10 \%$ a $20 \%$ em relação à massa específica do agregado natural. Para os agregados miúdos, o procedimento da NBR 9776 (1987) utilizando-se o Frasco de Chapman, não se mostrou muito adequada para a determinação da massa específica, devido à formação de espuma superficial provocada pela presença de finos e pelo fato do material não se encontrar na condição saturada superfície seca.

- Após o processo de britagem, os agregados graúdos reciclados foram classificados como angulosos (NEVILLE, 1997). A utilização desses agregados requer um cuidado especial na produção do concreto reciclado, uma vez que, certamente, ocorrerá uma diminuição da trabalhabilidade e da coesão da mistura devido o formato das partículas.

- Com relação ao ensaio de abrasão Los Angeles, nenhum agregado apresentou valores de perda de massa por abrasão superior ao recomendado pela ASTM C33 (2003), sendo que todos os agregados foram considerados aptos para a produção de concreto. A perda de massa por abrasão foi influenciada pela qualidade do resíduo de concreto e pelo agregado reciclado.

- A determinação da quantidade de argamassa aderida é um parâmetro essencial para a avaliação preliminar das propriedades físicas dos agregados reciclados. Com base nos resultados obtidos, pode-se dizer que a elevação da absorção de água e da quantidade de finos e a redução da massa específica e unitária são intimamente ligadas ao aumento da taxa de argamassa aderida ao agregado reciclado. $\mathrm{Na}$ realidade, a utilização de agregados reciclados com grande quantidade de argamassa aderida e que sejam provenientes de um resíduo de baixa resistência devem ser evitados, para que não haja prejuízo das propriedades físicas e mecânicas do concreto com agregados reciclados (HANSEN; BOEGH,1985).

- De maneira geral, dada à representatividade dos resíduos de concreto analisados, pode-se afirmar que a fração graúda reciclada, independentemente 
da sua qualidade e origem, cumpriu todos os requisitos normativos necessários para o seu emprego como agregado reciclado para a produção das unidades de alvenaria. Por outro lado, a utilização da fração miúda reciclada, independentemente da sua qualidade, deve ser realizada para pequenas substituições nos blocos de concreto ou até mesmo ser evitada devido à sua elevada absorção e grande quantidade de finos.

Na figura 5.26 é apresentado um fluxograma contendo as etapas fundamentais para caracterização dos materiais reciclados e que pode ser adotada por fábricas de prémoldados.

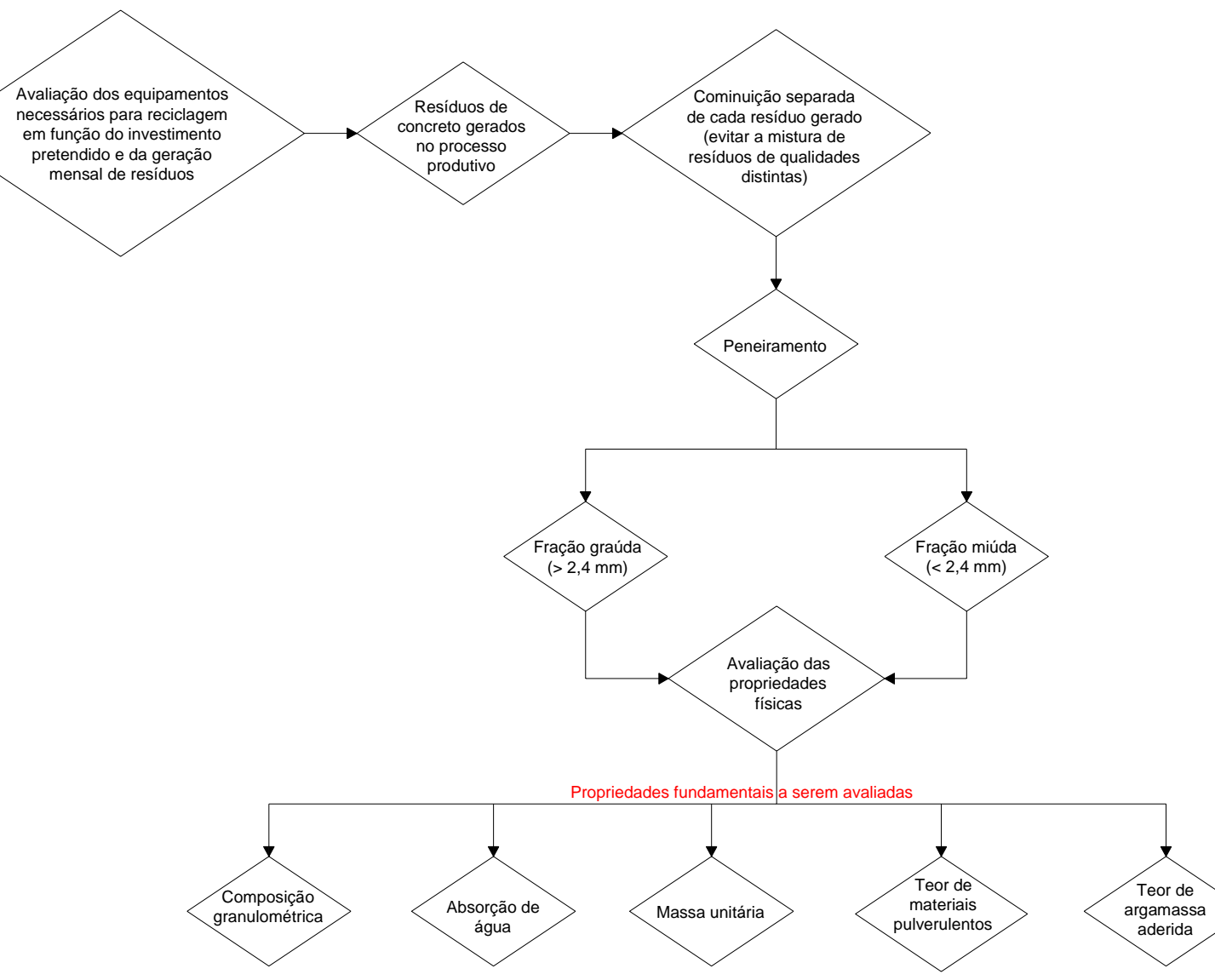

Figura 5.26 - Fluxograma simplificado para caracterização dos materiais. 
Neste capítulo é apresentado um estudo preliminar para a produção de corpos-deprova cilíndricos $(5 \mathrm{~cm} \times 10 \mathrm{~cm}$ ) utilizando-se concreto de consistência seca de característica similar ao empregado nos blocos estruturais. São analisados comparativamente diversos parâmetros que influem nas propriedades físicas e mecânicas dos corpos-de-prova cilíndricos, tais como, umidade, composição da mistura, energia de adensamento, tipo de cura, condição de umidade do exemplar no momento do ensaio, procedimento de mistura, etc. A influência desses parâmetros nas propriedades supracitadas é verificada empregando-se o teste "t de Student" e a Análise de Variância ANOVA. A formulação desses dois testes, conjuntamente com as condições exigidas para a realização do teste ANOVA, encontram-se no Anexo A.

\subsection{DESCRIÇÃO DAS ETAPAS}

Em razão do número de variáveis envolvidas no estudo e da importância de cada uma delas, seria praticamente impossível a produção de blocos de concreto visando avaliar a influência de todos esses parâmetros. O processo seria extremamente cansativo, oneroso e de difícil reprodução. Além disso, por se tratar de um processo semi-industrial (produção de blocos) e que geralmente apresenta inúmeras fontes de variabilidade, os resultados e as análises poderiam ficar comprometidos. Diante desse contexto, foram encontrados na literatura alguns trabalhos que buscaram correlacionar as propriedades do material do bloco através do emprego de corpos-de-prova cilíndricos (Frasson Junior, 2000; Maia et al, 2002; Barbosa, 2004). Outros programas de pesquisa buscaram essa correlação através da retirada de corpos-de-prova do próprio bloco (Becica; Harris, 1983; Ganzerli et al, 2003; Marzahn, 2003).

No presente trabalho, julgou-se que o procedimento citado por Becica e Harris (1983) e demais pesquisadores, apesar de representarem fielmente as características dos 
materiais através da extração de corpos-de-prova do bloco, seria de execução extremamente complicada, demandaria tempo apreciável e com a possibilidade de ocorrência de danos durante a extração dos exemplares. O procedimento citado por Maia et al. (2002), apesar de várias particularidades interessantes, não foi adotado neste trabalho. A principal razão refere-se à dificuldade para moldagem dos corpos-de-prova de dimensões $10 \mathrm{~cm} \times 20 \mathrm{~cm}$ empregando concreto de consistência seca, necessidade de uma prensa hidráulica para compactação do material e comprometimento da reprodutibilidade. No presente trabalho, foram produzidos cerca de 1500 corpos-de-prova $(5 \mathrm{~cm} \times 10 \mathrm{~cm})$, em três meses de pesquisa, sendo aproximadamente 36 exemplares por dia; caso os corpos-deprova fossem de dimensões maiores, essa produção ficaria comprometida e demandaria muito mais tempo. Além disso, a escolha de corpos-de-prova cilíndricos $5 \mathrm{~cm} \times 10 \mathrm{~cm}$ devese ao fato de que eles são mais fáceis de serem manuseados e com baixo consumo de materiais é possível produzir uma grande quantidade de CPs.

Barbosa (2004) relata que a correlação entre as propriedades mecânicas de blocos e corpos-de-prova é dificultada devido às diferentes formas geométricas de blocos e exemplares existentes, efeito de confinamento e o próprio processo de adensamento, que é função de cada máquina e dos tempos de produção pré-estabelecidos. O pesquisador produziu corpos-de-prova de diferentes dimensões $(5 \times 10,10 \times 20$ e $15 \times 30)$ e blocos utilizando concreto de consistência plástica, em condições semelhantes de moldagem e adensamento; os resultados indicaram que não houve um fator fixo de correlação entre CPs e blocos. A resistência para os CPs $5 \times 10 \mathrm{~cm}$ foi entre $13 \%$ a $31 \%$ superior à do bloco, já para os CPs $10 \times 20 \mathrm{~cm}$ esse intervalo foi de $3 \%$ a $16 \%$ superior. Diante dos resultados de Barbosa (2004), a presente pesquisa não terá como objetivo principal o estabelecimento de um fator de correlação fixo entre as propriedades dos blocos e corpos-de-prova; na realidade, será buscado um intervalo de valores que permitam aferir com razoável precisão as propriedades dos blocos que serão produzidos na fábrica através de corpos-de-prova cilíndricos produzidos em laboratório. Além disso, a produção dos exemplares, sob uma determinada energia de compactação, permitirá uma comparação imediata das propriedades dos CPs com agregados reciclados com aqueles fabricados com agregados naturais.

Para o desenvolvimento do programa experimental é utilizado o Método de Dosagem do Menor Volume de Vazios e, principalmente, o procedimento de Frasson Junior (2000) com algumas adaptações. As principais adaptações referem-se ao processo de moldagem dos CPs cilíndricos $5 \mathrm{~cm} \times 10 \mathrm{~cm}$. O pesquisador produziu exemplares com diferentes massas específicas, mantendo-se constante a energia de adensamento e variando a 
quantidade de material para cada série de corpos-de-prova, isto é, antes da produção de cada exemplar era feita a pesagem do material a ser adensado. Na presente pesquisa, a produção dos exemplares com diferentes massas específicas será realizada pela modificação da energia de adensamento, isto é, variando-se o número de golpes e o número de camadas; acredita-se que esse procedimento apresente facilidade e reprodutibilidade maior que o método recomendado por Frasson Junior (2000). Uma das grandes vantagens do processo citado pelo referido autor é a consideração da coesão da mistura, isto é, não basta à mistura ter uma compacidade elevada com reduzido número de vazios para que seja adequada à produção dos blocos. Segundo o pesquisador, a mistura deve possuir uma coesão adequada para que não ocorram problemas durante a desforma e transporte dos blocos.

Diante da definição do programa experimental, a presente metodologia foi dividida em três etapas fundamentais:

- $1^{\text {a }}$ etapa: aplicação do método de dosagem do menor volume de vazios para a definição do esqueleto da mistura. Produção de misturas experimentais, em laboratório, variando-se o consumo de cimento, a porcentagem de agregado graúdo/miúdo, tipo de cura e energia de adensamento com o intuito de avaliar as propriedades físicas e mecânicas dos CPs, coesão da mistura e textura final.

- $2^{a}$ etapa: produção de corpos-de-prova na fábrica de pré-moldados. As amostras de concreto são retiradas durante a produção de uma determinada série de blocos de concreto; posteriormente, os CPs são moldados e submetidos ao processo de cura, juntamente com os blocos de sua série. Dessa forma, é garantida a semelhança de traços, umidade e cura das séries de corpos-de-prova e blocos produzidos. Os blocos de concreto e CPs são ensaiados aos 7 e 28 dias avaliando-se suas propriedades físicas e mecânicas, com o objetivo de estabelecer um intervalo de correlação para essas unidades (blocos e CPs);

- $3^{\mathrm{a}}$ etapa: produção de corpos-de-prova, em laboratório, com agregados naturais e agregados reciclados, para três classes de resistência. Avaliação da influência da incorporação de agregados reciclados de concreto (graúdos e/ou miúdos) na coesão, textura, propriedades físicas e mecânicas dos corpos-de-prova. Verificação da influência de outros parâmetros, tais como, tipo de cura (úmida ou térmica), tipo de mistura (simples ou dupla) nas propriedades físicas e mecânicas dos exemplares. Todas as dosagens com agregados reciclados são comparadas com similares produzidas com agregados naturais. 


\subsubsection{PRIMEIRA ETAPA}

Inicialmente, seguindo as recomendações da Associação Brasileira de Cimento Portland (1995) e Maia et al. (2004), foi empregado o Método do Menor Volume de Vazios para a determinação da composição ideal de agregados. Esse procedimento baseia-se na formulação de uma mistura com um mínimo de vazios possíveis, visando alcançar as maiores massas unitárias. A busca por um menor volume de vazios tem como objetivo encontrar um proporcionamento entre agregados que resulte em uma mistura mais compacta por ter relação direta com a resistência à compressão. Por outro lado, de acordo com Frasson Junior (2000), esse método não leva em consideração a granulometria nem as características particulares do agregado, o que resulta, muitas vezes, no alcance de misturas compactas, mas pouco coesivas. Outra deficiência apontada se refere à exclusão do cimento nos estudos de composição, uma vez que esse material fino é importante na redução do volume de vazios e, principalmente, no aumento da coesão das misturas. Diante disso, pela produção de corpos-de-prova cilíndricos foram verificadas outras propriedades que foram decisivas na escolha da composição ideal de agregados. As propriedades foram as seguintes: coesão, absorção de água, massa específica, resistência à compressão e tração, módulo de elasticidade e textura visual para cada uma das misturas proporcionadas.

Apesar da Associação Brasileira de Cimento Portland (1995) citar que a composição deva ser feita inicialmente com os dois agregados mais graúdos e depois a composição desses agregados com o miúdo, Frasson Junior (2000), cita que para alguns traços, quando foi empregada areia fina nas misturas, houve um consumo excessivo desse agregado para um menor volume de vazios com conseqüente redução da resistência mecânica dos blocos (alta superfície específica do material demandando quantidades elevadas de água e pasta de cimento). Fonseca (2002) também não obteve resultados representativos pelo método supracitado quando foi empregada a fração areia fina conjuntamente com as frações graúdas do material. Devido a esses motivos, foi realizada a mistura de dois agregados (pó de pedra e pedrisco) pelo Método do Menor Volume de Vazios e manteve-se fixa a porcentagem de areia para cada uma dessas composições. A formulação desse ensaio encontra-se no Apêndice E. Os resultados para cada uma das composições encontram-se na Tabela 6.1. 
Tabela 6.1 - Resultados de massa unitária e volume de vazios para cada uma das composições avaliadas.

\begin{tabular}{|c|c|c|c|c|c|c|c|c|}
\hline $\begin{array}{c}\% \text { Areia } \\
\text { Itaporanga } \\
(\mathrm{M} . \mathrm{F}= \\
1,98)\end{array}$ & $\begin{array}{c}\text { Massa } \\
\text { areia } \\
(g)\end{array}$ & $\begin{array}{c}\text { \% pó-de- } \\
\text { pedra } \\
\text { basalto } \\
\text { (M.F = } \\
2,71)\end{array}$ & $\begin{array}{c}\text { Massa } \\
\text { pó de } \\
\text { pedra } \\
(g)\end{array}$ & $\begin{array}{c}\% \\
\text { pedrisco } \\
(M . F= \\
5,65)\end{array}$ & $\begin{array}{c}\text { Massa } \\
\text { pedrisco } \\
(\mathrm{g})\end{array}$ & $\begin{array}{c}\text { Massa } \\
\text { conjunto } \\
(\mathrm{g})\end{array}$ & $\begin{array}{c}\text { Massa } \\
\text { unitária } \\
\left(\mathrm{kg} / \mathrm{dm}^{3}\right)\end{array}$ & $\begin{array}{c}\text { Volume } \\
\text { de vazios } \\
(\%)\end{array}$ \\
\hline 20 & 1400 & 20 & 1400 & 60 & 4200 & $\begin{array}{l}5671 \\
5785 \\
\end{array}$ & 1,909 & 31,09 \\
\hline 20 & 1680 & 30 & 2520 & 50 & 4200 & $\begin{array}{l}6008 \\
6121\end{array}$ & 2,022 & 27,26 \\
\hline 20 & 2100 & 40 & 4200 & 40 & 4200 & $\begin{array}{l}6149 \\
6200\end{array}$ & 2,058 & 26,16 \\
\hline 20 & 2800 & 50 & 7000 & 30 & 4200 & $\begin{array}{l}6135 \\
6159 \\
\end{array}$ & 2,049 & 26,70 \\
\hline 20 & 4200 & 60 & 12600 & 20 & 4200 & $\begin{array}{l}6128 \\
6084\end{array}$ & 2,035 & 27,41 \\
\hline
\end{tabular}

A Figura 6.1 indica o volume de vazios, em relação à porcentagem de pedrisco presente, para cada uma das composições estudadas.

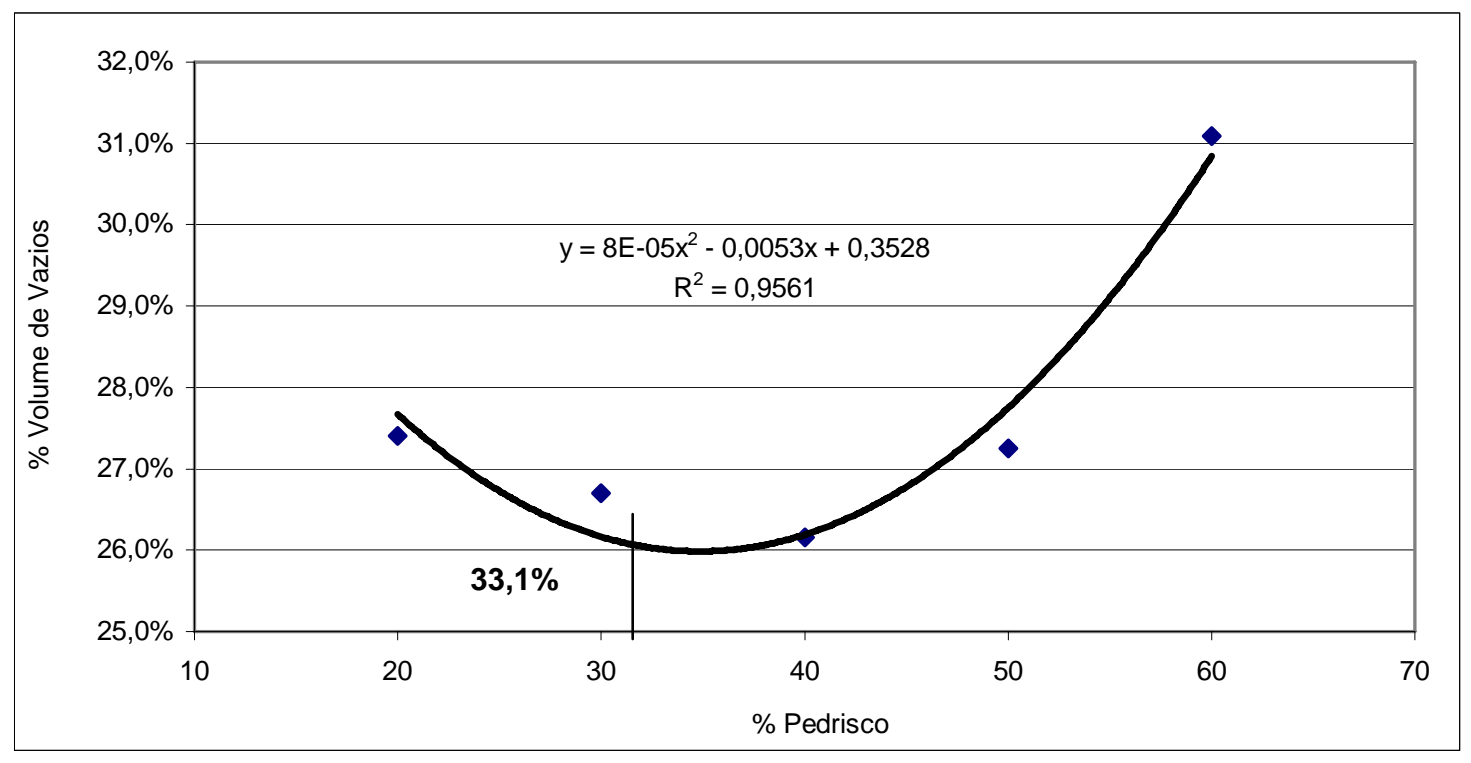

Figura 6.1 - Curva do menor volume de vazios das composições.

Pela Figura 6.1, nota-se que o ponto de mínimo da parábola ajustada corresponde à porcentagem de pedrisco igual a 33,1\%, que teoricamente representaria o menor volume de vazios da mistura. Portanto, a composição ideal pelo Método do Menor Volume de Vazios, seria composta pelos seguintes agregados e respectivas porcentagens: 33,1\% de pedrisco, $46,9 \%$ de pó de pedra e $20 \%$ de areia. É claro que essa composição, apesar de possuir a maior compacidade e menor índice de vazios, terá que ser avaliada detalhadamente em conjunto com as outras composições. Dessa forma, serão caracterizadas as propriedades físicas e mecânicas das composições citadas na Tabela 6.1 para diferentes traços e 
condições de adensamento; além disso, outro aspecto importante será avaliar a coesão da mistura e textura superficial dos exemplares produzidos.

$\mathrm{Na}$ produção dos blocos foi empregado um concreto de consistência seca, basicamente para que fossem desformados logo após a produção. Diante da metodologia apresentada, que visa correlacionar as propriedades dos blocos com corpos-de-prova cilíndricos de características praticamente similares, julgou-se fundamental o desenvolvimento de fôrmas cilíndricas $5 \times 10 \mathrm{~cm}$ que possibilitassem uma moldagem rápida e, principalmente, uma desforma precisa e rápida, sem comprometer a integridade do corpode-prova. As fôrmas desenvolvidas e alguns detalhes são apresentados no Apêndice F.

Todas as misturas foram realizadas manualmente em um recipiente metálico, em razão da inexistência de um misturador mecânico de pequena capacidade de produção. As argamassadeiras mecânicas utilizadas comumente para argamassas não são adequadas para a produção de concreto, uma vez que a granulometria do agregado graúdo pode prejudicar a cuba do equipamento. A ordem de colocação dos materiais foi a seguinte: $1^{0}$ mistura e homogeneização dos agregados graúdos e miúdos; $2^{0}$ - adição do cimento e homogeneização da mistura; $3^{0}$ - adição de metade da quantidade de água prevista conjuntamente com o aditivo; $4^{0}$ - adição do restante da água e homogeneização final da mistura. Durante o processo de mistura e produção dos corpos-de-prova foi registrada a temperatura e a umidade no ambiente do laboratório. O processo de mistura pode ser visualizado na Figura 6.2.
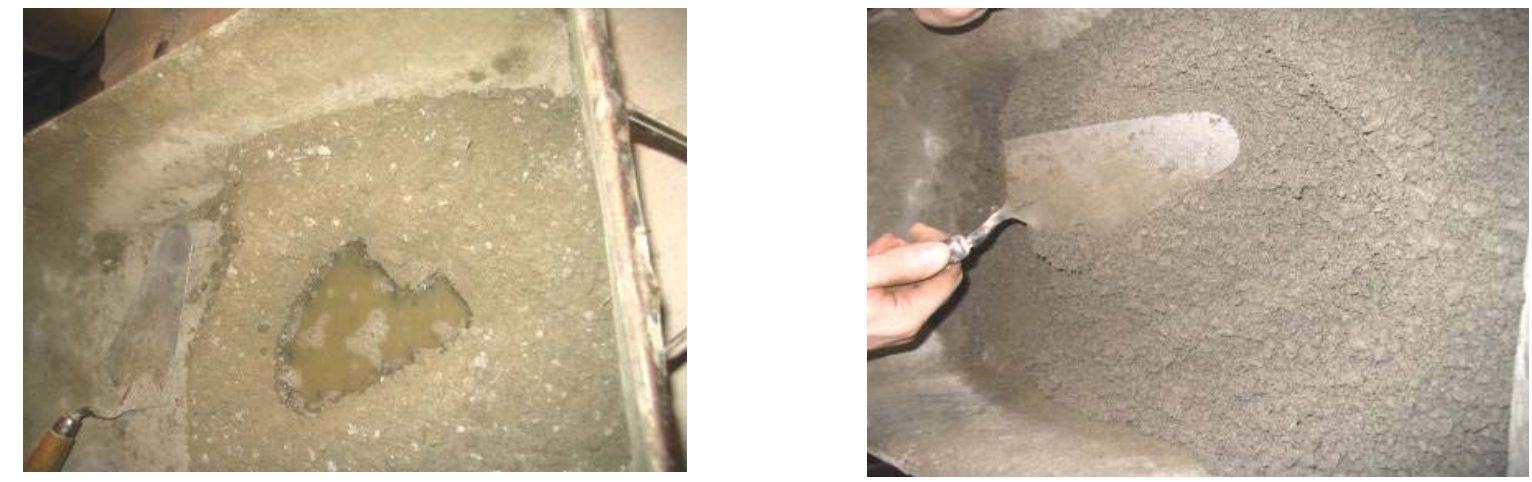

Figura 6.2 - Processo de mistura manual.

Na primeira etapa, após a moldagem, todos os corpos-de-prova foram pesados e, depois da produção do último corpo-de-prova, os exemplares foram colocados na cura úmida por sete dias, Figura 6.3. Após o período de sete dias, os exemplares restantes foram mantidos no ambiente do laboratório até a data de ensaio. 


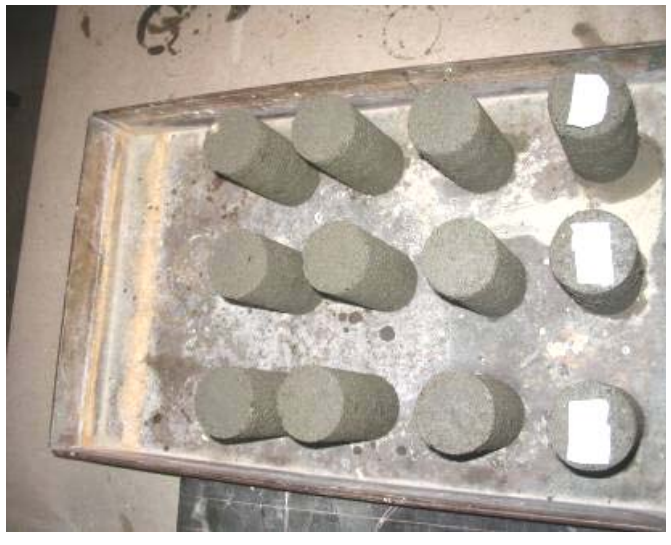

a) produção dos exemplares

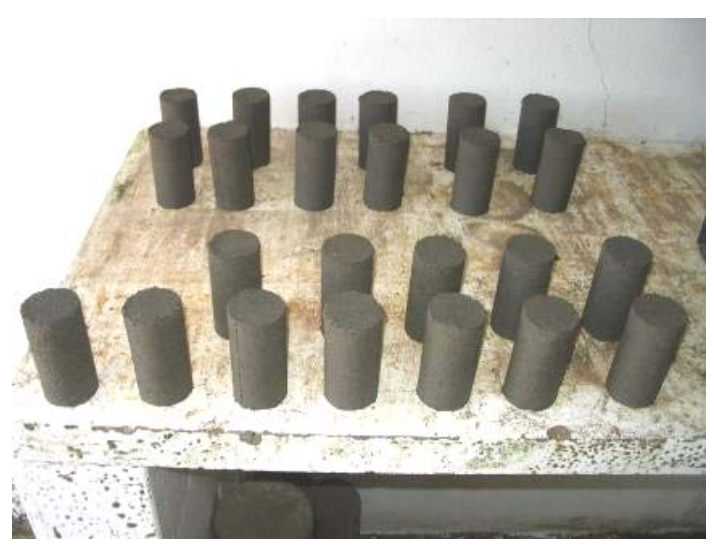

b) cura úmida por sete dias

Figura 6.3 - Moldagem dos corpos-de-prova e manutenção na cura úmida por sete dias.

As principais propriedades físicas e mecânicas analisadas para os corpos-de-prova cilíndricos estão na Tabela 6.2. Os equipamentos e detalhes da execução dos ensaios empregados para a avaliação das propriedades físicas e mecânicas dos CPs são apresentados no Apêndice G.

Tabela 6.2 - Ensaios referentes ao concreto fresco e endurecido.

\begin{tabular}{cc}
\hline Propriedade & Norma \\
\hline Massa específica fresca e teor de ar & NBR 9833 (1987) \\
\hline Absorção de água, massa específica e índice de vazios & NBR $9778(1987)$ \\
\hline Resistência à compressão axial & NBR $5739(1984)$ \\
\hline Resistência à tração por compressão diametral & NBR 7222 (1983) \\
\hline Módulo de deformação & NBR 8522 (1984) \\
\hline Textura e Aparência & - \\
\hline Coesão da mistura & Frasson Junior (2000)
\end{tabular}

As dosagens utilizadas serão apresentadas em etapas, conjuntamente com seus resultados e respectivas análises. Na Tabela 6.3, são expostas as principais características do traço 1:18 e suas diferentes composições (20\%, 30\%, 40\% e 50\% de pedrisco) empregadas para averiguar os resultados do Método do Menor Volume de Vazios. Todos os materiais empregados, nessa primeira etapa, tiveram suas propriedades físicas analisadas e os resultados encontram-se no Capítulo 5. 
Tabela 6.3 - Composições de materiais para o traço 1:18.

\begin{tabular}{|c|c|c|c|c|c|c|c|c|c|}
\hline \multirow{2}{*}{\multicolumn{2}{|c|}{ Traço 1:18 }} & \multicolumn{8}{|c|}{ Designação das dosagens } \\
\hline & & 1a & $1 \mathrm{~b}$ & $2 a$ & $2 \mathbf{b}$ & $3 a$ & $3 \mathbf{b}$ & $4 a$ & $4 b$ \\
\hline \multicolumn{2}{|c|}{ Energia de adensamento (golpes) } & 30 & 20 & 30 & 20 & 30 & 20 & 30 & 20 \\
\hline \multirow{5}{*}{$\begin{array}{c}\text { Consumo } \\
\text { de } \\
\text { materiais } \\
\left(\mathrm{kg} / \mathrm{m}^{3}\right)\end{array}$} & Cimento & 126,9 & 126,9 & 126,6 & 126,6 & 126,3 & 126,3 & 126,0 & 126,0 \\
\hline & Pedrisco & 457,0 & 457,0 & 683,8 & 683,8 & 909,3 & 909,3 & 1133,8 & 1133,8 \\
\hline & Pó de pedra & 1371,0 & 1371,0 & 1139,6 & 1139,6 & 909,3 & 909,3 & 680,3 & 680,3 \\
\hline & Areia & 457,0 & 457,0 & 455,8 & 455,8 & 454,7 & 454,7 & 453,5 & 453,5 \\
\hline & Água & 144,7 & 144,7 & 144,3 & 144,3 & 144,0 & 144,0 & 143,6 & 143,6 \\
\hline \multicolumn{2}{|c|}{$\%$ pedrisco } & 20 & 20 & 30 & 30 & 40 & 40 & 50 & 50 \\
\hline \multicolumn{2}{|c|}{$\%$ areia Itap. } & 20 & 20 & 20 & 20 & 20 & 20 & 20 & 20 \\
\hline \multicolumn{2}{|c|}{ \% pó de pedra } & 60 & 60 & 50 & 50 & 40 & 40 & 30 & 30 \\
\hline \multicolumn{2}{|c|}{ Umidade (\%) } & 6,0 & 6,0 & 6,0 & 6,0 & 6,0 & 6,0 & 6,0 & 6,0 \\
\hline \multicolumn{2}{|c|}{ Aditivo, em relação à massa de cimento (\%) } & 0,35 & 0,35 & 0,35 & 0,35 & 0,35 & 0,35 & 0,35 & 0,35 \\
\hline \multicolumn{2}{|c|}{ Teor de argamassa (\%) } & 81,1 & 81,1 & 71,6 & 71,6 & 62,1 & 62,1 & 52,6 & 52,6 \\
\hline \multicolumn{2}{|c|}{ Módulo de finura da mistura } & 3,14 & 3,14 & 3,43 & 3,43 & 3,72 & 3,72 & 4,01 & 4,01 \\
\hline \multicolumn{2}{|c|}{ Material grosso - retido peneiras $(4,8$ e $2,4 \mathrm{~mm})$} & $32 \%$ & $32 \%$ & $40 \%$ & $40 \%$ & $48 \%$ & $48 \%$ & $56 \%$ & $56 \%$ \\
\hline \multicolumn{2}{|c|}{ Material médio - retido peneiras $(1,2,0,6$ e $0,3 \mathrm{~mm})$} & $45 \%$ & $45 \%$ & $40 \%$ & $40 \%$ & $35 \%$ & $35 \%$ & $31 \%$ & $31 \%$ \\
\hline \multicolumn{2}{|c|}{ Material fino - retido peneiras $(0,15 \mathrm{~mm}$ e fundo $)$} & $23 \%$ & $23 \%$ & $20 \%$ & $20 \%$ & $17 \%$ & $17 \%$ & $14 \%$ & $14 \%$ \\
\hline
\end{tabular}

Conforme a Tabela 6.3, nota-se que a umidade para todos os traços foi fixada em $6,0 \%$, em relação a quantidade total de materiais secos; a porcentagem de aditivo, foi mantida constante e igual a 0,35\%, segundo recomendações do fabricante, e a energia de adensamento foi de 30 golpes e 20 golpes para quatro camadas de adensamento.

Analisando-se a Tabela 6.3 , nota-se que para os traços $1 \mathrm{a}$ e $1 \mathrm{~b}$, com $20 \%$ de pedrisco e $60 \%$ de pó de pedra, o módulo de finura final da mistura $(3,04)$ e a grande quantidade de finos (23\%) poderiam indicá-los como sendo apropriados para a produção de blocos de vedação, que usualmente possuem uma textura mais fechada. Para os traços $2 a$, 2b, 3a e 3b, o módulo de finura final da mistura $(3,43$ e 3,73$)$ e a quantidade média de finos (20\% e 17\%) poderiam classificá-los como sendo adequados para a produção de blocos de concreto estruturais (textura aberta). Frasson Junior (2000), citando algumas recomendações da fabricante de vibro-prensas "Besser Company", recomenda que para a produção de blocos de concreto, a porcentagem de materiais graúdos represente $40 \%$ do total, a porcentagem de materiais médios seja igual a $45 \%$ e a porcentagem de finos igual a 15\%. No entanto, apenas os resultados das propriedades físicas e mecânicas conjuntamente com a avaliação da textura dos exemplares poderão validar as afirmações feitas. Os resultados para as propriedades físicas do referido traço são apresentados na Tabela 6.4. 
Tabela 6.4 - Resultados das propriedades físicas para o traço 1:18.

\begin{tabular}{|c|c|c|c|c|c|c|c|c|c|}
\hline \multirow{2}{*}{ Traço 1:18 } & \multirow{2}{*}{ Param. } & \multicolumn{8}{|c|}{ Designação das dosagens } \\
\hline & & $1 \mathbf{a}$ & $2 a$ & $3 a$ & $4 a$ & $1 b$ & 2b & $3 \mathbf{b}$ & $4 b$ \\
\hline Energia de adensamento (golpes) & & 30 & 30 & 30 & 30 & 20 & 20 & 20 & 20 \\
\hline Temperatura $\left({ }^{\circ} \mathrm{C}\right)$ & & - & - & - & - & 26 & 23 & 24 & 24 \\
\hline Umidade (\%) & & - & - & - & - & 64 & 68 & 67 & 69 \\
\hline \multirow{3}{*}{ Massa específica fresca $\left(\mathrm{kg} / \mathrm{dm}^{3}\right)$} & Média & 2,351 & 2,405 & 2,416 & 2,424 & 2,312 & 2,380 & 2,400 & 2,409 \\
\hline & $\mathrm{S}_{\mathrm{d}}$ & 0,038 & 0,026 & 0,025 & 0,024 & 0,018 & 0,016 & 0,018 & 0,017 \\
\hline & C.V & $1,62 \%$ & $1,06 \%$ & $1,04 \%$ & $0,98 \%$ & $0,78 \%$ & $0,68 \%$ & $0,74 \%$ & $0,71 \%$ \\
\hline \multirow{3}{*}{ Consumo real de cimento $\left(\mathrm{kg} / \mathrm{m}^{3}\right)$} & Média & 116,7 & 119,4 & 120,0 & 120,4 & 114,8 & 118,2 & 119,2 & 119,6 \\
\hline & $\mathrm{S}_{\mathrm{d}}$ & 1,89 & 1,27 & 1,18 & 1,18 & 0,90 & 0,80 & 0,88 & 0,86 \\
\hline & C.V & $1,62 \%$ & $1,06 \%$ & $0,98 \%$ & 0,98 & $0,78 \%$ & $0,68 \%$ & $0,74 \%$ & $0,71 \%$ \\
\hline \multirow{3}{*}{ Teor de ar incorporado (\%) } & Média & 8,05 & 5,70 & 5,02 & 4,45 & 9,56 & 6,68 & 5,64 & 5,04 \\
\hline & $\mathrm{S}_{\mathrm{d}}$ & 1,49 & 1,00 & 0,93 & 0,93 & 0,71 & 0,63 & 0,70 & 0,68 \\
\hline & C.V & $18,48 \%$ & $17,58 \%$ & $18,54 \%$ & $20,94 \%$ & $7,39 \%$ & $9,45 \%$ & $12,35 \%$ & $13,45 \%$ \\
\hline \multirow{3}{*}{ Massa específica seca $\left(\mathrm{kg} / \mathrm{dm}^{3}\right)$} & Média & 2,263 & 2,305 & 2,312 & 2,306 & 2,224 & 2,283 & 2,293 & 2,306 \\
\hline & $\mathrm{S}_{\mathrm{d}}$ & 0,023 & 0,023 & 0,024 & 0,028 & 0,014 & 0,008 & 0,012 & 0,008 \\
\hline & C.V & $1,03 \%$ & $0,99 \%$ & $1,07 \%$ & $1,22 \%$ & $0,63 \%$ & $0,37 \%$ & $0,50 \%$ & $0,34 \%$ \\
\hline \multirow{3}{*}{$\begin{array}{l}\text { Massa específica saturada } \\
\text { superfície seca }\left(\mathrm{kg} / \mathrm{dm}^{3}\right)\end{array}$} & Média & 2,395 & 2,430 & 2,442 & 2,438 & 2,373 & 2,417 & 2,429 & 2,437 \\
\hline & $\mathrm{S}_{\mathrm{d}}$ & 0,022 & 0,018 & 0,021 & 0,023 & 0,013 & 0,005 & 0,011 & 0,005 \\
\hline & C.V & $0,93 \%$ & $0,76 \%$ & $0,85 \%$ & $0,96 \%$ & 0,53 & $0,20 \%$ & $0,45 \%$ & $0,21 \%$ \\
\hline \multirow{3}{*}{ Absorção de água (\%) } & Média & 5,84 & 5,40 & 5,66 & 5,72 & 6,70 & 5,86 & 5,91 & 5,68 \\
\hline & $\mathrm{S}_{\mathrm{d}}$ & 0,11 & 0,25 & 0,23 & 0,27 & 0,12 & 0,18 & 0,06 & 0,16 \\
\hline & C.V & $1,90 \%$ & $4,62 \%$ & $4,01 \%$ & $4,73 \%$ & $1,75 \%$ & $3,09 \%$ & $0,99 \%$ & $2,75 \%$ \\
\hline \multirow{3}{*}{ Índice de vazios (\%) } & Média & 13,21 & 12,45 & 13,08 & 13,20 & 14,91 & 13,38 & 13,56 & 13,10 \\
\hline & $\mathrm{S}_{\mathrm{d}}$ & 0,12 & 0,45 & 0,38 & 0,46 & 0,18 & 0,36 & 0,07 & 0,32 \\
\hline & C.V & $0,88 \%$ & $3,64 \%$ & $2,93 \%$ & $3,52 \%$ & $1,21 \%$ & $2,72 \%$ & $0,52 \%$ & $2,43 \%$ \\
\hline
\end{tabular}

$\mathbf{1 a}-20 \%$ de pedrisco; $20 \%$ de areia; $60 \%$ de pó de pedra; adensamento = 30 golpes; $\mathbf{1} \mathbf{b}-$ adensamento = 20 golpes

$\mathbf{2 a}-30 \%$ de pedrisco; $20 \%$ de areia; $50 \%$ de pó de pedra; adensamento $=30$ golpes; $\mathbf{2 b}-$ adensamento $=20$ golpes

$3 \mathbf{a}-40 \%$ de pedrisco; $20 \%$ de areia; $40 \%$ de pó de pedra; adensamento $=30$ golpes; $3 \mathbf{b}-$ adensamento $=20$ golpes

$\mathbf{4 a}-50 \%$ de pedrisco; $20 \%$ de areia; $30 \%$ de pó de pedra; adensamento $=30$ golpes; $\mathbf{4 b}-$ adensamento $=20$ golpes

Analisando-se os resultados da Tabela 6.4, observa-se que, para todos os traços, a porcentagem de pedrisco adotada influiu em algumas propriedades físicas. Para verificar a influência de cada uma das composições nessas propriedades, foi empregado o teste "t de Student". Os resultados utilizando-se esse procedimento estatístico são apresentados na Tabela 6.5. 
Tabela 6.5 - Avaliação da influência das composições adotadas para o traço 1:18 nas propriedades físicas dos corpos-de-prova.

\begin{tabular}{|c|c|c|c|c|c|}
\hline Comparações & $\begin{array}{c}\text { Teor de ar } \\
\text { incorporado }\end{array}$ & $\begin{array}{c}\text { Massa específica } \\
\text { seca }\end{array}$ & $\begin{array}{c}\text { Massa } \\
\text { específica } \\
\text { saturada } \\
\text { superfície seca } \\
\end{array}$ & $\begin{array}{c}\text { Absorção de } \\
\text { água }\end{array}$ & Índice de vazios \\
\hline \multirow{2}{*}{$1 a \times 2 a$} & $\operatorname{Sim}^{*} ; 1 a>2 a$ & Sim; $1 \mathrm{a}<2 \mathrm{a}$ & - & Sim; $1 a>2 a$ & Sim; $1 \mathrm{a}>2 \mathrm{2a}$ \\
\hline & $p=1,30 \cdot 10^{-4}$ & $p=0,044$ & $p=0,052$ & $p=0,025$ & $p=0,024$ \\
\hline \multirow{2}{*}{$2 a \times 3 a$} & $-{ }^{* *}$ & - & - & - & - \\
\hline & $p=0,090$ & $p=0,38$ & $p=0,23$ & $p=0,13$ & $p=0,070$ \\
\hline \multirow{2}{*}{$3 a \times 4 a$} & Sim; $3 a>4 a$ & - & - & - & - \\
\hline & $p=0,046$ & $p=0,41$ & $p=0,42$ & $p=0,38$ & $p=0,38$ \\
\hline \multirow{2}{*}{$1 b \times 2 b$} & Sim; 1 b > 2b & Sim; $1 b<2 b$ & Sim; $1 b<2 b$ & Sim; $1 \mathbf{b}>\mathbf{2 b}$ & Sim; $1 b>2 b$ \\
\hline & $p=5,4 \cdot 10^{-8}$ & $p=0,002$ & $p=0,002$ & $p=0,001$ & $p=0,007$ \\
\hline \multirow{2}{*}{$2 b \times 3 b$} & Sim; $2 b>\mathbf{3 b}$ & - & - & - & - \\
\hline & $p=0,004$ & $p=0,14$ & $p=0,076$ & $p=0,32$ & $p=0,24$ \\
\hline \multirow{2}{*}{$3 b \times 4 b$} & Sim; $3 b>4 b$ & - & - & Sim; $3 b>4 b$ & - \\
\hline & $p=0,005$ & $p=0,10$ & $p=0,17$ & $p=0,037$ & $p=0,067$ \\
\hline
\end{tabular}

$\mathbf{1 a}-20 \%$ de pedrisco; $20 \%$ de areia; $60 \%$ de pó de pedra; adensamento = 30 golpes; $1 \mathbf{b}-$ adensamento = 20 golpes

$\mathbf{2 a}-30 \%$ de pedrisco; $20 \%$ de areia; $50 \%$ de pó de pedra; adensamento $=30$ golpes; $\mathbf{2} \mathbf{b}-$ adensamento $=20$ golpes

$3 \mathbf{a}-40 \%$ de pedrisco; $20 \%$ de areia; $40 \%$ de pó de pedra; adensamento $=30$ golpes; $3 \mathbf{b}-$ adensamento $=20$ golpes

$\mathbf{4 a}-50 \%$ de pedrisco; $20 \%$ de areia; $30 \%$ de pó de pedra; adensamento = 30 golpes; $4 \mathbf{b}-$ adensamento $=20$ golpes

* (Sim): influência significativa para um nível de significância de $5 \%(p<0,05)$

** $(-)$ : sem influência significativa $(p>0,05)$

Analisando-se a Tabela 6.5, podem ser estabelecidos os seguintes comentários:

- Com relação ao teor de ar incorporado e propriedades correlatas, tais como, massa específica fresca e consumo real de cimento, foi observada uma influência significativa da composição do traço $(p<0,05)$, independentemente da energia de adensamento; exceção feita para a comparação entre os traços 2a e 3a.

- Pelos resultados do teste estatístico, pode-se afirmar que as propriedades físicas dos corpos-de-prova não foram influenciadas pelos diferentes traços avaliados, com exceção da comparação entre os traços 1 e 2. Para esses dois traços, pode-se dizer que os menores valores médios de massa específica e maiores valores médios de absorção e índice de vazios foram obtidos para o traço 1 (20\% de pedrisco). Pelo método do menor volume de vazios, as composições com $20 \%$ de pedrisco apresentaram as maiores porcentagens de vazios comparativamente às demais.

- As propriedades físicas para as dosagens compostas por 30\%, 40\% e 50\% de pedrisco não diferiram significativamente entre si, conforme o teste estatístico realizado. Esse resultado já era esperado, uma vez que os resultados de volume de vazios para as três composições foram muito próximos. Considerando-se as três 
dosagens, apenas os CPs da composição com 50\% de pedrisco apresentaram uma textura extremamente porosa e áspera, Figura 6.4.
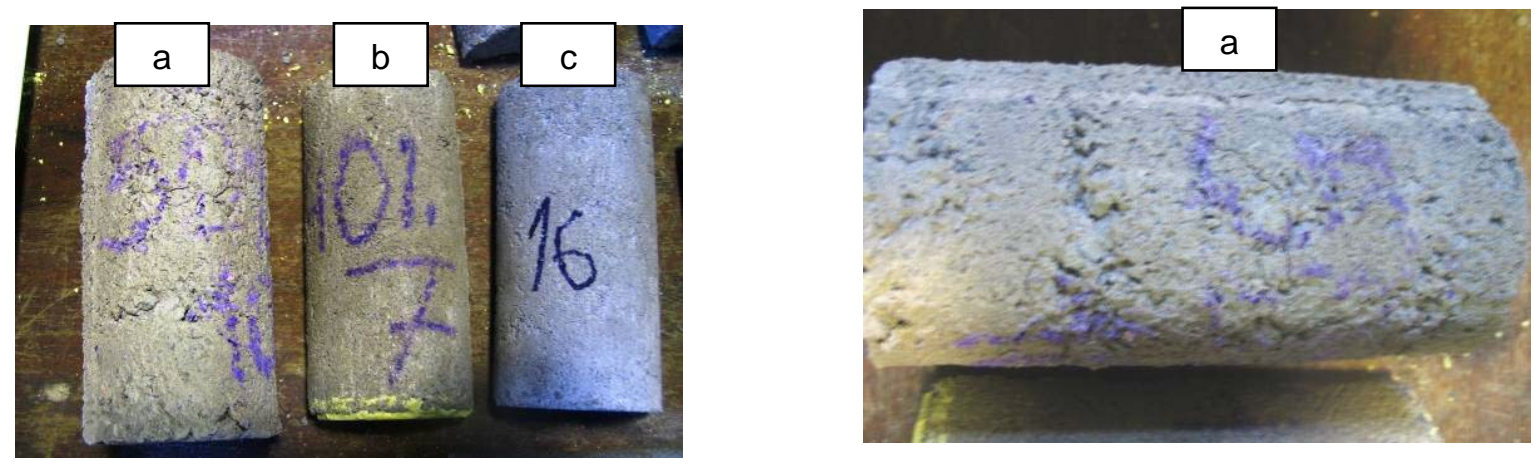

Figura 6.4 - Textura superficial dos CPs de diferentes composições: a) 50\% de pedrisco; b) $40 \%$ de pedrisco; c) $30 \%$ de pedrisco.

Os resultados referentes às propriedades mecânicas dos CPs (sete dias) encontramse na Tabela 6.6.

Tabela 6.6 - Resultados das propriedades mecânicas para o traço 1:18.

\begin{tabular}{|c|c|c|c|c|c|c|c|c|c|}
\hline \multirow{2}{*}{ Traço 1:18 } & \multirow{2}{*}{ Param. } & \multicolumn{8}{|c|}{ Designação das dosagens } \\
\hline & & $1 a$ & $2 a$ & $3 a$ & $4 a$ & 1b & $2 b$ & $3 b$ & $4 b$ \\
\hline Energia de adensamento (golpes) & & 30 & 30 & 30 & 30 & 20 & 20 & 20 & 20 \\
\hline \multirow{3}{*}{ Resistência à compressão (MPa) } & Média & 9,16 & 11,16 & 10,64 & 10,71 & 6,99 & 8,53 & 9,20 & 8,28 \\
\hline & D. P. & 0,66 & 1,37 & 0,60 & 0,81 & 0,55 & 0,64 & 0,56 & 0,30 \\
\hline & C. V. & 7,25 & $12,30 \%$ & $5,66 \%$ & $7,58 \%$ & $7,84 \%$ & $7,51 \%$ & $6,12 \%$ & $3,63 \%$ \\
\hline \multirow{3}{*}{ Resistência tração (MPa) } & Média & 1,23 & 1,32 & 1,14 & 1,12 & 0,96 & 0,98 & 1,06 & 1,11 \\
\hline & D. P. & 0,05 & 0,19 & 0,15 & 0,05 & 0,08 & 0,01 & 0,12 & 0,17 \\
\hline & C. V. & $1,50 \%$ & $14,16 \%$ & $12,96 \%$ & $4,65 \%$ & $8,66 \%$ & $0,92 \%$ & $11,76 \%$ & $15,47 \%$ \\
\hline \multirow{3}{*}{ Módulo de deformação (GPa) } & Média & 12,92 & 14,65 & 14,48 & 12,34 & 10,12 & 10,99 & 13,31 & 11,97 \\
\hline & D. P. & 1,20 & 0,82 & 1,13 & 0,28 & 0,68 & 1,30 & 0,44 & 0,24 \\
\hline & C. V. & $9,32 \%$ & $5,59 \%$ & $7,79 \%$ & $2,23 \%$ & $6,68 \%$ & $11,84 \%$ & $3,31 \%$ & $2,04 \%$ \\
\hline
\end{tabular}

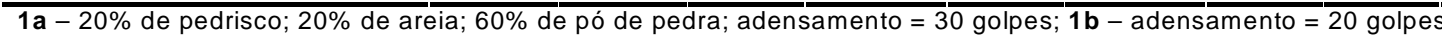

$\mathbf{2 a}-30 \%$ de pedrisco; $20 \%$ de areia; $50 \%$ de pó de pedra; adensamento $=30$ golpes; $\mathbf{2} \mathbf{b}-$ adensamento $=20$ golpes

$3 \mathbf{a}-40 \%$ de pedrisco; $20 \%$ de areia; $40 \%$ de pó de pedra; adensamento $=30$ golpes; $3 \mathbf{b}-$ adensamento $=20$ golpes

$\mathbf{4 a}-50 \%$ de pedrisco; $20 \%$ de areia; $30 \%$ de pó de pedra; adensamento $=30$ golpes; $4 \mathbf{b}-$ adensamento $=20 \mathrm{golpes}$

Pela Tabela 6.6, nota-se que os traços com $20 \%$ de pedrisco (1a e 2 a) obtiveram os menores resultados para as propriedades mecânicas, quando comparado com as demais dosagens. Os resultados do teste estatístico "t de Student" são apresentados na Tabela 6.7. 
Tabela 6.7 - Avaliação da influência das composições adotadas para o traço 1:18 nas propriedades mecânicas dos corpos-de-prova.

\begin{tabular}{|c|c|c|c|}
\hline Comparações & Resistência à compressão & $\begin{array}{l}\text { Resistência à tração por } \\
\text { compressão diametral }\end{array}$ & Módulo de deformação \\
\hline \multirow{2}{*}{$1 a \times 2 a$} & $\operatorname{Sim}^{*} ; 1 a<2 a$ & - & - \\
\hline & $p=0,042$ & $p=0,23$ & $p=0,055$ \\
\hline \multirow{2}{*}{$2 a \times 3 a$} & $-{ }^{* *}$ & - & - \\
\hline & $p=0,29$ & $p=0,13$ & $p=0,42$ \\
\hline \multirow{2}{*}{$3 a \times 4 a$} & - & - & Sim; $3 a>4 a$ \\
\hline & $p=0,15$ & $p=0,43$ & $p=0,017$ \\
\hline \multirow{2}{*}{$1 b \times 2 b$} & $\operatorname{Sim} ; 1 \mathbf{b}<2 b$ & - & - \\
\hline & $p=0,017$ & $p=0,38$ & $p=0,18$ \\
\hline \multirow{2}{*}{$2 b \times 3 b$} & - & - & $\operatorname{Sim} ; 3 b>2 b$ \\
\hline & $p=0,12$ & $p=0,23$ & $p=0,049$ \\
\hline \multirow{2}{*}{$3 b \times 4 b$} & $\operatorname{Sim} ; 3 b>4 b$ & - & $\operatorname{Sim} ; 3 b>4 b$ \\
\hline & $p=0,033$ & $p=0,36$ & $p=0,005$ \\
\hline
\end{tabular}

$\mathbf{1 a}-20 \%$ de pedrisco; $20 \%$ de areia; $60 \%$ de pó de pedra; adensamento = 30 golpes; $\mathbf{1} \mathbf{b}-$ adensamento = 20 golpes

$\mathbf{2 a}-30 \%$ de pedrisco; $20 \%$ de areia; $50 \%$ de pó de pedra; adensamento $=30$ golpes; $\mathbf{2} \mathbf{b}-$ adensamento $=20$ golpes

$3 \mathbf{a}-40 \%$ de pedrisco; $20 \%$ de areia; $40 \%$ de pó de pedra; adensamento $=30$ golpes; $3 \mathbf{b}-$ adensamento $=20$ golpes

$\mathbf{4 a}-50 \%$ de pedrisco; $20 \%$ de areia; $30 \%$ de pó de pedra; adensamento $=30$ golpes; $4 \mathbf{b}-$ adensamento $=20$ golpes

* (Sim): influência significativa para um nível de significância de $5 \%(p<0,05)$

** $(-)$ : sem influência significativa $(p>0,05)$

Analisando-se os resultados da Tabela 6.7 são estabelecidos os seguintes comentários:

- Com relação à propriedade de resistência à compressão, pode-se afirmar que os CPs do traço com $20 \%$ de pedrisco apresentaram os menores valores médios de resistência comparativamente à composição com 30\% de pedrisco. Possivelmente, o maior volume de vazios da composição com $20 \%$ de pedrisco $(27,41 \%)$, comparativamente à dosagem com $30 \%$ de pedrisco, contribuiu para esse resultado. Por outro lado, não foram notadas diferenças significativas nos resultados de resistência à compressão para as composições com 30\%, 40\% e 50\% de pedrisco, com exceção das dosagens $3 b$ (40\% de pedrisco) e 4b (50\%).

- Para a propriedade de resistência à tração, independentemente da composição de cada dosagem, pode-se dizer que todos os resultados foram semelhantes. Provavelmente, o elevado coeficiente de variação dessa propriedade contribuiu para esses resultados.

- Com relação ao módulo de deformação, pode-se afirmar que os maiores valores médios para essa propriedade foram obtidos para as composições com $40 \%$ de pedrisco. As composições $2 \mathrm{~b}$ ( $30 \%$ de pedrisco) e $4 \mathrm{~b}$ ( $50 \%$ de pedrisco) 
apresentaram uma redução de $18 \%$ e 10\%, respectivamente em relação ao módulo de deformação da composição 3b (40\% de pedrisco).

De certa maneira, os valores obtidos para as propriedades físicas e mecânicas dos corpos-de-prova corroboram os resultados obtidos pelo Método do Menor Volume de Vazios. As composições com 30\% de pedrisco e $40 \%$ de pedrisco obtiveram os resultados mais favoráveis para as propriedades físicas e mecânicas, sendo essas as mesmas composições que obtiveram os menores valores de volume de vazios $(26,70 \%$ e $26,16 \%$, respectivamente).

$\mathrm{Na}$ Tabela 6.8, são apresentadas as características de quatro traços produzidos sob uma energia de adensamento de 20 golpes. Um desses traços foi fabricado para verificar a influência da substituição total da areia por pó de pedra e o outro para averiguar a influência da adição de maior porcentagem de areia na mistura, ambos foram comparados com traços denominados de referência já avaliados na Tabela 6.3. Conforme recomendações de Frasson Junior (2000) foi utilizado um ensaio para medir a coesão da mistura e sua resistência à desagregação, Figura 6.5. De acordo com o pesquisador, valores de coesão superiores a 6,0 kg significam que as misturas são apropriadas para a produção de blocos de concreto.

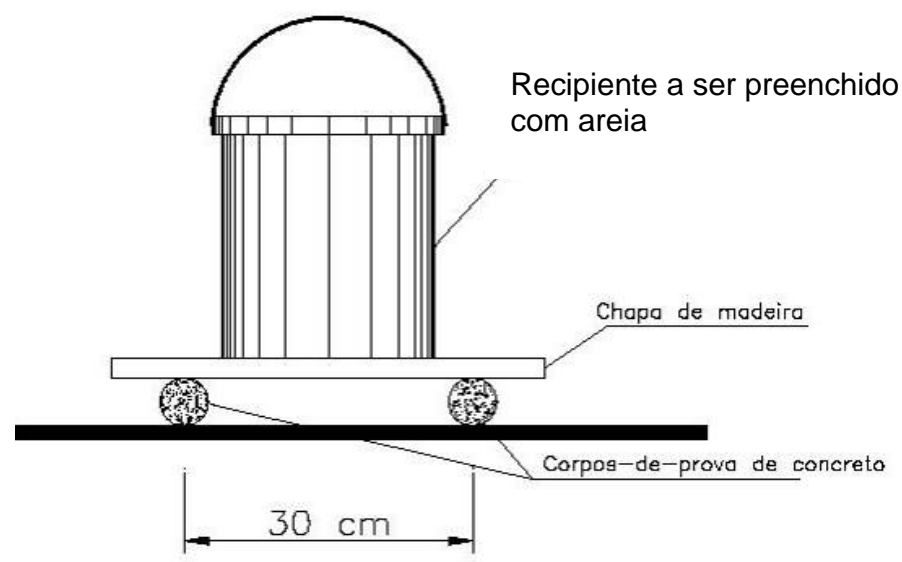

Figura 6.5 - Equipamento utilizado para a determinação da coesão das misturas (FRASSON JUNIOR, 2000) 
Tabela 6.8 - Traços avaliados para verificar a influência de algumas substituições na mistura.

\begin{tabular}{|c|c|c|c|c|c|}
\hline \multirow{2}{*}{\multicolumn{2}{|c|}{ Traço 1:18 }} & \multicolumn{4}{|c|}{ Dosagens } \\
\hline & & 2b (Ref) & 5 & 3b (Ref) & 6 \\
\hline \multicolumn{2}{|c|}{ Energia de adensamento (golpes) } & 20 & 20 & 20 & 20 \\
\hline \multirow{5}{*}{$\begin{array}{c}\text { Consumo } \\
\text { de } \\
\text { materiais } \\
\left(\mathrm{kg} / \mathrm{m}^{3}\right)\end{array}$} & Cimento & 126,6 & 128,6 & 126,3 & 125,3 \\
\hline & Pedrisco & 683,8 & 694,4 & 909,3 & 902,5 \\
\hline & Pó de pedra & 1139,6 & 1620,2 & 909,3 & 676,8 \\
\hline & Areia & 455,8 & - & 454,7 & 676,8 \\
\hline & Água & 144,7 & 146,6 & 144,0 & 142,9 \\
\hline \multicolumn{2}{|c|}{$\%$ pedrisco } & 30 & 30 & 40 & 40 \\
\hline \multicolumn{2}{|c|}{$\%$ areia Itap. } & 20 & - & 20 & 30 \\
\hline \multicolumn{2}{|c|}{ \% pó de pedra } & 50 & 70 & 40 & 30 \\
\hline \multicolumn{2}{|c|}{ Umidade (\%) } & 6,0 & 6,0 & 6,0 & 6,0 \\
\hline \multicolumn{2}{|c|}{ Aditivo, em relação à massa de cimento (\%) } & 0,35 & 0,35 & 0,35 & 0,35 \\
\hline \multicolumn{2}{|c|}{ Teor de argamassa (\%) } & 71,6 & 71,6 & 62,1 & 62,1 \\
\hline \multicolumn{2}{|c|}{ Módulo de finura da mistura } & 3,43 & 3,58 & 3,72 & 3,65 \\
\hline \multicolumn{2}{|c|}{ Material grosso - retido peneiras $(4,8$ e $2,4 \mathrm{~mm})$} & $40 \%$ & $44 \%$ & $48 \%$ & $46 \%$ \\
\hline \multicolumn{2}{|c|}{ Material médio - retido peneiras $(1,2,0,6$ e $0,3 \mathrm{~mm})$} & $40 \%$ & $35 \%$ & $35 \%$ & $38 \%$ \\
\hline \multicolumn{2}{|c|}{ Material fino - retido peneiras $(0,15 \mathrm{~mm}$ e fundo $)$} & $20 \%$ & $21 \%$ & $17 \%$ & $16 \%$ \\
\hline
\end{tabular}

A substituição total da areia pelo pó de pedra (traço 5) elevou o módulo de finura da mistura devido à granulometria mais graúda do material, quando comparado com o traço $2 \mathrm{~b}$ (20\% de areia). Frasson Junior (2000) recomenda que para a produção de blocos de concreto, a porcentagem de materiais graúdos represente $40 \%$ do total; o traço com substituição da areia pelo pó de pedra (5) apresentou uma porcentagem de materiais graúdos igual a $44 \%$ e o traço $2 \mathrm{~b}$ uma porcentagem igual a $40 \%$. O traço 6 , quando comparado ao traço $3 \mathrm{~b}$, apresentou uma redução no módulo de finura provocado pela presença de maior porcentagem de areia na mistura. Os resultados para as propriedades físicas e mecânicas são apresentados na Tabela 6.9 . 
Tabela 6.9 - Propriedades físicas e mecânicas para os traços 2b x 5 e 3b x 6 .

\begin{tabular}{|c|c|c|c|c|c|}
\hline \multirow{2}{*}{ Traço 1:18 } & \multirow{2}{*}{ Parâmetros } & \multicolumn{4}{|c|}{ Dosagens } \\
\hline & & $2 \mathbf{b}$ & 5 & $3 \mathbf{b}$ & 6 \\
\hline Energia de adensamento (golpes) & & 20 & 20 & 20 & 20 \\
\hline Temperatura $\left({ }^{\circ} \mathrm{C}\right)$ & & 23 & 23 & 24 & 23 \\
\hline Umidade (\%) & & 68 & 65 & 67 & 67 \\
\hline \multirow{3}{*}{ Coesão (g) } & Média & 7929 & 15361 & 9529 & 6985 \\
\hline & D. P. & 846 & - & 1313 & 1276 \\
\hline & C. V. & $12,05 \%$ & - & $15,24 \%$ & $21,01 \%$ \\
\hline \multirow{3}{*}{ Massa específica fresca $\left(\mathrm{kg} / \mathrm{dm}^{3}\right)$} & Média & 2,380 & 2,331 & 2,400 & 2,379 \\
\hline & D. P. & 0,016 & 0,021 & 0,018 & 0,022 \\
\hline & C. V. & $0,68 \%$ & $0,89 \%$ & $0,74 \%$ & $0,93 \%$ \\
\hline \multirow{3}{*}{ Consumo real de cimento $\left(\mathrm{kg} / \mathrm{m}^{3}\right)$} & Média & 118,2 & 115,7 & 119,2 & 118,1 \\
\hline & D. P. & 0,80 & 1,03 & 0,88 & 1,10 \\
\hline & C. V. & $0,68 \%$ & $0,89 \%$ & $0,74 \%$ & $0,93 \%$ \\
\hline \multirow{3}{*}{ Teor de ar incorporado (\%) } & Média & 6,68 & 9,99 & 5,64 & 5,99 \\
\hline & D. P. & 0,63 & 0,80 & 0,70 & 0,87 \\
\hline & C. V. & $9,45 \%$ & 7,99 & $12,35 \%$ & $14,54 \%$ \\
\hline \multirow{3}{*}{ Massa específica seca $\left(\mathrm{kg} / \mathrm{dm}^{3}\right)$} & Média & 2,283 & 2,209 & 2,293 & 2,272 \\
\hline & D. P. & 0,008 & 0,015 & 0,012 & 0,020 \\
\hline & C. V. & $0,37 \%$ & $0,66 \%$ & $0,50 \%$ & $0,86 \%$ \\
\hline \multirow{3}{*}{$\begin{array}{l}\text { Massa específica saturada superfície } \\
\text { seca }\left(\mathrm{kg} / \mathrm{dm}^{3}\right)\end{array}$} & Média & 2,417 & 2,390 & 2,429 & 2,403 \\
\hline & D. P. & 0,005 & 0,009 & 0,011 & 0,018 \\
\hline & C. V. & $0,20 \%$ & $0,39 \%$ & $0,45 \%$ & $0,73 \%$ \\
\hline \multirow{3}{*}{ Absorção de água (\%) } & Média & 5,86 & 8,16 & 5,91 & 5,76 \\
\hline & D. P. & 0,18 & 0,31 & 0,06 & 0,14 \\
\hline & C. V. & $3,09 \%$ & $3,75 \%$ & $0,99 \%$ & $2,44 \%$ \\
\hline \multirow{3}{*}{ Índice de vazios (\%) } & Média & 13,38 & 18,02 & 13,56 & 13,09 \\
\hline & D. P. & 0,36 & 0,56 & 0,07 & 0,21 \\
\hline & C. V. & $2,72 \%$ & $3,09 \%$ & $0,52 \%$ & $1,60 \%$ \\
\hline \multirow{3}{*}{ Resistência à compressão (MPa) } & Média & 8,53 & 8,44 & 9,20 & 8,96 \\
\hline & D. P. & 0,64 & 0,15 & 0,56 & 0,28 \\
\hline & C. V. & $7,51 \%$ & $1,74 \%$ & $6,12 \%$ & 3,16 \\
\hline \multirow{3}{*}{ Resistência à tração (MPa) } & Média & 0,98 & 0,94 & 1,06 & 1,10 \\
\hline & D. P. & 0,01 & 0,08 & 0,12 & 0,04 \\
\hline & C. V. & $0,92 \%$ & $8,22 \%$ & $11,76 \%$ & 3,86 \\
\hline \multirow{3}{*}{ Módulo de Deformação (GPa) } & Média & 10,99 & 10,62 & 13,31 & 14,53 \\
\hline & D. P. & 1,30 & 0,38 & 0,44 & 0,56 \\
\hline & C. V. & $11,84 \%$ & $3,57 \%$ & $3,31 \%$ & 3,85 \\
\hline
\end{tabular}

Analisando-se os resultados da Tabela 6.9, são feitas as seguintes considerações com relação aos traços 2 b ( $50 \%$ de pó de pedra) e 5 ( $70 \%$ de pó de pedra): a) a substituição de areia pelo pó de pedra elevou consideravelmente a coesão da mistura (aumento de 100\%); b) o aumento da porcentagem de pó de pedra não afetou significativamente as propriedades mecânicas do concreto; c) as propriedades físicas, tais como, absorção de água e índice de vazios, foram afetadas pela maior porcentagem de pó de pedra na mistura (traço 5), apresentando um aumento de aproximadamente $40 \%$ e $35 \%$ nos valores dessas propriedades, quando comparados com os valores obtidos para o traço $2 \mathrm{~b}$, respectivamente.

Com relação ao traço 3b (20\% de areia), o traço 6 (30\% de areia) apresentou uma redução de $30 \%$ na coesão da mistura e diminuição de aproximadamente três porcento na absorção de água e índice de vazios. Para verificar a influência de cada dosagem nas propriedades físicas e mecânicas dos CPs foi empregado o teste "t de Student". Os resultados estão na Tabela 6.10 . 
Tabela 6.10 - Teste "t de Student" para verificar a influência da porcentagem de pó de pedra e areia nas propriedades físicas e mecânicas.

\begin{tabular}{|c|c|c|c|c|c|c|c|}
\hline Comparações & $\begin{array}{l}\text { Teor de ar } \\
\text { incorporado }\end{array}$ & $\begin{array}{c}\text { Massa } \\
\text { específica } \\
\text { seca }\end{array}$ & $\begin{array}{l}\text { Absorção } \\
\text { de água }\end{array}$ & $\begin{array}{l}\text { Índice de } \\
\text { vazios }\end{array}$ & $\begin{array}{c}\text { Resistência } \\
\text { à } \\
\text { compressão }\end{array}$ & $\begin{array}{l}\text { Resistência } \\
\text { à tração }\end{array}$ & $\begin{array}{l}\text { Módulo de } \\
\text { deformação }\end{array}$ \\
\hline \multirow{2}{*}{$5 \times 2 b$} & $\operatorname{Sim}^{*} ; 5>2 b$ & Sim; $5<2 b$ & Sim; $5>2 b$ & $\operatorname{Sim} ; 5>2 b$ & - & - & - \\
\hline & $p=5,2 * 10^{-10}$ & $p=8,10 * 10^{-4}$ & $p=1,80 * 10^{-4}$ & $p=1,30 * 10^{-4}$ & $p=0,41$ & $p=0,28$ & $p=0,33$ \\
\hline \multirow{2}{*}{$6 \times 3 b$} & $-{ }^{* *}$ & - & - & Sim; $6<3 b$ & - & - & Sim; $6>3 b$ \\
\hline & $p=0,12$ & $p=0,088$ & $p=0,078$ & $p=0,010$ & $p=0,27$ & $p=0,31$ & $p=0,021$ \\
\hline
\end{tabular}

$\mathbf{2 b}-30 \%$ de pedrisco; $20 \%$ de areia; $50 \%$ de pó de pedra; adensamento = 20 golpes

5 - 30\% de pedrisco; $70 \%$ de pó de pedra; adensamento $=20$ golpes

3b $-40 \%$ de pedrisco; $20 \%$ de areia; $40 \%$ de pó de pedra; adensamento $=20$ golpes

6 - $40 \%$ de pedrisco; $30 \%$ de areia; $30 \%$ de pó de pedra; adensamento $=20$ golpes

* (Sim): influência significativa para um nível de significância de $5 \%(p<0,05)$

** (-): sem influência significativa $(p>0,05)$

Analisando-se os resultados da Tabela 6.10, são feitos os seguintes comentários:

- Com relação à comparação entre os traços 5 (70\% de pó de pedra) e $2 b$ ( $50 \%$ de pó de pedra), foi observado para o traço 5 um aumento significativo das propriedades de absorção de água e índice de vazios (cerca de 40\%) e uma redução significativa na massa específica (4\%). Por outro lado, as duas dosagens apresentaram valores semelhantes para as propriedades mecânicas.

- Para a comparação entre os traços 6 (30\% de areia) e 3b (20\% de areia), apenas as propriedades de índice de vazios (redução de 3,5\%) e módulo de deformação (aumento de 9,2\%) foram afetadas significativamente pela presença de maior porcentagem de areia na mistura (traço 6).

Esses resultados servirão de parâmetro para a terceira etapa da pesquisa. Em razão da maior absorção dos agregados reciclados, as composições serão constituídas por uma menor porcentagem de pó de pedra (40\%) e, consequentemente, maior porcentagem de areia (30\%). Conforme os resultados apresentados nas Tabelas 6.9 e 6.10, elevadas taxas de pó de pedra na mistura acarretam um aumento da absorção de água e índice de vazios.

As próximas análises são realizadas para avaliar a influência da energia de adensamento (20, 15 e 10 golpes para quatro camadas) nas propriedades físicas e mecânicas dos corpos-de-prova. Na Tabela 6.11, encontram-se as características do traço adotado para a verificação da influência da energia de adensamento nas propriedades dos corpos-de-prova. 
Tabela 6.11 - Características dos traços produzidos para avaliar a influência da energia de adensamento.

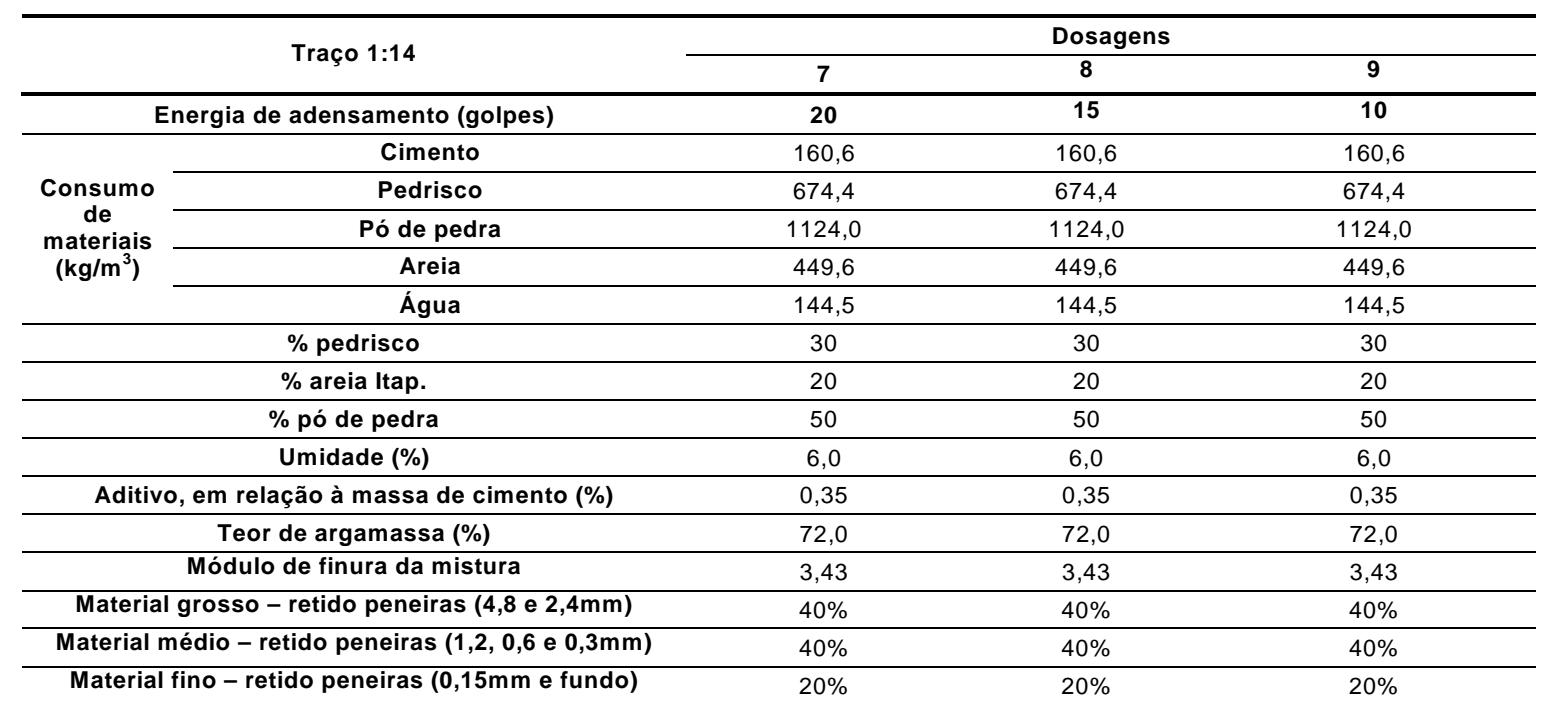

Os resultados das propriedades físicas e mecânicas são encontrados na Tabela 6.12 .

Tabela 6.12 - Propriedades físicas e mecânicas dos traços produzidos para avaliar a influência da energia de adensamento.

\begin{tabular}{|c|c|c|c|c|}
\hline \multirow{2}{*}{ Traço 1:14 } & \multirow{2}{*}{ Parâmetros } & \multicolumn{3}{|c|}{ Dosagens } \\
\hline & & 7 & 8 & 9 \\
\hline Energia de adensamento (golpes) & & 20 & 15 & 10 \\
\hline Temperatura $\left({ }^{\circ} \mathrm{C}\right)$ & & 24 & 24 & 24 \\
\hline Umidade (\%) & & 79 & 79 & 79 \\
\hline \multirow{3}{*}{ Coesão (g) } & Média & 8227 & 9377 & 5771 \\
\hline & D. P. & - & - & - \\
\hline & C. V. & - & - & - \\
\hline \multirow{3}{*}{ Massa específica fresca $\left(\mathrm{kg} / \mathrm{dm}^{3}\right)$} & Média & 2,404 & 2,373 & 2,322 \\
\hline & D. P. & 0,016 & 0,021 & 0,021 \\
\hline & C. V. & $0,68 \%$ & $0,90 \%$ & 0,90 \\
\hline \multirow{3}{*}{ Consumo real de cimento $\left(\mathrm{kg} / \mathrm{m}^{3}\right)$} & Média & 151,2 & 149,3 & 146,1 \\
\hline & D. P. & 1,02 & 1,34 & 1,30 \\
\hline & C. V. & $0,68 \%$ & $0,90 \%$ & $0,90 \%$ \\
\hline \multirow{3}{*}{ Teor de ar incorporado (\%) } & Média & 5,83 & 7,04 & 9,03 \\
\hline & D. P. & 0,64 & 0,84 & 0,81 \\
\hline & C. V. & $10,90 \%$ & $11,86 \%$ & $8,95 \%$ \\
\hline \multirow{3}{*}{ Massa específica seca $\left(\mathrm{kg} / \mathrm{dm}^{3}\right)$} & Média & 2,302 & 2,286 & 2,242 \\
\hline & D. P. & 0,014 & 0,0005 & 0,023 \\
\hline & C. V. & $0,62 \%$ & $0,02 \%$ & $1,04 \%$ \\
\hline \multirow{3}{*}{ Massa específica saturada superfície seca $\left(\mathrm{kg} / \mathrm{dm}^{3}\right)$} & Média & 2,440 & 2,428 & 2,392 \\
\hline & D. P. & 0,012 & 0,004 & 0,016 \\
\hline & C. V. & $0,50 \%$ & $0,14 \%$ & $0,68 \%$ \\
\hline \multirow{3}{*}{ Absorção de água (\%) } & Média & 5,98 & 6,17 & 6,69 \\
\hline & D. P. & 0,13 & 0,13 & 0,45 \\
\hline & C. V. & $2,21 \%$ & $2,16 \%$ & $6,66 \%$ \\
\hline \multirow{3}{*}{ Índice de vazios (\%) } & Média & 13,77 & 14,11 & 15,00 \\
\hline & D. P. & 0,22 & 0,31 & 0,86 \\
\hline & C. V. & $1,60 \%$ & $2,17 \%$ & $5,72 \%$ \\
\hline \multirow{3}{*}{ Resistência à compressão (MPa) } & Média & 12,09 & 11,50 & 9,34 \\
\hline & D. P. & 2,47 & 0,78 & 1,25 \\
\hline & C. $v$. & $20,44 \%$ & $6,80 \%$ & $13,41 \%$ \\
\hline \multirow{3}{*}{ Resistência à tração (MPa) } & Média & 1,65 & 1,52 & 1,33 \\
\hline & D. P. & 0,11 & 0,08 & 0,02 \\
\hline & C. V. & $6,36 \%$ & $5,11 \%$ & $1,47 \%$ \\
\hline \multirow{3}{*}{ Módulo de Deformação (GPa) } & Média & 20,24 & 15,38 & 12,89 \\
\hline & D. P. & 3,48 & 1,13 & 0,09 \\
\hline & C. V. & $17,20 \%$ & $7,32 \%$ & $0,74 \%$ \\
\hline
\end{tabular}


Analisando-se os resultados da Tabela 6.12, observa-se a princípio que a energia de adensamento afetou significativamente as propriedades físicas e mecânicas dos CPs. A aplicação dos testes "t de Student" e Análise de variância permitem uma análise rigorosa a respeito da influência da energia de adensamento sobre as propriedades estudadas, Tabela 6.13.

Tabela 6.13 - Teste ANOVA e "t de student" para verificar a influência da energia de adensamento nas propriedades físicas e mecânicas dos CPs.

\begin{tabular}{|c|c|c|c|c|c|c|c|c|}
\hline Comparações & $\begin{array}{c}\text { Teste } \\
\text { estatístico }\end{array}$ & $\begin{array}{l}\text { Teor de ar } \\
\text { incorporado }\end{array}$ & $\begin{array}{c}\text { Massa } \\
\text { específica } \\
\text { seca }\end{array}$ & $\begin{array}{l}\text { Absorção } \\
\text { de água }\end{array}$ & $\begin{array}{l}\text { Índice de } \\
\text { vazios }\end{array}$ & $\begin{array}{l}\text { Resistência à } \\
\text { compressão }\end{array}$ & $\begin{array}{l}\text { Resistência } \\
\text { à tração }\end{array}$ & $\begin{array}{l}\text { Módulo de } \\
\text { deformação }\end{array}$ \\
\hline \multirow{2}{*}{$7 \times 8 \times 9$} & \multirow{2}{*}{ ANOVA } & $\operatorname{Sim}^{*}$ & $-^{* *}$ & - & - & - & Sim & - \\
\hline & & $\left(22,69^{\text {k*k}}\right)$ & $(6,47)$ & $(2,89)$ & $(2,30)$ & $(1,27)$ & $(7,57)$ & $(3,85)$ \\
\hline \multirow{2}{*}{$7 \times 8$} & \multirow{2}{*}{$\begin{array}{c}\text { t de } \\
\text { Student }\end{array}$} & $\operatorname{Sim} ; 7<8$ & - & - & - & - & - & $\operatorname{Sim} ; 7>8$ \\
\hline & & $p=2,82^{*} 10^{-3}$ & $p=0,10$ & $p=0,080$ & $p=0,099$ & $p=0,36$ & $p=0,075$ & $p=0,048$ \\
\hline \multirow{2}{*}{$8 \times 9$} & \multirow{2}{*}{$\begin{array}{c}\text { t de } \\
\text { Student }\end{array}$} & Sim; $8<9$ & Sim; $8>9$ & - & - & Sim; $8>9$ & Sim; $8>9$ & $\operatorname{Sim} ; 8>9$ \\
\hline & & $p=1,30 * 10^{-4}$ & $p=0,040$ & $p=0,061$ & $p=0,082$ & $p=2,82 * 10^{-3}$ & $p=7,45^{\star} 10^{-3}$ & $p=0,030$ \\
\hline \multicolumn{9}{|c|}{ 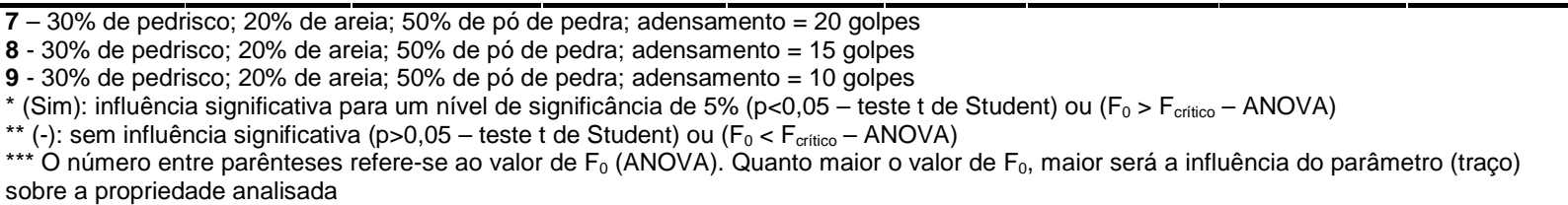 } \\
\hline
\end{tabular}

Analisando-se os resultados da Tabela 6.13 são elaborados os seguintes comentários:

- Pelo teste ANOVA, pode-se afirmar que, independentemente da energia de adensamento adotada, os valores das propriedades físicas e mecânicas foram considerados semelhantes $\left(F_{0}<F_{\text {crítico }}\right)$; com exceção das propriedades de teor de ar incorporado e resistência à tração.

- A energia de adensamento influenciou grande parte das propriedades físicas e mecânicas apenas na comparação entre os traços 8 (15 golpes) e 9 (10 golpes). Nesse caso, os maiores valores médios de massa específica, resistência à compressão e tração e módulo de deformação foram obtidos para a dosagem produzida sob uma energia de adensamento correspondente a 15 golpes. $\mathrm{Na}$ comparação entre os traços 7 (20 golpes) e 8 (15 golpes), grande parte das propriedades avaliadas (cerca de 70\%) não foi influenciada significativamente ( $p$ > $0,05)$ pela energia de adensamento.

- $\mathrm{Na}$ continuidade da pesquisa, em razão da similaridade nos resultados das propriedades físicas e mecânicas para os traços 7 (20 golpes) e 8 (15 golpes), será adotada a energia de adensamento correspondente a 15 golpes. Além disso, grande 
parte dos CPs produzidos sob uma energia de adensamento de 10 golpes apresentaram problemas no instante de desforma.

\subsubsection{SEGUNDA ETAPA}

A segunda etapa foi realizada na fábrica da Tatu Pré-Moldados. O objetivo dessa etapa foi o estabelecimento de um intervalo de correlação visando à comparação das propriedades físicas e mecânicas de corpos-de-prova cilíndricos com blocos de concreto.

Inicialmente, as amostras de concreto foram retiradas durante a produção de uma determinada série de blocos de concreto, Figura 6.6. As amostras foram retiradas na correia transportadora, entre o misturador e a vibro-prensa.
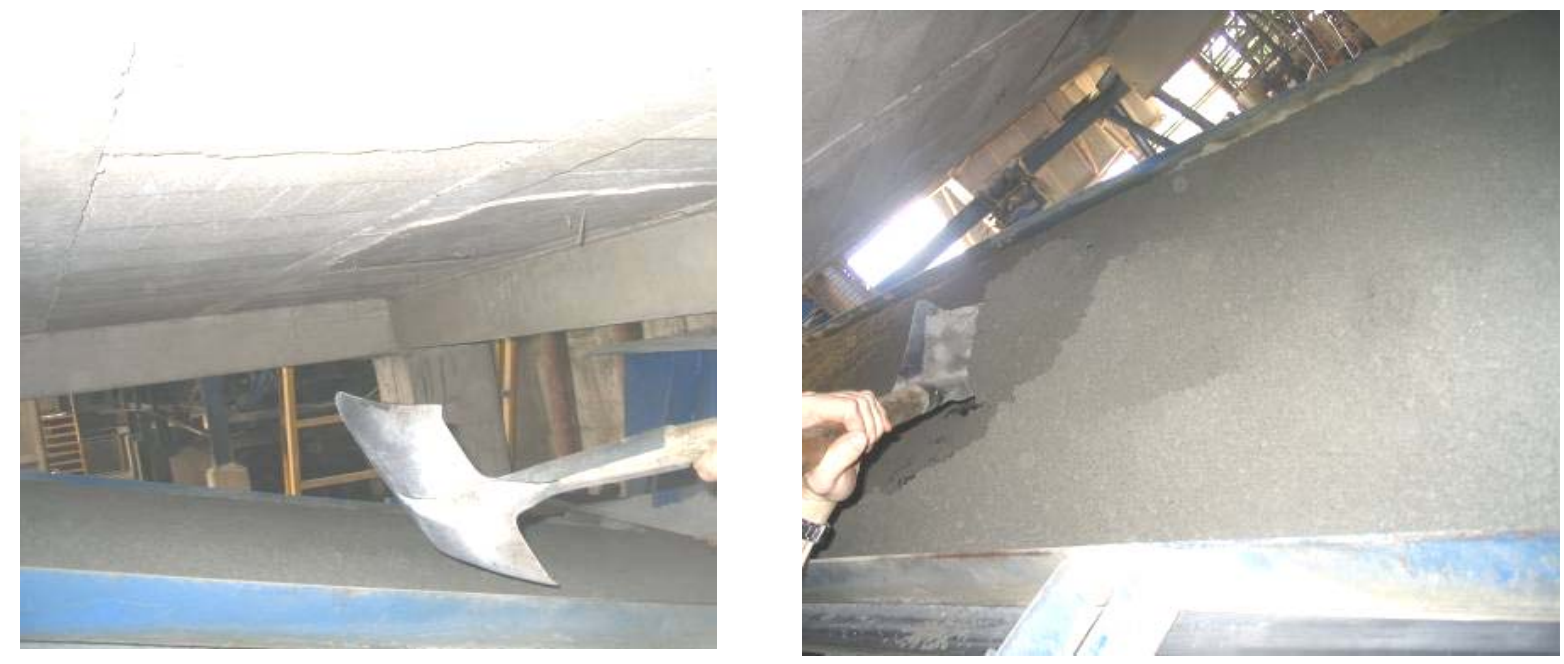

Figura 6.6 - Retirada das amostras de concreto para a produção dos corpos-de-prova.

Posteriormente, as amostras foram levadas para o laboratório da fábrica para a moldagem dos corpos-de-prova cilíndricos, Figura 6.7. Conforme comentado no final da primeira etapa, foi escolhida uma energia de adensamento igual a 15 golpes para quatro camadas de preenchimento. 


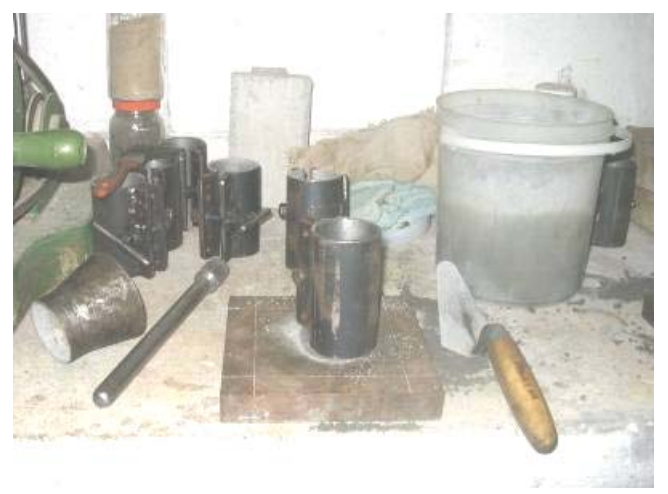

a) dispositivos utilizados para a produção dos CPs

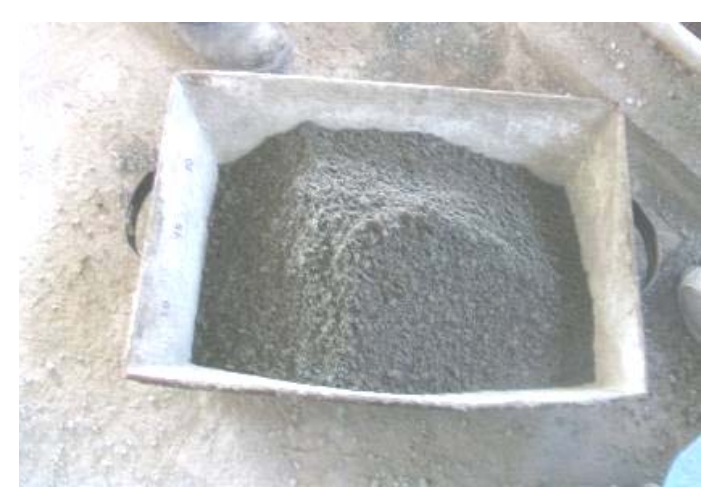

b) amostra retirada durante a produção dos blocos

Figura 6.7 - Produção dos corpos-de-prova no laboratório da fábrica.

Após a moldagem, os corpos-de-prova foram colocados na câmara de cura, conjuntamente com os blocos de sua série. A cura aplicada foi à térmica durante o período noturno, essa cura consistia de um ciclo com duração de quatro a cinco horas e regime isotérmico $\left(60^{\circ} \mathrm{C}-67^{\circ} \mathrm{C}\right)$, Figura 6.8. Dessa maneira, ficou garantida a semelhança de traços, umidade e cura das séries de CPS e blocos produzidos.
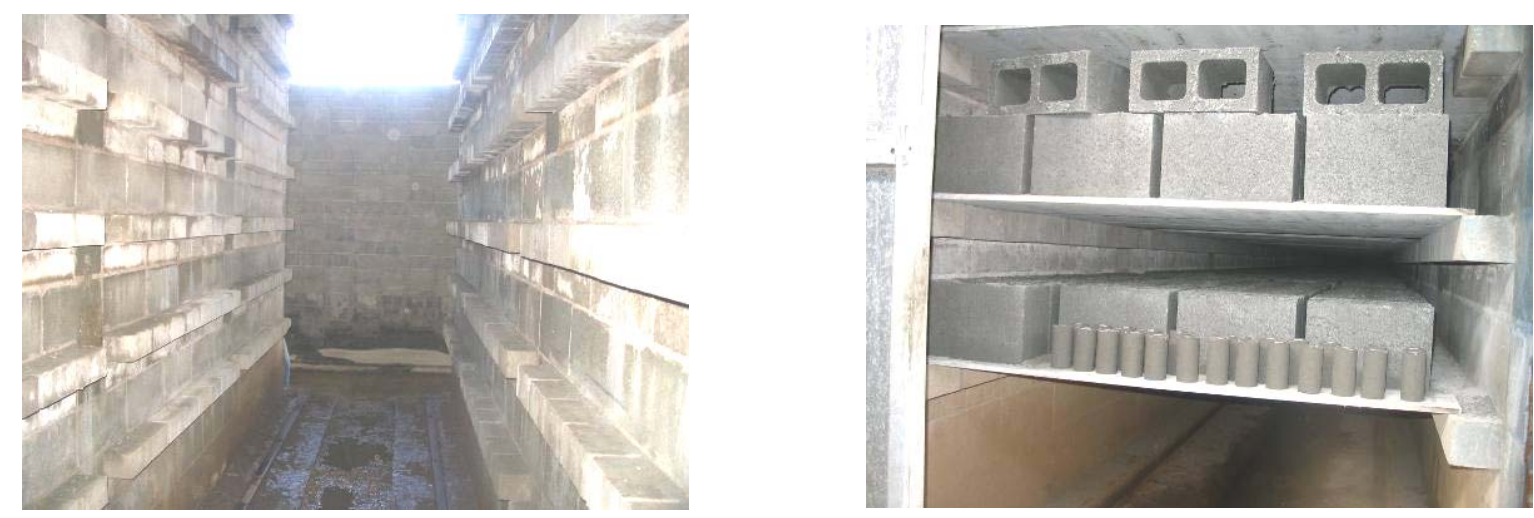

Figura 6.8 - Processo de cura térmica aplicada aos blocos e respectivos corpos-de-prova.

Após o processo de cura, os corpos-de-prova foram mantidos no ambiente do laboratório até a data de ensaio. Para a produção dos blocos (vedação e estruturais) manteve-se a regulagem da máquina vibro-prensa, isto é, os tempos de alimentação, vibração e compressão foram praticamente os mesmos, Tabela 6.14. Segundo Frasson Junior (2000), a obtenção de produtos porosos e de baixa resistência são indicativos de tempos insuficientes de produção; por outro lado, tempos excessivos aumentarão o período de produção e o desgaste de equipamentos e fôrmas. 
Tabela 6.14 - Parâmetros para a produção dos blocos.

\begin{tabular}{ccc}
\hline Tempo de Alimentação & Tempo de vibração & Tempo de compressão \\
\hline $2,0 \mathrm{~s}$ & $4,5 \mathrm{~s}$ & $1,5 \mathrm{~s}$ \\
\hline
\end{tabular}

Em razão da comercialização do bloco de 4,5 MPa pela fábrica, que foi produzido conjuntamente com os CPs, foi analisado outro lote de blocos da mesma classe de resistência e com parâmetros similares de produção. Os blocos produzidos e os respectivos corpos-de-prova encontram-se na Tabela 6.15.

Tabela 6.15 - Nomenclatura adotada para os blocos de concreto e respectivos corpos-deprova.

\begin{tabular}{ccr}
\hline Designação & $\begin{array}{c}\text { Data de } \\
\text { produção }\end{array}$ & Unidade \\
\hline BV-3,0 & $29 / 03$ & Bloco de vedação (não estrutural) $-\mathrm{f}_{\mathrm{bk}}{ }^{1}=3,0 \mathrm{MPa}$ \\
\hline $\mathrm{CPV}-3,0$ & $29 / 03$ & Corpo-de-prova cilíndrico $5 \times 10 \mathrm{~cm}$ produzido com o concreto do bloco BV-3,0 \\
\hline BE-4,5 & $20 / 04$ & Bloco estrutural $-\mathrm{f}_{\mathrm{bk}}{ }^{1}=4,5 \mathrm{MPa}$ \\
\hline $\mathrm{CPE}-4,5$ & $30 / 03$ & Corpo-de-prova cilíndrico $5 \times 10 \mathrm{~cm}$ produzido com o concreto do bloco de 4,5 \\
\hline BE-6,0 & $29 / 03$ & Bloco estrutural $-\mathrm{f}_{\mathrm{bk}}{ }^{1}=6,0$ \\
\hline $\mathrm{CPE}-6,0$ & $29 / 03$ & Corpo-de-prova cilíndrico 5x10cm produzido com o concreto do bloco BE1-6,0 \\
\hline BE-8,0 & $30 / 03$ & Bloco estrutural $-\mathrm{f}_{\mathrm{bk}}{ }^{1}=8,0 \mathrm{MPa}$ \\
\hline CPE-8,0 & $30 / 03$ & Corpo-de-prova cilíndrico $5 \times 10 \mathrm{~cm}$ produzido com o concreto do bloco BE-8,0 \\
\hline
\end{tabular}

\footnotetext{
${ }^{1} \mathrm{f}_{\mathrm{bk}}$ planejado e não necessariamente o obtido
}

$\mathrm{Na}$ Tabela 6.16, são apresentadas as principais características dos traços utilizados para a produção dos corpos-de-prova e blocos.

Tabela 6.16 - Dosagens utilizadas para a produção dos CPs e blocos de concreto.

\begin{tabular}{|c|c|c|c|c|c|}
\hline & & \multicolumn{4}{|c|}{ Dosagens } \\
\hline & & $\begin{array}{l}\text { CPV-3,0 } \\
\text { BV-3,0 }\end{array}$ & $\begin{array}{c}\text { CPE-4,5 } \\
\text { BE-4,5 }\end{array}$ & $\begin{array}{c}\text { CPE-6,0 } \\
\text { BE-6,0 }\end{array}$ & $\begin{array}{c}\text { CPE-8,0 } \\
\text { BE-8,0 }\end{array}$ \\
\hline \multirow{6}{*}{$\begin{array}{c}\text { Consumo de } \\
\text { materiais }\left(\mathrm{kg} / \mathrm{m}^{3}\right)\end{array}$} & Cimento & 136,6 & 149,4 & 135,0 & 151,5 \\
\hline & Pedrisco & 175,3 & 350,3 & 401,4 & 633,7 \\
\hline & Pó de pedra & 1523,8 & 1100,0 & 1275,4 & 835,9 \\
\hline & Areia Tietz & 631,3 & 649,6 & 522,2 & 667,5 \\
\hline & GRvp + MRvp* & - & 196,4 & 126,3 & 151,9 \\
\hline & Água & 123,3 & 122,3 & 123,0 & 122,0 \\
\hline \multicolumn{2}{|c|}{ Energia de adensamento (golpes) } & 15 & 15 & 15 & 15 \\
\hline \multicolumn{2}{|c|}{ Umidade (\%) } & 5,0 & 5,0 & 5,0 & 5,0 \\
\hline \multicolumn{2}{|c|}{ Aditivo, em relação à massa de cimento (\%) } & 0,20 & 0,20 & 0,20 & 0,20 \\
\hline \multicolumn{2}{|c|}{ Teor de argamassa (\%) } & 92,9 & 85,7 & 83,7 & 74,0 \\
\hline \multicolumn{2}{|c|}{ Módulo de finura da mistura } & 2,74 & 3,04 & 3,11 & 3,38 \\
\hline \multicolumn{2}{|c|}{ Material grosso - retido peneiras $(4,8$ e $2,4 \mathrm{~mm})$} & $22 \%$ & $29 \%$ & $31 \%$ & $38 \%$ \\
\hline \multicolumn{2}{|c|}{ Material médio - retido peneiras $(1,2,0,6$ e $0,3 \mathrm{~mm})$} & $53 \%$ & $50 \%$ & $47 \%$ & $44 \%$ \\
\hline \multicolumn{2}{|c|}{ Material fino - retido peneiras $(0,15 \mathrm{~mm}$ e fundo $)$} & $25 \%$ & $21 \%$ & $21 \%$ & $17 \%$ \\
\hline
\end{tabular}


Analisando-se a Tabela 6.16, nota-se um fato interessante; o consumo de cimento do traço CPE-6,0 foi aproximadamente 10\% inferior ao consumo do traço CPE-4,5 e 1\% em relação ao traço CPV-3,0. No entanto, o consumo da fração graúda (pedrisco) foi 129\% e $15 \%$ superior quando comparado com os traços CPV-3,0 e CPE-4,5, respectivamente. Neville (1997) cita que para misturas com reduzidas relações água/cimento, a influência do agregado graúdo na resistência aumenta consideravelmente. A razão para a esperada maior resistência do traço CPE-8,0 não se deve ao consumo de cimento (apenas 1,5\% superior ao apresentado pelo traço CPE-4,5), mas, provavelmente, ao maior consumo de pedrisco (cerca de $80 \%$ ) e a redução no emprego de pó de pedra (cerca de $40 \%$ ), quando comparado com o traço CPE-4,5.

O módulo de finura final da mistura $(2,74)$ e a grande quantidade de finos $(25 \%)$ melhoram sensivelmente a aparência e a textura dos exemplares produzidos com o traço CPV-3,0. Os elementos produzidos com essa dosagem podem ser utilizados em aplicações aparentes, sem qualquer tipo de revestimento. A composição do traço CPE-8,0 aproxima-se dos limites recomendados por Frasson Junior (2000).

As próximas Tabelas 6.17 e 6.18 apresentam os resultados das propriedades físicas para os blocos e os respectivos corpos-de-prova e a relação existente entre essas propriedades. A amostra de blocos foi constituída de seis unidades, já a amostra de corposde-prova era constituída de três exemplares. As propriedades de massa específica fresca, consumo real de cimento e teor de ar incorporado não foram avaliadas em virtude do laboratório da empresa não possuir uma balança de precisão. As outras propriedades foram avaliadas após os 28 dias, em função do atraso na chegada dos blocos. Os procedimentos adotados de ensaio, os resultados e as respectivas análises para os blocos de concreto serão detalhados no Capítulo 6. 
Tabela 6.17 - Propriedades físicas dos blocos e respectivos corpos-de-prova (3,0 MPa e 4,5 $\mathrm{MPa})$.

\begin{tabular}{|c|c|c|c|c|c|c|c|}
\hline & \multirow[b]{2}{*}{ Parâmetros } & \multicolumn{6}{|c|}{ Dosagens } \\
\hline & & BV $-\mathbf{3}, 0$ & CPV $-\mathbf{3}, 0$ & $\begin{array}{l}\text { Relação } \\
\text { CPVIBV }\end{array}$ & $\begin{array}{l}\text { BE 1- } \\
4,5\end{array}$ & CPE-4,5 & $\begin{array}{l}\text { Relação } \\
\text { CPE/BE }\end{array}$ \\
\hline $\begin{array}{l}\text { Temperatura na moldagem } \\
\left({ }^{\circ} \mathrm{C}\right)\end{array}$ & & - & 25 & & - & 27 & \\
\hline Umidade na moldagem (\%) & & - & 73 & & - & 57 & \\
\hline Coesão (g) & Média & - & 14031 & & - & 10611 & \\
\hline \multirow{3}{*}{$\begin{array}{c}\text { Massa específica seca } \\
\left(\mathrm{kg} / \mathrm{dm}^{3}\right)\end{array}$} & Média & 2,183 & 2,224 & \multirow{3}{*}{1,019} & 2,210 & 2,259 & \multirow{3}{*}{1,022} \\
\hline & D.P. & 0,017 & 0,015 & & 0,007 & 0,006 & \\
\hline & C. V. & $0,77 \%$ & $0,67 \%$ & & $0,31 \%$ & $0,26 \%$ & \\
\hline \multirow{3}{*}{$\begin{array}{c}\text { Massa específica saturada } \\
\text { superfície seca }\left(\mathrm{kg} / \mathrm{dm}^{3}\right)\end{array}$} & Média & 2,354 & 2,377 & \multirow{3}{*}{1,010} & 2,362 & 2,390 & \multirow{3}{*}{1,012} \\
\hline & D. P. & 0,013 & 0,008 & & 0,005 & 0,004 & \\
\hline & C. V. & $0,57 \%$ & $0,35 \%$ & & $0,21 \%$ & $0,16 \%$ & \\
\hline \multirow{2}{*}{ Índice de vazios (\%) } & D.P. & 0,49 & 0,69 & \multirow[t]{2}{*}{0,889} & 0,57 & 0,85 & \multirow[t]{2}{*}{0,867} \\
\hline & C. V. & $2,88 \%$ & $4,55 \%$ & & $3,76 \%$ & $6,48 \%$ & \\
\hline
\end{tabular}

Tabela 6.18 - Propriedades físicas dos blocos e respectivos corpos-de-prova (6,0 MPa e 8,0 MPa).

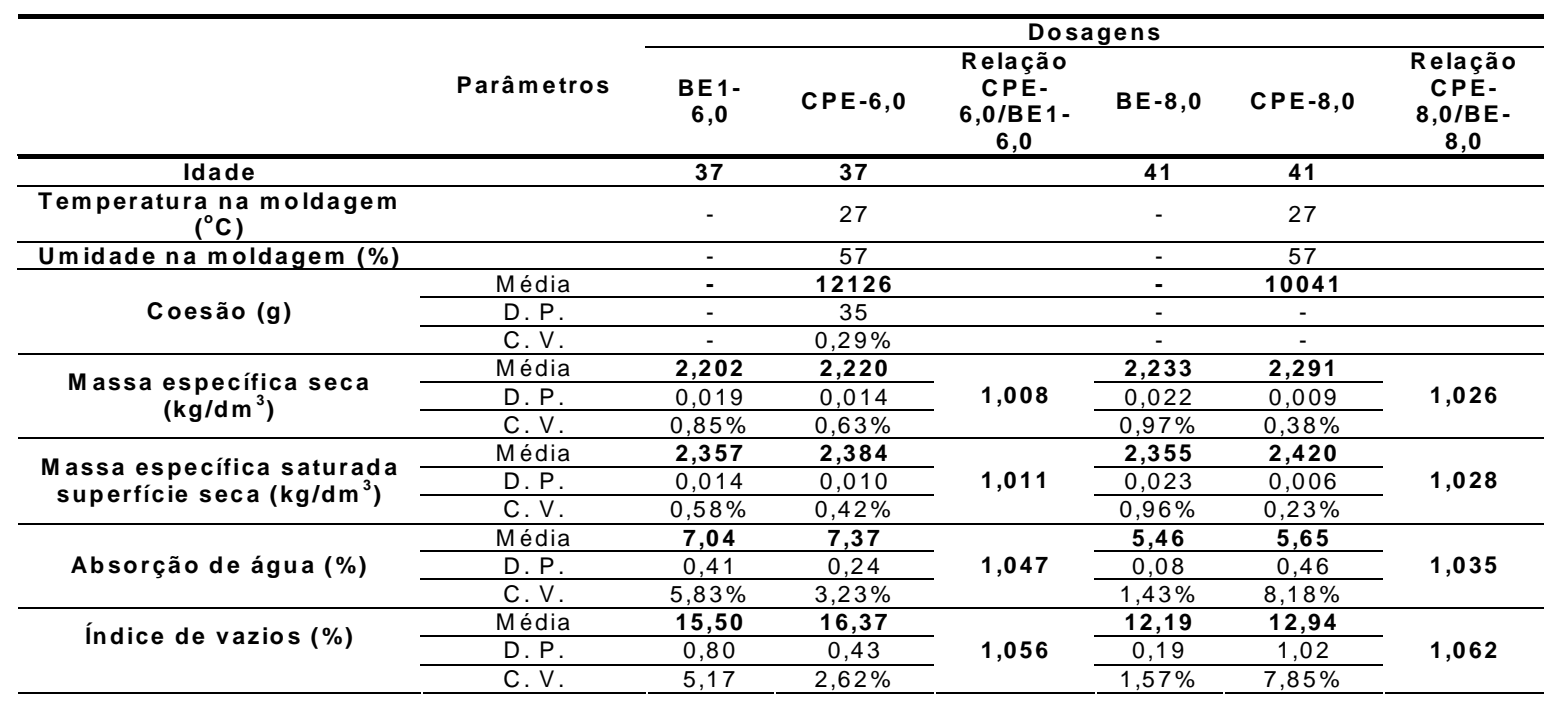

Analisando-se a Tabela 6.18, nota-se que os resultados para as propriedades físicas de blocos e CPs das classes de resistência 6,0 MPa e 8,0 MPa foram equivalentes; as diferenças nos valores dessas propriedades foram de até $6 \%$. Por outro lado, pela Tabela 6.17, nota-se que as diferenças entre os valores das propriedades físicas (absorção de água e índice de vazios) dos CPs e blocos das classes de resistência 3,0 $\mathrm{MPa}$ e 4,5 $\mathrm{MPa}$ situaram-se em torno de 15\%; os CPs apresentaram menores valores de absorção e índice de vazios quando comparado com os blocos de concreto. Certamente, para essas classes 
de resistência, a energia de adensamento no processo de produção dos corpos-de-prova foi superior à empregada na fabricação dos blocos.

Para as classes de resistência de 6,0 MPa e 8,0 MPa, pode-se dizer que a energia de adensamento adotada promoveu uma compacidade da mistura muito próxima daquela obtida na produção dos blocos de concreto; os resultados das propriedades mecânicas validarão esses resultados e indicarão um intervalo de correlação. Os blocos BE-8,0 e os exemplares CPE-8,0 obtiveram os menores valores para as propriedades de absorção e índice de vazios, comparativamente aos exemplares das outras classes de resistência, em função do maior consumo de cimento e, principalmente, devido ao maior consumo de agregado graúdo e a redução na quantidade de pó de pedra.

De acordo com os resultados obtidos nas Tabelas 6.17 e 6.18 , acredita-se que apenas a avaliação da massa específica fresca, seca ou saturada superfície seca não seja suficiente para o estabelecimento de uma correlação confiável entre corpos-de-prova e blocos, uma vez que pequenas diferenças na massa específica dos CPs e blocos podem representar variações significativas em outras propriedades, tais como, índice de vazios e absorção de água. Por exemplo, uma diferença de $2 \%$ na massa específica de dois diferentes exemplares, pode representar uma diferença de até 15\% na absorção de água e 13\% no índice de vazios desses exemplares.

Na Tabela 6.19 são apresentados os valores das propriedades mecânicas para os blocos e respectivos corpos-de-prova e a relação existente entre os resultados obtidos para essas unidades.

Tabela 6.19 - Propriedades mecânicas dos blocos e respectivos corpos-de-prova.

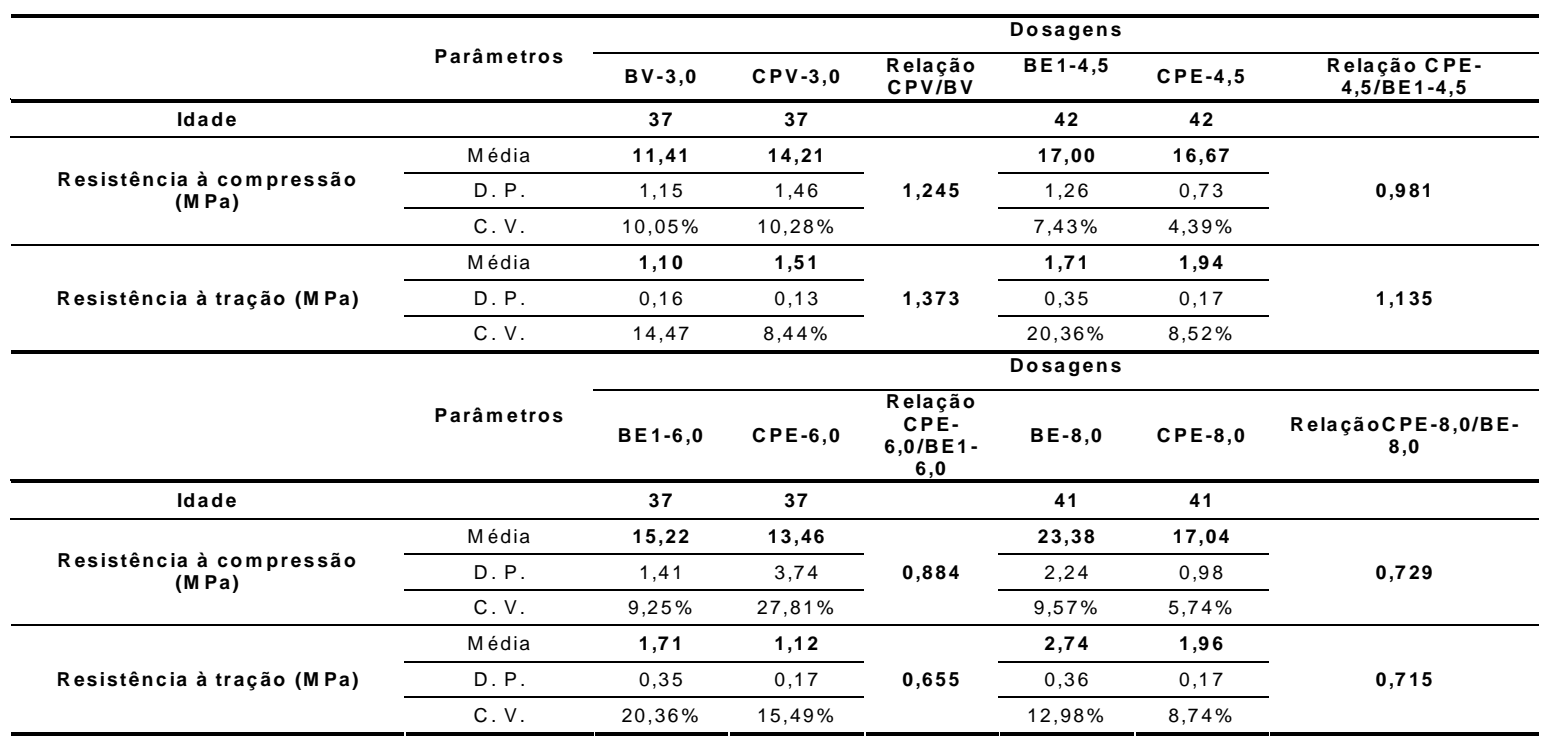


Analisando-se os resultados, observa-se que para as classes de resistência de 3,0 MPa e 4,5 MPa, a razão entre as resistências à compressão e tração para os CPs e blocos de concreto apresentou valor médio de 1,11 e 1,25, respectivamente. Por outro lado, para as unidades de 6,0 MPa e 8,0 MPa, essa razão ficou com o valor médio de 0,80 e 0,69, respectivamente. Os resultados obtidos para as propriedades físicas (diferenças de no máximo 6\%) indicaram que a energia de adensamento aplicada nos corpos-de-prova (CPE6,0 e CPE-8,0) foi muito próxima daquela empregada na produção dos blocos. Portanto, pode-se afirmar que o coeficiente de correlação para as propriedades mecânicas dos CPs e blocos, em função dos resultados obtidos na Tabela 6.19, é algo em torno de $0,80 \pm 0,10$, conforme resultados da Tabela 6.19. A resistência de um corpo-de-prova cilíndrico representaria cerca de $80 \pm 10 \%$ da resistência do bloco na área líquida, desde que as propriedades físicas desses materiais fossem semelhantes, principalmente, os valores de absorção de água e índice de vazios. No Apêndice $\mathrm{H}$, encontra-se uma expressão para a conversão dos valores de resistência dos CPs cilíndricos para a resistência esperada dos blocos de concreto.

Barbosa (2004) obteve valores situados entre 1,13 e 1,31 para a relação entre a resistência à compressão de CPs e blocos de concreto, produzidos com concreto plástico; entretanto, o pesquisador não relacionou às propriedades físicas dessas diferentes unidades. Frasson Junior (2000) correlacionou a resistência à compressão de CPs $5 \times 10$ $\mathrm{cm}$ e blocos através da massa específica fresca dessas unidades; o pesquisador obteve um valor médio de 0,80 para a relação entre a resistência do corpo-de-prova e do bloco.

Os resultados relativos para as propriedades avaliadas são apresentados na Figura 6.9. 


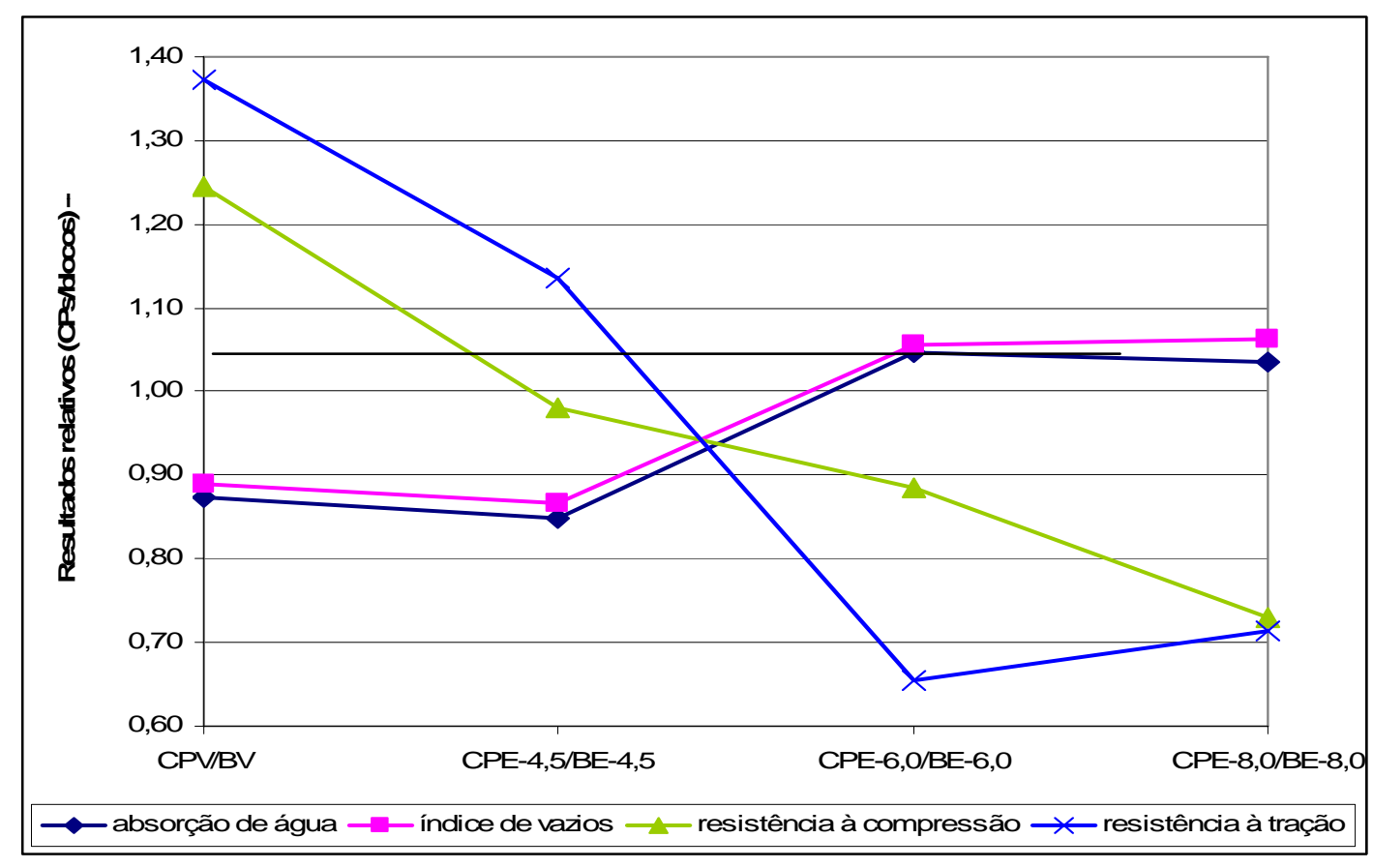

Figura 6.9 - Resultados relativos (CPs/blocos) para as propriedades avaliadas.

\subsubsection{TERCEIRA ETAPA}

Após o estabelecimento de um intervalo de correlação para as propriedades mecânicas dos corpos-de-prova e blocos, a terceira etapa consistiu na avaliação da incorporação de agregados reciclados de concreto (graúdos e/ou miúdos) na coesão, textura, propriedades físicas e mecânicas dos corpos-de-prova. Inicialmente, foi verificada a influência de outros parâmetros, tais como, tipo de cura (úmida ou térmica), tipo de mistura (simples ou dupla) nas propriedades físicas e mecânicas desses exemplares. Todas as dosagens com agregados reciclados foram comparadas com similares produzidas com agregados naturais.

Os resultados dessa etapa possibilitarão uma avaliação criteriosa da incorporação de agregados reciclados na mistura e, com isso, haverá subsídios suficientes para a produção de blocos de concreto, em fábrica, com a adição de agregados reciclados.

\subsubsection{Escolha dos agregados reciclados}

Em virtude da grande quantidade de variáveis, foram escolhidos dois agregados reciclados para serem analisados. O critério utilizado na escolha baseou-se na quantidade de resíduo gerado pela fábrica, representatividade da fração graúda e na qualidade dos agregados graúdos reciclados. Diante disso, foram escolhidos dois agregados pelas seguintes razões: 
- Agregado reciclado de vigota (ARv): resíduo de média resistência, boa qualidade, elevado consumo de cimento, fração graúda após o processamento em torno de $72 \%$ e geração mensal em torno de $15 \mathrm{~m}^{3} / \mathrm{mês}$;

- Agregado reciclado de bloco (ARb): resíduo de baixa resistência, baixa qualidade, reduzido consumo de cimento, fração graúda após o processamento em torno de $57 \%$ e geração mensal em torno de $60 \mathrm{~m}^{3} / \mathrm{mês}$.

Além disso, a escolha desses agregados possibilitará uma avaliação criteriosa da influência da qualidade do material reciclado nas propriedades físicas e mecânicas do concreto, uma vez que serão produzidos exemplares utilizando agregados reciclados de boa qualidade (ARv) e também de baixa qualidade (ARb). Para os agregados reciclados que não serão utilizados, acredita-se que, por exemplo, a incorporação dos agregados reciclados gerados durante as etapas de produção dos blocos (GRvp e GRpb) não afetarão significativamente as propriedades dos blocos, já que tais materiais apresentaram valores de propriedades físicas muito próximas daquelas obtidas para o agregado natural (referência).

Antes do início da etapa, foi recebido outro lote de resíduos, já processados na fábrica. A análise expedita desses materiais indicou semelhanças na granulometria do agregado graúdo reciclado de vigota com o material já processado anteriormente (segundo processamento); entretanto, em função da mudança na abertura da mandíbula para a produção dos agregados reciclados de bloco (ARb), realizada no segundo processamento, esses agregados graúdos apresentaram distribuição granulométrica e módulo de finura diferentes quando comparados aos agregados reciclados originários da fábrica. Diante disso e em função de que na próxima etapa serão utilizados os resíduos processados pela própria fábrica, a granulometria do resíduo obtido no segundo processamento foi modificada de maneira que sua distribuição granulométrica se assemelhasse ao agregado reciclado processado na fábrica. As principais propriedades do agregado graúdo reciclado de bloco (GRb), após esse ajuste, foram as seguintes: módulo de finura igual a 5,39 e absorção de água igual a 4,57\%. 


\subsubsection{Diretrizes Básicas}

Os resultados obtidos para os blocos e corpos-de-prova da segunda etapa forneceram parâmetros fundamentais para a definição dos traços. Um deles refere-se ao fato que a classe de resistência do bloco não indica precisamente a resistência à compressão real dessas unidades. Por exemplo, os blocos de vedação, teoricamente, teriam que apresentar uma resistência média de 4,0 MPa, considerando-se um coeficiente de variação de $15 \%$ na produção, entretanto, já com sete dias esses blocos apresentavam uma resistência média $\left(\mathrm{f}_{\mathrm{bm}}\right)$ de 5,8 $\mathrm{MPa}$ e aos 28 dias cerca de 6,5 MPa; outro exemplo: os blocos de concreto da classe de 4,5 MPa, teoricamente, teriam que apresentar um $\mathrm{f}_{\mathrm{bm}}$ de 6,0 $\mathrm{MPa}$; entretanto, obtiveram aos sete dias uma resistência de 7,7 MPa e aos 28 dias uma resistência de 9,5 $\mathrm{MPa}$. Outro parâmetro fundamental obtido através das dosagens avaliadas refere-se ao fato que para traços com o mesmo consumo de cimento, tais como, os traços das unidades das classes de 4,5 MPa e 8,0 MPa, a simples inclusão de uma maior porcentagem de pedrisco e redução no consumo de pó de pedra acarretou um aumento de $42 \%$ na resistência à compressão e 57\% na resistência à tração indireta. Tais resultados foram muito importantes para a definição das diretrizes para a produção dos corpos-deprova.

As diretrizes básicas para a realização da presente etapa são enumeradas a seguir:

- Todas as dosagens a serem produzidas contarão com uma porcentagem média de $30 \%$ de agregado graúdo na mistura, semelhante à quantidade utilizada nos blocos estruturais de $8,0 \mathrm{MPa}$, e aproximadamente $40 \%$ de pó de pedra com a finalidade de se aumentar a coesão da mistura. Estima-se que o módulo de finura final da mistura seja próximo a 3,38.

- As dosagens pertencentes a uma mesma classe de resistência deverão ter um consumo teórico de cimento e um teor de argamassa (em volume) semelhantes. A simples substituição, em massa, do agregado natural pelo agregado reciclado acarretaria um aumento de volume da mistura devido à menor massa específica do material reciclado.

- A cura úmida será realizada entre 3h e 4h da adição do cimento na mistura, após o início de pega do cimento. A cura será mantida até o sexto dia e, depois disso, os CPs serão mantidos no ambiente do laboratório; resultados de ensaios piloto desenvolvidos preliminarmente indicaram a influência negativa da elevada umidade dos exemplares, no momento do ensaio, nas propriedades mecânicas do concreto. 
- A umidade para as misturas com agregados naturais será fixada em 5\%, em relação à massa total de agregados. Para as dosagens com agregados reciclados, o material reciclado foi adicionado na mistura na condição seca ao ar, entretanto, foi prevista uma quantidade adicional de água em razão da elevada absorção de água dos agregados reciclados. Essa quantidade de água foi fixada em aproximadamente $70 \%$ da absorção final do agregado reciclado, conforme os resultados da taxa de absorção média (Capítulo 5);

- Serão avaliados três traços (1:20, 1:15 e 1:10) com o objetivo de produzir, na próxima etapa, blocos estruturais de concreto das classes de resistência de 4,5 MPa; 8,0 MPa e 12,0 MPa;

- Três níveis de substituição de agregados reciclados na mistura (em volume): $50 \%$ de agregado graúdo reciclado em substituição parcial ao pedrisco, 100\% de agregado graúdo reciclado em substituição ao pedrisco, 50\% de agregado graúdo reciclado em substituição ao pedrisco $+33 \%$ de agregado miúdo reciclado em substituição ao pó de pedra;

- Idades para avaliação das propriedades: 7 e 28 dias. Propriedades físicas a serem avaliadas nessas idades: massa específica fresca, teor de ar incorporado, consumo real de cimento, massa específica seca, massa específica saturada superfície seca, absorção de água e índice de vazios; propriedades mecânicas a serem avaliadas nas idades mencionadas: resistência à compressão, resistência à tração por compressão diametral e módulo de deformação; além das propriedades de coesão (seis exemplares para cada traço) e textura superficial;

- Todos os corpos-de-prova terão sua umidade avaliada no instante do ensaio, uma vez que para concretos com consistência seca esse parâmetro tem uma influência significativa nas propriedades mecânicas;

- Os corpos-de-prova cilíndricos $5 \mathrm{~cm}$ x $10 \mathrm{~cm}$ serão moldados utilizando-se uma energia de adensamento igual a 15 golpes, em quatro camadas; a quantidade de aditivo foi fixada em $0,2 \%$, em relação à massa de cimento, em função de recomendações do fabricante e parâmetros da fábrica.

Inicialmente, serão verificados mais dois parâmetros que segundo a literatura influenciam nas propriedades dos concretos. O primeiro deles é a cura térmica e o segundo é o procedimento de mistura adotado para a produção de concretos com agregados 
reciclados. Os resultados e as respectivas análises são apresentados no próximo item 6.1.3.3.

\subsubsection{Investigações preliminares (cura térmica e procedimento de mistura)}

De acordo com De Melo (2000), o ganho significativo de resistência mecânica, nas primeiras idades, motivada pela cura térmica proporciona inúmeras vantagens para as fábricas de pré-moldados: a) rápida liberação das formas e dispositivos de protensão; b) dispensa de tanques de imersão ou outros processos; c) menor necessidade de estoques; d) facilidade em cumprir os prazos de entrega. Por outro lado, segundo o pesquisador, o processo de cura acelerada permite obter resistências elevadas em idades iniciais, mas ocorre uma redução da resistência final devido à formação de uma microestrutura modificada. Um dos maiores inconvenientes da cura acelerada (cura térmica) é o aumento no tamanho dos poros, principalmente na zona de interface pasta/agregado, prejudicando a resistência mecânica. Na cura térmica, as temperaturas não devem exceder $80^{\circ} \mathrm{C}$ para não causar modificações na microestrutura do concreto. Aldea et al. (2000 apud BARDELLA et al., 2005) ${ }^{26}$, em estudos com concretos curados termicamente a $80^{\circ} \mathrm{C}$, notaram uma queda na resistência em relação ao concreto curado por imersão após os 28 dias. Os autores atribuíram essa queda de resistência a uma distribuição não uniforme dos produtos de hidratação devido à rápida hidratação inicial dos compostos. Martins (2001 apud Bardella et al., 2005) $)^{27}$ notou que com a aplicação de cura térmica a $60^{\circ} \mathrm{C}$, as resistência à compressão e tração por compressão diametral aos 28 dias dos CPs foram inferiores àqueles produzidos pela cura em imersão.

$\mathrm{Na}$ presente pesquisa, o procedimento de cura térmica foi realizado em um equipamento de banho-maria localizado no Laboratório de Materiais Avançados à Base de Cimento. Os corpos-de-prova foram submetidos ao processo de cura aproximadamente três horas após o início da mistura, conforme recomendações de De Melo (2000). De acordo com o pesquisador, o melhor momento para a aplicação de ciclos térmicos é durante o estágio de aceleração, após o período de indução (após o início de pega do cimento), cerca de três horas. O aumento da temperatura de cura contribui para que ocorram mais rapidamente os picos característicos das curvas calorimétricas referente à hidratação do

\footnotetext{
${ }^{26}$ ALDEA, C. M.; YOUNG, F. B.; SHAH, S. P. Effects of curing conditions on properties of concrete using slag replacement. Cement and Concrete Research, v. 30, n. 3, p. 465-472, march 2000.

27 MARTINS, A. R. Efeito da cura térmica e de cimentos com escória granulada de alto-forno na durabilidade do concreto de cobrimento. 2001. 166f. Dissertação (Mestrado) - Faculdade de Engenharia Civil, Arquitetura e Urbanismo, Universidade Estadual de Campinas, Campinas, 2001.
} 
cimento Porland, sendo que as velocidades das reações das diferentes fases do cimento também são afetadas pela temperatura de cura. Por outro lado, em temperaturas elevadas, a taxa de hidratação do cimento diminui ao longo do tempo, devido a um provável encapsulamento dos grãos anidros de clínquer durante os ciclos térmicos.

O ciclo de cura adotado foi relativamente curto em relação àquele empregado usualmente na fábrica, em virtude do horário de funcionamento do laboratório. O ciclo empregado consistia de uma hora de elevação constante de temperatura até $65 \pm 5^{\circ} \mathrm{C}$, manutenção dessa temperatura por cerca de duas horas e, finalmente, redução da temperatura a uma taxa constante durante aproximadamente uma hora. Após isso, os corpos-de-prova foram mantidos no ambiente do laboratório até a data prevista de ensaio. No momento da moldagem dos CPs destinados à cura térmica, foram moldados outros exemplares destinados à cura úmida que servirão como parâmetro de referência.

$\mathrm{Na}$ Tabela 6.20, são apresentadas as características do traço destinado à produção dos exemplares.

Tabela 6.20 - Dosagem utilizada para verificação da influência do tipo de cura nas propriedades dos CPs.

\begin{tabular}{|c|c|c|}
\hline \multicolumn{2}{|c|}{ Traço 1:10 } & Dosagem - Ref \\
\hline \multicolumn{2}{|c|}{ Energia de adensamento (golpes) } & 15 \\
\hline \multirow{5}{*}{ Consumo de materiais $\left(\mathrm{kg} / \mathrm{m}^{3}\right)$} & Cimento & 223,2 \\
\hline & Pedrisco & 669,6 \\
\hline & Pó de pedra & 892,8 \\
\hline & Areia Tietz & 669,6 \\
\hline & Água & 122,8 \\
\hline \multicolumn{2}{|c|}{ \% pedrisco } & 30 \\
\hline \multicolumn{2}{|c|}{$\%$ areia Tietz } & 30 \\
\hline \multicolumn{2}{|c|}{ \% pó de pedra } & 40 \\
\hline \multicolumn{2}{|c|}{ Umidade (\%) } & 5,0 \\
\hline \multicolumn{2}{|c|}{ Aditivo, em relação à massa de cimento (\%) } & 0,20 \\
\hline \multicolumn{2}{|c|}{ Teor de argamassa (\%) } & 72,73 \\
\hline \multicolumn{2}{|c|}{ Teor de argamassa em volume (\%) } & 72,62 \\
\hline \multicolumn{2}{|c|}{ Módulo de finura da mistura } & 3,38 \\
\hline \multicolumn{2}{|c|}{ Material grosso - retido peneiras $(4,8$ e $2,4 \mathrm{~mm})$} & $39 \%$ \\
\hline \multicolumn{2}{|c|}{ Material médio - retido peneiras $(1,2,0,6$ e $0,3 \mathrm{~mm})$} & $43 \%$ \\
\hline \multicolumn{2}{|c|}{ Material fino - retido peneiras $(0,15 \mathrm{~mm}$ e fundo) } & $18 \%$ \\
\hline
\end{tabular}

Os resultados das propriedades físicas e mecânicas dos CPs considerando-se o tipo de cura adotado são apresentados na Tabela 6.21. 
Tabela 6.21 - Resultados das propriedades para os CPs submetidos à cura térmica e cura úmida.

\begin{tabular}{|c|c|c|c|c|c|c|c|}
\hline \multirow{2}{*}{ Traço 1:10 } & \multirow{2}{*}{ Parâmetros } & \multicolumn{2}{|c|}{ IDADE } & \multirow{3}{*}{$\begin{array}{c}\text { Relação } \\
\text { resultados } \\
\text { térmica/úmida }\end{array}$} & \multicolumn{2}{|c|}{ IDADE } & \multirow{3}{*}{$\begin{array}{l}\text { Relação } \\
\text { resultados } \\
\text { térmica/úmida }\end{array}$} \\
\hline & & 1 & 1 & & 7 & 7 & \\
\hline Tipo de Cura & & Úmida & Térmica & & Úmida & Térmica & \\
\hline $\begin{array}{c}\text { Energia de } \\
\text { adensamento } \\
\text { (golpes) }\end{array}$ & & 15 & 15 & - & 15 & 15 & - \\
\hline Temperatura $\left({ }^{\circ} \mathrm{C}\right)$ & & 20 & 20 & - & 20 & 20 & - \\
\hline Umidade (\%) & & 78 & 78 & - & 78 & 78 & - \\
\hline \multirow{3}{*}{ Coesão (g) } & Média & 9827 & 9827 & - & 9827 & 9827 & - \\
\hline & D. P. & - & - & - & - & - & - \\
\hline & C. V. & - & - & - & - & - & - \\
\hline \multirow{3}{*}{$\begin{array}{l}\text { Massa específica } \\
\text { fresca }\left(\mathrm{kg} / \mathrm{dm}^{3}\right)\end{array}$} & Média & 2,392 & 2,412 & \multirow{3}{*}{1,008} & 2,386 & 2,394 & \multirow{3}{*}{1,003} \\
\hline & D. P. & 0,019 & 0,016 & & 0,006 & 0,031 & \\
\hline & C. V. & $0,81 \%$ & $0,64 \%$ & & $0,27 \%$ & $1,30 \%$ & \\
\hline \multirow{3}{*}{$\begin{array}{l}\text { Consumo real de } \\
\text { cimento }\left(\mathrm{kg} / \mathrm{m}^{3}\right)\end{array}$} & Média & 207,1 & 208,8 & \multirow{3}{*}{1,008} & 206,5 & 207,2 & \multirow{3}{*}{1,003} \\
\hline & D.P. & 1,68 & 1,35 & & 0,55 & 2,70 & \\
\hline & C.V. & $0,81 \%$ & $0,64 \%$ & & $0,27 \%$ & $1,30 \%$ & \\
\hline \multirow{3}{*}{$\begin{array}{c}\text { Teor de ar } \\
\text { incorporado (\%) }\end{array}$} & Média & 7,22 & 6,44 & \multirow{3}{*}{0,892} & 7,47 & 7,15 & \multirow{3}{*}{0,957} \\
\hline & D. P. & 0,75 & 0,60 & & 0,25 & 1,20 & \\
\hline & C. V. & 10,43 & $9,37 \%$ & & $3,32 \%$ & $16,92 \%$ & \\
\hline \multirow{3}{*}{$\begin{array}{c}\text { Massa específica } \\
\text { seca }\left(\mathrm{kg} / \mathrm{dm}^{3}\right)\end{array}$} & Média & 2,330 & 2,345 & \multirow{3}{*}{1,006} & 2,333 & 2,353 & \multirow{3}{*}{1,009} \\
\hline & D. P. & 0,025 & 0,015 & & 0,009 & 0,002 & \\
\hline & C. V. & $1,07 \%$ & $0,64 \%$ & & $0,38 \%$ & $0,08 \%$ & \\
\hline \multirow{3}{*}{$\begin{array}{c}\text { Massa específica } \\
\text { saturada superfície } \\
\text { seca }\left(\mathrm{kg} / \mathrm{dm}^{3}\right)\end{array}$} & Média & 2,450 & 2,459 & \multirow{3}{*}{1,004} & 2,447 & 2,464 & \multirow{3}{*}{1,007} \\
\hline & D. P. & 0,019 & 0,012 & & 0,004 & 0,001 & \\
\hline & C. V. & $0,76 \%$ & $0,51 \%$ & & $0,16 \%$ & $0,06 \%$ & \\
\hline \multirow{3}{*}{ Absorção de água (\%) } & Média & 5,12 & 4,88 & \multirow{3}{*}{0,953} & 4,88 & 4,72 & \multirow{3}{*}{0,967} \\
\hline & D. P. & 0,39 & 0,14 & & 0,34 & 0,07 & \\
\hline & C. V. & $7,68 \%$ & $2,80 \%$ & & $7,05 \%$ & $1,52 \%$ & \\
\hline \multirow{3}{*}{ Índice de vazios (\%) } & Média & 11,92 & 11,44 & & 11,38 & 11,10 & \\
\hline & D. P. & 0,80 & 0,25 & 0,960 & 0,76 & 0,16 & 0,975 \\
\hline & C. V. & $6,68 \%$ & $2,18 \%$ & & $6,70 \%$ & $1,46 \%$ & \\
\hline Umidade do CP no & Média & - & - & & 69,56 & 47,22 & \\
\hline momento do ensaio, & D. P. & - & - & - & 2,23 & 0,72 & 0,679 \\
\hline $\begin{array}{c}\text { em relação à } \\
\text { absorção total (\%) }\end{array}$ & c. v. & - & - & & $3,21 \%$ & $1,53 \%$ & 0,010 \\
\hline & Média & 12,61 & 14,72 & & 26,77 & 23,07 & \\
\hline Resistência à & D. P. & 0,85 & 1,29 & 1,167 & 2,81 & 0,79 & 0,862 \\
\hline compre & C. v. & $6,71 \%$ & $8,77 \%$ & & $10,48 \%$ & $3,44 \%$ & \\
\hline & Média & 17,29 & 18,52 & & 25,12 & 22,16 & \\
\hline Módulo de & D. P. & 1,54 & 2,22 & 1,071 & 1,25 & 1,60 & 0,882 \\
\hline Deformação (GPa) & C. V. & $8,93 \%$ & $11,98 \%$ & & $4,99 \%$ & $7,21 \%$ & \\
\hline
\end{tabular}

Analisando-se os resultados da Tabela 6.21, nota-se que os valores das propriedades físicas (absorção de água e índice de vazios) para os CPs submetidos à cura térmica, independentemente da idade, foram cerca de $4 \%$ menores quando comparados com os CPs da cura úmida; provavelmente, a maior massa incorporada durante a moldagem (massa específica fresca), cerca de 0,5\%, para esses corpos-de-prova pode ser enumerada como uma das justificativas para os menores valores obtidos.

Com relação às propriedades mecânicas, observa-se que a resistência à compressão dos CPs submetidos à cura térmica, no primeiro dia, foi aproximadamente $17 \%$ superior à obtida para os CPs submetidos à cura úmida; possivelmente, os maiores valores de resistência e também de módulo de deformação devem-se à aceleração dos picos característicos das curvas calorimétricas referentes à hidratação do cimento Portland que ocorre na cura térmica (DE MELO, 2000). Essa tendência inverte-se no sétimo dia, os CPs submetidos à cura úmida apresentaram valores de resistência e módulo de deformação aproximadamente $14 \%$ e $12 \%$ superiores, respectivamente em relação aos valores obtidos para os exemplares da cura térmica. Esse fato ocorreu provavelmente devido ao prolongamento da hidratação do cimento para os CPs que estavam na cura úmida e 
também devido ao reduzido e insuficiente ciclo de cura térmico a que estavam submetidos os outros exemplares. Segundo Neville (1997), a hidratação plena do cimento somente é conseguida se os capilares do concreto estiverem preenchidos com água e quando a pressão de saturação for suficientemente alta, cerca de $80 \%$ da pressão de saturação; portanto, a partir dessas afirmações pode-se dizer que, no período compreendido entre o segundo e o sexto dia, a hidratação do cimento nos CPs submetidos à cura úmida foi muito mais efetiva e rápida do que nos CPs submetidos à cura térmica.

Para verificar a influência do tipo de cura adotada e da idade nas propriedades físicas e mecânicas dos CPs foi empregada a Análise de Variância. As variáveis serão analisadas isoladamente (análise de $1^{\mathrm{a}}$ ordem) e duas a duas (análise de $2^{\mathrm{a}}$ ordem). Os resultados encontram-se na Tabela 6.22 .

Tabela 6.22 - Teste ANOVA para verificar a influência do tipo de cura adotada e da idade nas propriedades físicas e mecânicas dos CPs.

\begin{tabular}{|c|c|c|c|c|}
\hline & & \multicolumn{2}{|c|}{ Análise de $1^{\circ}$ Ordem } & \multirow{2}{*}{$\begin{array}{l}\text { Análise de } 2^{\circ} \text { ordem } \\
\text { Tipo de cura } x \text { idade }\end{array}$} \\
\hline & & Tipo de cura (úmida e térmica) & Idade (1 e 7 dias) & \\
\hline \multirow{5}{*}{ Propriedades } & Massa específica seca & - & - & - \\
\hline & Absorção de água & - & - & - \\
\hline & Índice de vazios & - & - & - \\
\hline & Resistência à compressão & - & $S(139,7)$ & $\mathrm{S}(9,3)$ \\
\hline & Módulo de deformação & - & $S(34,5)$ & - \\
\hline
\end{tabular}

Analisando-se a Tabela 6.22, nota-se que o procedimento de cura adotado não influenciou significativamente as propriedades físicas e mecânicas. Dessa maneira, pode-se dizer que os valores das propriedades físicas e mecânicas foram semelhantes para os exemplares submetidos à cura úmida e térmica. Com relação a variável "idade", pode-se afirmar que apenas as propriedades mecânicas foram afetadas por essa variável. Devido à hidratação progressiva do cimento, os maiores valores médios de resistência à compressão e módulo de deformação foram obtidos para os exemplares com sete dias de idade.

Para a análise de $2^{\mathrm{a}}$ ordem, observou-se uma influência significativa dos parâmetros (cura $x$ idade) apenas sobre a resistência à compressão dos CPs. Nesse caso, pode-se afirmar que, para a idade de um dia, os maiores valores médios de resistência foram obtidos para os exemplares submetidos à cura térmica; já para a idade de sete dias, essa tendência inverteu-se, sendo os maiores valores médios de resistência obtidos para os exemplares 
submetidos à cura úmida. As justificativas para esse comportamento já foram apresentadas anteriormente.

Alguns pesquisadores, tais como, Tam et al. (2005) e Ryu (2002) citam que a ordem de colocação dos materiais no misturador influi nas propriedades do concreto, principalmente para dosagens com agregados reciclados. Um dos métodos consiste na adição da água em duas frações distintas e possui as seguintes particularidades de acordo com o fluxograma da Figura 6.10.

\begin{tabular}{|c|c|c|c|c|c|c|c|c|}
\hline Agr. Miúdo & $+60 \mathrm{~s}$ & $50 \%$ & $+60 \mathrm{~s}$ & Cimento & $+30 \mathrm{~s}$ & $50 \%$ & $+120 \mathrm{~s}$ & Final \\
\hline Agr. graúdo & & água & & C & & água & & $\mathrm{m}$ istura \\
\hline
\end{tabular}

Figura 6.10 - Procedimento de mistura (Tam et al., 2005).

Segundo os pesquisadores, para substituições de até 30\% de agregados naturais por agregados graúdos reciclados, foi constatado um aumento de 20\% e 14\% na resistência à compressão aos sete dias e 28 dias, respectivamente quando comparado com o procedimento convencional de mistura. Após análises de Microscopia Eletrônica de Varredura, Tam et al. (2005) concluíram que o aumento da resistência é provocado por partículas de cimento que preenchem os vazios e fissuras existentes na argamassa aderida ao agregado reciclado. Esse processo ocorre durante o primeiro estágio da mistura e garante a formação de uma zona de transição mais densa, com conseqüente incremento nas propriedades mecânicas do concreto. Através da mesma metodologia, Ryu (2002) pode observar um aumento de $17 \%$ na resistência à compressão e $26 \%$ na resistência à tração, comparativamente aos valores de referência.

A eficácia desse procedimento de mistura proposto por Tam et al. (2005) e Ryu (2002) também foi testado na presente pesquisa. Foram produzidos quatro traços, dois deles contendo agregados graúdos reciclados de vigota (GRv); os exemplares produzidos foram submetidos à cura úmida até o sexto dia e então ensaiados aos sete e vinte e oito dias. O procedimento padrão de mistura foi constituído das seguintes etapas: $1^{0}$ - colocação dos agregados na argamassadeira; $2^{0}$ - homogeneização desses materiais; $3^{0}$ - adição do cimento e homogeneização; $4^{0}$ - adição do total de água e homogeneização final; já o procedimento duplo de mistura proposto por Tam (2005) foi dividido nas seguintes etapas: $1^{0}$ - colocação dos agregados na mistura; $2^{0}$ - adição de metade da água prevista; $3^{0}$ homogeneização da mistura; $4^{0}$ - adição do cimento e homogeneização; $5^{0}$ - adição do restante da água. As principais características dos traços empregados são apresentadas na Tabela 6.23. 
Tabela 6.23 - Características dos traços para a verificação da influência do tipo de mistura nas propriedades dos CPS.

\begin{tabular}{|c|c|c|c|c|c|}
\hline \multicolumn{2}{|c|}{ Traço 1:10 } & \multicolumn{2}{|c|}{ REF } & \multicolumn{2}{|c|}{ RGV - 100\% } \\
\hline \multicolumn{2}{|c|}{ Tipo de Mistura } & Normal & Duplo & Normal & Duplo \\
\hline \multicolumn{2}{|c|}{ Designação } & REF-N & REF-D & RGV-N & RGV-D \\
\hline \multicolumn{2}{|c|}{ Energia de adensamento (golpes) } & 15 & 15 & 15 & 15 \\
\hline \multirow{6}{*}{$\begin{array}{l}\text { Consumo de } \\
\text { materiais }\left(\mathrm{kg} / \mathrm{m}^{3}\right)\end{array}$} & Cimento & 223,2 & 223,2 & 223,2 & 223,2 \\
\hline & Pedrisco & 669,6 & 669,6 & - & - \\
\hline & Vigota - GRv & - & - & 587,5 & 587,5 \\
\hline & Pó de pedra & 892,8 & 892,8 & 892,5 & 892,5 \\
\hline & Areia Tietz & 669,6 & 669,6 & 676,8 & 676,8 \\
\hline & Água & 122,8 & 122,8 & 138,0 & 138,0 \\
\hline \multicolumn{2}{|c|}{$\%$ pedrisco } & 30 & 30 & - & - \\
\hline \multicolumn{2}{|c|}{ \% GRv } & - & - & 27,24 & 27,24 \\
\hline \multicolumn{2}{|c|}{$\%$ areia Tietz } & 30 & 30 & 31,38 & 31,38 \\
\hline \multicolumn{2}{|c|}{ \% pó de pedra } & 40 & 40 & 41,38 & 41,38 \\
\hline \multicolumn{2}{|c|}{ Umidade total* (\%) } & 5,00 & 5,00 & 5,80 & 5,80 \\
\hline \multicolumn{2}{|c|}{ Umidade efetiva** (\%) } & - & - & 5,40 & 5,40 \\
\hline \multicolumn{2}{|c|}{$\begin{array}{l}\text { Aditivo, em relação à massa de } \\
\text { cimento (\%) }\end{array}$} & 0,20 & 0,20 & 0,20 & 0,20 \\
\hline \multicolumn{2}{|c|}{ Teor de argamassa (\%) } & 72,73 & 72,73 & 75,73 & 75,73 \\
\hline \multicolumn{2}{|c|}{ Teor de argamassa em volume (\%) } & 72,62 & 72,62 & 72,61 & 72,61 \\
\hline \multicolumn{2}{|c|}{ Módulo de finura da mistura } & 3,38 & 3,38 & 3,38 & 3,38 \\
\hline \multicolumn{2}{|c|}{$\begin{array}{l}\text { Material grosso - retido peneiras } \\
(4,8 \text { e } 2,4 \mathrm{~mm})\end{array}$} & $39 \%$ & $39 \%$ & $37 \%$ & $37 \%$ \\
\hline \multicolumn{2}{|c|}{$\begin{array}{c}\text { Material médio - retido peneiras } \\
(1,2,0,6 \text { e } 0,3 \mathrm{~mm})\end{array}$} & $43 \%$ & $43 \%$ & $45 \%$ & $45 \%$ \\
\hline \multicolumn{2}{|c|}{$\begin{array}{l}\text { Material fino - retido peneiras } \\
(0,15 \mathrm{~mm} \text { e fundo })\end{array}$} & $18 \%$ & $18 \%$ & $18 \%$ & $18 \%$ \\
\hline
\end{tabular}

REF-N: traço produzido com agregados de referência utilizando-se o procedimento padrão de mistura REF-D: traço produzido com agregados de referência utilizando-se o procedimento duplo de mistura RGV-N: traço produzido com agregados graúdos reciclados de vigota utilizando-se o procedimento padrão de mistura RGV-D: traço produzido com agregados graúdos reciclados de vigota utilizando-se o procedimento duplo de mistura * Umidade total: refere-se à quantidade total de água adicionada na mistura. Para o traço RGV - 100\%, foi adicionada também uma parcela de água referente à absorção do agregado reciclado (cerca de $70 \%$ da absorção final do material)

** Umidade efetiva: nesse caso, desconta-se da quantidade total de água adicionada na mistura à parcela que será absorvida pelo agregado até se chegar à condição de $70 \%$ da absorção final. Para se conhecer a quantidade de água absorvida pelo agregado, considera-se também a umidade inicial do agregado (GRv - 1,55\%)

Analisando-se a Tabela 6.23, observa-se que para as misturas com agregados graúdos reciclados foram mantidos o consumo de cimento e o teor de argamassa (em volume); em função disso, a porcentagem de agregados graúdos reciclados na mistura foi reduzida para $27,24 \%$. Os traços REF e RGV-100\% apresentaram módulos de finura equivalentes, apesar do maior módulo de finura do agregado graúdo reciclado de vigota. Os resultados para as propriedades físicas e mecânicas considerando-se os dois tipos de mistura são encontrados nas Tabelas 6.24 e 6.25. 
Tabela 6.24 - Resultados para os CPs de referência (REF) considerando-se os dois tipos de mistura.

\begin{tabular}{|c|c|c|c|c|c|c|c|}
\hline \multirow{2}{*}{ Traço 1:10 - REF } & \multirow{3}{*}{ Parâmetros } & \multicolumn{2}{|c|}{ Idade } & \multirow{3}{*}{$\begin{array}{c}\text { Relação } \\
\text { resultados } \\
\text { mistura } \\
\text { dupla/padrão }\end{array}$} & \multicolumn{2}{|c|}{ Idade } & \multirow{3}{*}{$\begin{array}{c}\text { Relação } \\
\text { resultados } \\
\text { mistura } \\
\text { dupla/padrão }\end{array}$} \\
\hline & & 7 & 7 & & 28 & 28 & \\
\hline Tipo de mistura & & PADRÃO & DUPLA & & PADRÃO & DUPLA & \\
\hline $\begin{array}{c}\text { Energia de } \\
\text { adensamento } \\
\text { (golpes) }\end{array}$ & & 15 & 15 & (a) & 15 & 15 & 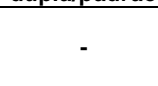 \\
\hline Temperatura $\left({ }^{\circ} \mathrm{C}\right)$ & & 20 & 22 & - & 20 & 22 & - \\
\hline Umidade (\%) & & 70 & 64 & - & 70 & 64 & - \\
\hline \multirow{3}{*}{$\begin{array}{l}\text { Massa específica } \\
\text { fresca }\left(\mathrm{kg} / \mathrm{dm}^{3}\right)\end{array}$} & Média & 2,371 & 2,377 & \multirow{3}{*}{1,003} & 2,375 & 2,393 & \multirow{3}{*}{1,008} \\
\hline & D. P. & 0,006 & 0,022 & & 0,012 & 0,034 & \\
\hline & C. V. & $0,27 \%$ & $0,91 \%$ & & $0,52 \%$ & $1,41 \%$ & \\
\hline \multirow{3}{*}{$\begin{array}{c}\text { Consumo real de } \\
\text { cimento }\left(\mathrm{kg} / \mathrm{m}^{3}\right)\end{array}$} & Média & 205,3 & 205,8 & \multirow{3}{*}{1,003} & 205,6 & 207,2 & \multirow{3}{*}{1,008} \\
\hline & D. P. & 0,55 & 1,87 & & 1,06 & 2,92 & \\
\hline & C. V. & $0,27 \%$ & $0,91 \%$ & & $0,51 \%$ & $1,41 \%$ & \\
\hline \multirow{3}{*}{$\begin{array}{c}\text { Teor de ar } \\
\text { incorporado (\%) }\end{array}$} & Média & 8,04 & 7,81 & \multirow{3}{*}{0,971} & 7,87 & 7,18 & \multirow{3}{*}{0,912} \\
\hline & D. P. & 0,25 & 0,84 & & 0,47 & 1,31 & \\
\hline & C. V. & $3,08 \%$ & $10,74 \%$ & & $6,02 \%$ & $18,22 \%$ & \\
\hline \multirow{3}{*}{$\begin{array}{c}\text { Massa específica } \\
\text { seca }\left(\mathrm{kg} / \mathrm{dm}^{3}\right)\end{array}$} & Média & 2,333 & 2,325 & \multirow{3}{*}{0,997} & 2,348 & 2,340 & \multirow{3}{*}{0,997} \\
\hline & D. P. & 0,005 & 0,013 & & 0,012 & 0,020 & \\
\hline & C. V. & $0,22 \%$ & $0,55 \%$ & & $0,53 \%$ & $0,85 \%$ & \\
\hline \multirow{3}{*}{$\begin{array}{c}\text { Massa específica } \\
\text { saturada superfície } \\
\text { seca }\left(\mathrm{kg} / \mathrm{dm}^{3}\right)\end{array}$} & Média & 2,441 & 2,443 & \multirow{3}{*}{1,001} & 2,462 & 2,457 & \multirow{3}{*}{0,998} \\
\hline & D. P. & 0,005 & 0,011 & & 0,011 & 0,016 & \\
\hline & C. V. & $0,21 \%$ & $0,43 \%$ & & $0,46 \%$ & $0,67 \%$ & \\
\hline \multirow{3}{*}{ Absorção de água (\%) } & Média & 4,63 & 5,05 & \multirow{3}{*}{1,091} & 4,84 & 4,99 & \multirow{3}{*}{1,031} \\
\hline & D. P. & 0,20 & 0,29 & & 0,08 & 0,21 & \\
\hline & C. V. & $4,35 \%$ & $5,73 \%$ & & $1,62 \%$ & $4,13 \%$ & \\
\hline \multirow{3}{*}{ Índice de vazios (\%) } & Média & 10,79 & 11,74 & \multirow{3}{*}{1,088} & 11,36 & 11,67 & \multirow{3}{*}{1,027} \\
\hline & D. P. & 0,46 & 0,64 & & 0,12 & 0,38 & \\
\hline & C. V. & $4,25 \%$ & $5,41 \%$ & & $1,08 \%$ & $3,30 \%$ & \\
\hline & Média & 70,80 & 65,45 & & 34,41 & 37,23 & \\
\hline momento do ensaio, & D. P. & 3,19 & 3,42 & - & 3,79 & 3,56 & - \\
\hline $\begin{array}{c}\text { em relação à } \\
\text { absorção total (\%) }\end{array}$ & C. V. & $4,51 \%$ & 5,22 & & $11,01 \%$ & $9,55 \%$ & \\
\hline & Média & 20,49 & 22,46 & & 26,79 & 29,35 & \\
\hline Resistência à & D. P. & 2,27 & 2,43 & 1,096 & 2,42 & 5,57 & 1,096 \\
\hline compressão (MPa) & C. $v$. & $11,07 \%$ & $10,80 \%$ & & $9,04 \%$ & $18,96 \%$ & \\
\hline & Média & 25,38 & 25,04 & & 29,46 & 29,88 & \\
\hline Módulo de & D. P. & 1,02 & 0,76 & 0,987 & 2,98 & 2,24 & 1,014 \\
\hline Deformação (GPa) & C. V. & $4,02 \%$ & $3,04 \%$ & & $10,11 \%$ & $7,49 \%$ & \\
\hline
\end{tabular}

Pela Tabela 6.24, observa-se que os CPs produzidos utilizando o procedimento duplo de mistura, comparativamente ao procedimento padrão, apresentaram os maiores valores de massa específica fresca, resistência à compressão, maiores taxas de absorção de água e índice de vazios. Entretanto, devido ao elevado coeficiente de variação observado em algumas propriedades, é adequada a utilização do teste estatístico ANOVA. 
Tabela 6.25 - Resultados para os CPs com agregados reciclados de vigota (RGV-100\%) considerando-se os dois tipos de mistura.

\begin{tabular}{|c|c|c|c|c|c|c|c|}
\hline \multirow{2}{*}{$\begin{array}{l}\text { Traço 1:10 - } \\
\text { RGV - 100\% }\end{array}$} & \multirow{2}{*}{ Parâmetros } & \multicolumn{2}{|c|}{ Idade } & \multirow{3}{*}{$\begin{array}{c}\text { Relação } \\
\text { resultados } \\
\text { mistura } \\
\text { dupla/padrão }\end{array}$} & \multicolumn{2}{|c|}{ Idade } & \multirow{3}{*}{$\begin{array}{c}\text { Relação } \\
\text { resultados } \\
\text { mistura } \\
\text { dupla/padrãc }\end{array}$} \\
\hline & & 7 & 7 & & 28 & 28 & \\
\hline Tipo de mistura & & PADRÃO & DUPLA & & PADRÃO & DUPLA & \\
\hline $\begin{array}{c}\text { Energia de } \\
\text { adensamento } \\
\text { (golpes) }\end{array}$ & & 15 & 15 & - & 15 & 15 & - \\
\hline Temperatura $\left({ }^{\circ} \mathrm{C}\right)$ & & 20 & 22 & - & 20 & 22 & - \\
\hline Umidade (\%) & & 67 & 62 & - & 67 & 62 & - \\
\hline \multirow{3}{*}{$\begin{array}{l}\text { Massa específica } \\
\text { fresca }\left(\mathrm{kg} / \mathrm{dm}^{3}\right)\end{array}$} & Média & 2,312 & 2,308 & \multirow{3}{*}{0,998} & 2,321 & 2,309 & \multirow{3}{*}{0,995} \\
\hline & D. P. & 0,019 & 0,012 & & 0,026 & 0,028 & \\
\hline & C. V. & $0,80 \%$ & $0,53 \%$ & & $1,11 \%$ & $1,23 \%$ & \\
\hline \multirow{3}{*}{$\begin{array}{l}\text { Consumo real de } \\
\text { cimento }\left(\mathrm{kg} / \mathrm{m}^{3}\right)\end{array}$} & Média & 205,8 & 205,4 & \multirow{3}{*}{0,998} & 206,6 & 205,5 & \multirow{3}{*}{0,995} \\
\hline & D. P. & 1,66 & 1,09 & & 2,29 & 2,53 & \\
\hline & C. V. & $0,80 \%$ & $0,53 \%$ & & $1,11 \%$ & $1,23 \%$ & \\
\hline \multirow{3}{*}{$\begin{array}{c}\text { Teor de ar } \\
\text { incorporado (\%) }\end{array}$} & Média & 7,80 & 7,97 & \multirow{3}{*}{1,022} & 7,43 & 7,93 & \multirow{3}{*}{1,067} \\
\hline & D. P. & 0,74 & 0,49 & & 1,03 & 1,13 & \\
\hline & C. V. & $9,51 \%$ & $6,12 \%$ & & $13,81 \%$ & $14,28 \%$ & \\
\hline \multirow{3}{*}{$\begin{array}{c}\text { Massa específica } \\
\text { seca }\left(\mathrm{kg} / \mathrm{dm}^{3}\right)\end{array}$} & Média & 2,234 & 2,238 & \multirow{3}{*}{1,002} & 2,244 & 2,250 & \multirow{3}{*}{1,003} \\
\hline & D.P. & 0,011 & 0,003 & & 0,013 & 0,011 & \\
\hline & C. $V$. & $0,47 \%$ & $0,11 \%$ & & $0,58 \%$ & $0,48 \%$ & \\
\hline \multirow{3}{*}{$\begin{array}{l}\text { Massa específica } \\
\text { saturada superfície } \\
\text { seca }\left(\mathrm{kg}^{2} \mathrm{dm}^{3}\right)\end{array}$} & Média & 2,362 & 2,363 & \multirow{3}{*}{1,000} & 2,374 & 2,377 & \multirow{3}{*}{1,001} \\
\hline & D. P. & 0,011 & 0,007 & & 0,011 & 0,009 & \\
\hline & C. V. & $0,46 \%$ & $0,28 \%$ & & $0,47 \%$ & $0,37 \%$ & \\
\hline \multirow{3}{*}{ Absorção de água (\%) } & Média & 5,73 & 5,61 & \multirow{3}{*}{0,980} & 5,83 & 5,63 & \multirow{3}{*}{0,966} \\
\hline & D. P. & 0,08 & 0,18 & & 0,31 & 0,13 & \\
\hline & C. V. & 1,31 & 3,22 & & $5,32 \%$ & $2,22 \%$ & \\
\hline \multirow{3}{*}{ Índice de vazios (\%) } & Média & 12,80 & 12,55 & \multirow{3}{*}{0,980} & 13,08 & 12,68 & \multirow{3}{*}{0,969} \\
\hline & D.P. & 0,17 & 0,42 & & 0,65 & 0,22 & \\
\hline & C. V. & $1,32 \%$ & $3,34 \%$ & & $4,99 \%$ & 1,77 & \\
\hline & Média & 71,54 & 72,12 & & 36,05 & 37,77 & \\
\hline momento do ensaio, & D. P. & 3,61 & 1,17 & - & 3,27 & 2,37 & - \\
\hline $\begin{array}{l}\text { em relação à } \\
\text { absorcão total (\%) }\end{array}$ & C. V. & $5,05 \%$ & $1,62 \%$ & & $9,08 \%$ & 6,27 & \\
\hline & Média & 21,44 & 25,41 & & 29,45 & 29,71 & \\
\hline Resistência à & D. P. & 2,95 & 2,23 & 1,185 & 4,95 & 3,85 & 1,009 \\
\hline compressão (MPa) & C. v. & $13,76 \%$ & $8,76 \%$ & & $16,81 \%$ & $12,95 \%$ & \\
\hline & Média & 26,11 & 26,37 & & 29,09 & 29,17 & \\
\hline Módulo de & D. P. & 1,93 & 3,03 & 1,010 & 2,34 & 3,22 & 1,003 \\
\hline Deformação (GPa) & C. V. & $7,40 \%$ & $11,47 \%$ & & $8,03 \%$ & $11,02 \%$ & \\
\hline
\end{tabular}

Analisando-se os resultados da Tabela 6.25, observa-se que os CPs produzidos pelo procedimento duplo de mistura, comparativamente aos produzidos pelo procedimento padrão, apresentaram as menores taxas de absorção e índice de vazios e os maiores valores para as propriedades mecânicas. Para verificar a influência do tipo de mistura e da idade nas propriedades físicas e mecânicas dos CPs foi empregada a Análise de Variância. As variáveis são analisadas isoladamente (análise de $1^{\mathrm{a}}$ ordem) e duas a duas (análise de $2^{\mathrm{a}}$ ordem). Os resultados encontram-se na Tabela 6.26. 
Tabela 6.26 - Teste ANOVA para verificar a influência do procedimento de mistura e idade nas propriedades físicas e mecânicas dos CPs.

\begin{tabular}{|c|c|c|c|c|}
\hline \multirow{2}{*}{ Traços } & \multirow{2}{*}{ Propriedades } & \multicolumn{2}{|c|}{ Análise de $1^{\circ}$ Ordem } & \multirow{2}{*}{$\begin{array}{c}\text { Análise de } 2^{\circ} \text { ordem } \\
\text { Tipo de mistura } x \\
\text { idade }\end{array}$} \\
\hline & & $\begin{array}{l}\text { Tipo de mistura } \\
\text { (padrão x dupla) }\end{array}$ & Idade (1 e 7 dias) & \\
\hline \multirow{5}{*}{ REF } & $\begin{array}{c}\text { Massa específica } \\
\text { seca }\end{array}$ & - & - & - \\
\hline & $\begin{array}{c}\text { Absorção de } \\
\text { água }\end{array}$ & $S(5,7)$ & - & - \\
\hline & Índice de vazios & $S(6,1)$ & - & - \\
\hline & $\begin{array}{l}\text { Resistência à } \\
\text { compressão }\end{array}$ & - & $\mathrm{S}(10,9)$ & - \\
\hline & $\begin{array}{l}\text { Módulo de } \\
\text { deformação }\end{array}$ & - & $S(15,5)$ & - \\
\hline \multirow{5}{*}{ RGV-100\% } & $\begin{array}{c}\text { Massa específica } \\
\text { seca }\end{array}$ & - & - & - \\
\hline & $\begin{array}{c}\text { Absorção de } \\
\text { água }\end{array}$ & - & - & - \\
\hline & Índice de vazios & - & - & - \\
\hline & $\begin{array}{c}\text { Resistência à } \\
\text { compressão }\end{array}$ & - & $\mathrm{S}(8,6)$ & - \\
\hline & $\begin{array}{l}\text { Módulo de } \\
\text { deformação }\end{array}$ & - & - & - \\
\hline
\end{tabular}

Analisando-se os resultados da Tabela 6.26, observa-se que o tipo de mistura adotado influenciou apenas as propriedades de absorção de água e índice de vazios para o traço de referência. Nesse caso, os menores valores médios para essas propriedades foram obtidos para os CPs produzidos com o tipo de mistura padrão. De maneira geral, pode-se afirmar que os resultados obtidos através desses dois procedimentos de mistura foram semelhantes, principalmente para as propriedades mecânicas.

Com relação à variável "idade", pode-se dizer que apenas as propriedades mecânicas foram afetadas por essa variável. Devido a hidratação progressiva do cimento, os maiores valores médios de resistência e módulo de deformação foram obtidos para os CPs com vinte e oito dias de idade. Considerando-se a análise de $2^{a}$ ordem, não foi observada nenhuma influência significativa dos parâmetros (tipo de mistura e idade) sobre as propriedades avaliadas.

Como conclusões da etapa de investigações preliminares, podem ser enumeradas os seguintes tópicos a seguir:

- A cura térmica tem um papel fundamental no desenvolvimento da resistência de elementos pré-moldados, principalmente nas primeiras idades; entretanto, para ciclos relativamente curtos de cura térmica, conforme realizado pela presente pesquisa, os resultados ficaram comprometidos, pois não ocorreu uma elevação 
significativa da resistência nas primeiras idades (diferentemente do que ocorre nas fábricas de pré-moldados). Em função disso, será empregada a cura úmida na continuação do trabalho.

- Com relação ao procedimento de mistura, novos estudos precisam ser desenvolvidos visando à avaliação criteriosa do procedimento duplo de mistura e seu real efeito nas propriedades das unidades, uma vez que no presente trabalho não foram observadas diferenças significativas nas propriedades dos CPs quando da adoção desse procedimento. Em virtude disso, será adotado na continuação da pesquisa o procedimento convencional de mistura.

\subsubsection{Avaliação das propriedades dos CPs para diferentes classes de resistência}

Os resultados a serem apresentados referem-se às propriedades físicas e mecânicas dos CPs aos sete dias e vinte e oito dias. Conforme já relatado, os resultados das diferentes dosagens avaliadas através dos corpos-de-prova cilíndricos fornecerão valiosos parâmetros sobre o comportamento dos blocos estruturais de concreto. Após a conclusão dessa etapa, os resultados serão analisados comparativamente e as dosagens envolvendo agregados reciclados, que apresentarem os melhores resultados, comparativamente aos traços com agregados naturais, serão selecionadas para a produção dos blocos de concreto.

Deve-se esclarecer que apesar do estabelecimento de um intervalo de correlação para as propriedades dos CPS e blocos, os corpos-de-prova que serão produzidos na presente etapa, provavelmente apresentarão menores taxas de absorção e índice de vazios, maiores valores de resistência à compressão e tração quando comparado com os resultados que serão obtidos futuramente pelos blocos de concreto. A razão para isso devese ao fato que os exemplares produzidos no laboratório contam com um controle rigoroso da umidade dos materiais, dosagem dos insumos em massa, energia de adensamento praticamente constante e manutenção da cura por seis dias. Por outro lado, na produção dos blocos, as dosagens são estabelecidas em volume (maior velocidade de produção) apesar do elevado coeficiente de variação, controle de umidade dos materiais realizada de maneira deficitária, variação da massa dos blocos em função da distribuição não-uniforme do concreto nos moldes, mudança freqüente nos tempos de alimentação, pré-vibração e compactação da vibro-prensa durante a produção e outros fatores intervenientes.

Para facilitar o entendimento dessa etapa, os resultados e análises serão apresentados da seguinte maneira: 
a) GRUPO 4,5 - nesse grupo inserem-se todos as dosagens produzidas com o traço 1:20 (cimento:agregados). Os agregados empregados foram os naturais e os materiais reciclados (reciclado de vigota e bloco). Os corpos-de-prova foram avaliados criteriosamente com o propósito de subsidiar, na próxima etapa, a produção de blocos de concreto estruturais da classe de 4,5 $\mathrm{MPa}\left(f_{\mathrm{bk}}=4,5 \mathrm{MPa}\right)$ que são comumente empregados em edifícios de alvenaria estrutural de até quatro pavimentos;

b) GRUPO 8,0 - nesse grupo inserem-se todos as dosagens produzidas com o traço 1:15 (cimento:agregados). Os agregados empregados foram os naturais e os materiais reciclados (reciclado de vigota e bloco). Os exemplares foram avaliados criteriosamente com a finalidade de subsidiar, na próxima etapa, a produção de blocos de concreto estruturais da classe de $8,0 \mathrm{MPa}\left(f_{\mathrm{bk}}=8,0 \mathrm{MPa}\right)$ que são comumente empregados em edifícios de alvenaria estrutural de até oito pavimentos;

c) GRUPO 12,0 - nesse grupo inserem-se todos as dosagens produzidas com o traço 1:10 (cimento:agregados). Os agregados empregados foram os naturais e os materiais reciclados (reciclado de vigota e bloco). Os corpos-de-prova foram avaliados criteriosamente com o objetivo de subsidiar, na próxima etapa, a produção de blocos de concreto estruturais da classe de 12,0 MPa ( $f_{b k}=12,0 \mathrm{MPa}$ ) que são comumente empregados em edifícios de alvenaria estrutural de até doze pavimentos;

\subsection{Grupos avaliados}

Antes da apresentação das características das dosagens avaliadas; na Tabela 6.27, encontram-se as respectivas terminologias adotadas para cada um desses traços.

Tabela 6.27 - Terminologias adotadas para as dosagens.

\begin{tabular}{|c|c|}
\hline Terminologia & Características \\
\hline REF & Dosagem de referência produzida inteiramente com agregados naturais \\
\hline RGV - 100\% & $\begin{array}{l}\text { Dosagem com substituição de } 100 \% \text { da fração graúda natural por agregado graúdo } \\
\text { reciclado de vigota (GRv) }\end{array}$ \\
\hline RGV - 50\% + RMV - 33\% & $\begin{array}{c}\text { Dosagem com } 50 \% \text { de substituição, em massa, da fração graúda natural por agregado } \\
\text { reciclado (GRv) + 33\% de substituição, em massa, do pó de pedra por agregado miúdo } \\
\text { reciclado de vigota (MRv) }\end{array}$ \\
\hline RGB - 100\% & $\begin{array}{l}\text { Dosagem com 100\% de substituição da fração graúda natural por agregado graúdo } \\
\text { reciclado de bloco (GRb) }\end{array}$ \\
\hline RGB - 50\% & $\begin{array}{l}\text { Dosagem com 50\% de substituição, em massa, da fração graúda natural por agregado } \\
\text { graúdo reciclado de bloco (GRb) }\end{array}$ \\
\hline$R G B-50 \%+R G B-33 \%$ & $\begin{array}{l}\text { Dosagem com } 50 \% \text { de substituição, em massa, da fração graúda natural por agregado } \\
\text { reciclado (GRb) + 33\% de substituição, em massa, do pó de pedra por agregado miúdo } \\
\text { reciclado de bloco (MRb) }\end{array}$ \\
\hline
\end{tabular}




\subsection{Grupo 4,5}

$\mathrm{Na}$ Tabela 6.28, encontram-se as dosagens avaliadas pertencentes ao Grupo 4,5.

Tabela 6.28 - Dosagens do Grupo 4,5.

\begin{tabular}{|c|c|c|c|c|c|c|c|}
\hline GRUPO 4,5 & REF & $\begin{array}{l}\text { RGV - } \\
100 \%\end{array}$ & $\begin{array}{c}\text { RGV - } \\
50 \%\end{array}$ & $\begin{array}{c}\text { RGV - } \\
50 \%+ \\
\text { RMV - } \\
33 \%\end{array}$ & $\begin{array}{l}\text { RGB - } \\
100 \%\end{array}$ & $\begin{array}{c}\text { RGB - } \\
50 \%\end{array}$ & $\begin{array}{c}\text { RGB - } \\
50 \%+ \\
\text { RMB - } \\
33 \%\end{array}$ \\
\hline TRAÇO (Cimento:Agregados) & $1: 20,00$ & $1: 19,33$ & $1: 19,64$ & $1: 19,29$ & $1: 19,45$ & $1: 19,71$ & $1: 19,52$ \\
\hline Energia de adensamento (golpes) & 15 & 15 & 15 & 15 & 15 & 15 & 15 \\
\hline \begin{tabular}{cc} 
& Cimento \\
\cline { 2 - 2 }
\end{tabular} & 116,4 & 116,4 & 116,4 & 116,4 & 116,4 & 116,4 & 116,4 \\
\hline Pedrisco & 698,6 & - & 326,6 & 327,3 & - & 330,9 & 331,1 \\
\hline Vigota-GRv & - & 613,0 & 326,6 & 327,3 & - & - & - \\
\hline Consumo de & - & - & - & - & 628,1 & 330,9 & 331,1 \\
\hline materiais & 931,5 & 931,2 & 931,3 & 605,2 & 931,3 & 931,5 & 612,6 \\
\hline Vigota - MRv & - & - & - & 302,6 & - & - & - \\
\hline Bloco - MRb & - & - & - & - & - & - & 306,3 \\
\hline Areia Tietz & 698,6 & 706,2 & 702,6 & 683,3 & 704,8 & 701,5 & 691,6 \\
\hline Água & 122,3 & 138,2 & 130,7 & 148,1 & 139,1 & 131,1 & 143,0 \\
\hline Pedrisco (\%) & 30,00 & - & 14,28 & 14,58 & - & 14,42 & 14,57 \\
\hline GRvl \%GRb (\%) & - & 27,24 & 14,28 & 14,58 & 27,74 & 14,42 & 14,57 \\
\hline Areia Tietz (\%) & 30,00 & 31,38 & 30,72 & 30,43 & 31,13 & 30,58 & 30,43 \\
\hline MRvl \%MRb (\%) & - & - & - & 13,48 & - & - & 13,48 \\
\hline Pó de pedra (\%) & 40,00 & 41,38 & 40,72 & 26,95 & 41,13 & 40,58 & 26,95 \\
\hline Umidade total* (\%) & 5,00 & 5,84 & 5,44 & 6,27 & 5,84 & 5,44 & 5,99 \\
\hline Umidade efetiva ${ }^{\star \star}(\%)$ & - & 5,40 & 5,21 & 5,52 & 5,29 & 5,15 & 5,28 \\
\hline Aditivo, em relação à massa de cimento (\%) & 0,20 & 0,20 & 0,20 & 0,20 & 0,20 & 0,20 & 0,20 \\
\hline Teor de argamassa (\%) & 71,43 & 74,10 & 72,82 & 72,29 & 73,62 & 72,55 & 72,28 \\
\hline Teor de argamassa em volume (\%) & 71,45 & 71,45 & 71,45 & 71,45 & 71,45 & 71,44 & 71,45 \\
\hline Módulo de finura da mistura & 3,38 & 3,38 & 3,38 & 3,40 & 3,25 & 3,31 & 3,34 \\
\hline Material grosso - retido peneiras $(4,8$ e $2,4 \mathrm{~mm})$ & $39 \%$ & $37 \%$ & $38 \%$ & $37 \%$ & $36 \%$ & $37 \%$ & $36 \%$ \\
\hline $\begin{array}{c}\text { Material médio - retido peneiras }(1,2,0,6 \mathrm{e} \\
0,3 \mathrm{~mm})\end{array}$ & $43 \%$ & $45 \%$ & $44 \%$ & $46 \%$ & $46 \%$ & $45 \%$ & $48 \%$ \\
\hline Material fino - retido peneiras $(0,15 \mathrm{~mm}$ e fundo) & $18 \%$ & $18 \%$ & $18 \%$ & $17 \%$ & $18 \%$ & $18 \%$ & $16 \%$ \\
\hline
\end{tabular}

Pela Tabela 6.28, nota-se que para todas as dosagens foi mantido o mesmo consumo de cimento $\left(116,4 \mathrm{~kg} / \mathrm{m}^{3}\right)$ e o mesmo teor de argamassa $(71,45 \%$, em volume). A elevada absorção do material reciclado motivou um aumento da umidade total da mistura, justamente para suprir a elevada absorção do material. Para as dosagens com agregados reciclados de bloco (ARb) ocorreu uma diminuição do módulo de finura final da mistura, quando comparadas com as demais dosagens, devido ao menor módulo de finura do agregado graúdo reciclado de bloco.

\subsection{Grupo 8,0}

$\mathrm{Na}$ Tabela 6.29, encontram-se as dosagens avaliadas pertencentes ao Grupo 8,0. 
Tabela 6.29 - Dosagens do Grupo 8,0.

\begin{tabular}{|c|c|c|c|c|c|c|c|c|}
\hline & GRUPO 8,0 & REF & $\begin{array}{l}\text { RGV - } \\
100 \%\end{array}$ & $\begin{array}{c}\text { RGV - } \\
50 \%\end{array}$ & $\begin{array}{c}\text { RGV - } \\
50 \%+ \\
\text { RMV - } \\
33 \%\end{array}$ & $\begin{array}{l}\text { RGB - } \\
100 \%\end{array}$ & $\begin{array}{c}\text { RGB - } \\
50 \%\end{array}$ & $\begin{array}{c}\text { RGB - } \\
50 \%+ \\
\text { RMB - } \\
33 \%\end{array}$ \\
\hline \multicolumn{2}{|c|}{ TRAÇO (Cimento:Agregados) } & $1: 15,00$ & $1: 14,50$ & $1: 14,73$ & $1: 14,47$ & $1: 14,58$ & $1: 14,78$ & $1: 14,64$ \\
\hline \multicolumn{2}{|c|}{ Energia de adensamento (golpes) } & 15 & 15 & 15 & 15 & 15 & 15 & 15 \\
\hline \multirow{9}{*}{$\begin{array}{c}\text { Consumo de } \\
\text { materiais } \\
\left(\mathrm{kg} / \mathrm{m}^{3}\right)\end{array}$} & Cimento & 153,0 & 153,0 & 153,0 & 153,0 & 153,0 & 153,0 & 153,0 \\
\hline & Pedrisco & 688,7 & - & 321,8 & 322,6 & - & 326,1 & 326,4 \\
\hline & Vigota - GRv & - & 604,3 & 321,8 & 322,6 & - & - & - \\
\hline & Bloco - GRb & - & - & - & - & 619,1 & 326,1 & 326,4 \\
\hline & Pó de pedra & 918,2 & 917,9 & 918,1 & 596,7 & 918,0 & 918,1 & 603,9 \\
\hline & Vigota-MRv & - & - & - & 298,4 & - & - & - \\
\hline & Bloco - MRb & - & - & - & - & - & - & 301,9 \\
\hline & Areia Tietz & 688,7 & 696,1 & 692,7 & 673,7 & 694,8 & 691,9 & 681,8 \\
\hline & Água & 122,4 & 138,1 & 120,4 & 147,9 & 139,0 & 131,2 & 142,9 \\
\hline \multicolumn{2}{|r|}{ Pedrisco (\%) } & 30,00 & - & 14,28 & 14,57 & - & 14,42 & 14,57 \\
\hline \multicolumn{2}{|r|}{ GRvl \%GRb (\%) } & - & 27,24 & 14,28 & 14,57 & 27,74 & 14,42 & 14,57 \\
\hline \multicolumn{2}{|r|}{ Areia Tietz (\%) } & 30,00 & 31,38 & 30,72 & 30,43 & 31,13 & 30,58 & 30,43 \\
\hline \multicolumn{2}{|r|}{ MRvl \%MRb (\%) } & - & - & - & 13,48 & - & - & 13,48 \\
\hline \multicolumn{2}{|r|}{ Pó de pedra (\%) } & 40,00 & 41,38 & 40,72 & 26,95 & 41,13 & 40,58 & 26,95 \\
\hline \multicolumn{2}{|r|}{ Umidade total $(\%)^{*}$} & 5,00 & 5,83 & 5,43 & 6,25 & 5,83 & 5,43 & 5,97 \\
\hline \multicolumn{2}{|r|}{ Umidade efetiva (\%) ${ }^{\star \star}$} & - & 5,39 & 5,21 & 5,51 & 5,28 & 5,15 & 5,28 \\
\hline \multicolumn{2}{|c|}{ Aditivo, em relação à massa de cimento (\%) } & 0,20 & 0,20 & 0,20 & 0,20 & 0,20 & 0,20 & 0,20 \\
\hline \multicolumn{2}{|c|}{ Teor de argamassa (\%) } & 71,88 & 74,52 & 73,26 & 72,74 & 74,04 & 73,00 & 72,72 \\
\hline \multicolumn{2}{|c|}{ Teor de argamassa em volume (\%) } & 71,85 & 71,85 & 71,85 & 71,85 & 71,85 & 71,85 & 71,85 \\
\hline \multicolumn{2}{|c|}{ Módulo de finura da mistura } & 3,38 & 3,38 & 3,38 & 3,40 & 3,25 & 3,31 & 3,34 \\
\hline \multicolumn{2}{|c|}{ Material grosso - retido peneiras $(4,8$ e $2,4 \mathrm{~mm})$} & $39 \%$ & $37 \%$ & $38 \%$ & $37 \%$ & $36 \%$ & $37 \%$ & $36 \%$ \\
\hline \multicolumn{2}{|c|}{ Material médio - retido peneiras $(1,2,0,6$ e $0,3 \mathrm{~mm})$} & $43 \%$ & $45 \%$ & $44 \%$ & $46 \%$ & $46 \%$ & $45 \%$ & $48 \%$ \\
\hline \multicolumn{2}{|c|}{ Material fino - retido peneiras $(0,15 \mathrm{~mm}$ e fundo $)$} & $18 \%$ & $18 \%$ & $18 \%$ & $17 \%$ & $18 \%$ & $18 \%$ & $16 \%$ \\
\hline
\end{tabular}

* Umidade total: refere-se à quantidade total de água adicionada na mistura. Para os traços com agregados reciclados, foi adicionada

também uma parcela de água referente à absorção do agregado reciclado (cerca de $70 \%$ da absorção final do material)

** Umidade efetiva: nesse caso, desconta-se da quantidade total de água adicionada na mistura à parcela que será absorvida pelo

agregado até se chegar à condição de $70 \%$ da absorção final. Para se conhecer a quantidade de água absorvida pelo agregado,

considera-se também a umidade inicial do agregado (GRv - 1,55\%; MRv - 2,35\%; GRb - 1,09\%; MRb - 1,01\%)

Pela Tabela 6.29, nota-se que para todas as dosagens foi mantido o mesmo consumo de cimento $\left(153,0 \mathrm{~kg} / \mathrm{m}^{3}\right)$ e o mesmo teor de argamassa $(71,85 \%$, em volume). A elevada absorção do material reciclado motivou um aumento da umidade total da mistura, justamente para suprir a elevada absorção do material.

\subsection{Grupo 12,0}

$\mathrm{Na}$ Tabela 6.30, encontram-se as dosagens avaliadas pertencentes ao Grupo 12,0. 
Tabela 6.30 - Dosagens do Grupo 12,0.

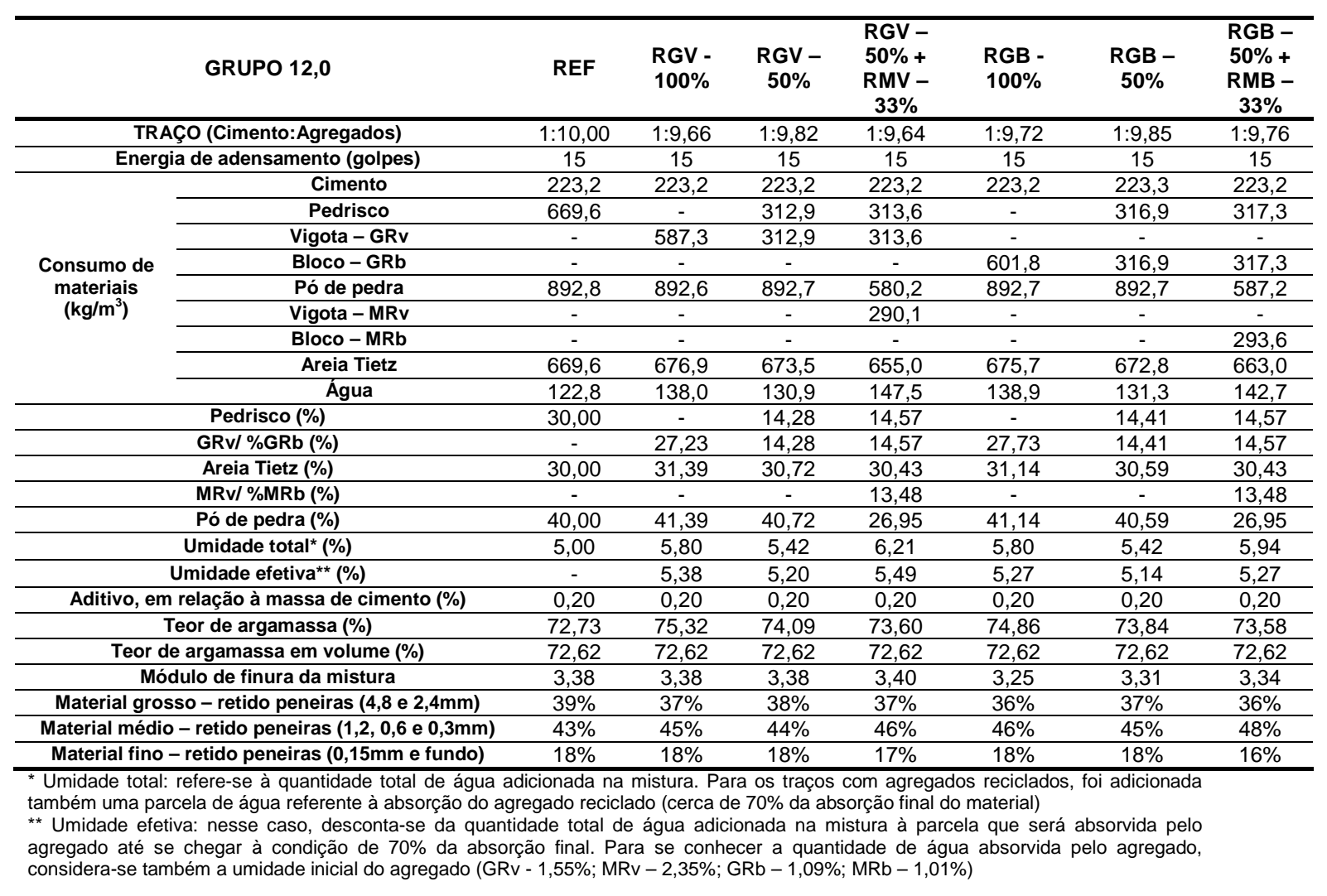

\subsection{Propriedades físicas}

Os resultados das propriedades físicas são apresentados nos itens a seguir e, posteriormente, é feita uma análise global desses resultados mediante a utilização do teste ANOVA. As propriedades físicas avaliadas para os exemplares dos Grupos 4,5, 8,0 e 12,0 aos sete e vinte e oito dias foram: coesão, massa específica fresca, teor de ar incorporado, massa específica seca, massa específica saturada superfície seca, absorção de água e índice de vazios. Os resultados das propriedades físicas permitirão a definição de quais dosagens serão adequadas para a produção dos blocos de concreto, uma vez que será admitida, no máximo, um aumento de $30 \%$ nos valores de absorção de água e índice de vazios para as dosagens com agregados reciclados comparativamente às dosagens de referência.

\subsection{Grupo 4,5}

$\mathrm{Na}$ Tabela 6.31, encontram-se os resultados das propriedades físicas dos CPs produzidos com as dosagens do Grupo 4,5. 
Tabela 6.31 - Propriedades físicas dos CPs do Grupo 4,5.

\begin{tabular}{|c|c|c|c|c|c|c|c|c|c|}
\hline \multirow[b]{2}{*}{ GRUPO 4,5 } & \multirow[b]{2}{*}{ Idade } & \multirow[b]{2}{*}{$\begin{array}{l}\text { Parâme- } \\
\text { tros }\end{array}$} & \multicolumn{7}{|c|}{ Dosagens } \\
\hline & & & REF & $\begin{array}{l}\text { RGV - } \\
100 \%\end{array}$ & $\begin{array}{l}\text { RGV - } \\
50 \%\end{array}$ & $\begin{array}{c}\text { RGV - } \\
50 \%+ \\
\text { RMV - } \\
33 \%\end{array}$ & $\begin{array}{l}\text { RGB - } \\
100 \%\end{array}$ & $\begin{array}{l}\text { RGB - } \\
50 \%\end{array}$ & $\begin{array}{c}\text { RGB - } \\
50 \%+ \\
\text { RMB - } \\
33 \%\end{array}$ \\
\hline $\begin{array}{l}\text { Energia de adensamento } \\
\text { (golpes) }\end{array}$ & & & 15 & 15 & 15 & 15 & 15 & 15 & 15 \\
\hline $\begin{array}{c}\text { Temperatura durante a } \\
\text { moldagem }\left({ }^{\circ} \mathrm{C}\right)\end{array}$ & & & 20,7 & 19,3 & 20,2 & 19,5 & 21,0 & 18,6 & 19,4 \\
\hline $\begin{array}{c}\text { Umidade durante a } \\
\text { moldagem (\%) }\end{array}$ & & & 59 & 61 & 58 & 66 & 55 & 57 & 62 \\
\hline \multirow{3}{*}{ Coesão (g) } & & Média & 6725 & 6546 & 7160 & 6830 & 4940 & 7280 & 5538 \\
\hline & & $\mathrm{S}_{\mathrm{d}}$ & 1543 & 1272 & 813 & 1279 & 51 & 482 & 258 \\
\hline & & C. V. (\%) & 22,94 & 19,43 & 11,35 & 18,73 & 1,03 & 6,62 & 4,66 \\
\hline \multirow{6}{*}{$\begin{array}{l}\text { Massa específica fresca } \\
\left(\mathbf{k g} / \mathrm{dm}^{3}\right)\end{array}$} & \multirow{3}{*}{7} & Média & 2,367 & 2,267 & 2,308 & 2,243 & 2,252 & 2,315 & 2,272 \\
\hline & & $S_{d}$ & 0,010 & 0,015 & 0,006 & 0,007 & 0,016 & 0,011 & 0,005 \\
\hline & & C. V. (\%) & 0,41 & 0,67 & 0,27 & 0,31 & 0,72 & 0,49 & 0,22 \\
\hline & \multirow{3}{*}{28} & Média & 2,362 & 2,280 & 2,315 & 2,220 & 2,240 & 2,309 & 2,275 \\
\hline & & $S_{d}$ & 0,019 & 0,004 & 0,010 & 0,012 & 0,003 & 0,008 & 0,012 \\
\hline & & C. V. (\%) & 0,79 & 0,20 & 0,42 & 0,55 & 0,12 & 0,35 & 0,51 \\
\hline \multirow{6}{*}{ Teor de ar incorporado (\%) } & \multirow{3}{*}{7} & Média & 7,81 & 9,13 & 8,73 & 10,03 & 10,14 & 8,70 & 9,67 \\
\hline & & $\mathrm{S}_{\mathrm{d}}$ & 0,38 & 0,60 & 0,25 & 0,28 & 0,65 & 0,44 & 0,20 \\
\hline & & C. V. (\%) & 4,83 & 6,62 & 2,88 & 2,77 & 6,39 & 5,11 & 2,02 \\
\hline & \multirow{3}{*}{28} & Média & 8,01 & 8,62 & 8,45 & 10,94 & 10,62 & 8,93 & 9,53 \\
\hline & & $\mathrm{S}_{d}$ & 0,72 & 0,18 & 0,38 & 0,49 & 0,11 & 0,32 & 0,46 \\
\hline & & C. V. (\%) & 9,04 & 2,07 & 4,51 & 4,46 & 1,01 & 3,53 & 4,83 \\
\hline \multirow{6}{*}{$\gamma \mathrm{s}^{*}\left(\mathrm{~kg} / \mathrm{dm}^{3}\right)$} & \multirow{3}{*}{7} & Média & 2,331 & 2,191 & 2,246 & 2,157 & 2,174 & 2,240 & 2,201 \\
\hline & & $\mathrm{S}_{\mathrm{d}}$ & 0,018 & 0,006 & 0,007 & 0,004 & 0,002 & 0,031 & 0,013 \\
\hline & & C. V. (\%) & 0,76 & 0,30 & 0,33 & 0,19 & 0,07 & 1,36 & 0,57 \\
\hline & \multirow{3}{*}{28} & Média & 2,328 & 2,198 & 2,270 & 2,159 & 2,180 & 2,255 & 2,229 \\
\hline & & $\mathrm{S}_{\mathrm{d}}$ & 0,018 & 0,008 & 0,010 & 0,018 & 0,028 & 0,028 & 0,007 \\
\hline & & C. V. (\%) & 0,79 & 0,40 & 0,45 & 0,84 & 1,27 & 1,26 & 0,33 \\
\hline \multirow{6}{*}{$\gamma \mathrm{ssd}^{\star \star}\left(\mathrm{kg} / \mathrm{dm}^{3}\right)$} & \multirow{3}{*}{7} & Média & 2,443 & 2,324 & 2,369 & 2,301 & 2,310 & 2,373 & 2,338 \\
\hline & & $S_{d}$ & 0,001 & 0,003 & 0,004 & 0,003 & 0,001 & 0,033 & 0,015 \\
\hline & & C. V. (\%) & 0,36 & 0,12 & 0,16 & 0,13 & 0,04 & 1,37 & 0,63 \\
\hline & \multirow{3}{*}{28} & Média & 2,440 & 2,334 & 2,390 & 2,303 & 2,316 & 2,387 & 2,353 \\
\hline & & $\mathrm{S}_{\mathrm{d}}$ & 0,013 & 0,010 & 0,005 & 0,010 & 0,016 & 0,019 & 0,010 \\
\hline & & C. V. (\%) & 0,52 & 0,42 & 0,22 & 0,43 & 0,68 & 0,77 & 0,42 \\
\hline \multirow{6}{*}{ Absorção de água (\%) } & \multirow{3}{*}{7} & Média & 4,81 & 6,09 & 5,45 & 6,68 & 6,28 & 5,95 & 6,21 \\
\hline & & $\mathrm{S}_{\mathrm{d}}$ & 0,42 & 0,24 & 0,27 & 0,23 & 0,11 & 0,31 & 0,17 \\
\hline & & C. V. (\%) & 8,76 & 4,00 & 4,90 & 3,51 & 1,80 & 5,14 & 2,77 \\
\hline & \multirow{3}{*}{28} & Média & 4,84 & 6,18 & 5,26 & 6,64 & 6,26 & 5,87 & 5,57 \\
\hline & & $S_{d}$ & 0,33 & 0,23 & 0,24 & 0,58 & 0,63 & 0,56 & 0,10 \\
\hline & & C. V. (\%) & 6,89 & 3,69 & 4,47 & 8,66 & 10,04 & 9,50 & 1,73 \\
\hline \multirow{6}{*}{ Índice de vazios (\%) } & \multirow{3}{*}{7} & Média & 11,20 & 13,34 & 12,25 & 14,41 & 13,65 & 13,32 & 13,68 \\
\hline & & $S_{d}$ & 0,90 & 0,50 & 0,56 & 0,48 & 0,24 & 0,69 & 0,40 \\
\hline & & C. V. (\%) & 8,02 & 3,72 & 4,61 & 3,36 & 1,74 & 5,19 & 2,95 \\
\hline & & Média & 11,27 & 13,57 & 11,94 & 14,33 & 13,63 & 13,24 & 12,43 \\
\hline & 28 & $S_{d}$ & 0,70 & 0,49 & 0,48 & 1,13 & 1,19 & 1,10 & 0,26 \\
\hline & & C. V. (\%) & 6,21 & 3,64 & 4,02 & 7,89 & 8,74 & 8,30 & 2,05 \\
\hline
\end{tabular}

* massa específica seca; ** massa específica saturada superfície seca

\subsection{Grupo 8,0}

$\mathrm{Na}$ Tabela 6.32, encontram-se os resultados das propriedades físicas dos CPs produzidos com as dosagens do Grupo 8,0. 
Tabela 6.32 - Propriedades físicas dos CPs do Grupo 8,0.

\begin{tabular}{|c|c|c|c|c|c|c|c|c|c|}
\hline \multirow[b]{2}{*}{ GRUPO 8,0 } & \multirow[b]{2}{*}{ Idade } & \multirow[b]{2}{*}{$\begin{array}{l}\text { Parâme- } \\
\text { tros }\end{array}$} & \multicolumn{7}{|c|}{ Dosagens } \\
\hline & & & REF & $\begin{array}{l}\text { RGV - } \\
100 \%\end{array}$ & $\begin{array}{c}\text { RGV - } \\
50 \%\end{array}$ & $\begin{array}{c}\text { RGV - } \\
50 \%+ \\
\text { RMV - } \\
33 \%\end{array}$ & $\begin{array}{l}\text { RGB - } \\
100 \%\end{array}$ & $\begin{array}{c}\text { RGB - } \\
50 \%\end{array}$ & $\begin{array}{c}\text { RGB - } \\
50 \%+ \\
\text { RMB - } \\
33 \%\end{array}$ \\
\hline $\begin{array}{c}\text { Energia de adensamento } \\
\text { (golpes) }\end{array}$ & & & 15 & 15 & 15 & 15 & 15 & 15 & 15 \\
\hline $\begin{array}{c}\text { Temperatura durante a } \\
\text { moldagem }\left({ }^{\circ} \mathrm{C}\right)\end{array}$ & & & 20,3 & 17,4 & 17,2 & 19,1 & 16,8 & 18,1 & 21,9 \\
\hline $\begin{array}{c}\text { Umidade durante a } \\
\text { moldagem (\%) }\end{array}$ & & & 55 & 70 & 69 & 59 & 71 & 74 & 52 \\
\hline \multirow{3}{*}{ Coesão $(g)$} & & Média & 8108 & 8267 & 7916 & 7028 & 6765 & 7348 & 6841 \\
\hline & & $\mathrm{S}_{\mathrm{d}}$ & 248 & 463 & 253 & 667 & 1237 & 766 & 406 \\
\hline & & C. V. (\%) & 3,06 & 5,60 & 3,29 & 9,49 & 18,28 & 10,42 & 5,93 \\
\hline \multirow{6}{*}{$\begin{array}{c}\text { Massa específica fresca } \\
\left(\mathbf{k g} / \mathrm{dm}^{3}\right)\end{array}$} & \multirow{3}{*}{7} & Média & 2,408 & 2,302 & 2,351 & 2,281 & 2,311 & 2,359 & 2,286 \\
\hline & & $S_{d}$ & 0,007 & 0,006 & 0,012 & 0,006 & 0,016 & 0,004 & 0,006 \\
\hline & & C. V. (\%) & 0,28 & 0,26 & 0,50 & 0,26 & 0,69 & 0,18 & 0,26 \\
\hline & \multirow{3}{*}{28} & Média & 2,401 & 2,298 & 2,361 & 2,258 & 2,299 & 2,352 & - \\
\hline & & $S_{d}$ & 0,015 & 0,013 & 0,007 & 0,004 & 0,006 & 0,013 & - \\
\hline & & C. V. (\%) & 0,62 & 0,54 & 0,28 & 0,16 & 0,25 & 0,55 & - \\
\hline \multirow{6}{*}{ Teor de ar incorporado (\%) } & \multirow{3}{*}{7} & Média & 6,32 & 7,90 & 7,20 & 8,65 & 7,97 & 7,11 & 9,29 \\
\hline & & $\mathrm{S}_{\mathrm{d}}$ & 0,26 & 0,23 & 0,46 & 0,24 & 0,63 & 0,17 & 0,23 \\
\hline & & C. V. (\%) & 4,07 & 2,97 & 6,43 & 2,75 & 7,91 & 2,40 & 2,51 \\
\hline & \multirow{3}{*}{28} & Média & 6,61 & 8,05 & 6,80 & 9,58 & 8,46 & 7,37 & - \\
\hline & & $S_{d}$ & 0,58 & 0,50 & 0,26 & 0,15 & 0,23 & 0,51 & - \\
\hline & & C. V. (\%) & 8,78 & 6,22 & 3,84 & 1,54 & 2,68 & 6,95 & - \\
\hline \multirow{6}{*}{$\gamma_{\mathrm{s}^{*}}\left(\mathrm{~kg} / \mathrm{dm}^{3}\right)$} & \multirow{3}{*}{7} & Média & 2,348 & 2,208 & 2,272 & 2,181 & 2,221 & 2,287 & 2,215 \\
\hline & & $\mathrm{S}_{\mathrm{d}}$ & 0,016 & 0,012 & 0,010 & 0,008 & 0,005 & 0,007 & 0,009 \\
\hline & & C. V. (\%) & 0,70 & 0,55 & 0,44 & 0,35 & 0,20 & 1,29 & 0,39 \\
\hline & \multirow{3}{*}{28} & Média & 2,350 & 2,229 & 2,274 & 2,202 & 2,234 & 2,305 & - \\
\hline & & $S_{d}$ & 0,003 & 0,022 & 0,019 & 0,004 & 0,015 & 0,009 & - \\
\hline & & C. V. (\%) & 0,12 & 1,00 & 0,85 & 0,20 & 0,67 & 0,39 & - \\
\hline \multirow{6}{*}{$\gamma \mathrm{ssd}^{\star \star}\left(\mathrm{kg} / \mathrm{dm}^{3}\right)$} & \multirow{3}{*}{7} & Média & 2,463 & 2,348 & 2,398 & 2,317 & 2,353 & 2,408 & 2,351 \\
\hline & & $S_{d}$ & 0,011 & 0,013 & 0,002 & 0,005 & 0,004 & 0,007 & 0,001 \\
\hline & & C. V. (\%) & 0,45 & 0,54 & 0,10 & 0,23 & 0,15 & 0,30 & 0,05 \\
\hline & \multirow{3}{*}{28} & Média & 2,466 & 2,363 & 2,395 & 2,336 & 2,378 & 2,439 & - \\
\hline & & $S_{d}$ & 0,004 & 0,020 & 0,016 & 0,004 & 0,012 & 0,009 & - \\
\hline & & C. V. (\%) & 0,17 & 0,83 & 0,65 & 0,16 & 0,49 & 0,37 & - \\
\hline \multirow{6}{*}{ Absorção de água (\%) } & \multirow{3}{*}{7} & Média & 4,90 & 6,36 & 5,56 & 6,22 & 5,95 & 5,29 & 6,13 \\
\hline & & $S_{d}$ & 0,37 & 0,16 & 0,40 & 0,18 & 0,06 & 0,02 & 0,35 \\
\hline & & C. V. (\%) & 7,54 & 2,51 & 7,25 & 2,91 & 1,02 & 0,36 & 5,74 \\
\hline & \multirow{3}{*}{28} & Média & 4,97 & 6,04 & 5,33 & 6,07 & 6,46 & 5,79 & - \\
\hline & & $S_{d}$ & 0,05 & 0,26 & 0,22 & 0,07 & 0,31 & 0,02 & - \\
\hline & & C. V. (\%) & 1,08 & 4,33 & 4,04 & 1,12 & 4,75 & 0,35 & - \\
\hline \multirow{6}{*}{ Índice de vazios (\%) } & \multirow{3}{*}{7} & Média & 11,50 & 14,03 & 12,63 & 13,57 & 13,21 & 12,10 & 13,59 \\
\hline & & $S_{d}$ & 0,80 & 0,35 & 0,86 & 0,36 & 0,11 & 0,06 & 0,73 \\
\hline & & C. V. (\%) & 6,98 & 2,47 & 6,82 & 2,64 & 0,84 & 0,53 & 5,35 \\
\hline & & Média & 11,68 & 13,46 & 12,12 & 13,36 & 14,43 & 13,34 & - \\
\hline & 28 & $S_{d}$ & 0,14 & 0,49 & 0,39 & 0,13 & 0,62 & 0,04 & - \\
\hline & & C. V. (\%) & 1,20 & 3,61 & 3,21 & 0,99 & 4,29 & 0,27 & - \\
\hline
\end{tabular}

* massa específica seca; ** massa específica saturada superfície seca

\subsection{Grupo 12,0}

$\mathrm{Na}$ Tabela 6.33, encontram-se os resultados das propriedades físicas dos CPs produzidos com as dosagens do Grupo 12,0. 
Tabela 6.33 - Propriedades físicas dos CPs do Grupo 12,0.

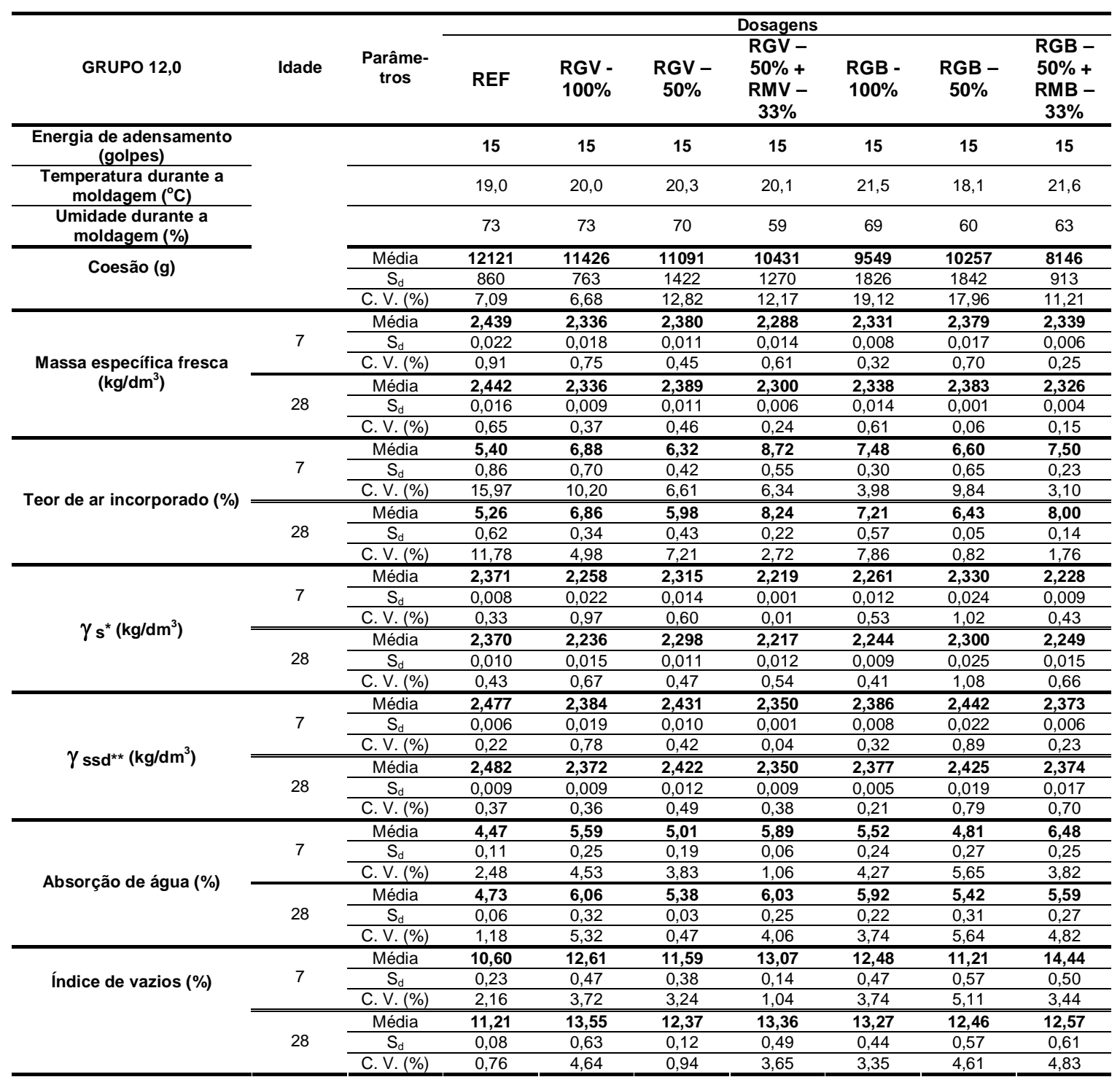

* massa específica seca; ** massa específica saturada superfície seca

\subsection{Análise dos resultados - propriedades físicas}

Neste item, é utilizado o teste de Análise de Variância na avaliação global dos resultados obtidos para as propriedades físicas dos exemplares. As variáveis são analisadas isoladamente, isto é, verifica-se a influência separada dessas variáveis sobre as propriedades físicas. As variáveis em questão são as seguintes: a) Grupos/Classes de Resistência (4,5; 8,0 e 12,0); b) Dosagens/Composições dos traços (REF, RGV-100\%, RGV-50\%, RGV-50\% + RMV-33\%; RGB-100\%, RGB-50\%, RGB-50\% +RMB-33\%); c) Idade (7 dias e 28 dias). $\mathrm{Na}$ análise de $2^{\mathrm{a}}$ ordem, os parâmetros são avaliados dois a dois (grupos e traços; grupos e idades; dosagens e idades) e, finalmente, na análise de $3^{\mathrm{a}}$ ordem, os parâmetros são avaliados três a três (grupos e traços e idades). Essa análise permitirá uma 
avaliação precisa da influência desses três parâmetros sobre as propriedades físicas dos CPs. Na Tabela 6.34, são apresentados os resultados do teste ANOVA. 
Tabela 6.34 - Teste ANOVA para as propriedades físicas dos corpos-de-prova.

\begin{tabular}{|c|c|c|c|c|c|c|c|c|c|c|c|c|c|}
\hline \multirow[b]{3}{*}{ 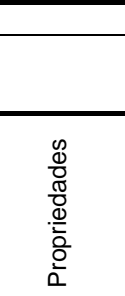 } & \multirow[b]{3}{*}{ Variáveis } & \multicolumn{12}{|c|}{ Comparações } \\
\hline & & \multicolumn{3}{|c|}{ Comparação com o traço de referência } & \multicolumn{5}{|c|}{ Diferentes porcentagens do mesmo resíduo } & \multicolumn{4}{|c|}{$\begin{array}{l}\text { Diferentes resíduos (porcentagens } \\
\text { similares de substituição) }\end{array}$} \\
\hline & & $\begin{array}{l}\text { REF X } \\
\operatorname{REC}^{6}\end{array}$ & $\begin{array}{c}\text { REF x } \\
\text { RGV100\% } \\
\text { x RGV50\% } \\
\text { x RGV50\% } \\
+ \text { RMV33\% }\end{array}$ & $\begin{array}{c}\text { REF x } \\
\text { RGB100\% } \\
\text { x RGB50\% } \\
\text { x RGB50\% } \\
+ \text { RMB33\% }\end{array}$ & $\begin{array}{l}\text { RGV100\% } \\
\text { x RGV50\% } \\
\text { x RGV50\% } \\
+ \text { RMV33\% }\end{array}$ & $\begin{array}{l}\text { RGB100\% } \\
\text { x RGB50\% } \\
\text { x RGB50\% } \\
+ \text { RMB33\% }\end{array}$ & $\begin{array}{c}\text { RGV100\% } \\
x \\
\text { RGV-50\% }\end{array}$ & $\begin{array}{c}\text { RGB100\% } \\
x \\
\text { RGB-50\% }\end{array}$ & $\begin{array}{c}\text { RGV50\% x } \\
\text { RGV50\% + } \\
\text { RMV33\% }\end{array}$ & $\begin{array}{c}\text { RGB50\% x } \\
\text { RGB50\% + } \\
\text { RMB33\% }\end{array}$ & $\begin{array}{l}\text { RGV100\% x } \\
\text { RGB100\% }\end{array}$ & $\begin{array}{l}\text { RGV50\% x } \\
\text { RGB50\% }\end{array}$ & $\begin{array}{c}\text { RGV50\%+ } \\
\text { RMV33\% x } \\
\text { RGB50\% + } \\
\text { RMB33\% }\end{array}$ \\
\hline \multirow{3}{*}{ Coesão $^{0}$} & Grupos & $S(86,7)$ & $S(66,8)$ & $\mathrm{S}(43,2)$ & $S(44,8)$ & $S(24,0)$ & $\mathrm{S}(38,1)$ & $S(15,3)$ & $S(23,5)$ & $S(14,3)$ & $\mathrm{S}(29,6)$ & $S(18,3)$ & $S(19,9)$ \\
\hline & Traços & $S(6,1)$ & - & $\mathrm{S}(8,4)$ & - & $\mathrm{S}(5,0)$ & - & - & - & $\mathrm{S}(11,1)$ & $\mathrm{S}(10,7)$ & - & $\mathrm{S}(8,9)$ \\
\hline & $\mathrm{Gr} \times \mathrm{Tr}^{2}$ & - & - & - & - & - & - & - & - & - & - & - & - \\
\hline \multirow{3}{*}{$\begin{array}{l}\text { Teor de } \\
\text { ar } \\
\text { incorpo- } \\
\text { rado }^{0}\end{array}$} & Grupos & $\mathrm{S}(290,8)$ & $\mathrm{S}(145,2)$ & $\mathrm{S}(163,1)$ & $\mathrm{S}(130,2)$ & $\mathrm{S}(150,5)$ & $\mathrm{S}(82,6)$ & $\mathrm{S}(117,3)$ & $\mathrm{S}(115,1)$ & $\mathrm{S}(89,3)$ & $\mathrm{S}(84,7)$ & $\mathrm{S}(112,5)$ & $\mathrm{S}(84,7)$ \\
\hline & Traços & $\mathrm{S}(87,7)$ & $\mathrm{S}(120,3)$ & $\mathrm{S}(87,8)$ & $\mathrm{S}(130,3)$ & $S(49,4)$ & $S(21,7)$ & $S(59,0)$ & $\mathrm{S}(301,5)$ & $\mathrm{S}(22,8)$ & $\mathrm{S}(22,6)$ & $\mathrm{S}(4,5)$ & $S(22,6)$ \\
\hline & $\mathrm{Gr} \times \operatorname{Tr}^{2}$ & $\mathrm{~S}(2,4)$ & - & $\mathrm{S}(3,3)$ & - & $\mathrm{S}(6,1)$ & - & - & - & $S(6,2)$ & $\mathrm{S}(3,9)$ & - & $\mathrm{S}(3,9)$ \\
\hline \multirow{7}{*}{$\gamma_{s}{ }^{1}$} & Grupos & $\mathrm{S}(129,8)^{\top}$ & $\mathrm{S}(91,5)$ & $S(50,3)^{8}$ & $S(80,0)$ & $\mathrm{S}(46,7)^{8}$ & $\mathrm{~S}(39,8)$ & $\mathrm{S}(45,5)$ & $\mathrm{S}(72,7)$ & $\mathrm{S}(16,7)^{8}$ & $\mathrm{~S}(55,4)$ & $\mathrm{S}(31,0)$ & $\mathrm{S}(45,9)^{8}$ \\
\hline & Traços & $\mathrm{S}(271,5)^{\prime}$ & $S(539,7)$ & $\mathrm{S}(165,6)^{8}$ & $\mathrm{~S}(233,3)$ & $S(63,7)^{8}$ & $\mathrm{~S}(162,3)$ & $\mathrm{S}(115,1)$ & $S(602,5)$ & $\mathrm{S}(73,1)^{8}$ & - & - & $S(58,7)^{8}$ \\
\hline & Idades & - & - & & & & - & - & - & - & - & - & - \\
\hline & $\mathrm{Gr} \times \mathrm{Tr}^{2}$ & - & - & $\mathrm{S}(3,6)^{8}$ & & $\mathrm{~S}(4,2)^{8}$ & - & - & - & $\mathrm{S}(4,8)^{8}$ & - & - & $\mathrm{S}(7,2)^{8}$ \\
\hline & $\mathrm{Gr} \times \mathrm{Id}^{3}$ & $\mathrm{~S}(8,5)^{\prime}$ & $S(4,7)$ & - & $S(6,4)$ & - & $S(5,4)$ & $\mathrm{S}(3,8)$ & $S(3,8)$ & - & $\mathrm{S}(4,7)$ & $S(4,6)$ & - \\
\hline & $\operatorname{Tr} \times 1 d^{4}$ & - & - & - & - & - & - & - & - & - & - & - & - \\
\hline & $\mathrm{Gr} \times \operatorname{Tr} \times \mathrm{Id}^{5}$ & - & - & - & - & - & - & - & - & - & - & - & - \\
\hline \multirow{7}{*}{$\begin{array}{l}\text { Absorção } \\
\text { de água }\end{array}$} & Grupos & $\mathrm{S}(25,9)^{\top}$ & $\mathrm{S}(12,1)$ & $\mathrm{S}(11,2)^{8}$ & $\mathrm{~S}(10,7)$ & $S(13,6)^{8}$ & $S(5,3)$ & $S(14,4)$ & $\mathrm{S}(8,1)$ & $\mathrm{S}(5,2)^{8}$ & $S(9,0)$ & $S(9,5)$ & - \\
\hline & Traços & $\mathrm{S}(71,3)^{\prime}$ & $\mathrm{S}(119,2)$ & $S(63,4)^{8}$ & $\mathrm{~S}(63,2)$ & $\mathrm{S}(38,9)^{8}$ & $\mathrm{~S}(77,8)$ & $S(26,8)$ & $S(110,6)$ & $S(60,6)^{8}$ & - & - & - \\
\hline & Idades & $\mathrm{S}(6,2)^{\prime}$ & - & - & - & - & - & $\mathrm{S}(9,4)$ & - & - & - & - & - \\
\hline & $\mathrm{Gr} \times \mathrm{Tr}$ & - & $\mathrm{S}(2,3)$ & $\mathrm{S}(4,8)^{8}$ & $\mathrm{~S}(3,0)$ & $\mathrm{S}(8,2)^{8}$ & - & 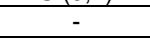 & $\mathrm{S}(4,7)$ & $\mathrm{S}(11,7)^{8}$ & - & $\mathrm{S}(4,2)$ & $\mathrm{S}(8,4)^{8}$ \\
\hline & Gr $\times$ Id & $\mathrm{S}(5,2)^{\prime}$ & $S(5,1)$ & - & $\mathrm{S}(5,5)$ & - & $\mathrm{S}(6,3)$ & - & - & - & - & $\mathrm{S}(3,8)$ & - \\
\hline & Tr $\times$ Id & - & - & - & - & - & - & - & - & - & - & - & - \\
\hline & Gr $\times \operatorname{Tr} \times I d$ & - & - & - & - & - & - & - & - & - & - & - & - \\
\hline \multirow{7}{*}{$\begin{array}{l}\text { Índice de } \\
\text { vazios }\end{array}$} & Grupos & $\mathrm{S}(16,8)^{7}$ & $\mathrm{~S}(6,9)$ & $\mathrm{S}(6,2)^{8}$ & $S(5,6)$ & $\mathrm{S}(7,4)^{8}$ & $S(3,4)$ & $S(10,8)$ & $S(4,3)$ & - & $S(6,6)$ & $S(6,5)$ & - \\
\hline & Traços & $\mathrm{S}(50,2)^{\prime}$ & $\mathrm{S}(81,7)$ & $\mathrm{S}(44,1)^{8}$ & $\mathrm{~S}(45,1)$ & $\mathrm{S}(28,5)^{8}$ & $\mathrm{~S}(60,0)$ & $\mathrm{S}(16,2)$ & $\mathrm{S}(75,0)$ & $\mathrm{S}(44,1)^{8}$ & - & $S(6,0)$ & - \\
\hline & Idades & $\mathrm{S}(8,8)^{\prime}$ & - & - & - & - & - & $S(12,6)$ & - & - & $S(5,4)$ & $S(4,4)$ & - \\
\hline & $\mathrm{Gr} \times \mathrm{Tr}$ & - & - & $\mathrm{S}(4,4)^{8}$ & $\mathrm{~S}(3,0)$ & $\mathrm{S}(7,6)^{8}$ & - & - & $\mathrm{S}(4,4)$ & $\mathrm{S}(10,8)^{8}$ & - & $\mathrm{S}(4,2)$ & $\mathrm{S}(7,7)^{8}$ \\
\hline & Gr $\times$ Id & $\mathrm{S}(4,8)^{\prime}$ & $S(4,8)$ & - & $\mathrm{S}(5,2)$ & - & $\mathrm{S}(6,1)$ & $\mathrm{S}(3,7)$ & - & - & - & $S(3,5)$ & - \\
\hline & $\operatorname{Tr} \times \mathrm{Id}$ & - & - & - & - & - & - & - & - & - & - & $S(4,7)$ & - \\
\hline & Gr $\times \operatorname{Tr} \times I d$ & - & - & - & - & - & - & - & - & - & - & - & - \\
\hline \multicolumn{14}{|c|}{ 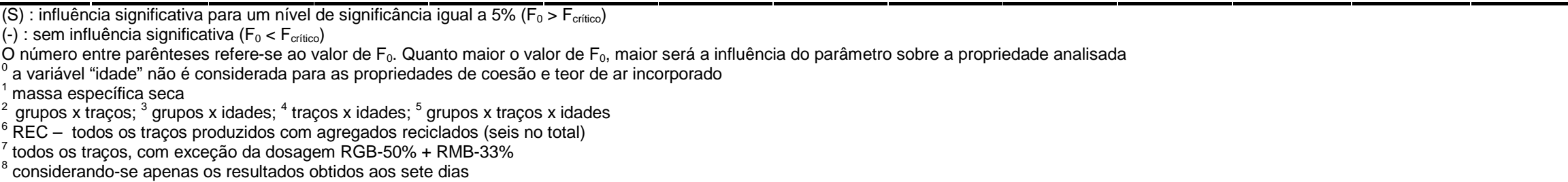 } \\
\hline
\end{tabular}


Com relação aos resultados de coesão, apresentados na Tabela 6.34, são elaborados os seguintes comentários:

- Considerando-se as comparações que envolvem o traço de referência, pode-se dizer que a variável "grupos" teve uma influência mais significativa sobre a coesão dos corpos-de-prova comparativamente à variável "traços". Nesse caso, os maiores valores médios de coesão foram obtidos para as dosagens do Grupo 12,0 e os menores valores para os traços do Grupo 4,5. Diante dos resultados, pode-se afirmar que a coesão é proporcional ao aumento do consumo de cimento da mistura e a elevação do teor de finos.

- Para a comparação entre o traço de referência e as dosagens com agregados reciclados de vigota, pode-se afirmar que, independentemente do grupo avaliado, os valores de coesão foram similares para todas essas dosagens. A inclusão dos agregados reciclados de vigota não alterou a coesão da mistura. De maneira geral, as dosagens mostraram-se adequadas para a produção de blocos de concreto, uma vez que os valores de coesão foram superiores a 6000 g (FRASSON JUNIOR, 2000).

- Para a comparação entre o traço de referência e as dosagens com agregados reciclados de bloco, pode-se dizer que a variável "traços" teve influência significativa sobre a coesão. Para os traços RGB-100\% e RGB-50\% + RMB-33\%, ocorreu uma diminuição significativa da coesão comparativamente ao traço de referência. As dosagens RGB-100\% e RGB-50\% + RMB-33\% do Grupo 4,5 não se mostraram adequadas à produção de blocos de concreto, uma vez que os valores de coesão foram inferiores a $6000 \mathrm{~g}$.

- Para as comparações envolvendo diferentes porcentagens de substituição do mesmo resíduo, pode-se afirmar que a variável "grupos" teve influência mais significativa sobre os valores de coesão. Com relação à variável "traços", pode-se dizer que apenas as comparações envolvendo agregados reciclados de bloco (RGB$100 \% \times$ RGB-50\% x RGB-50\% + RMB-33\% e RGB-50\% x RGB-50\% + RMB-33\%) foram influenciadas pela variável. Nesse caso, a incorporação da fração miúda reciclada de bloco e a substituição total da fração natural pela reciclada afetou significativamente a coesão da mistura comparativamente à dosagem com substituição parcial (RGB-50\%). 
- Para as comparações entre os diferentes resíduos, pode-se afirmar que os valores de coesão foram influenciados preponderantemente pela variável "grupos". Com relação à variável "traços", pode-se afirmar que os menores valores médios de coesão, comparativamente às dosagens com agregados reciclados de vigota, foram obtidos para os traços com agregados reciclados de bloco, com exceção da comparação entre os traços RGV-50\% e RGB-50\%. Possivelmente, a menor resistência e a fragilidade do agregado reciclado de bloco (comprovada pelo ensaio de Abrasão Los Angeles) contribuíram para esse comportamento.

Com relação aos resultados referentes à propriedade de teor de ar incorporado são feitos os seguintes comentários:

- Para as comparações envolvendo o traço de referência, pode-se afirmar que todas as variáveis influenciaram a propriedade de teor de ar incorporado. De maneira geral, à medida do aumento do consumo de cimento houve uma diminuição do teor de ar incorporado, isto é, as dosagens do Grupo 12,0 e do Grupo 4,5 apresentaram os menores e maiores teores médios de ar incorporado, respectivamente. Com relação a variável "traços", pode-se afirmar que a incorporação da fração reciclada acarretou um aumento significativo do teor de ar incorporado na mistura comparativamente à dosagem de referência. Provavelmente, a argamassa porosa aderida ao agregado reciclado contribuiu para esse comportamento. Por outro lado, de acordo com a análise de $2^{\mathrm{a}}$ ordem (grupos $\mathrm{x}$ traços), dependendo do grupo em análise há um determinado traço que obteve, por exemplo, os maiores valores médios de teor de ar incorporado. Essa afirmação não é válida para as comparações envolvendo agregados reciclados de vigota.

- Para as comparações envolvendo diferentes porcentagens de substituição do mesmo resíduo, pode-se dizer que a propriedade de teor de ar incorporado foi influenciada pelas duas variáveis. De maneira geral, pode-se afirmar que os menores valores médios para essa propriedade foram obtidos para as dosagens com maior consumo de cimento (Grupo 12,0) e com menores porcentagens de substituição da fração natural pela reciclada (RGV-50\% e RGB-50\%). Pela análise de $2^{\mathrm{a}}$ ordem (grupos $\mathrm{x}$ traços), para a comparação envolvendo agregados reciclados de bloco, pode-se dizer que para um determinado grupo $(4,5$, ex.) houve um determinado traço (RGB-100\%) que apresentou os maiores teores médios de ar incorporado, já para outro grupo (8,0 e 12,0, ex.), esse mesmo traço não apresentou necessariamente os maiores teores médios de ar incorporado, sendo tais valores obtidos pelo traço RGB$50 \%+$ RMB-33\%. Para as composições com agregados reciclados de vigota, as 
variáveis (grupos e traços) não influenciaram significativamente a propriedade de teor de ar incorporado.

- Para as comparações envolvendo diferentes tipos de resíduos, pode-se dizer novamente que os resultados foram influenciados significativamente pelas variáveis (grupos e traços). Das duas variáveis, a variável "grupos" foi a que exerceu maior influência sobre a propriedade de teor de ar incorporado. De maneira geral, os menores valores médios para a propriedade foram obtidos para as dosagens com maior consumo de cimento (Grupo 12,0) e para as dosagens com agregados graúdos reciclados de vigota. Entretanto, pela análise de $2^{\mathrm{a}}$ ordem, considerando-se as comparações com influência significativa, pode-se afirmar que, dependendo do grupo em análise, nem sempre as dosagens com agregados reciclados de vigota apresentaram os menores teores de ar incorporado. Por exemplo, na comparação entre os traços RGV-100\% e RGB-100\%, pode-se dizer que, para os Grupos 4,5 e 12,0 , os menores valores médios de teor de ar incorporado foram obtidos para o traço RGV-100\%; entretanto, para o Grupo 8,0, os menores valores médios não foram obtidos necessariamente por este traço (RGV-100\%).

Com relação aos resultados da propriedade de massa específica seca são estabelecidos os seguintes comentários:

- Para as comparações envolvendo o traço de referência, pode-se afirmar que a variável "traços" exerceu influência mais significativa sobre a propriedade de massa específica seca comparativamente a variável "grupos". De maneira geral, os maiores valores de massa específica foram obtidos para as dosagens com maior consumo de cimento (Grupo 12,0) e para os traços com agregados naturais (REF). Os menores valores médios de massa específica para os traços com agregados reciclados, comparativamente à dosagem de referência, podem ser explicados pela grande quantidade de argamassa porosa que se encontra aderida à superfície do agregado reciclado de bloco (cerca de 49\%) e agregado reciclado de vigota (53\%). Pela análise de $2^{\mathrm{a}}$ ordem, pode-se dizer que, dependendo do grupo em análise, os maiores/menores valores médios de massa específica não foram obtidos para apenas uma determinada idade. Por exemplo, considerando-se os Grupos 4,5 e 8,0, pode-se afirmar que os maiores valores médios de massa específica foram obtidos para exemplares com vinte e oito dias de idade; no entanto, para o Grupo 12,0, os maiores valores foram obtidos para CPs com sete dias de idade. 
- Para a comparação entre o traço de referência e os traços com agregados reciclados de bloco, pode-se dizer com base nos resultados obtidos que para um dado traço houve um determinado grupo que conduziu aos maiores valores médios de massa específica; no entanto, para outro traço não foi necessariamente esse grupo que levou aos maiores valores médios. Esse comportamento ocorreu devido à similaridade de resultados de massa específica para os três grupos do traço RGB$50 \%$ + RMB-33\%; já para os demais traços (RGB-100\% e RGB-50\%), pode-se afirmar que os maiores valores médios de massa específica foram obtidos necessariamente pelas dosagens do Grupo 12,0.

- Para as comparações envolvendo diferentes porcentagens do mesmo resíduo, podese dizer que a variável "traços" teve influência mais significativa sobre a propriedade de massa específica comparativamente a variável "grupos". A variável "idades" não teve influência significativa sobre a massa específica, dessa maneira, pode-se afirmar que os resultados foram semelhantes para qualquer uma das idades consideradas. De maneira geral, os maiores valores médios de massa específica foram obtidos para os traços com substituição parcial do pedrisco por agregado graúdo reciclado (RGV-50\% e RGB-50\%) e para as dosagens com maior consumo de cimento (Grupo 12,0). Comparativamente às dosagens com substituições parciais da fração graúda natural pela graúda reciclada, a substituição total da fração natural pela reciclada (RGV-100\% e RGB-100\%) acarretou uma diminuição da massa específica devido à argamassa porosa que se encontra aderida ao agregado reciclado, sendo esse fato também observado com a inclusão da fração miúda reciclada (RGV-50\% + RMV-33\% e RGB-50\% + RMB-33\%). Para as comparações envolvendo traços com agregados reciclados de vigota e para a comparação com agregados graúdos reciclados de bloco, pode-se dizer, com base na análise de $2^{a}$ ordem, que os maiores valores médios de massa específica não foram obtidos necessariamente para uma determinada idade. De certa forma, os maiores valores médios de massa específica para os Grupos 4,5 e 8,0 foram obtidos para os CPs com vinte e oito dias de idade; já para o Grupo 12,0, os maiores valores médios foram obtidos para os CPs com sete dias de idade.

- Com relação às comparações envolvendo diferentes resíduos com porcentagens similares de substituição, pode-se afirmar que a variável "grupos" foi o parâmetro que influenciou mais significativamente a propriedade de massa específica. Nesse caso, os maiores valores médios de massa específica foram obtidos para as dosagens com maior consumo de cimento (Grupo 12,0). Por outro lado, para as comparações 
envolvendo composições com agregados graúdos reciclados, pode-se afirmar que as demais variáveis isoladas (traços e idades) não tiveram influência sobre a propriedade em análise. Dessa maneira, pode-se afirmar que os valores de massa específica foram semelhantes para dosagens compostas por diferentes tipos/qualidades de agregados graúdos reciclados (vigota e bloco) e para qualquer uma das idades consideradas (7 dias e 28 dias). Pela análise de $2^{a}$ odem, conforme observado nas análises anteriores, para diferentes grupos pode haver diferentes idades que conduzem aos maiores valores de massa específica.

- Para a comparação entre os traços com agregados graúdos e miúdos reciclados (RGV-50\% + RMV-33\% e RGB-50\% + RMB-33\%), pode-se afirmar que a variável "traços" teve influência mais significativa sobre a propriedade de massa específica. Nesse caso, pode afirmar que os maiores valores médios de massa específica foram obtidos para a dosagem com agregados reciclados de bloco; provavelmente, a elevada absorção da fração miúda reciclada de vigota $(9,15 \%)$, comparativamente ao reciclado de bloco $(6,05 \%)$, foi responsável pela redução significativa da massa específica para a dosagem RGV-50\% + RMV-33\%.

Com relação às propriedades de absorção de água e índice de vazios são estabelecidos os seguintes comentários:

- Considerando-se as comparações envolvendo o traço de referência, pode-se afirmar que a variável "traços" teve influência mais significativa sobre as propriedades de absorção de água e índice de vazios comparativamente aos demais parâmetros (grupos e idades). Dessa forma, pode-se dizer que os menores valores médios para essas propriedades foram obtidos para as dosagens de referência (REF) e para os traços com maior consumo de cimento (Grupo 12,0). Para grande parte das comparações, pode-se afirmar que a variável "idades" não influenciou significativamente os resultados das propriedades avaliadas. Pela análise de $2^{a}$ ordem, observa-se que os parâmetros (grupos e idades) influenciaram significativamente as propriedades avaliadas, ou seja, para diferentes grupos $(4,5$, 8,0 e 12,0), pode haver diferentes idades (7 dias e 28 dias) que conduzem aos menores ou maiores valores médios de absorção de água e índice de vazios.

- Para a comparação envolvendo o traço de referência e os traços com agregados reciclados de bloco, pode-se dizer que os parâmetros (grupos e traços) tiveram influência significativa sobre as propriedades avaliadas, ou seja, considerando-se os diferentes traços (REF, RGB-100\%, RGB-50\% e RGB-50\% + RMB-33\%) pode haver 
diferentes grupos $(4,5,8,0$ e 12,0) que conduzem aos valores extremos para as propriedades. Considerando-se todas as dosagens, com exceção do traço RGB-50\% + RMB-30\%, notou-se que os menores valores médios de absorção e índice de vazios foram obtidos para as dosagens com maior consumo de cimento (Grupo 12,0), por outro lado, para o traço RGB-50\% + RMB-33\%, os menores valores para essas propriedades foram obtidos para os Grupos 4,5 e 8,0. Provavelmente, algum problema ocorrido na moldagem dos exemplares do Grupo 12,0 ou na execução do ensaio contribuiu para esses resultados.

- Para as comparações envolvendo diferentes porcentagens de substituição do mesmo resíduo, pode-se dizer que a variável "traços" teve influência mais significativa, quando comparada com as demais variáveis, sobre as propriedades físicas. De maneira geral, os menores valores médios para essas propriedades foram obtidos para as dosagens com substituição parcial de pedrisco por agregado graúdo reciclado (RGV-50\% e RGB-50\%) e para as dosagens com maior consumo de cimento (Grupo 12,0). Com relação a variável "idades", pode-se afirmar que, em grande parte das comparações, esse parâmetro não influenciou as propriedades. Diante disso, os resultados de absorção e índice de vazios podem ser considerados similares para qualquer idade considerada.

- Considerando-se as dosagens com agregados reciclados de vigota, pode-se dizer que os parâmetros (grupos e traços) e (grupos e idades) influenciaram significativamente as propriedades de absorção e índice de vazios. Com relação aos parâmetros (grupos e traços), pode-se afirmar que, considerando-se diferentes traços, pode haver diferentes grupos que conduzem aos menores ou maiores valores para as propriedades, isto significa dizer que, por exemplo, para o traço RGV-50\% + RMV-33\%, os maiores valores de índice de vazios e absorção foram obtidos para o Grupo 4,5; já para os traços com agregados graúdos reciclados, esses valores foram obtidos para um grupo que apresenta maior consumo de cimento (Grupo 8,0). Para os parâmetros (grupos e idades), afirma-se que para diferentes grupos (4,5; 8,0 e 12,0), pode haver diferentes idades (7 dias e 28 dias) que levam aos menores ou maiores valores para as propriedades em análise.

- Para as dosagens com agregados reciclados de bloco, pode-se dizer que, pela análise de $2^{\mathrm{a}}$ ordem, os parâmetros (grupos e traços) influenciaram significativamente as propriedades físicas, ou seja, para diferentes traços, pode haver diferentes grupos que conduzem aos maiores/menores valores médios para as propriedades. Na comparação entre os traços RGB-50\% e RGB-50\% + RMB-33\%, 
pode-se afirmar que não houve influência significativa da variável "grupos" sobre a propriedade de índice de vazios. Nesse caso, os valores de índice de vazios para os diferentes grupos avaliados (distintos consumos de cimento) podem ser considerados semelhantes.

- Para as comparações englobando diferentes tipos de resíduos, pode-se afirmar que, em duas das três comparações avaliadas, a variável "grupos" afetou significativamente as propriedades de absorção e índice de vazios. Nesse caso, conforme já esperado, os menores valores médios para as propriedades foram obtidos para as dosagens com maior consumo de cimento (Grupo 12,0). Com relação à propriedade de absorção de água, não foram observadas diferenças significativas quando comparadas dosagens com diferentes tipos de resíduos; já com relação ao índice de vazios, pode-se afirmar que, na comparação entre os traços RGV-50\% e RGB-50\%, os menores valores médios foram obtidos para a dosagem RGV-50\%. Com relação à variável "idade", nota-se que esse parâmetro influenciou significativamente apenas a propriedade de índice de vazios; nesse caso, os menores valores médios foram obtidos para os exemplares ensaiados aos sete dias.

- Considerando-se a análise de $2^{\mathrm{a}}$ ordem, para a comparação entre as dosagens RGV$50 \%$ x RGB-50\%, pode-se dizer que os parâmetros (grupos e traços) e (grupos e idades) influenciaram significativamente as propriedades avaliadas, ou seja, para diferentes grupos, pode haver diferentes traços ou idades que conduzem, por exemplo, aos menores valores médios de absorção de água e índice de vazios. Para a propriedade de índice de vazios, os parâmetros (traços e idades) também influenciaram essa propriedade.

- Na comparação entre os traços com agregados graúdos e miúdos reciclados, não foi observada influência significativa dos três parâmetros sobre as propriedades avaliadas. Nesse caso, pode-se afirmar que os valores das propriedades foram semelhantes para qualquer um dos grupos, traços e idades avaliadas. Para a análise de $2^{\mathrm{a}}$ ordem, pode-se dizer que houve influência significativa dos parâmetros (grupos e traços) sobre as propriedades avaliadas, ou seja, para diferentes grupos, pode haver diferentes traços que conduzem, por exemplo, aos menores valores médios de índice de vazios e absorção de água. Por exemplo, considerando-se os Grupos 4,5 e 8,0 , pode-se dizer que os menores valores médios foram obtidos para a dosagem RGB-50\% + RMB-33\%; já para o Grupo 12,0, a dosagem RGV-50\% + RMV-33\% apresentou os menores valores para as propriedades em análise. 
Nas Figuras 6.11 a 6.14, são apresentados quatros gráficos ilustrando os resultados obtidos para as propriedades físicas das dosagens com agregados reciclados comparativamente aos resultados obtidos para a dosagem de referência. Os resultados referem-se a uma média dos valores das propriedades aos sete dias e aos vinte e oito dias.

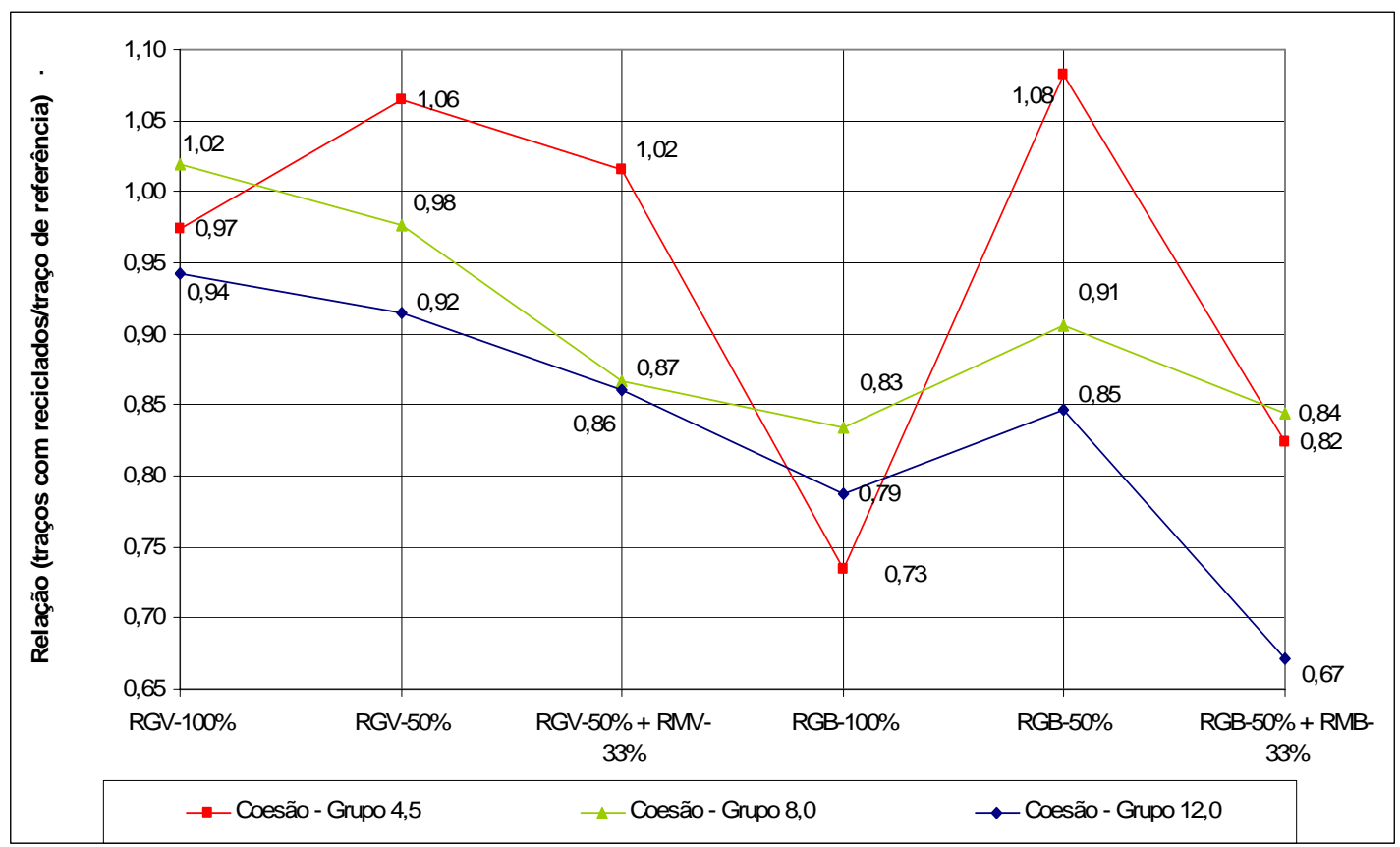

Figura 6.11 - Resultados relativos para a propriedade de coesão.

Analisando-se os resultados da Figura 6.11, nota-se que as dosagens com agregados graúdos reciclados de vigota (RGV-100\% e RGV-50\%) apresentaram uma redução média da coesão de apenas $3 \%$ e $2 \%$, respectivamente em relação à dosagem de referência; por outro lado, para as dosagens com agregados reciclados de bloco (RGB100\% e RGB-50\%), essa redução foi de $22 \%$ e $8 \%$, respectivamente em relação aos valores de referência. Possivelmente, conforme já comentado, a maior fragilidade do agregado reciclado de bloco, comparativamente ao agregado reciclado de vigota, provocou uma redução mais significativa da coesão da mistura. Para os traços com agregados graúdos e miúdos reciclados (RGV-50\% + RMV-33\% e RGB-50\% + RMB-33\%) foi observada uma redução média na coesão de $9 \%$ e $23 \%$, respectivamente em relação aos valores de referência.

Para as dosagens RGB-100\% e RGB-50\% + RMB-33\% do Grupo 4,5, os valores de coesão ficaram abaixo de 6000 g; provavelmente, essas dosagens não serão adequadas para a produção dos blocos de concreto. Apesar da redução significativa da coesão para as dosagens, os traços pertencentes aos Grupos 8,0 e 12,0 não devem apresentar problemas 
durante a produção, uma vez que o consumo de cimento foi mais elevado (maior teor de finos na mistura) e os valores obtidos no ensaio de coesão foram superiores a $6000 \mathrm{~g}$.

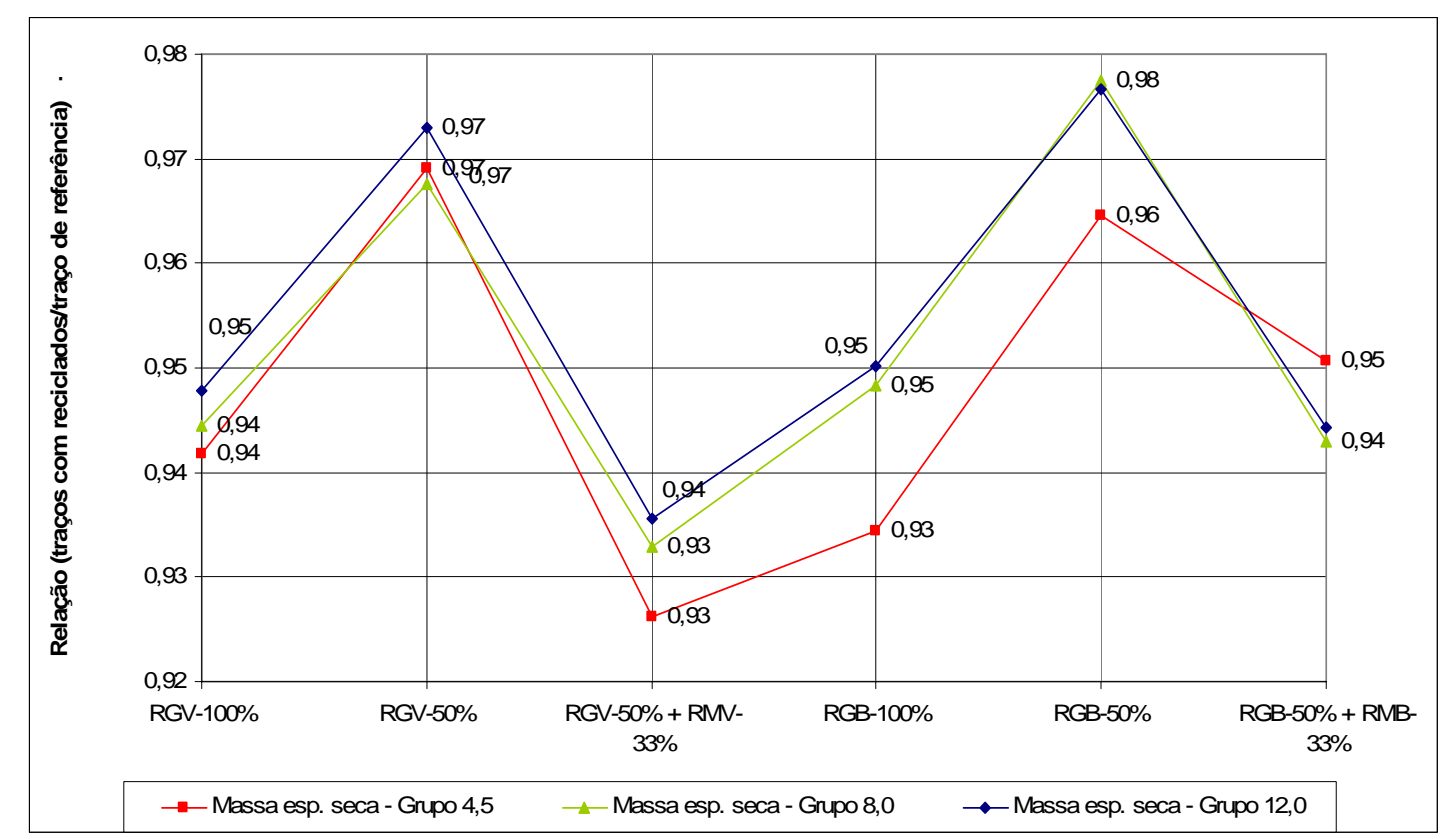

Figura 6.12 - Resultados relativos para a propriedade de massa específica seca.

Analisando-se os resultados da Figura 6.12, observa-se uma redução média na massa específica de 6\% (RGV-100\%, RGB-100\% e RGB-50\% + RMB-33\%), 3\% (RGV-50\% e RGB-50\%) e 7\% (RGV-50\% + RMV-33\%) comparativamente aos valores obtidos para o traço de referência. Essa redução da massa específica para as dosagens com agregados reciclados pode ser explicada pela camada porosa de argamassa que se encontra aderida à superfície do agregado reciclado. 


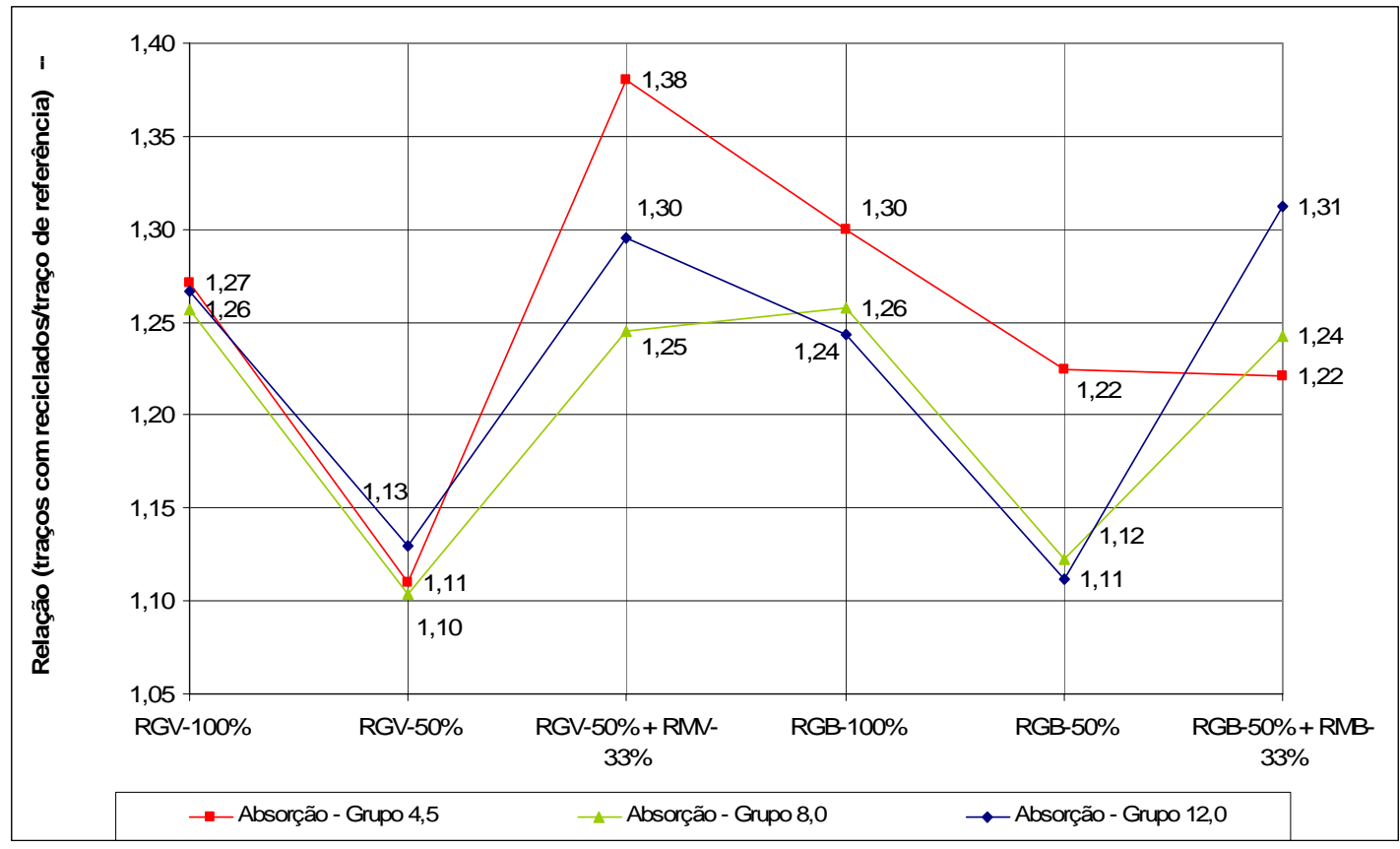

Figura 6.13 - Resultados relativos para a propriedade de absorção de água

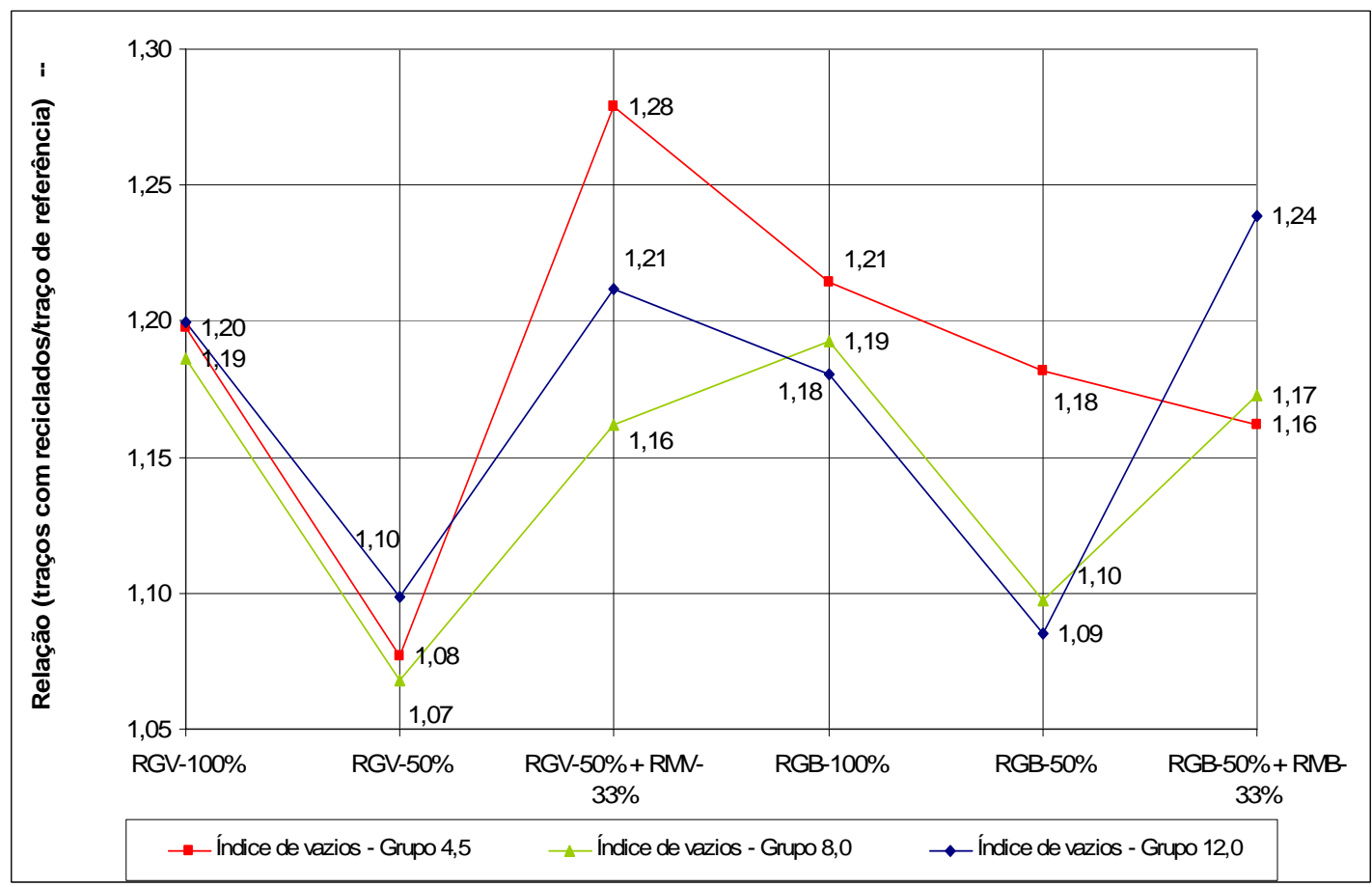

Figura 6.14 - Resultados relativos para a propriedade de índice de vazios

Analisando-se os gráficos das Figuras 6.13 e 6.14 são estabelecidos os seguintes comentários:

- Para a propriedade de absorção de água, os resultados das dosagens com agregados reciclados de vigota e bloco foram muito próximos. Dessa maneira, pode- 
se afirmar que a incorporação de diferentes tipos/qualidades de agregados reciclados de concreto não influenciou os resultados de absorção de água. De maneira geral, essas dosagens apresentaram um aumento de 27\% [RGV(B)-100\%], $13 \%$ [RGV(B)-50\%] e 28\% [RGV(B)-50\% + RMV(B)-33\%] comparativamente aos valores de absorção da dosagem de referência.

- Com relação à propriedade de índice de vazios, novamente, os resultados das dosagens com agregados reciclados (\% similares de substituição) foram muito próximos, com exceção da comparação entre os traços com $50 \%$ de substituição. De maneira geral, essas dosagens apresentaram um aumento de 20\% [RGV(B)-100\%], $8 \% \quad(R G V-50 \%), \quad 12 \% \quad(R G B-50 \%)$ e $20 \% \quad[R G V(B)-50 \%+R M V(B)-33 \%]$ comparativamente aos valores de índice de vazios obtidos para o traço de referência.

- Considerando-se a elevação de até 30\% admitida para as propriedades físicas dos concretos com agregados reciclados, pode-se afirmar que apenas o traço com agregados graúdos e miúdos reciclados de vigota (RGV-50\% + RMV-33\%) do Grupo 4,5 apresentou valores de absorção de água que ultrapassaram esse limite. Devido à elevada absorção de água, a produção de blocos de concreto do Grupo 4,5 com esse traço ficará inviabilizada.

\subsection{Propriedades mecânicas}

Os resultados das propriedades mecânicas são apresentados nos itens a seguir e, posteriormente, é feita uma análise conjunta desses resultados mediante o teste ANOVA. As propriedades mecânicas avaliadas para os exemplares dos Grupos 4,5, 8,0 e 12,0 foram: resistência à compressão, resistência à tração por compressão diametral e módulo de deformação. Os resultados obtidos permitirão a definição de quais dosagens serão adequadas para a produção dos blocos de concreto, uma vez que será admitido, no máximo, uma redução de até $15 \%$ nas propriedades mecânicas das dosagens com agregados reciclados comparativamente ao traço de referência.

\subsection{Grupo 4,5}

$\mathrm{Na}$ Tabela 6.35, encontram-se os resultados das propriedades mecânicas dos CPs produzidos com as dosagens do Grupo 4,5. 
Tabela 6.35 - Propriedades mecânicas dos CPs do Grupo 4,5.

\begin{tabular}{|c|c|c|c|c|c|c|c|c|c|}
\hline \multirow[b]{2}{*}{ GRUPO 4,5 } & \multirow[b]{2}{*}{ Idade } & \multirow[b]{2}{*}{$\begin{array}{l}\text { Parâme- } \\
\text { tros }\end{array}$} & \multicolumn{7}{|c|}{ Dosagens } \\
\hline & & & REF & $\begin{array}{l}\text { RGV - } \\
100 \%\end{array}$ & $\begin{array}{l}\text { RGV - } \\
50 \%\end{array}$ & $\begin{array}{l}\text { RGV - } \\
50 \%+ \\
\text { RMV - } \\
33 \%\end{array}$ & $\begin{array}{l}\text { RGB - } \\
100 \%\end{array}$ & $\begin{array}{l}\text { RGB - } \\
50 \%\end{array}$ & $\begin{array}{c}\text { RGB - } \\
50 \%+ \\
\text { RMB - } \\
33 \%\end{array}$ \\
\hline $\begin{array}{c}\text { Energia de adensamento } \\
\text { (golpes) }\end{array}$ & & & 15 & 15 & 15 & 15 & 15 & 15 & 15 \\
\hline $\begin{array}{c}\text { Temperatura durante a } \\
\text { moldagem }\left({ }^{\circ} \mathrm{C}\right)\end{array}$ & & & 20,7 & 19,3 & 20,2 & 19,5 & 21,0 & 18,6 & 19,4 \\
\hline $\begin{array}{c}\text { Umidade durante a } \\
\text { moldagem (\%) }\end{array}$ & & & 59 & 61 & 58 & 66 & 55 & 57 & 62 \\
\hline \multirow{6}{*}{$\begin{array}{l}\text { Umidade do CP, no } \\
\text { momento do ensaio, em } \\
\text { relação à absorção total } \\
(\%)\end{array}$} & \multirow{3}{*}{7} & Média & 64,20 & 67,97 & 66,40 & 63,86 & 62,44 & 53,85 & 52,97 \\
\hline & & $\mathrm{S}_{\mathrm{d}}$ & 2,85 & 1,59 & 1,06 & 3,21 & 2,63 & 0,93 & 0,55 \\
\hline & & C. V. (\%) & 4,43 & 2,34 & 1,60 & 5,03 & 4,22 & 1,73 & 1,03 \\
\hline & \multirow{3}{*}{28} & Média & 36,83 & 35,97 & 39,64 & 39,81 & 37,46 & 35,62 & 28,57 \\
\hline & & $\mathrm{S}_{\mathrm{d}}$ & 5,73 & 5,10 & 7,43 & 1,60 & 0,90 & 4,89 & 3,12 \\
\hline & & C. V. (\%) & 15,55 & 14,18 & 18,75 & 4,01 & 2,41 & 13,74 & 10,93 \\
\hline \multirow{6}{*}{$\begin{array}{l}\text { Resistência à compressão } \\
\text { (MPa) }\end{array}$} & \multirow{3}{*}{7} & Média & 12,60 & 11,65 & 13,23 & 10,29 & 10,32 & 12,65 & 11,14 \\
\hline & & $\mathrm{S}_{\mathrm{d}}$ & 1,24 & 1,24 & 1,81 & 0,51 & 0,79 & 0,32 & 0,85 \\
\hline & & C. V. (\%) & 9,87 & 10,68 & 13,65 & 4,95 & 7,65 & 2,56 & 7,60 \\
\hline & \multirow{3}{*}{28} & Média & 18,84 & 16,28 & 17,86 & 13,24 & 13,45 & 16,20 & 13,79 \\
\hline & & $\mathrm{S}_{\mathrm{d}}$ & 0,96 & 1,19 & 0,67 & 1,23 & 1,09 & 0,58 & 0,91 \\
\hline & & C. V. (\%) & 5,10 & 7,31 & 3,72 & 9,27 & 8,10 & 3,57 & 6,63 \\
\hline \multirow{6}{*}{$\begin{array}{l}\text { Resistência à tração por } \\
\text { compressão diametral } \\
\text { (MPa) }\end{array}$} & \multirow{3}{*}{7} & Média & 1,58 & 1,39 & 1,55 & 1,25 & 1,17 & 1,37 & 1,38 \\
\hline & & $\mathrm{S}_{\mathrm{d}}$ & 0,19 & 0,06 & 0,11 & 0,05 & 0,15 & 0,18 & 0,04 \\
\hline & & C. V. (\%) & 12,18 & 4,51 & 7,00 & 3,83 & 13,04 & 12,91 & 2,78 \\
\hline & \multirow{3}{*}{28} & Média & 1,98 & 1,91 & 2,28 & 1,64 & 1,73 & 1,99 & 1,63 \\
\hline & & $S_{d}$ & 0,14 & 0,11 & 0,08 & 0,04 & 0,07 & 0,06 & 0,12 \\
\hline & & C. V. (\%) & 6,96 & 5,60 & 3,34 & 2,16 & 4,11 & 3,22 & 7,45 \\
\hline \multirow{6}{*}{$\begin{array}{l}\text { Módulo de deformação } \\
\text { (GPa) }\end{array}$} & \multirow{3}{*}{7} & Média & 17,21 & 17,47 & 19,57 & 15,28 & 14,92 & 17,12 & 13,87 \\
\hline & & $S_{d}$ & 1,68 & 1,31 & 2,80 & 0,47 & 0,96 & 1,02 & 1,60 \\
\hline & & C. V. (\%) & 9,75 & 7,50 & 14,32 & 3,05 & 6,44 & 5,94 & 11,55 \\
\hline & \multirow{3}{*}{28} & Média & 21,26 & 19,17 & 21,67 & 16,40 & 17,96 & 18,90 & 16,74 \\
\hline & & $\mathrm{S}_{\mathrm{d}}$ & 3,43 & 2,76 & 4,52 & 2,20 & 1,52 & 1,45 & 0,35 \\
\hline & & C. V. (\%) & 16,13 & 14,41 & 20,85 & 13,40 & 8,47 & 7,65 & 2,08 \\
\hline
\end{tabular}

\subsection{Grupo 8,0}

$\mathrm{Na}$ Tabela 6.36, encontram-se os resultados das propriedades mecânicas dos CPs produzidos com as dosagens do Grupo 8,0. 
Tabela 6.36 - Propriedades mecânicas dos CPs do Grupo 8,0.

\begin{tabular}{|c|c|c|c|c|c|c|c|c|c|}
\hline \multirow[b]{2}{*}{ GRUPO 8,0 } & \multirow[b]{2}{*}{ Idade } & \multirow[b]{2}{*}{$\begin{array}{l}\text { Parâme- } \\
\text { tros }\end{array}$} & \multicolumn{7}{|c|}{ Dosagens } \\
\hline & & & REF & $\begin{array}{l}\text { RGV - } \\
100 \%\end{array}$ & $\begin{array}{l}\text { RGV - } \\
50 \%\end{array}$ & $\begin{array}{c}\text { RGV - } \\
50 \%+ \\
\text { RMV - } \\
33 \% \\
\end{array}$ & $\begin{array}{l}\text { RGB - } \\
100 \%\end{array}$ & $\begin{array}{l}\text { RGB - } \\
50 \%\end{array}$ & $\begin{array}{c}\text { RGB - } \\
50 \%+ \\
\text { RMB - } \\
33 \% \\
\end{array}$ \\
\hline $\begin{array}{c}\text { Energia de adensamento } \\
\text { (golpes) }\end{array}$ & & & 15 & 15 & 15 & 15 & 15 & 15 & 15 \\
\hline $\begin{array}{c}\text { Temperatura durante a } \\
\text { moldagem }\left({ }^{\circ} \mathrm{C}\right)\end{array}$ & & & 20,3 & 17,4 & 17,2 & 19,1 & 16,8 & 18,1 & 21,9 \\
\hline $\begin{array}{c}\text { Umidade durante a } \\
\text { moldagem (\%) }\end{array}$ & & & 55 & 70 & 69 & 59 & 71 & 74 & 52 \\
\hline \multirow{6}{*}{$\begin{array}{c}\text { Umidade do CP, no } \\
\text { momento do ensaio, em } \\
\text { relação à absorção total } \\
(\%)\end{array}$} & \multirow{3}{*}{7} & Média & 63,57 & 67,62 & 69,24 & 67,96 & 67,35 & 66,74 & 61,43 \\
\hline & & $\mathrm{S}_{\mathrm{d}}$ & 2,79 & 1,06 & 1,09 & 1,40 & 2,91 & 1,51 & 2,65 \\
\hline & & C. V. (\%) & 4,39 & 1,56 & 1,58 & 2,07 & 4,32 & 2,26 & 4,31 \\
\hline & \multirow{3}{*}{28} & Média & 41,10 & 44,26 & 42,89 & 33,37 & 41,70 & 38,98 & - \\
\hline & & $S_{d}$ & 1,75 & 3,93 & 2,08 & 0,68 & 5,33 & 2,83 & - \\
\hline & & C. V. (\%) & 4,25 & 8,87 & 4,85 & 2,03 & 12,77 & 7,27 & - \\
\hline \multirow{6}{*}{$\begin{array}{l}\text { Resistência à compressão } \\
\text { (MPa) }\end{array}$} & \multirow{3}{*}{7} & Média & 20,80 & 18,17 & 20,59 & 18,66 & 16,98 & 20,13 & 16,44 \\
\hline & & $S_{d}$ & 1,21 & 1,55 & 2,69 & 0,46 & 2,70 & 0,51 & 0,71 \\
\hline & & C. V. (\%) & 5,80 & 8,55 & 13,06 & 2,46 & 15,90 & 2,55 & 4,32 \\
\hline & \multirow{3}{*}{28} & Média & 29,90 & 22,43 & 27,18 & 21,75 & 20,86 & 25,77 & 21,22 \\
\hline & & $S_{d}$ & 1,15 & 3,55 & 0,91 & 0,33 & 0,67 & 1,84 & 0,85 \\
\hline & & C. V. (\%) & 3,84 & 15,84 & 3,36 & 1,54 & 3,22 & 7,13 & 3,99 \\
\hline \multirow{6}{*}{$\begin{array}{l}\text { Resistência à tração por } \\
\text { compressão diametral } \\
\text { (MPa) }\end{array}$} & \multirow{3}{*}{7} & Média & 2,59 & 2,36 & 2,29 & 1,60 & 1,93 & 2,36 & 1,85 \\
\hline & & $\mathrm{S}_{\mathrm{d}}$ & 0,20 & 0,14 & 0,10 & 0,27 & 0,28 & 0,13 & 0,08 \\
\hline & & C. V. (\%) & 7,84 & 5,77 & 4,17 & 16,67 & 14,48 & 5,32 & 4,49 \\
\hline & \multirow{3}{*}{28} & Média & 3,60 & 3,12 & 3,22 & 2,65 & 2,58 & 2,80 & - \\
\hline & & $S_{d}$ & 0,94 & 0,45 & 0,12 & 0,36 & 0,26 & 0,16 & - \\
\hline & & C. V. (\%) & 26,09 & 14,51 & 3,59 & 13,62 & 9,88 & 5,66 & - \\
\hline \multirow{6}{*}{$\begin{array}{l}\text { Módulo de deformação } \\
\text { (GPa) }\end{array}$} & \multirow{3}{*}{7} & Média & 24,44 & 21,65 & 23,11 & 21,57 & 19,01 & 20,20 & 19,68 \\
\hline & & $\mathrm{S}_{\mathrm{d}}$ & 0,23 & 2,29 & 2,14 & 0,92 & 1,64 & 1,10 & 1,18 \\
\hline & & C. V. (\%) & 0,93 & 10,58 & 9,25 & 4,24 & 8,61 & 5,46 & 6,01 \\
\hline & \multirow{3}{*}{28} & Média & 26,67 & 24,87 & 26,29 & 23,72 & 21,58 & 24,02 & 21,77 \\
\hline & & $\mathrm{S}_{\mathrm{d}}$ & 0,46 & 2,40 & 1,77 & 1,85 & 1,23 & 1,09 & 2,07 \\
\hline & & C. V. (\%) & 1,74 & 9,66 & 6,73 & 7,80 & 5,72 & 4,54 & 9,50 \\
\hline
\end{tabular}

\subsection{Grupo 12,0}

Na Tabela 6.37, encontram-se os resultados das propriedades mecânicas dos CPs produzidos com as dosagens do Grupo 12,0. 
Tabela 6.37 - Propriedades mecânicas dos CPs do Grupo 12,0.

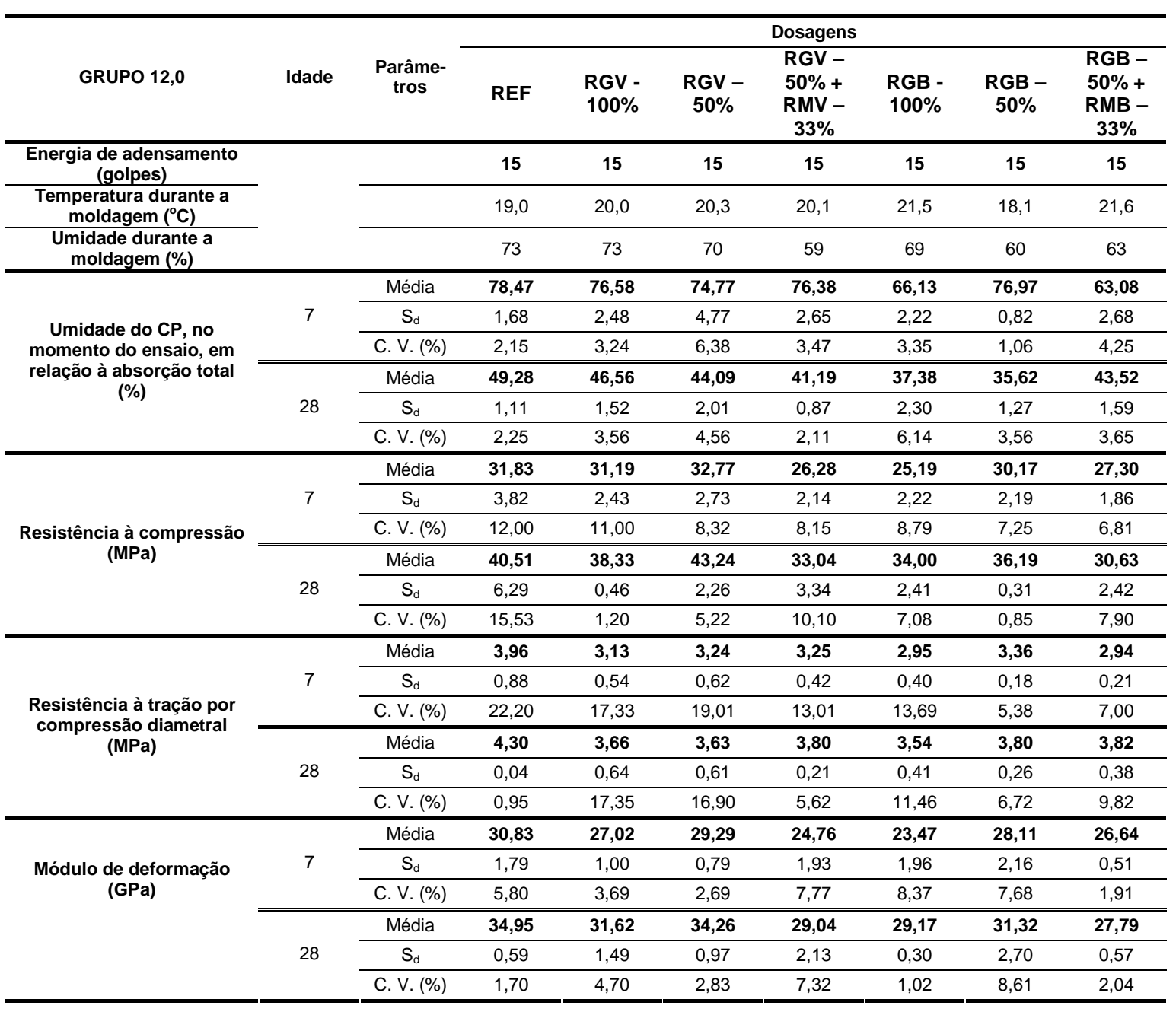

\subsection{Análise dos resultados - propriedades mecânicas}

Neste item, é utilizado o teste de Análise de Variância para avaliação global dos resultados obtidos. As variáveis são analisadas isoladamente, isto é, é verificada a influência separada desses parâmetros sobre as propriedades mecânicas. As variáveis em questão são as seguintes: a) Grupos/Classes de Resistência (4,5; 8,0 e 12,0); b) Dosagens/Composições dos traços (REF, RGV-100\%, RGV-50\%, RGV-50\% + RMV-33\%; RGB-100\%, RGB-50\%, RGB-50\% +RMB-33\%); c) Idade (7 dias e 28 dias). Na análise de $2^{\mathrm{a}}$ ordem, os parâmetros serão avaliados dois a dois (grupos e traços; grupos e idades; traços e idades) e, finalmente, na análise de $3^{\mathrm{a}}$ ordem, os parâmetros serão avaliados três a três (grupos e traços e idades). Essa análise permitirá uma avaliação precisa da influência desses três parâmetros sobre as propriedades mecânicas dos CPs. Na Tabela 6.38, são apresentados os resultados do teste ANOVA. 
Tabela 6.38 - Teste ANOVA para as propriedades mecânicas dos corpos-de-prova.

\begin{tabular}{|c|c|c|c|c|c|c|c|c|c|c|c|c|c|}
\hline \multirow[b]{3}{*}{$\begin{array}{l}\frac{0}{0} \\
\frac{0}{0} \\
\frac{\pi}{0} \\
\frac{\bar{z}}{0} \\
\frac{0}{0}\end{array}$} & \multirow[b]{3}{*}{ Variáveis } & \multicolumn{12}{|c|}{ Comparações } \\
\hline & & \multicolumn{4}{|c|}{ Comparação com o traço de referência } & \multicolumn{4}{|c|}{ Diferentes porcentagens do mesmo resíduo } & \multicolumn{4}{|c|}{$\begin{array}{l}\text { Diferentes resíduos (porcentagens } \\
\text { similares de substituição) }\end{array}$} \\
\hline & & $\begin{array}{l}\text { REF X } \\
\text { REC }^{8}\end{array}$ & $\begin{array}{c}\text { REF x } \\
\text { RGV100\% } \\
\text { x RGV50\% } \\
\text { x RGV50\% } \\
+ \text { RMV33\% }\end{array}$ & $\begin{array}{c}\text { REF x } \\
\text { RGB100\% } \\
\text { x RGB50\% } \\
\text { x RGB50\% } \\
+ \text { RMB33\% }\end{array}$ & $\begin{array}{l}\text { RGV100\% } \\
\text { x RGV50\% } \\
\text { x RGV50\% } \\
+ \text { RMV33\% }\end{array}$ & $\begin{array}{l}\text { RGB100\% } \\
\text { x RGB50\% } \\
\times \text { RGB50\% } \\
+ \text { RMB33\% }\end{array}$ & $\begin{array}{c}\text { RGV100\% } \\
x \\
\text { RGV-50\% }\end{array}$ & $\begin{array}{c}\text { RGB100\% } \\
x \\
\text { RGB-50\% }\end{array}$ & $\begin{array}{c}\text { RGV50\% x } \\
\text { RGV50\% + } \\
\text { RMV33\% }\end{array}$ & $\begin{array}{c}\text { RGB50\% x } \\
\text { RGB50\% + } \\
\text { RMB33\% }\end{array}$ & $\begin{array}{l}\text { RGV100\% x } \\
\text { RGB100\% }\end{array}$ & $\begin{array}{c}\text { RGV50\% x } \\
\text { RGB50\% }\end{array}$ & $\begin{array}{c}\text { RGV50\%+ } \\
\text { RMV33\% x } \\
\text { RGB50\% + } \\
\text { RMB33\% }\end{array}$ \\
\hline \multirow{7}{*}{$f_{c}{ }^{1}$} & Grupos & $\mathrm{S}(953,1)$ & $\mathrm{S}(461,7)$ & $\mathrm{S}(483,8)$ & $\mathrm{S}(476,3)$ & $\mathrm{S}(319,8)$ & $\mathrm{S}(321,1)$ & $\mathrm{S}(412,8)$ & $\mathrm{S}(351,5)$ & $\mathrm{S}(530,1)$ & $S(274,0)$ & $\mathrm{S}(465,2)$ & $\mathrm{S}(355,6)$ \\
\hline & Traços & $\mathrm{S}(27,5)$ & $\mathrm{S}(20,9)$ & $\mathrm{S}(32,7)$ & $\mathrm{S}(31,2)$ & $\mathrm{S}(15,7)$ & $\mathrm{S}(15,7)$ & $\mathrm{S}(42,3)$ & $\mathrm{S}(71,2)$ & $\mathrm{S}(59,7)$ & $\mathrm{S}(17,7)$ & $\mathrm{S}(17,1)$ & \\
\hline & Idades & $\mathrm{S}(234,6)$ & $\mathrm{S}(126,9)$ & $\mathrm{S}(128,6)$ & $\mathrm{S}(106,3)$ & $S(65,6)$ & $\mathrm{S}(78,8)$ & $\mathrm{S}(98,9)$ & $\mathrm{S}(84,8)$ & $\mathrm{S}(94,9)$ & $\mathrm{S}(60,6)$ & $\mathrm{S}(123,0)$ & $S(55,1)$ \\
\hline & $\mathrm{Gr} \times \mathrm{Tr}^{4}$ & $\mathrm{~S}(2,4)$ & - & - & $\mathrm{S}(3,6)$ & - & - & - & $S(6,1)$ & - & - & $\mathrm{S}(5,2)$ & - \\
\hline & $G r \times I d^{5}$ & $\mathrm{~S}(7,2)$ & $\mathrm{S}(3,8)$ & - & $S(5,4)$ & - & - & $\mathrm{S}(5,3)$ & $S(5,5)$ & - & $\mathrm{S}(3,8)$ & $\mathrm{S}(4,7)$ & - \\
\hline & $\operatorname{Tr} \times 1 d^{6}$ & $\mathrm{~S}(2,7)$ & - & $\mathrm{S}(3,6)$ & - & - & - & - & $S(5,6)$ & - & - & - & - \\
\hline & $\mathrm{Gr} \times \operatorname{Tr} \times \mathrm{Id}^{\prime}$ & - & - & 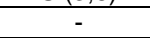 & - & - & - & - & - & - & - & - & - \\
\hline \multirow{7}{*}{$\mathrm{f}_{\mathrm{t}}^{2}$} & Grupos & $\mathrm{S}(259,8)^{9}$ & $\mathrm{~S}(139,4)$ & $\mathrm{S}(108,4)^{10}$ & $\mathrm{~S}(124,1)$ & $\mathrm{S}(163,4)^{10}$ & $\mathrm{~S}(56,1)$ & $\mathrm{S}(183,1)$ & $\mathrm{S}(103,5)$ & $\mathrm{S}(220,4)^{10}$ & $\mathrm{~S}(78,9)$ & $\mathrm{S}(108,5)$ & $\mathrm{S}(146,3)^{10}$ \\
\hline & Traços & $\mathrm{S}(8,8)^{9}$ & $\mathrm{~S}(7,8)$ & $\mathrm{S}(9,0)^{10}$ & $\mathrm{~S}(4,5)$ & $\mathrm{S}(7,3)^{10}$ & - & $\mathrm{S}(13,9)$ & $\mathrm{S}(10,5)$ & $\mathrm{S}(19,7)^{10}$ & $\mathrm{~S}(5,7)$ & - & - \\
\hline & Idades & $\mathrm{S}(78,7)^{9}$ & $\mathrm{~S}(45,0)$ & - & $\mathrm{S}(49,3)$ & - & $\mathrm{S}(25,7)$ & $\mathrm{S}(48,2)$ & $\mathrm{S}(42,8)$ & & $\mathrm{S}(27,1)$ & $\mathrm{S}(38,8)$ & - \\
\hline & $\mathrm{Gr} \times \mathrm{Tr}$ & - & - & - & - & - & - & - & $S(4,5)$ & $\mathrm{S}(5,2)^{10}$ & - & - & \\
\hline & Gr $\times$ Id & - & - & - & - & - & - & - & - & - & - & - & - \\
\hline & Tr $\times I d$ & - & - & - & - & - & - & - & - & - & - & - & - \\
\hline & Gr $\times \operatorname{Tr} \times I d$ & - & - & - & - & - & - & - & - & - & - & - & - \\
\hline \multirow{7}{*}{$\mathrm{E}_{\mathrm{c}}^{3}$} & Grupos & $\mathrm{S}(439,9)$ & $S(209,2)$ & $\mathrm{S}(357,2)$ & $\mathrm{S}(130,4)$ & $\mathrm{S}(268,5)$ & $\mathrm{S}(73,2)$ & $\mathrm{S}(148,7)$ & $\mathrm{S}(84,4)$ & $\mathrm{S}(190,2)$ & $\mathrm{S}(213,2)$ & $S(87,8)$ & $\mathrm{S}(194,6)$ \\
\hline & Traços & $\mathrm{S}(23,8)$ & $\mathrm{S}(17,1)$ & $\mathrm{S}(40,9)$ & $S(16,2)$ & $S(14,3)$ & $S(7,5)$ & $S(19,1)$ & $\mathrm{S}(31,3)$ & $S(20,2)$ & $\mathrm{S}(21,1)$ & $S(11,5)$ & \\
\hline & Idades & $\mathrm{S}(93,1)$ & $\mathrm{S}(45,2)$ & $\mathrm{S}(72,1)$ & $\mathrm{S}(29,4)$ & $S(55,0)$ & $S(19,2)$ & $\mathrm{S}(42,1)$ & $\mathrm{S}(18,1)$ & $\mathrm{S}(25,7)$ & $\mathrm{S}(37,2)$ & $\mathrm{S}(19,8)$ & $S(23,7)$ \\
\hline & $\mathrm{Gr} \times \mathrm{Tr}$ & - & - & - & - & - & - & - & - & - & - & - & \\
\hline & Gr $\times$ Id & - & - & - & - & - & - & - & - & - & - & - & - \\
\hline & $\operatorname{Tr} \times \operatorname{Id}$ & - & - & - & - & - & - & - & - & - & - & - & - \\
\hline & Gr $\times \operatorname{Tr} \times I d$ & - & - & - & - & - & - & - & - & - & - & - & - \\
\hline
\end{tabular}

(S) : influência significativa para um nível de significância igual a $5 \%\left(F_{0}>F_{\text {critico }}\right)$

$(-)$ : sem influência significativa $\left(F_{0}<F\right.$ do $)$

ânteses refere-se ao valor de $F_{0}$. Quanto maior o valor de $F_{0}$, maior será a influência do parâmetro sobre a propriedade analisada

resistência à compressão; ${ }^{2}$ resistência à tração por compressão diametral; ${ }^{3}$ módulo de deformação

grupos $\mathrm{x}$ traços;' grupos $\mathrm{x}$ idades; ' traços $\mathrm{x}$ idades; ' grupos $\mathrm{x}$ traços $\mathrm{x}$ idades

REC - todos os traços produzidos com agregados reciclados (seis no total)

${ }_{10}$ todos os traços, com exceção da dosagem RGB-50\% + RMB-33\% 
Analisando-se os resultados de resistência à compressão da Tabela 6.38 são estabelecidos os seguintes comentários:

- Para as comparações envolvendo o traço de referência, nota-se que todas as variáveis influenciaram significativamente a resistência à compressão. A variável "grupo" teve influência mais significativa sobre a resistência comparativamente às demais variáveis. De maneira geral, os maiores valores médios de resistência à compressão foram obtidos para as dosagens do Grupo 12,0 (53\% e 140\% superiores aos resultados dos Grupos 8,0 e Grupo 4,5, respectivamente) e para os CPs ensaiados aos vinte e oito dias (28\% superior, em média, aos resultados dos CPs aos sete dias). Com relação à variável "traço", pode-se afirmar que os resultados para as dosagens com agregados reciclados foram significativamente menores quando comparados com o traço de referência, com exceção da dosagem com agregados reciclados de vigota (RGV-50\%). Comparativamente ao traço de referência, as dosagens com agregados reciclados apresentaram uma redução média na resistência à compressão igual a 10\% (RGV-100\%), 20\% (RGV-50\% + RMV-33\%), 22\% (RGB-100\% e RGB-50\%+RMB-33\%) e 8\% (RGB-50\%). Hansen (1985) cita que a resistência à compressão de concretos com agregados graúdos reciclados sofre uma redução de cerca de 5\% em relação à resistência de um concreto com agregados naturais de características similares.

- Pela análise de $2^{\mathrm{a}}$ ordem, nota-se que os parâmetros (grupos e idades) e (traços e idades) influenciaram a resistência à compressão para as composições com agregados reciclados de vigota e agregados reciclados de bloco, respectivamente. Para o segundo caso (traços e idades), afirma-se que dependendo da idade pode haver um traço que conduz aos valores extremos de resistência, mas, para outra idade, pode não ser necessariamente esse traço que levará aos maiores/menores valores médios de resistência. Para a idade de sete dias, pode-se afirmar que os menores valores de resistência foram obtidos pela dosagem RGB-100\%; no entanto, aos vinte e oito dias, pode não ser necessariamente essa dosagem que obteve os menores valores médios de resistência; nesse caso, os menores valores médios foram obtidos pela dosagem RGB-50\% + RMB-33\%, que apresentou um acréscimo de apenas $19 \%$ na resistência aos vinte e oito dias comparativamente aos valores de sete dias, enquanto que, para a dosagem RGB-100\%, esse mesmo acréscimo foi de $30 \%$. 
- Para as comparações envolvendo diferentes porcentagens de substituição do mesmo resíduo, pode-se dizer que todas as variáveis (grupos, traços e idades) influenciaram significativamente a resistência à compressão, sendo a variável "grupos" o parâmetro que teve maior influência sobre a propriedade analisada. De maneira geral, os maiores valores médios de resistência foram obtidos para as dosagens com maior consumo de cimento (Grupo 12,0), para os CPs ensaiados aos vinte e oito dias de idade e para as dosagens com menor porcentagem de substituição de agregado natural por reciclado (RGV-50\% e RGB-50\%). Pela análise de $2^{\mathrm{a}}$ ordem, para as comparações com agregados reciclados de vigota (RGV-100\% x RGV-50\% x RGV-50\%+RMV-33\% e RGV-50\% x RGV-50\%+RMV-33\%), pode-se afirmar que todos os parâmetros influenciaram na resistência à compressão, ou seja, para diferentes grupos (grupos $x$ traços e grupos $x$ idades) e diferentes idades (traços $\mathrm{x}$ idades) pode haver diferentes traços (grupos $\mathrm{x}$ traços e traços $\mathrm{x}$ idades) $\mathrm{e}$ diferentes idades (grupos $x$ idades) que conduzem aos valores extremos de resistência. Dessa forma, por exemplo, considerando-se os parâmetros grupos e traços, pode-se dizer que dependendo do grupo haverá um determinado traço que conduzirá aos valores extremos de resistência, mas, para outro grupo, pode não ser esse mesmo traço que levará aos maiores/menores valores médios de resistência.

- Para as composições envolvendo agregados graúdos reciclados de bloco, pode-se dizer que os parâmetros (grupos e idades) influenciaram a resistência à compressão, ou seja, para diferentes grupos pode haver diferentes idades que conduzem a valores extremos de resistência. Esse fato demonstra que a elevação da resistência para alguns grupos desses traços não foi significativa.

- Para as comparações envolvendo diferentes tipos de resíduos, pode-se afirmar que as variáveis "grupos" e "idades" influenciaram significativamente a resistência à compressão. Com relação à variável "traço", pode-se dizer que as dosagens com agregados graúdos reciclados de vigota apresentaram valores de resistência significativamente superiores aos obtidos para as dosagens com agregados graúdos reciclados de bloco. Esse aumento foi de cerca de 10\% (RGV-50\%) e 14\% (RGV$100 \%$ ) comparativamente aos traços RGB-50\% e RGB-100\%, respectivamente. A explicação para esse fato deve-se a menor resistência e fragilidade do resíduo de bloco comparativamente ao resíduo de vigota. Diversos pesquisadores, tais como, Hansen (1985), Kikuchi et al. (1998) e Ajdukiewicz e Kliszczewicz (2002) citam que a resistência do concreto com agregados reciclados depende fundamentalmente da 
resistência e qualidade do resíduo de concreto e da relação água/cimento adotada na mistura.

- Considerando-se a análise de $2^{\mathrm{a}}$ ordem, para as comparações envolvendo agregados graúdos reciclados, observou-se uma influência significativa dos parâmetros (grupos e traços) e (grupos e idades) sobre a resistência à compressão, ou seja, para diferentes grupos pode haver diferentes traços (grupos $x$ traços) $\mathrm{e}$ diferentes idades (grupos e idades) que conduzem aos valores extremos de resistência. Por exemplo, para os parâmetros (grupos e traços), pode-se afirmar que, para os grupos 4,5 e 8,0, a dosagem RGV-50\% apresentou valores de resistência, em média, 10\% superiores aos valores obtidos para a dosagem RGB-50\%; já para o Grupo 8,0, essa diferença foi reduzida para apenas 4\%.

Analisando-se os resultados de resistência à tração da Tabela 6.38 são estabelecidos os seguintes comentários:

- Considerando-se as comparações envolvendo o traço de referência, pode-se afirmar que todos os parâmetros (grupos, traços e idades) influenciaram significativamente a resistência à tração. De maneira geral, os maiores valores médios de resistência à tração foram obtidos para as dosagens do Grupo 12,0 (37\% e 148\% superiores aos resultados dos Grupos 8,0 e Grupo 4,5, respectivamente) e para os CPs ensaiados aos vinte e oito dias (26\% superior, em média, aos resultados de sete dias). Com relação à variável "traço", pode-se afirmar que os resultados de resistência à tração para as dosagens com agregados reciclados foram significativamente menores quando comparados com o traço de referência, com exceção da dosagem com agregados reciclados de vigota (RGV-50\%). Comparativamente ao traço de referência, as dosagens com agregados reciclados apresentaram uma redução média da resistência à tração igual a 14\% (RGV-100\%), 21\% (RGV-50\% + RMV33\%), 23\% (RGB-100\%) e 13\% (RGB-50\%). Apesar disso, Buttler (2003) cita que as características do agregado reciclado, tais como, sua superfície áspera e irregular e partículas angulares favorecem a resistência à tração do concreto, pois provocam a retenção de grande quantidade de partículas de cimento na sua superfície resultando em uma excelente aderência entre agregado e pasta. Pela análise de diversos trabalhos, Hansen (1985) relata que não há diferença significativa entre a resistência à tração para concretos com agregados graúdos reciclados e concretos com agregados naturais. 
- Considerando-se as comparações envolvendo diferentes porcentagens do mesmo resíduo, pode-se afirmar que a variável "grupo" teve influência mais significativa, comparativamente às demais variáveis, sobre a propriedade de resistência à tração. De maneira geral, os maiores valores médios de resistência foram obtidos para as dosagens do grupo 12,0 e para os CPs ensaiados aos vinte e oito dias.

- Para as composições com agregados reciclados de vigota, pode-se afirmar que a variável "traços" influenciou os resultados de resistência à tração, com exceção da comparação entre os traços com agregados graúdos reciclados. De maneira geral, os maiores valores médios de resistência foram obtidos para os traços com menor taxa de substituição de agregado natural por agregado reciclado (RGV-50\%), apesar disso não foram notadas diferenças significativas entre os resultados desse traço (RGV-50\%) e ao traço RGV-100\% (diferença de apenas 4\%). A presença da fração miúda reciclada (RGV-50\% + RMV-33\%) acarretou uma redução significativa da resistência à tração comparativamente aos traços RGV-50\% (13\%) e ao traço REF (21\%). Pela análise de $2^{\mathrm{a}}$ ordem, para a comparação entre os traços RGV-50\% e RGV-50\% + RMV-33\%, observou-se uma influência significativa dos parâmetros (grupos e traços) sobre a resistência à tração, ou seja, para diferentes grupos pode haver diferentes traços que conduzem aos maiores valores médios de resistência à tração. Por exemplo, para os Grupos 4,5 e 8,0, os maiores valores médios de resistência foram obtidos para o traço RGV-50\% (31\% superior, em média, ao traço RGV-50\% + RMV-33\%); já para o Grupo 12,0, os maiores valores médios foram obtidos para o traço RGV-50\% + RMV-33\% (2,6\% superior comparativamente ao traço RGV-50\%).

- Para as composições com agregados reciclados de bloco, pode-se afirmar que a variável "traços" teve influência significativa sobre a resistência à tração para todas as comparações avaliadas. De certa forma, os maiores valores médios de resistência foram obtidos para os traços com menor porcentagem de substituição de agregado natural por agregado reciclado (RGB-50\%). A dosagem RGB-50\% apresentou valores de resistência à tração, em média, 17\% e 14\% superiores aos traços RGB100\% e RGB-50\%+RMB-33\%, respectivamente. Pela análise de $2^{\mathrm{a}}$ ordem, para a comparação entre os traços RGB-50\% e RGB-50\% + RMB-33\%, observou-se uma influência significativa dos parâmetros (grupos e traços) sobre a resistência à tração, ou seja, para diferentes grupos pode haver diferentes traços que conduzem aos maiores valores médios de resistência à tração. Por exemplo, para os Grupos 8,0 e 12,0 , os maiores valores médios de resistência foram obtidos para o traço RGB-50\% 
(19\% superior comparativamente ao traço RGB-50\% + RMB-33\%); já para o Grupo 12,0 , os maiores valores foram obtidos para o traço RGB-50\% + RMB-33\% (0,3\% superior comparativamente ao traço RGB-50\%).

- Para as comparações envolvendo diferentes tipos de resíduos, pode-se afirmar que as variáveis "grupos" e "idades" tiveram influência significativa sobre a resistência à tração. Os maiores valores médios de resistência à tração foram obtidos para as dosagens do grupo 12,0 e para os CPs ensaiados aos vinte e oito dias. Com relação à variável "traços", pode-se dizer que as dosagens com agregados reciclados de vigota apresentaram valores de resistência à tração semelhantes aos obtidos para as dosagens com agregados graúdos reciclados de bloco, com exceção da comparação entre os traços RGV-100\% e RGB-100\%. Comparando-se os traços com agregados reciclados de vigota e os traços com reciclados de bloco, observou-se um aumento significativo de $12 \%$ na resistência à tração (RGV-100\% em relação ao traço RGB100\%), aumento de 3\% na resistência à tração (RGV-50\% em relação ao traço RGB$50 \%$ ) e redução de $0,8 \%$ na resistência à tração (RGV-50\% + RMV-33\% em relação ao traço RGB-50\% + RMB-33\%).

- Na propriedade de resistência à tração, similarmente ao que ocorreu na resistência à compressão, a maior fragilidade e a menor resistência do agregado graúdo reciclado de bloco, comparativamente ao agregado graúdo reciclado de vigota, acabou afetando negativamente, embora algumas vezes não significativamente, a resistência à tração das dosagens produzidas com esse tipo de agregado.

Com relação aos resultados de módulo de deformação apresentados na Tabela 6.38 são estabelecidos os seguintes comentários:

- Considerando-se as comparações envolvendo o traço de referência, pode-se afirmar que todos os parâmetros (grupos, traços e idades) influenciaram no módulo de deformação. De maneira geral, os maiores valores médios de módulo de deformação foram obtidos para as dosagens do Grupo 12,0 (28\% e 65\% superiores aos resultados dos Grupos 8,0 e Grupo 4,5, respectivamente) e para os CPs ensaiados aos vinte e oito dias (14\% superior, em média, aos resultados obtidos pelos CPs aos sete dias). Com relação à variável "traço", pode-se afirmar que os resultados de módulo de deformação para as dosagens com agregados reciclados foram significativamente menores quando comparados com o traço de referência, com exceção da dosagem com agregados reciclados de vigota (RGV-50\%). Comparativamente ao traço de referência, as dosagens com agregados reciclados 
apresentaram uma redução média no módulo de deformação igual a 9\% (RGV100\%), 16\% (RGV-50\% + RMV-33\%), 19\% (RGB-100\% e RGB-50\% + RMB-33\%) e 10\% (RGB-50\%). De acordo com Buttler (2003), a porosidade do agregado determina sua rigidez, que por sua vez controla a capacidade do agregado em restringir deformações da matriz; os agregados reciclados, que possuem uma maior porosidade devido a camada de argamassa aderida a sua superfície, apresentarão menores valores de módulo de deformação comparativamente ao concreto com agregados naturais. A Rilem Recommendation (1994) fornece um coeficiente de correção igual a 0,80 para o módulo de deformação do concreto com agregados reciclados que deverá ser multiplicado pelo valor do módulo de deformação do concreto com agregados naturais de características similares. Esse valor está em concordância com os resultados experimentais.

- Para as comparações envolvendo diferentes porcentagens do mesmo resíduo, podese afirmar que todas as variáveis influenciaram significativamente o módulo de deformação. De maneira geral, os maiores valores médios de módulo de deformação foram obtidos para os traços do Grupo 12,0, para os exemplares ensaiados aos vinte e oito dias e para as dosagens com menor porcentagem de substituição de agregado natural por agregado reciclado (RGV-50\% e RGB-50\%). A substituição total da fração graúda natural pela reciclada (RGV-100\% e RGB-100\%) e a presença da fração miúda reciclada (RGV-50\% + RMV-33\% e RGB-50\% + RMB-33\%) acarretaram uma redução substancial do módulo de deformação comparativamente as dosagens com substituição parcial (RGV-50\% e RGB-50\%). Apenas os traços RGB-100\% e RGB-50\% + RMB-33\% apresentaram valores semelhantes de módulo de deformação.

- Para as comparações entre os diferentes tipos de resíduos, pode-se afirmar que as variáveis "grupos" e "idades" influenciaram significativamente o módulo de deformação. Novamente, os maiores valores médios foram obtidos para as dosagens do grupo 12,0 e pelos CPs ensaiados aos vinte e oito dias. Com relação à variável "traço", pode-se afirmar que as dosagens com agregados graúdos reciclados de vigota apresentaram valores de módulo de deformação significativamente superiores aos obtidos para as dosagens com agregados graúdos reciclados de bloco. Esse aumento foi de 10\% (RGV-50\%) e 12\% (RGV-100\%) comparativamente aos traços RGB-50\% e RGB-100\%, respectivamente. A explicação para esse comportamento deve-se a menor resistência e fragilidade do resíduo de bloco comparativamente ao resíduo de vigota. Por outro lado, para os traços RGV-50\% + 
RMV-33\% e RGB-50\% + RMB-33\%, não foram notadas diferenças significativas nos valores de módulo de deformação.

Nas Figuras 6.15 a 6.17, são apresentados três gráficos ilustrando os resultados obtidos para as propriedades mecânicas das dosagens com agregados reciclados comparativamente aos resultados obtidos para a dosagem de referência. Os resultados referem-se aos valores médios das propriedades aos sete dias e aos vinte e oito dias.

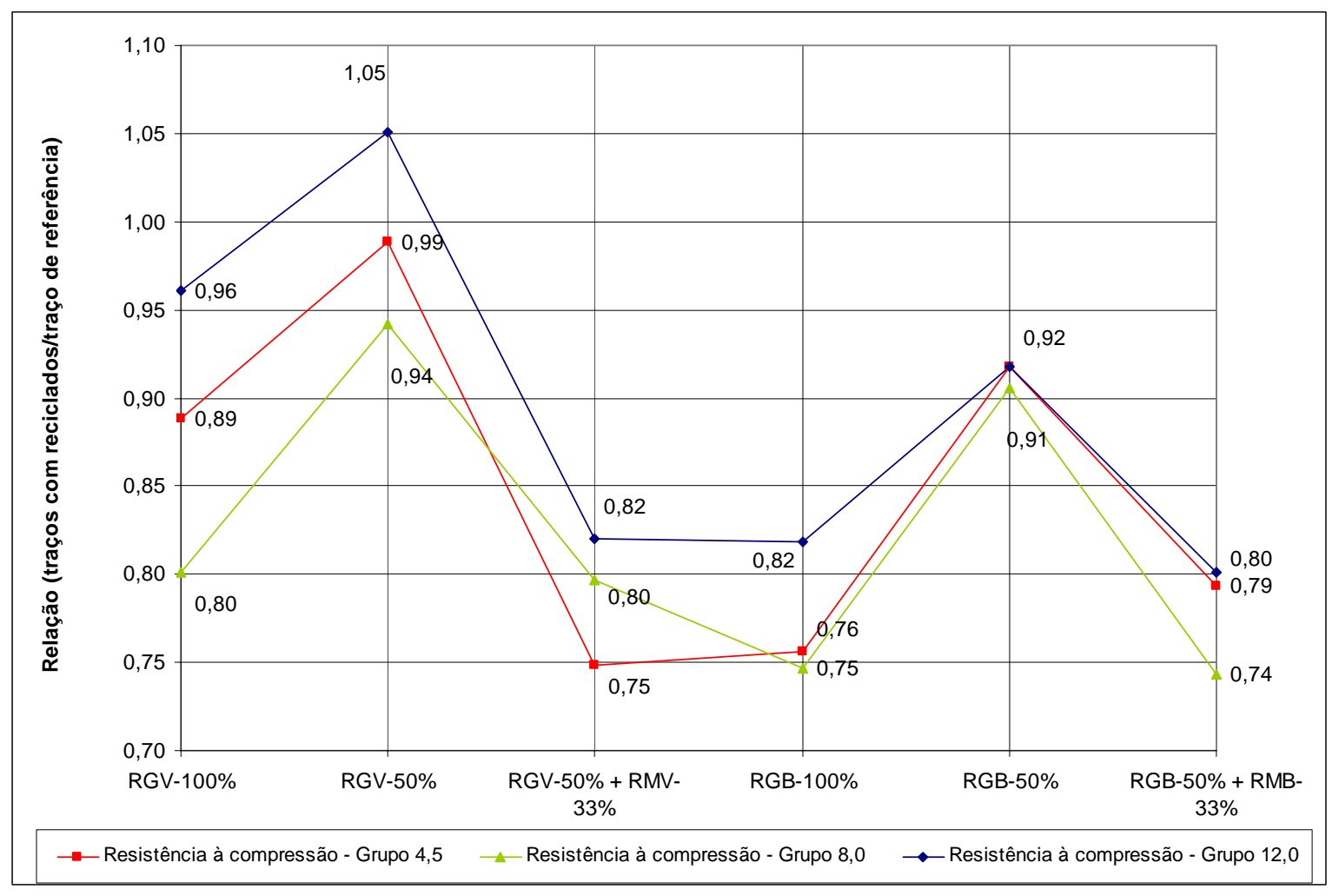

Figura 6.15 - Resultados relativos para a propriedade de resistência à compressão. 


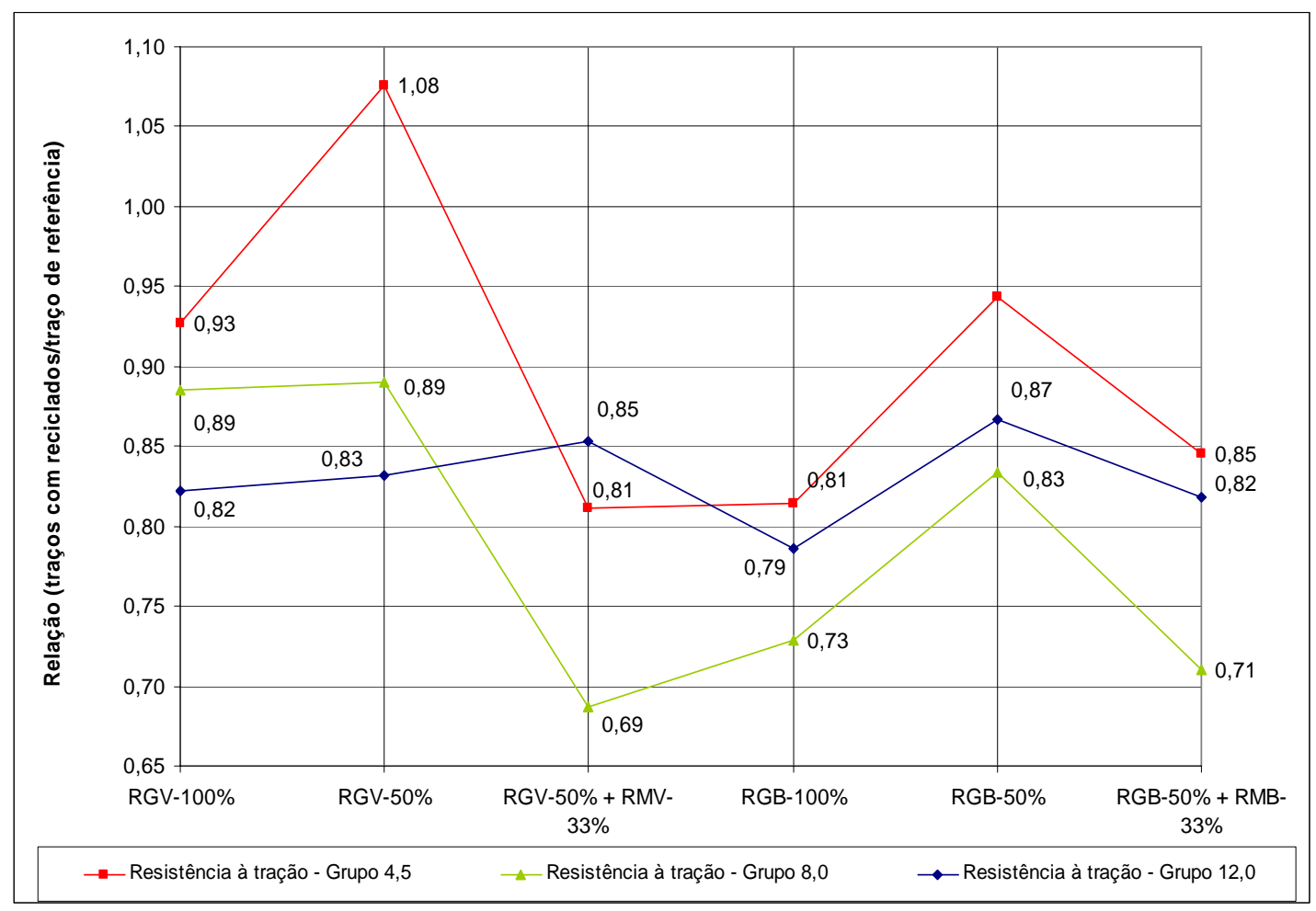

Figura 6.16 - Resultados relativos para a propriedade de resistência à tração.

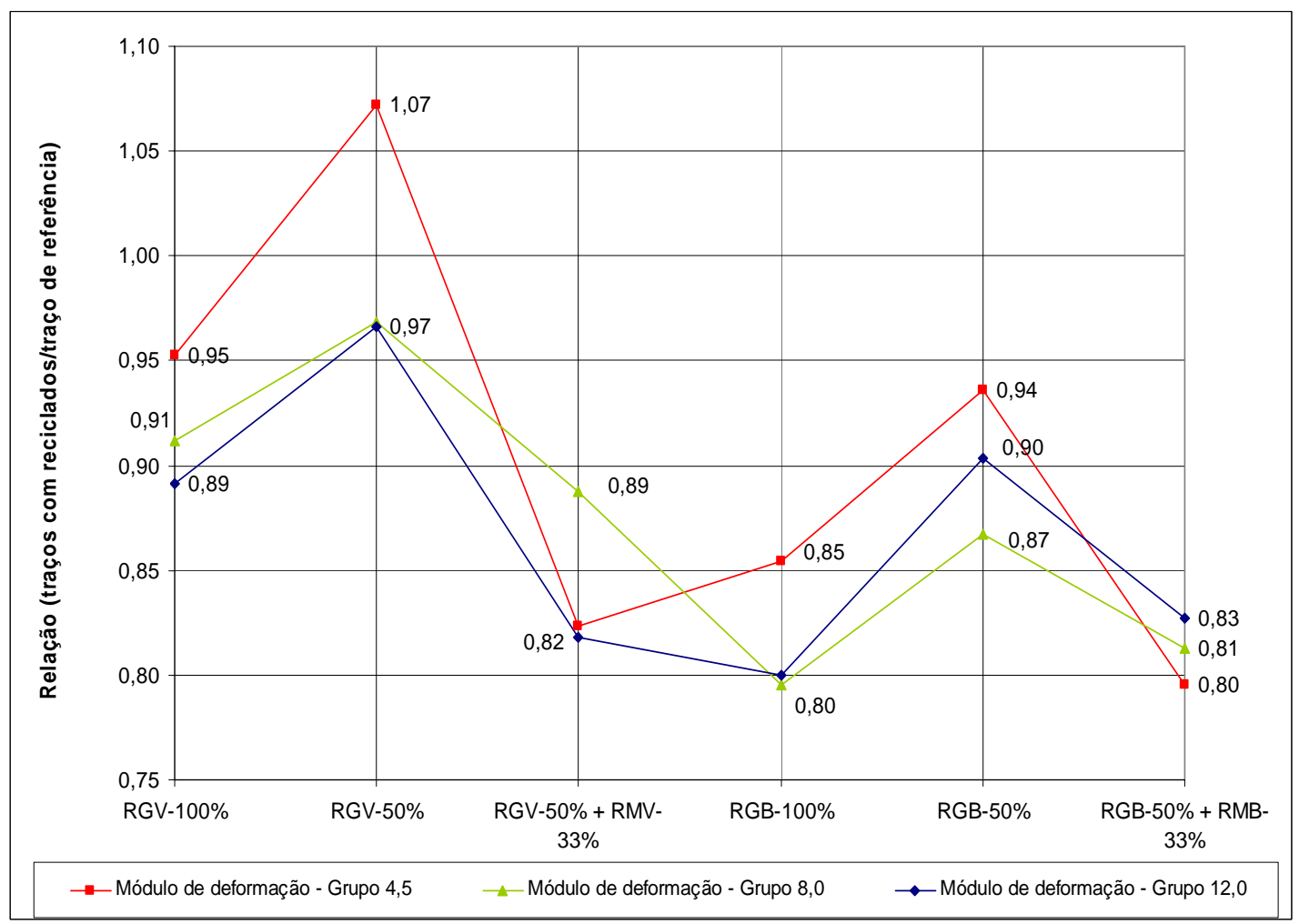

Figura 6.17 - Resultados relativos para a propriedade de módulo de deformação. 
Analisando-se os gráficos das Figuras 6.15 a 6.17 são feitos os seguintes comentários:

- Comparativamente ao traço de referência, apenas a dosagem com substituição parcial do pedrisco por agregado graúdo reciclado de vigota (RGV-50\%) apresentou valores próximos para as propriedades mecânicas. Os demais traços com agregados reciclados apresentaram valores de propriedades mecânicas que diferiram e foram significativamente menores comparativamente aos resultados da dosagem de referência.

- As características dos resíduos empregados, a porcentagem de substituição e a presença da fração miúda reciclada influenciaram significativamente as propriedades mecânicas. Com relação às características do resíduo, pode-se dizer que os maiores valores para as propriedades mecânicas foram obtidos para os traços com agregados graúdos reciclados de vigota, uma vez que esses resíduos foram provenientes de um concreto de média resistência (35 MPa) comparativamente ao concreto de baixa resistência dos resíduos de bloco. Devido às características dos resíduos de bloco, os agregados graúdos reciclados apresentaram maior fragilidade e menor resistência (perda de massa por abrasão $82 \%$ superior ao valor obtido para os agregados reciclados de vigota), fato esse que acabou provocando uma diminuição significativa da resistência e módulo de deformação dos concretos produzidos com esses resíduos.

- Com relação à porcentagem de substituição, pode-se afirmar que os menores valores para as propriedades mecânicas foram obtidos para os traços com substituição total da fração graúda natural pela fração reciclada. A diminuição nas propriedades mecânicas pode ser explicada pela grande quantidade de argamassa porosa que se encontra aderida ao agregado reciclado e a fragilidade do agregado reciclado (resíduo de bloco). Comparativamente aos traços com substituição parcial, os traços com substituição total da fração natural pela graúda reciclada apresentaram uma diminuição de 11\% (RGV-100\%) e 15\% (RGB-100\%) da resistência à compressão, redução de 6\% (RGV-100\%) e 12\% (RGB-100\%) da resistência à tração e redução de 9\% (RGV-100\%) e 10\% (RGB-100\%) do módulo de deformação.

- O emprego da fração miúda reciclada, especialmente a fração miúda de vigota, provocou uma redução significativa das propriedades mecânicas comparativamente às dosagens com substituição parcial da fração natural pela graúda reciclada. Essa 
diminuição pode ser explicada pela elevada porosidade e absorção de água da fração miúda reciclada comparativamente a fração graúda (aumento de 98\% na absorção de água para o agregado miúdo reciclado de vigota e $25 \%$ para o agregado miúdo reciclado de bloco). Comparativamente aos traços com substituição parcial (RGV-50\% e RGB-50\%), os traços com agregados miúdos e graúdos reciclados apresentaram uma diminuição de 20\% (RGV-50\% + RMV-33\%) e 15\% (RGB-50\% + RMB-33\%) da resistência à compressão, redução de 16\% (RGV-50\% + RMV-33\%) e 10\% (RGB-50\% + RMB-33\%) da resistência à tração e redução de 16\% (RGV-50\% + RMV-33\%) e 10\% (RGB-50\% + RMB-33\%) no módulo de deformação.

- Conforme já estabelecido anteriormente, apenas as dosagens que apresentassem, em média, uma diminuição de até $15 \%$ nas propriedades mecânicas, comparativamente ao traço de referência, seriam adequadas à produção de blocos de concreto. Diante disso, as dosagens com agregados graúdos e miúdos reciclados e os traços com substituição total da fração natural pela graúda reciclada de bloco não se mostraram adequadas à produção dos blocos, uma vez que a redução das propriedades mecânicas foi superior a 15\%. De maneira geral, comparativamente ao traço de referência, essas dosagens apresentaram uma redução de 22\% (RGB100\% e RGB-50\% + RMB-33\%) e 21\% (RGV-50\% + RMV-33\%) na resistência à compressão, diminuição de 22\% (RGB-100\% e RGV-50\% + RMV-33\%) e 21\% (RGB-50\% + RMB-33\%) na resistência à tração e, finalmente, redução de 16\% (RGV-50\% + RMV-33\%) e 19\% (RGB-100\% e RGB-50\% + RMB-33\%) do módulo de deformação.

\subsection{Estimativa da resistência dos blocos através da correlação com os CPs}

Nesse tópico são apresentadas as estimativas de resistência dos blocos em função dos valores de resistência obtidos para os corpos-de-prova. São considerados apenas os traços que obtiveram valores de índice de vazios e absorção de água até $30 \%$ superiores aos valores de referência e redução de até 15\% nas propriedades mecânicas.

Em razão dos resultados obtidos anteriormente, considerou-se um intervalo de correlação situado entre 0,80 e 1,30 para a relação entre a resistência do corpo-de-prova e do bloco, um coeficiente de variabilidade na produção dos blocos de $10 \%$ e a relação entre área líquida e área bruta das unidades igual a 0,575. A formulação da correlação entre corpos-de-prova e blocos é apresentada no Apêndice H. Pela eq. (6.1) extraída de Frasson Junior (2000), pode-se encontrar a resistência média a partir da resistência característica 
desejada e o coeficiente de variação estipulado (10\%), a fim de garantir a resistência especificada para os blocos.

$$
f b_{m}=\frac{f b_{k}}{1-1,65 . C V}
$$

Onde:

$\mathrm{fb}_{\mathrm{m}}$ - resistência média; $\mathrm{fb}_{\mathrm{k}}$ - resistência característica desejada; CV - coeficiente de variação

Considerando-se as resistências características pretendidas de 4,5 MPa, 8,0 MPa e $12,0 \mathrm{MPa}$, as resistências médias a serem atingidas pelos blocos de concreto, através da correlação existente com os CPs, serão de 5,4 MPa, 9,6 MPa e 14,4 MPa, respectivamente.

Na Tabela 6.39, são apresentadas as previsões de resistência dos blocos em função dos resultados dos corpos-de-prova dos Grupos 4,5, 8,0 e 12,0.

Tabela 6.39 - Estimativa da resistência dos blocos, na área bruta, em função dos resultados dos corpos-de-prova.

\begin{tabular}{|c|c|c|c|c|c|c|}
\hline \multirow[b]{2}{*}{ Grupos } & \multirow[b]{2}{*}{ Traços } & \multicolumn{2}{|c|}{ CPs } & \multicolumn{3}{|c|}{ Blocos } \\
\hline & & Idade & $\mathrm{f}_{\mathrm{cp}}{ }^{1}(\mathrm{MPa})$ & $\begin{array}{c}\mathbf{f}_{\text {b-prevista }}{ }^{2}(\mathrm{MPa}) \\
\text { Coef. de Correlação } \\
(1,30-0,80)\end{array}$ & $f_{b k}^{3}(M P a)$ & $\mathrm{f}_{\mathrm{bm}}{ }^{4}(\mathrm{MPa})$ \\
\hline \multirow{8}{*}{4,5} & \multirow{2}{*}{ REF } & 7 & 12,60 & $5,57-9,06$ & \multirow{8}{*}{4,50} & \multirow{8}{*}{$>5,40$} \\
\hline & & 28 & 18,84 & $8,33-13,54$ & & \\
\hline & \multirow{2}{*}{ RGV-100\% } & 7 & 11,65 & $5,15-8,37$ & & \\
\hline & & 28 & 16,28 & $7,20-11,70$ & & \\
\hline & \multirow{2}{*}{ RGV-50\% } & 7 & 13,23 & $5,85-9,51$ & & \\
\hline & & 28 & 17,86 & $7,90-12,84$ & & \\
\hline & \multirow{2}{*}{ RGB-50\% } & 7 & 12,65 & $5,59-9,09$ & & \\
\hline & & 28 & 16,20 & $7,17-11,64$ & & \\
\hline \multirow{8}{*}{8,0} & \multirow{2}{*}{ REF } & 7 & 20,80 & $9,20-14,95$ & \multirow{8}{*}{8,00} & \multirow{8}{*}{$>9,60$} \\
\hline & & 28 & 29,90 & $13,23-21,49$ & & \\
\hline & & 7 & 18,17 & $8,04-13,06$ & & \\
\hline & RGV-100\% & 28 & 22,43 & $9,92-16,12$ & & \\
\hline & \multirow{2}{*}{ RGV-50\% } & 7 & 20,59 & $9,11-14,80$ & & \\
\hline & & 28 & 27,18 & $12,02-19,54$ & & \\
\hline & \multirow{2}{*}{ RGB-50\% } & 7 & 20,13 & $8,90-14,47$ & & \\
\hline & & 28 & 25,77 & $11,40-18,52$ & & \\
\hline \multirow{8}{*}{12,0} & \multirow{2}{*}{ REF } & 7 & 31,83 & $14,08-22,88$ & \multirow{8}{*}{12,00} & \multirow{8}{*}{$>14,40$} \\
\hline & & 28 & 40,51 & $17,92-19,12$ & & \\
\hline & & 7 & 31,19 & $13,80-22,42$ & & \\
\hline & RGV-100\% & 28 & 38,33 & $16,95-27,55$ & & \\
\hline & \multirow{2}{*}{ RGV-50\% } & 7 & 32,77 & $14,49-23,55$ & & \\
\hline & & 28 & 43,24 & $19,13-31,08$ & & \\
\hline & \multirow{2}{*}{ RGB-50\% } & 7 & 30,17 & $13,34-21,68$ & & \\
\hline & & 28 & 36,19 & $16,01-26,01$ & & \\
\hline $\begin{array}{l}\text { resistênci } \\
\text { resistênci } \\
\text { resistênci }\end{array}$ & $\begin{array}{l}\text { obtida pelos } \\
\text { ida para os bl } \\
\text { erística desej }\end{array}$ & $\begin{array}{l}\text { de-prov } \\
\text { ravés da }\end{array}$ & lação com & corpos-de-prova cilíndr & & \\
\hline sistênc & 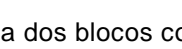 & a d &. & stica & & \\
\hline
\end{tabular}


Analisando-se os dados da Tabela 6.39, nota-se que todas as dosagens dos grupos avaliados mostraram-se adequadas à produção dos blocos de concreto, uma vez que a resistência média pretendida para os blocos de concreto foi alcançada aos sete dias e aos vinte e oito dias.

\subsection{CONCLUSÕES DO CAPÍTULO}

Com relação ao método utilizado para a moldagem dos CPs, pode-se dizer que esse se mostrou adequado ao propósito do trabalho, uma vez que foi possível varrer uma grande gama de variáveis com pequena quantidade de materiais e em tempo reduzido. A utilização desse método também possibilitou uma comparação entre as propriedades físicas e mecânicas dos CPs com agregados reciclados com os produzidos com agregados naturais e exclusão daqueles traços que não apresentaram desempenho satisfatório. Uma das desvantagens do método refere-se à necessidade da uniformização da energia de adensamento, uma vez que essa pode variar de acordo com o operador de moldagem. Para solucionar esse problema, pode ser adaptado um dispositivo mecânico que uniformize a energia de adensamento através da queda de um corpo de massa e altura conhecida (semelhante ao utilizado no ensaio de adensamento de solos).

A estimativa da resistência das unidades de alvenaria pode ser realizada com o estabelecimento de um intervalo de correlação baseado nos resultados de resistência à compressão de corpos-de-prova cilíndricos. O intervalo de correlação ao contrário de um fator único de correlação considera as diferenças que podem ocorrer nos processos produtivos de corpos-de-prova e blocos de concreto, os quais também são responsáveis pelas diferenças nas propriedades físicas dessas diferentes unidades. Comumente no processo produtivo dos blocos, diferentemente do que ocorre nos corpos-de-prova, a distribuição dos materiais nas fôrmas não ocorre de maneira uniforme, o controle de umidade dos materiais é realizado de maneira deficitária e os tempos de vibro-prensagem são variáveis.

Considerando-se as propriedades físicas dos CPs, pode-se dizer que, independente da qualidade do resíduo, há um aumento significativo nos valores de absorção de água e índice de vazios e redução da massa específica proporcional à taxa de substituição de agregados naturais por reciclados, principalmente quando a fração miúda natural é substituída pela fração miúda reciclada. Por outro lado, pode-se dizer que a propriedade de coesão é influenciada pelas características do resíduo, sendo que a inclusão de agregados 
oriundos de resíduos de baixa resistência acarreta uma redução significativa nos valores de coesão, fato esse que pode até inviabilizar a produção de alguns traços com esses resíduos. Para as propriedades mecânicas, tais como, resistência à compressão, resistência à tração e módulo de deformação, pode-se afirmar que as características dos resíduos, a porcentagem de substituição e a presença da fração miúda reciclada influenciam significativamente essas propriedades. De maneira geral, para traços com agregados reciclados de resíduos de baixa resistência e que possuam porcentagens elevadas de substituição de agregados naturais por agregados graúdos e miúdos reciclados são obtidos os menores valores para as propriedades mecânicas.

Na Figura 6.18 é apresentado um fluxograma contendo as principais etapas da metodologia de produção dos CPs bem como a caracterização das propriedades físicas e mecânicas. 


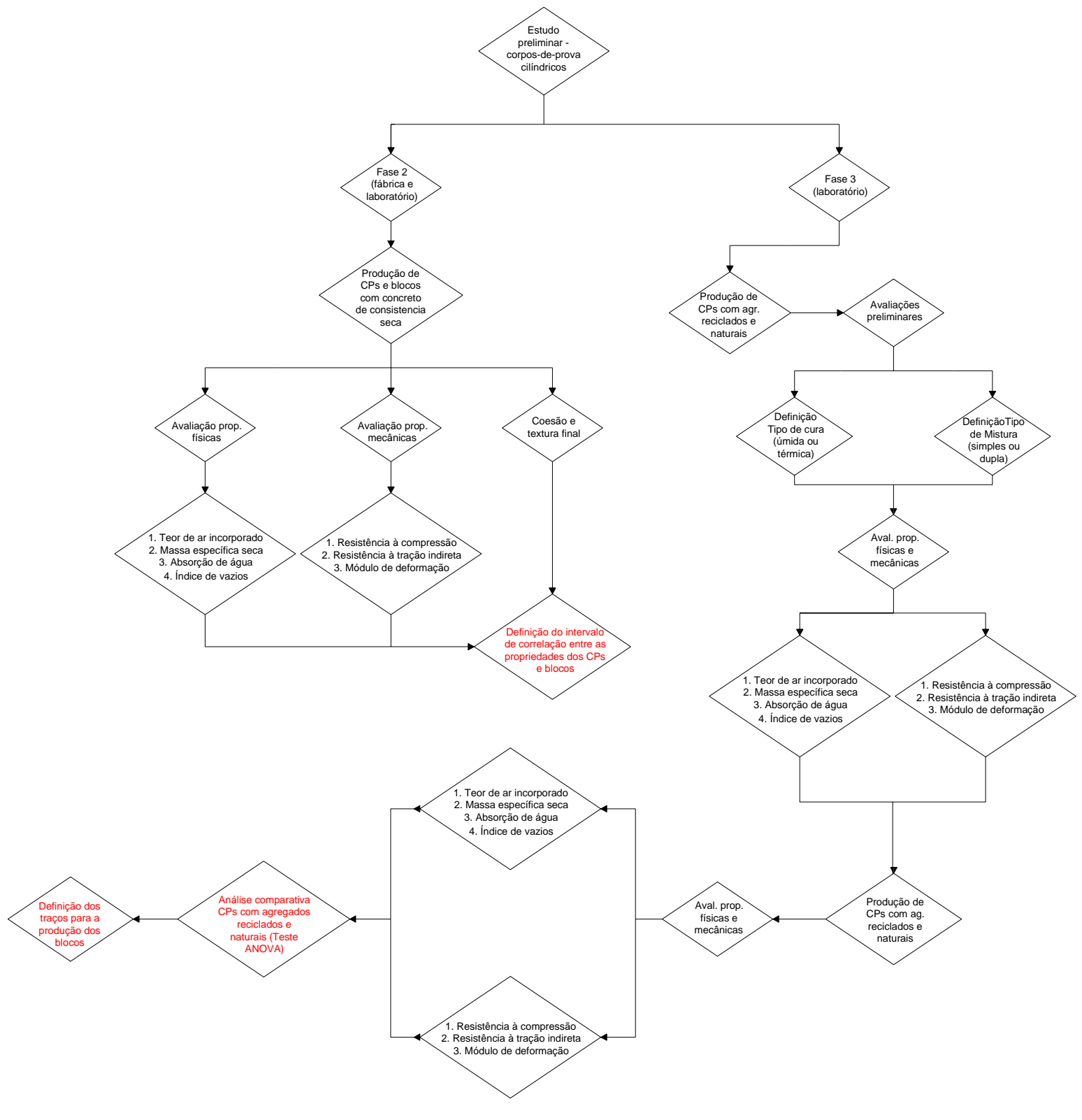

Figura 6.18 - Fluxograma contendo as principais etapas da produção e caracterização das propriedades dos CPs. 


\section{UNIDADES DE ALVENARIA COM AGREGADOS RECICLADOS}

Inicialmente, são descritos os ensaios realizados para os blocos e meios-blocos produzidos com agregados reciclados e agregados naturais, sendo os últimos adotados como referência. Posteriormente, são expostos os principais detalhes referentes à produção dos blocos de concreto, os resultados obtidos e as análises pertinentes e, finalmente, a produção dos meios-blocos, os resultados obtidos e as respectivas análises. Para os blocos de concreto, também são apresentados os resultados de um estudo de viabilidade econômica considerando inúmeras variáveis intervenientes. Na comparação dos resultados foi utilizado o teste estatístico de Análise de Variância. As exigências para a realização desse teste, ou seja, a condição de normalidade e a semelhança de variâncias dos resultados foram verificadas e a formulação encontra-se no Anexo $A$.

\subsection{DESCRIÇÃO DAS PROPRIEDADES FÍSICAS AVALIADAS}

O correto desempenho das unidades é garantido desde que atendam aos limites impostos pelas normas técnicas e literatura quanto às propriedades físicas, principalmente, em relação à absorção de água, índice de vazios e absorção capilar.

\subsubsection{ANÁLISE DIMENSIONAL}

Para a avaliação das dimensões reais dos blocos estruturais com agregados reciclados foram seguidas as prescrições da norma NBR 6136 (1994). As tolerâncias são de $\pm 2 \mathrm{~mm}$ para a largura e $\pm 3 \mathrm{~mm}$ na altura e comprimento. A espessura das paredes transversais e longitudinais deve ser de no mínimo $25 \mathrm{~mm}$ para os blocos estruturais da classe M-15. Utilizou-se uma amostra de seis blocos, escolhidos aleatoriamente, para a verificação dimensional. Os blocos produzidos apresentavam dimensões nominais de 140 $\mathrm{mm} \times 190 \mathrm{~mm} \times 290 \mathrm{~mm}$ (largura, altura, comprimento). Na Figura 7.1, é apresentado um croqui típico dessas unidades. 


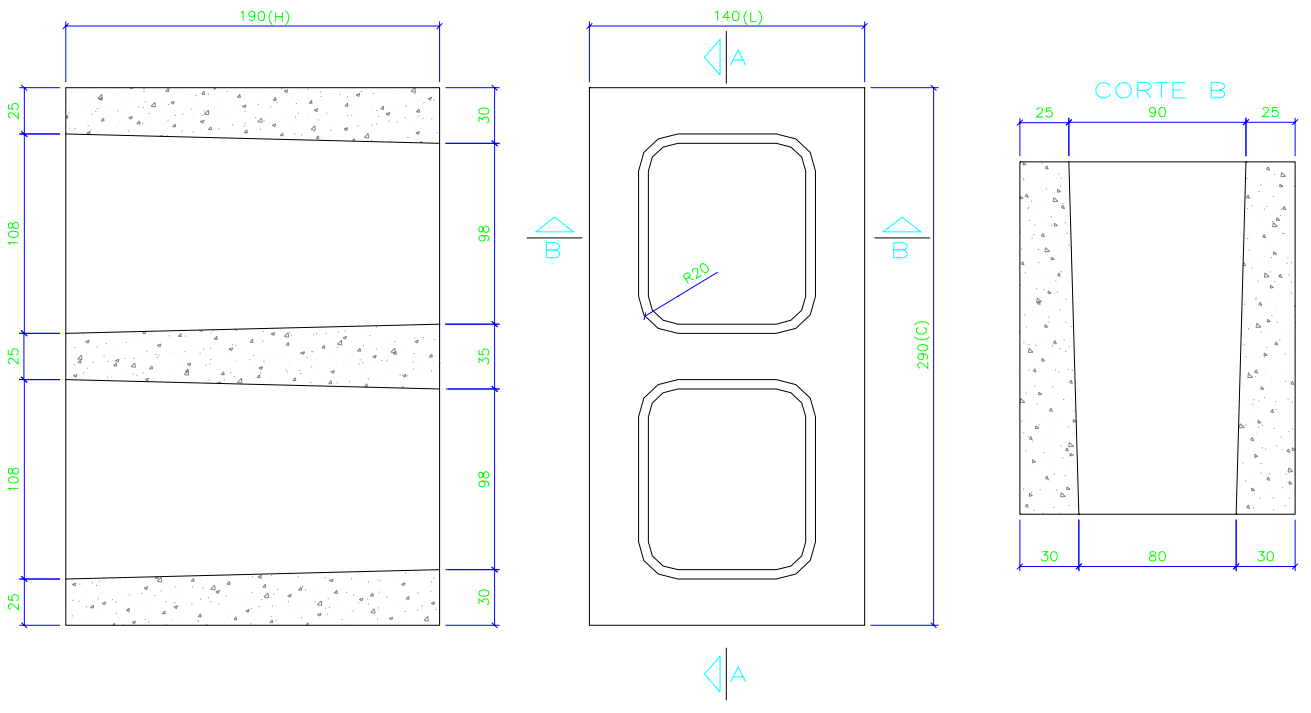

Figura 7.1 - Croqui do bloco estrutural (14x29).

Os dispositivos utilizados para a verificação das dimensões reais dos blocos e o croqui esquemático representando as dimensões verificadas encontram-se no Apêndice I.

\subsubsection{ABSORÇÃO DE ÁGUA E ÁREA LÍQUIDA}

Os ensaios de absorção de água e área líquida foram realizados conforme as prescrições da NBR 12118 (1992). Segundo a NBR 6136 (1994), especificada para blocos de concreto com função estrutural, a absorção de água deve ser menor ou igual a 10\%. Foram utilizados seis blocos e três meios-blocos para avaliação dessas propriedades. Os equipamentos empregados bem como alguns detalhes do ensaio encontram-se no Apêndice J.

\subsubsection{MASSA ESPECÍFICA E ÍNDICE DE VAZIOS}

A massa específica da amostra seca e saturada e o índice de vazios foram determinados utilizando as prescrições da NBR 9778 (1987). Essa norma é aplicável para argamassas e concretos endurecidos e foi adaptada para as unidades de alvenaria.

Os equipamentos foram os mesmos utilizados para o ensaio descrito no item anterior. A balança possuía uma adaptação para realizar medições de massa aparente. Foram utilizados seis blocos para a avaliação dessas propriedades. 


\subsubsection{TAXA DE ABSORÇÃO INICIAL (IRA)}

Conforme Taha et al. (2001), a unidade de alvenaria retira a água presente na argamassa de assentamento por efeito de capilaridade. Essa propriedade pode ser razoavelmente estimada pela taxa de absorção inicial ou IRA (Initial Rate Absorption). Para a determinação do IRA das unidades (blocos e meios-blocos), foi empregada a norma americana ASTM C67 (1996). O ensaio foi realizado com uma amostra de seis blocos e três meios-blocos, ambos secos em estufa, mantendo-se a lâmina d'água normalizada $(3,1860,25 \mathrm{~mm})$. Os equipamentos utilizados e alguns detalhes do ensaio são apresentados no Apêndice K.

\subsubsection{ABSORÇÃO CAPILAR}

O ensaio de absorção capilar foi proposto em virtude das limitações do ensaio da taxa de absorção inicial (IRA). Inúmeros pesquisadores, tais como, Groot (1995), Jansson (1965 apud TAHA et al., 2001) ${ }^{28}$ e Taha et al. (2001) citam que a interação entre argamassa e unidade não pode ser prevista adequadamente pela taxa de absorção inicial (IRA) devido aos seguintes fatores: a) tempo limitado de teste (apenas um minuto), b) o transporte de água da argamassa para a unidade é função de poros capilares menores que 0,5 a 1,5 $\mu \mathrm{m}$, enquanto que o IRA é função de poros capilares maiores que 1,5 $\mu \mathrm{m}$. Além disso, segundo Taha et al. (2001), o ensaio de absorção capilar deverá ser incluído na revisão do código canadense de alvenaria.

O ensaio de absorção capilar também é utilizado para avaliar comparativamente o desempenho das unidades, uma vez que, segundo Nepomuceno (2005), a absorção capilar é um dos mecanismos de transporte que mais afetam a durabilidade das edificações, principalmente, as expostas à chuva e ciclos de umedecimento e secagem. Da Silva et al. (2005) citam que a porosidade do concreto promove o avanço dos processos de degradação pela entrada de agentes agressivos, sendo que uma das formas de avaliar a permeabilidade de sólidos porosos é através do ensaio de absorção capilar. Segundo Da Silva (2006), a durabilidade do concreto depende da facilidade com que os fluidos possam ingressar e deslocar-se no seu interior; dessa maneira, o tamanho, volume dos poros e sua continuidade, assim como o entendimento do mecanismo de transporte dos agentes agressivos no concreto, são fatores apropriados para estimar a vida útil das estruturas de concreto, bem como garantir sua qualidade. 
O ensaio de absorção capilar foi realizado conforme as recomendações da ASTM C1585 (2004) utilizando-se uma amostra de três blocos. Essas unidades foram secas em estufa a $60^{\circ} \mathrm{C}$ e, posteriormente, impermeabilizadas lateralmente com a utilização de uma resina acrílica. A lâmina d'água utilizada foi de 3,18 $\mathrm{mm}$ (semelhante à empregada no ensaio de IRA). Os dispositivos utilizados e alguns detalhes do ensaio são apresentados no Apêndice L.

No cálculo da absorção foi utilizada a expressão (7.1) retirada da ASTM C1585 (2004):

$$
I=\frac{m_{t}}{a / d}
$$

Onde:

$\mathrm{I}=$ absorção (mm).

$\mathrm{m}_{\mathrm{t}}=$ variação da massa $(\mathrm{g})$, no tempo $\mathrm{t}(\min$.$) .$

$\mathrm{a}=$ área da unidade em contato com a água $\left(\mathrm{mm}^{2}\right)$.

$\mathrm{d}=$ densidade da água $\left(\mathrm{g} / \mathrm{mm}^{3}\right)$.

Segundo a ASTM C1585 (2004), a absorção capilar inicial $\left(\mathrm{mm} / \mathrm{s}^{2}\right)$ é definida pela inclinação da reta que melhor se ajusta ao gráfico $\left(1 \times \mathrm{t}^{1 / 2}\right)$. Para a análise da regressão, deve-se utilizar todos os pontos de 1' até 360'. Caso os dados entre 1' e 360' não apresentem uma relação linear, isto é, o coeficiente de correlação seja menor do que 0,98 $\left(R^{2}<0,96\right)$, a absorção capilar inicial não pode ser determinada. Para a determinação da absorção capilar, também foi seguida às recomendações de Taha et al. (2001) e Totoev e James (2004); segundo esses pesquisadores, para o cálculo da absorção capilar, em unidades de alvenaria, deve-se utilizar os dados compreendidos entre o intervalo de 1' e 25' (desde que $\mathrm{R}^{2}>0,96$ ), uma vez que esse período é geralmente crítico para o desenvolvimento da aderência na alvenaria. De acordo com Lange et al. (1996 apud TAHA et al., 2001) ${ }^{29}$, o período inicial (até 25 minutos) é considerado crítico devido ao processo de migração da água e dos produtos de hidratação da argamassa para os poros da unidade.

\footnotetext{
${ }^{28}$ JANSSON, I. Testing the rate of water absorption. In: RILEM/CIB SYMPOSIUM ON MOISTURE PROBLEMS IN BUILDING, 1965, Helsinke. Proceedings... Finlândia, 1965, v. 2, p. 25.1-25.10.

${ }^{29}$ LANGE, D. A.; DEFORD, H. D.; AHMED, A. Microstructure and mechanics of bond in masonry. In: NORTH AMERICAN MASONRY CONFERENCE, 7., 1996, University of Notre Dame, South Bend, Indiana. Proceedings... USA, 1996, p. 167-174.
} 


\subsection{DESCRIÇÃO DAS PROPRIEDADES MECÂNICAS AVALIADAS}

Neste item são detalhados os procedimentos e equipamentos utilizados nos ensaios referentes às propriedades mecânicas dos blocos e meios-blocos de concreto. Basicamente, as propriedades avaliadas são: resistência à compressão, resistência à tração indireta e módulo de deformação.

\subsubsection{RESISTÊNCIA À COMPRESSÃO}

\subsubsection{Blocos de Concreto}

A resistência à compressão dos blocos foi determinada seguindo os preceitos da NBR 7184 (1992) utilizando-se uma amostra de seis unidades. A regularização da superfície foi feita com pasta de enxofre. Os blocos foram ensaiados com umidade natural e não secos ao ar como prescreve a NBR 7184 (1992). Os detalhes do ensaio podem ser encontrados no Apêndice $M$.

\subsubsection{Meios-blocos de Concreto}

A resistência à compressão dos meios-blocos foi determinada seguindo os preceitos da NBR 7184 (1992), utilizando três meios-blocos para cada traço. A regularização da superfície foi feita com pasta de enxofre. Os blocos foram ensaiados com umidade natural e não secos ao ar como prescreve a NBR 7184 (1992). Os detalhes do ensaio encontram-se no Apêndice N.

\subsubsection{RESISTÊNCIA À TRAÇÃO INDIRETA}

A resistência à tração indireta dos blocos de concreto foi determinada conforme a norma americana ASTM C1006 (1996). Esse ensaio não foi realizado para os meios-blocos devido ao pequeno número de unidades produzidas. Os equipamentos utilizados e alguns detalhes do ensaio são apresentados no Apêndice O. Para a determinação da resistência à tração indireta, a ASTM C1006 (1996) recomenda a seguinte equação:

$$
T=\frac{20 P}{\pi \cdot L \cdot H}
$$

Onde:

$\mathrm{T}=$ resistência à tração indireta $(\mathrm{MPa})$;

$\mathrm{P}=$ força máxima aplicada pela máquina de ensaio $(\mathrm{kN})$;

$\mathrm{L}=$ espessura das paredes onde ocorre a aplicação do carregamento $(\mathrm{cm})$; 
$\mathrm{H}=$ altura da seção onde é aplicada a força $(\mathrm{cm})$.

\subsubsection{MÓDULO DE DEFORMAÇÃO}

Um parâmetro fundamental para caracterizar o comportamento do bloco de concreto é a determinação do seu módulo de deformação na direção normal à junta de assentamento. Na presente pesquisa, o módulo de deformação foi calculado de acordo com as prescrições do $\mathrm{ACl}$ 530-92 (1995). Segundo essa norma, o módulo é dado pela inclinação da reta secante no diagrama tensão versus deformação, entre $5 \%$ e $33 \%$ da tensão de ruptura. Os equipamentos utilizados e alguns detalhes do ensaio são apresentados no Apêndice $P$.

\subsection{BLOCOS DE CONCRETO COM AGREGADOS RECICLADOS}

Essa etapa foi desenvolvida na fábrica de elementos pré-moldados "Tatu PréMoldados", situada em Limeira - SP, que cedeu suas instalações para a fabricação dos blocos de concreto com materiais reciclados e com agregados naturais (referência). Nessa fase, foram produzidos quinze traços com a incorporação de agregados reciclados de vigota e bloco e três traços com agregados naturais, para três classes de resistência (4,5 MPa, 8,0 MPa e 12,0 MPa), totalizando 1600 blocos de concreto (140 mm x $190 \mathrm{~mm} \times 290 \mathrm{~mm}$ ). Os principais detalhes referentes à produção dos blocos de concreto são encontrados no próximo item.

\subsubsection{PRODUÇÃO DOS BLOCOS DE CONCRETO}

Nessa etapa, para facilitar o enquadramento das unidades produzidas, as dosagens foram divididas em suas respectivas classes de resistência. Essa divisão é apresentada a seguir:

a) GRUPO 4,5 - nesse grupo inserem-se todas as dosagens produzidas com a relação cimento/agregado próxima a vinte (20). Os agregados empregados foram os naturais (referência) e os materiais reciclados (reciclado de vigota e bloco). O estabelecimento dessas dosagens objetivou a produção de blocos estruturais com resistência característica de 4,5 MPa aos vinte e oito dias.

b) GRUPO 8,0 - nesse grupo inserem-se todas as dosagens produzidas com a relação cimento/agregado próxima a quinze (15). Os agregados empregados foram os naturais e os materiais reciclados (reciclado de vigota e bloco). $\mathrm{O}$ estabelecimento 
dessas dosagens objetivou a produção de blocos estruturais com resistência característica de 8,0 MPa aos vinte e oito dias.

c) GRUPO 12,0 - nesse grupo inserem-se todas as dosagens produzidas com a relação cimento/agregado próxima a dez (10). Os agregados empregados foram os naturais e os materiais reciclados (reciclado de vigota e bloco). O estabelecimento dessas dosagens objetivou a produção de blocos estruturais com resistência característica de 12,0 MPa aos vinte e oito dias.

A respectiva terminologia e as características de cada traço encontram-se na Tabela 7.1.

Tabela 7.1 - Terminologia e características de cada uma das dosagens.

\begin{tabular}{|c|c|c|}
\hline GRUPO & DESIGNAÇÃO & CARACTERISTICAS \\
\hline \multirow{6}{*}{4,5} & B4,5-REF & $\begin{array}{l}\text { Dosagem de referência produzida inteiramente com materiais } \\
\text { naturais }\end{array}$ \\
\hline & B4,5-RGV-100\% & $\begin{array}{l}\text { Dosagem com 100\% de substituição, em massa, da fração graúda } \\
\text { natural (pedrisco) por agregado graúdo reciclado de vigota (GRv) }\end{array}$ \\
\hline & B4,5-RGV-50\% & $\begin{array}{l}\text { Dosagem com aproximadamente } 50 \% \text { de substituição, em massa, da } \\
\text { fração graúda natural por agregado graúdo reciclado de vigota (GRv) }\end{array}$ \\
\hline & B4,5-RMV-33\% & $\begin{array}{l}\text { Dosagem com aproximadamente } 33 \% \text { de substituição, em massa, do } \\
\text { pó de pedra por agregado miúdo reciclado de vigota (MRv) }\end{array}$ \\
\hline & B4,5-RGB-50\% & $\begin{array}{l}\text { Dosagem com aproximadamente } 50 \% \text { de substituição, em massa, da } \\
\text { fração graúda natural por agregado graúdo reciclado de bloco (GRb) }\end{array}$ \\
\hline & B4,5-RMB-33\% & $\begin{array}{l}\text { Dosagem com aproximadamente } 33 \% \text { de substituição, em massa, do } \\
\text { pó de pedra por agregado miúdo reciclado de bloco (MRb) }\end{array}$ \\
\hline \multirow{6}{*}{8,0} & B8,0-REF & $\begin{array}{c}\text { Dosagem de referência produzida inteiramente com materiais } \\
\text { naturais }\end{array}$ \\
\hline & B8,0-RGV-100\% & $\begin{array}{l}\text { Dosagem com 100\% de substituição, em massa, da fração graúda } \\
\text { natural (pedrisco) por agregado graúdo reciclado de vigota (GRv) }\end{array}$ \\
\hline & B8,0-RGV-50\% & $\begin{array}{l}\text { Dosagem com aproximadamente } 50 \% \text { de substituição, em massa, da } \\
\text { fração graúda natural por agregado graúdo reciclado de vigota (GRv) }\end{array}$ \\
\hline & B8,0-RMV-33\% & $\begin{array}{l}\text { Dosagem com aproximadamente } 33 \% \text { de substituição, em massa, do } \\
\text { pó de pedra por agregado miúdo reciclado de vigota (MRv) }\end{array}$ \\
\hline & B8,0-RGB-50\% & $\begin{array}{l}\text { Dosagem com aproximadamente } 50 \% \text { de substituição, em massa, da } \\
\text { fração graúda natural por agregado graúdo reciclado de bloco (GRb) }\end{array}$ \\
\hline & B8,0-RMB-33\% & $\begin{array}{c}\text { Dosagem com aproximadamente } 33 \% \text { de substituição, em massa, do } \\
\text { pó de pedra por agregado miúdo reciclado de bloco (MRb) }\end{array}$ \\
\hline \multirow{6}{*}{12,0} & B12,0-REF & $\begin{array}{l}\text { Dosagem de referência produzida inteiramente com materiais } \\
\text { naturais }\end{array}$ \\
\hline & B12,0-RGV-100\% & $\begin{array}{l}\text { Dosagem com 100\% de substituição, em massa, da fração graúda } \\
\text { natural (pedrisco) por agregado graúdo reciclado de vigota (GRv) }\end{array}$ \\
\hline & B12,0-RGV-50\% & $\begin{array}{l}\text { Dosagem com aproximadamente } 50 \% \text { de substituição, em massa, da } \\
\text { fração graúda natural por agregado graúdo reciclado de vigota (GRv) }\end{array}$ \\
\hline & B12,0-RMV-33\% & $\begin{array}{l}\text { Dosagem com aproximadamente } 33 \% \text { de substituição, em massa, do } \\
\text { pó de pedra por agregado miúdo reciclado de vigota (MRv) }\end{array}$ \\
\hline & B12,0-RGB-50\% & $\begin{array}{l}\text { Dosagem com aproximadamente } 50 \% \text { de substituição, em massa, da } \\
\text { fração graúda natural por agregado graúdo reciclado de bloco (GRb) }\end{array}$ \\
\hline & B12,0-RMB-33\% & $\begin{array}{c}\text { Dosagem com aproximadamente } 33 \% \text { de substituição, em massa, do } \\
\text { pó de pedra por agregado miúdo reciclado de bloco (MRb) }\end{array}$ \\
\hline
\end{tabular}

Pela Tabela 7.1, nota-se que as dosagens com agregados graúdos reciclados (50\%) conjuntamente com miúdos reciclados (33\%) (RG-50\% + RM-33\%), independentemente do tipo de resíduo, não foram avaliadas nessa fase do trabalho. A razão para isso deve-se ao fato da existência de apenas quatro silos para armazenamento de agregados, sendo que 
três deles foram ocupados pelos agregados naturais (pó-de-pedra, areia e pedrisco) e o outro foi ocupado pela fração graúda ou miúda reciclada. Para suprir a ausência das dosagens supracitadas, foram produzidos dois traços, para cada classe de resistência, com a substituição parcial do pó-de-pedra pela fração miúda reciclada. Os silos para estoque dos agregados podem ser visualizados na Figura 7.2.
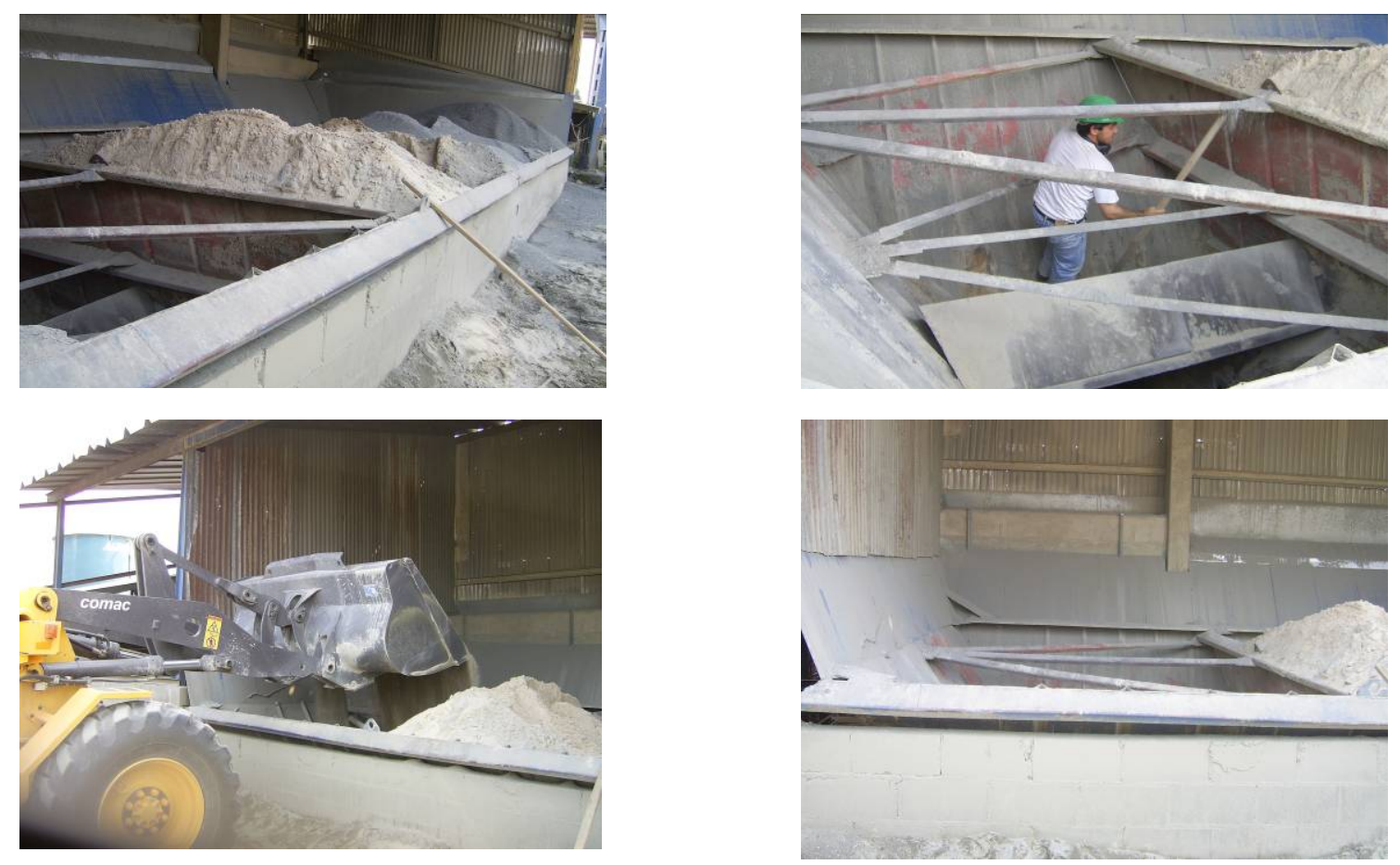

Figura 7.2 - Silos para estoque dos agregados.

As baias para estoque dos agregados situavam-se ao lado dos silos, Figura 7.3. Tais baias eram protegidas da chuva por meio de lonas plásticas; essa medida evitava a variação volumétrica dos agregados miúdos, especialmente, o inchamento da areia.

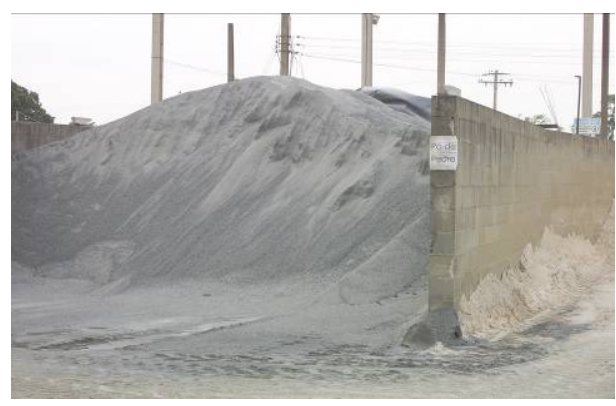

a) baia com pó-de-pedra

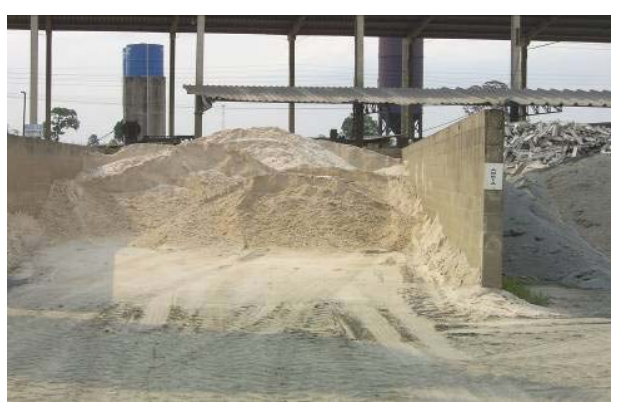

b) baia com areia

Figura 7.3 - Baias para estoque dos agregados. 
Os blocos de concreto foram produzidos na máquina vibro-prensa Blocopac 1300 da marca Piorotti. Segundo dados da fabricante, essa máquina possui as seguintes características, Tabela 7.2. Na Figura 7.4, podem ser observados alguns blocos de concreto produzidos pelo equipamento.

Tabela 7.2 - Dados técnicos da vibro-prensa.

\begin{tabular}{cc}
\hline Características & Dados Técnicos \\
\hline Moldagem & Área útil de moldagem: $1254 \times 480 \mathrm{~mm}$ \\
\cline { 2 - 2 } & Altura de moldagem: $40 \mathrm{a} 300 \mathrm{~mm}$ \\
Pallets em aço & Comprimento: $1320 \mathrm{~mm}$ \\
\hline Potência instalada & Largura: 460 a $550 \mathrm{~mm}$ \\
\hline Peso aproximado & Área útil de moldagem: $480 \mathrm{~mm} \times 125 \mathrm{~mm}$ \\
\hline Dimensões & Altura de moldagem: $40 \mathrm{a} 300 \mathrm{~mm}$ \\
\hline & Vibradores: $2 \times 12,5=25,0 \mathrm{CV}$ \\
\hline & Aistema Hidráulico: $70 \mathrm{CV}$ \\
\hline
\end{tabular}

(fonte: www.piorotti.com.br)
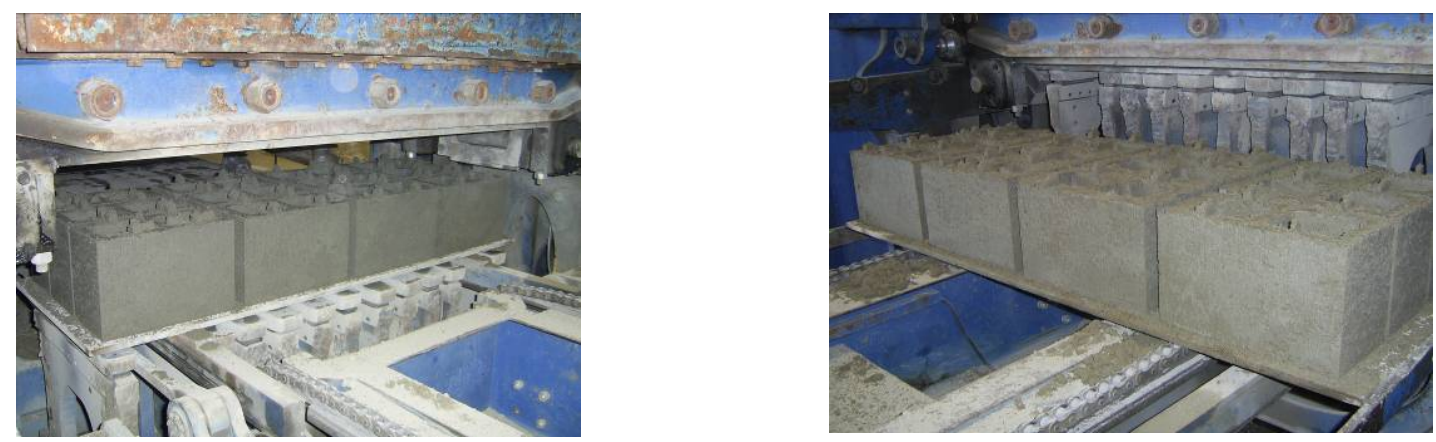

Figura 7.4 - Vibro-prensa utilizada para a produção dos blocos de concreto.

$\mathrm{Na}$ fábrica, apesar da maior variabilidade, todos os insumos, com exceção do cimento, foram dosados em volume. Nesse caso, foi determinada, para cada tipo de agregado, a quantidade de material (massa) para cada volta da esteira de dosagem, Figura 7.5. Após essa definição, cada traço foi determinado pelo correspondente número de voltas. De acordo com Medeiros (1993), para a produção de blocos de concreto estruturais com qualidade adequada devem-se proporcionar os materiais em massa; no caso da dosagem volumétrica, devem ser corrigidas também as variações de volume provenientes do fenômeno de inchamento dos agregados miúdos. 

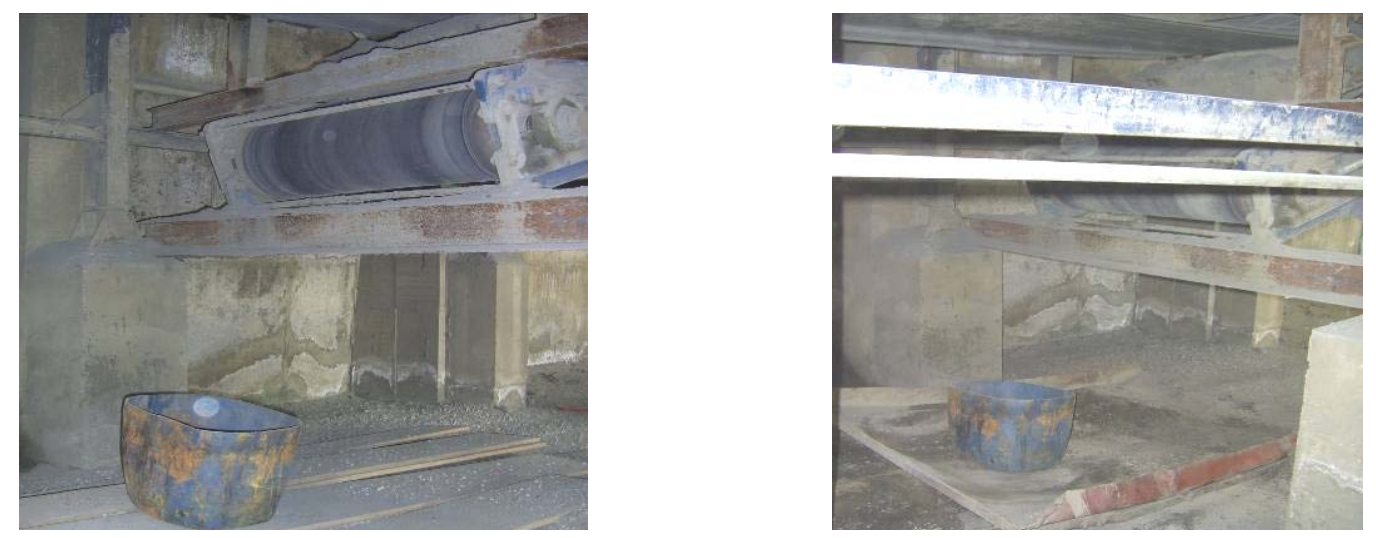

Figura 7.5 - Definição da quantidade de material em função de uma volta da esteira de dosagem.

$\mathrm{Na}$ Tabela 7.3, podem ser encontradas as correspondentes quantidades de materiais, para cada tipo de agregado, em função de uma volta da esteira de dosagem.

Tabela 7.3 - Quantidades de materiais em função de uma volta da esteira de dosagem.

\begin{tabular}{cccc}
\hline Material & $\begin{array}{c}\text { Uma volta da esteira } \\
\text { de dosagem } \mathbf{( k g )}\end{array}$ & Desvio padrão (kg) & $\begin{array}{c}\text { Coeficiente de } \\
\text { variação (\%) }\end{array}$ \\
\hline Pedrisco $^{*}$ & 18,21 & & \\
\hline Areia Tietz & 16,77 & & 3,67 \\
\hline Pó de pedra (basalto) & 22,48 & 0,59 & 5,84 \\
\hline $\begin{array}{c}\text { Agregado graúdo reciclado } \\
\text { de vigota (GRv)** }\end{array}$ & 16,01 & 1,16 & 1,76 \\
\hline $\begin{array}{c}\text { Agregado miúdo reciclado } \\
\text { de vigota (MRv) }\end{array}$ & 19,90 & 0,32 & 3,40 \\
\hline $\begin{array}{c}\text { Agregado graúdo reciclado } \\
\text { de bloco (GRb) }\end{array}$ & 18,16 & 0,78 & \\
\hline $\begin{array}{c}\text { Agregado miúdo reciclado } \\
\text { de bloco (MRb) }\end{array}$ & 22,99 & & \\
\hline
\end{tabular}

* valores fornecidos pela fábrica

** referente a duas determinações

*** referente a três determinações

Na Figura 7.6, é apresentado um fluxograma do processo de dosagem e transporte dos agregados até o misturador. 


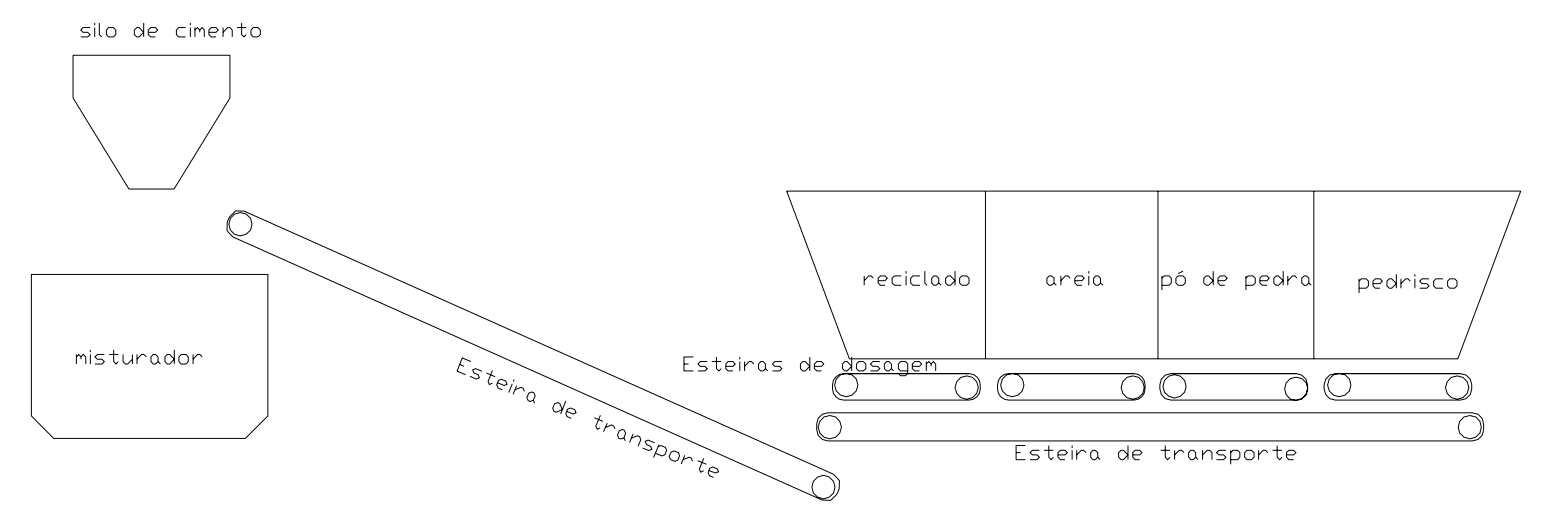

Figura 7.6 - Fluxograma do processo de dosagem e transporte dos agregados dos silos até o misturador.

O misturador empregado possuía eixo horizontal, cuba fixa e pás móveis, com capacidade nominal de aproximadamente $2000 \mathrm{~kg}$ de material. No interior desse equipamento havia um sensor de umidade que verificava, com razoável precisão, o teor de umidade da mistura. Para cada dosagem, o ajuste fino (final) da umidade era realizado visualmente por um funcionário da fábrica. O tempo mínimo de mistura foi de três minutos. $\mathrm{Na}$ Figura 7.7, podem ser encontrados alguns detalhes desse equipamento.
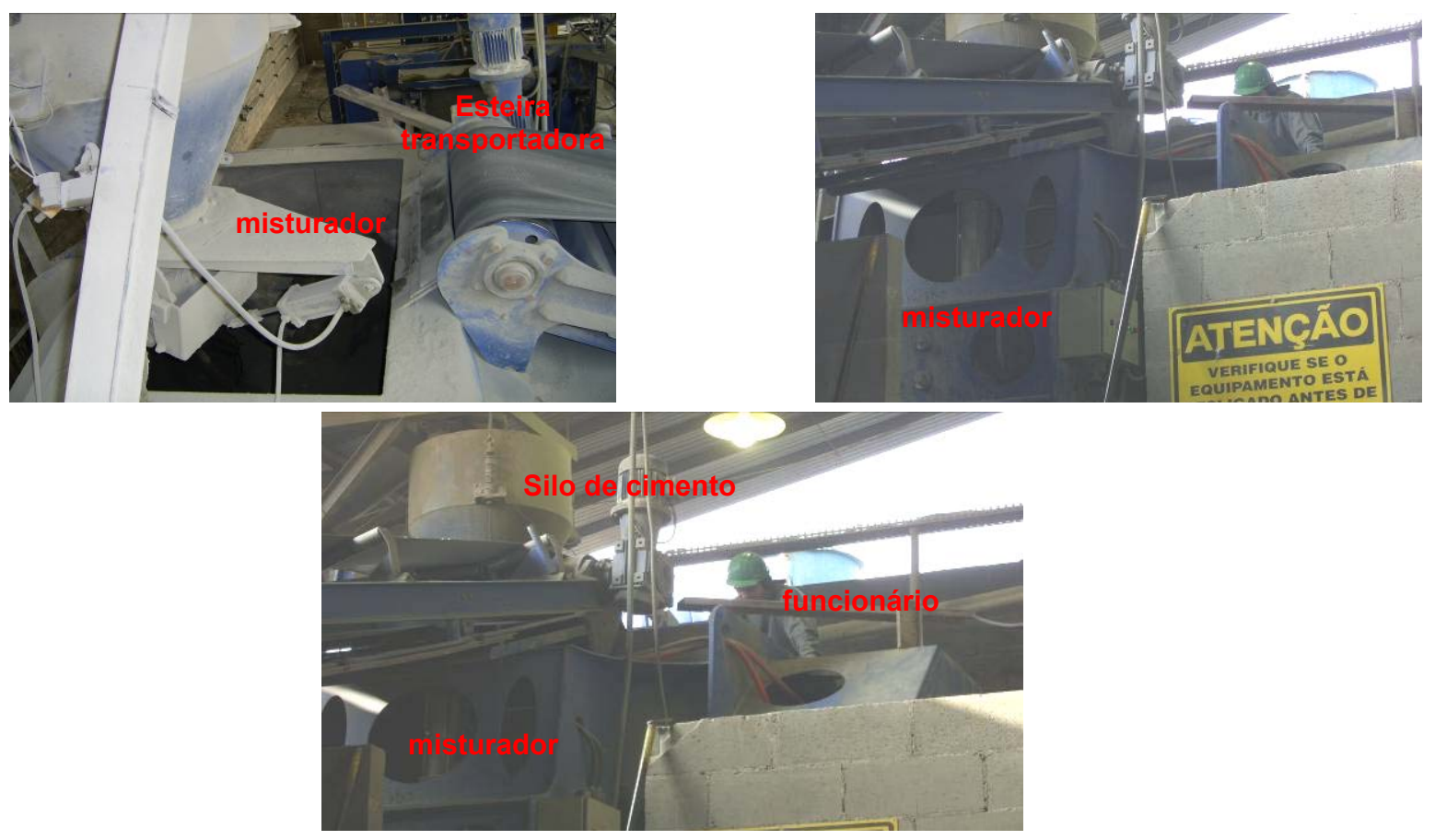

Figura 7.7 - Detalhes do misturador mecânico.

A ordem de colocação dos materiais no misturador seguiu a respectiva ordem: $1^{0}$ dosagem de todos os agregados; $2^{0}$ - introdução do cimento; $3^{0}$ - mistura dos materiais por 
cerca de um minuto; $4^{0}$ - acréscimo da água e aditivo; $5^{0}$ - mistura final por cerca de três minutos. Depois da mistura, os materiais foram despejados em uma correia transportadora que abasteceu o recipiente de alimentação dos moldes, também conhecido como gaveta, Figura 7.8.
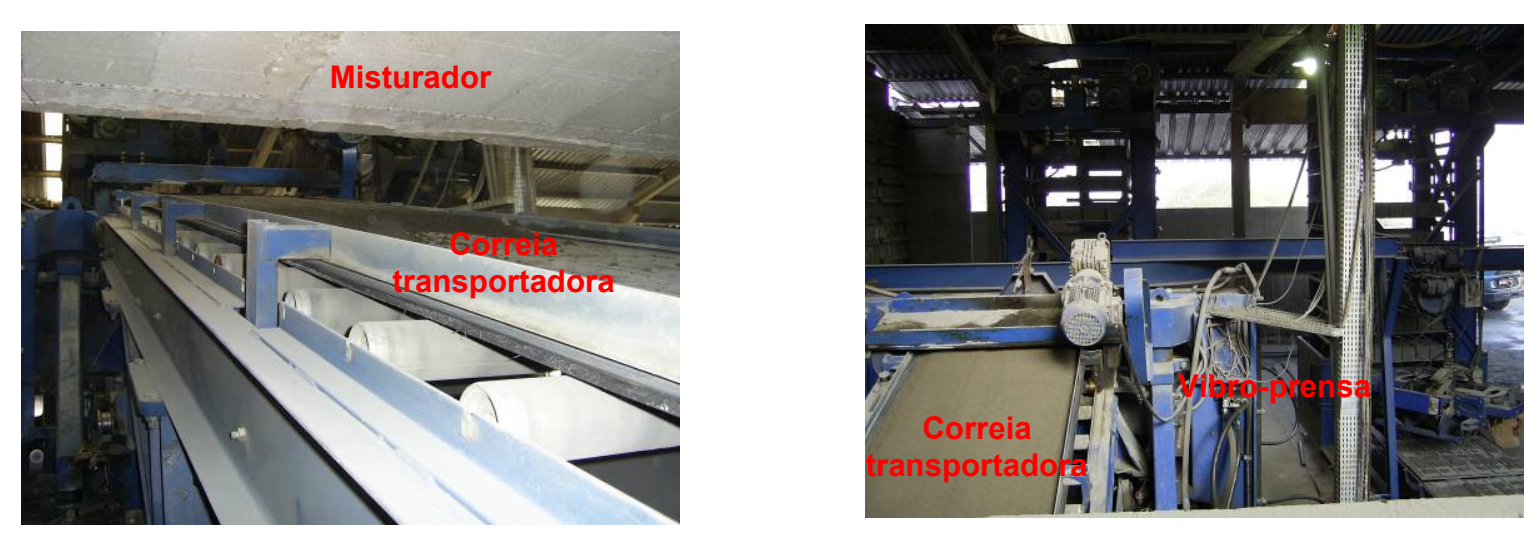

Figura 7.8 - Correia transportadora situada entre o misturador e a vibro-prensa.

A moldagem dos blocos foi realizada através do ajuste dos tempos de alimentação, vibração e compactação da máquina vibro-prensa. Esses tempos variaram em função de cada dosagem, especialmente, para os traços com a incorporação de agregados reciclados de bloco, que necessitaram de um maior tempo de alimentação e compactação da máquina, para que fosse garantida a coesão necessária. Na definição desses tempos, a experiência do operador de moldagem foi fundamental; caso a primeira chapa de blocos (12 blocos) não fosse produzida corretamente, isto é, por exemplo, coesão insuficiente, quebra de cantos e altura maior que a especificada, o operador interrompia a moldagem dos blocos e ajustava novos tempos de produção no painel da máquina. Na Figura 7.9, pode ser observada a regulagem nos tempos de moldagem da vibro-prensa. 

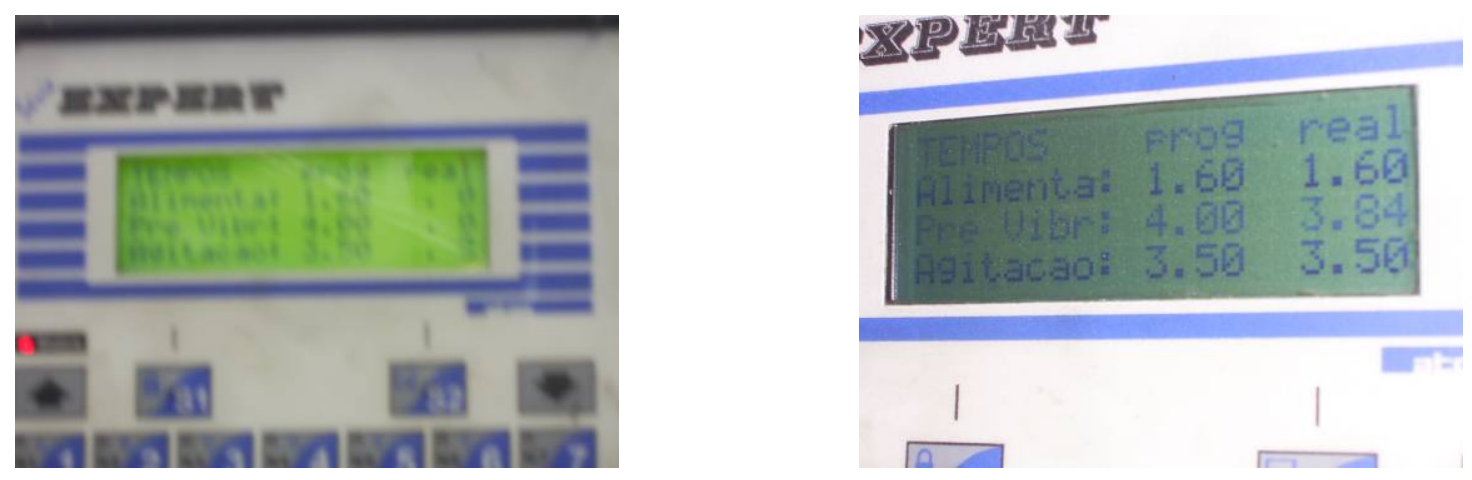

Figura 7.9 - Regulagem dos tempos de alimentação, vibração e compactação da vibroprensa.

Os blocos, após a moldagem, foram transferidos para um carro de transporte que conduziu as unidades até o interior das câmaras de cura, Figura 7.10.
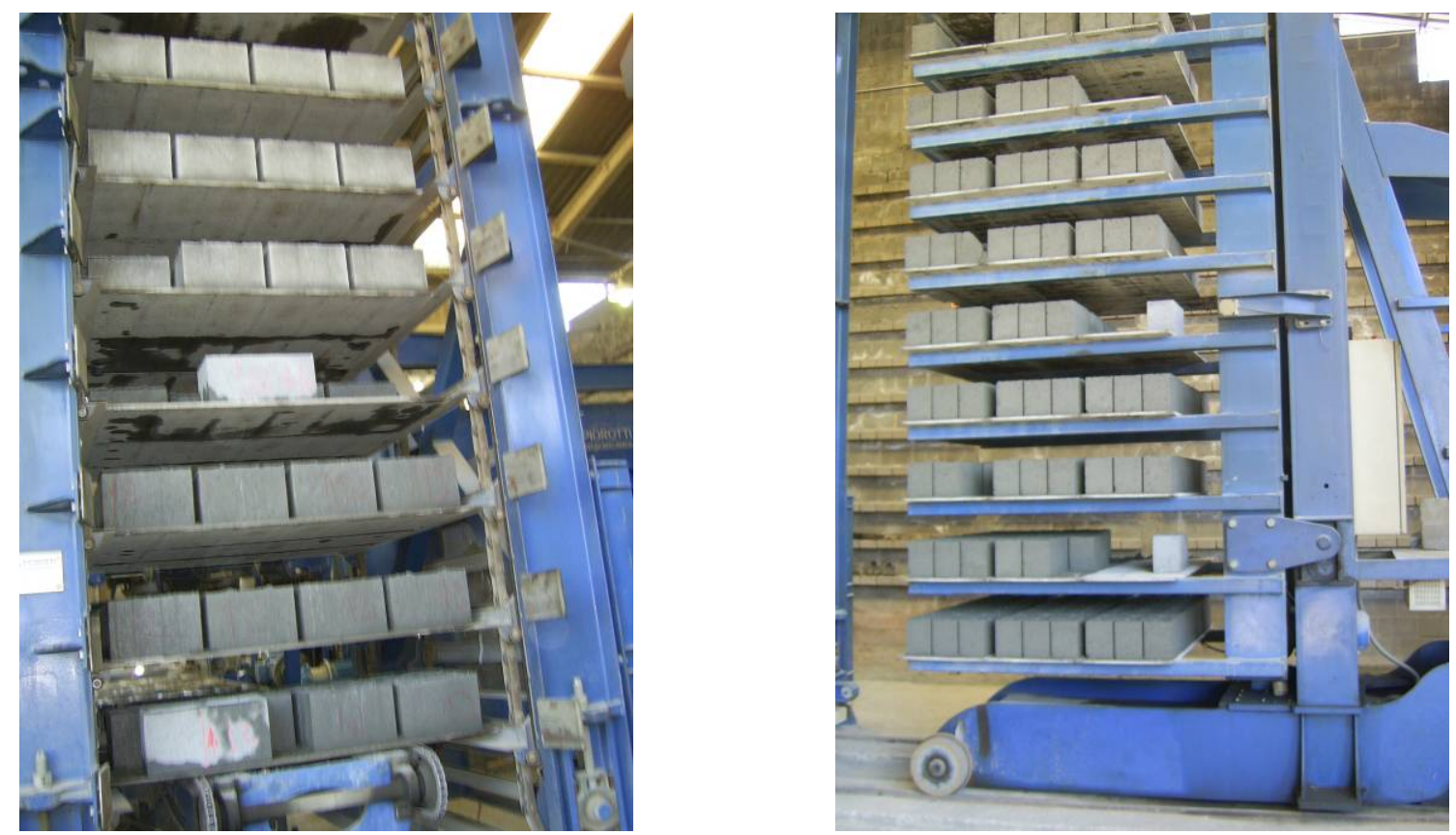

Figura 7.10 - Carro de transporte dos blocos.

A cura aplicada foi a térmica durante o período noturno. Essa cura consistia em um ciclo com duração de quatro a cinco horas e regime isotérmico $\left(60^{\circ} \mathrm{C}-67^{\circ} \mathrm{C}\right)$. De acordo com Medeiros (1993), o objetivo principal do vapor na cura térmica é fazer com que a umidade seja forçada a penetrar no interior da massa do bloco garantindo, dessa forma, a hidratação do cimento. No dia posterior à moldagem, os blocos foram retirados da câmara de cura, Figura 7.11. 

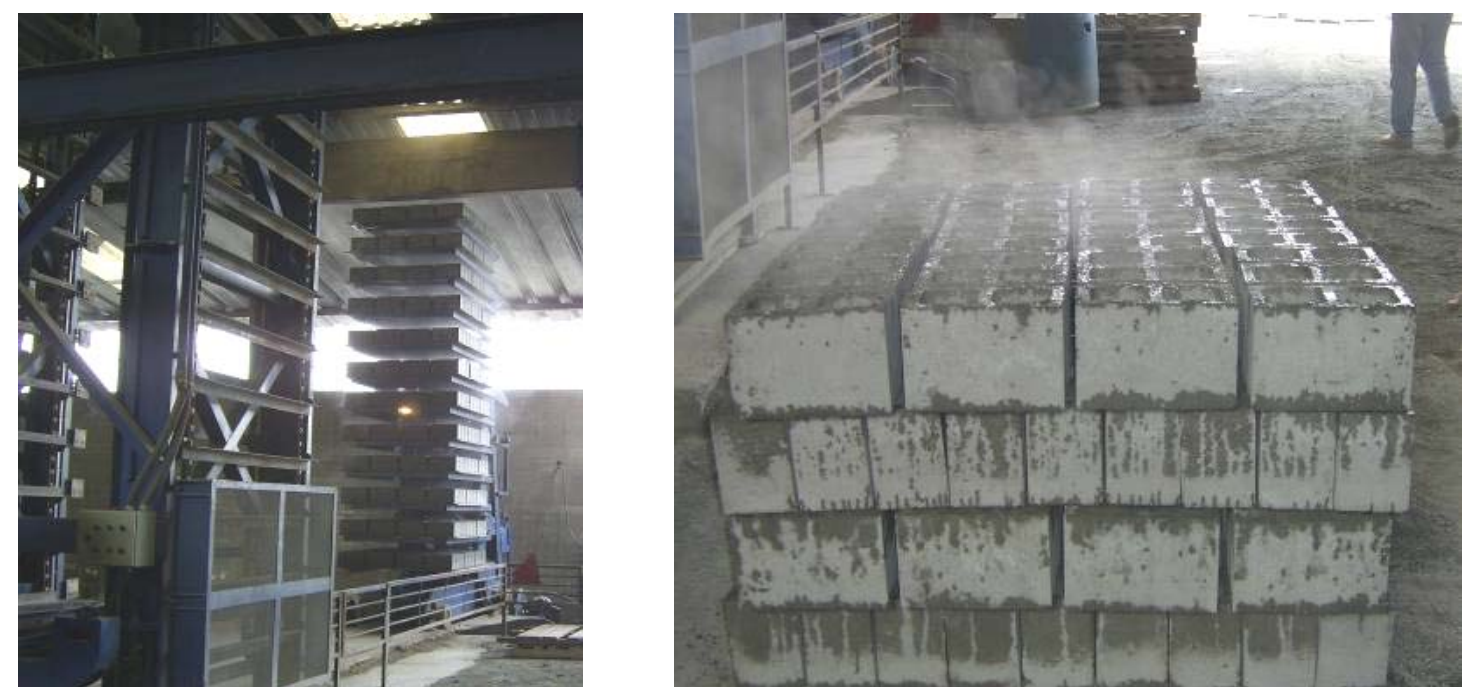

Figura 7.11 - Retirada dos blocos da câmara de cura térmica.

Depois da cura, os blocos foram dispostos em pallets, numerados de acordo com a ordem de produção e estocados no pátio da fábrica, Figura 7.12.
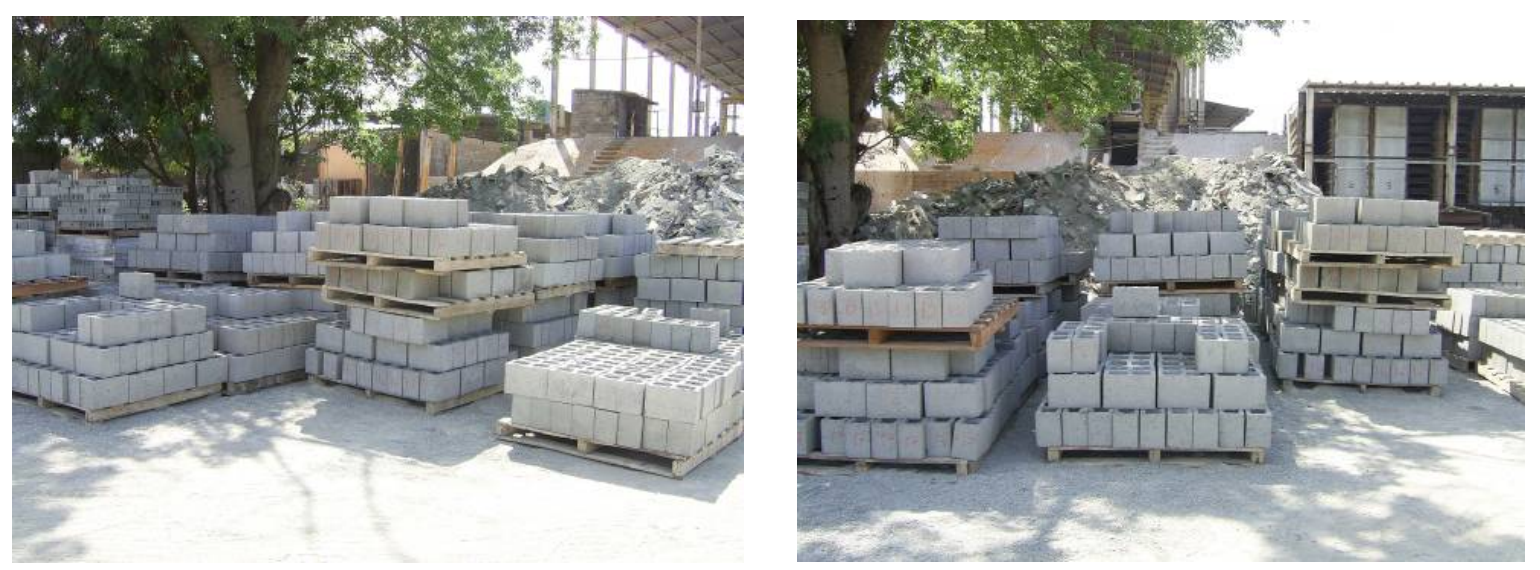

Figura 7.12 - Estocagem dos blocos no pátio da fábrica.

Dois dias após a produção das unidades, os blocos de concreto foram transportados para o Laboratório de Estruturas da EESC-USP. Na Figura 7.13, encontra-se alguns detalhes dessa operação. 

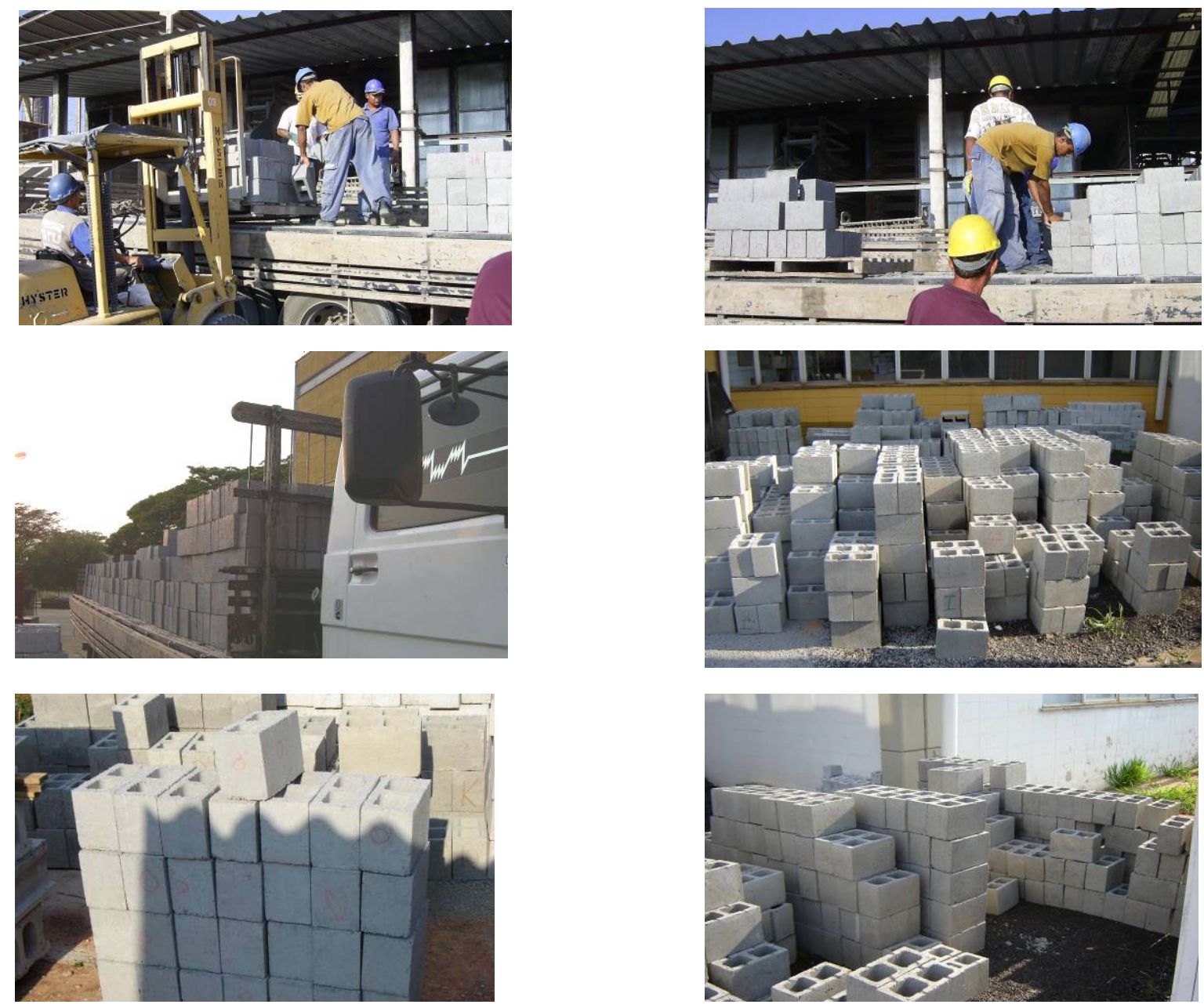

Figura 7.13 - Transporte/estocagem dos blocos.

Nos próximos itens, são apresentados os resultados e as análises das propriedades físicas e mecânicas dos blocos produzidos, divididos em seus respectivos grupos (classes de resistência).

\subsubsection{GRUPOS AVALIADOS}

\subsubsection{Grupo 4,5}

Conforme já comentado, os seis traços produzidos apresentavam uma relação agregado/cimento próxima a vinte (20). O objetivo primordial do estabelecimento desse grupo é a produção de blocos estruturais de resistência característica de 4,5 MPa e que apresentem valores de absorção de água inferiores a 10\%. A terminologia adotada para o Grupo 4,5 é apresentada, novamente, na Tabela 7.4. 
Tabela 7.4 - Dosagens do Grupo 4,5.

\begin{tabular}{|c|c|c|c|}
\hline GRUPO & DESIGNAÇÃO & DATA DE PRODUÇÃO & CARACTERISTICAS \\
\hline \multirow{6}{*}{4,5} & B4,5-REF & $20 / 10$ & $\begin{array}{c}\text { Dosagem de referência produzida inteiramente } \\
\text { com materiais naturais }\end{array}$ \\
\hline & B4,5-RGV-100\% & $19 / 09$ & $\begin{array}{l}\text { Dosagem com } 100 \% \text { de substituição, em massa, } \\
\text { da fração graúda natural (pedrisco) por agregado } \\
\text { graúdo reciclado de vigota (GRv) }\end{array}$ \\
\hline & B4,5-RGV-50\% & $19 / 09$ & $\begin{array}{l}\text { Dosagem com aproximadamente } 50 \% \text { de } \\
\text { substituição, em massa, da fração graúda natural } \\
\text { por agregado graúdo reciclado de vigota (GRv) }\end{array}$ \\
\hline & B4,5-RMV-33\% & $19 / 09$ & $\begin{array}{l}\text { Dosagem com aproximadamente } 33 \% \text { de } \\
\text { substituição, em massa, do pó de pedra por } \\
\text { agregado miúdo reciclado de vigota (MRv) }\end{array}$ \\
\hline & B4,5-RGB-50\% & $20 / 09$ & $\begin{array}{l}\text { Dosagem com aproximadamente } 50 \% \text { de } \\
\text { substituição, em massa, da fração graúda natural } \\
\text { por agregado graúdo reciclado de bloco (GRb) }\end{array}$ \\
\hline & B 4,5-RMB-33\% & $20 / 09$ & $\begin{array}{l}\text { Dosagem com aproximadamente } 33 \% \text { de } \\
\text { substituição, em massa, do pó de pedra por } \\
\text { agregado miúdo reciclado de bloco (MRb) }\end{array}$ \\
\hline
\end{tabular}

As características de cada uma das dosagens produzidas encontram-se na Tabela

7.5.

Tabela 7.5 - Dosagens do Grupo 4,5.

\begin{tabular}{|c|c|c|c|c|c|c|c|}
\hline & GRUPO 4,5 & $\begin{array}{l}\text { B4,5- } \\
\text { REF }\end{array}$ & $\begin{array}{l}\text { B4,5- } \\
\text { RGV - } \\
100 \%\end{array}$ & $\begin{array}{c}\text { B4,5- } \\
\text { RGV - } \\
50 \%\end{array}$ & $\begin{array}{c}\text { B4,5- } \\
\text { RMV - } \\
33 \%\end{array}$ & $\begin{array}{c}\text { B4,5- } \\
\text { RGB - } \\
50 \%\end{array}$ & $\begin{array}{c}\text { B4,5- } \\
\text { RMB - } \\
33 \%\end{array}$ \\
\hline \multicolumn{2}{|r|}{ Umidade/Temperatura } & \multicolumn{6}{|c|}{$25-30 \mathrm{C}-50 \%-60 \%$} \\
\hline \multicolumn{2}{|c|}{ TRAÇO (Cimento:Agregados) } & $1: 19,46$ & $1: 18,75$ & $1: 19,09$ & $1: 19,62$ & $1: 19,18$ & $1: 19,60$ \\
\hline \multirow{9}{*}{$\begin{array}{l}\text { Consumo } \\
\text { estimado de } \\
\text { materiais } \\
\left(\mathrm{kg} / \mathrm{m}^{3}\right)\end{array}$} & Cimento & 122 & 119 & 119 & 114 & 118 & 115 \\
\hline & Pedrisco & 721 & - & 331 & 677 & 332 & 685 \\
\hline & Vigota - GRv & - & 619 & 327 & - & - & - \\
\hline & Bloco-GRb & - & - & - & - & 331 & - \\
\hline & Pó de pedra & 942 & 920 & 919 & 590 & 921 & 597 \\
\hline & Vigota - MRv & - & - & - & 305 & - & - \\
\hline & Bloco-MRb & - & - & - & - & - & 305 \\
\hline & Areia Tietz & 703 & 686 & 685 & 660 & 687 & 668 \\
\hline & Água & 107 & 127 & 129 & 141 & 129 & 140 \\
\hline \multicolumn{2}{|r|}{ Pedrisco (\%) } & 30,47 & - & 14,62 & 30,34 & 14,61 & 30,38 \\
\hline \multicolumn{2}{|r|}{ GRv/ \%GRb (\%) } & - & 27,81 & 14,46 & - & 14,56 & - \\
\hline \multicolumn{2}{|r|}{ Areia Tietz (\%) } & 29,71 & 30,84 & 30,30 & 29,58 & 30,26 & 29,62 \\
\hline \multicolumn{2}{|r|}{ MRv/ \%MRb (\%) } & - & - & - & 13,65 & - & 13,54 \\
\hline \multicolumn{2}{|r|}{ Pó de pedra (\%) } & 39,82 & 41,35 & 40,62 & 26,43 & 40,57 & 26,47 \\
\hline \multicolumn{2}{|c|}{ Umidade estimada adicionada na mistura (\%) } & - & 5,40 & 5,40 & 6,00 & 5,40 & 5,90 \\
\hline \multicolumn{2}{|c|}{ Aditivo, em relação à massa de cimento (\%) } & 0,25 & 0,25 & 0,25 & 0,25 & 0,25 & 0,25 \\
\hline \multicolumn{2}{|c|}{ Teor de argamassa (\%) } & 71,02 & 73,60 & 72,36 & 71,14 & 72,28 & 71,10 \\
\hline \multicolumn{2}{|c|}{ Teor de argamassa em volume (\%) } & 71,04 & 70,90 & 70,97 & 71,72 & 71,15 & 71,42 \\
\hline \multicolumn{2}{|c|}{ Módulo de finura da mistura } & 3,39 & 3,40 & 3,40 & 3,40 & 3,32 & 3,41 \\
\hline \multicolumn{2}{|c|}{ Material grosso - retido peneiras $(4,8$ e $2,4 \mathrm{~mm})$} & $39 \%$ & $37 \%$ & $38 \%$ & $38 \%$ & $38 \%$ & $38 \%$ \\
\hline \multicolumn{2}{|c|}{ Material médio - retido peneiras $(1,2,0,6$ e $0,3 \mathrm{~mm})$} & $43 \%$ & $45 \%$ & $44 \%$ & $45 \%$ & $44 \%$ & $46 \%$ \\
\hline \multicolumn{2}{|c|}{ Material fino - retido peneiras $(0,15 \mathrm{~mm}$ e fundo) } & $18 \%$ & $18 \%$ & $18 \%$ & $17 \%$ & $18 \%$ & $16 \%$ \\
\hline \multirow{4}{*}{$\begin{array}{l}\text { Tempos da } \\
\text { máquina (s) }\end{array}$} & Alimentação & 1,10 & 1,30 & 1,30 & 1,30 & 1,80 & 2,50 \\
\hline & Vibração & 3,00 & 3,00 & 3,00 & 3,00 & 3,00 & 3,00 \\
\hline & Compressão & 3,00 & 3,00 & 3,00 & 3,00 & 4,00 & 4,50 \\
\hline & Comentários & & & & & - & 66 \\
\hline
\end{tabular}

${ }^{1}$ Provavelmente, a umidade adotada para esse traço ficou um pouco abaixo da umidade ótima, fato esse que foi constatado durante a produção das unidades e no ensaio da taxa de absorção inicial. A umidade não foi mensurada devido a problemas ocorridos no sensor de umidade local

$2,3,5$ nenhum problema verificado durante a moldagem;

${ }^{4}$ A umidade teve que ser elevada para aumentar a coesão da mistura/bloco fresco. As unidades apresentaram cantos quebrados e uma textura áspera.

${ }_{6}^{6}$ Novamente, adotou-se uma umidade maior para elevar a coesão do bloco fresco; além disso, para aumentar a coesão, os tempos de alimentação e compressão foram elevados para 2,50 e 4,50 segundos, respectivamente. Apesar de todas essas modificações, aproximadamente $60 \%$ das unidades produzidas foram descartadas por falta de coesão, sendo que as restantes apresentaram textura áspera e cantos quebrados. 
Analisando-se os dados da Tabela 7.5, nota-se que, pelo fato das dosagens serem estabelecidas em volume, o consumo de cimento e o teor de argamassa (em volume) não foram iguais; entretanto, foram próximos, apresentando diferença de no máximo 6\%. A elevada absorção do material reciclado exigiu um aumento da umidade total da mistura; provavelmente, as dosagens B4,5-RMV-33\% e B4,5-RMB-33\% apresentaram uma umidade muito elevada (acima da umidade ótima), fato esse que foi responsável pela textura superficial áspera e surgimento de fissuras em algumas dessas unidades. De acordo com Frasson Junior (2000), na produção de blocos, umidades excessivas dificultam a desforma e provocam muitas fissuras nas unidades ao serem transportadas para cura e estocagem.

$\mathrm{Na}$ Figura 7.14, pode ser observada a produção das unidades do traço B4,5-RMB$33 \%$, que apesar do aumento da umidade e dos tempos da máquina, apresentaram baixa coesão e, consequentemente, grande número de unidades rejeitadas.
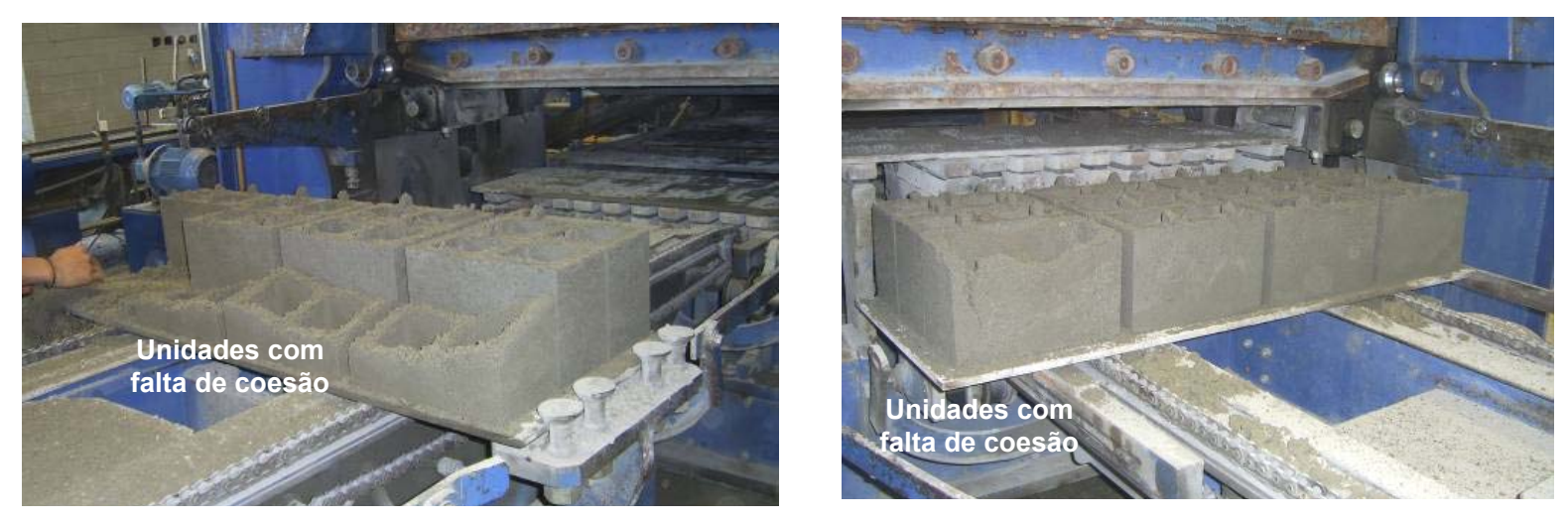

Figura 7.14 - Produção das unidades do traço B4,5-RMB-33\%.

Provavelmente, a substituição do pó de pedra pelo agregado miúdo reciclado de bloco acarretou uma redução considerável da quantidade de finos "filler" da mistura. Certamente, esses finos são responsáveis pela garantia da coesão da mistura e da textura superficial da unidade, principalmente nos traços mais pobres com baixo consumo de cimento. No estudo preliminar realizado com corpos-de-prova, notou-se uma diminuição de aproximadamente $25 \%$ na coesão quando foi incorporada a fração miúda reciclada de bloco; além disso, nesse estudo, a coesão (5538 g) para a dosagem RGB-50\%+RMB-33\% ficou abaixo do valor recomendado por Frasson Junior (2000).

Na Figura 7.15, podem ser observadas as paredes longitudinais das unidades da classe 4,5. Nesses cortes longitudinais, pode ser notada a presença dos agregados reciclados de vigota através dos pontos mais claros. 


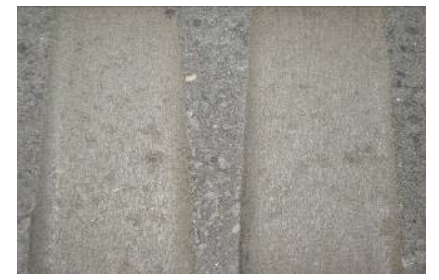

B4,5-REF

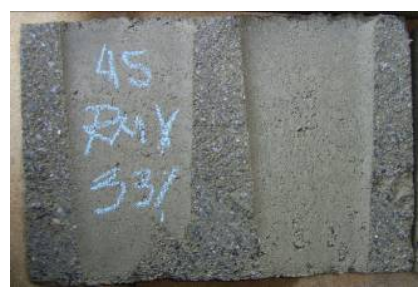

B4,5-RMV-33\%

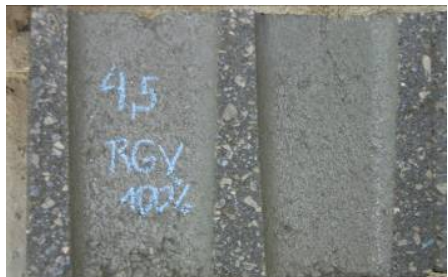

B4,5-RGV-100\%

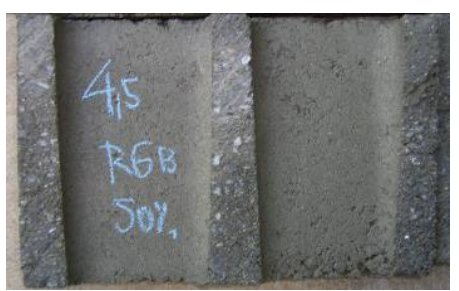

B4,5-RGB-50\%

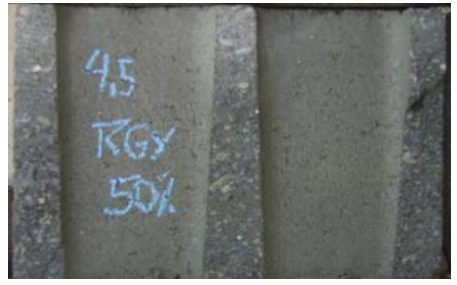

B4,5-RGV-50\%

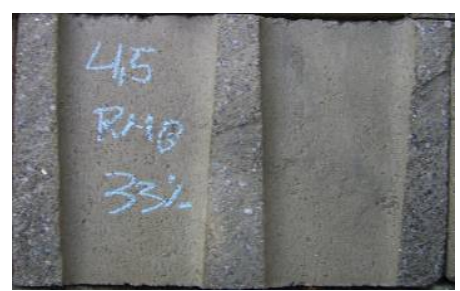

B4,5-RMB-33\%

Figura 7.15 - Paredes longitudinais das unidades da classe 4,5.

Na Figura 7.16, a presença dos agregados reciclados de vigota no traço B4,5-RGV$100 \%$ pode ser notada mais claramente.
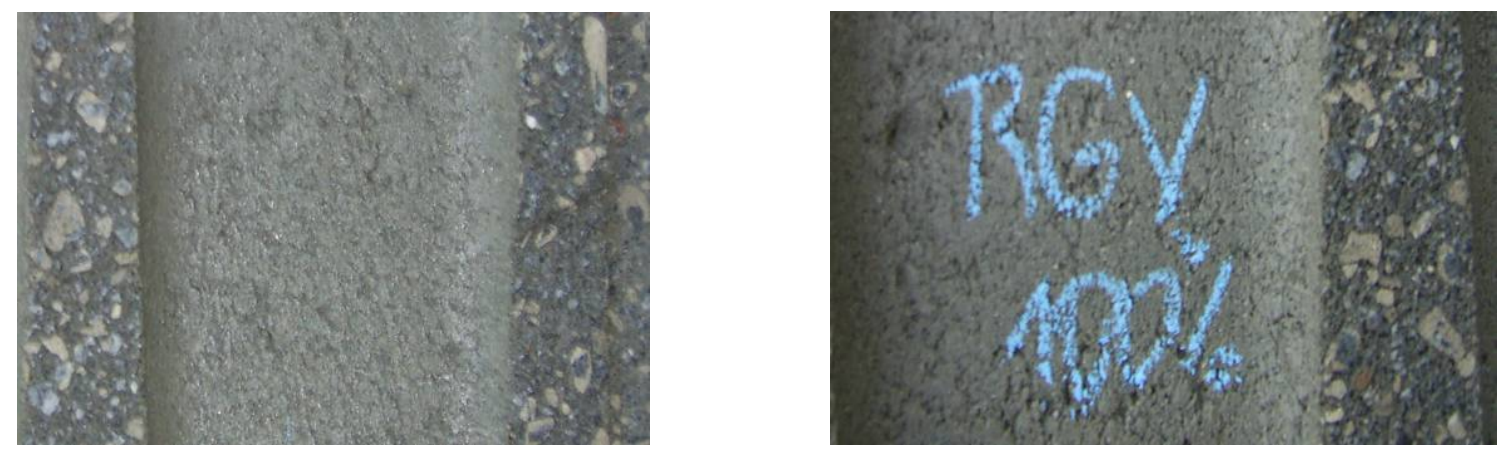

Figura 7.16 - Presença dos agregados reciclados no traço B4,5-RGV-100\%. 


\subsubsection{Grupo 8,0}

Conforme já comentado, os seis traços produzidos apresentavam uma relação agregado/cimento próxima a quinze (15). O objetivo primordial do estabelecimento desse grupo é a produção de blocos estruturais de resistência característica de 8,0 MPa e que apresentem valores de absorção de água inferiores a 10\%. Conforme já discutido, os resultados das propriedades físicas e mecânicas dos CPs cilíndricos habilitam todas essas dosagens para a produção dos blocos de concreto estruturais. Através das correlações obtidas com os corpos-de-prova cilíndricos; provavelmente, aos sete dias, algumas das unidades produzidas na fábrica podem apresentar resistência média inferior a 8,0 MPa. Aa terminologia adotada para o Grupo 8,0 é apresentada, novamente, na Tabela 7.6.

Tabela 7.6 - Dosagens do Grupo 8,0.

\begin{tabular}{|c|c|c|c|}
\hline GRUPO & DESIGNAÇÃO & DATA DE PRODUÇĀO & CARACTERISTICAS \\
\hline \multirow{6}{*}{8,0} & B 8,0-REF & $19 / 09$ & $\begin{array}{c}\text { Dosagem de referência produzida inteiramente com } \\
\text { materiais naturais }\end{array}$ \\
\hline & B 8,0-R G V-100\% & $19 / 09$ & $\begin{array}{c}\text { Dosagem com } 100 \% \text { de substituição, em massa, da } \\
\text { fração graúda natural (pedrisco) por agregado } \\
\text { graúdo reciclado de vigota (GRv) }\end{array}$ \\
\hline & B $8,0-R G V-50 \%$ & $19 / 09$ & $\begin{array}{l}\text { Dosagem com aproximadamente } 50 \% \text { de } \\
\text { substituição, em massa, da fração graúda natural } \\
\text { por agregado graúdo reciclado de vigota (GRv) }\end{array}$ \\
\hline & B 8,0-R M V-33\% & $19 / 09$ & $\begin{array}{l}\text { Dosagem com aproximadamente } 33 \% \text { de } \\
\text { substituição, em massa, do pó de pedra por } \\
\text { agregado miúdo reciclado de vigota (MRv) }\end{array}$ \\
\hline & B 8,0-RG B -50\% & $20 / 09$ & $\begin{array}{l}\text { Dosagem com aproximadamente } 50 \% \text { de } \\
\text { substituição, em massa, da fração graúda natural } \\
\text { por agregado graúdo reciclado de bloco (GRb) }\end{array}$ \\
\hline & B 8,0-RMB-33\% & $20 / 09$ & $\begin{array}{l}\text { Dosagem com aproximadamente } 33 \% \text { de } \\
\text { substituição, em massa, do pó de pedra por } \\
\text { agregado miúdo reciclado de bloco (MRb) }\end{array}$ \\
\hline
\end{tabular}

As características de cada uma das dosagens do Grupo 8,0 encontram-se na Tabela 7.7. 
Tabela 7.7 - Características das dosagens do Grupo 8,0.

\begin{tabular}{|c|c|c|c|c|c|c|c|}
\hline & GRUPO 8,0 & $\begin{array}{l}\text { B8,0- } \\
\text { REF }\end{array}$ & $\begin{array}{l}\text { B8,0- } \\
\text { RGV - } \\
100 \%\end{array}$ & $\begin{array}{c}\text { B8,0- } \\
\text { RGV - } \\
50 \%\end{array}$ & $\begin{array}{c}\text { B8,0- } \\
\text { RMV - } \\
33 \%\end{array}$ & $\begin{array}{c}\text { B8,0- } \\
\text { RGB - } \\
50 \%\end{array}$ & $\begin{array}{c}\text { B8,0- } \\
\text { RMB - } \\
33 \%\end{array}$ \\
\hline \multicolumn{2}{|c|}{ Umidade/Temperatura } & \multicolumn{6}{|c|}{$25-30 \mathrm{C}-50 \%-60 \%$} \\
\hline \multicolumn{2}{|c|}{ TRAÇO (Cimento:Agregados) } & $1: 14,73$ & $1: 14,43$ & $1: 14,68$ & $1: 14,79$ & $1: 14,46$ & $1: 14,77$ \\
\hline \multirow{7}{*}{$\begin{array}{c}\text { Consumo } \\
\text { estimado de } \\
\text { materiais } \\
\left(\mathrm{kg} / \mathrm{m}^{3}\right)\end{array}$} & Cimento & 154 & 152 & 152 & 149 & 155 & 150 \\
\hline & Pedrisco & 692 & - & 321 & 668 & 326 & 672 \\
\hline & Pó de pedra & 904 & 892 & 891 & 582 & 907 & 585 \\
\hline & Vigota-MRv & - & - & - & 301 & - & - \\
\hline & Bloco - MRb & - & - & - & - & - & 299 \\
\hline & Areia Tietz & 675 & 703 & 702 & 651 & 676 & 655 \\
\hline & Água & 131 & 127 & 129 & 141 & 130 & 145 \\
\hline & Pó de pedra (\%) & 39,82 & 40,65 & 39,94 & 26,43 & 40,57 & 26,47 \\
\hline \multicolumn{2}{|c|}{ Umidade estimada da mistura (\%) } & 5,40 & 5,40 & 5,40 & 6,00 & 5,50 & 6,20 \\
\hline \multicolumn{2}{|c|}{ Aditivo, em relação à massa de cimento (\%) } & 0,25 & 0,25 & 0,25 & 0,25 & 0,25 & 0,25 \\
\hline \multicolumn{2}{|c|}{ Teor de argamassa (\%) } & 71,47 & 74,43 & 73,22 & 71,59 & 72,72 & 71,55 \\
\hline \multicolumn{2}{|c|}{ Teor de argamassa em volume (\%) } & 71,44 & 71,77 & 71,83 & 72,11 & 71,55 & 71,81 \\
\hline \multicolumn{2}{|c|}{ Módulo de finura da mistura } & 3,39 & 3,38 & 3,37 & 3,40 & 3,32 & 3,41 \\
\hline \multicolumn{2}{|c|}{ Material grosso - retido peneiras $(4,8$ e $2,4 \mathrm{~mm})$} & $39 \%$ & $37 \%$ & $38 \%$ & $38 \%$ & $38 \%$ & $38 \%$ \\
\hline \multicolumn{2}{|c|}{ Material médio - retido peneiras $(1,2,0,6$ e $0,3 \mathrm{~mm})$} & $43 \%$ & $45 \%$ & $44 \%$ & $45 \%$ & $44 \%$ & $46 \%$ \\
\hline \multicolumn{2}{|c|}{ Material fino - retido peneiras $(0,15 \mathrm{~mm}$ e fundo) } & $18 \%$ & $18 \%$ & $18 \%$ & $17 \%$ & $18 \%$ & $16 \%$ \\
\hline \multirow{2}{*}{$\begin{array}{l}\text { Tempos da } \\
\text { máquina (s) }\end{array}$} & Alimentação & 1,30 & 1,30 & 1,30 & 1,30 & 1,80 & 2,50 \\
\hline & Vibração & 3,00 & 3,00 & 3,00 & 3,00 & 3,00 & 3,00 \\
\hline
\end{tabular}

${ }^{1}$ nenhum problema verificado durante a moldagem. Provavelmente, a umidade adotada ficou abaixo da umidade ótima;

2,3 a umidade adotada para esses dois traços ficou um pouco abaixo da umidade ótima, no entanto, não foi constatada nenhuma influência significativa nas propriedades físicas e mecânicas das unidades;

${ }^{4}$ A umidade ficou um pouco acima da umidade ótima. Apesar do maior consumo de cimento, algumas unidades apresentaram uma textura superficial áspera;

${ }_{6}^{5}$ nenhum problema verificado durante a moldagem;

${ }^{6}$ Adotou-se uma umidade maior para elevar a coesão do bloco fresco; além disso, para aumentar a coesão, os tempos de alimentação e compressão foram elevados para 2,50 e 4,50 segundos, respectivamente, seguindo o procedimento adotado na produção das unidades B4,5-RMB-33\%. Apesar de todas essas modificações, algumas das unidades foram descartadas por motivo de fissuração e cantos quebrados.

Analisando-se os dados da Tabela 7.7, observa-se que pelo fato das dosagens serem estabelecidas em volume, o consumo de cimento e o teor de argamassa (em volume) não foram iguais; mas, pelo menos, foram próximos (diferença de no máximo três porcento para o consumo de cimento). Apesar da umidade adotada para a produção das unidades com agregados graúdos reciclados ter sido próxima daquela adota para as unidades de referência, não foi notado nenhum problema durante a produção. Algumas unidades do traço B8,0-RMB-33\%, apesar da elevação da umidade da mistura e tempos de produção da máquina, apresentaram problemas relacionados a cantos quebrados e fissuras nos septos transversais. Frasson Junior (2000) cita que umidades excessivas dificultam a desforma e provocam muitas fissuras nas unidades ao serem transportadas para sua cura e estocagem. 
$\mathrm{Na}$ Figura 7.17, podem ser observadas as paredes longitudinais das unidades da classe 8,0. Nesses cortes longitudinais, pode ser notada a presença dos agregados reciclados de vigota através dos pontos mais claros.
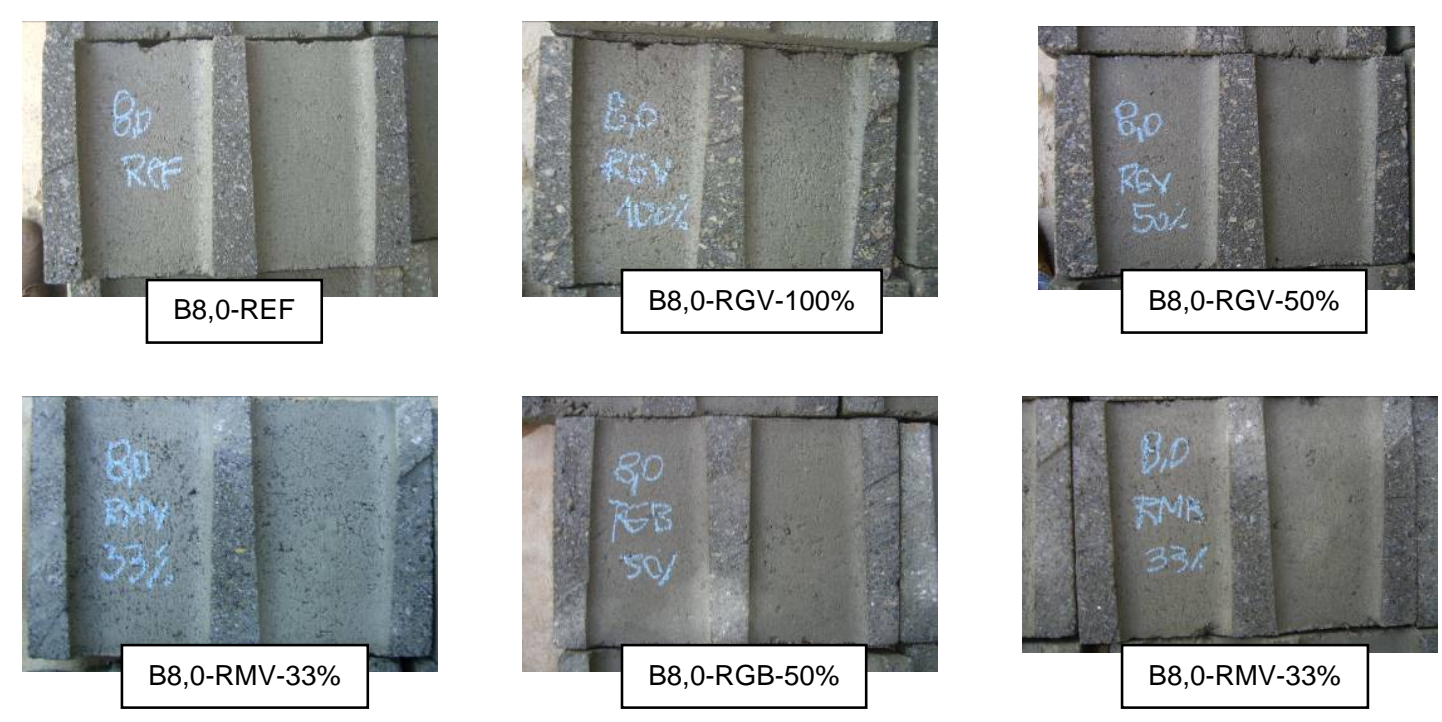

Figura 7.17 - Paredes das unidades do Grupo 8,0.

\subsubsection{Grupo 12,0}

O objetivo primordial do estabelecimento desse grupo é a produção de blocos estruturais de resistência característica de 12,0 MPa e que apresentem valores de absorção de água inferiores a $10 \%$. Conforme já discutido, os resultados das propriedades físicas e mecânicas dos CPs cilíndricos habilitam todas essas dosagens para a produção dos blocos de concreto estruturais. Através das correlações obtidas com os corpos-de-prova cilíndricos; provavelmente, aos sete dias, algumas das unidades produzidas na fábrica poderão não apresentar resistência característica superior a 12,0 MPa. A terminologia adotada para o Grupo 12,0 é apresentada, novamente, na Tabela 7.8. 
Tabela 7.8 - Terminologia adotada para o Grupo 12,0.

\begin{tabular}{|c|c|c|c|}
\hline GRUPO & DESIG NAÇÃO & DATA DE PRODUÇÃO & CARACTERISTICAS \\
\hline \multirow{6}{*}{12,0} & B 12,0-REF & $19 / 09$ & $\begin{array}{c}\text { Dosagem de referência produzida inteiramente com } \\
\text { materiais naturais }\end{array}$ \\
\hline & B $12,0-R$ G V $-100 \%$ & $19 / 09$ & $\begin{array}{c}\text { Dosagem com } 100 \% \text { de substituição, em massa, da } \\
\text { fração graúda natural (pedrisco) por agregado } \\
\text { graúdo reciclado de vigota (GRv) }\end{array}$ \\
\hline & B 12,0-R G V-50\% & $19 / 09$ & $\begin{array}{l}\text { Dosagem com aproximadamente } 50 \% \text { de } \\
\text { substituição, em massa, da fração graúda natural } \\
\text { por agregado graúdo reciclado de vigota (GRV) }\end{array}$ \\
\hline & B 12,0-R M V-33\% & $19 / 09$ & $\begin{array}{l}\text { Dosagem com aproximadamente } 33 \% \text { de } \\
\text { substituição, em massa, do pó de pedra por } \\
\text { agregado miúdo reciclado de vigota (MRv) }\end{array}$ \\
\hline & B 12,0-R G B -50\% & $20 / 09$ & $\begin{array}{l}\text { Dosagem com aproximadamente } 50 \% \text { de } \\
\text { substituição, em massa, da fração graúda natural } \\
\text { por agregado graúdo reciclado de bloco (GRb) }\end{array}$ \\
\hline & B 12,0-R M B-33\% & $20 / 09$ & $\begin{array}{l}\text { Dosagem com aproximadamente } 33 \% \text { de } \\
\text { substituição, em massa, do pó de pedra por } \\
\text { agregado miúdo reciclado de bloco (MRb) }\end{array}$ \\
\hline
\end{tabular}

As características dos traços encontram-se na Tabela 7.9.

Tabela 7.9 - Características dos traços do Grupo 12,0.

\begin{tabular}{|c|c|c|c|c|c|c|c|}
\hline & GRUPO 12,0 & $\begin{array}{l}\text { B12,0- } \\
\text { REF }\end{array}$ & $\begin{array}{l}\text { B12,0- } \\
\text { RGV - } \\
100 \%\end{array}$ & $\begin{array}{c}\text { B12,0- } \\
\text { RGV - } \\
50 \%\end{array}$ & $\begin{array}{l}\text { B12,0- } \\
\text { RMV - } \\
33 \%\end{array}$ & $\begin{array}{c}\text { B12,0- } \\
\text { RGB - } \\
50 \%\end{array}$ & $\begin{array}{c}\text { B12,0- } \\
\text { RM B - } \\
33 \%\end{array}$ \\
\hline \multicolumn{2}{|c|}{ Umidade/Temperatura } & \multicolumn{6}{|c|}{$25-30^{\circ} \mathrm{C}-50 \%-60 \%$} \\
\hline \multicolumn{2}{|c|}{ TRAÇO (Cimento:Agregados) } & $1: 9,98$ & $1: 9,79$ & $1: 9,96$ & $1: 10,04$ & $1: 9,97$ & $1: 10,19$ \\
\hline \multirow{9}{*}{$\begin{array}{l}\text { Consumo } \\
\text { estimado de } \\
\text { materiais } \\
\left(\mathrm{kg} / \mathrm{m}^{3}\right)\end{array}$} & Cimento & 221 & 218 & 218 & 214 & 218 & 210 \\
\hline & Pedrisco & 645 & - & 318 & 661 & 317 & 651 \\
\hline & Vigota-GRv & - & 594 & 314 & - & - & - \\
\hline & Bloco-GRb & - & - & - & - & 316 & - \\
\hline & Pó de pedra & 896 & 884 & 883 & 576 & 880 & 567 \\
\hline & Vigota-MRv & - & - & - & 298 & - & - \\
\hline & Bloco - MRb & - & - & - & - & - & 290 \\
\hline & Areia Tietz & 668 & 659 & 658 & 609 & 657 & 635 \\
\hline & Água & 131 & 127 & 129 & 141 & 134 & 151 \\
\hline & Pedrisco (\%) & 29,20 & - & 14,62 & 30,84 & 14,61 & 30,38 \\
\hline & GRv/ \%GRb (\%) & - & 27,81 & 14,46 & - & 14,56 & - \\
\hline & Areia Tietz (\%) & 30,25 & 30,84 & 30,30 & 28,40 & 30,26 & 29,62 \\
\hline & M Rv/ \%M Rb (\%) & - & - & - & 13,88 & - & 13,54 \\
\hline & Pó de pedra (\%) & 40,55 & 41,35 & 40,62 & 26,88 & 40,57 & 26,47 \\
\hline \multicolumn{2}{|c|}{ Umidade estimada adicionada na mistura (\%) } & 5,40 & 5,40 & 5,40 & 6,00 & 5,60 & 6,40 \\
\hline \multicolumn{2}{|c|}{ Aditivo, em relação à massa de cimento $(\%)$} & 0,25 & 0,25 & 0,25 & 0,25 & 0,25 & 0,25 \\
\hline \multicolumn{2}{|c|}{ Teor de argamassa (\%) } & 73,46 & 74,77 & 73,57 & 71,95 & 73,49 & 72,34 \\
\hline \multicolumn{2}{|c|}{ Teor de argamassa em volume (\%) } & 73,35 & 72,02 & 72,08 & 72,36 & 72,26 & 72,51 \\
\hline \multicolumn{2}{|c|}{ Módulo de finura da mistura } & 3,35 & 3,40 & 3,40 & 3,43 & 3,32 & 3,41 \\
\hline \multicolumn{2}{|c|}{ Material grosso - retido peneiras $(4,8$ e $2,4 \mathrm{~mm})$} & $38 \%$ & $37 \%$ & $38 \%$ & $39 \%$ & $38 \%$ & $38 \%$ \\
\hline \multicolumn{2}{|c|}{ Material médio - retido peneiras $(1,2,0,6$ e $0,3 \mathrm{~mm})$} & $44 \%$ & $45 \%$ & $44 \%$ & $45 \%$ & $44 \%$ & $46 \%$ \\
\hline \multicolumn{2}{|c|}{ Material fino - retido peneiras $(0,15 \mathrm{~mm}$ e fundo $)$} & $18 \%$ & $18 \%$ & $18 \%$ & $17 \%$ & $18 \%$ & $16 \%$ \\
\hline \multirow{3}{*}{$\begin{array}{l}\text { Tempos da } \\
\text { máquina (s) }\end{array}$} & Alimentação & 1,30 & 1,30 & 1,30 & 1,30 & 1,80 & 1,80 \\
\hline & Vibração & 3,00 & 3,00 & 3,00 & 3,00 & 3,00 & 3,00 \\
\hline & Compressão & 3,00 & 3,00 & 3,00 & 3,00 & 4,00 & 4,00 \\
\hline & Comentários & & & & & & \\
\hline
\end{tabular}

1,2,3 a umidade adotada para esses dois traços ficou um pouco abaixo da umidade ótima; além disso, os tempos de produção da máquina poderiam ter sido aumentados;

${ }^{4}$ os tempos da máquina poderiam ter sido elevados;

${ }^{5,6}$ nenhum problema verificado durante a moldagem. Umidade adotada e tempos da máquina corretamente estabelecidos;

Analisando-se os dados da Tabela 7.9, observa-se que pelo fato das dosagens serem estabelecidas em volume, o consumo de cimento e o teor de argamassa (em volume) não foram iguais; mas, pelo menos, foram próximos (diferença de no máximo 5\% para o consumo de cimento). Após a produção das unidades B12,0-REF e B12,0-RGV-100\%, apesar da experiência do operador da produção, foi constatada que a umidade adotada estava abaixo da umidade ótima. Conforme Frasson Junior (2000), as misturas mais secas 
tendem a produzir blocos de menor compacidade, devido à diminuição da eficiência de compactação da máquina. Outra constatação feita para essas unidades, juntamente com os blocos dos traços B12,0-RGV-50\% e B12,0-RMV-33\%, refere-se à necessidade da elevação dos tempos de produção. Segundo Frasson Junior (2000), para os traços mais ricos tornase desejável aumentar os tempos de alimentação e vibração, pois as misturas mais ricas em finos e com elevada umidade possuem grande dificuldade de alimentar os moldes das formas. Na Figura 7.18, podem ser observadas algumas unidades desses traços que apresentaram falhas e defeitos na face inferior, provavelmente devido aos motivos enumerados acima.
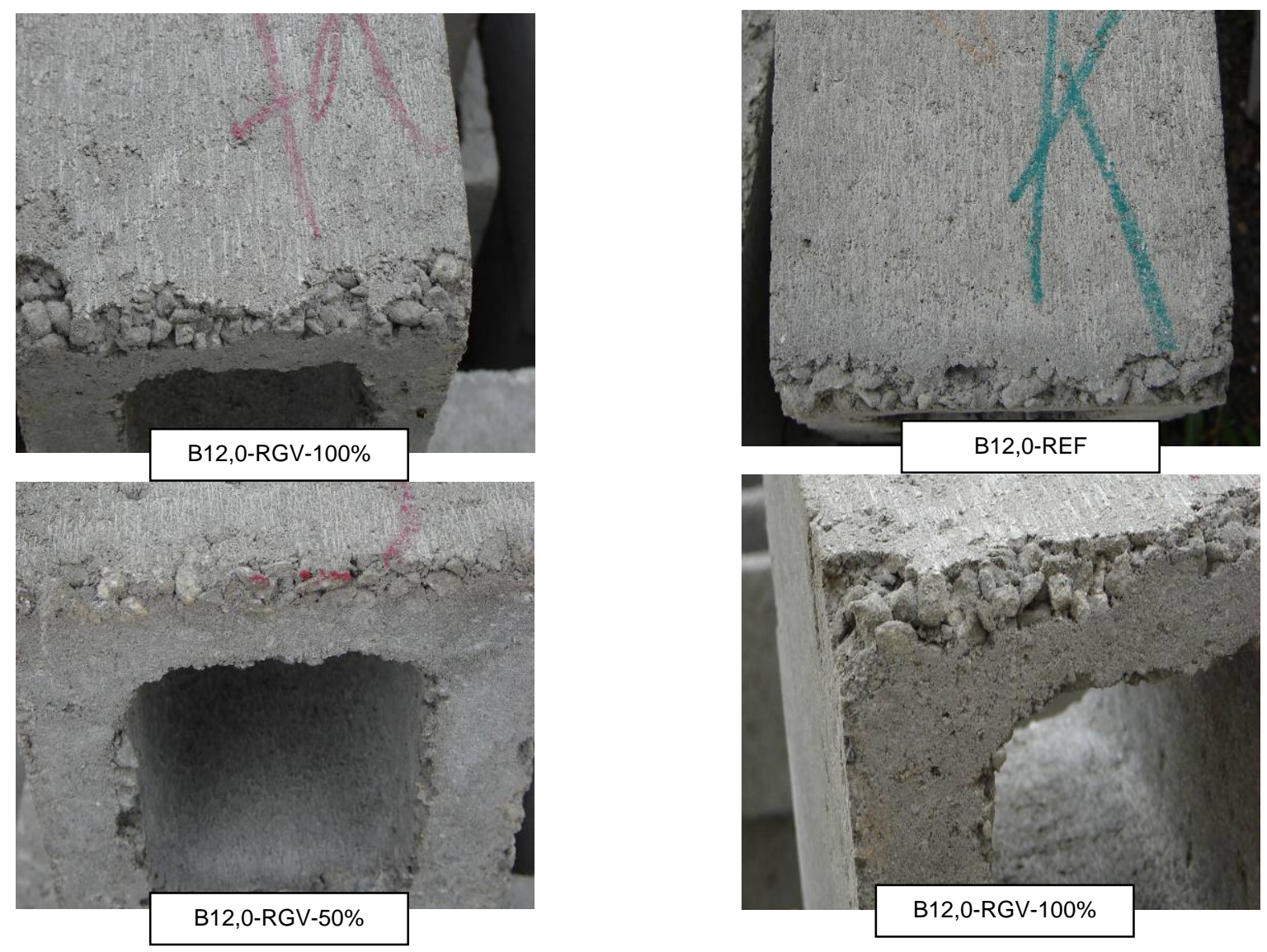

Figura 7.18 - Defeitos na face inferior de algumas unidades dos traços B12,0-REF, B12,0RGV-100\% e B12,0-RGV-50\%.

Gallegos (1989) cita que na produção, enquanto o concreto do bloco está sendo vibrado, a pasta de cimento deve se liquefazer e fluir em direção às partículas de agregados promovendo a união dessas partículas. A situação ideal ocorre quando as partículas de agregado estão aderidas pela pasta de cimento nos pontos de contato entre os agregados; provavelmente, na produção das unidades B12,0-REF e B12,0-RGV-100\%, o tempo de vibração e compactação adotado não foi adequado, bem como a definição da umidade da mistura. 
Em virtude da adoção de tempos maiores de alimentação e compressão, para as unidades mais pobres dos traços com agregados reciclados de bloco, esses parâmetros de produção foram mantidos para as unidades dos traços mais ricos (B12,0-RGB-50\% e B12,0RMB-33\%). Aparentemente, tais unidades não apresentaram nenhum problema relacionado à sua produção.

$\mathrm{Na}$ Figura 7.19, podem ser observadas as paredes longitudinais das unidades do Grupo 12,0. Nesses cortes longitudinais, pode ser notada a presença dos agregados reciclados de vigota através dos pontos mais claros.
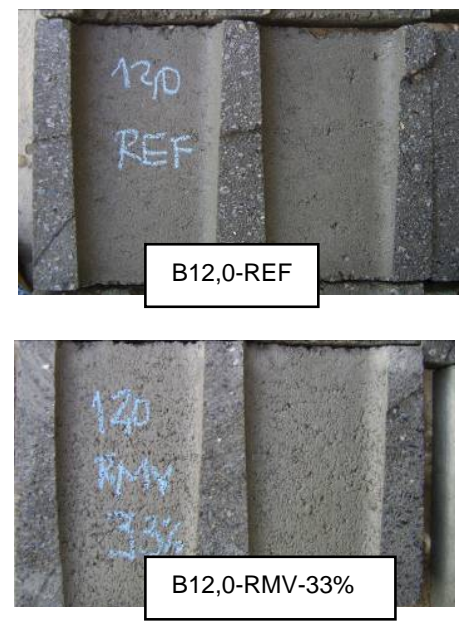
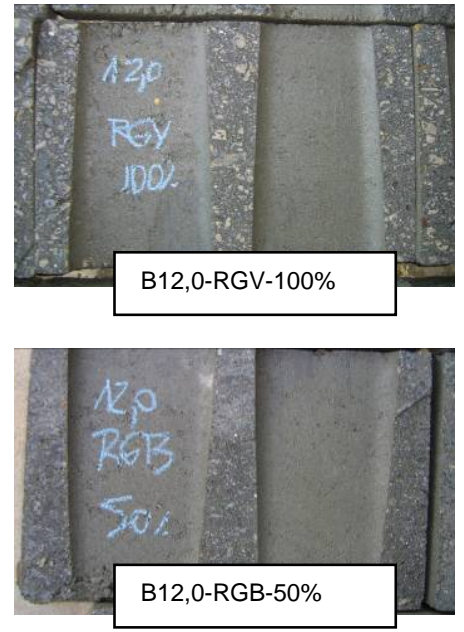
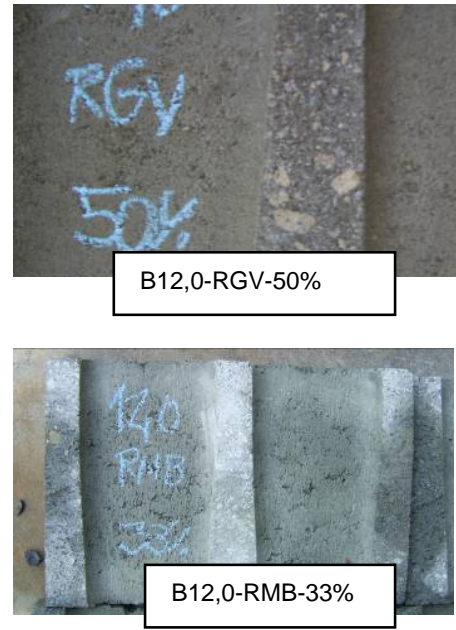

Figura 7.19 - Paredes das unidades do Grupo 12,0.

\subsubsection{PROPRIEDADES FÍSICAS}

Conforme já relatado, o cumprimento dos limites impostos pelos códigos normativos, quanto às propriedades físicas, é condição essencial para um correto desempenho das unidades sem o surgimento de futuras patologias. Diante desse contexto, todas as unidades produzidas com agregados reciclados têm que obedecer a esses limites, especialmente, para as propriedades de absorção de água e retração por secagem (Capítulo 9).

\subsubsection{Análise dimensional}

\subsection{Grupo 4,5}

Conforme descrito, utilizou-se uma amostra de seis blocos, escolhidos aleatoriamente, para a verificação dimensional. A análise dimensional, para cada um dos lotes avaliados, é apresentada na Tabela 7.10. 
Tabela 7.10 - Análise dimensional das unidades do Grupo 4,5.

\begin{tabular}{|c|c|c|c|c|c|c|c|c|c|c|}
\hline & \multicolumn{5}{|c|}{ B4,5-REF } & \multicolumn{5}{|c|}{ B4,5-RGV-100\% } \\
\hline & \multicolumn{5}{|c|}{ Paredes } & & & & \multicolumn{2}{|c|}{ Paredes } \\
\hline & $\begin{array}{c}\text { Larg. } \\
(\mathrm{cm})\end{array}$ & $\begin{array}{c}\text { Alt. } \\
\text { (cm) }\end{array}$ & $\begin{array}{c}\text { Comp. } \\
\text { (cm) }\end{array}$ & $\begin{array}{c}\text { Transv. } \\
(\mathrm{mm})\end{array}$ & $\begin{array}{l}\text { Long. } \\
(\mathrm{mm})\end{array}$ & $\begin{array}{l}\text { Larg. } \\
\text { (cm) }\end{array}$ & $\begin{array}{c}\text { Alt. } \\
\text { (cm) }\end{array}$ & $\begin{array}{c}\text { Comp. } \\
\text { (cm) }\end{array}$ & $\begin{array}{c}\text { Transv. } \\
\text { (mm) }\end{array}$ & $\begin{array}{l}\text { Long. } \\
(\mathrm{mm})\end{array}$ \\
\hline Média & 14,00 & 19,12 & 29,22 & 26,02 & 26,48 & 14,00 & 19,15 & 29,13 & 26,36 & 26,31 \\
\hline Máx. & 14,00 & 19,20 & 29,30 & 27,70 & 29,00 & 14,00 & 19,20 & 29,20 & 28,00 & 28,10 \\
\hline Mín. & 14,00 & 19,00 & 29,10 & 23,80 & 23,40 & 14,00 & 19,10 & 29,10 & 24,80 & 24,90 \\
\hline $\begin{array}{c}\text { D.Padrão } \\
\text { (cm) }\end{array}$ & 0,00 & 0,10 & 0,08 & 1,07 & 1,30 & 0,00 & 0,05 & 0,05 & 0,72 & 0,94 \\
\hline \multirow[t]{4}{*}{$\begin{array}{c}\text { Coef. } \\
\text { Variação } \\
(\%)\end{array}$} & 0,00 & 0,51 & 0,26 & 4,13 & 4,89 & 0,00 & 0,29 & 0,18 & 2,74 & 3,56 \\
\hline & \multicolumn{5}{|c|}{ B4,5-RGV-50\% } & \multicolumn{5}{|c|}{ B4,5-RMV-33\% } \\
\hline & \multicolumn{8}{|c|}{ Paredes } & \multicolumn{2}{|c|}{ Paredes } \\
\hline & $\begin{array}{l}\text { Larg. } \\
(\mathrm{cm})\end{array}$ & $\begin{array}{l}\text { Alt. } \\
\text { (cm) }\end{array}$ & $\begin{array}{c}\text { Comp. } \\
\text { (cm) }\end{array}$ & $\begin{array}{c}\text { Transv. } \\
(\mathrm{mm})\end{array}$ & $\begin{array}{l}\text { Long. } \\
(\mathrm{mm})\end{array}$ & $\begin{array}{l}\text { Larg. } \\
\text { (cm) }\end{array}$ & $\begin{array}{l}\text { Alt. } \\
\text { (cm) }\end{array}$ & $\begin{array}{c}\text { Comp. } \\
\text { (cm) }\end{array}$ & $\begin{array}{c}\text { Transv. } \\
(\mathrm{mm})\end{array}$ & $\begin{array}{l}\text { Long. } \\
\text { (mm) }\end{array}$ \\
\hline Média & 13,98 & 19,02 & 29,13 & 26,44 & 26,13 & 14,02 & 19,00 & 29,22 & 26,57 & 26,44 \\
\hline Máx. & 14,00 & 19,10 & 29,20 & 27,80 & 27,80 & 14,10 & 19,20 & 29,30 & 28,00 & 28,10 \\
\hline Mín. & 13,90 & 18,90 & 29,10 & 25,50 & 24,90 & 14,00 & 18,80 & 29,20 & 25,60 & 24,90 \\
\hline $\begin{array}{c}\text { D.Padrão } \\
\text { (cm) }\end{array}$ & 0,04 & 0,08 & 0,05 & 0,67 & 0,81 & 0,04 & 0,13 & 0,04 & 0,65 & 0,97 \\
\hline \multirow[t]{4}{*}{$\begin{array}{c}\text { Coef. } \\
\text { Variação } \\
(\%)\end{array}$} & 0,29 & 0,40 & 0,18 & 2,53 & 3,11 & 0,29 & 0,67 & 0,14 & 2,43 & 3,68 \\
\hline & \multicolumn{5}{|c|}{ B4,5-RGB-50\% } & \multicolumn{5}{|c|}{ B4,5-RMB-33\% } \\
\hline & \multicolumn{8}{|c|}{ Paredes } & \multicolumn{2}{|c|}{ Paredes } \\
\hline & $\begin{array}{l}\text { Larg. } \\
(\mathrm{cm})\end{array}$ & $\begin{array}{l}\text { Alt. } \\
\text { (cm) }\end{array}$ & $\begin{array}{c}\text { Comp. } \\
\text { (cm) }\end{array}$ & $\begin{array}{c}\text { Transv. } \\
(\mathbf{m m})\end{array}$ & $\begin{array}{l}\text { Long. } \\
(\mathrm{mm})\end{array}$ & $\begin{array}{l}\text { Larg. } \\
\text { (cm) }\end{array}$ & $\begin{array}{l}\text { Alt. } \\
\text { (cm) }\end{array}$ & $\begin{array}{c}\text { Comp. } \\
\text { (cm) }\end{array}$ & $\begin{array}{c}\text { Transv. } \\
(\mathbf{m m})\end{array}$ & $\begin{array}{l}\text { Long. } \\
(\mathrm{mm})\end{array}$ \\
\hline Média & 14,00 & 19,27 & 29,22 & 26,05 & 26,29 & 14,05 & 19,27 & 29,27 & 26,40 & 26,37 \\
\hline Máx. & 14,00 & 19,30 & 29,30 & 27,30 & 27,30 & 14,10 & 19,40 & 29,40 & 28,20 & 28,00 \\
\hline Mín. & 14,00 & 19,10 & 29,20 & 25,30 & 25,40 & 14,00 & 19,10 & 29,10 & 25,00 & 24,60 \\
\hline $\begin{array}{c}\text { D.Padrão } \\
\text { (cm) }\end{array}$ & 0,00 & 0,08 & 0,04 & 0,52 & 0,55 & 0,05 & 0,14 & 0,10 & 1,04 & 0,97 \\
\hline $\begin{array}{c}\text { Coef. } \\
\text { Variação } \\
(\%)\end{array}$ & 0,00 & 0,42 & 0,14 & 2,01 & 2,08 & 0,39 & 0,71 & 0,35 & 3,92 & 3,70 \\
\hline
\end{tabular}

Analisando-se os resultados da Tabela 7.10, cabem os seguintes comentários:

- Todas as unidades satisfizeram aos requisitos da NBR 6136 ( $\pm 2 \mathrm{~mm}$ para a largura e $\pm 3 \mathrm{~mm}$ no comprimento e altura); entretanto, uma unidade do traço B4,5-RMB-33\% apresentou dimensões (altura e comprimento) superiores aos valores estipulados pela norma (19,40 mm e 29,40 mm). Possivelmente, o maior tempo de alimentação (2,5 s) e a elevada umidade utilizada nesse traço foram os responsáveis por esses valores; de acordo com Frasson Junior (2000), caso a umidade seja elevada, as unidades podem apresentar variações nas dimensões e formato.

- Com relação à espessura das paredes transversais e longitudinais, todos os lotes analisados apresentaram valores médios superiores aos prescritos pela NBR 6136 (1994). Algumas unidades do traço B4,5-REF apresentaram valores individuais ligeiramente inferiores aos prescritos pela referida norma $(23,80 \mathrm{~mm}$ e $23,40 \mathrm{~mm})$ e, devido a isso, o coeficiente de variação para esse traço foi superior quando comparado com os demais lotes. Provavelmente, um problema ocorrido no molde 
metálico, antes da moldagem, foi responsável por essas variações mais representativas nas espessuras das paredes.

Na Figura 7.20 são apresentadas algumas vistas das unidades do Grupo 4,5.
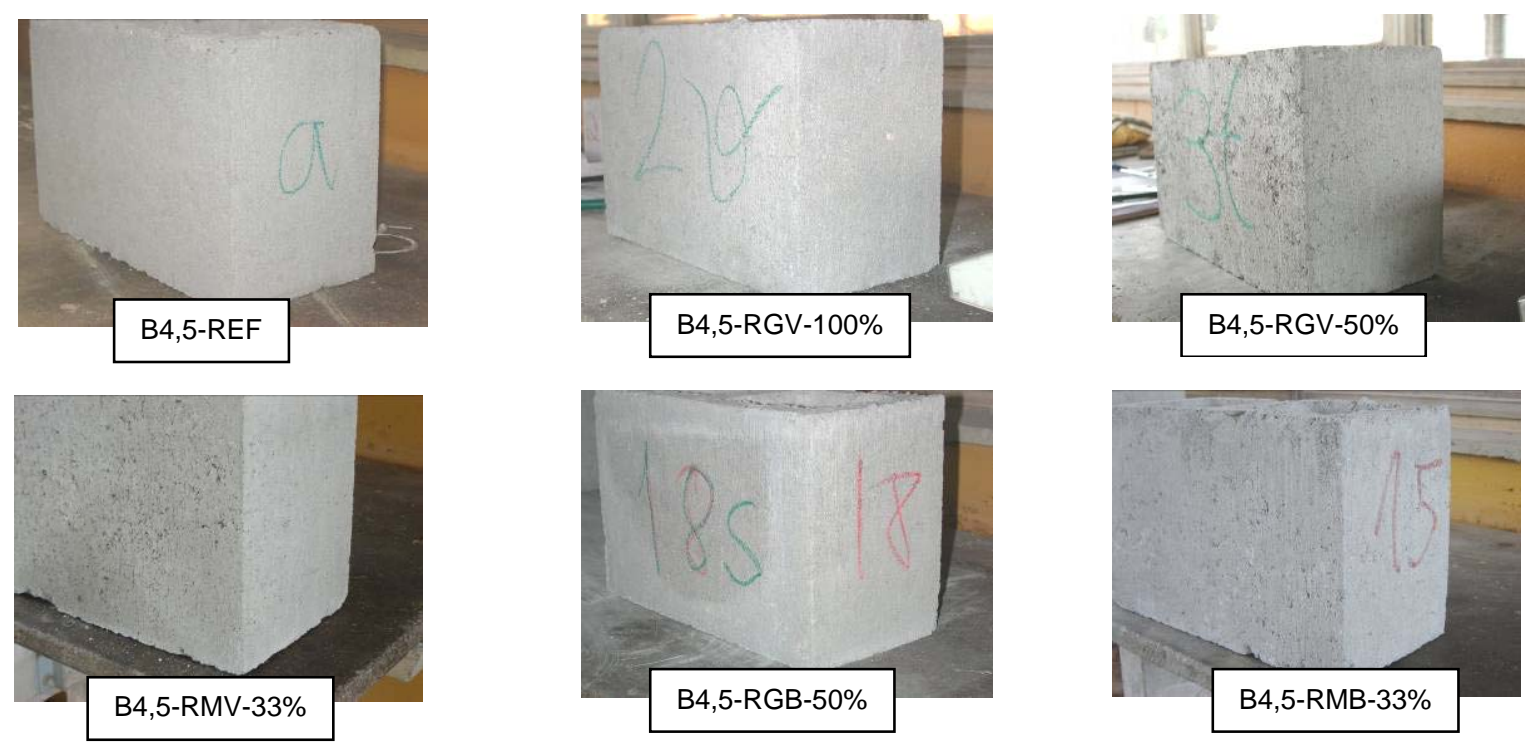

*A numeração existente nas Figuras deve ser desconsiderada

Figura 7.20 - Blocos do Grupo 4,5.

Na Figura 7.21 pode ser notada a textura áspera das unidades produzidas com agregados miúdos reciclados em comparação com a do traço de referência. Essa textura áspera é devida à falta de finos, em razão da substituição parcial do pó-de-pedra pelo material reciclado.
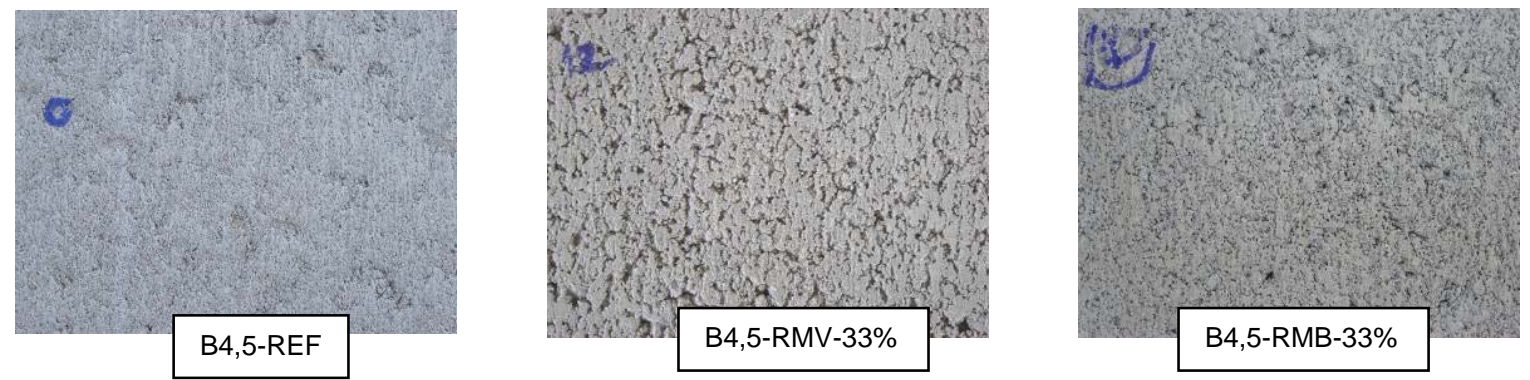

Figura 7.21 - Textura áspera das unidades com agregados miúdos reciclados comparativamente às unidades de referência.

$\mathrm{Na}$ Figura 7.22, são apresentadas as texturas dos demais blocos com agregados graúdos reciclados comparativamente às unidades de referência. 

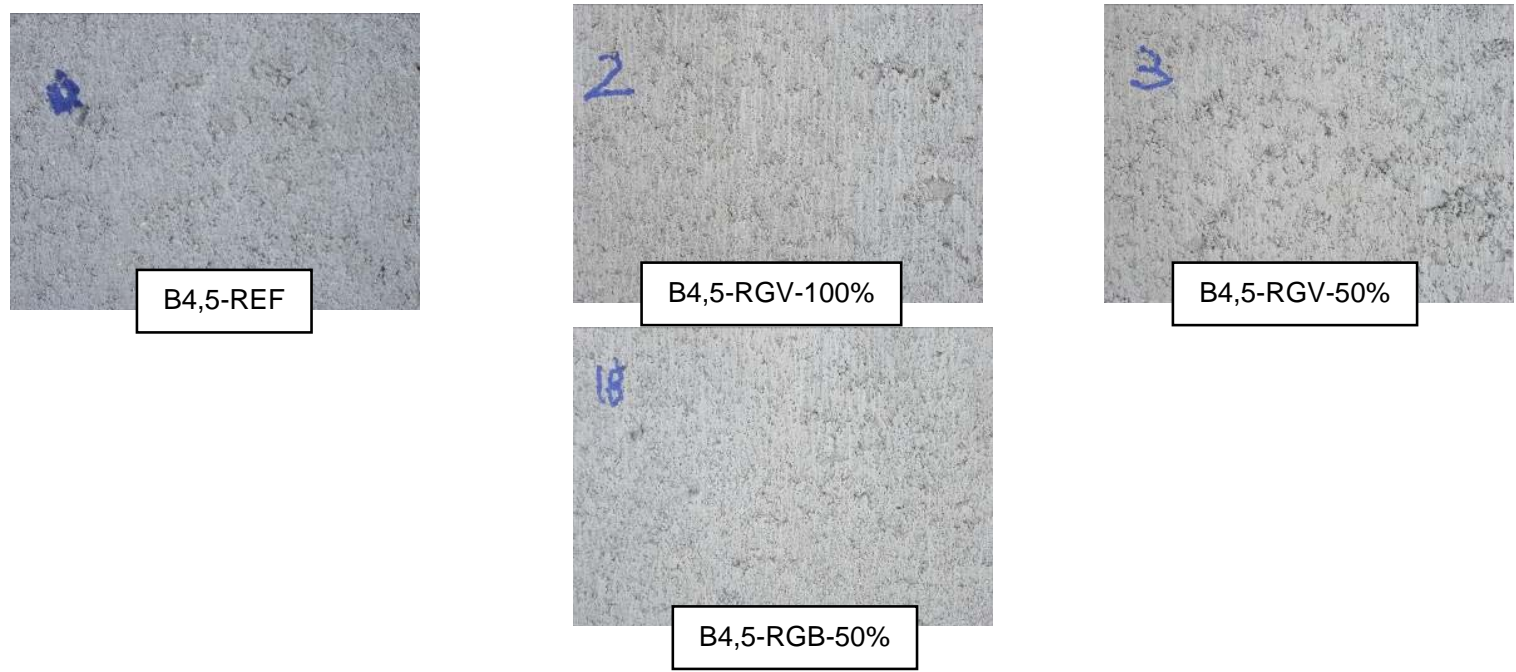

Figura 7.22 - Textura das unidades com agregados graúdos reciclados comparativamente às unidades de referência.

Analisando-se a Figura 7.22, nota-se que as unidades com agregados reciclados não apresentaram diferenças significativas de textura superficial quando comparadas com as unidades de referência; apenas as unidades do traço B4,5-RGV-50\% apresentaram uma textura mais rugosa; possivelmente, devido a deficiências ocorridas na moldagem ou na definição da umidade da mistura.

\subsection{Grupo 8,0}

A análise dimensional, para cada um dos lotes avaliados, é apresentada na Tabela 7.11 . 
Tabela 7.11 - Análise dimensional das unidades do Grupo 8,0.

\begin{tabular}{|c|c|c|c|c|c|c|c|c|c|c|}
\hline & \multicolumn{5}{|c|}{ B8,0-REF } & \multicolumn{5}{|c|}{ B8,0-RGV-100\% } \\
\hline & \multicolumn{5}{|c|}{ Paredes } & & & & Pare & es \\
\hline & $\begin{array}{l}\text { Larg. } \\
(\mathrm{cm})\end{array}$ & $\begin{array}{l}\text { Alt. } \\
(\mathrm{cm})\end{array}$ & $\begin{array}{c}\text { Comp. } \\
(\mathrm{cm})\end{array}$ & $\begin{array}{c}\text { Transv. } \\
(\mathrm{mm})\end{array}$ & $\begin{array}{l}\text { Long. } \\
(\mathrm{mm})\end{array}$ & $\begin{array}{l}\text { Larg. } \\
(\mathrm{cm})\end{array}$ & $\begin{array}{l}\text { Alt. } \\
\text { (cm) }\end{array}$ & $\begin{array}{c}\text { Comp. } \\
(\mathrm{cm})\end{array}$ & $\begin{array}{c}\text { Transv. } \\
(\mathrm{mm})\end{array}$ & $\begin{array}{l}\text { Long. } \\
(\mathrm{mm})\end{array}$ \\
\hline Média & 13,93 & 19,10 & 29,17 & 26,33 & 26,38 & 14,00 & 19,03 & 29,17 & 26,47 & 26,33 \\
\hline Máx. & 14,00 & 19,30 & 29,20 & 27,70 & 27,90 & 14,00 & 19,20 & 29,30 & 28,60 & 27,70 \\
\hline Mín. & 13,90 & 19,10 & 29,10 & 25,30 & 25,00 & 14,00 & 18,90 & 29,10 & 25,00 & 25,20 \\
\hline $\begin{array}{l}\text { D.Padrão } \\
\text { (cm) }\end{array}$ & 0,05 & 0,13 & 0,05 & 0,70 & 0,95 & 0,00 & 0,10 & 0,08 & 0,92 & 0,82 \\
\hline \multirow[t]{4}{*}{$\begin{array}{c}\text { Coef. } \\
\text { Variação } \\
(\%)\end{array}$} & 0,37 & 0,66 & 0,18 & 2,66 & 3,60 & 0,00 & 0,54 & 0,28 & 3,49 & 3,12 \\
\hline & \multicolumn{5}{|c|}{ B8,0-RGV-50\% } & \multicolumn{5}{|c|}{ B8,0-RMV-33\% } \\
\hline & \multicolumn{5}{|c|}{ Paredes } & & & & \multicolumn{2}{|c|}{ Paredes } \\
\hline & $\begin{array}{c}\begin{array}{c}\text { Larg. } \\
(\mathrm{cm})\end{array} \\
14,03\end{array}$ & $\begin{array}{c}\begin{array}{c}\text { Alt. } \\
\text { (cm) }\end{array} \\
19.20\end{array}$ & $\begin{array}{c}\text { Comp. } \\
\text { (cm) }\end{array}$ & $\begin{array}{c}\text { Transv. } \\
(\mathrm{mm})\end{array}$ & $\begin{array}{l}\begin{array}{c}\text { Long. } \\
(\mathrm{mm})\end{array} \\
26,48\end{array}$ & $\begin{array}{c}\begin{array}{c}\text { Larg. } \\
(\mathrm{cm})\end{array} \\
14,02\end{array}$ & $\begin{array}{c}\begin{array}{c}\text { Alt. } \\
\text { (cm) }\end{array} \\
19.07\end{array}$ & $\begin{array}{c}\text { Comp. } \\
\text { (cm) }\end{array}$ & $\begin{array}{c}\text { Transv. } \\
(\mathrm{mm})\end{array}$ & $\begin{array}{l}\text { Long. } \\
(\mathrm{mm}) \\
26,44\end{array}$ \\
\hline $\begin{array}{l}\text { Média } \\
\text { Máx. }\end{array}$ & $\begin{array}{l}14,03 \\
14,10\end{array}$ & $\begin{array}{l}19,20 \\
19,30\end{array}$ & \begin{tabular}{|l|}
$\mathbf{2 9 , 1 8}$ \\
29,30
\end{tabular} & $\begin{array}{l}\mathbf{2 6 , 4 2} \\
27,70\end{array}$ & $\begin{array}{l}\mathbf{2 6 , 4 8} \\
27,60\end{array}$ & $\begin{array}{l}\mathbf{1 4 , 0 2} \\
14,10\end{array}$ & $\begin{array}{l}19,07 \\
19,10\end{array}$ & $\begin{array}{l}29,22 \\
29,30\end{array}$ & $\begin{array}{l}26,40 \\
28,10\end{array}$ & $\begin{array}{l}26,44 \\
28,40\end{array}$ \\
\hline $\begin{array}{l}\text { Max. } \\
\text { Mín. }\end{array}$ & $\begin{array}{l}14,10 \\
14,00\end{array}$ & $\begin{array}{l}19,00 \\
19,00\end{array}$ & $\frac{29,30}{29,10}$ & 25,40 & 25,00 & $\begin{array}{l}14,100 \\
14,00\end{array}$ & $\begin{array}{l}19,10 \\
19,00\end{array}$ & $\frac{29,30}{29,10}$ & 24,60 & $\begin{array}{l}28,40 \\
25,00\end{array}$ \\
\hline $\begin{array}{l}\text { D.Padrão } \\
\text { (cm) }\end{array}$ & 0,05 & 0,11 & 0,08 & 0,67 & 0,87 & 0,04 & 0,05 & 0,08 & 0,82 & 0,97 \\
\hline \multirow[t]{4}{*}{$\begin{array}{c}\text { Coef. } \\
\text { Variação } \\
(\%)\end{array}$} & 0,37 & 0,57 & 0,26 & 2,52 & 3,29 & 0,29 & 0,27 & 0,26 & 3,11 & 3,68 \\
\hline & \multicolumn{5}{|c|}{ B8,0-RGB-50\% } & \multicolumn{5}{|c|}{ B8,0-RMB-33\% } \\
\hline & \multicolumn{5}{|c|}{ Paredes } & & & & \multicolumn{2}{|c|}{ Paredes } \\
\hline & $\begin{array}{c}\begin{array}{c}\text { Larg. } \\
(\mathrm{cm})\end{array} \\
13,98\end{array}$ & $\begin{array}{c}\text { Alt. } \\
(\mathrm{cm})\end{array}$ & $\begin{array}{c}\text { Comp. } \\
\text { (cm) }\end{array}$ & $\begin{array}{c}\begin{array}{c}\text { Transv. } \\
(\mathrm{mm})\end{array} \\
26,28\end{array}$ & $\begin{array}{l}\begin{array}{l}\text { Long. } \\
(\mathrm{mm})\end{array} \\
26,10\end{array}$ & $\begin{array}{c}\begin{array}{c}\text { Larg. } \\
(\mathrm{cm})\end{array} \\
14,03\end{array}$ & $\begin{array}{c}\begin{array}{c}\text { Alt. } \\
\text { (cm) }\end{array} \\
19,23\end{array}$ & $\begin{array}{c}\text { Comp. } \\
\text { (cm) }\end{array}$ & $\begin{array}{c}\text { Transv. } \\
(\mathrm{mm})\end{array}$ & $\begin{array}{l}\begin{array}{c}\text { Long. } \\
(\mathrm{mm})\end{array} \\
26,16\end{array}$ \\
\hline Máx. & 14,00 & 19,20 & 29,30 & 28,10 & 27,40 & 14,10 & 19,40 & 29,40 & 27,80 & 28,10 \\
\hline Mín. & 13,90 & 18,80 & 29,20 & 24,70 & 24,90 & 14,00 & 19,00 & 29,10 & 25,10 & 24,70 \\
\hline $\begin{array}{c}\text { D.Padrão } \\
\text { (cm) }\end{array}$ & 0,04 & 0,14 & 0,04 & 1,04 & 0,78 & 0,05 & 0,16 & 0,10 & 0,78 & 0,83 \\
\hline $\begin{array}{c}\text { Coef. } \\
\text { Variação } \\
(\%)\end{array}$ & 0,29 & 0,72 & 0,14 & 3,94 & 2,97 & 0,37 & 0,85 & 0,36 & 2,95 & 3,16 \\
\hline
\end{tabular}

Analisando-se os resultados da Tabela 7.11, são feitos os seguintes comentários:

- Todas as unidades satisfizeram os requisitos da NBR 6136 ( $\pm 2 \mathrm{~mm}$ para a largura e $\pm 3 \mathrm{~mm}$ no comprimento e altura); entretanto, uma unidade do traço com agregados miúdos reciclados de bloco, fato já ocorrido no Grupo 4,5, apresentou dimensões (altura e comprimento) superiores aos valores estipulados pela norma (19,40 mm e 29,40 mm). Possivelmente, o maior tempo de alimentação (2,5 s), quando comparado com o tempo adotado para as outras unidades, foi responsável por esses valores;

- Com relação à espessura das paredes transversais e longitudinais, todas as unidades analisadas apresentaram valores médios superiores aos prescritos pela NBR 6136 (1994).

Na Figura 7.23, são apresentadas algumas vistas dos blocos pertencentes ao Grupo 8,0 . 

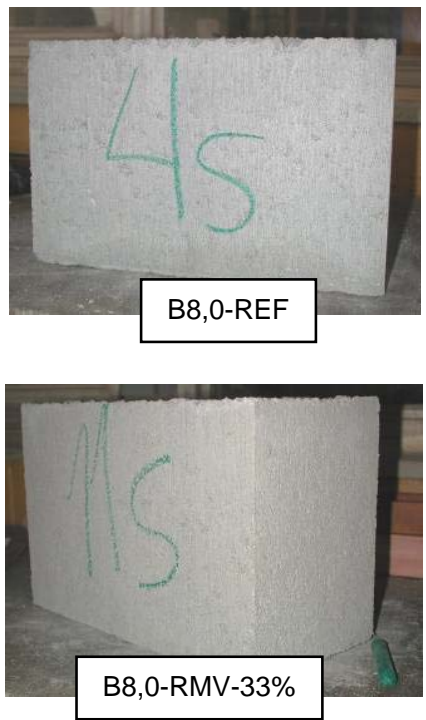

B8,0-RMV-33\%
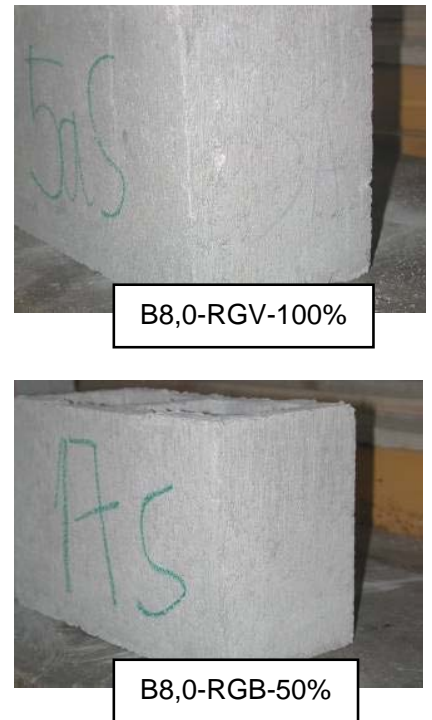
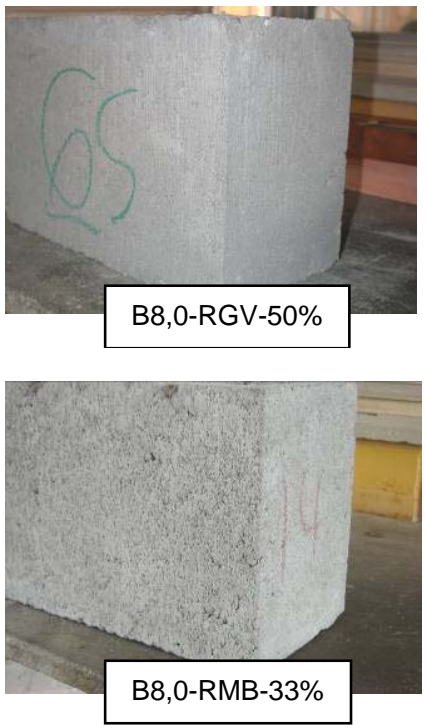

* a numeração existente nas Figuras deve ser desconsiderada

Figura 7.23 - Unidades do Grupo 8,0.

Na Figuras 7.24 e 7.25, são apresentadas as texturas dos blocos do Grupo 8,0.
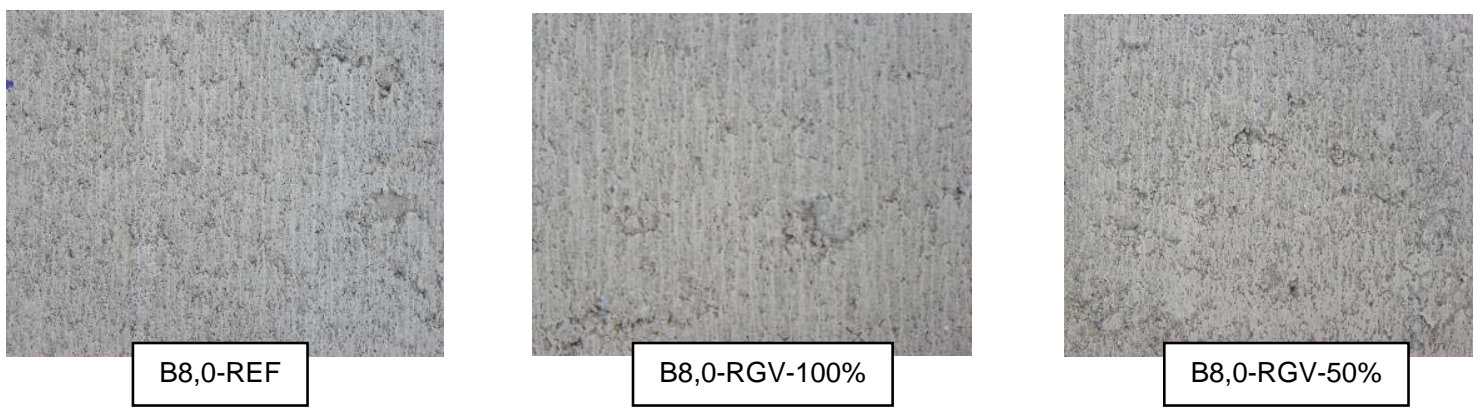

Figura 7.24 - Textura das unidades de referência e das unidades com agregados graúdos reciclados de vigota.

Analisando-se a Figura 7.25, nota-se que a textura das unidades com agregados reciclados de vigota foi semelhante à textura superficial das unidades de referência. $A$ inclusão da fração graúda reciclada não afetou a aparência dos blocos, visto que o módulo de finura final da mistura foi semelhante ao obtido pela mistura de referência. 

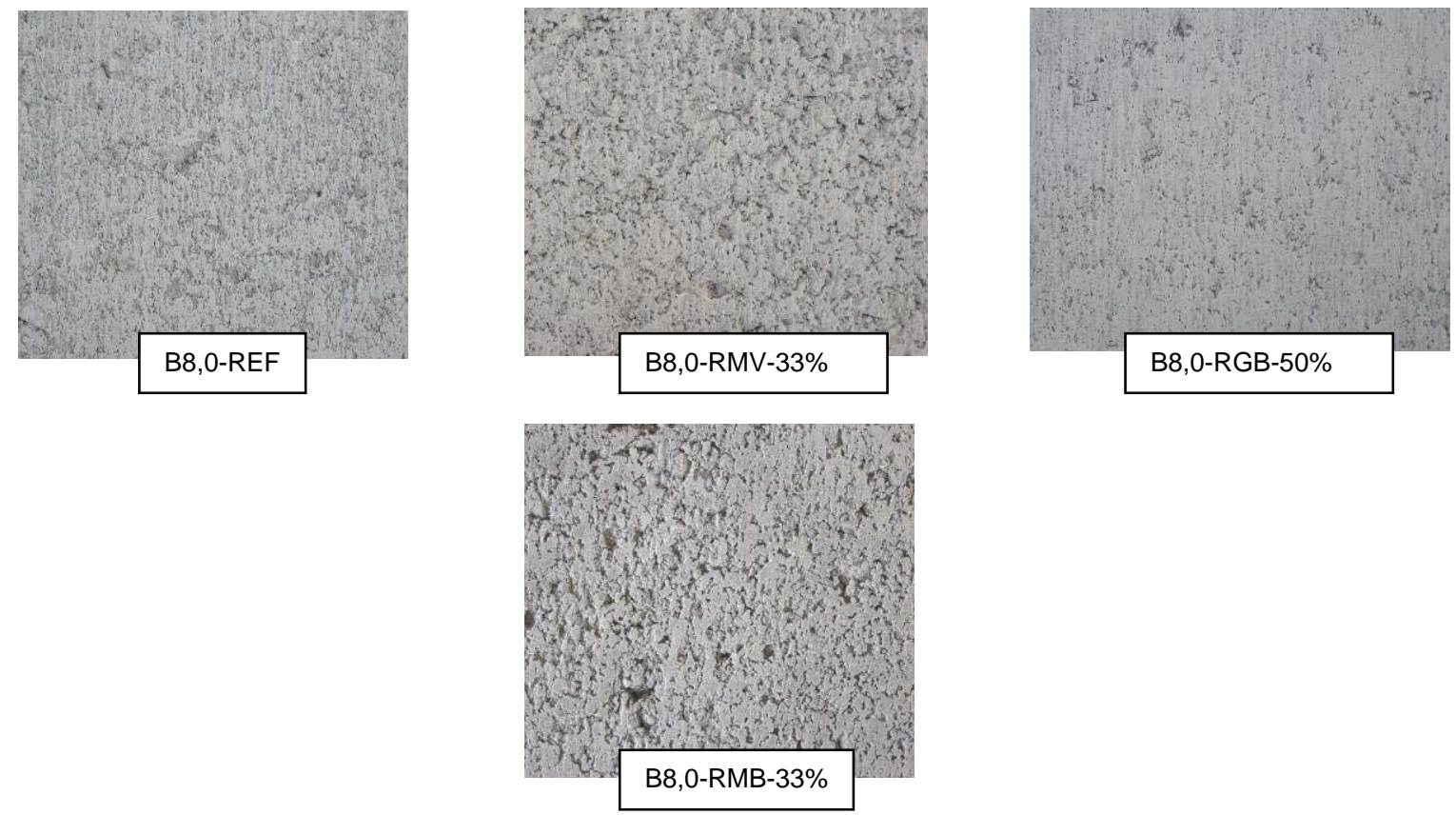

Figura 7.25 - Textura das unidades de referência e das unidades com agregados reciclados de vigota e bloco.

Conforme a Figura 7.25, nota-se que as unidades com agregados miúdos reciclados (B8,0-RMV-33\% e B8,0-RMB-33\%) apresentaram uma textura superficial áspera comparativamente à unidade de referência; possivelmente, a elevada umidade adotada na produção dessas unidades e a redução da quantidade de finos (substituição parcial do póde-pedra pelo material reciclado) foram responsáveis por essa textura áspera. As unidades do traço B8,0-RGB-50\% apresentaram uma textura ligeiramente mais lisa quando comparadas com as unidades do traço de referência; provavelmente, o menor módulo de finura da mistura, os maiores tempos de alimentação e compressão e a umidade adotada foram responsáveis por essa aparência.

\subsection{Grupo 12,0}

A análise dimensional é apresentada na Tabela 7.12. 
Tabela 7.12 - Análise dimensional das unidades do Grupo 12,0.

\begin{tabular}{|c|c|c|c|c|c|c|c|c|c|c|}
\hline & \multicolumn{5}{|c|}{ B12,0-REF } & \multicolumn{5}{|c|}{ B12,0-RGV-100\% } \\
\hline & \multicolumn{5}{|c|}{ Paredes } & & & & \multicolumn{2}{|c|}{ Paredes } \\
\hline & $\begin{array}{l}\text { Larg. } \\
(\mathrm{cm})\end{array}$ & $\begin{array}{c}\text { Alt. } \\
\text { (cm) }\end{array}$ & $\begin{array}{c}\text { Comp. } \\
\text { (cm) }\end{array}$ & $\begin{array}{c}\text { Transv. } \\
(\mathrm{mm})\end{array}$ & $\begin{array}{l}\text { Long. } \\
(\mathrm{mm})\end{array}$ & $\begin{array}{l}\text { Larg. } \\
(\mathrm{cm})\end{array}$ & $\begin{array}{c}\text { Alt. } \\
\text { (cm) }\end{array}$ & $\begin{array}{c}\text { Comp. } \\
\text { (cm) }\end{array}$ & $\begin{array}{c}\text { Transv. } \\
(\mathrm{mm})\end{array}$ & $\begin{array}{l}\text { Long. } \\
(\mathrm{mm})\end{array}$ \\
\hline Média & 13,97 & 19,07 & 29,12 & 26,28 & 26,22 & 13,95 & 19,15 & 29,13 & 26,28 & 26,13 \\
\hline Máx. & 14,00 & 19,20 & 29,20 & 27,60 & 28,40 & 14,00 & 19,20 & 29,20 & 27,10 & 27,90 \\
\hline Mín. & 13,90 & 19,00 & 29,10 & 25,20 & 25,00 & 13,90 & 19,10 & 29,10 & 25,60 & 25,00 \\
\hline $\begin{array}{c}\text { D.Padrão } \\
(\mathrm{cm})\end{array}$ & 0,05 & 0,08 & 0,04 & 0,70 & 0,95 & 0,05 & 0,05 & 0,05 & 0,40 & 0,94 \\
\hline \multirow[t]{4}{*}{$\begin{array}{c}\text { Coef. } \\
\text { Variação } \\
(\%)\end{array}$} & 0,37 & 0,43 & 0,14 & 2,68 & 3,61 & 0,39 & 0,29 & 0,18 & 1,54 & 3,60 \\
\hline & \multicolumn{5}{|c|}{ B12,0-RGV-50\% } & \multicolumn{5}{|c|}{ B12,0-RMV-33\% } \\
\hline & \multicolumn{5}{|c|}{ Paredes } & & & & \multicolumn{2}{|c|}{ Paredes } \\
\hline & $\begin{array}{c}\begin{array}{c}\text { Larg. } \\
(\mathrm{cm})\end{array} \\
14,02\end{array}$ & $\begin{array}{c}\begin{array}{c}\text { Alt. } \\
(\mathrm{cm})\end{array} \\
19,00\end{array}$ & $\begin{array}{c}\begin{array}{c}\text { Comp. } \\
\text { (cm) }\end{array} \\
29,12\end{array}$ & $\begin{array}{c}\begin{array}{c}\text { Transv. } \\
(\mathrm{mm})\end{array} \\
26,35\end{array}$ & $\begin{array}{c}\begin{array}{c}\text { Long. } \\
(\mathrm{mm})\end{array} \\
26,10\end{array}$ & $\begin{array}{c}\text { Larg. } \\
(\mathrm{cm})\end{array}$ & $\begin{array}{c}\begin{array}{c}\text { Alt. } \\
\text { (cm) }\end{array} \\
18,97\end{array}$ & $\begin{array}{c}\text { Comp. } \\
\text { (cm) }\end{array}$ & $\begin{array}{c}\begin{array}{c}\text { Transv. } \\
(\mathrm{mm})\end{array} \\
26.24\end{array}$ & $\begin{array}{l}\begin{array}{c}\text { Long. } \\
(\mathrm{mm})\end{array} \\
26,19\end{array}$ \\
\hline Máx. & 14,10 & 19,10 & 29,20 & 27,60 & 27,80 & 14,00 & 19,00 & 29,20 & 28,20 & 27,70 \\
\hline Mín. & 14,00 & 18,90 & 29,00 & 25,00 & 24,80 & 13,90 & 18,90 & 29,10 & 24,60 & 24,90 \\
\hline $\begin{array}{c}\text { D.Padrão } \\
(\mathbf{c m})\end{array}$ & 0,04 & 0,09 & 0,08 & 0,95 & 0,81 & 0,05 & 0,05 & 0,05 & 0,95 & 0,77 \\
\hline \multirow[t]{4}{*}{$\begin{array}{c}\text { Coef. } \\
\text { Variação } \\
(\%)\end{array}$} & 0,29 & 0,47 & 0,26 & 3,61 & 3,10 & 0,37 & 0,27 & 0,18 & 3,61 & 2,93 \\
\hline & \multicolumn{5}{|c|}{ B12,0-RGB-50\% } & \multicolumn{5}{|c|}{ B12,0-RMB-33\% } \\
\hline & \multicolumn{5}{|c|}{ Paredes } & & & & \multicolumn{2}{|c|}{ Paredes } \\
\hline & $\begin{array}{l}\text { Larg. } \\
(\mathrm{cm})\end{array}$ & $\begin{array}{l}\text { Alt. } \\
\text { (cm) }\end{array}$ & $\begin{array}{c}\text { Comp. } \\
\text { (cm) }\end{array}$ & $\begin{array}{c}\text { Transv. } \\
(\mathrm{mm})\end{array}$ & $\begin{array}{l}\text { Long. } \\
(\mathrm{mm})\end{array}$ & $\begin{array}{l}\text { Larg. } \\
(\mathrm{cm})\end{array}$ & $\begin{array}{l}\text { Alt. } \\
\text { (cm) }\end{array}$ & $\begin{array}{c}\text { Comp. } \\
(\mathrm{cm})\end{array}$ & $\begin{array}{c}\text { Transv. } \\
(\mathrm{mm})\end{array}$ & $\begin{array}{l}\text { Long. } \\
(\mathrm{mm})\end{array}$ \\
\hline Média & 13,98 & 18,98 & 29,18 & 26,08 & 26,54 & 14,00 & 19,10 & 29,27 & 26,40 & 26,55 \\
\hline Máx. & 14,00 & 19,10 & 29,30 & 27,20 & 28,30 & 14,00 & 19,20 & 29,30 & 28,30 & 27,80 \\
\hline Mín. & 13,90 & 18,90 & 29,10 & 25,30 & 24,70 & 14,00 & 19,00 & 29,20 & 25,00 & 25,10 \\
\hline $\begin{array}{c}\text { D.Padrão } \\
(\mathbf{c m})\end{array}$ & 0,04 & 0,08 & 0,08 & 0,53 & 1,04 & 0,00 & 0,09 & 0,05 & 0,91 & 0,78 \\
\hline $\begin{array}{c}\text { Coef. } \\
\text { Variação } \\
(\%)\end{array}$ & 0,29 & 0,40 & 0,26 & 2,04 & 3,92 & 0,00 & 0,47 & 0,18 & 3,44 & 2,94 \\
\hline
\end{tabular}

Analisando-se os resultados da Tabela 7.12, são enumerados os seguintes comentários:

- Todas as unidades satisfizeram aos requisitos da NBR 6136 ( $\pm 2 \mathrm{~mm}$ para a largura e $\pm 3 \mathrm{~mm}$ no comprimento e altura);

- Com relação à espessura das paredes transversais e longitudinais, todas as unidades analisadas apresentaram valores médios superiores aos prescritos pela NBR 6136 (1994). A variação dimensional situou-se dentro do intervalo citado por Gallegos (1989), entre 3\% a 5\%;

Na Figura 7.26, são apresentadas algumas vistas dos blocos pertencentes ao Grupo 12,0 . 

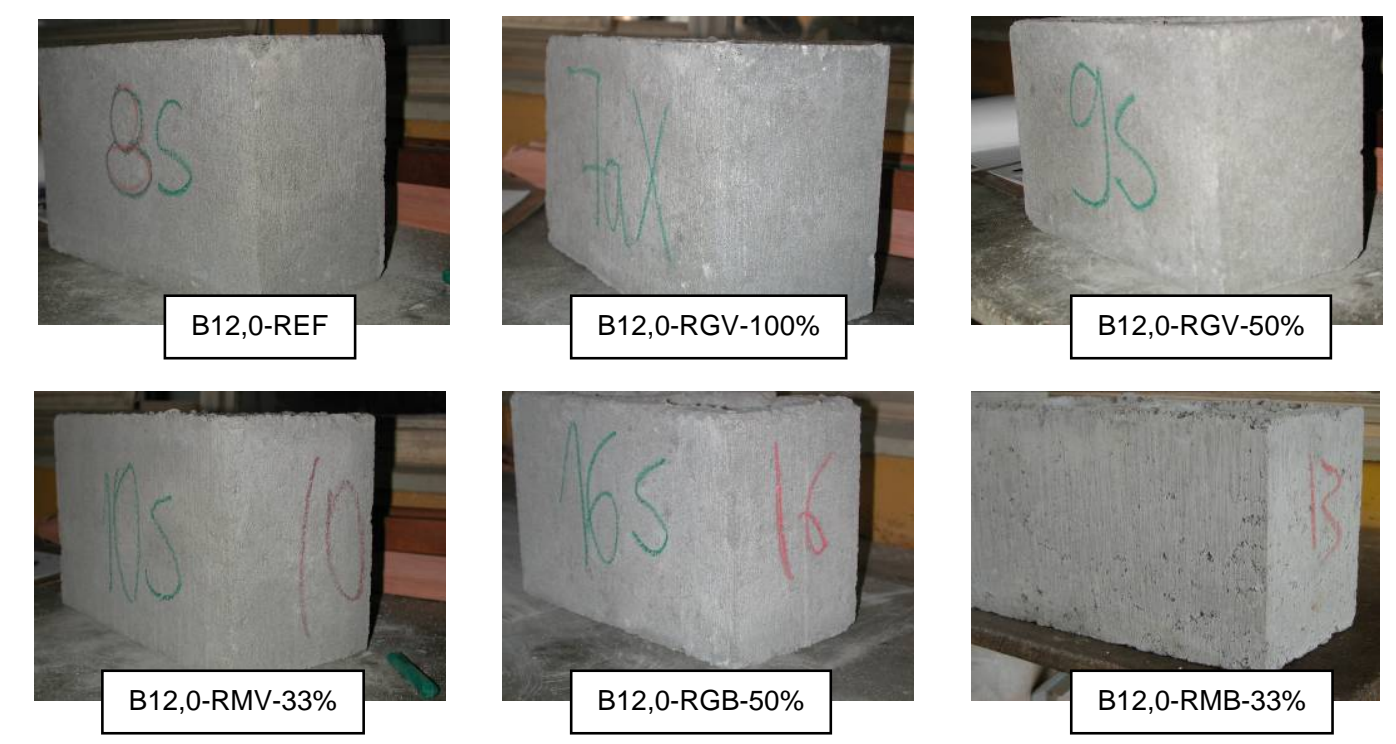

* a numeração existente deve ser desconsiderada

Figura 7.26 - Unidades do Grupo 12,0.

Nas Figuras 7.27 e 7.28, são apresentadas as texturas superficiais das unidades do Grupo 12,0.
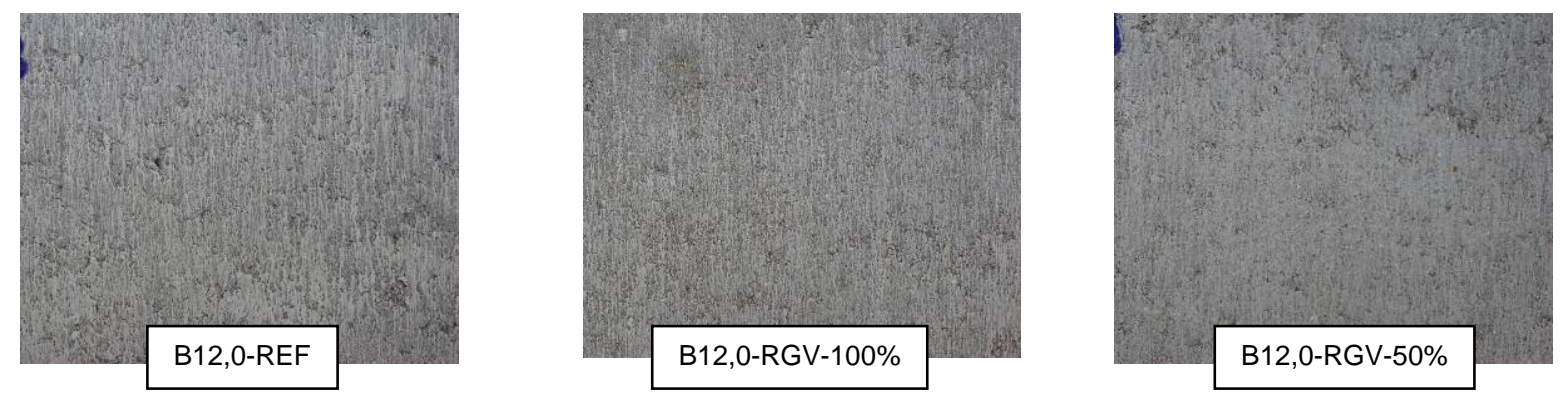

Figura 7.27 - Textura das unidades de referência e com agregados reciclados de vigota.

Analisando-se a Figura 7.27, observa-se que todas as unidades apresentaram uma textura lisa, inclusive às unidades produzidas com agregados reciclados de vigota. As dosagens do Grupo 12,0 não apresentaram problemas relacionados com a textura superficial e coesão, uma vez que, devido ao consumo elevado de cimento, a quantidade de finos foi significativa. Na produção das unidades de resistência mais elevada (acima de 10 $\mathrm{MPa}$ ), as fábricas de blocos, usualmente, elevam a porcentagem de pedrisco para até $40 \%$, em relação à quantidade total de materiais. Esse procedimento eleva a resistência das unidades e não prejudica a coesão da mistura, uma vez que a quantidade de finos é elevada. 

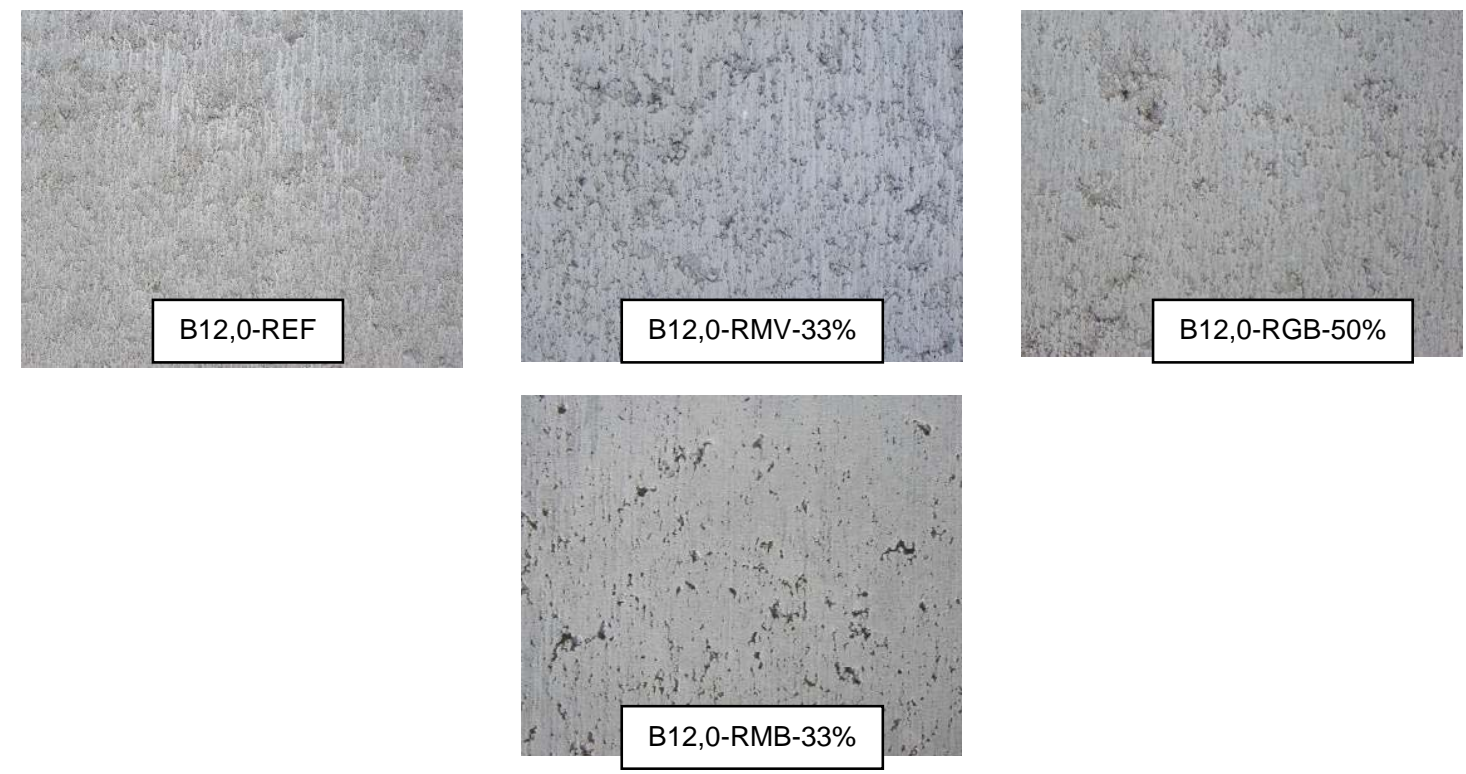

Figura 7.28 - Textura das unidades de referência e com agregados reciclados de bloco.

Conforme a Figura 7.28, nota-se que as unidades com agregados reciclados de bloco apresentaram uma textura superficial praticamente lisa, contendo apenas algumas imperfeições, em relação às unidades de referência.

\subsubsection{Absorção de água e área líquida}

Os ensaios de absorção de água e área líquida foram realizados conforme as prescrições da NBR 12118 (1992). A norma técnica NBR 6136 (1994) estabelece que a absorção de água, para blocos estruturais de concreto, deve ser menor ou igual a 10\%. Provavelmente, os blocos de concreto com agregados reciclados apresentarão maiores valores de absorção, comparativamente aos blocos de referência, devido à elevada quantidade de argamassa aderida ao agregado.

\subsection{Grupo 4,5}

Os resultados de absorção de água, bem como os valores de massa seca das unidades, encontram-se na Tabela 7.13. 
Tabela 7.13 - Absorção de água e valores de massa seca para as unidades do Grupo 4,5.

\begin{tabular}{cccccccccccc}
\hline \multirow{2}{*}{ Traços } & \multicolumn{4}{c}{ Absorção de água } & \multicolumn{5}{c}{ Massa seca (em estufa) } \\
\cline { 2 - 10 } & $\begin{array}{c}\text { Média } \\
(\%)\end{array}$ & $\begin{array}{c}\text { Máx. } \\
(\%)\end{array}$ & $\begin{array}{c}\text { Mín. } \\
(\%)\end{array}$ & $\begin{array}{c}\text { D.Padrão } \\
(\%)\end{array}$ & $\begin{array}{c}\text { C.Var. } \\
(\%)\end{array}$ & $\begin{array}{c}\text { Média } \\
(\mathbf{g})\end{array}$ & $\begin{array}{c}\text { Máx. } \\
\text { (g) }\end{array}$ & $\begin{array}{c}\text { Mín. } \\
(\mathbf{g})\end{array}$ & $\begin{array}{c}\text { D.Padrão } \\
\text { (g) }\end{array}$ & $\begin{array}{c}\text { C.Var. } \\
\text { (\%) }\end{array}$ \\
\hline B4,5-REF & $\mathbf{5 , 9 2}$ & 6,23 & 5,53 & 0,25 & 4,31 & $\mathbf{1 0 3 2 8}$ & 10554 & 10111 & 146,5 & 1,42 \\
\hline B4,5-RGV-100\% & $\mathbf{7 , 3 1}$ & 7,57 & 7,09 & 0,19 & 2,54 & $\mathbf{9 5 4 0}$ & 9724 & 9344 & 147,4 & 1,54 \\
\hline B4,5-RGV-50\% & $\mathbf{6 , 8 6}$ & 7,32 & 6,52 & 0,29 & 4,29 & $\mathbf{9 7 6 1}$ & 9847 & 9669 & 71,9 & 0,74 \\
\hline B4,5-RMV-33\% & $\mathbf{6 , 6 0}$ & 6,73 & 6,43 & 0,11 & 1,68 & $\mathbf{9 7 5 3}$ & 10151 & 9464 & 282,8 & 2,90 \\
\hline B4,5-RGB-50\% & $\mathbf{6 , 5 0}$ & 6,82 & 6,30 & 0,23 & 3,48 & $\mathbf{1 0 0 2 2}$ & 10059 & 9928 & 48,1 & 0,48 \\
\hline B4,5-RMB-33\% & $\mathbf{6 , 4 3}$ & 7,10 & 5,77 & 0,48 & 7,40 & $\mathbf{9 8 8 3}$ & 10091 & 9255 & 321,4 & 3,25 \\
\hline
\end{tabular}

Analisando-se a Tabela 7.13, nota-se que todas as unidades cumpriram com os requisitos da NBR 6136 (1994), com relação à absorção máxima de água; tal comportamento já havia sido previsto com os corpos-de-prova cilíndricos.

A área líquida para cada um dos traços avaliados, bem como a relação entre área líquida e área bruta é apresentada na Tabela 7.14.

Tabela 7.14 - Área líquida e relação entre área líquida e bruta para as unidades do Grupo 4,5 .

\begin{tabular}{ccccccc}
\hline $\begin{array}{c}\text { Área líquida } \\
\left(\mathbf{c m}^{2}\right)\end{array}$ & $\mathbf{B 4 , 5 - R E F}$ & $\begin{array}{c}\text { B4,5-RGV- } \\
\mathbf{1 0 0 \%}\end{array}$ & $\begin{array}{c}\text { B4,5-RGV- } \\
\mathbf{5 0} \%\end{array}$ & $\begin{array}{c}\text { B4,5-RMV- } \\
\mathbf{3 3 \%}\end{array}$ & $\begin{array}{c}\text { B4,5-RGB- } \\
\mathbf{5 0} \%\end{array}$ & $\begin{array}{c}\text { B4,5-RMB- } \\
\mathbf{3 3 \%}\end{array}$ \\
\hline Média & $\mathbf{2 3 8 , 9}$ & $\mathbf{2 3 8 , 7}$ & $\mathbf{2 3 9 , 3}$ & $\mathbf{2 3 8 , 0}$ & $\mathbf{2 4 0 , 0}$ & $\mathbf{2 4 1 , 6}$ \\
\hline Máximo & 242,5 & 242,3 & 242,3 & 243,9 & 242,3 & 248,2 \\
\hline Mínimo & 233,5 & 234,9 & 235,3 & 232,8 & 238,1 & 233,7 \\
\hline D.Padrão $\left(\mathbf{c m}^{2}\right)$ & 3,15 & 2,64 & 2,77 & 4,71 & 1,71 & 5,48 \\
\hline C.Var. (\%) & 1,32 & $\mathbf{1 , 1 1}$ & $\mathbf{1 , 1 6}$ & $\mathbf{1 , 9 8}$ & 0,71 & 2,27 \\
\hline $\begin{array}{c}\text { Relação área } \\
\text { líquida/bruta }\end{array}$ & $\mathbf{0 , 5 8 8}$ & $\mathbf{0 , 5 8 8}$ & $\mathbf{0 , 5 8 9}$ & $\mathbf{0 , 5 8 6}$ & $\mathbf{0 , 5 9 1}$ & $\mathbf{0 , 5 9 5}$ \\
\hline
\end{tabular}

Analisando-se a Tabela 7.14, nota-se que todas as unidades apresentaram valores de área líquida e relações entre área líquida e bruta praticamente iguais, uma vez que foram produzidas, em seqüência, na mesma máquina e utilizando-se o mesmo molde. De maneira geral, a relação entre área líquida e bruta foi de 0,590.

\subsection{Grupo 8,0}

Os resultados da propriedade de absorção de água, bem como os valores de massa seca das unidades encontram-se na Tabela 7.15. 
Tabela 7.15 - Absorção de água e valores de massa seca para as unidades do Grupo 8,0.

\begin{tabular}{ccccccccccc}
\hline \multirow{2}{*}{ Traços } & \multicolumn{4}{c}{ Absorção de água } & \multicolumn{4}{c}{ Massa seca (em estufa) } \\
\cline { 2 - 11 } & $\begin{array}{c}\text { Média } \\
(\%)\end{array}$ & $\begin{array}{c}\text { Máx. } \\
(\%)\end{array}$ & $\begin{array}{c}\text { Mín. } \\
(\%)\end{array}$ & $\begin{array}{c}\text { D.Padrão } \\
(\%)\end{array}$ & $\begin{array}{c}\text { C.Var. } \\
(\%)\end{array}$ & $\begin{array}{c}\text { Média } \\
(\mathbf{g})\end{array}$ & $\begin{array}{c}\text { Máx. } \\
(\mathbf{g})\end{array}$ & $\begin{array}{c}\text { Mín. } \\
(\mathbf{g})\end{array}$ & $\begin{array}{c}\text { D.Padrão } \\
(\mathbf{g})\end{array}$ & $\begin{array}{c}\text { C.Var. } \\
(\%)\end{array}$ \\
\hline B 8,0-REF & $\mathbf{6 , 1 0}$ & 6,79 & 5,86 & 0,35 & 5,69 & $\mathbf{9 9 6 9}$ & 10193 & 9780 & 146 & 1,47 \\
\hline B 8,0-RG V-100\% & $\mathbf{7 , 0 4}$ & 7,23 & 6,71 & 0,22 & 3,11 & $\mathbf{9 4 5 4}$ & 9636 & 9308 & 105 & 1,11 \\
\hline B 8,0-RG V-50\% & $\mathbf{6 , 8 9}$ & 7,16 & 6,67 & 0,17 & 2,44 & $\mathbf{9 7 8 1}$ & 9863 & 9650 & 82 & 0,84 \\
\hline B 8,0-RM V-33\% & $\mathbf{6 , 3 0}$ & 6,59 & 6,07 & 0,21 & 3,32 & $\mathbf{9 6 4 9}$ & 9946 & 9403 & 229 & 2,37 \\
\hline B 8,0-RG B-50\% & $\mathbf{5 , 8 9}$ & 6,32 & 5,40 & 0,34 & 5,76 & $\mathbf{9 9 9 6}$ & 10164 & 9867 & 101 & 1,01 \\
\hline B 8,0-RM B-33\% & $\mathbf{6 , 0 8}$ & 6,35 & 5,73 & 0,23 & 3,77 & $\mathbf{9 9 6 5}$ & 10126 & 9573 & 208 \\
\hline
\end{tabular}

Analisando-se a Tabela 7.15, nota-se que todas as unidades cumpriram com os requisitos da NBR 6136 (1994), com relação à absorção máxima de água; tal comportamento já havia sido previsto através da correlação com os corpos-de-prova. O valor da absorção do traço de referência foi aproximadamente três porcento maior quando comparado com o traço de referência do Grupo 4,5 e também superior ao valor obtido para algumas unidades com agregados reciclados (B8,0-RGB-50\% e B8,0-RMB-33\%); esse comportamento deve-se aos seguintes motivos: a) apesar do maior consumo de cimento, as unidades B8,0-REF apresentaram um decréscimo de 3,5\% na massa seca, comparativamente aos blocos do traço B4,5-REF. Dessa maneira, pode-se aferir que a umidade utilizada na produção dessas unidades ficou abaixo da umidade ótima, resultando em menores massas para os blocos. Segundo Frasson Junior (2000), uma variação da umidade pode interferir de maneira significativa na massa dos blocos e, consequentemente, na sua resistência; b) as unidades dos traços com agregados reciclados de bloco foram produzidas com maiores tempos de alimentação e compressão quando comparadas com os demais traços.

A área líquida para cada um dos traços avaliados, bem como a relação entre área líquida e área bruta é apresentada na Tabela 7.16.

Tabela 7.16 - Área líquida e relação entre área líquida e bruta para as unidades do Grupo 8,0 .

\begin{tabular}{|c|c|c|c|c|c|c|}
\hline $\begin{array}{l}\text { Área líquida } \\
\left(\mathrm{cm}^{2}\right)\end{array}$ & B $8,0-R$ E F & $\begin{array}{c}\text { B 8,0-R G V - } \\
100 \%\end{array}$ & $\begin{array}{c}\text { B 8,0-R G V - } \\
50 \%\end{array}$ & $\begin{array}{c}\text { B 8,0-R M V - } \\
33 \%\end{array}$ & $\begin{array}{c}\text { B 8,0-R G B - } \\
50 \%\end{array}$ & $\begin{array}{c}\text { B 8,0-R M B - } \\
33 \%\end{array}$ \\
\hline Máximo & 239,9 & 238,2 & 240,5 & 238,7 & 239,6 & 245,4 \\
\hline Mínim o & 233,4 & 232,0 & 236,1 & 230,8 & 234,8 & 234,7 \\
\hline D.Padrão $\left(\mathrm{cm}^{2}\right)$ & 2,20 & 2,37 & 1,73 & 2,91 & 1,64 & 3,48 \\
\hline $\begin{array}{l}\text { Relação área } \\
\text { líquida/bruta }\end{array}$ & 0,583 & 0,580 & 0,587 & 0,578 & 0,585 & 0,594 \\
\hline
\end{tabular}




\subsection{Grupo 12,0}

Os resultados da propriedade de absorção de água, bem como os valores de massa seca das unidades encontram-se na Tabela 7.17.

Tabela 7.17 - Absorção de água e valores de massa seca para as unidades do Grupo 12,0.

\begin{tabular}{|c|c|c|c|c|c|c|c|c|c|c|}
\hline \multirow{2}{*}{ Traços } & \multicolumn{5}{|c|}{ Absorção de água } & \multicolumn{5}{|c|}{ Massa seca (em estufa) } \\
\hline & $\begin{array}{c}\text { Média } \\
(\%)\end{array}$ & $\begin{array}{c}\text { Máx. } \\
(\%)\end{array}$ & $\begin{array}{c}\text { Mín. } \\
(\%)\end{array}$ & $\begin{array}{c}\text { D.Padrão } \\
(\%)\end{array}$ & $\begin{array}{c}\text { C.Var. } \\
(\%)\end{array}$ & $\begin{array}{l}\text { Média } \\
\text { (g) }\end{array}$ & $\begin{array}{c}\text { Máx. } \\
\text { (g) }\end{array}$ & $\begin{array}{c}\text { Mín. } \\
\text { (g) }\end{array}$ & $\begin{array}{c}\text { D.Padrão } \\
\text { (g) }\end{array}$ & $\begin{array}{c}\text { C.Var. } \\
(\%)\end{array}$ \\
\hline B 12,0-REF & 6,35 & 6,97 & 5,86 & 0,42 & 6,60 & 9726 & 9999 & 9604 & 179 & 1,84 \\
\hline B 12,0-RGV-100\% & 7,34 & 7,70 & 7,07 & 0,22 & 3,01 & 9463 & 9584 & 9282 & 110 & 1,17 \\
\hline B 12,0-RG V-50\% & 6,65 & 7,19 & 6,08 & 0,48 & 7,27 & 9572 & 9662 & 9422 & 99 & 1,03 \\
\hline B 12,0-RM V-33\% & 6,18 & 6,54 & 5,84 & 0,34 & 5,55 & 9638 & 9960 & 9442 & 198 & 2,06 \\
\hline B12,0-RG B-50\% & 5,85 & 6,03 & 5,50 & 0,19 & 3,17 & 9805 & 10012 & 9605 & 131 & 1,33 \\
\hline B 12,0-RM B-33\% & 5,19 & 5,30 & 5,01 & 0,13 & 2,51 & 10285 & 10485 & 9955 & 215 & 2,09 \\
\hline
\end{tabular}

Analisando-se a Tabela 7.17, observa-se que todas as unidades cumpriram com os requisitos da NBR 6136 (1994), com relação à absorção máxima de água. Apesar do maior consumo de cimento, os valores de absorção dos traços B12,0-REF e B12,0-RGV-100\% foram superiores quando comparados com os valores obtidos para os traços do Grupo 8,0; além disso, a absorção dos traços com agregados reciclados de bloco foram menores comparativamente as unidades do traço B12,0-REF. Podem ser enumeradas as seguintes justificativas para esses resultados:

- As unidades do traço B12,0-REF apresentaram um decréscimo de 2,4\% na massa seca (cerca de $240 \mathrm{~g}$ ), comparativamente aos blocos do traço B8,0-REF. Provavelmente, a manutenção dos tempos de produção, que teoricamente deveriam ser aumentados conforme Frasson Junior (2000), e a definição da umidade da mistura abaixo da ótima podem ser enumeradas como algumas das justificativas para o decréscimo de massa e, consequentemente, aumento dos valores de absorção. Essas justificativas também explicam os resultados obtidos para as unidades do traço B12,0-RGV-100\%.

- As unidades com agregados reciclados de bloco apresentaram menores valores de absorção, comparativamente as demais dosagens, devido basicamente aos maiores tempos de produção adotados na fabricação dessas unidades. Segundo Frasson Junior (2000), para misturas com maior consumo de cimento, há necessidade de aumentar os tempos de alimentação e vibração das vibro-prensas, pois misturas ricas em finos apresentam grande dificuldade para alimentar as fôrmas. 
A área líquida para cada um dos traços avaliados, bem como a relação entre área líquida e área bruta é apresentada na Tabela 7.18.

Tabela 7.18 - Área líquida e relação entre área líquida e bruta para as unidades do Grupo 12,0 .

\begin{tabular}{ccccccc}
\hline $\begin{array}{c}\text { Área líquida } \\
\left(\mathbf{c m}^{2}\right)\end{array}$ & $\mathbf{B 1 2 , 0 - R E F}$ & $\begin{array}{c}\text { B12,0-RGV- } \\
\mathbf{1 0 0} \%\end{array}$ & $\begin{array}{c}\text { B12,0-RGV- } \\
\mathbf{5 0} \%\end{array}$ & $\begin{array}{c}\text { B12,0-RMV- } \\
\mathbf{3 3 \%}\end{array}$ & $\begin{array}{c}\text { B12,0-RGB- } \\
\mathbf{5 0} \%\end{array}$ & $\begin{array}{c}\text { B12,0-RMB- } \\
\mathbf{3 3 \%}\end{array}$ \\
\hline Média & $\mathbf{2 3 4 , 6}$ & $\mathbf{2 3 5 , 5}$ & $\mathbf{2 3 5 , 1}$ & $\mathbf{2 3 1 , 4}$ & $\mathbf{2 3 4 , 2}$ & $\mathbf{2 4 1 , 6}$ \\
\hline Máximo & 238,5 & 237,4 & 236,3 & 234,5 & 236,4 & 244,9 \\
\hline Mínimo & 232,5 & 233,7 & 234,5 & 230,3 & 229,7 & 236,8 \\
\hline D.Padrão (cm $\left.{ }^{2}\right)$ & 2,51 & 1,41 & 0,67 & 1,68 & 2,39 & 3,69 \\
\hline C.Var. (\%) & 1,07 & 0,60 & 0,29 & 0,72 & 1,02 & 1,53 \\
\hline $\begin{array}{c}\text { Relação área } \\
\text { líquida/bruta }\end{array}$ & $\mathbf{0 , 5 7 8}$ & $\mathbf{0 , 5 8 0}$ & $\mathbf{0 , 5 7 9}$ & $\mathbf{0 , 5 7 0}$ & $\mathbf{0 , 5 7 7}$ & $\mathbf{0 , 5 9 5}$ \\
\hline
\end{tabular}

\subsection{Análise dos resultados - absorção de água e área líquida}

Para facilitar a análise dos resultados de absorção de água e área líquida é apresentada, na Tabela 7.19, o teste estatístico de Análise de Variância.

Tabela 7.19 - Teste ANOVA para valores de absorção de água e área líquida dos blocos de concreto.

\begin{tabular}{|c|c|c|c|c|c|c|c|c|}
\hline & & & \multicolumn{6}{|c|}{ Propriedades } \\
\hline & & & Grupos & & Grupos $x$ & Grupos & & Grupos $x$ \\
\hline & & & 4,$5 ; 8,0 ; 12,0$ & Ilaçu & Traços & 4,$5 ; 8,0 ; 12,0$ & II & Traços \\
\hline \multirow{6}{*}{ 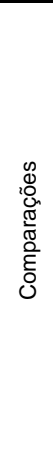 } & \multirow{2}{*}{$\begin{array}{l}\text { Comparações com } \\
\text { o traço de } \\
\text { referência }\end{array}$} & REF $\times$ RECICLADOS ${ }^{1}$ & $\mathrm{~S}\left(\mathrm{~F}_{\mathrm{O}}=14,4\right)$ & $S(60,1)$ & $S(7,8)$ & $\begin{array}{c}\mathrm{S} \\
\left(\mathrm{F}_{0}=18,0\right)\end{array}$ & $\mathrm{S}(10,8)$ & - \\
\hline & & $\begin{array}{c}\text { REF x RGB- } 50 \% \times \\
\text { RMB- } 33 \%\end{array}$ & $S(24,1)$ & - & $S(9,7)$ & $S(5,4)$ & $S(12,0)$ & - \\
\hline & \multirow{3}{*}{$\begin{array}{l}\text { Diferentes } \\
\text { porcentagens do } \\
\text { mesmo resíduo }\end{array}$} & $\begin{array}{c}\text { RGV-100\% } \times \text { RGV-50\% } \\
\times \text { RMV-33\% }\end{array}$ & - & $S(46,4)$ & - & $S(15,0)$ & $S(6,1)$ & - \\
\hline & & RGV-100\% x RGV-50\% & - & $S(20,8)$ & - & $S(9,7)$ & - & - \\
\hline & & RGV-50\% x RMV-33\% & $S(3,5)$ & $S(19,6)$ & - & $\mathrm{S}(11,9)$ & $S(10,5)$ & - \\
\hline & $\begin{array}{l}\text { Diferentes resíduos } \\
\text { (\% similares de } \\
\text { substituição) }\end{array}$ & RMV-33\% x RMB-33\% & $S(27,1)$ & $\mathrm{S}(24,8)$ & $\mathrm{S}(8,1)$ & - & $S(27,4)$ & - \\
\hline
\end{tabular}

Analisando-se os resultados da Tabela 7.19, são estabelecidos os seguintes comentários: 
- Com relação à variável "grupo", pode-se afirmar que, para grande parte das comparações efetuadas, houve influência significativa da classe de resistência sobre a absorção de água. Nesse caso, os menores valores médios de absorção foram obtidos para as unidades do Grupo 12,0 (maior consumo de cimento) e os maiores valores médios para as unidades do Grupo 4,5 (menor consumo de cimento). Para a propriedade de área líquida, pode-se dizer que a variável "grupo" afetou essa propriedade para grande parte das comparações analisadas; nesse caso, os maiores valores médios de área líquida foram obtidos para as unidades do Grupo 4,5 e os menores valores para as unidades do Grupo 12,0. Provavelmente, isso pode ser explicado por variações na umidade da mistura durante a produção.

- Com relação à variável "traço", pode-se dizer que os valores de absorção para os traços de referência foram similares aos obtidos para as dosagens com agregados reciclados de bloco. Esse fato pode ser explicado pelos maiores tempos de produção utilizado na produção dessas unidades comparativamente aos blocos de referência. Por outro lado, as unidades com agregados reciclados de vigota apresentaram valores médios de absorção significativamente maiores devido à camada de argamassa que se encontra aderida ao agregado comparativamente aos valores das unidades de referência. Para as comparações realizadas dois a dois, pode-se afirmar (5\% de significância) que os menores valores médios de absorção foram obtidos para os seguintes traços: RGV-50\% (RGV-50\% x RGV-100\%), RMV-33\% (RGV-50\% x RMV-33\%), RGB-50\% (RGV-50\% x RGB-50\%) e RMB-33\% (RMV-33\% x RMB$33 \%)$.

- Com relação à área líquida, nota-se que a variável "traço" teve influência significativa para grande parte das comparações efetuadas. De certa forma, os maiores valores médios de área líquida foram obtidos para as dosagens com agregados graúdos reciclados de vigota (RGV-50\%) e agregados miúdos reciclados de bloco (RMB-33\%) comparativamente às demais dosagens.

- Considerando-se a análise de $2^{\mathrm{a}}$ ordem (variáveis analisadas duas a duas), observou-se uma influência significativa dos parâmetros (grupos e traços), para grande parte das comparações efetuadas, sobre a propriedade de absorção de água. De maneira geral, afirma-se, nos casos de influência significativa, que para um determinado traço pode-se ter uma determinada classe de resistência que conduzirá aos menores valores médios de absorção; por outro lado, para outro traço pode não ser essa mesma classe de resistência que conduzirá aos menores valores médios de absorção. Provavelmente, variações na umidade da mistura durante a produção e a 
manutenção dos tempos de vibro-prensagem para os traços mais ricos podem ter sido responsáveis por esse comportamento.

- Com relação às comparações envolvendo dosagens com agregados reciclados de bloco, tais como, RGB-50\% x RMB-33\% e REF x RGB-50\% x RMB-33\%, é provável que para um determinado grupo (4,5, por ex.) pode-se ter um determinado traço (REF) que levará aos menores valores médios de absorção; mas, por outro lado, para outro grupo (12,0, por ex.), os menores valores médios de absorção podem ser obtidos para a dosagem com agregados miúdos reciclados de bloco (RMB-33\%).

\subsubsection{Massa específica e índice de vazios}

\subsection{Grupo 4,5}

Na Tabela 7.20, encontram-se os resultados para a propriedade de massa específica para as unidades do Grupo 4,5.

Tabela 7.20 - Massa específica seca e saturada superfície seca para as unidades do Grupo 4,5 .

\begin{tabular}{|c|c|c|c|c|c|c|c|c|c|c|c|c|}
\hline \multirow{2}{*}{$\begin{array}{c}\text { Massa } \\
\text { específica } \\
\left(\mathrm{kg} / \mathrm{dm}^{3}\right)\end{array}$} & \multicolumn{2}{|c|}{ B4,5-REF } & \multicolumn{2}{|c|}{ B4,5-RGV-100\% } & \multicolumn{2}{|c|}{ B4,5-RGV-50\% } & \multicolumn{2}{|c|}{ B4,5-RMV-33\% } & \multicolumn{2}{|c|}{ B4,5-RGB-50\% } & \multicolumn{2}{|c|}{ B4,5-RMB-33\% } \\
\hline & $d_{s}$ & $d_{\text {ssd }}$ & $\mathbf{d}_{\mathrm{s}}$ & $d_{\text {ssd }}$ & $\mathbf{d}_{\mathrm{s}}$ & $d_{\text {ssd }}$ & $d_{s}$ & $d_{\text {ssd }}$ & $d_{s}$ & $d_{\text {ssd }}$ & $d_{s}$ & $d_{\text {ssd }}$ \\
\hline Média & 2,275 & 2,410 & 2,104 & 2,257 & 2,147 & 2,294 & 2,156 & 2,299 & 2,197 & 2,340 & 2,153 & 2,291 \\
\hline Máximo & 2,298 & 2,425 & 2,124 & 2,275 & 2,170 & 2,314 & 2,191 & 2,331 & 2,215 & 2,355 & 2,185 & 2,318 \\
\hline Mínimo & 2,256 & 2,397 & 2,083 & 2,240 & 2,114 & 2,269 & 2,136 & 2,279 & 2,181 & 2,329 & 2,084 & 2,232 \\
\hline $\begin{array}{c}\text { D.Padrão } \\
\left(\mathrm{cm}^{2}\right)\end{array}$ & 0,017 & 0,012 & 0,014 & 0,013 & 0,020 & 0,016 & 0,022 & 0,021 & 0,015 & 0,012 & 0,038 & 0,031 \\
\hline C.Var. (\%) & 0,75 & 0,51 & 0,68 & 0,56 & 0,95 & 0,69 & 1,00 & 0,90 & 0,68 & 0,51 & 1,76 & 1,37 \\
\hline
\end{tabular}

$d_{s}-$ massa específica seca

$d_{\text {ssd }}-$ massa específica saturada superfície seca

$\mathrm{Na}$ Tabela 7.21, encontram-se os resultados para a propriedade de índice de vazios.

Tabela 7.21 - Índice de vazios para as unidades do Grupo 4,5.

\begin{tabular}{ccccccc}
\hline $\begin{array}{c}\text { Indice de } \\
\text { Vazios (\%) }\end{array}$ & B4,5-REF & $\begin{array}{c}\text { B4,5-RGV- } \\
\mathbf{1 0 0} \%\end{array}$ & $\begin{array}{c}\text { B4,5-RGV- } \\
\mathbf{5 0} \%\end{array}$ & $\begin{array}{c}\text { B4,5-RMV- } \\
\mathbf{3 3} \%\end{array}$ & $\begin{array}{c}\text { B4,5-RGB- } \\
\mathbf{5 0 \%}\end{array}$ & $\begin{array}{c}\text { B4,5-RMB- } \\
\mathbf{3 3 \%}\end{array}$ \\
\hline Média & $\mathbf{1 3 , 4 7}$ & $\mathbf{1 5 , 3 7}$ & $\mathbf{1 4 , 7 2}$ & $\mathbf{1 4 , 2 4}$ & $\mathbf{1 4 , 2 8}$ & $\mathbf{1 3 , 8 2}$ \\
\hline Máximo & 14,05 & 15,77 & 15,46 & 14,38 & 14,92 & 14,80 \\
\hline Mínimo & 12,71 & 14,96 & 14,09 & 14,09 & 13,91 & 12,61 \\
\hline D.Padrão (\%) & 0,48 & 0,32 & 0,49 & 0,12 & 0,42 & 0,80 \\
\hline C.Var. (\%) & 3,59 & 2,09 & 3,36 & 0,83 & 2,92 & 5,77 \\
\hline
\end{tabular}


Levy (2001) elaborou uma proposta para classificação dos concretos de acordo com a porosidade e a absorção de água. Segundo essa classificação, os concretos duráveis devem apresentar porosidade inferior a $10 \%$, os concretos normais devem possuir porosidade inferior a $15 \%$ e, para valores acima de $15 \%$, os concretos são classificados como deficientes. De acordo com os resultados obtidos, apenas as unidades do traço B4,5RGV-100\% apresentaram valores de índice de vazios ligeiramente superiores àquele recomendado para concretos normais.

\subsection{Grupo 8,0}

$\mathrm{Na}$ Tabela 7.22, encontram-se os resultados para a propriedade de massa específica.

Tabela 7.22 - Massa específica seca e saturada superfície seca para as unidades do Grupo 8,0 .

\begin{tabular}{|c|c|c|c|c|c|c|c|c|c|c|c|c|}
\hline \multirow{2}{*}{$\begin{array}{c}\text { Massa } \\
\text { específica } \\
\left(\mathrm{kg} / \mathrm{dm}^{3}\right)\end{array}$} & \multicolumn{2}{|c|}{ B8,0-REF } & \multicolumn{2}{|c|}{ B8,0-RGV-100\% } & \multicolumn{2}{|c|}{ B8,0-RGV-50\% } & \multicolumn{2}{|c|}{ B8,0-RMV-33\% } & \multicolumn{2}{|c|}{ B8,0-RGB-50\% } & \multicolumn{2}{|c|}{ B8,0-RMB-33\% } \\
\hline & $\mathbf{d}_{\mathrm{s}}$ & $d_{\text {ssd }}$ & $d_{s}$ & $d_{\text {ssd }}$ & $d_{s}$ & $\mathbf{d}_{\mathrm{ssd}}$ & $d_{s}$ & $d_{s s d}$ & $d_{s}$ & $d_{s s d}$ & $d_{s}$ & $d_{s s d}$ \\
\hline Média & 2,216 & 2,351 & 2,113 & 2,262 & 2,159 & 2,308 & 2,165 & 2,301 & 2,216 & 2,346 & 2,176 & 2,309 \\
\hline Máximo & 2,236 & 2,369 & 2,130 & 2,278 & 2,170 & 2,317 & 2,193 & 2,328 & 2,245 & 2,366 & 2,212 & 2,339 \\
\hline Mínimo & 2,174 & 2,321 & 2,101 & 2,253 & 2,147 & 2,300 & 2,134 & 2,273 & 2,185 & 2,323 & 2,147 & 2,278 \\
\hline $\begin{array}{c}\text { D.Padrão } \\
\left(\mathrm{cm}^{2}\right)\end{array}$ & 0,022 & 0,017 & 0,014 & 0,011 & 0,009 & 0,006 & 0,025 & 0,023 & 0,023 & 0,018 & 0,023 & 0,021 \\
\hline C.Var. (\%) & 1,02 & 0,73 & 0,64 & 0,48 & 0,40 & 0,28 & 1,17 & 0,98 & 1,05 & 0,75 & 1,08 & 0,91 \\
\hline
\end{tabular}

Na Tabela 7.23, encontram-se os resultados para a propriedade de índice de vazios.

Tabela 7.23 - Índice de vazios para as unidades do Grupo 8,0.

\begin{tabular}{ccccccc}
\hline $\begin{array}{c}\text { Indice de } \\
\text { Vazios (\%) }\end{array}$ & $\mathbf{B 8 , 0 - R E F}$ & $\begin{array}{c}\mathbf{B 8 , 0 - R G V -} \\
\mathbf{1 0 0} \%\end{array}$ & $\begin{array}{c}\text { B8,0-RGV- } \\
\mathbf{5 0} \%\end{array}$ & $\begin{array}{c}\text { B8,0-RMV- } \\
\mathbf{3 3} \%\end{array}$ & $\begin{array}{c}\text { B8,0-RGB- } \\
\mathbf{5 0} \%\end{array}$ & $\begin{array}{c}\text { B8,0-RMB- } \\
\mathbf{3 3 \%} \mathbf{0}\end{array}$ \\
\hline Média & $\mathbf{1 3 , 5 1}$ & $\mathbf{1 4 , 8 7}$ & $\mathbf{1 4 , 8 7}$ & $\mathbf{1 3 , 6 4}$ & $\mathbf{1 3 , 0 4}$ & $\mathbf{1 3 , 2 3}$ \\
\hline Máximo & 14,76 & 15,19 & 15,36 & 14,07 & 13,82 & 13,68 \\
\hline Mínimo & 13,06 & 14,29 & 14,45 & 13,26 & 12,12 & 12,67 \\
\hline D.Padrão (\%) & 0,63 & 0,39 & 0,31 & 0,30 & 0,62 & 0,40 \\
\hline C.Var. (\%) & 4,70 & 2,59 & 2,09 & 2,22 & 4,75 & 2,99 \\
\hline
\end{tabular}

\subsection{Grupo 12,0}

$\mathrm{Na}$ Tabela 7.24, encontram-se os resultados para a propriedade de massa específica. 
Tabela 7.24 - Massa específica seca e saturada superfície seca para as unidades do Grupo 12,0 .

\begin{tabular}{|c|c|c|c|c|c|c|c|c|c|c|c|c|}
\hline \multirow{2}{*}{$\begin{array}{c}\text { Massa } \\
\text { especifica } \\
\left(\mathrm{kg} / \mathrm{dm}^{3}\right)\end{array}$} & \multicolumn{2}{|c|}{ B12,0-REF } & \multicolumn{2}{|c|}{$\begin{array}{c}\text { B12,0-RGV- } \\
100 \%\end{array}$} & \multicolumn{2}{|c|}{$\begin{array}{c}\text { B12,0-RGV- } \\
50 \%\end{array}$} & \multicolumn{2}{|c|}{$\begin{array}{c}\text { B12,0-RMV- } \\
33 \%\end{array}$} & \multicolumn{2}{|c|}{$\begin{array}{c}\text { B12,0-RGB- } \\
50 \%\end{array}$} & \multicolumn{2}{|c|}{$\begin{array}{c}\text { B12,0-RMB- } \\
33 \%\end{array}$} \\
\hline & $d_{s}$ & $d_{\text {ssd }}$ & $d_{s}$ & $d_{\text {ssd }}$ & $d_{s}$ & $\mathbf{d}_{\mathrm{ssd}}$ & $d_{s}$ & $d_{s s d}$ & $d_{s}$ & $d_{s s d}$ & $d_{s}$ & $d_{\text {ssd }}$ \\
\hline Média & 2,182 & 2,321 & 2,115 & 2,270 & 2,143 & 2,285 & 2,192 & 2,327 & 2,204 & 2,333 & 2,240 & 2,357 \\
\hline Máximo & 2,207 & 2,336 & 2,130 & 2,282 & 2,168 & 2,305 & 2,236 & 2,364 & 2,229 & 2,352 & 2,253 & 2,372 \\
\hline Mínimo & 2,157 & 2,308 & 2,089 & 2,250 & 2,112 & 2,264 & 2,158 & 2,298 & 2,193 & 2,321 & 2,212 & 2,330 \\
\hline $\begin{array}{l}\text { D.Padrão } \\
\left(\mathrm{cm}^{2}\right)\end{array}$ & 0,019 & 0,012 & 0,015 & 0,012 & 0,022 & 0,014 & 0,030 & 0,025 & 0,014 & 0,012 & 0,015 & 0,012 \\
\hline C.Var. (\%) & 0,87 & 0,50 & 0,69 & 0,53 & 1,04 & 0,63 & 1,38 & 1,07 & 0,62 & 0,51 & 0,66 & 0,51 \\
\hline
\end{tabular}

$\mathrm{Na}$ Tabela 7.25, encontram-se os resultados para a propriedade de índice de vazios.

Tabela 7.25 - Índice de vazios para as unidades do Grupo 12,0.

\begin{tabular}{|c|c|c|c|c|c|c|}
\hline $\begin{array}{c}\text { Indice de } \\
\text { Vazios (\%) } \\
\end{array}$ & B 12,0-REF & $\begin{array}{c}\text { B 12,0 -RG V - } \\
100 \%\end{array}$ & $\begin{array}{c}\text { B12,0-RG V- } \\
50 \% \\
\end{array}$ & $\begin{array}{c}\text { B 12,0-R M V - } \\
33 \% \\
\end{array}$ & $\begin{array}{c}\text { B 12,0-RG B - } \\
50 \% \\
\end{array}$ & $\begin{array}{c}\text { B 12,0-RM B - } \\
33 \% \\
\end{array}$ \\
\hline Média & 13,84 & 15,51 & 14,23 & 13,53 & 12,88 & 11,62 \\
\hline Máximo & 15,03 & 16,09 & 15,35 & 14,16 & 13,32 & 11,87 \\
\hline Mínimo & 12,93 & 15,06 & 13,13 & 12,79 & 12,27 & 11,21 \\
\hline D.Padrão (\%) & 0,80 & 0,38 & 0,89 & 0,57 & 0,36 & 0,28 \\
\hline C.Var. (\%) & 5,78 & 2,46 & 6,28 & 4,24 & 2,79 & 2,41 \\
\hline
\end{tabular}

De acordo com os resultados obtidos, apenas as unidades do traço B12,0-RGV$100 \%$ apresentaram valores de índice de vazios ligeiramente superiores ao recomendado para concretos normais, conforme citado por Levy (2001).

\subsection{Análise dos resultados - massa específica e índice de vazios}

Para facilitar a análise dos resultados de massa específica e índice de vazios é apresentada, na Tabela 7.26, o teste estatístico de Análise de Variância. 
Tabela 7.26 - Teste ANOVA para valores de massa específica e índice de vazios.

\begin{tabular}{|c|c|c|c|c|c|c|c|c|}
\hline & & & \multicolumn{6}{|c|}{ Propriedades } \\
\hline & & & \multicolumn{3}{|c|}{ Massa específica seca } & \multicolumn{3}{|c|}{ Índice de vazios } \\
\hline & & & Grupos & & & Grupos & & \\
\hline & & & 4,$5 ; 8,0 ; 12,0$ & II & Traços & 4,$5 ; 8,0 ; 12,0$ & IIŢ̧⿻ి & Traços \\
\hline \multirow{9}{*}{ 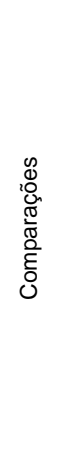 } & \multirow{3}{*}{$\begin{array}{l}\text { Comparações } \\
\text { com o traço de } \\
\text { referência }\end{array}$} & REF x RECICLADOS ${ }^{1}$ & - & $S\left(F_{\circ}=68,8\right)$ & $S(12,9)$ & $S(17,5)$ & $S(49,7)$ & $S(6,8)$ \\
\hline & & $\begin{array}{c}\text { REF } \times \text { RGV-100\% } \times \\
\text { RGV-50\% } \times \text { RMV-33\% }\end{array}$ & - & $\mathrm{S}(102,2)$ & $S(12,6)$ & - & $\mathrm{S}(38,3)$ & $S(2,6)$ \\
\hline & & $\begin{array}{c}\text { REF } \times \text { RGB- } 50 \% \times \\
\text { RMB-33\% }\end{array}$ & - & $\mathrm{S}(11,3)$ & $\mathrm{S}(27,1)$ & $S(16,5)$ & $\mathrm{S}(7,8)$ & \\
\hline & \multirow{4}{*}{$\begin{array}{l}\text { Diferentes } \\
\text { porcentagens do } \\
\text { mesmo resíduo }\end{array}$} & $\begin{array}{c}\text { RGV-100\% } \times \text { RGV-50\% } \\
\times \text { RMV-33\% }\end{array}$ & - & $S(41,9)$ & - & - & $S(43,2)$ & $S(10,1)$ \\
\hline & & RGV-100\% x RGV-50\% & - & $S(51,4)$ & - & - & $S(14,6)$ & $S(4,8)$ \\
\hline & & RGV-50\% x RMV-33\% & - & $\mathrm{S}(8,2)$ & $\mathrm{S}(3,4)$ & $S(4,1)$ & $\mathrm{S}(22,1)$ & - \\
\hline & & RGB-50\% x RMB-33\% & - & $\mathrm{S}(4,3)$ & $\mathrm{S}(11,8)$ & $S(37,4)$ & $\mathrm{S}(9,1)$ & $S(6,2)$ \\
\hline & \multirow{2}{*}{$\begin{array}{l}\text { Diferentes } \\
\text { resíduos (\% } \\
\text { similares de } \\
\text { substituição) }\end{array}$} & RGV-50\% x RGB-50\% & - & $\mathrm{S}(87,9)$ & - & $\mathrm{S}(8,7)$ & $S(43,0)$ & $S(5,0)$ \\
\hline & & RMV-33\% x RMB-33\% & $S(17,4)$ & $S(4,6)$ & - & $S(29,5)$ & $\mathrm{S}(34,7)$ & $S(10,4)$ \\
\hline
\end{tabular}

Analisando-se os resultados da Tabela 7.26, são estabelecidos os seguintes comentários:

- Para a propriedade de massa específica seca, a variável "grupo" não influenciou os resultados, com exceção dos traços RMV-33\% x RMB-33\%. Dessa maneira, pode-se afirmar que os valores de massa específica foram semelhantes para unidades de diferentes classes de resistência e que apresentavam distintos consumos de cimento, tais como, o traço RGV-100\% dos Grupos 4,5; 8,0 e 12,0.

- A variável "grupo" influenciou os valores de índice de vazios para grande parte das comparações avaliadas; especialmente, para as composições RGB-50\% x RMB-33\% e RMV-33\% x RMB-33\%. Nesse caso, pode-se afirmar que as dosagens pertencentes ao Grupo 12,0 apresentaram os menores valores médios de índice de vazios e, as dosagens do Grupo 4,5, com menor consumo de cimento, obtiveram os maiores valores médios para essa propriedade. Por outro lado, para as combinações envolvendo unidades com agregados reciclados de vigota, pode-se dizer que os valores de índice de vazios foram semelhantes, independentemente do grupo avaliado.

- Com relação à variável "traço", nota-se que todas as propriedades foram influenciadas pela variável. Considerando-se as comparações avaliadas, os maiores valores médios de massa específica e menores valores médios de índices de vazios foram obtidos para as dosagens indicadas na Tabela 7.27. 
- Para a análise de $2^{\mathrm{a}}$ ordem, observou-se uma influência significativa dos parâmetros (grupos e traços), principalmente sobre a propriedade de índice de vazios. Com relação à propriedade de massa específica seca, pode-se afirmar, para as comparações com influência significativa, que para um dado traço/dosagem haverá um determinado grupo/classe de resistência que conduzirá aos maiores valores médios de massa específica; entretanto, já para outro traço, pode não ser esse grupo que levará aos maiores valores médios de massa específica. Para a propriedade de índice de vazios, considerando-se todas as comparações avaliadas, com exceção das combinações REF x RGB-50\% x RMB-33\% e RGB-50\% x RMB$33 \%$, também pode ser utilizada a mesma justificativa estabelecida para a massa específica seca.

- Para as comparações REF x RGB-50\% x RMB-33\% e RGB-50\% x RMB-33\%, podese dizer que para um dado grupo/classe de resistência haverá um determinado traço que levará aos menores valores médios de índice de vazios; entretanto, para outra classe de resistência, esse mesmo traço pode não levar necessariamente aos menores valores médios de absorção. Dessa última justificativa, observa-se a influência dos maiores tempos de produção, na fabricação das unidades com agregados reciclados de bloco, sobre as propriedades físicas; uma vez que, para alguns grupos, os menores valores de índice de vazios, comparativamente às unidades de referência, foram obtidos para os blocos com agregados reciclados de bloco.

Tabela 7.27 - Dosagens que apresentaram valores de absorção e índice de vazios significativamente diferentes (5\% de significância).

\begin{tabular}{|c|c|c|c|}
\hline & & $\begin{array}{c}\text { Traço com valores } \\
\text { significativamente maiores de } \\
\text { massa específica }\end{array}$ & $\begin{array}{c}\text { Traço com valores } \\
\text { significativamente menores de } \\
\text { índice de vazios }\end{array}$ \\
\hline \multirow{9}{*}{ Comparações } & REF x RECICLADOS & REF & RMB-33\% \\
\hline & REF $\times$ RGV- $100 \% \times$ RGV- $50 \% \times$ RMV- $33 \%$ & REF & REF \\
\hline & RGV-100\% $\%$ RGV-50\% $\times$ RMV-33\% & RMV-33\% & RMV-33\% \\
\hline & REF x RGB-50\% x RMB-33\% & REF & RMB-33\% \\
\hline & RGV-100\% x RGV-50\% & RGV-50\% & RGV-50\% \\
\hline & RGV-50\% $\times$ RMV-33\% & RMV-33\% & RMV-33\% \\
\hline & RGB-50\% x RMB-33\% & RGB-50\% & RMB-33\% \\
\hline & RGV-50\% x RGB-50\% & RGB-50\% & RGB-50\% \\
\hline & RMV-33\% x RMB-33\% & RMB-33\% & RMB-33\% \\
\hline
\end{tabular}

Pelos resultados obtidos na Tabela 7.27, podem ser enumerados dois pontos fundamentais: a) para condições de produção similares, os resultados foram influenciados 
basicamente pela composição da dosagem, isto é, a presença da fração reciclada e a porcentagem de substituição; b) prováveis mudanças nas condições de produção, isto é, aumento dos tempos de vibro-prensagem com o intuito de elevar a coesão da mistura, afetaram às propriedades físicas das unidades com agregados reciclados e, particularmente, nesse caso, os resultados foram considerados semelhantes aos obtidos para unidades comumente produzidas em fábrica.

\subsubsection{Taxa de absorção inicial}

Apesar da existência de inúmeros pesquisadores que questionam a utilização da taxa de absorção inicial (IRA), esse teste continua sendo prescrito em diversos códigos normativos. Gallegos (1989) recomenda para blocos de concreto, valores situados entre 10 a $30 \mathrm{~g} / 193,55 \mathrm{~cm}^{2} / \mathrm{min}$.

\subsection{Grupo 4,5}

Os resultados para as unidades do Grupo 4,5 encontram-se na Tabela 7.28.

Tabela 7.28 - Taxa de absorção inicial para os blocos de concreto do Grupo 4,5.

\begin{tabular}{|c|c|c|c|c|c|c|c|c|c|c|c|c|}
\hline \multirow{2}{*}{$\begin{array}{c}\text { IRA } \\
(\mathrm{g} / \\
\left.193,55 \mathrm{~cm}^{2} / \mathrm{min}\right)\end{array}$} & \multicolumn{2}{|c|}{ B4,5-REF } & \multicolumn{2}{|c|}{$\begin{array}{c}\text { B4,5-RGV- } \\
100 \%\end{array}$} & \multicolumn{2}{|c|}{ B4,5-RGV-50\% } & \multicolumn{2}{|c|}{ B4,5-RMV-33\% } & \multicolumn{2}{|c|}{ B4,5-RGB-50\% } & \multicolumn{2}{|c|}{ B4,5-RMB-33\% } \\
\hline & $\begin{array}{c}\text { IRA } \\
\text { (face } \\
\text { maior) } \\
\end{array}$ & $\begin{array}{c}\text { IRA } \\
\text { (face } \\
\text { menor) } \\
\end{array}$ & $\begin{array}{c}\text { IRA } \\
\text { (face } \\
\text { maior) } \\
\end{array}$ & $\begin{array}{c}\text { IRA } \\
\text { (face } \\
\text { menor) } \\
\end{array}$ & $\begin{array}{c}\text { IRA } \\
\text { (face } \\
\text { maior) } \\
\end{array}$ & $\begin{array}{c}\text { IRA } \\
\text { (face } \\
\text { menor) } \\
\end{array}$ & $\begin{array}{c}\text { IRA } \\
\text { (face } \\
\text { maior) } \\
\end{array}$ & $\begin{array}{c}\text { IRA } \\
\text { (face } \\
\text { menor) } \\
\end{array}$ & $\begin{array}{c}\text { IRA } \\
\text { (face } \\
\text { maior) } \\
\end{array}$ & $\begin{array}{c}\text { IRA } \\
\text { (face } \\
\text { menor) } \\
\end{array}$ & $\begin{array}{c}\text { IRA } \\
\text { (face } \\
\text { maior) } \\
\end{array}$ & $\begin{array}{c}\text { IRA } \\
\text { (face } \\
\text { menor) } \\
\end{array}$ \\
\hline Média & 72,8 & 40,4 & 38,8 & 18,4 & 28,1 & 12,9 & 15,5 & 13,8 & 28,0 & 12,4 & 22,7 & 20,0 \\
\hline Máximo & 99,5 & 49,6 & 57,9 & 33,5 & 32,8 & 18,5 & 17,5 & 16,8 & 31,3 & 15,0 & 35,1 & 68,8 \\
\hline Mínimo & 52,0 & 31,0 & 22,1 & 12,4 & 23,6 & 10,6 & 13,0 & 12,4 & 24,4 & 11,5 & 13,0 & 8,8 \\
\hline D. Padrão & 19,9 & 7,2 & 11,7 & 7,7 & 3,3 & 3,0 & 1,7 & 1,7 & 3,4 & 1,5 & 7,3 & 23,9 \\
\hline $\begin{array}{c}\text { Coef. Variação } \\
(\%)\end{array}$ & 27,3 & 17,8 & 30,2 & 42,0 & 11,6 & 23,1 & 10,6 & 12,6 & 12,2 & 11,9 & 32,1 & 119,9 \\
\hline $\begin{array}{c}\text { Elevação do } \\
\text { menisco (cm)* }\end{array}$ & 3,3 & 2,1 & 2,0 & 1,5 & 1,8 & 1,5 & 1,2 & 1,0 & 1,5 & 1,0 & 1,5 & 1,4 \\
\hline $\begin{array}{c}\text { IRA médio } \\
(\mathrm{g} / \\
\left.193,55 \mathrm{~cm}^{2} / \mathrm{min}\right)\end{array}$ & \multicolumn{2}{|c|}{57,8} & \multicolumn{2}{|c|}{29,3} & \multicolumn{2}{|c|}{21,1} & \multicolumn{2}{|c|}{14,7} & \multicolumn{2}{|c|}{20,7} & \multicolumn{2}{|c|}{21,5} \\
\hline $\begin{array}{l}\text { IRA médio } \\
\left(\mathrm{kg} / \mathrm{m}^{2} / \mathrm{min}\right)\end{array}$ & \multicolumn{2}{|c|}{2,99} & \multicolumn{2}{|c|}{1,51} & \multicolumn{2}{|c|}{1,09} & \multicolumn{2}{|c|}{0,76} & \multicolumn{2}{|c|}{1,07} & \multicolumn{2}{|c|}{1,11} \\
\hline $\begin{array}{l}\text { Absorção de } \\
\text { água (\%) }\end{array}$ & \multicolumn{2}{|c|}{5,92} & \multicolumn{2}{|c|}{7,31} & \multicolumn{2}{|c|}{6,86} & \multicolumn{2}{|c|}{6,60} & \multicolumn{2}{|c|}{6,50} & \multicolumn{2}{|c|}{6,43} \\
\hline
\end{tabular}

Elevação do menisco: altura em que a água se eleva na parede do bloco

Analisando-se a Tabela 7.28, nota-se que todas as unidades, com exceção dos blocos B4,5-REF, apresentaram valores para a taxa de absorção inicial dentro do intervalo prescrito por Gallegos (1989). Provavelmente, o valor elevado para a taxa de absorção inicial dos blocos B4,5-REF pode ser explicado pela baixa umidade utilizada na produção dessas unidades. A umidade da mistura sendo inferior à umidade ótima ocasiona a 
produção de blocos com menor compacidade e, consequentemente, maiores índices de vazios. Segundo Groot (1995) o total de água absorvida por um sistema de capilares é função da dimensão, distribuição e volume dos poros. A absorção pode ser similar para elementos com distribuições distintas de poros, isto é, valores semelhantes para a taxa de absorção inicial (IRA) podem representar sistemas de poros com diferentes diâmetros e volumes.

A altura de elevação do menisco para os blocos B4,5-REF foram significativamente maiores quando comparados com as demais unidades. De acordo com Groot (1995), a massa de água absorvida pelos capilares é diretamente proporcional à elevação do menisco. As imperfeições existentes na face inferior, sobressaltos e falhas provocaram variações substanciais nos valores do IRA, principalmente, para as unidades do traço B4,5RMB-33\%.

\subsection{Grupo 8,0}

Os resultados para essa propriedade encontram-se na Tabela 7.29.

Tabela 7.29 - Taxa de absorção inicial para os blocos de concreto do Grupo 8,0.

\begin{tabular}{|c|c|c|c|c|c|c|c|c|c|c|c|c|}
\hline \multirow{2}{*}{$\begin{array}{c}\text { IRA } \\
(\mathrm{g} / \\
\left.193,55 \mathrm{~cm}^{2} / \mathrm{min}\right)\end{array}$} & \multicolumn{2}{|c|}{ B8,0-REF } & \multicolumn{2}{|c|}{$\begin{array}{c}\text { B8,0-RGV- } \\
100 \%\end{array}$} & \multicolumn{2}{|c|}{ B8,0-RGV-50\% } & \multicolumn{2}{|c|}{ B8,0-RMV-33\% } & \multicolumn{2}{|c|}{ B8,0-RGB-50\% } & \multicolumn{2}{|c|}{ B8,0-RMB-33\% } \\
\hline & $\begin{array}{c}\text { IRA } \\
\text { (face } \\
\text { maior) }\end{array}$ & $\begin{array}{c}\text { IRA } \\
\text { (face } \\
\text { menor) }\end{array}$ & $\begin{array}{c}\text { IRA } \\
\text { (face } \\
\text { maior) }\end{array}$ & $\begin{array}{c}\text { IRA } \\
\text { (face } \\
\text { menor) }\end{array}$ & $\begin{array}{c}\text { IRA } \\
\text { (face } \\
\text { maior) }\end{array}$ & $\begin{array}{l}\text { IRA } \\
\text { (face } \\
\text { menor) }\end{array}$ & $\begin{array}{l}\text { IRA } \\
\text { (face } \\
\text { maior) }\end{array}$ & $\begin{array}{l}\text { IRA } \\
\text { (face } \\
\text { menor) }\end{array}$ & $\begin{array}{l}\text { IRA } \\
\text { (face } \\
\text { maior) }\end{array}$ & $\begin{array}{c}\text { IRA } \\
\text { (face } \\
\text { menor) }\end{array}$ & $\begin{array}{c}\text { IRA } \\
\text { (face } \\
\text { maior) }\end{array}$ & $\begin{array}{l}\text { IRA } \\
\text { (face } \\
\text { menor) }\end{array}$ \\
\hline Média & 43,6 & 15,9 & 31,8 & 12,2 & 42,3 & 18,5 & 11,4 & 9,1 & 26,4 & 9,1 & 23,8 & 10,9 \\
\hline Máximo & 54,9 & 18,5 & 34,3 & 15,0 & 53,4 & 22,1 & 19,1 & 13,2 & 38,9 & 10,6 & 30,5 & 15,0 \\
\hline Mínimo & 36,6 & 13,2 & 22,1 & 8,8 & 34,3 & 15,0 & 8,4 & 7,1 & 15,2 & 7,1 & 21,3 & 7,9 \\
\hline D. Padrão & 7,5 & 1,85 & 4,7 & 2,6 & 8,2 & 2,3 & 4,0 & 2,4 & 8,3 & 1,4 & 3,9 & 2,8 \\
\hline $\begin{array}{c}\text { Coef. Variação } \\
(\%)\end{array}$ & 17,2 & 11,7 & 15,0 & 21,2 & 19,3 & 12,4 & 34,5 & 25,7 & 31,5 & 15,8 & 16,5 & 26,0 \\
\hline $\begin{array}{l}\text { Elevação do } \\
\text { menisco }(\mathrm{cm})^{*}\end{array}$ & 2,0 & 1,2 & 1,5 & 1,0 & 1,9 & 1,5 & 1,1 & 1,0 & 1,4 & 1,0 & 1,3 & 1,0 \\
\hline $\begin{array}{c}\text { IRA médio } \\
(\mathrm{g} / \\
\left.193,55 \mathrm{~cm}^{2} / \mathrm{min}\right)\end{array}$ & \multicolumn{2}{|c|}{30,7} & \multicolumn{2}{|c|}{22,7} & \multicolumn{2}{|c|}{31,3} & \multicolumn{2}{|c|}{10,4} & \multicolumn{2}{|c|}{18,4} & \multicolumn{2}{|c|}{17,8} \\
\hline $\begin{array}{l}\text { IRA médio } \\
\left(\mathrm{kg} / \mathrm{m}^{2} / \mathrm{min}\right)\end{array}$ & \multicolumn{2}{|c|}{1,59} & \multicolumn{2}{|c|}{1,17} & \multicolumn{2}{|c|}{1,62} & \multicolumn{2}{|c|}{0,54} & \multicolumn{2}{|c|}{0,95} & \multicolumn{2}{|c|}{0,92} \\
\hline $\begin{array}{l}\text { Absorção de } \\
\text { água (\%) }\end{array}$ & \multicolumn{2}{|c|}{6,10} & \multicolumn{2}{|c|}{7,04} & \multicolumn{2}{|c|}{6,89} & \multicolumn{2}{|c|}{6,30} & \multicolumn{2}{|c|}{5,89} & \multicolumn{2}{|c|}{6,08} \\
\hline
\end{tabular}

* Elevação do menisco: altura que a água se eleva na parede do bloco

Analisando-se os resultados da Tabela 7.29, observa-se que todas as unidades avaliadas apresentaram valores para a taxa de absorção inicial dentro do intervalo prescrito por Gallegos (1989), isto é, entre $10 \mathrm{~g} / 193,55 \mathrm{~cm}^{2} / \mathrm{min}$ e $30 \mathrm{~g} / 193,55 \mathrm{~cm}^{2} / \mathrm{min}$. Provavelmente, o valor elevado para a taxa de absorção inicial dos blocos B8,0-REF e B8,0-RGV-50\%, em 
comparação com as demais unidades, pode ser explicada pela baixa umidade utilizada na produção dessas unidades, isto é, a umidade empregada na mistura ficou abaixo da umidade ótima. Entretanto, conforme já relatado, o emprego do IRA é contestado por diversos pesquisadores devido seu tempo limitado de teste (um minuto) e descrever apenas parte do fenômeno da interação bloco/argamassa.

\subsection{Grupo 12,0}

Os resultados para essa propriedade encontram-se na Tabela 7.30.

Tabela 7.30 - Taxa de absorção inicial para as unidades do Grupo 12,0.

\begin{tabular}{|c|c|c|c|c|c|c|c|c|c|c|c|c|}
\hline \multirow{2}{*}{$\begin{array}{c}\text { IRA } \\
(\mathrm{g} / \\
193,55 \mathrm{~cm}^{2} / \\
\min )\end{array}$} & \multicolumn{2}{|c|}{ B12,0-REF } & \multicolumn{2}{|c|}{ B12,0-RGV-100\% } & \multicolumn{2}{|c|}{ B12,0-RGV-50\% } & \multicolumn{2}{|c|}{ B12,0-RMV-33\% } & \multicolumn{2}{|c|}{$\begin{array}{c}\text { B12,0-RGB- } \\
50 \%\end{array}$} & \multicolumn{2}{|c|}{ B12,0-RMB-33\% } \\
\hline & $\begin{array}{c}\text { IRA } \\
\text { (face } \\
\text { maior) }\end{array}$ & $\begin{array}{l}\text { IRA } \\
\text { (face } \\
\text { menor) }\end{array}$ & $\begin{array}{l}\text { IRA } \\
\text { (face } \\
\text { maior) }\end{array}$ & $\begin{array}{c}\text { IRA } \\
\text { (face menor) }\end{array}$ & $\begin{array}{l}\text { IRA } \\
\text { (face } \\
\text { maior) }\end{array}$ & $\begin{array}{l}\text { IRA } \\
\text { (face } \\
\text { menor) }\end{array}$ & $\begin{array}{l}\text { IRA } \\
\text { (face } \\
\text { maior) }\end{array}$ & $\begin{array}{l}\text { IRA } \\
\text { (face } \\
\text { menor) }\end{array}$ & $\begin{array}{c}\text { IRA } \\
\text { (face } \\
\text { maior) }\end{array}$ & $\begin{array}{l}\text { IRA } \\
\text { (face } \\
\text { menor) }\end{array}$ & $\begin{array}{l}\text { IRA } \\
\text { (face } \\
\text { maior) }\end{array}$ & $\begin{array}{l}\text { IRA } \\
\text { (face } \\
\text { menor) }\end{array}$ \\
\hline Média & 68,7 & 38,4 & 78,0 & 39,1 & 53,8 & 28,4 & 12,8 & 8,2 & 39,1 & 21,5 & 7,0 & 5,0 \\
\hline Máximo & 92,3 & 66,2 & 83,9 & 52,1 & 82,3 & 37,9 & 16,0 & 14,1 & 51,1 & 39,7 & 8,4 & 6,2 \\
\hline Mínimo & 45,7 & 21,2 & 70,1 & 33,5 & 44,2 & 21,2 & 10,7 & 5,3 & 30,5 & 15,9 & 3,8 & 3,5 \\
\hline D. Padrão & 19,4 & 19,1 & 6,4 & 6,6 & 14,6 & 7,4 & 1,9 & 3,4 & 7,2 & 9,2 & 1,8 & 0,9 \\
\hline $\begin{array}{c}\text { Coef. } \\
\text { Variação } \\
(\%)\end{array}$ & 28,2 & 49,9 & 8,1 & 16,9 & 27,1 & 25,9 & 14,8 & 41,6 & 18,3 & 42,7 & 25,3 & 18,2 \\
\hline $\begin{array}{c}\text { Elevação } \\
\text { do menisco } \\
(\mathrm{cm})^{*}\end{array}$ & 2,9 & 2,0 & 3,5 & 2,3 & 2,8 & 1,8 & 1,3 & 1,3 & 2,2 & 1,7 & 1,0 & 1,0 \\
\hline $\begin{array}{l}\text { IRA médio } \\
\text { (g/ } \\
193,55 \mathrm{~cm}^{2} / \\
\text { min) }\end{array}$ & \multicolumn{2}{|c|}{54,7} & \multicolumn{2}{|r|}{60,0} & \multicolumn{2}{|c|}{42,0} & \multicolumn{2}{|c|}{10,7} & \multicolumn{2}{|c|}{30,9} & \multicolumn{2}{|c|}{6,1} \\
\hline $\begin{array}{l}\text { IRA médio } \\
\left(\mathrm{kg} / \mathrm{m}^{2} / \mathrm{min}\right)\end{array}$ & \multicolumn{2}{|c|}{2,82} & \multicolumn{2}{|r|}{3,10} & \multicolumn{2}{|c|}{2,17} & \multicolumn{2}{|c|}{0,55} & \multicolumn{2}{|c|}{1,60} & \multicolumn{2}{|c|}{0,31} \\
\hline $\begin{array}{c}\text { Absorção } \\
\text { de água (\%) }\end{array}$ & \multicolumn{2}{|c|}{6,35} & \multicolumn{2}{|r|}{7,34} & \multicolumn{2}{|c|}{6,65} & \multicolumn{2}{|c|}{6,18} & \multicolumn{2}{|c|}{5,85} & \multicolumn{2}{|c|}{5,19} \\
\hline
\end{tabular}

* Elevação do menisco: altura que a água se eleva na parede do bloco

Analisando-se os resultados da Tabela 7.30, observa-se que: a) as unidades avaliadas, com exceção das unidades B12,0-REF, B12,0-RGV-100\% e B12,0-RGV-50\%, apresentaram valores para a taxa de absorção inicial dentro do intervalo prescrito por Gallegos (1989). Para as demais unidades, que apresentaram IRA acima de 30 $\mathrm{g} / 193,55 \mathrm{~cm}^{2} / \mathrm{min}$, deve-se avaliar a medida mais adequada para evitar a sucção excessiva de água da argamassa para o bloco; b) provavelmente, o valor elevado para a taxa de absorção inicial dos blocos B12,0-REF, B12,0-RGV-100\% e B12,0-RGV-50\%, em comparação com as demais unidades, pode ser explicada pela baixa umidade $(5,40 \%)$ utilizada na produção dessas unidades, isto é, a umidade empregada ficou abaixo da umidade ótima. Para as unidades dos traços B12,0-RMV-33\% e B12,0-RMB-33\%, que 
obtiveram os menores valores para a taxa de absorção inicial, a umidade adotada foi de $6,00 \%$ e $6,40 \%$, respectivamente.

\subsection{Análise dos resultados - taxa de absorção inicial}

Para facilitar a análise global dos resultados da taxa de absorção inicial (IRA) é apresentada, na Tabela 7.31, o teste estatístico de Análise de Variância.

Tabela 7.31 - Teste ANOVA para valores de IRA.

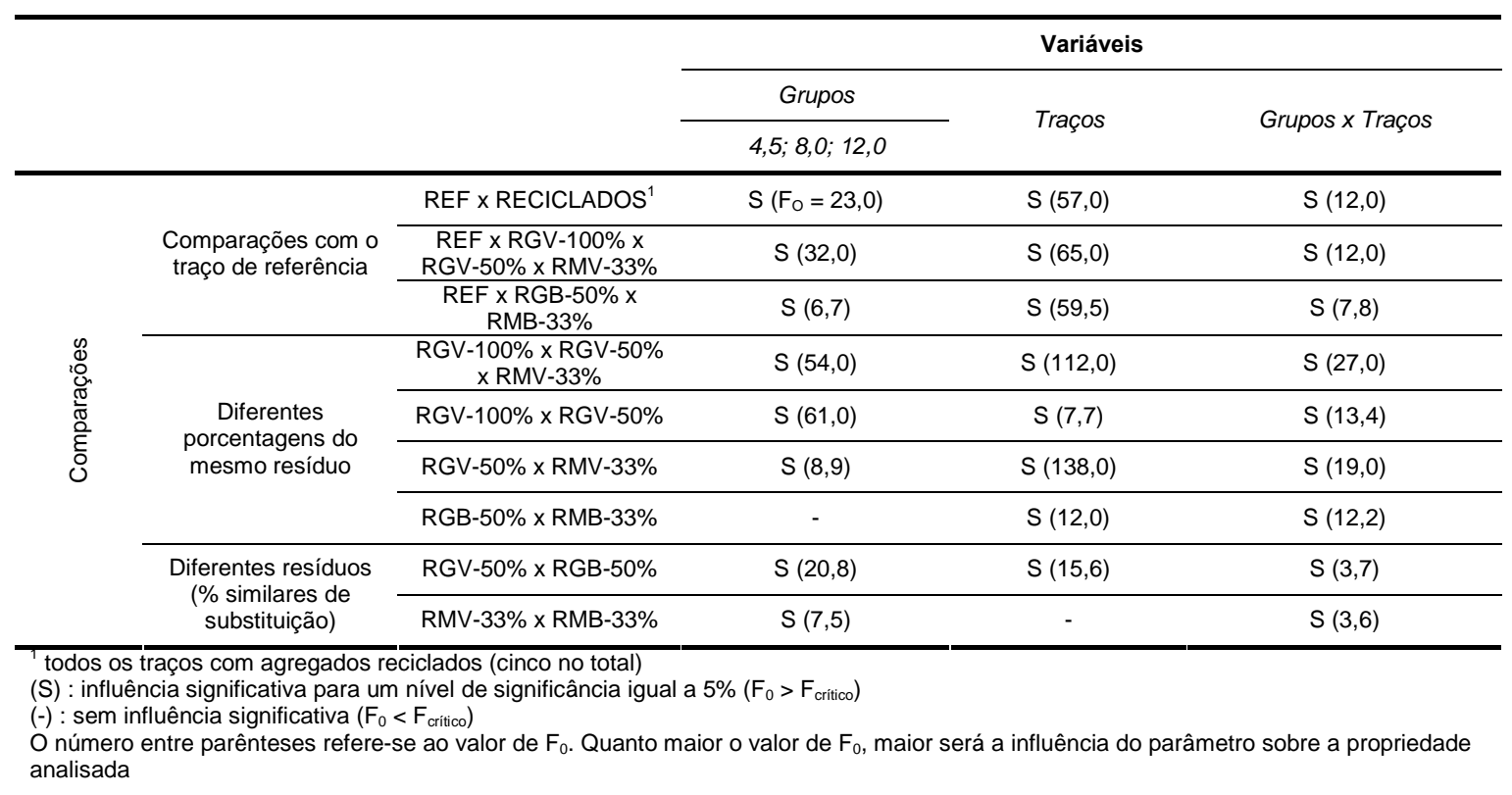

Analisando-se os resultados da Tabela 7.31, são estabelecidos os seguintes comentários:

- Para a análise da $1^{\mathrm{a}}$ ordem, houve, para a grande maioria das comparações efetuadas, influência significativa das variáveis "grupos" e "traços" sobre a taxa de absorção inicial. Das duas variáveis, a que exerceu influência mais significativa na taxa de absorção inicial foi a variável "traço". Com relação a variável "grupo", pode-se afirmar que, em grande parte das comparações, os maiores e menores valores médios de IRA foram obtidos para as dosagens dos Grupos 12,0 e 4,5, respectivamente. Os maiores valores médios de IRA para as dosagens do Grupo 12,0 são explicados pela umidade adotada na produção que, possivelmente, ficou abaixo da ótima comparativamente às dosagens do Grupo 4,5. A umidade da mistura sendo inferior à umidade ótima gera unidades com menor compacidade e, consequentemente, maiores índices de vazios. 
- Considerando-se a variável "traço", pode-se afirmar que os maiores valores médios de IRA foram obtidos para as dosagens de referência. Para as dosagens com agregados reciclados de vigota, os maiores valores médios de IRA foram obtidos para os traços RGV-100\%; já para as dosagens com agregados reciclados de bloco, os menores valores médios foram obtidos para os traços RMB-33\%. De certa forma, os menores valores médios de IRA foram obtidos para as dosagens com agregados miúdos reciclados.

- Pela análise de $2^{\mathrm{a}}$ ordem (grupos $\mathrm{x}$ traços) pode-se afirmar que para um dado traço (REF, por ex) há um determinado grupo que conduz aos menores valores médios de IRA $(8,0)$; por outro lado, para outro traço (RGV-50\%, por ex.), não é necessariamente esse grupo que conduz aos menores valores médios de IRA. Essa análise demonstra a grande variabilidade dos resultados obtidos, sendo que os menores valores médios de IRA não foram obtidos apenas para um determinado grupo/classe de resistência.

\subsubsection{Absorção Capilar}

Conforme já comentado, o ensaio de absorção capilar foi realizado em razão das limitações do teste da taxa de absorção inicial (IRA).

\subsection{Grupo 4,5}

Os resultados para as unidades do Grupo 4,5 encontram-se na Tabela 7.32.

Tabela 7.32 - Absorção capilar para os blocos de concreto do Grupo 4,5.

\begin{tabular}{|c|c|c|c|c|c|c|c|c|c|c|c|}
\hline & \multirow{3}{*}{$\begin{array}{c}\text { Idade } \\
\text { dos } \\
\text { blocos } \\
\text { (dias) }\end{array}$} & \multirow{3}{*}{$\begin{array}{c}{ }^{\top} \\
\left({ }^{\circ} \mathrm{C}\right)\end{array}$} & \multirow{3}{*}{$\mathrm{U}(\%)$} & \multicolumn{5}{|c|}{ Absorção capilar inicial (1' - 360') - ASTM C1585(2004) } & \multirow{3}{*}{$\begin{array}{c}\begin{array}{c}\text { Absorçãão } \\
\text { capilar }\left(1^{\prime}-\right. \\
\left.25^{\prime}\right)^{1}\end{array} \\
\text { Média } \\
\left(\mathrm{mm} / \mathrm{min}^{1 / 2}\right)\end{array}$} & \multirow{3}{*}{$\begin{array}{c}\text { IRA } \\
\left(\mathrm{kg} / \mathrm{m}^{2} /\right. \\
\mathrm{min})\end{array}$} & \multirow{3}{*}{$\begin{array}{c}\text { Absorção } \\
\text { (\%) }\end{array}$} \\
\hline & & & & Média & Máximo & Mínimo & $S_{d}$ & C. V & & & \\
\hline & & & & $\left(\mathrm{mm} / \mathrm{min}^{1 / 2}\right)$ & $\left(\mathrm{mm} / \mathrm{min}^{1 / 2}\right)$ & $\left(\mathrm{mm} / \mathrm{min}^{1 / 2}\right)$ & $\left(\mathrm{mm} / \mathrm{min}^{1 / 2}\right)$ & $(\%)$ & & & \\
\hline B4,5-REF & 347 & 25,0 & 66,4 & 0,301 & 0,318 & 0,289 & 0,016 & 5,21 & $0,464^{(1)^{*}}$ & $2,99^{(1)}$ & $5,92^{(6)}$ \\
\hline B4,5-RGV-100\% & 408 & 27,0 & 50,7 & 0,175 & 0,178 & 0,169 & 0,005 & 2,95 & $0,253^{(6)}$ & $1,51^{(2)}$ & $7,31^{(1)}$ \\
\hline B4,5-RGV-50\% & 408 & 27,0 & 50,7 & 0,257 & 0,262 & 0,252 & 0,005 & 1,98 & $0,339^{(4)}$ & $1,09^{(4)}$ & $6,86^{(2)}$ \\
\hline B4,5-RMV-33\% & 421 & 24,0 & 55,6 & 0,336 & 0,372 & 0,301 & 0,036 & 10,59 & $0,381^{(2)}$ & $0,76^{(6)}$ & $6,60^{(3)}$ \\
\hline B4,5-RGB-50\% & 372 & 24,2 & 49,4 & 0,206 & 0,217 & 0,187 & 0,016 & 7,70 & $0,309^{(5)}$ & $1,07^{(5)}$ & $6,50^{(4)}$ \\
\hline B4,5-RMB-33\% & 418 & 22,0 & 52,1 & 0,272 & 0,290 & 0,249 & 0,021 & 7,70 & $0,344^{(3)}$ & $1,11^{(3)}$ & $6,43^{(5)}$ \\
\hline
\end{tabular}

Analisando-se os resultados da Tabela 7.32, observa-se que os maiores valores de absorção por capilaridade, no intervalo de 1 a 25 minutos, foram obtidos para o traço de referência e para as dosagens com agregados miúdos reciclados, respectivamente. 
Provavelmente, as unidades dessas dosagens apresentavam maiores diâmetros de poros capilares comparativamente às demais unidades. Segundo Helene (1993), quanto maior o diâmetro dos poros capilares, menor é a pressão capilar e, consequentemente, menor é a altura de ascensão capilar da água, porém a quantidade total de água absorvida é maior.

Comparando-se os resultados de absorção capilar, absorção de água e taxa de absorção inicial (IRA), nota-se que não ocorreu uma correspondência entre esses ensaios. Segundo Taha et al. (2001), esse fato pode ser atribuído às diferenças físicas existentes entre esses ensaios; de acordo com o pesquisador, a absorção total representa a quantidade total de água absorvida pela unidade, o IRA representa a taxa de absorção quando a unidade está em contato com a água por apenas um minuto e, finalmente, a absorção capilar que corresponde a taxa de água absorvida pela unidade até que essa fique saturada.

Os resultados de absorção capilar para as unidades com agregados graúdos reciclados de vigota e bloco apresentaram uma redução de $36 \%$ e $33 \%$, respectivamente em relação aos valores de referência. A presença da fração graúda e miúda reciclada não provocou aumento nos valores de absorção capilar; por outro lado, Taus et al. (2005) observaram um aumento de 54\% (relação água/cimento de 0,50) e 100\% (relação água/cimento de 0,40 ) na absorção capilar de concretos com agregados graúdos reciclados, respectivamente quando comparados a concretos com agregados naturais de características similares; já Mc Carter et al. (1996 apud TAUS et al., 2005) ${ }^{30}$ concluiu que a absorção por capilaridade não é influenciada pelo tipo de agregado.

Os valores de absorção por capilaridade das unidades situaram-se entre 0,253 e $0,464 \mathrm{~mm} / \mathrm{min}^{1 / 2}$; Totoev e James (2004), para blocos de concreto com IRA de 3,28 $\mathrm{kg} / \mathrm{m}^{2} / \mathrm{min}$ e absorção de $7,85 \%$, obtiveram valores próximos a $0,88 \mathrm{~mm} / \mathrm{min}^{1 / 2}$ para a absorção por capilaridade; no entanto, diferentemente da temperatura utilizada na presente pesquisa $\left(60^{\circ} \mathrm{C}\right)$, os referidos pesquisadores adotaram a temperatura de $110^{\circ} \mathrm{C}$ para secagem dos blocos.

\footnotetext{
${ }^{30}$ MC CARTER, W. J.; EZIRIM, H.; EMERSON, M. Properties of concrete in the cover zone: water penetration, sorptivity and ionic ingress. Magazine of Concrete Research, v. 48, n. 176, p. 149-156, 1996.
} 


\subsection{Grupo 8,0}

Os resultados para as unidades do Grupo 8,0 encontram-se na Tabela 7.33.

Tabela 7.33 - Absorção capilar para os blocos de concreto do Grupo 8,0.

\begin{tabular}{|c|c|c|c|c|c|c|c|c|c|c|c|}
\hline & \multirow{3}{*}{$\begin{array}{l}\text { Idade } \\
\text { dos } \\
\text { blocos } \\
\text { (dias) }\end{array}$} & \multirow{3}{*}{$\begin{array}{c}\mathrm{T} \\
\left({ }^{\circ} \mathrm{C}\right)\end{array}$} & \multirow{3}{*}{$\mathrm{U}(\%)$} & \multicolumn{5}{|c|}{ Absorção capilar inicial (1' - 360') - ASTM C1585(2004) } & \multirow{3}{*}{$\begin{array}{c}\text { Absorção } \\
\text { capilar (1'- } \\
\left.25^{\prime}\right)^{1} \\
\text { Média } \\
\left(\mathrm{mm} / \mathrm{min}^{1 / 2}\right)\end{array}$} & \multirow{3}{*}{$\begin{array}{c}\text { IRA } \\
\left(\mathrm{kg} / \mathrm{m}^{2} /\right. \\
\mathrm{min})\end{array}$} & \multirow{3}{*}{$\begin{array}{c}\text { Absorção } \\
(\%)\end{array}$} \\
\hline & & & & Média & Máximo & Mínimo & $\mathrm{S}_{\mathrm{d}}$ & C. V & & & \\
\hline & & & & $\left(\mathrm{mm} / \mathrm{min}^{1 / 2}\right)$ & $\left(\mathrm{mm} / \mathrm{min}^{1 / 2}\right)$ & $\left(\mathrm{mm} / \mathrm{min}^{1 / 2}\right)$ & $\left(\mathrm{mm} / \mathrm{min}^{1 / 2}\right)$ & $(\%)$ & & & \\
\hline B8,0-REF & 396 & 24,3 & 72,1 & 0,136 & 0,143 & 0,131 & 0,006 & 4,35 & $0,191^{(3)^{*}}$ & $1,59^{(2)}$ & $6,10^{(4)}$ \\
\hline B8,0-RGV-100\% & 415 & 24,6 & 58,1 & 0,122 & 0,127 & 0,112 & 0,008 & 6,65 & $0,155^{(6)}$ & $1,17^{(3)}$ & $7,04^{(1)}$ \\
\hline B8,0-RGV-50\% & 372 & 23,7 & 48,0 & 0,148 & 0,153 & 0,145 & 0,005 & 3,33 & $0,283^{(1)}$ & $1,62^{(1)}$ & $6,89^{(2)}$ \\
\hline B8,0-RMV-33\% & 386 & 25,5 & 65,0 & 0,147 & 0,159 & 0,140 & 0,010 & 6,88 & $0,159^{(5)}$ & $0,54^{(6)}$ & $6,30^{(3)}$ \\
\hline B8,0-RGB-50\% & 388 & 25,7 & 60,7 & 0,121 & 0,136 & 0,108 & 0,014 & 11,58 & $0,189^{(4)}$ & $0,95^{(4)}$ & $5,89^{(6)}$ \\
\hline B8,0-RMB-33\% & 420 & 26,8 & 55,7 & 0,178 & 0,236 & 0,143 & 0,051 & 28,34 & $0,229^{(2)}$ & $0,92^{(5)}$ & $6,08^{(5)}$ \\
\hline
\end{tabular}

Analisando-se os resultados da Tabela 7.33, observa-se que os valores de absorção capilar inicial das diferentes unidades foram muito próximos. As unidades de referência, as unidades com agregados reciclados de vigota e agregados reciclados de bloco apresentaram respectivamente uma redução de 55\%, 46\% e 37\% nos valores de absorção por capilaridade comparativamente as unidades do Grupo 4,5. Provavelmente, as unidades do Grupo 8,0 possuem diâmetros menores de poros capilares comparativamente às unidades do Grupo 4,5. Segundo Helene (1993), quanto menor o diâmetro dos poros capilares, maior é a pressão capilar e, consequentemente, maior será a altura de ascensão capilar da água, porém a quantidade total de água absorvida por capilaridade será menor.

Comparando-se os resultados de absorção capilar, absorção de água e taxa de absorção inicial (IRA), nota-se que novamente não ocorreu correspondência entre esses ensaios. Diferentemente do ocorrido para as unidades do Grupo 4,5, os resultados de absorção capilar para as unidades com agregados reciclados de vigota e bloco foram próximos dos obtidos para os blocos de referência.

\subsection{Grupo 12,0}

Os resultados para as unidades do Grupo 12,0 encontram-se na Tabela 7.34. 
Tabela 7.34 - Absorção capilar para os blocos de concreto do Grupo 12,0.

\begin{tabular}{|c|c|c|c|c|c|c|c|c|c|c|c|}
\hline & \multirow{3}{*}{$\begin{array}{l}\text { Idade } \\
\text { dos } \\
\text { blocos } \\
\text { (dias) }\end{array}$} & \multirow{3}{*}{$\begin{array}{c}\mathrm{T} \\
\left({ }^{0} \mathrm{C}\right)\end{array}$} & \multirow{3}{*}{$\mathrm{U}(\%)$} & \multicolumn{5}{|c|}{ Absorção capilar inicial (1' - 360') - ASTM C1585(2004) } & \multirow{3}{*}{$\begin{array}{c}\text { Absorção } \\
\text { capilar (1'- } \\
\left.25^{\prime}\right)^{1} \\
\text { Média } \\
\left(\mathrm{mm} / \mathrm{min}^{1 / 2}\right)\end{array}$} & \multirow{3}{*}{$\begin{array}{c}\text { IRA } \\
\left(\mathrm{kg} / \mathrm{m}^{2} /\right. \\
\mathrm{min})\end{array}$} & \multirow{3}{*}{$\begin{array}{c}\text { Absorção } \\
(\%)\end{array}$} \\
\hline & & & & Média & Máximo & Mínimo & $\mathrm{S}_{\mathrm{d}}$ & C. V & & & \\
\hline & & & & $\left(\mathrm{mm} / \mathrm{min}^{1 / 2}\right)$ & $\left(\mathrm{mm} / \mathrm{min}^{1 / 2}\right)$ & $\left(\mathrm{mm} / \mathrm{min}^{1 / 2}\right)$ & $\left(\mathrm{mm} / \mathrm{min}^{1 / 2}\right)$ & (\%) & & & \\
\hline B12,0-REF & 395 & 24,3 & 72,1 & 0,332 & 0,394 & 0,274 & 0,060 & 17,99 & $0,456^{(1)^{\star}}$ & $2,82^{(2)}$ & $6,35^{(3)}$ \\
\hline B12,0-RGV-100\% & 403 & 25,8 & 64,4 & 0,306 & 0,374 & 0,252 & 0,062 & 20,34 & $0,439^{(2)}$ & $3,10^{(1)}$ & $7,34^{(1)}$ \\
\hline B12,0-RGV-50\% & 382 & 25,1 & 73,3 & 0,218 & 0,268 & 0,184 & 0,044 & 20,29 & $0,342^{(3)}$ & $2,17^{(3)}$ & $6,65^{(2)}$ \\
\hline B12,0-RMV-33\% & 382 & 25,1 & 73,3 & 0,089 & 0,117 & 0,062 & 0,026 & 29,73 & $0,122^{(5)}$ & $0,55^{(5)}$ & $6,18^{(4)}$ \\
\hline B12,0-RGB-50\% & 398 & 22,9 & 56,1 & 0,133 & 0,143 & 0,119 & 0,013 & 9,49 & $0,218^{(4)}$ & $1,60^{(4)}$ & $5,85^{(5)}$ \\
\hline
\end{tabular}

Analisando-se os resultados da Tabela 7.34, observa-se que os maiores valores de absorção por capilaridade, no intervalo de 1 a 25 minutos, foram obtidos para o traço de referência e para as dosagens com agregados com agregados graúdos reciclados de vigota. Provavelmente, as unidades dessas dosagens apresentavam diâmetros maiores de poros capilares comparativamente às demais unidades e, consequentemente, maiores taxas de absorção por capilaridade. Certamente, na produção dessas unidades, a umidade ficou abaixo da ideal e os tempos de vibro-prensagem deveriam ter sido aumentados.

\subsection{Análise dos resultados - absorção por capilaridade}

Para facilitar a análise global dos resultados é apresentada, na Tabela 7.35, o teste estatístico de Análise de Variância. A análise foi realizada para os dados obtidos conforme procedimento da ASTM C1585 (2004). 
Tabela 7.35 - Teste ANOVA para valores de absorção por capilaridade.

\begin{tabular}{|c|c|c|c|c|c|}
\hline & & & \multicolumn{3}{|c|}{ Variáveis } \\
\hline & & & Grupos & \multirow{2}{*}{ Traços } & \multirow{2}{*}{ Grupos $x$ Traços } \\
\hline & & & 4,$5 ; 8,0 ; 12,0$ & & \\
\hline \multirow{10}{*}{ 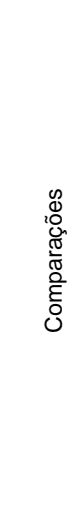 } & \multirow{4}{*}{$\begin{array}{c}\text { Comparações com } \\
\text { o traço de } \\
\text { referência }\end{array}$} & REF $\times$ RECICLADOS ${ }^{1}$ & $S\left(F_{0}=66,3\right)$ & $S(14,7)$ & $S(21,2)$ \\
\hline & & REF $\times$ RECICLADOS ${ }^{2}$ & $S(252,7)$ & $S(17,0)$ & $S(8,3)$ \\
\hline & & $\begin{array}{c}\text { REF } \times \text { RGV- } 100 \% \times \\
\text { RGV-50\% } \times \text { RMV-33\% }\end{array}$ & $S(53,9)$ & $\mathrm{S}(7,8)$ & $\mathrm{S}(22,3)$ \\
\hline & & $\begin{array}{c}\text { REF X RGB- } 50 \% \times \\
\text { RMB- } 33 \%^{3}\end{array}$ & $S(94,5)$ & $S(11,1)$ & $S(4,6)$ \\
\hline & \multirow{4}{*}{$\begin{array}{l}\text { Diferentes } \\
\text { porcentagens do } \\
\text { mesmo resíduo }\end{array}$} & $\begin{array}{c}\text { RGV- } 100 \% \times \text { RGV- } 50 \% \\
\times \text { RMV- } 33 \%\end{array}$ & $S(34,0)$ & - & $S(31,4)$ \\
\hline & & RGB-50\% $\%$ RMB-33 $\%^{3}$ & $S(27,6)$ & $\mathrm{S}(13,4)$ & - \\
\hline & & RGV- $100 \% \times$ RGV- $50 \%$ & $\mathrm{~S}(25,1)$ & - & $S(11,4)$ \\
\hline & & RGV-50\% x RMV-33\% & $S(61,8)$ & - & $S(24,8)$ \\
\hline & \multirow{2}{*}{$\begin{array}{l}\text { Diferentes resíduos } \\
\text { (\% similares de } \\
\text { substituição) }\end{array}$} & RGV-50\% $\times$ RGB-50\% & $\mathrm{S}(32,6)$ & $\mathrm{S}(30,6)$ & - \\
\hline & & RMV-33\% $\%$ RMB- $33 \%^{3}$ & $\mathrm{~S}(55,1)$ & - & $S(6,2)$ \\
\hline $\begin{array}{l}1 \text { todo } \\
2 \text { todo } \\
3 \text { comp } \\
\text { (S) : ir } \\
\text { (-) : se }\end{array}$ & $\begin{array}{l}\text { traços produzidos con } \\
\text { traços dos Grupos } 4, \\
\text { ção realizada apenas } \\
\text { ncia significativa para } \\
\text { fluência significativa } \\
\text { entre parênteses refe }\end{array}$ & $\begin{array}{l}\text { agregados reciclados, co } \\
\text { e } 8,0 \text { produzidos com agr } \\
\text { ara os Grupos } 4,5 \text { e } 8,0 \\
\text { Im nível de significância ig } \\
0<F_{\text {critico) }} \\
\text { e-se ao valor de } F_{0} \text {. Quant }\end{array}$ & $\begin{array}{l}\text { ȩão do traço } R \\
\text { s reciclados } \\
5 \%\left(F_{0}>F_{\text {critico }}\right) \\
\text { or o valor de } F_{0} \text {, }\end{array}$ & & o sobre \\
\hline
\end{tabular}

Analisando-se os resultados da Tabela 7.35, são feitos os seguintes comentários:

- Pela análise de $1^{a}$ ordem, houve, para grande parte das comparações, influência significativa das variáveis "grupos" e "traços" sobre a absorção por capilaridade. Das duas variáveis, a variável "grupos" exerceu influência mais significativa sobre a propriedade em questão, isto é, os maiores e menores valores médios de absorção por capilaridade foram obtidos para as unidades dos Grupos 4,5 e 8,0, respectivamente. Comparando-se os valores de absorção capilar das unidades do grupo 12,0 com as unidades do Grupo 8,0, observa-se que ocorreu um aumento médio de 144\% (REF), 151\% (RGV-100\%), 47\% (RGV-50\%), 10\% (RGB-50\%), isto é, os diâmetros dos poros capilares das unidades dos Grupo 12,0 foram maiores que os respectivos do Grupo 8,0 devido os tempos de vibro-prensagem não terem sido adequados, isto é, menores que o necessário para uma correta compactação das unidades.

- Considerando-se a variável traço, pode-se afirmar, para as comparações envolvendo o traço de referência, que os maiores valores médios de absorção capilar foram obtidos para as unidades de referência, fato já observado na propriedade da taxa de absorção inicial; já para as comparações envolvendo diferentes porcentagens do mesmo resíduo, pode-se dizer, com exceção dos traços com agregados reciclados de bloco, que a composição dos diferentes traços (\% de substituição) não afetou 
significativamente os valores de capilaridade. Finalmente, para as comparações envolvendo os diferentes resíduos, pode-se dizer que as características do resíduo influenciaram na capilaridade, sendo que os menores valores foram obtidos para os traços com agregados reciclados de bloco.

- Para a análise de $2^{\mathrm{a}}$ ordem, pode-se dizer, para grande parte das comparações, que dependendo do grupo/classe de resistência haverá um dado traço que conduzirá aos menores ou maiores valores médios de absorção por capilaridade.

\subsubsection{Propriedades mecânicas}

As propriedades mecânicas foram influenciadas pela presença da fração reciclada. Outros fatores que influenciaram as propriedades mecânicas foram: a) a umidade utilizada na produção das unidades que variou em função da presença da fração reciclada; b) tempos de alimentação e compressão da vibro-prensa, sendo maiores quando da produção das unidades com agregados reciclados de bloco; c) variação na massa dos blocos de um mesmo lote. De acordo com Frasson Junior (2000), as misturas mais úmidas tendem a produzir blocos de maior compacidade e resistência, pois os concretos são mais fáceis de adensar e compactar nos maquinários; além disso, segundo o pesquisador, para tempos de alimentação e vibração maiores, a massa dos blocos apresenta um aumento significativo.

\subsubsection{Resistência à compressão}

\subsection{Grupo 4,5}

Os resultados de resistência à compressão aos sete dias são apresentados na Tabela 7.36. 
Tabela 7.36 - Resistência à compressão das unidades de alvenaria do Grupo 4,5 aos sete dias.

\begin{tabular}{|c|c|c|c|c|c|c|c|}
\hline Unidades & Parâmetros & $\begin{array}{l}\text { Idade } \\
\text { (dias) }\end{array}$ & $\begin{array}{c}\text { Massa da } \\
\text { unidade (g) }\end{array}$ & Força $(k N)$ & $\begin{array}{l}\text { Tensão - } \\
\text { Área bruta } \\
\text { (MPa) }\end{array}$ & $\begin{array}{l}\text { Tensão - } \\
\text { Área } \\
\text { líquida } \\
\text { (MPa) }\end{array}$ & $\begin{array}{c}\text { Resistência } \\
\text { característica } \\
\mathrm{f}_{\mathrm{bk}}(\mathrm{MPa})\end{array}$ \\
\hline \multirow{5}{*}{ B4,5-REF } & Média & \multirow{5}{*}{7} & 10349 & 349 & 8,59 & 14,69 & \multirow{5}{*}{7,31} \\
\hline & Máximo & & 10586 & 391 & 9,64 & 16,48 & \\
\hline & Mínimo & & 10191 & 327 & 8,05 & 13,77 & \\
\hline & D. Padrão & & 144 & 25 & 0,61 & 1,05 & \\
\hline & C.Variação & & $1,39 \%$ & $7,15 \%$ & $7,15 \%$ & $7,15 \%$ & \\
\hline \multirow{5}{*}{ B4,5-RGV-100\% } & Média & \multirow{5}{*}{7} & 9990 & 306 & 7,54 & 12,83 & \multirow{5}{*}{6,25} \\
\hline & Máximo & & 10046 & 333 & 8,20 & 13,94 & \\
\hline & Mínimo & & 9914 & 271 & 6,68 & 11,36 & \\
\hline & D. Padrão & & 53 & 23 & 0,56 & 0,95 & \\
\hline & C.Variação & & $0,53 \%$ & $7,42 \%$ & $7,42 \%$ & $7,42 \%$ & \\
\hline \multirow{5}{*}{ B4,5-RGV-50\% } & Média & \multirow{5}{*}{7} & 10073 & 286 & 7,04 & 11,96 & \multirow{5}{*}{5,99} \\
\hline & Máximo & & 10250 & 318 & 7,83 & 13,29 & \\
\hline & Mínimo & & 9846 & 258 & 6,36 & 10,80 & \\
\hline & D. Padrão & & 153 & 27 & 0,67 & 1,14 & \\
\hline & C.Variação & & $1,52 \%$ & $9,49 \%$ & $9,49 \%$ & $9,49 \%$ & \\
\hline \multirow{5}{*}{ B4,5-RMV-33\% } & Média & \multirow{5}{*}{7} & 10143 & 225 & 5,54 & 9,46 & \multirow{5}{*}{4,41} \\
\hline & Máximo & & 10366 & 278 & 6,85 & 11,68 & \\
\hline & Mínimo & & 9855 & 198 & 4,87 & 8,32 & \\
\hline & D. Padrão & & 203 & 30 & 0,73 & 1,25 & \\
\hline & C.Variação & & $2,00 \%$ & $13,25 \%$ & $13,25 \%$ & $13,25 \%$ & \\
\hline \multirow{5}{*}{ B4,5-RGB-50\% } & Média & \multirow{5}{*}{7} & 10184 & 284 & 7,01 & 11,91 & \multirow{5}{*}{5,95} \\
\hline & Máximo & & 10352 & 309 & 7,61 & 12,94 & \\
\hline & Mínimo & & 9800 & 246 & 6,07 & 10,32 & \\
\hline & D. Padrão & & 208 & 21 & 0,52 & 0,89 & \\
\hline & C.Variação & & $2,04 \%$ & $7,48 \%$ & $7,48 \%$ & $7,48 \%$ & \\
\hline \multirow{5}{*}{ B4,5-RMB-33\% } & Média & \multirow{5}{*}{7} & 9980 & 216 & 5,33 & 8,96 & \multirow{5}{*}{4,25} \\
\hline & Máximo & & 10292 & 253 & 6,22 & 10,46 & \\
\hline & Mínimo & & 9753 & 178 & 4,39 & 7,38 & \\
\hline & D. Padrão & & 187 & 24 & 0,60 & 1,00 & \\
\hline & C.Variação & & $1,88 \%$ & $11,20 \%$ & $11,20 \%$ & $11,20 \%$ & \\
\hline
\end{tabular}

Pela Tabela 7.36, nota-se que todos os resultados apresentaram um coeficiente de variação aceitável, inferior a 15\%. Apenas as unidades com agregados miúdos reciclados (RMB-33\% e RMV-33\%) apresentaram valores característicos de resistência à compressão $\left(f_{b k}\right)$ inferiores ao recomendado para blocos da classe 4,5. Possivelmente, a baixa coesão das misturas com agregados miúdos reciclados e o elevado coeficiente de variação dos resultados (> 10\%) contribuíram para esses valores.

$\mathrm{Na}$ Tabela 7.37, são apresentadas as previsões de resistência das unidades pela correlação com corpos-de-prova cilíndricos produzidos anteriormente no laboratório, os resultados reais obtidos pelos blocos e o coeficiente de correlação real encontrado para essas unidades (CPs/blocos). É evidente que as diferenças existentes entre a produção dos CPs e blocos são inúmeras, tais como, elevada variabilidade na produção dos blocos, tempos de produção variáveis (energia de adensamento) e controle deficitário da umidade dos materiais. 
Tabela 7.37 - Coeficientes de correlação considerando os resultados dos CPs e dos blocos aos sete dias - Grupo 4,5.

\begin{tabular}{|c|c|c|c|c|c|c|c|}
\hline \multirow[t]{3}{*}{ Traços } & \multirow{3}{*}{$\begin{array}{c}\text { Consumo } \\
\text { de } \\
\text { cimento - } \\
\text { CPs } \\
\left(\mathrm{kg} / \mathrm{m}^{3}\right)\end{array}$} & \multirow[t]{3}{*}{$\begin{array}{c}\text { Resistência } \\
\text { dos CPs } \\
\text { (MPa) }\end{array}$} & \multirow{2}{*}{\multicolumn{2}{|c|}{$\begin{array}{c}\text { Previsão da } \\
\text { resistência dos } \\
\text { blocos - } \\
\text { Resultados dos } \\
\text { CPs (MPa) } \\
\text { Coeficiente de } \\
\text { correlação }\end{array}$}} & \multirow{3}{*}{$\begin{array}{c}\text { Consumo } \\
\text { de } \\
\text { cimento - } \\
\text { blocos } \\
\left(\mathrm{kg} / \mathrm{m}^{3}\right)\end{array}$} & \multirow{3}{*}{$\begin{array}{c}\text { Resistência } \\
\text { das } \\
\text { unidades } \\
\text { (MPa) }\end{array}$} & \multirow{3}{*}{$\begin{array}{l}\text { Coeficiente de } \\
\text { correlação } \\
\text { encontrado } \\
\text { (CPs/blocos) }\end{array}$} \\
\hline & & & & & & & \\
\hline & & & 0,80 & 1,30 & & & \\
\hline REF & 116,4 & 12,60 & 9,06 & 5,57 & 121,6 & 8,59 & 0,84 \\
\hline RGV-100\% & 116,4 & 11,65 & 8,37 & 5,15 & 118,7 & 7,54 & 0,89 \\
\hline RGV-50\% & 116,4 & 13,23 & 9,51 & 5,85 & 118,5 & 7,04 & 1,08 \\
\hline RGB-50\% & 116,4 & 12,65 & 9,09 & 5,59 & 118,3 & 7,01 & 1,04 \\
\hline
\end{tabular}

Analisando-se a Tabela 7.37, nota-se que os resultados dos CPs produzidos no laboratório forneceram um razoável parâmetro para a previsão da resistência das unidades aos sete dias. Conforme já relatado, torna-se difícil o estabelecimento de um coeficiente de correlação único, visto que o processo de produção dos blocos de concreto apresenta uma variabilidade muito elevada em comparação com a produção dos corpos-de-prova no laboratório. Os resultados de resistência à compressão das unidades aos vinte e oito dias são apresentados na Tabela 7.38.

Tabela 7.38 - Resistência à compressão das unidades de alvenaria do Grupo 4,5 aos vinte e oito dias.

\begin{tabular}{|c|c|c|c|c|c|c|c|c|}
\hline Unidades & Parâmetros & $\begin{array}{l}\text { Idade } \\
\text { (dias) }\end{array}$ & $\begin{array}{l}\text { Massa da } \\
\text { unidade } \\
\text { (g) }\end{array}$ & $\begin{array}{l}\text { Força } \\
(\mathbf{k N})\end{array}$ & $\begin{array}{c}\text { Tensão - } \\
\text { Área } \\
\text { bruta } \\
\text { (MPa) }\end{array}$ & $\begin{array}{c}\text { Tensão } \\
\text { - Área } \\
\text { líquida } \\
\text { (MPa) }\end{array}$ & $\begin{array}{c}\text { Resistência } \\
\text { característica } \\
\mathrm{f}_{\mathrm{bk}}(\mathrm{MPa})\end{array}$ & $f_{b 28} / f_{b 7}$ \\
\hline \multirow{5}{*}{ B4,5-REF } & Média & \multirow{5}{*}{28} & 10392 & 440 & 10,84 & 18,53 & \multirow{5}{*}{9,29} & \multirow{5}{*}{1,26} \\
\hline & Máximo & & 10482 & 476 & 11,73 & 20,05 & & \\
\hline & Mínimo & & 10330 & 424 & 10,44 & 17,85 & & \\
\hline & D. Padrão & & 66 & 19 & 0,47 & 0,81 & & \\
\hline & C.Variação & & $0,64 \%$ & $4,63 \%$ & $4,36 \%$ & $4,36 \%$ & & \\
\hline \multirow{5}{*}{$\begin{array}{c}\text { B4,5-RGV- } \\
100 \%\end{array}$} & Média & \multirow{5}{*}{28} & 9850 & 364 & 8,96 & 15,23 & \multirow{5}{*}{7,61} & \multirow{5}{*}{1,19} \\
\hline & Máximo & & 10006 & 394 & 9,71 & 16,51 & & \\
\hline & Mínimo & & 9722 & 340 & 8,38 & 14,26 & & \\
\hline & D. Padrão & & 103 & 21 & 0,52 & 0,88 & & \\
\hline & C.Variação & & $1,04 \%$ & $5,77 \%$ & $5,77 \%$ & $5,77 \%$ & & \\
\hline \multirow{5}{*}{$\begin{array}{c}\text { B4,5-RGV- } \\
50 \%\end{array}$} & Média & \multirow{5}{*}{28} & 10004 & 341 & 8,39 & 14,24 & \multirow{5}{*}{6,38} & \multirow{5}{*}{1,19} \\
\hline & Máximo & & 10154 & 407 & 10,03 & 17,02 & & \\
\hline & Mínimo & & 9836 & 290 & 7,15 & 12,14 & & \\
\hline & D. Padrão & & 125 & 41 & 1,01 & 1,72 & & \\
\hline & C.Variação & & $1,25 \%$ & $12,06 \%$ & $12,06 \%$ & $12,06 \%$ & & \\
\hline \multirow{5}{*}{$\begin{array}{c}\text { B4,5-RMV- } \\
33 \%\end{array}$} & Média & \multirow{5}{*}{28} & 10076 & 307 & 7,56 & 12,90 & \multirow{5}{*}{5,59} & \multirow{5}{*}{1,36} \\
\hline & Máximo & & 10181 & 343 & 8,46 & 14,43 & & \\
\hline & Mínimo & & 9946 & 243 & 6,00 & 10,23 & & \\
\hline & D. Padrão & & 78 & 35 & 0,87 & 1,48 & & \\
\hline & C.Variação & & $0,77 \%$ & $11,49 \%$ & $11,49 \%$ & $11,49 \%$ & & \\
\hline \multirow{5}{*}{$\begin{array}{c}\text { B4,5-RGB- } \\
50 \%\end{array}$} & Média & \multirow{5}{*}{28} & 10010 & 364 & 8,96 & 15,24 & \multirow{5}{*}{7,15} & \multirow{5}{*}{1,28} \\
\hline & Máximo & & 10205 & 410 & 10,11 & 17,19 & & \\
\hline & Mínimo & & 9840 & 302 & 7,43 & 12,64 & & \\
\hline & D. Padrão & & 153 & 42 & 1,04 & 1,77 & & \\
\hline & C.Variação & & $1,53 \%$ & $11,61 \%$ & $11,61 \%$ & $11,61 \%$ & & \\
\hline \multirow{5}{*}{$\begin{array}{c}\text { B4,5-RMB- } \\
33 \%\end{array}$} & Média & \multirow{5}{*}{28} & 10127 & 268 & 6,60 & 11,09 & \multirow{5}{*}{4,86} & \multirow{5}{*}{1,24} \\
\hline & Máximo & & 10357 & 310 & 7,63 & 12,82 & & \\
\hline & Mínimo & & 9846 & 222 & 5,46 & 9,17 & & \\
\hline & D. Padrão & & 173 & 35 & 0,86 & 1,45 & & \\
\hline & C.Variação & & $1,71 \%$ & $13,08 \%$ & $13,08 \%$ & $13,08 \%$ & & \\
\hline
\end{tabular}


Pela Tabela 7.38, observa-se que todos os resultados apresentaram um coeficiente de variação aceitável, inferior a $15 \%$. Todas as unidades apresentaram valores característicos de resistência à compressão que se enquadraram na classe de blocos estruturais de 4,5 MPa; as unidades dos traços com agregados graúdos reciclados podem até ser enquadradas na classe de blocos estruturais de 6,0 MPa; já as unidades de referência podem ser enquadrados na classe de blocos estruturais de 8,0 MPa.

A produção das unidades com agregados miúdos reciclados (B4,5-RMV-33\% e B4,5-RMB-33\%), apesar de terem alcançado a resistência característica pretendida de 4,5 $\mathrm{MPa}$, apresentaram uma redução média de 30\% e 39\%, em relação ao traço de referência (7 dias). Nos resultados dos CPs cilíndricos, foi relatado que a produção das unidades com agregados reciclados seria viabilizada desde que a redução na resistência fosse de até, no máximo, $20 \%$ em relação aos resultados das unidades de referência. Outro ponto fundamental refere-se à redução considerável da coesão da mistura com a incorporação da fração miúda reciclada, fato esse que conduziu a um grande número de unidades com cantos quebrados, fissuras e blocos rejeitados durante a produção, Figura 7.29.

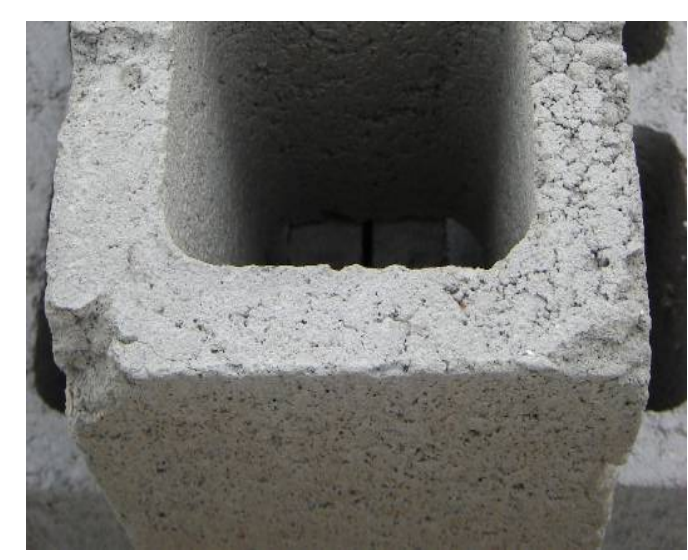

B4,5-RMV-33\%
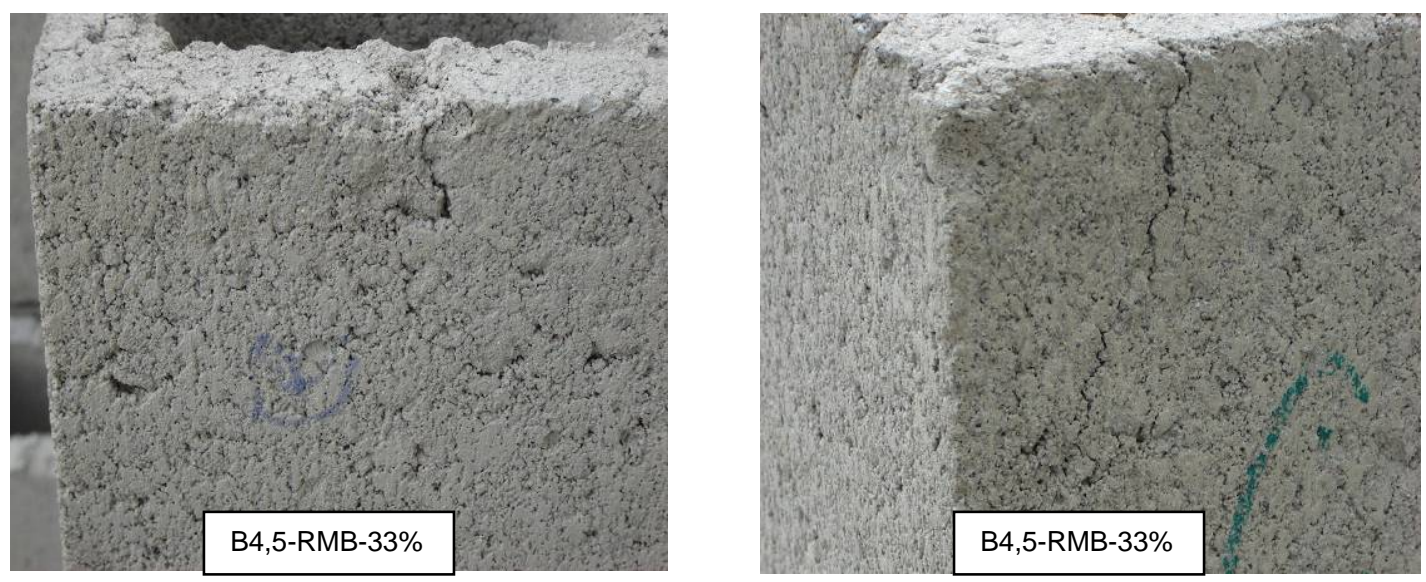

Figura 7.29 - Fissuras e cantos quebrados nas unidades com agregados miúdos reciclados. 
Devido aos motivos relatados anteriormente, as unidades do Grupo 4,5 com agregados miúdos reciclados não serão avaliadas nas próximas etapas do trabalho. Os ensaios de compressão de prismas de três blocos e miniparedes bem como os de retração de miniparedes não serão realizados para essas unidades.

Na Tabela 7.39, são apresentadas as previsões de resistência das unidades através da correlação com os corpos-de-prova cilíndricos produzidos anteriormente no laboratório, os resultados reais obtidos pelos blocos e o coeficiente de correlação real encontrado para essas unidades (CPs/blocos).

Tabela 7.39 - Coeficientes de correlação considerando os resultados dos CPs e dos blocos aos vinte e oito dias - Grupo 4,5.

\begin{tabular}{|c|c|c|c|c|c|c|c|}
\hline \multirow{3}{*}{ Traços } & \multirow{3}{*}{$\begin{array}{c}\text { Consumo } \\
\text { de } \\
\text { cimento- } \\
\text { CPs } \\
\left(\mathbf{k g} / \mathbf{m}^{3}\right)\end{array}$} & \multirow{3}{*}{$\begin{array}{l}\text { Resistência } \\
\text { dos CPs } \\
\text { (MPa) }\end{array}$} & \multirow{2}{*}{\multicolumn{2}{|c|}{$\begin{array}{c}\text { Previsão da } \\
\text { resistência das } \\
\text { unidades (MPa) } \\
\text { Coeficiente de } \\
\text { correlação }\end{array}$}} & \multirow{3}{*}{$\begin{array}{c}\text { Consumo } \\
\text { de } \\
\text { cimento - } \\
\text { blocos } \\
\left(\mathrm{kg} / \mathrm{m}^{3}\right)\end{array}$} & \multirow{3}{*}{$\begin{array}{c}\text { Resistência } \\
\text { das } \\
\text { unidades } \\
\text { (MPa) }\end{array}$} & \multirow{3}{*}{$\begin{array}{c}\text { Coeficiente de } \\
\text { correlação } \\
\text { encontrado } \\
\text { (CPs/blocos) }\end{array}$} \\
\hline & & & & & & & \\
\hline & & & 0,80 & 1,30 & & & \\
\hline REF & 116,4 & 18,84 & 13,54 & 8,33 & 122,0 & 10,84 & 1,00 \\
\hline RGV-100\% & 116,4 & 16,28 & 11,70 & 7,20 & 118,7 & 8,96 & 1,04 \\
\hline RGV-50\% & 116,4 & 17,86 & 12,84 & 7,90 & 118,5 & 8,39 & 1,22 \\
\hline RGB-50\% & 116,4 & 16,20 & 11,64 & 7,17 & 118,3 & 8,96 & 1,04 \\
\hline
\end{tabular}

Analisando-se a Tabela 7.39, nota-se que os resultados dos CPs forneceram um razoável parâmetro para a previsão da resistência das unidades, uma vez que o coeficiente de correlação situou-se dentro do intervalo proposto $(0,80$ - 1,30). Devido ao processo de cura, os CPs (cura úmida) apresentaram um aumento médio de cerca de $38 \%$ na resistência à compressão aos 28 dias e as unidades (submetidas a cura térmica) apresentaram um aumento médio de $23 \%$, comparativamente aos valores de resistência aos sete dias.

$\mathrm{Na}$ Tabela 7.40, encontram-se os resultados de resistência à compressão das unidades para idades superiores a cem dias e a comparação com os resultados obtidos aos vinte e oito dias. Foram avaliadas três unidades que se encontravam na condição seca ao ar. Deve-se ressaltar que esses ensaios foram realizados com o intuito de comparar os valores de resistência das unidades com os valores obtidos para prismas de três blocos, os quais foram ensaiados na mesma data. Nessa etapa, não foram ensaiados blocos com agregados miúdos reciclados do Grupo 4,5, uma vez que, conforme já relatado, não foram produzidos prismas com essas unidades. 
Tabela 7.40 - Resultados de resistência à compressão para idades superiores a cem dias.

\begin{tabular}{|c|c|c|c|c|c|c|c|c|}
\hline Unidades & Parâmetros & $\begin{array}{l}\text { Idade } \\
\text { (dias) }\end{array}$ & $\begin{array}{c}\text { Massa da } \\
\text { unidade } \\
(g)\end{array}$ & $\begin{array}{c}\text { Força } \\
\text { (kN) }\end{array}$ & $\begin{array}{c}\text { Tensão - } \\
\text { Área } \\
\text { bruta } \\
\text { (MPa) } \\
\end{array}$ & $\begin{array}{c}\text { Tensão } \\
\text { - Área } \\
\text { líquida } \\
\text { (MPa) } \\
\end{array}$ & $\begin{array}{c}\mathbf{f}_{\mathrm{b}} / \\
\mathrm{fb}_{\mathrm{c} 28^{*}}\end{array}$ & $\begin{array}{c}\text { Diferença de } \\
\text { massa } \\
\left(m_{c}-m_{28}\right)^{\star *}\end{array}$ \\
\hline \multirow{5}{*}{ B4,5-REF } & Média & \multirow{5}{*}{103} & 10700 & 618 & 15,23 & 25,91 & \multirow{5}{*}{1,40} & \multirow{5}{*}{+308} \\
\hline & Máximo & & 10700 & 634 & 15,62 & 26,57 & & \\
\hline & Mínimo & & 10700 & 606 & 14,92 & 25,37 & & \\
\hline & D. Padrão & & 0 & 15 & 0,36 & 0,61 & & \\
\hline & C.Variação & & $0,00 \%$ & $2,35 \%$ & $2,35 \%$ & $2,35 \%$ & & \\
\hline \multirow{5}{*}{$\begin{array}{c}\text { B4,5-RGV- } \\
100 \%\end{array}$} & Média & \multirow{5}{*}{134} & 9883 & 404 & 9,94 & 16,90 & \multirow{5}{*}{1,11} & \multirow{5}{*}{+33} \\
\hline & Máximo & & 9950 & 439 & 10,81 & 18,38 & & \\
\hline & Mínimo & & 9750 & 378 & 9,31 & 15,84 & & \\
\hline & D. Padrão & & 116 & 32 & 0,78 & 1,32 & & \\
\hline & C.Variação & & $1,17 \%$ & $7,82 \%$ & $7,82 \%$ & $7,82 \%$ & & \\
\hline \multirow{5}{*}{$\begin{array}{c}\text { B4,5-RGV- } \\
50 \%\end{array}$} & Média & \multirow{5}{*}{134} & 9975 & 351 & 8,65 & 14,68 & \multirow{5}{*}{1,03} & \multirow{5}{*}{-29} \\
\hline & Máximo & & 10000 & 376 & 9,26 & 15,72 & & \\
\hline & Mínimo & & 9950 & 326 & 8,04 & 13,65 & & \\
\hline & D. Padrão & & 35 & 35 & 0,86 & 1,46 & & \\
\hline & C.Variação & & $0,35 \%$ & $9,95 \%$ & $9,95 \%$ & $9,95 \%$ & & \\
\hline \multirow{5}{*}{$\begin{array}{c}\text { B4,5-RGB- } \\
50 \%\end{array}$} & Média & \multirow{5}{*}{134} & 10283 & 379 & 9,33 & 15,78 & \multirow{5}{*}{1,04} & \multirow{5}{*}{+273} \\
\hline & Máximo & & 10500 & 416 & 10,25 & 17,35 & & \\
\hline & Mínimo & & 10150 & 342 & 8,41 & 14,23 & & \\
\hline & D. Padrão & & 189 & 37 & 0,92 & 1,56 & & \\
\hline & C.Variação & & $1,84 \%$ & $9,88 \%$ & $9,88 \%$ & $9,88 \%$ & & \\
\hline
\end{tabular}

* relação entre os resultados de resistência na idade considerada $\left(f_{b}\right)$ e aos vinte e oito dias ( $\left.f_{b 28}\right)$

** diferença de massa das unidades na idade considerada $\left(m_{c}\right)$ e aos vinte e oito dias $\left(m_{28}\right)$

Analisando-se os resultados da Tabela 7.40, nota-se que as unidades de referência apresentaram um aumento expressivo de resistência, comparativamente aos 28 dias, aproximadamente 40\%; enquanto que, para as unidades com agregados reciclados, 0 aumento médio foi inferior a 10\%. Podem ser enumeradas algumas razões para esse comportamento: a) as unidades de referência apresentaram um aumento atípico de massa, relativamente às unidades ensaiadas aos vinte e oito dias, superior a $300 \mathrm{~g}$; fato esse que não foi observado para os blocos com agregados reciclados de vigota. A elevação da massa pode ter ocasionado um aumento expressivo da resistência das unidades de referência, devido à sua maior compacidade e menor índice de vazios comparativamente às unidades ensaiadas aos 28 dias; b) a elevada absorção do agregado reciclado pode ter provocado a mobilização de água da matriz de cimento em direção às partículas de agregado; dessa maneira, não houve disponibilidade suficiente de umidade (água) na matriz para hidratar as partículas de cimento remanescentes, fato esse que não ocorreu com as unidades de referência.

\subsection{Grupo 8,0}

Os resultados de resistência à compressão são apresentados na Tabela 7.41. 
Tabela 7.41 - Resistência à compressão das unidades aos sete dias - Grupo 8,0.

\begin{tabular}{|c|c|c|c|c|c|c|c|}
\hline Unidades & Parâmetros & $\begin{array}{l}\text { Idade } \\
\text { (dias) }\end{array}$ & $\begin{array}{l}\text { Massa da } \\
\text { unidade (g) }\end{array}$ & Força (kN) & $\begin{array}{l}\text { Tensão - } \\
\text { Área bruta } \\
\text { (MPa) }\end{array}$ & $\begin{array}{l}\text { Tensão - } \\
\text { Área } \\
\text { líquida } \\
\text { (MPa) }\end{array}$ & $\begin{array}{c}\text { Resistência } \\
\text { característica } \\
\mathrm{f}_{\mathrm{bk}}(\mathrm{MPa})\end{array}$ \\
\hline \multirow{5}{*}{ B8,0-REF } & Média & \multirow{5}{*}{7} & 10264 & 408 & 10,04 & 17,23 & \multirow{5}{*}{7,66} \\
\hline & Máximo & & 10434 & 457 & 11,24 & 19,29 & \\
\hline & Mínimo & & 10135 & 350 & 8,61 & 14,77 & \\
\hline & D. Padrão & & 136 & 42 & 1,02 & 1,75 & \\
\hline & C.Variação & & $1,32 \%$ & $10,18 \%$ & $10,18 \%$ & $10,18 \%$ & \\
\hline \multirow{5}{*}{ B8,0-RGV-100\% } & Média & \multirow{5}{*}{7} & 9897 & 423 & 10,42 & 17,96 & \multirow{5}{*}{8,48} \\
\hline & Máximo & & 10084 & 469 & 11,55 & 19,92 & \\
\hline & Mínimo & & 9695 & 367 & 9,03 & 15,57 & \\
\hline & D. Padrão & & 126 & 36 & 0,89 & 1,53 & \\
\hline & C.Variação & & $1,28 \%$ & $8,52 \%$ & $8,52 \%$ & $8,52 \%$ & \\
\hline \multirow{5}{*}{ B8,0-RGV-50\% } & Média & \multirow{5}{*}{7} & 10081 & 367 & 9,05 & 15,41 & \multirow{5}{*}{7,23} \\
\hline & Máximo & & 10245 & 424 & 10,45 & 17,80 & \\
\hline & Mínimo & & 9947 & 310 & 7,63 & 13,00 & \\
\hline & D. Padrão & & 114 & 42 & 1,04 & 1,77 & \\
\hline & C.Variação & & $1,13 \%$ & $11,48 \%$ & $11,48 \%$ & $11,48 \%$ & \\
\hline \multirow{5}{*}{ B8,0-RMV-33\% } & Média & \multirow{5}{*}{7} & 10043 & 357 & 8,79 & 15,21 & \multirow{5}{*}{7,16} \\
\hline & Máximo & & 10330 & 450 & 11,08 & 19,17 & \\
\hline & Mínimo & & 9841 & 297 & 7,31 & 12,65 & \\
\hline & D. Padrão & & 204 & 64 & 1,58 & 2,73 & \\
\hline & C.Variação & & $2,03 \%$ & $17,95 \%$ & $17,95 \%$ & $17,95 \%$ & \\
\hline \multirow{5}{*}{ B8,0-RGB-50\% } & Média & \multirow{5}{*}{7} & 10206 & 404 & 9,96 & 17,02 & \multirow{5}{*}{8,46} \\
\hline & Máximo & & 10349 & 425 & 10,46 & 17,89 & \\
\hline & Mínimo & & 9973 & 379 & 9,33 & 15,94 & \\
\hline & D. Padrão & & 135 & 22 & 0,55 & 0,95 & \\
\hline & C.Variação & & $1,32 \%$ & $5,55 \%$ & $5,55 \%$ & $5,55 \%$ & \\
\hline \multirow{5}{*}{ B8,0-RMB-33\% } & Média & \multirow{5}{*}{7} & 10138 & 311 & 7,65 & 12,88 & \multirow{5}{*}{6,10} \\
\hline & Máximo & & 10314 & 349 & 8,58 & 14,45 & \\
\hline & Mínimo & & 9816 & 269 & 6,63 & 11,16 & \\
\hline & D. Padrão & & 172 & 33 & 0,82 & 1,39 & \\
\hline & C.Variação & & $1,69 \%$ & $10,76 \%$ & $10,76 \%$ & $10,76 \%$ & \\
\hline
\end{tabular}

Pela Tabela 7.41, nota-se que todos os resultados, com exceção dos relativos às unidades do traço B8,0-RMV-33\%, apresentaram um coeficiente de variação aceitável, inferior a 15\%. A variação representativa da massa das unidades do traço B8,0-RMV-33\% pode ser enumerada como uma das causas da variabilidade dos seus resultados de resistência; segundo Frasson Junior (2000), blocos de concreto que possuam a mesma geometria e utilizam a mesma mistura podem ter resistências muito diferentes, caso a massa incorporada nos moldes seja maior ou menor. Todas as unidades, com exceção dos blocos dos traços B8,0-RGV-100\% e B8,0-RGB-50\%, apresentaram valores de resistência característica à compressão $\left(\mathrm{f}_{\mathrm{bk}}\right)$ inferiores ao recomendado para blocos estruturais da classe 8,0 MPa. Possivelmente, o elevado coeficiente de variação dos resultados de resistência à compressão (> 10\%) observado para as unidades (B8,0-REF, B8,0-RGV-50\%, B8,0-RMV-33\% e B8,0-RMB-33\%) contribuiu para esses resultados.

Na Tabela 7.42, são apresentadas as previsões de resistência das unidades através da correlação com os corpos-de-prova cilíndricos produzidos anteriormente no laboratório, os resultados reais obtidos pelos blocos e o coeficiente de correlação real encontrado para essas unidades (CPs/blocos). É evidente que as diferenças existentes entre a produção dos CPs e blocos são inúmeras, tais como, elevada variabilidade na produção dos blocos, 
tempos de produção variáveis (energia de adensamento) e controle deficitário da umidade dos materiais.

Tabela 7.42 - Coeficientes de correlação considerando os resultados dos CPs e dos blocos aos sete dias - Grupo 8,0.

\begin{tabular}{|c|c|c|c|c|c|c|c|}
\hline \multirow{3}{*}{ Traços } & \multirow{3}{*}{$\begin{array}{c}\text { Consumo } \\
\text { de } \\
\text { cimento - } \\
\text { CPs } \\
\left(\mathrm{kg} / \mathrm{m}^{3}\right)\end{array}$} & \multirow{3}{*}{$\begin{array}{c}\text { Resistência } \\
\text { dos CPs } \\
(M P a)\end{array}$} & \multirow{2}{*}{\multicolumn{2}{|c|}{$\begin{array}{l}\text { Previsão da } \\
\text { resistência das } \\
\text { unidades (MPa) } \\
\text { Coeficiente de } \\
\text { correlação }\end{array}$}} & \multirow{3}{*}{$\begin{array}{c}\text { Consumo } \\
\text { de } \\
\text { cimento - } \\
\text { blocos } \\
\left(\mathrm{kg} / \mathrm{m}^{3}\right)\end{array}$} & \multirow{3}{*}{$\begin{array}{c}\text { Resistência } \\
\text { das } \\
\text { unidades } \\
(\mathrm{MPa})\end{array}$} & \multirow{3}{*}{$\begin{array}{l}\text { Coeficiente de } \\
\text { correlação } \\
\text { encontrado } \\
\text { (CPs/blocos) }\end{array}$} \\
\hline & & & & & & & \\
\hline & & & 0,80 & 1,30 & & & \\
\hline REF & 153,0 & 20,80 & 14,95 & 9,20 & 154,0 & 10,04 & 1,19 \\
\hline RG V-100\% & 153,0 & 18,17 & 13,06 & 8,04 & 152,0 & 10,42 & 1,00 \\
\hline RG V-50\% & 153,0 & 20,59 & 14,80 & 9,11 & 152,0 & 9,05 & 1,31 \\
\hline RGB-50\% & 153,0 & 20,13 & 14,47 & 8,90 & 155,0 & 9,96 & 1,16 \\
\hline
\end{tabular}

Analisando-se a Tabela 7.42, nota-se que os resultados dos CPs forneceram um razoável parâmetro para a previsão da resistência das unidades; o coeficiente de correlação médio foi igual a 1,16. Conforme já relatado, torna-se difícil o estabelecimento de um coeficiente de correlação único, visto que o processo de produção dos blocos de concreto apresenta uma variabilidade muito grande em comparação com a produção dos corpos-deprova no laboratório (dosagem em volume, homogeneização da massa no misturador, regulagem dos tempos de produção e definição da umidade da mistura). Os resultados de resistência à compressão das unidades aos vinte e oito dias são apresentados na Tabela 7.43 . 
Tabela 7.43 - Resistência à compressão das unidades aos vinte e oito dias - Grupo 8,0.

\begin{tabular}{|c|c|c|c|c|c|c|c|c|}
\hline Unidades & Parâmetros & $\begin{array}{l}\text { Idade } \\
\text { (dias) }\end{array}$ & $\begin{array}{c}\text { Massa da } \\
\text { unidade } \\
\text { (g) }\end{array}$ & $\begin{array}{c}\text { Força } \\
\text { (kN) }\end{array}$ & $\begin{array}{l}\text { Tensão - } \\
\text { Área } \\
\text { bruta } \\
\text { (MPa) }\end{array}$ & $\begin{array}{c}\text { Tensão } \\
\text { - Área } \\
\text { líquida } \\
\text { (MPa) }\end{array}$ & $\begin{array}{c}\text { Resistência } \\
\text { característica } \\
\text { f }_{\mathrm{bk}}(\mathrm{MPa})\end{array}$ & $\mathbf{f}_{\mathrm{b} 28} / \mathbf{f}_{\mathrm{b} 7}$ \\
\hline \multirow{5}{*}{ B8,0-REF } & Média & & 10271 & 519 & 12,79 & 21,94 & \multirow{5}{*}{9,92} & \multirow{5}{*}{1,27} \\
\hline & Máximo & & 10449 & 567 & 13,96 & 23,94 & & \\
\hline & Mínimo & 28 & 10048 & 432 & 10,64 & 18,26 & & \\
\hline & D. Padrão & & 152 & 51 & 1,26 & 2,17 & & \\
\hline & C.Variação & & $1,48 \%$ & $9,87 \%$ & $9,87 \%$ & $9,87 \%$ & & \\
\hline \multirow{5}{*}{$\begin{array}{c}\text { B8,0-RGV- } \\
100 \%\end{array}$} & Média & \multirow{5}{*}{28} & 9820 & 499 & 12,29 & 21,20 & \multirow{5}{*}{10,41} & \multirow{5}{*}{1,18} \\
\hline & Máximo & & 9964 & 531 & 13,07 & 22,53 & & \\
\hline & Mínimo & & 9546 & 450 & 11,09 & 19,12 & & \\
\hline & D. Padrão & & 144 & 32 & 0,79 & 1,36 & & \\
\hline & C.Variação & & $1,47 \%$ & $6,41 \%$ & $6,41 \%$ & $6,41 \%$ & & \\
\hline \multirow{5}{*}{$\begin{array}{c}\text { B8,0-RGV- } \\
50 \%\end{array}$} & Média & \multirow{5}{*}{28} & 10144 & 479 & 11,80 & 20,10 & \multirow{5}{*}{10,03} & \multirow{5}{*}{1,30} \\
\hline & Máximo & & 10210 & 504 & 12,42 & 21,16 & & \\
\hline & Mínimo & & 10088 & 453 & 11,16 & 19,01 & & \\
\hline & D. Padrão & & 42 & 20 & 0,49 & 0,84 & & \\
\hline & C.Variação & & $0,41 \%$ & $4,19 \%$ & $4,19 \%$ & $4,19 \%$ & & \\
\hline \multirow{5}{*}{$\begin{array}{c}\text { B8,0-RMV- } \\
33 \%\end{array}$} & Média & \multirow{5}{*}{28} & 10146 & 457 & 11,25 & 19,47 & \multirow{5}{*}{8,91} & \multirow{5}{*}{1,28} \\
\hline & Máximo & & 10406 & 497 & 12,23 & 21,17 & & \\
\hline & Mínimo & & 9883 & 365 & 8,98 & 15,54 & & \\
\hline & D. Padrão & & 171 & 48 & 1,17 & 2,03 & & \\
\hline & C.Variação & & $1,68 \%$ & $10,40 \%$ & $10,40 \%$ & $10,40 \%$ & & \\
\hline \multirow{5}{*}{$\begin{array}{c}\text { B8,0-RGB- } \\
50 \%\end{array}$} & Média & \multirow{5}{*}{28} & 10081 & 543 & 13,39 & 22,88 & \multirow{5}{*}{10,30} & \multirow{5}{*}{1,34} \\
\hline & Máximo & & 10280 & 581 & 14,31 & 24,46 & & \\
\hline & Mínimo & & 9890 & 470 & 11,57 & 19,78 & & \\
\hline & D. Padrão & & 162 & 46 & 1,12 & 1,92 & & \\
\hline & C.Variação & & $1,62 \%$ & $8,37 \%$ & $8,37 \%$ & $8,37 \%$ & & \\
\hline \multirow{5}{*}{$\begin{array}{c}\text { B8,0-RMB- } \\
33 \%\end{array}$} & Média & \multirow{5}{*}{28} & 10186 & 431 & 10,62 & 17,87 & \multirow{5}{*}{9,02} & \multirow{5}{*}{1,39} \\
\hline & Máximo & & 10458 & 462 & 11,46 & 19,30 & & \\
\hline & Mínimo & & 9859 & 386 & 9,52 & 17,19 & & \\
\hline & D. Padrão & & 244 & 31 & 0,76 & 1,28 & & \\
\hline & C.Variação & & $2,39 \%$ & $7,18 \%$ & $7,18 \%$ & $7,18 \%$ & & \\
\hline
\end{tabular}

Pela Tabela 7.43, nota-se que todos os resultados apresentaram um coeficiente de variação aceitável, inferior a 15\%. A relação entre os resultados de resistência à compressão $\left(\mathrm{f}_{\mathrm{b} 28} / \mathrm{f}_{\mathrm{b} 7}\right)$ ficou com o valor médio de 1,29; possivelmente, o menor aumento relativo registrado para as unidades do traço B8,0-RGV-100\% pode ter sido provocado pela redução da massa média dos blocos em relação à massa das unidades que foram ensaiadas aos sete dias. Todas as unidades apresentaram valores de resistência característica à compressão que se enquadraram na classe de blocos estruturais de 8,0 $\mathrm{MPa}$; inclusive, com os resultados obtidos aos 28 dias, as unidades com agregados graúdos reciclados podem ser enquadradas na classe de blocos estruturais de 10,0 MPa.

Para as unidades do traço B8,0-RMB-33\% observa-se que a inclusão da fração miúda reciclada acarretou uma redução significativa da resistência à compressão, cerca de $21 \%$, em relação às unidades do traço B8,0-RGB-50\%; conforme já relatado, a inclusão da fração miúda reciclada de bloco provocou uma diminuição da coesão da mistura e, consequentemente, redução da resistência e presença de fissuração em algumas unidades, Figura 7.30. 

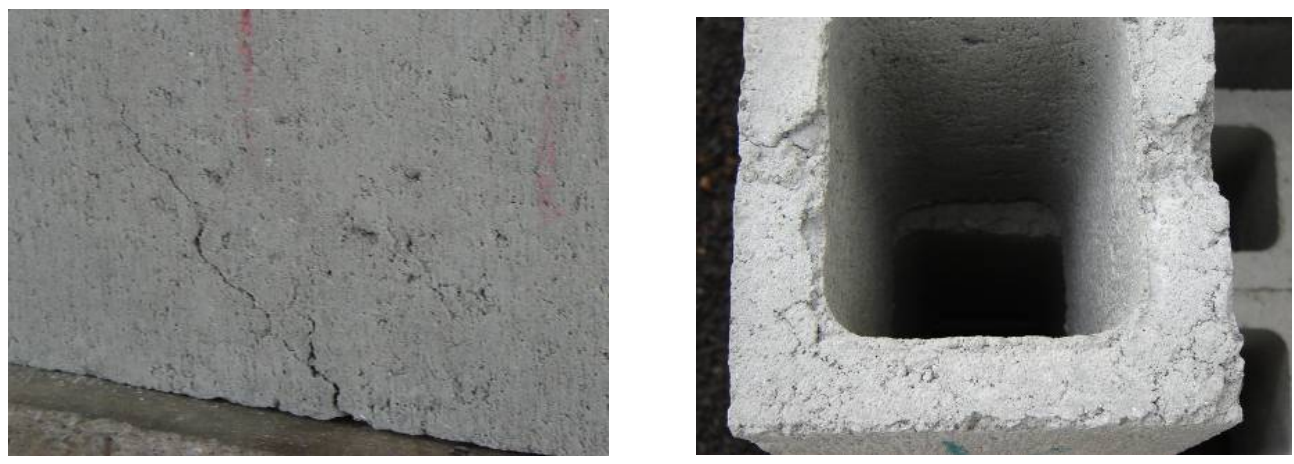

Figura 7.30 - Fissuras e cantos quebrados em algumas unidades do traço B8,0-RMB-33\% ocasionadas pela falta de coesão e pela umidade excessiva da mistura.

Na Tabela 7.44, são apresentadas as previsões de resistência das unidades através da correlação com os corpos-de-prova cilíndricos produzidos no laboratório e os resultados reais obtidos pelas unidades.

Tabela 7.44 - Coeficientes de correlação considerando os resultados dos CPs e dos blocos aos vinte e oito dias - Grupo 8,0.

\begin{tabular}{|c|c|c|c|c|c|c|c|}
\hline \multirow{3}{*}{ Traços } & \multirow{3}{*}{$\begin{array}{c}\text { Consumo } \\
\text { de } \\
\text { cimento- } \\
\text { CPs } \\
\left(\mathbf{k g} / \mathbf{m}^{3}\right)\end{array}$} & \multirow{3}{*}{$\begin{array}{c}\text { Resistência } \\
\text { dos CPs } \\
\text { (MPa) }\end{array}$} & \multirow{2}{*}{\multicolumn{2}{|c|}{$\begin{array}{c}\text { Previsão da } \\
\text { resistência das } \\
\text { unidades (MPa) } \\
\begin{array}{c}\text { Coeficiente de } \\
\text { correlação }\end{array}\end{array}$}} & \multirow{3}{*}{$\begin{array}{c}\text { Consumo } \\
\text { de } \\
\text { cimento - } \\
\text { blocos } \\
\left(\mathbf{k g} / \mathbf{m}^{3}\right)\end{array}$} & \multirow{3}{*}{$\begin{array}{l}\text { Resistência } \\
\text { real das } \\
\text { unidades } \\
(\mathrm{MPa})\end{array}$} & \multirow{3}{*}{$\begin{array}{c}\text { Coeficiente de } \\
\text { correlação } \\
\text { encontrado } \\
\text { (CPs/blocos) }\end{array}$} \\
\hline & & & & & & & \\
\hline & & & 0,80 & 1,30 & & & \\
\hline REF & 153,0 & 29,90 & 21,49 & 13,23 & 154,0 & 12,79 & 1,34 \\
\hline RGV-100\% & 153,0 & 22,43 & 16,12 & 9,92 & 152,0 & 12,29 & 1,05 \\
\hline RGV-50\% & 153,0 & 27,18 & 19,54 & 12,02 & 152,0 & 11,80 & 1,32 \\
\hline RGB-50\% & 153,0 & 25,77 & 18,52 & 11,40 & 155,0 & 13,39 & 1,11 \\
\hline
\end{tabular}

Analisando-se a Tabela 7.44, nota-se que os resultados dos CPs forneceram um razoável parâmetro para a previsão da resistência das unidades; o coeficiente de correlação médio foi igual a 1,20. Barbosa (2004) que correlacionou a resistência à compressão de corpos-de-prova cilíndricos ( $5 \mathrm{~cm} \times 10 \mathrm{~cm})$ com blocos de concreto $(14 \mathrm{~cm} \times 19 \mathrm{~cm} \times 39 \mathrm{~cm})$, encontrou um intervalo entre 1,13 a 1,31 para a relação da resistência dos CPs pela resistência dos blocos. Conforme já relatado, torna-se difícil o estabelecimento de um coeficiente de correlação unívoco, visto que o processo de produção dos blocos de concreto apresenta uma variabilidade muito grande em comparação com a produção dos corpos-deprova no laboratório (dosagem em volume, homogeneização deficiente da massa no misturador, regulagem distinta dos tempos de produção e definição da umidade da mistura 
de maneira deficitária). Na Tabela 7.45, são apresentados os resultados de resistência à compressão para idades superiores a cem dias.

Tabela 7.45 - Resistência à compressão das unidades para idades superiores a cem dias Grupo 8,0.

\begin{tabular}{|c|c|c|c|c|c|c|c|c|}
\hline Unidades & Parâmetros & $\begin{array}{l}\text { Idade } \\
\text { (dias) }\end{array}$ & $\begin{array}{c}\text { Massa da } \\
\text { unidade } \\
\text { (g) }\end{array}$ & $\begin{array}{l}\text { Força } \\
\text { (kN) }\end{array}$ & $\begin{array}{c}\text { Tensão - } \\
\text { Área } \\
\text { bruta } \\
\text { (MPa) }\end{array}$ & $\begin{array}{c}\text { Tensão } \\
\text { - Área } \\
\text { líquida } \\
\text { (MPa) }\end{array}$ & $\mathbf{f}_{\mathrm{c}} / \mathbf{f}_{\mathrm{c} 28^{*}}$ & $\begin{array}{c}\text { Diferença de } \\
\text { massa } \\
\left(m_{c}-m_{28}\right)^{\star *}\end{array}$ \\
\hline \multirow{5}{*}{ B8,0-REF } & Média & \multirow{5}{*}{126} & 10367 & 591 & 14,55 & 24,96 & \multirow{5}{*}{1,14} & \multirow{5}{*}{+96} \\
\hline & Máximo & & 10500 & 652 & 16,06 & 27,54 & & \\
\hline & Mínimo & & 10250 & 512 & 12,61 & 21,63 & & \\
\hline & D. Padrão & & 126 & 72 & 1,77 & 3,03 & & \\
\hline & C.Variação & & $1,21 \%$ & $12,14 \%$ & $12,14 \%$ & $12,14 \%$ & & \\
\hline \multirow{5}{*}{ B8,0-RGV-100\% } & Média & \multirow{5}{*}{126} & 9867 & 634 & 15,61 & 26,92 & \multirow{5}{*}{1,27} & \multirow{5}{*}{+47} \\
\hline & Máximo & & 9950 & 669 & 16,47 & 28,39 & & \\
\hline & Mínimo & & 9800 & 567 & 13,97 & 24,09 & & \\
\hline & D. Padrão & & 76 & 58 & 1,42 & 2,45 & & \\
\hline & C.Variação & & $0,77 \%$ & $9,09 \%$ & $9,09 \%$ & $9,09 \%$ & & \\
\hline \multirow{5}{*}{ B8,0-RGV-50\% } & Média & \multirow{5}{*}{133} & 10100 & 558 & 13,75 & 23,42 & \multirow{5}{*}{1,17} & \multirow{5}{*}{-44} \\
\hline & Máximo & & 10150 & 597 & 14,69 & 25,03 & & \\
\hline & Mínimo & & 10050 & 517 & 12,73 & 21,68 & & \\
\hline & D. Padrão & & 50 & 40 & 0,98 & 1,68 & & \\
\hline & C.Variação & & $0,50 \%$ & $7,15 \%$ & $7,15 \%$ & $7,15 \%$ & & \\
\hline \multirow{5}{*}{ B8,0-RMV-33\% } & Média & \multirow{5}{*}{134} & 10200 & 549 & 13,53 & 23,41 & \multirow{5}{*}{1,20} & \multirow{5}{*}{+54} \\
\hline & Máximo & & 10400 & 561 & 13,83 & 23,92 & & \\
\hline & Mínimo & & 10000 & 528 & 13,01 & 22,51 & & \\
\hline & D. Padrão & & 200 & 18 & 0,45 & 0,78 & & \\
\hline & C.Variação & & $1,96 \%$ & $3,32 \%$ & $3,32 \%$ & $3,32 \%$ & & \\
\hline \multirow{5}{*}{ B8,0-RGB-50\% } & Média & \multirow{5}{*}{136} & 10133 & 611 & 15,05 & 25,72 & \multirow{5}{*}{1,12} & \multirow{5}{*}{+52} \\
\hline & Máximo & & 10200 & 646 & $\begin{array}{l}10,00 \\
15,91\end{array}$ & $\begin{array}{l}24,12 \\
27,19\end{array}$ & & \\
\hline & Mínimo & & 10000 & 552 & 13,61 & 23,26 & & \\
\hline & D. Padrão & & 115 & 51 & $\begin{array}{l}1,25 \\
1,25\end{array}$ & 2,14 & & \\
\hline & C.Variação & & $1,14 \%$ & $8,34 \%$ & $8,34 \%$ & $8,34 \%$ & & \\
\hline \multirow{5}{*}{ B8,0-RMB-33\% } & Média & \multirow{5}{*}{136} & 9917 & 406 & 10,01 & 16,85 & \multirow{5}{*}{0,94} & \multirow{5}{*}{-269} \\
\hline & Máximo & & 10150 & 443 & 10,90 & 18,35 & & \\
\hline & Mínimo & & 9800 & 387 & 9,54 & 16,06 & & \\
\hline & D. Padrão & & 202 & 31 & 0,77 & 1,30 & & \\
\hline & C.Variação & & $2,04 \%$ & $7,70 \%$ & $7,70 \%$ & $7,70 \%$ & & \\
\hline
\end{tabular}

Analisando-se os resultados da Tabela 7.45, nota-se que todas as unidades, com exceção dos blocos do traço B8,0-RMB-33\%, apresentaram um aumento de resistência, comparativamente aos 28 dias, situado entre 12\% e 27\%. Para essas unidades também pode ser observado que não houve diferença significativa na sua massa comparativamente ao valor encontrado aos vinte e oito dias. Por outro lado, para as unidades do traço B8,0RMB-33\%, ocorreu uma redução atípica de $269 \mathrm{~g}$ em relação à massa das unidades aos vinte e oito dias; esse fato pode ter provocado a diminuição relativa da resistência na idade considerada (cerca de 6\% comparativamente à resistência aos 28 dias). Presume-se que a redução na massa das unidades prejudique a resistência à compressão, devido à menor compacidade e maiores índices de vazios. Essa variação atípica pode ter ocorrido pela distribuição não uniforme da mistura nos moldes e por pequenas variações nos tempos de vibro-prensagem durante a produção. 


\subsection{Grupo 12,0}

As propriedades mecânicas das unidades do Grupo 12,0 foram influenciadas pela presença da fração reciclada. Outros fatores que influenciaram decisivamente as propriedades mecânicas foram: a) a umidade utilizada na produção das unidades, geralmente, quanto mais elevada a umidade da mistura, maiores são os valores obtidos para as propriedades mecânicas; b) tempos de alimentação e compressão da vibro-prensa, sendo adotados tempos maiores quando da produção das unidades com agregados reciclados de bloco; c) variação na massa dos blocos para um mesmo traço. Conforme já relatado, de acordo com Frasson Junior (2000), para os traços mais ricos, com elevada quantidade de finos, torna-se desejável aumentar os tempos de alimentação e vibração, pois tais misturas possuem grande dificuldade de alimentar os moldes das formas. Dessa maneira, com relação às propriedades mecânicas, é esperado que os traços com agregados reciclados de bloco, principalmente as unidades do traço B12,0-RMB-33\% apresentem os maiores valores comparativamente aos demais traços produzidos.

Os resultados de resistência à compressão aos sete dias são apresentados na Tabela 7.46. Nessa Tabela, também são apresentadas, a relação entre os resultados das unidades do Grupo 12,0 pelos resultados das unidades do Grupo 8,0, bem como a relação entre as massas dessas unidades (Grupo 12,0/Grupo 8,0). 
Tabela 7.46 - Resistência à compressão das unidades aos sete dias - Grupo 12,0.

\begin{tabular}{|c|c|c|c|c|c|c|c|c|c|}
\hline Unidades & Parâmetros & $\begin{array}{l}\text { Idade } \\
\text { (dias) }\end{array}$ & $\begin{array}{c}\text { Massa da } \\
\text { unidade } \\
\text { (g) }\end{array}$ & $\begin{array}{c}\text { Força } \\
(\mathbf{k N})\end{array}$ & $\begin{array}{c}\text { Tensão } \\
\text { - Área } \\
\text { bruta } \\
\text { (MPa) }\end{array}$ & $\begin{array}{c}\text { Tensão } \\
\text { - Área } \\
\text { líquida } \\
\text { (MPa) }\end{array}$ & $\begin{array}{c}\text { Resistência } \\
\text { característica } \\
\text { à } \\
\text { compressão } \\
(\mathrm{MPa})-\mathrm{f}_{\mathrm{bk}}\end{array}$ & $\begin{array}{l}\mathrm{m}_{\text {grupo } 12,0} \\
\mathrm{~m}_{\text {grupo } 8,0^{*}}\end{array}$ & $\begin{array}{l}\left(f_{b} \text { grupo } 12,0\right) / \\
\left(f_{b} \text { grupo } 8,0\right)^{* *}\end{array}$ \\
\hline \multirow{5}{*}{ B12,0-REF } & Média & & 9922 & 450 & 11,09 & 19,18 & \multirow{5}{*}{9,16} & \multirow{5}{*}{$\begin{array}{l}0,967 \\
(-342 g)\end{array}$} & \multirow{5}{*}{1,10} \\
\hline & Máximo & & 10164 & 560 & 13,79 & 23,85 & & & \\
\hline & Mínimo & 7 & 9754 & 377 & 9,29 & 16,08 & & & \\
\hline & D. Padrão & & 154 & 72 & 1,77 & 3,06 & & & \\
\hline & C.Variação & & $1,56 \%$ & $15,96 \%$ & $15,96 \%$ & $15,96 \%$ & & & \\
\hline \multirow{5}{*}{$\begin{array}{c}\text { B12,0- } \\
\text { RGV-100\% }\end{array}$} & Média & \multirow{5}{*}{7} & 9718 & 450 & 11,10 & 19,13 & \multirow{5}{*}{8,34} & \multirow{5}{*}{$\begin{array}{c}0,982 \\
(-179 g)\end{array}$} & \multirow{5}{*}{1,07} \\
\hline & Máximo & & 9817 & 528 & 13,00 & 22,41 & & & \\
\hline & Mínimo & & 9407 & 342 & 8,42 & 14,51 & & & \\
\hline & D. Padrão & & 156 & 61 & 1,50 & 2,59 & & & \\
\hline & C.Variação & & 1,61 & $13,55 \%$ & $13,55 \%$ & $13,55 \%$ & & & \\
\hline \multirow{5}{*}{$\begin{array}{c}\text { B12,0- } \\
\text { RGV-50\% }\end{array}$} & Média & \multirow{5}{*}{7} & 9862 & 492 & 12,12 & 20,93 & \multirow{5}{*}{9,47} & \multirow{5}{*}{$\begin{array}{c}0,978 \\
(-219 \mathrm{~g})\end{array}$} & \multirow{5}{*}{1,34} \\
\hline & Máximo & & 9900 & 524 & 12,92 & 22,31 & & & \\
\hline & Mínimo & & 9778 & 432 & 10,64 & 18,38 & & & \\
\hline & D. Padrão & & 46 & 43 & 1,06 & 1,83 & & & \\
\hline & C.Variação & & $0,47 \%$ & $8,76 \%$ & $8,76 \%$ & $8,76 \%$ & & & \\
\hline \multirow{5}{*}{$\begin{array}{c}\text { B12,0- } \\
\text { RMV-33\% }\end{array}$} & Média & \multirow{5}{*}{7} & 10092 & 506 & 12,47 & 21,89 & \multirow{5}{*}{9,22} & \multirow{5}{*}{$\begin{array}{c}1,005 \\
(+49 g)\end{array}$} & \multirow{5}{*}{1,42} \\
\hline & Máximo & & 10306 & 540 & 13,29 & 23,20 & & & \\
\hline & Mínimo & & 9747 & 421 & 10,36 & 18,18 & & & \\
\hline & D. Padrão & & 190 & 49 & 1,20 & 2,10 & & & \\
\hline & C.Variação & & $1,88 \%$ & $9,60 \%$ & $9,60 \%$ & $9,60 \%$ & & & \\
\hline \multirow{5}{*}{$\begin{array}{c}\text { B12,0- } \\
\text { RGB-50\% }\end{array}$} & Média & \multirow{5}{*}{7} & 9997 & 467 & 11,51 & 19,94 & \multirow{5}{*}{9,78} & \multirow{5}{*}{$\begin{array}{c}0,980 \\
(-209 g)\end{array}$} & \multirow{5}{*}{1,16} \\
\hline & Máximo & & 10144 & 559 & 13,76 & 23,85 & & & \\
\hline & Mínimo & & 9726 & 400 & 9,84 & 17,06 & & & \\
\hline & D. Padrão & & 166 & 55 & 1,36 & 2,36 & & & \\
\hline & C.Variação & & $1,66 \%$ & $11,82 \%$ & $11,82 \%$ & $11,82 \%$ & & & \\
\hline \multirow{5}{*}{$\begin{array}{c}\text { B12,0- } \\
\text { RMB-33\% }\end{array}$} & Média & \multirow{5}{*}{7} & 10486 & 630 & 15,52 & 26,09 & \multirow{5}{*}{13,32} & \multirow{5}{*}{$\begin{array}{c}1,034 \\
(+348 \mathrm{~g})\end{array}$} & \multirow{5}{*}{2,03} \\
\hline & Máximo & & 10926 & 687 & 16,92 & 28,43 & & & \\
\hline & Mínimo & & 10244 & 608 & 14,97 & 25,15 & & & \\
\hline & D. Padrão & & 265 & 29 & 0,72 & 1,20 & & & \\
\hline & C.Variação & & $2,53 \%$ & $4,61 \%$ & $4,61 \%$ & $4,61 \%$ & & & \\
\hline
\end{tabular}

Pela Tabela 7.46, nota-se que todas as unidades, com exceção dos blocos do traço B12,0-RMB-33\%, apresentaram valores de resistência característica à compressão ( $\left.\mathrm{f}_{\mathrm{bk}}\right)$ inferiores ao recomendado para blocos estruturais da classe 12,0 MPa. Provavelmente, o elevado coeficiente de variação dos resultados de resistência à compressão observado para as unidades (B12,0-REF, B12,0-RGV-50\% e B12,0-RGB-50\%) contribuiu para esses resultados. Analisando-se a relação entre os resultados das unidades do Grupo 12,0 pelos resultados das unidades do Grupo 8,0, são estabelecidos os seguintes comentários:

- Para as unidades dos traços B12,0-REF e B12,0-RGV-100\% foi observado um pequeno aumento da resistência à compressão relativamente aos resultados do Grupo 8,0; no entanto, pelo teste "t de Student", essa diferença não foi considerada significativa $(p>0,05)$. A redução significativa da massa das unidades do Grupo 12,0, em relação às unidades do Grupo 8,0, afetou negativamente a resistência das unidades, provavelmente, esse fato foi provocado por uma diferença de umidade entre os traços (as misturas dos traços do Grupo 8,0 apresentaram maior umidade em relação as dosagens do Grupo 12,0). Conforme já relatado, para as unidades dos traços mais ricos também é recomendável à elevação dos tempos de produção. 
- Para as unidades dos traços B12,0-RGV-50\% e B12,0-RGB-50\%, apesar do decréscimo significativo da massa das unidades relativamente às unidades do Grupo 8,0, o acréscimo de resistência das unidades do Grupo 12,0 pode ser considerado significativo, de acordo com o teste "t de Student". Para as unidades do traço B12,0RMV-33\% foi observado um pequeno aumento na massa das unidades, comparativamente às unidades do traço B8,0-RMV-33\%, embora não possa ser considerado significativo $(p>0,05)$. A elevação da resistência das unidades do traço B12,0-RMV-33\%, em relação às unidades do traço B8,0-RMV-33\%, foi considerada significativa de acordo com o teste "t de Student";

- Para as unidades do traço B12,0-RMB-33\% foi observado um aumento significativo da resistência das unidades comparativamente as unidades do traço B8,0-RMB-33\% $(p<0,05)$; possivelmente, devido o aumento significativo da massa das unidades (cerca de $243 \mathrm{~g}$ em relação às unidades do traço B8,0-RMB-33\%), definição correta da umidade da mistura e eliminação dos problemas de coesão da mistura. As unidades do traço B8,0-RMB-33\% apresentaram alguns problemas de coesão que prejudicaram as propriedades mecânicas dessas unidades; já para as unidades do traço mais rico (B12,0-RMB-33\%), apesar da substituição parcial do pó de pedra pela fração miúda reciclada, a quantidade de finos foi elevada devido o maior consumo de cimento.

Na Tabela 7.47, são apresentadas as previsões de resistência das unidades através da correlação com corpos-de-prova cilíndricos produzidos anteriormente no laboratório, os resultados obtidos pelos blocos e o coeficiente de correlação real encontrado para essas unidades (CPs/blocos). É evidente que as diferenças existentes entre a produção dos CPs e blocos são inúmeras, tais como, elevada variabilidade na produção dos blocos, tempos de produção variáveis (energia de adensamento) e controle deficitário da umidade dos materiais.

Tabela 7.47 - Resistências reais das unidades do Grupo 12,0 e os valores previstos através da correlação com os corpos-de-prova cilíndricos aos sete dias.

\begin{tabular}{|c|c|c|c|c|c|c|c|}
\hline \multirow{3}{*}{ Traços } & \multirow{3}{*}{$\begin{array}{c}\text { Consumo } \\
\text { de } \\
\text { cimento - } \\
\text { CPs } \\
\left(\mathrm{kg} / \mathrm{m}^{3}\right)\end{array}$} & \multirow{3}{*}{$\begin{array}{c}\text { Resistência } \\
\text { dos CPs } \\
\text { (MPa) }\end{array}$} & \multirow{2}{*}{\multicolumn{2}{|c|}{$\begin{array}{c}\text { Previsão da } \\
\text { resistência dos } \\
\text { blocos (MPa) } \\
\text { Coeficiente de } \\
\text { correlação }\end{array}$}} & \multirow{3}{*}{$\begin{array}{c}\text { Consumo } \\
\text { de } \\
\text { cimento - } \\
\text { blocos } \\
\left(\mathrm{kg} / \mathrm{m}^{3}\right)\end{array}$} & \multirow{3}{*}{$\begin{array}{c}\text { Resistência } \\
\text { real das } \\
\text { unidades } \\
(\mathrm{MPa})\end{array}$} & \multirow{3}{*}{$\begin{array}{l}\text { Coeficiente de } \\
\text { correlação } \\
\text { encontrado } \\
\text { (CPs/blocos) }\end{array}$} \\
\hline & & & & & & & \\
\hline & & & 0,80 & 1,30 & & & \\
\hline REF & 223,2 & 31,83 & 22,88 & 14,08 & 221,0 & 11,09 & 1,65 \\
\hline RGV-100\% & 223,2 & 31,19 & 22,42 & 13,79 & 218,0 & 11,10 & 1,62 \\
\hline RGV-50\% & 223,2 & 32,77 & 23,55 & 14,50 & 218,0 & 12,12 & 1,55 \\
\hline RGB-50\% & 223,2 & 30,17 & 21,68 & 13,35 & 218,0 & 11,51 & 1,51 \\
\hline
\end{tabular}


Analisando-se a Tabela 7.47, nota-se que os resultados dos CPs produzidos no laboratório não forneceram um parâmetro adequado para a previsão da resistência das unidades dos traços mais ricos; o coeficiente de correlação médio foi igual a 1,58. As seguintes justificativas para esse comportamento são enumeradas a seguir:

- Diferentemente do processo de produção dos corpos-de-prova, em que a energia de adensamento foi mantida constante; na produção dos blocos, que apresentam uma elevada quantidade de finos (traços ricos), torna-se necessário o aumento dos tempos de produção, em relação aos traços mais pobres, para se elevar a energia de vibração e compactação como objetivo de melhorar as propriedades mecânicas das unidades. Segundo Frasson Junior (2000), para os traços com grande quantidade de finos há necessidade de se elevar os tempos de produção, uma vez que tais misturas possuem grande dificuldade para alimentar as formas dos moldes.

- A umidade utilizada na produção das unidades do Grupo 12,0 ficou abaixo da umidade considerada ótima, uma vez que, grande parte dos blocos apresentou valores menores de massa comparativamente às unidades mais pobres. Esse fato provocou redução significativa da resistência à compressão das unidades e aumento pouco expressivo em relação aos traços mais pobres.

Os resultados de resistência à compressão das unidades aos vinte e oito dias são apresentados na Tabela 7.48. Nessa Tabela, também é apresentada a razão entre os resultados das unidades do Grupo 12,0 e os do Grupo 8,0, bem como a relação entre as suas massas. 
Tabela 7.48 - Resistência à compressão das unidades aos vinte e oito dias - Grupo 12,0.

\begin{tabular}{|c|c|c|c|c|c|c|c|c|c|c|}
\hline Unidades & Parâmetros & $\begin{array}{l}\text { Idade } \\
\text { (dias) }\end{array}$ & $\begin{array}{c}\text { Massa } \\
\text { da } \\
\text { unidade } \\
\text { (g) }\end{array}$ & $\begin{array}{c}\text { Força } \\
(\mathbf{k N})\end{array}$ & $\begin{array}{c}\text { Tensão } \\
\text { - Área } \\
\text { bruta } \\
\text { (MPa) }\end{array}$ & $\begin{array}{c}\text { Tensão } \\
\text { - Área } \\
\text { líquida } \\
\text { (MPa) }\end{array}$ & $f_{b k}(M P a)$ & $f_{b 28} / f_{b 7} *$ & $\underset{\substack{\text { grupo } \\
\star *}}{\mathrm{~m}_{\text {grupo }} \text { g,0 }}$ & $\begin{array}{c}\left(f_{b} \text { grupo }\right. \\
12,0) / \\
\left(f_{b} \underset{* \text { grupo } 8,0}{* \star \star}\right) \\
\end{array}$ \\
\hline \multirow{5}{*}{$\begin{array}{l}\text { B12,0- } \\
\text { REF }\end{array}$} & Média & \multirow{5}{*}{28} & 10091 & 637 & 15,69 & 27,15 & \multirow{5}{*}{11,34} & \multirow{5}{*}{1,41} & \multirow{5}{*}{$\begin{array}{c}0,982 \\
(-180 \mathrm{~g})\end{array}$} & \multirow{5}{*}{1,23} \\
\hline & Máximo & & 10252 & 761 & 18,74 & 32,42 & & & & \\
\hline & Mínimo & & 9831 & 517 & 12,74 & 22,04 & & & & \\
\hline & D. Padrão & & 177 & 103 & 2,54 & 4,40 & & & & \\
\hline & C.Variação & & $1,75 \%$ & $16,19 \%$ & $16,19 \%$ & $16,19 \%$ & & & & \\
\hline \multirow{5}{*}{$\begin{array}{l}\text { B12,0- } \\
\text { RGV- } \\
100 \%\end{array}$} & Média & \multirow{5}{*}{28} & 9739 & 540 & 13,30 & 22,94 & \multirow{5}{*}{11,31} & \multirow{5}{*}{1,20} & \multirow{5}{*}{$\begin{array}{l}0,992 \\
(-81 g)\end{array}$} & \multirow{5}{*}{1,08} \\
\hline & Máximo & & 9795 & 593 & 14,59 & 25,16 & & & & \\
\hline & Mínimo & & 9615 & 481 & 11,85 & 20,43 & & & & \\
\hline & D. Padrão & & 66 & 45 & 1,11 & 1,91 & & & & \\
\hline & C.Variação & & $0,67 \%$ & $8,32 \%$ & $8,32 \%$ & $8,32 \%$ & & & & \\
\hline \multirow{5}{*}{$\begin{array}{c}\text { B12,0- } \\
\text { RGV-50\% }\end{array}$} & Média & \multirow{5}{*}{28} & 9888 & 639 & 15,73 & 27,17 & \multirow{5}{*}{13,36} & \multirow{5}{*}{1,30} & \multirow{5}{*}{$\begin{array}{c}0,975 \\
(-256 g)\end{array}$} & \multirow{5}{*}{1,33} \\
\hline & Máximo & & 10042 & 751 & 18,49 & 31,93 & & & & \\
\hline & Mínimo & & 9639 & 545 & 13,43 & 23,19 & & & & \\
\hline & D. Padrão & & 159 & 82 & 2,02 & 3,49 & & & & \\
\hline & C.Variação & & $1,61 \%$ & $12,85 \%$ & $12,85 \%$ & $12,85 \%$ & & & & \\
\hline \multirow{5}{*}{$\begin{array}{c}\text { B12,0- } \\
\text { RMV- } \\
33 \%\end{array}$} & Média & \multirow{5}{*}{28} & 10076 & 602 & 14,82 & 26,00 & \multirow{5}{*}{11,46} & \multirow{5}{*}{1,19} & \multirow{5}{*}{$\begin{array}{l}0,993 \\
(-70 g)\end{array}$} & \multirow{5}{*}{1,32} \\
\hline & Máximo & & 10309 & 699 & 17,22 & 30,21 & & & & \\
\hline & Mínimo & & 9650 & 489 & 12,05 & 21,15 & & & & \\
\hline & D. Padrão & & 233 & 94 & 2,31 & 4,05 & & & & \\
\hline & C.Variação & & $2,31 \%$ & $15,56 \%$ & $15,56 \%$ & $15,56 \%$ & & & & \\
\hline \multirow{5}{*}{$\begin{array}{c}\text { B12,0- } \\
\text { RGB- } \\
50 \%\end{array}$} & Média & \multirow{5}{*}{28} & 9988 & 657 & 16,19 & 28,06 & \multirow{5}{*}{13,76} & \multirow{5}{*}{1,41} & & \\
\hline & Máximo & & 10127 & 736 & 18,13 & 31,42 & & & & \\
\hline & Mínimo & & 9892 & 620 & 15,26 & 26,45 & & & 0,991 & 1,21 \\
\hline & D. Padrão & & 92 & 42 & 1,04 & 1,81 & & & & \\
\hline & C.Variação & & $0,93 \%$ & $6,45 \%$ & $6,45 \%$ & $6,45 \%$ & & & & \\
\hline & Média & & 10449 & 761 & 18,75 & 31,52 & & & & \\
\hline B12,0- & Máximo & & 10622 & 847 & 20,86 & 35,07 & & & & \\
\hline RMB- & Mínimo & 28 & 10226 & 721 & 17,76 & 29,85 & 15,94 & 1,21 & $\begin{array}{c}1,026 \\
(+263 a)\end{array}$ & 1,77 \\
\hline $33 \%$ & D. Padrão & & 130 & 46 & 1,23 & 1,90 & & & & \\
\hline & C.Variação & & $1,25 \%$ & 6,035 & $6,03 \%$ & $6,03 \%$ & & & & \\
\hline
\end{tabular}

Pela Tabela 7.48, nota-se que todos os resultados apresentaram um coeficiente de variação aceitável, inferior a 15\%. A relação entre os resultados de resistência à compressão $\left(\mathrm{f}_{\mathrm{b} 28} / \mathrm{f}_{\mathrm{b} 7}\right)$ ficou com o valor médio de 1,29; sendo que as unidades B12,0-RGV100\%, B12,0-RMV-33\% e B12,0-RMB-33\% apresentaram os menores acréscimos relativos de resistência, cerca de $20 \%$. As unidades dos traços de referência e com agregados reciclados de vigota (B12,0-RGV-100\% e B12,0-RMV-33\%) não obtiveram a resistência mínima característica à compressão exigida para blocos estruturais da classe 12,0 MPa; o correto seria enquadrá-los na classe de blocos estruturais de $10 \mathrm{MPa}$.

Analisando-se a relação entre os resultados das unidades do Grupo 12,0 e os resultados das unidades do Grupo 8,0, foi notado um aumento significativo da resistência à compressão dos traços mais ricos em relação aos traços mais pobres $(p<0,05)$. Apenas para as unidades do traço B12,0-RGV-50\%, foi observada uma redução significativa da massa em relação às unidades do traço B8,0-RGV-50\%; para as demais unidades, os valores de massa foram considerados semelhantes aos obtidos para os blocos do Grupo 8,0 . 
Na Tabela 7.49, são apresentadas as previsões de resistência das unidades através da correlação com os corpos-de-prova cilíndricos produzidos anteriormente no laboratório, os resultados reais obtidos pelos blocos e o coeficiente de correlação real encontrado para essas unidades (CPs/blocos).

Tabela 7.49 - Coeficientes de correlação considerando os resultados dos CPs e dos blocos aos vinte e oito dias - Grupo 12,0.

\begin{tabular}{|c|c|c|c|c|c|c|c|}
\hline \multirow{3}{*}{ Traços } & \multirow{3}{*}{$\begin{array}{c}\text { Consumo } \\
\text { de } \\
\text { cimento- } \\
\text { CPs } \\
\left(\mathrm{kg} / \mathrm{m}^{3}\right)\end{array}$} & \multirow{3}{*}{$\begin{array}{c}\text { Resistência } \\
\text { dos CPs } \\
(\mathrm{MPa})\end{array}$} & \multirow{2}{*}{\multicolumn{2}{|c|}{$\begin{array}{c}\text { Previsão da } \\
\text { resistência dos } \\
\text { blocos (MPa) } \\
\text { Coeficiente de } \\
\text { correlação }\end{array}$}} & \multirow{3}{*}{$\begin{array}{c}\text { Consumo } \\
\text { de } \\
\text { cimento - } \\
\text { blocos } \\
\left(\mathrm{kg} / \mathrm{m}^{3}\right)\end{array}$} & \multirow{3}{*}{$\begin{array}{c}\text { Resistência } \\
\text { real das } \\
\text { unidades } \\
(\mathrm{MPa})\end{array}$} & \multirow{3}{*}{$\begin{array}{l}\text { Coeficiente de } \\
\text { correlação } \\
\text { encontrado } \\
\text { (CPs/blocos) }\end{array}$} \\
\hline & & & & & & & \\
\hline & & & 0,80 & 1,30 & & & \\
\hline REF & 223,2 & 40,51 & 29,12 & 17,92 & 221,0 & 15,69 & 1,48 \\
\hline RG V-100\% & 223,2 & 38,33 & 27,55 & 16,95 & 218,0 & 13,30 & 1,66 \\
\hline RGV-50\% & 223,2 & 43,24 & 31,08 & 19,13 & 218,0 & 15,73 & 1,58 \\
\hline RGB-50\% & 223,2 & 36,19 & 26,01 & 16,01 & 218,0 & 16,19 & 1,29 \\
\hline
\end{tabular}

Analisando-se a Tabela 7.49, nota-se que, novamente, os resultados dos CPs não forneceram um razoável parâmetro para a previsão da resistência das unidades dos traços mais ricos; o coeficiente de correlação médio foi igual a 1,50. As justificativas já foram apresentadas na análise dos resultados aos sete dias. Na Tabela 7.50, são apresentados os resultados de resistência à compressão para idades superiores a cem dias.

Tabela 7.50 - Resistência à compressão das unidades para idades superiores a cem dias Grupo 12,0.

\begin{tabular}{|c|c|c|c|c|c|c|c|c|}
\hline Unidades & Parâmetros & $\begin{array}{l}\text { Idade } \\
\text { (dias) }\end{array}$ & $\begin{array}{c}\text { Massa da } \\
\text { unidade } \\
(\mathrm{g})\end{array}$ & $\begin{array}{c}\text { Força } \\
(k N)\end{array}$ & $\begin{array}{c}\text { Tensão- } \\
\text { Área } \\
\text { bruta } \\
\text { (MPa) } \\
\end{array}$ & $\begin{array}{c}\text { Tensão } \\
\text { - Área } \\
\text { líquida } \\
\text { (MPa) }\end{array}$ & $f_{b} / f_{b 28^{*}}$ & $\begin{array}{c}\text { Diferença de } \\
\text { massa } \\
\left(m_{c}-m_{28}\right)^{* *}\end{array}$ \\
\hline \multirow{5}{*}{ B 12,0-REF } & Média & \multirow{5}{*}{133} & 10117 & 814 & 20,04 & 34,67 & \multirow{5}{*}{1,29} & \multirow{5}{*}{+26} \\
\hline & Máximo & & 10250 & 890 & 21,91 & 37,90 & & \\
\hline & Mínimo & & 10000 & 768 & 18,91 & 32,72 & & \\
\hline & D. Padrão & & 126 & 66 & 1,63 & 2,82 & & \\
\hline & C.Variação & & $1,21 \%$ & $8,14 \%$ & $8,14 \%$ & $8,14 \%$ & & \\
\hline \multirow{5}{*}{ B 12,0-RG V-100\% } & Média & \multirow{5}{*}{133} & 9783 & 725 & 17,87 & 30,80 & \multirow{5}{*}{1,34} & \multirow{5}{*}{+44} \\
\hline & Máximo & & 9900 & 756 & 18,62 & 32,10 & & \\
\hline & Mínimo & & 9700 & 665 & 16,38 & 28,25 & & \\
\hline & D. Padrão & & 104 & 52 & 1,28 & 2,21 & & \\
\hline & C.Variação & & $1,10 \%$ & $7,20 \%$ & $7,20 \%$ & $7,20 \%$ & & \\
\hline \multirow{5}{*}{ B 12,0-RGV-50\% } & Média & \multirow{5}{*}{133} & 9900 & 707 & 17,40 & 30,06 & \multirow{5}{*}{1,11} & \multirow{5}{*}{+12} \\
\hline & Máximo & & 9900 & 762 & 18,77 & 32,42 & & \\
\hline & Mínimo & & 9900 & 645 & 15,88 & 27,43 & & \\
\hline & D. Padrão & & 0,00 & 59 & 1,45 & 2,51 & & \\
\hline & C.Variação & & $0,00 \%$ & $8,30 \%$ & $8,30 \%$ & $8,30 \%$ & & \\
\hline \multirow{5}{*}{ B 12,0-R M V-33\% } & Média & \multirow{5}{*}{133} & 10183 & 776 & 19,12 & 33,55 & \multirow{5}{*}{1,29} & \multirow{5}{*}{+107} \\
\hline & Máximo & & 10400 & 815 & 20,07 & 35,21 & & \\
\hline & Mínimo & & 10050 & 757 & 18,65 & 32,72 & & \\
\hline & D. Padrão & & 189 & 33 & 0,82 & 1,44 & & \\
\hline & C.Variação & & $1,90 \%$ & $4,28 \%$ & $4,28 \%$ & $4,28 \%$ & & \\
\hline \multirow{5}{*}{ B 12,0-RG B-50\% } & Média & \multirow{5}{*}{136} & 10067 & 765 & 18,84 & 32,65 & \multirow{5}{*}{1,16} & \multirow{5}{*}{+78} \\
\hline & Máximo & & 10250 & 880 & 21,67 & 37,55 & & \\
\hline & Mínimo & & 9850 & 738 & 16,68 & 28,91 & & \\
\hline & D. Padrão & & 202 & 104 & 2,56 & 4,44 & & \\
\hline & C.Variação & & $2,00 \%$ & $13,60 \%$ & $13,60 \%$ & $13,60 \%$ & & \\
\hline \multirow{5}{*}{ B 12,0-R M B-33\% } & Média & \multirow{5}{*}{134} & 10450 & 828 & 20,38 & 34,26 & \multirow{5}{*}{1,09} & \multirow{5}{*}{+1} \\
\hline & Máximo & & 10850 & 906 & 22,32 & 27,50 & & \\
\hline & Mínimo & & 10050 & 706 & 17,40 & 29,24 & & \\
\hline & D. Padrão & & 400 & 107 & 2,62 & 4,41 & & \\
\hline & C.Variação & & $3,80 \%$ & $12,87 \%$ & $12,87 \%$ & $12,87 \%$ & & \\
\hline
\end{tabular}


Analisando-se os resultados da Tabela 7.50, nota-se que todas as unidades apresentaram um aumento de resistência, comparativamente aos 28 dias, situado entre 9\% e 34\%. Para essas unidades, não ocorreram diferenças significativas nos valores de massa comparativamente ao valor encontrado aos vinte e oito dias $(p>0,05)$.

\subsection{Análise dos resultados - resistência à compressão}

Para facilitar a análise dos resultados de resistência à compressão é apresentada, na Tabela 7.51, o teste estatístico de Análise de Variância.

Tabela 7.51 - Teste ANOVA para valores de resistência à compressão.

\begin{tabular}{|c|c|c|c|c|c|c|c|c|c|}
\hline & & & \multicolumn{7}{|c|}{ Variáveis } \\
\hline & & & Grupos & \multirow{2}{*}{ Traços } & Idades & \multirow{2}{*}{$\begin{array}{c}\text { Grupos } x \\
\text { traços }\end{array}$} & \multirow{2}{*}{$\begin{array}{l}\text { Grupos } x \\
\text { idades }\end{array}$} & \multirow{2}{*}{$\begin{array}{c}\text { Traços } x \\
\text { idades }\end{array}$} & \multirow{2}{*}{$\begin{array}{c}\text { Grupos } x \\
\text { traços } x \\
\text { idades }\end{array}$} \\
\hline & & & 4,$5 ; 8,0 ; 12,0$ & & 7, 28 dias & & & & \\
\hline \multirow{9}{*}{ 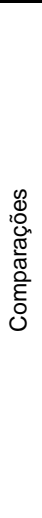 } & \multirow{3}{*}{$\begin{array}{l}\text { Comparações } \\
\text { com o traço } \\
\text { de referência }\end{array}$} & $\begin{array}{c}\text { REF } x \\
\text { RECICLADOS }^{1}\end{array}$ & $S\left(F_{O}=538,6\right)$ & $S(6,6)$ & S $(276,8)$ & $\mathrm{S}(21,2)$ & $S(10,2)$ & - & - \\
\hline & & $\begin{array}{c}\text { REF } \times \text { RGV-100\% } \\
\times \text { RGV-50\% } \times \\
\text { RMV-33\% }\end{array}$ & S $(206,4)$ & $\mathrm{S}(7,9)$ & S $(137,9)$ & $S(6,5)$ & $\mathrm{S}(3,9)$ & - & - \\
\hline & & $\begin{array}{c}\text { REF } \times \text { RGB- } 50 \% \times \\
\text { RMB-33\% }\end{array}$ & $\mathrm{S}(341,5)$ & $\mathrm{S}(4,2)$ & $S(193,4)$ & $S(43,6)$ & $\mathrm{S}(9,8)$ & - & - \\
\hline & \multirow{4}{*}{$\begin{array}{l}\text { Diferentes } \\
\text { porcentagens } \\
\text { do mesmo } \\
\text { resíduo }\end{array}$} & $\begin{array}{c}\text { RGV-100\% } \% \text { RGV- } \\
50 \% \times \text { RMV-33\% }\end{array}$ & S $(211,4)$ & - & $\mathrm{S}(94,9)$ & $\mathrm{S}(7,4)$ & - & - & \\
\hline & & $\begin{array}{c}\text { RGV-100\% x RGV- } \\
50 \%\end{array}$ & $\mathrm{~S}(138,7)$ & - & $\mathrm{S}(77,7)$ & $\mathrm{S}(11,0)$ & $\mathrm{S}(3,2)$ & - & - \\
\hline & & $\begin{array}{c}\text { RGV-50\% x RMV- } \\
33 \% \\
\end{array}$ & $\mathrm{~S}(160,3)$ & $S(4,1)$ & $\mathrm{S}(63,7)$ & - & - & - & - \\
\hline & & $\begin{array}{c}\text { RGB-50\% } \% \text { RMB- } \\
33 \% \\
\end{array}$ & $\mathrm{~S}(529,0)$ & - & $\mathrm{S}(184,3)$ & $\mathrm{S}(74,8)$ & $\mathrm{S}(10,3)$ & $\mathrm{S}(4,1)$ & - \\
\hline & \multirow{2}{*}{$\begin{array}{c}\text { Diferentes } \\
\text { resíduos (\% } \\
\text { similares de } \\
\text { substituição) }\end{array}$} & $\begin{array}{c}\text { RGV-50\% } \% \text { RGB- } \\
50 \%\end{array}$ & S $(189,5)$ & - & $\mathrm{S}(136,8)$ & - & $\mathrm{S}(8,2)$ & - & - \\
\hline & & $\begin{array}{c}\text { RMV-33\% x RMB- } \\
33 \%\end{array}$ & $S(383,6)$ & $S(6,0)$ & $S(76,3)$ & $S(26,8)$ & - & - & - \\
\hline
\end{tabular}

Analisando-se os resultados da Tabela 7.51, são feitos os seguintes comentários:

- Para a análise de $1^{\mathrm{a}}$ ordem, houve, para todos os casos, influência significativa das variáveis "grupos" e "traços" sobre a resistência à compressão. Nesse caso, a variável "grupo" é a que teve maior influência nos resultados obtidos; pode-se afirmar que os maiores valores médios de resistência à compressão foram obtidos para as unidades do Grupo 12,0 e os menores valores médios para as unidades do Grupo 4,5. Para a variável "idade", conforme já esperado, os maiores valores médios de resistência à compressão foram obtidos para as unidades ensaiadas aos vinte e oito dias. 
- Com relação à variável "traço", pode-se dizer que, para algumas das comparações efetuadas, ocorreu influência significativa da composição do traço sobre a resistência à compressão. De maneira geral, pode-se dizer que os maiores valores médios foram obtidos para as unidades de referência; entretanto, para algumas classes de resistência, de acordo com a análise de $2^{\mathrm{a}}$ ordem, os maiores valores médios de resistência não foram obtidos necessariamente para as unidades com agregados naturais. Os menores valores médios de resistência para os traços com agregados reciclados, comparativamente aos traços de referência, podem ser explicados pela menor resistência do agregado reciclado, sua elevada porosidade e a diminuição da coesão da mistura (traços com agregados miúdos reciclados do Grupo 4,5).

- Comparando-se os traços com agregados reciclados de vigota, pode-se dizer que os resultados de resistência à compressão não diferiram significativamente entre si. Diante disto, pode-se afirmar que a incorporação de diferentes porcentagens de agregado reciclado de vigota para a produção dos blocos, independentemente da classe de resistência, não afetaram os resultados de resistência das unidades. De acordo com a análise de $2^{\mathrm{a}}$ ordem (grupos $\mathrm{x}$ traços), pode-se dizer que dependendo da classe de resistência em análise haverá um determinado traço que conduzirá a valores médios de resistência ligeiramente maiores comparativamente aos demais traços.

- Para os traços com agregados reciclados de bloco, novamente, pode-se dizer que os resultados de resistência à compressão não diferiram significativamente entre si. Pela análise de $2^{\mathrm{a}}$ ordem, dependendo da classe de resistência, haverá uma determinada dosagem que conduzirá a valores médios de resistência ligeiramente maiores comparativamente às demais dosagens. Por exemplo, para a comparação RGB-50\% x RMB-33\%, os maiores valores médios de resistência, considerando-se o Grupo 4,5, foram obtidos para as unidades do traço RGB-50\%; já para o Grupo 12,0, os maiores valores médios de resistência foram obtidos para os blocos do traço RMB-33\%.

- Considerando-se a análise de $2^{\mathrm{a}}$ ordem (grupos $\mathrm{x}$ idades), pode-se dizer que, em grande parte das comparações, houve influência significativa desses parâmetros sobre a propriedade de resistência à compressão. Nesse caso, pode-se dizer que para um dado grupo haverá uma determinada idade que conduzirá aos maiores valores médios de resistência; no entanto, para outro grupo pode não ser necessariamente essa mesma idade que levará aos maiores valores médios de 
resistência. Essa influência foi significativa, principalmente para as seguintes comparações: REF x RGB-50\% x RMB-33\% e RGB-50\% x RMB-33\%.

- Com relação à análise de $2^{\mathrm{a}}$ ordem (traços $\mathrm{x}$ idades), pode-se afirmar que em todas as comparações, com exceção dos traços com agregados reciclados de bloco, não houve influência significativa dos parâmetros sobre a resistência à compressão. Dessa maneira, pode-se afirmar que para qualquer idade considerada (7 ou 28 dias) haverá, para cada comparação avaliada, apenas um traço que conduzirá aos maiores valores médios de resistência à compressão. Com relação à comparação que foi considerada significativa (RGB-50\% x RMB-33\%), pode-se dizer que para uma determinada idade ( 7 dias, por ex.), os maiores valores médios de resistência foram obtidos para as unidades do traço RMB-33\%; no entanto, para a idade de 28 dias, os maiores valores médios de resistência podem ser obtidos para as unidades do outro traço (RGB-50\%).

\subsubsection{Resistência à tração indireta}

\subsection{Grupo 4,5}

Os resultados para as unidades do Grupo 4,5 são apresentados na Tabela 7.52.

Tabela 7.52 - Resultados de resistência à tração indireta - Grupo 4,5.

\begin{tabular}{|c|c|c|c|c|c|c|}
\hline Unidades & Parâmetros & $\begin{array}{l}\text { Idade } \\
\text { (dias) }\end{array}$ & $\begin{array}{c}\text { Massa da } \\
\text { unidade } \\
\text { (g) }\end{array}$ & Força $(k N)$ & $\begin{array}{c}\text { Tensão } \\
(\mathrm{MPa})\end{array}$ & $\begin{array}{c}\text { Resist. à } \\
\text { tração/com pressão } \\
\left(f_{t} / f_{c 7}\right)\end{array}$ \\
\hline \multirow{5}{*}{ B4,5-REF } & Média & \multirow{5}{*}{12} & 10467 & 14,87 & 1,88 & \multirow{5}{*}{0,128} \\
\hline & Máximo & & 10700 & 17,61 & 2,22 & \\
\hline & Mínimo & & 10100 & 11,32 & 1,43 & \\
\hline & D. Padrão & & 216 & 2,26 & 0,28 & \\
\hline & C.Variação & & $2,06 \%$ & $15,18 \%$ & $15,18 \%$ & \\
\hline \multirow{5}{*}{ B4,5-RGV-100\% } & Média & \multirow{5}{*}{9} & 9940 & 12,67 & 1,60 & \multirow{5}{*}{0,124} \\
\hline & Máximo & & 9989 & 14,50 & 1,83 & \\
\hline & Mínimo & & 9808 & 7,60 & 0,96 & \\
\hline & D. Padrão & & 70 & 2,62 & 0,33 & \\
\hline & C.Variação & & $0,70 \%$ & $20,69 \%$ & $20,69 \%$ & \\
\hline \multirow{5}{*}{ B4,5-RGV-50\% } & Média & \multirow{5}{*}{9} & 10093 & 8,83 & 1,12 & \multirow{5}{*}{0,094} \\
\hline & Máximo & & 10323 & 10,60 & 1,34 & \\
\hline & Mínimo & & 9790 & 6,90 & 0,87 & \\
\hline & D. Padrão & & 175 & 1,7 & 0,19 & \\
\hline & C.Variação & & $1,73 \%$ & $16,60 \%$ & $16,60 \%$ & \\
\hline \multirow{5}{*}{ B4,5-RMV-33\% } & Média & \multirow{5}{*}{11} & 10010 & 9,62 & 1,21 & \multirow{5}{*}{0,128} \\
\hline & Máximo & & 10328 & 10,70 & 1,35 & \\
\hline & Mínimo & & 9738 & 8,50 & 1,07 & \\
\hline & D. Padrão & & 189 & 0,85 & 0,11 & \\
\hline & C.Variação & & $1,89 \%$ & $8,88 \%$ & $8,88 \%$ & \\
\hline \multirow{5}{*}{ B4,5-RGB-50\% } & Média & \multirow{5}{*}{14} & 10021 & 14,45 & 1,83 & \multirow{5}{*}{0,154} \\
\hline & Máximo & & 10205 & 16,70 & 2,12 & \\
\hline & Mínimo & & 9811 & 10,80 & 1,37 & \\
\hline & D. Padrão & & 149 & 2,03 & 0,26 & \\
\hline & C.Variação & & $1,49 \%$ & $14,08 \%$ & $14,08 \%$ & \\
\hline \multirow{5}{*}{ B4,5-RMB -33\% } & Média & \multirow{5}{*}{13} & 9906 & 10,57 & 1,32 & \multirow{5}{*}{0,148} \\
\hline & Máximo & & 10397 & 13,00 & 1,63 & \\
\hline & Mínimo & & 9606 & 8,50 & 1,06 & \\
\hline & D. Padrão & & 277 & 1,55 & 0,19 & \\
\hline & C.Variação & & $2,79 \%$ & $14,64 \%$ & $14,64 \%$ & \\
\hline
\end{tabular}


Analisando-se a Tabela 7.52, observa-se que o coeficiente de variação dos resultados foi relativamente elevado; conforme a ASTM C1006 (1996), o coeficiente de variação para esse ensaio, considerando-se uma amostra de cinco blocos, é igual a 20\%. A relação entre os resultados de resistência à tração e compressão, considerando a área líquida, ficou com o valor médio de 0,129. Deve-se ressaltar que os ensaios de tração apresentados na Tabela 7.52 foram realizados em idades superiores a sete dias, enquanto que os ensaios de compressão foram realizados integralmente aos sete dias.

\subsection{Grupo 8,0}

Os resultados para as unidades do Grupo 8,0 são apresentados na Tabela 7.53.

Tabela 7.53 - Resultados de resistência à tração indireta - Grupo 8,0.

\begin{tabular}{|c|c|c|c|c|c|c|}
\hline Unidades & Parâmetros & $\begin{array}{l}\text { Idade } \\
\text { (dias) }\end{array}$ & $\begin{array}{l}\text { Massa da } \\
\text { unidade } \\
\text { (g) }\end{array}$ & Força $(k N)$ & $\begin{array}{c}\text { Tensão } \\
\text { (MPa) }\end{array}$ & $\begin{array}{c}\text { Resist. à } \\
\text { tração/compressão } \\
\left(f_{t} / f_{c 7}\right)\end{array}$ \\
\hline \multirow{5}{*}{ B8,0-REF } & Média & \multirow{5}{*}{9} & 10296 & 15,62 & 1,98 & \multirow{5}{*}{0,115} \\
\hline & Máximo & & 10443 & 18,50 & 2,34 & \\
\hline & Mínimo & & 10200 & 12,30 & 1,56 & \\
\hline & D. Padrão & & 110 & 2,39 & 0,30 & \\
\hline & C.Variação & & $1,07 \%$ & $15,29 \%$ & $15,29 \%$ & \\
\hline \multirow{5}{*}{ B8,0-RGV-100\% } & Média & \multirow{5}{*}{10} & 9760 & 16,98 & 2,15 & \multirow{5}{*}{0,119} \\
\hline & Máximo & & 9971 & 20,30 & 2,57 & \\
\hline & Mínimo & & 9565 & 24,00 & 1,77 & \\
\hline & D. Padrão & & 164 & 2,39 & 0,30 & \\
\hline & C.Variação & & $1,68 \%$ & $14,09 \%$ & $14,09 \%$ & \\
\hline \multirow{5}{*}{ B8,0-RGV-50\% } & Média & \multirow{5}{*}{10} & 10100 & 15,55 & 1,95 & \multirow{5}{*}{0,127} \\
\hline & Máximo & & 10204 & 18,90 & 2,37 & \\
\hline & Mínimo & & 9945 & 13,50 & 1,69 & \\
\hline & D. Padrão & & 93 & 2,07 & 0,26 & \\
\hline & C.Variação & & $0,92 \%$ & $13,33 \%$ & $13,33 \%$ & \\
\hline \multirow{5}{*}{ B8,0-RMV-33\% } & Média & \multirow{5}{*}{11} & 10092 & 16,17 & 2,04 & \multirow{5}{*}{0,134} \\
\hline & Máximo & & 10215 & 20,30 & 2,57 & \\
\hline & Mínimo & & 9787 & 12,10 & 1,53 & \\
\hline & D. Padrão & & 167 & 2,73 & 0,35 & \\
\hline & C.Variação & & $1,66 \%$ & $16,88 \%$ & $16,88 \%$ & \\
\hline \multirow{5}{*}{ B8,0-RGB-50\% } & Média & \multirow{5}{*}{14} & 10096 & 16,45 & 2,09 & \multirow{5}{*}{0,123} \\
\hline & Máximo & & 10272 & $\frac{10,40}{23,70}$ & 3,02 & \\
\hline & Mínimo & & 9894 & 11,50 & 1,46 & \\
\hline & D. Padrão & & 155 & 4,81 & 0,61 & \\
\hline & C.Variação & & $1,53 \%$ & $29,22 \%$ & $29,22 \%$ & \\
\hline \multirow{5}{*}{ B8,0-RMB-33\% } & Média & \multirow{5}{*}{13} & 10240 & 14,77 & 1,86 & \multirow{5}{*}{0,145} \\
\hline & Máximo & & 10539 & 17,50 & 2,21 & \\
\hline & Mínimo & & 10025 & 11,80 & 1,49 & \\
\hline & D. Padrão & & 210 & 2,07 & 0,26 & \\
\hline & C.Variação & & $2,05 \%$ & $14,03 \%$ & $14,03 \%$ & \\
\hline
\end{tabular}

Analisando-se a Tabela 7.53, observa-se que o coeficiente de variação dos resultados foi relativamente elevado. A relação entre os resultados de resistência à tração e compressão, considerando-se a área líquida, ficou com o valor médio de 0,127. Deve-se ressaltar que os ensaios de tração apresentados na Tabela 7.53 foram realizados em idades superiores a sete dias, enquanto que os ensaios de compressão foram realizados integralmente aos sete dias. 


\subsection{Grupo 12,0}

Os resultados para as unidades do Grupo 12,0 são apresentados na Tabela 7.54.

Tabela 7.54 - Resultados de resistência à tração indireta - Grupo 12,0.

\begin{tabular}{|c|c|c|c|c|c|c|}
\hline Unidades & Parâmetros & $\begin{array}{l}\text { Idade } \\
\text { (dias) }\end{array}$ & $\begin{array}{c}\text { Massa da } \\
\text { unidade } \\
\text { (g) }\end{array}$ & Força (kN) & $\begin{array}{c}\text { Tensão } \\
\text { (MPa) }\end{array}$ & $\begin{array}{c}\text { Resist. à } \\
\text { tração/compressão } \\
\left(\mathbf{f}_{\mathrm{t}} / \mathbf{f}_{\mathrm{c} 7}\right)\end{array}$ \\
\hline \multirow{5}{*}{ B12,0-REF } & Média & \multirow{5}{*}{10} & 10232 & 22,87 & 2,91 & \multirow{5}{*}{0,151} \\
\hline & Máximo & & 10381 & 25,60 & 3,25 & \\
\hline & Mínimo & & 10152 & 20,60 & 2,62 & \\
\hline & D. Padrão & & 89 & 1,61 & 0,20 & \\
\hline & C.Variação & & $0,87 \%$ & $7,03 \%$ & $7,03 \%$ & \\
\hline \multirow{5}{*}{ B12,0-RGV-100\% } & Média & \multirow{5}{*}{10} & 9822 & 20,23 & 2,56 & \multirow{5}{*}{0,134} \\
\hline & Máximo & & 10076 & 23,00 & 2,91 & \\
\hline & Mínimo & & 9609 & 18,50 & 2,34 & \\
\hline & D. Padrão & & 181 & 1,67 & 0,21 & \\
\hline & C.Variação & & $1,84 \%$ & $8,26 \%$ & $8,26 \%$ & \\
\hline \multirow{5}{*}{ B12,0-RGV-50\% } & Média & \multirow{5}{*}{11} & 9906 & 24,48 & 3,11 & \multirow{5}{*}{0,149} \\
\hline & Máximo & & 10073 & 29,00 & 3,69 & \\
\hline & Mínimo & & 9795 & 21,40 & 2,72 & \\
\hline & D. Padrão & & 112 & 2,78 & 0,35 & \\
\hline & C.Variação & & $1,13 \%$ & $11,34 \%$ & $11,34 \%$ & \\
\hline \multirow{5}{*}{ B12,0-RMV-33\% } & Média & \multirow{5}{*}{11} & 10188 & 25,62 & 3,28 & \multirow{5}{*}{0,150} \\
\hline & Máximo & & 10558 & 27,00 & 3,45 & \\
\hline & Mínimo & & 9865 & 22,70 & 2,90 & \\
\hline & D. Padrão & & 260 & 1,71 & 0,22 & \\
\hline & C.Variação & & $2,55 \%$ & $6,66 \%$ & $6,66 \%$ & \\
\hline \multirow{5}{*}{ B12,0-RGB-50\% } & Média & \multirow{5}{*}{14} & 10052 & 25,60 & 3,29 & \multirow{5}{*}{0,165} \\
\hline & Máximo & & 10350 & 29,30 & 3,77 & \\
\hline & Mínimo & & 9843 & 22,50 & 2,89 & \\
\hline & D. Padrão & & 186 & 2,61 & 0,34 & \\
\hline & C.Variação & & $1,85 \%$ & $10,20 \%$ & $10,20 \%$ & \\
\hline \multirow{5}{*}{ B12,0-RMB-33\% } & Média & \multirow{5}{*}{13} & 10460 & 25,07 & 3,16 & \multirow{5}{*}{0,121} \\
\hline & Máximo & & 10577 & 31,70 & 4,00 & \\
\hline & Mínimo & & 10375 & 19,70 & 2,49 & \\
\hline & D. Padrão & & 73 & 4,41 & 0,34 & \\
\hline & C.Variação & & $0,70 \%$ & $17,61 \%$ & $17,61 \%$ & \\
\hline
\end{tabular}

Analisando-se a Tabela 7.54, observa-se que o coeficiente de variação dos resultados foi relativamente elevado. A relação entre os resultados de resistência à tração e compressão, considerando a área líquida, ficou com o valor médio de 0,145. Deve-se novamente ressaltar que os ensaios de tração apresentados na Tabela 7.54 foram realizados em idades superiores a sete dias, enquanto que os ensaios de compressão foram realizados integralmente aos sete dias.

\subsection{Análise dos resultados - resistência à tração indireta}

Para facilitar a análise dos resultados de resistência à tração indireta é apresentada, na Tabela 7.55, o teste estatístico de Análise de Variância. 
Tabela 7.55 - Teste ANOVA para valores de resistência à tração indireta.

\begin{tabular}{|c|c|c|c|c|c|}
\hline & & & \multicolumn{3}{|c|}{ Variáveis } \\
\hline & & & Grupos & Traços & Grupos x Traços \\
\hline \multirow{6}{*}{ 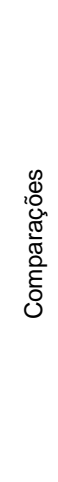 } & \multirow[b]{2}{*}{$\begin{array}{l}\text { Comparações com o } \\
\text { traço de referência }\end{array}$} & REF $\times$ RECICLADOS ${ }^{1}$ & $\mathrm{~S}\left(\mathrm{~F}_{\mathrm{O}}=222,0\right)$ & $\mathrm{S}(2,8)$ & $\mathrm{S}(4,2)$ \\
\hline & & $\begin{array}{c}\text { REF } \times \text { RGV- } 100 \% \times \\
\text { RGV- } 50 \% \text { x RMV-33\% }\end{array}$ & $S(194,0)$ & - & $S(8,5)$ \\
\hline & \multirow{3}{*}{$\begin{array}{l}\text { Diferentes } \\
\text { porcentagens do } \\
\text { mesmo resíduo }\end{array}$} & $\begin{array}{c}\text { RGV-100\% x RGV-50\% } \\
\times \text { RMV-33\% }\end{array}$ & $S(175,0)$ & - & $S(8,5)$ \\
\hline & & RGV-100\% x RGV-50\% & $S(83,0)$ & - & $S(10,8)$ \\
\hline & & RGV-50\% x RMV-33\% & $S(185,0)$ & - & - \\
\hline & $\begin{array}{l}\text { Diferentes resíduos (\% } \\
\text { similares de } \\
\text { substituição) }\end{array}$ & RMV-33\% x RMB-33\% & S $(118,0)$ & - & - \\
\hline
\end{tabular}

Analisando-se os resultados da Tabela 7.55, são enumerados os seguintes comentários:

- Para a análise de $1^{a}$ ordem, nota-se que houve, para todas as comparações, influência significativa da variável "grupo" sobre a resistência à tração indireta. Devido ao maior consumo de cimento das unidades do grupo $12,0\left(220 \mathrm{~kg} / \mathrm{m}^{3}\right)$, comparativamente às unidades do Grupo 4,5 $\left(120 \mathrm{~kg} / \mathrm{m}^{3}\right)$ e Grupo 8,0 $\left(150 \mathrm{~kg} / \mathrm{m}^{3}\right)$, esses blocos apresentaram os maiores valores médios de resistência à compressão; já os menores valores médios foram obtidos para as unidades do Grupo 4,5.

- Com relação à variável "traço", nota-se que ocorreu, para apenas três casos de comparação, influência significativa dessa variável sobre a resistência à tração. Considerando-se essas comparações, os maiores valores médios de resistência à tração indireta foram obtidos para as unidades do traço RGB-50\%. Possivelmente, os maiores tempos de produção adotados para a fabricação dessas unidades contribuíram para tais resultados.

- Com relação à análise de $2^{\mathrm{a}}$ ordem, pode-se afirmar que para um dado grupo há um determinado traço que conduz aos maiores valores médios de resistência; entretanto, para outro grupo, pode não ser esse traço que conduz aos maiores valores médios de resistência. Esse comportamento pode ser explicado por pequenas variações na fabricação das unidades, tais como, definição dos tempos de 
produção e do teor de umidade ótima. O presente fato ocorreu para as dosagens apresentadas na Tabela 7.56.

Tabela 7.56 - Dosagens que apresentaram valores ligeiramente maiores de resistência à tração.

\begin{tabular}{|c|c|c|c|c|}
\hline & & \multicolumn{3}{|c|}{$\begin{array}{c}\text { Dosagem que apresentou valores médios ligeiramente maiores } \\
\text { de resistência à tração }\end{array}$} \\
\hline & & Grupo 4,5 & Grupo 8,0 & Grupo 12,0 \\
\hline \multirow{4}{*}{ Comparações } & REF x RECICLADOS & REF & RGV-100\% & RGB-50\% \\
\hline & REF $\times$ RGV-100\% $\times$ RGV-50\% $\times$ RMV-33\% & REF & RGV-100\% & RMV-33\% \\
\hline & RGV-100\% x RGV-50\% $\times$ RMV-33\% & RGV-100\% & RGV-100\% & RMV-33\% \\
\hline & RGV-100\% x RGV-50\% & RGV-100\% & RGV-100\% & RGV-50\% \\
\hline
\end{tabular}

Analisando-se a Tabela 7.56, nota-se que, apenas para o Grupo 4,5, os valores de resistência à tração da dosagem de referência foram superiores aos obtidos para as demais dosagens. Para as demais classes de resistência, os maiores valores médios foram obtidos para as unidades com agregados reciclados. Esse fato mostra que apesar da maior porosidade e, consequentemente, menor resistência do agregado reciclado, comparativamente ao agregado natural, os resultados de resistência à tração não foram afetados significativamente pela presença da fração reciclada. Conforme Buttler (2003), a superfície áspera e irregular das partículas de agregado reciclado favorece a resistência à tração do concreto, pois ocasiona a retenção de grande quantidade de partículas de cimento na superfície do agregado resultando em uma excelente aderência entre agregado e pasta de cimento.

\subsubsection{Módulo de deformação}

\subsection{Grupo 4,5}

$\mathrm{Na}$ Tabela 7.57, são apresentados os resultados da força máxima aplicada, da tensão de ruptura, do módulo de deformação referente a área bruta e área líquida, a deformação referente a 33\% da tensão última e a deformação última para cada uma das unidades avaliadas. No Apêndice Q, são apresentados gráficos referentes a curvas típicas de tensão x deformação para as unidades dos Grupos 4,5; 8,0 e 12,0. 
Tabela 7.57 - Módulo de deformação dos blocos - Grupo 4,5.

\begin{tabular}{|c|c|c|c|c|c|c|c|c|c|c|}
\hline Blocos & Idade & Parâmetros & $\begin{array}{c}\text { Massa } \\
\text { (g) }\end{array}$ & $\begin{array}{c}\text { Força } \\
\text { (kN) }\end{array}$ & $\begin{array}{c}\text { Tensão } \\
\text { Abruta } \\
\text { (MPa) }\end{array}$ & $\begin{array}{c}\text { Módulo } \\
\text { - Abruta } \\
\text { (MPa) }\end{array}$ & $\begin{array}{c}\text { Tensão } \\
\text { Aliquida } \\
\text { (MPa) }\end{array}$ & $\begin{array}{c}\text { Módulo } \\
\text { Aliquida } \\
\text { (MPa) }\end{array}$ & $\begin{array}{c}\text { Def. } \\
33 \% \text { da } \\
\text { tensão } \\
\text { última }\end{array}$ & $\begin{array}{c}\text { Deform. } \\
\text { Última }\end{array}$ \\
\hline \multirow{5}{*}{$\begin{array}{l}\text { B4,5- } \\
\text { REF }\end{array}$} & \multirow{5}{*}{46} & Média & - & 443 & 10,90 & 10100 & 18,54 & 17177 & $-0,36 \%$ & $-3,16 \%$ \\
\hline & & Máx. & - & 470 & 11,58 & 10857 & 19,69 & 18464 & $-0,40 \%$ & $-3,18 \%$ \\
\hline & & Mín. & - & 407 & 11,12 & 9343 & 17,03 & 15890 & $-0,32 \%$ & $-3,14 \%$ \\
\hline & & D. Padrão & - & 33 & 0,80 & 1070 & 1,37 & 1820 & $0,05 \%$ & 0,03\% \\
\hline & & Coef. Var. & - & $7,38 \%$ & $7,38 \%$ & $10,60 \%$ & $7,38 \%$ & $10,60 \%$ & $14,23 \%$ & $0,87 \%$ \\
\hline \multirow{5}{*}{$\begin{array}{l}\text { B4,5- } \\
\text { RGV- } \\
100 \%\end{array}$} & \multirow{5}{*}{35} & Média & 9783 & 344 & 8,46 & 6745 & 14,39 & 11471 & $-0,40 \%$ & $-3,39 \%$ \\
\hline & & Máx. & 9900 & 376 & 9,27 & 8262 & 15,77 & 14050 & $-0,47 \%$ & $-3,60 \%$ \\
\hline & & Mín. & 9700 & 303 & 7,47 & 5744 & 12,70 & 9769 & $-0,33 \%$ о & $-2,97 \%$ \\
\hline & & D. Padrão & 104 & 37 & 0,92 & 1336 & 1,56 & 2272 & $0,07 \%$ & $0,36 \%$ \\
\hline & & Coef. Var. & $1,06 \%$ & $10,83 \%$ & $10,83 \%$ & $19,80 \%$ & $10,83 \%$ & $19,80 \%$ & $16,95 \%$ & $10,75 \%$ \\
\hline \multirow{5}{*}{$\begin{array}{c}\text { B4,5- } \\
\text { RGV- } \\
50 \%\end{array}$} & \multirow{5}{*}{35} & Média & 10083 & 304 & 7,48 & 5717 & 12,70 & 9706 & $-0,43 \%$ & $-4,54 \%$ \\
\hline & & Máx. & 10150 & 342 & 8,41 & 7395 & 14,28 & 12555 & $-0,58 \%$ & $-5,42 \%$ \\
\hline & & Mín. & 10000 & 265 & 6,53 & 4633 & 11,09 & 7865 & $-0,32 \%$ & $-3,55 \%$ \\
\hline & & D. Padrão & 76 & 38 & 0,94 & 1474 & 1,60 & 2502 & $0,13 \%$ о & $0,94 \%$ о \\
\hline & & Coef. Var. & $0,76 \%$ & $12,58 \%$ & $12,58 \%$ & $25,78 \%$ & $12,58 \%$ & $25,78 \%$ & $31,10 \%$ & $20,63 \%$ \\
\hline \multirow{5}{*}{$\begin{array}{c}\text { B4,5- } \\
\text { RMV- } \\
33 \%\end{array}$} & \multirow{5}{*}{35} & Média & 9867 & 243 & 6,00 & 5543 & 10,23 & 9459 & $-0,34 \%$ о & $-4,34 \%$ \\
\hline & & Máx. & 10250 & 275 & 6,78 & 6114 & 11,57 & 10434 & $-0,39 \%$ & $-4,97 \%$ \\
\hline & & Mín. & 9500 & 217 & 5,35 & 5047 & 9,13 & 8613 & $-0,30 \%$ & $-3,84 \%$ \\
\hline & & D. Padrão & 375 & 30 & 0,73 & 538 & 1,24 & 917 & 0,04\% & 0,58\% \\
\hline & & Coef. Var. & $3,80 \%$ & $12,13 \%$ & $12,13 \%$ & $9,70 \%$ & $12,13 \%$ & $9,70 \%$ & $12,89 \%$ & $13,29 \%$ \\
\hline \multirow{5}{*}{$\begin{array}{c}\text { B4,5- } \\
\text { RGB- } \\
50 \%\end{array}$} & \multirow{5}{*}{35} & Média & 10300 & 333 & 8,20 & 6634 & 13,87 & 11225 & $-0,40 \%$ & $-4,38 \%$ \\
\hline & & Máx. & 10350 & 336 & 8,29 & 6697 & 14,02 & 11332 & $-0,41 \%$ & $-4,45 \%$ \\
\hline & & Mín. & 10250 & 329 & 8,11 & 6570 & 13,72 & 11118 & $-0,39 \%$ & $-4,30 \%$ \\
\hline & & D. Padrão & 71 & 5 & 0,13 & 90 & 0,22 & 152 & 0,01\% & $0,10 \%$ \\
\hline & & Coef. Var. & $0,69 \%$ & $1,56 \%$ & $1,56 \%$ & $1,35 \%$ & $1,56 \%$ & $1,35 \%$ & $2,47 \%$ & $2,27 \%$ \\
\hline \multirow{5}{*}{$\begin{array}{c}\text { B4,5- } \\
\text { RMB- } \\
33 \%\end{array}$} & \multirow{5}{*}{35} & Média & 10217 & 267 & 6,58 & 5292 & 11,06 & 8894 & $-0,41 \%$ & $-2,92 \%$ \\
\hline & & Máx. & 10350 & 273 & 6,72 & 6259 & 11,30 & 10520 & $-0,47 \%$ & $-3,10 \%$ \\
\hline & & Mín. & 10050 & 259 & 6,37 & 4401 & 10,71 & 7397 & $-0,34 \%$ & $-2,69 \%$ \\
\hline & & D. Padrão & 153 & 8 & 0,19 & 931 & 0,31 & 1565 & 0,06\% & $0,21 \%$ о \\
\hline & & Coef. Var. & $1,50 \%$ & $2,81 \%$ & $2,81 \%$ & $17,60 \%$ & $2,81 \%$ & $17,60 \%$ & $15,06 \%$ & $7,19 \%$ \\
\hline
\end{tabular}

Analisando-se a Tabela 7.57, observa-se que todas as unidades com agregados reciclados apresentaram menores valores (33\% a 48\%) de módulo de deformação quando comparados com as unidades de referência. A inclusão da fração reciclada acarretou uma diminuição do módulo de deformação devido à porosidade do agregado reciclado; conforme Buttler (2003), a rigidez do agregado está ligada diretamente com a sua porosidade.

As deformações unitárias correspondentes à tensão de ruptura situaram-se entre 2,92\% e 4,54\%, com um valor médio igual a 3,91\%. Esses valores foram superiores, em relação à deformação unitária de ruptura de 3,00\%, citada por Gallegos (1989).

Drysdale (1994) cita que o módulo de deformação do bloco pode variar na faixa de 500 a 1000 vezes a resistência à compressão da unidade; enquanto que Sahlin (1971) relata que esse valor pode variar entre 500 a 1500 . A razão entre o módulo de deformação e a resistência à compressão das unidades do Grupo 4,5 encontra-se na Tabela 7.58. 
Tabela 7.58 - Relação entre o módulo de deformação e a resistência à compressão das unidades do Grupo 4,5.

\begin{tabular}{|c|c|c|c|c|c|c|c|}
\hline & Parâmetros & $\begin{array}{l}\text { B-4,5- } \\
\text { REF }\end{array}$ & $\begin{array}{c}\text { B4,5-RGV- } \\
100 \% \\
\end{array}$ & $\begin{array}{c}\text { B4,5-RGV- } \\
50 \% \\
\end{array}$ & $\begin{array}{c}\text { B4,5-RMV- } \\
33 \% \\
\end{array}$ & $\begin{array}{c}\text { B4,5- } \\
\text { RGB-50\% }\end{array}$ & $\begin{array}{c}\text { B4,5-RMB- } \\
33 \% \\
\end{array}$ \\
\hline \multirow{5}{*}{$\begin{array}{c}\text { Módulo de } \\
\text { deformação/resistência } \\
\text { à compressão }\end{array}$} & Média & 892 & 623 & 774 & 931 & 809 & 802 \\
\hline & Máx. & 976 & 726 & 987 & 1044 & 826 & 941 \\
\hline & Mín. & 807 & 531 & 551 & 806 & 793 & 691 \\
\hline & D. Padrão & 120 & 98 & 219 & 120 & 24 & 127 \\
\hline & Coef. Var. & $13,41 \%$ & $15,75 \%$ & $28,24 \%$ & $12,84 \%$ & $2,91 \%$ & $15,85 \%$ \\
\hline
\end{tabular}

Analisando-se a Tabela 7.58, nota-se que os valores da relação entre o módulo de deformação e a resistência à compressão das unidades ficaram dentro do intervalo proposto pelos pesquisadores. Juste (2001) obteve uma relação entre módulo e resistência à compressão entre 986 e 1010, para blocos de concreto de 4,5 MPa e 10,0 MPa, respectivamente. O ACl 318-89 (1995) fornece uma equação para calcular o módulo de elasticidade secante do concreto com faixa de massa específica entre 1442 e $2483 \mathrm{~kg} / \mathrm{m}^{3}$, que também pode ser utilizada para o cálculo do módulo de elasticidade secante do bloco, conforme citam Romagna (2000) e Mohamad (1998):

$$
E_{b}=0,0428 \cdot \sqrt{f_{b}} \cdot \gamma_{b}^{1,5}
$$

$\mathrm{E}_{\mathrm{b}}$ - módulo de elasticidade na área líquida (MPa)

$\mathrm{f}_{\mathrm{b}}$ - resistência à compressão na área líquida da unidade

$\gamma_{b}$ - massa específica da unidade $\left(\mathrm{kg} / \mathrm{m}^{3}\right)$

Considerando-se os valores experimentais de massa específica e resistência à compressão, é apresentada, na Tabela 7.59, os resultados de módulo de elasticidade e a razão entre módulo e resistência à compressão considerando as prescrições do $\mathrm{ACl}$ 318-89 (1995).

Tabela 7.59 - Módulo de elasticidade e relação entre módulo/resistência considerando as prescrições do ACI 318-89 (1995) para as unidades do Grupo 4,5.

\begin{tabular}{ccccccc}
\hline & B4,5-REF & $\begin{array}{c}\text { B4,5-RGV- } \\
\mathbf{1 0 0} \%\end{array}$ & $\begin{array}{c}\text { B4,5-RGV- } \\
\mathbf{5 0 \%}\end{array}$ & $\begin{array}{c}\text { B4,5-RMV- } \\
\mathbf{3 3 \%}\end{array}$ & $\begin{array}{c}\text { B4,5- } \\
\text { RGB-50\% }\end{array}$ & $\begin{array}{c}\text { B4,5- } \\
\text { RMB-33\% }\end{array}$ \\
\hline Massa específica $\left(\mathrm{kg} / \mathrm{m}^{3}\right)$ & 2275 & 2104 & 2147 & 2156 & 2197 & 2153 \\
\hline $\begin{array}{c}\text { Resistência à compressão }-\mathrm{fb}(\mathrm{MPa})- \\
\text { área líquida }\end{array}$ & 18,54 & 14,39 & 12,70 & 10,23 & 13,87 & 11,06 \\
\hline Eb (MPa) & 20464 & 16035 & 15528 & 14024 & 16798 & 14552 \\
\hline Eb/fb & 1103 & 1114 & 1222 & 1370 & 1211 & 1315 \\
\hline Eb/fb experimental & 892 & 623 & 774 & 931 & 809 & 802 \\
\hline
\end{tabular}


Conforme a Tabela 7.59, observa-se uma expressiva diferença entre os resultados dos módulos experimentais e aqueles obtidos utilizando as prescrições do $\mathrm{ACl}$ 318-89 (1995). Entretanto, segundo Juste (2001), a expressão do ACl refere-se a uma estimativa originalmente utilizada para determinar o módulo de elasticidade do concreto e não da alvenaria, o que se comprova com os resultados aqui apresentados.

\subsection{Grupo 8,0}

$\mathrm{Na}$ Tabela 7.60, são apresentados os resultados da força máxima aplicada, da tensão de ruptura, do módulo de deformação referente a área bruta e área líquida, a deformação referente a 33\% da tensão última e a deformação última para cada uma das unidades avaliadas do Grupo 8,0.

Tabela 7.60 - Módulo de deformação dos blocos - Grupo 8,0.

\begin{tabular}{|c|c|c|c|c|c|c|c|c|c|c|}
\hline Blocos & Idade & Parâmetros & $\begin{array}{c}\text { Massa } \\
(\mathrm{g})\end{array}$ & $\begin{array}{c}\text { Força } \\
(\mathbf{k N})\end{array}$ & $\begin{array}{c}\text { Tensão } \\
\text { Abruta } \\
\text { (MPa) }\end{array}$ & $\begin{array}{c}\text { Módulo } \\
\text { - Abruta } \\
\text { (MPa) }\end{array}$ & $\begin{array}{c}\text { Tensão } \\
\text { Aliquida } \\
\text { (MPa) }\end{array}$ & $\begin{array}{c}\text { Módulo } \\
\text { Aliquida } \\
\text { (MPa) }\end{array}$ & $\begin{array}{c}\text { Def. } \\
33 \% \text { da } \\
\text { tensão } \\
\text { última }\end{array}$ & $\begin{array}{c}\text { Deform. } \\
\text { Última }\end{array}$ \\
\hline \multirow{5}{*}{$\begin{array}{l}\text { B8,0- } \\
\text { REF }\end{array}$} & \multirow{5}{*}{35} & Média & 10250 & 518 & 12,75 & 10033 & 21,88 & 17209 & $-0,41 \%$ & $-3,11 \%$ \\
\hline & & Máx. & 10400 & 555 & 13,66 & 10846 & 23,43 & 18603 & $-0,45 \%$ & $-3,41 \%$ \\
\hline & & Mín. & 10050 & 458 & 11,29 & 9572 & 19,36 & 16419 & $-0,34 \%$ & $-2,58 \%$ \\
\hline & & D. Padrão & 180 & 52 & 1,28 & 706 & 2,20 & 1210 & $0,06 \%$ & $0,46 \%$ \\
\hline & & Coef. Var. & $1,76 \%$ & $10,04 \%$ & $10,04 \%$ & $7,03 \%$ & $10,04 \%$ & $7,03 \%$ & $14,75 \%$ & $14,67 \%$ \\
\hline \multirow{5}{*}{$\begin{array}{l}\text { B8,0- } \\
\text { RGV- } \\
100 \%\end{array}$} & \multirow{5}{*}{35} & Média & 9750 & 434 & 10,69 & 8982 & 18,43 & 15487 & $-0,38 \%$ & $-2,66 \%$ \\
\hline & & Máx. & 9800 & 443 & 10,92 & 9975 & 18,83 & 17199 & $-0,42 \%$ & $-3,03 \%$ \\
\hline & & Mín. & 9700 & 427 & 10,51 & 8088 & 18,12 & 13945 & $-0,33 \%$ & $-2,38 \%$ \\
\hline & & D. Padrão & 50 & 8 & 0,21 & 947 & 0,36 & 1633 & $0,05 \%$ & $0,34 \%$ о \\
\hline & & Coef. Var. & $0,51 \%$ & $1,96 \%$ & $1,96 \%$ & $10,55 \%$ & $1,96 \%$ & $10,55 \%$ & $12,50 \%$ & $12,77 \%$ \\
\hline \multirow{5}{*}{$\begin{array}{c}\text { B8,0- } \\
\text { RGV- } \\
50 \%\end{array}$} & \multirow{5}{*}{35} & Média & 10083 & 509 & 12,54 & 8033 & 21,36 & 13685 & $-0,51 \%$ & $-2,92 \%$ \\
\hline & & Máx. & 10200 & 526 & 12,96 & 8320 & 22,08 & 14173 & $-0,53 \%$ & $-3,16 \%$ \\
\hline & & Mín. & 10000 & 500 & 12,31 & 7542 & 20,98 & 12848 & $-0,47 \%$ & $-2,69 \%$ \\
\hline & & D. Padrão & 104 & 15 & 0,37 & 428 & 0,63 & 729 & $0,03 \%$ & $0,24 \%$ \\
\hline & & Coef. Var. & $1,03 \%$ & $2,94 \%$ & $2,94 \%$ & $5,32 \%$ & $2,94 \%$ & $5,32 \%$ & $5,94 \%$ & $8,08 \%$ \\
\hline \multirow{5}{*}{$\begin{array}{l}\text { B8,0- } \\
\text { RMV- } \\
33 \%\end{array}$} & \multirow{5}{*}{35} & Média & 10000 & 428 & 10,54 & 7405 & 18,24 & 12812 & $-0,46 \%$ & $-4,03 \%$ \\
\hline & & Máx. & 10300 & 498 & 12,26 & 9282 & 21,22 & 16059 & $-0,62 \%$ & $-4,23 \%$ \\
\hline & & Mín. & 9700 & 305 & 7,51 & 6315 & 13,00 & 10926 & $-0,36 \%$ & $-3,91 \%$ \\
\hline & & D. Padrão & 300 & 107 & 2,63 & 1632 & 4,55 & 2824 & $0,14 \%$ & $0,17 \%$ \\
\hline & & Coef. Var. & $3,00 \%$ & $24,96 \%$ & $24,96 \%$ & $22,04 \%$ & $24,96 \%$ & $22,04 \%$ & $30,76 \%$ & $4,31 \%$ \\
\hline \multirow{5}{*}{$\begin{array}{c}\text { B8,0- } \\
\text { RGB- } \\
50 \%\end{array}$} & \multirow{5}{*}{35} & Média & 10217 & 567 & 13,96 & 10318 & 23,87 & 17638 & $-0,43 \%$ & $-3,25 \%$ \\
\hline & & Máx. & 10400 & 610 & 15,02 & 10945 & 25,67 & 18709 & $-0,49 \%$ & $-3,40 \%$ \\
\hline & & Mín. & 10050 & 503 & 12,39 & 9747 & 21,18 & 16662 & $-0,38 \%$ & $-3,06 \%$ \\
\hline & & D. Padrão & 176 & 56 & 1,39 & 601 & 2,37 & 1027 & $0,05 \%$ & $0,18 \%$ \\
\hline & & Coef. Var. & $1,72 \%$ & $9,92 \%$ & $9,92 \%$ & $5,82 \%$ & $9,92 \%$ & $5,82 \%$ & $12,69 \%$ & $5,40 \%$ \\
\hline \multirow{5}{*}{$\begin{array}{c}\text { B8,0- } \\
\text { RMB- } \\
33 \%\end{array}$} & \multirow{5}{*}{35} & Média & 10167 & 358 & 8,81 & * & 14,83 & * & * & * \\
\hline & & Máx. & 10350 & 404 & 9,96 & * & 16,77 & * & * & * \\
\hline & & Mín. & 9900 & 309 & 7,60 & * & 12,80 & * & * & * \\
\hline & & D. Padrão & 236 & 48 & 1,18 & * & 1,99 & * & * & * \\
\hline & & Coef. Var. & $2,32 \%$ & $13,39 \%$ & $13,39 \%$ & * & $13,39 \%$ & * & * & * \\
\hline
\end{tabular}

A razão entre o módulo de deformação e a resistência à compressão das unidades do Grupo 8,0 encontra-se na Tabela 7.61. 
Tabela 7.61 - Relação entre o módulo de deformação e a resistência à compressão das unidades do Grupo 8,0.

\begin{tabular}{ccccccc}
\hline & Parâmetros & $\mathbf{B 8 , 0 - R E F}$ & $\begin{array}{c}\text { B8,0-RGV- } \\
\mathbf{1 0 0} \%\end{array}$ & $\begin{array}{c}\text { B8,0-RGV- } \\
\mathbf{5 0} \%\end{array}$ & $\begin{array}{c}\text { B8,0-RMV- } \\
\mathbf{3 3 \%}\end{array}$ & $\begin{array}{c}\text { B8,0- } \\
\text { RGB-50\% }\end{array}$ \\
\hline \multirow{4}{*}{$\begin{array}{c}\text { Módulo de } \\
\text { deformação/resistência } \\
\text { à compressão }\end{array}$} & Média & 796 & 841 & 641 & 726 & 744 \\
\cline { 2 - 7 } & Máx. & 961 & 949 & 675 & 881 & 828 \\
\cline { 2 - 7 } & Mín. & 709 & 760 & 612 & 515 & 649 \\
\cline { 2 - 7 } & D. Padrão & 143 & 98 & 31 & 189 & 90 \\
\cline { 2 - 7 } & Coef. Var. & $17,91 \%$ & $11,63 \%$ & $4,89 \%$ & $26,09 \%$ & $12,10 \%$ \\
\hline
\end{tabular}

Pela Tabela 7.61, nota-se que os resultados estão em concordância com os valores citados por Sahlin (1971). O pesquisador cita que o módulo de elasticidade do bloco pode variar na faixa de 500 a 1500 vezes o valor da resistência à compressão da unidade. Juste (2001) obteve uma relação entre módulo e resistência à compressão entre 986 e 1010, para blocos de concreto de 4,5 MPa e 10,0 MPa, respectivamente. Considerando-se os valores experimentais de massa específica e resistência à compressão, é apresentada, na Tabela 7.62, os resultados de módulo de elasticidade e a relação entre módulo e resistência à compressão segundo as prescrições do ACl 318-89 (1995).

Tabela 7.62 - Módulo de elasticidade e relação entre módulo/resistência considerando as prescrições do ACl 318-89 (1995).

\begin{tabular}{cccccc}
\hline & $\mathbf{B 8 , 0 - R E F}$ & $\begin{array}{c}\mathbf{B 8 , 0 - R G V -} \\
\mathbf{1 0 0} \%\end{array}$ & $\begin{array}{c}\text { B8,0-RGV- } \\
\mathbf{5 0 \%}\end{array}$ & $\begin{array}{c}\mathbf{B 8 , 0 - R M V -} \\
\mathbf{3 3 \%}\end{array}$ & $\begin{array}{c}\text { B8,0- } \\
\text { RGB-50\% }\end{array}$ \\
\hline Massa específica $\left(\mathrm{kg} / \mathrm{m}^{3}\right)$ & 2216 & 2113 & 2159 & 2165 & 2216 \\
\hline $\begin{array}{c}\text { Resistência à compressão }-\mathrm{fb}(\mathrm{MPa})- \\
\text { área líquida }\end{array}$ & 21,88 & 18,43 & 21,36 & 18,24 & 23,87 \\
\hline Eb (MPa) & 21372 & 18264 & 20307 & 18844 & 22323 \\
\hline Eb/fb & 977 & 991 & 951 & 1033 & 935 \\
\hline Eb/fb experimental & 796 & 841 & 641 & 726 & 744 \\
\hline
\end{tabular}

Conforme a Tabela 7.62, observa-se uma expressiva diferença entre os resultados dos módulos experimentais e aqueles obtidos utilizando as prescrições do $\mathrm{ACl}$ 318-89 (1995).

\subsection{Grupo 12,0}

Na Tabela 7.63, são apresentados os resultados da força máxima aplicada, da tensão de ruptura, do módulo de deformação referente à área bruta e à área líquida, a deformação referente a 33\% da tensão última e a deformação última para cada uma das unidades avaliadas do Grupo 12,0. 
Tabela 7.63 - Módulo de deformação dos blocos - Grupo 12,0.

\begin{tabular}{|c|c|c|c|c|c|c|c|c|c|c|}
\hline Blocos & Id ade & Parâm etros & $\begin{array}{c}\text { M assa } \\
(\mathrm{g})\end{array}$ & $\begin{array}{c}\text { Força } \\
(k N)\end{array}$ & $\begin{array}{c}\text { Tensão } \\
A_{\text {bruta }} \\
(\mathrm{M} \mathrm{Pa})\end{array}$ & $\begin{array}{c}\text { Módulo } \\
-A_{\text {bruta }} \\
(\mathrm{M} \mathrm{Pa})\end{array}$ & $\begin{array}{c}\text { Tensão } \\
\text { A }_{\text {liquida }} \\
(\mathrm{MPa} \text { ) }\end{array}$ & $\begin{array}{c}\text { Módulo } \\
\text { A liquida } \\
\text { (M Pa) }\end{array}$ & $\begin{array}{c}\text { Def. } \\
33 \% \text { da } \\
\text { tensão } \\
\text { últim a }\end{array}$ & $\begin{array}{l}\text { Deform. } \\
\text { Últim a }\end{array}$ \\
\hline \multirow{5}{*}{$\begin{array}{l}\text { B 12,0- } \\
\text { REF }\end{array}$} & \multirow{5}{*}{35} & Média & 9933 & 591 & 14,57 & 11428 & 25,20 & 19771 & $-0,43 \%$ & $-1,98 \%$ \\
\hline & & Máx. & 9950 & 651 & 16,04 & 13150 & 27,75 & 22751 & $-0,52 \%$ & $-2,40 \%$ \\
\hline & & Mín. & 9900 & 530 & 13,04 & 10101 & 22,57 & 17475 & $-0,36 \%$ & $-1,46 \%$ \\
\hline & & D. Padrão & 29 & 61 & 1,50 & 1563 & 2,59 & 2703 & $0,08 \%$ & $0,47 \%$ \\
\hline & & Coef. Var. & $0,29 \%$ & $10,28 \%$ & $10,28 \%$ & $13,67 \%$ & $10,28 \%$ & $13,67 \%$ & $19,16 \%$ & $24,00 \%$ \\
\hline \multirow{5}{*}{$\begin{array}{l}\text { B12,0- } \\
\text { RGV- } \\
100 \%\end{array}$} & \multirow{5}{*}{35} & Média & 9867 & 630 & 15,52 & 11745 & 26,76 & 20250 & $-0,43 \%$ & $-2,00 \%$ \\
\hline & & Máx. & 10000 & 716 & 17,63 & 13409 & 30,40 & 23119 & $-0,47 \%$ & $-2,37 \%$ \\
\hline & & Mín. & 9700 & 548 & 13,49 & 10830 & 23,27 & 18672 & $-0,40 \%$ & $-1,75 \%$ \\
\hline & & D. Padrão & 153 & 84 & 2,07 & 1443 & 3,57 & 2489 & $0,03 \%$ & $0,33 \%$ \\
\hline & & Coef. Var. & $1,55 \%$ & $13,34 \%$ & $13,34 \%$ & $12,29 \%$ & $13,34 \%$ & $12,29 \%$ & $7,81 \%$ & $16,29 \%$ \\
\hline \multirow{5}{*}{$\begin{array}{c}\text { B 12,0- } \\
\text { R G V- } \\
50 \%\end{array}$} & \multirow{5}{*}{35} & Média & 9883 & 666 & 16,39 & 12230 & 28,31 & 21123 & $-0,44 \%$ & $-1,89 \%$ \\
\hline & & Máx. & 9950 & 744 & 18,32 & 13510 & 31,64 & 23333 & $-0,53 \%$ & $-2,24 \%$ \\
\hline & & Mín. & 9800 & 594 & 14,64 & 11522 & 25,29 & 19899 & $-0,34 \%$ & $-1,53 \%$ \\
\hline & & D. Padrão & 76 & 75 & 1,85 & 1110 & 3,19 & 1918 & $0,09 \%$ & $0,35 \%$ \\
\hline & & Coef. Var. & $0,77 \%$ & $11,27 \%$ & $11,27 \%$ & $9,08 \%$ & $11,27 \%$ & $9,08 \%$ & $20,76 \%$ & $18,73 \%$ \\
\hline \multirow{5}{*}{$\begin{array}{l}\text { B 12,0- } \\
\text { RM V - } \\
33 \%\end{array}$} & \multirow{5}{*}{35} & Média & 9950 & 576 & 14,18 & 11097 & 24,88 & 19468 & $-0,41 \%$ & $-2,59 \%$ \\
\hline & & Máx. & 10100 & 696 & 17,15 & 12341 & 30,09 & 21652 & $-0,48 \%$ & $-3,35 \%$ \\
\hline & & Mín. & 9850 & 500 & 12,32 & 9528 & 21,61 & 16716 & $-0,32 \%$ & $-1,83 \%$ \\
\hline & & D. Padrão & 132 & 105 & 2,60 & 1434 & 4,56 & 2517 & $0,08 \%$ & $0,76 \%$ \\
\hline & & Coef. Var. & $1,33 \%$ & $18,32 \%$ & $18,32 \%$ & $12,93 \%$ & $18,32 \%$ & $12,93 \%$ & $19,49 \%$ & $29,32 \%$ \\
\hline \multirow{5}{*}{$\begin{array}{c}\text { B 12,0- } \\
\text { RG B - } \\
50 \%\end{array}$} & \multirow{5}{*}{35} & Média & 10183 & 691 & 17,02 & 12032 & 29,49 & 20853 & $-0,46 \%$ & $-2,14 \%$ \\
\hline & & Máx. & 10200 & 733 & 18,05 & 12914 & 31,28 & 22381 & $-0,50 \%$ & $-2,51 \%$ \\
\hline & & Mín. & 10150 & 668 & 16,44 & 10654 & 28,50 & 18465 & $-0,41 \%$ & $-1,71 \%$ \\
\hline & & D. Padrão & 29 & 36 & 0,90 & 1209 & 1,55 & 2095 & $0,05 \%$ & $0,40 \%$ \\
\hline & & Coef. Var. & $0,28 \%$ & $5,27 \%$ & $5,27 \%$ & $10,05 \%$ & $5,27 \%$ & $10,05 \%$ & $10,75 \%$ & $18,87 \%$ \\
\hline \multirow{5}{*}{$\begin{array}{l}\text { B 12,0- } \\
\text { RM B- } \\
33 \%\end{array}$} & \multirow{5}{*}{35} & Média & 10550 & 692 & 17,06 & 13037 & 28,66 & 21911 & $-0,43 \%$ & $-2,90 \%$ \\
\hline & & Máx. & 10700 & 738 & 18,17 & 13511 & 30,54 & 22708 & $-0,46 \%$ & $-3,31 \%$ \\
\hline & & Mín. & 10400 & 642 & 15,82 & 12739 & 26,59 & 21410 & $-0,39 \%$ & $-2,51 \%$ \\
\hline & & D. Padrão & 150 & 48 & 1,18 & 415 & 1,98 & 698 & $0,04 \%$ & $0,40 \%$ \\
\hline & & Coef. Var. & $1,42 \%$ & $6,92 \%$ & $6,92 \%$ & $3,19 \%$ & $6,92 \%$ & $3,19 \%$ & $8,33 \%$ & $13,78 \%$ \\
\hline
\end{tabular}

A razão entre o módulo de deformação e a resistência à compressão das unidades do Grupo 12,0 encontra-se na Tabela 7.64.

Tabela 7.64 - Relação entre o módulo de deformação e a resistência à compressão das unidades do Grupo 12,0.

\begin{tabular}{cccccccc}
\hline & Parâmetros & B12,0-REF & $\begin{array}{c}\text { B12,0- } \\
\text { RGV-100\% }\end{array}$ & $\begin{array}{c}\text { B12,0- } \\
\text { RGV-50\% }\end{array}$ & $\begin{array}{c}\text { B12,0- } \\
\text { RMV-33\% }\end{array}$ & $\begin{array}{c}\text { B12,0- } \\
\text { RGB-50\% }\end{array}$ & $\begin{array}{c}\text { B12,0- } \\
\text { RMB-33\% }\end{array}$ \\
\hline \multirow{3}{*}{$\begin{array}{c}\text { Módulo de } \\
\text { deformação/resistência } \\
\text { à compressão }\end{array}$} & Média & 792 & 759 & 757 & 799 & 708 & 767 \\
\cline { 2 - 8 } & Máx. & 900 & 803 & 923 & 1002 & 785 & 813 \\
\cline { 2 - 8 } & Mín. & 630 & 713 & 629 & 666 & 644 & 701 \\
\cline { 2 - 8 } & D. Padrão & 143 & 45 & 151 & 179 & 72 & 59 \\
\cline { 2 - 8 } & Coef. Var. & $18,04 \%$ & $5,94 \%$ & $19,89 \%$ & $22,38 \%$ & $10,14 \%$ & $7,63 \%$ \\
\hline
\end{tabular}

Considerando-se os valores experimentais de massa específica e resistência à compressão para as unidades do Grupo 12,0, é apresentada, na Tabela 7.65, os resultados de módulo de elasticidade e a relação entre módulo e resistência à compressão segundo as prescrições do ACI 318-89 (1995). 
Tabela 7.65 - Módulo de elasticidade e relação entre módulo/resistência considerando as prescrições do ACl 318-89 (1995) para as unidades do grupo 12,0.

\begin{tabular}{ccccccc}
\hline & $\mathbf{B 1 2 , 0 - R E F}$ & $\begin{array}{c}\text { B12,0- } \\
\text { RGV-100\% }\end{array}$ & $\begin{array}{c}\text { B12,0- } \\
\text { RGV-50\% }\end{array}$ & $\begin{array}{c}\text { B12,0- } \\
\text { RMV-33\% }\end{array}$ & $\begin{array}{c}\text { B12,0- } \\
\text { RGB-50\% }\end{array}$ & $\begin{array}{c}\text { B12,0- } \\
\text { RMB-33\% }\end{array}$ \\
\hline Massa específica $\left(\mathrm{kg} / \mathrm{m}^{3}\right)$ & 2182 & 2115 & 2143 & 2192 & 2204 & 2240 \\
\hline Resistência à compressão $-\mathrm{fb}(\mathrm{MPa})-$ & 25,20 & 26,76 & 28,31 & 24,88 & 29,49 & 28,66 \\
área líquida & 22411 & 22039 & 23119 & 22421 & 24611 & 24859 \\
\hline Eb (MPa) & 889 & 824 & 817 & 901 & 835 & 867 \\
\hline Eb/fb & 792 & 759 & 757 & 799 & 708 & 767 \\
\hline Eb/fb experimental & & & & & &
\end{tabular}

Pela Tabela 7.65, nota-se que os resultados experimentais de módulo de elasticidade ficaram muito próximos dos resultados obtidos utilizando as prescrições do $\mathrm{ACl}$ 318-89 (1995). Provavelmente os resultados com a expressão do ACl estejam calibrados para resistências típicas do concreto que são superiores às usualmente praticadas na alvenaria.

\subsection{Análise dos resultados - módulo de deformação}

Para facilitar a análise dos resultados de módulo de deformação é apresentada, na Tabela 7.66, o teste estatístico de Análise de Variância.

Tabela 7.66 - Teste ANOVA para valores de módulo de deformação.

\begin{tabular}{|c|c|c|c|c|c|}
\hline & & & \multicolumn{3}{|c|}{ Variáveis } \\
\hline & & & Grupos & Traços & Grupos x Traços \\
\hline \multirow{7}{*}{ 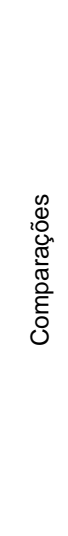 } & \multirow{3}{*}{$\begin{array}{c}\text { Comparações com o traço de } \\
\text { referência }\end{array}$} & REF x RECICLADOS ${ }^{1}$ & $S\left(F_{O}=65,4\right)$ & $S(6,7)$ & - \\
\hline & & REF x RECICLADOS ${ }^{2}$ & $\mathrm{~S}(183,7)$ & $\mathrm{S}(3,0)$ & $S(3,1)$ \\
\hline & & $\begin{array}{l}\text { REF x RGB- } 50 \% \times \\
\text { RMB- } 33 \%{ }^{2}\end{array}$ & $S(93,6)$ & - & $\mathrm{S}(10,9)$ \\
\hline & \multirow{2}{*}{$\begin{array}{l}\text { Diferentes porcentagens do } \\
\text { mesmo resíduo }\end{array}$} & $\begin{array}{c}\text { RGV-100\% } \times \text { RGV-50\% } \\
\text { x RMV-33\% } \\
\end{array}$ & $S(50,0)$ & - & - \\
\hline & & RGV-100\% x RGV-50\% & $\mathrm{S}(36,2)$ & - & - \\
\hline & \multirow{2}{*}{$\begin{array}{l}\text { Diferentes resíduos (\% similares } \\
\text { de substituição) }\end{array}$} & RGV-50\% x RGB-50\% & $S(50,7)$ & $S(8,2)$ & - \\
\hline & & $\mathrm{RMV}-33 \% \times \mathrm{RMB}-33 \%{ }^{2}$ & $S(156,7)$ & - & - \\
\hline \multicolumn{6}{|c|}{$\begin{array}{l}1 \text { com exceção das unidades do traço RMB-33\% } \\
2 \text { comparação realizada apenas para os Grupos } 4,5 \text { e } 12,0 \text {. } \\
\text { (S) : influência significativa para um nível de significância igual a } 5 \%\left(F_{0}>F_{\text {critico }}\right) \\
(-) \text { : sem influência significativa }\left(F_{0}<F_{\text {crítico }}\right) \\
\text { O número entre parênteses refere-se ao valor de } F_{0} \text {. Quanto maior o valor de } F_{0} \text {, maior será a influência do parâmetro sobre a propriedad } \\
\text { analisada }\end{array}$} \\
\hline
\end{tabular}

Analisando-se os resultados da Tabela 7.66, são estabelecidos os seguintes comentários: 
- Para a análise de $1^{\mathrm{a}}$ ordem, observou-se uma influência significativa da variável "grupo" sobre a propriedade de módulo de deformação. Nesse caso, pode-se dizer que os maiores e menores valores médios de módulo de deformação foram obtidos para as unidades dos Grupos 12,0 e 4,5, respectivamente. Evidentemente, a maior resistência das unidades do Grupo 12,0, comparativamente às unidades do Grupo 4,5, contribuiu para os maiores valores médios de módulo de deformação.

- De maneira geral, com relação à variável "traço", pode-se dizer que os maiores valores médios de módulo de deformação foram obtidos para as unidades de referência. A presença da fração reciclada acarretou uma diminuição do módulo de deformação devido à porosidade do agregado reciclado; de acordo com Buttler (2003), a rigidez do agregado está ligada diretamente com a sua porosidade. Com relação às unidades com agregados reciclados de vigota, não foram observadas diferenças significativas nos valores de módulo de deformação; fato esse que também foi observado para a comparação entre as unidades com agregados reciclados de bloco.

- Com relação à análise de $2^{\mathrm{a}}$ ordem, pode-se dizer que, em grande das comparações, não ocorreu influência significativa das variáveis (grupos $\mathrm{x}$ traços) sobre o módulo de deformação.

\subsubsection{ANÁLISE DE VIABILIDADE ECONÔMICA}

No presente item, é desenvolvido um estudo simplificado de viabilidade econômica da produção de blocos de concreto com agregados reciclados de concreto, focado principalmente no custo dos insumos. Nessa análise, os custos do processo de reciclagem do resíduo não são considerados, uma vez que envolvem inúmeras variáveis (composição de custos) que dependem da escala de reciclagem adotada. De acordo com Jadovski (2005), os custos típicos de uma usina de reciclagem podem ser divididos em: a) custos de implantação (aquisição de equipamentos, aquisição de máquinas e veículos, instalação de equipamentos, aquisição do terreno e obras civis); b) os custos de operação (mão-de-obra, veículos e máquinas alugadas, insumos de operação, despesas administrativas e aluguel de terreno); c) os custos de manutenção (troca de peças de desgaste, manutenção preventiva dos equipamentos de britagem, manutenção corretiva, depreciação de equipamentos, manutenção das obras civis e depreciação das obras civis).

Segundo Buttler (2006) e John e Ângulo (2002), os prováveis benefícios para uma empresa geradora de resíduos que invistam em tecnologias e equipamentos de reciclagem 
são: a) redução do impacto ambiental global; b) diminuição do custo para gerenciamento dos resíduos; c) adequação às normas ISO 14000; d) melhoria da imagem perante o mercado consumidor; e) mudança na cultura da empresa: o "lixo" transforma-se em um novo produto. Em contrapartida, essa mesma empresa espera que as seguintes metas sejam alcançadas para o sucesso do empreendimento: a) estabilidade no fornecimento de resíduo por período suficientemente longo para amortizar o investimento; b) taxa atrativa de retorno do investimento; c) aumento do faturamento; d) produtos reciclados de qualidade similar aos que são produzidos normalmente; d) custo final dos elementos com agregados reciclados inferior aos elementos comumente fabricados; e) aceitação pelo mercado consumidor (viabilidade de mercado).

Segundo Jadovski (2005), é imprescindível, para o sucesso econômico da reciclagem, minimizar a distância entre o reciclador, o fornecedor de resíduos e o mercado consumidor. Por outro lado, devido ao investimento necessário na montagem de instalações de reciclagem, algumas fábricas de pré-moldados podem comprar os agregados reciclados diretamente de usinas de reciclagem, desde que seu preço seja inferior e com qualidade comparável aos agregados naturais.

Considerando-se que as fábricas de pré-moldados optem em reciclar os resíduos gerados na própria fábrica ou decidam comprar/processar os resíduos em usinas de reciclagem de terceiros, este trabalho avaliará três hipóteses para análise de viabilidade econômica da produção de blocos de concreto. As hipóteses são as seguintes:

- Hipótese A: considerando-se que a fábrica de pré-moldados já disponha de um sistema de reciclagem e não necessite dispor os seus resíduos em aterros. Os resíduos gerados nas etapas produtivas são processados nesse sistema e, posteriormente, os agregados reciclados são utilizados para a fabricação de blocos estruturais de concreto das classes de resistência de 4,5 MPa, 8,0 MPa e 12,0 MPa. Alguns funcionários da própria fábrica são alocados para essa britagem. As dosagens para produção dos blocos de concreto apresentam algumas similaridades com as empregadas nos CPs de consistência seca, isto é, os traços de um dado grupo, independentemente da sua composição, apresentam o mesmo consumo de cimento e teor de argamassa (em volume). Deve-se frisar que não são computados os custos referentes ao processo de reciclagem, conforme descrito em Jadovski (2005).

- Hipótese B: considerando-se que a fábrica de pré-moldados não disponha de um sistema de reciclagem. Essa fábrica pretende comprar agregados reciclados de 
concreto, em grande quantidade, de uma usina de reciclagem situada entre $10 \mathrm{~km}$ e $75 \mathrm{~km}$ de distância. As dosagens para a produção dos blocos de concreto das classes de resistência de 4,5 MPa, 8,0 MPa e 12,0 MPa são adaptadas em relação àquelas empregadas para a produção dos CPs de consistência seca, uma vez que comumente nas usinas de reciclagem os resíduos são separados apenas granulometricamente, não ocorrendo triagem em função da qualidade do resíduo de concreto. Dessa forma, é considerado um agregado reciclado misto de concreto com propriedades intermediárias entre as apresentadas para os agregados reciclados de bloco e vigota. Nessa hipótese, também é avaliado o acréscimo relativo no custo dos insumos e no valor final dos blocos de referência quando os resíduos gerados pela empresa são destinados a aterros de RCD situados a até $75 \mathrm{~km}$ da fábrica, considerando-se um índice de perdas de $1 \%$ do volume total produzido.

- Hipótese C: considerando-se que a fábrica de pré-moldados não disponha de um sistema de reciclagem e, periodicamente, os resíduos gerados, em estado bruto, são levados até uma usina de reciclagem, situada entre $10 \mathrm{~km}$ e $75 \mathrm{~km}$ de distância, para serem processados. Posteriormente, a usina de reciclagem comercializa esse material (agregados reciclados de concreto) para a mesma fábrica a um custo $60 \%$ menor quando comparado ao preço de comercialização habitual desse agregado. As dosagens para a produção dos blocos de concreto das classes de resistência de 4,5 MPa, 8,0 MPa e 12,0 MPa são adaptadas em relação àquelas empregadas para a produção dos CPs de consistência seca, uma vez que comumente nas usinas de reciclagem os resíduos são separados apenas granulometricamente, não ocorrendo triagem em função da qualidade do resíduo de concreto. Dessa forma, é considerado um agregado reciclado misto de concreto com propriedades intermediárias entre as apresentadas para os agregados reciclados de bloco e vigota.

Em razão das informações necessárias para avaliação de cada uma das hipóteses, foi realizado um levantamento, no mês de novembro de 2006, na fábrica da Tatu PréMoldados, em algumas usinas de reciclagem e aterros de resíduos. Os dados obtidos encontram-se nas Tabelas 7.67 e 7.68 . 
Tabela 7.67 - Valores de insumos, frete e preço de comercialização das unidades.

\begin{tabular}{|c|c|c|}
\hline & & Valor (R\$) \\
\hline \multirow{6}{*}{ Insumos (frete já considerado) } & Cimento & $270,00 / t$ \\
\hline & Areia $^{1}$ & $32,23 / \mathrm{m}^{3}$ \\
\hline & Pedrisco $^{1}$ & $27,50 / \mathrm{m}^{3}$ \\
\hline & Pó-de-Pedra $^{1}$ & $26,50 / \mathrm{m}^{3}$ \\
\hline & Aditivo & $2,42 / 1$ \\
\hline & Água & $5,78 / \mathrm{m}^{3}$ \\
\hline \multirow{3}{*}{$\begin{array}{c}\text { Valores de comercialização das } \\
\text { unidades }\end{array}$} & $4,5 \mathrm{MPa}^{2}$ & $0,694 /$ un. \\
\hline & $8,0 \mathrm{MPa}^{2}$ & 0,820/un. \\
\hline & $12,0 \mathrm{MPa}^{2}$ & 1,104/un. \\
\hline \multicolumn{2}{|c|}{$\begin{array}{c}\Delta_{\text {custo }}(4,5 \mathrm{MPa})=\text { valor de comercialização da unidade - } \\
\text { custo de insumos para a produção da unidade }\end{array}$} & 0,30/un. \\
\hline \multicolumn{2}{|c|}{$\begin{array}{l}\Delta_{\text {custo }}(8,0 \mathrm{MPa})^{3}=\text { valor de comercialização da unidade - } \\
\text { custo de insumos para a produção da unidade }\end{array}$} & 0,40/un. \\
\hline \multicolumn{2}{|c|}{$\begin{array}{c}\Delta_{\text {custo }}(12,0 \mathrm{MPa})^{3}=\text { valor de comercialização da unidade } \\
\text { - custo de insumos para a produção da unidade }\end{array}$} & 0,50/un. \\
\hline
\end{tabular}

${ }^{1}$ estes valores referem-se a fornecedores situados a até $50 \mathrm{~km}$ da fábrica

2 estes valores referem-se às unidades produzidas utilizando-se o traço de fábrica

${ }^{3}$ para as unidades dos Grupos 8,0 e 12,0 MPa, acredita-se que os custos operacionais sejam mais elevados em função dos ajustes necessários na vibro-prensa, a pequena demanda (especialmente, para as unidades do Grupo 12,0) e os estoques reduzidos para essas unidades (são comumente produzidas sob encomenda)

(fonte: Tatu Pré-Moldados, 2006)

Tabela 7.68 - Valores de comercialização do agregado reciclado de concreto e para deposição dos resíduos em aterros de RCD.

\begin{tabular}{|c|c|c|c|c|c|c|}
\hline & & \multicolumn{5}{|c|}{ Valor $(R \$)$ - Frete $(R \$ 0,25 / \mathrm{km})$} \\
\hline & & $\begin{array}{l}\text { sem } \\
\text { frete }\end{array}$ & $\begin{array}{c}\text { até } \\
10 \mathrm{~km}\end{array}$ & $\begin{array}{c}\text { até } \\
25 \mathrm{~km}\end{array}$ & $\begin{array}{c}\text { até } \\
50 \mathrm{~km}\end{array}$ & $\begin{array}{c}\text { até } \\
75 \mathrm{~km}\end{array}$ \\
\hline \multirow[b]{2}{*}{ Insumos } & $\begin{array}{l}\text { Agregado reciclado de concreto (grande } \\
\text { quantidade) }\end{array}$ & $13,80 / \mathrm{m}^{3}$ & $16,30 / \mathrm{m}^{3}$ & $20,05 / \mathrm{m}^{3}$ & $26,30 / \mathrm{m}^{3}$ & $32,55 / \mathrm{m}^{3}$ \\
\hline & $\begin{array}{c}\text { Processamento do resíduo da fábrica em } \\
\text { usina de reciclagem e comercialização } \\
\text { desse resíduo para a mesma fábrica de } \\
\text { pré-moldados }\end{array}$ & $8,28 / \mathrm{m}^{3}$ & $10,78 / \mathrm{m}^{3}$ & $14,53 / \mathrm{m}^{3}$ & $20,78 / \mathrm{m}^{3}$ & $27,03 / \mathrm{m}^{3}$ \\
\hline \multicolumn{2}{|c|}{ Deposição dos resíduos em aterros de RCD } & $10,00 / \mathrm{m}^{3}$ & $12,50 / \mathrm{m}^{3}$ & $16,25 / \mathrm{m}^{3}$ & $22,50 / \mathrm{m}^{3}$ & $28,75 / \mathrm{m}^{3}$ \\
\hline
\end{tabular}

7 Informação verbal fornecida pelo Eng. Samir Fagury da Prohab (Secretaria Municipal de Desenvolvimento Sustentável, Ciência e Tecnologia e Progresso Habitação de São Carlos), em 2006.

${ }^{3}$ Informação verbal fornecida pelo funcionário Valtercir da Prefeitura Municipal de São Paulo, em 2006. 
Na Tabela 7.69 a 7.71, são apresentados os resultados para as unidades do Grupo 4,5, 8,0 e 12,0, considerando-se a Hipótese A.

Tabela 7.69 - Resultados do Grupo 4,5 considerando-se a Hipótese A.

\begin{tabular}{|c|c|c|c|c|c|c|c|c|c|c|c|c|}
\hline \multirow[b]{3}{*}{ Insumos } & \multicolumn{12}{|c|}{ GRUPO 4,5 } \\
\hline & \multicolumn{2}{|c|}{ REF } & \multicolumn{2}{|c|}{ RGV-100\% } & \multicolumn{2}{|c|}{ RGV-50\% } & \multicolumn{2}{|c|}{ RMV-33\% } & \multicolumn{2}{|c|}{ RGB-50\% } & \multicolumn{2}{|c|}{ RMB-33\% } \\
\hline & $\begin{array}{l}\mathrm{R} \$ / \mathrm{m}^{3} \text { de } \\
\text { concreto }\end{array}$ & $\begin{array}{c}\mathrm{R} \$ / 100 \\
\text { unidades }\end{array}$ & $\begin{array}{c}\mathrm{R} \$ / \mathrm{m}^{3} \\
\text { de } \\
\text { concreto }\end{array}$ & $\begin{array}{c}\mathrm{R} \$ / 100 \\
\text { unidades }\end{array}$ & $\begin{array}{c}\mathrm{R} \$ / \mathrm{m}^{3} \\
\text { de } \\
\text { concreto }\end{array}$ & $\begin{array}{c}\mathrm{R} \$ / 100 \\
\text { unidades }\end{array}$ & $\begin{array}{c}\mathrm{R} \$ / \mathrm{m}^{3} \\
\text { de } \\
\text { concreto }\end{array}$ & $\begin{array}{c}\mathrm{R} \$ / 100 \\
\text { unidades }\end{array}$ & $\begin{array}{c}\mathrm{R} \$ / \mathrm{m}^{3} \\
\text { de } \\
\text { concreto }\end{array}$ & $\begin{array}{c}\mathrm{R} \$ / 100 \\
\text { unidades }\end{array}$ & $\begin{array}{c}\mathrm{R} \$ / \mathrm{m}^{3} \\
\text { de } \\
\text { concreto }\end{array}$ & $\begin{array}{c}\mathrm{R} \$ / 100 \\
\text { unidades }\end{array}$ \\
\hline Cimento & 31,43 & 15,02 & 31,43 & 15,02 & 31,43 & 15,02 & 31,43 & 15,02 & 31,43 & 15,02 & 31,43 & 15,02 \\
\hline Pedrisco & 13,79 & 6,59 & - & - & 6,05 & 3,08 & 13,83 & 6,61 & 6,53 & 3,12 & 13,81 & 6,60 \\
\hline $\begin{array}{l}\text { Agregado } \\
\text { graúdo } \\
\text { reciclado }\end{array}$ & - & - & 2 & 2 & 2 & 2 & - & - & 2 & 2 & - & - \\
\hline Areia & 14,31 & 6,84 & 14,47 & 6,91 & 14,40 & 6,88 & 13,91 & 6,65 & 14,37 & 6,87 & 14,10 & 6,74 \\
\hline Pó-de-pedra & 15,00 & 7,17 & 14,99 & 7,16 & 14,99 & 7,17 & 9,74 & 4,66 & 15,00 & 7,17 & 9,86 & 4,71 \\
\hline $\begin{array}{l}\text { Agregado } \\
\text { miúdo } \\
\text { reciclado }\end{array}$ & - & - & - & - & - & - & 2 & 2 & - & - & 2 & 2 \\
\hline Aditivo & 0,56 & 0,27 & 0,56 & 0,27 & 0,56 & 0,27 & 0,56 & 0,27 & 0,56 & 0,27 & 0,56 & 0,27 \\
\hline Água & 0,71 & 0,34 & 0,80 & 0,38 & 0,76 & 0,36 & 0,81 & 0,39 & 0,76 & 0,36 & 0,77 & 0,37 \\
\hline $\begin{array}{c}\text { Total } \\
\text { (insumos) }\end{array}$ & 75,80 & 36,22 & 62,25 & 29,75 & 68,58 & 32,78 & 70,29 & 33,59 & 68,65 & 32,81 & 70,54 & 33,71 \\
\hline $\begin{array}{l}\text { Redução de } \\
\text { custo dos } \\
\text { insumos }(\%)^{1}\end{array}$ & 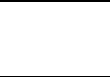 & & 17 & 87 & & 52 & & 27 & & 43 & & 94 \\
\hline $\begin{array}{l}\text { Valor de } \\
\text { venda (100 } \\
\text { un.) }\end{array}$ & - & 66,20 & - & 59,75 & - & 62,77 & - & 63,59 & - & 62,80 & - & 63,71 \\
\hline $\begin{array}{c}\text { Redução de } \\
\text { custo na } \\
\text { venda }(\%)^{1}\end{array}$ & - & - & - & 9,78 & - & 5,21 & - & 3,98 & - & 5,16 & - & 3,79 \\
\hline
\end{tabular}

Tabela 7.70 - Resultados do Grupo 8,0 considerando-se a Hipótese A.

\begin{tabular}{|c|c|c|c|c|c|c|c|c|c|c|c|c|}
\hline \multirow[b]{3}{*}{ Insumos } & \multicolumn{12}{|c|}{ GRUPO 8,0 } \\
\hline & \multicolumn{2}{|c|}{ REF } & \multicolumn{2}{|c|}{ RGV-100\% } & \multicolumn{2}{|c|}{ RGV-50\% } & \multicolumn{2}{|c|}{ RMV-33\% } & \multicolumn{2}{|c|}{ RGB-50\% } & \multicolumn{2}{|c|}{ RMB-33\% } \\
\hline & $\begin{array}{l}\mathrm{R} \$ / \mathrm{m}^{3} \text { de } \\
\text { concreto }\end{array}$ & $\begin{array}{c}\mathrm{R} \$ / 100 \\
\text { unidades }\end{array}$ & $\begin{array}{c}\mathrm{R} \$ / \mathrm{m}^{3} \\
\mathrm{de} \\
\text { concreto }\end{array}$ & $\begin{array}{c}\mathrm{R} \$ / 100 \\
\text { unidades }\end{array}$ & $\begin{array}{c}\mathrm{R} \$ / \mathrm{m}^{3} \\
\text { de } \\
\text { concreto }\end{array}$ & $\begin{array}{c}\mathrm{R} \$ / 100 \\
\text { unidades }\end{array}$ & $\begin{array}{c}\mathrm{R} \$ / \mathrm{m}^{3} \\
\text { de } \\
\text { concreto }\end{array}$ & $\begin{array}{c}\mathrm{R} \$ / 100 \\
\text { unidades }\end{array}$ & $\begin{array}{l}\mathrm{R} \$ / \mathrm{m}^{3} \\
\text { de } \\
\text { concreto }\end{array}$ & $\begin{array}{c}\mathrm{R} \$ / 100 \\
\text { unidades }\end{array}$ & $\begin{array}{c}\mathrm{R} \$ / \mathrm{m}^{3} \\
\text { de } \\
\text { concreto }\end{array}$ & $\begin{array}{c}\mathrm{R} \$ / 100 \\
\text { unidades }\end{array}$ \\
\hline Cimento & 41,31 & 19,74 & 41,31 & 19,74 & 41,31 & 19,74 & 41,31 & 19,74 & 41,31 & 19,74 & 41,31 & 19,74 \\
\hline Pedrisco & 13,60 & 6,50 & - & - & 6,35 & 3,04 & 13,63 & 6,51 & 6,44 & 3,08 & 13,62 & 6,51 \\
\hline $\begin{array}{l}\text { Agregado } \\
\text { graúdo } \\
\text { reciclado }\end{array}$ & - & - & 2 & 2 & 2 & 2 & - & - & 2 & 2 & - & - \\
\hline Areia & 14,11 & 6,74 & 14,26 & 6,82 & 14,19 & 6,78 & 13,72 & 6,56 & 14,18 & 6,77 & 13,90 & 6,64 \\
\hline Pó-de-pedra & 14,78 & 7,06 & 14,78 & 7,06 & 14,78 & 7,06 & 9,61 & 4,59 & 14,78 & 7,06 & 9,72 & 4,65 \\
\hline $\begin{array}{l}\text { Agregado } \\
\text { miúdo } \\
\text { reciclado }\end{array}$ & - & - & - & - & - & - & 2 & 2 & - & - & 2 & 2 \\
\hline Aditivo & 0,74 & 0,35 & 0,74 & 0,35 & 0,74 & 0,35 & 0,74 & 0,35 & 0,74 & 0,35 & 0,74 & 0,35 \\
\hline Água & 0,71 & 0,34 & 0,80 & 0,38 & 0,76 & 0,36 & 0,81 & 0,39 & 0,76 & 0,36 & 0,78 & 0,37 \\
\hline $\begin{array}{c}\text { Total } \\
\text { (insumos) }\end{array}$ & 85,25 & 40,74 & 71,89 & 34,36 & 78,13 & 37,34 & 79,81 & 38,14 & 78,20 & 37,37 & 80,06 & 38,26 \\
\hline $\begin{array}{l}\text { Redução de } \\
\text { custo dos } \\
\text { insumos }(\%)^{1}\end{array}$ & & 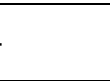 & & & & 35 & & 37 & & 26 & & 08 \\
\hline $\begin{array}{c}\text { Valor de } \\
\text { venda (100 } \\
\text { un.) }\end{array}$ & - & 80,74 & - & 74,36 & - & 77,34 & - & 78,14 & - & 77,37 & - & 78,26 \\
\hline $\begin{array}{c}\text { Redução de } \\
\text { custo na } \\
\text { venda }(\%)^{1}\end{array}$ & - & - & - & 7,91 & - & 4,21 & - & 3,22 & - & 4,17 & - & 3,07 \\
\hline
\end{tabular}


Tabela 7.71 - Resultados do Grupo 12,0 considerando-se a Hipótese A.

\begin{tabular}{|c|c|c|c|c|c|c|c|c|c|c|c|c|}
\hline \multirow[b]{2}{*}{ Insumos } & \multicolumn{12}{|c|}{ GRUPO 12,0 } \\
\hline & $\begin{array}{l}\mathrm{R} \$ / \mathrm{m}^{3} \mathrm{de} \\
\text { concreto }\end{array}$ & $\begin{array}{c}\mathrm{R} \$ / 100 \\
\text { unidades }\end{array}$ & $\begin{array}{c}\mathrm{R} \$ / \mathrm{m}^{3} \\
\text { de } \\
\text { concreto }\end{array}$ & $\begin{array}{c}\mathrm{R} \$ / 100 \\
\text { unidades }\end{array}$ & $\begin{array}{c}\mathrm{R} \$ / \mathrm{m}^{3} \\
\text { de } \\
\text { concreto }\end{array}$ & $\begin{array}{c}\mathrm{R} \$ / 100 \\
\text { unidades }\end{array}$ & $\begin{array}{c}\mathrm{R} \$ / \mathrm{m}^{3} \\
\text { de } \\
\text { concreto } \\
\end{array}$ & $\begin{array}{c}\mathrm{R} \$ / 100 \\
\text { unidades }\end{array}$ & $\begin{array}{c}\mathrm{R} \$ / \mathrm{m}^{3} \\
\text { de } \\
\text { concreto } \\
\end{array}$ & $\begin{array}{c}\mathrm{R} \$ / 100 \\
\text { unidades }\end{array}$ & $\begin{array}{c}\mathrm{R} \$ / \mathrm{m}^{3} \\
\mathrm{de} \\
\text { concreto } \\
\end{array}$ & $\begin{array}{r}\mathrm{R} \$ / 100 \\
\text { unidades }\end{array}$ \\
\hline Cimento & 60,26 & 28,80 & 60,26 & 28,80 & 60,26 & 28,80 & 60,26 & 28,80 & 60,26 & 28,80 & 60,26 & 28,80 \\
\hline Pedrisco & 13,22 & 6,32 & - & - & 6,18 & 2,95 & 13,25 & 6,33 & 6,26 & 2,99 & 13,23 & 6,32 \\
\hline Areia & 13,72 & 6,56 & 13,87 & 6,63 & 13,80 & 6,59 & 13,34 & 6,38 & 13,79 & 6,59 & 13,52 & 6,46 \\
\hline Pó-de-pedra & 14,37 & 6,87 & 14,37 & 6,87 & 14,37 & 6,87 & 9,34 & 4,46 & 14,37 & 6,87 & 9,45 & 4,52 \\
\hline $\begin{array}{l}\text { Agregado } \\
\text { miúdo } \\
\text { reciclado }\end{array}$ & - & - & - & - & - & - & 2 & 2 & - & - & 2 & 2 \\
\hline $\begin{array}{c}\text { Total } \\
\text { (insumos) }\end{array}$ & 103,37 & 49,40 & 90,38 & 43,19 & 96,45 & 46,09 & 98,08 & 46,87 & 96,52 & 46,12 & 98,32 & 46,99 \\
\hline $\begin{array}{l}\text { Redução de } \\
\text { custo dos } \\
\text { insumos }(\%)^{1}\end{array}$ & rat & - & & 56 & & & 5, & 11 & & 63 & & 88 \\
\hline $\begin{array}{l}\text { Valor de } \\
\text { venda (100 } \\
\text { un.) }\end{array}$ & - & 99,40 & - & 93,20 & - & 96,09 & - & 96,87 & - & 96,13 & - & 96,99 \\
\hline $\begin{array}{c}\text { Redução de } \\
\text { custo na } \\
\text { venda }(\%)^{1} \\
\end{array}$ & - & - & - & 6,24 & - & 3,33 & - & 2,54 & - & 3,29 & - & 2,42 \\
\hline
\end{tabular}

${ }^{1}$ redução de custo em relação aos blocos de referência

2 os agregados reciclados não representam custo para a empresa, uma vez que são gerados no próprio processo produtivo

Analisando-se os resultados das Tabelas 7.69 a 7.71 , são estabelecidos os seguintes comentários:

- Para o Grupo 4,5, nota-se que a redução no custo de insumos para os blocos com agregados reciclados, comparativamente às unidades de referência, situou-se entre 7,3\% e 17,9\%; já a redução no preço de comercialização dessas unidades esteve entre $3,7 \%$ e $9,8 \%$. O cimento representou de $45 \%$ a $50 \%$ do custo total, os agregados miúdos (areia e pó-de-pedra) representaram de $34 \%$ a $47 \%$ do custo e a parcela dada pela água e aditivo contribuiu com apenas $2 \%$ para o custo total das unidades com agregados reciclados.

- Para o Grupo 12,0, nota-se que a redução no custo de insumos para os blocos com agregados reciclados, comparativamente as unidades de referência, foi menor e situou-se entre $4,9 \%$ e $12,6 \%$; já a redução no preço de comercialização dessas unidades esteve entre $2,4 \%$ e $6,2 \%$. O cimento representou $64 \%$ a $67 \%$ do custo total, os agregados miúdos (areia e pó-de-pedra) representaram 23\% a 31\% do custo e a parcela dada pela água e aditivo contribuiu com apenas $2 \%$ para o custo total das unidades com agregados reciclados. Para as unidades do Grupo 8,0, 0 comportamento foi intermediário entre os apresentados para os blocos do Grupo 4,5 e Grupo 12,0. 
- De maneira geral, os blocos com agregados reciclados, independentemente da taxa de substituição, apresentaram um custo de produção e comercialização inferiores ao custo das unidades de referência. No entanto, deve-se ressaltar que o custo do processo de reciclagem não foi considerado. Alguns comentários pertinentes serão realizados no final deste item.

Na Tabela 7.72 a 7.74, são apresentados os resultados para as unidades do Grupo 4,5, 8,0 e 12,0, considerando-se a Hipótese B.

Tabela 7.72 - Resultados do Grupo 4,5 considerando-se a Hipótese B.

\begin{tabular}{|c|c|c|c|c|c|c|c|c|c|c|c|c|c|c|}
\hline & & \multicolumn{13}{|c|}{ GRUPO 4,5 } \\
\hline & & \multirow[b]{2}{*}{ REF } & \multicolumn{4}{|c|}{ RG- $100 \%{ }^{1}$} & \multicolumn{4}{|c|}{ RG-50\% ${ }^{1}$} & \multicolumn{4}{|c|}{$\mathrm{RM}-33 \%{ }^{1}$} \\
\hline & & & \multicolumn{4}{|c|}{ Frete } & \multicolumn{4}{|c|}{ Frete } & \multicolumn{4}{|c|}{ Frete } \\
\hline \multicolumn{2}{|c|}{ Insumos } & $\begin{array}{c}\mathrm{R} \$ / 100 \\
\text { un. }\end{array}$ & $\begin{array}{c}\mathrm{R} \$ / 100 \\
\text { un. }\end{array}$ & $\begin{array}{c}\mathrm{R} \$ / 100 \\
\text { un. }\end{array}$ & $\begin{array}{c}\mathrm{R} \$ / 100 \\
\text { un. }\end{array}$ & $\begin{array}{c}\mathrm{R} \$ / 100 \\
\text { un. }\end{array}$ & $\begin{array}{c}\mathrm{R} \$ / 100 \\
\text { un. }\end{array}$ & $\begin{array}{c}\mathrm{R} \$ / 100 \\
\text { un. }\end{array}$ & $\begin{array}{c}\mathrm{R} \$ / 100 \\
\text { un. }\end{array}$ & $\begin{array}{c}\mathrm{R} \$ / 100 \\
\text { un. }\end{array}$ & $\begin{array}{c}\mathrm{R} \$ / 100 \\
\text { un. }\end{array}$ & $\begin{array}{c}\mathrm{R} \$ / 100 \\
\text { un. }\end{array}$ & $\begin{array}{c}\mathrm{R} \$ / 100 \\
\text { un. }\end{array}$ & $\begin{array}{c}\mathrm{R} \$ / 100 \\
\text { un. }\end{array}$ \\
\hline \multicolumn{2}{|c|}{ Cimento } & 15,02 & 15,02 & 15,02 & 15,02 & 15,02 & 15,02 & 15,02 & 15,02 & 15,02 & 15,02 & 15,02 & 15,02 & 15,02 \\
\hline \multicolumn{2}{|c|}{ Agregado graúdo reciclado } & - & 3,93 & 4,83 & 6,34 & 7,85 & 2,11 & 2,59 & 3,40 & 4,21 & - & - & - & - \\
\hline \multicolumn{2}{|c|}{ Areia } & 6,84 & 6,91 & 6,91 & 6,91 & 6,91 & 6,87 & 6,87 & 6,87 & 6,87 & 6,69 & 6,69 & 6,69 & 6,69 \\
\hline \multicolumn{2}{|c|}{ Pó-de-pedra } & 7,17 & 7,16 & 7,16 & 7,16 & 7,16 & 7,17 & 7,17 & 7,17 & 7,17 & 4,68 & 4,68 & 4,68 & 4,68 \\
\hline \multicolumn{2}{|c|}{ Agregado miúdo reciclado } & - & - & - & - & - & - & - & - & - & 1,83 & 2,25 & 2,95 & 3,65 \\
\hline \multicolumn{2}{|c|}{$\begin{array}{l}\text { Custo dos insumos em relação } \\
\text { às unidades de referência (\%) }\end{array}$} & - & $-7,02$ & $-4,53$ & $-0,37$ & $+3,79$ & $-3,66$ & $-2,32$ & $-0,09$ & $+2,14$ & $-2,06$ & $-0,89$ & $+1,04$ & $+2,98$ \\
\hline \multicolumn{2}{|c|}{ Valor de venda (100 un.) } & 66,20 & 63,68 & 64,58 & 66,09 & 67,60 & 64,90 & 65,38 & 66,19 & 67,00 & 65,48 & 65,90 & 66,60 & 67,30 \\
\hline \multicolumn{2}{|c|}{$\begin{array}{l}\text { Preço de venda em relação às } \\
\text { unidades de referência (\%) }\end{array}$} & - & $-3,84$ & $-2,48$ & $-0,20$ & $+2,07$ & $-2,00$ & $-1,27$ & $-0,05$ & $+1,17$ & $-1,12$ & $-0,49$ & $+0,57$ & $+1,63$ \\
\hline \multirow{4}{*}{$\begin{array}{l}\text { Consumo } \\
\text { previsto de } \\
\text { agregado } \\
\text { reciclado }\left(\mathrm{m}^{3}\right) \\
\text { em função da } \\
\text { escala de } \\
\text { produção } \\
\text { (un.) }\end{array}$} & 10.000 un. & - & \multicolumn{4}{|c|}{$24 \mathrm{~m}^{3}$} & \multicolumn{4}{|c|}{$13 \mathrm{~m}^{3}$} & \multicolumn{4}{|c|}{$11 \mathrm{~m}^{3}$} \\
\hline & 100.000 un. & - & \multicolumn{4}{|c|}{$241 \mathrm{~m}^{3}$} & \multicolumn{4}{|c|}{$129 \mathrm{~m}^{3}$} & \multicolumn{4}{|c|}{$112 \mathrm{~m}^{3}$} \\
\hline & 500.000 un. & - & \multicolumn{4}{|c|}{$1206 \mathrm{~m}^{3}$} & \multicolumn{4}{|c|}{$647 \mathrm{~m}^{3}$} & \multicolumn{4}{|c|}{$561 \mathrm{~m}^{3}$} \\
\hline & 1.000 .000 un. & - & & & $1 \mathrm{~m}^{3}$ & & & & $3 \mathrm{~m}^{3}$ & & & & $2 \mathrm{~m}^{3}$ & \\
\hline
\end{tabular}

${ }^{1}$ foi considerado um resíduo com características intermediárias entre as apresentadas pelos resíduos de vigota e bloco 
Tabela 7.73 - Resultados do Grupo 8,0 considerando-se a Hipótese B.

\begin{tabular}{|c|c|c|c|c|c|c|c|c|c|c|c|c|c|c|}
\hline & & \multicolumn{13}{|c|}{ GRUPO 8,0 } \\
\hline & & \multirow{3}{*}{ REF } & \multicolumn{4}{|c|}{ RG- $100 \%{ }^{1}$} & \multicolumn{4}{|c|}{ RG-50\% ${ }^{1}$} & \multicolumn{4}{|c|}{$\mathrm{RM}-33 \%{ }^{1}$} \\
\hline & & & \multicolumn{4}{|c|}{ Frete } & \multicolumn{4}{|c|}{ Frete } & \multicolumn{4}{|c|}{ Frete } \\
\hline & & & $\begin{array}{c}\text { Até } 10 \\
\mathrm{~km}\end{array}$ & $\begin{array}{c}\text { Até } 25 \\
\mathrm{~km}\end{array}$ & $\begin{array}{c}\text { Até } 50 \\
\mathrm{~km}\end{array}$ & Até $75 \mathrm{~km}$ & $\begin{array}{c}\text { Até } 10 \\
\mathrm{~km}\end{array}$ & $\begin{array}{c}\text { Até } 25 \\
\mathrm{~km}\end{array}$ & $\begin{array}{c}\text { Até } 50 \\
\mathrm{~km}\end{array}$ & $\begin{array}{c}\text { Até } \\
75 \mathrm{~km} \\
\end{array}$ & $\begin{array}{c}\text { Até } 10 \\
\mathrm{~km}\end{array}$ & $\begin{array}{c}\text { Até } 25 \\
\mathrm{~km}\end{array}$ & $\begin{array}{c}\text { Até } 50 \\
\mathrm{~km}\end{array}$ & $\begin{array}{c}\text { Até } \\
75 \mathrm{~km} \\
\end{array}$ \\
\hline \multicolumn{2}{|c|}{ Insumos } & $\begin{array}{c}\mathrm{R} \$ / 100 \\
\text { un. }\end{array}$ & $\begin{array}{c}\mathrm{R} \$ / 100 \\
\text { un. }\end{array}$ & $\begin{array}{c}\mathrm{R} \$ / 100 \\
\text { un. }\end{array}$ & $\begin{array}{l}\mathrm{R} \$ / 100 \\
\text { un. }\end{array}$ & $\begin{array}{l}\mathrm{R} \$ / 100 \\
\text { un. }\end{array}$ & $\begin{array}{c}\mathrm{R} \$ / 100 \\
\text { un. }\end{array}$ & $\begin{array}{c}\mathrm{R} \$ / 100 \\
\text { un. }\end{array}$ & $\begin{array}{c}\mathrm{R} \$ / 100 \\
\text { un. }\end{array}$ & $\begin{array}{c}\mathrm{R} \$ / 100 \\
\text { un. }\end{array}$ & $\begin{array}{l}\mathrm{R} \$ / 100 \\
\text { un. }\end{array}$ & $\begin{array}{c}\mathrm{R} \$ / 100 \\
\text { un. }\end{array}$ & $\begin{array}{c}\mathrm{R} \$ / 100 \\
\text { un. }\end{array}$ & $\begin{array}{l}\mathrm{R} \$ / 100 \\
\text { un. }\end{array}$ \\
\hline \multicolumn{2}{|c|}{ Cimento } & 19,74 & 19,74 & 19,74 & 19,74 & 19,74 & 19,74 & 19,74 & 19,74 & 19,74 & 19,74 & 19,74 & 19,74 & 19,74 \\
\hline \multicolumn{2}{|c|}{ Pedrisco } & 6,50 & - & - & - & - & 3,06 & 3,06 & 3,06 & 3,06 & 6,51 & 6,51 & 6,51 & 6,51 \\
\hline \multicolumn{2}{|c|}{ Agregado graúdo reciclado } & - & 3,87 & 4,77 & 6,25 & 7,74 & 2,08 & 2,55 & 3,35 & 4,15 & - & - & - & - \\
\hline \multicolumn{2}{|c|}{ Areia } & 6,74 & 6,82 & 6,82 & 6,82 & 6,82 & 6,78 & 6,78 & 6,78 & 6,78 & 6,60 & 6,60 & 6,60 & 6,60 \\
\hline \multicolumn{2}{|c|}{ Pó-de-pedra } & 7,06 & 7,06 & 7,06 & 7,06 & 7,06 & 7,06 & 7,06 & 7,06 & 7,06 & 4,62 & 4,62 & 4,62 & 4,62 \\
\hline \multicolumn{2}{|c|}{ Agregado miúdo reciclado } & - & - & - & - & - & - & - & - & - & 1,80 & 2,22 & 2,91 & 3,60 \\
\hline \multicolumn{2}{|c|}{ Aditivo } & 0,35 & 0,35 & 0,35 & 0,35 & 0,35 & 0,35 & 0,35 & 0,35 & 0,35 & 0,35 & 0,35 & 0,35 & 0,35 \\
\hline \multicolumn{2}{|c|}{ Água } & 0,34 & 0,38 & 0,38 & 0,38 & 0,38 & 0,36 & 0,36 & 0,36 & 0,36 & 0,38 & 0,38 & 0,38 & 0,38 \\
\hline \multicolumn{2}{|c|}{ Total (insumos) } & 40,74 & 38,23 & 39,12 & 40,61 & 42,09 & 39,43 & 39,91 & 40,71 & 41,50 & 40,00 & 40,42 & 41,11 & 41,80 \\
\hline \multicolumn{2}{|c|}{$\begin{array}{l}\text { Custo dos insumos em relação } \\
\text { às unidades de referência (\%) }\end{array}$} & - & $-6,16$ & $-3,97$ & $-0,32$ & $+3,32$ & $-3,21$ & $-2,03$ & $-0,08$ & $+1,88$ & $-1,80$ & $-0,78$ & $+0,91$ & $+2,61$ \\
\hline \multicolumn{2}{|c|}{ Valor de venda (100 un.) } & 80,74 & 78,23 & 79,12 & 80,61 & 82,09 & 79,43 & 79,91 & 80,71 & 81,50 & 80,00 & 80,42 & 81,11 & 81,80 \\
\hline \multicolumn{2}{|c|}{$\begin{array}{l}\text { Preço de venda em relação às } \\
\text { unidades de referência (\%) }\end{array}$} & - & $-3,11$ & $-2,00$ & $-0,16$ & $+1,68$ & $-1,62$ & $-1,03$ & $-0,04$ & $+0,95$ & $-0,91$ & $-0,40$ & $+0,46$ & $+1,32$ \\
\hline \multirow{4}{*}{$\begin{array}{l}\text { Consumo } \\
\text { previsto de } \\
\text { agregado } \\
\text { reciclado }\left(\mathrm{m}^{3}\right) \\
\text { em função da } \\
\text { escala de } \\
\text { produção } \\
\text { (un.) }\end{array}$} & 10.000 un. & - & \multicolumn{4}{|c|}{$24 \mathrm{~m}^{3}$} & \multicolumn{4}{|c|}{$13 \mathrm{~m}^{3}$} & \multicolumn{4}{|c|}{$11 \mathrm{~m}^{3}$} \\
\hline & 100.000 un. & - & \multicolumn{4}{|c|}{$238 \mathrm{~m}^{3}$} & \multicolumn{4}{|c|}{$127 \mathrm{~m}^{3}$} & \multicolumn{4}{|c|}{$111 \mathrm{~m}^{3}$} \\
\hline & 500.000 un. & - & \multicolumn{4}{|c|}{$1188 \mathrm{~m}^{3}$} & \multicolumn{4}{|c|}{$637 \mathrm{~m}^{3}$} & \multicolumn{4}{|c|}{$553 \mathrm{~m}^{3}$} \\
\hline & 1.000 .000 un. & - & & & $7 \mathrm{~m}^{3}$ & & & & $4 \mathrm{~m}^{3}$ & & & & $\mathrm{~m}^{3}$ & \\
\hline
\end{tabular}

${ }^{1}$ foi considerado um resíduo com características intermediárias entre as apresentadas pelos resíduos de vigota e bloco

Tabela 7.74 - Resultados do Grupo 12,0 considerando-se a Hipótese B.

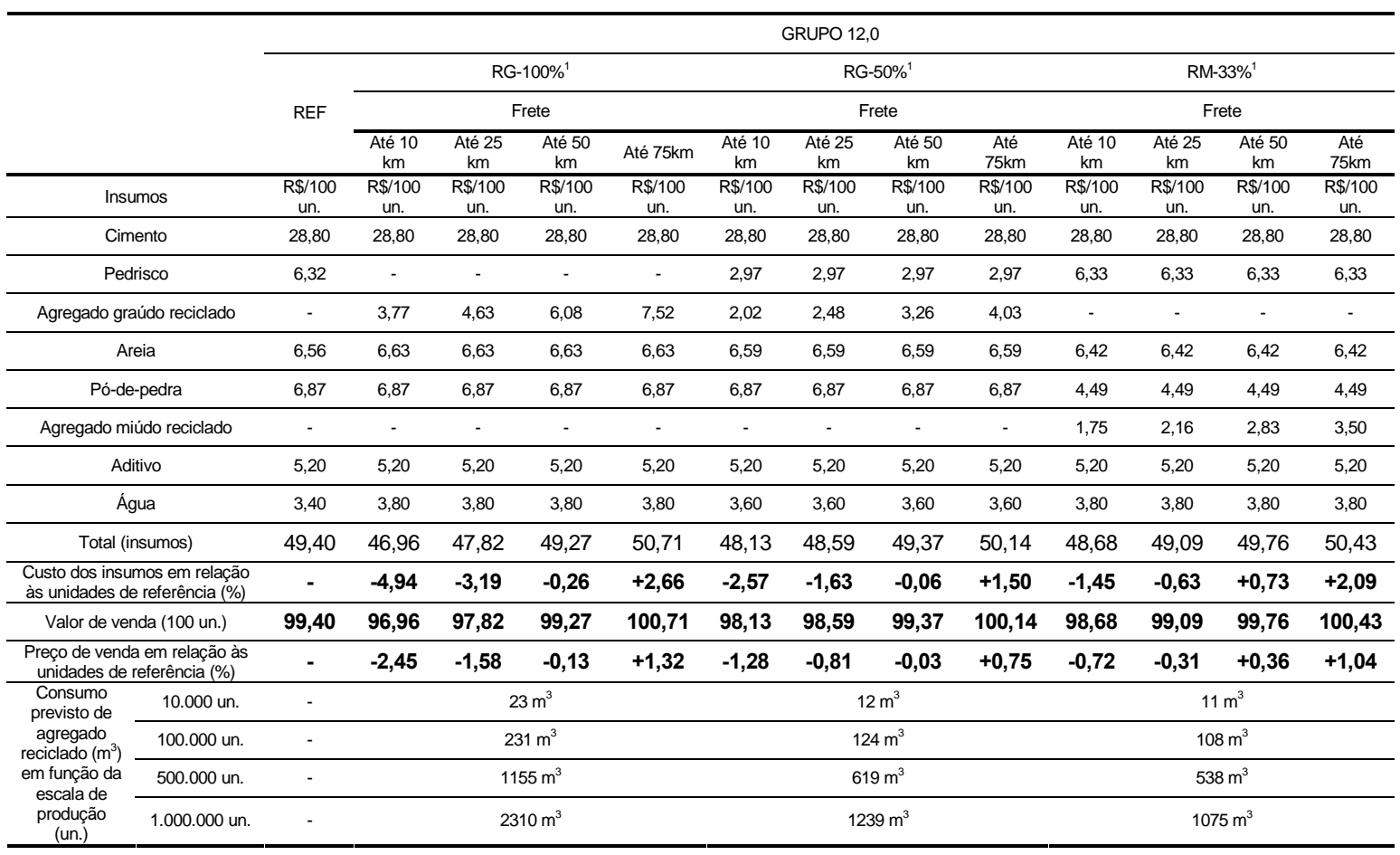

${ }^{1}$ foi considerado um resíduo com características intermediárias entre as apresentadas pelos resíduos de vigota e bloco 
Analisando-se os resultados das Tabelas 7.72 a 7.74 , nota-se que o preço do agregado reciclado foi influenciado basicamente pela distância da usina de reciclagem até a fábrica de pré-moldados. Nesse sentido, para distâncias superiores a $50 \mathrm{~km}$, o custo dos insumos e a comercialização das unidades com agregados reciclados foram superiores ao custo das unidades de referência. Para as unidades do Grupo 4,5, com 100\% de substituição de agregado natural por reciclado, ocorreu um aumento de 6,7\% para 11,6\% no custo do agregado graúdo reciclado, em relação ao custo total, quando elevada de $10 \mathrm{~km}$ para $75 \mathrm{~km}$ a distância até a usina de reciclagem. Deve-se ressaltar que, na composição do custo dos agregados naturais, os fornecedores estão situados a até $50 \mathrm{~km}$ da fábrica e atendem à realidade de fábricas localizadas no interior paulista (caso da Tatu PréMoldados); provavelmente, para fábricas situadas em áreas metropolitanas, onde as reservas de agregados naturais são escassas, as distâncias de transporte são consideráveis e a demanda é maior, o preço desses insumos será mais elevado. Após contato com alguns fornecedores de agregados naturais situados na cidade de São Paulo, em novembro de 2006, foram obtidos os seguintes valores médios considerando-se uma distância de frete de $50 \mathrm{~km}$ : pedrisco $\left(\mathrm{R} \$ 40 / \mathrm{m}^{3}\right)$, pó-de-pedra $\left(\mathrm{R} \$ 40 / \mathrm{m}^{3}\right)$ e areia $\left(\mathrm{R} \$ 44 / \mathrm{m}^{3}\right)$.

O acréscimo relativo no custo dos insumos e no valor final da unidade de referência, quando os resíduos gerados são destinados a aterros de RCD, é apresentado na Tabela 7.75 .

Tabela 7.75 - Acréscimo no custo dos insumos e comercialização das unidades quando os resíduos são depositados em aterros (Grupo 4,5).

\begin{tabular}{|c|c|c|c|c|}
\hline & \multicolumn{4}{|c|}{ Grupo 4,5 } \\
\hline & \multicolumn{4}{|c|}{ Distância até o aterro de RCD } \\
\hline & Até $10 \mathrm{~km}$ & Até $25 \mathrm{~km}$ & Até $50 \mathrm{~km}$ & Até $75 \mathrm{~km}$ \\
\hline Custo dos insumos para a produção de 100 un. de referência $(R \$)^{1}$ & \multicolumn{4}{|c|}{36,22} \\
\hline $\begin{array}{c}\text { Acréscimo no custo de insumos (\% e R\$) quando da deposição dos } \\
\text { resíduos gerados em aterros }\end{array}$ & $0,290 \%(R \$ 0,11)$ & $0,377 \%(\mathrm{R} \$ 0,14)$ & $0,522 \%(R \$ 0,19)$ & $0,668 \%(R \$ 0,24)$ \\
\hline Valor de comercialização (100 un.) & \multicolumn{4}{|c|}{66,22} \\
\hline $\begin{array}{l}\text { Acréscimo no valor final de comercialização das unidades (\%) } \\
\text { quando da deposição dos resíduos gerados em aterros }\end{array}$ & $0,166 \%$ & $0,211 \%$ & $0,287 \%$ & $0,362 \%$ \\
\hline
\end{tabular}

${ }^{1}$ é considerado um índice médio de perdas de $1 \%$ em relação ao volume total produzido

Analisando-se a Tabela 7.75, nota-se que o acréscimo no custo dos insumos e na comercialização das unidades foi relativamente pequeno com a deposição dos resíduos em aterros. O aumento no custo dos insumos situou-se entre $0,29 \%$ e $0,67 \%$ e dependeu exclusivamente da distância entre a fábrica e o aterro. Considerando-se uma fábrica com escala de produção de 10.000 blocos (110 t) e 500.000 blocos (5500 t), o custo relacionado 
à deposição dos resíduos em aterros foi de $R$ \$ 11,00 a $R$ \$ 526,00 (aterros situados até 10 $\mathrm{km}$ ) e $\mathrm{R} \$ 24,00$ e $\mathrm{R} \$ 1209,00$ (aterros situados até $75 \mathrm{~km}$ ), respectivamente. Diferentemente do que ocorre em outros países, tais como Holanda, Estados Unidos, Dinamarca e Inglaterra, as taxas para deposição de resíduos no Brasil ainda são relativamente baixas $\left(\mathrm{R} \$ 10,00 / \mathrm{m}^{3}\right)$. Nos Estados Unidos, de acordo com Kibert et al. (2000), as taxas de deposição variam entre $R \$ 22 / \mathrm{m}^{3}$ e $\mathrm{R} \$ 120 / \mathrm{m}^{3}$ (dados de 1996), sendo que, em alguns locais, o aumento dessa taxa, entre 1985 e 1996, superou os 400\%.

Na Tabela 7.76 a 7.78, são apresentados os resultados para as unidades do Grupo 4,5, 8,0 e 12,0, considerando-se a Hipótese C.

Tabela 7.76 - Resultados do Grupo 4,5 considerando-se a Hipótese C.

\begin{tabular}{|c|c|c|c|c|c|c|c|c|c|c|c|c|c|}
\hline & \multicolumn{13}{|c|}{ GRUPO 4,5} \\
\hline & \multirow{3}{*}{ REF } & \multicolumn{4}{|c|}{ RG- $100 \%{ }^{1}$} & \multicolumn{4}{|c|}{ RG-50\% ${ }^{1}$} & \multicolumn{4}{|c|}{$\mathrm{RM}-33 \%{ }^{1}$} \\
\hline & & \multicolumn{4}{|c|}{ Frete } & \multicolumn{4}{|c|}{ Frete } & \multicolumn{4}{|c|}{ Frete } \\
\hline & & Até $10 \mathrm{~km}$ & $\begin{array}{c}\text { Até } 25 \\
\mathrm{~km}\end{array}$ & $\begin{array}{c}\text { Ate } 50 \\
\mathrm{~km}\end{array}$ & Ate $75 \mathrm{~km}$ & $\begin{array}{c}\text { Até } 10 \\
\mathrm{~km}\end{array}$ & $\begin{array}{c}\text { Até } 25 \\
\mathrm{~km}\end{array}$ & $\begin{array}{c}\text { Ate } 50 \\
\mathrm{~km}\end{array}$ & $\begin{array}{c}\text { Ate } \\
75 \mathrm{~km} \\
\end{array}$ & $\begin{array}{c}\text { Até } 10 \\
\mathrm{~km}\end{array}$ & $\begin{array}{c}\text { Até } 25 \\
\mathrm{~km}\end{array}$ & $\begin{array}{c}\text { Ate } 50 \\
\mathrm{~km}\end{array}$ & $\begin{array}{c}\text { Ate } \\
75 \mathrm{~km} \\
\end{array}$ \\
\hline Insumos & $\begin{array}{c}\mathrm{R} \$ / 100 \\
\text { un. }\end{array}$ & $\begin{array}{c}\mathrm{R} \$ / 100 \\
\text { un. }\end{array}$ & $\begin{array}{c}\mathrm{R} \$ / 100 \\
\text { un. }\end{array}$ & $\begin{array}{c}\mathrm{R} \$ / 100 \\
\text { un. }\end{array}$ & $\begin{array}{c}\mathrm{R} \$ / 100 \\
\text { un. }\end{array}$ & $\begin{array}{c}\mathrm{R} \$ / 100 \\
\text { un. }\end{array}$ & $\begin{array}{c}\mathrm{R} \$ / 100 \\
\text { un. }\end{array}$ & $\begin{array}{c}\mathrm{R} \$ / 100 \\
\text { un. }\end{array}$ & $\begin{array}{c}\mathrm{R} \$ / 100 \\
\text { un. }\end{array}$ & $\begin{array}{c}\mathrm{R} \$ / 100 \\
\text { un. }\end{array}$ & $\begin{array}{c}\mathrm{R} \$ / 100 \\
\text { un. }\end{array}$ & $\begin{array}{c}\mathrm{R} \$ / 100 \\
\text { un. }\end{array}$ & $\begin{array}{c}\mathrm{R} \$ / 100 \\
\text { un. }\end{array}$ \\
\hline Cimento & 15,02 & 15,02 & 15,02 & 15,02 & 15,02 & 15,02 & 15,02 & 15,02 & 15,02 & 15,02 & 15,02 & 15,02 & 15,02 \\
\hline Pedrisco & 6,59 & - & - & - & - & 3,10 & 3,10 & 3,10 & 3,10 & 6,61 & 6,61 & 6,61 & 6,61 \\
\hline Agregado graúdo reciclado & - & 2,60 & 3,50 & 5,01 & 6,54 & 1,39 & 1,88 & 2,69 & 3,50 & - & - & - & - \\
\hline Areia & 6,84 & 6,91 & 6,91 & 6,91 & 6,91 & 6,87 & 6,87 & 6,87 & 6,87 & 6,69 & 6,69 & 6,69 & 6,69 \\
\hline Pó-de-pedra & 7,17 & 7,16 & 7,16 & 7,16 & 7,16 & 7,17 & 7,17 & 7,17 & 7,17 & 4,68 & 4,68 & 4,68 & 4,68 \\
\hline Agregado miúdo reciclado & - & - & - & - & - & - & - & - & - & 1,21 & 1,63 & 2,33 & 3,03 \\
\hline Aditivo & 0,27 & 0,27 & 0,27 & 0,27 & 0,27 & 0,27 & 0,27 & 0,27 & 0,27 & 0,27 & 0,27 & 0,27 & 0,27 \\
\hline Água & 0,34 & 0,38 & 0,38 & 0,38 & 0,38 & 0,36 & 0,36 & 0,36 & 0,36 & 0,38 & 0,38 & 0,38 & 0,38 \\
\hline Total (insumos) & 36,22 & 32,35 & 33,25 & 34,76 & 36,27 & 34,19 & 34,67 & 35,48 & 36,29 & 34,86 & 35,28 & 35,98 & 36,68 \\
\hline $\begin{array}{l}\text { Custo dos insumos em relação } \\
\text { às unidades de referência (\%) }\end{array}$ & - & $-10,70$ & $-8,20$ & $-4,04$ & $+0,12$ & $-5,63$ & $-4,29$ & $-2,06$ & $+0,17$ & $-3,76$ & $-2,60$ & $-0,67$ & $+1,27$ \\
\hline Valor de venda (100 un.) & 66,20 & 62,35 & 63,25 & 64,76 & 66,27 & 64,19 & 64,67 & 65,48 & 66,29 & 64,86 & 65,28 & 65,98 & 66,68 \\
\hline $\begin{array}{l}\text { Preço de venda em relação às } \\
\text { unidades de referência (\%) }\end{array}$ & - & $-5,85$ & $-4,49$ & $-2,21$ & $+0,06$ & $-3,08$ & $-2,35$ & $-1,13$ & $+0,10$ & $-2,06$ & $-1,42$ & $-0,37$ & $+0,69$ \\
\hline
\end{tabular}

${ }^{1}$ foi considerado um resíduo com características intermediárias entre as apresentadas pelos resíduos de vigota e bloco 
Tabela 7.77 - Resultados do Grupo 8,0 considerando-se a Hipótese C.

\begin{tabular}{|c|c|c|c|c|c|c|c|c|c|c|c|c|c|}
\hline & \multicolumn{13}{|c|}{ GRUPO 8,0 } \\
\hline & \multirow{3}{*}{ REF } & \multicolumn{4}{|c|}{ RG-100\% ${ }^{1}$} & \multicolumn{4}{|c|}{ RG-50\% ${ }^{1}$} & \multicolumn{4}{|c|}{$\mathrm{RM}-33 \%{ }^{1}$} \\
\hline & & \multicolumn{4}{|c|}{ Frete } & \multicolumn{4}{|c|}{ Frete } & \multicolumn{4}{|c|}{ Frete } \\
\hline & & $\begin{array}{c}\text { Até } 10 \\
\mathrm{~km}\end{array}$ & $\begin{array}{c}\text { Até } 25 \\
\mathrm{~km}\end{array}$ & $\begin{array}{l}\text { Até } 50 \\
\mathrm{~km}\end{array}$ & Até $75 \mathrm{~km}$ & $\begin{array}{c}\text { Até } 10 \\
\mathrm{~km}\end{array}$ & $\begin{array}{c}\text { Até } 25 \\
\mathrm{~km}\end{array}$ & $\begin{array}{l}\text { Até } 50 \\
\mathrm{~km}\end{array}$ & $\begin{array}{c}\text { Até } \\
75 \mathrm{~km}\end{array}$ & $\begin{array}{c}\text { Até } 10 \\
\mathrm{~km}\end{array}$ & $\begin{array}{c}\text { Até } 25 \\
\mathrm{~km}\end{array}$ & $\begin{array}{c}\text { Até } 50 \\
\mathrm{~km}\end{array}$ & $\begin{array}{c}\text { Até } \\
75 \mathrm{~km}\end{array}$ \\
\hline Insumos & $\begin{array}{c}\mathrm{R} \$ / 100 \\
\text { un. }\end{array}$ & $\begin{array}{c}\mathrm{R} \$ / 100 \\
\text { un. }\end{array}$ & $\begin{array}{c}\mathrm{R} \$ / 100 \\
\text { un. }\end{array}$ & $\begin{array}{l}\mathrm{R} \$ / 100 \\
\text { un. }\end{array}$ & $\begin{array}{l}\mathrm{R} \$ / 100 \\
\text { un. }\end{array}$ & $\begin{array}{c}\mathrm{R} \$ / 100 \\
\text { un. }\end{array}$ & $\begin{array}{c}\mathrm{R} \$ / 100 \\
\text { un. }\end{array}$ & $\begin{array}{c}\mathrm{R} \$ / 100 \\
\text { un. }\end{array}$ & $\begin{array}{l}\mathrm{R} \$ / 100 \\
\text { un. }\end{array}$ & $\begin{array}{c}\mathrm{R} \$ / 100 \\
\text { un. }\end{array}$ & $\begin{array}{c}\mathrm{R} \$ / 100 \\
\text { un. }\end{array}$ & $\begin{array}{c}\mathrm{R} \$ / 100 \\
\text { un. }\end{array}$ & $\begin{array}{c}\mathrm{R} \$ / 100 \\
\text { un. }\end{array}$ \\
\hline Cimento & 19,74 & 19,74 & 19,74 & 19,74 & 19,74 & 19,74 & 19,74 & 19,74 & 19,74 & 19,74 & 19,74 & 19,74 & 19,74 \\
\hline Pedrisco & 6,50 & - & - & - & - & 3,06 & 3,06 & 3,06 & 3,06 & 6,51 & 6,51 & 6,51 & 6,51 \\
\hline Agregado graúdo reciclado & - & 2,56 & 3,45 & 4,94 & 6,42 & 1,37 & 1,85 & 2,65 & 3,44 & - & - & - & - \\
\hline Areia & 6,74 & 6,82 & 6,82 & 6,82 & 6,82 & 6,78 & 6,78 & 6,78 & 6,78 & 6,60 & 6,60 & 6,60 & 6,60 \\
\hline Pó-de-pedra & 7,06 & 7,06 & 7,06 & 7,06 & 7,06 & 7,06 & 7,06 & 7,06 & 7,06 & 4,62 & 4,62 & 4,62 & 4,62 \\
\hline Agregado miúdo reciclado & - & - & - & - & - & - & - & - & - & 1,19 & 1,61 & 2,30 & 2,99 \\
\hline Aditivo & 0,35 & 0,35 & 0,35 & 0,35 & 0,35 & 0,35 & 0,35 & 0,35 & 0,35 & 0,35 & 0,35 & 0,35 & 0,35 \\
\hline Água & 0,34 & 0,38 & 0,38 & 0,38 & 0,38 & 0,36 & 0,36 & 0,36 & 0,36 & 0,38 & 0,38 & 0,38 & 0,38 \\
\hline Total (insumos) & 40,74 & 36,92 & 37,81 & 39,29 & 40,78 & 38,73 & 39,21 & 40,00 & 40,80 & 39,39 & 39,81 & 40,50 & 41,19 \\
\hline $\begin{array}{l}\text { Custo dos insumos em relação } \\
\text { às unidades de referência (\%) }\end{array}$ & - & $-9,38$ & $-7,19$ & $-3,55$ & $+0,10$ & $-4,93$ & $-3,76$ & $-1,81$ & $+0,15$ & $-3,30$ & $-2,28$ & $-0,59$ & $+1,11$ \\
\hline Valor de venda (100 un.) & 80,74 & 76,92 & 77,81 & 79,29 & 80,78 & 78,73 & 79,21 & 80,00 & 80,80 & 79,39 & 79,81 & 80,50 & 81,19 \\
\hline $\begin{array}{l}\text { Preço de venda em relação às } \\
\text { unidades de referência (\%) }\end{array}$ & - & $-4,73$ & $-3,63$ & $-1,79$ & $+0,05$ & $-2,49$ & $-1,90$ & $-0,91$ & $+0,08$ & $-1,67$ & $-1,15$ & $-0,30$ & $+0,56$ \\
\hline
\end{tabular}

Tabela 7.78 - Resultados do Grupo 12,0 considerando-se a Hipótese C.

\begin{tabular}{|c|c|c|c|c|c|c|c|c|c|c|c|c|c|}
\hline & \multicolumn{13}{|c|}{ GRUPO 12,0} \\
\hline & \multirow{3}{*}{ REF } & \multicolumn{4}{|c|}{ RG- $100 \%{ }^{1}$} & \multicolumn{4}{|c|}{ RG-50\% ${ }^{1}$} & \multicolumn{4}{|c|}{ RM- $33 \%{ }^{1}$} \\
\hline & & \multicolumn{4}{|c|}{ Frete } & \multicolumn{4}{|c|}{ Frete } & \multicolumn{4}{|c|}{ Frete } \\
\hline & & $\begin{array}{c}\text { Até } 10 \\
\mathrm{~km}\end{array}$ & $\begin{array}{c}\text { Até } 25 \\
\mathrm{~km}\end{array}$ & $\begin{array}{c}\text { Até } 50 \\
\mathrm{~km}\end{array}$ & Até $75 \mathrm{~km}$ & $\begin{array}{c}\text { Até } 10 \\
\mathrm{~km}\end{array}$ & $\begin{array}{c}\text { Até } 25 \\
\mathrm{~km}\end{array}$ & $\begin{array}{c}\text { Até } 50 \\
\mathrm{~km}\end{array}$ & $\begin{array}{c}\text { Até } \\
75 \mathrm{~km}\end{array}$ & $\begin{array}{c}\text { Até } 10 \\
\mathrm{~km}\end{array}$ & $\begin{array}{c}\text { Até } 25 \\
\mathrm{~km}\end{array}$ & $\begin{array}{c}\text { Até } 50 \\
\mathrm{~km}\end{array}$ & $\begin{array}{c}\text { Até } \\
75 \mathrm{~km}\end{array}$ \\
\hline Insumos & $\begin{array}{c}\mathrm{R} \$ / 100 \\
\text { un. }\end{array}$ & $\begin{array}{c}\mathrm{R} \$ / 100 \\
\text { un. }\end{array}$ & $\begin{array}{c}\mathrm{R} \$ / 100 \\
\text { un. }\end{array}$ & $\begin{array}{c}\mathrm{R} \$ / 100 \\
\text { un. }\end{array}$ & $\begin{array}{c}\mathrm{R} \$ / 100 \\
\text { un. }\end{array}$ & $\begin{array}{c}\mathrm{R} \$ / 100 \\
\text { un. }\end{array}$ & $\begin{array}{c}\mathrm{R} \$ / 100 \\
\text { un. }\end{array}$ & $\begin{array}{c}\mathrm{R} \$ / 100 \\
\text { un. }\end{array}$ & $\begin{array}{c}\mathrm{R} \$ / 100 \\
\text { un. }\end{array}$ & $\begin{array}{c}\mathrm{R} \$ / 100 \\
\text { un. }\end{array}$ & $\begin{array}{c}\mathrm{R} \$ / 100 \\
\text { un. }\end{array}$ & $\begin{array}{c}\mathrm{R} \$ / 100 \\
\text { un. }\end{array}$ & $\begin{array}{c}\mathrm{R} \$ / 100 \\
\text { un. }\end{array}$ \\
\hline Cimento & 28,80 & 28,80 & 28,80 & 28,80 & 28,80 & 28,80 & 28,80 & 28,80 & 28,80 & 28,80 & 28,80 & 28,80 & 28,80 \\
\hline Pedrisco & 6,32 & - & - & - & - & 2,97 & 2,97 & 2,97 & 2,97 & 6,33 & 6,33 & 6,33 & 6,33 \\
\hline Agregado graúdo reciclado & - & 2,49 & 3,36 & 4,80 & 6,24 & 1,34 & 1,80 & 2,57 & 3,35 & - & - & - & - \\
\hline Areia & 6,56 & 6,63 & 6,63 & 6,63 & 6,63 & 6,59 & 6,59 & 6,59 & 6,59 & 6,42 & 6,42 & 6,42 & 6,42 \\
\hline Pó-de-pedra & 6,87 & 6,87 & 6,87 & 6,87 & 6,87 & 6,87 & 6,87 & 6,87 & 6,87 & 4,49 & 4,49 & 4,49 & 4,49 \\
\hline Agregado miúdo reciclado & - & - & - & - & - & - & - & - & - & 1,17 & 1,56 & 2,23 & 2,91 \\
\hline Aditivo & 5,20 & 5,20 & 5,20 & 5,20 & 5,20 & 5,20 & 5,20 & 5,20 & 5,20 & 5,20 & 5,20 & 5,20 & 5,20 \\
\hline Água & 3,40 & 3,80 & 3,80 & 3,80 & 3,80 & 3,60 & 3,60 & 3,60 & 3,60 & 3,80 & 3,80 & 3,80 & 3,80 \\
\hline Total (insumos) & 49,40 & 45,68 & 46,55 & 47,99 & 49,44 & 47,44 & 47,91 & 48,68 & 49,46 & 48,09 & 48,49 & 49,16 & 49,84 \\
\hline $\begin{array}{l}\text { Custo dos insumos em relação } \\
\text { às unidades de referência (\%) }\end{array}$ & - & $-7,52$ & $-5,77$ & $-2,84$ & $+0,08$ & $-3,96$ & $-3,02$ & $-1,45$ & $+0,12$ & $-2,65$ & $-1,83$ & $-0,47$ & $+0,89$ \\
\hline Valor de venda (100 un.) & 99,40 & 95,68 & 96,55 & 97,99 & 99,44 & 97,44 & 97,91 & 98,68 & 99,46 & 98,09 & 98,49 & 99,16 & 99,84 \\
\hline $\begin{array}{l}\text { Preço de venda em relação às } \\
\text { unidades de referência (\%) }\end{array}$ & - & $-3,74$ & $-2,87$ & $-1,41$ & $+0,04$ & $-1,97$ & $-1,50$ & $-0,72$ & $+0,06$ & $-1,32$ & $-0,91$ & $-0,23$ & $+0,44$ \\
\hline
\end{tabular}

Pelas Tabelas 7.76 a 7.78 , nota-se que a hipótese proposta é muito interessante para fábricas de pré-moldados, uma vez que além da redução no preço do agregado reciclado (35\% comparativamente ao agregado reciclado comprado diretamente da usina de reciclagem), existe a possibilidade da redução do custo de gerenciamento dos resíduos produzidos pela própria fábrica (que pode representar até $0,67 \%$ do custo de materiais para a fabricação das unidades) e redução no custo dos insumos, comparativamente as unidades 
de referência, que pode chegar até a 7,5\% (dependendo do valor do frete). De maneira indireta, a fábrica também poderá obter certificados de qualidade (ISO 14000), inserção de produtos ecologicamente corretos, conquista de novos clientes e marketing diferenciado.

Outra possibilidade é a reciclagem na própria fábrica de pré-moldados, conforme exposto na hipótese $A$, fato esse que eliminaria a necessidade de transporte até a usina de reciclagem. Por outro lado, a determinação do custo exato de processamento, conforme já relatado, envolve inúmeras variáveis e não será tratado no presente trabalho; no entanto, a partir dos dados expostos até o momento é possível fazer algumas suposições baseando-se em fábricas com diferentes escalas de produção, Tabela 7.79.

Tabela 7.79 - Análise de viabilidade econômica da Hipótese A considerando-se fábricas de pré-moldados com diferentes escalas de produção.

\begin{tabular}{|c|c|c|c|c|c|c|c|c|c|c|c|c|}
\hline \multirow[b]{2}{*}{$\begin{array}{l}\text { Unidades } \\
\text { produzidas } \\
\text { (un./mês) }\end{array}$} & \multirow[b]{2}{*}{$\begin{array}{l}\text { Unidades } \\
\text { produzidas } \\
\text { (un./dia) })^{1}\end{array}$} & \multirow[b]{2}{*}{$\begin{array}{l}\text { Massa } \\
\text { produzida } \\
{\text { (t/dia })^{2}}^{\text {a }}\end{array}$} & \multirow[b]{2}{*}{$\begin{array}{l}\text { Resíduos } \\
\text { produzidos } \\
\text { (t/dia) })^{3}\end{array}$} & \multirow[b]{2}{*}{$\begin{array}{l}\text { Volume } \\
\text { gerado de } \\
\text { resíduos } \\
\left(\mathrm{m}^{3} / \mathrm{dia}\right)\end{array}$} & \multirow[b]{2}{*}{$\begin{array}{l}\text { Volume } \\
\text { gerado de } \\
\text { resíduos } \\
\text { (mlmês) }\end{array}$} & \multirow[b]{2}{*}{$\begin{array}{l}\text { Volume de } \\
\text { agregados } \\
\text { reciclados } \\
\text { que poderiam } \\
\text { ser utilizados } \\
\quad\left(\mathrm{m}^{3}\right)^{4}\end{array}$} & \multirow[b]{2}{*}{$\begin{array}{l}\text { Unidades do } \\
\text { traço RG- } \\
50 \% \text { que } \\
\text { são } \\
\text { produzidas } \\
\text { utilizando-se } \\
\text { os resíduos } \\
\text { gerados } \\
\text { (un./mês) }\end{array}$} & \multicolumn{3}{|c|}{ Redução de custos (R\$/mês) } & \multicolumn{2}{|c|}{$\begin{array}{c}\text { Implantação de uma estação } \\
\text { de reciclagem }\end{array}$} \\
\hline & & & & & & & & $\begin{array}{l}\text { Redução do } \\
\text { custo com } \\
\text { insumos (ex. } \\
\text { produção do } \\
\text { RG-50\%) }\end{array}$ & $\begin{array}{c}\text { Redução } \\
\text { de custo - } \\
\text { deposição } \\
\text { em aterros } \\
(75 \mathrm{~km})^{7}\end{array}$ & $\begin{array}{l}\text { Redução } \\
\text { total } \\
\text { (R\$/mês) }\end{array}$ & $\begin{array}{l}\text { Período } \\
\text { estimado de } \\
\text { retorno do } \\
\text { investimento } \\
\text { (anos) }^{8}\end{array}$ & $\begin{array}{c}\text { Número de } \\
\text { horas/mês de } \\
\text { funcionamento } \\
\text { da estação de } \\
\text { reciclagem } \\
\text { (prod. média = } \\
\left.16 \mathrm{~m}^{3} / \mathrm{h}\right)^{9}\end{array}$ \\
\hline 10.000 & 460 & 5,1 & 0,05 & 0,04 & 0,88 & 24,0 & 677 & 23,3 & 25,3 & 48,6 & - & 5'/mês \\
\hline 100.000 & 4550 & 50,0 & 0,50 & 0,40 & 8,80 & 241,0 & 6770 & 233,4 & 253,0 & 486,4 & 37 & 30 'mês \\
\hline 500.000 & 22800 & 251,0 & 2,51 & 2,01 & 44,22 & 1206,0 & 34280 & 1182,0 & 1271,3 & 2453,3 & 7 & $3 \mathrm{~h} / \mathrm{mês}$ \\
\hline 1.000 .000 & 45500 & 500,0 & 5,00 & 4,00 & 88,00 & 2411,0 & 68220 & 2352,3 & 2530,0 & 4882,3 & 4 & $6 \mathrm{~h} / \mathrm{mês}$ \\
\hline 2.000 .000 & 90100 & 991,0 & 9,91 & 7,93 & 174,46 & 4822,0 & 134822 & 4650,0 & 5015,7 & 9665,7 & 2 & $11 \mathrm{~h} / \mathrm{mês}$ \\
\hline \multicolumn{13}{|c|}{ 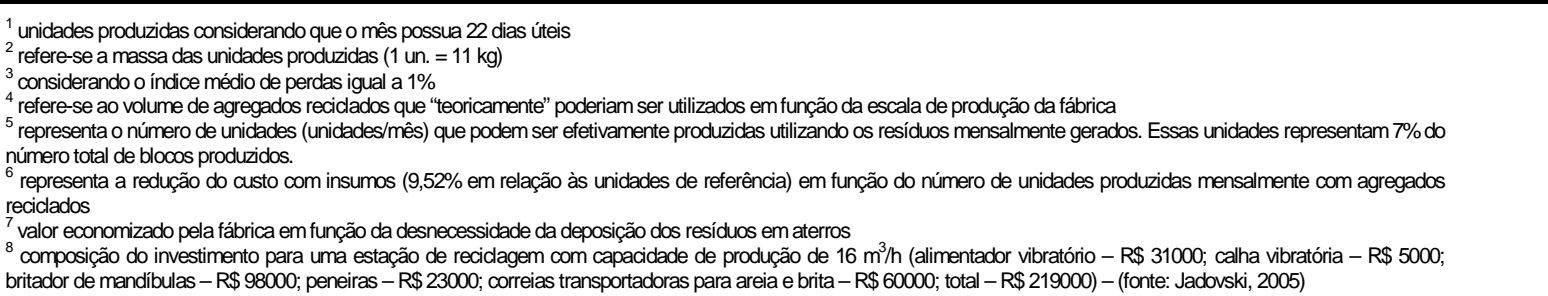 } \\
\hline
\end{tabular}

Analisando-se os dados da Tabela 7.79, observa-se que:

- Considerando-se fábricas com escala reduzida de produção (até 100.000 unidades/mês), nota-se que o volume de resíduos gerados foi pequeno $(<10$ $\mathrm{m}^{3} / \mathrm{mês}$ ) e a redução de custos com a reciclagem (insumos + deposição) foi inferior a $\mathrm{R} \$ 500,00$ (representando $1,5 \%$ do custo total de insumos). Nesse caso, o investimento em uma estação de reciclagem com capacidade de produção de 16 $\mathrm{m}^{3} / \mathrm{h}$ e custo estimado em $\mathrm{R} \$ 220.000,00$ (dados de 2005) não representa uma alternativa viável, uma vez que o período estimado de retorno do investimento, para 
a fábrica com escala de produção de 100.000 unidades, foi superior a 35 anos. Provavelmente, para fábricas que se enquadrem nessa situação, a alternativa mais apropriada é a descrita na Hipótese $\mathrm{C}$ ou também o investimento em pequenos equipamentos de reciclagem (britadores de laboratório com valor estimado de até $\mathrm{R} \$$ $25.000,00)$ e separação manual das diferentes frações granulométricas dos agregados reciclados. Uma alternativa interessante para o referido caso, que existe em outros países, são as instalações de reciclagem móveis.

- Para fábricas com escala média de produção (superior a 500.000 unidades), o volume de resíduos gerados já pode ser considerado significativo ( $>44 \mathrm{~m}^{3} / \mathrm{mês}$ ) e o número de unidades produzidas com agregados reciclados pode chegar a 134.822 blocos RG-50\% (representando 7\% da produção). No presente caso, a instalação de um sistema de reciclagem constitui uma alternativa viável, uma vez que o período de retorno do investimento variou entre 2 e 7 anos, dependendo da escala de produção da fábrica. Considerando-se que, semanalmente, são geradas nas fábricas $11,05 \mathrm{~m}^{3}$ (500.000 un.), $22 \mathrm{~m}^{3}$ (1.000.000 un.) e $44 \mathrm{~m}^{3}$ (2.000.000 un.) de resíduos de concreto, uma alternativa é o processamento destes resíduos no final da semana; dessa maneira, a estação de reciclagem entraria em operação semanalmente por um período de 1 h (500.000 un./mês), 2 h (1.000.000 un./mês) e 4 h (2.000.000 un./mês).

\subsection{MEIOS-BLOCOS DE CONCRETO COM AGREGADOS RECICLADOS}

A produção dos meios-blocos ocorreu na fábrica da Tatu Pré-Moldados, situada em Limeira-SP, que cedeu suas instalações para a fabricação dos meios-blocos de referência (agregados naturais) e com agregados reciclados de concreto. Nessa fase, foram produzidos seis traços com a incorporação de agregados reciclados de vigota e bloco e três traços de referência, para três classes de resistência (4,5 $\mathrm{MPa}, 8 \mathrm{MPa}, 12,0 \mathrm{MPa})$, totalizando aproximadamente 160 meios-blocos de concreto (140 mm x 190 mm x $140 \mathrm{~mm}$ ). 


\subsubsection{PRODUÇÃO DAS UNIDADES}

A produção dos meios-blocos ocorreu em um setor da fábrica que não possuía um controle de qualidade tão rigoroso como o existente na fabricação dos blocos. Na Figura 7.31, podem ser observados os silos para estoque dos agregados.

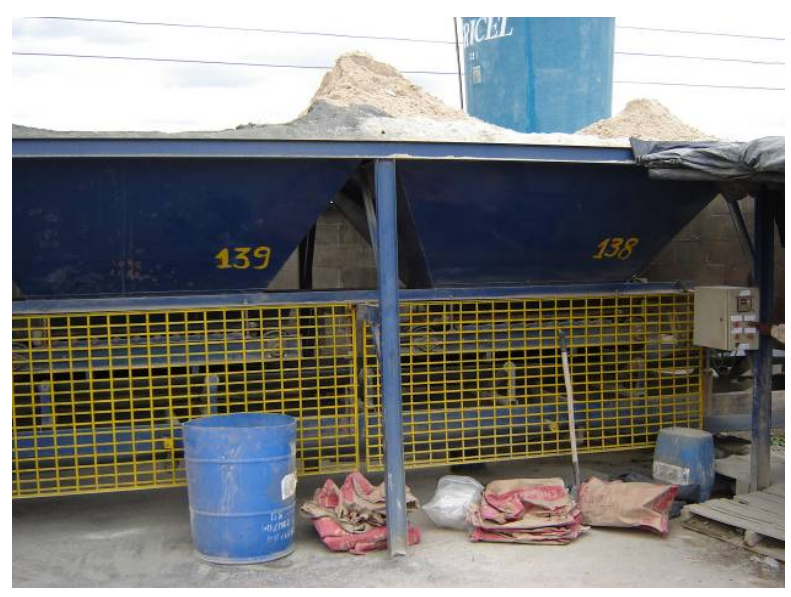

Figura 7.31 - Silos para estoque dos agregados.

Os meios-blocos de concreto foram produzidos em uma máquina vibro-prensa automática que apresentava regulagem dos tempos de produção, Figura 7.32.
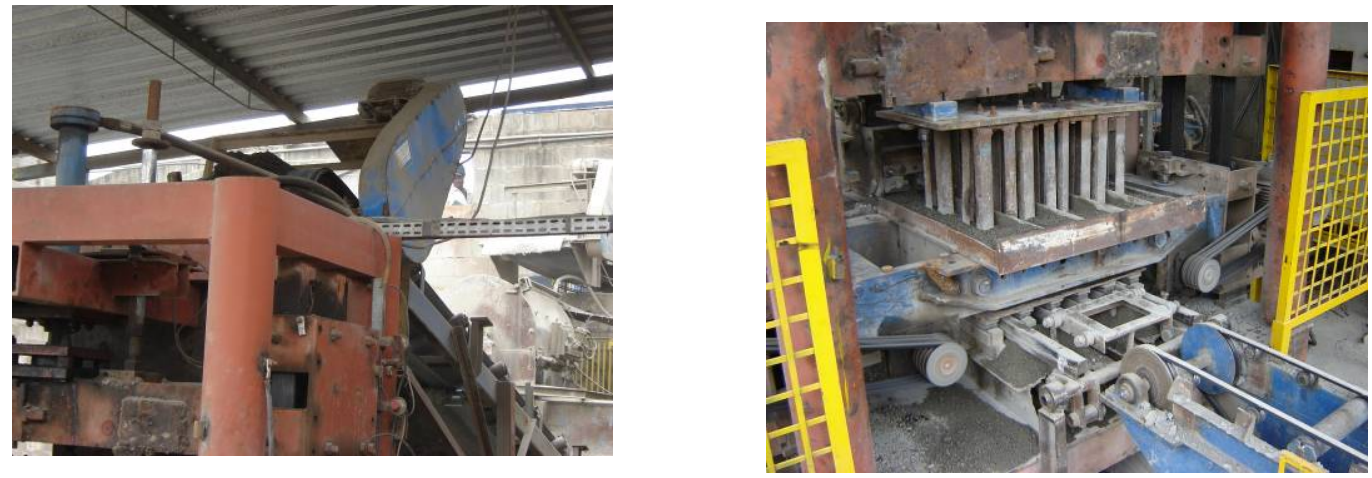

Figura 7.32 - Vibro-prensa utilizada para a produção dos meios-blocos.

Na fábrica, apesar da maior variabilidade, todos os insumos, com exceção do cimento e agregados reciclados, foram dosados em volume. Nesse caso, foi determinada, para cada tipo de agregado (pedrisco, areia e pó de pedra) a quantidade de material (em massa) para cada volta da esteira de dosagem. Após essa definição, cada traço pode ser estabelecido através do número de voltas. Devido à pequena quantidade de materiais necessária para a produção de cada traço, os agregados reciclados e o cimento foram pesados separadamente e colocados diretamente no misturador, Figura 7.33. 


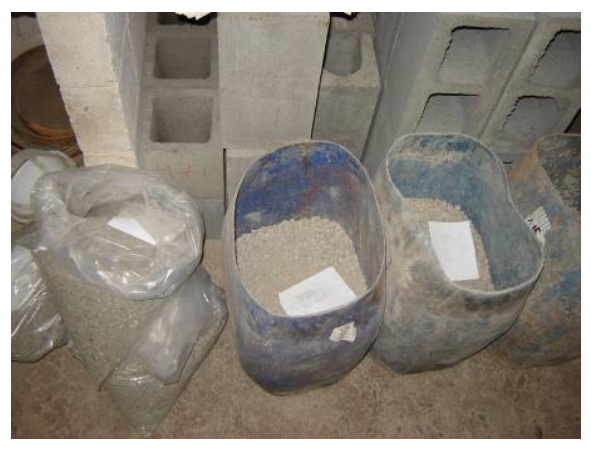

a) separação dos agregados reciclados para produção dos seis traços

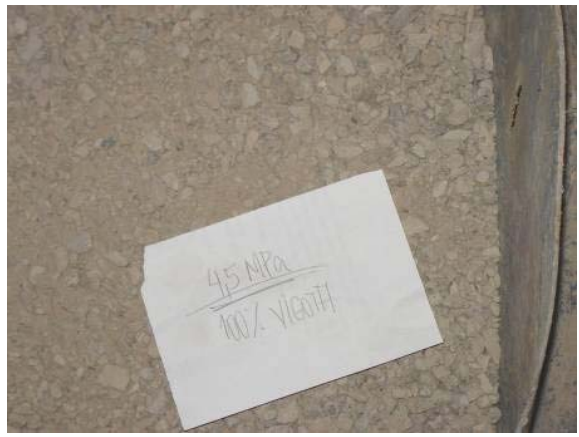

b) agregado reciclado de vigota a ser utilizado na produção dos meios-blocos de 4,5 MPa

Figura 7.33 - Separação dos agregados reciclados para a produção dos meios-blocos.

$\mathrm{Na}$ Tabela 7.80, podem ser encontradas as correspondentes quantidades de materiais, para cada tipo de agregado, em função de uma volta da esteira de dosagem.

Tabela 7.80 - Quantidades de materiais em função de uma volta da esteira de dosagem.

\begin{tabular}{cc}
\hline Material & Uma volta da esteira de dosagem (kg) \\
\hline Pedrisco $^{*}$ & 16,20 \\
\hline Areia Tietz $^{*}$ & 17,80 \\
\hline Pó de pedra (basalto) $^{\star}$ & 21,65 \\
\hline
\end{tabular}

* valores estabelecidos pela fábrica

O misturador possuía eixo horizontal, cuba fixa e pás móveis, com capacidade aproximada de $300 \mathrm{~kg}$, Figura 7.34. Esse equipamento não possuía sensor de umidade; para cada dosagem, o ajuste da umidade foi feito visualmente por um funcionário da fábrica. $O$ tempo mínimo de mistura foi de três minutos.
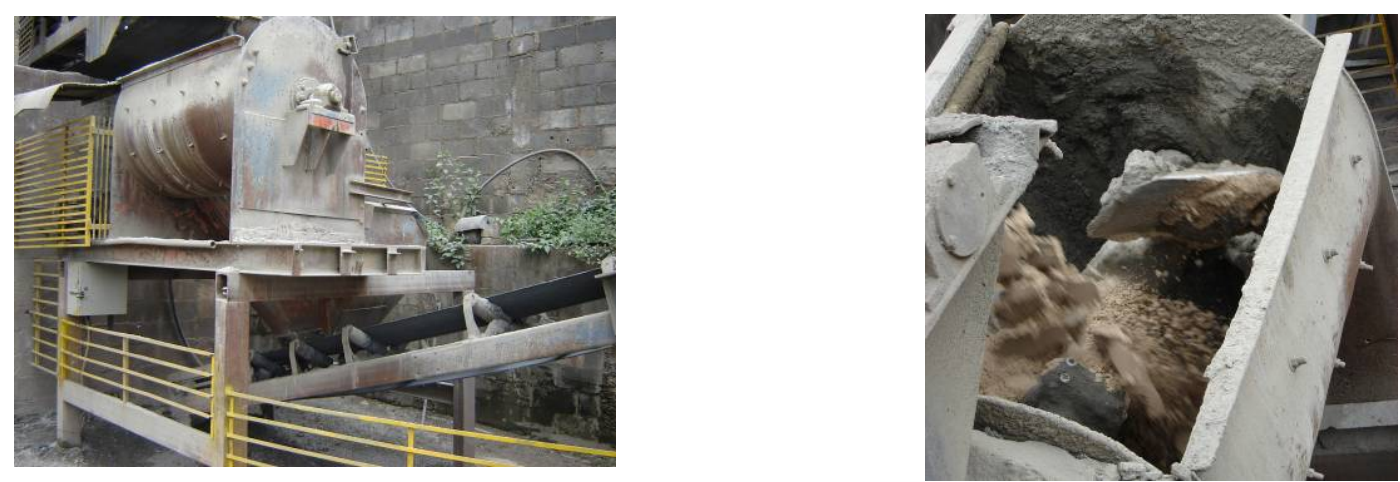

Figura 7.34 - Detalhe do misturador mecânico utilizado na produção dos meios-blocos.

A ordem de colocação dos materiais seguiu a respectiva ordem: $1^{0}$ - dosagem de todos os agregados; $2^{\circ}$ - introdução do cimento; $3^{\circ}$ - mistura dos materiais por cerca de um minuto; $4^{\circ}$ - acréscimo da água e aditivo; $5^{\circ}$ - mistura final por cerca de três minutos. Depois 
da mistura, os materiais foram despejados em uma correia transportadora que abasteceu o recipiente de alimentação dos moldes, também conhecido como gaveta. Os principais equipamentos utilizados na produção dos blocos são indicados na Figura 7.35.
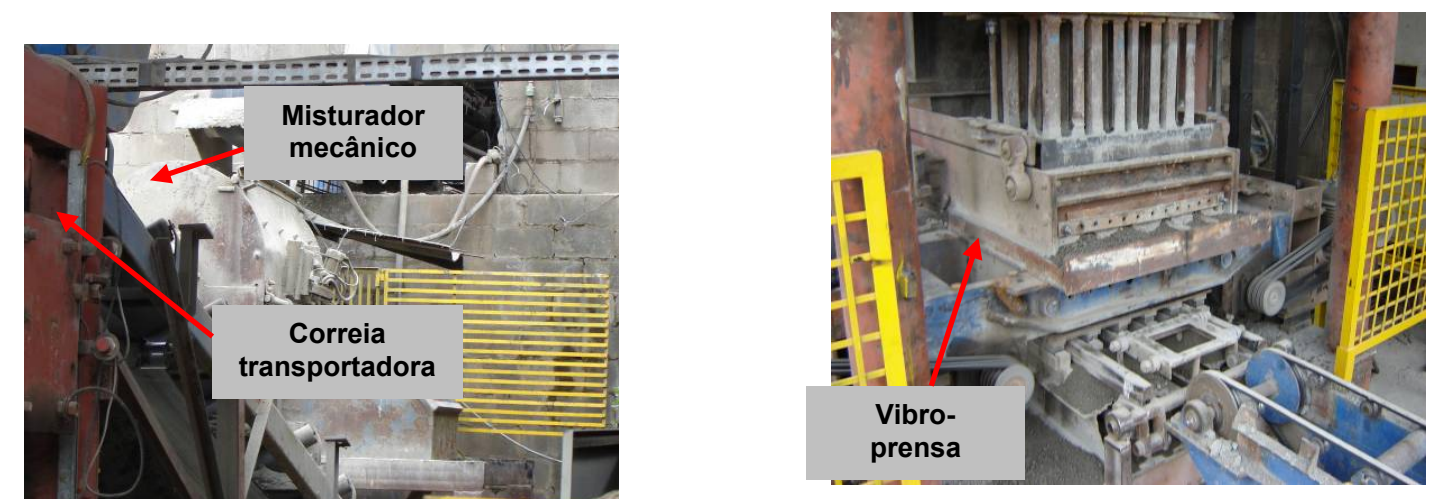

Figura 7.35 - Equipamentos utilizados na produção dos blocos.

A moldagem dos meios-blocos foi realizada pelo ajuste dos tempos de alimentação, vibração, agitação, sobre-vibração e desforma da máquina vibro-prensa. Esses tempos variaram em função de cada traço; sendo utilizados tempos mais elevados de alimentação e vibro-compressão à medida que se aumentava o consumo de cimento, isto é, para a produção dos traços mais ricos foram empregados tempos maiores de alimentação e vibrocompressão. Segundo Frasson Junior (2000), para os traços mais ricos, torna-se desejável aumentar os tempos de alimentação e vibração, pois misturas mais ricas em finos e com elevada umidade apresentam grande dificuldade para alimentar os moldes das formas. $\mathrm{Na}$ definição desses tempos, a experiência do operador de moldagem foi fundamental; caso a primeira chapa de meios-blocos não fosse produzida corretamente, isto é, por exemplo, coesão insuficiente, quebra de cantos e altura superior à especificada, o operador interrompia o processo e ajustava novos tempos de produção no painel da máquina. $\mathrm{Na}$ Figura 7.36, pode ser observado o painel que ajustava os tempos de produção.

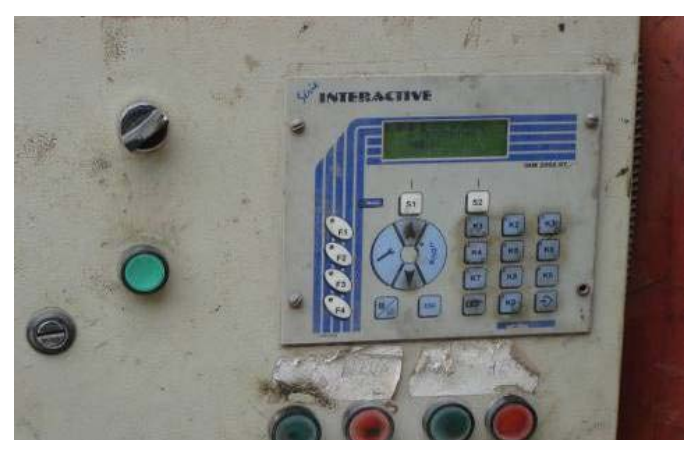

Figura 7.36 - Painel de ajuste dos tempos de produção. 
Na Figura 7.37 podem ser observadas algumas das unidades produzidas.
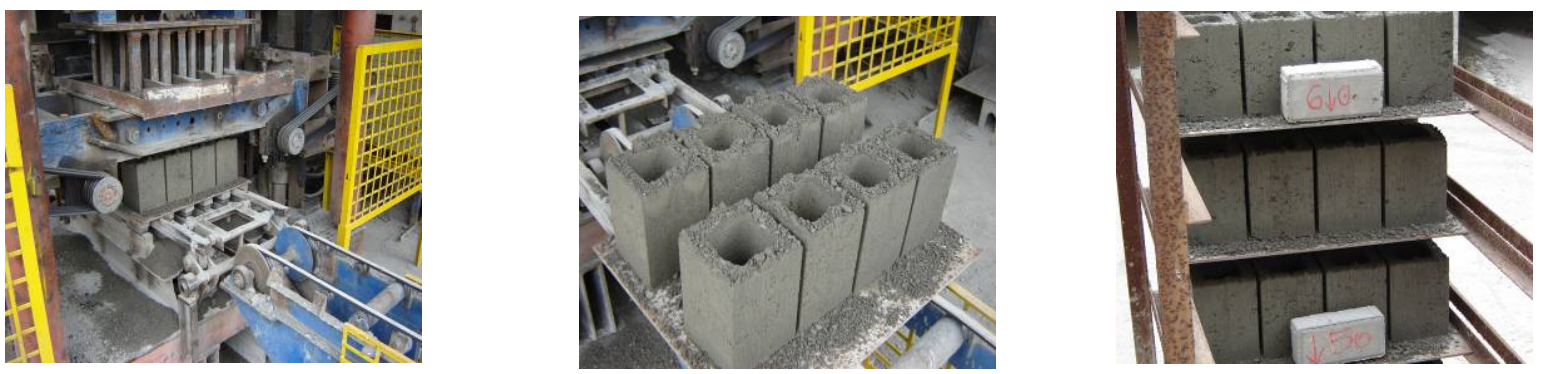

Figura 7.37 - Produção dos meios-blocos.

Os meios-blocos, após a moldagem, foram transferidos para o interior das câmaras de cura. A cura térmica foi aplicada no período noturno, sendo constituída de um ciclo com duração de quatro a cinco horas e regime isotérmico $\left(60^{\circ} \mathrm{C}-67^{\circ} \mathrm{C}\right)$, Figura 7.38.

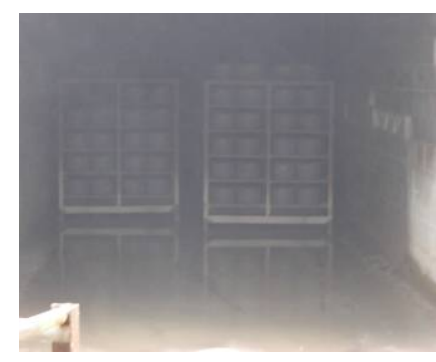

a) meios-blocos recémmoldados dipostos na câmara de cura

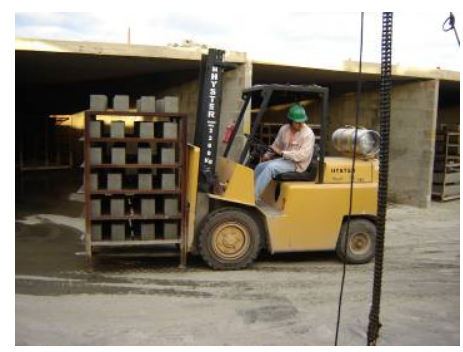

b) retirada dos meios-blocos após o processo de cura térmica

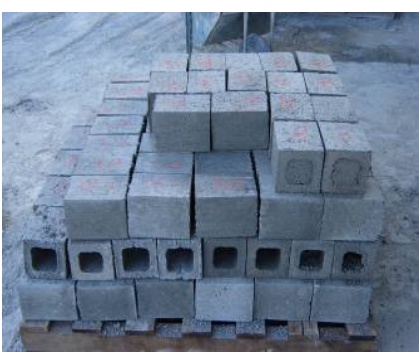

c) disposição das unidades em pallets

Figura 7.38 - Processo de cura dos meios-blocos.

Após a cura, as unidades foram dispostas em pallets (Figura 7.39), numeradas de acordo com a ordem de produção e estocadas no pátio da fábrica. Três dias após a produção, as unidades foram transportadas para o Laboratório de Estruturas.
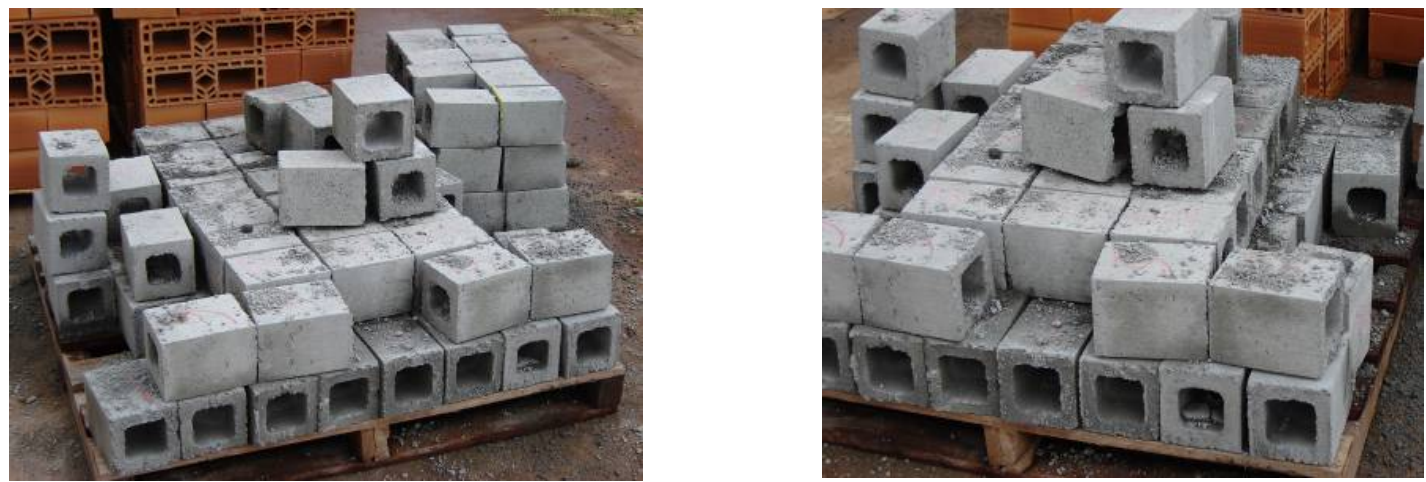

Figura 7.39 - Estocagem dos meios-blocos no Laboratório de Estruturas. 
Nos próximos itens, serão apresentados os resultados e as análises das propriedades físicas e mecânicas dos meios-blocos produzidos.

\subsubsection{CARACTERÍSTICAS DOS TRAÇOS}

Nessa etapa, não foram produzidas todas as dosagens estabelecidas anteriormente para os blocos de concreto (18 traços no total). As seguintes justificativas podem ser enumeradas para a redução do número de dosagens e a escolha dos traços:

- A avaliação do comportamento mecânico de prismas de três blocos, realizado para todas as dosagens com exceção dos traços pobres com agregados miúdos reciclados, já seria adequada e suficiente para o conhecimento do comportamento do conjunto bloco reciclado/argamassa e extrapolação desses resultados, com os devidos cuidados, para a alvenaria de blocos de concreto. Dessa maneira, a produção de miniparedes, que utilizariam meios-blocos de concreto, foi realizada apenas para alguns traços, em virtude dos ensaios de prismas (realizado para todos os traços) já fornecerem uma avaliação preliminar de como seria o comportamento da alvenaria com blocos de concreto reciclados;

- O comportamento satisfatório das unidades produzidas com $100 \%$ de agregados reciclados de vigota em relação às unidades de referência; dessa maneira, julgou-se desnecessária a produção de unidades (meios-blocos) com substituição parcial do agregado natural pelo agregado reciclado (RGV-50\%);

- Nessa etapa, priorizou-se a produção de unidades (meios-blocos) que maximizassem a substituição de agregado natural por agregado reciclado (RGV100\% e RGB-50\%). Posteriormente, essas unidades são utilizadas na fabricação de miniparedes, as quais são avaliadas quanto à propriedade de retração por secagem. Dessa maneira, pode se aferir a influência de taxas elevadas de substituições de agregados naturais por reciclados sobre a retração;

- O espaço físico reduzido da câmara climatizada que não comporta um número superior a 24 miniparedes de retração (3 miniparedes por traço; 8 traços no total);

Para facilitar o enquadramento das unidades produzidas, as dosagens foram divididas nas suas respectivas classes de resistência. A divisão é apresentada a seguir:

a) Grupo 4,5 - nesse grupo inserem-se todos os traços com relação cimento/agregado próxima a vinte (20). Os agregados utilizados foram os naturais e os materiais reciclados (reciclado de vigota e bloco). O estabelecimento dessas dosagens 
objetivou a produção de meios-blocos estruturais com resistência média de 4,5 MPa aos vinte e oito dias;

b) Grupo 8,0 - nesse grupo inserem-se todos os traços com relação cimento/agregado próxima a vinte (15). Os agregados utilizados foram os naturais e os materiais reciclados (reciclado de vigota e bloco). O estabelecimento destas dosagens objetivou a produção de meios-blocos estruturais com resistência média de 8,0 MPa aos vinte e oito dias;

c) Grupo 12,0 - nesse grupo inserem-se todos os traços com relação cimento/agregado próxima a vinte (10). Os agregados utilizados foram os naturais e os materiais reciclados (reciclado de vigota e bloco). O estabelecimento dessas dosagens objetivou a produção de meios-blocos estruturais com resistência média de 12,0 MPa aos vinte e oito dias;

A respectiva terminologia e as características gerais de cada traço encontram-se na Tabela 7.81.

Tabela 7.81 - Terminologia e características gerais das dosagens utilizadas para a produção dos meios-blocos.

\begin{tabular}{|c|c|c|}
\hline GRUPO & DESIGNAÇÃO & CARACTERÍSTICAS \\
\hline \multirow{3}{*}{4,5} & MB4,5-REF & $\begin{array}{l}\text { Dosagem de referência produzida inteiramente com materiais } \\
\text { naturais }\end{array}$ \\
\hline & MB4,5-RGV-100\% & $\begin{array}{l}\text { Dosagem com 100\% de substituição, em massa, da fração graúda } \\
\text { natural (pedrisco) por agregado graúdo reciclado de vigota (GRv) }\end{array}$ \\
\hline & MB4,5-RGB-50\% & $\begin{array}{l}\text { Dosagem com aproximadamente } 50 \% \text { de substituição, em massa, da } \\
\text { fração graúda natural por agregado graúdo reciclado de bloco (GRb) }\end{array}$ \\
\hline \multirow{3}{*}{8,0} & MB8,0-REF & $\begin{array}{c}\text { Dosagem de referência produzida inteiramente com materiais } \\
\text { naturais }\end{array}$ \\
\hline & MB8,0-RGV-100\% & $\begin{array}{l}\text { Dosagem com 100\% de substituição, em massa, da fração graúda } \\
\text { natural (pedrisco) por agregado graúdo reciclado de vigota (GRv) }\end{array}$ \\
\hline & MB8,0-RGB-50\% & $\begin{array}{l}\text { Dosagem com aproximadamente } 50 \% \text { de substituição, em massa, da } \\
\text { fração graúda natural por agregado graúdo reciclado de bloco (GRb) }\end{array}$ \\
\hline \multirow{3}{*}{12,0} & MB12,0-REF & $\begin{array}{c}\text { Dosagem de referência produzida inteiramente com materiais } \\
\text { naturais }\end{array}$ \\
\hline & MB12,0-RGV-100\% & $\begin{array}{l}\text { Dosagem com 100\% de substituição, em massa, da fração graúda } \\
\text { natural (pedrisco) por agregado graúdo reciclado de vigota (GRv) }\end{array}$ \\
\hline & MB12,0-RGB-50\% & $\begin{array}{l}\text { Dosagem com aproximadamente } 50 \% \text { de substituição, em massa, da } \\
\text { fração graúda natural por agregado graúdo reciclado de bloco (GRb) }\end{array}$ \\
\hline
\end{tabular}

As propriedades das dosagens do Grupo 4,5, encontram-se na Tabela 7.82. Devese ressaltar que o consumo de materiais foi estimado, uma vez que não houve controle de umidade durante a produção das unidades. A definição da umidade era realizada precariamente pelo operador de moldagem. 
Tabela 7.82 - Dosagens para a produção dos meios-blocos - Grupo 4,5.

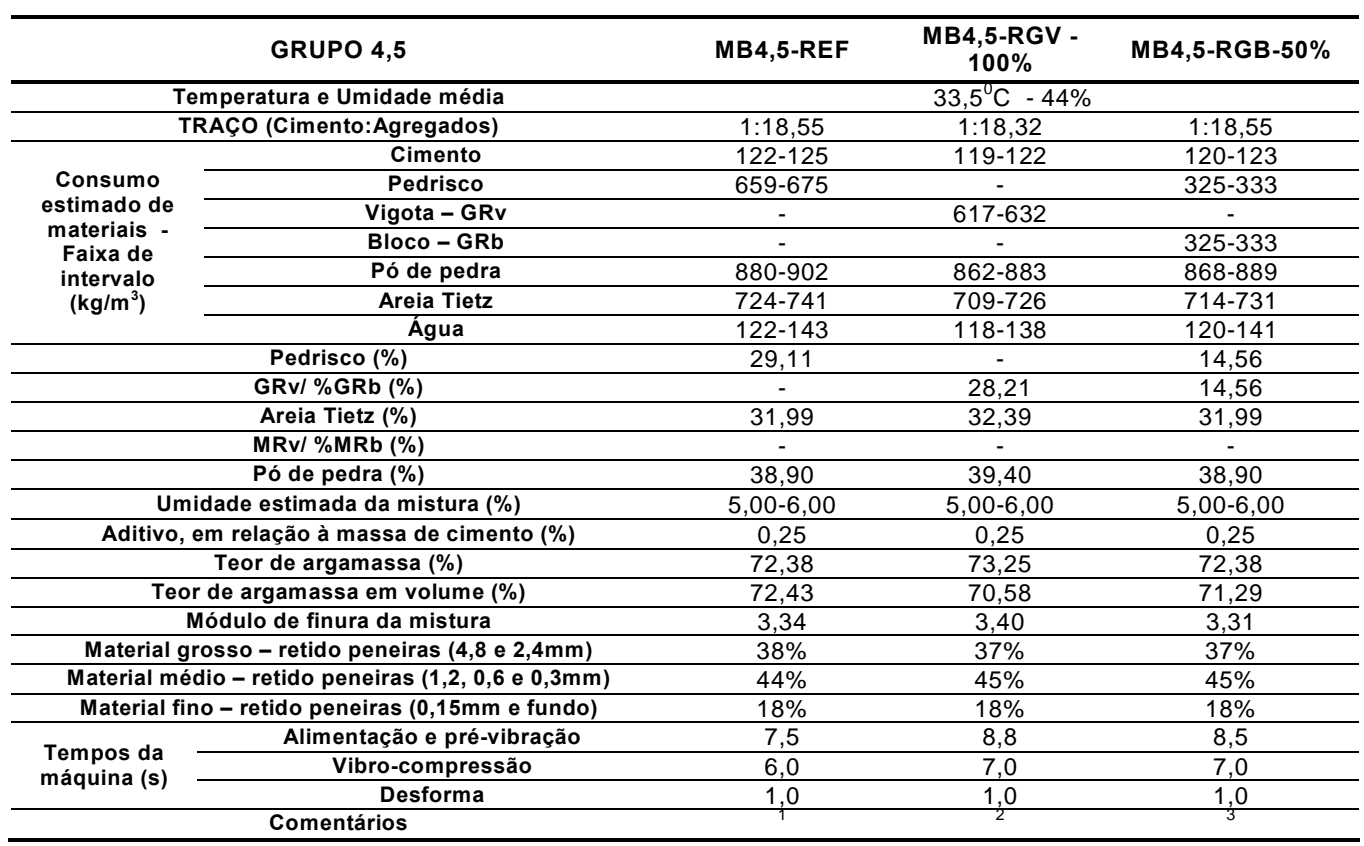

${ }^{1}$ a mistura dos materiais não foi feita de maneira eficiente, fato esse que prejudicou as propriedades mecânicas das unidades; ${ }^{2,3}$ tempos de produção relativamente elevados com o intuito de aumentar a coesão da mistura; estes tempos foram estabelecidos pelo operador de moldagem

Analisando-se os dados da Tabela 7.82, observa-se, que devido ao controle deficitário da umidade da mistura, foi estabelecida uma faixa de intervalo de consumo de materiais. Com relação à produção das unidades, foi observada que a mistura dos materiais para a fabricação das unidades de referência (MB4,5-REF) não foi realizada de maneira eficiente, uma vez que alguns meios-blocos apresentavam regiões de concentração de materiais miúdos (areia) ao longo das paredes dessas unidades, Figura 7.40.
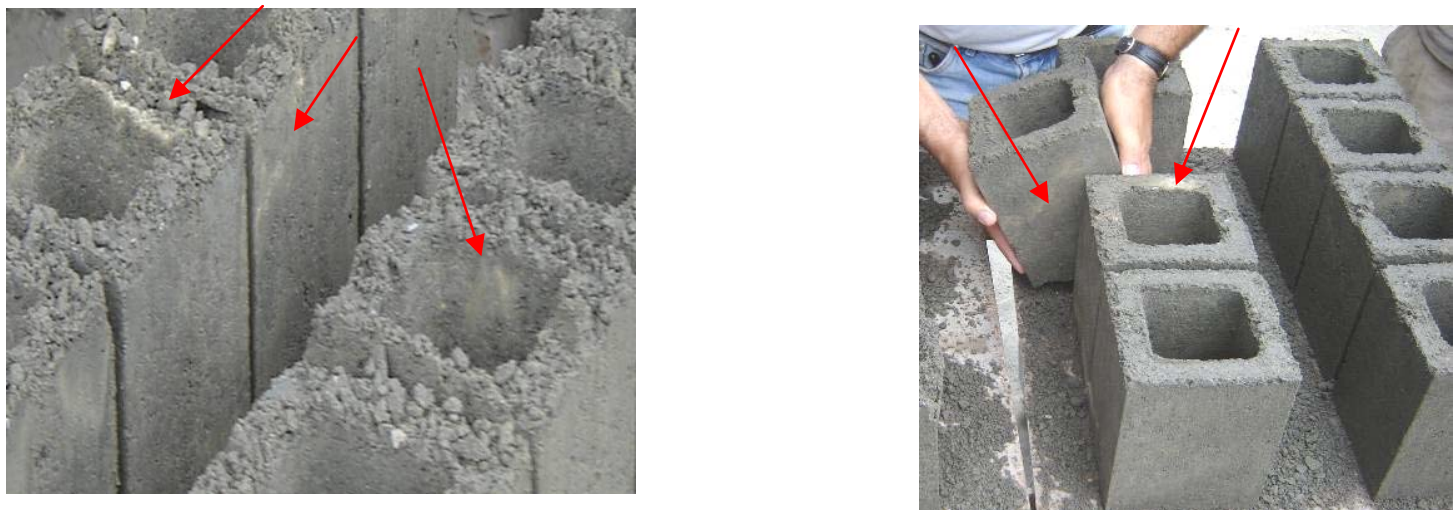

Figura 7.40 - Mistura deficiente dos materiais (MB4,5-REF).

As propriedades das dosagens do Grupo 8,0, encontram-se na Tabela 7.83. Devese ressaltar que o consumo de materiais foi estimado, uma vez que não houve controle de 
umidade durante a produção das unidades. A definição da umidade era realizada precariamente pelo operador de moldagem.

Tabela 7.83 - Dosagens para a produção dos meios-blocos - Grupo 8,0.

\begin{tabular}{|c|c|c|c|c|}
\hline & GRUPO 8,0 & MB8,0-REF & MB8,0-RGV - $100 \%$ & MB8,0-RGB-50\% \\
\hline \multicolumn{2}{|c|}{ Temperatura e Umidade média } & \multicolumn{3}{|c|}{$33,5^{\circ} \mathrm{C}-44 \%$} \\
\hline \multicolumn{2}{|c|}{ TRAÇO (Cimento:Agregados) } & $1: 14,84$ & $1: 14,60$ & $1: 14,84$ \\
\hline \multirow{7}{*}{$\begin{array}{l}\text { Consumo } \\
\text { estimado de } \\
\text { materiais - } \\
\text { Faixa de } \\
\text { intervalo } \\
\left(\mathrm{kg} / \mathrm{m}^{3}\right)\end{array}$} & Cimento & $151-154$ & $148-152$ & $149-152$ \\
\hline & Pedrisco & $651-667$ & $\frac{-}{1+00}$ & $321-329$ \\
\hline & Vigota-GRv & -4 & $605-619$ & 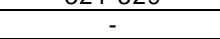 \\
\hline & Bloco-GRb & - & - & $321-329$ \\
\hline & Pó de pedra & $870-891$ & $856-876$ & $858-879$ \\
\hline & Areia Tietz & $715-733$ & $703-720$ & $706-723$ \\
\hline & Água & $122-143$ & $118-139$ & $121-141$ \\
\hline & Pedrisco (\%) & 29,11 & - & 14,56 \\
\hline & GRv/\%GRb (\%) & - & 27,95 & 14,56 \\
\hline & Areia Tietz (\%) & 31,99 & 32,51 & 31,99 \\
\hline & MRv/ \%MRb (\%) & - & - & - \\
\hline & Pó de pedra (\%) & 38,90 & 39,54 & 38,90 \\
\hline \multicolumn{2}{|c|}{ Umidade estimada da mistura (\%) } & $5,00-6,00$ & $5,00-6,00$ & $5,00-6,00$ \\
\hline \multicolumn{2}{|c|}{ Aditivo, em relação à massa de cimento (\%) } & 0,25 & 0,25 & 0,25 \\
\hline \multirow{2}{*}{\multicolumn{2}{|c|}{$\begin{array}{c}\text { Teor de argamassa (\%) } \\
\text { Teor de argamassa em volume (\%) }\end{array}$}} & 72,73 & 73,85 & 72,73 \\
\hline & & 72,74 & 71,17 & 71,61 \\
\hline \multicolumn{2}{|c|}{ Módulo de finura da mistura } & 3,34 & 3,39 & 3,31 \\
\hline \multicolumn{2}{|c|}{ Material grosso - retido peneiras $(4,8$ e $2,4 \mathrm{~mm})$} & $38 \%$ & $37 \%$ & $37 \%$ \\
\hline \multicolumn{2}{|c|}{ Material médio - retido peneiras $(1,2,0,6$ e $0,3 \mathrm{~mm})$} & $44 \%$ & $45 \%$ & $45 \%$ \\
\hline \multicolumn{2}{|c|}{ Material fino - retido peneiras $(0,15 \mathrm{~mm}$ e fundo $)$} & $18 \%$ & $18 \%$ & $18 \%$ \\
\hline \multirow{3}{*}{$\begin{array}{l}\text { Tempos da } \\
\text { máquina (s) }\end{array}$} & Alimentação e pré-vibração & 7,8 & 8,5 & 8,5 \\
\hline & Vibro-compressão & 6,0 & 6,5 & 7,0 \\
\hline & Desforma & 1,0 & 1,0 & 1,0 \\
\hline
\end{tabular}

Analisando-se a Tabela 7.83, nota-se que os tempos de produção adotados para os traços com agregados reciclados foram superiores ao adotado para a dosagem de referência; provavelmente, a necessidade de aumento da coesão da mistura pode ser enumerada como uma das justificativas. Comparando-se os dois traços com agregados reciclados, observa-se que para a dosagem com agregado reciclado de bloco houve necessidade de aumento do tempo de vibro-compressão (6,5s para 7,0s); possivelmente, a menor coesão da mistura, já observada anteriormente quando da produção dos corpos-deprova cilíndricos (redução de 12\% em relação ao traço RGV-100\%), ocasionou o aumento do tempo de vibro-compressão.

As propriedades das dosagens do Grupo 12,0, encontram-se na Tabela 7.84. 
Tabela 7.84 - Dosagens para a produção dos meios-blocos - Grupo 12,0.

\begin{tabular}{|c|c|c|c|c|}
\hline & GRUPO 12,0 & MB12,0-REF & MB12,0-RGV - $100 \%$ & MB12,0-RGB-50\% \\
\hline \multicolumn{2}{|c|}{ Temperatura e Umidade média } & \multicolumn{3}{|c|}{$33,5^{\circ} \mathrm{C}-44 \%$} \\
\hline \multicolumn{2}{|c|}{ TRAÇO (Cimento:Agregados) } & $1: 10,12$ & $1: 9,58$ & $1: 9,68$ \\
\hline \multirow{7}{*}{$\begin{array}{l}\text { Consumo } \\
\text { estimado de } \\
\text { materiais - } \\
\text { Faixa de } \\
\text { intervalo } \\
\left(\mathrm{kg} / \mathrm{m}^{3}\right)\end{array}$} & Cimento & $215-221$ & $219-224$ & $221-227$ \\
\hline & Pedrisco & $634-649$ & - & $312-319$ \\
\hline & Vigota - GRv & - & $597-611$ & - \\
\hline & Bloco - GRb & - & - & $312-319$ \\
\hline & Pó de pedra & $847-868$ & $825-845$ & $833-853$ \\
\hline & Areia Tietz & $697-714$ & $679-695$ & $685-701$ \\
\hline & Água & $123-144$ & $119-139$ & $121-142$ \\
\hline & Pedrisco (\%) & 29,11 & - & 14,56 \\
\hline & GRv/ \%GRb (\%) & - & 28,40 & 14,56 \\
\hline & Areia Tietz (\%) & 31,99 & 32,30 & 31,99 \\
\hline & MRv/ \%MRb (\%) & - & - & - \\
\hline & Pó de pedra (\%) & 38,90 & 39,29 & 38,90 \\
\hline \multicolumn{2}{|c|}{ Umidade estimada da mistura (\%) } & $5,00-6,00$ & $5,00-6,00$ & $5,00-6,00$ \\
\hline \multicolumn{2}{|c|}{ Aditivo, em relação à massa de cimento (\%) } & 0,25 & 0,25 & 0,25 \\
\hline \multicolumn{2}{|c|}{ Teor de argamassa (\%) } & 73,51 & 74,28 & 73,62 \\
\hline \multicolumn{2}{|c|}{ Teor de argamassa em volume (\%) } & 73,44 & 71,53 & 72,42 \\
\hline \multicolumn{2}{|c|}{ Módulo de finura da mistura } & 3,34 & 3,41 & 3,31 \\
\hline \multicolumn{2}{|c|}{ Material grosso - retido peneiras $(4,8$ e $2,4 \mathrm{~mm})$} & $38 \%$ & $37 \%$ & $37 \%$ \\
\hline \multicolumn{2}{|c|}{ Material médio - retido peneiras $(1,2,0,6$ e $0,3 \mathrm{~mm})$} & $44 \%$ & $45 \%$ & $45 \%$ \\
\hline \multicolumn{2}{|c|}{ Material fino - retido peneiras $(0,15 \mathrm{~mm}$ e fundo) } & $18 \%$ & $18 \%$ & $18 \%$ \\
\hline \multirow{3}{*}{$\begin{array}{l}\text { Tempos da } \\
\text { máquina (s) }\end{array}$} & Alimentação e pré-vibração & 8,0 & 8,8 & 8,8 \\
\hline & Vibro-compressão & 6,0 & 7,0 & 7,0 \\
\hline & Desforma & 1,0 & 1,0 & 1,0 \\
\hline
\end{tabular}

Analisando-se a Tabela 7.84, nota-se que os tempos de produção adotados para os traços com agregados reciclados foram superiores ao adotado para a dosagem de referência e semelhantes entre si; provavelmente, a necessidade de aumento da coesão da mistura pode ser enumerada como uma das justificativas. Na etapa de produção dos corpos-de-prova, foi observada uma redução de $6 \%$ e 15\% na coesão dos traços RGV100\% e RGB-50\%, respectivamente em relação à coesão da dosagem de referência.

\subsubsection{PROPRIEDADES FÍSICAS}

Conforme já relatado, o cumprimento aos requisitos normativos e limites recomendados na literatura, quanto às propriedades físicas, são condições primordiais para um correto desempenho das unidades sem o surgimento de futuras patologias. Novamente, todos os meios-blocos produzidos com agregados reciclados terão que obedecer a esses limites, especialmente, quanto às propriedades de absorção de água e índice de vazios.

Para cada propriedade são apresentados os resultados obtidos para todos os grupos avaliados.

\subsubsection{Absorção de água e área líquida}

Os ensaios de absorção de água e área líquida foram realizados conforme as prescrições da NBR 12118 (1992). A norma técnica NBR 6136 (1994) estabelece que a absorção de água, para unidades estruturais de concreto, deve ser menor ou igual a 10\%. 
Os resultados para a propriedade de absorção de água, bem como os valores de massa seca das unidades para todos os grupos avaliados (classes de resistência), encontram-se na Tabela 7.85.

Tabela 7.85 - Absorção de água e valores de massa seca (em estufa) para os três grupos avaliados $(4,5 ; 8,0 ; 12,0)$.

\begin{tabular}{|c|c|c|c|c|c|c|c|c|c|c|c|}
\hline \multirow{2}{*}{ Grupos } & \multirow{2}{*}{ Traços } & \multicolumn{5}{|c|}{ Absorção de água } & \multicolumn{5}{|c|}{ Massa seca (em estufa) } \\
\hline & & $\begin{array}{c}\begin{array}{c}\text { Média } \\
(\%)\end{array} \\
\end{array}$ & $\begin{array}{c}\text { Máx. } \\
(\%)\end{array}$ & $\begin{array}{c}\text { Mín. } \\
(\%)\end{array}$ & $\begin{array}{c}S_{d} \\
(\%)\end{array}$ & $\begin{array}{l}\text { C.V. } \\
(\%)\end{array}$ & $\begin{array}{c}\text { Média } \\
\text { (g) }\end{array}$ & $\begin{array}{c}\text { Máx. } \\
\text { (g) }\end{array}$ & $\begin{array}{c}\text { Mín. } \\
\text { (g) }\end{array}$ & $\begin{array}{l}S_{d} \\
(g)\end{array}$ & $\begin{array}{l}\text { C.V. } \\
\text { (\%) }\end{array}$ \\
\hline \multirow{3}{*}{4,5} & MB4,5-REF & 6,36 & 6,46 & 6,27 & 0,09 & 1,46 & 5155 & 5218 & 5103 & 58,4 & 1,13 \\
\hline & MB4,5-RGV-100\% & 5,52 & 5,90 & 5,15 & 0,37 & 6,78 & 5278 & 5335 & 5168 & 95,0 & 1,80 \\
\hline & MB4,5-RGB-50\% & 5,74 & 5,82 & 5,66 & 0,08 & 1,42 & 5124 & 5170 & 5095 & 40,3 & 0,79 \\
\hline \multirow{3}{*}{8,0} & MB8,0-REF & 6,22 & 6,52 & 5,92 & 0,30 & 4,84 & 5098 & 5152 & 5022 & 67,9 & 1,33 \\
\hline & MB8,0-RGV-100\% & 6,54 & 6,76 & 6,41 & 0,19 & 2,94 & 5145 & 5195 & 5074 & 63,0 & 1,22 \\
\hline & MB8,0-RGB-50\% & 5,73 & 5,79 & 5,61 & 0,10 & 1,69 & 5274 & 5340 & 5192 & 75,3 & 1,43 \\
\hline \multirow{3}{*}{12,0} & MB12,0-REF & 5,24 & 5,41 & 5,14 & 0,15 & 2,94 & 5337 & 5385 & 5284 & 50,6 & 0,95 \\
\hline & MB12,0-RGV-100\% & 6,01 & 6,08 & 5,93 & 0,07 & 1,24 & 5177 & 5217 & 5109 & 59,4 & 1,15 \\
\hline & MB12,0-RGB-50\% & 5,78 & 5,90 & 5,68 & 0,11 & 1,95 & 5269 & 5312 & 5210 & 52,8 & 1,00 \\
\hline
\end{tabular}

Analisando-se a Tabela 7.85, nota-se que todos os meios-blocos cumpriram os requisitos da NBR 6136 (1994), com relação à absorção máxima de água. Devido à falta de controle da quantidade de água adicionada na mistura (umidade), observou-se uma variação muito grande na massa das unidades, sendo que em alguns grupos, as unidades dos traços com agregados reciclados, apresentaram valores de massa seca maiores do que os obtidos para as unidades de referência. Esse fato, ocorrido para as unidades com agregados reciclados dos Grupos 4,5 e 8,0, reduziu a absorção de água para valores inferiores aos encontrados para os blocos de referência. De acordo com Frasson Junior (2000), uma variação da umidade da mistura pode interferir significativamente na massa dos blocos e, consequentemente, na sua resistência. Para facilitar o entendimento global dos resultados é apresentada, na Tabela 7.86, o teste estatístico de Análise de Variância. 
Tabela 7.86 - Teste ANOVA para valores de absorção dos meios-blocos.

\begin{tabular}{|c|c|c|c|c|}
\hline \multirow{2}{*}{ Comparações } & \multirow{2}{*}{ Grupos } & \multicolumn{2}{|c|}{ Análise de $1^{0}$ Ordem } & \multirow{2}{*}{$\begin{array}{c}\text { Análise de } 2^{0} \text { Ordem } \\
\text { Grupos } \mathrm{x} \\
\text { Traços }\end{array}$} \\
\hline & & $\begin{array}{c}\text { Grupos/Classes de } \\
\text { resistência }\end{array}$ & Traços & \\
\hline REF x RGV-100\% & $4,5 \times 8,0 \times 12,0$ & $S\left(F_{0}=16,95\right)$ & - & $S(20,47)$ \\
\hline REF $\times$ RGB- $50 \%$ & $4,5 \times 8,0 \times 12,0$ & $S(20,36)$ & $S(6,15)$ & $S(24,10)$ \\
\hline RGV-100\% x RGB-50\% & $4,5 \times 8,0 \times 12,0$ & $S(10,75)$ & $S(9,50)$ & $S(11,55)$ \\
\hline
\end{tabular}

Analisando-se os resultados da Tabela 7.86, nota-se que para a análise de $1^{\mathrm{a}}$ ordem, houve, para todos os casos, influência significativa das variáveis grupos/classes de resistência e traços (referência, agregados reciclados de vigota e bloco) sobre a propriedade de absorção de água; exceto para a comparação entre os traços REF x RGV-100\%. Dentre as duas variáveis, a que mais exerceu influência na absorção de água foi a classe de resistência dos meios-blocos, isto é, para cada classe de resistência avaliada $(4,5 ; 8,0 ; 12,0)$ foram obtidos valores de absorção significativamente diferentes entre si, sendo que os menores valores médios foram obtidos para as unidades do Grupo 12,0.

De maneira geral, pode-se afirmar que os valores de absorção foram similares para as dosagens de referência e com agregados reciclados de vigota; por outro lado, os menores valores médios de absorção de água, comparativamente aos citados, foram obtidos pelas dosagens com agregados reciclados de bloco. Entretanto, para a análise de $2^{\mathrm{a}}$ ordem, observou-se uma influência significativa dos parâmetros (grupos e traços) sobre a propriedade de absorção de água; isto significa dizer que, dependendo da classe de resistência, há uma determinada dosagem que conduz aos menores valores médios de absorção. Por exemplo, para uma dada classe de resistência (4,5, por exemplo) pode-se ter um determinado traço (RGV-100\%) que conduz aos menores valores médios de absorção, entretanto, para outra classe de resistência (8,0, por exemplo), os menores valores médios de absorção são obtidos para as unidades do traço RGB-50\%.

Antes de apresentar os resultados de área líquida e relação entre área líquida e bruta; na Figura 7.41, pode ser visualizado um croqui típico dos meios-blocos produzidos. 


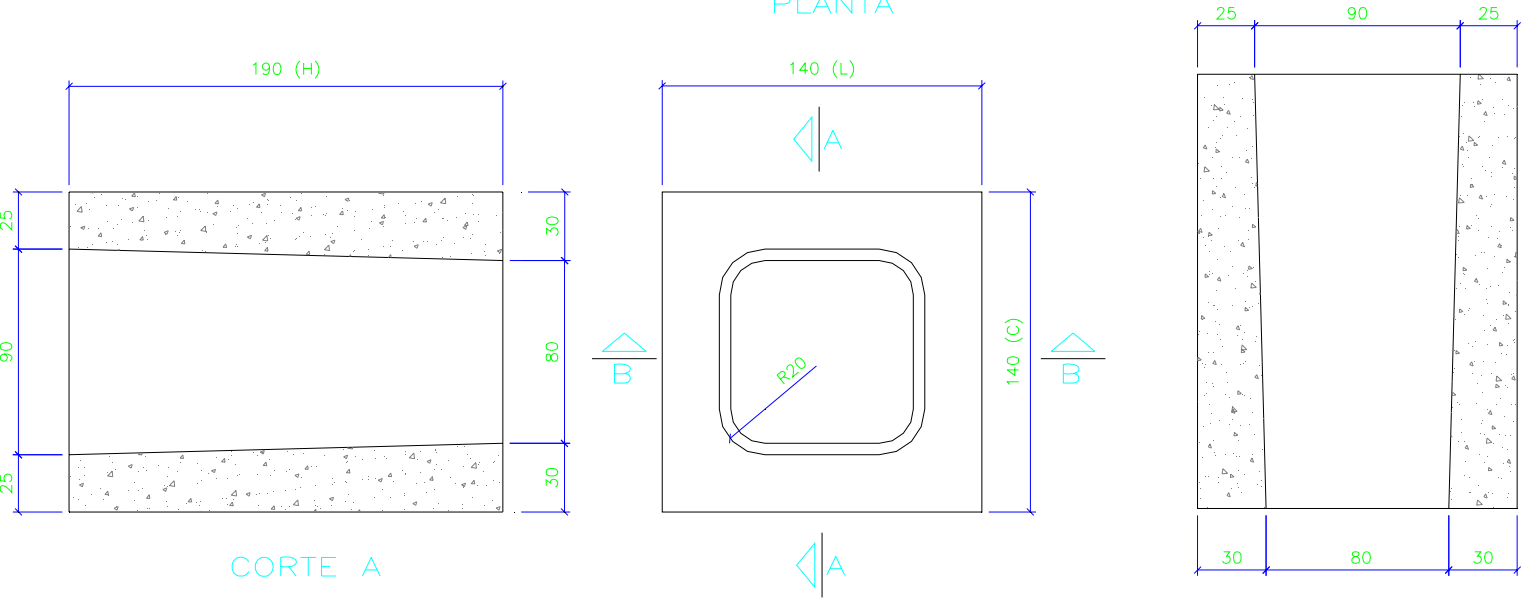

Figura 7.41 - Croqui dos meios-blocos produzidos.

A área líquida para cada um dos três grupos avaliados, bem como a relação entre área líquida e área bruta encontra-se na Tabela 7.87.

Tabela 7.87 - Área líquida e relação entre área líquida e área bruta para os meios-blocos dos três grupos avaliados $(4,5 ; 8,0 ; 12,0)$.

\begin{tabular}{|c|c|c|c|c|c|c|c|}
\hline \multirow{2}{*}{ Grupos } & \multirow{2}{*}{ Traços } & \multicolumn{5}{|c|}{ Área líquida } & \multirow{2}{*}{$\begin{array}{l}\text { Relação área } \\
\text { líquidalárea bruta }\end{array}$} \\
\hline & & $\begin{array}{l}\text { Média } \\
\left(\mathrm{cm}^{2}\right)\end{array}$ & $\begin{array}{l}\text { Máx. } \\
\left(\mathrm{cm}^{2}\right)\end{array}$ & $\begin{array}{l}\text { Min. } \\
\left(\mathrm{cm}^{2}\right)\end{array}$ & $\begin{array}{c}S_{d} \\
\left(\mathrm{~cm}^{2}\right)\end{array}$ & $\begin{array}{l}\text { C.V. } \\
(\%)\end{array}$ & \\
\hline \multirow{3}{*}{4,5} & MB 4,5-REF & 124,8 & 125,7 & 123,3 & 1,28 & 1,03 & 0,637 \\
\hline & M B 4,5-RGV-100\% & 125,2 & 126,5 & 124,3 & 1,15 & 0,92 & 0,639 \\
\hline & M B 4,5-RGB-50\% & 122,8 & 124,0 & 122,1 & 1,08 & 0,88 & 0,626 \\
\hline \multirow{3}{*}{8,0} & MB 8,0-REF & 123,1 & 124,5 & 121,8 & 1,34 & 1,09 & 0,628 \\
\hline & M B 8,0-RGV-100\% & 126,4 & 126,7 & 125,8 & 0,48 & 0,38 & 0,645 \\
\hline & M B 8,0-RG B -50\% & 126,1 & 127,9 & 124,9 & 1,60 & 1,27 & 0,643 \\
\hline \multirow{3}{*}{12,0} & MB 12,0-REF & 124,3 & 125,0 & 123,5 & 0,71 & 0,57 & 0,634 \\
\hline & MB 12,0-RGV-100\% & 124,6 & 125,5 & 123,5 & 1,04 & 0,83 & 0,636 \\
\hline & M B 12,0-RG B -50\% & 125,8 & 126,5 & 124,6 & 1,00 & 0,79 & 0,642 \\
\hline
\end{tabular}

Para facilitar o entendimento global dos resultados é apresentada, na Tabela 7.88, o teste estatístico de Análise de Variância. 
Tabela 7.88 - Teste ANOVA para valores de área líquida dos meios-blocos.

\begin{tabular}{|c|c|c|c|c|}
\hline \multirow{2}{*}{ Comparações } & \multirow{2}{*}{ Grupos } & \multicolumn{2}{|c|}{ Análise de $1^{0}$ Ordem } & \multirow{2}{*}{$\begin{array}{c}\text { Análise de } 2^{0} \text { Ordem } \\
\text { Grupos x } \\
\text { Traços } \\
\end{array}$} \\
\hline & & $\begin{array}{l}\text { Grupos/Classes de } \\
\text { resistência }\end{array}$ & Traços & \\
\hline REF x RGV-100\% & $4,5 \times 8,0 \times 12,0$ & - & $S(7,21)$ & - \\
\hline REF x RGB-50\% & $4,5 \times 8,0 \times 12,0$ & - & - & $S(6,73)$ \\
\hline RGV-100\% x RGB-50\% & $4,5 \times 8,0 \times 12,0$ & $\mathrm{~S}\left(\mathrm{~F}_{0}=6,08\right)$ & - & $S(4,02)$ \\
\hline
\end{tabular}

Analisando-se os dados da Tabela 7.88, pode-se afirmar que houve influência significativa da composição do traço apenas para as unidades do traço RGV-100\%, as quais apresentaram valores médios de área líquida significativamente maiores, em relação aos valores obtidos para as unidades de referência. Com relação aos diferentes grupos/classes de resistência, apenas os traços com agregados reciclados apresentaram valores de área líquida que diferiram significativamente entre si, sendo os maiores valores médios obtidos para as dosagens pertencentes ao Grupo 8,0. Para a análise de $2^{\mathrm{a}}$ ordem, observou-se uma influência significativa dos parâmetros (grupos e traços) sobre a área líquida das unidades.

\subsubsection{Massa específica e índice de vazios}

$\mathrm{Na}$ Tabela 7.89, encontram-se os resultados para a propriedade de massa específica. Para facilitar a compreensão dos resultados de massa específica seca, é apresentada, na Tabela 7.90, o teste ANOVA.

Tabela 7.89 - Massa específica seca e saturada superfície seca para os meios-blocos dos três grupos avaliados.

\begin{tabular}{|c|c|c|c|c|c|c|c|c|c|c|c|}
\hline \multirow[t]{2}{*}{ Grupos } & \multirow[t]{2}{*}{ Traços } & \multicolumn{5}{|c|}{$\begin{array}{c}\text { Massa específica seca }\left(d_{s}\right) \\
\mathrm{kg} / \mathrm{dm}^{3}\end{array}$} & \multicolumn{5}{|c|}{$\begin{array}{c}\text { Massa específica saturada superfície } \\
\text { seca }\left(d_{\text {ssd }}\right) \\
\mathrm{kg} / \mathrm{dm}^{3}\end{array}$} \\
\hline & & Média & Máx. & Mín. & $\mathbf{S}_{\mathrm{d}}$ & $\begin{array}{l}\text { C.V. } \\
(\%)\end{array}$ & Média & Máx. & Mín. & $\mathbf{S}_{\mathrm{d}}$ & $\begin{array}{l}\text { C.V. } \\
(\%)\end{array}$ \\
\hline \multirow{3}{*}{4,5} & MB 4,5-REF & 2,174 & 2,185 & 2,159 & 0,013 & 0,61 & 2,313 & 2,324 & 2,299 & 0,013 & 0,55 \\
\hline & MB4,5-RGV-100\% & 2,219 & 2,260 & 2,179 & 0,041 & 1,83 & 2,341 & 2,376 & 2,307 & 0,035 & 1,47 \\
\hline & MB 4,5-RGB-50\% & 2,197 & 2,200 & 2,194 & 0,003 & 0,14 & 2,323 & 2,325 & 2,322 & 0,001 & 0,06 \\
\hline \multirow{3}{*}{8,0} & MB8,0-REF & 2,179 & 2,203 & 2,165 & 0,021 & 0,94 & 2,315 & 2,333 & 2,305 & 0,016 & 0,69 \\
\hline & MB8,0-RGV-100\% & 2,143 & 2,157 & 2,123 & 0,018 & 0,84 & 2,283 & 2,296 & 2,266 & 0,015 & 0,67 \\
\hline & MB8,0-RGB-50\% & 2,202 & 2,220 & 2,188 & 0,016 & 0,75 & 2,328 & 2,345 & 2,314 & 0,015 & 0,66 \\
\hline \multirow{3}{*}{12,0} & MB12,0-REF & 2,260 & 2,275 & 2,237 & 0,020 & 0,89 & 2,379 & 2,392 & 2,358 & 0,018 & 0,75 \\
\hline & MB12,0-RGV-100\% & 2,187 & 2,193 & 2,178 & 0,008 & 0,36 & 2,318 & 2,326 & 2,307 & 0,010 & 0,42 \\
\hline & MB12,0-RGB-50\% & 2,205 & 2,215 & 2,199 & 0,009 & 0,39 & 2,332 & 2,342 & 2,325 & 0,009 & 0,38 \\
\hline
\end{tabular}


Tabela 7.90 - Teste ANOVA para valores de massa específica dos meios-blocos.

\begin{tabular}{|c|c|c|c|c|}
\hline \multirow{2}{*}{ Comparações } & \multirow{2}{*}{ Grupos } & \multicolumn{2}{|c|}{ Análise de $1^{0}$ Ordem } & \multirow{2}{*}{$\begin{array}{c}\text { Análise de } 2^{0} \text { Ordem } \\
\text { Grupos } x \\
\text { Traços } \\
\end{array}$} \\
\hline & & $\begin{array}{l}\text { Grupos/Classes de } \\
\text { resistência }\end{array}$ & Traços & \\
\hline REF x RGV-100\% & $4,5 \times 8,0 \times 12,0$ & $S\left(F_{0}=11,60\right)$ & - & $\mathrm{S}(10,79)$ \\
\hline REF x RGB-50\% & $4,5 \times 8,0 \times 12,0$ & $\mathrm{~S}(17,57)$ & - & $S(13,46)$ \\
\hline RGV-100\% x RGB-50\% & $4,5 \times 8,0 \times 12,0$ & $\mathrm{~S}(4,88)$ & - & $\mathrm{S}(6,19)$ \\
\hline
\end{tabular}

Analisando-se os resultados da Tabela 7.90, nota-se que para a análise de $1^{\mathrm{a}}$ ordem, houve, para todos os casos, influência significativa da variável grupos/classes de resistência $(4,5 ; 8,0 ; 12,0)$ sobre a propriedade de massa específica seca. Em grande parte dos resultados, os maiores valores médios de massa específica foram obtidos para as classes de resistência mais elevadas. Por outro lado, a composição do traço, isto é, a presença ou não de agregados reciclados não afetou a propriedade de massa específica. Devido a grande quantidade de argamassa aderida ao agregado reciclado era esperado que as dosagens com reciclados apresentassem valores significativamente diferentes e menores quando comparados com as unidades de referência; possivelmente, a falta de controle da quantidade de água adicionada na mistura e os maiores tempos de produção adotados para as dosagens com agregados reciclados contribuíram para que essas prováveis diferenças não fossem significativas.

Para a análise de $2^{\mathrm{a}}$ ordem (variáveis analisadas duas a duas), observou-se uma influência significativa dos parâmetros (grupos e traços) sobre a propriedade de massa específica seca para todas as comparações avaliadas; isto significa que, dependendo da classe de resistência, há um determinado traço que conduzirá aos maiores valores de massa específica. Por exemplo, para uma dada classe de resistência (4,5, por exemplo) pode-se ter um determinado traço (RGV-100\%) que conduz aos maiores valores médios de massa específica seca, entretanto, para outra classe de resistência (12,0, por exemplo), este mesmo traço pode não levar necessariamente aos maiores valores médios de massa específica.

Na Tabela 7.91, encontram-se os resultados para a propriedade de índice de vazios. 
Tabela 7.91 - Índice de vazios para os meios-blocos dos três grupos avaliados.

\begin{tabular}{|c|c|c|c|c|c|c|}
\hline \multirow{2}{*}{ Grupos } & \multirow{2}{*}{ Traços } & \multicolumn{5}{|c|}{ Índice de Vazios (\%) } \\
\hline & & Média & Máx. & Mín. & $\mathbf{S}_{d}$ & C.V. (\%) \\
\hline \multirow{3}{*}{4,5} & MB4,5-REF & 13,82 & 13,94 & 13,66 & 0,15 & 1,05 \\
\hline & MB4,5-RGV-100\% & 12,23 & 12,86 & 11,65 & 0,61 & 4,96 \\
\hline & MB4,5-RGB-50\% & 12,62 & 12,77 & 12,45 & 0,16 & 1,29 \\
\hline \multirow{3}{*}{8,0} & MB8,0-REF & 13,55 & 14,12 & 13,04 & 0,54 & 4,01 \\
\hline & MB8,0-RGV-100\% & 14,01 & 14,35 & 13,83 & 0,29 & 2,09 \\
\hline & MB8,0-RGB-50\% & 12,61 & 12,72 & 12,46 & 0,13 & 1,03 \\
\hline \multirow{3}{*}{12,0} & MB12,0-REF & 11,83 & 12,11 & 11,67 & 0,24 & 2,05 \\
\hline & MB12,0-RGV-100\% & 13,15 & 13,30 & 12,92 & 0,20 & 1,54 \\
\hline & MB12,0-RGB-50\% & 12,75 & 12,98 & 12,50 & 0,24 & 1,90 \\
\hline
\end{tabular}

Com relação aos valores de índice de vazios, todas as unidades cumpriram com os requisitos prescritos por Levy (2001) para concretos classificados como normais quanto à durabilidade (índice de vazios menor que 15\%). Para facilitar o entendimento global dos resultados é apresentada, na Tabela 7.92, o teste estatístico de Análise de Variância.

Tabela 7.92 - Teste ANOVA para valores de índice de vazios dos meios-blocos.

\begin{tabular}{|c|c|c|c|c|}
\hline \multirow{2}{*}{ Comparações } & \multirow{2}{*}{ Grupos } & \multicolumn{2}{|c|}{ Análise de $1^{0}$ Ordem } & \multirow{2}{*}{$\begin{array}{c}\text { Análise de } 2^{0} \text { Ordem } \\
\text { Grupos } \mathrm{x} \\
\text { Traços } \\
\end{array}$} \\
\hline & & $\begin{array}{c}\text { Grupos/Classes de } \\
\text { resistência }\end{array}$ & Traços & \\
\hline REF $\times$ RGV-100\% & $4,5 \times 8,0 \times 12,0$ & $\mathrm{~S}\left(\mathrm{~F}_{0}=17,37\right)$ & - & $S(23,08)$ \\
\hline REFx RGB-50\% & $4,5 \times 8,0 \times 12,0$ & $S(18,97)$ & $S(9,46)$ & $S(25,17)$ \\
\hline RGV-100\% x RGB-50\% & $4,5 \times 8,0 \times 12,0$ & $\mathrm{~S}(11,91)$ & $S(10,13)$ & $S(12,11)$ \\
\hline
\end{tabular}

Analisando-se os resultados da Tabela 7.93, nota-se que para a análise de $1^{\text {a }}$ ordem, houve, para todos os casos, influência significativa das variáveis grupos/classes de resistência e traços (referência, agregados reciclados de vigota e bloco) sobre a propriedade de índice de vazios; exceto para a comparação entre os traços REF x RGV-100\%, onde não foi observada uma influência significativa da presença de agregados reciclados sobre a propriedade de índice de vazios. Dentre as duas variáveis, a que exerceu maior influência nos valores de índice de vazios foi a classe de resistência dos meios-blocos, isto é, em grande parte dos resultados, os menores valores médios de índice de vazios foram obtidos 
para as classes de resistência mais elevadas (Grupo 12,0). Para a análise de $2^{\mathrm{a}}$ ordem, observou-se uma influência significativa dos parâmetros (grupos e traços) sobre a propriedade de índice de vazios. Nesse caso, pode-se afirmar que, dependendo da classe de resistência, há uma determinada dosagem que conduz aos menores valores médios de índice de vazios.

\subsubsection{Taxa de absorção inicial}

Os resultados para essa propriedade encontram-se na Tabela 7.93.

Tabela 7.93 - Taxa de absorção inicial para as unidades dos três grupos avaliados.

\begin{tabular}{|c|c|c|c|c|c|c|c|c|c|c|}
\hline Grupos & Traços & $\begin{array}{c}\text { IRA } \\
(\mathrm{g} / \mathrm{min} / \\
\left.193,55 \mathrm{~cm}^{2}\right)\end{array}$ & Média & Máximo & Mínimo & $S_{d}$ & $\begin{array}{l}\text { CV } \\
(\%)\end{array}$ & $\begin{array}{l}\text { IRA médio } \\
(\mathrm{g} / \mathrm{min} / \\
\left.193,55 \mathrm{~cm}^{2}\right)\end{array}$ & $\begin{array}{c}\text { IRA } \\
\text { médio } \\
(\mathbf{k g} / \mathrm{min} / \\
\left.\mathrm{m}^{2}\right)\end{array}$ & $\begin{array}{c}\text { Absorção } \\
\text { de água } \\
(\%)\end{array}$ \\
\hline \multirow{6}{*}{4,5} & \multirow{2}{*}{ MB4,5-REF } & Face Maior & 46,0 & 50,3 & 40,3 & 5,2 & 11,3 & \multirow{2}{*}{31,7} & \multirow{2}{*}{1,64} & \multirow{2}{*}{6,36} \\
\hline & & Face Menor & 15,6 & 16,2 & 14,6 & 0,9 & 6,0 & & & \\
\hline & \multirow{2}{*}{$\begin{array}{c}\text { MB4,5- } \\
\text { RGV-100\% }\end{array}$} & Maior & 13,4 & 21,6 & 5,8 & 7,9 & 59,0 & \multirow{2}{*}{10,9} & \multirow{2}{*}{0,56} & \multirow{2}{*}{5,52} \\
\hline & & Menor & 8,1 & 8,1 & 8,1 & 0,0 & 0,0 & & & \\
\hline & \multirow{2}{*}{$\begin{array}{c}\text { MB4,5- } \\
\text { RGB-50\% }\end{array}$} & Maior & 5,3 & 5,8 & 4,3 & 0,8 & 15,8 & \multirow{2}{*}{5,6} & \multirow{2}{*}{0,29} & \multirow{2}{*}{5,74} \\
\hline & & Menor & 5,9 & 6,5 & 4,9 & 0,9 & 15,8 & & & \\
\hline \multirow{6}{*}{8,0} & \multirow{2}{*}{ MB8,0-REF } & Maior & 32,1 & 43,1 & 20,1 & 11,5 & 35,9 & \multirow{2}{*}{24,4} & \multirow{2}{*}{1,26} & \multirow{2}{*}{6,22} \\
\hline & & Menor & 15,6 & 19,4 & 12,9 & 3,4 & 21,5 & & & \\
\hline & \multirow{2}{*}{$\begin{array}{c}\text { MB8,0- } \\
\text { RGV-100\% }\end{array}$} & Maior & 22,0 & 28,8 & 17,1 & 6,0 & 27,5 & \multirow{2}{*}{15,7} & \multirow{2}{*}{0,81} & \multirow{2}{*}{6,54} \\
\hline & & Menor & 8,5 & 12,6 & 6,5 & 3,5 & 41,7 & & & \\
\hline & \multirow{2}{*}{$\begin{array}{c}\text { MB8,0- } \\
\text { RGB-50\% }\end{array}$} & Maior & 24,3 & 37,4 & 15,8 & 11,5 & 47,1 & \multirow{2}{*}{17,7} & \multirow{2}{*}{0,91} & \multirow{2}{*}{5,73} \\
\hline & & Menor & 10,1 & 11,3 & 8,1 & 1,8 & 17,6 & & & \\
\hline \multirow{6}{*}{12,0} & \multirow{2}{*}{$\begin{array}{l}\text { MB12,0- } \\
\text { REF }\end{array}$} & Maior & 17,3 & 18,7 & 15,8 & 1,4 & 8,3 & \multirow{2}{*}{11,7} & \multirow{2}{*}{0,60} & \multirow{2}{*}{5,24} \\
\hline & & Menor & 5,4 & 6,5 & 4,9 & 0,9 & 17,3 & & & \\
\hline & \multirow{2}{*}{$\begin{array}{c}\text { MB12,0- } \\
\text { RGV-100\% }\end{array}$} & Maior & 11,5 & 14,4 & 8,6 & 2,9 & 25,0 & \multirow{2}{*}{9,1} & \multirow{2}{*}{0,47} & 60.01 \\
\hline & & Menor & 6,5 & 8,1 & 4,9 & 1,6 & 25,0 & & & \\
\hline & MB12,0- & Maior & 12,5 & 15,8 & 7,2 & 4,6 & 37,1 & $10 ?$ & 0 & 578 \\
\hline & RGB-50\% & Menor & 7,6 & 8,1 & 6,5 & 0,9 & 12,4 & & & 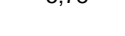 \\
\hline
\end{tabular}

Analisando-se a Tabela 7.93, nota-se que todas as unidades avaliadas, com exceção das unidades do traço MB4,5-RGB-50\%, apresentaram valores para a taxa de absorção inicial dentro do intervalo prescrito por Gallegos (1989), isto é, entre $10 \mathrm{~g} / \mathrm{min} / 193,55 \mathrm{~cm}^{2} \mathrm{e}$ $30 \mathrm{~g} / \mathrm{min} / 193,55 \mathrm{~cm}^{2}$. A Análise de Variância, utilizada para uma melhor compreensão dos resultados obtidos, é apresentada na Tabela 7.94. 
Tabela 7.94 - Teste ANOVA para valores de IRA dos meios-blocos.

\begin{tabular}{|c|c|c|c|c|}
\hline \multirow{2}{*}{ Comparações } & \multirow{2}{*}{ Grupos } & \multicolumn{2}{|c|}{ Análise de $1^{0}$ Ordem } & \multirow{2}{*}{$\begin{array}{c}\text { Análise de } 2^{0} \text { Ordem } \\
\text { Grupos } x \\
\text { Traços }\end{array}$} \\
\hline & & $\begin{array}{l}\text { Grupos/Classes de } \\
\text { resistência }\end{array}$ & Traços & \\
\hline REF $\times$ RGV-100\% & $4,5 \times 8,0 \times 12,0$ & $S\left(F_{0}=22,84\right)$ & $S(55,06)$ & $\mathrm{S}(13,89)$ \\
\hline REF x RGB-50\% & $4,5 \times 8,0 \times 12,0$ & $S(12,24)$ & $S(43,14)$ & $S(18,46)$ \\
\hline RGV-100\% x RGB-50\% & $4,5 \times 8,0 \times 12,0$ & $S(9,65)$ & - & - \\
\hline
\end{tabular}

Analisando-se os resultados da Tabela 7.94, nota-se que para a análise de $1^{\mathrm{a}}$ ordem, houve, para todos os casos, com exceção dos traços com agregados reciclados, influência significativa das variáveis grupos/classes de resistência e traços sobre a taxa de absorção inicial. Dentre as duas variáveis, a que exerceu maior influência nos valores de IRA foi à composição dos traços (presença ou não de agregados reciclados), sendo que os maiores valores médios (significativamente diferentes) de IRA foram obtidos para os traços de referência comparativamente às dosagens com agregados reciclados de vigota ou de bloco. Para a análise de $2^{\mathrm{a}}$ ordem, foi observada uma influência significativa dos parâmetros (grupos e traços) sobre a taxa de absorção inicial; exceto para as comparações entre os traços com agregados reciclados. Para as comparações que foram significativas, pode-se afirmar que, dependendo do traço, há um determinado grupo que conduz aos menores valores médios de IRA. Por exemplo, para uma dada dosagem (REF, por exemplo) pode-se ter um determinado grupo $(12,0)$ que conduzi aos menores valores médios de IRA, entretanto, para outro traço (RGB-50\%) esse mesmo grupo pode não levar necessariamente aos menores valores médios de IRA, sendo, nesse caso, os menores valores obtidos pelas unidades do Grupo 4,5.

\subsubsection{PROPRIEDADES MECÂNICAS}

\subsubsection{Resistência à compressão}

Os resultados de resistência à compressão aos sete dias são apresentados na Tabela 7.95 . 
Tabela 7.95 - Resistência à compressão aos sete dias para os meios-blocos dos três grupos avaliados

\begin{tabular}{|c|c|c|c|c|c|c|c|}
\hline Grupos & Traços & Parâmetros & $\begin{array}{l}\text { Idade } \\
\text { (dias) }\end{array}$ & $\begin{array}{c}\text { Massa da } \\
\text { unidade (g) }\end{array}$ & Força $(\mathbf{k N})$ & $\begin{array}{l}\text { Tensão - } \\
\text { Área bruta } \\
\text { (MPa) }\end{array}$ & $\begin{array}{c}\text { Tensão - } \\
\text { Área } \\
\text { líquida } \\
\text { (MPa) }\end{array}$ \\
\hline \multirow{15}{*}{4,5} & \multirow{5}{*}{ MB4,5-REF } & Média & \multirow{5}{*}{7} & 5322 & 144 & 7,33 & 11,50 \\
\hline & & Máximo & & 5383 & 160 & 8,16 & 12,82 \\
\hline & & Mínimo & & 5209 & 131 & 6,69 & 10,50 \\
\hline & & $S_{d}$ & & 98 & 15 & 0,76 & 1,19 \\
\hline & & C.V. & & $1,84 \%$ & $10,33 \%$ & $10,33 \%$ & $10,33 \%$ \\
\hline & \multirow{5}{*}{$\begin{array}{c}\text { MB4,5- } \\
\text { RGV-100\% }\end{array}$} & Média & \multirow{5}{*}{7} & 5341 & 198 & 10,09 & 15,79 \\
\hline & & Máximo & & 5425 & 216 & 11,04 & 17,28 \\
\hline & & Mínimo & & 5279 & 184 & 9,36 & 14,65 \\
\hline & & $\mathrm{S}_{\mathrm{d}}$ & & 75 & 17 & 0,86 & 1,35 \\
\hline & & C.V. & & $1,41 \%$ & $8,54 \%$ & $8,54 \%$ & $8,54 \%$ \\
\hline & \multirow{5}{*}{$\begin{array}{c}\text { MB4,5- } \\
\text { RGB-50\% }\end{array}$} & Média & \multirow{5}{*}{7} & 5501 & 206 & 10,50 & 16,78 \\
\hline & & Máximo & & 5522 & 218 & 11,10 & 17,73 \\
\hline & & Mínimo & & 5476 & 198 & 10,09 & 16,11 \\
\hline & & $\mathrm{S}_{\mathrm{d}}$ & & 23 & 10 & 0,53 & 0,85 \\
\hline & & C.V. & & $0,42 \%$ & $5,07 \%$ & $5,07 \%$ & $5,07 \%$ \\
\hline \multirow{15}{*}{8,0} & \multirow{5}{*}{ MB8,0-REF } & Média & \multirow{5}{*}{7} & 5438 & 191 & 9,75 & 15,52 \\
\hline & & Máximo & & 5480 & 202 & 10,31 & 16,42 \\
\hline & & Mínimo & & 5382 & 184 & 9,36 & 14,91 \\
\hline & & $\mathrm{S}_{\mathrm{d}}$ & & 51 & 10 & 0,50 & 0,80 \\
\hline & & C.V. & & $0,93 \%$ & $5,13 \%$ & $5,13 \%$ & $5,13 \%$ \\
\hline & \multirow{5}{*}{$\begin{array}{c}\text { MB8,0- } \\
\text { RGV-100\% }\end{array}$} & Média & \multirow{5}{*}{7} & 5373 & 229 & 11,68 & 18,11 \\
\hline & & Máximo & & 5395 & 253 & 12,92 & 20,03 \\
\hline & & Mínimo & & 5349 & 197 & 10,03 & 15,55 \\
\hline & & $\mathrm{S}_{\mathrm{d}}$ & & 23 & 29 & 1,49 & 2,31 \\
\hline & & C.V. & & $0,43 \%$ & $12,74 \%$ & $12,74 \%$ & $12,74 \%$ \\
\hline & \multirow{5}{*}{$\begin{array}{c}\text { MB8,0- } \\
\text { RGB-50\% }\end{array}$} & Média & \multirow{5}{*}{7} & 5367 & 205 & 10,46 & 16,27 \\
\hline & & Máximo & & 5393 & 223 & 11,35 & 17,65 \\
\hline & & Mínimo & & 5318 & 184 & 9,39 & 14,60 \\
\hline & & $\mathrm{S}_{\mathrm{d}}$ & & 42 & 20 & 0,99 & 1,55 \\
\hline & & C.V. & & $0,79 \%$ & $9,51 \%$ & $9,51 \%$ & $9,51 \%$ \\
\hline \multirow{15}{*}{12,0} & \multirow{5}{*}{$\begin{array}{l}\text { MB12,0- } \\
\text { REF }\end{array}$} & Média & \multirow{5}{*}{7} & 5445 & 217 & 11,06 & 17,44 \\
\hline & & Máximo & & 5533 & 235 & 11,99 & 18,91 \\
\hline & & Mínimo & & 5339 & 188 & 9,61 & 15,16 \\
\hline & & $S_{d}$ & & 98 & 25 & 1,27 & 2,00 \\
\hline & & C.V. & & $1,80 \%$ & $11,48 \%$ & $11,48 \%$ & $11,48 \%$ \\
\hline & \multirow{5}{*}{$\begin{array}{c}\text { MB12,0- } \\
\text { RGV-100\% }\end{array}$} & Média & \multirow{5}{*}{7} & 5394 & 236 & 12,06 & 18,96 \\
\hline & & Máximo & & 5448 & 262 & 13,36 & 21,01 \\
\hline & & Mínimo & & 5229 & 222 & 11,34 & 17,83 \\
\hline & & $S_{d}$ & & 91 & 22 & 1,13 & 1,78 \\
\hline & & C.V. & & $1,69 \%$ & $9,36 \%$ & $9,36 \%$ & $9,36 \%$ \\
\hline & \multirow{5}{*}{$\begin{array}{c}\text { MB12,0- } \\
\text { RGB-50\% }\end{array}$} & Média & \multirow{5}{*}{7} & 5494 & 242 & 12,35 & 19,23 \\
\hline & & Máximo & & 5565 & 250 & 12,76 & 19,88 \\
\hline & & Mínimo & & 5421 & 228 & 11,65 & 18,15 \\
\hline & & $S_{d}$ & & 72 & 12 & 0,60 & 0,94 \\
\hline & & C.V. & & $1,31 \%$ & $4,90 \%$ & $4,90 \%$ & $4,90 \%$ \\
\hline
\end{tabular}

Analisando-se a Tabela 7.95, observa-se que as unidades de referência, principalmente, os meios-blocos pertencentes ao Grupo 4,5, apresentaram valores de resistência à compressão inferiores aos obtidos para as unidades com agregados reciclados. Possivelmente, a falta de controle da quantidade de água adicionada na mistura e os menores tempos de alimentação, pré-vibração e vibro-compressão na produção das unidades de referência contribuiu para esses resultados. Novamente, de acordo com Frasson Junior (2000), uma variação da umidade da mistura pode interferir significativamente na massa dos blocos e, consequentemente, na sua resistência. A Análise de Variância, utilizada para uma melhor compreensão dos resultados obtidos, é apresentada na Tabela 7.96. 
Tabela 7.96 - Teste ANOVA para valores de resistência à compressão.

\begin{tabular}{|c|c|c|c|c|}
\hline \multirow{2}{*}{ Comparações } & \multirow{2}{*}{ Grupos } & \multicolumn{2}{|c|}{ Análise de $1^{0}$ Ordem } & \multirow{2}{*}{$\begin{array}{c}\text { Análise de } 2^{0} \text { Ordem } \\
\text { Grupos } x \\
\text { Traços }\end{array}$} \\
\hline & & $\begin{array}{c}\text { Grupos/Classes de } \\
\text { resistência }\end{array}$ & Traços & \\
\hline REF x RGV-100\% & $4,5 \times 8,0 \times 12,0$ & $\mathrm{~S}\left(\mathrm{~F}_{0}=11,59\right)$ & $S(14,63)$ & - \\
\hline REF x RGB-50\% & $4,5 \times 8,0 \times 12,0$ & $\mathrm{~S}(17,31)$ & $S(19,76)$ & - \\
\hline RGV-100\% x RGB-50\% & $4,5 \times 8,0 \times 12,0$ & $S(5,65)$ & - & - \\
\hline
\end{tabular}

Pelos resultados da Tabela 7.96, nota-se que para a análise de $1^{\mathrm{a}}$ ordem, houve influência significativa das variáveis grupos/classes de resistência $(4,5 ; 8,0 ; 12,0)$ e composição dos traços (agregados naturais ou reciclados) sobre a propriedade de resistência à compressão; apenas para a comparação entre os traços RGV-100\% e RGB$50 \%$ não foi observada influência significativa da incorporação de diferentes tipos de agregados reciclados sobre a resistência à compressão. De maneira geral, as composições com agregados reciclados e as unidades dos grupos 8,0 e 12,0 apresentaram os maiores valores médios de resistência à compressão comparativamente às unidades de referência e as unidades do grupo 4,5. Para a análise de $2^{\mathrm{a}}$ ordem, pode-se afirmar que não ocorreu influência significativa dos parâmetros (grupos e traços) sobre a propriedade de resistência à compressão; isto significa dizer que, por exemplo, para todas as classes de resistência $(4,5 ; 8,0 ; 12,0)$ houve um determinado traço (RGV-100\%) que conduziu aos maiores valores médios de resistência à compressão; além disso, para praticamente todos os traços/composições, os maiores valores médios de resistência foram obtidos pelas unidades do Grupo 12,0, como era esperado.

\subsubsection{Módulo de deformação}

$\mathrm{Na}$ Tabela 7.97, são apresentados os resultados da força máxima aplicada, da tensão de ruptura, do módulo de deformação referente a área bruta e área líquida, a deformação referente a 33\% da tensão última, a deformação última e a relação entre módulo de deformação e resistência à compressão para cada grupo de meios-blocos avaliados. 
Tabela 7.97 - Módulo de deformação para as unidades dos três grupos avaliados

\begin{tabular}{|c|c|c|c|c|c|c|c|c|c|c|c|c|}
\hline Grupos & Traços & $\begin{array}{l}\text { Idade } \\
\text { (dias) }\end{array}$ & Parâmetros & $\begin{array}{c}\text { Massa } \\
\text { da } \\
\text { unidade } \\
\text { (g) }\end{array}$ & $\begin{array}{c}\text { Força } \\
(\mathrm{kN})\end{array}$ & $\begin{array}{c}\text { Tensão } \\
\text { - Área } \\
\text { bruta } \\
\text { (MPa) }\end{array}$ & $\begin{array}{c}\text { Módulo } \\
\text { - Área } \\
\text { bruta } \\
\text { (MPa) }\end{array}$ & $\begin{array}{c}\text { Tensão } \\
\text { - Área } \\
\text { líquida } \\
\text { (MPa) }\end{array}$ & $\begin{array}{l}\text { Módulo } \\
\text { - Área } \\
\text { líquida } \\
\text { (MPa) }\end{array}$ & $\begin{array}{c}\text { Def. } \\
33 \% \text { da } \\
\text { tensão } \\
\text { Úlitima } \\
(\%)\end{array}$ & $\begin{array}{c}\text { Deform. } \\
\text { Última } \\
(\%)\end{array}$ & $E_{c} / f_{c}$ \\
\hline \multirow{15}{*}{4,5} & \multirow{5}{*}{$\begin{array}{c}\text { MB4,5- } \\
\text { REF }\end{array}$} & \multirow{5}{*}{7} & Média & 5322 & 144 & 7,33 & 6949 & 11,50 & 10909 & $-0,34$ & $-3,50$ & 949 \\
\hline & & & Máximo & 5383 & 160 & 8,16 & 9520 & 12,82 & 14945 & $-0,40$ & $-4,77$ & 1180 \\
\hline & & & Mínimo & 5209 & 131 & 6,69 & 5285 & 10,50 & 8297 & $-0,27$ & $-2,80$ & 867 \\
\hline & & & $\mathrm{S}_{\mathrm{d}}$ & 98 & 15 & 0,76 & 2259 & 1,19 & 3546 & 0,07 & 1,10 & 203 \\
\hline & & & C.V. & $1,84 \%$ & $10,33 \%$ & $10,33 \%$ & $32,50 \%$ & $10,33 \%$ & $32,50 \%$ & $19,78 \%$ & $31,55 \%$ & $21,37 \%$ \\
\hline & \multirow{5}{*}{$\begin{array}{c}\text { MB4,5- } \\
\text { RGV- } \\
100 \%\end{array}$} & \multirow{5}{*}{7} & Média & 5341 & 198 & 10,09 & 11283 & 15,79 & 17657 & $-0,28$ & $-4,05$ & 1132 \\
\hline & & & Máximo & 5425 & 216 & 11,04 & 12267 & 17,28 & 19197 & $-0,32$ & $-4,55$ & 1277 \\
\hline & & & Mínimo & 5279 & 184 & 9,36 & 9772 & 14,65 & 15293 & $-0,24$ & $-3,68$ & 999 \\
\hline & & & $S_{d}$ & 75 & 17 & 0,86 & 1328 & 1,35 & 2078 & 0,04 & 0,45 & 140 \\
\hline & & & C.V. & $1,41 \%$ & $8,54 \%$ & $8,54 \%$ & $11,77 \%$ & $8,54 \%$ & $11,77 \%$ & $12,70 \%$ & $11,19 \%$ & $12,34 \%$ \\
\hline & \multirow{5}{*}{$\begin{array}{c}\text { MB4,5- } \\
\text { RGB- } \\
50 \%\end{array}$} & \multirow{5}{*}{7} & Média & 5501 & 206 & 10,50 & 10678 & 16,78 & 17057 & $-0,30$ & $-3,41$ & 1061 \\
\hline & & & Máximo & 5522 & 218 & 11,10 & 11812 & 17,73 & 18869 & $-0,34$ & $-3,57$ & 1185 \\
\hline & & & Mínimo & 5476 & 198 & 10,09 & 9544 & 16,11 & 15246 & $-0,27$ & $-3,25$ & 937 \\
\hline & & & $\mathrm{S}_{\mathrm{d}}$ & 23 & 10 & 0,53 & 1604 & 0,85 & 2562 & 0,05 & 0,22 & 175 \\
\hline & & & C.V. & $0,42 \%$ & $5,07 \%$ & $5,07 \%$ & $15,02 \%$ & $5,07 \%$ & $15,02 \%$ & $17,19 \%$ & $6,54 \%$ & $16,51 \%$ \\
\hline \multirow{15}{*}{8,0} & \multirow{5}{*}{$\begin{array}{c}\text { MB8,0- } \\
\text { REF }\end{array}$} & \multirow{5}{*}{7} & Média & 5438 & 191 & 9,75 & 10625 & 15,52 & 16919 & $-0,29$ & $-4,48$ & 1144 \\
\hline & & & Máximo & 5480 & 202 & 10,31 & 12779 & 16,42 & 20348 & $-0,35$ & $-4,93$ & 1357 \\
\hline & & & Mínimo & 5382 & 184 & 9,36 & 8471 & 14,91 & 13490 & $-0,23$ & $-4,03$ & 931 \\
\hline & & & $\mathrm{S}_{\mathrm{d}}$ & 51 & 10 & 0,50 & 3046 & 0,80 & 4850 & 0,08 & 0,64 & 301 \\
\hline & & & C.V. & $0,93 \%$ & $5,13 \%$ & $5,13 \%$ & $28,66 \%$ & $5,13 \%$ & $28,66 \%$ & $28,18 \%$ & $14,22 \%$ & $26,32 \%$ \\
\hline & \multirow{5}{*}{$\begin{array}{c}\text { MB8,0- } \\
\text { RGV- } \\
100 \%\end{array}$} & \multirow{5}{*}{7} & Média & 5373 & 229 & 11,68 & 11009 & 18,11 & 17069 & $-0,36$ & $-3,64$ & 899 \\
\hline & & & Máximo & 5395 & 253 & 12,92 & 13320 & 20,03 & 20651 & $-0,42$ & $-4,39$ & 1040 \\
\hline & & & Mínimo & 5349 & 197 & 10,03 & 8699 & 15,55 & 13486 & $-0,30$ & $-2,89$ & 758 \\
\hline & & & $\mathrm{S}_{\mathrm{d}}$ & 23 & 29 & 1,49 & 3268 & 2,31 & 5066 & 0,08 & 1,06 & 200 \\
\hline & & & C.V. & $0,43 \%$ & $12,74 \%$ & $12,74 \%$ & $29,68 \%$ & $12,74 \%$ & $29,68 \%$ & $23,30 \%$ & $29,06 \%$ & $22,21 \%$ \\
\hline & \multirow{5}{*}{$\begin{array}{c}\text { MB8,0- } \\
\text { RGB- } \\
50 \%\end{array}$} & \multirow{5}{*}{7} & Média & 5367 & 205 & 10,46 & 10576 & 16,27 & 16449 & $-0,30$ & $-4,91$ & 1064 \\
\hline & & & Máximo & 5393 & 223 & 11,35 & 10668 & 17,65 & 16591 & $-0,31$ & $-5,13$ & 1116 \\
\hline & & & Mínimo & 5318 & 184 & 9,39 & 10485 & 14,60 & 16306 & $-0,28$ & $-4,70$ & 1011 \\
\hline & & & $S_{d}$ & 42 & 20 & 0,99 & 130 & 1,55 & 202 & 0,02 & 0,30 & 74 \\
\hline & & & C.V. & $0,79 \%$ & $9,51 \%$ & $9,51 \%$ & $1,23 \%$ & $9,51 \%$ & $1,23 \%$ & $6,76 \%$ & $6,20 \%$ & $7,00 \%$ \\
\hline \multirow{15}{*}{12,0} & \multirow{5}{*}{$\begin{array}{l}\text { MB12,0- } \\
\text { REF }\end{array}$} & \multirow{5}{*}{7} & Média & 5445 & 217 & 11,06 & 8264 & 17,44 & 13034 & $-0,43$ & $-4,52$ & 755 \\
\hline & & & Máximo & 5533 & 235 & 11,99 & 10354 & 18,91 & 16331 & $-0,51$ & $-5,19$ & 875 \\
\hline & & & Mínimo & 5339 & 188 & 9,61 & 7195 & 15,16 & 11349 & $-0,37$ & $-3,73$ & 628 \\
\hline & & & $\mathrm{S}_{\mathrm{d}}$ & 98 & 25 & 1,27 & 1810 & 2,00 & 2856 & 0,07 & 0,74 & 124 \\
\hline & & & C.V. & $1,80 \%$ & $11,48 \%$ & $11,48 \%$ & $21,91 \%$ & $11,48 \%$ & $21,91 \%$ & $16,85 \%$ & $16,37 \%$ & $16,37 \%$ \\
\hline & \multirow{5}{*}{$\begin{array}{c}\text { MB12,0- } \\
\text { RGV- } \\
100 \%\end{array}$} & \multirow{5}{*}{7} & Média & 5394 & 236 & 12,06 & 11856 & 18,96 & 18641 & $-0,33$ & $-4,53$ & 965 \\
\hline & & & Máximo & 5448 & 262 & 13,36 & 12900 & 21,01 & 20283 & $-0,33$ & $-4,57$ & 979 \\
\hline & & & Mínimo & 5229 & 222 & 11,34 & 10811 & 17,83 & 16999 & $-0,32$ & $-4,50$ & 952 \\
\hline & & & $\mathrm{S}_{\mathrm{d}}$ & 91 & 22 & 1,13 & 1477 & 1,78 & 2322 & 0,00 & 0,05 & 19 \\
\hline & & & C.V. & $1,69 \%$ & $9,36 \%$ & $9,36 \%$ & $12,46 \%$ & $9,36 \%$ & $12,46 \%$ & $1,47 \%$ & $1,15 \%$ & 2,01 \\
\hline & \multirow{5}{*}{$\begin{array}{c}\text { MB12,0- } \\
\text { RGB- } \\
50 \%\end{array}$} & & Média & 5494 & 242 & 12,35 & 11931 & 19,23 & 18584 & $-0,33$ & $-3,69$ & 974 \\
\hline & & & Máximo & 5565 & 250 & 12,76 & 15008 & 19,88 & 23377 & $-0,38$ & $-4,21$ & 1201 \\
\hline & & 7 & Mínimo & 5421 & 228 & 11,65 & 9648 & 18,15 & 15027 & $-0,26$ & $-3,29$ & 841 \\
\hline & & & $\mathrm{S}_{\mathrm{d}}$ & 72 & 12 & 0,60 & 2767 & 0,94 & 4310 & 0,07 & 0,47 & 198 \\
\hline & & & C.V. & $1,31 \%$ & $4,90 \%$ & $4,90 \%$ & $23,19 \%$ & $4,90 \%$ & $23,19 \%$ & $19,80 \%$ & $12,66 \%$ & $20,28 \%$ \\
\hline
\end{tabular}

A Análise de Variância, utilizada para uma melhor compreensão dos resultados obtidos, é apresentada na Tabela 7.98.

Tabela 7.98 - Teste ANOVA para valores de módulo de deformação.

\begin{tabular}{|c|c|c|c|c|}
\hline \multirow{2}{*}{ Comparações } & \multirow{2}{*}{ Grupos } & \multicolumn{2}{|c|}{ Análise de $1^{\mathrm{a}}$ Ordem } & \multirow{2}{*}{$\begin{array}{c}{\text { Análise de } 2^{\mathrm{a}} \text { Ordem }}^{\text {Grupos } \mathrm{x}} \\
\text { Traços } \\
\end{array}$} \\
\hline & & $\begin{array}{c}\text { Grupos/Classes de } \\
\text { resistência }\end{array}$ & Traços & \\
\hline REF $\times$ RGV-100\% & $4,5 \times 8,0 \times 12,0$ & - & $S\left(F_{0}=9,55\right)$ & - \\
\hline REF $\times$ RGB- $50 \%$ & $4,5 \times 8,0 \times 12,0$ & - & $S(8,14)$ & - \\
\hline RGV-100\% x RGB-50\% & $4,5 \times 8,0 \times 12,0$ & - & - & - \\
\hline
\end{tabular}

(S) : influência significativa para um nível de significância igual a $5 \%\left(F_{0}>F_{\text {critico }}\right)$

$(-)$ : sem influência significativa $\left(F_{0}<F_{\text {critico }}\right)$

O número entre parênteses refere-se ao valor de $F_{0}$. Quanto maior o valor de $F_{0}$, maior será a influência do parâmetro sobre a propriedade analisada 
Pelos resultados da Tabela 7.98, nota-se que, para a análise de $1^{\mathrm{a}}$ ordem, houve influência significativa da composição dos traços (agregados naturais ou reciclados) sobre a propriedade de módulo de deformação; apenas para a comparação entre os traços RGV100\% e RGB-50\% não foi observada influência significativa da incorporação de diferentes tipos de agregados reciclados sobre o módulo de deformação. De maneira geral, as composições com agregados reciclados apresentaram os maiores valores médios de módulo de deformação comparativamente às unidades de referência. Para a análise de $2^{\mathrm{a}}$ ordem (variáveis analisadas duas a duas), não foi observada influência significativa dos parâmetros (grupos e traços) sobre a propriedade de módulo de deformação.

\subsection{CONCLUSÕES DO CAPÍTULO}

De maneira geral, com relação aos blocos de concreto, independentemente do grupo avaliado, todas as unidades, com exceção dos blocos constituídos por agregados miúdos, cumpriram os requisitos referentes às propriedades físicas e mecânicas. Esse fato demonstra a viabilidade técnica da produção de blocos estruturais de concreto com agregados graúdos reciclados de concreto, independentemente da qualidade do resíduo, para diferentes níveis de resistência (4,5 MPa a 12,0 MPa). Por outro lado, a utilização da fração miúda reciclada deve ser evitada, independentemente da qualidade do resíduo, principalmente para as dosagens com baixo consumo de cimento $\left(<150 \mathrm{~kg} / \mathrm{m}^{3}\right)$, uma vez que há redução na coesão das unidades, possibilidade de aparecimento de fissuras e prejuízo da textura.

As propriedades físicas são as mais afetadas pela presença da fração reciclada, sendo que os maiores valores de absorção de água e índice de vazios e os menores valores de massa específica foram obtidos para as dosagens com maior porcentagem de substituição de agregado natural por reciclado. No entanto, as propriedades de absorção capilar e IRA não foram afetadas significativamente pela presença da fração reciclada, uma vez que essas propriedades dependem principalmente das condições de vibro-prensagem (ajuste correto dos tempos de produção) e o controle efetivo da umidade durante a produção das unidades (definição da umidade ótima).

Com relação à previsão da resistência das unidades através da correlação com os corpos-de-prova cilíndricos, pode-se dizer que essa correlação foi válida apenas para as unidades dos Grupos 4,5 e 8,0, já que o coeficiente de correlação situou-se entre 0,84 e 1,08 (Grupo 4,5) e 1,00 e 1,34 (Grupo 8,0). Dessa maneira, acredita-se que esse método 
precisa de algumas adaptações, tais como, a inclusão de dispositivos que permitam um controle mais rigoroso da energia de adensamento dos CPs em função da energia de vibroprensagem empregada na produção dos blocos.

A produção dos meios-blocos foi prejudicada pela falta de controle da quantidade de água adicionada na mistura. A indefinição da quantidade de água foi responsável pela elevada variabilidade dos resultados e pelo comportamento anômalo das unidades com agregados reciclados. Dessa forma, não é recomendada a produção de unidades com agregados reciclados em fábricas que não possuam dispositivos de controle da umidade adicionada na mistura.

Com relação ao estudo de viabilidade econômica, todas as hipóteses atestam a viabilidade da produção de unidades com agregados reciclados com custo de produção e comercialização inferiores ou, no máximo, semelhantes aos das unidades comumente produzidas. Dentre as hipóteses propostas, as alternativas B e C são mais adequadas para pequenas fábricas de pré-moldados (produção de até 100.000 blocos/mês); já para fábricas de médio e grande porte, além dessas duas alternativas, há possibilidade do investimento em estações de reciclagem com período máximo de retorno de sete anos (Hipótese A). Além dos benefícios econômicos, os benefícios indiretos são indiscutíveis, tais como redução do consumo de matérias primas e da deposição dos resíduos no meio-ambiente, certificações de qualidade ambiental (ISO 14000), melhora da imagem perante o mercado consumidor e marketing diferenciado focado na responsabilidade ambiental.

Na Figura 7.42 é apresentado um fluxograma contendo as principais etapas da produção de blocos com agregados reciclados e a subseqüente caracterização das suas propriedades físicas e mecânicas. Esse fluxograma pode ser adotado por fábricas de prémoldados. 


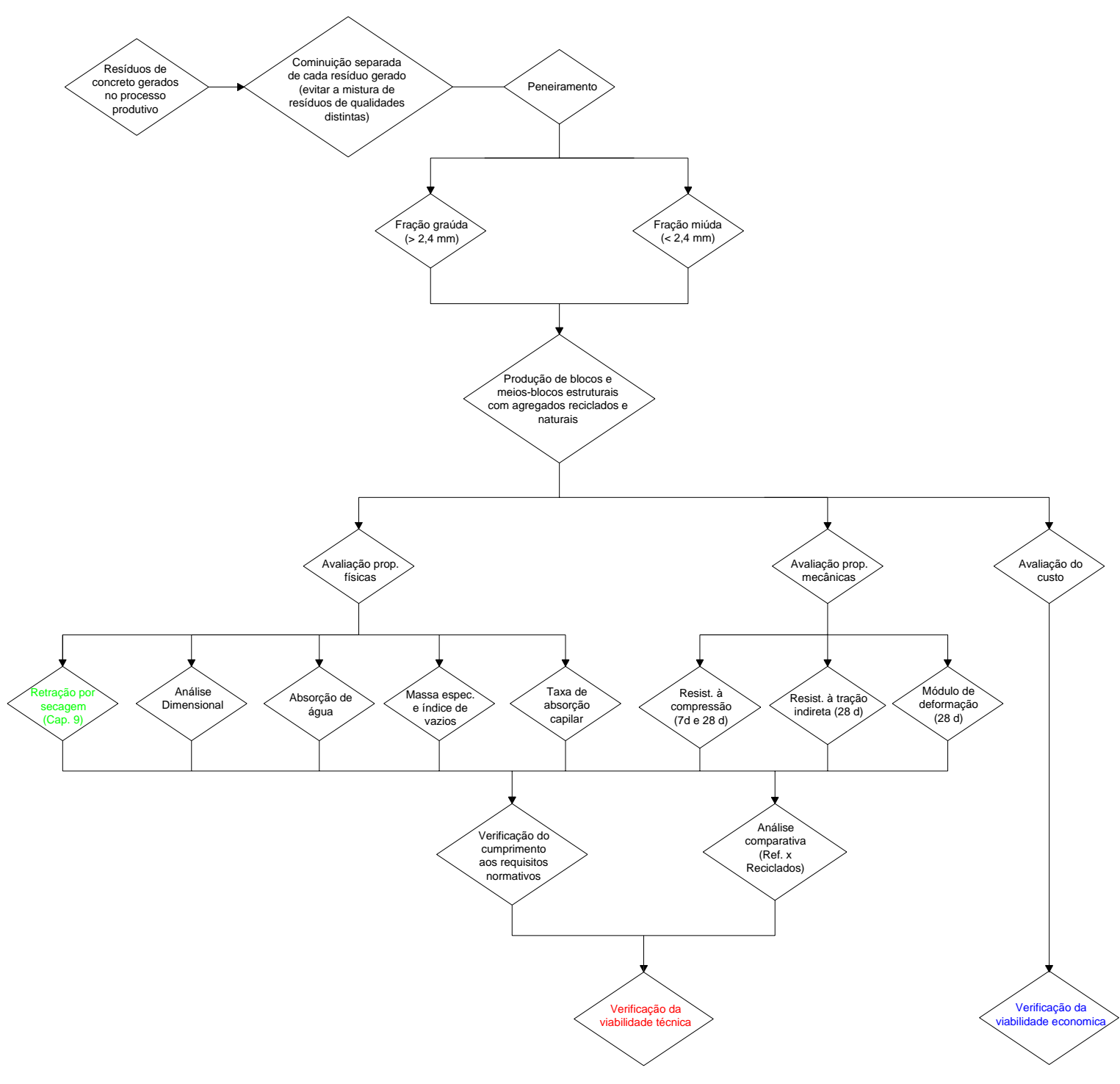

Figura 7.42 - Fluxograma contendo as principais etapas da produção e caracterização das propriedades dos blocos. 
Após a análise do comportamento dos blocos de concreto com agregados naturais e reciclados (Capítulo 7), neste capítulo é estudado o comportamento básico da alvenaria produzida com esses blocos. Preliminarmente, são descritos os ensaios realizados para caracterização da argamassa, prismas e miniparedes, instrumentações adotadas e procedimentos de execução. Posteriormente, são expostos os resultados e análises referentes à esses elementos. Para comparação dos resultados, são utilizados dois testes estatísticos (teste "t de Student" e análise de variância). As exigências para a realização do teste ANOVA, isto é, a condição de normalidade e a semelhança das variâncias encontramse no Anexo $A$.

\subsection{ARGAMASSA}

\subsubsection{CARACTERÍSTICAS DOS MATERIAIS}

O aglomerante utilizado na produção das argamassas foi o cimento CP-II-E-32 da marca Itaú e a cal hidratada foi a CH III também da marca Itaú. O agregado miúdo utilizado foi a areia fina do Rio Mogi-Guaçu. Os valores de massa específica e unitária desses materiais foram determinados de acordo com as NBR 9776 (1987) e NBR 7251 (1982), respectivamente, Tabela 8.1 .

Tabela 8.1 - Massa específica e massa unitária dos componentes da argamassa.

\begin{tabular}{ccc}
\hline Material & Massa específica $-\gamma_{\mathbf{s}}\left(\mathbf{k g} / \mathbf{d m}^{\mathbf{3}}\right)$ & $\begin{array}{c}\text { Massa unitária no estado solto - } \\
\delta\left(\mathbf{k g} / \mathbf{d m}^{\mathbf{3}}\right)\end{array}$ \\
\hline Cimento CPII - E -32 & 3,13 & 1,09 \\
\hline Cal CH - III & 2,65 & 0,75 \\
\hline Areia do Rio Mogi-Guaçu & 2,60 & 1,48 \\
\hline
\end{tabular}


A composição granulométrica do agregado miúdo foi determinada de acordo com a NBR 7217 (1987). Os resultados obtidos para a areia natural encontram-se na Tabela 8.2 e Figura 8.1.

Tabela 8.2 - Composição granulométrica do agregado miúdo natural.

\begin{tabular}{ccc}
\hline Peneira $(\mathbf{m m})$ & \% retida & \% retida acumulada \\
\hline 2,40 & 0 & 0 \\
\hline 1,20 & 11 & 11 \\
\hline 0,60 & 24 & 36 \\
\hline 0,30 & 39 & 74 \\
\hline 0,15 & 23 & 97 \\
\hline fundo & 3 & 100 \\
\hline \multicolumn{3}{c}{ Dimensão máxima característica $=2,40 \mathrm{~mm}$} \\
\hline \multicolumn{2}{c}{ Módulo de finura $=2,19$} \\
\hline
\end{tabular}

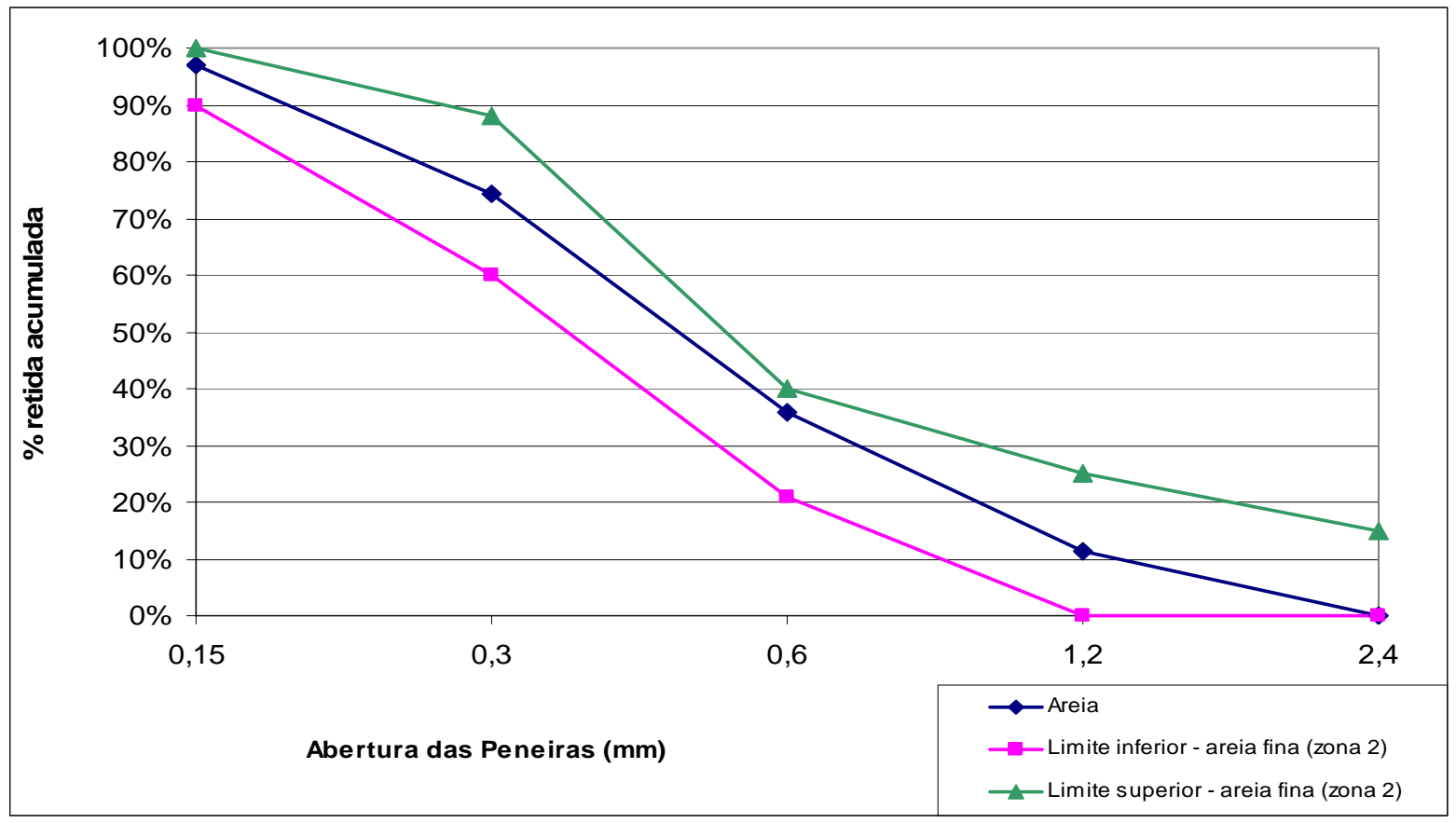

Figura 8.1 - Curva granulométrica da areia utilizada.

Conforme se observa na Figura 8.1, o agregado miúdo foi classificado como sendo areia fina (zona 2) segundo a NBR 8798 (1985). O valor obtido para o módulo de finura do agregado enquadrou-se dentro do limite recomendado por Sabbatini (1984) que está entre 1,80 e 2,80 .

\subsubsection{ESCOLHA DO TRAÇO DE ARGAMASSA}

Nesta etapa foi escolhido o traço de argamassa mais adequado para o assentamento das unidades. Diante disto, a seleção da argamassa de assentamento foi baseada em 
resultados de ensaios piloto de três traços prescritos pela Norma Britânica BS 5628: Part 1 (1992), Tabela 8.3.

Tabela 8.3 - Traços de argamassa especificados pela BS 5628: Part 1.

\begin{tabular}{cccc}
\hline \multirow{2}{*}{ Tipo de argamassa } & $\begin{array}{c}\text { Traço da argamassa } \\
\text { (em volume) }\end{array}$ & $\begin{array}{c}\text { Resistência média à compressão aos } \\
\text { 28 dias (MPa) }\end{array}$ \\
\cline { 2 - 4 } & Cimento:cal:areia & laboratório & Obra \\
\hline (i) & $1: 0$ a $0,25: 3$ & 16,0 & 11,0 \\
\hline (ii) & $1: 0,5: 4$ a 4,5 & 6,5 & 4,5 \\
\hline (iii) & $1: 1: 5$ a 6 & 3,6 & 2,5 \\
\hline (iv) & $1: 2: 8$ a 9 & 1,5 & 1,0 \\
\hline
\end{tabular}

(fonte: BS 5628: Part 1, 1992)

A mistura das argamassas foi realizada manualmente em uma argamassadeira, obedecendo-se à seguinte ordem de colocação dos materiais: a) adição do cimento e areia; b) mistura dos materiais e adição de $50 \%$ da água; c) adição gradual e mistura da cal; d) colocação do restante de água. As características das argamassas são apresentadas na Tabela 8.4. Foram utilizadas duas consistências de argamassa: a) segundo a NBR 8798 (1985), que recomenda valores de consistência entre $230 \pm 10 \mathrm{~mm}$, para argamassas de assentamento de blocos de concreto, medida no máximo após 15 minutos do início do amassamento; b) de acordo com a exigência do pedreiro, obtendo-se valores de consistência entre 270 e 290 mm, após 15 minutos do início do amassamento.

Tabela 8.4 - Características das argamassas utilizadas no estudo de traço.

\begin{tabular}{|c|c|c|c|c|c|c|c|c|c|}
\hline \multirow{2}{*}{$\begin{array}{l}\text { Traço BS } \\
5628(1992)\end{array}$} & \multirow{2}{*}{ Temperatura } & \multirow{2}{*}{ Umidade } & \multicolumn{4}{|c|}{$\begin{array}{c}\text { Proporções em massa de } \\
\text { materiais }\end{array}$} & \multirow{2}{*}{$\begin{array}{l}\text { Umidade } \\
\text { (\%) }\end{array}$} & \multirow{2}{*}{$\begin{array}{c}\text { Consumo } \\
\text { teórico } \\
\text { de } \\
\text { cimento } \\
\left(\mathrm{kg} / \mathrm{m}^{3}\right) \\
\end{array}$} & \multirow{2}{*}{$\begin{array}{c}\text { Consistência } \\
\text { (NBR 7215, } \\
\text { 1996) }\end{array}$} \\
\hline & & & Cimento & Cal & Areia & Água & & & \\
\hline (iii) - Pobre $^{1}$ & $22^{\circ} \mathrm{C}$ & $69 \%$ & 1,00 & 0,69 & 8,20 & 1,68 & 17 & 184,7 & 241 \\
\hline (iii) - Pobre $^{2}$ & $24^{\circ} \mathrm{C}$ & $52 \%$ & 1,00 & 0,69 & 8,20 & 1,78 & 18 & 181,4 & 270 \\
\hline (ii) - Médio ${ }^{1}$ & $23^{\circ} \mathrm{C}$ & $67 \%$ & 1,00 & 0,35 & 6,15 & 1,12 & 15 & 253,9 & 225 \\
\hline (ii) - Médio ${ }^{2}$ & $21^{\circ} \mathrm{C}$ & $76 \%$ & 1,00 & 0,35 & 6,15 & 1,35 & 18 & 240,2 & 290 \\
\hline (i) $-\mathrm{Rico}^{1}$ & $23^{\circ} \mathrm{C}$ & $67 \%$ & 1,00 & 0,17 & 4,10 & 0,84 & 16 & 356,6 & 239 \\
\hline (i) $-\mathrm{Rico}^{2}$ & $23^{\circ} \mathrm{C}$ & $53 \%$ & 1,00 & 0,17 & 4,10 & 0,87 & 16,5 & 353,3 & 270 \\
\hline
\end{tabular}

As propriedades físicas e mecânicas das argamassas avaliadas estão na Tabela 8.5. Os exemplares foram curados ao ar no ambiente do laboratório, sendo utilizados quatro exemplares para cada propriedade analisada. 
Tabela 8.5 - Propriedades físicas e mecânicas das argamassas avaliadas.

\begin{tabular}{|c|c|c|c|c|c|c|c|c|c|c|c|c|c|}
\hline \multirow{2}{*}{$\begin{array}{c}\text { Traço } \\
\text { BS } \\
5628 \\
(1992) \\
\end{array}$} & \multirow[b]{2}{*}{ Parâmetros } & \multirow{2}{*}{$\begin{array}{c}\text { Consumo } \\
\text { real de } \\
\text { cimento } \\
\left(\mathrm{kg} / \mathrm{m}^{3}\right)\end{array}$} & \multirow{2}{*}{$\begin{array}{c}\text { Massa } \\
\text { específica } \\
\text { fresca } \\
\left(\mathrm{kg} / \mathrm{dm}^{3}\right)\end{array}$} & \multicolumn{2}{|c|}{$\mathrm{f}_{\mathrm{c}}(\mathrm{MPa})$} & \multicolumn{2}{|c|}{$\left.\mathrm{f}_{\mathrm{t}} \mathrm{MPa}\right)$} & \multicolumn{2}{|c|}{$\mathrm{E}_{\mathrm{c}}(\mathrm{GPa})$} & \multirow[b]{2}{*}{$\begin{array}{c}\gamma_{\mathrm{s}} \\
\left(\mathrm{kg} / \mathrm{dm}^{3}\right)\end{array}$} & \multirow[b]{2}{*}{$\begin{array}{c}\gamma_{\text {ssd }} \\
\left(\mathrm{kg} / \mathrm{dm}^{3}\right)\end{array}$} & \multirow{2}{*}{$\begin{array}{l}\text { Abs } \\
(\%)\end{array}$} & \multirow[b]{2}{*}{$\begin{array}{l}I . V \\
(\%)\end{array}$} \\
\hline & & & & $7 d$ & 28d & $7 d$ & $28 d$ & $7 d$ & 28d & & & & \\
\hline \multirow{3}{*}{$\begin{array}{l}\text { (iii) - } \\
\text { Pobre }^{1}\end{array}$} & Média & 180,5 & 2,089 & 3,05 & 4,86 & 0,33 & 0,52 & 4,86 & 6,89 & 1,887 & 2,121 & 12,43 & 23,45 \\
\hline & $S_{d}$ & 1,59 & 0,018 & 0,13 & 0,36 & 0,04 & 0,11 & 0,46 & 0,19 & 0,016 & 0,017 & 0,16 & 0,29 \\
\hline & C.V (\%) & 0,88 & 0,88 & 4,17 & 7,43 & 12,36 & 20,54 & 9,45 & 2,73 & 0,84 & 0,79 & 1,31 & 1,22 \\
\hline \multirow{3}{*}{$\begin{array}{c}\text { (iii) - } \\
\text { Pobre }^{2}\end{array}$} & Média & 179,1 & 2,095 & 2,26 & 3,06 & 0,23 & 0,32 & 3,36 & 4,60 & 1,847 & 2,093 & 13,31 & 24,59 \\
\hline & $S_{d}$ & 1,79 & 0,028 & 0,18 & 0,33 & 0,03 & 0,03 & 0,66 & 0,42 & 0,015 & 0,009 & 0,42 & 0,58 \\
\hline & C.V (\%) & 1,00 & 1,36 & 7,88 & 10,78 & 13,61 & 8,10 & 19,74 & 9,17 & 0,80 & 0,43 & 3,14 & 2,35 \\
\hline \multirow{3}{*}{$\begin{array}{l}\text { (ii) - } \\
\text { Médio }^{1}\end{array}$} & Média & 246,2 & 2,122 & 7,05 & 10,19 & 0,89 & 1,17 & 10,13 & 11,95 & 1,944 & 2,148 & 10,50 & 20,42 \\
\hline & $\mathrm{S}_{\mathrm{d}}$ & 2,23 & 0,019 & 0,96 & 0,54 & 0,13 & 0,11 & 1,35 & 1,25 & 0,020 & 0,017 & 0,11 & 0,18 \\
\hline & C.V (\%) & 0,91 & 0,91 & 13,55 & 5,32 & 14,11 & 9,41 & 13,33 & 10,46 & 1,02 & 0,79 & 1,06 & 0,88 \\
\hline \multirow{3}{*}{$\begin{array}{c}\text { (ii) - } \\
\text { Médio }^{2}\end{array}$} & Média & 233,2 & 2,062 & 4,24 & 4,84 & 0,43 & 0,55 & 5,49 & 6,48 & 1,857 & 2,084 & 12,22 & 22,68 \\
\hline & $S_{d}$ & 3,05 & 0,027 & 0,41 & 0,52 & 0,04 & 0,03 & 0,65 & 0,58 & 0,009 & 0,008 & 0,16 & 0,23 \\
\hline & C.V (\%) & 1,31 & 1,31 & 9,62 & 10,74 & 9,67 & 5,19 & 11,87 & 8,91 & 0,46 & 0,37 & 1,31 & 1,02 \\
\hline \multirow{3}{*}{$\begin{array}{l}\text { (i) - } \\
\text { Rico }^{1}\end{array}$} & Média & 351,5 & 2,149 & 15,66 & 19,52 & 1,54 & 2,19 & 15,39 & 17,17 & 1,974 & 2,175 & 10,18 & 20,10 \\
\hline & $\mathrm{S}_{\mathrm{d}}$ & 3,48 & 0,021 & 0,92 & 0,96 & 0,28 & 0,09 & 1,32 & 1,48 & 0,016 & 0,015 & 0,19 & 0,26 \\
\hline & C.V (\%) & 0,99 & 0,99 & 5,90 & 4,89 & 18,34 & 3,93 & 8,55 & 8,59 & 0,82 & 0,69 & 1,86 & 1,31 \\
\hline \multirow{3}{*}{$\begin{array}{l}\text { (i) - } \\
\text { Rico }^{2}\end{array}$} & Média & 345,9 & 2,124 & 10,84 & 15,24 & 1,19 & 1,67 & 12,53 & 14,13 & 1,934 & 2,153 & 11,33 & 21,90 \\
\hline & $S_{d}$ & 3,53 & 0,022 & 0,59 & 0,82 & 0,13 & 0,10 & 0,55 & 0,64 & 0,007 & 0,005 & 0,25 & 0,43 \\
\hline & C.V (\%) & 1,02 & 1,02 & 5,43 & 5,40 & 10,72 & 5,96 & 4,38 & 4,53 & 0,35 & 0,22 & 2,20 & 1,94 \\
\hline
\end{tabular}

${ }^{1}$ consistência de acordo com a NBR 8798 (1985)

2 consistência requerida pelo pedreiro

Conforme os resultados do Capítulo 7, as unidades dos grupos 4,5, 8,0 e 12,0 apresentaram os seguintes valores médios de resistência à compressão aos 28 dias: 8,55 MPa, 12,02 MPa e 15,75 MPa, respectivamente. Analisando-se os resultados da Tabela 8.5, os valores de resistência à compressão da argamassa média variaram de 4,84 MPa a 10,19 MPa para as consistências de 290 mm e 225 mm, respectivamente. Na Tabela 8.6, é exposta a relação entre os valores de resistência à compressão das argamassas e a resistência à compressão das unidades.

Tabela 8.6 - Relação entre a resistência da argamassa e a resistência dos blocos obtidos experimentalmente.

\begin{tabular}{|c|c|c|c|c|c|}
\hline \multirow[t]{2}{*}{ Grupos } & \multirow{2}{*}{$\begin{array}{c}\text { Resistência média à } \\
\text { compressão das unidades } \\
\text { (MPa) }\end{array}$} & \multicolumn{2}{|c|}{$\begin{array}{c}\text { Resistência à compressão da } \\
\text { argamassa média }\end{array}$} & \multicolumn{2}{|c|}{$\begin{array}{c}\text { Relação entre os resultados } \\
\text { argamassa/unidade }\end{array}$} \\
\hline & & Consistência $^{1}$ & Consistência $^{2}$ & Consistência $^{1}$ & Consistência $^{2}$ \\
\hline 4,5 & 8,55 & \multirow{3}{*}{10,19} & \multirow{3}{*}{4,84} & 1,19 & 0,57 \\
\hline 8,0 & 12,02 & & & 0,85 & 0,40 \\
\hline 12,0 & 15,75 & & & 0,65 & 0,31 \\
\hline
\end{tabular}

1 consistência de acordo com a NBR 8798 (1985)

2 consistência requerida pelo pedreiro

Com base nesses resultados e em recomendações da literatura, será utilizada a argamassa média para a produção dos prismas e miniparedes, sendo a consistência definida pelo pedreiro. Hendry (2001) comenta que a resistência à compressão da argamassa não é um fator crítico; segundo ensaios conduzidos pelo referido pesquisador, diminuindo-se a resistência da argamassa em 50\% obteve-se uma redução de apenas 12,5\% na resistência da parede. Segundo Barbosa (2004), para acomodar as pequenas 
deformações da alvenaria, a argamassa deve ser menos rígida que os blocos e, consequentemente, menos resistente.

De acordo com Ramalho e Corrêa (2003), a resistência da argamassa é importante apenas quando inferior a $30 \%$ ou $40 \%$ da resistência do bloco. Os autores citam que argamassas com resistência de até $50 \%$ da resistência do bloco dificilmente afetam a resistência das paredes. Com base nos resultados obtidos e nas recomendações dos pesquisadores, é possível que a resistência da argamassa represente um fator limitante na produção dos prismas e miniparedes do grupo 12,0, uma vez que a relação entre os resultados (argamassas/unidades) foi de 0,31 a 0,45.

\subsubsection{PROPRIEDADES AVALIADAS}

As propriedades avaliadas para as argamassas encontram-se na Tabela 8.7.

Tabela 8.7 - Ensaios referentes à argamassa fresca e endurecida.

\begin{tabular}{ccc}
\hline Propriedade & $\begin{array}{c}\text { Propriedades avaliadas quando da } \\
\text { produção dos elementos }\end{array}$ & Norma \\
\hline Índice de Consistência & Prismas e miniparedes & NBR $7215(1996)$ \\
\hline $\begin{array}{c}\text { Absorção de água, massa específica e } \\
\text { índice de vazios }\end{array}$ & Prismas & NBR $9778(1987)$ \\
\hline Resistência à compressão axial & Prismas e miniparedes & NBR $5739(1984)$ \\
\hline Módulo de deformação & Prismas e miniparedes & NBR 8522 (1984) \\
\hline
\end{tabular}

(fonte: conforme citado na Tabela)

Para cada argamassa produzida, sua consistência foi determinada conforme a NBR 7215 (1991). Na produção dos prismas, foram moldados três corpos-prova; já na execução das miniparedes, foram moldados seis corpos-de-prova. Os corpos-de-prova foram dispostos no ambiente do laboratório até a data de ensaio do respectivo prisma ou miniparede. Para a regularização da superfície dos CPs foi utilizada pasta de enxofre. Os dispositivos e equipamentos utilizados no ensaio de compressão axial e módulo de deformação das argamassas encontram-se no Apêndice R. 


\subsection{PRISMAS}

Nos ensaios de resistência à compressão e módulo de deformação, optou-se por utilizar o prisma de três blocos pela razão entre sua altura e espessura ser superior a quatro. Drysdale e Hamid (1979, apud BARBOSA, 2004) ${ }^{31}$ e La Rovere e Rodrigues (1997) citam que prismas de dois blocos não são representativos de um ensaio uniaxial, devendo-se utilizar, no mínimo, prismas de três blocos para obtenção das propriedades de alvenaria à compressão. Segundo Capuzzo Neto (2004), para prismas de três blocos, a influência da restrição das placas de ensaio na resistência pode ser desprezada. Os procedimentos adotados para a execução dos prismas encontram-se no Apêndice S.

\subsubsection{DEFINIÇÃO DOS PRISMAS PRODUZIDOS}

Conforme já relatado, para a produção dos prismas foi utilizada a argamassa média da BS 5628: Part 1 (1992). Para cada traço avaliado no Capítulo 7, foram produzidos três prismas. Apenas as unidades B4,5-RMV-33\% e B4,5-RMB-33\%, que não apresentaram desempenho satisfatório com relação às propriedades físicas e mecânicas, não foram utilizadas na fabricação dos prismas. A terminologia adotada para cada prisma é apresentada na Tabela 8.8.

31 DRYSDALE, R. G.; HAMID, A. A. (1979). Behavior of concrete block masonry under axial compression. ACl Journal, v.76, n.6, p.707-721, june. 
Tabela 8.8 - Terminologia adotada para os prismas.

\begin{tabular}{|c|c|c|}
\hline $\begin{array}{l}\text { GRUPO/CLASSE } \\
\text { DE RESISTÊNCIA } \\
\text { DAS UNIDADES }\end{array}$ & DESIGNAÇÃO & CARACTERÍSTICAS \\
\hline \multirow{4}{*}{4,5} & PR4,5-REF & Prismas compostos por unidades produzidas com agregados naturais \\
\hline & PR4,5-RGV-100\% & $\begin{array}{l}\text { Prismas compostos por unidades com } 100 \% \text { de substituição, em } \\
\text { massa, da fração graúda natural (pedrisco) por agregado graúdo } \\
\text { reciclado de vigota (GRv) }\end{array}$ \\
\hline & PR4,5-RGV-50\% & $\begin{array}{l}\text { Prismas compostos por unidades com } 50 \% \text { de substituição, em massa, } \\
\text { da fração graúda natural por agregado graúdo reciclado de vigota (GRv) }\end{array}$ \\
\hline & PR4,5-RGB-50\% & $\begin{array}{l}\text { Prismas compostos por unidades com aproximadamente } 50 \% \text { de } \\
\text { substituição, em massa, da fração graúda natural por agregado graúdo } \\
\text { reciclado de bloco (GRb) }\end{array}$ \\
\hline \multirow{6}{*}{8,0} & PR8,0-REF & Prismas compostos por unidades produzidas com agregados naturais \\
\hline & PR8,0-RGV-100\% & $\begin{array}{l}\text { Prismas compostos por unidades com } 100 \% \text { de substituição, em } \\
\text { massa, da fração graúda natural (pedrisco) por agregado graúdo } \\
\text { reciclado de vigota (GRv) }\end{array}$ \\
\hline & PR8,0-RGV-50\% & $\begin{array}{l}\text { Prismas compostos por unidades com } 50 \% \text { de substituição, em massa, } \\
\text { da fração graúda natural por agregado graúdo reciclado de vigota (GRv) }\end{array}$ \\
\hline & PR8,0-RMV-33\% & $\begin{array}{c}\text { Prismas compostos por unidades com } 33 \% \text { de substituição, em massa, } \\
\text { do pó de pedra por agregado miúdo reciclado de vigota (MRv) }\end{array}$ \\
\hline & PR8,0-RGB-50\% & $\begin{array}{l}\text { Prismas compostos por unidades com } 50 \% \text { de substituição, em massa, } \\
\text { da fração graúda natural por agregado graúdo reciclado de bloco (GRb) }\end{array}$ \\
\hline & PR8,0-RMB-33\% & $\begin{array}{l}\text { Prismas compostos por unidades com 33\% de substituição, em massa, } \\
\text { do pó de pedra por agregado miúdo reciclado de bloco (MRb) }\end{array}$ \\
\hline \multirow{6}{*}{12,0} & PR12,0-REF & Dosagem de referência produzida inteiramente com materiais naturais \\
\hline & PR12,0-RGV-100\% & $\begin{array}{l}\text { Prismas compostos por unidades com 100\% de substituição, em } \\
\text { massa, da fração graúda natural (pedrisco) por agregado graúdo } \\
\text { reciclado de vigota (GRv) }\end{array}$ \\
\hline & PR12,0-RGV-50\% & $\begin{array}{l}\text { Prismas compostos por unidades com } 50 \% \text { de substituição, em massa, } \\
\text { da fração graúda natural por agregado graúdo reciclado de vigota (GRv) }\end{array}$ \\
\hline & PR12,0-RMV-33\% & $\begin{array}{l}\text { Prismas compostos por unidades com } 33 \% \text { de substituição, em massa, } \\
\text { do pó de pedra por agregado miúdo reciclado de vigota (MRv) }\end{array}$ \\
\hline & PR12,0-RGB-50\% & $\begin{array}{l}\text { Prismas compostos por unidades com } 50 \% \text { de substituição, em massa, } \\
\text { da fração graúda natural por agregado graúdo reciclado de bloco (GRb) }\end{array}$ \\
\hline & PR12,0-RMB-33\% & $\begin{array}{l}\text { Prismas compostos por unidades com } 33 \% \text { de substituição, em massa, } \\
\text { do pó de pedra por agregado miúdo reciclado de bloco (MRb) }\end{array}$ \\
\hline
\end{tabular}

O estudo desses diferentes prismas objetivou esclarecer os seguintes pontos: a) se a incorporação de agregados reciclados influencia na resistência à compressão e módulo de deformação comparativamente aos prismas de referência; b) avaliação do mecanismo de ruptura dos prismas compostos por unidades com agregados reciclados em comparação aos prismas de referência; c) avaliação do comportamento mecânico de prismas de diferentes classes de resistência $(4,5 ; 8,0 ; 12,0)$ executados com a mesma argamassa. As propriedades físicas e mecânicas das argamassas e dos prismas serão apresentadas nos itens subseqüentes.

\subsubsection{PROPRIEDADES AVALIADAS E INSTRUMENTAÇÃO ADOTADA}

As propriedades avaliadas para os prismas foram: resistência à compressão e módulo de deformação. O módulo de deformação foi calculado de acordo com as prescrições do ACI 530-92 (1995); segundo essa norma, o módulo é dado pela inclinação da reta secante no diagrama tensão versus deformação, entre 5\% e 33\% da tensão de ruptura. 
A instrumentação consistiu de quatro extensômetros removíveis de base de medida igual a $20 \mathrm{~mm}$ e resolução de $0,001 \mathrm{~mm}$; esses extensômetros foram posicionados exatamente na região central da cavidade da unidade, sendo determinados os deslocamentos relativos entre o primeiro e o último blocos, Figura 8.2. A velocidade de imposição de deslocamento foi de $0,005 \mathrm{~mm} / \mathrm{s}$, sendo as leituras e o armazenamento de dados realizados pelo sistema de aquisição SYSTEM 5000.
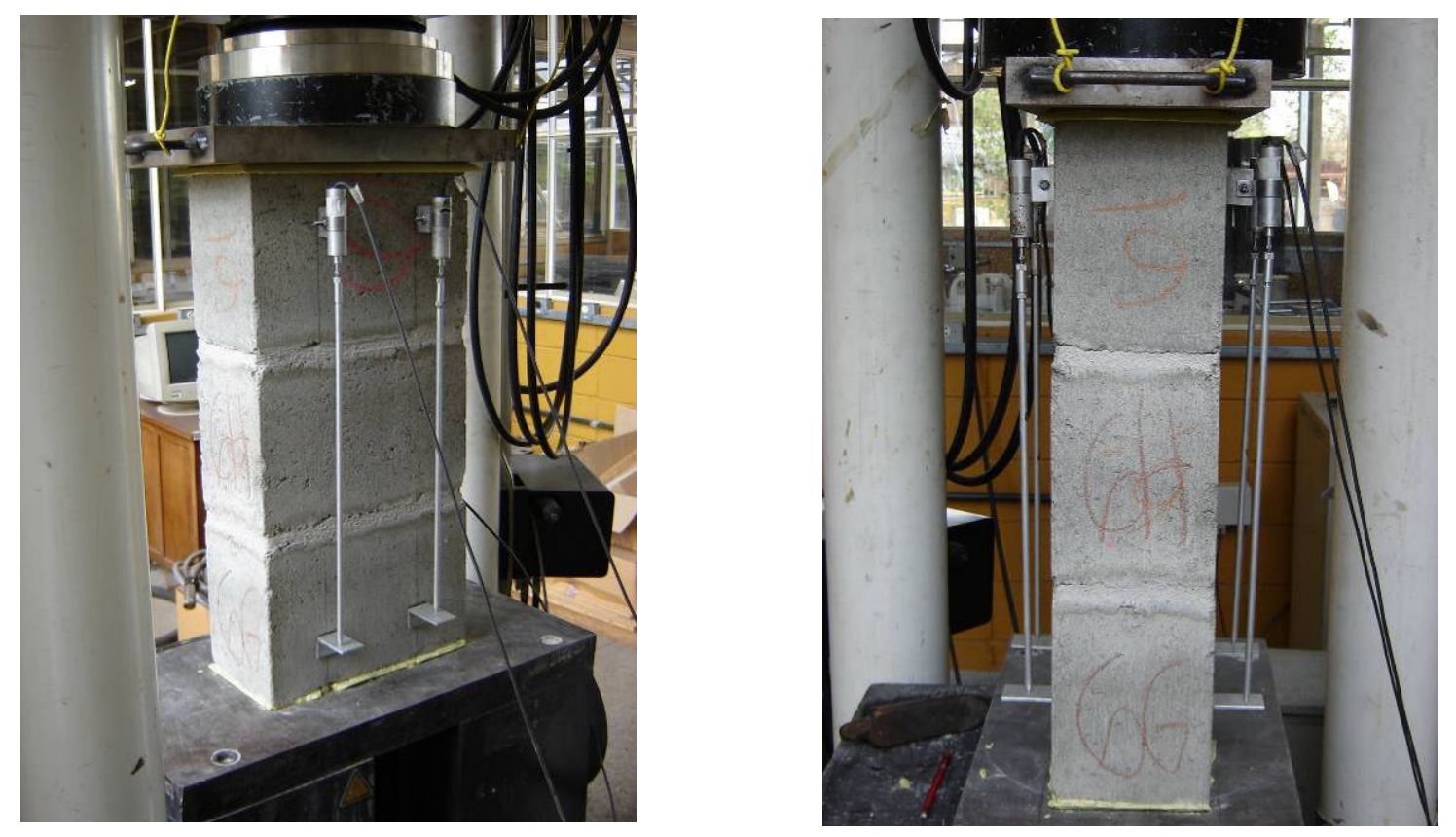

Figura 8.2 - Posicionamento dos extensômetros removíveis no ensaio de prismas.

As cantoneiras foram fixadas usando-se cola à base de epóxi. Na parte superior dos prismas foi disposta uma placa de aço de espessura de $35 \mathrm{~mm}$ para distribuição uniforme do carregamento. Os prismas foram ensaiados entre o $39^{\circ}$ e o $52^{\circ}$ dia, juntamente com os CPs de argamassa e os blocos de concreto. As unidades de concreto foram ensaiadas na prensa hidráulica da marca ELE e modelo Autotest 2000; a velocidade de imposição de carregamento foi de $2,03 \mathrm{kN} / \mathrm{s}$, com a disposição de placas de aço de $35 \mathrm{~mm}$ nas faces superior e inferior dos blocos.

\subsection{MINIPAREDES}

Nos ensaios de resistência à compressão e módulo de deformação, optou-se pelas miniparedes de três fiadas $(60 \times 60) \mathrm{cm}$. De acordo com Capuzzo Neto (2004), o termo 
miniparede serve para designar corpos-de-prova de parede. Casali (2003) cita que os ensaios de miniparedes e prismas são os mais utilizados no meio técnico, pois podem ser facilmente executados em qualquer laboratório que possua uma prensa de média capacidade. Os procedimentos adotados para a execução das miniparedes encontram-se no Apêndice $T$.

\subsubsection{DEFINIÇÃO DAS MINIPAREDES PRODUZIDAS}

Conforme já relatado, foram produzidos nove tipos de meio-blocos. Com essas unidades foram executados nove tipos de miniparedes. A redução do número de elementos, comparativamente aos prismas, pode ser justificada pela possibilidade de extrapolação dos resultados dos prismas com objetivo de prever o comportamento das miniparedes de blocos de concreto. A terminologia adotadas são apresentadas na Tabela 8.9.

Tabela 8.9 - Terminologia adotada para as miniparedes.

\begin{tabular}{|c|c|c|}
\hline $\begin{array}{l}\text { GRUPOICLASSE } \\
\text { DE RESISTÊNCIA } \\
\text { DAS UNIDADES }\end{array}$ & DESIGNAÇÃO & CARACTERÍSTICAS \\
\hline \multirow{3}{*}{4,5} & PAR4,5-REF & $\begin{array}{l}\text { Miniparedes compostas por unidades produzidas com agregados } \\
\text { naturais }\end{array}$ \\
\hline & PAR4,5-RGV-100\% & $\begin{array}{c}\text { Miniparedes compostas por unidades com 100\% de substituição, em } \\
\text { massa, da fração graúda natural (pedrisco) por agregado graúdo } \\
\text { reciclado de vigota (GRv) }\end{array}$ \\
\hline & PAR4,5-RGB-50\% & $\begin{array}{c}\text { Miniparedes compostas por unidades com aproximadamente } 50 \% \text { de } \\
\text { substituição, em massa, da fração graúda natural por agregado graúdo } \\
\text { reciclado de bloco (GRb) }\end{array}$ \\
\hline \multirow{3}{*}{8,0} & PAR8,0-REF & $\begin{array}{l}\text { Miniparedes compostas por unidades produzidas com agregados } \\
\text { naturais }\end{array}$ \\
\hline & PAR8,0-RGV-100\% & $\begin{array}{c}\text { Miniparedes compostas por unidades com } 100 \% \text { de substituição, em } \\
\text { massa, da fração graúda natural (pedrisco) por agregado graúdo } \\
\text { reciclado de vigota (GRv) }\end{array}$ \\
\hline & PAR8,0-RGB-50\% & $\begin{array}{c}\text { Miniparedes compostas por unidades com } 50 \% \text { de substituição, em } \\
\text { massa, da fração graúda natural por agregado graúdo reciclado de } \\
\text { bloco (GRb) }\end{array}$ \\
\hline \multirow{3}{*}{12,0} & PAR12,0-REF & $\begin{array}{l}\text { Miniparedes compostas por unidades produzidas com agregados } \\
\text { naturais }\end{array}$ \\
\hline & PAR12,0-RGV-100\% & $\begin{array}{l}\text { Miniparedes compostas por unidades com } 100 \% \text { de substituição, em } \\
\text { massa, da fração graúda natural (pedrisco) por agregado graúdo } \\
\text { reciclado de vigota (GRv) }\end{array}$ \\
\hline & PAR12,0-RGB-50\% & $\begin{array}{l}\text { Miniparedes compostas por unidades com } 50 \% \text { de substituição, em } \\
\text { massa, da fração graúda natural por agregado graúdo reciclado de } \\
\text { bloco (GRb) }\end{array}$ \\
\hline
\end{tabular}

O estudo de nove tipos diferentes de miniparedes objetivou esclarecer os seguintes pontos: a) se a incorporação de agregados reciclados de vigota e bloco influencia a resistência à compressão e módulo de deformação comparativamente às miniparedes de referência; b) avaliação do mecanismo de ruptura das miniparedes compostas por unidades com agregados reciclados em relação às miniparedes de referência; c) avaliação do comportamento mecânico de miniparedes de diferentes classes de resistência $(4,5 ; 8,0$; $12,0)$ executadas com a mesma argamassa. 


\subsubsection{PROPRIEDADES AVALIADAS E INSTRUMENTAÇÃO ADOTADA}

As propriedades avaliadas para as miniparedes foram as mesmas avaliadas para os prismas: resistência à compressão e módulo de deformação. O módulo de deformação foi calculado de acordo com as prescrições do ACl 530-92 (1995); segundo essa norma, o módulo é dado pela inclinação da reta secante no diagrama tensão versus deformação, entre $5 \%$ e $33 \%$ da tensão de ruptura.

A instrumentação consistiu de quatro extensômetros removíveis de base de medida igual a $20 \mathrm{~mm}$ e resolução de $0,001 \mathrm{~mm}$; esses extensômetros foram posicionados exatamente nas regiões centrais das cavidades das unidades, sendo determinados os deslocamentos relativos entre a primeira e a última fiadas da miniparede, Figura 8.3. A velocidade de imposição de deslocamento foi de $0,005 \mathrm{~mm} / \mathrm{s}$, sendo as leituras e o armazenamento de dados realizados pelo sistema de aquisição SYSTEM 5000.
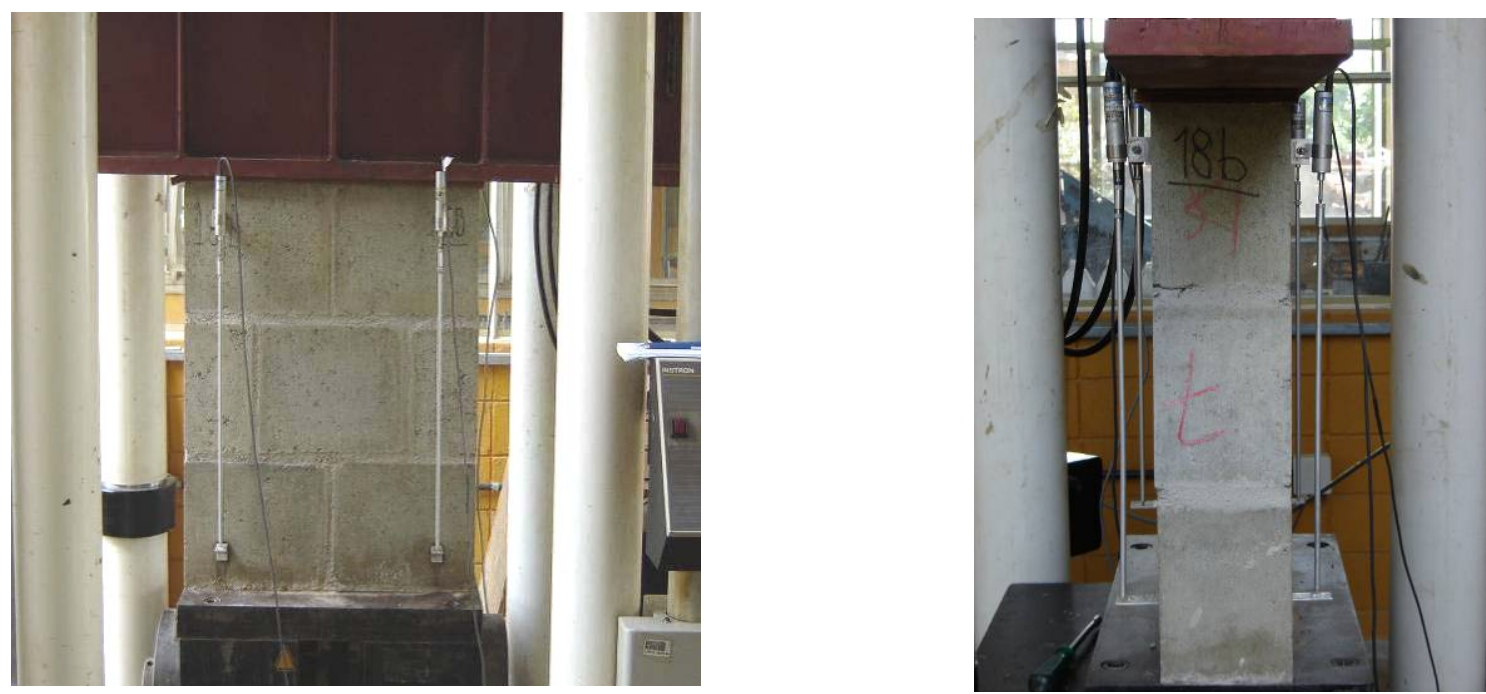

Figura 8.3 - Posicionamento dos extensômetros removíveis no ensaio de miniparedes.

As cantoneiras foram fixadas com auxílio de cola à base de epóxi. Na parte superior das miniparedes foi colocado um perfil "I" de 1,50 m de extensão, enrijecido com cinco nervuras ao longo do seu comprimento, Figura 8.4. 

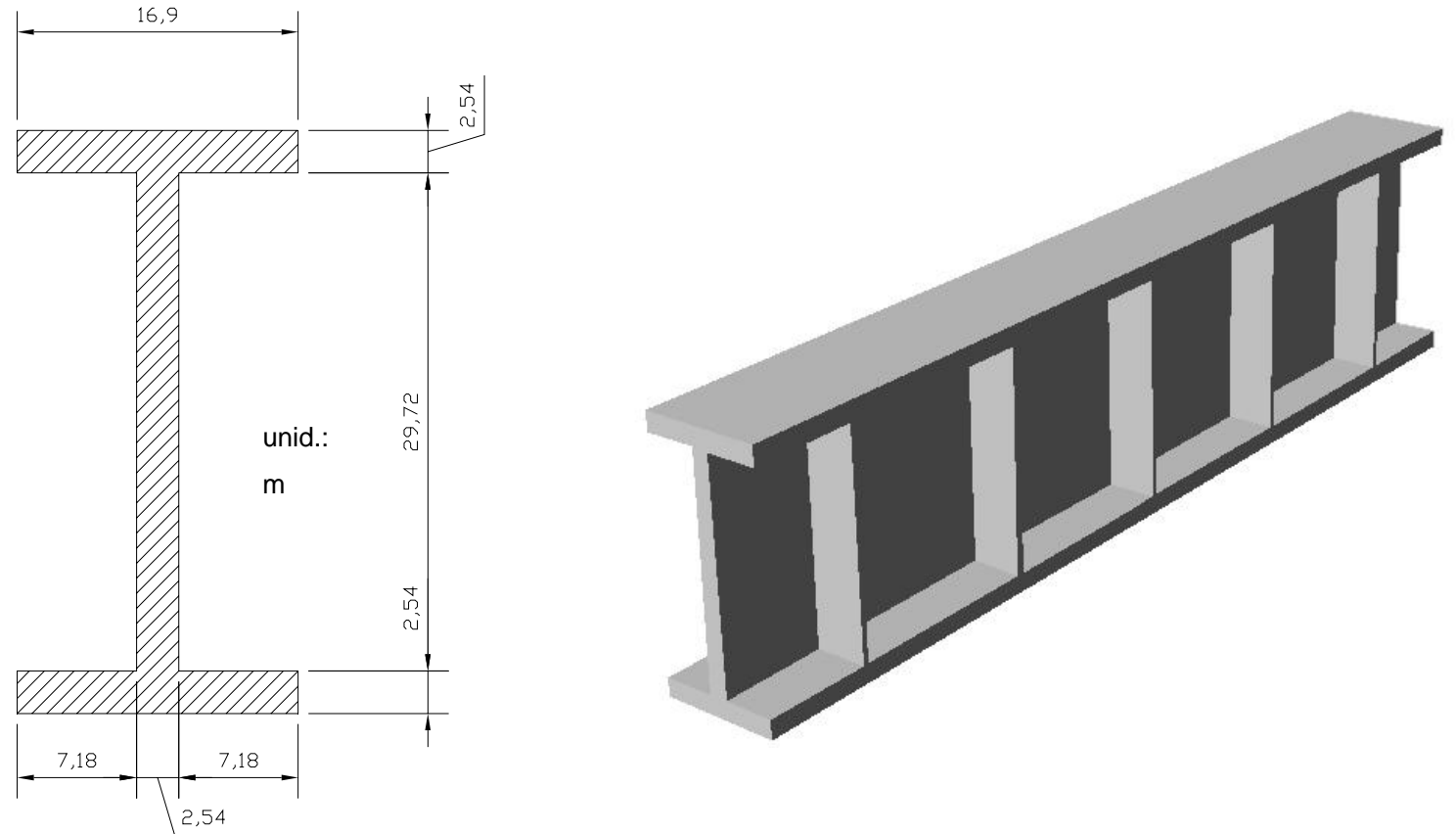

Figura 8.4 - Perfil "I" utilizado para distribuição uniforme do carregamento.

Além do capeamento das faces inferior e superior das miniparedes, foram dispostas duas placas de forro-pacote de $1,1 \mathrm{~cm}$ na sua base e topo, com a finalidade de evitar possíveis concentrações de tensões. A configuração típica dos ensaios de miniparedes é mostrada na Figura 8.5. As miniparedes foram ensaiadas entre o $35^{\circ}$ e o $43^{\circ}$ dias, juntamente com os CPs de argamassa. 


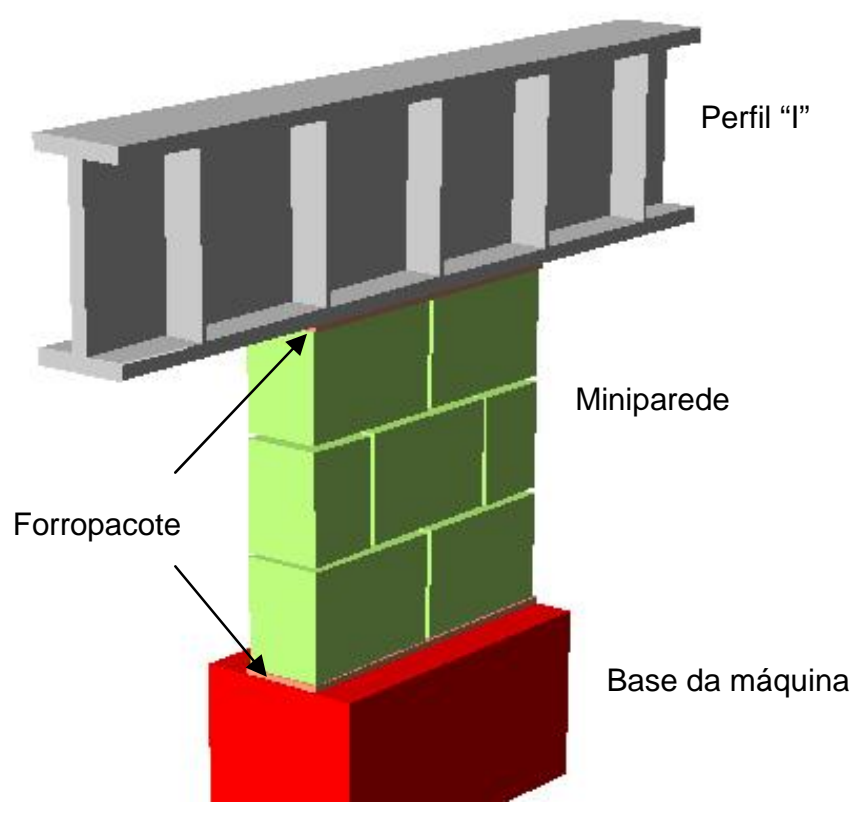

Figura 8.5 - Configuração típica dos ensaios de miniparede.

\subsection{RESULTADOS E ANÁLISES - PRISMAS}

Com o intuito de facilitar a compreensão, os resultados são apresentados separadamente para cada grupo de prisma avaliado (Grupo 4,5; Grupo 8,0; Grupo 12,0). Para a análise e comparação dos resultados obtidos, é utilizado o teste estatístico de análise de variância. No Apêndice $U$, são apresentados alguns gráficos típicos de curvas tensão x deformação dos prismas dos Grupos 4,5, 8,0 e 12,0. As principais características das dosagens de argamassa são apresentadas no item 8.4.1.

\subsubsection{CARACTERÍSTICAS DAS ARGAMASSAS}

$\mathrm{Na}$ Tabela 8.10, encontra-se as características das argamassas utilizadas para a execução dos prismas. 
Tabela 8.10 - Características das argamassas utilizadas para o assentamento das unidades.

\begin{tabular}{|c|c|c|c|c|c|c|c|c|c|c|c|c|}
\hline \multirow{2}{*}{ Desig. } & \multirow{2}{*}{ Prismas produzidos } & \multirow{2}{*}{$\begin{array}{l}\text { Quant. } \\
\text { Prismas }\end{array}$} & \multirow{2}{*}{ Data } & \multirow{2}{*}{$\begin{array}{l}\text { Horário de } \\
\text { moldagem }\end{array}$} & \multirow{2}{*}{$\begin{array}{c}\mathrm{T} \\
\left({ }^{\circ} \mathrm{C}\right)\end{array}$} & \multirow{2}{*}{$\underset{(\%)}{\cup}$} & \multicolumn{4}{|c|}{ Consumo de materiais $\left(\mathrm{kg} / \mathrm{m}^{3}\right)$} & \multirow{2}{*}{$\begin{array}{l}\text { Cons. } \\
(\mathrm{mm})\end{array}$} & \multirow{2}{*}{$\begin{array}{c}\mathrm{N}^{\circ} \mathrm{CPs} \\
\text { fabricados }\end{array}$} \\
\hline & & & & & & & Cimento & Areia & Cal & Água & & \\
\hline \multirow{4}{*}{$\operatorname{Arg} . A$} & PR8,0-RGV-50\% & 3 & \multirow{4}{*}{$13 / 12$} & \multirow{4}{*}{ 9:00 } & \multirow{4}{*}{22,4} & \multirow{4}{*}{71,2} & \multirow{4}{*}{245,7} & \multirow{4}{*}{1513,6} & \multirow{4}{*}{85,5} & \multirow{4}{*}{317,5} & \multirow{4}{*}{276} & 3 \\
\hline & PR12,0-REF & 3 & & & & & & & & & & 3 \\
\hline & PR12,0-RGV-50\% & 3 & & & & & & & & & & 3 \\
\hline & PR12,0-RGV-100\% & 1 & & & & & & & & & & 1 \\
\hline \multirow{4}{*}{ Arg. B } & PR8,0-RGB-50\% & 2 & \multirow{4}{*}{$13 / 12$} & \multirow{4}{*}{$10: 25$} & \multirow{4}{*}{24,5} & \multirow{4}{*}{66,5} & \multirow{4}{*}{245,7} & \multirow{4}{*}{1513,4} & \multirow{4}{*}{85,5} & \multirow{4}{*}{317,6} & \multirow{4}{*}{255} & 2 \\
\hline & PR8,0-RMB-33\% & 3 & & & & & & & & & & 3 \\
\hline & PR12,0-RGV-100\% & 2 & & & & & & & & & & 2 \\
\hline & PR12,0-RGB-50\% & 3 & & & & & & & & & & 3 \\
\hline \multirow{5}{*}{ Arg. C } & PR4,5-RGB-50\% & 3 & & & & & & & & & & 3 \\
\hline & PR8,0-RGB-50\% & 1 & & & & & & & & & & 1 \\
\hline & PR8,0-RMV-33\% & 1 & $14 / 12$ & $14: 00$ & 28,2 & 56,5 & 242,7 & 1503,8 & 83,0 & 323,1 & 268 & 1 \\
\hline & PR12,0-RMV-33\% & 3 & & & & & & & & & & 3 \\
\hline & PR12,0-RMB-33\% & 2 & & & & & & & & & & 2 \\
\hline & PR4,5-REF & 2 & & & & & & & & & & 2 \\
\hline & PR4,5-RGV-50\% & 2 & & & & & & & & & & 2 \\
\hline Arg. D & PR4,5-RGV-100\% & 3 & $15 / 12$ & $9: 40$ & 24,3 & 70,3 & 245,4 & 1520,7 & 83,9 & 315,4 & 274 & 3 \\
\hline & PR8,0-RMV-33\% & 2 & & & & & & & & & & 2 \\
\hline & PR12,0-RMB-33\% & 1 & & & & & & & & & & 1 \\
\hline & PR4,5-REF & 1 & & & & & & & & & & 1 \\
\hline $\operatorname{Arg} \mathrm{F}$ & PR4,5-RGV-50\% & 1 & 1512 & 11.00 & 260 & 643 & 2451 & 15095 & 852 & 3193 & 267 & 1 \\
\hline (ning. & PR8,0-REF & 3 & 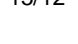 & 11.00 & 20,0 & 04,0 & 240,1 & U, & 0,2 & & 20 & 3 \\
\hline & PR8,0-RGV-100\% & 3 & & & & & & & & & & 3 \\
\hline
\end{tabular}

Pela Tabela 8.10, nota-se que do total de prismas produzidos, seis foram executados com argamassas de diferentes massadas; apesar disso, as argamassas ( $A, B, C, D$ e E) apresentaram características similares quanto ao consumo de materiais e consistência. Dessa forma, presume-se que as propriedades mecânicas dos prismas da mesma série (PR12,0-RGV-100\%, por exemplo), produzidos com argamassas de diferentes massadas, não apresentem diferenças significativas.

\subsubsection{GRUPO 4,5}

A terminologia adotada são apresentadas na Tabela 8.11.

Tabela 8.11 - Terminologia adotada para o Grupo 4,5.

\begin{tabular}{|c|c|c|c|}
\hline $\begin{array}{l}\text { GRUPO/CLASSE } \\
\text { DE RESISTÊNCIA } \\
\text { DAS UNIDADES }\end{array}$ & DESIGNAÇÃO & CARACTERÍSTICAS & $\begin{array}{l}\text { ARGAMASSA DE } \\
\text { ASSENTAMENTO }\end{array}$ \\
\hline \multirow{4}{*}{4,5} & PR4,5-REF & $\begin{array}{c}\text { Prismas compostos por unidades produzidas com } \\
\text { agregados naturais }\end{array}$ & De E \\
\hline & PR4,5-RGV-100\% & $\begin{array}{l}\text { Prismas compostos por unidades com } 100 \% \text { de } \\
\text { substituição, em massa, da fração graúda natural (pedrisco) } \\
\text { por agregado graúdo reciclado de vigota (GRv) }\end{array}$ & D \\
\hline & PR4,5-RGV-50\% & $\begin{array}{l}\text { Prismas compostos por unidades com } 50 \% \text { de substituição, } \\
\text { em massa, da fração graúda natural por agregado graúdo } \\
\text { reciclado de vigota (GRv) }\end{array}$ & $D$ e $E$ \\
\hline & PR4,5-RGB-50\% & $\begin{array}{l}\text { Prismas compostos por unidades com aproximadamente } \\
50 \% \text { de substituição, em massa, da fração graúda natural } \\
\text { por agregado graúdo reciclado de bloco (GRb) }\end{array}$ & C \\
\hline
\end{tabular}


Os resultados de resistência à compressão dos prismas e dos blocos ensaiados são apresentados na Tabela 8.12. Nessa tabela, também são expostos os fatores de eficiência (prisma/bloco).

Tabela 8.12 - Valores de resistência à compressão dos prismas e das unidades do Grupo 4,5 .

\begin{tabular}{|c|c|c|c|c|c|c|c|c|c|c|c|}
\hline \multirow[b]{2}{*}{ Prisma } & \multirow[b]{2}{*}{ Parâmetros } & \multicolumn{4}{|c|}{ Prismas } & \multicolumn{5}{|c|}{ Blocos } & \multirow{2}{*}{$\begin{array}{c}\text { Fator de } \\
\text { eficiência } \\
\text { (Prisma/bloco) }\end{array}$} \\
\hline & & $\begin{array}{l}\text { Idade } \\
\text { (dias) }\end{array}$ & $\begin{array}{l}\text { Força } \\
\text { (kN) }\end{array}$ & $\begin{array}{c}\text { Tensão } \\
\text { (MPa) }\end{array}$ & $\begin{array}{l}\text { Tensão } \\
\text { área } \\
\text { líquida } \\
\text { (MPa) }\end{array}$ & $\begin{array}{c}\text { Massa } \\
\text { (g) }\end{array}$ & Idade & $\begin{array}{l}\text { Força } \\
(\mathbf{k N})\end{array}$ & $\begin{array}{c}\text { Tensão } \\
\text { (MPa) }\end{array}$ & $\begin{array}{c}\text { Tensão } \\
\text { área } \\
\text { líquida } \\
\text { (MPa) }\end{array}$ & \\
\hline \multirow{5}{*}{ PR4,5-REF } & Média & \multirow{5}{*}{47} & 291 & 7,16 & 12,18 & 10700 & \multirow{5}{*}{103} & 618 & 15,23 & 25,91 & \multirow{5}{*}{0,470} \\
\hline & Máximo & & 300 & 7,38 & 12,56 & 10700 & & 634 & 15,62 & 26,57 & \\
\hline & Mínimo & & 279 & 6,87 & 11,69 & 10700 & & 606 & 14,92 & 25,37 & \\
\hline & $S_{d}$ & & 11 & 0,26 & 0,45 & 0,00 & & 15 & 0,36 & 0,61 & \\
\hline & C.V (\%) & & 3,67 & 3,67 & 3,67 & 0,00 & & 2,35 & 2,35 & 2,35 & \\
\hline \multirow{5}{*}{$\begin{array}{c}\text { PR4,5- } \\
\text { RGV-100\% }\end{array}$} & Média & \multirow{5}{*}{47} & 287 & 7,06 & 12,02 & 9883 & \multirow{5}{*}{134} & 404 & 9,94 & 16,90 & \multirow{5}{*}{0,711} \\
\hline & Máximo & & 305 & 7,52 & 12,79 & 9950 & & 439 & 10,81 & 18,38 & \\
\hline & Mínimo & & 270 & 6,66 & 11,32 & 9750 & & 378 & 9,31 & 15,84 & \\
\hline & $\mathrm{S}_{\mathrm{d}}$ & & 18 & 0,43 & 0,74 & 116 & & 32 & 0,78 & 1,32 & \\
\hline & C.V (\%) & & 6,13 & 6,13 & 6,13 & 1,17 & & 7,82 & 7,82 & 7,82 & \\
\hline \multirow{5}{*}{$\begin{array}{l}\text { PR4,5- } \\
\text { RGV-50\% }\end{array}$} & Média & \multirow{5}{*}{47} & 228 & 5,61 & 9,53 & 9975 & \multirow{5}{*}{134} & 351 & 8,65 & 14,68 & \multirow{5}{*}{0,649} \\
\hline & Máximo & & 252 & 6,20 & 10,53 & 10000 & & 376 & 9,26 & 15,72 & \\
\hline & Mínimo & & 214 & 5,28 & 8,97 & 9950 & & 326 & 8,04 & 13,65 & \\
\hline & $\mathrm{S}_{\mathrm{d}}$ & & 21 & 0,51 & 0,87 & 35 & & 35 & 0,86 & 1,46 & \\
\hline & C.V (\%) & & 9,08 & 9,08 & 9,08 & 0,35 & & 9,95 & 9,95 & 9,95 & \\
\hline \multirow{5}{*}{$\begin{array}{l}\text { PR4,5- } \\
\text { RGB-50\% }\end{array}$} & Média & \multirow{5}{*}{49} & 254 & 6,25 & 10,58 & 10283 & \multirow{5}{*}{134} & 379 & 9,33 & 15,78 & \multirow{5}{*}{0,670} \\
\hline & Máximo & & 258 & 6,36 & 10,77 & 10500 & & 416 & 10,25 & 17,35 & \\
\hline & Mínimo & & 251 & 6,18 & 10,46 & 10150 & & 342 & 8,41 & 14,23 & \\
\hline & $\mathrm{S}_{\mathrm{d}}$ & & 4 & 0,10 & 0,17 & 189 & & 37 & 0,92 & 1,56 & \\
\hline & C.V (\%) & & 1,58 & 1,58 & 1,58 & 1,84 & & 9,88 & 9,88 & 9,88 & \\
\hline \multicolumn{3}{|c|}{ Média geral do Grupo 4,5 } & 265 & 6,52 & 11,08 & & & 438 & 10,79 & 18,32 & 0,625 \\
\hline
\end{tabular}

Analisando-se os resultados da Tabela 8.12, observa-se que os prismas compostos por unidades com agregados reciclados apresentaram uma redução média de 12\% na resistência à compressão comparativamente aos prismas de referência; já considerando-se a resistência à compressão das unidades, a redução foi superior a 39\% (blocos reciclados em comparação com o referência). Com relação ao fator de eficiência ( $f_{\text {prisma }} / f_{\text {bloco }}$ ), o valor médio obtido foi igual a 0,625. Freitas (2006) obteve, para prismas de três blocos de concreto $\left(f_{\text {bloco }}=9,08 \mathrm{MPa}\right)$, assentados com as argamassas média ( $\left.f_{\text {arg }}=6,02 \mathrm{MPa}\right)$ e fraca $\left(f_{\text {arg }}=4,70 \mathrm{MPa}\right)$, fatores de eficiência iguais a 0,74 e 0,70, respectivamente. Juste (2001) obteve, para prismas de três blocos de concreto ( $\mathrm{f}_{\text {bloco }}=10,80 \mathrm{MPa}$ ), assentados com argamassa média, valores de eficiência próximos a 0,70. Ramalho e Corrêa (2003) citam que, para blocos vazados de concreto, a eficiência varia de 0,50 a 0,90 considerando-se argamassas usuais. 
Os resultados de módulo de deformação dos prismas são apresentados na Tabela 8.13.

Tabela 8.13 - Resultados de módulo de deformação dos prismas do Grupo 4,5.

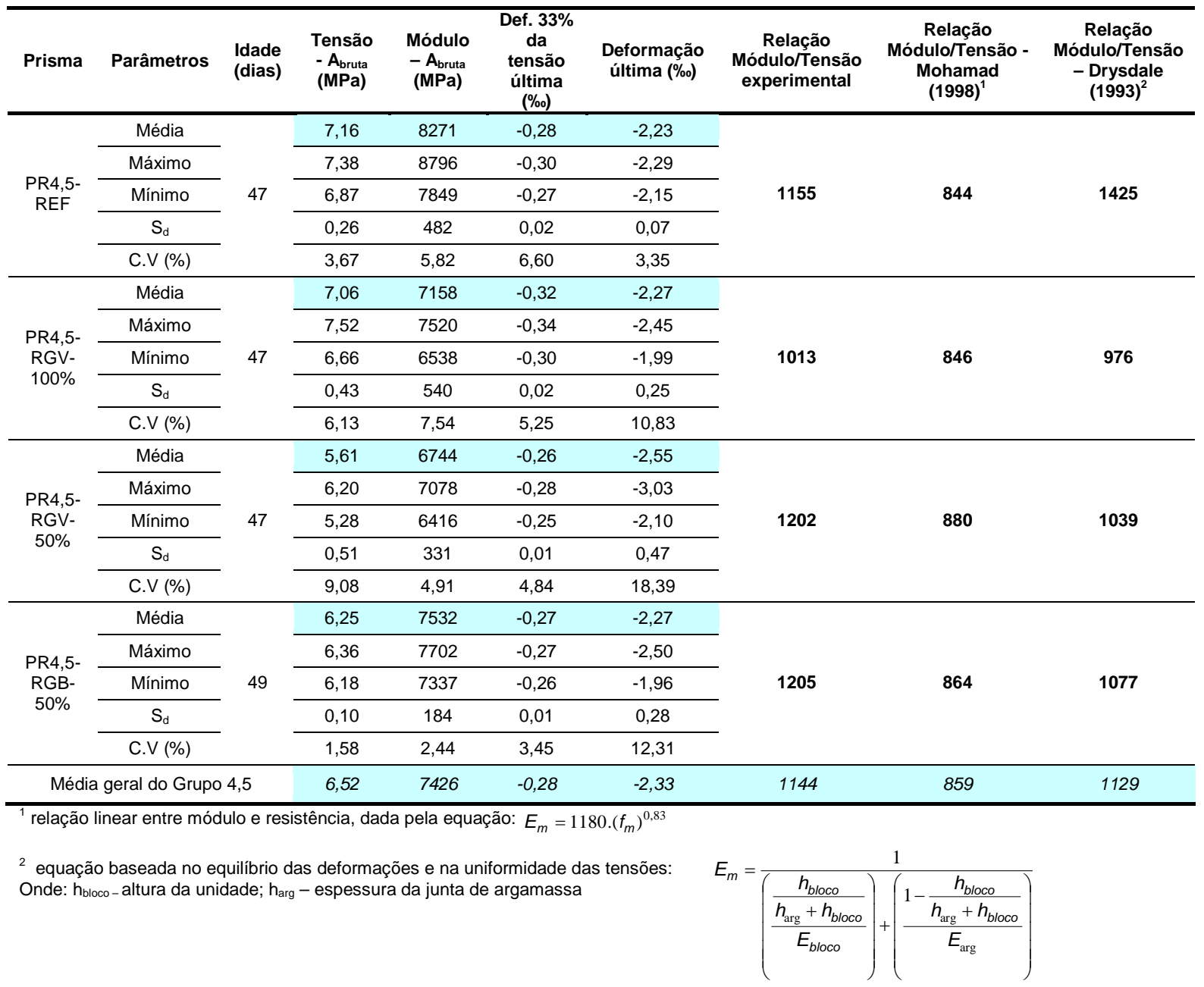

Analisando-se os resultados da Tabela 8.13, nota-se que houve uma redução média de $14 \%$ no módulo de deformação dos prismas compostos por unidades com agregados reciclados comparativamente aos prismas de referência. Esse comportamento pode ser explicado pela menor resistência dos blocos reciclados (40\%) e do menor módulo de deformação dessas unidades (37\%) comparativamente às unidades de referência.

Comparando-se os resultados obtidos com os valores teóricos, observa-se que apenas a expressão proposta por Drysdale et al. (1994), forneceu valores de módulo e razão entre módulo e resistência à compressão próximos dos valores obtidos experimentalmente. A expressão de Mohamad (1998) forneceu valores inferiores aos obtidos experimentalmente. 
Os resultados das propriedades físicas e mecânicas dos CPs de argamassa do grupo 4,5 encontram-se na Tabela 8.14.

Tabela 8.14 - Resultados das propriedades físicas e mecânicas dos CPs de argamassa do Grupo 4,5.

\begin{tabular}{|c|c|c|c|c|c|c|c|c|c|c|c|c|c|c|}
\hline \multirow[b]{2}{*}{ Prisma } & \multirow[b]{2}{*}{$\begin{array}{l}\text { Desig } \\
\text { Arg. }\end{array}$} & \multirow[b]{2}{*}{ Parâm. } & \multirow[b]{2}{*}{ Idade } & \multirow{2}{*}{$\begin{array}{c}\text { Massa } \\
\text { dos } \\
\text { CPs }\end{array}$} & \multicolumn{5}{|c|}{ Propriedades Mecânicas } & \multicolumn{5}{|c|}{ Propriedades físicas } \\
\hline & & & & & $\begin{array}{c}\begin{array}{c}\text { Força } \\
\text { última } \\
(\mathrm{kgf})\end{array} \\
\end{array}$ & $\begin{array}{l}\text { Tensão } \\
\text { (MPa) }\end{array}$ & $\begin{array}{l}\text { Módulo } \\
\text { (GPa) }\end{array}$ & $\begin{array}{c}\text { Def. } \\
\text { Última } \\
\text { (\%) }\end{array}$ & $\begin{array}{c}f_{\text {argl }}{ }_{1} \\
f_{\text {bloco }}\end{array}$ & Par. & $\begin{array}{c}\gamma_{\mathrm{s}} \\
\left(\mathrm{kg} / \mathrm{dm}^{3}\right)\end{array}$ & $\begin{array}{c}\gamma_{\mathrm{ssd}} \\
\left(\mathrm{kg} / \mathrm{dm}^{3}\right)\end{array}$ & $\begin{array}{l}\text { Abs. } \\
(\%)\end{array}$ & $\begin{array}{l}\text { I.V } \\
(\%)\end{array}$ \\
\hline \multirow{5}{*}{$\begin{array}{l}\text { PR4,5- } \\
\text { REF }\end{array}$} & \multirow{5}{*}{ DeE } & Média & \multirow{5}{*}{47} & 387,5 & 1555 & 7,92 & 12,74 & $-1,73$ & \multirow{5}{*}{0,520} & \multirow{19}{*}{ Média } & \multirow{19}{*}{1,909} & \multirow{19}{*}{2,130} & \multirow{19}{*}{11,56} & \multirow{19}{*}{22,06} \\
\hline & & Máx. & & 389,9 & 1570 & 8,00 & 13,97 & $-1,98$ & & & & & & \\
\hline & & Mín. & & 385,3 & 1545 & 7,89 & 11,18 & $-1,60$ & & & & & & \\
\hline & & $\mathrm{S}_{\mathrm{d}}$ & & 2,3 & 13 & 0,07 & 1,42 & 0,22 & & & & & & \\
\hline & & C.V (\%) & & 0,60 & 0,85 & 0,85 & 11,15 & 12,71 & & & & & & \\
\hline \multirow{5}{*}{$\begin{array}{l}\text { PR4,5- } \\
\text { RGV- } \\
100 \%\end{array}$} & \multirow{5}{*}{ D } & Média & \multirow{5}{*}{47} & 387,9 & 1598 & 8,14 & 11,76 & $-2,31$ & \multirow{5}{*}{0,819} & & & & & \\
\hline & & Máx. & & 394,8 & 1695 & 8,63 & 12,57 & $-2,72$ & & & & & & \\
\hline & & Mín. & & 384,1 & 1525 & 7,77 & 11,04 & $-1,62$ & & & & & & \\
\hline & & $\mathrm{S}_{\mathrm{d}}$ & & 6,0 & 87 & 0,44 & 0,77 & 0,60 & & & & & & \\
\hline & & C.V (\%) & & 1,54 & 5,47 & 5,47 & 6,53 & 26,09 & & & & & & \\
\hline \multirow{5}{*}{$\begin{array}{c}\text { PR4,5- } \\
\text { RGV- } \\
50 \%\end{array}$} & \multirow{5}{*}{ DeE } & Média & \multirow{5}{*}{47} & 388,1 & 1640 & 8,35 & 9,43 & $-2,91$ & \multirow{5}{*}{0,966} & & & & & \\
\hline & & Máx. & & 390,4 & 1760 & 8,96 & 11,19 & $-3,30$ & & & & & & \\
\hline & & Mín. & & 384,2 & 1565 & 7,97 & 8,03 & $-2,36$ & & & & & & \\
\hline & & $S_{d}$ & & 3,4 & 105 & 0,53 & 1,61 & 0,49 & & & & & & \\
\hline & & C.V (\%) & & 0,87 & 6,40 & 6,40 & 17,05 & 16,80 & & & & & & \\
\hline \multirow{5}{*}{$\begin{array}{c}\text { PR4,5- } \\
\text { RGB- } \\
50 \%\end{array}$} & \multirow{5}{*}{ C } & Média & \multirow{5}{*}{49} & 387,6 & 1203 & 6,13 & 9,53 & $-1,65$ & \multirow{5}{*}{0,657} & & & & & \\
\hline & & Máx. & & 390,9 & 1365 & 6,95 & 11,68 & $-1,95$ & & & & & & \\
\hline & & Mín. & & 383,4 & 1068 & 5,44 & 7,59 & $-1,32$ & & & & & & \\
\hline & & $S_{d}$ & & 3,8 & 150 & 0,77 & 2,06 & 0,32 & & & & & & \\
\hline & & C.V (\%) & & 0,99 & 12,51 & 12,51 & 21,58 & 19,16 & & $\mathrm{~S}_{\mathrm{d}}$ & 0,014 & 0,012 & 0,56 & 0,98 \\
\hline \multicolumn{4}{|c|}{ Média Geral } & 387,8 & 1499 & 7,63 & 10,86 & $-2,15$ & 0,740 & $\begin{array}{l}C . V \\
(\%)\end{array}$ & 0,72 & 0,55 & 4,85 & 4,43 \\
\hline
\end{tabular}

${ }^{1}$ relação entre a resistência da argamassa e os blocos ensaiados

Analisando-se os resultados da Tabela 8.14, observa-se que a resistência à compressão da argamassa esteve entre 52\% e 97\% da resistência à compressão do bloco. Apenas as argamassas dos prismas PR4,5-RGB-50\% apresentaram valores de resistência inferiores aos obtidos para as outras argamassas; possivelmente, alguns problemas ocorreram durante a moldagem dos CPs ou a mistura manual dos materiais não foi realizada de maneira eficiente.

De maneira geral, a ruptura dos prismas foi caracterizada pela fissuração generalizada nas faces dos blocos, inicialmente próximo às juntas e depois se espalhando por todo o bloco, Figura 8.6. De acordo com Mohamad et al. (2002), essa ruptura é típica de argamassas menos resistentes que a resistência à compressão das unidades. 

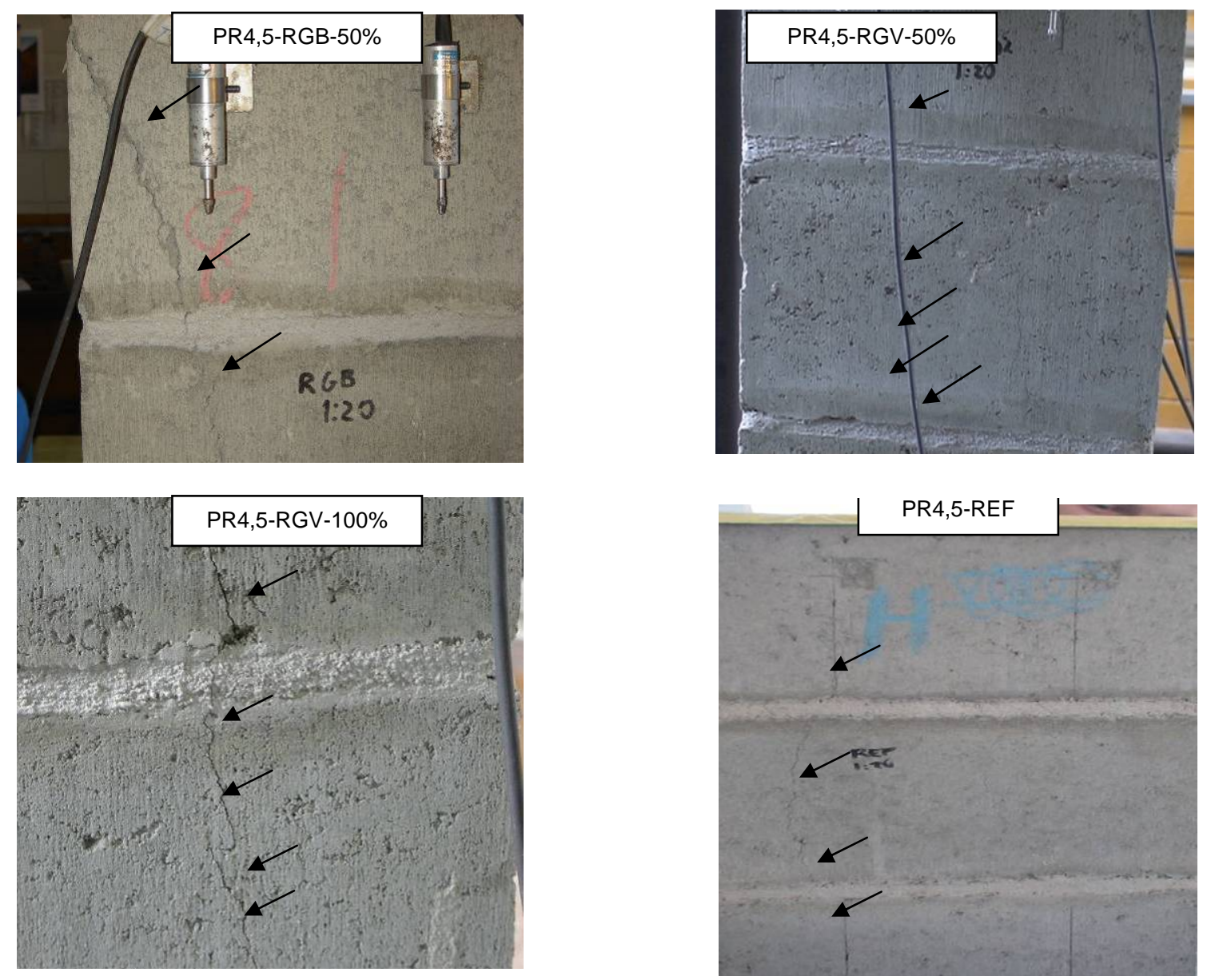

Figura 8.6 - Ruptura típica dos prismas do Grupo 4,5.

\subsubsection{GRUPO 8,0}

A terminologia adotada é apresentada na Tabela 8.15.

Tabela 8.15 - Terminologia adotada para o Grupo 8,0.

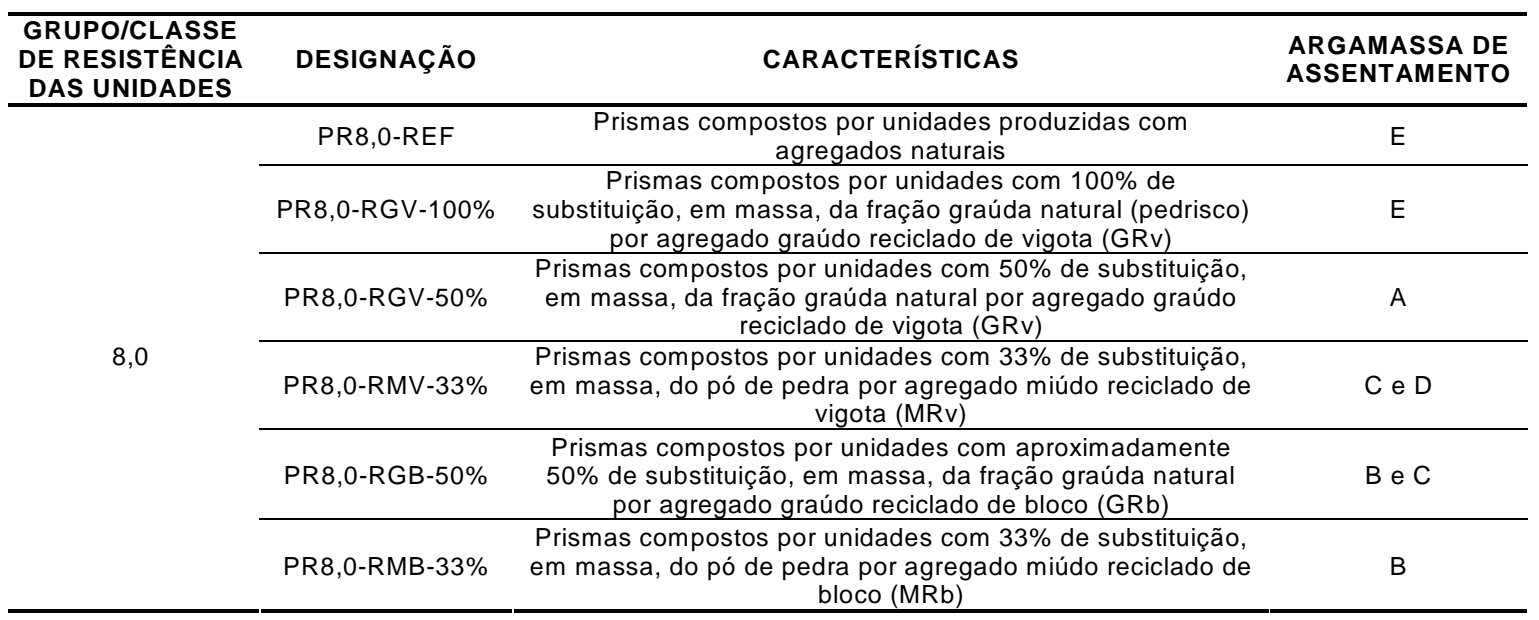


Os resultados de resistência à compressão dos prismas e das unidades ensaiadas são apresentados na Tabela 8.16. Nessa tabela, também são apresentados os fatores de eficiência (prisma/bloco).

Tabela 8.16 - Valores de resistência à compressão dos prismas e das unidades do Grupo 8,0 .

\begin{tabular}{|c|c|c|c|c|c|c|c|c|c|c|c|}
\hline \multirow[b]{2}{*}{ Prisma } & \multirow[b]{2}{*}{ Parâmetros } & \multicolumn{4}{|c|}{ Prismas } & \multicolumn{5}{|c|}{ Blocos } & \multirow{2}{*}{$\begin{array}{c}\text { Fator de } \\
\text { eficiência } \\
\text { (Prisma/bloco) }\end{array}$} \\
\hline & & $\begin{array}{l}\text { Idade } \\
\text { (dias) }\end{array}$ & $\begin{array}{c}\text { Força } \\
(\mathrm{kN})\end{array}$ & $\begin{array}{c}\text { Tensão } \\
\text { (MPa) }\end{array}$ & $\begin{array}{l}\text { Tensão } \\
\text { área } \\
\text { líquida } \\
\text { (MPa) } \\
\end{array}$ & $\begin{array}{c}\text { Massa } \\
\text { (g) }\end{array}$ & Idade & $\begin{array}{c}\text { Força } \\
(\mathbf{k N})\end{array}$ & $\begin{array}{c}\text { Tensão } \\
\text { (MPa) }\end{array}$ & $\begin{array}{l}\text { Tensão } \\
\text { área } \\
\text { líquida } \\
\text { (MPa) } \\
\end{array}$ & \\
\hline \multirow{5}{*}{ PR8,0-REF } & Média & \multirow{5}{*}{39} & 353 & 8,70 & 14,92 & 10367 & \multirow{5}{*}{126} & 591 & 14,55 & 24,96 & \multirow{5}{*}{0,598} \\
\hline & Máximo & & 382 & 9,41 & 16,13 & 10500 & & 652 & 16,06 & 27,54 & \\
\hline & Mínimo & & 339 & 8,34 & 14,31 & 10250 & & 512 & 12,61 & 21,63 & \\
\hline & $S_{d}$ & & 25 & 0,61 & 1,05 & 126 & & 72 & 1,77 & 3,03 & \\
\hline & C.V (\%) & & 7,05 & 7,05 & 7,05 & 1,21 & & 12,14 & 12,14 & 12,14 & \\
\hline \multirow{5}{*}{$\begin{array}{l}\text { PR8,0- } \\
\text { RGV-100\% }\end{array}$} & Média & \multirow{5}{*}{39} & 431 & 10,62 & 18,32 & 9867 & \multirow{5}{*}{126} & 634 & 15,61 & 26,92 & \multirow{5}{*}{0,681} \\
\hline & Máximo & & 447 & 11,00 & 18,96 & 9950 & & 669 & 16,47 & 28,39 & \\
\hline & Mínimo & & 411 & 10,12 & 17,45 & 9800 & & 567 & 13,97 & 24,09 & \\
\hline & $S_{d}$ & & 19 & 0,45 & 0,78 & 76 & & 58 & 1,42 & 2,45 & \\
\hline & C.V (\%) & & 4,28 & 4,28 & 4,28 & 0,77 & & 9,09 & 9,09 & 9,09 & \\
\hline \multirow{5}{*}{$\begin{array}{l}\text { PR8,0- } \\
\text { RGV-50\% }\end{array}$} & Média & \multirow{5}{*}{48} & 341 & 8,41 & 14,32 & 10100 & \multirow{5}{*}{133} & 558 & 13,75 & 23,42 & \multirow{5}{*}{0,612} \\
\hline & Máximo & & 357 & 8,79 & 14,98 & 10150 & & 597 & 14,69 & 25,03 & \\
\hline & Mínimo & & 331 & 8,15 & 13,89 & 10050 & & 517 & 12,73 & 21,68 & \\
\hline & $S_{d}$ & & 14 & 0,34 & 0,58 & 50 & & 40 & 0,98 & 1,68 & \\
\hline & C.V (\%) & & 4,04 & 4,04 & 4,04 & 0,50 & & 7,15 & 7,15 & 7,15 & \\
\hline \multirow{5}{*}{$\begin{array}{l}\text { PR8,0- } \\
\text { RMV-33\% }\end{array}$} & Média & \multirow{5}{*}{47} & 346 & 8,52 & 14,75 & 10200 & \multirow{5}{*}{134} & 549 & 13,53 & 23,41 & \multirow{5}{*}{0,630} \\
\hline & Máximo & & 375 & 9,23 & 15,97 & 10400 & & 558 & 13,83 & 23,92 & \\
\hline & Mínimo & & 329 & 8,09 & 14,00 & 10000 & & 528 & 13,01 & 22,51 & \\
\hline & $\mathrm{S}_{\mathrm{d}}$ & & 25 & 0,62 & 1,07 & 200 & & 18 & 0,45 & 0,78 & \\
\hline & C.V (\%) & & 7,22 & 7,22 & 7,22 & 1,96 & & 3,32 & 3,32 & 3,32 & \\
\hline \multirow{5}{*}{$\begin{array}{l}\text { PR8,0- } \\
\text { RGB-50\% }\end{array}$} & Média & \multirow{5}{*}{52} & 362 & 8,93 & 15,26 & 10133 & \multirow{5}{*}{136} & 611 & 15,05 & 25,72 & \multirow{5}{*}{0,593} \\
\hline & Máximo & & 395 & 9,72 & 16,61 & 10200 & & 646 & 15,91 & 27,19 & \\
\hline & Mínimo & & 335 & 8,24 & 14,09 & 10000 & & 552 & 13,61 & 23,26 & \\
\hline & $\mathrm{S}_{\mathrm{d}}$ & & 30 & 0,74 & 1,27 & 116 & & 51 & 1,25 & 2,14 & \\
\hline & C.V (\%) & & 8,34 & 8,34 & 8,34 & 1,14 & & 8,34 & 8,34 & 8,34 & \\
\hline \multirow{5}{*}{$\begin{array}{l}\text { PR8,0- } \\
\text { RMB-33\% }\end{array}$} & Média & \multirow{5}{*}{52} & 308 & 7,59 & 12,77 & 9917 & & 406 & 10,01 & 16,85 & \\
\hline & Máximo & & 329 & 8,09 & 13,63 & 10150 & & 443 & 10,90 & 18,35 & \\
\hline & Mínimo & & 294 & 7,24 & 12,19 & 9800 & 136 & 387 & 9,54 & 16,06 & 0,158 \\
\hline & $S_{d}$ & & 18 & 0,45 & 0,75 & 202 & & 31 & 0,77 & 1,30 & \\
\hline & C.V (\%) & & 5,91 & 5,91 & 5,91 & 2,04 & & 7,70 & 7,70 & 7,70 & \\
\hline Média & jeral do Grupo & & 357 & 8,79 & 15,06 & & & 558 & 13,75 & 23,55 & 0,645 \\
\hline
\end{tabular}

Analisando-se os resultados da Tabela 8.16, observa-se que os prismas compostos por unidades com agregados reciclados bem como os blocos com agregados reciclados apresentaram valores próximos de resistência quando comparados com os prismas de referência e unidades de referência. Com relação ao fator de eficiência ( $f_{\text {prisma }} / f_{\text {bloco }}$ ), o valor médio obtido foi igual a 0,645. Freitas (2006), para blocos vazados de concreto de resistência média igual a 9,08 $\mathrm{MPa}$, obteve um fator de eficiência igual a 0,74 e 0,70 para 
prismas de três blocos, utilizando as argamassas média ( $f_{\text {arg }}=6,02 \mathrm{MPa}$ ) e fraca $\left(f_{\text {arg }}=4,70\right.$ $\mathrm{MPa}$ ), respectivamente. Romagna (2000) obteve, para blocos com resistência à compressão entre $10 \mathrm{MPa}$ e $17 \mathrm{MPa}$ e argamassas de resistência entre 3,80 MPa e 5,60 MPa, fatores de eficiência situados entre 0,57 e 0,70.

Os resultados de módulo de deformação dos prismas do grupo 8,0 são apresentados na Tabela 8.17.

Tabela 8.17 - Resultados de módulo de deformação dos prismas do Grupo 8,0.

\begin{tabular}{|c|c|c|c|c|c|c|c|c|c|}
\hline Prisma & Parâmetros & $\begin{array}{l}\text { Idade } \\
\text { (dias) }\end{array}$ & $\begin{array}{c}\text { Tensão } \\
\text { - Abruta } \\
\text { (MPa) }\end{array}$ & $\begin{array}{l}\text { Módulo } \\
-A_{\text {bruta }} \\
\text { (MPa) }\end{array}$ & $\begin{array}{c}\text { Def. } \\
33 \% \text { da } \\
\text { tensão } \\
\text { última } \\
(\%)\end{array}$ & $\begin{array}{c}\text { Deformação } \\
\text { última (\%) }\end{array}$ & $\begin{array}{c}\text { Relação } \\
\text { Módulo/Tensão } \\
\text { experimental }\end{array}$ & $\begin{array}{c}\text { Relação } \\
\text { Módulo/Tensão } \\
\text { MOHAMAD } \\
(1998)^{1}\end{array}$ & $\begin{array}{c}\text { Relação } \\
\text { Módulo/Tensão } \\
\text { - DRYSDALE } \\
(1993)^{2}\end{array}$ \\
\hline \multirow{5}{*}{$\begin{array}{l}\text { PR8,0- } \\
\text { REF }\end{array}$} & Média & \multirow{5}{*}{39} & 8,70 & 8566 & $-0,33$ & $-2,32$ & \multirow{5}{*}{985} & \multirow{5}{*}{817} & \multirow{5}{*}{1133} \\
\hline & Máximo & & 9,41 & 9126 & $-0,37$ & $-2,82$ & & & \\
\hline & Mínimo & & 8,34 & 8277 & $-0,29$ & $-1,77$ & & & \\
\hline & $S_{d}$ & & 0,61 & 485 & 0,04 & 0,53 & & & \\
\hline & C.V (\%) & & 7,05 & 5,67 & 11,66 & 22,74 & & & \\
\hline \multirow{5}{*}{$\begin{array}{l}\text { PR8,0- } \\
\text { RGV- } \\
100 \%\end{array}$} & Média & \multirow{5}{*}{39} & 10,62 & 8668 & $-0,41$ & $-2,76$ & \multirow{5}{*}{816} & \multirow{5}{*}{790} & \multirow{5}{*}{844} \\
\hline & Máximo & & 11,00 & 9484 & $-0,45$ & $-2,93$ & & & \\
\hline & Mínimo & & 10,12 & 7809 & $-0,36$ & $-2,57$ & & & \\
\hline & $S_{d}$ & & 0,45 & 838 & 0,04 & 0,18 & & & \\
\hline & C.V (\%) & & 4,28 & 9,67 & 10,92 & 6,44 & & & \\
\hline \multirow{5}{*}{$\begin{array}{c}\text { PR8,0- } \\
\text { RGV-50\% }\end{array}$} & Média & \multirow{5}{*}{48} & 8,41 & 8449 & $-0,33$ & $-2,11$ & \multirow{5}{*}{1005} & \multirow{5}{*}{822} & \multirow{5}{*}{-} \\
\hline & Máximo & & 8,79 & 9059 & $-0,39$ & $-2,14$ & & & \\
\hline & Mínimo & & 8,15 & 7323 & $-0,29$ & $-2,07$ & & & \\
\hline & $\mathrm{S}_{\mathrm{d}}$ & & 0,34 & 976 & 0,05 & 0,04 & & & \\
\hline & C.V (\%) & & 4,04 & 11,55 & 15,25 & 1,68 & & & \\
\hline \multirow{5}{*}{$\begin{array}{c}\text { PR8,0- } \\
\text { RMV-33\% }\end{array}$} & Média & \multirow{5}{*}{47} & 8,52 & 8043 & $-0,35$ & $-2,41$ & \multirow{5}{*}{944} & \multirow{5}{*}{820} & \multirow{5}{*}{882} \\
\hline & Máximo & & 9,23 & 8908 & $-0,36$ & $-2,44$ & & & \\
\hline & Mínimo & & 8,09 & 7598 & $-0,34$ & $-2,37$ & & & \\
\hline & $\mathrm{S}_{\mathrm{d}}$ & & 0,62 & 749 & 0,01 & 0,04 & & & \\
\hline & C.V (\%) & & 7,22 & 9,31 & 2,49 & 1,71 & & & \\
\hline \multirow{5}{*}{$\begin{array}{c}\text { PR8,0- } \\
\text { RGB-50\% }\end{array}$} & Média & \multirow{5}{*}{52} & 8,93 & 9325 & $-0,31$ & $-2,49$ & \multirow{5}{*}{1045} & \multirow{5}{*}{813} & \multirow{5}{*}{1129} \\
\hline & Máximo & & 9,72 & 9887 & $-0,33$ & $-2,78$ & & & \\
\hline & Mínimo & & 8,24 & 8598 & $-0,28$ & $-2,14$ & & & \\
\hline & $S_{d}$ & & 0,74 & 660 & 0,03 & 0,32 & & & \\
\hline & C.V (\%) & & 8,34 & 7,08 & 9,38 & 12,86 & & & \\
\hline \multirow{5}{*}{$\begin{array}{c}\text { PR8,0- } \\
\text { RMB-33\% }\end{array}$} & Média & \multirow{5}{*}{52} & 7,59 & 9207 & $-0,27$ & $-1,89$ & & & \\
\hline & Máximo & & 8,09 & 9400 & $-0,29$ & $-1,93$ & & & \\
\hline & Mínimo & & 7,24 & 8922 & $-0,26$ & $-1,83$ & 1214 & 836 & - \\
\hline & $\mathrm{S}_{\mathrm{d}}$ & & 0,45 & 252 & 0,01 & 0,05 & & & \\
\hline & C.V (\%) & & 5,91 & 2,74 & 5,57 & 2,78 & & & \\
\hline Média & yeral do Grupo & & 8,79 & 8710 & $-0,33$ & $-2,33$ & 1001 & 816 & 997 \\
\hline${ }^{1}$ relação lin & rentre mód & resis & cia, dada & a equaçà & $\overline{E_{m}}=118$ & $\left(f_{m}\right)^{0,83}$ & & & \\
\hline $\begin{array}{l}2 \text { equação } \\
\text { Onde: } h_{\text {bloco }}\end{array}$ & $\begin{array}{l}\text { aseada no equ } \\
\text { altura da unida }\end{array}$ & $\begin{array}{l}\text { líbrio das } \\
\text { de; } h_{\text {arg }}-\end{array}$ & $\begin{array}{l}\text { deformaçõ } \\
\text { espessura }\end{array}$ & $\begin{array}{l}\text { e na unif } \\
\text { a junta de }\end{array}$ & $\begin{array}{l}\text { midade da } \\
\text { gamassa }\end{array}$ & tensões: & $\left(\frac{\frac{h_{\text {bloco }}}{h_{\text {arg }}+h_{\text {bloco }}}}{E_{\text {bloco }}}\right)+$ & $\frac{1}{+\left(\frac{1-\frac{h_{\text {bloco }}}{h_{\text {arg }}+h_{\text {bloco }}}}{E_{\text {arg }}}\right.}$ & \\
\hline
\end{tabular}


Analisando-se os resultados da Tabela 8.17, nota-se que não ocorreu redução no módulo de deformação dos prismas compostos por unidades com agregados reciclados comparativamente aos prismas de referência. Apesar disso, no capítulo 7, foi verificada uma redução de $14 \%$ no módulo de deformação das unidades com agregados reciclados comparativamente aos resultados das unidades de referência. Provavelmente, a argamassa empregada nos prismas constituídos por unidades com agregados reciclados compensou a maior deformabilidade dessas unidades.

Comparando-se os resultados obtidos com os valores teóricos, observou-se que, novamente, apenas a expressão proposta por Drysdale et al. (1994), forneceu valores de módulo e razão entre módulo e resistência à compressão próximos dos valores obtidos experimentalmente. A expressão de Mohamad (1998) forneceu valores sistematicamente inferiores aos experimentais.

Os resultados das propriedades físicas e mecânicas dos CPs de argamassa do grupo 8,0 encontram-se na Tabela 8.18. 
Tabela 8.18 - Resultados das propriedades físicas e mecânicas do CPs de argamassa do Grupo 8,0.

\begin{tabular}{|c|c|c|c|c|c|c|c|c|c|c|c|c|c|c|}
\hline \multirow[b]{2}{*}{ Prisma } & \multirow[b]{2}{*}{$\begin{array}{l}\text { Desig } \\
\text { Arg. }\end{array}$} & \multirow[b]{2}{*}{ Parâm. } & \multirow[b]{2}{*}{ Idade } & \multirow{2}{*}{$\begin{array}{c}\text { Massa } \\
\text { dos } \\
\text { CPs }\end{array}$} & \multicolumn{5}{|c|}{ Propriedades Mecânicas } & \multicolumn{5}{|c|}{ Propriedades físicas } \\
\hline & & & & & $\begin{array}{c}\text { Força } \\
\text { última } \\
\text { (kgf) }\end{array}$ & $\begin{array}{l}\text { Tensão } \\
(\mathrm{MPa})\end{array}$ & $\begin{array}{c}\text { Módulo } \\
\text { (GPa) }\end{array}$ & $\begin{array}{c}\text { Def. } \\
\text { Última } \\
(\%)\end{array}$ & $\begin{array}{c}f_{\text {ard }}{ }_{1} \\
f_{\text {floco }}\end{array}$ & Par. & $\begin{array}{c}\gamma_{\mathrm{s}} \\
\left(\mathrm{kg}^{\left.\mathrm{d} \mathrm{dm}^{3}\right)}\right) \\
\end{array}$ & $\begin{array}{c}\gamma_{\text {ssd }} \\
\left(\mathrm{kg}^{3} \mathrm{dm}^{3}\right)\end{array}$ & $\begin{array}{l}\text { Abs. } \\
(\%)\end{array}$ & $\begin{array}{l}\text { I.V } \\
(\%)\end{array}$ \\
\hline \multirow{5}{*}{$\begin{array}{c}\text { PR8,0- } \\
\text { REF }\end{array}$} & \multirow{5}{*}{$E$} & Média & \multirow{5}{*}{39} & 391,7 & 1720 & 8,76 & 7,34 & $-2,37$ & \multirow{5}{*}{0,602} & & & & & \\
\hline & & Máx. & & 393,8 & 1805 & 9,19 & 8,54 & $-2,60$ & & & & & & \\
\hline & & Mín. & & 390,0 & 1600 & 8,15 & 6,43 & $-2,22$ & & & & & & \\
\hline & & $S_{d}$ & & 1,9 & 107 & 0,54 & 1,08 & 0,20 & & & & & & \\
\hline & & C.V (\%) & & 0,50 & 6,21 & 6,21 & 14,72 & 8,63 & & & & & & \\
\hline \multirow{5}{*}{$\begin{array}{c}\text { PR8,0- } \\
\text { RGV- } \\
100 \%\end{array}$} & \multirow{5}{*}{ E } & Média & \multirow{5}{*}{39} & 385,8 & 1612 & 8,21 & 8,75 & $-2,21$ & \multirow{5}{*}{0,526} & & & & & \\
\hline & & Máx. & & 387,2 & 1725 & 8,79 & 11,03 & $-2,62$ & & & & & & \\
\hline & & Mín. & & 384,3 & 1450 & 7,38 & 6,69 & $-1,96$ & & & & & & \\
\hline & & $S_{d}$ & & 2,1 & 144 & 0,73 & 2,18 & 0,36 & & & & & & \\
\hline & & C.V (\%) & & 0,53 & 8,92 & 8,92 & 24,94 & 16,32 & & & & & & \\
\hline \multirow{5}{*}{$\begin{array}{c}\text { PR8,0- } \\
\text { RGV- } \\
50 \%\end{array}$} & \multirow{5}{*}{ A } & Média & \multirow{5}{*}{48} & 388,2 & 1167 & 5,94 & * & * & \multirow{5}{*}{0,432} & & & & & \\
\hline & & Máx. & & 391,1 & 1245 & 6,34 & * & * & & & & & & \\
\hline & & Mín. & & 384,4 & 1075 & 5,47 & * & * & & & & & & \\
\hline & & $S_{d}$ & & 3,5 & 86 & 0,44 & * & * & & & & & & \\
\hline & & C.V (\%) & & 0,89 & 7,35 & 7,35 & * & * & & Média & 1,929 & 2,144 & 11,18 & 21,55 \\
\hline \multirow{5}{*}{$\begin{array}{c}\text { PR8,0- } \\
\text { RMN- } \\
33 \%\end{array}$} & \multirow{5}{*}{ CeD } & Média & \multirow{5}{*}{47} & 386,4 & 1422 & 7,24 & 10,59 & $-2,85$ & \multirow{5}{*}{0,535} & & & & & \\
\hline & & Máx. & & 390,3 & 1685 & 8,58 & 11,87 & $-3,88$ & & & & & & \\
\hline & & Mín. & & 384,1 & 1050 & 5,35 & 8,05 & $-0,88$ & & & & & & \\
\hline & & $S_{d}$ & & 3,4 & 331 & 1,69 & 2,20 & 1,71 & & & & & & \\
\hline & & C.V (\%) & & 0,87 & 23,29 & 23,29 & 20,77 & 59,91 & & & & & & \\
\hline \multirow{5}{*}{$\begin{array}{c}\text { PR8,0- } \\
\text { RGB- } \\
50 \%\end{array}$} & \multirow{5}{*}{$\mathrm{BeC}$} & Média & & 387,8 & 1084 & 5,52 & 7,00 & $-2,32$ & & & & & & \\
\hline & & Máx. & & 390,5 & 1251 & 6,37 & 8,31 & $-3,07$ & & & & & & \\
\hline & & Mín. & 52 & 383,6 & 977 & 4,97 & 5,46 & $-1,60$ & 0,367 & & & & & \\
\hline & & $S_{d}$ & & 3,7 & 147 & 0,75 & 1,44 & 0,73 & & & & & & \\
\hline & & C.V (\%) & & 0,95 & 13,58 & 13,58 & 20,57 & 31,55 & & & & & & \\
\hline & & Média & & 385,4 & 1094 & 5,57 & 6,98 & $-1,92$ & & & & & & \\
\hline PR80- & & Máx. & & 386,7 & 1114 & 5,67 & 7,81 & $-2,30$ & & & & & & \\
\hline RMB- & B & Mín. & 52 & 383,5 & 1061 & 5,40 & 6,25 & $-1,67$ & 0,556 & & & & & \\
\hline $33 \%$ & & $\mathrm{~S}_{\mathrm{d}}$ & & 1,7 & 29 & 0,15 & 0,79 & 0,33 & & & & & & \\
\hline & & C.V (\%) & & 0,43 & 2,64 & 2,64 & 11,28 & 17,36 & & $S_{d}$ & 0,018 & 0,017 & 0,98 & 1,77 \\
\hline & Média & Geral & & 387,5 & 1350 & 6,87 & 8,13 & $-2,33$ & 0,503 & $\begin{array}{l}C . V \\
(\%)\end{array}$ & 0,92 & 0,80 & 8,80 & 8,21 \\
\hline
\end{tabular}

Pela Tabela 8.18, observa-se que a resistência à compressão da argamassa variou entre $37 \%$ e $60 \%$ da resistência à compressão do bloco, com valores médios próximos a 50\%. A resistência à compressão da argamassa esteve entre 5,52 MPa e 8,76 MPa (farg,média $=6,87 \mathrm{MPa})$.

De maneira geral, a ruptura dos prismas foi caracterizada pela fissuração generalizada nas faces dos blocos, inicialmente próximo às juntas e depois se espalhando por todo o bloco. De acordo com Mohamad et al. (2002), essa ruptura é típica de 
argamassas menos resistentes que a resistência à compressão das unidades. Além disto, a fissuração vertical observada em alguns prismas foi semelhante ao modo de ruína das paredes de alvenaria, isto é, caracterizada pela tração nas unidades segundo planos paralelos à aplicação de carga, Figura 8.7.
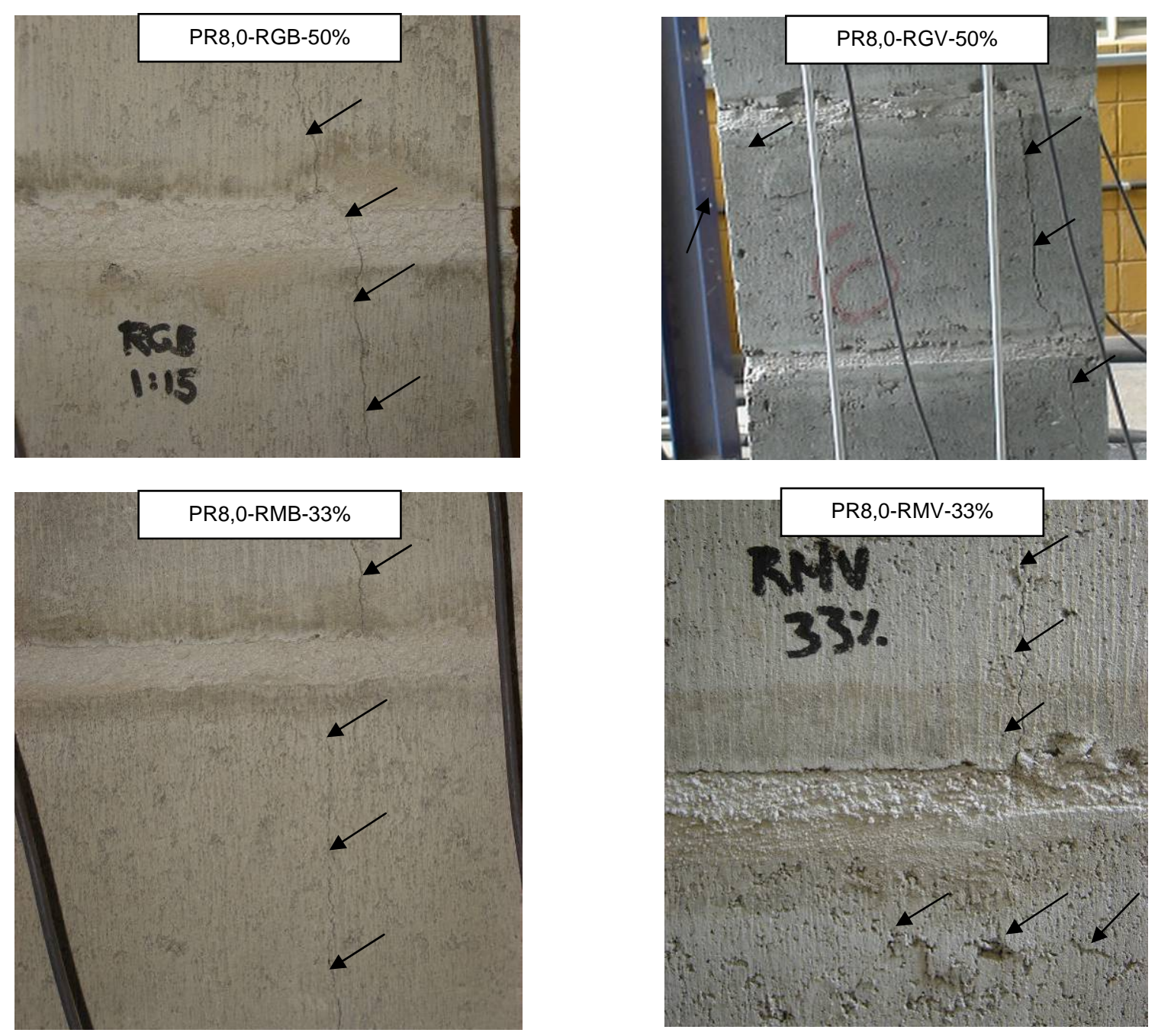

Figura 8.7 - Ruptura típica dos prismas do grupo 8,0.

\subsubsection{GRUPO 12,0}

A terminologia adotada são apresentadas na Tabela 8.19. 
Tabela 8.19 - Terminologia adotada para o Grupo 12,0.

\begin{tabular}{|c|c|c|c|}
\hline $\begin{array}{l}\text { GRUPOICLASSE } \\
\text { DERESISTENCIA } \\
\text { DAS UNIDADES }\end{array}$ & DESIGNAÇÃo & CARACTERÍSTICAS & $\begin{array}{l}\text { ARGAMASSA DE } \\
\text { ASSENTAMENTO }\end{array}$ \\
\hline \multirow{6}{*}{12,0} & PR 12,0-REF & $\begin{array}{c}\text { Prismas compostos por unidades produzidas com } \\
\text { agregados naturais }\end{array}$ & A \\
\hline & $\begin{array}{c}\text { PR } 12,0-R G \text { - } \\
100 \%\end{array}$ & $\begin{array}{l}\text { Prismas compostos por unidades com } 100 \% \text { de } \\
\text { substituição, em massa, da fração graúda natural (pedrisco) } \\
\text { por agregado graúdo reciclado de vigota (GRv) }\end{array}$ & $A$ e $B$ \\
\hline & PR12,0-RG V-50\% & $\begin{array}{c}\text { Prismas compostos por unidades com } 50 \% \text { de substituição, } \\
\text { em massa, da fração graúda natural por agregado graúdo } \\
\text { reciclado de vigota (GRv) }\end{array}$ & A \\
\hline & $\begin{array}{c}\text { PR } 12,0-R M V- \\
33 \%\end{array}$ & $\begin{array}{c}\text { Prismas compostos por unidades com } 33 \% \text { de substituição, } \\
\text { em massa, do pó de pedra por agregado miúdo reciclado de } \\
\text { vigota (MRv) }\end{array}$ & C \\
\hline & PR 12,0-RGB-50\% & $\begin{array}{l}\text { Prismas compostos por unidades com aproximadamente } \\
50 \% \text { de substituição, em massa, da fração graúda natural } \\
\text { por agregado graúdo reciclado de bloco (GRb) }\end{array}$ & B \\
\hline & $\begin{array}{c}\text { PR } 12,0-\mathrm{RMB} \text { - } \\
33 \%\end{array}$ & $\begin{array}{c}\text { Prismas compostos por unidades com } 33 \% \text { de substituição, } \\
\text { em massa, do pó de pedra por agregado miúdo reciclado de } \\
\text { bloco (MRb) }\end{array}$ & $C$ e $D$ \\
\hline
\end{tabular}

Os resultados de resistência à compressão dos prismas e das unidades ensaiadas são apresentados na Tabela 8.20. Nessa tabela, também são apresentados os fatores de eficiência (prisma/bloco).

Tabela 8.20 - Valores de resistência à compressão dos prismas e das unidades pertencentes ao Grupo 12,0.

\begin{tabular}{|c|c|c|c|c|c|c|c|c|c|c|c|}
\hline \multirow[b]{2}{*}{ Prisma } & \multirow[b]{2}{*}{ Parâmetros } & \multicolumn{4}{|c|}{ Prismas } & \multicolumn{5}{|c|}{ Blocos } & \multirow{2}{*}{$\begin{array}{c}\text { Fator de } \\
\text { eficiência } \\
\text { (Prisma/bloco) }\end{array}$} \\
\hline & & $\begin{array}{l}\text { Idade } \\
\text { (dias) }\end{array}$ & $\begin{array}{l}\text { Força } \\
(\mathrm{kN})\end{array}$ & $\begin{array}{c}\text { Tensão } \\
\text { (MPa) }\end{array}$ & $\begin{array}{l}\text { Tensão } \\
\text { área } \\
\text { líquida } \\
\text { (MPa) }\end{array}$ & $\begin{array}{c}\text { Massa } \\
(\mathrm{g})\end{array}$ & Idade & $\begin{array}{c}\text { Força } \\
(k N)\end{array}$ & $\begin{array}{c}\text { Tensão } \\
\text { (MPa) }\end{array}$ & $\begin{array}{l}\text { Tensão } \\
\text { área } \\
\text { líquida } \\
\text { (MPa) }\end{array}$ & \\
\hline \multirow{5}{*}{$\begin{array}{c}\text { PR12,0- } \\
\text { REF }\end{array}$} & Média & \multirow{5}{*}{48} & 513 & 12,63 & 21,86 & 10117 & \multirow{5}{*}{133} & 814 & 20,04 & 34,67 & \multirow{5}{*}{0,630} \\
\hline & Máximo & & 533 & 13,13 & 22,72 & 10250 & & 890 & 21,91 & 37,90 & \\
\hline & Mínimo & & 497 & 12,25 & 21,19 & 10000 & & 768 & 18,91 & 32,72 & \\
\hline & $\mathrm{S}_{\mathrm{d}}$ & & 18 & 0,45 & 0,78 & 126 & & 66 & 1,63 & 2,82 & \\
\hline & C.V (\%) & & 3,58 & 3,58 & 3,58 & 1,24 & & 8,14 & 8,14 & 8,14 & \\
\hline \multirow{5}{*}{$\begin{array}{l}\text { PR12,0- } \\
\text { RGV-100\% }\end{array}$} & Média & \multirow{5}{*}{48} & 403 & 9,92 & 17,10 & 9783 & \multirow{5}{*}{133} & 725 & 17,87 & 30,80 & \multirow{5}{*}{0,555} \\
\hline & Máximo & & 436 & 10,74 & 18,52 & 9900 & & 756 & 18,62 & 32,10 & \\
\hline & Mínimo & & 382 & 9,42 & 16,24 & 9700 & & 665 & 16,38 & 28,25 & \\
\hline & $\mathrm{S}_{\mathrm{d}}$ & & 29 & 0,72 & 1,24 & 104 & & 52 & 1,28 & 2,21 & \\
\hline & C.V (\%) & & 7,24 & 7,24 & 7,24 & 1,06 & & 7,18 & 7,18 & 7,18 & \\
\hline \multirow{5}{*}{$\begin{array}{l}\text { PR12,0- } \\
\text { RGV-50\% }\end{array}$} & Média & \multirow{5}{*}{48} & 435 & 10,71 & 18,50 & 9900 & \multirow{5}{*}{133} & 707 & 17,40 & 30,06 & \multirow{5}{*}{0,616} \\
\hline & Máximo & & 450 & 11,08 & 19,14 & 9900 & & 762 & 18,77 & 32,42 & \\
\hline & Mínimo & & 406 & 9,99 & 17,25 & 9900 & & 645 & 15,88 & 27,43 & \\
\hline & $S_{d}$ & & 26 & 0,63 & 1,08 & 0 & & 59 & 1,45 & 2,51 & \\
\hline & C.V (\%) & & 5,86 & 5,86 & 5,86 & 0,00 & & 8,34 & 8,34 & 8,34 & \\
\hline \multirow{5}{*}{$\begin{array}{l}\text { PR12,0- } \\
\text { RMV-33\% }\end{array}$} & Média & \multirow{5}{*}{49} & 469 & 11,55 & 20,26 & 10183 & \multirow{5}{*}{133} & 776 & 19,12 & 33,55 & \multirow{5}{*}{0,604} \\
\hline & Máximo & & 481 & 11,86 & 20,81 & 10400 & & 815 & 20,07 & 35,21 & \\
\hline & Mínimo & & 456 & 11,24 & 19,72 & 10050 & & 757 & 18,65 & 32,72 & \\
\hline & $S_{d}$ & & 13 & 0,31 & 0,54 & 189 & & 33 & 0,82 & 1,44 & \\
\hline & C.V (\%) & & 2,68 & 2,68 & 2,68 & 1,86 & & 4,28 & 4,28 & 4,28 & \\
\hline \multirow{5}{*}{$\begin{array}{l}\text { PR12,0- } \\
\text { RGB-50\% }\end{array}$} & Média & \multirow{5}{*}{52} & 437 & 10,77 & 18,66 & 10067 & \multirow{5}{*}{136} & 765 & 18,84 & 32,65 & \multirow{5}{*}{0,571} \\
\hline & Máximo & & 467 & 11,51 & 19,95 & 10350 & & 880 & 21,67 & 37,55 & \\
\hline & Mínimo & & 411 & 10,12 & 17,55 & 9850 & & 677 & 16,68 & 28,91 & \\
\hline & $S_{d}$ & & 28 & 0,70 & 1,21 & 202 & & 104 & 2,56 & 4,44 & \\
\hline & C.V (\%) & & 6,48 & 6,48 & 6,48 & 2,01 & & 13,58 & 13,58 & 13,58 & \\
\hline \multirow{5}{*}{$\begin{array}{l}\text { PR12,0- } \\
\text { RMB-33\% }\end{array}$} & Média & & 461 & 11,34 & 19,06 & 10450 & \multirow{5}{*}{134} & 828 & 20,38 & 34,26 & \\
\hline & Máximo & & 489 & 12,04 & 20,23 & 10850 & & 906 & 22,32 & 37,50 & \\
\hline & Mínimo & 49 & 436 & 10,73 & 18,04 & 10050 & & 706 & 17,40 & 29,24 & 0,556 \\
\hline & $S_{d}$ & & 27 & 0,66 & 1,10 & 400 & & 107 & 2,62 & 4,41 & \\
\hline & C.V (\%) & & 5,78 & 5,78 & 5,78 & 3,83 & & 12,87 & 12,87 & 12,87 & \\
\hline Média & eral do Grupo & 2,0 & 453 & 11,15 & 19,25 & & & 769 & 18,94 & 32,66 & 0,589 \\
\hline
\end{tabular}


Analisando-se os resultados da Tabela 8.20, observa-se que os prismas compostos por unidades com agregados reciclados apresentaram uma redução de 14\% na resistência à compressão comparativamente aos prismas de referência; em contrapartida, considerando-se a resistência à compressão das unidades, a redução foi de 6,5\% (blocos reciclados em comparação com o referência)

Com relação ao fator de eficiência ( $\left.f_{\text {prisma }} / f_{\text {bloco }}\right)$, o valor médio obtido foi igual a 0,59. Freitas (2006), para blocos vazados de concreto de resistência média igual a 13,4 MPa, obteve um fator de eficiência igual a 0,67 e 0,59 para prismas de três blocos, utilizando-se as argamassas média ( $f_{\text {arg }}=7,09 \mathrm{MPa}$ ) e fraca ( $\left.f_{\text {arg }}=4,47 \mathrm{MPa}\right)$, respectivamente. Romagna (2000) obteve, para blocos com resistência à compressão entre $10 \mathrm{MPa}$ e $17 \mathrm{MPa}$ e argamassas de resistência entre 3,80 MPa e 5,60 MPa, fatores de eficiência situados entre 0,57 e 0,70 . Os resultados de módulo de deformação dos prismas são apresentados na Tabela 8.21.

Tabela 8.21 - Resultados de módulo de deformação dos prismas do Grupo 12,0.

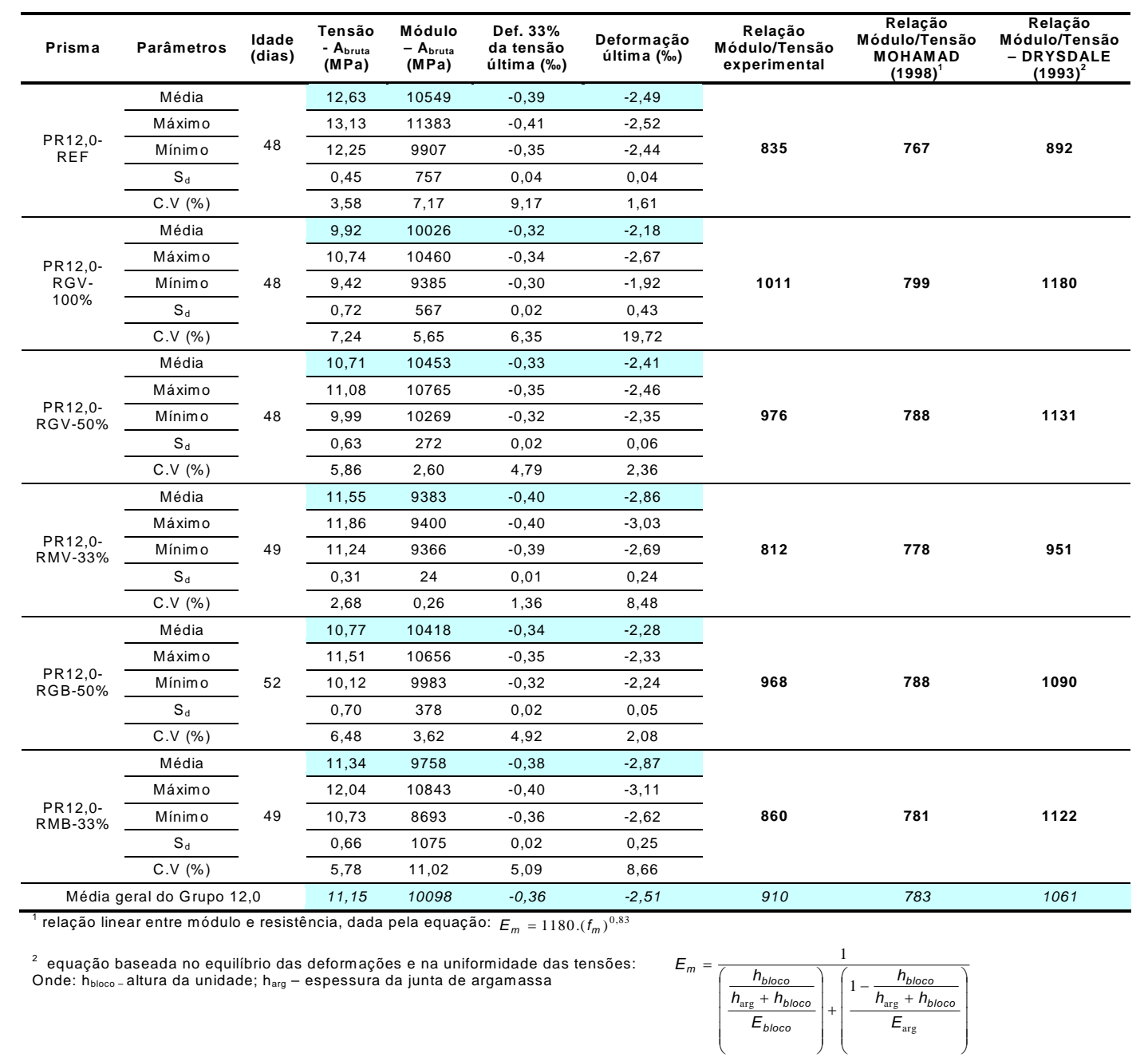


Pela Tabela 8.21, nota-se que ocorreu uma redução de 5\% no módulo de deformação dos prismas compostos por unidades com agregados reciclados comparativamente aos prismas de referência. Por outro lado, no capítulo 7, foi verificado um aumento de 5\% no módulo de deformação das unidades com agregados reciclados comparativamente aos resultados das unidades de referência. Provavelmente, esse comportamento foi influenciado pelas características da argamassa.

Utilizando-se a equação citada por Mohamad (1998), obteve-se um valor próximo a 783, para a razão entre o módulo e a resistência à compressão (valor inferior ao encontrado experimentalmente); já a utilização da expressão proposta por Drysdale et al. (1994) forneceu valores de módulo e razão entre módulo e resistência à compressão (1061) superiores aos valores obtidos experimentalmente (910). Os resultados das propriedades físicas e mecânicas dos CPs de argamassa do Grupo 12,0 encontram-se na Tabela 8.22.

Tabela 8.22 - Resultados das propriedades físicas e mecânicas do CPs de argamassa do Grupo 12,0.

\begin{tabular}{|c|c|c|c|c|c|c|c|c|c|c|c|c|c|c|}
\hline \multirow[b]{2}{*}{ Prisma } & \multirow[b]{2}{*}{$\begin{array}{l}\text { Desig } \\
\text { Arg. }\end{array}$} & \multirow[b]{2}{*}{ Parâm. } & \multirow[b]{2}{*}{ Idade } & \multirow{2}{*}{$\begin{array}{c}\text { Massa } \\
\text { dos } \\
\text { CPs }\end{array}$} & \multicolumn{5}{|c|}{ Propriedades Mecânicas } & \multicolumn{5}{|c|}{ Propriedades físicas } \\
\hline & & & & & $\begin{array}{c}\text { Força } \\
\text { última } \\
(\mathrm{kgf})\end{array}$ & $\begin{array}{c}\text { Tensão } \\
\text { (MPa) }\end{array}$ & $\begin{array}{c}\text { Módulo } \\
\text { (GPa) }\end{array}$ & $\begin{array}{c}\text { Def. } \\
\text { Última } \\
(\%)\end{array}$ & $\begin{array}{c}f_{\text {arg }} l \\
f_{\text {bloco }}{ }_{1}\end{array}$ & Par. & $\begin{array}{c}\gamma_{\mathrm{s}} \\
\left(\mathrm{kg} / \mathrm{dm}^{3}\right)\end{array}$ & $\begin{array}{c}\gamma_{\mathrm{ssd}} \\
\left(\mathrm{kg} / \mathrm{dm}^{3}\right)\end{array}$ & $\begin{array}{l}\text { Abs. } \\
(\%)\end{array}$ & $\begin{array}{l}I . V \\
(\%)\end{array}$ \\
\hline \multirow{5}{*}{$\begin{array}{l}\text { PR12,0 } \\
\text {-REF }\end{array}$} & \multirow{5}{*}{ A } & Média & \multirow{5}{*}{48} & 391,7 & 1147 & 5,84 & 8,84 & $-1,53$ & \multirow{5}{*}{0,291} & & & & & \\
\hline & & Máx. & & 396,8 & 1270 & 6,47 & 12,14 & $-1,92$ & & & & & & \\
\hline & & Mín. & & 388,1 & 1080 & 5,50 & 6,79 & $-1,28$ & & & & & & \\
\hline & & $S_{d}$ & & 4,5 & 107 & 0,54 & 2,88 & 0,34 & & & & & & \\
\hline & & C.V (\%) & & 1,15 & 9,33 & 9,33 & 32,61 & 22,19 & & & & & & \\
\hline \multirow{5}{*}{$\begin{array}{l}\text { PR12,0 } \\
\text {-RGV- } \\
100 \%\end{array}$} & \multirow{5}{*}{$A$ e $B$} & Média & \multirow{5}{*}{48} & 390,8 & 1107 & 5,64 & 11,02 & $-1,65$ & \multirow{5}{*}{0,315} & & & & & \\
\hline & & Máx. & & 394,4 & 1280 & 6,52 & 11,87 & $-2,40$ & & & & & & \\
\hline & & Mín. & & 388,4 & 1010 & 5,14 & 9,58 & $-1,02$ & & & & & & \\
\hline & & $S_{d}$ & & 3,2 & 150 & 0,77 & 1,25 & 0,70 & & & & & & \\
\hline & & C.V (\%) & & 00,81 & 13,59 & 13,59 & 11,36 & 42,15 & & & & & & \\
\hline \multirow{5}{*}{$\begin{array}{c}\text { PR12,0 } \\
\text {-RGV- } \\
50 \%\end{array}$} & \multirow{5}{*}{ A } & Média & \multirow{5}{*}{48} & 392,7 & 1268 & 6,46 & 10,27 & $-1,17$ & \multirow{5}{*}{0,371} & & & & & \\
\hline & & Máx. & & 395,5 & 1380 & 7,03 & 11,30 & $-1,28$ & & & & & & \\
\hline & & Mín. & & 389,0 & 1160 & 5,91 & 9,28 & $-1,12$ & & & & & & \\
\hline & & $S_{d}$ & & 3,4 & 110 & 0,56 & 1,01 & 0,09 & & & & & & \\
\hline & & C.V (\%) & & 0,85 & 8,68 & 8,68 & 9,87 & 7,87 & & Média & 1,946 & 2,162 & 11,09 & 21,55 \\
\hline \multirow{5}{*}{$\begin{array}{c}\text { PR12,0 } \\
\text {-RMV- } \\
33 \%\end{array}$} & \multirow{5}{*}{ C } & Média & \multirow{5}{*}{49} & 391,3 & 1118 & 5,70 & 9,21 & $-1,65$ & \multirow{5}{*}{0,298} & & & & & \\
\hline & & Máx. & & 393,1 & 1275 & 6,49 & 11,06 & $-1,66$ & & & & & & \\
\hline & & Mín. & & 388,1 & 985 & 5,02 & 7,35 & $-1,64$ & & & & & & \\
\hline & & $S_{d}$ & & 2,8 & 146 & 0,75 & 2,62 & 0,01 & & & & & & \\
\hline & & C.V (\%) & & 0,72 & 13,09 & 13,09 & 28,51 & 0,86 & & & & & & \\
\hline \multirow{5}{*}{$\begin{array}{l}\text { PR12,0 } \\
\text {-RGB- } \\
50 \%\end{array}$} & \multirow{5}{*}{ B } & Média & & 388,4 & 1162 & 5,92 & 7,99 & $-2,30$ & & & & & & \\
\hline & & Máx. & & 390,4 & 1206 & 6,14 & 9,38 & $-2,95$ & & & & & & \\
\hline & & Mín. & 52 & 386,3 & 1099 & 5,60 & 7,00 & $-1,86$ & 0,314 & & & & & \\
\hline & & $S_{d}$ & & 2,1 & 56 & 0,29 & 1,24 & 0,57 & & & & & & \\
\hline & & C.V (\%) & & 0,53 & 4,84 & 4,84 & 15,51 & 24,89 & & & & & & \\
\hline & & Média & & 386,9 & 1090 & 5,55 & 8,71 & $-1,99$ & & & & & & \\
\hline PR120 0 & & Máx. & & 387,7 & 1260 & 6,42 & 9,58 & $-3,20$ & & & & & & \\
\hline -RMB- & $C$ e D & Mín. & 49 & 286,1 & 950 & 4,84 & 7,38 & $-1,32$ & 0,272 & & & & & \\
\hline & & $S_{d}$ & & 0,8 & 157 & 0,80 & 1,17 & 1,05 & & & & & & \\
\hline & & C.V (\%) & & 0,21 & 14,42 & 14,42 & 13,44 & 52,54 & & $\mathrm{~S}_{\mathrm{d}}$ & 0,041 & 0,028 & 1,05 & 1,65 \\
\hline & Médi & Geral & & 390,3 & 1149 & 5,85 & 9,34 & $-1,72$ & 0,310 & $\begin{array}{l}\text { C.V } \\
\text { (\%) }\end{array}$ & 2,12 & 1,31 & 9,48 & 7,66 \\
\hline
\end{tabular}

${ }^{1}$ relação entre a resistência da argamassa e os blocos ensaiados 
Pela Tabela 8.22, observa-se que a resistência à compressão da argamassa situouse entre $27 \%$ e $37 \%$ da resistência à compressão do bloco. De acordo com Ramalho e Corrêa (2003), a resistência da argamassa apresenta influência significativa na resistência do elemento de alvenaria, apenas quando sua resistência for inferior a $30 \%$ ou $40 \%$ da resistência do bloco. Dessa maneira, acredita-se que a resistência da argamassa influenciou a resistência dos prismas; provavelmente, deveria ser adotada uma argamassa de resistência mais elevada. Segundo Calçada (1998), argamassas muito fracas podem provocar a ruptura da alvenaria por seu esmagamento; já segundo Barbosa (2004), argamassas menos resistentes e mais deformáveis provocam tensões de tração no bloco em virtude de sua expansão.

A ruptura dos prismas foi caracterizada pelo esfacelamento da parte externa das paredes dos blocos, inicialmente próximo às juntas e depois se espalhando por todo o bloco. De acordo com Mohamad et al. (2002), essa ruptura é típica de argamassas menos resistentes que a resistência do bloco. Além disso, a fissuração vertical observada em alguns prismas foi semelhante ao modo de ruína das paredes de alvenaria, sendo caracterizada pela tração nas unidades segundo planos paralelos à aplicação de carga, Figura 8.8 e 8.9 .
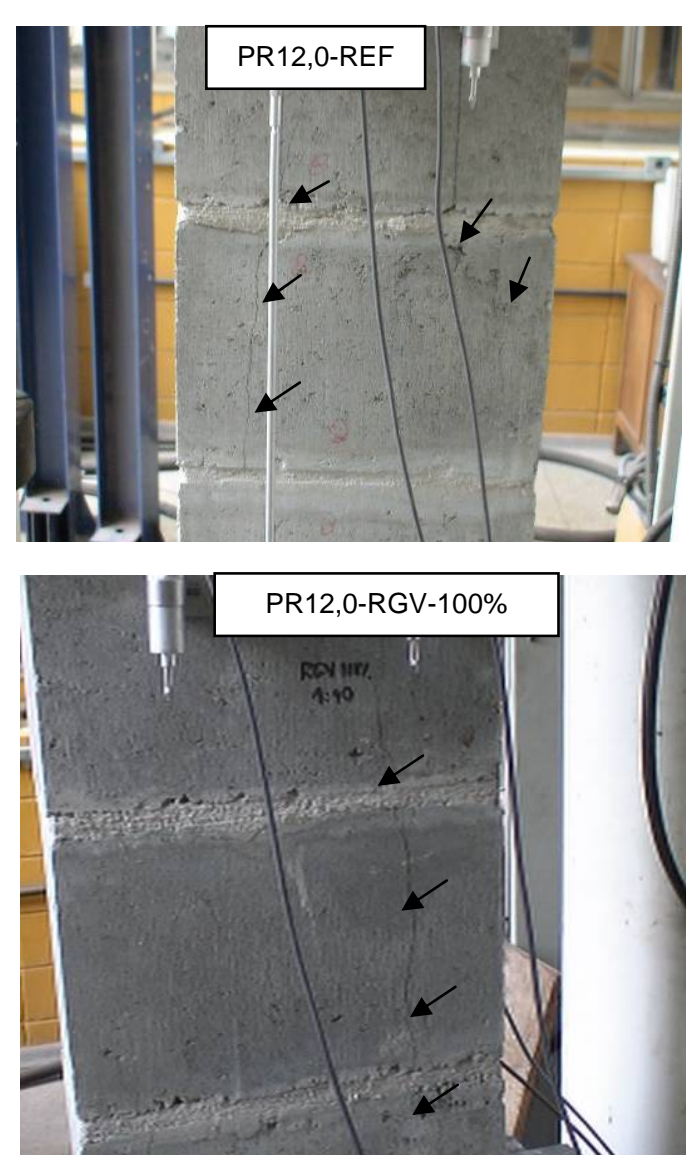
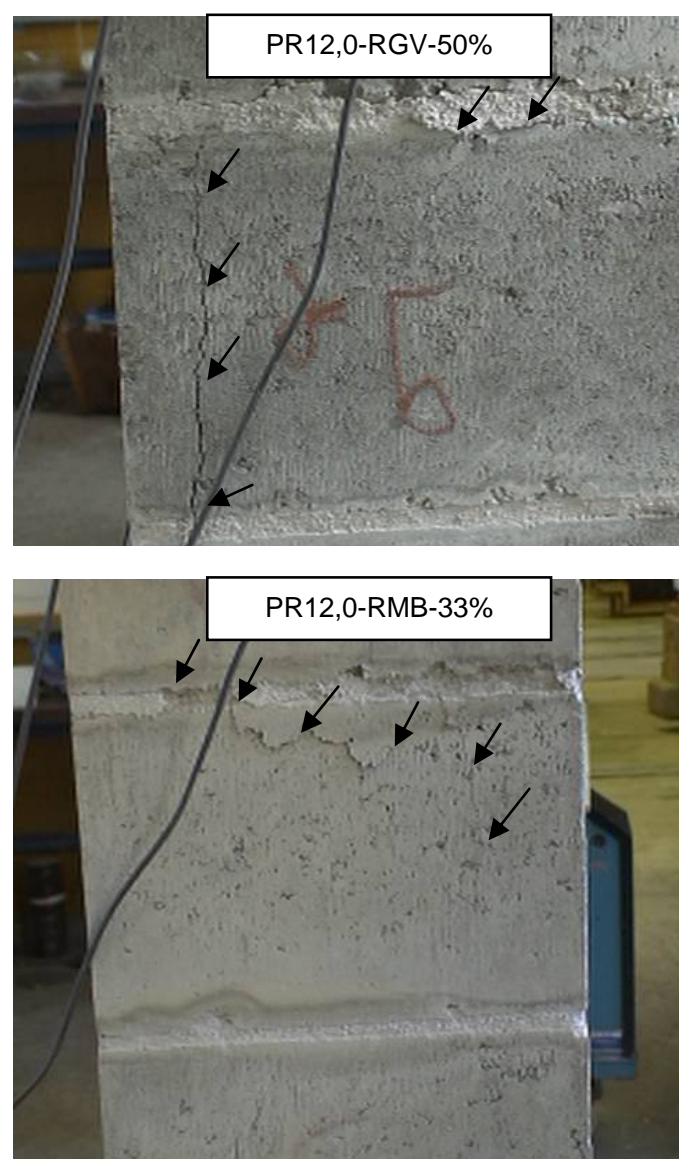

Figura 8.8 - Ruptura típica dos prismas do grupo 12,0. 

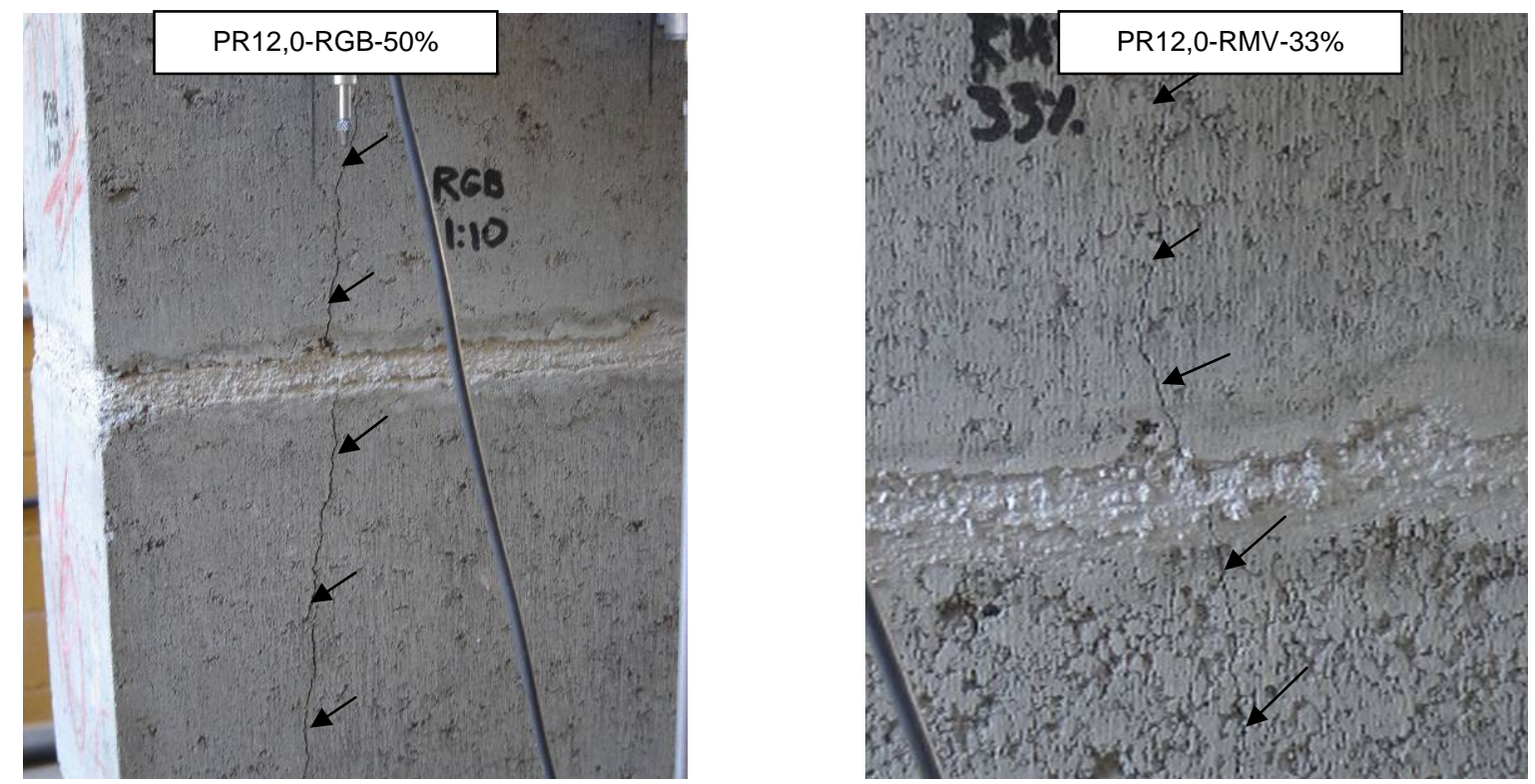

Figura 8.9 - Ruptura típica dos prismas do grupo 12,0 (PR12,0-RGB-50\% e PR12,0-RMV$33 \%)$.

Em alguns prismas foi observada fissuração vertical ao longo das paredes longitudinais da unidade provocada pelo esmagamento da argamassa, devida à sua menor resistência e maior deformabilidade comparativamente à unidade, Figura 8.10.
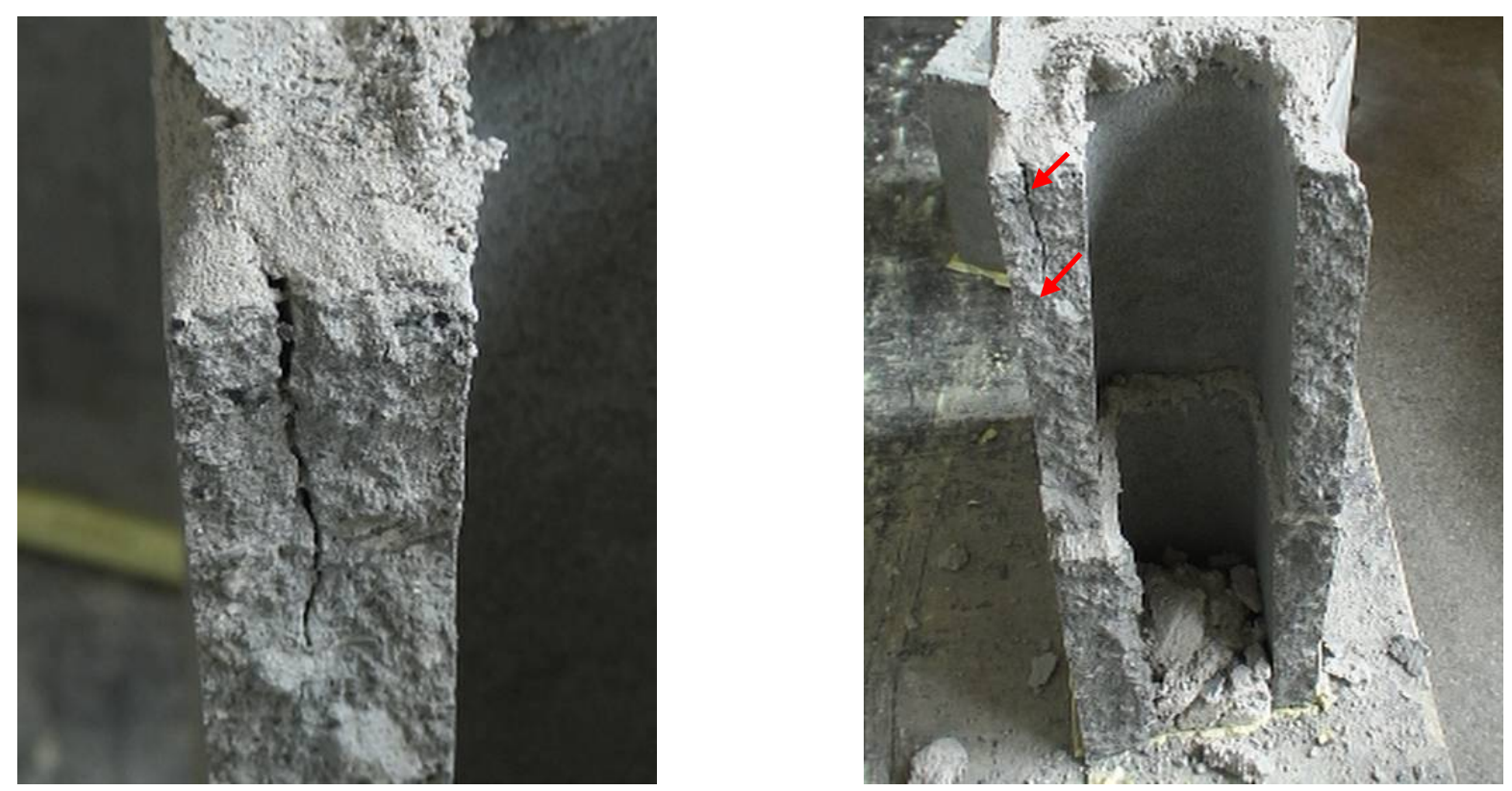

Figura 8.10 - Fissuração vertical dos blocos provocada pelo esmagamento da argamassa. 


\subsubsection{ANÁLISE DOS RESULTADOS OBTIDOS - PRISMAS}

Neste item, é utilizado o teste de Análise de Variância para avaliação global dos resultados obtidos (resistência à compressão dos prismas, argamassas, blocos e módulo de deformação dos prismas). Essa análise permitirá uma avaliação da influência das unidades com agregados reciclados nas propriedades mecânicas dos prismas.

$\mathrm{Na}$ Tabela 8.23, são apresentados os resultados do referido teste considerando-se a influência dos diferentes traços e grupos (variáveis) sobre as seguintes propriedades: resistência à compressão e módulo de deformação dos prismas e resistência à compressão de argamassas e blocos.

Tabela 8.23 - Teste ANOVA para as propriedades de resistência à compressão (prismas, blocos e argamassas) e módulo de deformação dos prismas.

\begin{tabular}{|c|c|c|c|c|c|c|c|c|c|c|c|c|}
\hline \multirow[b]{4}{*}{ Variáveis } & \multicolumn{12}{|c|}{ Propriedades } \\
\hline & \multicolumn{3}{|c|}{$f_{c}$.prismas } & \multicolumn{3}{|c|}{$E_{c}$.prismas } & \multicolumn{3}{|c|}{$f_{c}-$ blocos } & \multicolumn{3}{|c|}{$f_{c \text { - argamassa }}$} \\
\hline & Grupos & & & Grupos & & & Grupos & & & Grupos & & \\
\hline & $\begin{array}{c}4,5 ; 8,0 \\
12,0\end{array}$ & Traços & $\begin{array}{c}\text { Grupos } \\
x \\
\text { Traços }\end{array}$ & $\begin{array}{l}4,5 \\
8,0 ; \\
12,0\end{array}$ & Traços & $\begin{array}{c}\text { Grupos } \\
x \\
\text { Traços }\end{array}$ & $\begin{array}{l}4,5 ; \\
8,0 \\
12,0\end{array}$ & Traços & $\begin{array}{c}\text { Grupos } \\
x \\
\text { Traços }\end{array}$ & $\begin{array}{c}4,5 ; 8,0 \\
12,0\end{array}$ & Traços & $\begin{array}{c}\text { Grupos } \\
x \\
\text { Traços }\end{array}$ \\
\hline $\begin{array}{l}\text { REF x RGV-100\% } \% \\
\text { RGV-50\% x RGB-50\% }\end{array}$ & $\begin{array}{c}S \\
\left(F_{0}=\right. \\
216,5)\end{array}$ & $\begin{array}{c}\mathrm{S} \\
(10,0)\end{array}$ & $\begin{array}{c}\mathrm{S} \\
(10,2)\end{array}$ & $\begin{array}{c}\mathrm{S} \\
(75,8)\end{array}$ & - & - & $\begin{array}{c}\mathrm{S} \\
(95,8)\end{array}$ & $\mathrm{S}(9,3)$ & $S(4,2)$ & $\mathrm{S}(26,7)$ & $\begin{array}{c}\mathrm{S} \\
(15,0)\end{array}$ & $S(9,0)$ \\
\hline $\begin{array}{c}\text { REF } \times \text { RGV- }-100 \% \times \\
\text { RGV- } 50 \%\end{array}$ & $\begin{array}{c}\mathrm{S} \\
(175,9)\end{array}$ & $\begin{array}{c}\mathrm{S} \\
(14,9)\end{array}$ & $\begin{array}{c}\mathrm{S} \\
(16,6)\end{array}$ & $\begin{array}{c}\mathrm{S} \\
(51,3)\end{array}$ & - & - & $\begin{array}{c}\mathrm{S} \\
(76,4)\end{array}$ & $\begin{array}{c}\mathrm{S} \\
(17,0)\end{array}$ & $S(6,4)$ & $S(38,2)$ & - & $\begin{array}{c}\mathrm{S} \\
(10,9)\end{array}$ \\
\hline $\begin{array}{c}\text { RGV-100\% } \times \text { RGV-50\% } \\
\times \text { RGB-50\% }\end{array}$ & $\begin{array}{c}\mathrm{S} \\
(136,7)\end{array}$ & $S(6,9)$ & $S(6,9)$ & $\begin{array}{c}\mathrm{S} \\
(65,8)\end{array}$ & - & - & $\begin{array}{c}\mathrm{S} \\
(94,6)\end{array}$ & - & - & $S(14,6)$ & $\begin{array}{c}\mathrm{S} \\
(14,0)\end{array}$ & $S(8,2)$ \\
\hline REF x RGV-100\% & $\begin{array}{c}\mathrm{S} \\
(101,6)\end{array}$ & - & $\begin{array}{c}\mathrm{S} \\
(31,2)\end{array}$ & $\begin{array}{c}\mathrm{S} \\
(26,0)\end{array}$ & - & - & $\begin{array}{c}\mathrm{S} \\
(36,4)\end{array}$ & $\begin{array}{c}\mathrm{S} \\
(12,1)\end{array}$ & $\begin{array}{c}\mathrm{S} \\
(8,9)\end{array}$ & $\mathrm{S}(40,7)$ & - & - \\
\hline REF x RGV-50\% & $\begin{array}{c}\mathrm{S} \\
(179,0)\end{array}$ & $\begin{array}{c}\mathrm{S} \\
(29,9)\end{array}$ & $S(4,6)$ & $\begin{array}{c}\mathrm{S} \\
(38,4)\end{array}$ & - & - & $\begin{array}{c}\mathrm{S} \\
(46,0)\end{array}$ & $\begin{array}{c}\mathrm{S} \\
(32,2)\end{array}$ & $\begin{array}{c}\mathrm{S} \\
(8,4)\end{array}$ & $S(25,9)$ & $S(6,7)$ & $\begin{array}{c}\mathrm{S} \\
(24,2)\end{array}$ \\
\hline REF x RGB-50\% & $\begin{array}{c}\mathrm{S} \\
(132,9)\end{array}$ & $\begin{array}{c}\mathrm{S} \\
(11,4)\end{array}$ & $S(5,8)$ & $\begin{array}{c}\mathrm{S} \\
(36,7)\end{array}$ & - & - & $\begin{array}{c}\mathrm{S} \\
(31,9)\end{array}$ & $\begin{array}{c}\mathrm{S} \\
(8,8)\end{array}$ & $\begin{array}{c}\mathrm{S} \\
(6,7)\end{array}$ & $\mathrm{S}(9,5)$ & $\begin{array}{c}\mathrm{S} \\
(40,3)\end{array}$ & $\begin{array}{c}\mathrm{S} \\
(13,7)\end{array}$ \\
\hline RGV-100\% x RGV-50\% & $\mathrm{S}(94,9)$ & $\begin{array}{c}\mathrm{S} \\
(14,8)\end{array}$ & $\begin{array}{c}\mathrm{S} \\
(13,1)\end{array}$ & $\begin{array}{c}\mathrm{S} \\
(39,7)\end{array}$ & - & - & $\begin{array}{c}\mathrm{S} \\
(83,5)\end{array}$ & $\mathrm{S}(5,1)$ & - & $\mathrm{S}(20,6)$ & - & $\begin{array}{c}\mathrm{S} \\
(11,4)\end{array}$ \\
\hline RGV-100\% x RGB-50\% & $\mathrm{S}(72,3)$ & - & $S(7,7)$ & $\begin{array}{c}\mathrm{S} \\
(38,9)\end{array}$ & - & - & $\begin{array}{c}\mathrm{S} \\
(53,5)\end{array}$ & - & - & $\mathrm{S}(7,3)$ & $\begin{array}{c}\mathrm{S} \\
(23,0)\end{array}$ & $S(8,6)$ \\
\hline RGV-50\% X RGB-50\% & $\begin{array}{c}\mathrm{S} \\
(115,0) \\
\end{array}$ & - & - & $\begin{array}{c}\mathrm{S} \\
(56,0)\end{array}$ & - & - & $\begin{array}{c}\mathrm{S} \\
(61,2)\end{array}$ & - & - & $\mathrm{S}(10,7)$ & $\begin{array}{c}\mathrm{S} \\
(15,1)\end{array}$ & $\mathrm{S}(4,5)$ \\
\hline
\end{tabular}

Pela Tabela 8.23, nota-se que para análise de $1^{\mathrm{a}}$ ordem, houve, para todos os casos, influência significativa da variável "grupos" sobre as propriedades avaliadas. Os maiores valores médios de resistência à compressão (prismas e blocos) e módulo de deformação dos prismas foram obtidos para os elementos/unidades do Grupo 12,0 e os menores valores médios para os elementos/unidades do Grupo 4,5. Com relação às argamassas, apesar da utilização do mesmo traço, foram notadas diferenças significativas na resistência à compressão quando comparados os valores obtidos considerando-se as diferentes classes de resistência de prismas. De maneira geral, as argamassas que foram utilizadas para assentamento das unidades do Grupo 4,5 e do Grupo 12,0 apresentaram os maiores e menores valores médios de resistência à compressão, respectivamente. 
Com relação à variável "traço", pode-se dizer que houve influência significativa dos diferentes traços avaliados na resistência à compressão. De maneira geral, os valores médios para os prismas de referência foram superiores aos obtidos para os prismas com agregados reciclados, com exceção dos prismas PR-RGV-100\%. Com relação aos prismas compostos por unidades com agregados reciclados, pode-se afirmar que os valores médios de resistência à compressão dos prismas PR-RGV-100\% foram superiores aos obtidos para os prismas PR-RGV-50\%, provavelmente, a maior resistência das unidades RGV-100\% contribuiu para esses valores. Por outro lado, apesar da maior resistência da argamassa dos prismas PR-RGV-100\% e PR-RGV-50\%, comparativamente aos prismas PR-RGB-50\%, os valores de resistência à compressão dos seguintes prismas foram considerados semelhantes: (PR-RGV-100\% e PR-RGB-50\%) e (PR-RGV-50\% e PR-RGB-50\%); para esses traços, os valores de resistência dos blocos, independentemente da classe de resistência, também foram considerados semelhantes. Considerando-se o módulo de deformação dos prismas, pode-se afirmar que não houve influência significativa da variável "traço" sobre essa propriedade; nesse caso, os resultados obtidos para os prismas compostos por unidades de referência e com agregados reciclados foram considerados semelhantes.

Com relação aos resultados das argamassas, apesar das dosagens serem semelhantes, pode-se dizer que os maiores valores de resistência à compressão foram obtidos para as argamassas dos prismas PR-RGV-100\% (PR-RGV-100\% x PR-RGB-50\%), PR-RGV-50\% (PR-RGV-50\% x PR-RGB-50\%), PR-REF (PR-REF x PR-RGV-50\%) e PRREF (PR-REF x PR-RGB-50\%).

Para a análise de $2^{\mathrm{a}}$ ordem (variáveis analisadas duas a duas), observou-se uma influência significativa dos parâmetros (grupos $x$ traços), principalmente sobre a resistência dos prismas e argamassas. Nesse caso, por exemplo, para uma dada classe de resistência (4,5, por exemplo) pode-se ter um determinado tipo de prisma (PR-REF) que conduz aos maiores valores médios de resistência à compressão; entretanto, para outro grupo (8,0, por exemplo), esse mesmo tipo de prisma (PR-REF) pode não levar necessariamente aos maiores valores médios de resistência. Essa analogia também é válida para os resultados das argamassas.

Na Tabela 8.24, são apresentados os resultados do teste ANOVA considerando-se a influência dos diferentes traços, inclusive os traços com agregados miúdos reciclados, e grupos (8,0 e 12,0) sobre as seguintes propriedades: resistência à compressão e módulo de deformação dos prismas e resistência à compressão de argamassas e blocos. 
Tabela 8.24 - Teste ANOVA para as propriedades de resistência à compressão (prismas, blocos e argamassas) e módulo de deformação dos prismas (Grupos 8,0 e 12,0).

\begin{tabular}{|c|c|c|c|c|c|c|c|c|c|c|c|c|}
\hline \multirow[b]{4}{*}{ Variáveis } & \multicolumn{12}{|c|}{ Propriedades } \\
\hline & \multicolumn{3}{|c|}{$f_{c-p r i s m a s}$} & \multicolumn{3}{|c|}{$E_{c}$ prismas } & \multicolumn{3}{|c|}{$f_{c}-$ blocos } & \multicolumn{3}{|c|}{$f_{c \text { - argamassa }}$} \\
\hline & Grupos & \multirow[b]{2}{*}{ Traços } & \multirow{2}{*}{$\begin{array}{c}\text { Grupos } \\
x \\
\text { Traços }\end{array}$} & \multirow{2}{*}{$\begin{array}{c}\text { Grupos } \\
8,0 ; \\
12,0\end{array}$} & \multirow[b]{2}{*}{ Traços } & \multirow{2}{*}{$\begin{array}{c}\text { Grupos } \\
x \\
\text { Traços }\end{array}$} & \multirow{2}{*}{$\begin{array}{c}\text { Grupos } \\
8,0 ; \\
12,0\end{array}$} & \multirow[b]{2}{*}{ Traços } & \multirow{2}{*}{$\begin{array}{c}\text { Grupos } \\
x \\
\text { Traços }\end{array}$} & \multirow{2}{*}{$\begin{array}{c}\text { Grupos } \\
8,0 ; \\
12,0\end{array}$} & \multirow[b]{2}{*}{ Traços } & \multirow{2}{*}{$\begin{array}{c}\text { Grupos } \\
x \\
\text { Traços }\end{array}$} \\
\hline & 8,$0 ; 12,0$ & & & & & & & & & & & \\
\hline REF $\times$ RECICLADOS & $\begin{array}{c}S \\
\left(F_{0}=\right. \\
152,0)\end{array}$ & $\mathrm{S}(3,7)$ & $\begin{array}{c}\mathrm{S} \\
(13,2)\end{array}$ & $\begin{array}{c}\mathrm{S} \\
(39,9)\end{array}$ & - & - & $\begin{array}{c}\mathrm{S} \\
(100,5)\end{array}$ & - & $S(5,0)$ & $S(16,3)$ & $S(4,8)$ & $S(6,1)$ \\
\hline $\begin{array}{c}\text { REF } \times \text { RGV-100\% } \times \\
\text { RGV-50\% } \times \text { RMV-33\% }\end{array}$ & $\mathrm{S}(96,1)$ & $S(4,5)$ & $\begin{array}{c}\mathrm{S} \\
(21,2)\end{array}$ & $\begin{array}{c}\mathrm{S} \\
(39,2)\end{array}$ & - & - & $\begin{array}{c}\mathrm{S} \\
(64,7)\end{array}$ & - & - & $\mathrm{S}(22,7)$ & - & $\mathrm{S}(5,1)$ \\
\hline $\begin{array}{c}\text { RGV-100\% } \times \text { RGV-50\% } \\
\times \text { RMV-33\% }\end{array}$ & $\mathrm{S}(37,6)$ & - & $\begin{array}{c}\text { S } \\
(20,7)\end{array}$ & $\begin{array}{c}\mathrm{S} \\
(25,4)\end{array}$ & - & - & $\begin{array}{c}\mathrm{S} \\
(52,2)\end{array}$ & - & - & $\mathrm{S}(7,7)$ & - & $\mathrm{S}(4,4)$ \\
\hline $\begin{array}{c}\text { REF } \times \text { RGB- } 50 \% \times \\
\text { RMB-33\% }\end{array}$ & $\begin{array}{c}\mathrm{S} \\
(120,9)\end{array}$ & $S(6,0)$ & $\mathrm{S}(5,4)$ & $\begin{array}{c}\mathrm{S} \\
(15,1)\end{array}$ & - & - & $\begin{array}{c}\mathrm{S} \\
(54,2)\end{array}$ & - & $\mathrm{S}(4,9)$ & $\mathrm{S}(10,2)$ & $\begin{array}{c}\mathrm{S} \\
(17,5)\end{array}$ & $\begin{array}{c}\mathrm{S} \\
(15,5)\end{array}$ \\
\hline RGB-50\% x RMB-33\% & $\mathrm{S}(56,2)$ & - & $S(6,6)$ & $S(4,5)$ & - & - & $\begin{array}{c}\mathrm{S} \\
(38,6)\end{array}$ & - & $\mathrm{S}(8,3)$ & - & - & - \\
\hline RMV-33\% x RMB-33\% & S (125) & - & - & $S(6,0)$ & - & - & $\begin{array}{c}\mathrm{S} \\
(91,7)\end{array}$ & - & $\mathrm{S}(8,2)$ & - & - & - \\
\hline RGV-50\% x RMV-33\% & $\mathrm{S}(86,7)$ & - & - & $\begin{array}{c}\mathrm{S} \\
(21,1)\end{array}$ & - & - & $\begin{array}{c}\mathrm{S} \\
(65,1)\end{array}$ & - & - & - & - & - \\
\hline
\end{tabular}

Pela Tabela 8.24, nota-se que para a análise de $1^{\mathrm{a}}$ ordem, houve, para todos os casos, influência significativa da variável "grupos" sobre as propriedades avaliadas. Os maiores valores médios de resistência à compressão (prismas e blocos) e módulo de deformação dos prismas foram obtidos para os elementos/unidades do Grupo 12,0 e os menores valores médios para os elementos/unidades do Grupo 4,5. Com relação às argamassas, apesar do emprego do mesmo traço, foram notadas, para grande parte das comparações, diferenças significativas na resistência à compressão das argamassas para as distintas classes de resistência de prismas $(8,0$ e 12,0$)$. Comparando-se apenas os prismas compostos por unidades com agregados reciclados, pode-se afirmar que não houve diferenças significativas na resistência das argamassas desses elementos considerando-se as variáveis "grupos" e "traços". De maneira geral, as argamassas utilizadas para o assentamento das unidades do Grupo 8,0 e do Grupo 12,0 apresentaram os maiores e menores valores médios de resistência à compressão, respectivamente.

Com relação à variável "traço", pode-se dizer, com exceção das comparações entre os prismas compostos por unidades com agregados reciclados, que houve influência significativa dos diferentes traços avaliados na resistência à compressão. De maneira geral, os valores médios para os prismas de referência foram superiores aos obtidos para os prismas com agregados reciclados. Para os prismas compostos por unidades com agregados reciclados, não foram observadas diferenças significativas na resistência à compressão e módulo de deformação desses elementos, bem como nas propriedades de resistência dos blocos e argamassas. Considerando-se o módulo de deformação dos prismas, pode-se afirmar que não houve influência significativa da variável "traço" sobre 
essa propriedade; nesse caso, os resultados foram considerados semelhantes para qualquer um dos prismas avaliados.

Para a análise de segunda ordem (variáveis analisadas duas a duas), foi observada influência significativa dos parâmetros (grupos $x$ traços), principalmente sobre a resistência à compressão dos prismas, blocos e argamassas.

\subsection{RESULTADOS E ANÁLISES - MINIPAREDES}

Visando facilitar a compreensão dos resultados, é apresentado separadamente os valores obtidos para cada grupo de miniparede (Grupo 4,5; Grupo 8,0; Grupo 12,0). Para execução desses elementos, foi utilizada a mesma argamassa empregada nos prismas, sendo a consistência definida pelo pedreiro. No Apêndice $V$, são apresentados alguns gráficos típicos de curvas tensão x deformação das miniparedes dos Grupos 4,5, 8,0 e 12,0. As principais características de cada uma das dosagens de argamassa são apresentadas no item 6.5.1.

\subsubsection{CARACTERÍSTICAS DAS ARGAMASSAS}

$\mathrm{Na}$ Tabela 8.25, encontram-se as características das argamassas de assentamento, bem como da argamassa de capeamento dos blocos inferiores e superiores das miniparedes.

Tabela 8.25 - Características das argamassas utilizadas para o assentamento e capeamento das unidades.

\begin{tabular}{|c|c|c|c|c|c|c|c|c|c|c|c|c|}
\hline \multirow{2}{*}{$\begin{array}{l}\text { Desig. } \\
\text { Argam }\end{array}$} & \multirow{2}{*}{$\begin{array}{l}\text { Miniparedes } \\
\text { produzidas }\end{array}$} & \multirow{2}{*}{ Quant. } & \multirow{2}{*}{ Data } & \multirow{2}{*}{$\begin{array}{l}\text { Horário de } \\
\text { moldagem }\end{array}$} & \multirow{2}{*}{$\begin{array}{c}\mathrm{T} \\
\left({ }^{\circ} \mathrm{C}\right)\end{array}$} & \multirow{2}{*}{$\begin{array}{c}U \\
(\%)\end{array}$} & \multicolumn{4}{|c|}{ Consumo de materiais $\left(\mathrm{kg} / \mathrm{m}^{3}\right)$} & \multirow{2}{*}{$\begin{array}{l}\text { Cons. } \\
(\mathrm{mm})\end{array}$} & \multirow{2}{*}{$\begin{array}{c}\mathrm{N}^{\circ} \mathrm{CPs} \\
\text { fabricados }\end{array}$} \\
\hline & & & & & & & Cimento & Areia & Cal & Água & & \\
\hline G & PAR4,5-REF & 3 & $14 / 02$ & $8: 50$ & 24,5 & 74,7 & 245,4 & 1509,3 & 85,9 & 319,0 & 256 & 6 \\
\hline $\mathrm{H}$ & PAR4,5-RGV-100\% & 3 & $14 / 02$ & $10: 20$ & 26,4 & 75,7 & 242,4 & 1491,0 & 84,9 & 327,3 & 284 & 6 \\
\hline 1 & PAR4,5-RGB-50\% & 3 & $16 / 02$ & $14: 45$ & 23,7 & 87,0 & 242,4 & 1498,2 & 85,3 & 328,9 & 257 & 6 \\
\hline $\mathrm{J}$ & PAR8,0-REF & 3 & $14 / 02$ & $14: 15$ & 30,9 & 59,5 & 242,8 & 1493,3 & 85,0 & 326,2 & 277 & 6 \\
\hline $\mathrm{K}$ & PAR8,0-RGV-100\% & 3 & $14 / 02$ & $15: 30$ & 29,2 & 66,0 & 242,5 & 1491,4 & 84,9 & 327,1 & 268 & 6 \\
\hline L & PAR8,0-RGB-50\% & 3 & $16 / 02$ & $14: 00$ & 22,9 & 92,0 & 242,4 & 1498,2 & 85,3 & 328,9 & 270 & 6 \\
\hline M & PAR12,0-REF & 3 & $16 / 02$ & 9:00 & 20,7 & 94,5 & 242,5 & 1498,2 & 85,3 & 328,5 & 258 & 6 \\
\hline $\mathrm{N}$ & PAR12,0-RGV-100\% & 3 & $14 / 02$ & $16: 30$ & 26,9 & 72,5 & 243,6 & 1498,2 & 85,3 & 324,0 & 274 & 6 \\
\hline $\mathrm{O}$ & PAR12,0-RGB-50\% & 3 & $16 / 02$ & 10:00 & 21,2 & 93,5 & 242,5 & 1498,2 & 85,3 & 328,6 & 270 & 6 \\
\hline CAP & $\begin{array}{c}\text { Argamassa de } \\
\text { capeamento dos } \\
\text { blocos }\end{array}$ & - & $09 / 02$ & - & - & - & 903,0 & 903,0 & - & 364,1 & - & - \\
\hline
\end{tabular}


A argamassa de capeamento dos blocos foi ensaiada juntamente com os corpos-deprova de argamassa. $\mathrm{Na}$ idade de 48 dias, a argamassa de capeamento apresentou uma resistência à compressão média de 38,8 MPa.

\subsubsection{GRUPO 4,5}

A terminologia adotada é apresentada na Tabela 8.26.

Tabela 8.26 - Terminologia adotada para as miniparedes do Grupo 4,5.

\begin{tabular}{cccc}
\hline $\begin{array}{c}\text { GRUPO/CLASSE } \\
\text { DE RESISTENNCIA } \\
\text { DAS UNIDADES }\end{array}$ & DESIGNAÇÃo & CARACTERístICAS & $\begin{array}{c}\text { ARGAMASSA DE } \\
\text { ASSENTAMENTO }\end{array}$ \\
\hline & PAR4,5-REF & Miniparedes compostas por unidades produzidas com \\
agregados naturais & G \\
\cline { 2 - 4 } 4,5 & $\begin{array}{c}\text { PAR4,5-RGV- } \\
100 \%\end{array}$ & $\begin{array}{c}\text { Miniparedes compostas por unidades com 100\% de } \\
\text { substituição, em massa, da fração graúda natural (pedrisco) } \\
\text { por agregado graúdo reciclado de vigota (GRV) }\end{array}$ & $\mathrm{H}$ \\
\cline { 2 - 4 } & $\begin{array}{c}\text { Miniparedes compostas por unidades com } \\
\text { PAR4,5-RGB- } \\
50 \%\end{array}$ & $\begin{array}{c}\text { aproximadamente 50\% de substituição, em massa, da } \\
\text { fração graúda natural por agregado graúdo reciclado de } \\
\text { bloco (GRb) }\end{array}$ & $\mathrm{I}$ \\
\hline
\end{tabular}

Os resultados de resistência à compressão e módulo de deformação das miniparedes são apresentados na Tabela 8.27.

Tabela 8.27 - Valores de resistência à compressão e módulo de deformação das miniparedes do Grupo 4,5.

\begin{tabular}{|c|c|c|c|c|c|c|}
\hline Miniparede & Parâmetros & $\begin{array}{l}\text { Idade } \\
\text { (dias) }\end{array}$ & $\begin{array}{l}\begin{array}{c}\text { Tensão - } A_{\text {bruta }} \\
\text { (MPa) }\end{array} \\
\end{array}$ & $\begin{array}{c}\begin{array}{c}\text { Módulo - } A_{\text {bruta }} \\
\text { (MPa) }\end{array} \\
\end{array}$ & $\begin{array}{c}\text { Def. 33\% da } \\
\text { tensão última (\%o) }\end{array}$ & $\begin{array}{c}\text { Deformação última } \\
(\% \circ)\end{array}$ \\
\hline \multirow{5}{*}{ PAR4,5-REF } & Média & \multirow{2}{*}{43} & 6,61 & 8054 & $-0,27$ & $-1,79$ \\
\hline & Máximo & & 7,64 & 9796 & $-0,30$ & $-2,13$ \\
\hline & Mínimo & 42 & 5,60 & 6114 & $-0,25$ & $-1,39$ \\
\hline & $\mathrm{S}_{\mathrm{d}}$ & \multirow[t]{2}{*}{42} & 1,02 & 1849 & 0,02 & 0,37 \\
\hline & C.V (\%) & & 15,41 & 22,96 & 8,74 & 20,72 \\
\hline \multirow{5}{*}{ PAR4,5-RGV-100\% } & Média & \multirow{2}{*}{43} & 6,56 & 8697 & $-0,24$ & $-1,89$ \\
\hline & Máximo & & 7,04 & 9462 & $-0,29$ & $-2,13$ \\
\hline & Mínimo & 43 & 5,91 & 7798 & $-0,21$ & $-1,48$ \\
\hline & $\mathrm{S}_{\mathrm{d}}$ & \multirow[t]{2}{*}{43} & 0,58 & 840 & 0,04 & 0,35 \\
\hline & C.V (\%) & & 8,89 & 9,66 & 17,26 & 18,71 \\
\hline \multirow{5}{*}{ PAR4,5-RGB-50\% } & Média & \multirow[b]{2}{*}{39} & 6,28 & 10398 & $-0,19$ & $-1,71$ \\
\hline & Máximo & & 6,47 & 10492 & $-0,20$ & $-1,90$ \\
\hline & Mínimo & 35 & 6,11 & 10335 & $-0,18$ & $-1,60$ \\
\hline & $\mathrm{S}_{\mathrm{d}}$ & \multirow[t]{2}{*}{35} & 0,18 & 83 & 0,01 & 0,17 \\
\hline & C.V (\%) & & 2,88 & 0,80 & 3,35 & 9,69 \\
\hline \multicolumn{2}{|c|}{ Média geral do Grupo 4,5 } & & 6,48 & 9050 & $-0,23$ & $-1,80$ \\
\hline
\end{tabular}

Pela Tabela 8.27, nota-se que não houve diferença na resistência à compressão das miniparedes compostas por unidades com agregados reciclados comparativamente às miniparedes de referência. A resistência das miniparedes, assentadas com argamassa 
média $(1: 0,5: 4,5)$ de resistência de $5,63 \mathrm{MPa}$ e compostas por unidades de resistência média de 11,50 MPa, foi de 6,48 MPa. Freitas (2006), ensaiando miniparedes de 0,80 $\mathrm{m} \mathrm{x}$ 0,80 m, utilizando dois tipos de argamassas (1:0,5:4,5 e 1:1:6) e blocos de concreto de 4,5 $\mathrm{MPa}\left(\mathrm{f}_{\mathrm{cm}}=9,08 \mathrm{MPa}\right)$, produzidos pelo mesmo fabricante (Tatu Pré-Moldados) da presente pesquisa, obteve valores médios de resistência à compressão de 5,91 MPa e 2,92 MPa para as argamassas média ( $\left.f_{\text {arg }}=5,80 \mathrm{MPa}\right)$ e fraca $\left(f_{\text {arg }}=4,73 \mathrm{MPa}\right)$, respectivamente. JUSTE (2001), avaliando miniparedes de 0,80m x 0,80m, compostas por unidades de concreto de 10,80 MPa também produzidos pela Tatu Pré-Moldados, obteve valores médios de resistência à compressão de 4,12 MPa e 4,97 MPa para as argamassas fraca ( $f_{\text {arg }}=5,05$ $\mathrm{MPa}$ ) e média ( $\left.f_{\text {arg }}=10,24 \mathrm{MPa}\right)$, respectivamente.

Com relação ao módulo de deformação, o valor médio obtido para as miniparedes do grupo 4,5 foi de $9.050 \mathrm{MPa}$. Juste (2001) obteve valores de módulo de deformação entre 6.393MPa e 6.440MPa, para miniparedes $(0,80 \mathrm{~m} \times 0,80 \mathrm{~m})$, que apresentaram resistência à compressão de 4,97 MPa ( $\left.f_{\text {arg }}=10,24 \mathrm{MPa}\right)$ e 4,13 MPa ( $\left.f_{\text {arg }}=5,05 \mathrm{MPa}\right)$, respectivamente.

$\mathrm{Na}$ Tabela 8.28, são apresentados os fatores de eficiência (miniparede/prisma) e (miniparede/bloco), a razão entre o módulo de deformação e a resistência das miniparedes e a relação entre o módulo de deformação dos diferentes elementos (miniparede/prisma).

Tabela 8.28 - Fatores de eficiência, razão entre o módulo e resistência e relação entre o módulo de deformação dos diferentes elementos - Grupo 4,5.

\begin{tabular}{|c|c|c|c|c|}
\hline & \multicolumn{2}{|c|}{ Fatores de eficiência } & \multirow{2}{*}{$\underset{f_{\text {miniparede }}}{E_{\text {miniparede }} I}$} & \multirow{2}{*}{$\underset{E_{\text {prisma }}}{E_{\text {miniparede }} I}$} \\
\hline & $f_{\text {Miniparede }} / f_{\text {prisma }}$ & $f_{\text {Miniparede }} / f_{\text {bloco }}$ & & \\
\hline PAR4,5-REF & 0,923 & 0,434 & 1218 & 0,974 \\
\hline PAR4,5-RGV-100\% & 0,928 & 0,660 & 1326 & 1,215 \\
\hline PAR4,5-RGB-50\% & 1,005 & 0,674 & 1655 & 1,380 \\
\hline Média geral do Grupo 4,5 & 0,952 & 0,589 & 1400 & 1,190 \\
\hline
\end{tabular}

Pela Tabela 8.28, nota-se que os fatores de eficiência foram de 0,952 ( $f_{\text {miniparede }} / f_{\text {prisma }}$ ) e 0,589 $\left(f_{\text {miniparede }} / f_{\text {bloco }}\right)$. A razão entre o módulo de deformação e a resistência à compressão das miniparedes foi de 1400; Juste (2001) obteve valores próximos a 1425 para essa relação. FREITAS (2006) obteve fatores de eficiência (miniparede/prisma de três blocos) de $0,87\left(f_{\text {arg }}=5,80 \mathrm{MPa}\right)$ e 0,46 ( $f_{\text {arg }}=4,73 \mathrm{MPa}$ ) e fatores de eficiência (miniparede/bloco) de $0,65\left(f_{\text {arg }}=5,80 \mathrm{MPa}\right)$ e 0,32 ( $\left.f_{\text {arg }}=4,73 \mathrm{MPa}\right)$, para blocos de resistência média de 9,08 $\mathrm{MPa}$. 
Os resultados das propriedades físicas e mecânicas dos CPs de argamassa encontram-se na Tabela 8.29.

Tabela 8.29 - Resultados das propriedades físicas e mecânicas do CPs de argamassa das miniparedes do grupo 4,5.

\begin{tabular}{|c|c|c|c|c|c|c|c|c|c|}
\hline \multirow[b]{2}{*}{ Miniparede } & \multirow[b]{2}{*}{$\begin{array}{l}\text { Designação } \\
\text { Argamassa }\end{array}$} & \multirow[b]{2}{*}{ Parâm. } & \multirow[b]{2}{*}{ Idade } & \multirow[b]{2}{*}{$\begin{array}{c}\text { Massa } \\
\text { dos CPs }\end{array}$} & \multicolumn{5}{|c|}{ Propriedades Mecânicas } \\
\hline & & & & & $\begin{array}{c}\text { Força } \\
\text { última } \\
(\mathrm{kgf})\end{array}$ & $\begin{array}{c}\text { Tensão } \\
\text { (MPa) }\end{array}$ & $\begin{array}{l}\text { Módulo } \\
\text { (GPa) }\end{array}$ & $\begin{array}{l}\text { Def. } \\
\text { Última } \\
(\%)\end{array}$ & $\begin{array}{c}\mathrm{f}_{\text {arg }} l_{1} \\
\mathrm{f}_{\text {bloco }}\end{array}$ \\
\hline \multirow{5}{*}{ PAR4,5- REF } & \multirow{5}{*}{ G } & Média & \multirow{5}{*}{44} & 395,2 & 1169 & 5,95 & 7,38 & $-2,78$ & \multirow{5}{*}{0,391} \\
\hline & & Máx. & & 398,2 & 1335 & 6,80 & 8,16 & $-3,53$ & \\
\hline & & Mín. & & 389,3 & 977 & 4,97 & 6,04 & $-1,73$ & \\
\hline & & $S_{d}$ & & 3,5 & 135 & 0,69 & 0,84 & 0,72 & \\
\hline & & C.V (\%) & & 0,88 & 11,55 & 11,55 & 11,36 & 25,84 & \\
\hline \multirow{5}{*}{ PAR4,5-RGV-100\% } & \multirow{5}{*}{$\mathrm{H}$} & Média & \multirow{5}{*}{44} & 393,3 & 1187 & 6,05 & 7,59 & $-3,33$ & \multirow{5}{*}{0,608} \\
\hline & & Máx. & & 395,8 & 1290 & 6,61 & 9,55 & $-4,84$ & \\
\hline & & Mín. & & 388,9 & 1000 & 5,09 & 5,36 & $-1,69$ & \\
\hline & & $\mathrm{S}_{\mathrm{d}}$ & & 2,7 & 122 & 0,62 & 1,59 & 1,47 & \\
\hline & & C.V (\%) & & 0,68 & 10,24 & 10,24 & 20,91 & 44,04 & \\
\hline \multirow{5}{*}{ PAR4,5-RGB-50\% } & \multirow{5}{*}{1} & Média & \multirow{5}{*}{42} & 395,5 & 963 & 4,90 & 5,24 & $-2,74$ & \multirow{5}{*}{0,662} \\
\hline & & Máx. & & 400,6 & 1076 & 5,48 & 10,15 & $-3,53$ & \\
\hline & & Mín. & & 390,4 & 809 & 4,12 & 2,40 & $-1,95$ & \\
\hline & & $\mathrm{S}_{\mathrm{d}}$ & & 3,7 & 120 & 0,61 & 3,00 & 0,70 & \\
\hline & & C.V (\%) & & 0,93 & 12,44 & 12,44 & 57,30 & 25,52 & \\
\hline & Média Geral & & & 394,6 & 1106 & 5,63 & 6,74 & $-2,95$ & 0,554 \\
\hline
\end{tabular}

${ }^{1}$ relação entre a resistência da argamassa e os blocos ensaiados

Analisando-se os resultados da Tabela 8.29, observa-se que a resistência à compressão da argamassa situou-se entre 39\% e 66\% da resistência à compressão do bloco. Provavelmente, a resistência da argamassa não influenciou na resistência das miniparedes.

A ruptura das miniparedes foi caracterizada pela propagação de fissuras verticais. Além disso, foram observadas fissuras verticais ao longo dos septos transversais das miniparedes e, em alguns elementos, fissuras na interface entre argamassa e unidade decorrentes de prováveis falhas na aderência entre esses dois materiais, Figura 8.11. Em alguns ensaios, apesar do capeamento dos blocos e utilização do forropacote nas faces superior e inferior das miniparedes, ocorreu ruptura prematura de exemplares devido à concentração de tensões. 

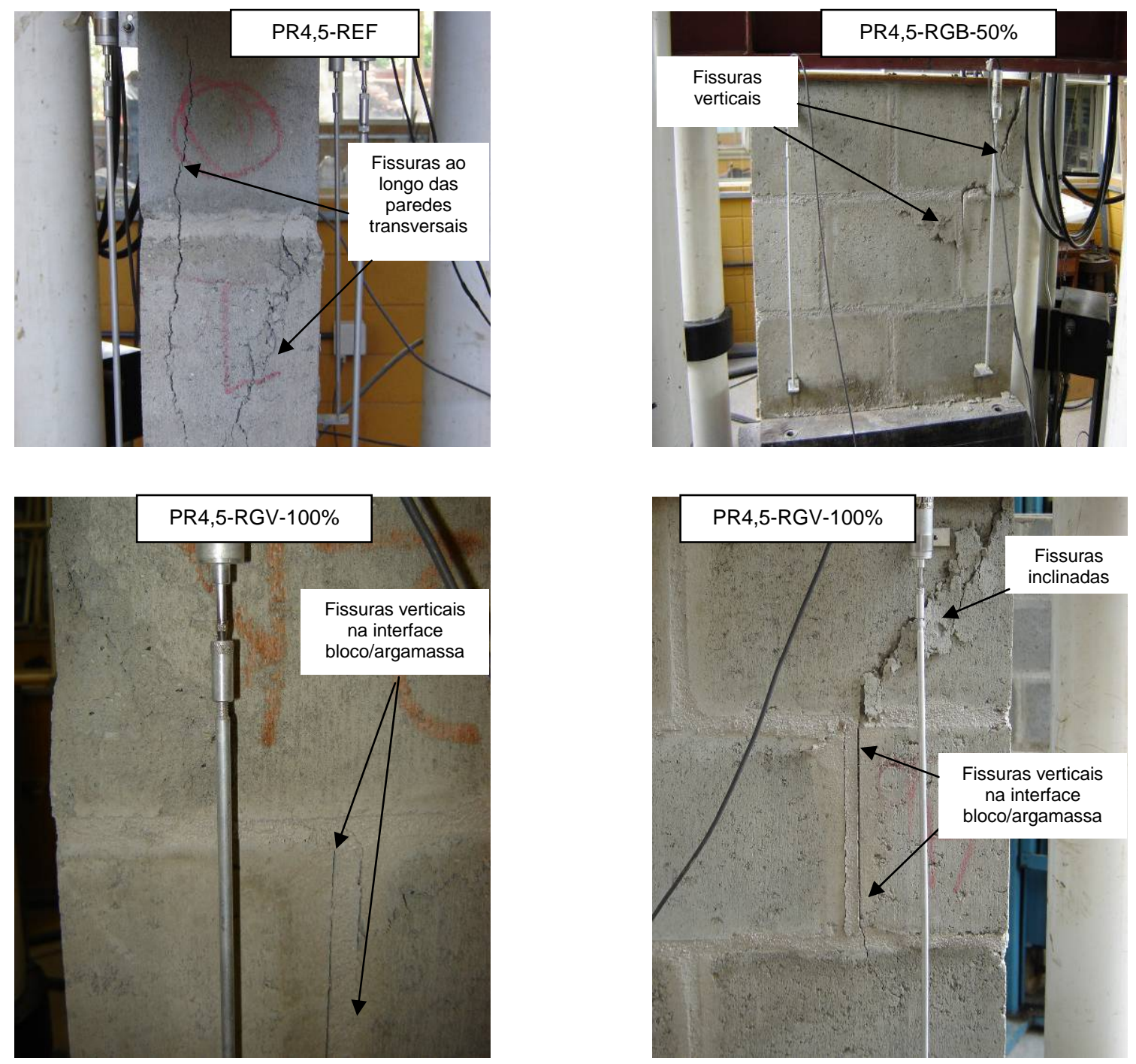

Figura 8.11 - Ruptura típica das miniparedes do Grupo 4,5.

\subsubsection{GRUPO 8,0}

A terminologia adotada são apresentadas na Tabela 8.30.

Tabela 8.30 - Terminologia adotada para as miniparedes do Grupo 8,0.

\begin{tabular}{|c|c|c|c|}
\hline $\begin{array}{l}\text { GRUPO/CLASSE } \\
\text { DE RESISTÊNCIA } \\
\text { DAS UNIDADES } \\
\end{array}$ & DESIGNAÇÃO & CARACTERÍSTICAS & $\begin{array}{l}\text { ARGAMASSA DE } \\
\text { ASSENTAMENTO }\end{array}$ \\
\hline \multirow{3}{*}{8,0} & PAR8,0-REF & $\begin{array}{l}\text { Miniparedes compostas por unidades produzidas com } \\
\text { agregados naturais }\end{array}$ & $\mathrm{J}$ \\
\hline & $\begin{array}{c}\text { PAR8,0-RGV- } \\
100 \%\end{array}$ & $\begin{array}{c}\text { Miniparedes compostas por unidades com } 100 \% \text { de } \\
\text { substituição, em massa, da fração graúda natural (pedrisco) } \\
\text { por agregado graúdo reciclado de vigota (GRv) }\end{array}$ & $\mathrm{K}$ \\
\hline & $\begin{array}{c}\text { PAR8,0-RGB- } \\
50 \%\end{array}$ & $\begin{array}{c}\text { Miniparedes compostas por unidades com } \\
\text { aproximadamente } 50 \% \text { de substituição, em massa, da } \\
\text { fração graúda natural por agregado graúdo reciclado de } \\
\text { bloco (GRb) }\end{array}$ & L \\
\hline
\end{tabular}


Os resultados de resistência à compressão e módulo de deformação das miniparedes do Grupo 8,0 são apresentados na Tabela 8.31.

Tabela 8.31 - Valores de resistência à compressão e módulo de deformação das miniparedes do Grupo 8,0.

\begin{tabular}{|c|c|c|c|c|c|c|}
\hline Miniparedes & Parâmetros & $\begin{array}{l}\text { Idade } \\
\text { (dias) }\end{array}$ & $\begin{array}{c}\text { Tensão - A } \text { A }_{\text {bruta }} \\
\text { (MPa) }\end{array}$ & Módulo - $A_{\text {bruta }}(\mathrm{MPa})$ & $\begin{array}{c}\text { Def. 33\% da } \\
\text { tensão última } \\
\text { (\%) }\end{array}$ & $\begin{array}{c}\text { Deformação } \\
\text { última (\%) }\end{array}$ \\
\hline \multirow{3}{*}{ PAR8,0-REF } & Média & 43 & 8,31 & 11676 & $-0,24$ & $-1,55$ \\
\hline & Mínimo & 43 & 7,71 & 10379 & $-0,18$ & $-1,24$ \\
\hline & $S_{d}$ & 43 & 0,57 & 1993 & 0,05 & 0,30 \\
\hline \multirow{4}{*}{ PAR8,0-RGV-100\% } & Média & \multirow{2}{*}{43} & 6,55 & 10121 & $-0,21$ & $-1,36$ \\
\hline & Máximo & & 7,28 & 11196 & $-0,21$ & $-1,57$ \\
\hline & Mínimo & 42 & 5,48 & 8660 & $-0,21$ & $-1,10$ \\
\hline & $\mathrm{S}_{\mathrm{d}}$ & 42 & 0,94 & 1312 & 0,00 & 0,24 \\
\hline \multirow[t]{3}{*}{ PAR8,0-RGB-50\% } & Mínimo & 39 & 7,63 & 9784 & $-0,25$ & $-1,84$ \\
\hline & $S_{d}$ & \multirow{2}{*}{35} & 0,40 & 369 & 0,01 & 0,35 \\
\hline & C.V (\%) & & 4,88 & 3,62 & 2,77 & 16,12 \\
\hline \multicolumn{3}{|c|}{ Média geral do Grupo 8,0 } & 7,71 & 10667 & $-0,24$ & $-1,69$ \\
\hline
\end{tabular}

Analisando-se a Tabela 8.31, nota-se que apenas as miniparedes compostas por unidades com agregados reciclados de vigota apresentaram redução da resistência à compressão (21\%) comparativamente aos elementos de referência. A resistência das miniparedes, assentadas com argamassa média (1:0,5:4,5) de resistência de 4,94 MPa e compostas por unidades de resistência média de 15,07 MPa, foi de 7,71 MPa. Freitas (2006), ensaiando miniparedes de 0,80 $\mathrm{m} \times 0,80 \mathrm{~m}$, utilizando dois tipos de argamassas $\left(1: 0,5: 4,5\right.$ e 1:1:6) e blocos de concreto de $8,0 \mathrm{MPa}\left(\mathrm{f}_{\mathrm{cm}}=13,74 \mathrm{MPa}\right)$, produzidos pelo mesmo fabricante (Tatu Pré-Moldados) da presente pesquisa, obteve valores médios de resistência à compressão de 5,89 MPa e 6,51 MPa para as argamassas média ( $f_{\text {arg }}=7,12$ $\mathrm{MPa}$ ) e fraca ( $\mathrm{f}_{\text {arg }}=4,00 \mathrm{MPa}$ ), respectivamente. Juste (2001), avaliando miniparedes de $0,80 \mathrm{~m} \times 0,80 \mathrm{~m}$, compostas por unidades de concreto de $12 \mathrm{MPa}\left(\mathrm{f}_{\mathrm{cm}}=22,92 \mathrm{MPa}\right)$, produzidos pela Tatu Pré-Moldados, obteve valores médios de resistência à compressão de $5,65 \mathrm{MPa}$ e 8,84 MPa para as argamassas fraca ( $\left.f_{\text {arg }}=5,05 \mathrm{MPa}\right)$ e média ( $\left.f_{\text {arg }}=10,24 \mathrm{MPa}\right)$, respectivamente.

Com relação ao módulo de deformação, o valor médio obtido para as miniparedes do Grupo 8,0 foi igual a $10.667 \mathrm{MPa}$. Juste (2001) obteve valores de módulo de deformação entre $8.693 \mathrm{MPa}$ e $9.128 \mathrm{MPa}$, para miniparedes $(0,80 \mathrm{~m} \times 0,80 \mathrm{~m})$, que apresentaram 
resistência à compressão de 5,65 $\mathrm{MPa}\left(\mathrm{f}_{\text {arg }}=5,05 \mathrm{MPa}\right)$ e 8,84 $\mathrm{MPa}\left(\mathrm{f}_{\text {arg }}=10,24 \mathrm{MPa}\right)$, respectivamente.

Na Tabela 8.32, são os apresentados os fatores de eficiência (miniparede/prisma) e (miniparede/bloco), a razão entre o módulo de deformação e a resistência das miniparedes e a relação entre o módulo dos diferentes elementos (miniparede/prisma).

Tabela 8.32 - Fatores de eficiência, razão entre o módulo e resistência e relação entre o módulo dos diferentes elementos para as miniparedes do Grupo 8,0.

\begin{tabular}{|c|c|c|c|c|}
\hline & \multicolumn{2}{|c|}{ Fatores de eficiência } & \multirow{2}{*}{$\begin{array}{c}\mathbf{E}_{\text {miniparede }} I \\
\mathbf{f}_{\text {miniparede }}\end{array}$} & \multirow{2}{*}{$\underset{E_{\text {prisma }}}{\mathrm{E}_{\text {miniparede }} I}$} \\
\hline & $\mathbf{f}_{\text {Miniparede }} / \mathbf{f}_{\text {prisma }}$ & $\mathbf{f}_{\text {Miniparede }} / \mathbf{f}_{\text {bloco }}$ & & \\
\hline PAR8,0-REF & 0,955 & 0,571 & 1405 & 1,363 \\
\hline PAR8,0-RGV-100\% & 0,616 & 0,419 & 1546 & 1,168 \\
\hline PAR8,0-RGB-50\% & 0,926 & 0,549 & 1235 & 1,094 \\
\hline Média geral do Grupo 8,0 & 0,832 & 0,513 & 1395 & 1,208 \\
\hline
\end{tabular}

Pela Tabela 8.32, nota-se que os fatores de eficiência foram de 0,832 ( $f_{\text {miniparede }} / f_{\text {prisma }}$ ) e $0,513\left(f_{\text {miniparede }} / f_{\text {bloco }}\right)$. A razão entre o módulo de deformação e a resistência à compressão das miniparedes ficou com o valor médio de 1395; Juste (2001) obteve valores próximos a 1285 para essa relação. Freitas (2006) obteve fatores de eficiência (miniparede/prisma de três blocos) de 0,64 ( $\left.f_{\text {arg }}=7,12 \mathrm{MPa}\right)$ e 0,81 ( $\left.\mathrm{f}_{\text {arg }}=4,00 \mathrm{MPa}\right)$ e fatores de eficiência (miniparede/bloco) de 0,43 ( $\left.f_{\text {arg }}=7,12 \mathrm{MPa}\right)$ e 0,47 ( $\left.f_{\text {arg }}=4,00 \mathrm{MPa}\right)$, considerando blocos de resistência média de 13,74 $\mathrm{MPa}$. Juste (2001) encontrou fatores de eficiência (miniparede/prisma de três blocos) de 0,61 ( $\left.\mathrm{f}_{\text {arg }}=5,05 \mathrm{MPa}\right)$ e 1,14 ( $\mathrm{f}_{\text {arg }}=10,24 \mathrm{MPa}$ ) e fatores de eficiência (miniparede/bloco) de 0,25 ( $\left.f_{\text {arg }}=5,05 \mathrm{MPa}\right)$ e 0,39 $\left(f_{\text {arg }}=10,24 \mathrm{MPa}\right)$, para blocos de resistência de 22,92 MPa.

Os resultados das propriedades físicas e mecânicas dos CPs de argamassa das miniparedes do grupo 8,0 encontram-se na Tabela 8.33. 
Tabela 8.33 - Resultados das propriedades físicas e mecânicas do CPs de argamassa das miniparedes do grupo 8,0.

\begin{tabular}{|c|c|c|c|c|c|c|c|c|c|}
\hline \multirow[b]{2}{*}{ Miniparede } & \multirow[b]{2}{*}{$\begin{array}{l}\text { Designação } \\
\text { Argamassa }\end{array}$} & \multirow[b]{2}{*}{ Parâm. } & \multirow[b]{2}{*}{ Idade } & \multirow[b]{2}{*}{$\begin{array}{c}\text { Massa } \\
\text { dos CPs }\end{array}$} & \multicolumn{5}{|c|}{ Propriedades Mecânicas } \\
\hline & & & & & $\begin{array}{c}\text { Força } \\
\text { última } \\
(\mathrm{kgf})\end{array}$ & $\begin{array}{c}\text { Tensão } \\
\text { (MPa) }\end{array}$ & $\begin{array}{c}\text { Módulo } \\
\text { (GPa) }\end{array}$ & $\begin{array}{c}\text { Def. } \\
\text { Última } \\
(\%)\end{array}$ & $\begin{array}{r}f_{\text {arg }} I_{1} \\
f_{\text {bloco }}\end{array}$ \\
\hline \multirow{5}{*}{ PAR8,0- REF } & \multirow{5}{*}{$\mathrm{J}$} & Média & \multirow{5}{*}{44} & 395,6 & 1062 & 5,41 & 8,20 & $-3,11$ & \multirow{5}{*}{0,372} \\
\hline & & Máx. & & 398,5 & 1351 & 6,88 & 11,06 & $-4,53$ & \\
\hline & & Mín. & & 389,3 & 900 & 4,59 & 5,07 & $-1,81$ & \\
\hline & & $S_{d}$ & & 3,4 & 170 & 0,87 & 2,24 & 0,94 & \\
\hline & & C.V (\%) & & 0,85 & 16,00 & 16,00 & 27,32 & 30,07 & \\
\hline \multirow{5}{*}{ PAR8,0-RGV-100\% } & \multirow{5}{*}{$\mathrm{K}$} & Média & \multirow{5}{*}{44} & 391,7 & 939 & 4,78 & 6,51 & $-2,71$ & \multirow{5}{*}{0,306} \\
\hline & & Máx. & & 395,3 & 1122 & 5,71 & 8,56 & $-5,25$ & \\
\hline & & Mín. & & 383,2 & 778 & 3,96 & 3,01 & $-1,85$ & \\
\hline & & $\mathrm{S}_{\mathrm{d}}$ & & 5,0 & 156 & 0,79 & 2,35 & 1,44 & \\
\hline & & C.V (\%) & & 1,27 & 16,63 & 16,63 & 36,16 & 53,23 & \\
\hline \multirow{5}{*}{ PAR8,0-RGB-50\% } & \multirow{5}{*}{ L } & Média & \multirow{5}{*}{42} & 391,0 & 909 & 4,63 & 6,58 & $-3,19$ & \multirow{5}{*}{0,308} \\
\hline & & Máx. & & 395,6 & 1380 & 7,03 & 9,05 & $-4,88$ & \\
\hline & & Mín. & & 387,6 & 702 & 3,58 & 3,15 & $-1,59$ & \\
\hline & & $\mathrm{S}_{\mathrm{d}}$ & & 3,0 & 280 & 1,42 & 2,64 & 1,38 & \\
\hline & & C.V (\%) & & 0,77 & 30,74 & 30,74 & 40,19 & 43,15 & \\
\hline & Média Geral & & & 392,8 & 970 & 4,94 & 7,10 & $-3,00$ & 0,329 \\
\hline
\end{tabular}

${ }^{1}$ relação entre a resistência da argamassa e os blocos ensaiados

Analisando-se os resultados da Tabela 8.33, observa-se que a resistência à compressão da argamassa foi de 30\% a 37\% da resistência à compressão do bloco. Provavelmente, a resistência da argamassa influenciou na redução da resistência das miniparedes; para esses elementos deveria ser utilizada uma argamassa de resistência mais elevada. Segundo Calçada (1998), argamassas muito fracas podem provocar a ruptura da alvenaria por seu esmagamento; já de acordo com Barbosa (2004), argamassas menos resistentes e mais deformáveis provocam tensões de tração no bloco em virtude da sua expansão.

A ruptura das miniparedes foi caracterizada pelo esfacelamento da parte externa das paredes dos blocos, inicialmente próximo às juntas e depois se espalhando por todo o bloco, sendo provocada, principalmente, pelo esmagamento da argamassa, Figura 8.12. 

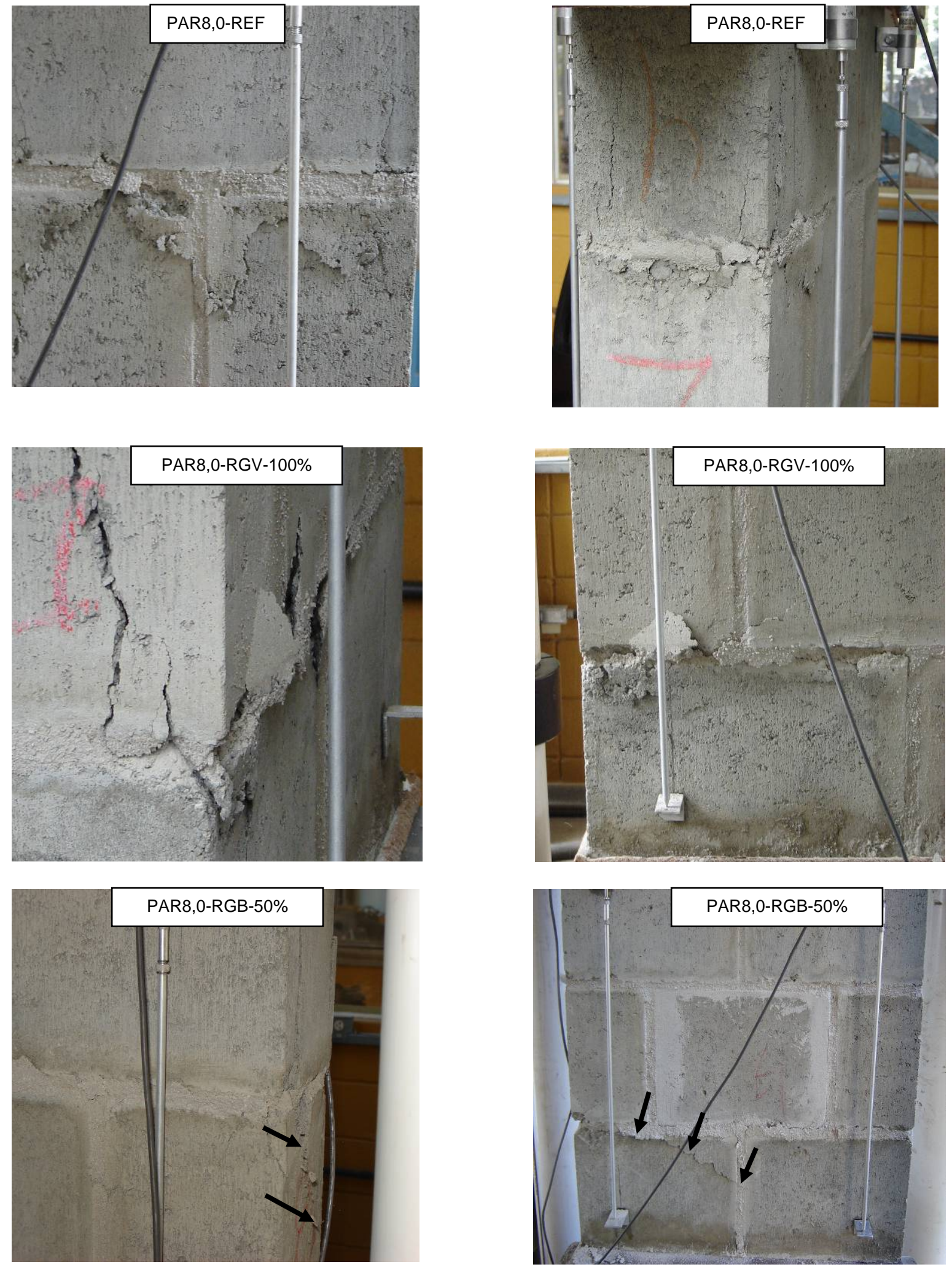

Figura 8.12 - Ruptura típica das miniparedes do Grupo 8,0. 


\subsubsection{GRUPO 12,0}

A terminologia adotada para o Grupo 12,0 são apresentadas na Tabela 8.34.

Tabela 8.34 - Terminologia adotada para as miniparedes do Grupo 12,0.

\begin{tabular}{|c|c|c|c|}
\hline $\begin{array}{l}\text { GRUPOICLASSE } \\
\text { DE RESISTENCIA } \\
\text { DAS UNIDADES }\end{array}$ & DESIGNAÇÃO & CARACTERÍSTICAS & $\begin{array}{l}\text { ARGAMASSA DE } \\
\text { ASSENTAMENTO }\end{array}$ \\
\hline \multirow{3}{*}{12,0} & PAR12,0-REF & $\begin{array}{c}\text { Miniparedes compostas por unidades produzidas com } \\
\text { agregados naturais }\end{array}$ & M \\
\hline & $\begin{array}{c}\text { PAR12,0-RGV- } \\
100 \%\end{array}$ & $\begin{array}{c}\text { Miniparedes compostas por unidades com } 100 \% \text { de } \\
\text { substituição, em massa, da fração graúda natural (pedrisco) } \\
\text { por agregado graúdo reciclado de vigota (GRv) }\end{array}$ & $\mathrm{N}$ \\
\hline & $\begin{array}{c}\text { PAR12,0-RGB- } \\
50 \%\end{array}$ & $\begin{array}{c}\text { Miniparedes compostas por unidades com } \\
\text { aproximadamente } 50 \% \text { de substituição, em massa, da } \\
\text { fração graúda natural por agregado graúdo reciclado de } \\
\text { bloco (GRb) }\end{array}$ & $\mathrm{O}$ \\
\hline
\end{tabular}

Os resultados de resistência à compressão e módulo de deformação das miniparedes do grupo 8,0 são apresentados na Tabela 8.35.

Tabela 8.35 - Valores de resistência à compressão e módulo de deformação das miniparedes do Grupo 12,0.

\begin{tabular}{|c|c|c|c|c|c|c|}
\hline Miniparede & Parâmetros & $\begin{array}{l}\text { Idade } \\
\text { (dias) }\end{array}$ & $\begin{array}{l}\text { Tensão - A } \text { Aruta } \\
\text { (MPa) }\end{array}$ & Módulo - A bruta (MPa) & $\begin{array}{c}\text { Def. 33\% da } \\
\text { tensão última } \\
(\%)\end{array}$ & $\begin{array}{c}\text { Deformação } \\
\text { última (\%o) }\end{array}$ \\
\hline \multirow{5}{*}{ PAR12,0-REF } & Média & \multirow{2}{*}{39} & 9,51 & 9877 & $-0,32$ & $-2,11$ \\
\hline & Máximo & & 11,53 & 11516 & $-0,34$ & $-2,37$ \\
\hline & Mínimo & \multirow{3}{*}{39} & 8,09 & 8720 & $-0,28$ & $-1,94$ \\
\hline & $S_{d}$ & & 1,80 & 1459 & 0,03 & 0,23 \\
\hline & C.V (\%) & & 18,94 & 14,77 & 9,64 & 10,69 \\
\hline \multirow{5}{*}{ PAR12,0-RGV-100\% } & Média & \multirow{2}{*}{42} & 8,38 & 9381 & $-0,31$ & $-1,86$ \\
\hline & Máximo & & 9,26 & 10509 & $-0,41$ & $-2,06$ \\
\hline & Mínimo & \multirow{3}{*}{$\begin{array}{l}42 \\
41\end{array}$} & 7,68 & 7918 & $-0,24$ & $-1,59$ \\
\hline & $\mathrm{S}_{\mathrm{d}}$ & & 0,80 & 1328 & 0,09 & 0,24 \\
\hline & C.V (\%) & & 9,59 & 14,15 & 29,73 & 12,96 \\
\hline \multirow{5}{*}{ PAR12,0-RGB-50\% } & Média & \multirow[b]{2}{*}{39} & 8,13 & 10783 & $-0,24$ & $-2,25$ \\
\hline & Máximo & & 8,48 & 11665 & $-0,27$ & $-2,44$ \\
\hline & Mínimo & 39 & 7,78 & 9902 & $-0,21$ & $-2,07$ \\
\hline & $S_{d}$ & & 0,49 & 1246 & 0,04 & 0,26 \\
\hline & C.V (\%) & & 6,02 & 11,56 & 17,73 & 11,67 \\
\hline \multicolumn{2}{|c|}{ Média geral do Grupo 12,0 } & & 8,67 & 10014 & $-0,29$ & $-2,08$ \\
\hline
\end{tabular}

Analisando-se a Tabela 8.35, nota-se que as miniparedes compostas por unidades com agregados reciclados apresentaram valores relativamente menores de resistência à compressão comparativamente aos elementos de referência (redução de 13\%). A resistência das miniparedes, assentadas com argamassa média (1:0,5:4,5) de resistência de 5,25 MPa e compostas por unidades de resistência média de 18,91 MPa, foi de 8,67 MPa. Juste (2001), avaliando miniparedes de $0,80 \mathrm{~m} \times 0,80 \mathrm{~m}$, compostas por unidades de 
concreto de $12 \mathrm{MPa}\left(\mathrm{f}_{\mathrm{cm}}=22,92 \mathrm{MPa}\right)$, produzidos pela Tatu Pré-Moldados, obteve valores médios de resistência à compressão de 5,65 $\mathrm{MPa}$ e $8,84 \mathrm{MPa}$, utilizando as argamassas fraca $\left(f_{\text {arg }}=5,05 \mathrm{MPa}\right)$ e média $\left(f_{\text {arg }}=10,24 \mathrm{MPa}\right)$, respectivamente.

Com relação ao módulo de deformação, o valor médio obtido para as miniparedes foi de 10.014 MPa. Juste (2001) obteve valores de módulo de deformação entre 8.693 MPa e 9.128 $\mathrm{MPa}$, para miniparedes $(0,80 \mathrm{~m} \times 0,80 \mathrm{~m})$, que apresentaram resistência à compressão de 5,65 MPa ( $\left.f_{\text {arg }}=5,05 \mathrm{MPa}\right)$ e 8,84 MPa ( $\left.f_{\text {arg }}=10,24 \mathrm{MPa}\right)$, respectivamente.

Na Tabela 8.36, são os apresentados os fatores de eficiência (miniparede/prisma) e (miniparede/bloco), a razão entre o módulo de deformação e a resistência das miniparedes e a relação entre o módulo dos diferentes elementos (miniparede/prisma).

Tabela 8.36 - Fatores de eficiência, razão entre o módulo e resistência e relação entre o módulo dos diferentes elementos para as miniparedes do Grupo 12,0.

\begin{tabular}{|c|c|c|c|c|}
\hline & \multicolumn{2}{|c|}{ Fatores de eficiência } & \multirow{2}{*}{$\underset{\mathbf{f}_{\text {miniparede }}}{\mathrm{E}_{\text {miniparede }} I}$} & \multirow{2}{*}{$\underset{E_{\text {prisma }}}{\mathrm{E}_{\text {miniparede }} /}$} \\
\hline & $f_{\text {Miniparede }} / f_{\text {prisma }}$ & $\mathbf{f}_{\text {Miniparede }} / \mathbf{f}_{\text {bloco }}$ & & \\
\hline PAR12,0-REF & 0,752 & 0,474 & 1039 & 0,936 \\
\hline PAR12,0-RGV-100\% & 0,845 & 0,469 & 1120 & 0,936 \\
\hline PAR12,0-RGB-50\% & 0,755 & 0,432 & 1326 & 1,035 \\
\hline $\begin{array}{c}\text { Média geral do Grupo } \\
12,0\end{array}$ & 0,784 & 0,458 & 1162 & 0,969 \\
\hline
\end{tabular}

Pela Tabela 8.36, nota-se que os fatores de eficiência foram de 0,784 ( $\left.f_{\text {miniparede }} / f_{\text {prisma }}\right)$ e 0,458 ( $\left.f_{\text {miniparede }} / f_{\text {bloco }}\right)$. A razão entre o módulo de deformação e a resistência à compressão das miniparedes ficou com o valor médio de 1162; Juste (2001) obteve valores próximos a 1285 para essa relação. A pesquisadora encontrou fatores de eficiência (miniparede/prisma de três blocos) de 0,61 ( $\left.f_{\text {arg }}=5,05 \mathrm{MPa}\right)$ e 1,14 ( $\left.\mathrm{f}_{\text {arg }}=10,24 \mathrm{MPa}\right)$ e fatores de eficiência (miniparede/bloco) de 0,25 ( $\left.f_{\text {arg }}=5,05 \mathrm{MPa}\right)$ e 0,39 ( $\left.f_{\text {arg }}=10,24 \mathrm{MPa}\right)$, para blocos de resistência de 22,92 MPa.

Os resultados das propriedades físicas e mecânicas dos CPs de argamassa das miniparedes do grupo 12,0 encontram-se na Tabela 8.37. 
Tabela 8.37 - Resultados das propriedades físicas e mecânicas do CPs de argamassa das miniparedes do Grupo 12,0.

\begin{tabular}{|c|c|c|c|c|c|c|c|c|c|}
\hline \multirow[b]{2}{*}{ Miniparede } & \multirow[b]{2}{*}{$\begin{array}{l}\text { Designação } \\
\text { Argamassa }\end{array}$} & \multirow[b]{2}{*}{ Parâm. } & \multirow[b]{2}{*}{ Idade } & \multirow[b]{2}{*}{$\begin{array}{c}\text { Massa } \\
\text { dos CPs }\end{array}$} & \multicolumn{5}{|c|}{ Propriedades Mecânicas } \\
\hline & & & & & $\begin{array}{c}\text { Força } \\
\text { última } \\
(\mathrm{kgf})\end{array}$ & $\begin{array}{c}\text { Tensão } \\
\text { (MPa) }\end{array}$ & $\begin{array}{c}\text { Módulo } \\
\text { (GPa) }\end{array}$ & $\begin{array}{c}\text { Def. } \\
\text { Última } \\
(\%)\end{array}$ & $\begin{array}{c}\mathrm{f}_{\text {arg }} / \\
\mathrm{f}_{\text {bloco }}\end{array}$ \\
\hline \multirow{5}{*}{ PAR12,0- REF } & \multirow{5}{*}{ M } & Média & \multirow{5}{*}{42} & 392,6 & 1030 & 5,25 & 8,31 & $-3,84$ & \multirow{5}{*}{0,262} \\
\hline & & Máx. & & 396,5 & 1183 & 6,02 & 11,37 & $-5,86$ & \\
\hline & & Mín. & & 389,8 & 847 & 4,31 & 4,05 & $-1,85$ & \\
\hline & & $S_{d}$ & & 2,4 & 124 & 0,63 & 2,64 & 1,84 & \\
\hline & & C.V (\%) & & 0,62 & 11,99 & 11,99 & 31,78 & 47,84 & \\
\hline \multirow{5}{*}{ PAR12,0-RGV-100\% } & \multirow{5}{*}{$\mathrm{N}$} & Média & \multirow{5}{*}{44} & 393,1 & 1032 & 5,25 & 9,42 & $-3,48$ & \multirow{5}{*}{0,294} \\
\hline & & Máx. & & 394,4 & 1145 & 5,83 & 9,88 & $-4,35$ & \\
\hline & & Mín. & & 392,1 & 900 & 4,59 & 8,91 & $-2,78$ & \\
\hline & & $S_{d}$ & & 0,8 & 109 & 0,55 & 0,40 & 0,62 & \\
\hline & & C.V (\%) & & 0,21 & 10,53 & 10,53 & 4,20 & 17,79 & \\
\hline \multirow{5}{*}{ PAR12,0-RGB-50\% } & \multirow{5}{*}{$\mathrm{O}$} & Média & \multirow{5}{*}{42} & 391,0 & 1032 & 5,26 & 7,43 & $-3,94$ & \multirow{5}{*}{0,279} \\
\hline & & Máx. & & 397,6 & 1190 & 6,06 & 10,30 & $-4,89$ & \\
\hline & & Mín. & & 384,3 & 916 & 4,66 & 4,12 & $-2,60$ & \\
\hline & & $\mathrm{S}_{\mathrm{d}}$ & & 5,4 & 132 & 0,67 & 2,97 & 0,96 & \\
\hline & & C.V (\%) & & 1,39 & 12,80 & 12,80 & 39,94 & 24,45 & \\
\hline & Média Geral & & & 392,2 & 1031 & 5,25 & 8,39 & $-3,75$ & 0,278 \\
\hline
\end{tabular}

\footnotetext{
${ }^{1}$ relação entre a resistência da argamassa e os blocos ensaiados
}

Analisando-se os resultados da Tabela 8.37, observa-se que a resistência à compressão da argamassa situou-se entre $26 \%$ e $29 \%$ da resistência à compressão do bloco. Devido à baixa resistência da argamassa em relação à resistência do bloco, presumese que a argamassa tenha influenciado na redução da resistência das miniparedes; provavelmente, para esses elementos deveria ser utilizada uma argamassa de resistência mais elevada.

Conforme já observado nas miniparedes do Grupo 8,0, a ruptura dos elementos do Grupo 12,0 foi caracterizada pelo esfacelamento da parte externa das paredes dos blocos, inicialmente próximo às juntas e depois se espalhando por todo o bloco, provocada, principalmente, pelo esmagamento da argamassa, Figura 8.13. 

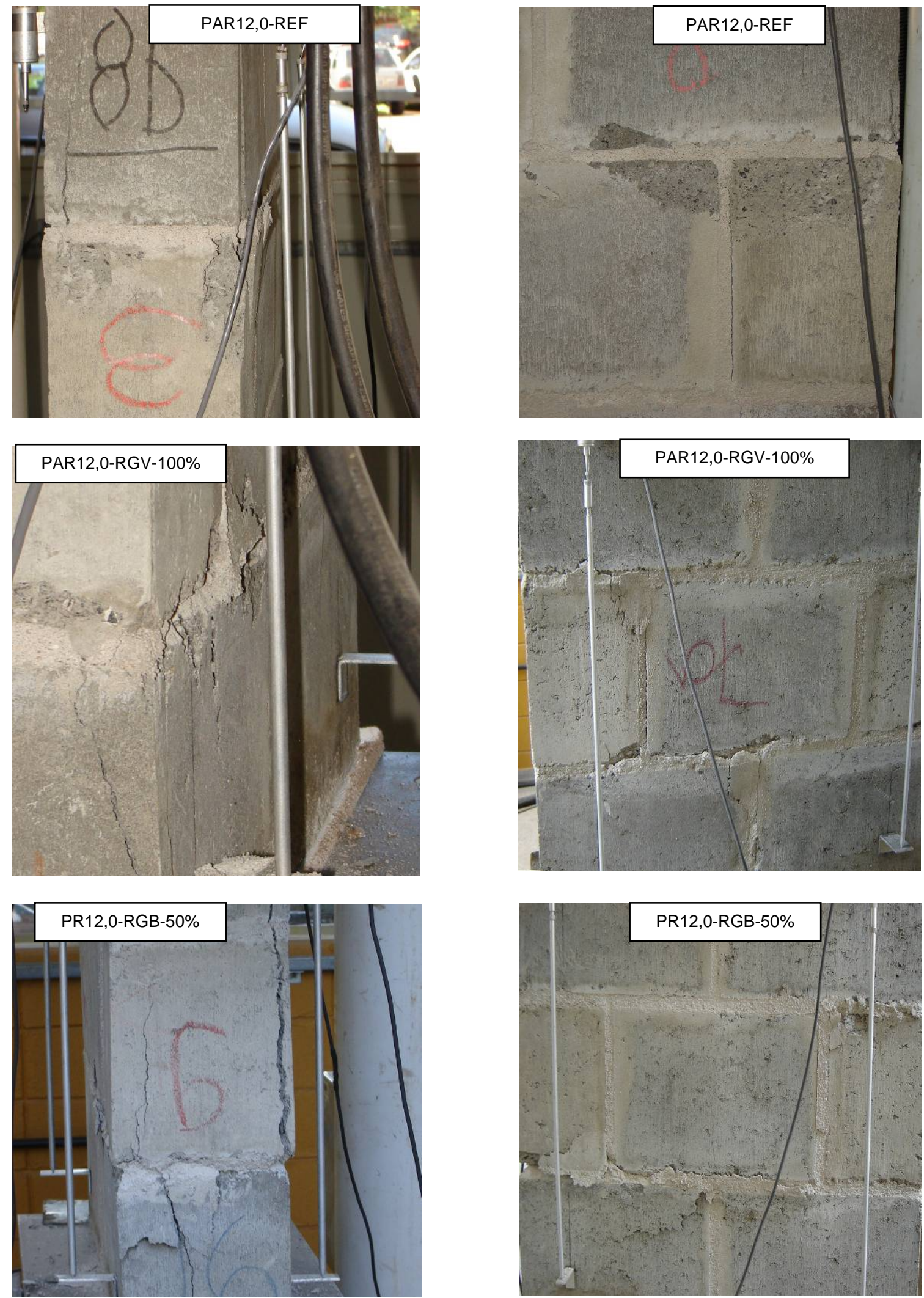

Figura 8.13 - Ruptura típica das unidades do Grupo 12,0. 


\subsubsection{ANÁLISE DOS RESULTADOS OBTIDOS - MINIPAREDES}

Na Tabela 8.38, são apresentados os resultados do teste estatístico de Análise de Variância considerando-se a influência dos diferentes traços e grupos (variáveis) sobre as seguintes propriedades: resistência à compressão e módulo de deformação das miniparedes e resistência à compressão de argamassas e blocos.

Tabela 8.38 - Teste ANOVA para as propriedades de resistência à compressão (miniparedes, blocos e argamassas) e módulo de deformação das miniparedes.

\begin{tabular}{|c|c|c|c|c|c|c|c|c|c|c|c|c|}
\hline \multirow[b]{4}{*}{ Variáveis } & \multicolumn{12}{|c|}{ Propriedades } \\
\hline & \multicolumn{3}{|c|}{$f_{c}$. miniparedes } & \multicolumn{3}{|c|}{$E_{c}$ - miniparedes } & \multicolumn{3}{|c|}{$f_{c}-$ blocos } & \multicolumn{3}{|c|}{$f_{c \text { - argamassa }}$} \\
\hline & Grupos & & Grupos & Grupos & & Grupos & Grupos & & Grupos & Grupos & & Grupos \\
\hline & $\begin{array}{c}4,5 ; 8,0 \\
12,0\end{array}$ & Traços & $\begin{array}{c}\text { X } \\
\text { Traços }\end{array}$ & $\begin{array}{l}4,5 \\
8,0 \\
12,0\end{array}$ & Traços & $\begin{array}{c}\text { X } \\
\text { Traços }\end{array}$ & $\begin{array}{l}4,5 \\
8,0 \\
12,0\end{array}$ & Traços & $\begin{array}{c}x \\
\text { Traços }\end{array}$ & $\begin{array}{c}4,5 ; 8,0 \\
12,0\end{array}$ & Traços & $\begin{array}{c}x \\
\text { Traços }\end{array}$ \\
\hline $\begin{array}{c}\text { REF } \times \text { RGV- }-100 \% \times \\
\text { RGV- } 50 \%\end{array}$ & $\begin{array}{c}\mathrm{S} \\
\left(F_{0}=\right. \\
14,3)\end{array}$ & - & - & $S(3,7)$ & - & - & $\begin{array}{c}\mathrm{S} \\
(58,2)\end{array}$ & $S(6,7)$ & $S(5,1)$ & - & $S(3,3)$ & - \\
\hline REF x RGV-100\% & $\mathrm{S}(7,9)$ & - & - & $\mathrm{S}(4,2)$ & - & - & $\begin{array}{c}\mathrm{S} \\
(36,4)\end{array}$ & $\begin{array}{c}\mathrm{S} \\
(12,1)\end{array}$ & $\mathrm{S}(8,9)$ & $\mathrm{S}(4,1)$ & - & - \\
\hline REF x RGB-50\% & $\mathrm{S}(11,3)$ & - & - & - & - & - & $\begin{array}{c}\mathrm{S} \\
(31,9)\end{array}$ & $\mathrm{S}(8,8)$ & $\mathrm{S}(6,7)$ & - & $\mathrm{S}(5,8)$ & - \\
\hline RGV-100\% x RGB-50\% & $\mathrm{S}(13,9)$ & - & $S(5,4)$ & - & $S(6,0)$ & - & $\begin{array}{c}\mathrm{S} \\
(53,3)\end{array}$ & - & - & - & - & - \\
\hline
\end{tabular}

Pela Tabela 8.38, nota-se que para a análise de $1^{\mathrm{a}}$ ordem, as propriedades de resistência à compressão das miniparedes e blocos foram influenciadas significativamente pela variável "grupos/classe de resistência". Dentre as duas variáveis (classe de resistência e traços), pode-se afirmar que a classe de resistência (4,5; 8,0 e 12,0) exerceu influência mais significativa sobre as propriedades avaliadas, isto é, para cada classe de resistência avaliada foram obtidos valores de resistência à compressão significativamente diferentes entre si.

Com relação à variável "traço", nota-se que essa variável teve influência significativa apenas para os resultados de resistência à compressão dos blocos. Apesar disso, as diferenças observadas nesses resultados não influenciaram a resistência à compressão e o módulo de deformação das miniparedes (PAR-REF = PAR-RGV-100\% = PAR-RGB-50\%); exceto para o caso RGV-100\% x RGB-50\%, onde se pode dizer que: $E_{R G B-50 \%}>E_{R G V-100 \%}$.

Para a análise de $2^{\mathrm{a}}$ ordem, observou-se uma influência significativa dos parâmetros (grupos e traços), principalmente sobre a resistência à compressão dos blocos, para grande parte das comparações. Nesse caso, pode-se afirmar que para uma dada classe de resistência (4,5, por exemplo), a dosagem de referência conduz aos maiores valores médios 
de resistência; mas, por outro lado, para outra classe de resistência $(8,0)$, esse mesmo traço pode não levar necessariamente aos maiores valores médios de resistência à compressão.

Na Tabela 8.39, são apresentados os resultados do teste ANOVA considerando os resultados de resistência à compressão dos prismas e das miniparedes.

Tabela 8.39 - Teste ANOVA para verificar a influência das diferentes classes de resistência $(4,5 ; 8,0 ; 12,0)$ e elementos (prismas e miniparedes) sobre a propriedade de resistência à compressão.

\begin{tabular}{|c|c|c|c|}
\hline \multirow{4}{*}{ Variáveis } & \multicolumn{3}{|c|}{ Propriedade } \\
\hline & \multicolumn{3}{|c|}{ Resistência à Compressão } \\
\hline & Grupos & Elementos & \multirow{2}{*}{ Grupos $x$ Elementos } \\
\hline & 4,$5 ; 8,0 ; 12,0$ & prismas; miniparedes & \\
\hline PR-REF x PAR-REF & $\mathrm{S}\left(\mathrm{F}_{0}=30,5\right)$ & $\mathrm{S}(9,4)$ & $\mathrm{S}(4,1)$ \\
\hline PR-RGV-100\% x PAR-RGV-100\% & $S(19,3)$ & $S(40,5)$ & $S(10,9)$ \\
\hline PR-RGB-50\% X PAR-RGB-50\% & $S(71,5)$ & $S(23,6)$ & $S(12,6)$ \\
\hline
\end{tabular}

Analisando-se os resultados da Tabela 8.39, observa-se que para a análise de $1^{\circ}$ ordem, a resistência à compressão foi influenciada pela classe de resistência e pelo tipo de elemento avaliado. Com relação ao tipo de elemento, pode-se dizer que os maiores valores médios de resistência à compressão foram obtidos para os prismas comparativamente às miniparedes. Para análise de $2^{\circ}$ ordem, pode-se afirmar que, para todas as comparações avaliadas, houve influência significativa dos parâmetros (grupos e elementos) sobre a resistência à compressão; isto significa que para um determinado grupo (REF e RGB-50\% do Grupo 12,0, por exemplo) pode-se ter um determinado tipo de elemento (prisma, por exemplo) que leva aos maiores valores médios de resistência à compressão; entretanto, para um outro grupo (REF do Grupo 8,0 e RGB-50\% do Grupo 4,5), os maiores valores médios de resistência podem não ser obtidos necessariamente pelos prismas.

\subsection{CONCLUSÕES DO CAPÍTULO}

De maneira geral, apenas os prismas compostos por unidades com agregados reciclados apresentaram um ligeiro decréscimo na resistência à compressão comparativamente aos prismas de referência. Os menores valores de resistência dos elementos com agregados reciclados podem ser explicados pela menor resistência dos blocos com agregados reciclados ou por variações na resistência das argamassas 
empregadas. Com relação à propriedade de módulo de deformação, pode-se dizer que os valores obtidos para os prismas e miniparedes constituídos por blocos com agregados reciclados não diferiram significativamente dos valores obtidos para os elementos de referência.

Com relação ao modo de ruptura, novamente não foi observada nenhuma influência dos elementos compostos por unidades com agregados reciclados comparativamente aos elementos de referência. A maior absorção dos blocos com agregados reciclados, provavelmente não reduziu a aderência entre argamassa e unidade, fato esse que poderia afetar o modo de ruptura, já que os valores de IRA e absorção capilar dessas unidades foram próximos aos das unidades convencionais.

De maneira geral, pode-se afirmar que a resistência do bloco teve influência mais significativa sobre a resistência dos elementos do que a resistência da argamassa. A resistência da argamassa apresentou efeito significativo na resistência do elemento quando o modo de ruptura do prisma ou miniparede foi caracterizado pelo esmagamento da argamassa e esfacelamento da parte externa das paredes das unidades. Nesses casos, a resistência à compressão da argamassa foi usualmente inferior a $40 \%$ da resistência à compressão das unidades. 
Neste capítulo, é apresentada a metodologia empregada para a avaliação da retração em blocos de concreto e miniparedes; posteriormente, são apresentados os resultados de retração por secagem dos blocos de concreto e miniparedes produzidas com essas unidades e, finalmente, a estimativa da distância necessária entre as juntas de controle em função da retração da alvenaria. Os traços utilizados para a produção dos blocos foram apresentados no Capítulo 7. Os resultados dos elementos com agregados reciclados serão analisados comparativamente aos resultados dos elementos de referência mediante o teste de Análise de Variância e com os valores existentes na literatura.

\subsection{PROGRAMA EXPERIMENTAL}

\subsubsection{BLOCOS DE CONCRETO - RETRAÇÃO}

\subsubsection{Traços avaliados}

A retração por secagem foi avaliada para todas as dosagens de blocos de concreto apresentadas no capítulo 7, Tabela 9.1. 
Tabela 9.1 - Terminologia e características de cada dosagem.

\begin{tabular}{|c|c|c|}
\hline GRUPO & DESIGNAÇÃO & CARACTERÍSTICAS \\
\hline \multirow{6}{*}{4,5} & B4,5-REF & $\begin{array}{l}\text { Dosagem de referência produzida inteiramente com materiais } \\
\text { naturais }\end{array}$ \\
\hline & B4,5-RGV-100\% & $\begin{array}{l}\text { Dosagem com 100\% de substituição, em massa, da fração graúda } \\
\text { natural (pedrisco) por agregado graúdo reciclado de vigota (GRv) }\end{array}$ \\
\hline & B4,5-RGV-50\% & $\begin{array}{l}\text { Dosagem com aproximadamente } 50 \% \text { de substituição, em massa, da } \\
\text { fração graúda natural por agregado graúdo reciclado de vigota (GRv) }\end{array}$ \\
\hline & B4,5-RMV-33\% & $\begin{array}{l}\text { Dosagem com aproximadamente } 33 \% \text { de substituição, em massa, do } \\
\text { pó de pedra por agregado miúdo reciclado de vigota (MRv) }\end{array}$ \\
\hline & B4,5-RGB-50\% & $\begin{array}{l}\text { Dosagem com aproximadamente } 50 \% \text { de substituição, em massa, da } \\
\text { fração graúda natural por agregado graúdo reciclado de bloco (GRb) }\end{array}$ \\
\hline & B4,5-RMB-33\% & $\begin{array}{c}\text { Dosagem com aproximadamente } 33 \% \text { de substituição, em massa, do } \\
\text { pó de pedra por agregado miúdo reciclado de bloco (MRb) }\end{array}$ \\
\hline \multirow{6}{*}{8,0} & B8,0-REF & $\begin{array}{l}\text { Dosagem de referência produzida inteiramente com materiais } \\
\text { naturais }\end{array}$ \\
\hline & B8,0-RGV-100\% & $\begin{array}{l}\text { Dosagem com 100\% de substituição, em massa, da fração graúda } \\
\text { natural (pedrisco) por agregado graúdo reciclado de vigota (GRv) }\end{array}$ \\
\hline & B8,0-RGV-50\% & $\begin{array}{l}\text { Dosagem com aproximadamente } 50 \% \text { de substituição, em massa, da } \\
\text { fração graúda natural por agregado graúdo reciclado de vigota (GRv) }\end{array}$ \\
\hline & B8,0-RMV-33\% & $\begin{array}{l}\text { Dosagem com aproximadamente } 33 \% \text { de substituição, em massa, do } \\
\text { pó de pedra por agregado miúdo reciclado de vigota (MRv) }\end{array}$ \\
\hline & B8,0-RGB-50\% & $\begin{array}{l}\text { Dosagem com aproximadamente } 50 \% \text { de substituição, em massa, da } \\
\text { fração graúda natural por agregado graúdo reciclado de bloco (GRb) }\end{array}$ \\
\hline & B8,0-RMB-33\% & $\begin{array}{l}\text { Dosagem com aproximadamente } 33 \% \text { de substituição, em massa, do } \\
\text { pó de pedra por agregado miúdo reciclado de bloco (MRb) }\end{array}$ \\
\hline \multirow{6}{*}{12,0} & B12,0-REF & $\begin{array}{c}\text { Dosagem de referência produzida inteiramente com materiais } \\
\text { naturais }\end{array}$ \\
\hline & B12,0-RGV-100\% & $\begin{array}{l}\text { Dosagem com 100\% de substituição, em massa, da fração graúda } \\
\text { natural (pedrisco) por agregado graúdo reciclado de vigota (GRv) }\end{array}$ \\
\hline & B12,0-RGV-50\% & $\begin{array}{l}\text { Dosagem com aproximadamente } 50 \% \text { de substituição, em massa, da } \\
\text { fração graúda natural por agregado graúdo reciclado de vigota (GRv) }\end{array}$ \\
\hline & B12,0-RMV-33\% & $\begin{array}{c}\text { Dosagem com aproximadamente } 33 \% \text { de substituição, em massa, do } \\
\text { pó de pedra por agregado miúdo reciclado de vigota (MRv) }\end{array}$ \\
\hline & B12,0-RGB-50\% & $\begin{array}{l}\text { Dosagem com aproximadamente } 50 \% \text { de substituição, em massa, da } \\
\text { fração graúda natural por agregado graúdo reciclado de bloco (GRb) }\end{array}$ \\
\hline & B12,0-RMB-33\% & $\begin{array}{l}\text { Dosagem com aproximadamente } 33 \% \text { de substituição, em massa, do } \\
\text { pó de pedra por agregado miúdo reciclado de bloco (MRb) }\end{array}$ \\
\hline
\end{tabular}

As propriedades físicas e mecânicas dos blocos de concreto foram descritas no capítulo 7. Com base nos valores obtidos, apenas as unidades com agregados miúdos reciclados do grupo 4,5 (B4,5-RMV-33\% e B4,5-RMB-33\%) não apresentaram um desempenho satisfatório.

\subsubsection{Procedimento de ensaio}

A realização do ensaio de retração baseou-se nos procedimentos da NBR 12117 (1991) e ASTM C426 (1999), com algumas adaptações. A norma NBR 12117 (1991) prescreve que os corpos-de-prova sejam dispostos em uma estufa $(50 \pm 5)^{0} \mathrm{C}$, com volume capaz de acomodar pelo menos três exemplares de blocos inteiros e provida de meios para secar as unidades para uma condição de equilíbrio com umidade relativa de $(17 \pm 3) \%$. No presente trabalho, diferentemente dessa condição de secagem acelerada prescrita pela norma, os corpos-de-prova foram dispostos em uma câmara climatizada com controle de 
temperatura $(25 \pm 2)^{0} \mathrm{C}$ e umidade $(48 \pm 2) \%$. As justificativas para a escolha desse procedimento são descritas a seguir:

- Os ensaios de retração dos corpos-de-prova de blocos seriam posteriormente comparados com os resultados de retração em miniparedes assentadas com essas unidades. Dessa maneira, visando possibilitar uma comparação direta entre os resultados obtidos para os CPs e as miniparedes, esses exemplares foram mantidos em um ambiente com temperatura e umidade similares (câmara climatizada).

- Em razão do grande número de diferentes traços produzidos (18 no total) e da quantidade de corpos-de-prova de retração necessários para o ensaio (três por traço, 54 no total), a estufa disponível no Departamento de Estruturas não comportaria todos os corpos-de-prova.

- O procedimento de secagem adotado neste trabalho baseou-se nas recomendações de Drysdale e Khattab (1995). Segundo esses pesquisadores, condições lentas de secagem, diferentemente das condições normativas, permitem o estabelecimento de relações entre a quantidade de umidade presente no corpo-de-prova e sua respectiva retração, sendo, portanto, mais adequadas.

O ensaio de retração por secagem consistiu na determinação das variações dimensionais dos corpos-de-prova de blocos devido à secagem a partir de uma condição saturada até que fosse atingido o equilíbrio variacional tanto no comprimento quanto na massa dos CPs, sob condições de temperatura e umidade controladas. Seguindo as recomendações da ASTM C426 (1999), o ensaio foi conduzido até que fosse atingida a condição de equilíbrio, isto é, a variação média do comprimento atingisse $0,002 \%$ e a variação do peso atingisse $0,2 \%$ ou menos em relação à última determinação; além disso, um problema ocorrido na câmara climatizada, após trinta dias do início do ensaio, prejudicou a continuação das leituras. Para as leituras dimensionais, foram utilizados o aparelho digital da marca Mitutoyo (precisão $=0,001 \mathrm{~mm}$ ) e a barra padrão de aço invar de comprimento igual a $300,000 \mathrm{~mm}$, Figura 9.1; para as leituras de massa, foi empregada a balança Metter Toledo, modelo SB24001, Delta Range com precisão de 0,1 g e capacidade de $2400 \mathrm{~g}$. 

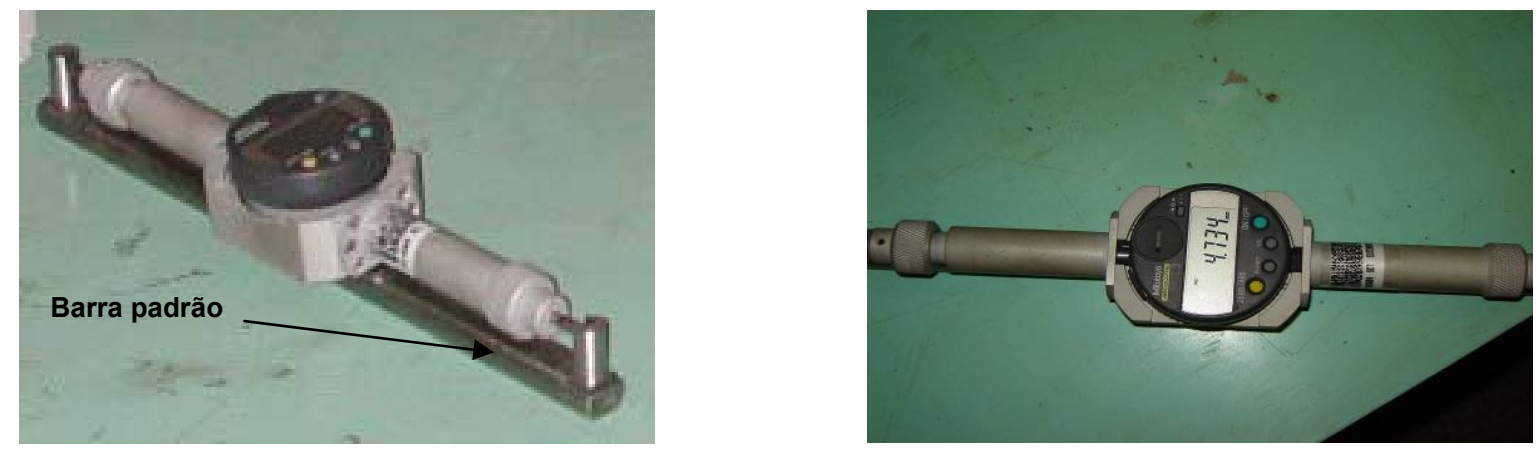

Figura 9.1 - Aparelho digital Mitutoyo e barra padrão de aço invar.

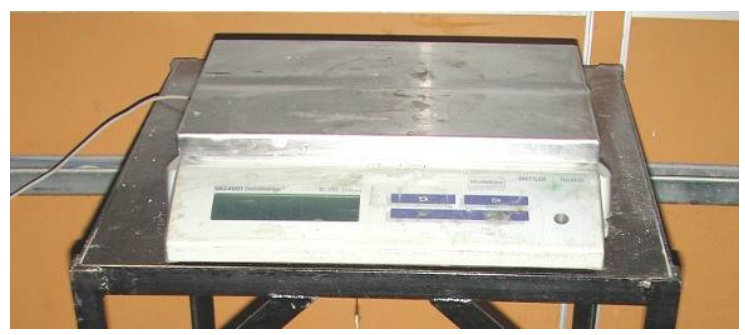

Figura 9.2 - Balança com precisão de $0,1 \mathrm{~g}$.

Com relação à preparação dos corpos-de-prova, inicialmente, foram escolhidos aleatoriamente três blocos de cada traço. De acordo com a NBR 12117 (1991), os corposde-prova devem ser blocos inteiros, livres de fissuras visíveis ou outros defeitos estruturais e representativos do lote. Esses blocos foram cortados com auxílio de uma serra diamantada existente no Departamento de Geotecnia, Figura 9.3.
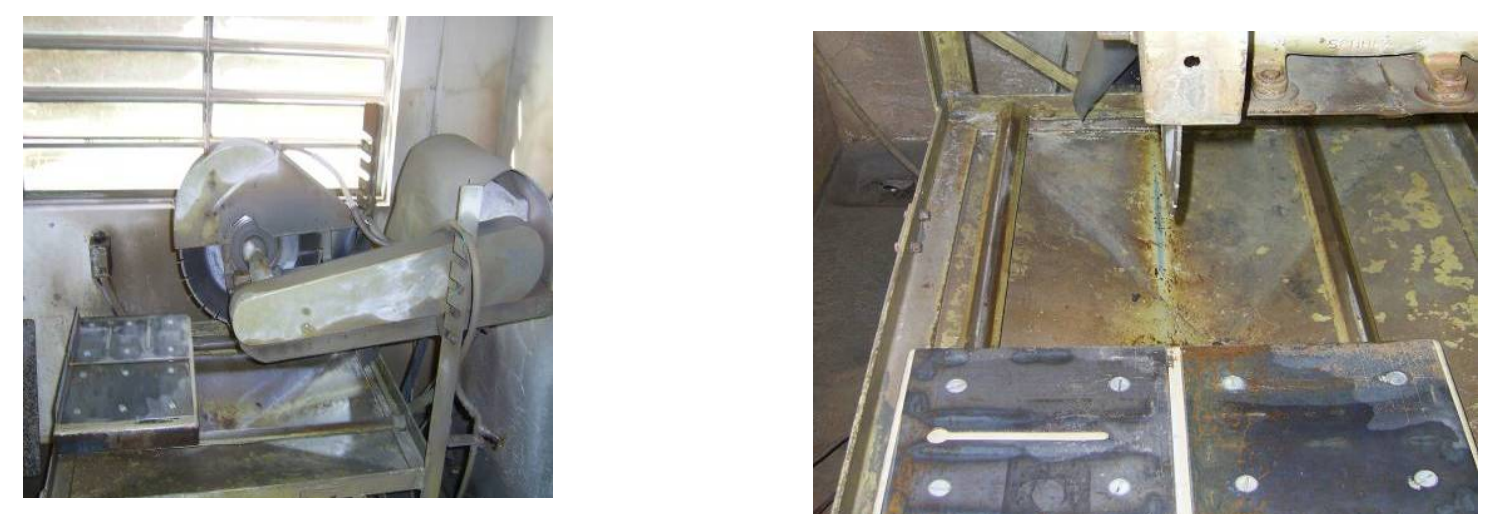

Figura 9.3 - Equipamento utilizado para o corte dos blocos de concreto.

Após o corte das unidades, os corpos-de-prova de blocos foram dispostos no pátio do laboratório e submetidos a uma lavagem sob pressão, para retirada da pasta de cimento aderida à superfície dos prismas, Figura 9.4. 

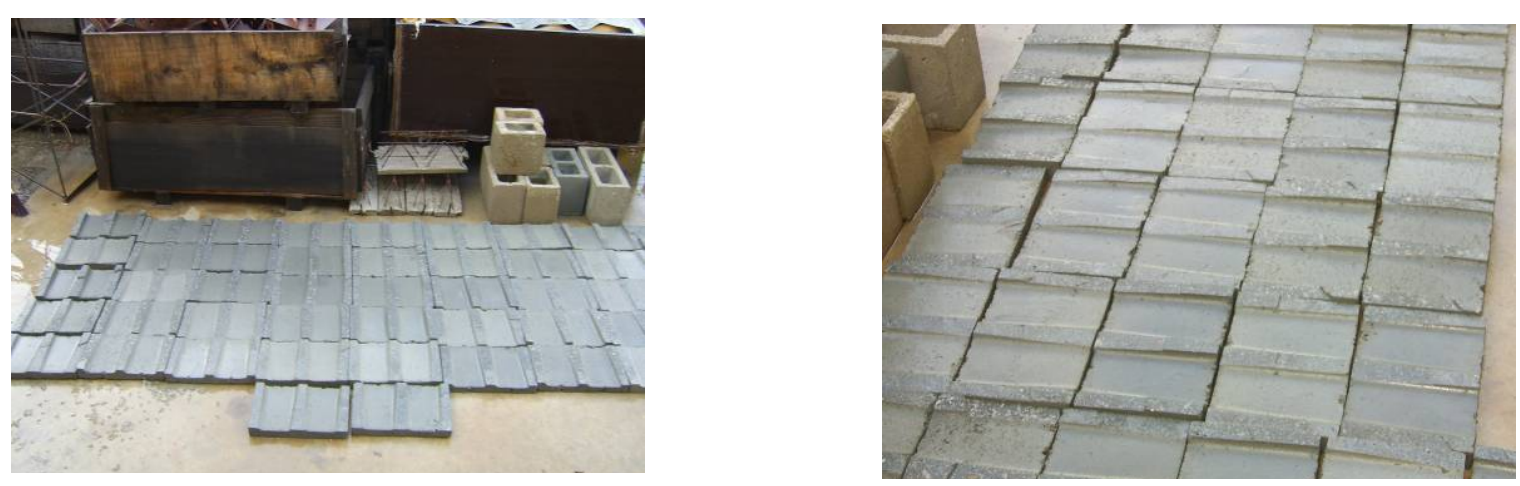

Figura 9.4 - Corpos-de-prova de blocos (prismas).

A NBR 12117 (1991) cita que os prismas extraídos devem ter pelo menos $100 \mathrm{~mm}$ de altura e ter preferencialmente o comprimento igual ao da parede do bloco (com no mínimo um comprimento de $350 \mathrm{~mm}$ ). $\mathrm{Na}$ presente pesquisa, os prismas avaliados apresentavam uma altura igual a $190 \mathrm{~mm}$ e comprimento igual a $290 \mathrm{~mm}$ (parede longitudinal do bloco).

Posteriormente, nos corpos-de-prova, foram colocados os apoios das bases de medida, sendo fixadas com cola à base de epóxi. Devido ao comprimento da barra padrão ser de $300 \mathrm{~mm}$ e, portanto, maior que o comprimento da parede longitudinal do bloco (290 $\mathrm{mm})$, todas as leituras de variações dimensionais foram realizadas diagonalmente, Figura 9.5 .
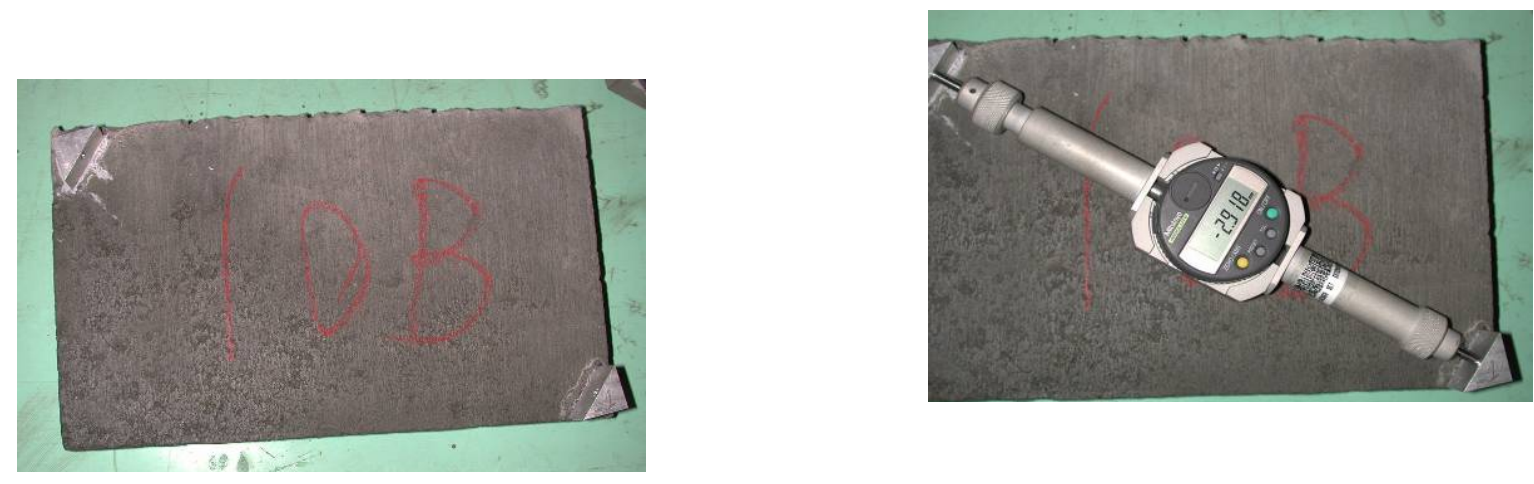

Figura 9.5 - Procedimento de leitura adotado para os corpos-de-prova de blocos.

Após a fixação das peças de apoio, os corpos-de-prova foram dispostos em um tanque com água à temperatura ambiente por um período de 48 horas, Figura 9.6. 

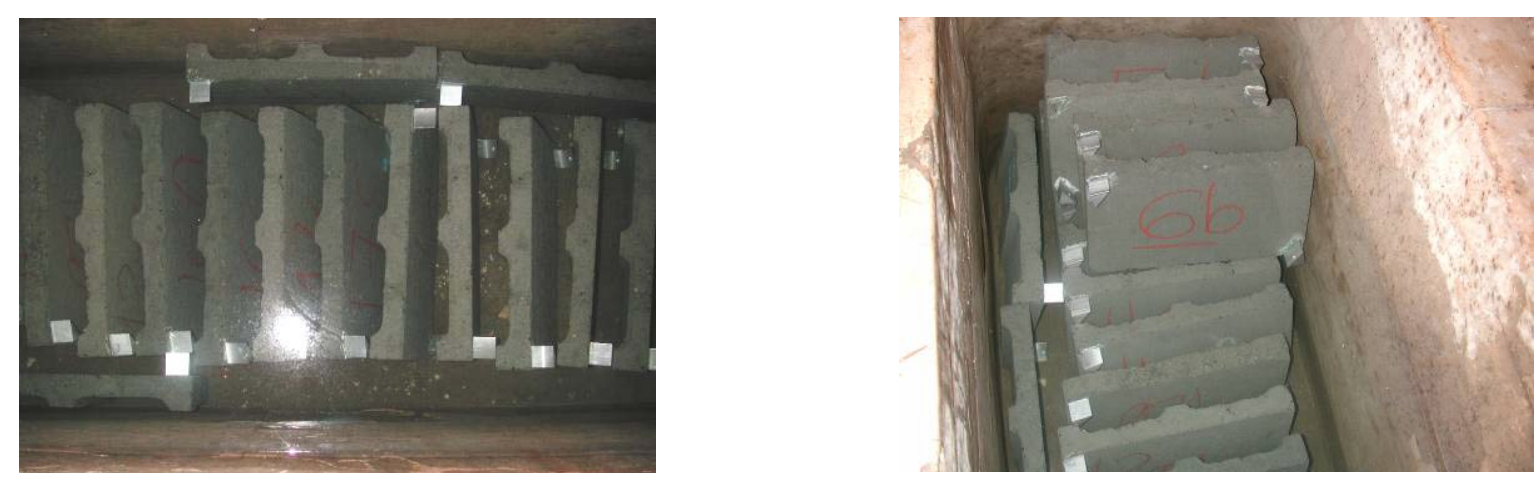

Figura 9.6 - Corpos-de-prova de blocos dispostos em tanque com água.

Posteriormente, ao período de 48 horas, os CPs foram retirados da água e colocados na câmara climatizada do Departamento de Estruturas, Figura 9.7. Nesse momento, todos os CPs, que estavam na condição saturada superfície seca, foram medidos com auxílio do aparelho digital Mitutoyo e determinada sua massa.
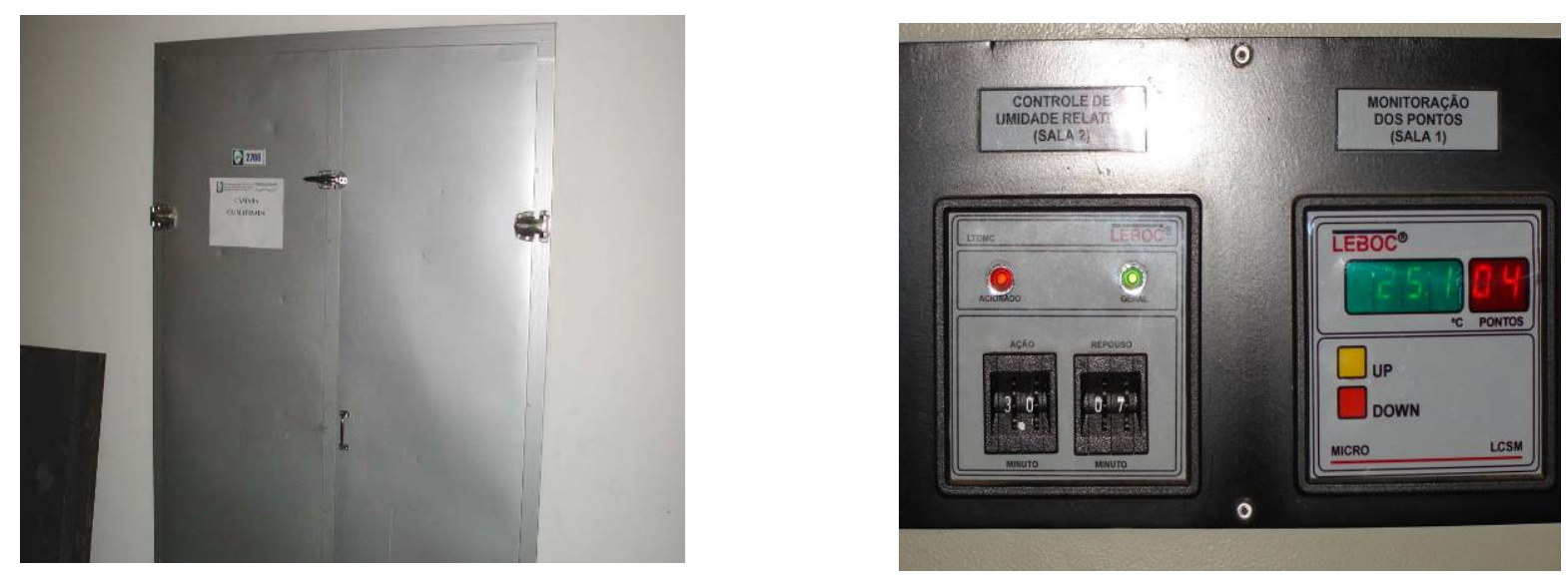

Figura 9.7 - Câmara climatizada com controle de umidade e temperatura.

Na Figura 9.8, observa-se os prismas dispostos na câmara climatizada em diferentes estágios do ensaio de retração por secagem. 

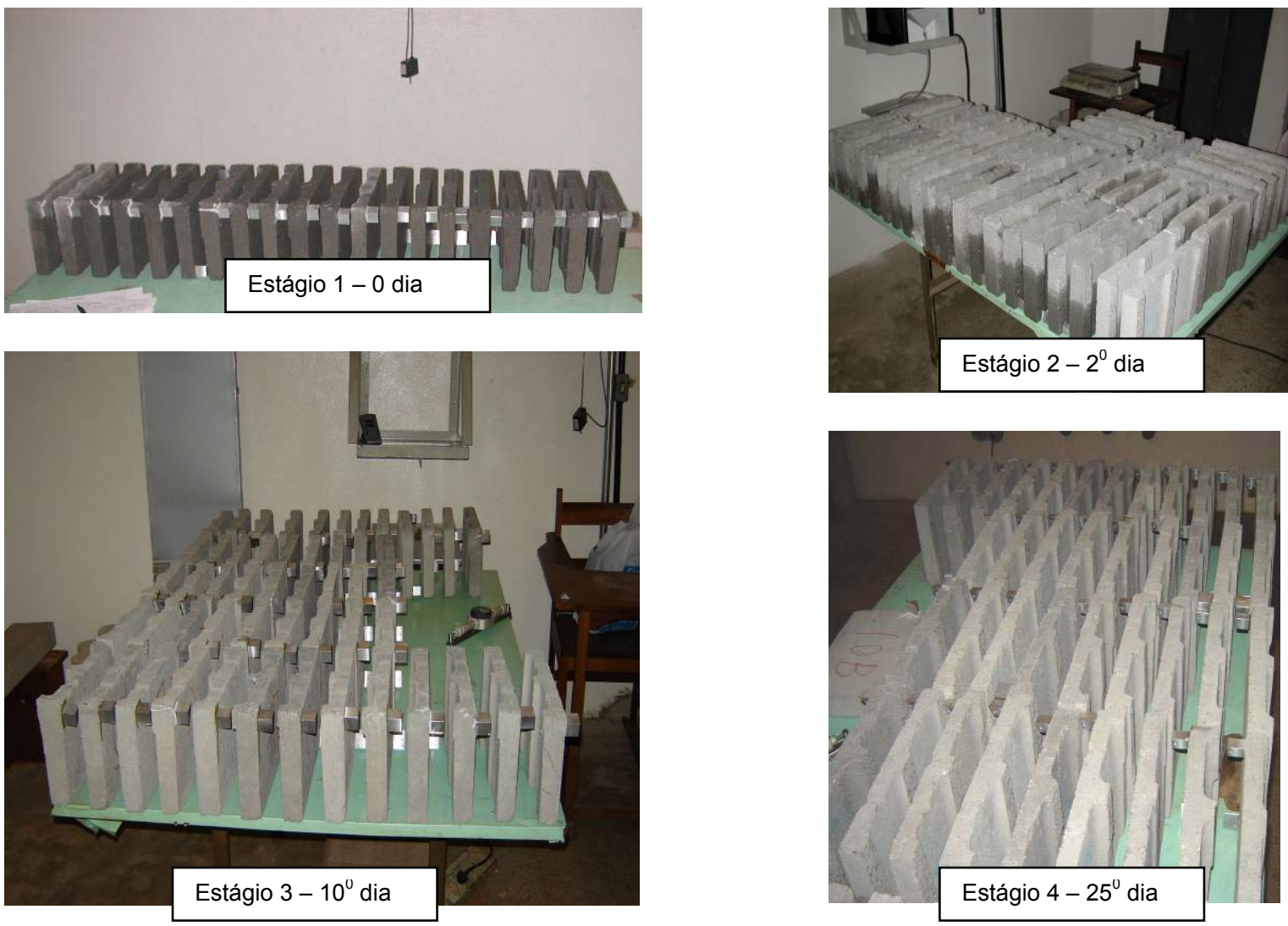

Figura 9.8 - Prismas de blocos em diferentes estágios do ensaio de retração.

Na Figura 9.9, apresenta-se um layout da câmara climatizada representando todos os equipamentos existentes no seu interior.

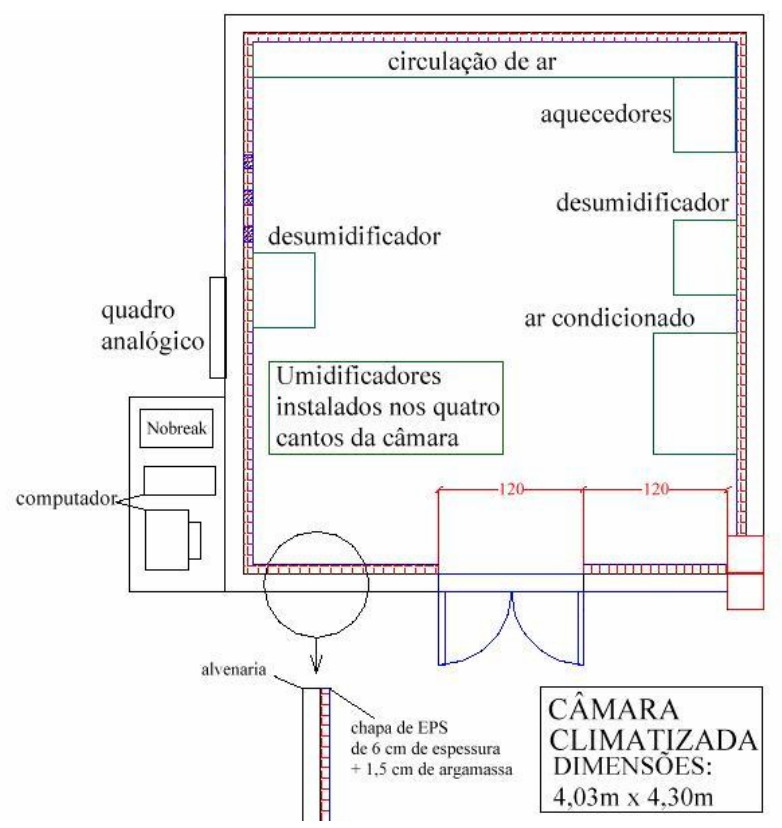

Figura 9.9 - Layout da câmara climatizada. 
$\mathrm{Na}$ Figura 9.10, observam-se os equipamentos de refrigeração, aquecimento, umidificação e desumidificação existentes na câmara.
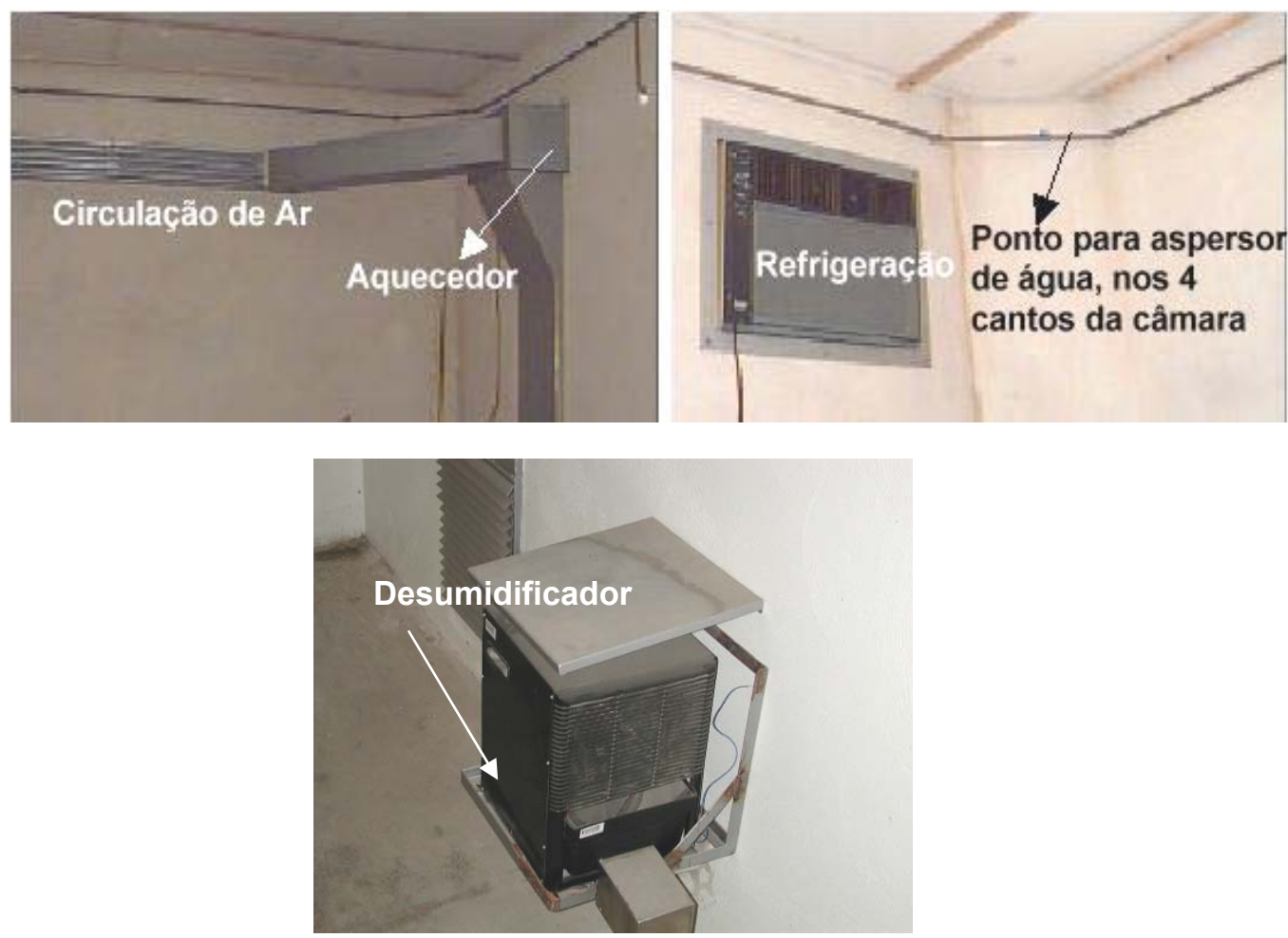

Figura 9.10 - Equipamentos de refrigeração, aquecimento, desumidificação e umidificação existentes na câmara climatizada.

O sistema de controle e o quadro analógico que monitoravam a umidade relativa em um ponto e a temperatura em quatro pontos distintos do interior da câmara são apresentados na Figura 9.11.
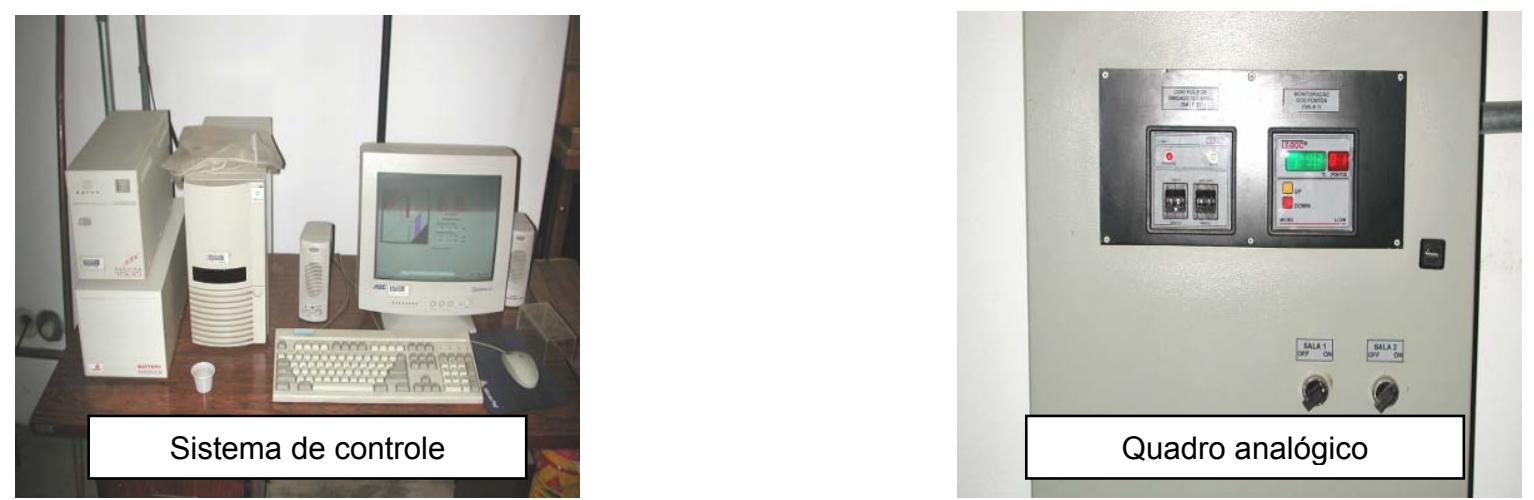

Figura 9.11 - Sistema de controle e quadro analógico. 


\subsubsection{MINIPAREDES - RETRAÇÃO}

Nesta etapa do trabalho foram moldadas miniparedes de $59 \mathrm{~cm} \times 59 \mathrm{~cm}$. Para cada tipo de unidade foram moldadas três miniparedes.

\subsubsection{Argamassa utilizada}

A argamassa utilizada foi semelhante à empregada para a produção dos prismas e miniparedes do capítulo 8. As características da argamassa são apresentadas na Tabela 9.2.

Tabela 9.2 - Argamassa utilizada para a execução das miniparedes de retração

\begin{tabular}{|c|c|c|c|c|c|c|c|c|c|c|}
\hline \multirow{2}{*}{$\begin{array}{l}\text { Miniparedes de retração } \\
\text { produzidas }\end{array}$} & \multirow{2}{*}{ Local } & \multirow{2}{*}{ Quant. } & \multirow{2}{*}{ Data } & \multirow{2}{*}{$\begin{array}{l}\text { Horário de } \\
\text { moldagem }\end{array}$} & \multirow{2}{*}{$\mathrm{T}\left({ }^{\circ} \mathrm{C}\right)$} & \multirow{2}{*}{ U (\%) } & \multicolumn{4}{|c|}{$\begin{array}{c}\text { Consumo aproximado de materiais } \\
\left(\mathrm{kg} / \mathrm{m}^{3}\right)\end{array}$} \\
\hline & & & & & & & $\begin{array}{c}\text { Cimento } \\
(1,00)\end{array}$ & $\begin{array}{l}\text { Areia } \\
(6,15) \\
\end{array}$ & $\begin{array}{c}\text { Cal } \\
(0,35)\end{array}$ & $\begin{array}{l}\text { Água } \\
(1,35) \\
\end{array}$ \\
\hline PAR4,5-REF & \multirow{6}{*}{$\begin{array}{c}\text { Câmara } \\
\text { Climatizada }\end{array}$} & 3 & \multirow{6}{*}{$\begin{array}{l}06 / 03 / \\
2006\end{array}$} & \multirow{6}{*}{$\begin{array}{c}08: 00 \\
- \\
12: 00\end{array}$} & 26,5 & 72,3 & \multirow{6}{*}{242,4} & \multirow{6}{*}{1493,0} & \multirow{6}{*}{84,3} & \multirow{6}{*}{326,7} \\
\hline PAR4,5-RGV-100\% & & 3 & & & 24,0 & 72,3 & & & & \\
\hline PAR4,5-RGB-50\% & & 3 & & & 26,8 & 75,7 & & & & \\
\hline PAR12,0-REF & & 3 & & & 26,8 & 75,3 & & & & \\
\hline PAR12,0-RGV-100\% & & 3 & & & 24,6 & 73,7 & & & & \\
\hline PAR12,0-RGB-50\% & & 3 & & & 26,4 & 78,0 & & & & \\
\hline PAR8,0-REF & \multirow{2}{*}{ Laboratório } & 3 & \multirow{2}{*}{$\begin{array}{c}07 / 03 / \\
2006\end{array}$} & \multirow{2}{*}{$\begin{array}{c}14: 00 \\
- \\
16: 00\end{array}$} & - & - & \multirow{2}{*}{242,4} & \multirow{2}{*}{1493,0} & \multirow{2}{*}{84,3} & \multirow{2}{*}{326,7} \\
\hline PAR8,0-RGV-100\% & & 3 & & & - & - & & & & \\
\hline
\end{tabular}

As miniparedes dos Grupos 4,5 e 12,0 foram produzidas diretamente na câmara climatizada sob controle de umidade e temperatura; por outro lado, as miniparedes do Grupo 8,0, foram produzidas no galpão do laboratório. Decorridas 24 horas, os elementos do Grupo 8,0 foram transferidos até a câmara úmida $\left(T=30^{\circ} \mathrm{C}\right.$ e $\left.U=95 \%\right)$ onde permaneceram por 48 horas; sendo, então, transferidos para a câmara climatizada. $\mathrm{O}$ objetivo desse procedimento foi verificar a influência das condições de umidade das unidades e miniparedes sobre a retração por secagem, simulando a possibilidade de ocorrência de chuva após a elevação da parede.

Nessa etapa não foram moldados corpos-de-prova de argamassa para avaliação das propriedades físicas e mecânicas, uma vez que foi utilizado o mesmo traço do Capítulo 8.

\subsubsection{Procedimentos adotados para execução das miniparedes de retração}

Nos próximos itens, são apresentados os detalhes referentes à produção das miniparedes de retração.

1 - Preliminarmente, os blocos e meios-blocos foram separados e dispostos no interior do laboratório sete dias antes do assentamento, com o intuito de reduzir a umidade das 
unidades e a retração por secagem. De acordo com a NBR 6136 (1994), para unidades com retração linear entre 0,30 e $0,45 \mathrm{~mm} / \mathrm{m}$ e ambientes com umidade relativa entre 50 e $75 \%$, a umidade dessas unidades no momento do assentamento deve ser, no máximo, de $35 \%$.

2 - Com relação à execução dos elementos, foi realizada a mistura manual dos materiais pelo pedreiro. Os materiais foram previamente misturados a seco e depois, gradualmente, foi adicionada água, Figura 9.12.

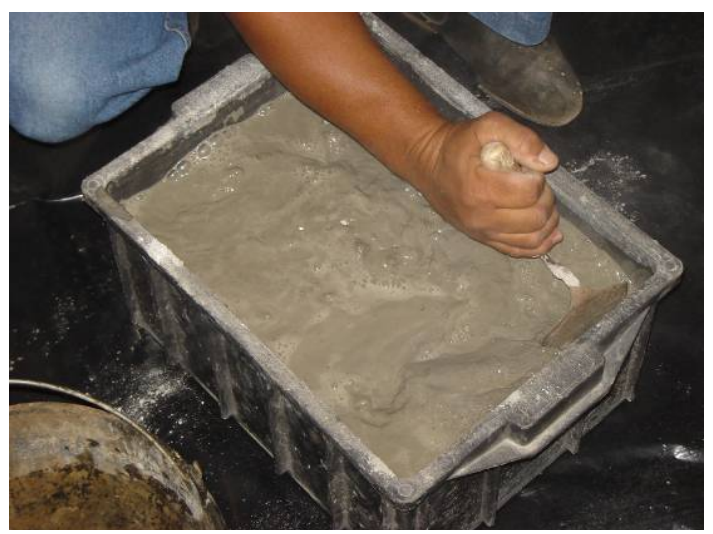

Figura 9.12 - Mistura manual da argamassa.

3 - A produção das miniparedes de retração foi iniciada pelo nivelamento dos dois blocos inferiores com auxílio de nível de bolha e disposição dos cordões de argamassa nas paredes transversais e longitudinais e na junta vertical. Posteriormente, foram assentados os meios-blocos da fiada intermediária e, finalmente, as unidades da última fiada com ajuste da espessura da argamassa e nivelamento do conjunto com nível de bolha e martelo de borracha, Figura 9.13.
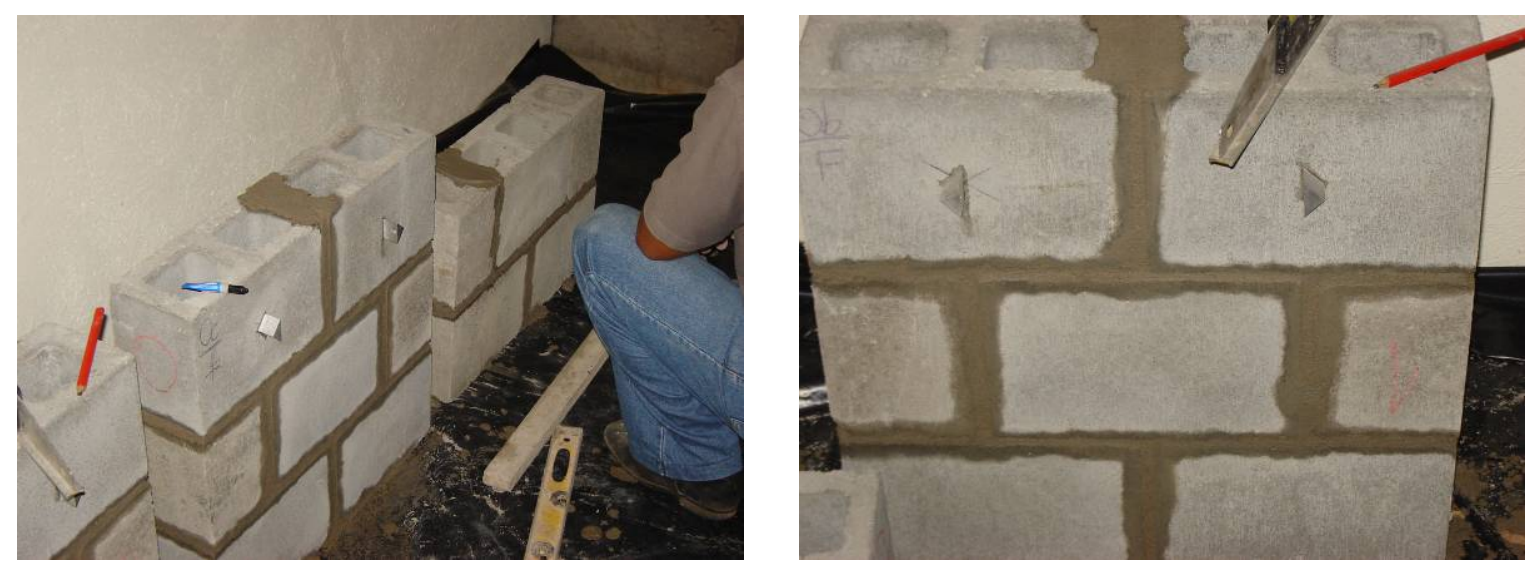

Figura 9.13 - Execução das miniparedes de retração. 
4 - Após a execução das miniparedes, foram colocados nas duas faces do elemento, na última fiada, os apoios das bases de medida (peças de alumínio) distantes $30 \mathrm{~cm}$ um do outro. Essas peças foram dispostas com auxílio de nível de bolha e fixadas com cola epóxi, Figura 9.14. A retração foi determinada na última fiada visando reduzir a influência da restrição da base de apoio; de acordo com Kleilson (2005), a restrição da primeira fiada da alvenaria, em função do contato com a base de apoio, acarreta uma redução dos valores de retração.

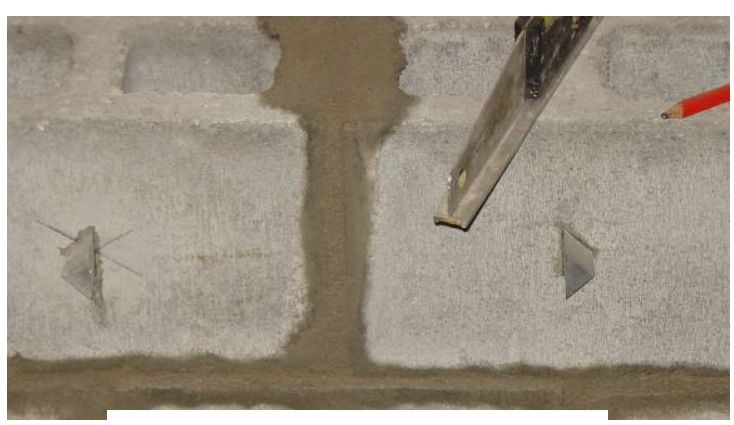

a) disposição das bases de apoio

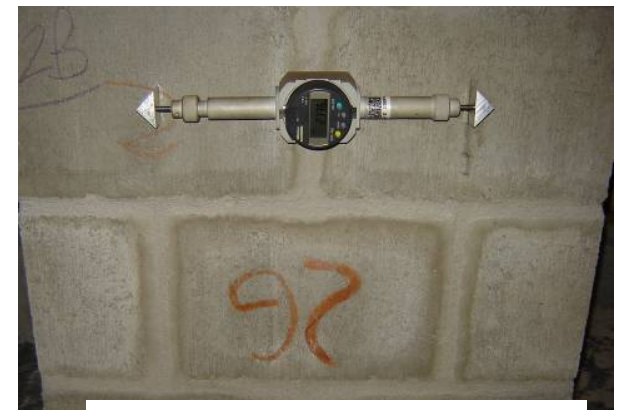

b) bases de apoio na última fiada

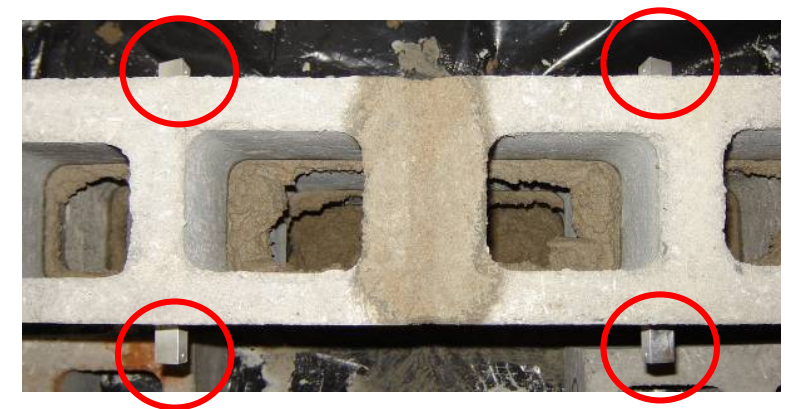

c) bases de apoio nas duas faces das miniparedes

Figura 9.14 - Disposição das bases de apoio.

$\mathrm{Na}$ Figura 9.15, observam-se as miniparedes que seriam verificadas quanto à retração. As miniparedes dos Grupos 4,5 e 12,0 foram produzidas diretamente na câmara climatizada com controle de umidade e temperatura; já as miniparedes do Grupo 8,0 foram produzidas no galpão do laboratório. 


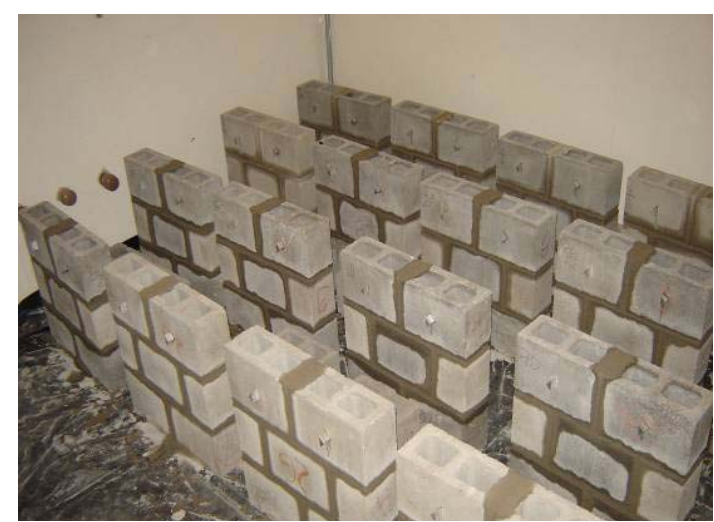

a) miniparedes dos Grupos 4,5 e 12,0

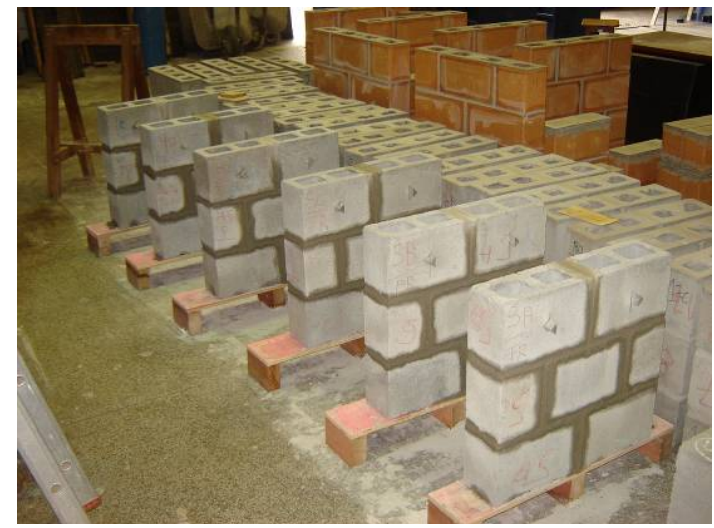

b) miniparedes do Grupo 8,0

Figura 9.15 - Miniparedes de retração.

Após 24 horas, os elementos do Grupo 8,0 foram transferidos para a câmara úmida onde permaneceram por 48 horas, Figura 9.16.
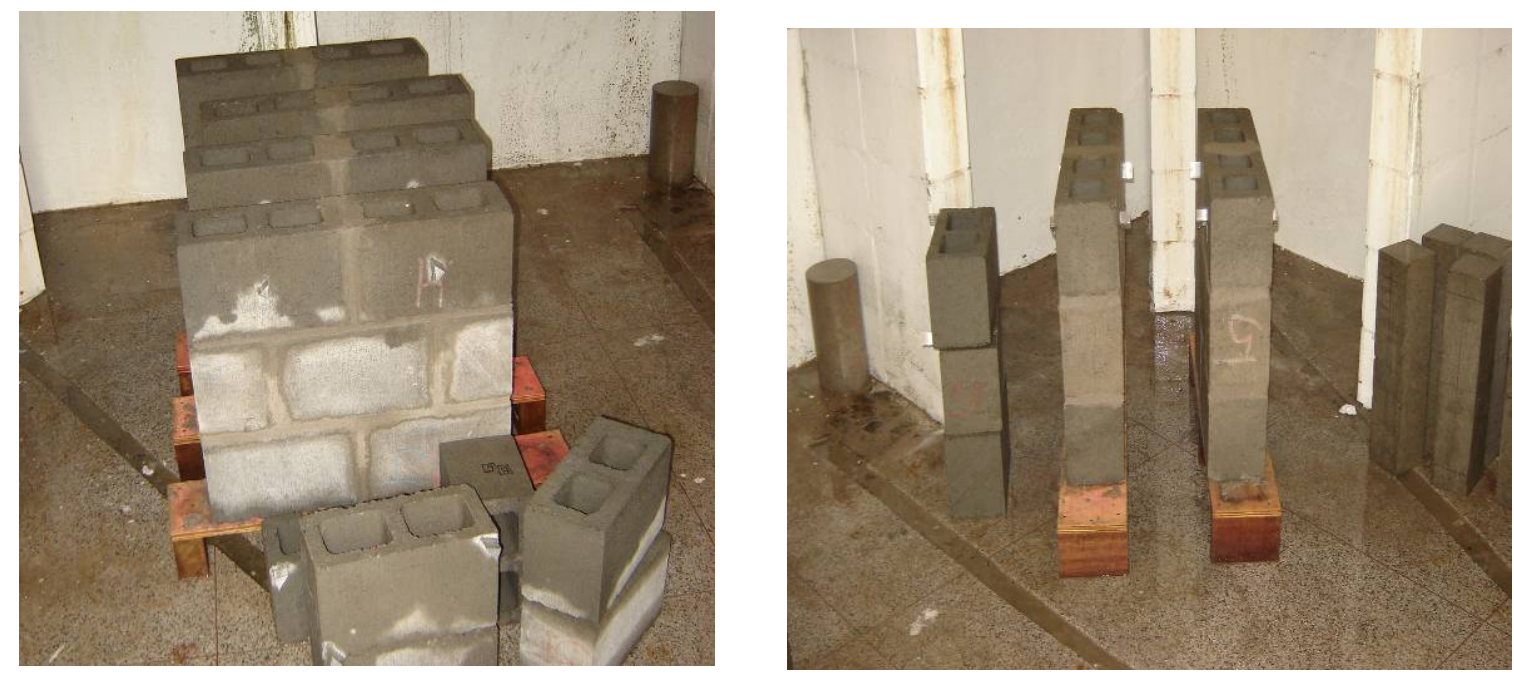

Figura 9.16 - Miniparedes do Grupo 8,0 dispostas na câmara úmida.

Posteriormente, esses elementos foram dispostos na câmara climatizada onde já se encontravam as demais miniparedes, Figura 9.17. 

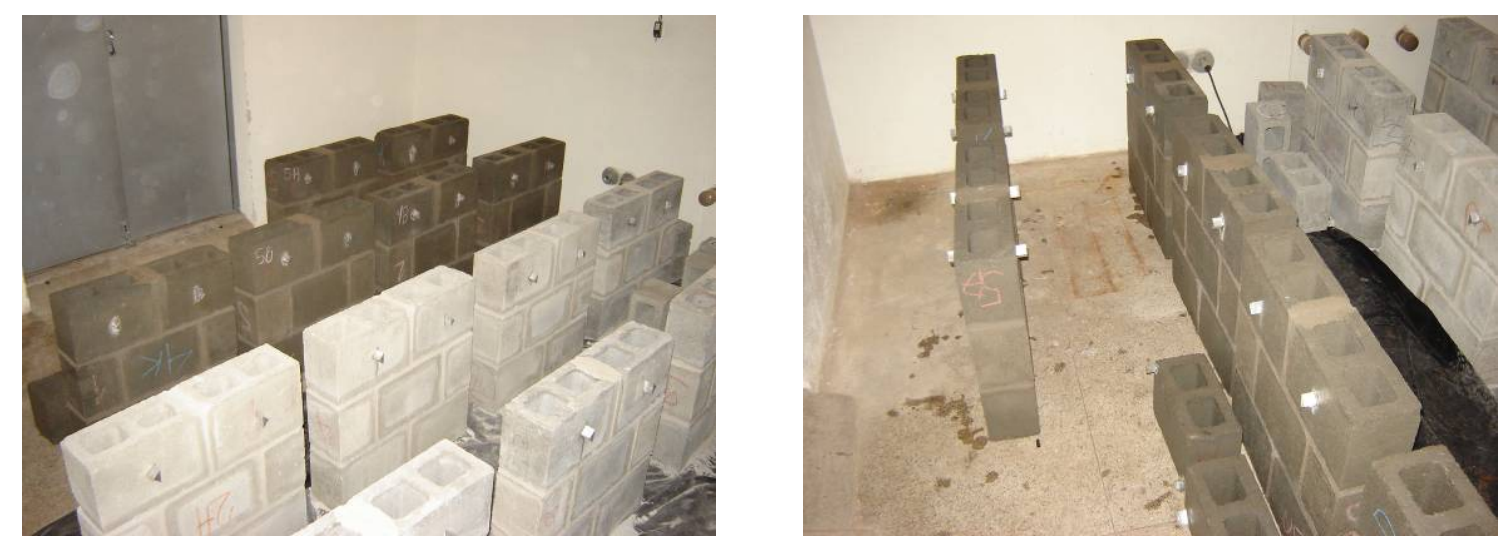

Figura 9.17 - Miniparedes do Grupo 8,0 dispostas na câmara climatizada.

\subsubsection{Definição das miniparedes}

Conforme já relatado no capítulo 7 , devido ao espaço reduzido da câmara climatizada não foi possível produzir mais do que 24 elementos (8 tipos de unidades). Diante disso e considerando-se os valores de retração dos blocos de concreto (ensaio realizado preliminarmente), para a produção das miniparedes de retração foram escolhidas as unidades dos Grupos 4,5 e 12,0, uma vez que apresentaram os menores e maiores valores de retração, respectivamente. As unidades adotadas para a produção dos elementos foram: unidades de referência, unidades com agregados graúdos reciclados de vigota (RGV-100\%) e as com adição de agregados graúdos reciclados de bloco (RGB-50\%). Os elementos do Grupo 8,0 (REF e RGV-100\%) foram produzidos com o intuito de avaliar a influência da condição de umidade da miniparede sobre a retração por secagem. A terminologia adotada para cada miniparede de retração é apresentada na Tabela 9.3. 
Tabela 9.3 - Terminologia adotada para as miniparedes.

\begin{tabular}{|c|c|c|}
\hline $\begin{array}{l}\text { GRUPO/CLASSE } \\
\text { DE RESISTENCIA } \\
\text { DAS UNIDADES }\end{array}$ & DESIGNAÇÃO & CARACTERÍSTICAS \\
\hline \multirow[b]{2}{*}{4,5} & PAR4,5-REF & $\begin{array}{c}\text { Miniparedes compostas por unidades produzidas com agregados } \\
\text { naturais }\end{array}$ \\
\hline & PAR4,5-RGV-100\% & $\begin{array}{c}\text { Miniparedes compostas por unidades com } 100 \% \text { de substituição, em } \\
\text { massa, da fração graúda natural (pedrisco) por agregado graúdo } \\
\text { reciclado de vigota (GRv) }\end{array}$ \\
\hline \multirow[b]{2}{*}{8,0} & PAR8,0-REF & $\begin{array}{l}\text { Miniparedes compostas por unidades produzidas com agregados } \\
\text { naturais }\end{array}$ \\
\hline & PAR8,0-RGV-100\% & $\begin{array}{c}\text { Miniparedes compostas por unidades com } 100 \% \text { de substituição, em } \\
\text { massa, da fração graúda natural (pedrisco) por agregado graúdo } \\
\text { reciclado de vigota (GRv) }\end{array}$ \\
\hline \multirow{3}{*}{12,0} & PAR12,0-REF & $\begin{array}{c}\text { Miniparedes compostas por unidades produzidas com agregados } \\
\text { naturais }\end{array}$ \\
\hline & PAR12,0-RGV-100\% & $\begin{array}{c}\text { Miniparedes compostas por unidades com } 100 \% \text { de substituição, em } \\
\text { massa, da fração graúda natural (pedrisco) por agregado graúdo } \\
\text { reciclado de vigota (GRv) }\end{array}$ \\
\hline & PAR12,0-RGB-50\% & $\begin{array}{c}\text { Miniparedes compostas por unidades com } 50 \% \text { de substituição, em } \\
\text { massa, da fração graúda natural por agregado graúdo reciclado de } \\
\text { bloco (GRb) }\end{array}$ \\
\hline
\end{tabular}

\subsection{RESULTADOS E ANÁLISES - BLOCOS DE CONCRETO}

Os resultados e as análises dos valores obtidos para a propriedade de retração por secagem serão separados em grupos/classes de resistência. Posteriormente, será empregado o teste de análise de variância para avaliação global dos resultados obtidos.

\subsubsection{GRUPO 4,5}

$\mathrm{Na}$ Tabela 9.4, são apresentadas as características dos traços pertencentes ao Grupo 4,5. 
Tabela 9.4 - Dosagens do Grupo 4,5.

\begin{tabular}{|c|c|c|c|}
\hline GRUPO & DESIGNAÇÃO & DATA DE PRODUÇÃO & CARACTERÍSTICAS \\
\hline \multirow{6}{*}{4,5} & B4,5-REF & $20 / 10 / 2005$ & $\begin{array}{l}\text { Dosagem de referência produzida inteiramente } \\
\text { com materiais naturais }\end{array}$ \\
\hline & B4,5-RGV-100\% & 19/09/2005 & $\begin{array}{l}\text { Dosagem com } 100 \% \text { de substituição, em massa, } \\
\text { da fração graúda natural (pedrisco) por agregado } \\
\text { graúdo reciclado de vigota (GRv) }\end{array}$ \\
\hline & B4,5-RGV-50\% & $19 / 09 / 2005$ & $\begin{array}{l}\text { Dosagem com aproximadamente } 50 \% \text { de } \\
\text { substituição, em massa, da fração graúda natural } \\
\text { por agregado graúdo reciclado de vigota (GRv) }\end{array}$ \\
\hline & B4,5-RMV-33\% & 19/09/2005 & $\begin{array}{l}\text { Dosagem com aproximadamente } 33 \% \text { de } \\
\text { substituição, em massa, do pó de pedra por } \\
\text { agregado miúdo reciclado de vigota (MRv) }\end{array}$ \\
\hline & B4,5-RGB-50\% & 20/09/2005 & $\begin{array}{l}\text { Dosagem com aproximadamente } 50 \% \text { de } \\
\text { substituição, em massa, da fração graúda natural } \\
\text { por agregado graúdo reciclado de bloco (GRb) }\end{array}$ \\
\hline & B4,5-RMB-33\% & 20/09/2005 & $\begin{array}{l}\text { Dosagem com aproximadamente } 33 \% \text { de } \\
\text { substituição, em massa, do pó de pedra por } \\
\text { agregado miúdo reciclado de bloco (MRb) }\end{array}$ \\
\hline
\end{tabular}

Os resultados de retração por secagem, os valores de umidade e a retração para cada idade comparativamente à retração total para os corpos-de-prova de bloco do Grupo 4,5 são apresentados na Tabela 9.5.

Tabela 9.5 - Valores de retração por secagem para os corpos-de-prova do Grupo 4,5.

\begin{tabular}{|c|c|c|c|c|c|c|c|c|c|c|c|}
\hline & & \multicolumn{10}{|c|}{ Tempo (dias) } \\
\hline & & 0 & 1 & 2 & 3 & 4 & 5 & 8 & 10 & 16 & 26 \\
\hline \multirow{5}{*}{$\begin{array}{l}\text { B4,5-REF } \\
(27 \text { dias })^{1}\end{array}$} & $\mathrm{~T}\left({ }^{\circ} \mathrm{C}\right)$ & 25,7 & 26,2 & 25,6 & 25,7 & 26,2 & 26,0 & 26,1 & 26,1 & 26,1 & 26,3 \\
\hline & $U_{\text {ambiente }}(\%)$ & 54,0 & 54 & 52,7 & 51,3 & 51,0 & 51,0 & 51,0 & 50,0 & 51,3 & 53,7 \\
\hline & $\begin{array}{l}\text { Umidade das } \\
\text { unidades(\%) }\end{array}$ & 100 & 43,33 & 32,40 & 27,78 & 25,60 & 24,37 & 22,34 & 21,78 & 21,15 & 20,14 \\
\hline & Retração $\left({ }^{*} 10^{-6}\right)$ & 0 & $-11,7$ & $-89,2$ & $-160,0$ & $-190,0$ & $-204,0$ & $-232,0$ & $-245,0$ & $-260,0$ & $-272,0$ \\
\hline & $\begin{array}{c}\text { \% da retração } \\
\text { total }\end{array}$ & 0 & 4,3 & 32,8 & 58,8 & 69,9 & 75,0 & 85,3 & 90,1 & 95,6 & 100 \\
\hline \multicolumn{2}{|c|}{ Tempo (dias) } & 0 & 1 & 2 & 3 & 5 & 7 & 9 & 13 & 20 & 27 \\
\hline \multirow{5}{*}{$\begin{array}{c}\text { B4,5-RGV- } \\
\text { 100\% } \\
(14 \text { dias })^{1}\end{array}$} & $\mathrm{~T}\left({ }^{\circ} \mathrm{C}\right)$ & 26,5 & 26,3 & 26,7 & 26,8 & 26,4 & 26,6 & 26,5 & 26,3 & 26,1 & 25,7 \\
\hline & $U_{\text {ambiente }}(\%)$ & 56,7 & 64,0 & 57,3 & 54,3 & 48,3 & 49,0 & 49,0 & 48,7 & 50,3 & 50,7 \\
\hline & $\begin{array}{l}\text { Umidade das } \\
\text { unidades(\%) }\end{array}$ & 100 & 75,68 & 52,87 & 44,23 & 33,95 & 30,79 & 29,14 & 27,38 & 26,17 & 25,60 \\
\hline & Retração $\left({ }^{*} 10^{-6}\right)$ & 0 & $-1,66$ & $-34,9$ & $-77,8$ & $-242,0$ & $-301,0$ & $-332,0$ & $-371,0$ & $-389,0$ & $-398,0$ \\
\hline & $\begin{array}{c}\% \text { da retração } \\
\text { total }\end{array}$ & 0 & 0,4 & 8,7 & 19,5 & 60,1 & 75,6 & 83,4 & 93,2 & 97,7 & 100 \\
\hline \multirow{5}{*}{$\begin{array}{c}\text { B4,5-RGV- } \\
\mathbf{5 0} \% \\
(14 \text { dias })^{1}\end{array}$} & $\mathrm{~T}\left({ }^{\circ} \mathrm{C}\right)$ & 26,3 & 26,4 & 26,8 & 26,5 & 26,4 & 26,5 & 26,6 & 26,5 & 25,8 & 25,9 \\
\hline & $U_{\text {ambiente }}(\%)$ & 57,7 & 62,3 & 57,7 & 54,7 & 49,0 & 49,0 & 49,7 & 48,7 & 50,3 & 51,0 \\
\hline & $\begin{array}{l}\text { Umidade das } \\
\text { unidades(\%) }\end{array}$ & 100 & 62,84 & 50,14 & 40,45 & 29,54 & 26,35 & 24,89 & 23,27 & 22,06 & 21,58 \\
\hline & Retração $\left({ }^{*} 10^{-6}\right)$ & 0 & $-39,2$ & $-64,9$ & $-108,0$ & $-273,0$ & $-328,0$ & $-343,0$ & $-377,0$ & $-390,0$ & $-399,0$ \\
\hline & $\begin{array}{c}\% \text { da retração } \\
\text { total }\end{array}$ & 0 & 9,8 & 16,3 & 27,1 & 68,4 & 82,2 & 86,0 & 94,5 & 97,7 & 100 \\
\hline \multirow{4}{*}{$\begin{array}{c}\text { B4,5-RMV- } \\
\mathbf{3 3 \%} \\
(14 \text { dias })^{1}\end{array}$} & $\begin{array}{c}\mathrm{T}\left({ }^{\circ} \mathrm{C}\right) \\
\mathrm{U}_{\text {ambiente }}(\%)\end{array}$ & $\begin{array}{l}26,2 \\
61,3\end{array}$ & $\begin{array}{l}26,3 \\
60,7\end{array}$ & $\begin{array}{l}26,9 \\
60,3\end{array}$ & $\begin{array}{l}26,8 \\
55,3\end{array}$ & $\begin{array}{l}26,2 \\
49,0\end{array}$ & $\begin{array}{l}26,2 \\
48,3\end{array}$ & $\begin{array}{l}26,1 \\
48,3\end{array}$ & \begin{tabular}{|l|}
26,3 \\
49,3
\end{tabular} & $\begin{array}{l}26,3 \\
53,0\end{array}$ & $\begin{array}{l}26,1 \\
51,0\end{array}$ \\
\hline & $\begin{array}{l}\text { Umidade das } \\
\text { unidades(\%) }\end{array}$ & 100 & 75,07 & 51,83 & 43,60 & 32,79 & 29,35 & 27,56 & 25,40 & 23,93 & 22,92 \\
\hline & Retração $\left({ }^{*} 10^{-6}\right)$ & 0 & $-20,5$ & $-49,1$ & $-100,0$ & $-275,0$ & $-308,0$ & $-317,0$ & $-346,0$ & $-358,0$ & $-378,0$ \\
\hline & $\begin{array}{c}\% \text { da retração } \\
\text { total }\end{array}$ & 0 & 5,4 & 13,0 & 26,5 & 72,8 & 81,5 & 83,9 & 91,5 & 94,7 & 100 \\
\hline \multirow{5}{*}{$\begin{array}{c}\text { B4,5-RGB- } \\
\mathbf{5 0 \%} \\
(13 \text { dias })^{1}\end{array}$} & $\mathrm{~T}\left({ }^{\circ} \mathrm{C}\right)$ & 26,4 & 26,5 & 26,3 & 26,5 & 26,4 & 26,6 & 26,6 & 26,3 & 26,3 & 26,0 \\
\hline & $\mathrm{U}_{\text {ambiente }}(\%)$ & 60,3 & 63,0 & 56,0 & 54,7 & 49,3 & 49,0 & 50,0 & 49,0 & 51,0 & 49,7 \\
\hline & $\begin{array}{l}\text { Umidade das } \\
\text { unidades }(\%)\end{array}$ & 100 & 78,71 & 54,50 & 42,55 & 32,62 & 29,22 & 27,50 & 24,92 & 23,63 & 23,06 \\
\hline & Retração $\left({ }^{*} 10^{-6}\right)$ & 0 & 0 & $-16,9$ & $-71,6$ & $-239,0$ & $-293,0$ & $-315,0$ & $-358,0$ & $-365,0$ & $-368,0$ \\
\hline & $\begin{array}{c}\text { \% da retração } \\
\text { total }\end{array}$ & 0 & 0 & 4,6 & 19,5 & 64,7 & 79,6 & 85,6 & 97,3 & 99,2 & 100 \\
\hline \multirow{4}{*}{$\begin{array}{c}\text { B4,5-RMB- } \\
\mathbf{3 3} \% \\
\left(^{(13 \text { dias })^{1}}\right.\end{array}$} & $\begin{array}{c}\mathrm{T}\left({ }^{\circ} \mathrm{C}\right) \\
\mathrm{U}_{\text {ambiente }}(\%)\end{array}$ & $\begin{array}{l}26,4 \\
57,0\end{array}$ & $\begin{array}{l}26,3 \\
627\end{array}$ & $\begin{array}{l}26,5 \\
57,0\end{array}$ & $\begin{array}{l}26,5 \\
54,7\end{array}$ & $\begin{array}{l}26,6 \\
49,7\end{array}$ & $\begin{array}{l}26,4 \\
48,3\end{array}$ & $\begin{array}{l}26,4 \\
49,3\end{array}$ & $\begin{array}{l}26,3 \\
490\end{array}$ & $\begin{array}{l}26,2 \\
510\end{array}$ & $\begin{array}{l}25,9 \\
507\end{array}$ \\
\hline & $\begin{array}{l}\text { Umidade das } \\
\text { unidades }(\%)\end{array}$ & 100 & 75,85 & 47,80 & 37,31 & 27,94 & 25,27 & 24,01 & 22,41 & 21,64 & 21,31 \\
\hline & Retração $\left({ }^{*} 10^{-6}\right)$ & 0 & $-1,42$ & $-1,25$ & $-45,7$ & $-200,0$ & $-241,0$ & $-265,0$ & $-306,0$ & $-328,0$ & $-335,0$ \\
\hline & $\begin{array}{c}\text { \% da retração } \\
\text { total }\end{array}$ & 0 & 0,4 & 0,4 & 13,6 & 59,7 & 71,9 & 79,1 & 91,3 & 97,9 & 100 \\
\hline
\end{tabular}


Na Figura 9.18, pode ser observada a evolução da retração por secagem em função do tempo de ensaio.

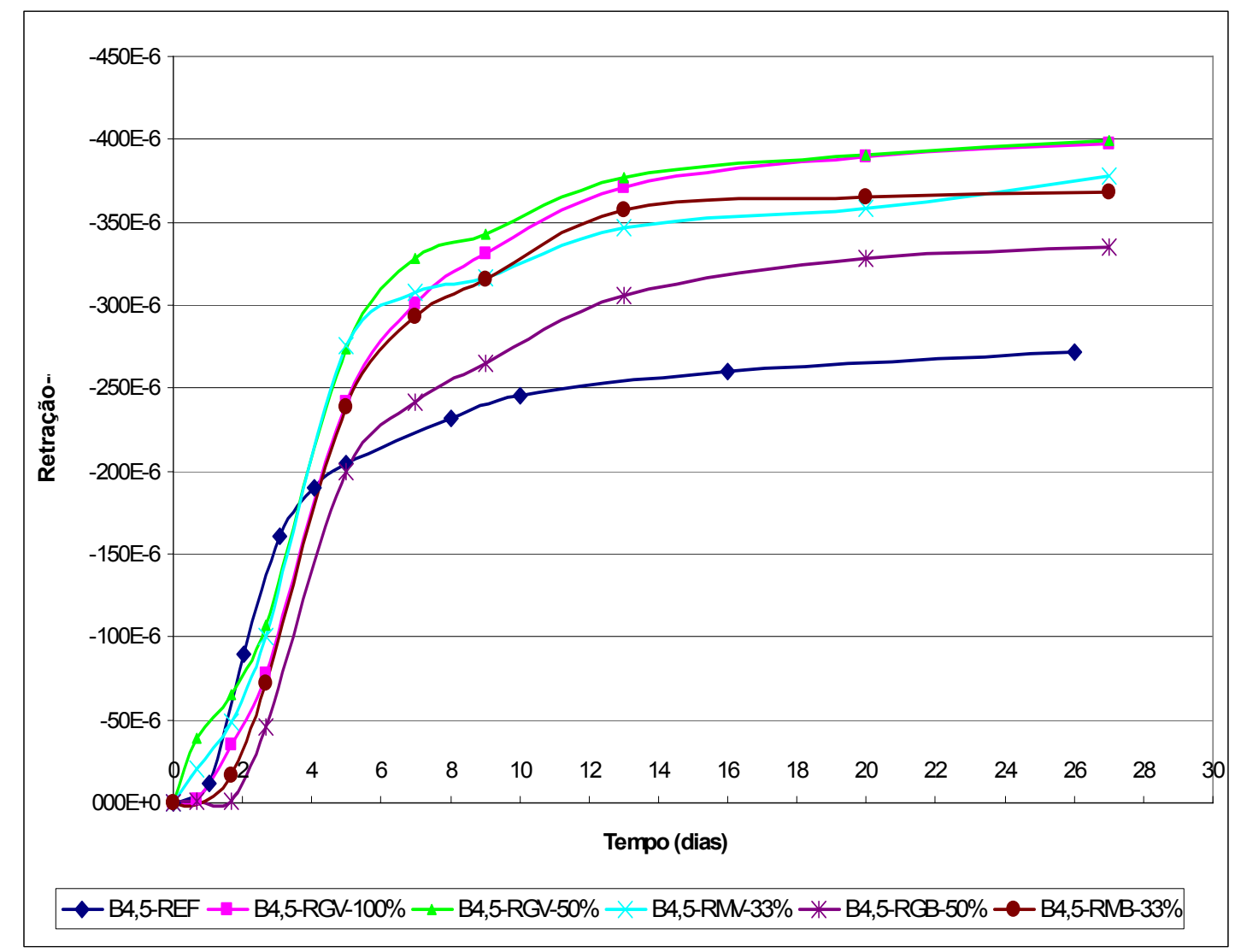

Figura 9.18 - Evolução da retração por secagem para os corpos-de-prova do Grupo 4,5.

Analisando-se os resultados da Tabela 9.5 e Figura 9.18, nota-se que os valores de retração para os corpos-de-prova de blocos com agregados reciclados foram significativamente maiores quando comparados com os valores de referência (B4,5-REF). Esses valores foram, em média, $47 \%, 35 \%$ e $31 \%$ maiores, para os CPs com agregados graúdos reciclados de vigota, CPs com agregados graúdos reciclados de bloco e CPs com agregados miúdos reciclados, respectivamente. Apesar disso, todos os blocos cumpriram as exigências da NBR 6136 (1994) que prescreve valores de retração por secagem inferiores a 0,065\%. Poon et al. (2002), para blocos de concretos maciços, com taxas de substituições de agregados naturais por reciclados de concreto de $50 \%\left(f_{b}=16,7 \mathrm{MPa}\right), 75 \%\left(f_{b}=15,0\right.$ MPa) e $100 \%\left(f_{b}=11,8 \mathrm{MPa}\right)$, obtiveram valores de retração cerca de $10 \%, 15 \%$ e $30 \%$ superiores, respectivamente, em relação aos valores de retração das unidades com agregados naturais.

Os ensaios de retração foram realizados para blocos com idades superiores a 13 dias. Conforme Barbosa (2005), para a execução da alvenaria, deve-se respeitar um 
período mínimo de 7 dias para blocos de resistência até 8,0 MPa e 14 dias para blocos de resistência superiores a 8,0 MPa; sendo que, em ambas as situações, foram consideradas unidades produzidas com rigoroso controle e submetidas à cura térmica. Medeiros (1993) cita que a retração por secagem para blocos de concreto é geralmente muito elevada nas primeiras idades; por isso, o pesquisador recomenda que deva ser respeitado um limite mínimo de três dias para unidades curadas a vapor e 14 dias para blocos submetidos à cura ambiente, para que um determinado lote seja liberado para utilização. A NBR 8798 (1985) cita que esse período mínimo deve ser respeitado para que seja minimizada a retração hidráulica e irreversível.

A comparação entre a umidade das unidades e a sua respectiva retração parcial (função da retração total aos 27 dias), no decorrer do ensaio, encontra-se nas Figuras 9.19 e 9.20 .

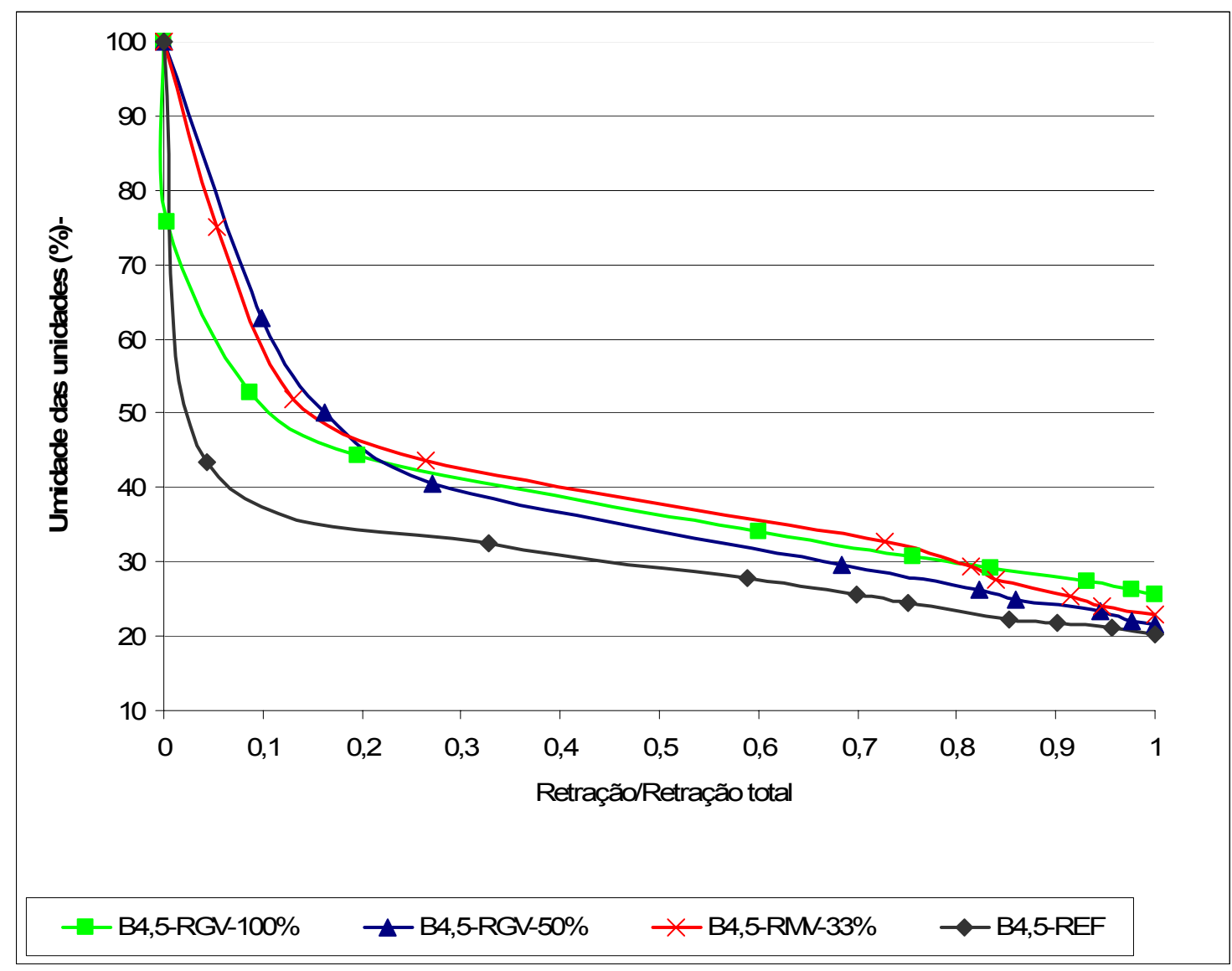

Figura 9.19 - Umidade das unidades x retração por secagem para os corpos-de-prova de referência e agregados reciclados de vigota - Grupo 4,5.

Analisando-se os resultados da Figura 9.19, nota-se que a retração por secagem das unidades foi significativa, representando cerca de $70 \%$ da retração total, apenas para 
valores de umidade abaixo de 30\%. Drysdale e Khattab (1995), que avaliaram 24 fábricas de blocos de concreto em Ontário, citam que grande parte da retração por secagem ocorre em estágios avançados de secagem. Partindo-se de um estágio na condição saturada, usualmente é necessário remover mais que a metade da água presente na unidade para que ocorra uma retração significativa. Para unidades com retração por secagem entre 0,30 $\mathrm{mm} / \mathrm{m}$ e $0,45 \mathrm{~mm} / \mathrm{m}$ e considerando valores médios de umidade local (50\% - 75\%), a NBR 6136 (1994) prescreve que a umidade máxima da unidade no momento do seu assentamento seja de $35 \%$, visando reduzir a retração por secagem; com base nos resultados obtidos, nota-se que, para essa umidade, os valores de retração por secagem ainda são significativos. Para os CPs de blocos, pode-se afirmar que para a umidade de $35 \%$, apenas $26 \%$ (B4,5-REF), 56\% (B4,5-RGV-100\%), 47\% (B4,5-RGV-50\%) e 63\% (B4,5RMV-33\%) da retração total haviam ocorrido.

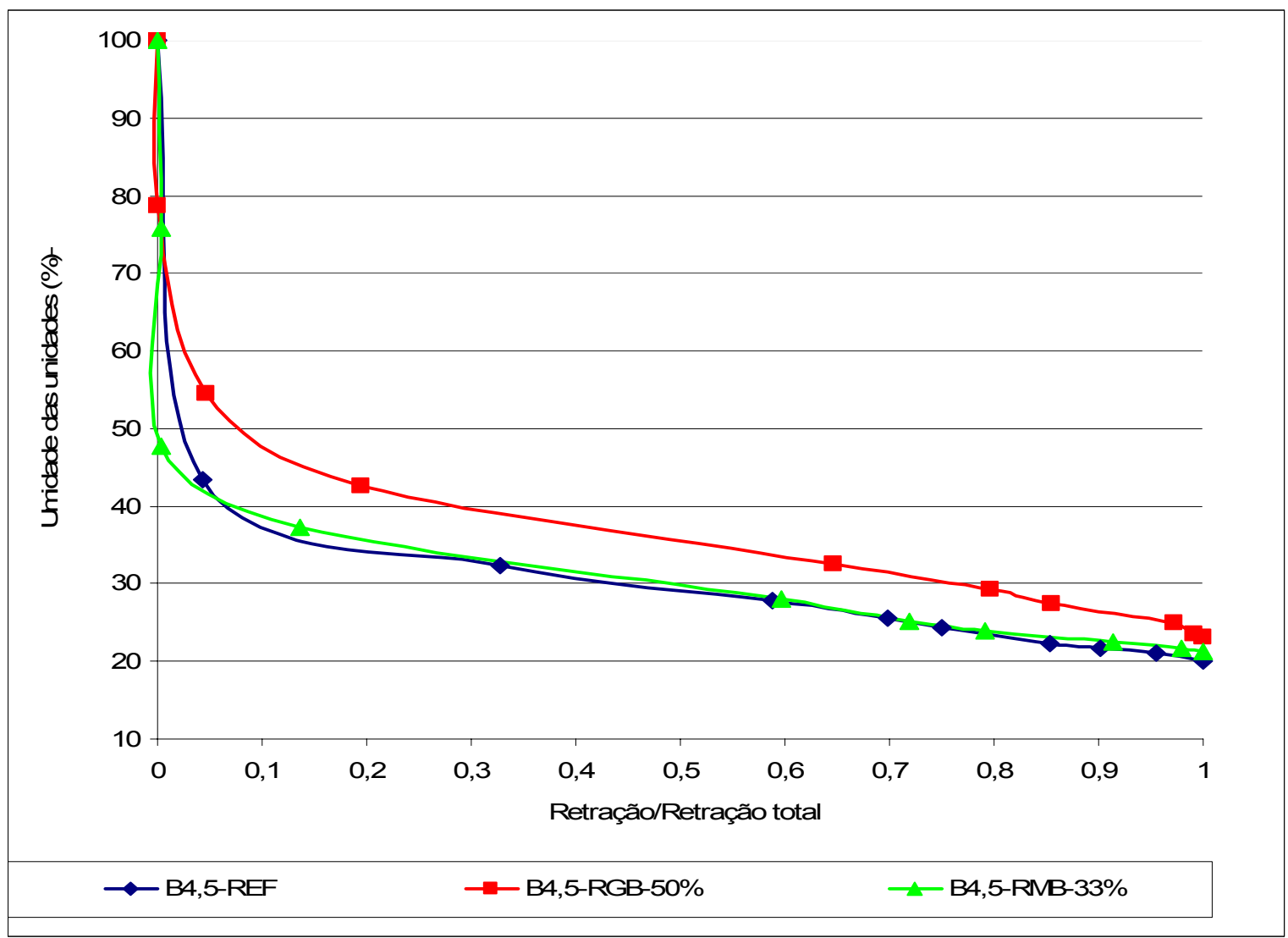

Figura 9.20 - Umidade das unidades x retração por secagem para os corpos-de-prova de referência e agregados reciclados de bloco - Grupo 4,5

Pela Figura 9.20, nota-se que a retração por secagem das unidades de referência e com agregados miúdos reciclados foi significativa ( $70 \%$ da retração total) apenas para valores de umidade abaixo de $25 \%$. Novamente, os resultados obtidos mostram que as prescrições da NBR 6136 (1994) para o assentamento das unidades desse Grupo não 
foram adequadas, uma vez que, para a umidade de $35 \%$, conforme recomendado pela norma, as unidades avaliadas ainda apresentavam um potencial elevado de retração. Dessa forma, recomenda-se, em função dos resultados desse Grupo como também para os obtidos para os demais, que as unidades de alvenaria sejam, na medida do possível, protegidas da ação de intempéries, pelo menos uma semana antes do seu assentamento.

\subsubsection{GRUPO 8,0}

$\mathrm{Na}$ Tabela 9.6, são apresentadas as características dos traços pertencentes ao Grupo 8,0.

Tabela 9.6 - Dosagens do Grupo 8,0.

\begin{tabular}{|c|c|c|c|}
\hline GRUPO & DESIGNAÇÃO & DATA DE PRODUÇÃO & CARACTERÍSTICAS \\
\hline \multirow{6}{*}{8,0} & B8,0-REF & $19 / 09 / 2005$ & $\begin{array}{c}\text { Dosagem de referência produzida inteiramente com } \\
\text { materiais naturais }\end{array}$ \\
\hline & B8,0-RGV-100\% & $19 / 09 / 2005$ & $\begin{array}{c}\text { Dosagem com } 100 \% \text { de substituição, em massa, da } \\
\text { fração graúda natural (pedrisco) por agregado } \\
\text { graúdo reciclado de vigota (GRv) }\end{array}$ \\
\hline & B8,0-RGV-50\% & 19/09/2005 & $\begin{array}{l}\text { Dosagem com aproximadamente } 50 \% \text { de } \\
\text { substituição, em massa, da fração graúda natural } \\
\text { por agregado graúdo reciclado de vigota (GRv) }\end{array}$ \\
\hline & B8,0-RMV-33\% & $19 / 09 / 2005$ & $\begin{array}{l}\text { Dosagem com aproximadamente } 33 \% \text { de } \\
\text { substituição, em massa, do pó de pedra por } \\
\text { agregado miúdo reciclado de vigota (MRv) }\end{array}$ \\
\hline & B8,0-RGB-50\% & $20 / 09 / 2005$ & $\begin{array}{l}\text { Dosagem com aproximadamente } 50 \% \text { de } \\
\text { substituição, em massa, da fração graúda natural } \\
\text { por agregado graúdo reciclado de bloco (GRb) }\end{array}$ \\
\hline & B8,0-RMB-33\% & $20 / 09 / 2005$ & $\begin{array}{l}\text { Dosagem com aproximadamente } 33 \% \text { de } \\
\text { substituição, em massa, do pó de pedra por } \\
\text { agregado miúdo reciclado de bloco (MRb) }\end{array}$ \\
\hline
\end{tabular}

Os resultados de retração por secagem, os valores de umidade e a retração para cada idade comparativamente à retração total para os corpos-de-prova de bloco do Grupo 8,0 são apresentados na Tabela 9.7. 
Tabela 9.7 - Valores de retração por secagem para os corpos-de-prova do Grupo 8,0.

\begin{tabular}{|c|c|c|c|c|c|c|c|c|c|c|c|}
\hline & & \multicolumn{10}{|c|}{ Tempo (dias) } \\
\hline & & 0 & 1 & 2 & 3 & 5 & 7 & 9 & 13 & 20 & 27 \\
\hline \multirow{5}{*}{$\begin{array}{l}\text { B8,0-REF } \\
(14 \text { dias })^{1}\end{array}$} & $\mathrm{~T}\left({ }^{\circ} \mathrm{C}\right)$ & 26,4 & 26,4 & 26,5 & 26,3 & 26,6 & 26,6 & 26,3 & 26,3 & 26,1 & 25,8 \\
\hline & $U_{\text {ambiente }}(\%)$ & 61,0 & 61,7 & 57,7 & 54,0 & 50,0 & 49,0 & 48,3 & 48,7 & 51,7 & 49,7 \\
\hline & $\begin{array}{l}\text { Umidade das } \\
\text { unidades(\%) }\end{array}$ & 100 & 78,77 & 61,15 & 49,28 & 36,97 & 34,24 & 32,74 & 31,05 & 29,97 & 29,24 \\
\hline & Retração $\left({ }^{*} 10^{-6}\right)$ & 0 & $-11,0$ & $-39,1$ & $-80,0$ & $-219,0$ & $-258,0$ & $-283,0$ & $-314,0$ & $-323,0$ & $-332,0$ \\
\hline & $\begin{array}{c}\text { \% da retração } \\
\text { total }\end{array}$ & 0 & 3,3 & 11,8 & 24,1 & 65,9 & 77,7 & 85,2 & 94,6 & 97,3 & 100 \\
\hline \multirow{4}{*}{ 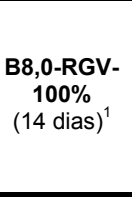 } & $\begin{array}{c}\mathrm{T}\left({ }^{\circ} \mathrm{C}\right) \\
\mathrm{U}_{\text {ambiente }}(\%)\end{array}$ & $\begin{array}{l}26,2 \\
58,7\end{array}$ & $\begin{array}{l}26,4 \\
62,7\end{array}$ & $\begin{array}{l}26,4 \\
57,0\end{array}$ & $\begin{array}{l}26,6 \\
54,7\end{array}$ & $\begin{array}{l}26,8 \\
50,0\end{array}$ & $\begin{array}{l}26,3 \\
48,7\end{array}$ & $\begin{array}{l}26,4 \\
49,7\end{array}$ & $\begin{array}{l}26,3 \\
49,0\end{array}$ & $\begin{array}{l}26,0 \\
49,3\end{array}$ & $\begin{array}{l}25,8 \\
50,7\end{array}$ \\
\hline & $\begin{array}{l}\text { Umidade das } \\
\text { unidades(\%) }\end{array}$ & 100 & 79,03 & 59,06 & 51,65 & 43,51 & 40,58 & 38,73 & 36,76 & 35,13 & 34,42 \\
\hline & Retração $\left({ }^{*} 10^{-6}\right)$ & 0 & $-12,5$ & $-40,9$ & $-84,8$ & $-259,0$ & $-312,0$ & $-338,0$ & $-382,0$ & $-405,0$ & $-418,0$ \\
\hline & $\begin{array}{c}\text { \% da retração } \\
\text { total }\end{array}$ & 0 & 3,0 & 9,8 & 20,3 & 62,0 & 74,6 & 80,9 & 91,4 & 96,9 & 100 \\
\hline \multirow{5}{*}{$\begin{array}{c}\text { B8,0-RGV- } \\
\mathbf{5 0 \%} \\
(14 \text { dias })^{1}\end{array}$} & $\mathrm{~T}\left({ }^{\circ} \mathrm{C}\right)$ & 26,1 & 26,3 & 26,7 & 26,5 & 26,4 & 26,5 & 26,7 & 26,6 & 25,8 & 26,2 \\
\hline & $U_{\text {ambiente }}(\%)$ & 56,0 & 62,3 & 58,0 & 54,7 & 49,7 & 48,7 & 49,7 & 49,7 & 51,3 & 51,3 \\
\hline & $\begin{array}{l}\text { Umidade das } \\
\text { unidades(\%) }\end{array}$ & 100 & 74,53 & 57,77 & 48,19 & 39,00 & 35,91 & 34,26 & 31,98 & 30,63 & 30,05 \\
\hline & Retração $\left({ }^{*} 10^{-6}\right)$ & 0 & $-4,2$ & $-25,9$ & $-64,8$ & $-209,0$ & $-259,0$ & $-281,0$ & $-319,0$ & $-336,0$ & $-340,0$ \\
\hline & $\begin{array}{c}\text { \% da retração } \\
\text { total }\end{array}$ & 0 & 1,2 & 7,6 & 19,1 & 61,5 & 76,2 & 82,6 & 93,8 & 98,8 & 100 \\
\hline \multirow{5}{*}{$\begin{array}{c}\text { B8,0-RMV- } \\
\mathbf{3 3 \%} \\
{(14 \text { dias })^{1}}^{1}\end{array}$} & $\mathrm{~T}\left({ }^{\circ} \mathrm{C}\right)$ & 26,1 & 26,2 & 26,7 & 26,3 & 26,2 & 26,4 & 26,3 & 26,6 & 26,0 & 25,9 \\
\hline & $U_{\text {ambiente }}(\%)$ & 60,3 & 60,3 & 59,0 & 53,7 & 49,3 & 48,7 & 48,7 & 49,3 & 51,7 & 50,7 \\
\hline & $\begin{array}{l}\text { Umidade das } \\
\text { unidades(\%) }\end{array}$ & 100 & 74,25 & 55,97 & 47,68 & 36,92 & 33,27 & 31,11 & 28,47 & 26,21 & 24,65 \\
\hline & Retração $\left({ }^{*} 10^{-6}\right)$ & 0 & $-13,4$ & $-43,4$ & $-99,8$ & $-278,0$ & $-331,0$ & $-349,0$ & $-385,0$ & $-408,0$ & $-414,0$ \\
\hline & $\begin{array}{c}\% \text { da retração } \\
\text { total }\end{array}$ & 0 & 3,3 & 10,5 & 24,1 & 67,1 & 80,0 & 84,3 & 93,0 & 98,6 & 100 \\
\hline \multirow{5}{*}{$\begin{array}{c}\text { B8,0-RGB- } \\
\mathbf{5 0} \% \\
(13 \text { dias })^{1}\end{array}$} & $\mathrm{~T}\left({ }^{\circ} \mathrm{C}\right)$ & 26,4 & 26,5 & 26,6 & 26,5 & 26,7 & 26,4 & 26,1 & 26,4 & 26,1 & 25,7 \\
\hline & $\bigcup_{\text {ambiente }}(\%)$ & 61,3 & 61,7 & 58,0 & 55,3 & 49,3 & 48,3 & 48,0 & 49,0 & 51,3 & 50,0 \\
\hline & $\begin{array}{l}\text { Umidade das } \\
\text { unidades(\%) }\end{array}$ & 100 & 80,92 & 61,46 & 46,82 & 35,74 & 32,24 & 30,62 & 28,17 & 26,48 & 25,69 \\
\hline & Retração $\left({ }^{*} 10^{-6}\right)$ & 0 & $-1,5$ & $-20,5$ & $-57,2$ & $-217,0$ & $-274,0$ & $-300,0$ & $-348,0$ & $-372,0$ & $-380,0$ \\
\hline & $\begin{array}{c}\% \text { da retração } \\
\text { total }\end{array}$ & 0 & 0,4 & 5,4 & 15,1 & 57,1 & 72,1 & 78,9 & 91,6 & 97,9 & 100 \\
\hline \multirow{5}{*}{$\begin{array}{c}\text { B8,0-RMB- } \\
33 \% \\
(13 \text { dias })^{1}\end{array}$} & $\mathrm{~T}\left({ }^{\circ} \mathrm{C}\right)$ & 26,2 & 26,5 & 26,9 & 26,7 & 26,5 & 26,3 & 26,2 & 26,3 & 25,9 & 26,0 \\
\hline & $U_{\text {ambiente }}(\%)$ & 59,0 & 62,7 & 59,0 & 56,0 & 49,0 & 48,3 & 48,3 & 49,0 & 51,3 & 51,0 \\
\hline & $\begin{array}{l}\text { Umidade das } \\
\text { unidades(\%) }\end{array}$ & 100 & 76,50 & 58,69 & 49,10 & 38,96 & 35,67 & 33,84 & 31,41 & 29,85 & 28,89 \\
\hline & Retração $\left({ }^{*} 10^{-6}\right)$ & 0 & 0 & $-21,9$ & $-75,1$ & $-221,0$ & $-281,0$ & $-299,0$ & $-344,0$ & $-354,0$ & $-364,0$ \\
\hline & $\begin{array}{c}\text { \% da retração } \\
\text { total }\end{array}$ & 0 & 0 & 6,0 & 20,6 & 60,7 & 77,2 & 82,1 & 94,5 & 97,3 & 100 \\
\hline
\end{tabular}

Na Figura 9.21, pode ser observada a evolução da retração por secagem em função do tempo de ensaio. 


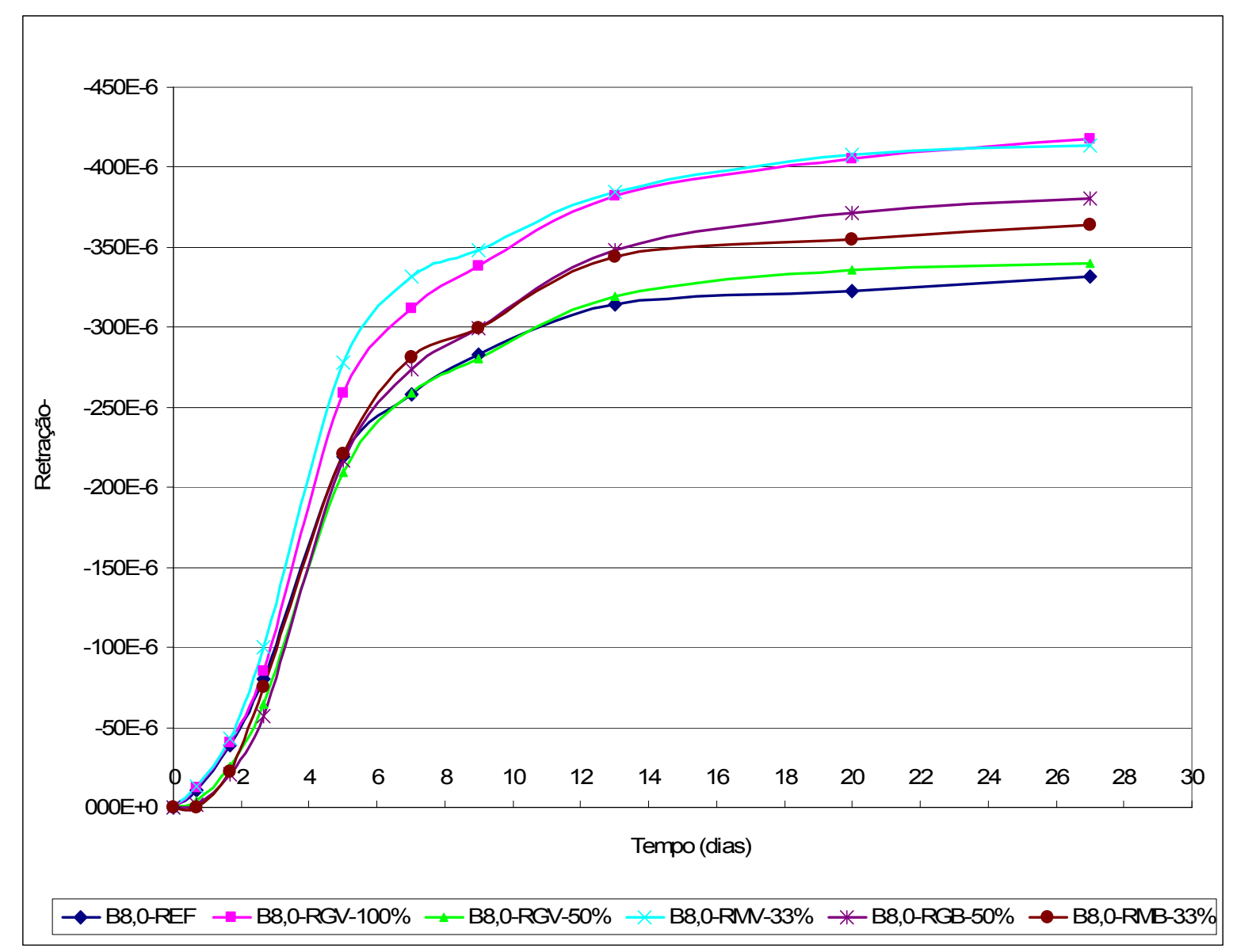

Figura 9.21 - Evolução da retração por secagem para os corpos-de-prova do Grupo 8,0.

Analisando-se os resultados da Tabela 9.7 e Figura 9.21, nota-se que os valores de retração para os corpos-de-prova de blocos com agregados reciclados, com exceção das unidades B8,0-RGV-50\%, foram maiores quando comparados com os valores de referência (B8,0-REF). Esses valores foram, em média, 25\% e 12\% maiores, comparativamente aos valores de referência, para os CPs com agregados reciclado de vigota e CPs com agregados reciclados de bloco, respectivamente. Apesar disso, todos os blocos cumpriram as exigências da NBR 6136 (1994) que prescreve valores de retração por secagem inferiores a 0,065\%.

A comparação entre a umidade das unidades e a retração parcial (em função da retração total), no decorrer do ensaio, encontra-se nas Figuras 9.22 e 9.23. 


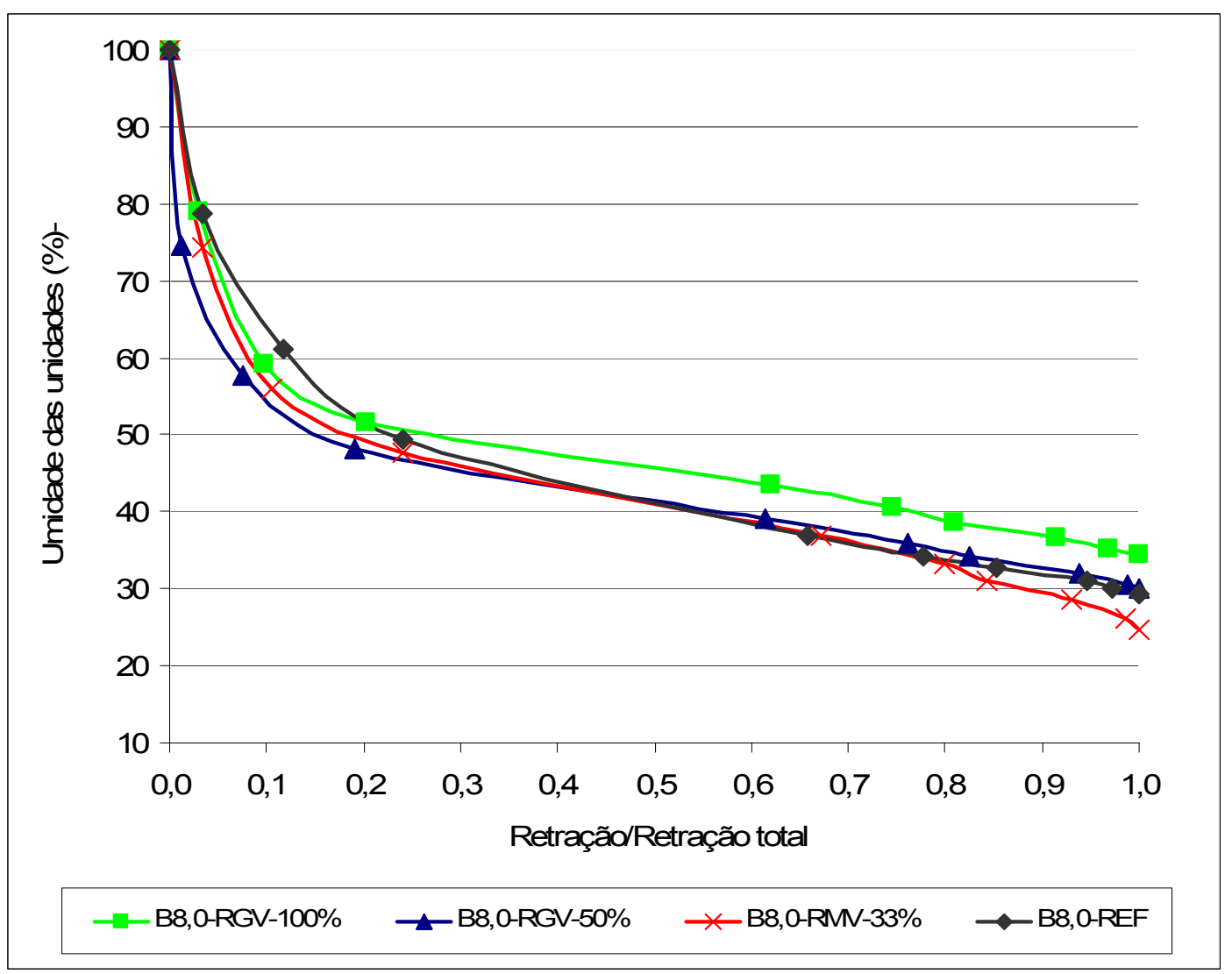

Figura 9.22 - Umidade das unidades x retração por secagem para os corpos-de-prova de referência e agregados reciclados de vigota - Grupo 8,0.

Analisando-se a Figura 9.22, nota-se que a retração por secagem das unidades foi significativa ( $70 \%$ da retração total) para valores de umidade situados entre $35 \%$ e $42 \%$. Diferentemente do que ocorreu para as unidades do Grupo 4,5, pode-se dizer que o valor de umidade igual a 35\%, prescrito pela NBR 6136 (1994), condiciona a valores subseqüentes de retração inferiores a $30 \%$ do valor total. 


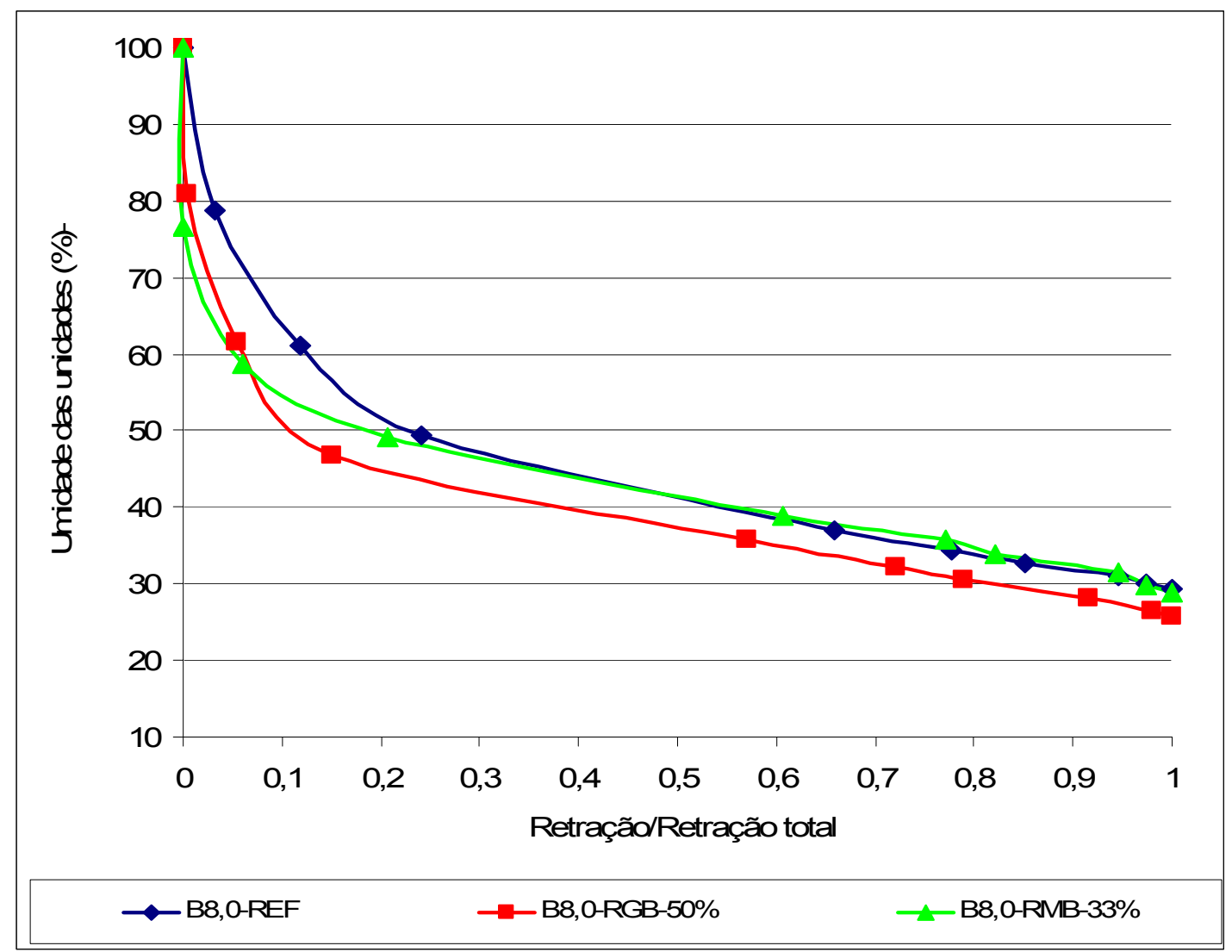

Figura 9.23 - Umidade das unidades x retração por secagem para os corpos-de-prova de referência e agregados reciclados de bloco - Grupo 8,0.

Analisando-se a Figura 9.23, nota-se que a retração por secagem das unidades foi significativa ( $70 \%$ da retração total) apenas para valores de umidade abaixo de $35 \%$. Diferentemente do que ocorreu para as unidades do Grupo 4,5, pode-se dizer que o valor de umidade igual a 35\%, prescrito pela NBR 6136 (1994), condiciona os valores subseqüentes de retração inferiores a $30 \%$ do valor total, para as unidades B8,0-REF e B8,0-RMB-33\%. Os resultados apresentados nas Figuras 9.22 e 9.23 ilustram a necessidade de controlar a umidade das unidades no momento do assentamento, já que para valores de umidade acima de $50 \%$ ocorreu, em média, apenas $20 \%$ da retração total.

\subsubsection{GRUPO 12,0}

$\mathrm{Na}$ Tabela 9.8, são apresentadas, novamente, as características dos traços pertencentes ao Grupo 12,0. 
Tabela 9.8 - Dosagens do Grupo 12,0.

\begin{tabular}{|c|c|c|c|}
\hline GRUPO & DESIGNAÇÃO & DATA DE PRODUÇÃO & CARACTERISTICAS \\
\hline \multirow{6}{*}{12,0} & B12,0-REF & $19 / 09 / 2005$ & $\begin{array}{c}\text { Dosagem de referência produzida inteiramente com } \\
\text { materiais naturais }\end{array}$ \\
\hline & B $12,0-R G V-100 \%$ & $19 / 09 / 2005$ & $\begin{array}{c}\text { Dosagem com } 100 \% \text { de substituição, em massa, da } \\
\text { fração graúda natural (pedrisco) por agregado } \\
\text { graúdo reciclado de vigota (GRv) }\end{array}$ \\
\hline & B12,0-RGV-50\% & $19 / 09 / 2005$ & $\begin{array}{l}\text { Dosagem com aproximadamente } 50 \% \text { de } \\
\text { substituição, em massa, da fração graúda natural } \\
\text { por agregado graúdo reciclado de vigota (GRv) }\end{array}$ \\
\hline & B 12,0-RMV-33\% & $19 / 09 / 2005$ & $\begin{array}{l}\text { Dosagem com aproximadamente } 33 \% \text { de } \\
\text { substituição, em massa, do pó de pedra por } \\
\text { agregado miúdo reciclado de vigota (MRv) }\end{array}$ \\
\hline & B 12,0-RGB-50\% & $20 / 09 / 2005$ & $\begin{array}{l}\text { Dosagem com aproximadamente } 50 \% \text { de } \\
\text { substituição, em massa, da fração graúda natural } \\
\text { por agregado graúdo reciclado de bloco (GRb) }\end{array}$ \\
\hline & B 12,0-RMB-33\% & $20 / 09 / 2005$ & $\begin{array}{l}\text { Dosagem com aproximadamente } 33 \% \text { de } \\
\text { substituição, em massa, do pó de pedra por } \\
\text { agregado miúdo reciclado de bloco (MRb) }\end{array}$ \\
\hline
\end{tabular}

Os resultados de retração por secagem, os valores de umidade e a retração para cada idade comparativamente à retração total para os corpos-de-prova de bloco do Grupo 12,0 são apresentados na Tabela 9.9.

Tabela 9.9 - Valores de retração por secagem para os corpos-de-prova do Grupo 12,0.

\begin{tabular}{|c|c|c|c|c|c|c|c|c|c|c|c|}
\hline & & \multicolumn{10}{|c|}{ Tempo (dias) } \\
\hline & & 0 & 1 & 2 & 3 & 5 & 7 & 9 & 13 & 20 & 27 \\
\hline \multirow{5}{*}{$\begin{array}{c}\text { B12,0- } \\
\text { REF } \\
(14 \text { dias })^{1}\end{array}$} & $\mathrm{~T}\left({ }^{\circ} \mathrm{C}\right)$ & 26,3 & 26,3 & 26,5 & 26,8 & 26,6 & 26,2 & 26,5 & 26,4 & 26,4 & 26,0 \\
\hline & $U_{\text {ambiente }}(\%)$ & 53,3 & 59,7 & 54,3 & 57,5 & 49,5 & 47,5 & 49,5 & 49,5 & 53,5 & 51,0 \\
\hline & $\begin{array}{l}\text { Umidade das } \\
\text { unidades(\%) }\end{array}$ & 100 & 77,40 & 54,63 & 48,23 & 41,25 & 37,87 & 36,71 & 34,85 & 33,85 & 32,82 \\
\hline & Retração $\left({ }^{*} 10^{-6}\right)$ & 0 & $-5,0$ & $-24,5$ & $-69,1$ & $-209,0$ & $-258,0$ & $-283,0$ & $-315,0$ & $-340,0$ & $-364,0$ \\
\hline & $\begin{array}{c}\% \text { da retração } \\
\text { total }\end{array}$ & 0 & 1,4 & 6,7 & 19,0 & 57,4 & 70,9 & 77,7 & 86,5 & 93,4 & 100 \\
\hline \multirow{5}{*}{$\begin{array}{l}\text { B12,0- } \\
\text { RGV- } \\
100 \% \\
(14 \text { dias })^{1}\end{array}$} & $\mathrm{~T}\left({ }^{\circ} \mathrm{C}\right)$ & 26,5 & 26,4 & 26,7 & 26,5 & 26,8 & 26,5 & 26,5 & 26,1 & 26,3 & 25,6 \\
\hline & $U_{\text {ambiente }}(\%)$ & 57,3 & 63,7 & 58,0 & 55,0 & 49,7 & 49,0 & 49,7 & 49,0 & 50,0 & 50,0 \\
\hline & $\begin{array}{l}\text { Umidade das } \\
\text { unidades(\%) }\end{array}$ & 100 & 75,85 & 55,97 & 48,92 & 40,18 & 37,25 & 35,67 & 33,76 & 32,44 & 31,75 \\
\hline & Retração $\left({ }^{*} 10^{-6}\right)$ & 0 & $-14,6$ & $-42,5$ & $-77,4$ & $-230,0$ & $-293,0$ & $-320,0$ & $-364,0$ & $-385,0$ & $-397,0$ \\
\hline & $\begin{array}{c}\% \text { da retração } \\
\text { total }\end{array}$ & 0 & 3,7 & 10,7 & 19,5 & 57,9 & 73,8 & 80,6 & 91,7 & 97,0 & 100 \\
\hline \multirow{5}{*}{$\begin{array}{c}\text { B12,0- } \\
\text { RGV-50\% } \\
\left(14 \text { dias) }{ }^{1}\right.\end{array}$} & $\mathrm{T}\left({ }^{\circ} \mathrm{C}\right)$ & 26,0 & 26,3 & 26,6 & 26,4 & 26,7 & 26,4 & 26,4 & 26,2 & 25,8 & 26,2 \\
\hline & $U_{\text {ambiente }}(\%)$ & 54,7 & 64,3 & 57,0 & 52,0 & 49,3 & 49,0 & 49,0 & 49,3 & 52,3 & 51,0 \\
\hline & $\begin{array}{l}\text { Umidade das } \\
\text { unidades(\%) }\end{array}$ & 100 & 76,50 & 55,01 & 47,09 & 38,47 & 35,92 & 34,14 & 32,55 & 31,37 & 30,82 \\
\hline & Retração $\left({ }^{*} 10^{-6}\right)$ & 0 & 1,1 & $-25,7$ & $-52,1$ & $-222,0$ & $-280,0$ & $-311,0$ & $-359,0$ & $-376,0$ & $-389,0$ \\
\hline & $\begin{array}{c}\text { \% da retração } \\
\text { total }\end{array}$ & 0 & 0 & 6,6 & 13,4 & 57,1 & 72,0 & 79,9 & 92,3 & 96,7 & 100 \\
\hline \multirow{5}{*}{$\begin{array}{c}\text { B12,0- } \\
\text { RMV-33\% } \\
(14 \text { dias })^{1}\end{array}$} & $\mathrm{~T}\left({ }^{\circ} \mathrm{C}\right)$ & 26,0 & 26,0 & 26,7 & 26,6 & 26,5 & 26,4 & 26,6 & 26,4 & 25,9 & 25,7 \\
\hline & $\mathrm{U}_{\text {ambiente }}(\%)$ & 53,3 & 63,0 & 59,0 & 55,3 & 49,0 & 48,7 & 48,7 & 49,0 & 51,0 & 50,0 \\
\hline & $\begin{array}{l}\text { Umidade das } \\
\text { unidades(\%) }\end{array}$ & 100 & 76,65 & 61,85 & 55,02 & 46,82 & 43,77 & 41,89 & 39,50 & 37,19 & 36,21 \\
\hline & Retração $\left({ }^{*} 10^{-6}\right)$ & 0 & $-0,1$ & $-45,7$ & $-90,1$ & $-248,0$ & $-302,0$ & $-330,0$ & $-380,0$ & $-401,0$ & $-408,0$ \\
\hline & $\begin{array}{c}\% \text { da retração } \\
\text { total }\end{array}$ & 0 & 0 & 11,2 & 22,1 & 60,8 & 74,0 & 80,9 & 93,1 & 98,3 & 100 \\
\hline \multirow{5}{*}{$\begin{array}{c}\text { B12,0- } \\
\text { RGB-50\% } \\
(13 \text { dias })^{1}\end{array}$} & $\mathrm{~T}\left({ }^{\circ} \mathrm{C}\right)$ & 26,5 & 26,3 & 26,4 & 26,4 & 26,4 & 26,7 & 26,2 & 26,4 & 25,9 & 25,9 \\
\hline & $\mathrm{U}_{\text {ambiente }}(\%)$ & 61,7 & 60,7 & 57,0 & 53,0 & 48,7 & 49,0 & 49,0 & 48,7 & 51,3 & 50,7 \\
\hline & $\begin{array}{l}\text { Umidade das } \\
\text { unidades }(\%)\end{array}$ & 100 & 79,71 & 53,61 & 42,21 & 33,05 & 29,28 & 27,41 & 25,03 & 22,83 & 22,27 \\
\hline & Retração $\left({ }^{*} 10^{-6}\right)$ & 0 & $-12,3$ & $-24,2$ & $-94,7$ & $-252,0$ & $-319,0$ & $-350,0$ & $-397,0$ & $-426,0$ & $-437,0$ \\
\hline & $\begin{array}{c}\% \text { da retração } \\
\text { total }\end{array}$ & 0 & 2,8 & 5,54 & 21,7 & 57,7 & 73,0 & 80,1 & 90,8 & 97,5 & 100 \\
\hline \multirow{5}{*}{$\begin{array}{c}\text { B12,0- } \\
\text { RMB-33\% } \\
(13 \text { dias })^{1}\end{array}$} & $\mathrm{~T}\left({ }^{\circ} \mathrm{C}\right)$ & 26,6 & 26,2 & 27,0 & 26,6 & 26,3 & 26,5 & 26,5 & 26,3 & 26,3 & 25,9 \\
\hline & $\cup_{\text {ambiente }}(\%)$ & 63,7 & 61,3 & 58,7 & 55,7 & 49,0 & 48,7 & 49,7 & 48,7 & 52,0 & 50,0 \\
\hline & $\begin{array}{l}\text { Umidade das } \\
\text { unidades(\%) }\end{array}$ & 100 & 79,65 & 66,67 & 59,45 & 49,35 & 45,73 & 43,27 & 40,25 & 37,42 & 35,63 \\
\hline & Retração $\left({ }^{*} 10^{-6}\right)$ & 0 & $-12,4$ & $-43,7$ & $-79,9$ & $-232,0$ & $-295,0$ & $-323,0$ & $-370,0$ & $-397,0$ & $-407,0$ \\
\hline & $\begin{array}{c}\text { \% da retração } \\
\text { total }\end{array}$ & 0 & 3,1 & 10,7 & 19,6 & 57,0 & 72,5 & 79,4 & 90,9 & 97,5 & 100 \\
\hline
\end{tabular}


Na Figura 9.24, pode ser observada a evolução da retração por secagem em função do tempo de ensaio.

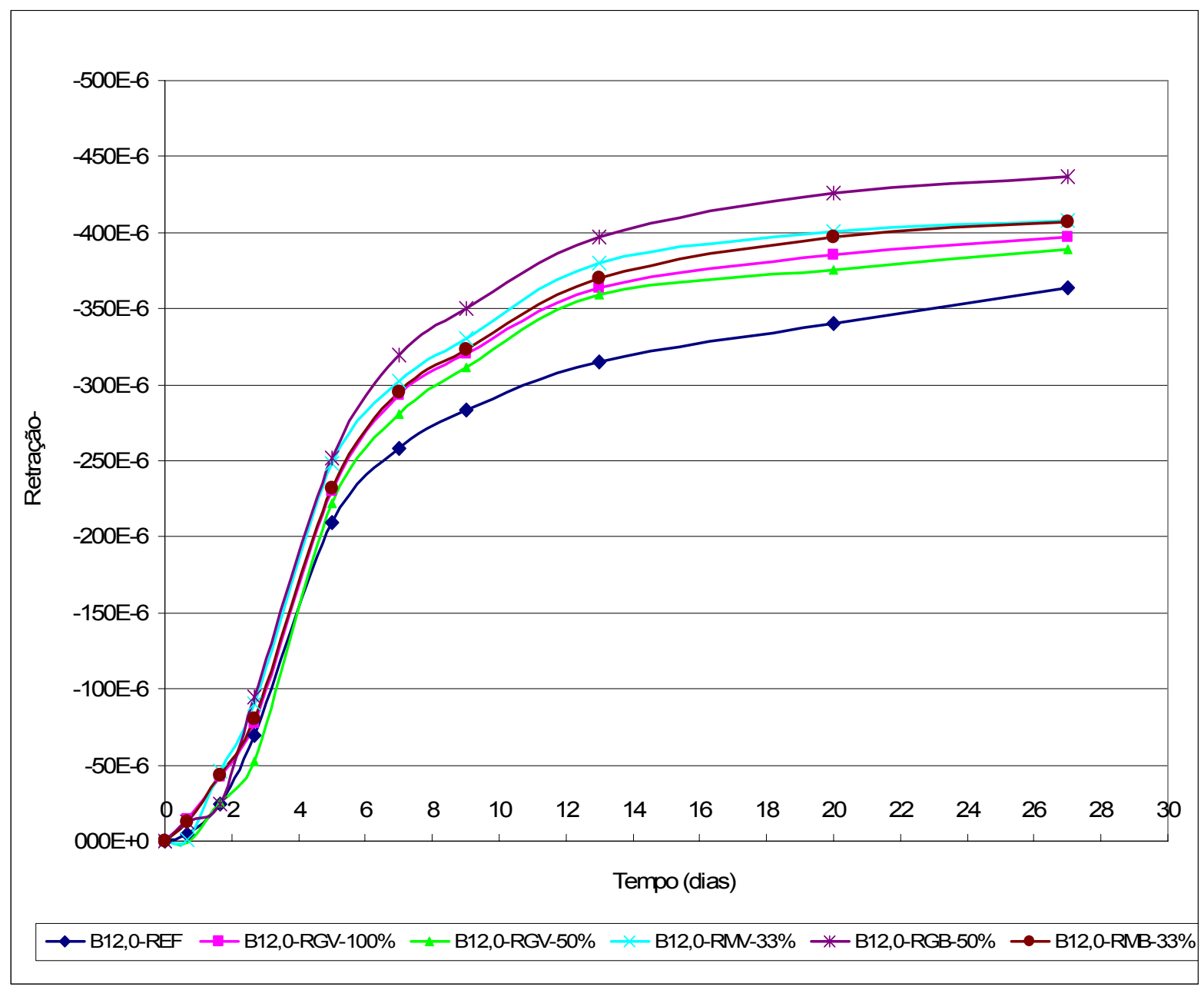

Figura 9.24 - Evolução da retração por secagem para os corpos-de-prova do Grupo 12,0.

Analisando-se os resultados da Tabela 9.9 e Figura 9.24, nota-se que os valores de retração para os corpos-de-prova de blocos com agregados reciclados, foram maiores quando comparados com os valores de referência (B12,0-REF). Esses valores foram, em média, $8 \%, 12 \%$ e $20 \%$ maiores, comparativamente aos valores de referência, para os CPs com agregados reciclado de vigota, CPs com agregados miúdos reciclados e unidades com agregados graúdos reciclados de bloco, respectivamente. Apesar disso, todos os blocos cumpriram as exigências da NBR 6136 (1994) que prescreve valores de retração por secagem inferiores a $0,065 \%$.

A comparação entre a umidade das unidades e a retração parcial (em função da retração total), no decorrer do ensaio, encontra-se nas Figuras 9.25 e 9.26. 


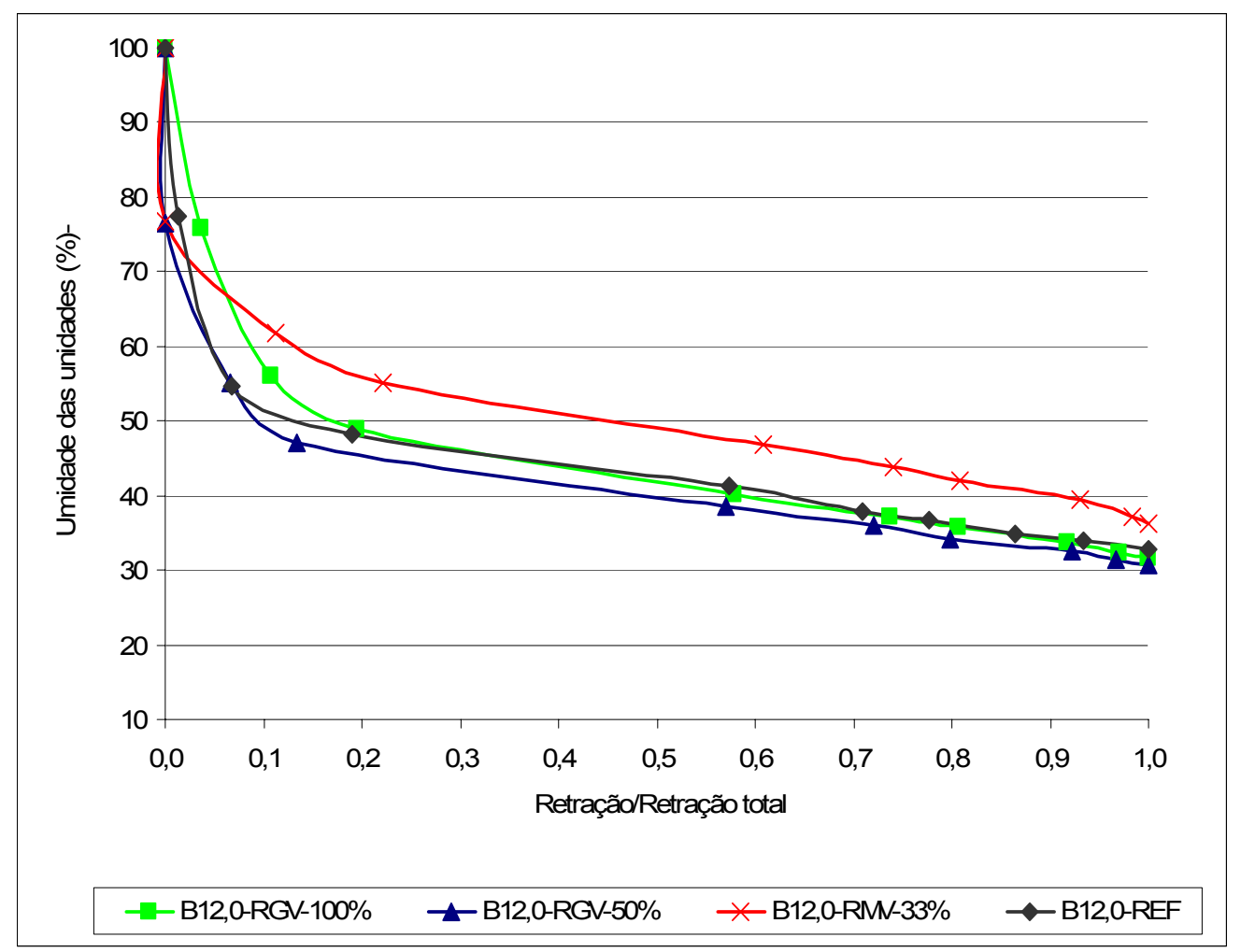

Figura 9.25 - Umidade das unidades x retração por secagem para os corpos-de-prova de referência e agregados reciclados de vigota - Grupo 12,0.

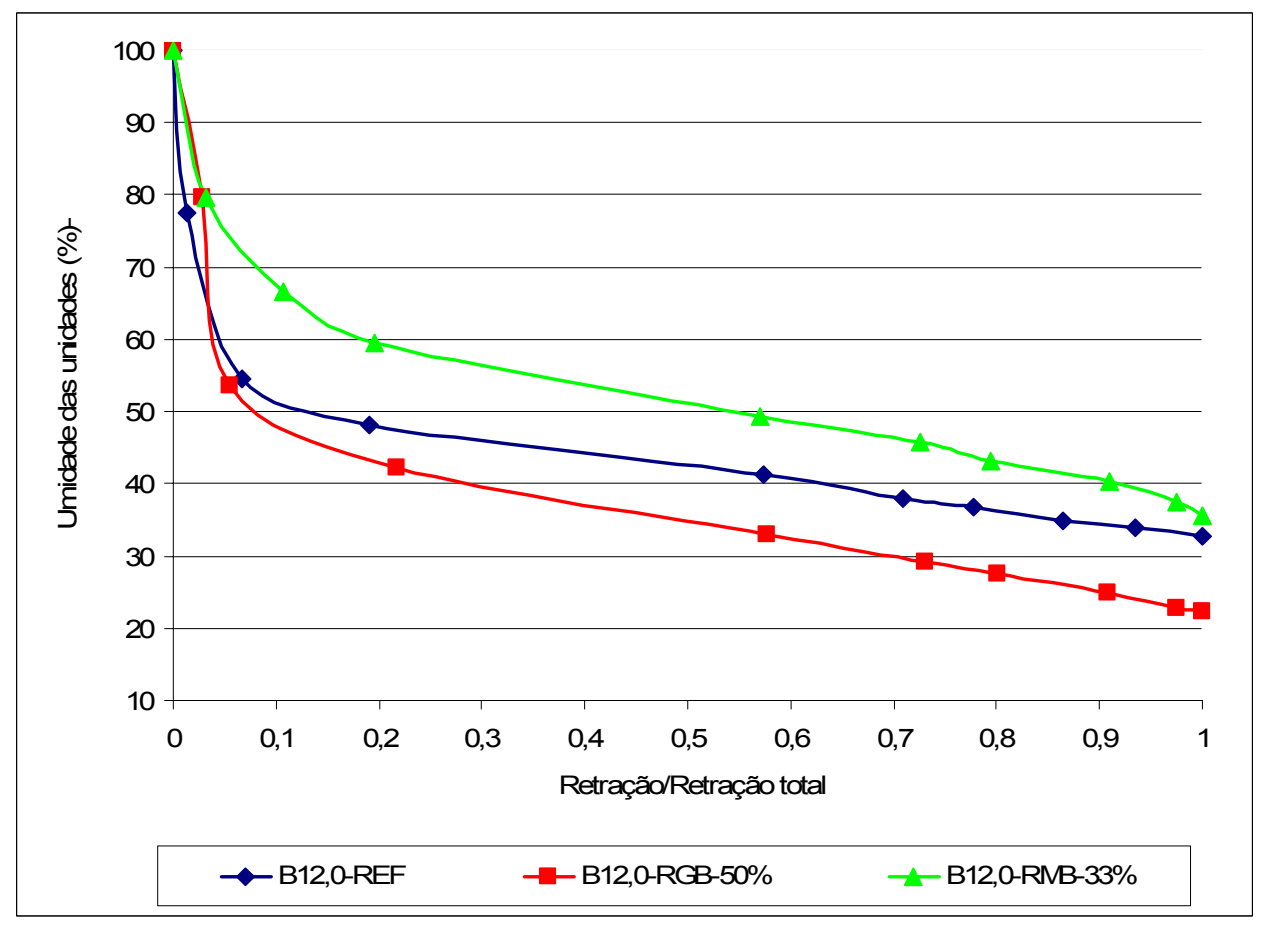

Figura 9.26 - Umidade das unidades x retração por secagem para os corpos-de-prova de referência e agregados reciclados de bloco - Grupo 12,0. 
Analisando-se os resultados das Figuras 9.25 e 9.26, nota-se que a retração por secagem das unidades foi significativa ( $70 \%$ da retração total) a partir de valores de umidade abaixo de 35\%, com exceção das unidades com agregados miúdos reciclados. De maneira geral, esses resultados mostram a importância do controle da umidade dos blocos no momento do assentamento, uma vez que, por exemplo, para umidades acima de $50 \%$, pode-se dizer que, para as unidades de referência e unidades com agregados graúdos reciclados, ocorreram apenas $10 \%$ da retração final.

\subsubsection{AVALIAÇÃO GLOBAL DOS RESULTADOS OBTIDOS}

Na Tabela 9.10, são apresentados os resultados do teste ANOVA para a propriedade de retração por secagem.

Tabela 9.10 - Teste ANOVA para a propriedade de retração por secagem.

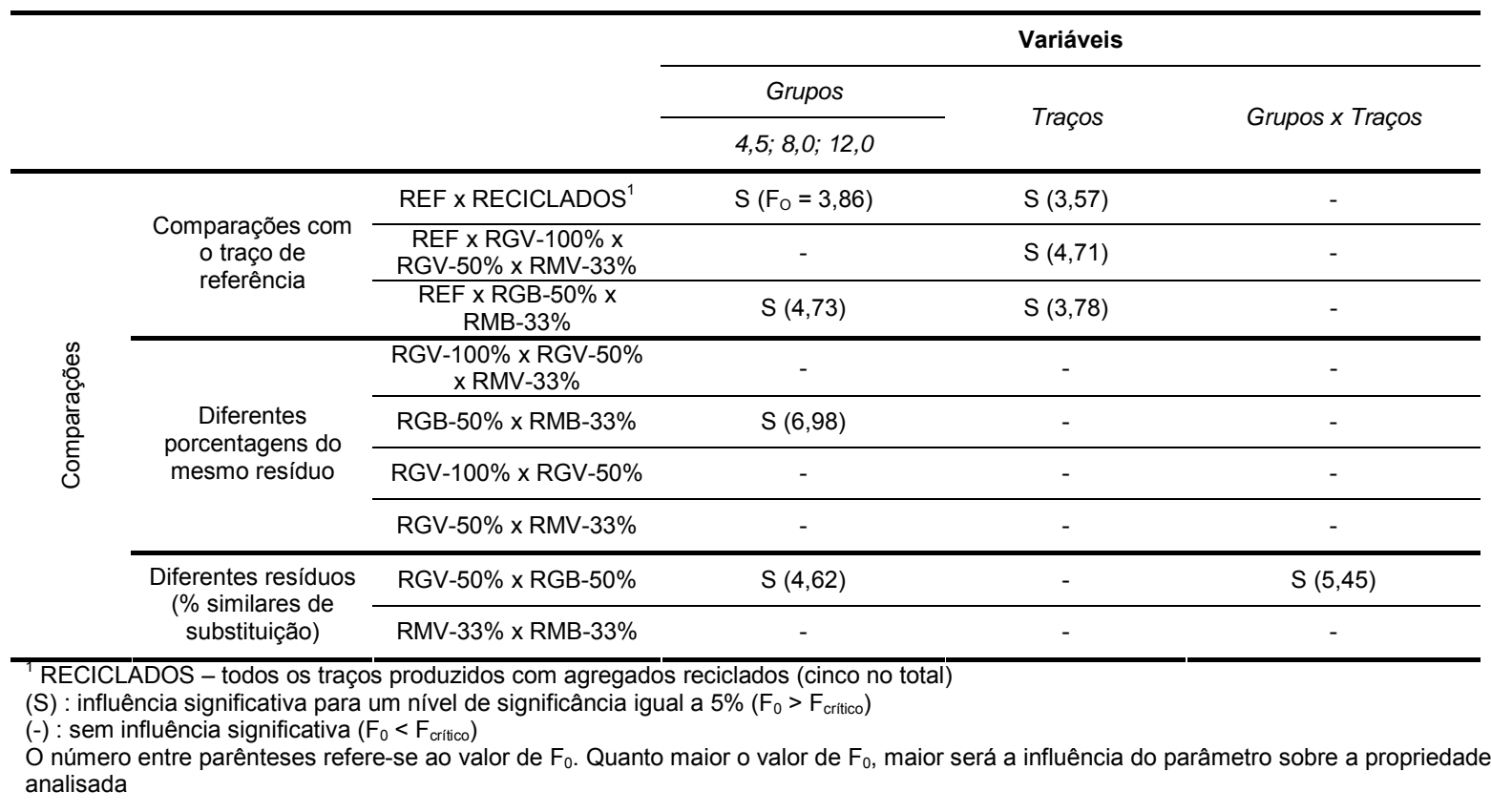

Analisando-se os resultados da Tabela 9.10, são estabelecidos os seguintes comentários:

- Para as comparações envolvendo o traço de referência, pode-se dizer que a variável "traço" teve influência mais significativa, comparativamente à variável "grupos", sobre a retração por secagem. Nesse caso, os menores valores médios de retração por secagem foram obtidos para o traço de referência. Comparativamente ao traço de referência, foi observado um aumento médio na retração por secagem de $27 \%$ (RGV-100\%), 18\% (RGV-50\%), 26\% (RMV-33\%), 21\% (RGB-50\%) e 20\% (RMB$33 \%)$. A razão para os maiores valores de retração das unidades com agregados 
reciclados deve-se à porosidade da camada de argamassa que se encontra aderida ao agregado reciclado. Essa camada é responsável pela elevada absorção de água e a redução da rigidez (módulo de deformação) do agregado e, consequentemente, pelo aumento significativo dos valores de retração.

- Com relação a variável "grupos", para as comparações REF x RECICLADOS e REF $x$ RGB-50\% x RMB-33\%, pode-se dizer que esse parâmetro influenciou significativamente a retração por secagem, ou seja, os menores valores médios de retração por secagem foram obtidos para as unidades do Grupo 4,5 (4,4\% inferior aos resultados do Grupo 8,0) e os maiores valores de retração para as unidades do Grupo 12,0 (7,4\% superior aos resultados do Grupo 8,0). De acordo com FURNAS (1997), um aumento do consumo de cimento ocasiona uma elevação da retração por secagem.

- Para as comparações envolvendo diferentes porcentagens de substituição do mesmo resíduo, pode-se afirmar que a variável "grupos", para apenas uma das comparações, teve influência significativa sobre a retração por secagem. De maneira geral, os resultados de retração por secagem não foram influenciados pelos diferentes grupos e traços avaliados, ou seja, pode-se afirmar que os resultados de retração foram semelhantes independentemente do consumo de cimento de cada grupo avaliado $(4,5=8,0=12,0)$ e também da porcentagem de substituição de agregado natural por agregado reciclado (RGV-100\% $=\mathrm{RGV}-50 \%=\mathrm{RMV}-33 \% \mathrm{e}$ RGB- $50 \%=$ RMB- $33 \%$ ).

- Considerando-se as comparações entre os diferentes resíduos, pode-se dizer que, apenas para a comparação entre os traços RGV-50\% e RGB-50\%, ocorreu influência significativa das variáveis "grupos" e "grupos e traços" sobre a retração por secagem. De maneira geral, os resultados de retração por secagem não foram influenciados pelos diferentes grupos e traços avaliados, ou seja, pode-se afirmar que os resultados de retração foram semelhantes independentemente do consumo de cimento de cada grupo e também do tipo de agregado. 


\subsection{RESULTADOS E ANÁLISES - MINIPAREDES}

\subsubsection{GRUPO 4,5}

Na Tabela 9.11, são apresentadas as características das miniparedes do Grupo 4,5.

Tabela 9.11 - Miniparedes do Grupo 4,5.

\begin{tabular}{ccc}
\hline $\begin{array}{c}\text { GRUPO/CLASSE } \\
\text { DE RESISTÊNCIA } \\
\text { DAS UNIDADES }\end{array}$ & DESIGNAÇÃo & CARACTERísTICAS \\
\hline & PAR4,5-REF & Miniparedes compostas por unidades produzidas com agregados \\
naturais
\end{tabular}

Os resultados de retração por secagem, os valores de umidade para blocos testemunhos e a retração para cada idade comparativamente à retração total das miniparedes são apresentados na Tabela 9.12.

Tabela 9.12 - Valores de retração por secagem para as miniparedes do Grupo 4,5.

\begin{tabular}{|c|c|c|c|c|c|c|c|c|c|c|c|c|}
\hline & & \multicolumn{5}{|c|}{ PAR4,5-REF $^{1}$} & \multicolumn{3}{|c|}{ PAR4,5-RGV-100\% ${ }^{2}$} & \multicolumn{3}{|c|}{ PAR4,5-RGB- $50 \%{ }^{3}$} \\
\hline & & $\mathrm{T}\left({ }^{0} \mathrm{C}\right)$ & $U(\%)$ & $\mathrm{U}_{\mathrm{un} .}(\%)^{4}$ & $\varepsilon\left({ }^{*} 10^{-6}\right)$ & $\begin{array}{l}\varepsilon / \varepsilon_{F}{ }^{5} \\
(\%)\end{array}$ & $\mathrm{U}_{\mathrm{un} .}(\%)^{4}$ & $\varepsilon\left({ }^{*} 10^{-6}\right)$ & $\begin{array}{c}\varepsilon / \varepsilon_{\mathrm{T}}{ }^{5} \\
(\%)\end{array}$ & $\mathrm{U}_{\mathrm{un} .}(\%)^{4}$ & $\varepsilon\left({ }^{*} 10^{-6}\right)$ & $\begin{array}{l}\varepsilon / \varepsilon_{T}^{5} \\
(\%) \\
\end{array}$ \\
\hline \multirow{28}{*}{ Tempo } & 0 & 25,9 & 74,6 & 17,71 & 0 & 0 & 31,16 & 0 & 0 & 26,88 & 0 & 0 \\
\hline & 1 & 25,2 & 59,1 & 15,86 & $-50,5$ & 24,2 & 27,25 & $-78,4$ & 31,6 & 26,03 & $-11,1$ & 6,3 \\
\hline & 2 & 25,3 & 53,1 & 13,76 & $-65,5$ & 31,4 & 24,25 & $-89,6$ & 36,1 & 22,45 & $-29,3$ & 16,6 \\
\hline & 3 & 25,1 & 53,2 & 12,48 & $-65,4$ & 31,3 & 22,44 & $-106,2$ & 42,7 & 20,35 & $-26,9$ & 15,3 \\
\hline & 4 & 25,1 & 53,7 & 11,75 & $-79,8$ & 38,2 & 21,39 & $-117,2$ & 47,2 & 19,34 & $-49,3$ & 28,1 \\
\hline & 5 & 25,4 & 58,3 & 11,59 & $-97,2$ & 46,4 & 21,25 & $-111,9$ & 45,0 & 19,02 & $-56,0$ & 31,8 \\
\hline & 6 & 25,2 & 54,6 & 11,59 & $-103,2$ & 49,3 & 21,11 & $-121,4$ & 48,9 & 19,10 & $-65,9$ & 37,5 \\
\hline & 7 & 24,7 & 52,9 & 11,19 & $-123,3$ & 59,0 & 20,69 & $-142,0$ & 57,1 & 18,41 & $-90,4$ & 51,4 \\
\hline & 9 & 24,9 & 51,8 & 10,55 & $-120,6$ & 57,6 & 19,51 & $-143,8$ & 57,9 & 17,48 & $-83,8$ & 47,6 \\
\hline & 10 & 24,9 & 54,1 & - & $-122,4$ & 58,5 & - & $-149,0$ & 59,9 & - & $-91,5$ & 52,0 \\
\hline & 11 & 25,0 & 53,9 & 10,63 & $-134,9$ & 64,5 & 19,30 & $-151,2$ & 60,8 & 17,40 & $-92,6$ & 52,7 \\
\hline & 14 & 25,1 & 50,9 & 10,30 & $-160,0$ & 76,5 & 18,53 & $-189,8$ & 76,4 & 16,78 & $-130,0$ & 73,9 \\
\hline & 17 & 25,4 & 49,9 & 10,14 & $-165,0$ & 78,9 & 18,18 & $-198,6$ & 79,9 & 16,47 & $-136,2$ & 77,5 \\
\hline & 21 & 25,5 & 48,1 & - & $-170,2$ & 81,3 & - & $-213,6$ & 86,0 & - & $-144,2$ & 82,0 \\
\hline & 25 & 25,0 & 49,1 & 10,38 & $-171,6$ & 82,0 & 17,56 & $-218,8$ & 88,0 & 16,16 & $-149,7$ & 85,1 \\
\hline & 32 & 25,3 & 53,2 & - & $-177,0$ & 84,6 & - & $-214,6$ & 86,3 & - & $-149,5$ & 85,0 \\
\hline & 38 & 25,2 & 48,7 & 10,30 & $-178,1$ & 85,1 & 16,86 & $-221,0$ & 88,9 & 15,62 & $-153,5$ & 87,3 \\
\hline & 45 & 25,3 & 49,3 & 10,47 & $-179,0$ & 85,6 & 16,86 & $-218,2$ & 87,8 & 15,62 & $-153,0$ & 87,0 \\
\hline & 53 & 24,8 & 49,7 & 10,47 & $-191,2$ & 91,4 & 16,51 & $-233,8$ & 94,1 & 15,31 & $-169,0$ & 96,1 \\
\hline & 72 & 24,5 & 48,7 & 10,95 & $-192,6$ & 92,1 & 16,37 & $-238,4$ & 95,9 & 15,46 & $-165,7$ & 94,2 \\
\hline & 88 & 25,3 & 48,6 & - & $-186,9$ & 89,4 & - & $-231,6$ & 93,2 & - & $-161,8$ & 92,0 \\
\hline & 100 & 24,9 & 46,0 & 10,87 & $-211,3$ & 101,0 & 15,88 & $-256,4$ & 103,2 & 15,00 & $-182,3$ & 103,7 \\
\hline & 126 & 24,7 & 48,2 & - & $-204,8$ & 97,9 & - & $-249,6$ & 100,4 & - & $-180,4$ & 102,6 \\
\hline & 157 & 25,3 & 47,3 & 10,95 & $-217,9$ & 104,1 & 15,67 & $-259,4$ & 104,4 & 14,76 & $-186,5$ & 106,1 \\
\hline & 189 & 24,9 & 49,5 & - & $-214,4$ & 102,5 & - & $-263,0$ & 105,8 & - & $-185,4$ & 105,4 \\
\hline & 218 & 25,2 & 51,8 & 11,89 & $-207,2$ & 99,0 & 16,41 & $-246,7$ & 99,3 & 15,55 & $-176,4$ & 100,3 \\
\hline & 249 & 25,6 & 49,0 & 11,78 & $-216,8$ & 103,6 & 16,23 & $-254,9$ & 102,6 & 15,06 & $-187,6$ & 106,7 \\
\hline & 284 & 25,1 & 53,6 & - & $-209,2$ & 100,0 & - & $-248,5$ & 100,0 & - & $-175,8$ & 100,0 \\
\hline
\end{tabular}


Na Figura 9.27, encontra-se a evolução da retração por secagem das miniparedes em função do tempo de ensaio.

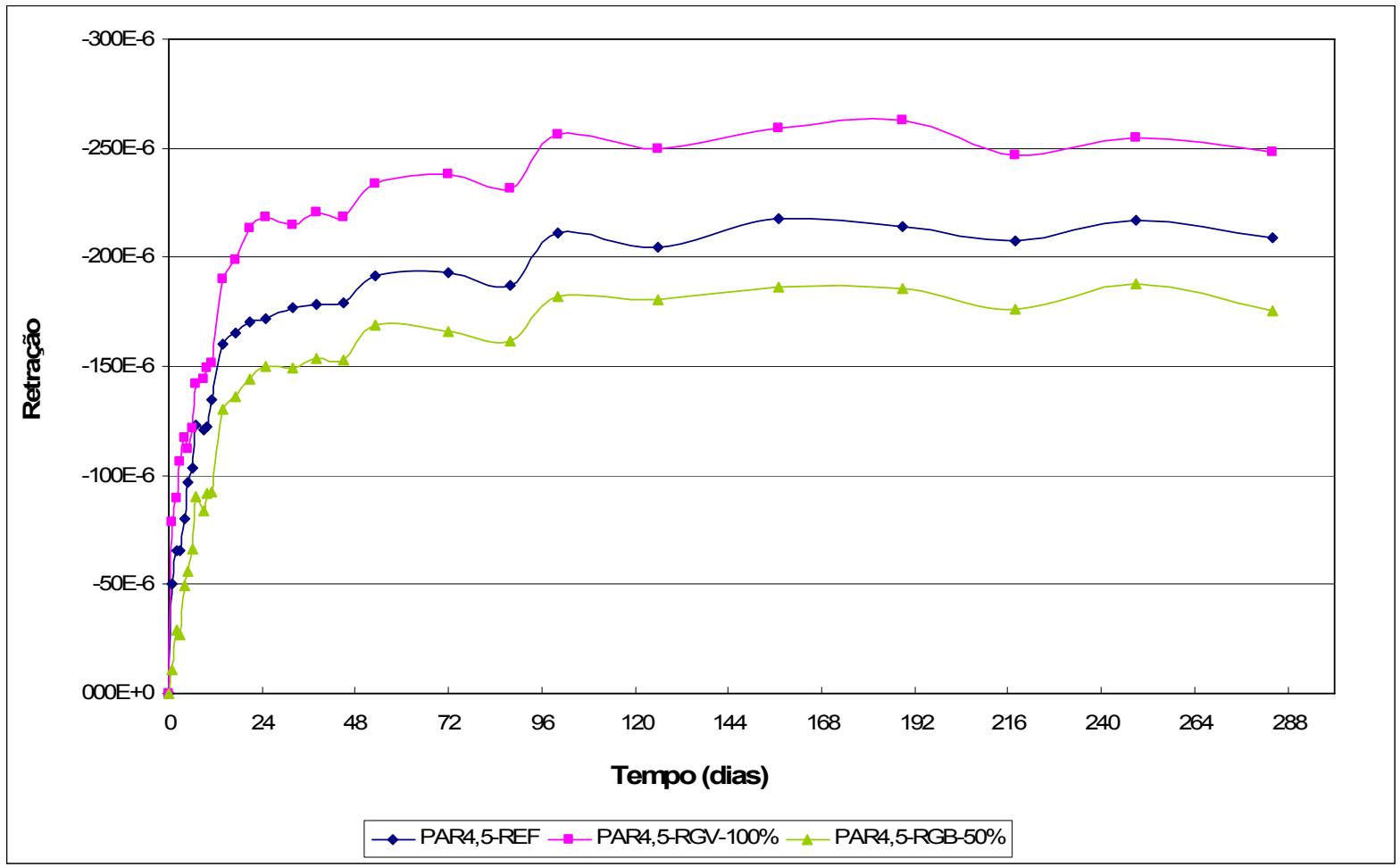

Figura 9.27 - Evolução da retração por secagem para as miniparedes do Grupo 4,5.

Pela Tabela 9.12 e Figura 9.27, nota-se que os valores de retração, ao longo do tempo ( $10^{\circ}$ dia ao $284^{\circ} \mathrm{dia}$ ), das miniparedes PAR4,5-RGV-100\% foram, em média, 21\% superiores aos valores de retração das miniparedes de referência; já as miniparedes PAR4,5-RGB-50\%, comparativamente aos valores de referência, apresentaram uma redução média de $16 \%$ na retração. Esse comportamento não era esperado, uma vez que pelos resultados dos corpos-de-prova de bloco, a retração média das unidades B4,5-RGB$50 \%$ foi $19 \%$ superior à retração das unidades de referência. Os resultados de retração mantiveram-se praticamente inalterados a partir de 100 dias, uma vez que ocorreu a estabilização da umidade das unidades; sendo que aos 7 dias e 30 dias, 50\% e 85\% da retração total já haviam ocorrido, respectivamente. Essa retração pode ser considerada reversível (dependente da umidade do ambiente) dada a idade das unidades no momento do assentamento (superior a 130 dias). Barbosa (2005) cita que blocos de resistência moderada (até 8,0 MPa), produzidos sob cura a vapor, devem ser utilizados após os 7 dias, visando reduzir a retração irreversível ou permanente. O pesquisador obteve para blocos de 4,5 $\mathrm{MPa}\left(\mathrm{f}_{\mathrm{bk}}=4,30 \mathrm{MPa}\right.$ ), produzidos sob cura úmida, valores de retração de $0,25 \mathrm{~mm} / \mathrm{m}$ e $0,40 \mathrm{~mm} / \mathrm{m}$ para alvenarias executadas com unidades de 5 dias e 19 dias de idade, respectivamente. 
Considerando-se a umidade máxima no momento do assentamento prescrita pela NBR 6136 (1994), que é de 35\%, para blocos cuja retração linear esteja situada entre 0,30 e $0,45 \mathrm{~mm} / \mathrm{m}$; observa-se que todas as miniparedes apresentaram unidades cujo valor ficou abaixo desse limite. Pelos resultados de retração para os corpos-de-prova de bloco, observou-se que $45 \%$ e $70 \%$ da retração total ocorreram para as umidades de $35 \%$ e $30 \%$, respectivamente.

$\mathrm{Na}$ Figura 9.28, são apresentadas as curvas que melhor ajustam os resultados obtidos para as miniparedes do Grupo 4,5.

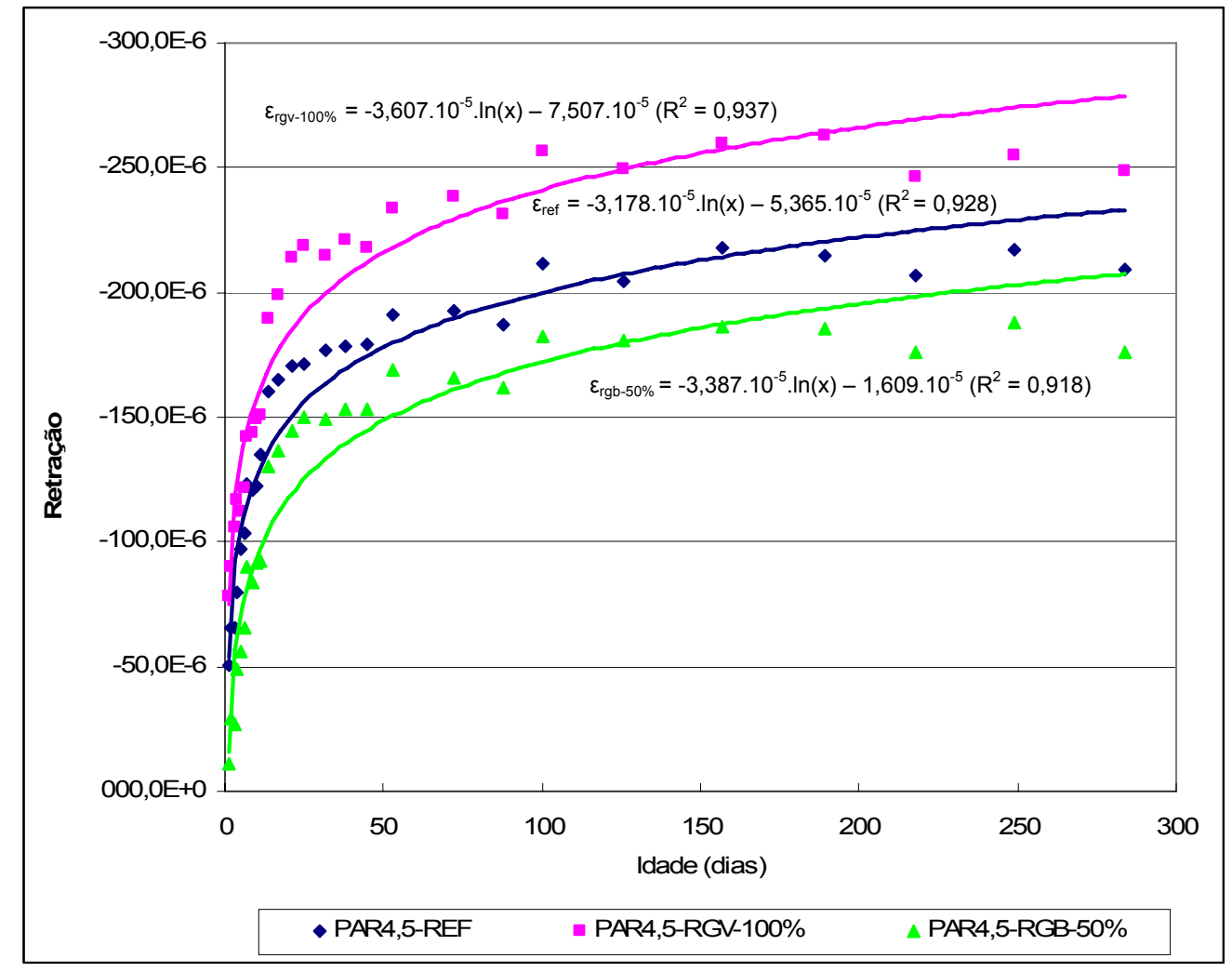

Figura 9.28 - Interpolação dos resultados de retração das miniparedes do Grupo 4,5.

Pela Figura 9.28, observa-se que a interpolação dos dados através das curvas propostas mostrou uma correlação satisfatória $\left(R^{2}>0,91\right)$. Utilizando-se estas curvas, é apresentada na Tabela 9.13 algumas estimativas dos valores de retração para idades superiores a 300 dias. Deve-se ressaltar que apesar da correlação satisfatória, os resultados da extrapolação para idades superiores a 300 dias tenderão a ser superiores aos que seriam obtidos experimentalmente, uma vez que os resultados experimentais de retração mantiveram-se praticamente inalterados após 200 dias de ensaio. 
Tabela 9.13 - Previsão dos valores de retração das miniparedes do Grupo 4,5.

\begin{tabular}{cccc}
\hline \multirow{2}{*}{ Tempo } & \multicolumn{3}{c}{ Retração $\left(\mathbf{x ~ 1 0} \mathbf{6}^{\mathbf{6}}\right)$} \\
\cline { 2 - 4 } & PAR4,5-REF & PAR4,5-RGV-100\% & PAR4,5-RGB-50\% \\
\hline 300 dias & $-234,9$ & $-280,8$ & $-209,3$ \\
\hline 1 ano & $-241,1$ & $-287,9$ & $-215,9$ \\
\hline 2 anos & $-263,2$ & $-312,9$ & $-239,4$ \\
\hline 3 anos & $-276,0$ & $-327,5$ & $-253,1$ \\
\hline 5 anos & $-292,2$ & $-345,9$ & $-270,4$ \\
\hline 10 anos & $-314,3$ & $-370,9$ & $-293,9$ \\
\hline 20 anos & $-336,4$ & $-396,0$ & $-317,4$ \\
\hline
\end{tabular}

\subsubsection{GRUPO 8,0}

Na Tabela 9.14, são apresentadas as características das miniparedes do Grupo 8,0.

Tabela 9.14 - Miniparedes do Grupo 8,0.

\begin{tabular}{ccc}
\hline $\begin{array}{c}\text { GRUPO/CLASSE } \\
\text { DE RESISTÊNCIA } \\
\text { DAS UNIDADES }\end{array}$ & DESIGNAÇÃo & CARACTERÍSTICAS \\
\hline & PAR8,0-REF & Miniparedes compostas por unidades produzidas com agregados \\
naturais
\end{tabular}

Os resultados de retração por secagem, os valores de umidade para blocos testemunha e a retração para cada idade comparativamente à retração total das miniparedes são apresentados na Tabela 9.15. 
Tabela 9.15 - Valores de retração por secagem para as miniparedes do Grupo 8,0.

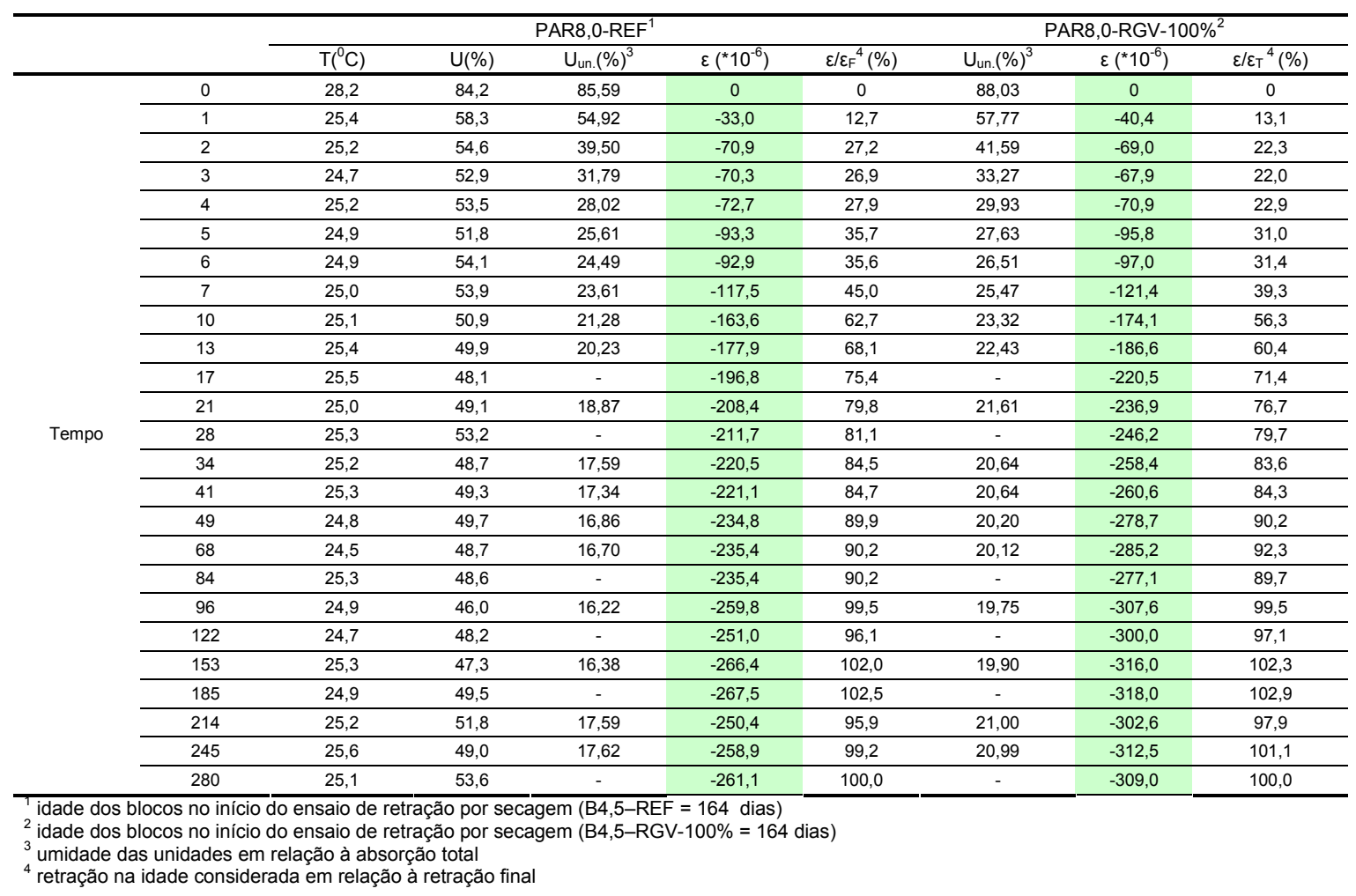

Na Figura 9.29, encontra-se a evolução da retração por secagem das miniparedes em função do tempo de ensaio.

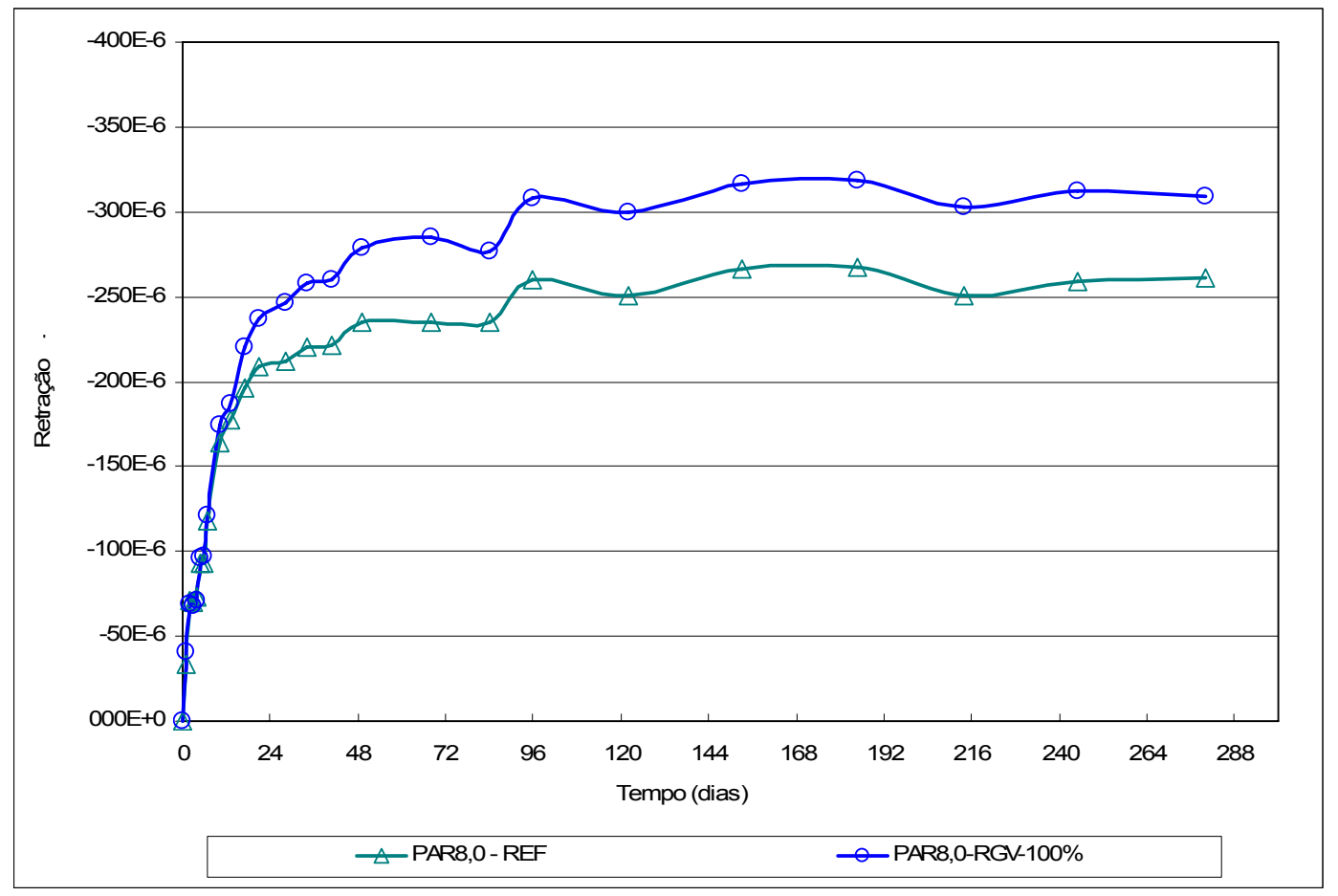

Figura 9.29 - Evolução da retração por secagem para as miniparedes do Grupo 8,0. 
Pela Tabela 9.15 e Figura 9.29, nota-se que os valores de retração, ao longo do tempo ( $1^{\circ}$ dia ao $284^{\circ}$ dia), das miniparedes PAR8,0-RGV-100\% foram, em média, 18\% superiores aos valores de retração das miniparedes de referência. Os resultados de retração mantiveram-se praticamente inalterados a partir de 100 dias, uma vez que ocorreu a estabilização da umidade das unidades $\left(\cup_{\text {unidade }} \cong 18 \%\right)$; sendo que aos 7 dias e 30 dias, $42 \%\left(U_{\text {unidade }}=24,5 \%\right)$ e $80 \%\left(U_{\text {unidade }}=19,1 \%\right)$ da retração total já haviam ocorrido, respectivamente. Essa retração pode ser considerada reversível (dependente da umidade do ambiente) dada a idade das unidades no momento do assentamento (superior a 160 dias). Barbosa (2005) cita que blocos de resistência elevada (acima de 8,0 MPa), produzidos sob cura à vapor, devem ser utilizados após os 14 dias, visando reduzir a retração irreversível ou permanente. O pesquisador obteve para blocos de $8,0 \mathrm{MPa}\left(\mathrm{f}_{\mathrm{bk}}=\right.$ $7,20 \mathrm{MPa}$ ), produzidos sob cura a vapor, valores de retração entre $0,20 \mathrm{~mm} / \mathrm{m}$ e $0,30 \mathrm{~mm} / \mathrm{m}$ para alvenarias executadas com unidades de 5 dias de idade.

Apesar das miniparedes terem sido dispostas na câmara úmida, um dia após a sua fabricação, esse fato não afetou significativamente a retração por secagem, uma vez que partindo-se da umidade inicial (próximo a 87\%) até a umidade de 35\% (2 a 3 dias na câmara climatizada) ocorreu uma retração média de apenas $25 \%\left(\cong 70.10^{-6} \mathrm{~mm} / \mathrm{m}\right)$ comparativamente à retração final. Esses valores são corroborados pelos resultados obtidos por Drysdale e Khattab (1995); segundo esses pesquisadores, é necessário remover mais que a metade da água presente na unidade para que ocorra uma retração significativa. Além disso, de acordo com Mehta e Monteiro (1994), a perda de água livre retida nas grandes cavidades não é acompanhada de retração significativa, uma vez que não está atrelada à estrutura dos poros hidratados por ligações físico-químicas fortes.

$\mathrm{Na}$ Figura 9.30, são apresentadas as curvas que melhor ajustam os resultados obtidos para as miniparedes do Grupo 8,0. 


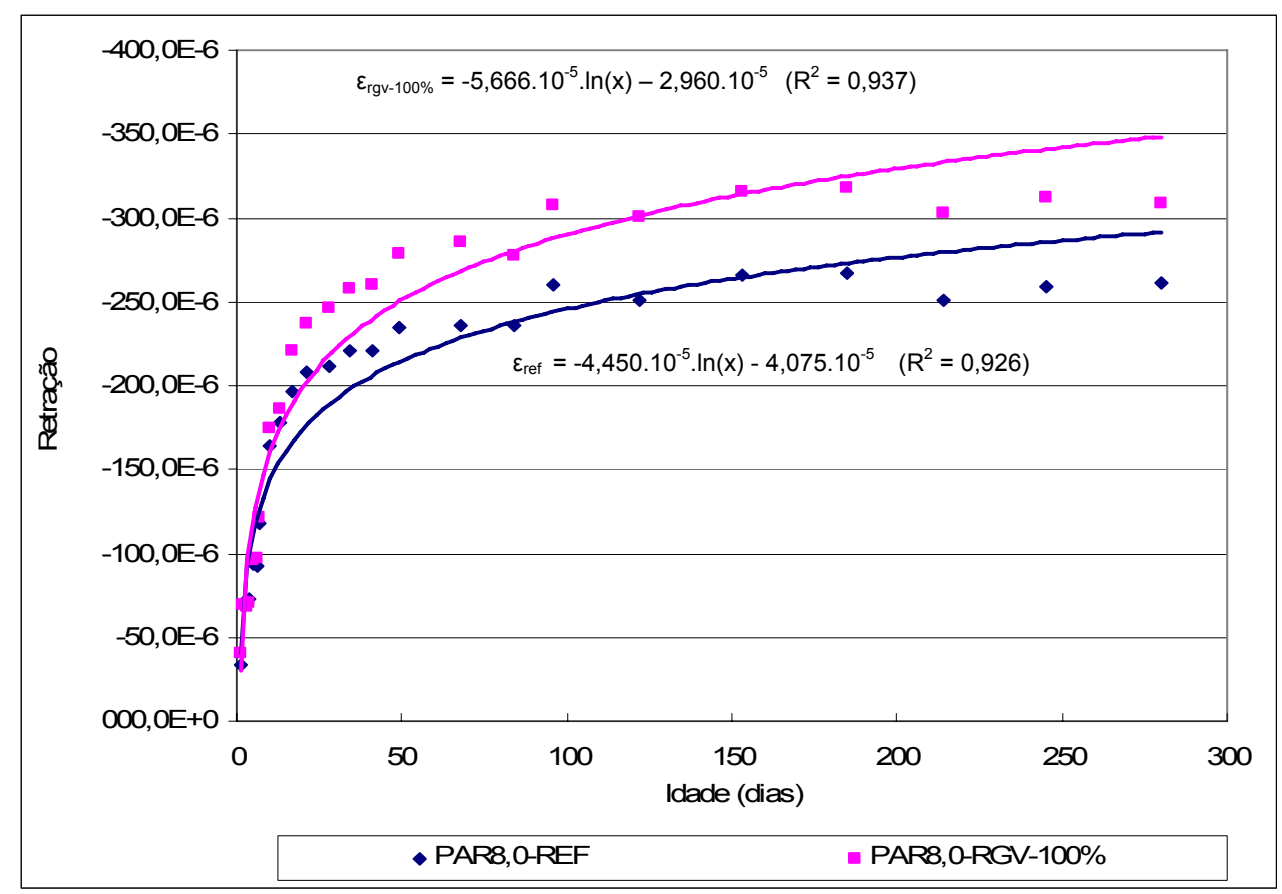

Figura 9.30 - Interpolação dos resultados de retração das miniparedes do Grupo 8,0.

Pela Figura 9.30, observa-se que a interpolação dos dados através das curvas propostas mostrou uma correlação satisfatória $\left(R^{2}>0,92\right)$. Utilizando-se essas curvas, é apresentada na Tabela 9.16 algumas estimativas dos valores de retração para idades superiores a 300 dias. Deve-se ressaltar que apesar da correlação satisfatória, os resultados da extrapolação para idades superiores a 300 dias tenderão a ser superiores aos que seriam obtidos experimentalmente, uma vez que os resultados experimentais de retração mantiveram-se praticamente inalterados após 200 dias de ensaio.

Tabela 9.16 - Previsão dos valores de retração das miniparedes do Grupo 8,0.

\begin{tabular}{ccc}
\hline \multirow{2}{*}{ Tempo } & \multicolumn{2}{c}{ Retração $\left(\mathbf{x} \mathbf{1 0}^{-6}\right)$} \\
\cline { 2 - 3 } & PAR8,0-REF & PAR8,0-RGV-100\% \\
\hline 300 dias & $-294,6$ & $-352,8$ \\
\hline 1 ano & $-303,3$ & $-363,9$ \\
\hline 2 anos & $-334,1$ & $-403,2$ \\
\hline 3 anos & $-352,2$ & $-426,1$ \\
\hline 5 anos & $-374,9$ & $-455,1$ \\
\hline 10 anos & $-405,8$ & $-494,4$ \\
\hline 2 anos & $-436,7$ & $-533,6$ \\
\hline
\end{tabular}

\subsubsection{GRUPO 12,0}

Na Tabela 9.17, são apresentadas as características das miniparedes do Grupo 12,0. 
Tabela 9.17 - Miniparedes do Grupo 12,0.

\begin{tabular}{|c|c|c|}
\hline $\begin{array}{l}\text { GRUPO/CLASSE } \\
\text { DE RESISTÊNCIA } \\
\text { DAS UNIDADES }\end{array}$ & DESIGNAÇÃO & CARACTERÍSTICAS \\
\hline \multirow{3}{*}{12,0} & PAR12,0-REF & $\begin{array}{l}\text { Miniparedes compostas por unidades produzidas com agregados } \\
\text { naturais }\end{array}$ \\
\hline & PAR12,0-RGV-100\% & $\begin{array}{c}\text { Miniparedes compostas por unidades com } 100 \% \text { de substituição, em } \\
\text { massa, da fração graúda natural (pedrisco) por agregado graúdo } \\
\text { reciclado de vigota (GRv) }\end{array}$ \\
\hline & PAR12,0-RGB-50\% & $\begin{array}{c}\text { Miniparedes compostas por unidades com } 50 \% \text { de substituição, em } \\
\text { massa, da fração graúda natural por agregado graúdo reciclado de } \\
\text { bloco (GRb) }\end{array}$ \\
\hline
\end{tabular}

Os resultados de retração por secagem, os valores de umidade para blocos testemunhos e a retração para cada idade comparativamente à retração total das miniparedes são apresentados na Tabela 9.18.

Tabela 9.18 - Valores de retração por secagem para as miniparedes do Grupo 12,0.

\begin{tabular}{|c|c|c|c|c|c|c|c|c|c|c|c|c|}
\hline & & \multicolumn{5}{|c|}{ PAR12,0-REF $^{1}$} & \multicolumn{3}{|c|}{ PAR12,0-RGV-100 ${ }^{2}{ }^{2}$} & \multicolumn{3}{|c|}{ PAR12,0-RGB-50\% ${ }^{3}$} \\
\hline & & $\mathrm{T}\left({ }^{0} \mathrm{C}\right)$ & $U(\%)$ & $\mathrm{U}_{\text {un. }}(\%)^{4}$ & $\varepsilon\left({ }^{*} 10^{-6}\right)$ & $\begin{array}{l}\varepsilon / \varepsilon_{F}^{5} \\
(\%)\end{array}$ & $\mathrm{U}_{\text {un. }}(\%)^{4}$ & $\varepsilon\left({ }^{*} 10^{-6}\right)$ & $\begin{array}{l}\varepsilon / \varepsilon_{\mathrm{T}}{ }^{5} \\
(\%)\end{array}$ & $\mathrm{U}_{\mathrm{un} .}(\%)^{4}$ & $\varepsilon\left({ }^{*} 10^{-6}\right)$ & $\begin{array}{l}\varepsilon^{\varepsilon / \varepsilon_{T}}{ }^{5} \\
(\%)\end{array}$ \\
\hline \multirow{28}{*}{ Tempo } & 0 & 25,9 & 74,6 & 37,80 & 0,0 & 0,0 & 32,50 & 0,0 & 0,0 & 35,13 & 0,0 & 0,0 \\
\hline & 1 & 25,2 & 59,1 & 35,70 & $-52,6$ & 15,5 & 30,28 & $\begin{array}{l}-69,2 \\
\end{array}$ & 18,0 & 33,24 & $-60,8$ & 17,0 \\
\hline & 2 & 25,3 & 53,1 & 34,15 & $-84,0$ & 24,8 & 27,58 & $-103,5$ & 26,9 & 31,18 & $-91,2$ & 25,4 \\
\hline & 3 & 25,1 & 53,2 & 32,51 & $-99,8$ & 29,5 & 25,60 & $-128,3$ & 33,3 & 29,80 & $-120,0$ & 33,4 \\
\hline & 4 & 25,1 & 53,7 & 31,58 & $-116,1$ & 34,3 & 24,39 & $-135,1$ & 35,1 & 28,77 & $-130,3$ & 36,3 \\
\hline & 5 & 25,4 & 58,3 & 31,11 & $-121,5$ & 35,9 & 24,32 & $-140,3$ & 36,4 & 28,77 & $-134,4$ & 37,4 \\
\hline & 6 & 25,2 & 54,6 & 30,96 & $-155,2$ & 45,9 & 23,97 & $\begin{array}{l}-154,1 \\
\end{array}$ & 40,0 & 28,34 & $-162,0$ & 45,1 \\
\hline & 7 & 24,7 & 52,9 & 30,02 & $-165,9$ & 49,0 & 23,33 & $-173,1$ & 45,0 & 27,74 & $-165,8$ & 46,2 \\
\hline & 9 & 24,9 & 51,8 & 28,62 & $-165,2$ & 48,8 & 21,98 & $-186,0$ & 48,3 & 26,45 & $-177,8$ & 49,5 \\
\hline & 10 & 24,9 & 54,1 & - & $-166,3$ & 49,1 & - & $-185,1$ & 48,1 & - & $-183,1$ & 51,0 \\
\hline & 11 & 25,0 & 53,9 & 28,00 & $-175,6$ & 51,9 & 21,42 & $-194,4$ & 50,5 & 26,10 & $-184,8$ & 51,5 \\
\hline & 14 & 25,1 & 50,9 & 26,91 & $-212,4$ & 62,8 & 20,43 & $-240,7$ & 62,5 & 25,16 & $-222,9$ & 62,1 \\
\hline & 17 & 25,4 & 49,9 & 26,14 & $-225,2$ & 66,6 & 20,00 & $-255,4$ & 66,3 & 24,47 & $-240,7$ & 67,1 \\
\hline & 21 & 25,5 & 48,1 & - & $-236,4$ & 69,9 & - & $-271,4$ & 70,5 & - & $-255,0$ & 71,1 \\
\hline & 25 & 25,0 & 49,1 & 24,81 & $-242,9$ & 71,8 & 19,44 & $-274,1$ & 71,2 & 23,70 & $-261,5$ & 72,9 \\
\hline & 32 & 25,3 & 53,2 & - & $-251,0$ & 74,2 & - & $-284,6$ & 73,9 & - & $-267,0$ & 74,4 \\
\hline & 38 & 25,2 & 48,7 & 23,02 & $-258,1$ & 76,3 & 18,87 & $-294,3$ & 76,4 & 22,76 & $-274,9$ & 76,6 \\
\hline & 45 & 25,3 & 49,3 & 22,79 & $-262,9$ & 77,7 & 19,95 & $-296,5$ & 77,0 & 22,59 & $-278,0$ & 77,5 \\
\hline & 53 & 24,8 & 49,7 & 22,09 & $-279,2$ & 82,5 & 18,59 & $-319,5$ & 83,0 & 22,24 & $-297,2$ & 82,8 \\
\hline & 72 & 24,5 & 48,7 & - & $-281,6$ & 83,2 & 19,09 & $-328,1$ & 85,2 & 22,07 & $-297,7$ & 83,0 \\
\hline & 88 & 25,3 & 48,6 & 21,62 & $-283,5$ & 83,8 & - & $-319,7$ & 83,0 & - & $-300,1$ & 83,6 \\
\hline & 100 & 24,9 & 46,0 & 21,00 & $-307,7$ & 90,9 & 18,81 & $-353,3$ & 91,7 & 21,64 & $-327,2$ & 91,2 \\
\hline & 126 & 24,7 & 48,2 & - & $-310,1$ & 91,6 & - & $-352,7$ & 91,6 & - & $-323,9$ & 90,3 \\
\hline & 157 & 25,3 & 47,3 & 21,08 & $-325,9$ & 96,3 & 19,23 & $-370,9$ & 96,3 & 21,82 & $-344,1$ & 95,9 \\
\hline & 189 & 24,9 & 49,5 & - & $-335,8$ & 99,2 & - & $-382,1$ & 99,2 & - & $-354,6$ & 98,8 \\
\hline & 218 & 25,2 & 51,8 & 22,36 & $-327,9$ & 96,9 & 20,61 & $-366,9$ & 95,3 & 22,53 & $-343,4$ & 95,7 \\
\hline & 249 & 25,6 & 49,0 & 22,61 & $-340,6$ & 100,7 & 20,84 & $-384,3$ & 99,8 & 21,93 & $-359,4$ & 100,2 \\
\hline & 284 & 25,1 & 53,6 & - & $-338,4$ & 100,0 & - & $-385,0$ & 100,0 & - & $-358,8$ & 100,0 \\
\hline
\end{tabular}

Na Figura 9.31, encontra-se a evolução da retração por secagem das miniparedes em função do tempo de ensaio. 


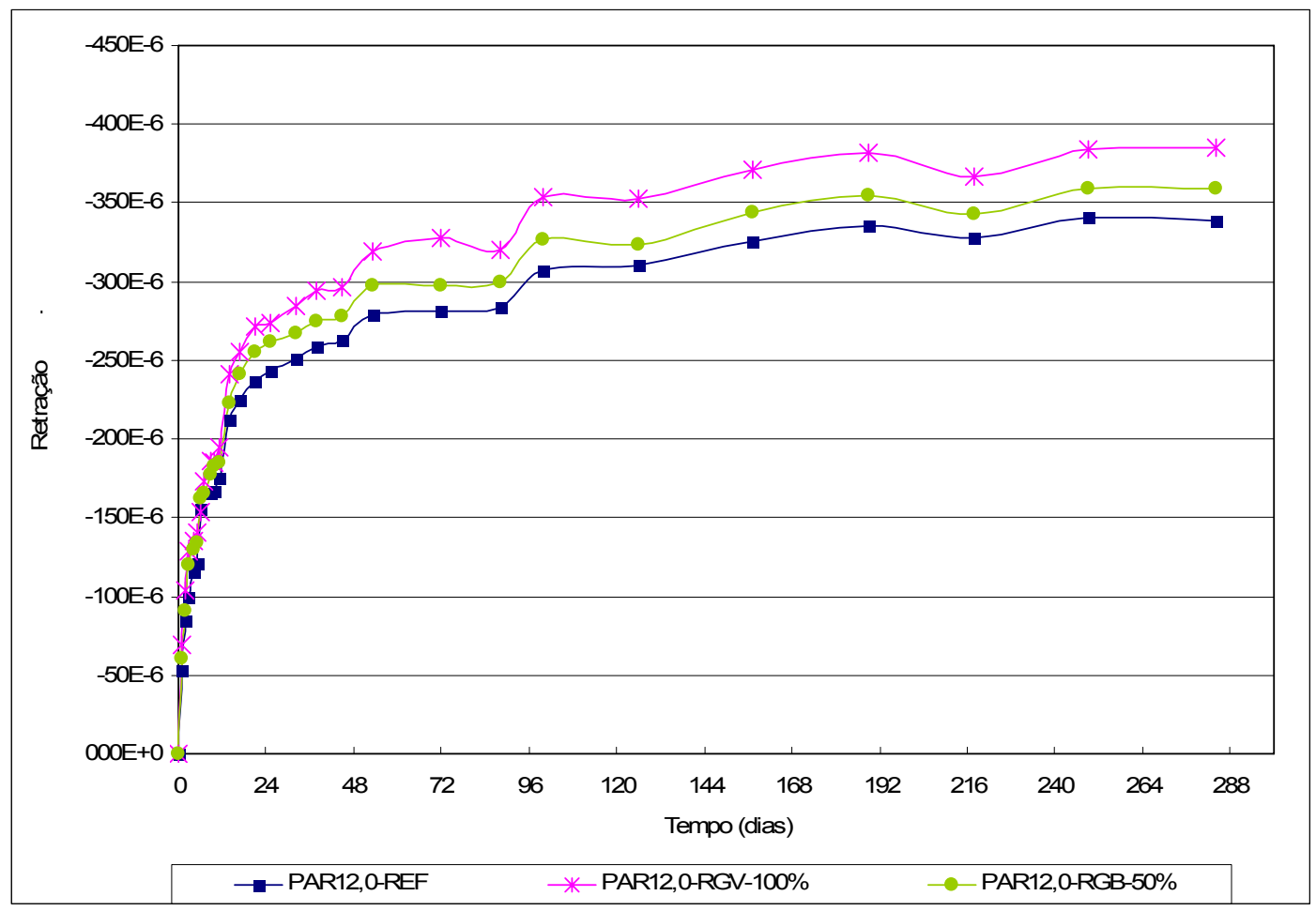

Figura 9.31 - Evolução da retração por secagem para as miniparedes do Grupo 12,0.

Pela Tabela 9.18 e Figura 9.31, nota-se que os valores de retração, ao longo do tempo ( $1^{\circ}$ dia ao $284^{\circ}$ dia), das miniparedes PAR12,0-RGV-100\% e PAR12,0-RGB-50\% foram, em média, $19 \%$ e $11 \%$ superiores aos valores de retração das miniparedes de referência. Diferentemente do ocorrido para as miniparedes dos demais grupos, os resultados de retração apresentaram tendência a estabilização somente a partir dos 250 dias de ensaio; sendo que aos 7 dias e 30 dias, $47 \%\left(\cup_{\text {unidade }}=26,6 \%\right)$ e $74 \%\left(\cup_{\text {unidade }}=\right.$ $21,6 \%)$ da retração total já haviam ocorrido, respectivamente. Essa retração pode ser considerada reversível (dependente da umidade do ambiente) dada a idade das unidades no momento do assentamento (superior a 160 dias). Barbosa (2005) cita que blocos de resistência elevada (acima de 8,0 MPa), produzidos sob cura à vapor, devem ser utilizados após os 14 dias, visando reduzir a retração irreversível ou permanente. O pesquisador obteve para blocos de concreto de 14,0 MPa $\left(f_{b k}=13,00 \mathrm{MPa}\right)$, produzidos sob cura a vapor, valores de retração entre $0,50 \mathrm{~mm} / \mathrm{m}$ e $0,60 \mathrm{~mm} / \mathrm{m}$ para alvenarias executadas com unidades de 5 dias de idade.

Considerando-se a umidade máxima no momento do assentamento prescrita pela NBR 6136 (1994), que é de 35\%, para blocos cuja retração linear seja situada entre 0,30 e $0,45 \mathrm{~mm} / \mathrm{m}$; observa-se que as miniparedes foram constituídas por unidades cujo valor de umidade média ficou abaixo desse limite. Pelos resultados de retração para os corpos-de- 
prova de bloco, notou-se que, em média, $65 \%$ da retração total ocorreu até a umidade de $35 \%$.

$\mathrm{Na}$ Figura 9.32, são apresentadas as curvas que melhor ajustam os resultados obtidos para as miniparedes do Grupo 12,0.

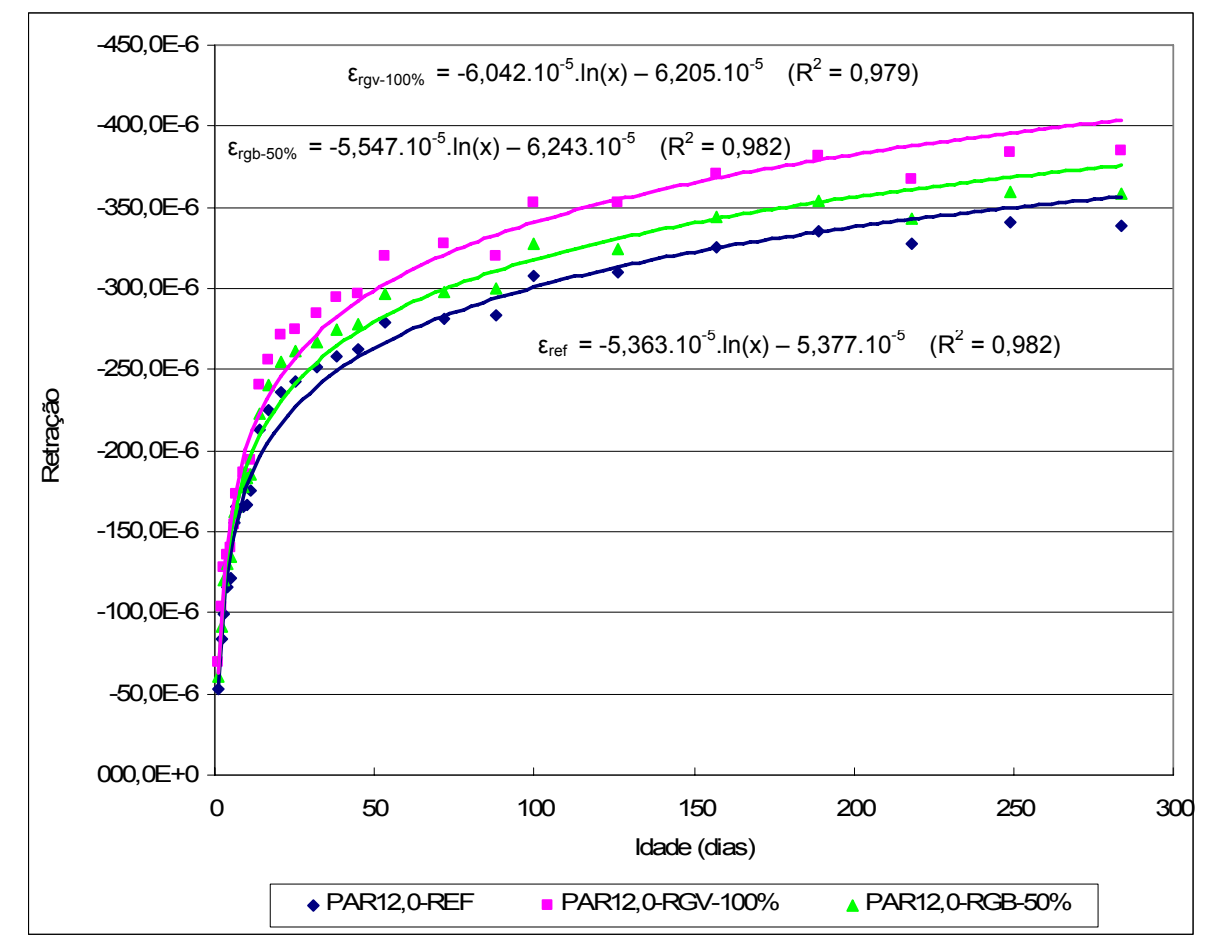

Figura 9.32 - Interpolação dos resultados de retração das miniparedes do Grupo 12,0.

Pela Figura 9.32, observa-se que a interpolação dos dados através das curvas propostas mostrou uma correlação muito satisfatória $\left(R^{2}>0,97\right)$. Utilizando-se essas curvas, é apresentada na Tabela 9.19 algumas estimativas dos valores de retração para idades superiores a 300 dias. Novamente, deve-se ressaltar que apesar da correlação satisfatória, os resultados da extrapolação para idades superiores a 300 dias tenderão a ser superiores aos que seriam obtidos experimentalmente, uma vez que os resultados experimentais de retração mantiveram-se praticamente inalterados após 200 dias de ensaio. 
Tabela 9.19 - Previsão dos valores de retração das miniparedes do Grupo 12,0.

\begin{tabular}{cccc}
\hline \multirow{2}{*}{ Tempo } & \multicolumn{3}{c}{ Retração $\left(\mathbf{x ~ 1 0 ^ { - 6 } )}\right.$} \\
\cline { 2 - 4 } & PAR12,0-REF & PAR12,0-RGV-100\% & PAR12,0-RGB-50\% \\
\hline 300 dias & $-359,7$ & $-406,7$ & $-378,8$ \\
\hline 1 ano & $-370,2$ & $-418,5$ & $-389,7$ \\
\hline 2 anos & $-407,4$ & $-460,4$ & $-428,1$ \\
\hline 3 anos & $-429,1$ & $-484,9$ & $-450,6$ \\
\hline 5 anos & $-456,5$ & $-515,8$ & $-478,9$ \\
\hline 10 anos & $-493,7$ & $-557,6$ & $-517,4$ \\
\hline 2 anos & $-530,9$ & $-599,5$ & $-555,9$ \\
\hline
\end{tabular}

\subsubsection{AVALIAÇÃO GLOBAL DOS RESULTADOS OBTIDOS - MINIPAREDES}

$\mathrm{Na}$ Tabela 9.20, são apresentados os resultados do teste ANOVA para a propriedade de retração por secagem.

Tabela 9.20 - Teste ANOVA para a propriedade de retração por secagem (miniparedes).

\begin{tabular}{|c|c|c|c|c|c|c|c|c|c|}
\hline & & & \multicolumn{7}{|c|}{ Variáveis } \\
\hline & & & Grupos & \multirow{2}{*}{ Traços } & \multirow{2}{*}{ Idades $^{2}$} & \multirow{2}{*}{$\begin{array}{c}\text { Grupos } x \\
\text { Traços }\end{array}$} & \multirow{2}{*}{$\begin{array}{l}\text { Grupos } x \\
\text { Idades }\end{array}$} & \multirow{2}{*}{$\begin{array}{l}\text { Traços } x \\
\text { Idades }\end{array}$} & \multirow{2}{*}{$\begin{array}{c}\text { Grupos } x \\
\text { Traços } x \\
\text { Idades }\end{array}$} \\
\hline & & & 4,$5 ; 8,0 ; 12,0$ & & & & & & \\
\hline \multirow{4}{*}{ 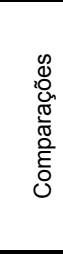 } & \multirow{3}{*}{$\begin{array}{l}\text { Comparações } \\
\text { com o traço de } \\
\text { referência }\end{array}$} & $\begin{array}{c}\text { REF x RGV- } \\
100 \% \times \text { RGB- } \\
50 \%^{1} \\
\end{array}$ & $S\left(F_{O}=112,5\right)$ & $S(7,67)$ & $S(47,1)$ & - & $S(5,00)$ & - & - \\
\hline & & $\begin{array}{c}\text { REF } \times \text { RGV- } \\
100 \% \\
\end{array}$ & $S(67,4)$ & $S(42,1)$ & $S(59,4)$ & $S(4,60)$ & - & - & - \\
\hline & & $\begin{array}{c}\text { REF } \times \text { RGB- } \\
50 \%{ }^{1} \\
\end{array}$ & $S(68,3)$ & - & $S(21,5)$ & - & - & - & - \\
\hline & $\begin{array}{l}\text { Diferentes } \\
\text { resíduos }\end{array}$ & $\begin{array}{c}\text { RGV-100\% }{ }^{x} \\
\text { RGB- } 50 \%{ }^{1}\end{array}$ & $S(94,2)$ & $S(14,9)$ & $S(37,9)$ & $S(4,47)$ & $S(4,14)$ & - & - \\
\hline $\begin{array}{l}\text { comp } \\
2 \text { idade } \\
\text { (S) : in } \\
(-): \text { se } \\
\text { O núm } \\
\text { analis }\end{array}$ & $\begin{array}{l}\text { são realizada ape } \\
\text { nsideradas para } \\
\text { ncia significativa } \\
\text { fluência significa } \\
\text { entre parênteses }\end{array}$ & $\begin{array}{l}\text { las para os Grup } \\
\text { inálise a partir d } \\
\text { ara um nível de } \\
\text { va }\left(F_{0}<F_{\text {critico }}\right) \\
\text { efere-se ao valc }\end{array}$ & $\begin{array}{l}4,5 \text { e } 12,0 \\
\text { ício do ensaio: } \\
\text { hificância igual } \\
\text { e } F_{0} \text {. Quanto ma }\end{array}$ & $\begin{array}{l}100 \mathrm{e} \\
\left(\mathrm{F}_{0}>\mathrm{F}\right. \\
\text { valor } \mathrm{d}\end{array}$ & as & . & 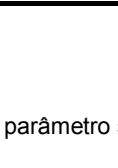 & . & de \\
\hline
\end{tabular}

Analisando-se os resultados da Tabela 9.20, são estabelecidos os seguintes comentários:

- Para as comparações envolvendo o traço de referência, pode-se dizer que a variável "grupos" teve influência mais significativa, comparativamente às variáveis "traços" e "idades", sobre a retração por secagem. Nesse caso, os maiores valores médios de retração por secagem foram obtidos para o Grupo 12,0. Comparativamente ao Grupo 12,0, foi observada uma redução média na retração por secagem de 15\% (Grupo 8,0) e 35\% (Grupo 4,5). De acordo com FURNAS (1997), um aumento do consumo de cimento ocasiona uma elevação da retração por secagem. 
- Com relação à variável "traços", pode-se dizer que os maiores valores médios de retração foram obtidos para as miniparedes PAR-RGV-100\%, ou seja, foi observado um aumento médio de $24 \%$ e $20 \%$, respectivamente em relação aos resultados das miniparedes PAR-REF e PAR-RGB-50\%. Por outro lado, na comparação PAR-REF $x$ PAR-RGB-50\%, os resultados de retração foram considerados semelhantes, isto é, não houve influência significativa.

- Para a variável "idades", pode-se dizer que os valores de retração crescem à medida do andamento do ensaio, ou seja, com o tempo de ensaio, sendo significativamente diferentes um do outro. Por exemplo, aos 30 dias, a retração foi, em média, $54 \%$ superior à retração aos sete dias; já aos 100 dias, a retração foi, em média, 17\% superior à retração aos 30 dias e, finalmente, aos 280 dias, a retração foi apenas, em média, $1,4 \%$ superior à retração aos 100 dias.

\subsubsection{ESTIMATIVA DA DISTÂNCIA ENTRE JUNTAS DE CONTROLE}

Neste item, é apresentado um estudo preliminar a respeito da distância entre juntas de controle para cada tipo de miniparede avaliada. O objetivo é avaliar qual o impacto dos maiores valores de retração das miniparedes compostas por agregados reciclados sobre a distância da juntas de controle comparativamente às miniparedes de referência. As seguintes hipóteses são consideradas:

- Para a determinação da distância entre juntas de controle é empregada a equação dada por Grimm (1993):

$$
s=\frac{\left(w_{j} \cdot e_{j}\right)}{\left(k_{m}+k_{t} \cdot \Delta T\right)}
$$

$\mathrm{s}=$ espaçamento entre juntas, em $\mathrm{mm}$

$\mathrm{w}_{\mathrm{j}}=$ espessura da junta, em $\mathrm{mm},(10 \mathrm{~mm}$ no presente caso)

$e_{\mathrm{j}}=$ extensividade do selante, em $\%$, (50\% no presente caso)

$\mathrm{k}_{\mathrm{m}}=$ coeficiente de retração da alvenaria $(\mathrm{mm} / \mathrm{m})$

$\mathrm{k}_{\mathrm{t}}=$ coeficiente de dilatação térmica, podendo ser admitido igual a $8,1.10^{-6}$ $\mathrm{mm} / \mathrm{mm} /{ }^{\circ} \mathrm{C}$ (BARBOSA, 2005)

$\Delta \mathrm{T}=$ variação térmica $\left({ }^{\circ} \mathrm{C}\right)$

- O modelo não considera a umidade relativa do ambiente e a taxa de armadura préexistente. 
- O coeficiente de retração da alvenaria é obtido mediante interpolação dos resultados obtidos, conforme gráficos das Figuras 9.28, 9.30 e 9.32, para um tempo de projeto de dois anos e dez anos. Provavelmente, esses valores são maiores do que os obtidos experimentalmente, no entanto, são a favor da segurança.

- Para a variação térmica são consideradas as amplitudes de $10^{\circ} \mathrm{C}, 20^{\circ} \mathrm{C}$ e $30^{\circ} \mathrm{C}$.

Na Tabela 9.21, são apresentados os coeficientes de retração, mediante interpolação dos resultados experimentais obtidos, para um tempo de projeto de dois e dez anos.

Tabela 9.21 - Coeficientes de retração da alvenaria (Grupos 4,5; 8,0 e 12,0) para dois e dez anos.

\begin{tabular}{ccccccccc}
\hline & \multicolumn{7}{c}{ Retração $\left(\times 10^{-6}\right)$} \\
\cline { 2 - 9 } Tempo & \multicolumn{3}{c}{ GRUPO 4,5 } & \multicolumn{2}{c}{ GRUPO 8,0 } \\
\cline { 2 - 10 } & $\begin{array}{c}\text { PAR4,5- } \\
\text { REF }\end{array}$ & $\begin{array}{c}\text { PAR4,5- } \\
\text { RGV-100\% }\end{array}$ & $\begin{array}{c}\text { PAR4,5- } \\
\text { RGB-50\% }\end{array}$ & $\begin{array}{c}\text { PAR8,0- } \\
\text { REF }\end{array}$ & $\begin{array}{c}\text { PAR8,0- } \\
\text { RGV-100\% }\end{array}$ & PAR12,0-REF & $\begin{array}{c}\text { PAR12,0- } \\
\text { RGV-100\% }\end{array}$ & $\begin{array}{c}\text { PAR12,0- } \\
\text { RGB- } \\
\mathbf{5 0 \%}\end{array}$ \\
\hline 2 anos & $-263,2$ & $-312,9$ & $-239,4$ & $-334,1$ & $-403,2$ & $-370,2$ & $-418,5$ & $-389,7$ \\
\hline 10 anos & $-314,3$ & $-370,9$ & $-293,9$ & $-405,8$ & $-494,4$ & $-493,7$ & $-557,6$ & $-517,4$ \\
\hline
\end{tabular}

A distância entre as juntas de controle, considerando-se as hipóteses propostas, é apresentada na Tabela 9.22.

Tabela 9.22 - Previsão da distância entre as juntas de controle.

\begin{tabular}{|c|c|c|c|c|c|c|c|c|}
\hline \multirow{3}{*}{$\Delta \mathrm{T}\left({ }^{\circ} \mathrm{C}\right)$} & \multicolumn{8}{|c|}{ Distância entre juntas de controle (m) } \\
\hline & \multicolumn{3}{|c|}{ GRUPO 4,5 } & \multicolumn{2}{|c|}{ GRUPO 8,0 } & \multicolumn{3}{|c|}{ GRUPO 12,0 } \\
\hline & PAR-REF & PAR-RGV-100\% & PAR-RGB-50\% & PAR-REF & PAR-RGV-100\% & PAR-REF & PAR-RGV-100\% & PAR-RGB-50\% \\
\hline 10 & $12,6-14,5$ & $11,1-12,7$ & $13,3-15,6$ & $10,3-12,0$ & $8,7-10,3$ & $8,7-11,1$ & $7,8-10,0$ & $8,4-10,6$ \\
\hline 20 & $10,5-11,8$ & $9,4-10,5$ & $11,0-12,5$ & $8,8-10,1$ & $7,6-8,8$ & $7,6-9,4$ & $6,9-8,6$ & $7,4-9,1$ \\
\hline 30 & $9,0-9,9$ & $8,1-9,0$ & $9,3-10,4$ & $7,7-8,7$ & $6,8-7,7$ & $6,8-8,2$ & $6,2-7,6$ & $6,6-7,9$ \\
\hline
\end{tabular}

Analisando-se a Tabela 9.22, são feitos os seguintes comentários:

- Para os elementos de referência do Grupo 4,5, dependendo da amplitude térmica e do tempo de projeto considerado, a distância entre as juntas de controle variou entre 9,0 m e 14,5 m; já para os elementos PAR-RGV-100\% ( $\left.\varepsilon_{\text {PAR-RGV-100\% }}=1,18 . \varepsilon_{\text {PAR-REF }}\right)$, essa distância variou entre $8,1 \mathrm{~m}$ e $12,7 \mathrm{~m}$ e foi reduzida, em média, de 10,7\% em relação aos elementos de referência. Para os elementos PAR-RGB-50\% ( $\varepsilon_{\text {PAR-RGB-50\% }}$ $=0,92 \cdot \varepsilon_{\text {PAR-REF }}$ ), essa distância variou entre $9,3 \mathrm{~m}$ e 15,6 $\mathrm{m}$ e pode ser aumentada, em média, de 5,3\% em relação aos elementos de referência. 
- Para os elementos de referência do Grupo 8,0, dependendo da amplitude térmica e do tempo de projeto considerado, a distância entre as juntas de controle variou entre $7,7 \mathrm{~m}$ e $12,0 \mathrm{~m}$; já para os elementos PAR-RGV-100\% ( $\left.\varepsilon_{\text {PAR-RGV-100\% }}=1,21 . \varepsilon_{\text {PAR-REF }}\right)$, essa distância variou entre 6,8 m e 10,3 m e foi reduzida, em média, de 13,0\% em relação aos elementos de referência.

- Para os elementos de referência do Grupo 12,0, dependendo da amplitude térmica e do tempo de projeto considerado, a distância entre as juntas de controle variou entre 6,8 m e 11,1 m; já para os elementos PAR-RGV-100\% ( $\left.\varepsilon_{\text {PAR-RGV-100\% }}=1,13 . \varepsilon_{\text {PAR-REF }}\right)$, essa distância variou entre 6,2 m e 10,0 m e foi reduzida, em média, de $8,7 \%$ em relação aos elementos de referência. Para os elementos PAR-RGB-50\% $\left(\varepsilon_{\text {PAR-RGB- } 50 \%}\right.$ $=1,05 . \varepsilon_{\text {PAR-REF }}$ ), essa distância variou entre $6,6 \mathrm{~m}$ e 10,6 $\mathrm{m}$ e pode ser reduzida, em média, de 3,6\% em relação aos elementos de referência.

- Considerando-se a variação de temperatura igual a $30^{\circ} \mathrm{C}$, foram obtidos os seguintes valores médios para a distância entre as juntas de controle: 8,8 m (Grupo 4,5), 7,3 m (Grupo 8,0) e 6,5 m (Grupo 12,0). A BS 5628: part 3 (1978) recomenda que as juntas de controle estejam situadas a cada $6,0 \mathrm{~m}$, já o código ACI/ASCE (1995) prescreve uma distância de $7 \mathrm{~m}$ entre juntas e, finalmente, a revisão da norma NBR 10837 (2007) cita que o espaçamento máximo não deve ultrapassar 7,5 m. De maneira geral, os espaçamentos entre as juntas de controle foram condizentes com os obtidos pelas normas supracitadas; com exceção do Grupo 12,0, aonde a distância média entre as juntas foi menor comparativamente aos valores prescritos pelos códigos ACI/ASCE (1995) e revisão da NBR 10837 (2007).

\subsection{CONCLUSÕES DO CAPÍTULO}

De maneira geral, os resultados de retração por secagem para os corpos-de-prova avaliados atenderam ao valor limite de retração prescrito pela NBR 6136 (1994). Além disso, as condições lentas de secagem adotadas neste trabalho, conforme recomendações de Drysdale e Khattab (1995) mostraram-se adequadas, uma vez que puderam ser estabelecidas relações entre a umidade presente na unidade e sua respectiva retração.

Em todos os grupos e elementos avaliados, observou-se que a retirada de cerca da metade da água contida nos blocos não provocou uma retração significativa; segundo Mehta e Monteiro (1994), a perda de água livre retida nas grandes cavidades não é acompanhada 
de retração significativa, uma vez que essa água livre não está atrelada à estrutura dos poros hidratados por ligações físico-químicas fortes. Os resultados mostraram que para valores de umidade abaixo de $50 \%$, qualquer perda de água adicional resultou em retração considerável. De acordo com Mehta e Monteiro (1994), esse fenômeno é atribuído principalmente à perda de água adsorvida e da água retida em pequenos capilares. A água adsorvida, quando confinada em espaços estreitos entre duas superfícies sólidas, causa pressão de desligamento; a remoção dessa água adsorvida reduz a pressão de desligamento e causa a retração do sistema.

A partir dos resultados obtidos, ressalta-se a importância do controle efetivo de umidade dos blocos no momento do assentamento, já que grande parte da retração por secagem ocorre para valores de umidade inferiores a 35\%. Esse fato é corroborado pelos resultados de retração de alguns elementos dispostos na câmara úmida, uma vez que apenas $25 \%$ da retração total ocorreu entre as umidades de $90 \%$ e $35 \%$. Dessa forma, recomenda-se que as unidades de alvenaria sejam protegidas de intempéries até sua utilização.

Os valores de retração por secagem das unidades com agregados reciclados, independentemente do grupo avaliado, foram superiores aos obtidos para as unidades de referência, sendo até 45\% maiores. De acordo com Neville (1997), esse fato pode ser explicado pelo menor módulo de deformação dos agregados reciclados comparativamente aos agregados naturais. Entretanto, para as miniparedes, de maneira geral, o aumento não foi significativo (até $20 \%$ ).

Com base nos resultados de retração das miniparedes, recomenda-se, independentemente da taxa de substituição e das características do resíduo, uma diminuição de $15 \%$ na distância entre as juntas de controle para paredes constituídas por unidades com agregados reciclados comparativamente às paredes convencionais, sendo desnecessária a adoção de medidas complementares. Acredita-se que essas recomendações também sejam válidas para as alvenarias compostas por unidades com agregados miúdos reciclados (taxas de substituição de até 33\%), uma vez que os resultados de retração dessas unidades, para todos os Grupos avaliados, foram muito próximos dos valores obtidos para as unidades com agregados graúdos reciclados de vigota (RGV-100\%). 


\subsection{PRINCIPAIS CONCLUSÕES}

Em razão da discussão dos resultados e apresentação das conclusões parciais nos capítulos anteriores, neste capítulo é feita uma análise geral de todos esses aspectos já comentados. Com relação aos resíduos de concreto e as propriedades dos agregados reciclados de concreto, deve-se atentar às seguintes necessidades:

- Escolha do método mais apropriado para a reciclagem de acordo com o volume de resíduos gerados, a aplicação futura do material e o investimento planejado.

- Gestão adequada dos resíduos de concreto, evitando-se a mistura de diferentes tipos de resíduos, fato esse que, quando negligenciado, pode reduzir a possibilidade de reciclagem do material e seu uso futuro.

- Avaliação das propriedades físicas, principalmente, com relação à absorção de água, índice de forma, abrasão Los Angeles e teor de argamassa aderida. Através dessas propriedades, é possível aferir a composição e a qualidade do resíduo e, dessa forma, restringir ou não o seu campo de aplicação. Por exemplo, agregados reciclados com grande quantidade de argamassa aderida (ensaio de absorção de água e teor de argamassa aderida), provenientes de um resíduo de baixa resistência (abrasão Los Angeles) e constituído de partículas alongadas (ensaio de índice de forma) devem ser evitados. De maneira geral, os agregados graúdos reciclados de concreto, independentemente de sua origem e qualidade, cumprem mais facilmente os requisitos necessários para seu emprego na produção de artefatos de concreto; por outro lado, a elevada absorção de água e o alto teor de finos dos agregados miúdos reciclados restringem sua utilização. 
Com relação às metodologias de dosagem e produção dos artefatos de concreto os seguintes pontos são relevantes:

- Realização de estudo de campo visando calibrar o método de produção de corposde-prova cilíndricos com as condições reais de produção, uma vez que cada equipamento de vibro-prensagem possui as suas particularidades. Neste caso, a correlação pode ser considerada adequada quando as propriedades físicas (massa específica, absorção de água e índice de vazios) destes elementos não diferirem significativamente entre si. O método de produção de CPs cilíndricos é particularmente interessante no que se refere à possibilidade de varrer uma grande gama de variáveis utilizando-se pequena quantidade de material e em tempo reduzido, além de eliminar a variabilidade típica encontrada na produção dos blocos.

- Avaliação das condições de produção, tais como, o sistema de dosagem, o equipamento de vibro-prensagem e o tipo de cura utilizada, uma vez que são fundamentais para o sucesso na fabricação de blocos com agregados reciclados e nas propriedades físicas e mecânicas destes elementos. Neste sentido, deve-se priorizar a utilização de sistemas baseados na dosagem pela massa dos agregados e que dispõem obrigatoriamente de controle de umidade, visando reduzir variações volumétricas indesejáveis e, consequentemente, reduzir o coeficiente de variação da produção; o equipamento de vibro-prensagem deve ser preferencialmente mecânico ou hidráulico, uma vez que contam com maior energia de adensamento e compactação e, dessa forma, para uma dada resistência, o consumo de cimento poderá ser menor. Com relação ao tipo de cura, essa deve ser térmica com o objetivo de garantir a qualidade e a resistência especificada para os produtos, mas também com a finalidade de reduzir substancialmente as deformações oriundas da retração por secagem (principal problema para as unidades com agregados reciclados). Essas medidas garantirão que as unidades com agregados reciclados tenham propriedades compatíveis com aquelas apresentadas pelas unidades comumente comercializadas.

- Considerando-se o aspecto econômico da reciclagem, deve-se avaliar qual hipótese é mais apropriada para a empresa, isto é, para fábricas de pequeno porte (produção inferior a 100.000 blocos/mês) pode ser interessante a compra de agregados reciclados ou a reciclagem do agregado reciclado em usinas de terceiros; por outro lado, para fábricas maiores (produção superior a 100.000 blocos/mês), além das 
duas opções citadas, há a possibilidade de aquisição de equipamentos de reciclagem com período de retorno do investimento estimado a partir de sete anos.

Com relação às propriedades dos elementos com agregados reciclados e a retração por secagem, os seguintes pontos são importantes:

- Desde que as condições de produção listadas nos itens anteriores sejam seguidas e a metodologia de dosagem esteja consolidada pela produção de CPs cilíndricos, os elementos compostos por unidades com agregados reciclados não apresentarão diferenças significativas quanto às suas propriedades mecânicas comparativamente aos elementos produzidos com blocos comerciais.

- Para que a retração por secagem seja reduzida é fundamental que as unidades com agregados reciclados sejam produzidas sob condições de cura térmica. Além disso, para reduzir a retração inicial e irreversível, as unidades devem ser liberadas para utilização, no mínimo, 14 dias após a sua fabricação. Outro fator importante é a necessidade de controle da umidade dos blocos antes do assentamento, uma vez que grande parte da retração por secagem reversível ocorre para valores de umidade abaixo de $35 \%$, devendo os mesmos serem protegidos das intempéries através do uso de lonas ou coberturas provisórias.

- Adotando-se as medidas citadas no parágrafo anterior, a retração dos elementos com agregados reciclados continuará superior à retração dos elementos constituídos por blocos com agregados naturais. No entanto, a magnitude do fenômeno será menor e compatível com as recomendações normativas. Dessa forma, não haverá necessidade da adoção de medidas complementares, tais como, a adoção de juntas horizontais armadas. A única medida a ser tomada será uma pequena redução da distância entre as juntas de controle, em torno de 15\%, comparativamente aos elementos convencionais. 


\subsection{SUGESTÕES PARA FUTURAS PESQUISAS}

Mesmo com um grande número de ensaios, faz-se necessário o desenvolvimento de novos trabalhos com intuito de atestar e avançar as sugestões aqui apresentadas.

As principais sugestões para novas pesquisas são descritas abaixo:

- Avaliação do índice de atividade pozolânica de agregados reciclados de concreto, especialmente a fração miúda reciclada.

- Desenvolvimento de método mais elaborado para uniformização da energia de adensamento dos corpos-de-prova visando uma correlação mais precisa com as propriedades das unidades de alvenaria, com a definição de um apropriado adensador.

- Verificação detalhada da influência do tipo de mistura (ordem de colocação e tempo de mistura) sobre as propriedades físicas e mecânicas dos corpos-de-prova, inclusive com a aplicação de ensaios de microestrutura eletrônica de varredura.

- Testes de lixiviação e solubilização em corpos-de-prova cilíndricos ou blocos compostos por agregados reciclados de concreto.

- Avaliação econômica detalhada do processo de reciclagem e produção de blocos com agregados reciclados considerando-se os custos do processo de reciclagem (custos de implantação, operação e manutenção) e do próprio custo de produção dos blocos com reciclados.

- Avaliação do comportamento de argamassas produzidas com agregados miúdos reciclados de concreto.

- Modelagem numérica do fenômeno de retração por secagem. 
ABRAMS, D. P. Effect of mortar shrinkage on in-plane stresses in clay brickwork. TMS Journal, fev. 1995.

ACI 555R-01. Removal and reuse of hardened concrete. ACI Materials Journal. p. 300-325, may - jun. 2002.

AÏTCIN, P. C. Concreto de alto desempenho. Tradução Geraldo Gomes Serra. São Paulo: Pini, 2000. 662p.

AJDUKIEWICZ, A.; KLISZCZEWICZ. Influence of recycled aggregates on mechanical properties of HS/HPC. Cement and Concrete Composites, v. 24, p. 269-279, 2002.

ALAEJOS, P.; VAZQUEZ, E.; MARTINEZ, F.; POLANCO, A.; ALEZA, F.; PARRA, J. L.; BURÓN, M. Draft of spanish regulations for the use of recycled aggregate in the production of structural concrete. In: INTERNATIONAL RILEM CONFERENCE ON THE USE OF RECYCLED MATERIALS IN BUILDINGS AND STRUCTURES, 2004, Barcelona. Proceedings... França: Elsevier publications, 2004.

ALBUQUERQUE, S. M. Estudo para uso de agregado de resíduos de construção e demolição em blocos de concreto para alvenaria. 2005. 104f. Dissertação (Mestrado em Habitação: Planejamento e Tecnologia) - Instituto de Pesquisas Tecnológicas do Estado de São Paulo, São Paulo, 2005.

ALLAN, W. D. M. Shrinkage measurements of concrete masonry. ACI Proceedings, v. 26, p. $699-716,1930$.

AMERICAN CONCRETE INSTITUTE (ACI) AND AMERICAN SOCIETY OF CIVIL ENGINEERS (ASCE). Commentary on specifications for masonry structures (ACI 530.195/ASCE G-95/TMS 602-95). Masonry Standards Joint Committee. New York, 1995.

AMERICAN CONCRETE INSTITUTE. ACI 318-89: building code requirements for masonry. Detroit. 1995.

AMERICAN SOCIETY FOR TESTING AND MATERIALS. ASTM C128: Standard test method for density, relative density (specific gravity), and absorption of fine aggregate. 1988.

ASTM C33: Standard specification for concrete aggregates. 2003, 11p. 1996.

ASTM C1006: Standard test methods for splitting tensile strength of masonry units. 
ASTM C1585: Standard test method for measurement of rate of absorption of water by hydraulic-cement concretes. 2004.

ASTM C426: Standard test methods for drying shrinkage of concrete block. 1999.

. ASTM C67: Standard test methods for sampling and testing brick and structural clay tile. 1996.

ANGULO, S. C. Caracterização de agregados de resíduos de construção e demolição reciclados e a influência de suas características no comportamento mecânico de concretos. 2005. 167 f. Tese (Doutorado) - Escola Politécnica, Universidade de São Paulo, São Paulo, 2005. ANGULO, S. C.; JOHN, V. M. Variabilidade dos agregados graúdos de resíduos de construção e demolição reciclados. Revista de Ciência e Tecnologia de Materiais de Construção Civil, v. 1, n. 1, p. 22-32, maio 2004.

ANGULO, S. C.; JOHN, V. M.; ULSEN, C.; KAHN, H. Caracterização de agregados de resíduos de construção e demolição reciclados separados por líquidos densos. ENCONTRO NACIONAL DE TECNOLOGIA DO AMBIENTE CONSTRUÍDO, 10., 2004, São Paulo. Anais... São Paulo: ANTAC, 2004. CD-ROM.

ANGULO, S. C.; ZORDAN, Z. E.; JOHN, V. M. Desenvolvimento sustentável e a reciclagem de resíduos na construção civil. In: SIMPÓSIO DESENVOLVIMENTO SUSTENTÁVEL E A RECICLAGEM NA CONSTRUÇÃO CIVIL - MATERIAIS RECICLADOS E SUAS APLICAÇÕES, 4., 2001, São Paulo. Anais... São Paulo: CT 206 - IBRACON, 2001. p. 43-56.

ASSOCIAÇÃO BRASILEIRA DAS EMPRESAS DE SERVIÇOS DE CONCRETAGEM.
Reciclagem de concreto residual. 2001. <http://www.abesc.org.br/pdf/mambiente.pdf $>$. Acesso em: 15 dez. 2006.

ASSOCIAÇÃO BRASILEIRA DE NORMAS TÉCNICAS (ABNT). NBR 7217: agregados: determinação da composição granulométrica. Rio de Janeiro, 1987.

. NBR 10004: resíduos sólidos - classificação. Rio de Janeiro, 1987.

. NBR 10837: projeto de estruturas de alvenaria de blocos vazados de concreto. Projeto de Norma Técnica. Rio de Janeiro, 2007.

NBR 12117: blocos vazados de concreto para alvenaria - retração por secagem. Rio de Janeiro, 1991.

NBR 12118: bloco vazado de concreto simples para alvenaria: determinação da absorção de água, do teor de umidade e da área líquida. Rio de Janeiro, 1992.

- NBR 15116: agregados reciclados de resíduos sólidos da construção civil: utilização em pavimentação e preparo de concreto sem função estrutural. Rio de Janeiro, 2004.

NBR 5739: ensaio de compressão de corpos-de-prova cilíndricos de concreto. Rio de Janeiro, 1984.

NBR 6136: blocos vazados de concreto simples para alvenaria estrutural. Rio de Janeiro, 1994.

NBR 6465: agregados: determinação da abrasão los angeles. Rio de Janeiro, 1984. 
NBR 7173: blocos vazados de concreto simples para alvenaria sem função estrutural. Rio de Janeiro, 1982.

. NBR 7184: blocos vazados de concreto simples para alvenaria: determinação da resistência à compressão. Rio de Janeiro, 1992.

. NBR 7215: determinação da resistência à compressão: cimento portland. Rio de Janeiro, 1991.

NBR 7219: agregados: determinação do teor de materiais pulverulentos. Rio de Janeiro, 1987.

. NBR 7222: argamassas e concretos: determinação da resistência à tração por compressão diametral de corpos-de-prova cilíndricos. Rio de Janeiro, 1983.

. NBR 7251: agregado em estado solto: determinação da massa unitária. Rio de Janeiro, 1982.

NBR 7810: agregado em estado compactado seco: determinação da massa unitária. Rio de Janeiro, 1983.

. NBR 8522: concreto: determinação do módulo de deformação estática e diagrama tensão-deformação. Rio de Janeiro, 1984.

. NBR 8798: execução e controle de obras de alvenaria estrutural de blocos vazados de concreto. Rio de Janeiro, 1985.

. NBR 9776: determinação da massa específica de agregados miúdos por meio do frasco de chapman. Rio de Janeiro, 1987.

. NBR 9778: argamassas e concretos endurecidos: determinação da absorção de água por imersão - índice de vazios e massa específica. Rio de Janeiro, 1987.

. NBR 9833: concreto fresco: determinação da massa específica e do teor de ar pelo método gravimétrico. Rio de Janeiro, 1987.

NBR 9937: agregados: determinação da absorção e da massa específica de agregado graúdo. Rio de Janeiro, 1987.

ASSOCIATED GENERAL CONTRACTORS OF AMERICA. Recycle this! 2001. Disponível em: <http://www.rmci-usa.com/benefits.htm>. Acesso em: 15 abr. 2003.

BALLISTA, L. P. Microconcretos leves estruturais com agregados graúdos reciclados modificados com látex estireno-butadieno - estudo das propriedades físicas, mecânicas e de durabilidade. 2003. 126 f. Dissertação (Mestrado em Engenharia de Estruturas) - Escola de Engenharia de São Carlos, Universidade de São Paulo, São Carlos, 2003.

BARBOSA, C. S. Resistência e deformabilidade de blocos vazados de concreto e prismas e suas correlações com as propriedades mecânicas do material constituinte. 2004. 153f. Dissertação (Mestrado em Engenharia de Estruturas) - Escola de Engenharia de São Carlos, Universidade de São Paulo, São Carlos, 2004.

BARBOSA, K. C. Avaliação experimental do fenômeno de retração em alvenaria de blocos de concreto. 2005. 235f. Dissertação (Mestrado em Construção Civil) - 
Departamento de Engenharia Civil, Universidade Federal de São Carlos, São Carlos, 2005.

BARBOSA, K. C.; PARSEKIAN, G. A.; SALES, A. Retração em alvenarias de blocos de concreto - previsão e prevenção de patologias. In: ENCONTRO NACIONAL DE TECNOLOGIA DO AMBIENTE CONSTRUÍDO, 10., 2004, São Paulo. Anais... São Paulo: ANTAC, 2004. CD-ROM.

BARDELLA, P. S.; BARBOSA, D. C.; CAMARINI, G. Influência da sílica ativa e das condições de cura na absorção capilar e na permeabilidade ao ar do concreto. In: CONGRESSO BRASILEIRO DO CONCRETO, 47., 2005, Olinda. Anais... Pernambuco: IBRACON, 2005. p. 310-325. CD-ROM.

BARRA, M.; VAZQUEZ, E. The influence of retained moisture in aggregates from recycling on the properties of new hardened concrete. Waste Management, v. 16, n. 3, p. 113117, 1996.

BASTOS, P. K. X.; CINCOTTO, M. A. Retração de compósitos à base de cimento. São Paulo: PCC/USP, 2000.

BAZUCO, R. S. Utilização de agregados reciclados de concreto para produção de novos concretos. 1999. 109 f. Dissertação (Mestrado) - Universidade Federal de Santa Catarina, Florianópolis, 1999.

BECICA, I. J.; HARRIS, H. G. Behavior of hollow concrete masonry prisms under axial load and bending. The Masonry Society Journal, v. 2, n. 2, p. T1-T26, jan.- jun. 1983.

BESSER COMPANY. How to produce concrete masonry units. 2006. Disponível em: <http://www.besser.com>. Acesso em: 21 nov. 2006.

BORTOLUZZO, C. W. Contribuição ao estudo do comportamento mecânico dos revestimentos de argamassa. 2000. 190 f. Dissertação (Mestrado) - Escola de Engenharia de São Carlos, Universidade de São Paulo, São Carlos, 2000.

BOSSINK, B. A. G.; BROUWERS, H. J. H. Construction waste: quantification and source evaluation. Journal of Construction Engineering and Management. Canadá, v. 122, n. 1, p. 55-60, mar. 1996.

BRASIL. Ministério do Meio Ambiente. Conselho Nacional do Meio Ambiente - CONAMA. Resolução $\mathrm{n}^{0}$ 307, de 05 de julho de 2002. Estabelece diretrizes, critérios e procedimentos para a gestão dos resíduos da construção civil. Diário Oficial da República Federativa do Brasil, Brasília, DF, n 136, 17 de julho de 2002. Seção 1, p. 95-96. Disponível em: <http://www.mma.gov.br/port/conama.res/res02/res30702.htm>. Acesso em: 10 nov. 2002.

BRITISH STANDARDS INSTITUTION. BS 8500: Part 2. Concrete - complementary british standard to BS EN 206-1 - part 2: specification for constituent materials and concrete. London, 2002.

BS 5628: Part 1. Code of practice for use of masonry - Structural use of unreinforced masonry. London, 1992.

BS 5628: Part 3. Code of practice for structural use of masonry - Materials and components, design and workmanship. London, 1978. 
BUTTLER, A. M. Concreto com agregados graúdos reciclados de concreto - Influência da idade de reciclagem nas propriedades dos agregados e concretos reciclados. 2003. 199f. Dissertação (Mestrado em Engenharia de Estruturas) - Escola de Engenharia de São Carlos, Universidade de São Paulo, São Carlos, 2003.

BUTTLER, A. M.; CORRÊA, M. R. S.; RAMALHO, M. A. Agregados reciclados na produção de artefatos de concreto. Revista Concreto. ano XXXIII, n. 37, p.24-27, dez. - fev. 2005.

BUTTLER, A. M.; MACHADO, E. F. Concreto com agregados graúdos reciclados de concreto - avaliação da retração por secagem. In: CONGRESSO BRASILEIRO DO CONCRETO, 46., 2004, Florianópolis. Anais... Santa Catarina: IBRACON, 2004. p. 512527. CD-ROM.

CAIRNS, R.; DI NIRO, G.; DOLARA, E. (1998). The use of RAC in prefabrication. In: INTERNATIONAL SYMPOSIUM: "SUSTAINABLE CONSTRUCTION: USE OF RECYCLED CONCRETE AGGREGATE”, 1998, Londres. Proceedings... Grã Bretanha: Thomas Telford, 1998, p. 371-380.

CALÇADA, L. M. L. Avaliação do comportamento de prismas grauteados e não grauteados de blocos de concreto. 1998. Dissertação (Mestrado - Engenharia de Produção). Universidade Federal de Santa Catarina, Florianópolis, 1998.

CAMPOS, A. A. Gestão de resíduos da construção civil: a visão do sinduscon - sp. In: SEMINÁRIO DE DESENVOLVIMENTO SUSTENTÁVEL E A RECICLAGEM NA CONSTRUÇÃO CIVIL, 7., 2006, São Paulo. Anais... São Paulo: Comitê Técnico CT-206 Meio Ambiente (IBRACON), 2006, CD-ROM. (palestra apresentada durante o evento).

CAPUZZO NETO, V. Interação de paredes em alvenaria estrutural sob ações verticais. 2005. Tese (Doutorado em Engenharia de Estruturas) - Escola de Engenharia de São Carlos, Universidade de São Paulo, São Carlos, 2004.

CASALI, J. M. Estudo comparativo do comportamento de diferentes tipos de argamassas de assentamento para alvenaria estrutural de blocos de concreto. 2003. Dissertação (Mestrado - Engenharia de Produção). Universidade Federal de Santa Catarina, Florianópolis, 2003.

CAVALCANTI, D. K. C. Políticas para a reciclagem de resíduos da construção civil. Cadernos Técnicos do AUT, n. 3, 2004. Disponível em: <http://www.usp.br/fau/public >. Acesso em: 10 mar. 2004.

ClOCCHI, L. Reciclagem de concreto. 2003. Disponível em: <http://www.piniweb.com.br>. Acesso em: 12 jul. 2004.

COELHO, P. E. Reciclagem de entulho - o melhor ainda está por vir. 2001. Disponível em: <http://www.unilivre.org.br/centro/experiencias/experiencias/>. Acesso em: 10 ab. 2002.

COSTA, F.; BUSNELLO, E. C.; ANDRADE, E.; SADOWSKI, F. Reciclagem de resíduos de concreto através de beneficiamento e suas aplicações em central de concreto na cidade de Florianópolis. In: CONGRESSO BRASILEIRO DO CONCRETO, 46., 2004, Florianópolis. Anais... Santa Catarina: IBRACON, 2004. CD-ROM.

CROWTHER, P. Building deconstruction in Australia. In: KIBERT, C. J.; CHINI, A. R. Overview of deconstruction in selected countries. Florida: CIB - International Council for Research and Innovation in Building Construction, 2000. cap. 2, p. 14-44. Disponível em: <http://s14.cfaa.ufl.edu/centers/sustainable/>. Acesso em: 15 nov. 2001. 
DA SILVA, F. G. Estudo de concretos de alto desempenho frente à ação de cloretos. 2006. 220f. Tese (Doutorado em Ciência e Engenharia dos Materiais) - Escola de Engenharia de São Carlos, Universidade de São Paulo, São Carlos, 2006.

DA SILVA, L. B.; VENQUIARUTO, S.; DAL MOLIN, D.; DE ABREU, A. G. Estudo da absorção capilar em concretos brancos. In: CONGRESSO BRASILEIRO DO CONCRETO, 47., 2005, Olinda. Anais... Pernambuco: IBRACON, 2005. p. 709-720. CD-ROM.

DAL MOLIN, D. C. C. Adições minerais para concreto estrutural. In: ISAIA, G. C. Concreto: Ensino, Pesquisa e Realizações. São Paulo: Ibracon, 2005, cap. 12, v. 1, p. 345-380.

DE BRITO, L. A.; ROCHA, J. C.; CHERIAF, M. Estudo comparativo do comportamento de concretos produzidos com agregados graúdos reciclados secos e saturados. In: ENCONTRO NACIONAL DE TECNOLOGIA DO AMBIENTE CONSTRUÍDO, 10., 2004, São Paulo. Anais... São Paulo: ANTAC, 2004. CD-ROM.

DE MELLO, F. F. B. Gestão dos resíduos da construção civil no município de São Paulo. In: SEMINÁRIO DE DESENVOLVIMENTO SUSTENTÁVEL E A RECICLAGEM NA CONSTRUÇÃO CIVIL, 7., 2006, São Paulo. Anais... São Paulo: Comitê Técnico CT-206 Meio Ambiente (IBRACON), 2006. CD-ROM. (palestra apresentada durante o evento).

DE MELO, A. B. Influência da cura térmica (vapor) sob pressão atmosférica no desenvolvimento da microestrutura dos concretos de cimento portland. 2000. 271f. Tese (Interunidades - Ciência e Engenharia de Materiais). Universidade de São Paulo, São Carlos, 2000.

DE PAUW, C. Recyclage des decombres d'une ville sinistree. CSTC Revue, n. 4, p. 12-28, dez. 1980.

DE VRIES, P. Concrete recycled: crushed concrete as aggregate. Concrete, p. 9-13, maio jun. 1993.

DEGANI, C. M. Sistemas de gestão ambiental em empresas construtoras de edifício. 2003. 263 f. Dissertação (Mestrado) - Escola Politécnica, Universidade de São Paulo, São Paulo, 2003.

DELALIBERA, R. G. Análise numérica e experimental de blocos de concreto armado sobre duas estacas submetidos à ação de força centrada e excêntrica. 2006. 308 f. Tese (Doutorado) - Escola de Engenharia de São Carlos, Universidade de São Paulo, São Carlos, 2006.

DEPARTAMENTO DE MEIO AMBIENTE. Política estadual de resíduos sólidos - São Paulo. In: SEMINÁRIO DE DESENVOLVIMENTO SUSTENTÁVEL E A RECICLAGEM NA CONSTRUÇÃO CIVIL, 7., 2006, São Paulo. Anais... São Paulo: Comitê Técnico CT-206 Meio Ambiente (IBRACON), 2006, CD-ROM. (palestra apresentada durante o evento).

DEUTSCHE INSTITUT FÜR NORMUNG (DIN). DIN 4226-100: aggregates for mortar and concrete - part 100: recycled aggregates. Germany, 2002.

DI NIRO, G.; CAIRNS, R.; DOLARA, E. Properties of hardened RAC for structural purposes. In: INTERNATIONAL SYMPOSIUM: "SUSTAINABLE CONSTRUCTION: USE OF RECYCLED CONCRETE AGGREGATE", 1998, Londres. Proceedings... Grã Bretanha: Thomas Telford, 1998, p. 177-188. 
DIAS, J. F. Avaliação de resíduos da fabricação de telhas cerâmicas para seu emprego em camadas de pavimento de baixo custo. 2004. 246 f. Tese (Doutorado). Escola Politécnica da Universidade de São Paulo, Universidade de São Paulo, São Paulo, 2004.

DIAS, J. F.; AGOPYAN, V. Determinação da absorção de agregados minerais reciclados porosos. In: ENCONTRO NACIONAL DE TECNOLOGIA DO AMBIENTE CONSTRUÍDO, 10., 2004, São Paulo. Anais... São Paulo: ANTAC, 2004. CD-ROM.

DINIZ FILHO, S. P. Relatório de ensaios de cimento: CP V ARI PLUS. Limeira, 2005, Período 12/02/2005 a 12/04/2005. 1p.

DOLARA, E.; CAIRNS, R.; DI NIRO, G. (1998). RAC prestressed beams. In: INTERNATIONAL SYMPOSIUM: "SUSTAINABLE CONSTRUCTION: USE OF RECYCLED CONCRETE AGGREGATE", 1998, Londres. Proceedings... Grã Bretanha: Thomas Telford, 1998, p. 255-262.

DRYSDALE, R. G.; HAMID, A. A.; BAKER, L. R. Masonry structures: behavior and design. New Jersey: Prentice Hall, 1994. 784p.

DRYSDALE, R. G.; KHATTAB, M. M. Shrinkage characteristics of concrete blocks. In: CANADIAN MASONRY SYMPOSIUM, 7., 1995, Hamilton, Ontario. Proceedings... Canada, 1995, p. 950-960.

ENVIRONMENTAL COUNCIL OF CONCRETE ORGANIZATIONS. Recycling concrete saves resources, eliminates dumping. 1997. Disponível em: $\leq$ http://www.ecco.org $>$ Acesso em: 20 maio 2005.

ETXEBERRIA, M.; VÁZQUEZ, E.; MARÍ, A.; BARRA, M.; HENDRICKS, C. F.; VAN MAASAKKERS, M. H. J. The role and influence of recycled aggregate, in "recycled aggregate concrete". In: INTERNATIONAL RILEM CONFERENCE ON THE USE OF RECYCLED MATERIALS IN BUILDINGS AND STRUCTURES, 2004, Barcelona. Proceedings... França: Elsevier publications, 2004.

FARIAS, R. S.; LIMA, I. B.; VIEIRA, G. L. ; BARBOSA, A. S.; GOMES, P. C. Análise das propriedades de resistência à compressão e módulo de elasticidade em prismas de blocos de concreto produzidos com agregados reciclados de resíduos de construção e demolição. In: CONGRESSO BRASILEIRO DO CONCRETO, 47., 2005, Olinda. Anais... Pernambuco: IBRACON, 2005. p. 139-152. CD-ROM.

FEDERAL HIGHWAY ADMINISTRATION. Recycled concrete study identifies current uses, best practices. 2004. Disponível em: <http://www.tfhrc.gov/focus/apr04>. Acesso em: 05 maio 2005.

FERREIRA, S. Produção de blocos de concreto para alvenaria: prática recomendada. São Paulo: Associação Brasileira de Cimento Portland, 1990. (Boletim Técnico 107).

FINANCIADORA DE ESTUDOS E PROJETOS. Alternativas para a redução do desperdício de materiais nos canteiros de obras. São Paulo, v. 4, 1998. (Relatório técnico).

FONSECA, F. B. Desempenho estrutural de paredes de alvenaria de blocos de concreto de agregados reciclados de rejeitos de construção e demolição. 2002. 140f. Dissertação (Mestrado em Engenharia de Estruturas) - Escola de Engenharia de São Carlos, Universidade de São Paulo, São Carlos, 2002. 
FONTES, B. M. Reciclagem de concreto se solidifica. Folha de São Paulo, São Paulo, 30 nov. 2003. Folha Classificados, Caderno Construção e Decoração. p. 1 e 3.

FRANCO, L. S. Desempenho estrutural do elemento parede de alvenaria empregado na alvenaria estrutural não armada, quando submetido a esforços de compressão. 1987. 136f. Dissertação (Mestrado) - Escola Politécnica, Universidade de São Paulo, São Paulo, 1987.

FRASSON JUNIOR, A. Proposta de metodologia de dosagem e controle do processo produtivo de blocos de concreto para alvenaria estrutural. 2000. 146f. Dissertação (Mestrado) - Departamento de Engenharia Civil, Universidade Federal de Santa Catarina, Florianópolis, 2000.

FREITAS, A. A. Estudo numérico e experimental da compressão de peças de alvenaria estrutural. Relatório técnico final do projeto de auxílio à pesquisa apresentado à FAPESP, 2006.

FURNAS. Concretos (massa, estrutural, projetado e compactado com rolo) - ensaios e propriedades. São Paulo: Pini, 1997.

GALLEGOS, H. Albañileria estructural. Pontificia Universidad Católica Del Peru, Primera Edición, 372p. 1989.

GANZERLI, S.; ROSSLOW, J.; YOUNG, T.; KREBS, K.; MUJUMDAR, V. Compressive strength testing for nonstandard concrete masonry units. In: NORTH AMERICAN MASONRY CONFERENCE, 9., 2003, Clemson, South Carolina. Proceedings... Estados Unidos, 2003, p. 60-71.

GLAVIND, M.; HAUGAARD, M. Future aspects for the use of recycled concrete aggregate in Denmark. In: INTERNATIONAL SYMPOSIUM: "SUSTAINABLE CONSTRUCTION: USE OF RECYCLED CONCRETE AGGREGATE", 1998, Londres. Proceedings... Grã Bretanha: Thomas Telford, 1998, p. 401-408.

GOMEZ-SOBERÓN, J. M. Porosity of recycled concrete with substitution of recycled concrete aggregate. Cement and Concrete Research, v. 32, p. 1301-1311, 2002.

GONÇALVES, R. D. Agregados reciclados de resíduos de concreto - um novo material para dosagens estruturais. 2001. 130f. Dissertação (Mestrado) - Escola de Engenharia de São Carlos, Universidade de São Paulo, São Carlos, 2001.

GRIMM, C. T. Masonry cracks: cause, prevention and repair. Masonry International, v. 10, n. 3, 1997.

GRIMM, C. T. Movements. In: MATTHYS, J. H. Masonry Designers' Guide. $1^{0}$ ed. Colorado: The Masonry Society and American Concrete Institute, 1993. cap. 10, p. 10.110.22 .

GROOT, C. Initial rate of absorption and porosity. In: JOINT INTERNATIONAL WORKSHOP, 2005, Padua. Proceedings... Italia: RILEM, 1995, p. 117-125.

GRÜBL, P.; NEALEN, A. Construction of an office building using concrete made from recycled demolition material. In: INTERNATIONAL SYMPOSIUM: "SUSTAINABLE CONSTRUCTION: USE OF RECYCLED CONCRETE AGGREGATE", 1998, Londres. Proceedings... Grã Bretanha: Thomas Telford, 1998, p. 263-274. 
HANSEN, T. C. Rilem Technical Committee - 37 - DRC: Recycled aggregates and recycled aggregate concrete second state of-the-art report developments 1945-1985. Matériaux et Constructions. v. 19, n. 111, p. 201-246, 1985.

HANSEN, T.; BOEGH, E. Elasticity and drying shrinkage of recycled-aggregate concrete. Journal of American Concrete Institute Proceedings, v. 82, n. 5, p. 648-652, set. out. 1985.

HANSEN, T.; NARUD, H. Strenght of recycled concrete made from chushed concrete coarse aggregate. Concrete International - Design and Construction, v. 5, n. 1, p. 79-83, jan. 1983.

HELENE, P.; TERZIAN, P. Manual de Dosagem e Controle do Concreto, São Paulo: Pini, 1993.

HENDRY, A. W. Masonry walls: materials and construction. Construction and Building Materials, v. 15, p. 323-328, 2001.

HSIAO, T. Y.; YU, Y. H.; WERNICK, I. K. A note on material flows of construction aggregates in Taiwan. Resources Policy, v. 27, p. 135-137, 2001.

JADOVSKI, I. Diretrizes técnicas e econômicas para usinas de reciclagem de resíduos de construção e demolição. 2005. 178f. Dissertação (Mestrado Profissionalizante em Engenharia) - Escola de Engenharia, Universidade Federal do Rio Grande do Sul, Porto Alegre, 2005.

JOHN, V. M. Reciclagem de resíduos na construção civil - contribuição à metodologia de pesquisa e desenvolvimento. 2000. Tese (Livre Docência) - Escola Politécnica, Universidade de São Paulo, São Paulo, 2000.

JOHN, V. M.; AGOPYAN, V. Reciclagem de resíduos da construção. In: RECICLAGEM DE RESÍDUOS SÓLIDOS DOMICILIARES, 2000, São Paulo. Anais eletrônico... São Paulo: Secretaria de Estado do Meio Ambiente, 2000. Disponível em: <http://www.ambiente.sp.org.br/residuos/ressolid domic/inicio.htm>. Acesso em: $14 \mathrm{dez}$. 2006.

JOHN, V. M.; ANGULO, S. C. Metodologia para desenvolvimento de reciclagem de resíduos. In: ROCHA, J. C.; JOHN, V. M. Utilização de resíduos na construção habitacional. Porto Alegre: ANTAC, 2003. v. 4, p. 8-71.

JOHN, V. M.; ÂNGULO, S. C. Metodologia para desenvolvimento de reciclagem de resíduos. In: ROCHA, J. C.; JOHN, V. M. Utilização de resíduos na construção habitacional. São Paulo: Coletânea Habitare, 2002. v. 4, p. 9-71.

JULIÃO, M. Cidade busca alternativas para destinação do entulho. Jornal Primeira Página, São Carlos, 21 out. 2004, ano XVII, n. 4206, p.A5.

JUNGMANN, A.; QUINDT, J. Alljig - technology for separation of building rubble and other secondary raw materials. In: GLOBAL SYMPOSIUM ON RECYCLING WASTE TREATMENT AND CLEAN TECHNOLOGY, 1999, San Sebastian. Proceedings... Warrendale: TMS/NASMET, 1999, p. 367-379.

JUSTE, A. E. Estudo da resistência e da deformabilidade da alvenaria de blocos de concreto submetida a esforços de compressão. 2001. 236f. Dissertação (Mestrado) - Escola de Engenharia de São Carlos, Universidade de São Paulo, São Carlos, 2001. 
KALOUSEK, G. L. Drying shrinkage and cracking tendency of concrete block walls. Concrete. v. 63, p. 17-36, sept. 1955.

KIBERT; C. J.; CHINI, A. R. Introduction: deconstruction as an essential component of sustainable construction. In: Overview of deconstruction in selected countries. Florida: CIB - International Council for Research and Innovation in Building Construction, 2000. cap. 1, p. 6-13. Disponível em: <http://s14.cfaa.ufl.edu/centers/sustainable/>. Acesso em: 15 nov. 2001.

KIBERT; C. J.; CHINI, A. R.; LANGUELL, J. L.; RINKER, M. E. Implementing deconstruction in the United States. In: KIBERT, C. J.; CHINI, A. R. Overview of deconstruction in selected countries. Florida: CIB - International Council for Research and Innovation in Building Construction, 2000. cap. 9, p. 181-239. Disponível em: <http://s14.cfaa.ufl.edu/centers/sustainable/>. Acesso em: 15 nov. 2001.

KIKUCHI, M.; DOSHO, Y.; NARIKAWA, M.; MIURA, T. Application of recycled concrete aggregate for structural concrete. part 1 - experimental study on the quality of recycled aggregate and recycled aggregate concrete. In: INTERNATIONAL SYMPOSIUM: "SUSTAINABLE CONSTRUCTION: USE OF RECYCLED CONCRETE AGGREGATE", 1998, Londres. Proceedings... Grã Bretanha: Thomas Telford, 1998, p. 55-68.

KREZEL, Z. A.; MCMANUS, K. J. Recycling demolition waste to fight noise pollution. In: ANNUAL AUSTRALIAN ENVIRONMENTAL ENGINEERING RESEARCH EVENT, 4., Proceedings... Australia: Victor Harbor, nov. 2000.

LA ROVERE, H. L.; RODRIGUES, R. M. Análise do comportamento mecânico de prismas de alvenaria de blocos de concreto pelo MEF. In: JORNADAS SULAMERICANAS DE ENGENHARIA ESTRUTURAL, 28., 1997. São Carlos. Anais... São Carlos. p. 179-188.

LATTERZA, L. M. Concreto com agregado graúdo proveniente da reciclagem de resíduos de construção e demolição: um novo material para fabricação de painéis leves de vedação. 1997. Dissertação (Mestrado) - Escola de Engenharia de São Carlos, Universidade de São Paulo, São Carlos, 1997.

LAURITZEN, E. K. Recycling concrete - an overview of development and challenges. In: INTERNATIONAL RILEM CONFERENCE ON THE USE OF RECYCLED MATERIALS IN BUILDINGS AND STRUCTURES, 2004, Barcelona. Proceedings... França: Elsevier publications, 2004.

LEI 12.300. Política estadual de resíduos sólidos - princípios e diretrizes - em processo de regulamentação. São Paulo, 2006.

LEITE, M. B. Avaliação das propriedades mecânicas de concretos produzidos com agregados reciclados de resíduos de construção e demolição. 2001. 270 f. Tese (Doutorado) - Universidade Federal do Rio Grande do Sul, Porto Alegre, 2001.

LEVY, S. M. Contribuição ao estudo da durabilidade de concretos produzidos com resíduos de concreto e alvenaria. 2001. 199 f. Tese (Doutorado) - Escola Politécnica, Universidade de São Paulo, São Paulo, 2001.

LEVY, S. M. Reciclagem do entulho de construção civil, para utilização como agregado de argamassas e concretos. 1997. 146f. Dissertação (Mestrado) - Escola Politécnica, Universidade de São Paulo, São Carlos, 1997. 
LEVY, S. M.; HELENE, P. R. L. Evolução histórica da utilização do concreto como material de construção. Boletim Técnico da Escola Politécnica da Universidade de São Paulo. São Paulo: Universidade de São Paulo, 2002. (BT/PCC/318).

LIBORIO, J. Notas de aula da disciplina de materiais da construção civil. Escola de Engenharia de São Carlos, USP, 2003.

LOTURCO, B. A nova lei do lixo. Revista Téchne, São Paulo, n. 82, p. 52-55, jan. 2004.

MAIA, M. J.; SILVEIRA, J. P.; CHERIAF, M.; ROCHA, J. C. Dosagem de blocos prémoldados com substituição parcial do cimento e substituição parcial ou total da areia fina por cinza pesada. In: ENCONTRO NACIONAL DE TECNOLOGIA DO AMBIENTE CONSTRUÍDO, 9., 2002, Foz do Iguaçu. Anais... Paraná: ANTAC, 2002. CD-ROM.

MANUAL POLI-ENCOL. Manual do processo construtivo: blocos e pré-moldados. São Paulo: EPUSP/ENCOL, 1991. (Relatório técnico R5-26/91).

MARCIANO JR, E. Resíduos da construção civil. Wabe International. 2000. Disponível em: <http://www2.ciesp.org.br/bolsa>. Acesso em: 10 jun. 2004.

MARZAHN, G. A. Extended investigation of mechanical properties of masonry units. In: NORTH AMERICAN MASONRY CONFERENCE, 9., 2003, South Carolina. Proceedings... Estados Unidos, 2003, p. 813-824.

MATTOS, G.; WAGNER, L. Consumption of Materials in the United States 1900-1995. US Geological Survey, 1999.

MEDEIROS, J. S. Alvenaria estrutural não armada de blocos de concreto: produção de componentes e parâmetros de projeto. São Paulo. 1993. 449f. Dissertação (Mestrado)Escola Politécnica, Universidade de São Paulo, São Paulo, 1993.

MEHTA, P. K. Greening of the concrete industry for sustainable development. Concrete International, p. 23-27, jul. 2002.

MEHTA, P. K.; MONTEIRO, P. J. M. Concreto: estrutura, propriedades e materiais. São Paulo: Pini, 1994.

MOHAMAD, G. Comportamento mecânico na ruptura de prismas de alvenaria de blocos de concreto. 1998. Dissertação (Mestrado). Universidade Federal de Santa Catarina, Florianópolis, 1998.

MOHAMAD, G.; ROMAN, H. R.; SEGAVE, A. M. Comportamento mecânico na rupture de prismas de blocos de concreto. In: INTERNATIONAL SEMINAR ON STRUCTURAL MASONRY FOR DEVELOPING COUNTRIES, 7., 2002, Belo Horizonte. Proceedings... Minas Gerais. p. 119-124.

MÜLLER, A. Closed loop of concrete rubble? In: SEMINÁRIO DE DESENVOLVIMENTO SUSTENTÁVEL E A RECICLAGEM NA CONSTRUÇÃO CIVIL, 7., 2006, São Paulo. Anais... São Paulo: Comitê Técnico CT-206 Meio Ambiente (IBRACON), 2006, CDROM. (palestra apresentada durante o evento).

NASCIMENTO, A. A.; ASSIS, C. S.; NETO, C. S.; MARCIANO JR, E.; DA SILVA, K.; D'AGOSTINO, L. Z.; SOARES, L.; OLIVEIRA, M. E.; LEVY, S. M.; ZAMATARO, R. Comitê técnico do "meio ambiente": 8 anos de vitórias e contribuições à sustentabilidade da construção civil. Revista Concreto. ano XXXIII, n. 37, p. 10-15, dez. - fev. 2005. 
NEPOMUCENO, A. A. Mecanismo de transporte de fluidos no concreto. In: ISAIA, G. C. Concreto: Ensino, Pesquisas e Realizações. São Paulo: IBRACON, 2005, v. 2, cap. 26 , p. $723-828$.

NEVILLE, A.M. Propriedades do Concreto. 2 ed. São Paulo: Pini, 1997, 828p.

NOGUCHI, T.; TAMURA, M. Concrete design towards complete recycling. Structural Concrete, v. 2, n. 3, p. 155-167, set. 2001.

OBRA LIMPA. Boletim obra limpa - informativo digital. fev. 2005. Disponível em: $\leq$ http://www.obralimpa.com.br>. Acesso em: 10 mar. 2005.

OIKONOMOU, N. D. Recycled concrete aggregates. Cement and Concrete Composites, v. 27, n. 2, p. 315 -318, Jan. 2005.

OKAWA, Y.; YAMAMIYA, H., NISHIBAYASHI, S. Study on the reuse of returned concrete. Magazine of Concrete Research, v. 52, n. 2, p. 109-115, apr. 2000.

OLIVEIRA, M. E.; ASSIS, C. S. Resíduo de concreto: uma contribuição para a revisão da norma NBR 10004. In: CONGRESSO BRASILEIRO DO CONCRETO, 43., 2002, Foz do Iguaçu. Anais... Paraná: IBRACON, 2002. CD-ROM.

OLIVEIRA, M. J. Materiais descartados pelas obras de construção civil: estudo dos resíduos de concreto para reciclagem. 2002. 191f. Tese (Doutorado) - Instituto de Geociências e Ciências Exatas, Universidade Estadual Paulista, Rio Claro, 2002.

OLIVEIRA, M. J.; ASSIS, C. S.; DE MATTOS, J. T. Recycled aggregate standardization in brazil. In: INTERNATIONAL RILEM CONFERENCE ON THE USE OF RECYCLED MATERIALS IN BUILDINGS AND STRUCTURES, 2004, Barcelona. Proceedings... França: Elsevier publications, 2004.

ORGANISATION FOR ECONOMIC CO-OPERATION AND DEVELOPMENT. Recycling strategies for road work. France: Road Transport Research, 1997, 108p.

PADMINI, A. K.; RAMAMURTHY, K.; MATHEWS, M. S. Relative moisture movement through recycled aggregate concrete. Magazine of Concrete Research, v. 54, n. 5, out. 2002.

PARK, S. G. Recycled concrete construction rubble as aggregate for new concrete. New Zealand: Building Research Association of New Zealand, 1999. 16 p. (Study Report No. 86).

PATTO, A. L.; OLIVEIRA, M. J. E. Produção de blocos de concreto com agregado reciclado e minimização de impactos ambientais. In: SEMINÁRIO DE DESENVOLVIMENTO SUSTENTÁVEL E A RECICLAGEM NA CONSTRUÇÃO CIVIL, 7., 2006, São Paulo. Anais... São Paulo: Comitê Técnico CT-206 Meio Ambiente (IBRACON), 2006. CDROM.

PETKOVIC, G.; ENGELSEN, C. J.; HÄØYA, A.; BREEDVELD, G. Environmental impact from the use of recycled materials in road construction: method for decision-making in Norway. Resources Conservation \& Recycling, v. 42, n. 3, p. 249-264, out. 2004.

PIMIENTA, P.; DELMOTTE, P., TRAN, T.; COLOMBARD-PROUT, M. Recycled aggregate used for making building blocks. In: INTERNATIONAL SYMPOSIUM: "SUSTAINABLE CONSTRUCTION: USE OF RECYCLED CONCRETE AGGREGATE”, 1998, Londres. Proceedings... Grã Bretanha: Thomas Telford, 1998, p. 297-307. 
PINTO, T. P. A nova legislação para resíduos de construção. Revista Téchne, São Paulo, n. 82, p. 62-64, jan. 2004.

PINTO, T. P. Metodologia para a gestão diferenciada de resíduos sólidos da construção urbana. 1999. Tese (doutorado) - Escola Politécnica, Universidade de São Paulo, São Paulo, 1999.

PINTO, T. P. Resultados da gestão diferenciada. Revista Téchne, São Paulo, n. 31, p. 3134, nov. - dez. 1997.

POLLET, V.; LOUTZ, S.; FONTAINE, R.; GHODSI, A. Recycled aggregates: alternative resources for the construction industry. In: INTERNATIONAL CONFERENCE BUILDINGS AND THE ENVIRONMENT, 1997, Paris. Proceedings... França, 1997, p. 635-642.

POON, C. S.; KOU, S. C.; CHAN, D. Influence of steam curing on hardened properties of recycled aggregate concrete. Magazine of Concrete Research, v. 58, n. 5, p. 289-299, jun. 2006.

POON, C. S.; KOU, S. C.; LAM, L. Use of recycled aggregates in moulded concrete bricks and blocks. Construction and Building Materials, v. 16, n. 5, p. 281-289, july. 2002.

POON, C. S.; SHUI, Z. H.; LAM, L. Effect of microstructure of ITZ on compressive strength of concrete prepared with recycled aggregates. Construction and Building Materials, $\mathrm{n}$. 18, p. 461-468, 2004a.

POON, C. S.; SHUI, Z. H.; LAM, L.; FOK, H.; KOU, S. C. Influence of moisture states of natural and recycled aggregates on the slump and compressive strength of concrete. Cement and Concrete Research, v. 34, p. 31-36, 2004b.

PORTLAND CEMENT ASSOCIATION. Recycled aggregates. 2005. Disponível em: <http://www.cement.org/tech/cct aggregates recycled.asp>. Acesso em: 10 maio 2005.

PRADO, D. M. Propriedades físicas e mecânicas de blocos estruturais produzidos com agregados reciclados de concreto. 2006. 130f. Dissertação (Mestrado) - Escola de Engenharia de São Carlos, Universidade de São Paulo, 2006.

PRADO, D. M.; BUTtLeR, A. M.; RAMALHO, M. A.; CORREA, M. R. S. Avaliação da absorção de agregados reciclados de concreto. In: SEMINÁRIO DE DESENVOLVIMENTO SUSTENTÁVEL E A RECICLAGEM NA CONSTRUÇÃO CIVIL, 2006, São Paulo. Anais... São Paulo: Comitê Técnico CT-206 Meio Ambiente (IBRACON), 2006, CD-ROM.

PRUDÊNCIO JÚNIOR, L. R. Métodos estatísticos. Universidade Federal de Santa Catarina, Núcleo de Pesquisa em Construção, Florianópolis, 1999. (Notas de aula).

RACIONAL ENGENHARIA. Projeto reciclar é construir um futuro melhor. São Paulo, 2003. (Relatório técnico, DCO-009/24).

RAMALHO, M. A.; CORRÊA, M. R. S. Projeto de edifícios de alvenaria estrutural. São Paulo: Editora Pini, $1^{a}$ edição, 2003. 188p.

RAVINDRARAJAH, R. S.; LOO, Y. H.; TAM, T.C. Recycled concrete as fine and coarse aggregates in concrete. Magazine of Concrete Research, v. 39, n. 141, p. 214-220, dez. 1987. 
REZENDE, L. Reciclagem de concreto residual em centrais dosadoras. 2000. Disponível em: <http://www.abesc.org.br/meio/reciclagem concreto.htm>. Acesso em: $10 \mathrm{mar}$. 2002.

RILEM RECOMMENDATION. Specifications for concrete with recycled aggregates. Materials and Structures, v. 27, p. 557-559, 1994.

RODRIGUES, P. P. F. Fabricação de blocos pré-moldadas de concreto para pavimentação: prática recomendada. São Paulo: Associação Brasileira de Cimento Portland, 1995, 8p. (Boletim Técnico 103).

ROMAGNA, R. H. Resistência à compressão de prismas de blocos de concreto grauteados e não grauteados. 2000. 193f. Dissertação (Mestrado). Universidade Federal de Santa Catarina, Florianópolis, 2000.

RUIVO, J.; VEIGA, J. Resíduos de construção e demolição: estratégia para um modelo de gestão. Revista Internacional Construlink, v. 2, n.7, nov. 2004.

RYU, J. S. An experimental study on the effect of recycled aggregate on concrete properties. Magazine of Concrete Research, v. 54, n. 1, p. 7-12, fev. 2002.

SABBATINI, F.H. O processo construtivo de edifícios de alvenaria estrutural sílicocalcária. 1984. 298 f. Dissertação (Mestrado) - Escola Politécnica, Universidade de São Paulo, São Paulo, 1984.

SAGOE-CRENTSIL, K. K.; BROWN, T.; TAYLOR, A. H. Perfomance of concrete made with comercially produced coarse recycled concrete aggregate. Cement and Concrete Research, v. 31, n. 5, p. 707-712, 1998.

SAHLIN, S. Structural masonry. New Jersey: Prentice Hall, 1971.

SANTOS, J. R.; BRANCO, I.; DE BRITO, J. Mechanical properties of concrete with coarse recycled aggregates. Structural Engineering International, v. 3, p. 213-215, 2004.

SCHNEIDER, D. M. Deposições irregulares de resíduos da construção civil na cidade de São Paulo. 2003. 103 f. Dissertação (Mestrado) - Faculdade de Saúde Pública, Universidade de São Paulo, São Paulo, 2003.

SCHULTMANN, F.; RENTZ, O. The state of deconstruction in Germany. In: KIBERT, C. J.; $\mathrm{CHINI}, \mathrm{A}$. R. Overview of deconstruction in selected countries. Florida: CIB International Council for Research and Innovation in Building Construction, 2000. cap. 3, p. 45-74. Disponível em: <http://s14.cfaa.ufl.edu/centers/sustainable/>. Acesso em: 15 nov. 2001.

SEALEY, B. J.; PHILLIPS, P. S.; HILL, G. J. Waste management issues for the UK readymixed concrete industry. Resources, Conservation and Recycling, v. 31, p. 321-331, 2001.

SILVA, I. J. Contribuição ao estudo dos concretos de elevado desempenho: propriedades mecânicas, durabilidade e microestrutura. 2000, 279f. Tese (Doutorado) - Ciência e Engenharia de Materiais, Universidade de São Paulo, São Paulo, 2000.

SILVEIRA, J. P.; ROCHA, J. C.; CHERIAF, M. Desenvolvimento de blocos de concreto com uso das cinzas de termelétricas. In: ENCONTRO NACIONAL DE TECNOLOGIA DO 
AMBIENTE CONSTRUÍDO, 10., 2004, São Paulo. Anais... São Paulo: ANTAC, 2004. CD-ROM.

SOLÓRZANO, M. G. P. Características e desempenho de juntas de argamassa na alvenaria estrutural de blocos de concreto. 1994. Dissertação (Mestrado) - Escola Politécnica, Universidade de São Paulo, São Paulo, 1994.

SOROUSHIAN, P.; TAVAKOLI, M. Strengths of recycled aggregate concrete made using fiel-demolished concrete as aggregate. Journal of American Concrete Institute Proceedings, v. 93, n. 2, p. 182-190, 1996.

SOUTSOS, M. N.; JONES, N.; MILLARD, S. G.; BUNGEY, J. H.; TICKELL, R. G.; GRADWELL, J. Precast concrete building blocks made with aggregates derived from construction and demolition waste. In: INTERNATIONAL RILEM CONFERENCE ON THE USE OF RECYCLED MATERIALS IN BUILDINGS AND STRUCTURES, 2004, Barcelona. Proceedings... França: Elsevier publications, 2004.

SOUZA, J. G. G. Contribuição ao estudo da relação entre propriedades e proporcionamento de blocos de concreto - aplicação ao uso de entulho como agregado reciclado. 2001. 142f. Dissertação (Mestrado) - Departamento de Engenharia Civil e Ambiental, Universidade de Brasília, Brasília, 2001.

SOUZA, J. G.; BAUER, E.; SPOSTO, R. M. (2002). Blocos de concreto produzidos com agregados provenientes da reciclagem de resíduos gerados pela construção civil. In: ENCONTRO NACIONAL DE TECNOLOGIA DO AMBIENTE CONSTRUÍDO, 9., 2002, Foz do Iguaçu. Anais... Paraná: ANTAC, 2002. CD-ROM.

TAHA, M. M. R.; EL-DIEB, A. S.; SHRIVE, N. G.. Sorptivity: a surface absorption criterion for brick units: a proposal for the Canadian Masonry Standard. In: CANADIAN MASONRY SYMPOSIUM, 9., 2001, Fredericton, New Brunswick. Proceedings... Canada, 2001.

TAM, V. W. Y.; GAO, X. F.; TAM, C. M. Microstructural analysis of recycled aggregate concrete produced from two-Stage mixing approach. Cement and Concrete Research, n. 35, p. 1195-1203, 2005.

TANGO, C. E. Fundamentos de dosagem de concreto para blocos estruturais. In: INTERNATIONAL SEMINAR ON STRUCTURAL MASONRY FOR DEVELOPING COUNTRIES, 5., 1994, Florianópolis. Anais... Santa Catarina, 1994.

TAUS, V. L.; DI MAIO, A. A.; TRAVERSA, L. P. Sorptivity: parameter for the evaluation of cover concrete quality. In: INTERNATIONAL CONFERENCE ON QUALITY OF CONCRETE STRUCTURES AND RECENT ADVANCES IN CONCRETE MATERIALS AND TESTING, 4., Olinda. Proceedings... Recife: American Concrete Institute (SP229), 2005, p. 121-134.

TAVAKOLI, M.; SOROUSHIAN, P. Strengths of recycled aggregate concrete made using field-demolished concrete as aggregate. ACI Materials Journal, v. 93, n. 2, p. 182-190, 1996.

TERANISHI, K.; DOSHO, Y.; NARIKAWA, M.; KIKUSHI, M. Application of recycled aggregate concrete for structural concrete. part 3 - production of recycled aggregate by real-scale plant and quality of recycled concrete aggregate. In: INTERNATIONAL SYMPOSIUM: "SUSTAINABLE CONSTRUCTION: USE OF RECYCLED CONCRETE AGGREGATE", 1998, Londres. Proceedings... Grã Bretanha: Thomas Telford, 1998, p. 69-82. 
THOMAZ, E. Trincas em edifícios: causas, prevenção e recuperação. São Paulo: Pini, 1989.

TOPÇU, I. B. Pysical and mechanical properties of concretes produced with waste concrete. Cement and Concrete Research, v. 27, n. 12, p. 1817-1823, 1997.

TOPÇU, I. B.; GUNÇAN, N. F. Using Waste Concrete as Aggregate. Cement and Concrete Research, v. 25, n. 7, p. 1385-1390, 1995.

TOTOEV, Y. Z.; JAMES, M. A. Development of the Water Absorption from Fresh Mortar Test. In: INTERNATIONAL BRICK AND BLOCK MASONRY CONFERENCE, 13., 2004, Amesterdam. Proceedings... Holanda, 2004.

URBEM. Urbem tecnologia ambiental. In: SEMINÁRIO DE DESENVOLVIMENTO SUSTENTÁVEL E A RECICLAGEM NA CONSTRUÇÃO CIVIL, 7., 2006, São Paulo. Anais... São Paulo: Comitê Técnico CT-206 Meio Ambiente (IBRACON), 2006, CDROM. (palestra apresentada durante o evento).

VALVERDE, F. M. Agregados para construção civil. 2003. Disponível em: <http://www.dnpm.gov.br/suma2002/>. Acesso em: 20 mar. 2004.

VAN ACKER, A. Recycling of concrete at a precast concrete plant. BIBM, Paris, p. 55-67, 1996.

VAN DIJK, K.; BOEDIANTO, P.; TE DORSTHORST, B.; KOWALCZYK, A. State of the art deconstruction in the Netherlands. In: KIBERT, C. J.; CHINI, A. R. Overview of deconstruction in selected countries. Florida: CIB - International Council for Research and Innovation in Building Construction, 2000. cap. 6, p. 95-143. Disponível em: <http://s14.cfaa.ufl.edu/centers/sustainable/>. Acesso em: 15 nov. 2001.

VAN LOO, W. Closing the concrete loop - from reuse to recycling. In: INTERNATIONAL SYMPOSIUM: "SUSTAINABLE CONSTRUCTION: USE OF RECYCLED CONCRETE AGGREGATE", 1998, Londres. Proceedings... Grã Bretanha: Thomas Telford, 1998, p. 82-98.

VAZQUEZ, E. Personalidade entrevistada. Revista Concreto, ano XXXIII, n. 37, p. 6-7, dez. - fev. 2005.

VAZQUEZ, E.; BARRA, M. Hormigón de áridos reciclados: retracción. In: SEMINÁRIO DE DESENVOLVIMENTO SUSTENTÁVEL E A RECICLAGEM NA CONSTRUÇÃO CIVIL, 5., 2002, São Paulo. Anais... São Paulo: Comitê Técnico CT-206 Meio Ambiente (IBRACON), 2002, CD-ROM.

VILATÓ, R. R.; FRANCO, L. S. As juntas de movimentação na alvenaria estrutural. Boletim Técnico da Escola Politécnica da Universidade de São Paulo. São Paulo: Universidade de São Paulo, 1998. (BT/PCC/227).

VIVEIROS, M. 81\% do entulho de SP é jogado em local irregular. Folha de São Paulo, São Paulo, Caderno Cotidiano. 2004. Disponível em: <http://www.folha.com.br>. Acesso em: 10 nov. 2004.

WARMER BULLETIN. Uma tonelada e meia de bifenila policlorada (PCB) nos resíduos de concreto da Noruega. 2001. Disponível em: <http://www.resol.com.br/curiosidades2.asp?id=963>. Acesso em: 10 dez. 2006. 
WINSTON, S. Denver's old stapleton airport gives its all for aggregates. ENR. New York, v. 246, p. 21, jan. 2001.

WORKS BUREAU TECHNICAL IRCULAR (2002). Specifications facilitating the use of recycled aggregates. Disponível em: <http://www.wb.gov.hk/circular/data/2002/wb1202.doc>. Acesso em: 15 abr. 2002. 


\section{APÊNDICES}




\section{APÊNDICE A - EQUIPAMENTOS UTILIZADOS NO ENSAIO DE GRANULOMETRIA}

Agitador mecânico de peneiras da marca Produtest com controle de vibração e temporizador (Figura 1), balança da marca Metter Toledo, modelo SB 24001 Delta Range com precisão de $0,1 \mathrm{~g}$ e capacidade de $24000 \mathrm{~g}$ (Figura 1), escovas com cerdas de náilon e peneiras da série normal e intermediária.

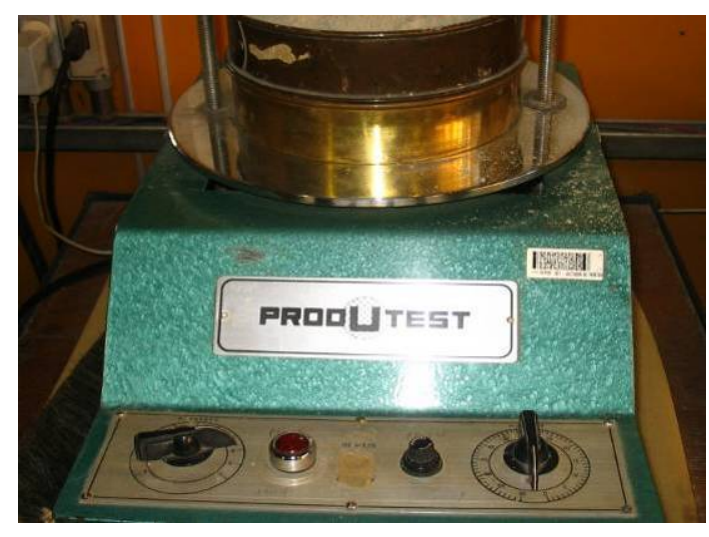

a) agitador mecânico de peneiras

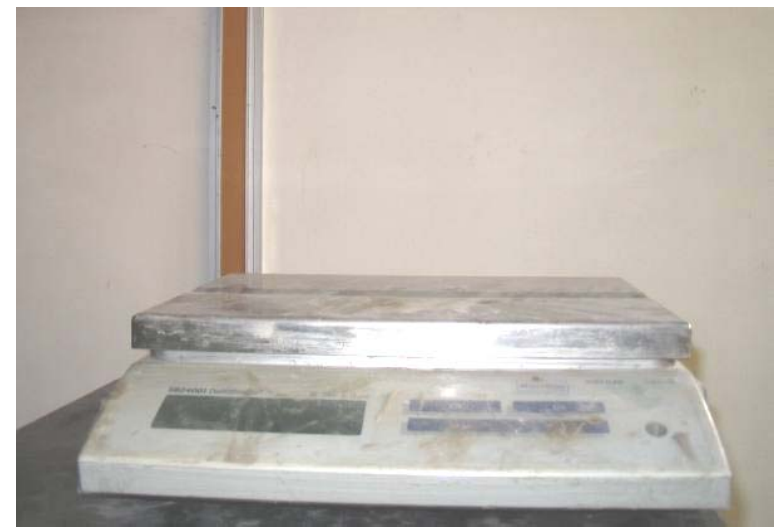

b) balança com precisão de $0,1 \mathrm{~g}$

Figura 1 - Equipamentos utilizados no ensaio de granulometria.

\section{APÊNDICE B - ENSAIO DE ABSORÇÃO (MÉTODO DE DIAS E AGOPYAN, 2004)}

Seguindo as recomendações de Dias e Agopyan (2004), as amostras de agregados miúdos e graúdos, próximas a $1000 \mathrm{~g}$, foram imersas em água à temperatura ambiente até a saturação (mínimo de $24 \mathrm{~h}$ ). A secagem foi realizada em estufa a $105^{\circ} \mathrm{C}$, com balança digital adaptada, sobre prato (prato padrão da ABNT), que segundo os pesquisadores, permitiu uma melhor definição dos períodos de secagem. Os valores das massas úmidas foram determinados a cada quatro minutos até o final do ensaio. Na Figura 2 são mostrados alguns detalhes desse ensaio. 


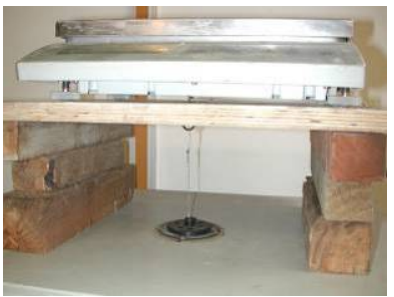

a) balança adaptada

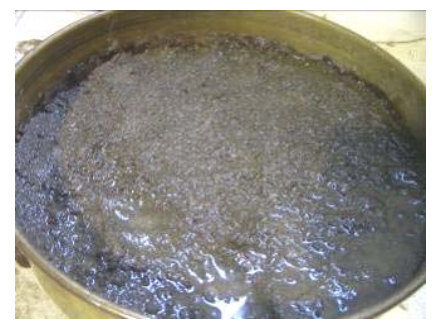

d) material miúdo sobre o prato

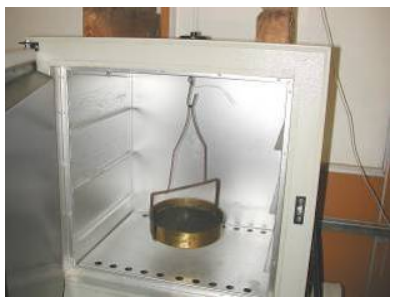

b) prato com amostra no interior da estufa

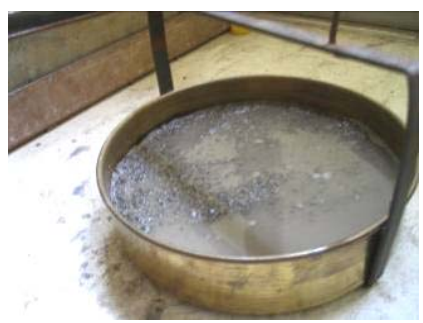

e) formação de um filme d'água na superfície do material

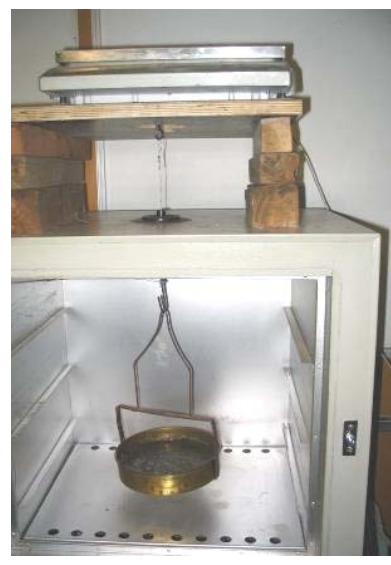

c) aparato de ensaio

Figura 2 - Detalhe dos procedimentos adotados para secagem dos agregados.

\section{APÊNDICE C - ENSAIO DE ABRASÃO LOS ANGELES}

Neste ensaio, os materiais foram colocados na máquina "Los Angeles", conjuntamente com oito bolas de aço sendo submetidos a 500 rotações, conforme NBR 6465 (1984), Figura 3. A rolagem e as quedas sucessivas do agregado e das esferas resultam em ações de abrasão e atrito sobre o agregado.
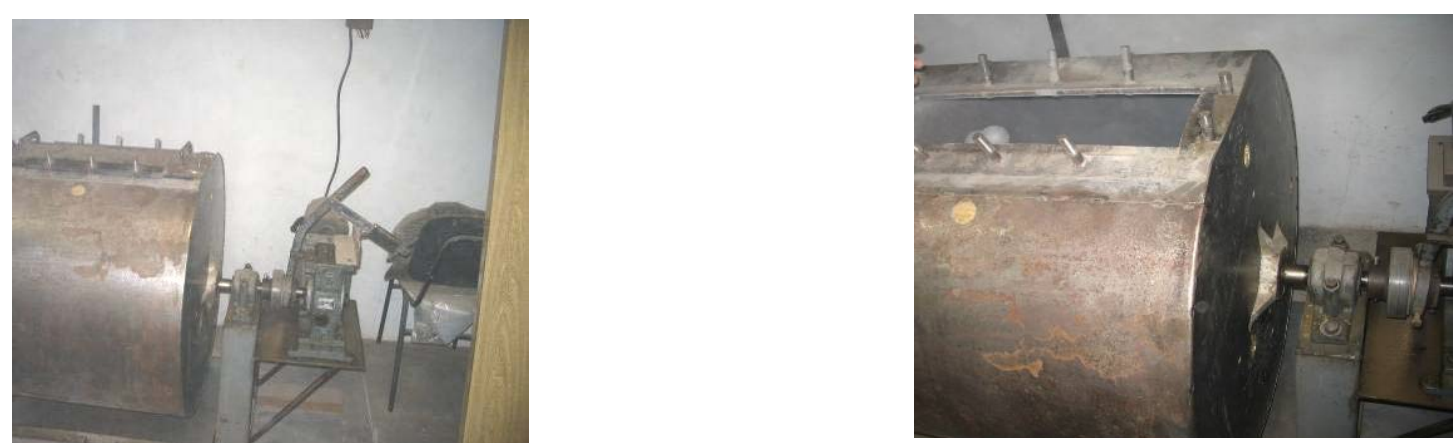

Figura 3 - Ensaio de Abrasão Los Angeles.

O ensaio de Abrasão foi realizado no Departamento de Transportes da Escola de Engenharia de São Carlos 


\section{APÊNDICE D - ENSAIO PARA DETERMINAÇÃO DA QUANTIDADE DE ARGAMASSA ADERIDA}

Visando quantificar a argamassa aderida ao agregado, foi utilizada uma solução de ácido clorídrico de concentração próxima a 10\%, conforme recomendações de Hansen (1985) e Basuco (1999). Para cada tipo de agregado, foram separadas duas amostras, secas em estufa, sendo então imersas na solução de ácido clorídrico, por pelo menos duas vezes, até a completa desagregação da argamassa presente nesses agregados. O período total de ensaio foi de aproximadamente 72 horas. Durante a execução do ensaio deve-se tomar o cuidado de proteger as mãos e os olhos com equipamentos de segurança individuais (EPIs).

Posteriormente, os agregados foram lavados em água corrente sob a peneira $1,20 \mathrm{~mm}$, para certificar-se da retirada total da argamassa aderida. O material foi colocado na estufa e determinada a massa seca final. Na Figura seguinte, podem ser observadas algumas das fases desse ensaio.

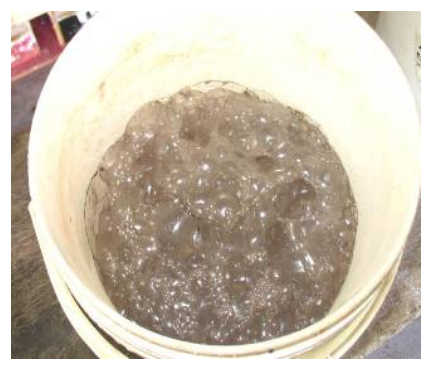

a) Contato inicial do material com o ácido

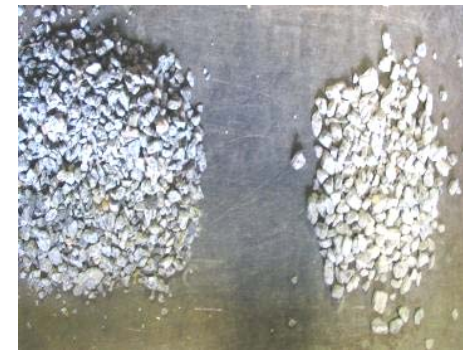

d) material após o ensaio $x$ material original

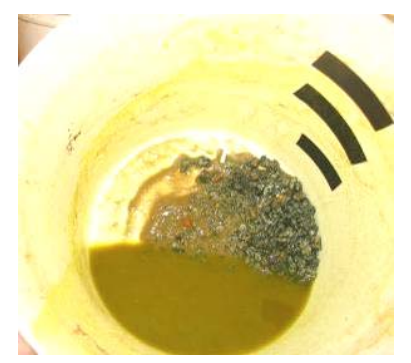

b) Material em contato com o ácido

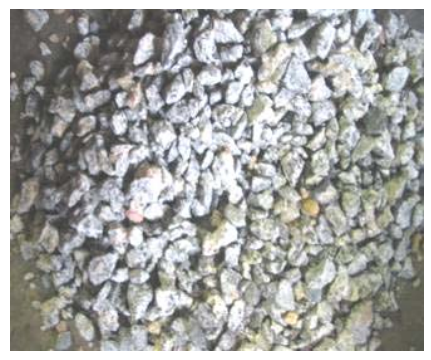

e) material retido na peneira $1,2 \mathrm{~mm}$, após o ensaio

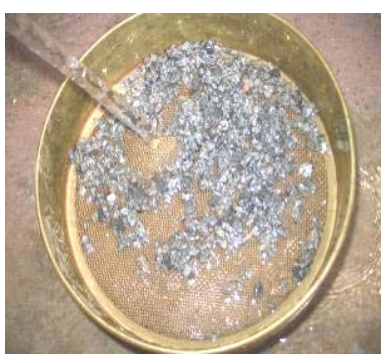

c) lavagem do material na peneira $1,20 \mathrm{~mm}$

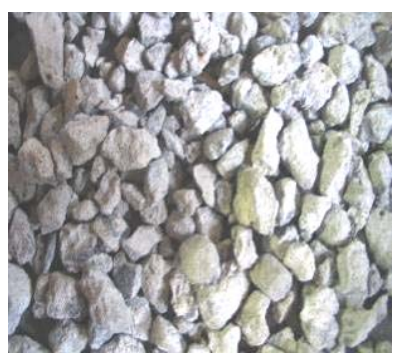

f) material de referência

Figura 4 - Etapas de execução do ensaio para mensurar a quantidade de argamassa aderida ao agregado reciclado. 


\section{APÊNDICE E - ENSAIO DO MÉTODO DO MENOR VOLUME DE VAZIOS}

Para a realização deste ensaio, foi utilizado um recipiente cilíndrico de capacidade de 3,00 litros e uma haste metálica de $16 \mathrm{~mm}$ de diâmetro e comprimento de $60 \mathrm{~cm}$, com uma das extremidades arredondadas. As principais etapas desse ensaio são descritas abaixo:

- Secagem prévia dos agregados (pedrisco, pó-de-pedra e areia).

- Produção de misturas homogeneizadas, contendo quantidades variáveis de dois componentes da mistura (Pó-de-pedra basalto e pedrisco) e mantendo-se igual a $20 \%$ a porcentagem de areia em todas as misturas.

- Lançamento das misturas no recipiente cilíndrico, em três camadas iguais, compactando cada uma com 25 golpes. Terminada a compactação da última camada e rasado o material excedente, pesa-se o recipiente cheio.

- O ensaio foi repetido por pelo menos duas vezes para cada uma das composições de agregados.

A expressão que fornece o volume de vazios para cada uma das composições é dada pela seguinte equação:

$$
V_{\text {vazios }}=\frac{\left[V_{\text {rec }}-\left(\frac{\%_{\text {areia }} \times M}{100 \times d_{\text {areia }}}+\frac{\%_{\text {pedrisco }} \times M}{100 \times d_{\text {pedrisco }}}+\frac{\%_{\text {pó-de-pedra }} \times M}{100 \times d_{\text {pó-de-pedra }}}\right)\right]}{V_{\text {rec }}} \times 100
$$

onde:

d - massa específica dos agregados; $M$ - massa da composição necessária; $V_{\text {rec }}$ - volume do recipiente; \% - proporção dos materiais na composição. Os valores de massa específica foram obtidos através do Método do Frasco de Chapman. 


\section{APÊNDICE F - FÔRMAS DESENVOLVIDAS PARA OS CORPOS-DE-PROVA}
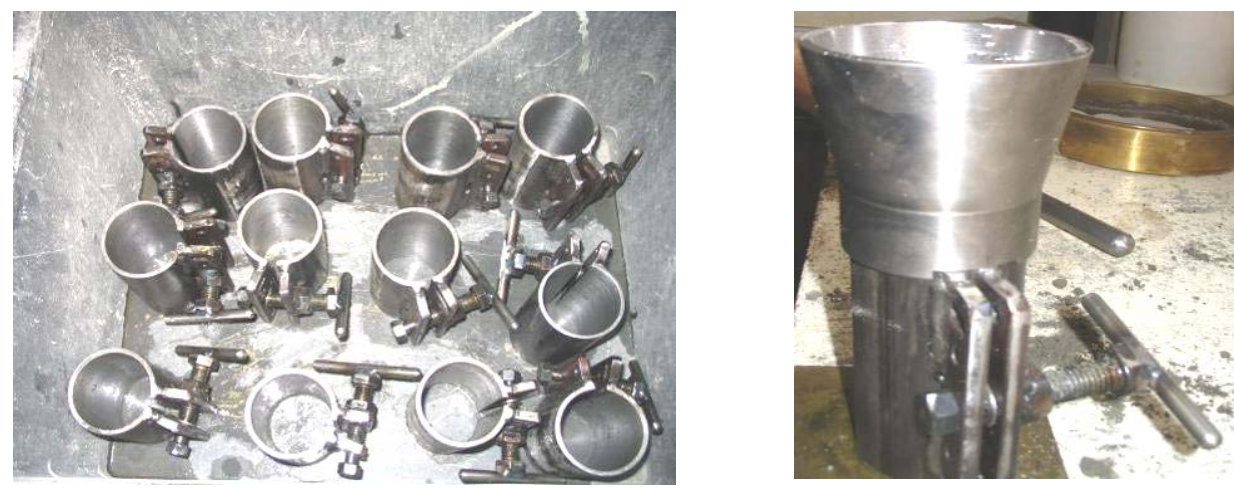

Figura 5 - Fôrmas metálicas para a produção dos CPs.
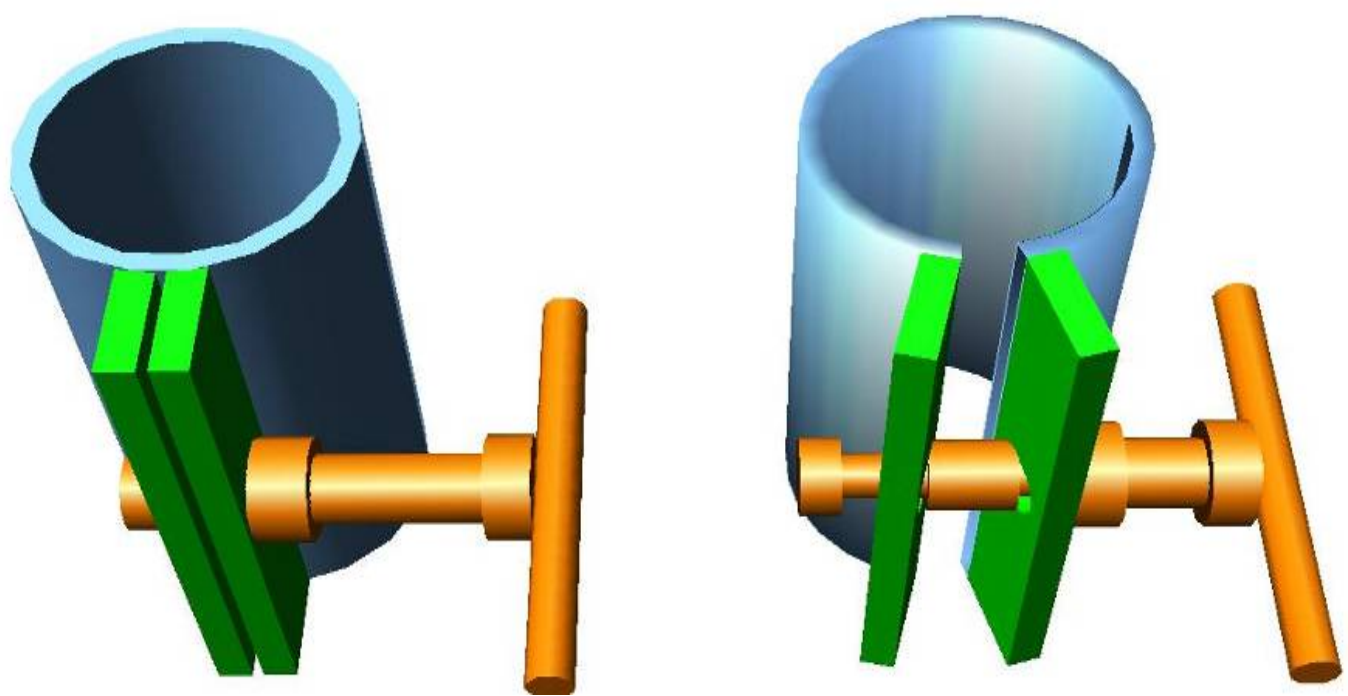

Figura 6 - Detalhe do funcionamento das fôrmas metálicas.

APÊNDICE G - EQUIPAMENTOS E DETALHES DOS ENSAIOS PARA AVALIAÇÃO DAS PROPRIEDADES FÍSICAS E MECÂNICAS DOS CORPOS-DE-PROVA

Nos ensaios de absorção de água, massa específica e índice de vazios (propriedades físicas dos corpos-de-prova) foram utilizados os seguintes equipamentos: Estufa da marca Quimis, balança com precisão de 0,1 g e capacidade de $24000 \mathrm{~g}$. Na figura 
7, são apresentados alguns detalhes destes ensaios bem como dos equipamentos utilizados.

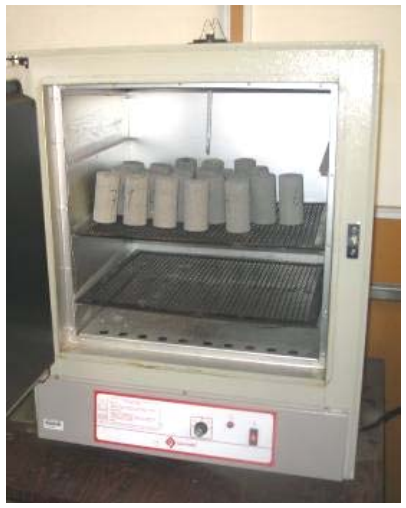

a) secagem dos CPs na estufa

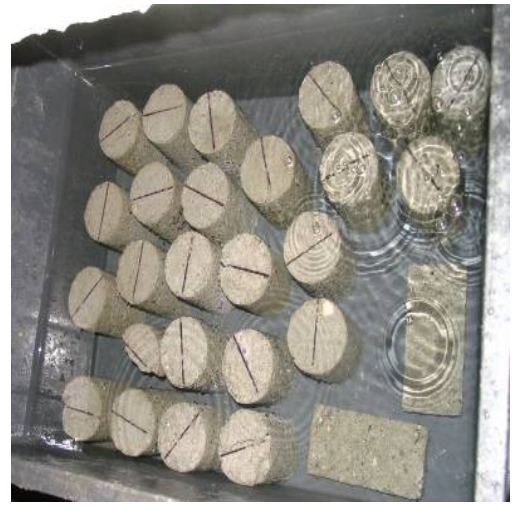

b) Imersão dos CPs na água

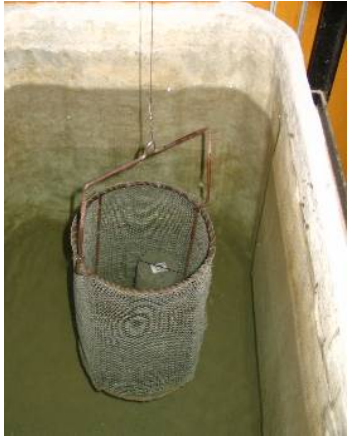

c) determinação da massa imersa na balança hidrostática

Figura 7 - Execução dos ensaios referentes às propriedades físicas dos CPs.

Para os ensaios de resistência à compressão e tração por compressão diametral foram utilizadas as máquinas hidráulicas Soiltest (para cargas de ruptura até $25 \mathrm{kN}$ ) e ELE Autotest (para cargas esperadas de ruptura superiores a $25 \mathrm{kN}$ ). A velocidade de carregamento imposta para os referidos ensaios foi de $0,25 \mathrm{kN} / \mathrm{s}$. Na figura 8, podem ser observados alguns detalhes dos ensaios.

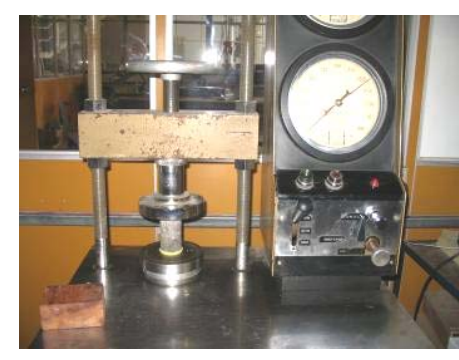

a) Ensaio de compressão na máquina Soiltest

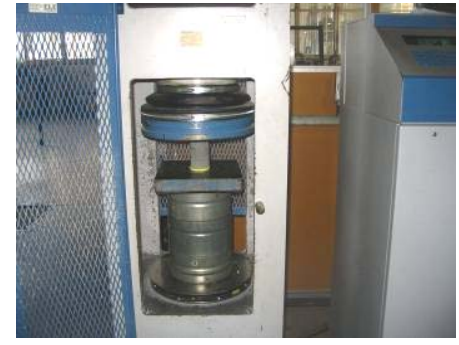

b) Ensaio de compressão na máquina ELE - Autotest

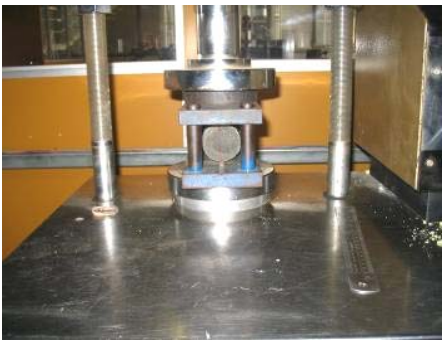

c) Ensaio de tração indireta na máquina Soiltest

Figura 8 - Ensaios de compressão axial e tração indireta dos corpos-de-prova.

Nos ensaios de módulo de deformação, o módulo foi dado pela inclinação da reta secante no diagrama tensão versus deformação, entre 5\% e 33\% da tensão de ruptura. Neste ensaio foi utilizada a máquina Soiltest devido aos baixos valores de carga e a maior precisão do equipamento para cargas menores do que $7 \mathrm{kN}$, figura 9 . As deformações foram medidas por extensômetros removíveis com base de $50 \mathrm{~mm}$. 

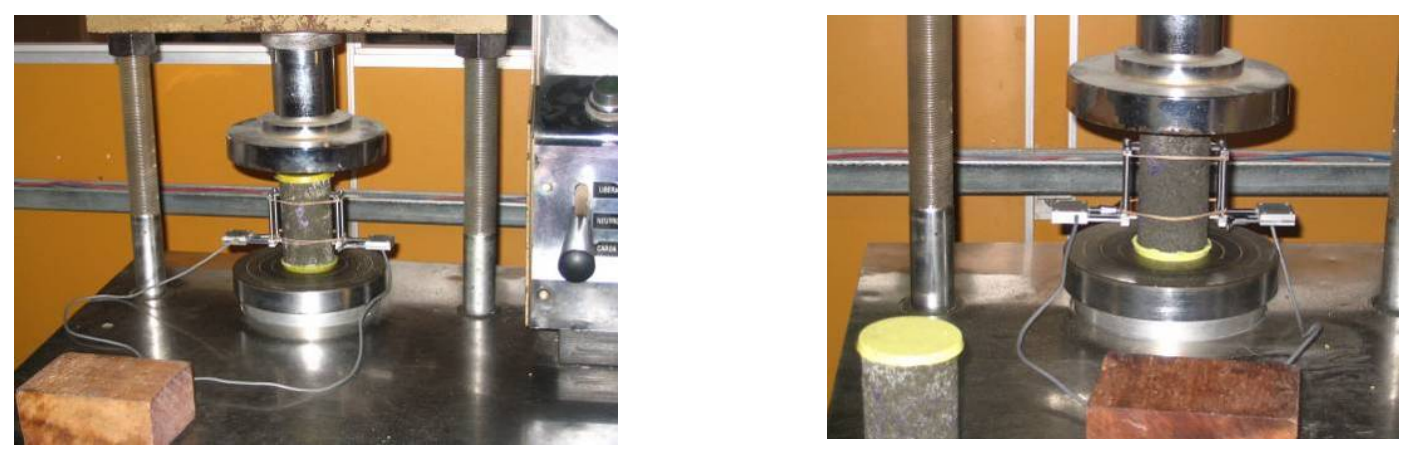

Figura 9 - Ensaio de módulo de deformação na máquina hidráulica Soiltest.

\section{APÊNDICE H - CORRELAÇÃO ENTRE CORPOS-DE-PROVA E BLOCOS}

Caso haja similaridade das propriedades físicas dos CPs e blocos, isto é, valores semelhantes para as propriedades de absorção de água e índice de vazios; pode-se dizer que a resistência do corpo-de-prova está situada entre $70 \%$ e $90 \%$ da resistência do bloco na área líquida. Para a conversão dos valores de resistência dos CPs cilíndricos para a resistência esperada dos blocos em área bruta pode-se utilizar a seguinte expressão:

$$
\mathrm{f}_{\mathrm{b}} \text { (área bruta) }=\left(\frac{\mathrm{f}_{\mathrm{CP}}}{\text { coef. correlação }}\right) \cdot\left(\frac{\text { Área líquida do bloco }}{\text { Área bruta do bloco }}\right)
$$

Onde:

$\mathrm{f}_{\mathrm{b}}$ (área bruta) - resistência à compressão esperada do bloco na área bruta

$f_{c p}$ - resistência à compressão dos corpos-de-prova obtida experimentalmente

coef. correlação - valor situado entre 0,70 e 0,90 caso haja similaridade nas propriedades físicas dos CPs e blocos

área líquida do bloco - área do bloco descontando os vazios

área bruta do bloco - área do bloco sem descontar os vazios 


\section{APÊNDICE I - ANÁLISE DIMENSIONAL}

Para a verificação das dimensões reais dos blocos foram utilizadas réguas metálicas com graduação de $1 \mathrm{~mm}$ e um paquímetro digital com precisão de 0,1 $\mathrm{mm}$ para a leitura das dimensões das paredes longitudinais e transversais. A Figura 10 apresenta alguns dos blocos verificados quanto à análise dimensional.
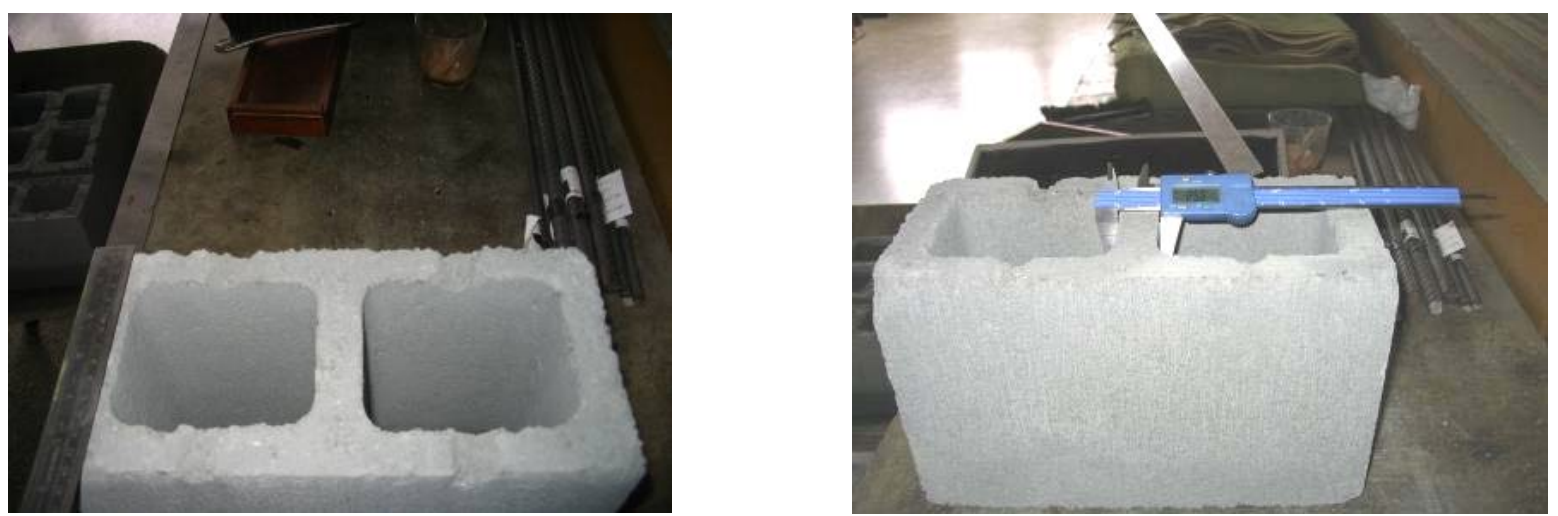

Figura 10 - Blocos verificados dimensionalmente.

Na Figura 11, é apresentado um croqui esquemático simbolizando as dimensões que foram verificadas nos blocos. A verificação das dimensões das paredes transversais e longitudinais foi realizada na base do bloco (seção de menor espessura).

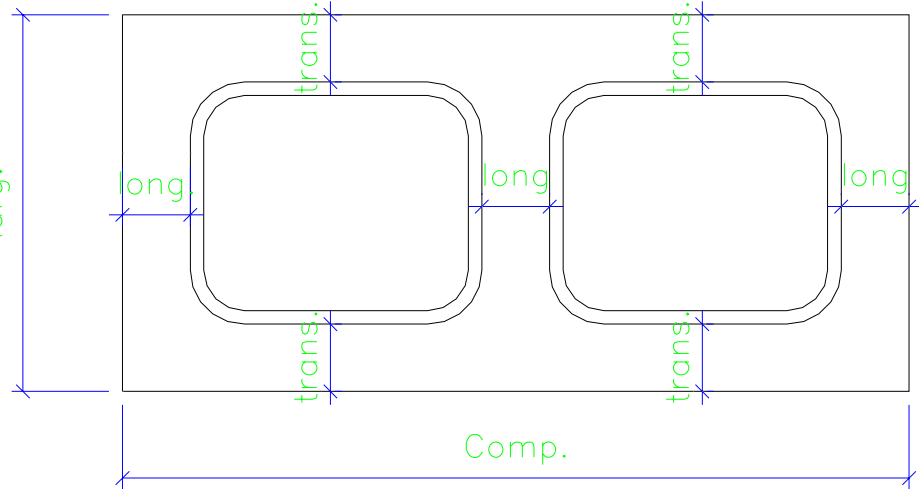

Figura 11 - Croqui esquemático simbolizando as dimensões que foram verificadas. 


\section{APÊNDICE J - ENSAIO DE ABSORÇÃO DE ÁGUA E ÁREA LÍQUIDA - BLOCOS DE CONCRETO}

Os equipamentos empregados nesse ensaio foram: Estufa da marca Quimis, modelo Q317 com precisão de $\pm 5^{\circ} \mathrm{C}$ e balança da marca Metter Toledo, modelo SB 24001 Delta Range com precisão de 0,1 g e capacidade de 24000 g. Na Figura 12, são apresentados alguns detalhes do ensaio bem como dos equipamentos empregados.

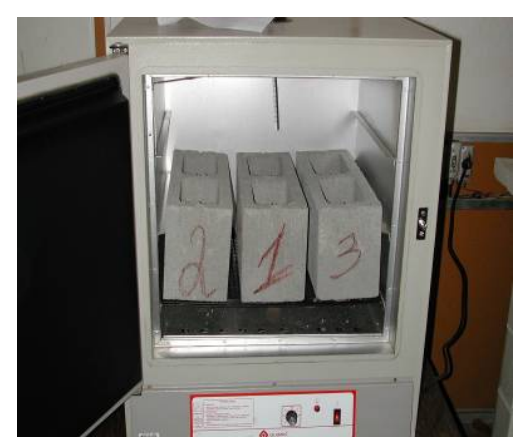

a) Secagem dos blocos na estufa até constância de massa

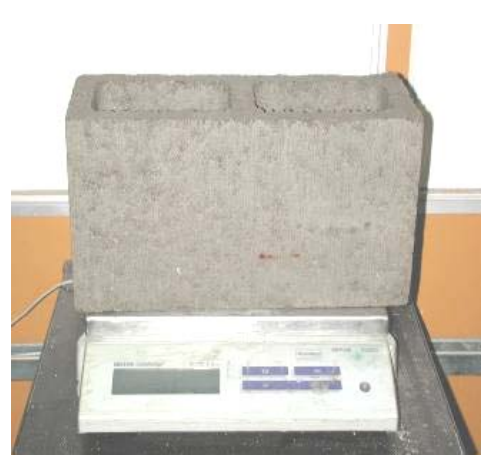

b) Pesagem dos blocos na balança

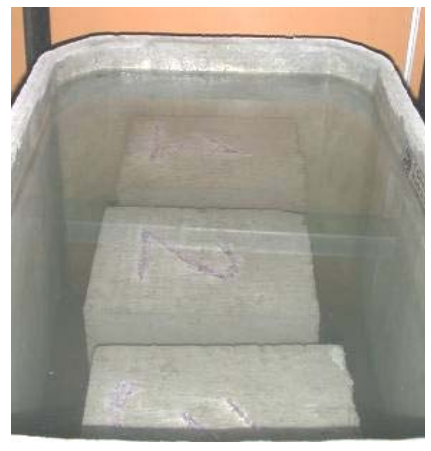

c) Imersão dos blocos na água por no mínimo 24 horas

Figura 12 - Etapas de execução dos ensaios (propriedades físicas).

\section{APÊNDICE K - ENSAIO DA TAXA DE ABSORÇÃO INICIAL (IRA)}

Os equipamentos utilizados no ensaio de IRA foram: estufa marca Quimis-Q317, nível de bolha para ajuste dos suportes, balança Metter Toledo, cronômetro com precisão de um segundo e bandeja plástica adaptada com dois suportes reguláveis de seção triangular. A metodologia está descrita nos próximos itens: $1^{0}$ - nivelamento da bandeja e dos suportes reguláveis com auxílio de um nível de bolha; $2^{\circ}$ - marcação e verificação do nível d'água com auxílio de uma placa de aço ; $3^{\circ}$ - determinação da massa do bloco seco; $4^{0}$ colocação do bloco (face inferior) sobre os dois suportes pelo período de um minuto; $5^{\circ}$ retirada do bloco e secagem da sua superfície com um pano; $6^{\circ}$ - determinação da massa do bloco; $7^{\circ}$ - complementação do nível d'água para suprir a sucção do bloco; $8^{\circ}$ disposição do bloco (face superior) sobre os dois suportes pelo período de um minuto e execução dos itens anteriores. A ordem de colocação do bloco (face inferior ou superior) não influenciou nos resultados. Na Figura 13 são mostrados esses detalhes bem como os equipamentos empregados. 


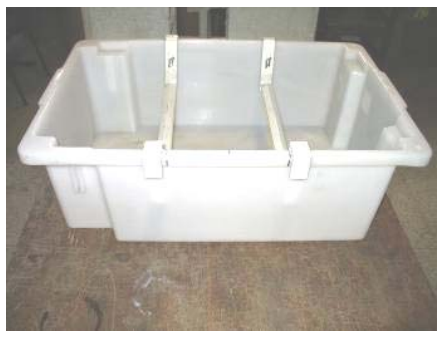

a) bandeja plástica

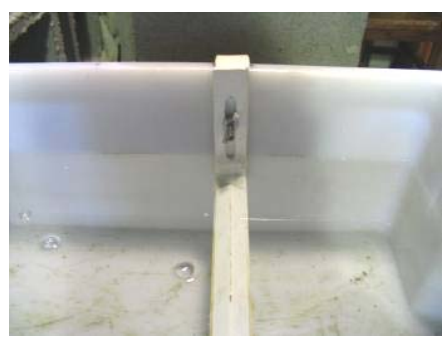

d) bandeja preenchida com água até o nível de $3,1860,25 \mathrm{~mm}$

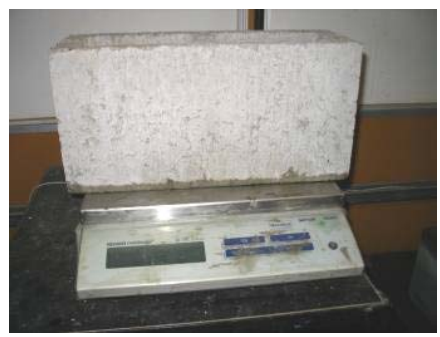

g) pesagem do bloco

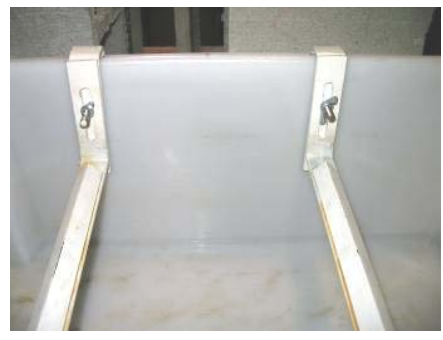

b) suportes reguláveis

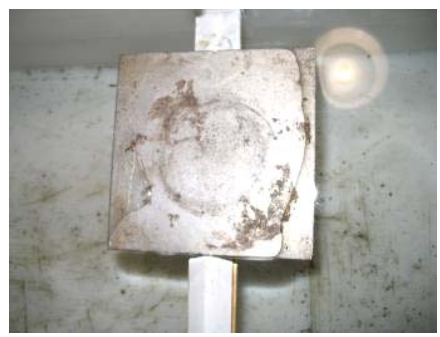

e) placa de aço colocada sobre o suporte para verificar o nível d'água

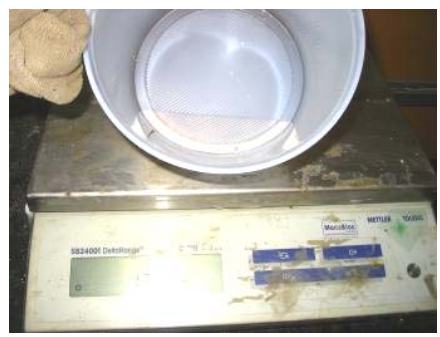

h) determinação da massa d'água para compensar a sucção do bloco

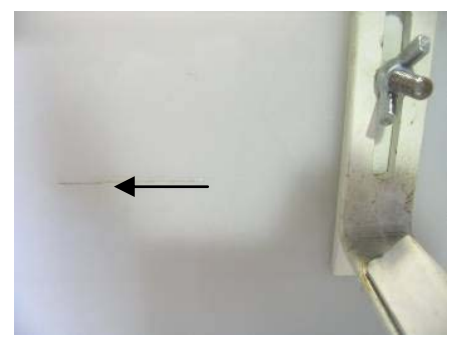

c) marcação do nível d'água

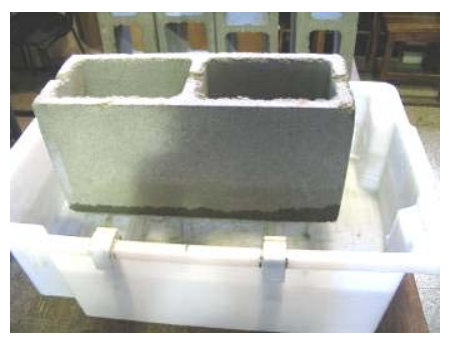

f) face inferior do bloco em contato com a água

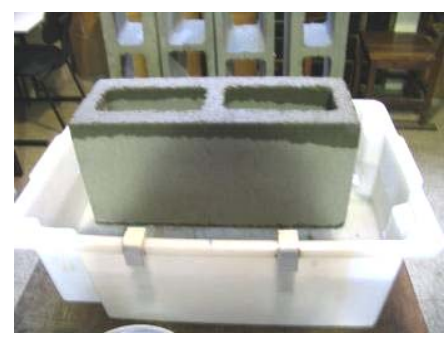

i) face superior do bloco em contato com a água

Figura 13 - Equipamentos e alguns detalhes do ensaio da taxa de absorção inicial de água (IRA).

\section{APÊNDICE I - ENSAIO DE ABSORÇÃO CAPILAR}

Os equipamentos e dispositivos utilizados no ensaio de absorção capilar foram: estufa marca Quimis-Q317, nível de bolha para ajuste dos suportes, balança Metter Toledo, cronômetro com precisão de um segundo, bandeja plástica adaptada com dois suportes reguláveis de seção triangular, resina acrílina impermeabilizante da marca Hydronorth e trincha. A metodologia está descrita nos próximos itens de acordo com sua execução: $1^{\mathrm{a}}$ disposição dos blocos na estufa $\left(t=60^{\circ} \mathrm{C}\right)$ por no mínimo $48 \mathrm{~h} ; 2^{\mathrm{a}}-$ disposição dos blocos na câmara climatizada por no mínimo três horas ( $T=25^{\circ} \mathrm{C}$ e $\left.U=50 \%\right) ; 3^{a}$ - aplicação da primeira demão de resina acrílica nas laterais das unidades; $4^{\mathrm{a}}$ - disposição dos blocos na câmara climatizada por no mínimo seis horas até a secagem da resina; $5^{a}$ - aplicação da segunda 
demão; $6^{\mathrm{a}}$ - disposição dos blocos na câmara climatizada por no mínimo doze horas; $7^{\mathrm{a}}$ pesagem dos blocos registrando-se a massa seca $\left(m_{s}\right) ; 8^{a}$ - nivelamento da bandeja e dos suportes reguláveis com auxílio de um nível de bolha; $9^{a}$ - marcação e verificação do nível d'água com auxílio de uma placa de aço ; $10^{\mathrm{a}}$ - colocação do bloco (face superior) sobre os dois suportes pelo período de um minuto; $11^{\mathrm{a}}$ - retirada do bloco e secagem da sua superfície com um pano; $12^{\mathrm{a}}$ - determinação da massa do bloco $\left(\mathrm{m}_{1}\right) ; 13^{\mathrm{a}}$ - disposição do bloco sobre os suportes, realizando-se a leitura periódica da massa (3', 5', 10', 15', 20', 25', 30', 40', 50', 60', 120', 180', 240', 300' e 360'), temperatura e umidade. Na Figura 14 são apresentados alguns detalhes bem como os dispositivos empregados.

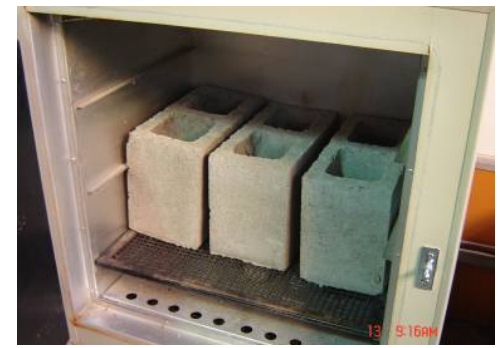

a) colocação das unidades na estufa $\left(\mathrm{T}=60^{\circ} \mathrm{C}\right.$ e $\left.\mathrm{t}=48 \mathrm{~h}\right)$

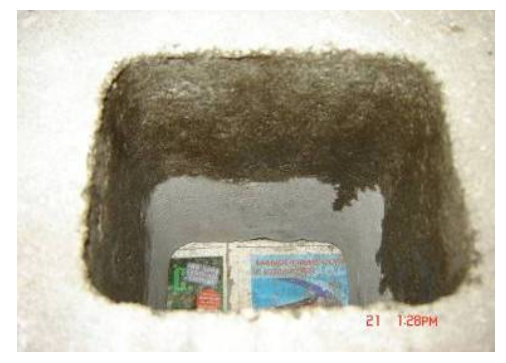

d) vista interna da parede do bloco impermeabilizada

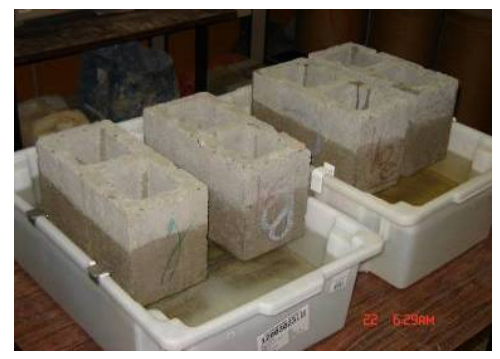

g) blocos colocados sobre o suporte

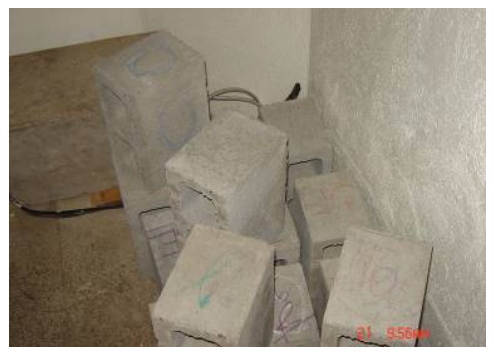

b) colocação das unidades na câmara climatizada $\left(\mathrm{T}=25^{\circ} \mathrm{C}\right.$ e $\left.\mathrm{U}=50 \%\right)$

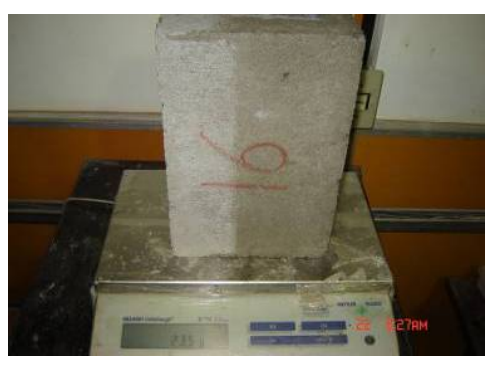

e) determinação da massa inicial $\left(m_{0}\right)$

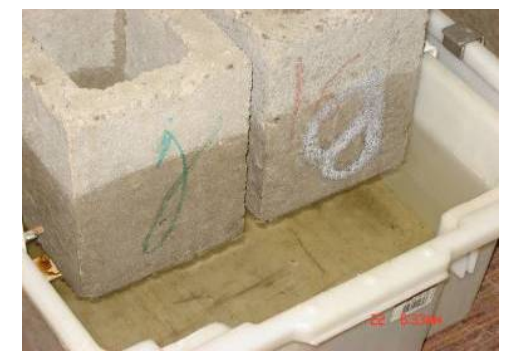

h) detalhe dos blocos sobre o suporte

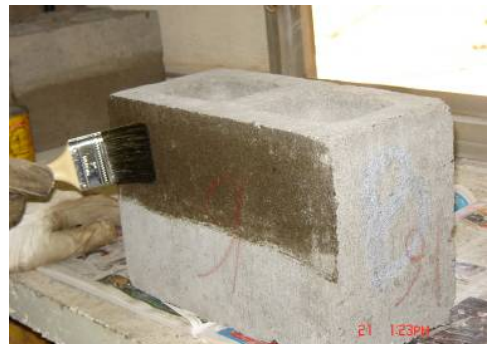

c) aplicação da demão de resina acrílica impermeabilizante

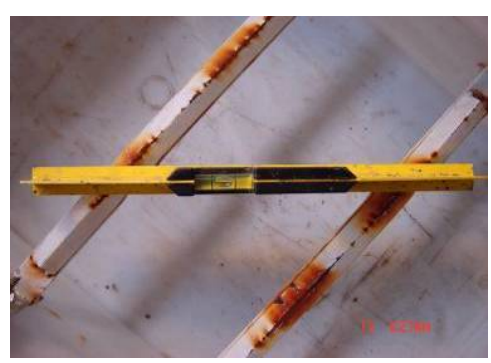

f) nivelamento dos suportes

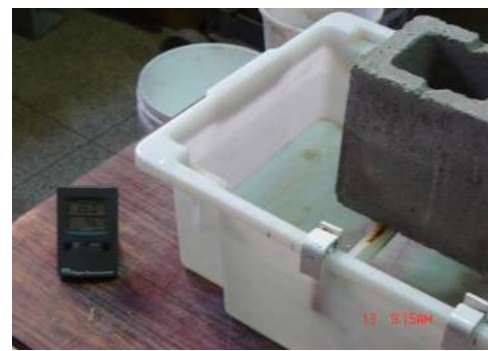

i) registro da temperatura $e$ umidade durante o ensaio

Figura 14 - Equipamentos e alguns detalhes do ensaio de absorção capilar. 


\section{APÊNDICE M - ENSAIO DE RESISTÊNCIA À COMPRESSÃO (BLOCOS DE CONCRETO)}

O ensaio de resistência à compressão dos blocos de concreto foi realizado na prensa hidráulica da Marca ELE e Modelo Autotest 2000, com capacidade de 2000 kN, figura 15.
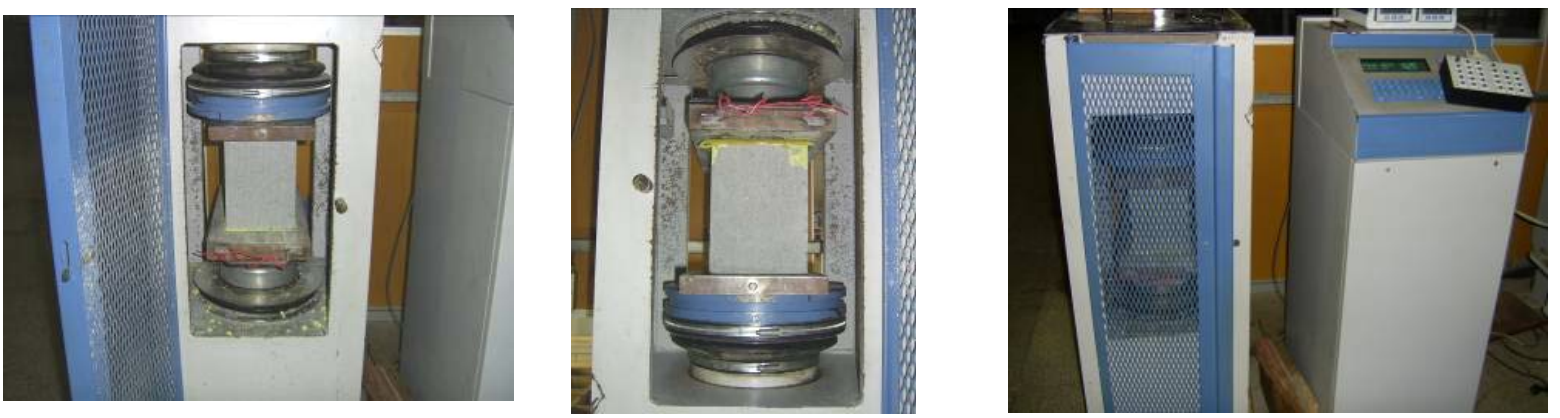

Figura 15 - Prensa hidráulica utilizada nos ensaios de resistência à compressão dos blocos de concreto.

A velocidade de imposição de carregamento foi de 2,03 kN/s. Na face superior e inferior das unidades foram dispostas placas de aço de espessura de $35 \mathrm{~mm}$ para distribuição uniforme do carregamento.

\section{APÊNDICE N - ENSAIO DE RESISTÊNCIA À COMPRESSÃO (MEIO-BLOCOS DE CONCRETO)}

Para o ensaio de resistência à compressão dos meio-blocos, a velocidade de imposição de deslocamento foi de $0,005 \mathrm{~mm} / \mathrm{s}$ e as unidades foram ensaiadas na máquina servo-controlada INSTRON, figura 16.

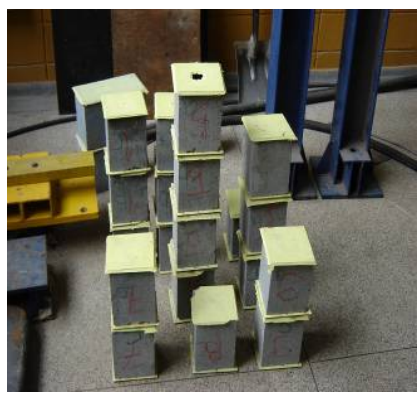

a) capeamento dos meio-blocos
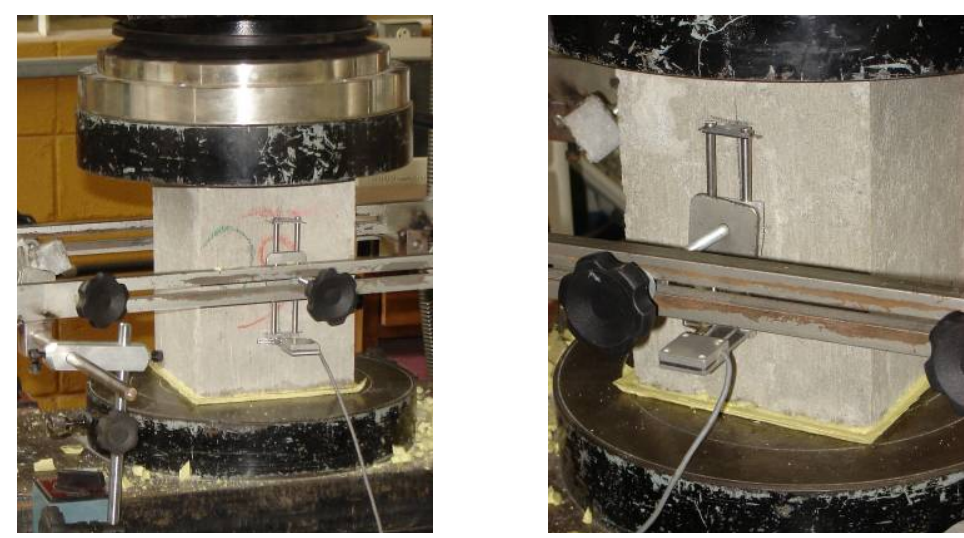

b) ensaio de resistência à compressão

Figura 16 - Detalhes da execução do ensaio de resistência à compressão dos meio-blocos. 
O ensaio foi realizado com o intuito de se obter, simultaneamente, o valor da resistência à compressão e o módulo de deformação dos meio-blocos.

\section{APÊNDICE O - ENSAIO DE RESISTÊNCIA À TRAÇÃO INDIRETA}

O ensaio foi realizado na máquina de ensaios ELE - Autotest, com capacidade de $2000 \mathrm{kN}$; a velocidade empregada para esse ensaio foi de 1,2 kN/s. O procedimento de ensaio consistiu em dispor duas barras cilíndricas na face superior (aplicação da força) e inferior da unidade (apoio), Figura 17. Estas barras foram dispostas exatamente na região central do vazio do bloco. A força de compressão aplicada pela máquina de ensaios resultará no surgimento de tensões de tração ao longo da altura da unidade. Na Figura 18 são apresentados alguns detalhes da montagem do ensaio de tração indireta.

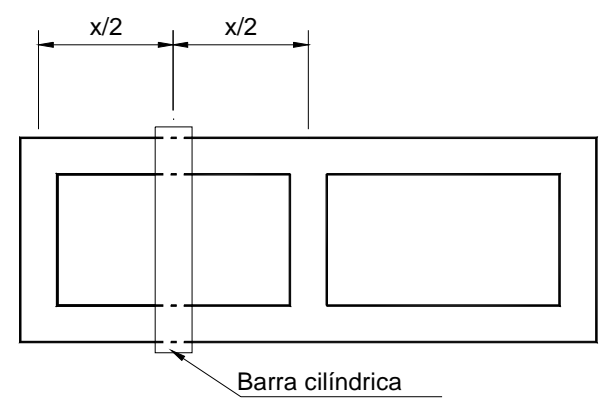

Vista de Topo

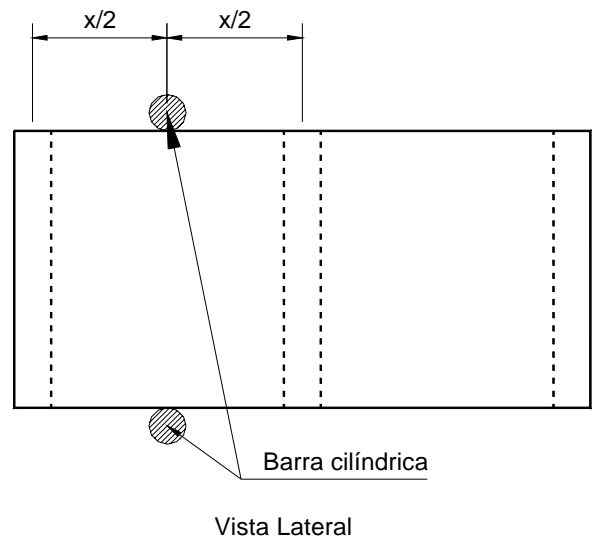

Figura 17 - Região de aplicação da força no ensaio de tração indireta. 

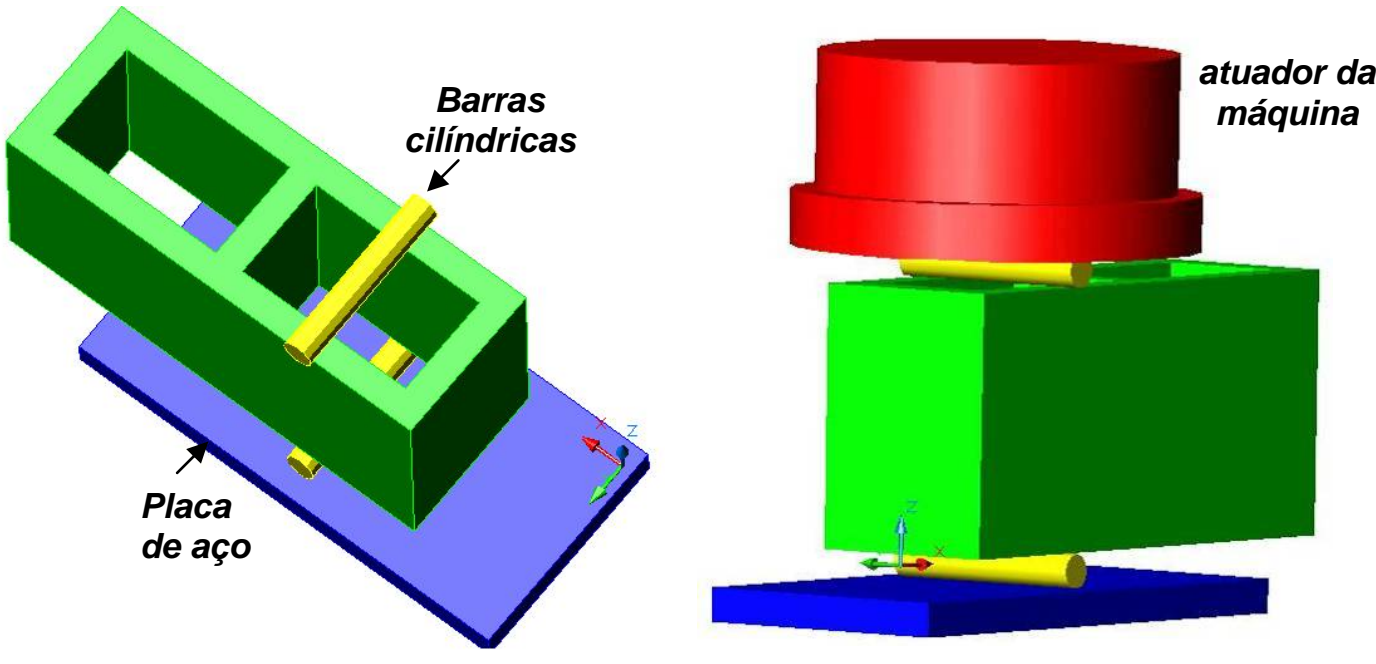

Figura 18 - Detalhes da disposição da unidade, atuador da máquina, barras cilíndricas e placa de aço no ensaio de tração indireta.

\section{APÊNDICE P - ENSAIO DE MÓDULO DE DEFORMAÇÃO}

Para a regularização da superfície dos blocos foi utilizada pasta de enxofre. Apesar disso, devido ao grande número de imperfeições existentes na face inferior dos blocos, alguns blocos não apresentaram uma superfície perfeitamente regularizada mesmo após o capeamento; fato esse que acabou prejudicando alguns dos ensaios realizados. Para os blocos de concreto, foi utilizada uma placa de aço de espessura de $35 \mathrm{~mm}$ para a regularização do carregamento; já para os meio-blocos, o carregamento foi aplicado diretamente pelo pistão da máquina. Em razão da grande quantidade de dosagens estudadas, foram avaliadas três unidades (blocos e meio-blocos) para cada traço.

O experimento foi realizado na máquina servo-controlada INSTRON. Esse equipamento dispõe de espaço suficiente para a instrumentação da unidade e, por meio do controle de deslocamento do pistão da máquina, permite evitar a ruptura brusca da unidade o que poderia danificar os extensômetros removíveis. Os deslocamentos relativos foram medidos por quatro extensômetros removíveis (blocos de concreto) ou dois extensômetros removíveis (meio-blocos de concreto) de base de medida igual a $100 \mathrm{~mm}$ e resolução de $0,001 \mathrm{~mm}$, colocados na meia altura da região central da cavidade, de forma a verificar possíveis excentricidades, figura 19. 

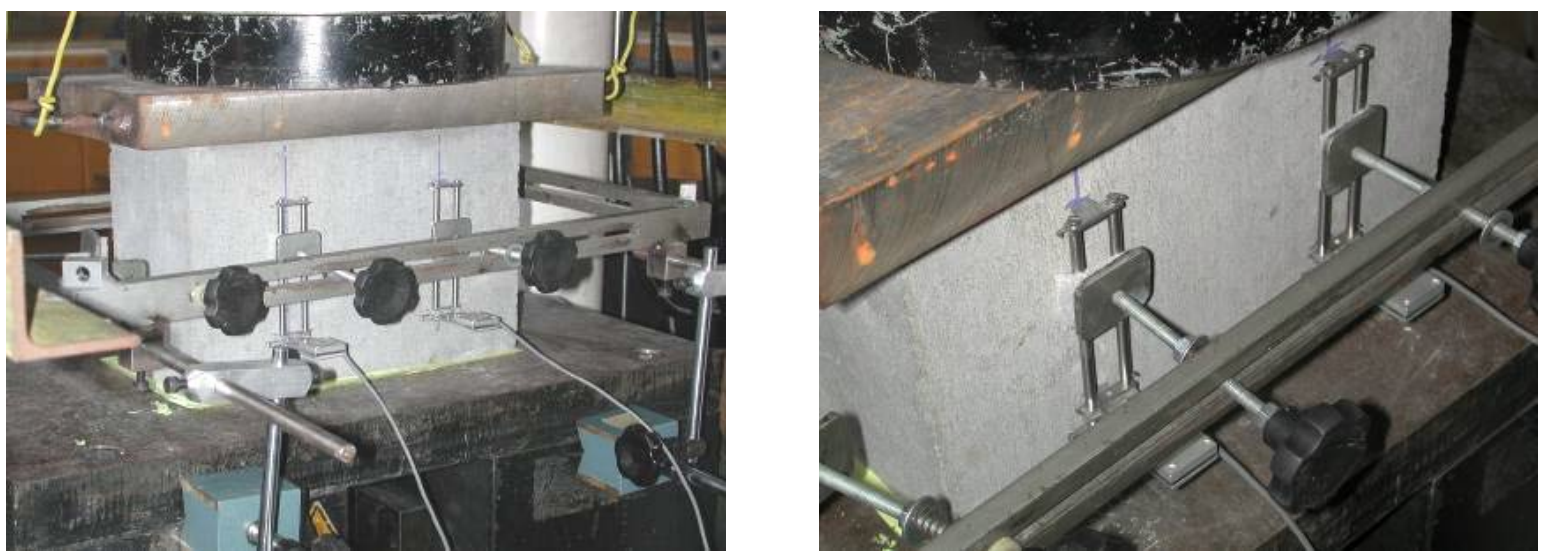

a) blocos de concreto
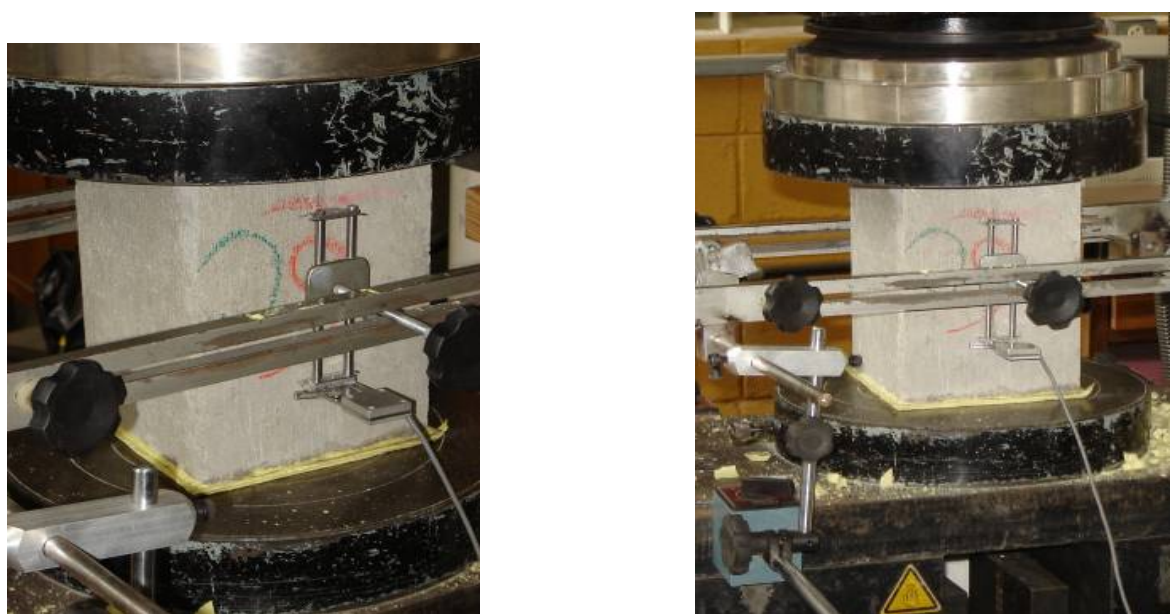

b) meio-blocos de concreto

Figura 19 - Posicionamento dos extensômetros removíveis nos blocos e meio-blocos de concreto para a determinação do módulo de deformação.

As deformações específicas foram calculadas com os deslocamentos relativos dos transdutores e a base de medida dos mesmos. A velocidade de imposição de deslocamento foi de $0,005 \mathrm{~mm} / \mathrm{s}$, sendo que as leituras e o armazenamento de dados foram feitos pelo sistema SYSTEM 5000. 


\section{APÊNDICE Q - CURVAS TENSÃO x DEFORMAÇÃO DOS BLOCOS DE CONCRETO}

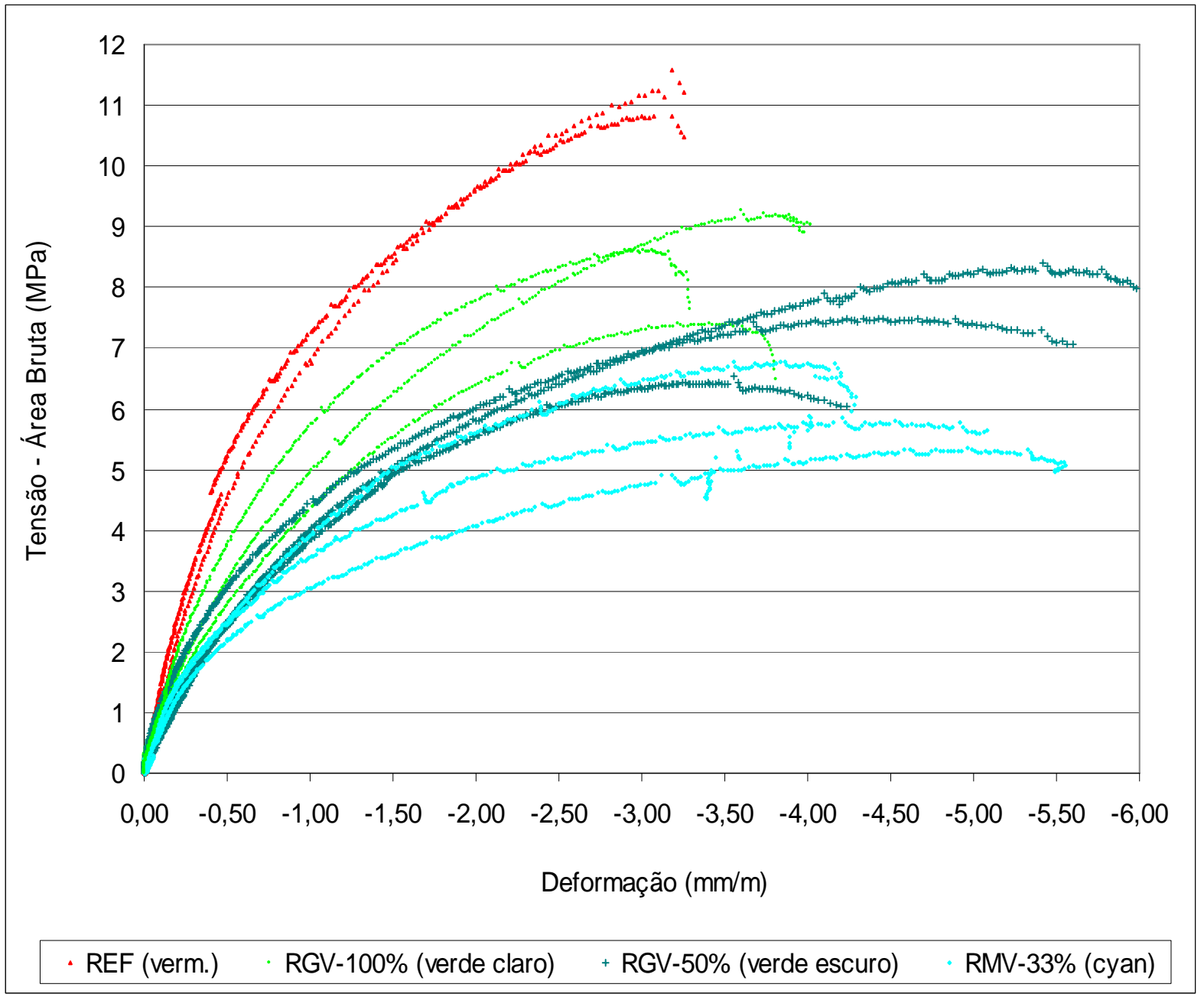

Figura 20 - Curva Tensão x Deformação das unidades do Grupo 4,5 (REF, RGV-100\%, RGV-50\% e RMV-33\%). 


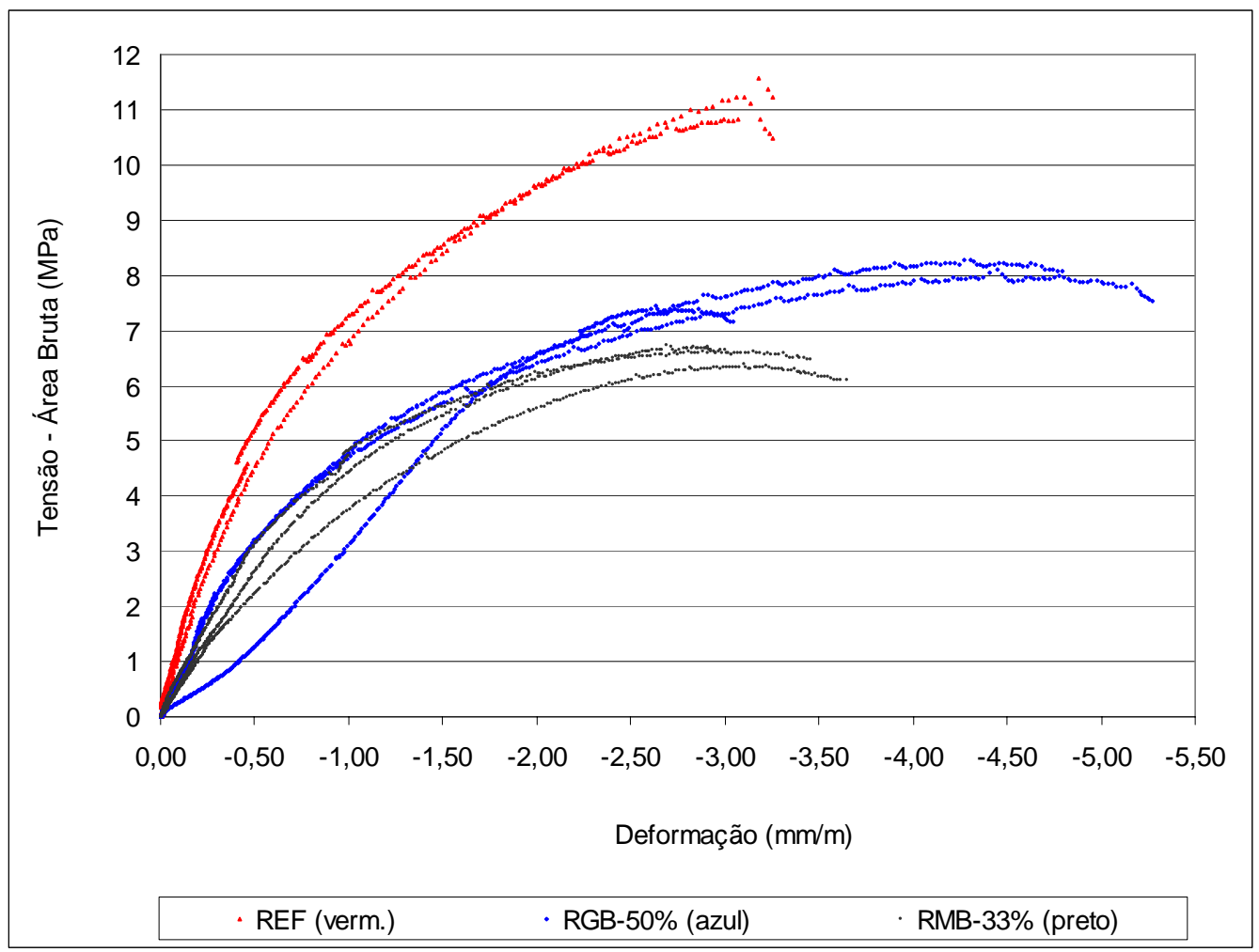

Figura 21 - Curva Tensão x Deformação das unidades do Grupo 4,5 (REF, RGB-50\% E RMB-33\%).

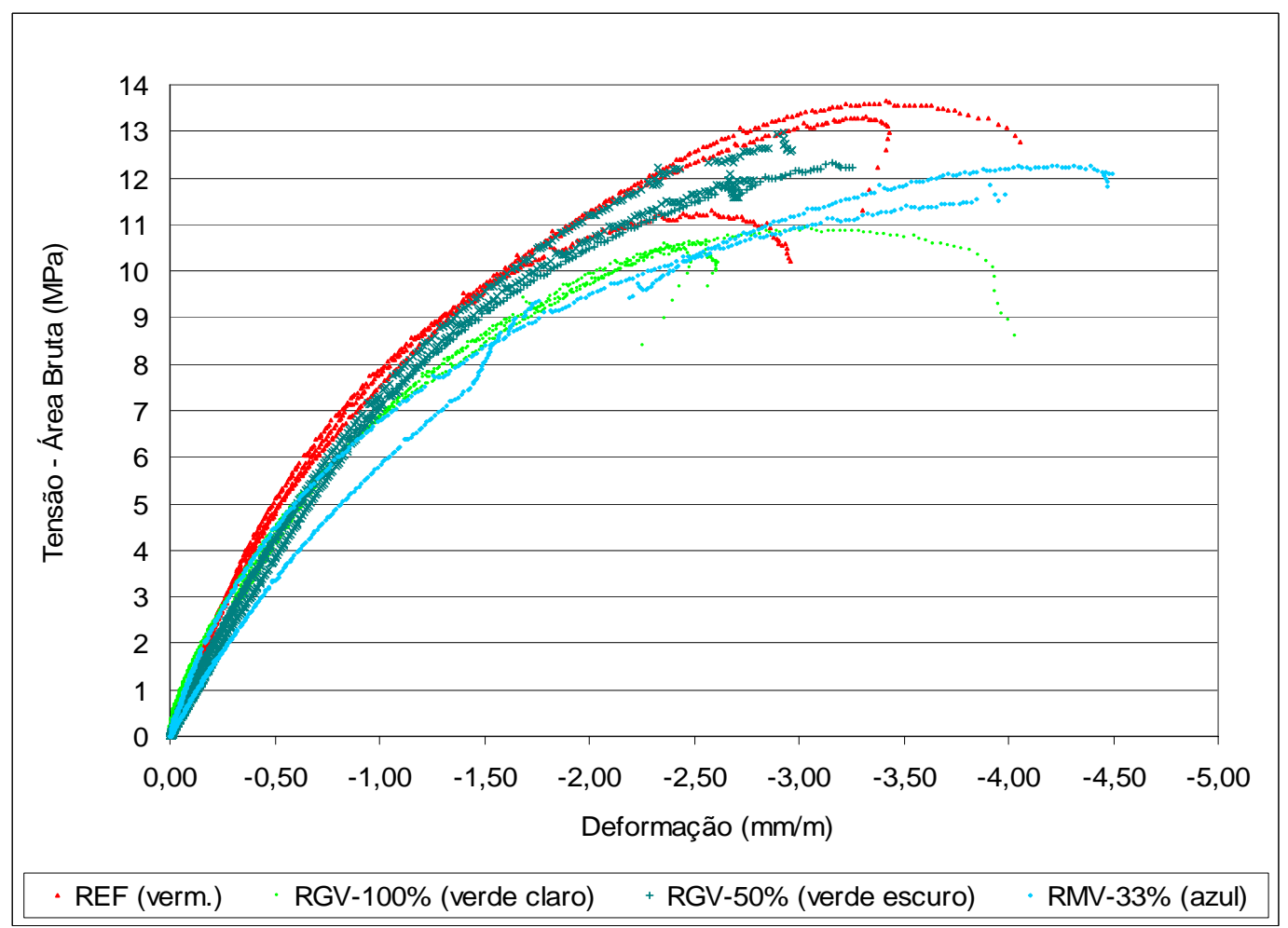

Figura 22 - Curva Tensão x Deformação das unidades do Grupo 8,0 (REF, RGV-100\%, RGV-50\% e RMV-33\%). 


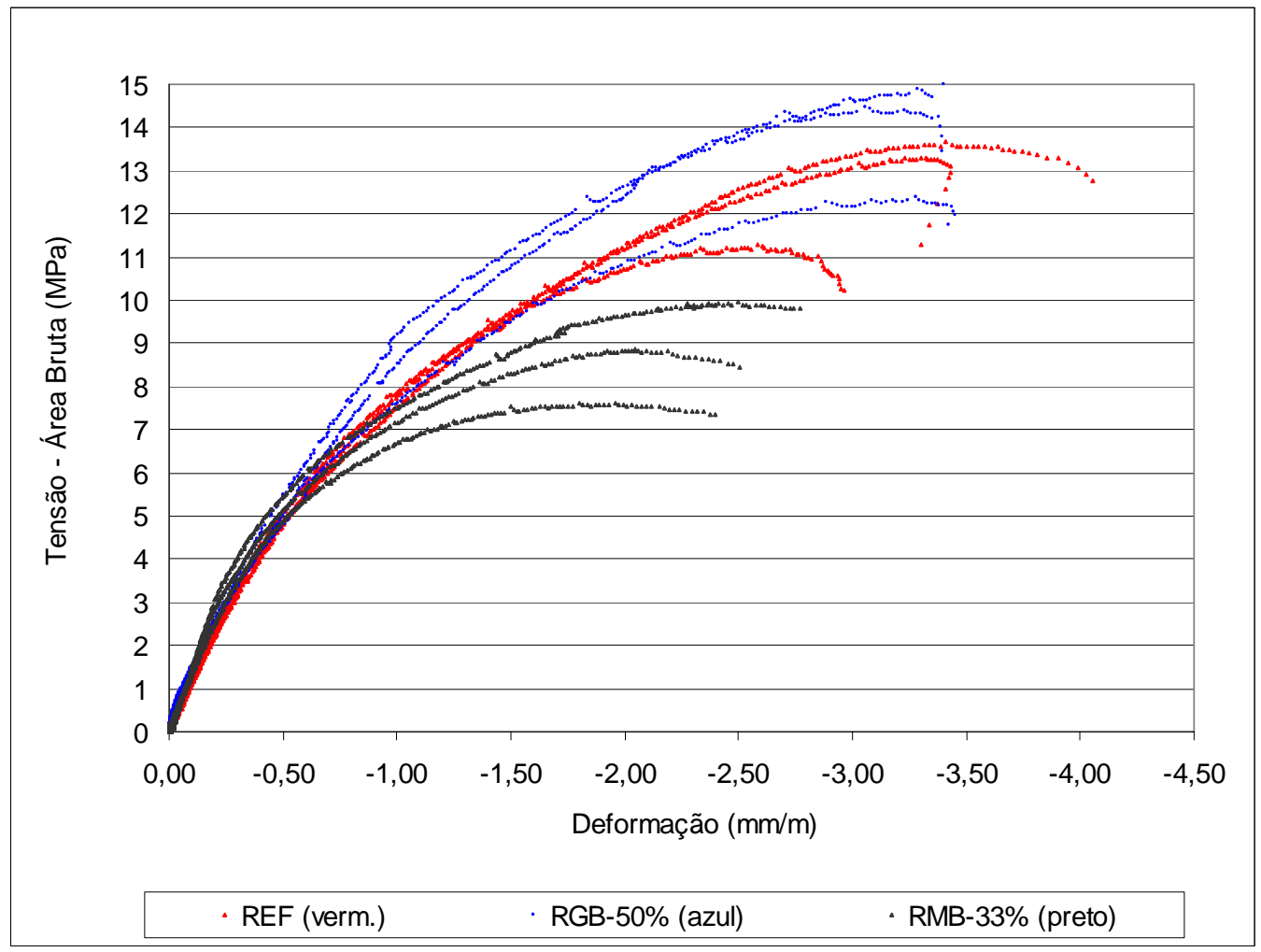

Figura 23 - Curva Tensão x Deformação das unidades do Grupo 8,0 (REF, RGB-50\% E RMB-33\%).

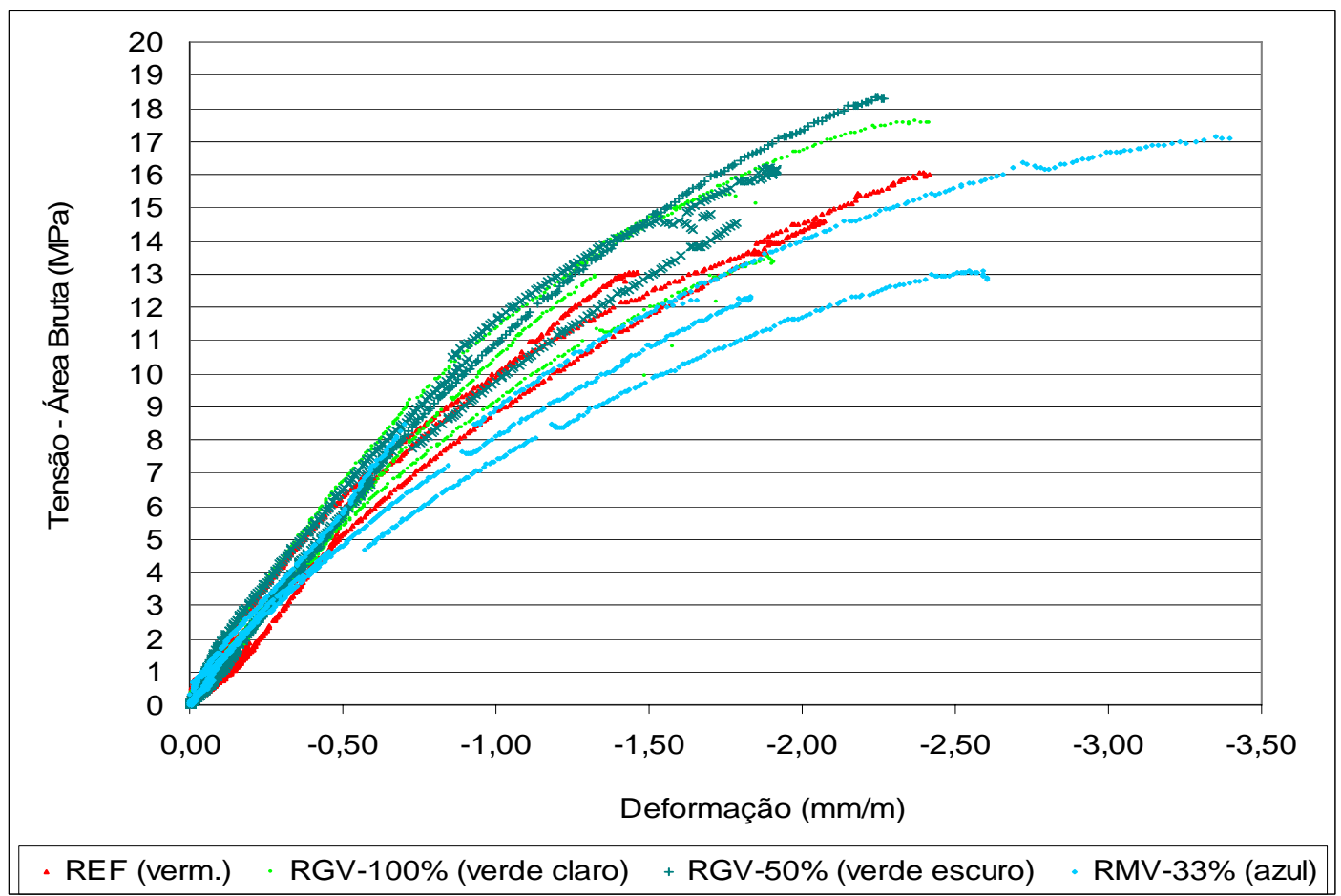

Figura 24 - Curva Tensão x Deformação das unidades do Grupo 12,0 (REF, RGV-100\% RGV-50\% e RMV-33\%). 


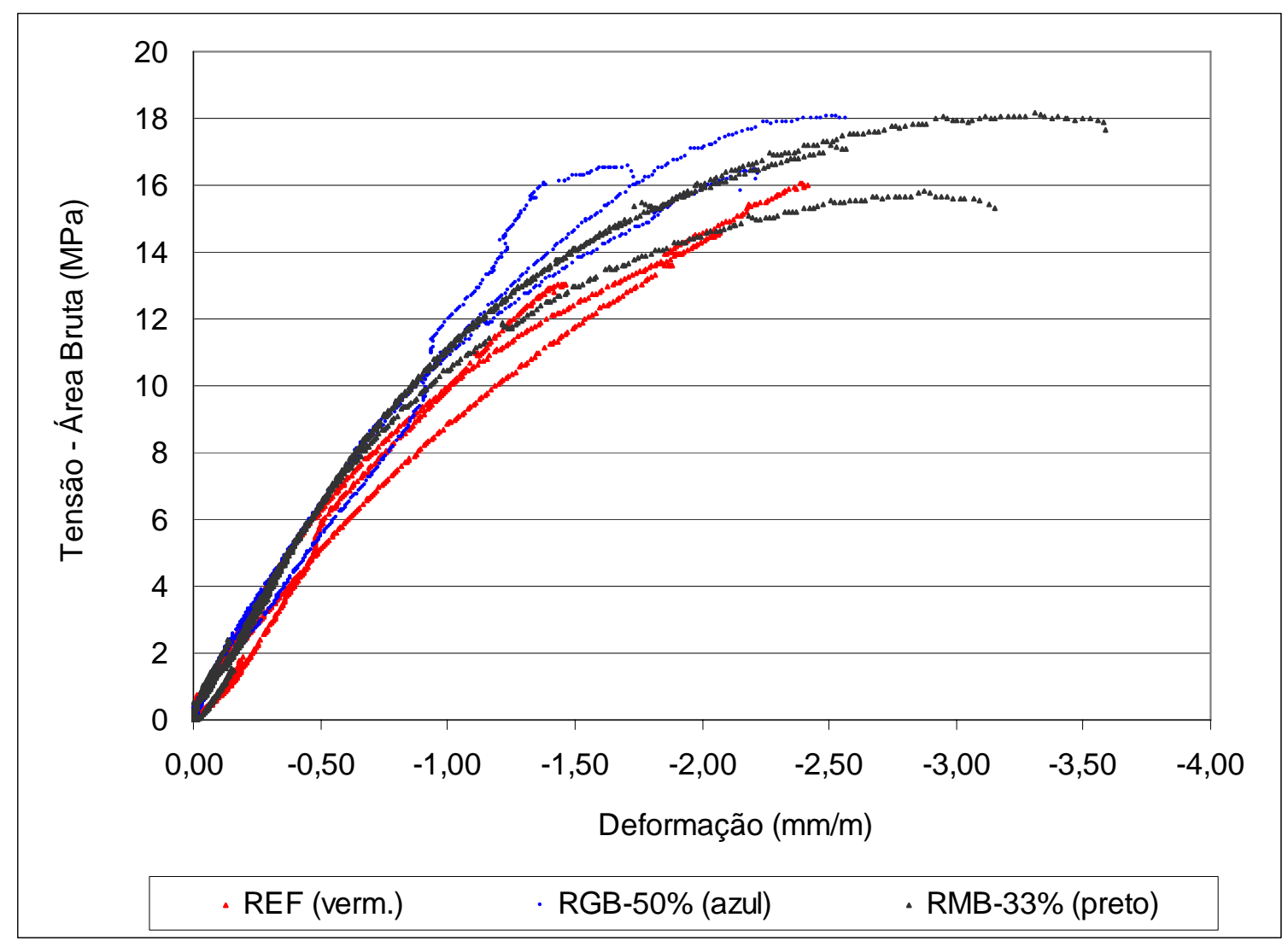

Figura 25 - Curva Tensão x Deformação das unidades do Grupo 12,0 (REF, RGB-50\% e RMB-33\%).

\section{APÊNDICE R - ENSAIO DE RESISTÊNCIA À COMPRESSÃO $E$ MÓdULO DE DEFORMAÇÃO DOS CPS DE ARGAMASSA}

Para os ensaios de resistência à compressão axial e módulo de deformação foi utilizada a máquina servo-controlada INSTRON. Os deslocamentos relativos do CP foram medidos por dois extensômetros removíveis com base de $50 \mathrm{~mm}$. As deformações específicas foram determinadas através dos deslocamentos relativos dos extensômetros e a base de medida dos mesmos. A velocidade de imposição de deslocamento foi igual a 0,005 $\mathrm{mm} / \mathrm{s}$, sendo que as leituras e o armazenamento dos dados foram feitos pelo sistema de aquisição SYSTEM 5000, figura 26. 

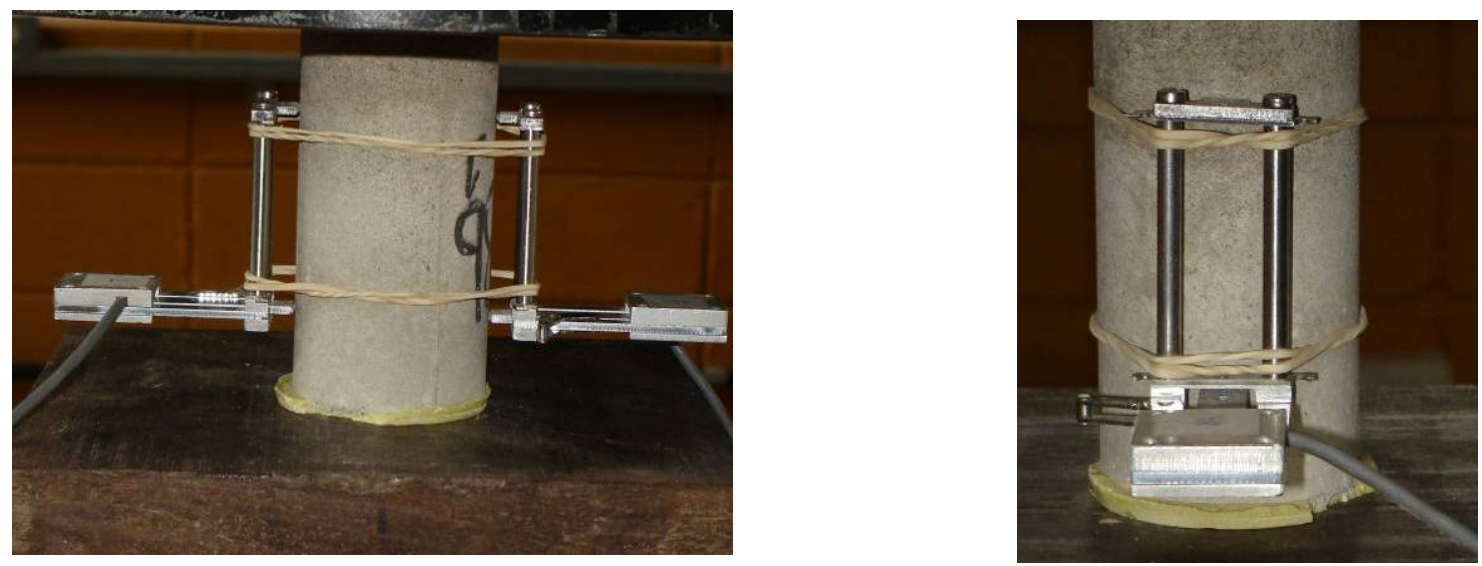

Figura 26 - Instrumentação dos CPs para a realização do ensaio de módulo de deformação.

\section{APÊNDICE S - PROCEDIMENTOS ADOTADOS PARA EXECUÇÃO DOS PRISMAS}

Nos próximos itens, serão apresentados os principais detalhes referentes às etapas de produção dos prismas de três blocos.

1 - Inicialmente, os blocos de concreto foram separados e colocados no interior do laboratório pelo menos dois dias antes do assentamento, com o intuito de reduzir a umidade das unidades e a retração por secagem. A norma NBR 7173 (1982) cita que, no momento de entrega na obra, os blocos não deverão apresentar umidade superior a $40 \%$ da quantidade de água fixada como absorção máxima.

2 - Para cada prisma, foram capeados o bloco inferior e o bloco superior utilizando pasta de enxofre. As irregularidades existentes na superfície de alguns blocos foram retiradas, pois poderiam ser pontos de concentração de tensões. Os materiais necessários à produção da argamassa foram previamente separados e pesados; a quantidade de materiais seria suficiente para a fabricação de dez prismas.

3 - Com relação à execução dos prismas, foi realizada a mistura manual dos materiais pelo pedreiro. Os materiais foram previamente misturados a seco e depois, gradualmente, foi adicionada a água, figura 27. A consistência adequada da argamassa foi determinada pela experiência do pedreiro. Deve-se ressaltar que a mistura foi realizada manualmente devido à pequena quantidade de materiais a serem misturados e pelo fato de não se dispor de uma argamassadeira mecânica. 


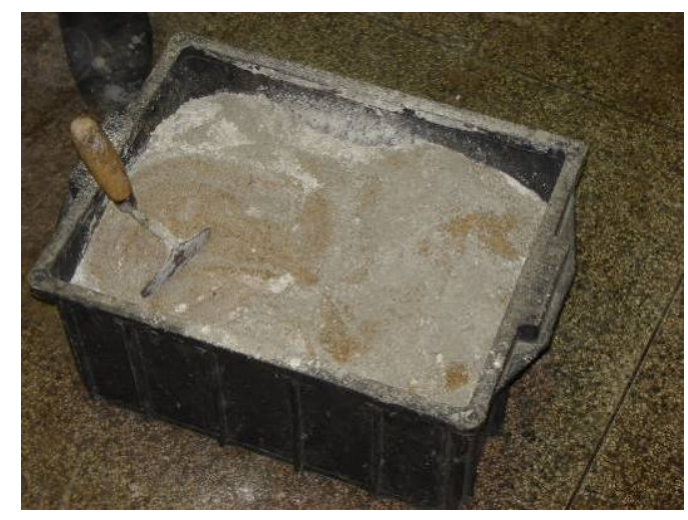

a) mistura preliminar dos materiais a seco

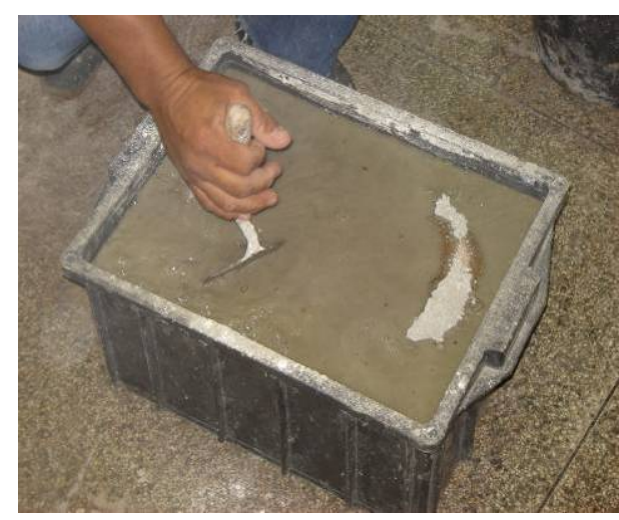

b) adição gradual da água até a obtenção da consistência adequada

Figura 27 - Mistura manual da argamassa.

4 - Após a mistura dos materiais, foi recolhida uma determinada quantidade de argamassa para a execução do ensaio de índice de consistência, figura 28. Deve ser frisado que a cada 10 minutos, eram registradas as temperaturas e umidades no local de produção dos prismas.
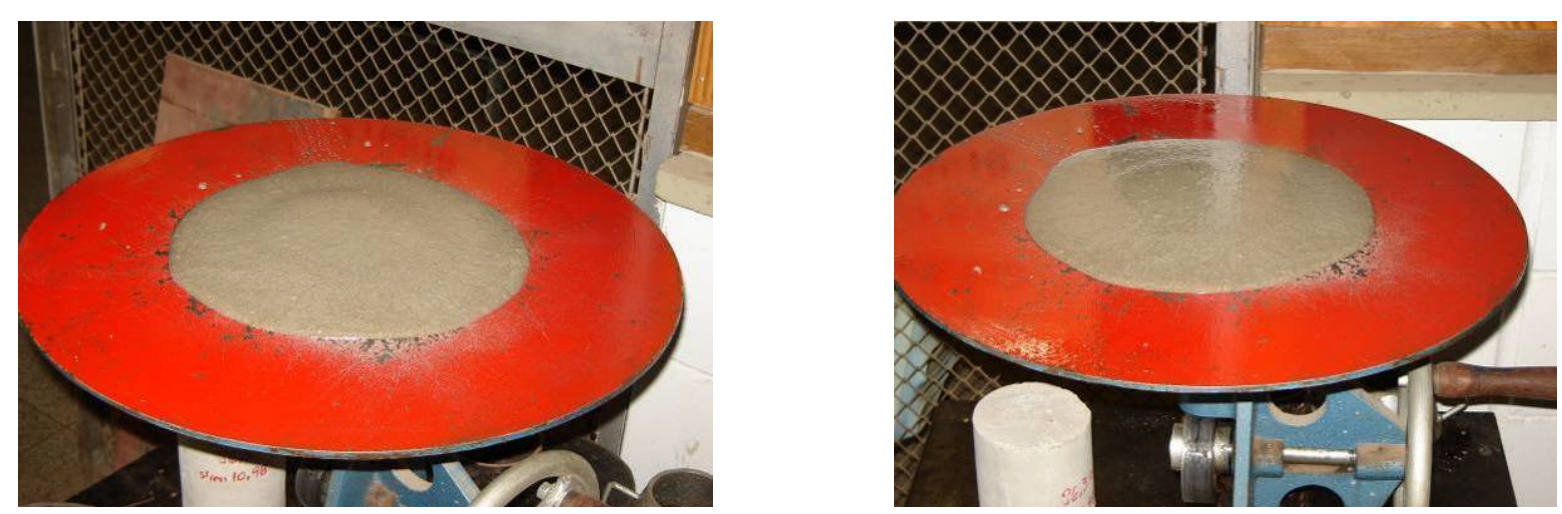

Figura 28 - Ensaio de índice de consistência.

5 - A produção dos prismas foi iniciada pelo nivelamento do bloco inferior (capeado com enxofre) com auxílio de nível de bolha e posterior disposição dos cordões de argamassa nas paredes transversais e longitudinais, figura 29. 


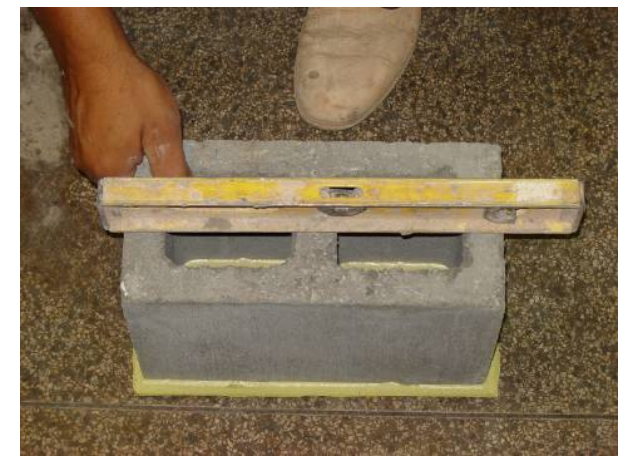

a) nivelamento do bloco inferior

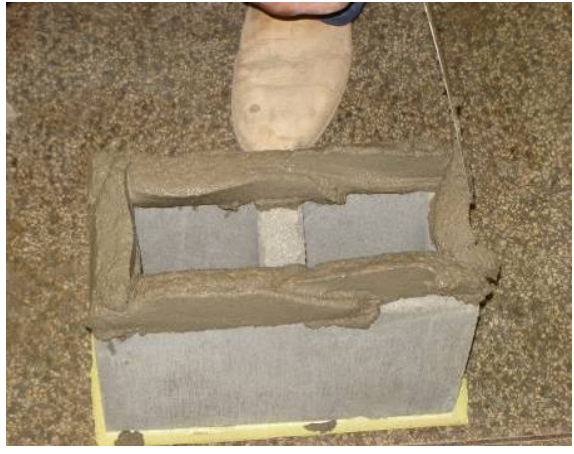

b) disposição dos cordões de argamassa

Figura 29 - Nivelamento e disposição dos cordões de argamassa.

6 - Assentamento do segundo bloco, ajuste da espessura da argamassa $(1 \mathrm{~cm})$ e nivelamento da unidade com auxílio de nível de bolha e martelo de borracha, figura 30.
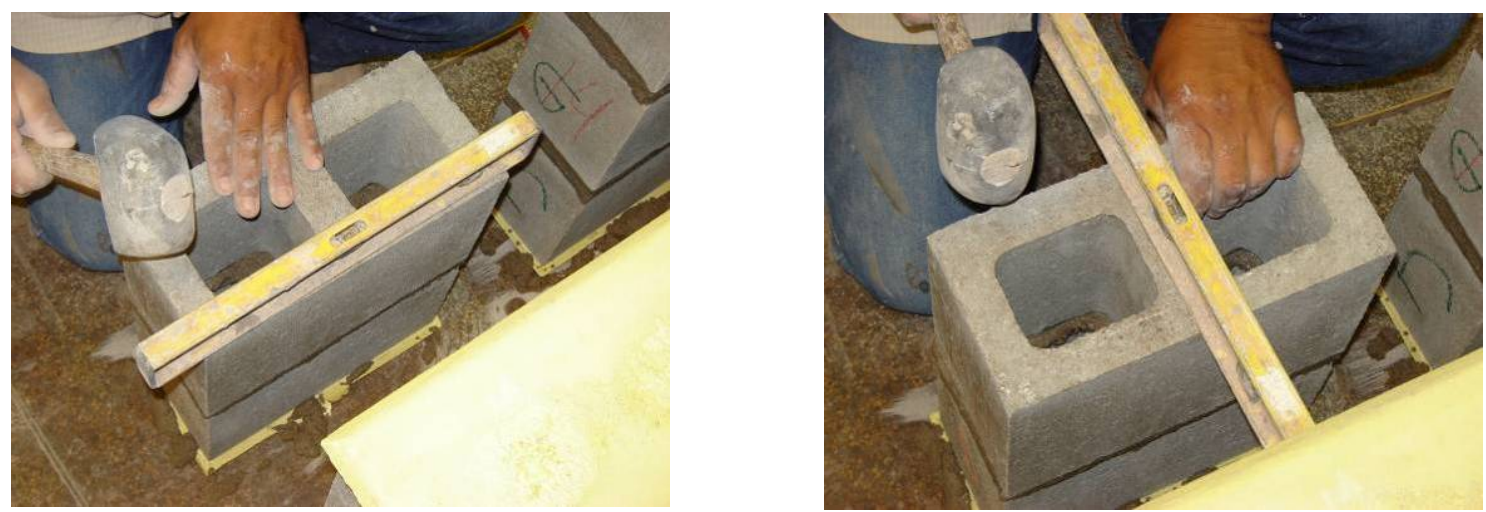

Figura 30 - Nivelamento da segunda fiada com auxílio de nível de bolha e martelo de borracha.

7 - Aplicação da segunda junta de argamassa, ajuste da espessura e nivelamento da unidade superior, que já se encontrava capeada, e do prisma, figura 31. 


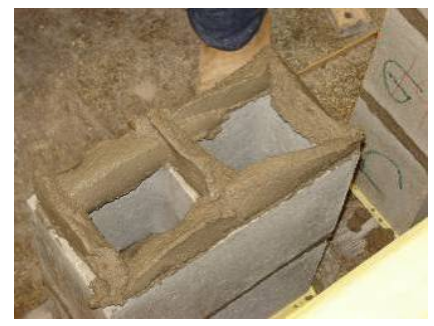

a) aplicação da segunda junta de argamassa
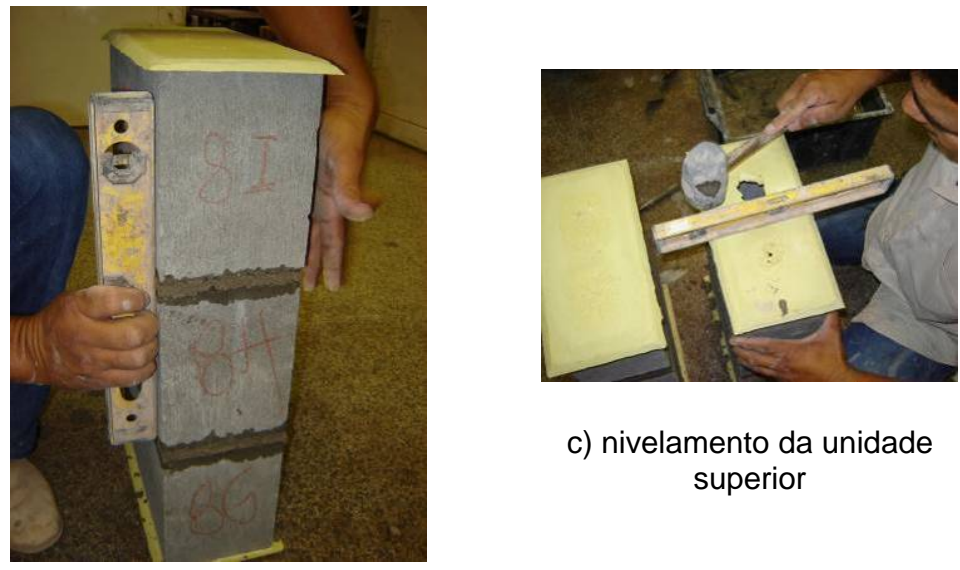

c) nivelamento da unidade superior

b) nivelamento do prisma

Figura 31 - Execução da segunda junta de argamassa, nivelamento do prisma e unidade superior.
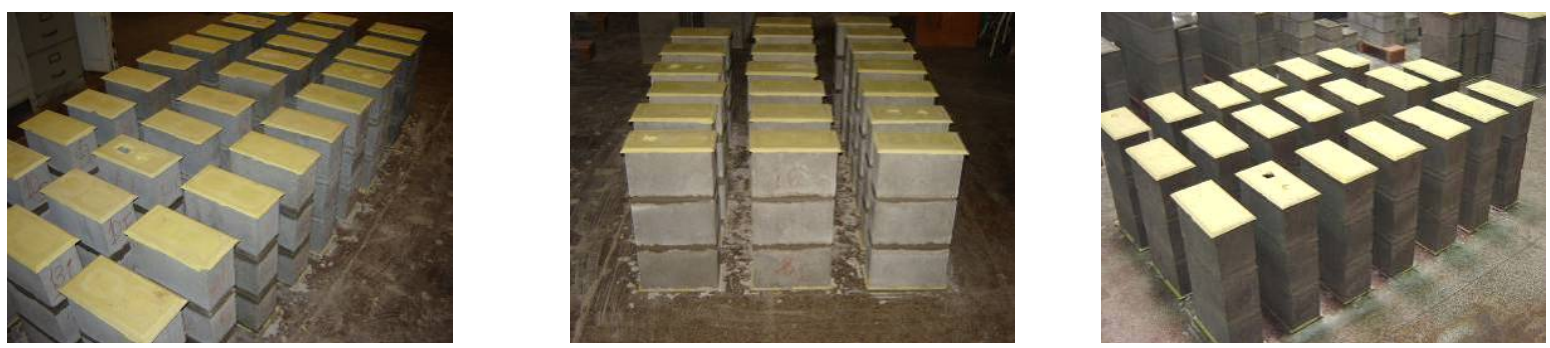

Figura 32 - Vista geral dos 48 prismas produzidos.

8 - À medida da produção do prisma, uma amostra da argamassa era retirada para a moldagem de CPs $(5 \times 10) \mathrm{cm}$, conforme prescrições da NBR 7215 (1982), figura 33. Os CPs foram curados no ambiente do laboratório até a data de ensaio dos prismas.

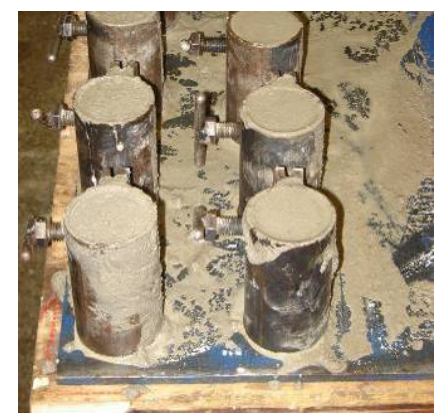

a) CPs recém-moldados

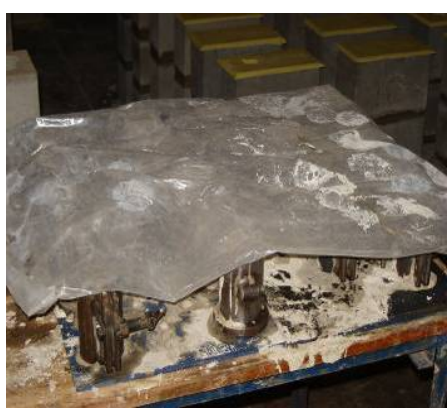

b) CPs protegidos da exsudação

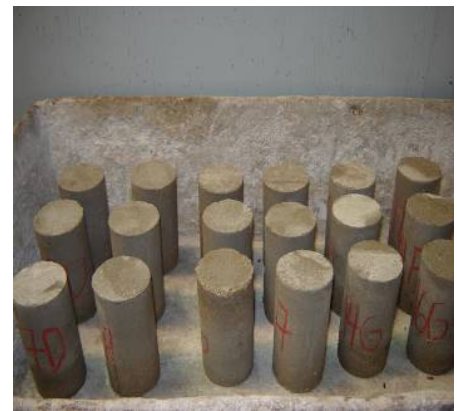

c) CPs no ambiente do laboratório

Figura 33 - Produção dos CPs de argamassa. 
9 - Com relação ao transporte dos elementos, na data de ensaio, foi utilizada uma paleteira elétrica. Para a colocação dos elementos na paleteira, o processo foi realizado manualmente com o cuidado de se evitarem movimentos bruscos que pudessem afetar a ligação bloco-argamassa.

\section{APÊNDICE T - PROCEDIMENTOS ADOTADOS PARA EXECUÇÃO DAS MINIPAREDES}

Nos próximos itens, serão apresentados os principais detalhes referentes às etapas de produção das miniparedes.

1 - Inicialmente, os meio-blocos e blocos de concreto foram separados e colocados no interior do laboratório pelo menos dois dias antes do assentamento, com o intuito de reduzir a umidade das unidades e a retração por secagem. A norma NBR 7173 (1982) cita que, no momento de entrega na obra, os blocos não deverão apresentar umidade superior a 40\% da quantidade de água fixada como absorção máxima.

2 - Para cada miniparede, foram capeados os dois blocos inferiores e os dois blocos superiores utilizando argamassa de cimento e areia, figura 34. As irregularidades existentes na superfície de alguns blocos foram retiradas, pois poderiam ser pontos de concentrações de tensões.
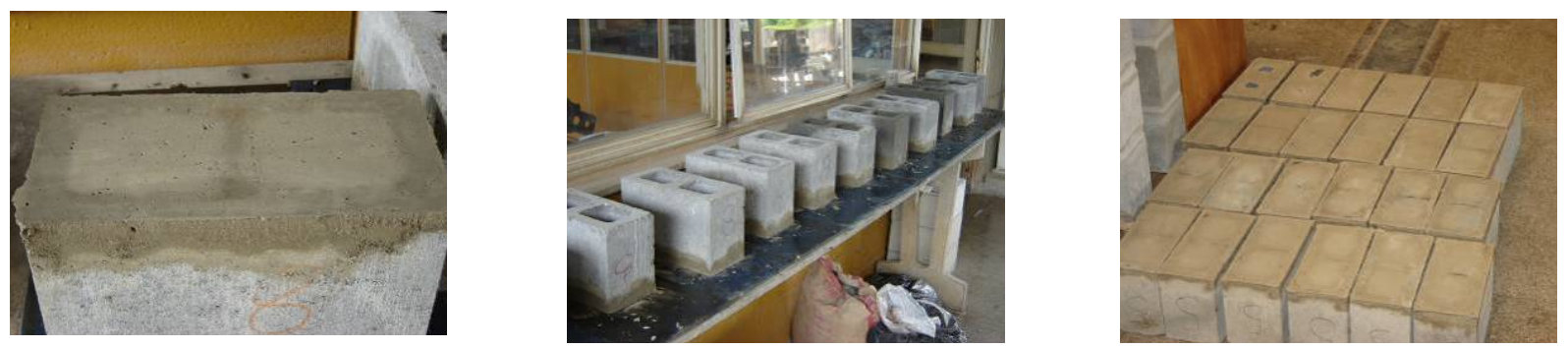

Figura 34 - Blocos capeados com argamassa de cimento e areia.

3 - Os materiais necessários à produção da argamassa foram previamente separados e pesados; a quantidade de materiais, para cada massada, seria suficiente para a fabricação de três miniparedes;

4 - A mistura dos materiais foi realizada manualmente pelo pedreiro. Os materiais foram previamente misturados a seco e depois, gradualmente, foi adicionada a água. A consistência adequada da argamassa foi determinada pela experiência do pedreiro. Deve-se ressaltar que a mistura foi realizada manualmente devido à pequena quantidade de 
materiais a serem misturados e pelo fato de não se dispor de uma argamassadeira mecânica.

5 - Após a mistura dos materiais, foi recolhida uma determinada quantidade de argamassa para a execução do ensaio de índice de consistência. Deve ser frisado que a cada 10 minutos, foram registradas as temperaturas e umidades no local de produção das miniparedes, figura 35.

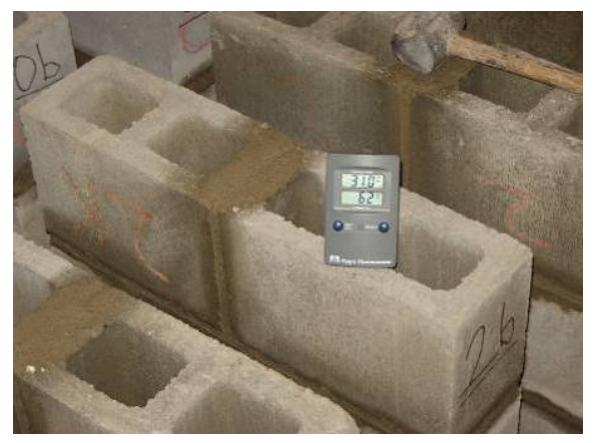

Figura 35 - Registro da temperatura e umidade no local de produção das miniparedes.

6 - A produção das miniparedes foi iniciada pelo nivelamento dos dois blocos inferiores (capeados com argamassa) com auxílio de nível de bolha e, posterior, disposição dos cordões de argamassa nas paredes transversais e longitudinais e na junta vertical, figura 36.

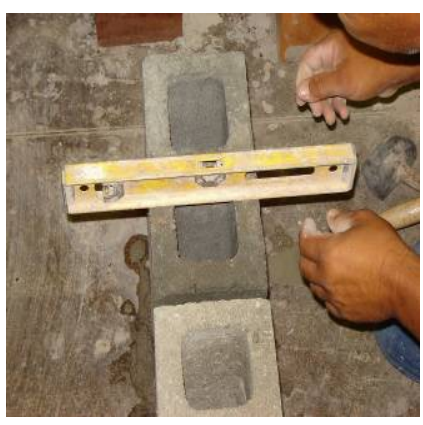

a) nivelamento dos blocos de base da miniparede

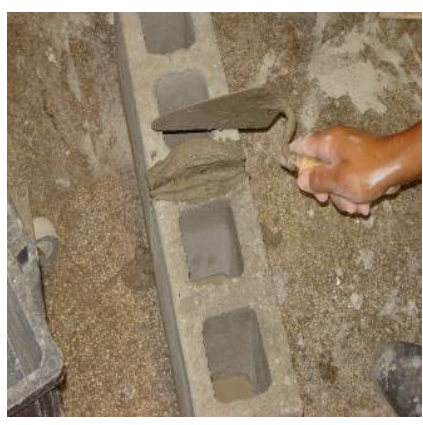

b) execução da junta vertical de argamassa

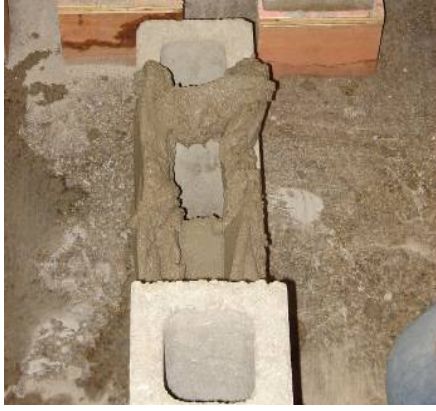

c) disposição dos cordões longitudinais e transversais de argamassa

Figura 36 - Nivelamento, execução da junta vertical e disposição dos cordões de argamassa.

7 - Assentamento das unidades da fiada superior, ajuste da espessura da argamassa (1 $\mathrm{cm}$ ) e nivelamento do conjunto com auxílio de nível de bolha e martelo de borracha, figura 37. 

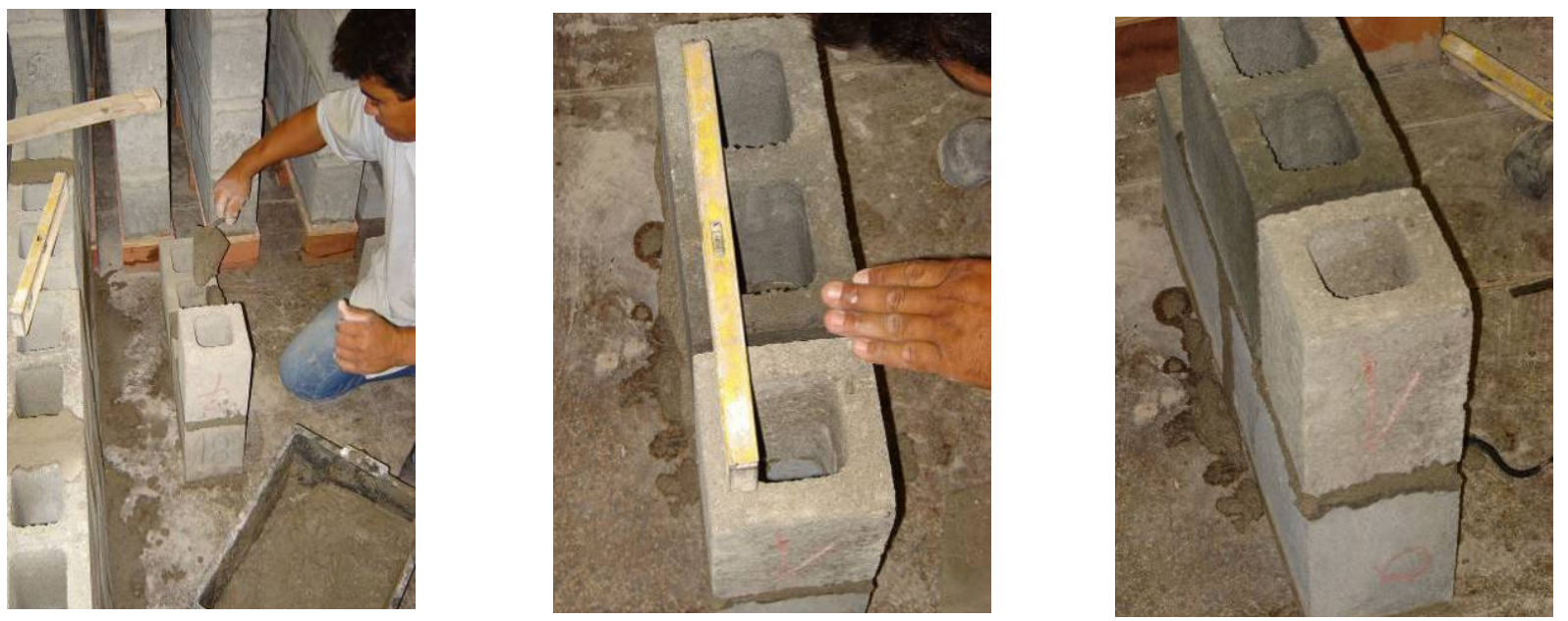

Figura 37 - Execução da segunda fiada.

8 - Assentamento das unidades da última fiada, ajuste da espessura da argamassa e nivelamento do conjunto com auxílio de nível de bolha e martelo de borracha, figura 38 .
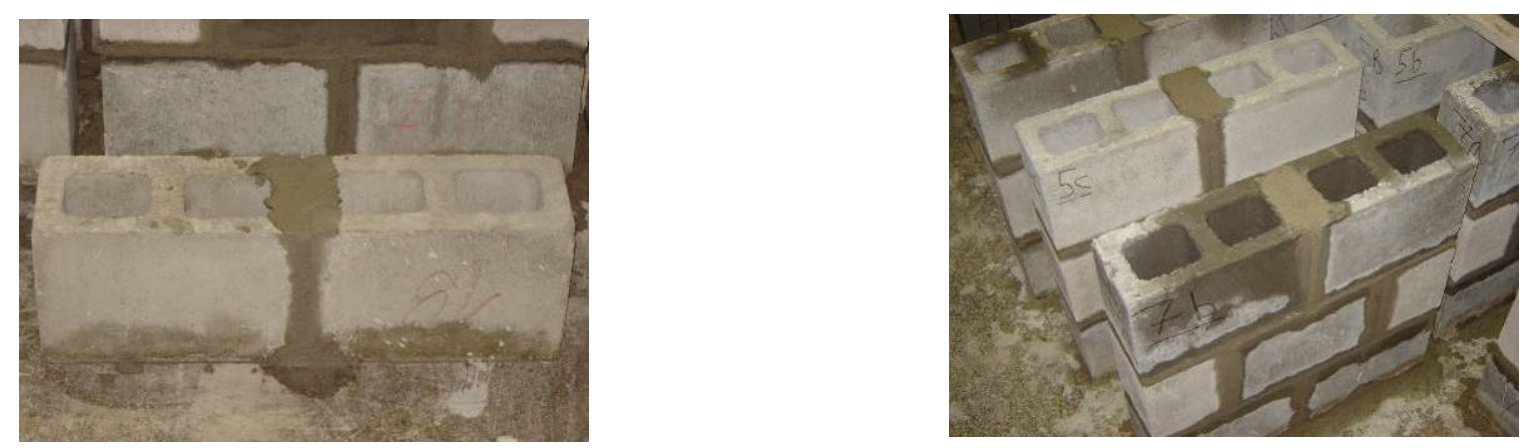

Figura 38 - Execução da última fiada.

9 - Nivelamento da face superior da miniparede com argamassa de cimento e areia (1:2), figura 39. 

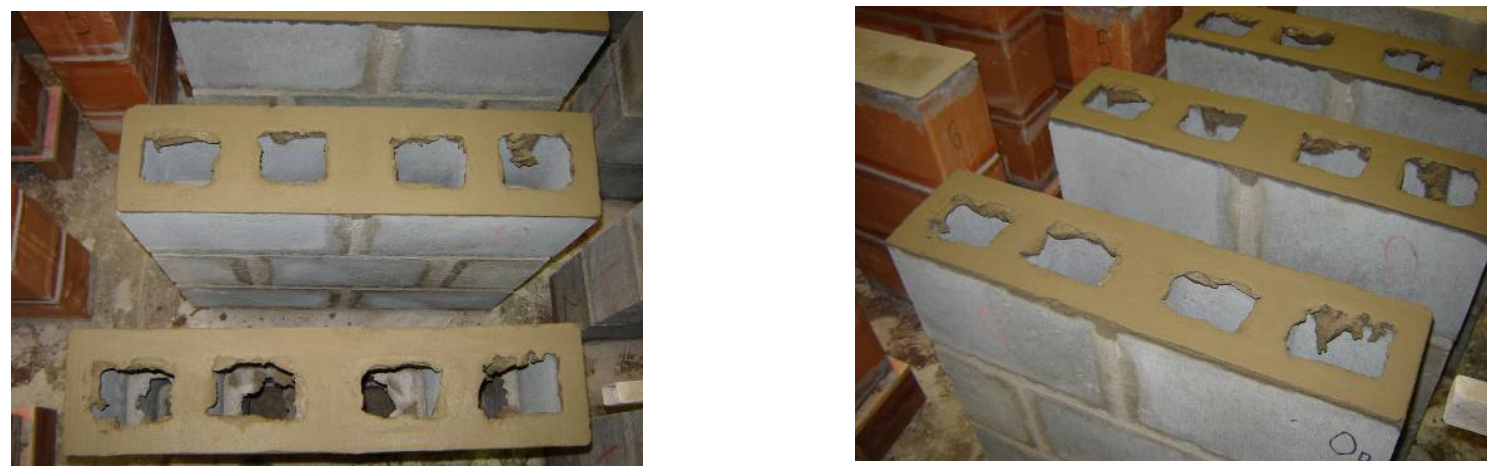

Figura 39 - Nivelamento da face superior com argamassa de cimento e areia.
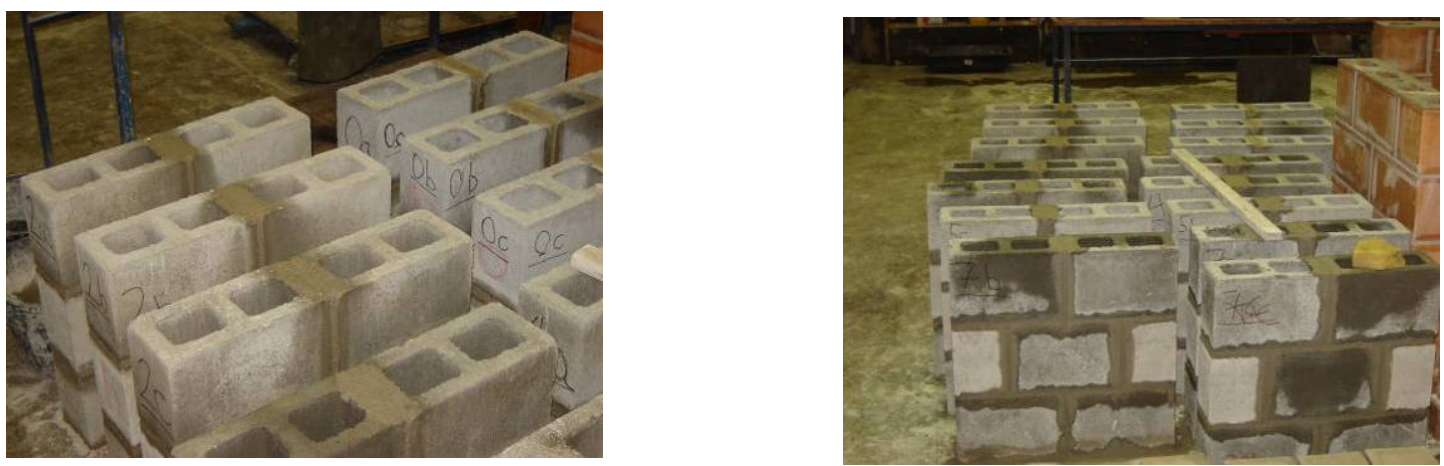

Figura 40 - Vista geral das 27 miniparedes produzidas. 


\section{APÊNDICE U - CURVAS TENSÃO X DEFORMAÇÃO DOS PRISMAS DE BLOCOS DE CONCRETO}

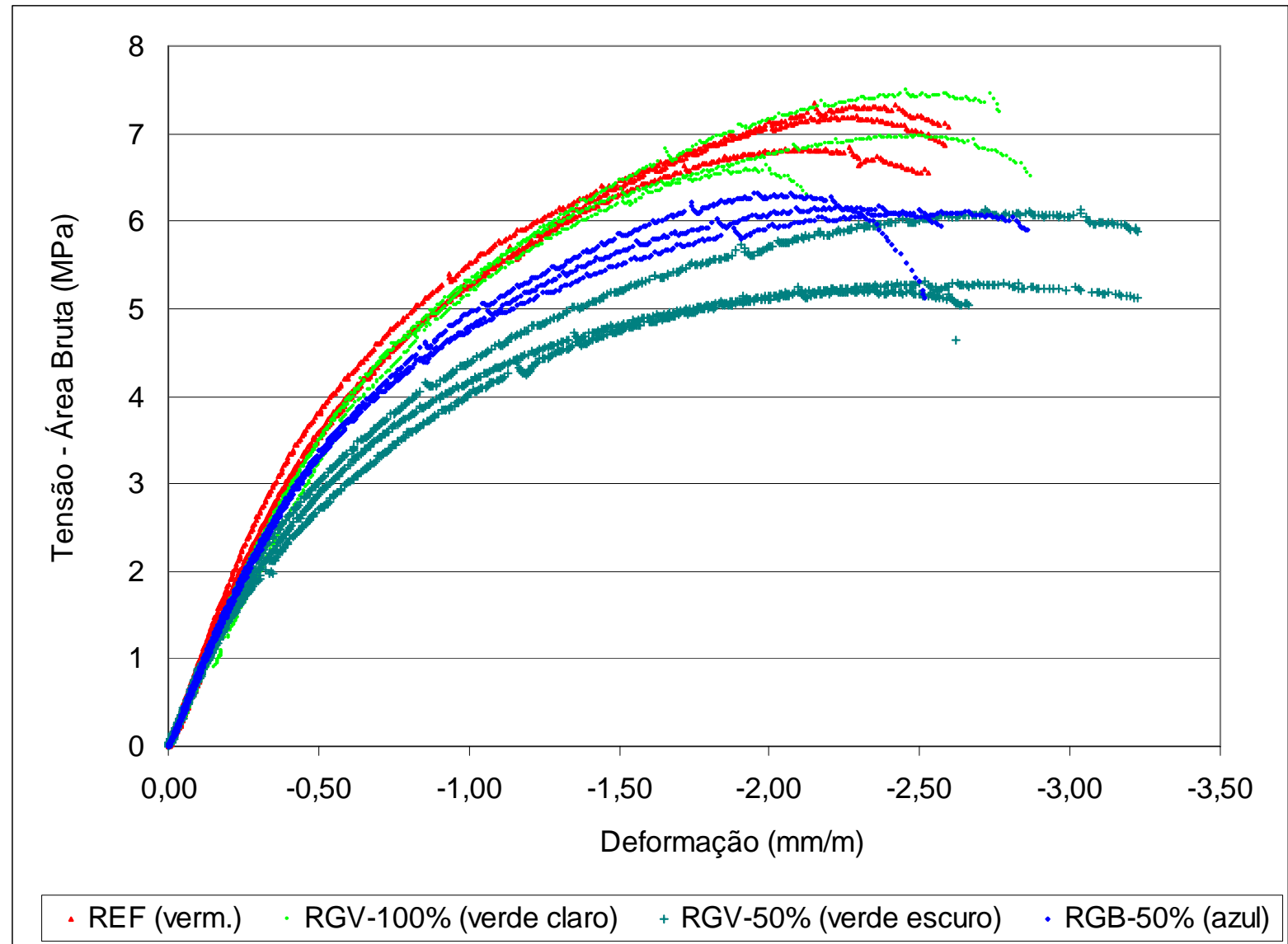

Figura 41 - Curva Tensão x Deformação dos prismas do Grupo 4,5 (REF, RGV-100\%, RGV$50 \%$ e RGB-50\%). 


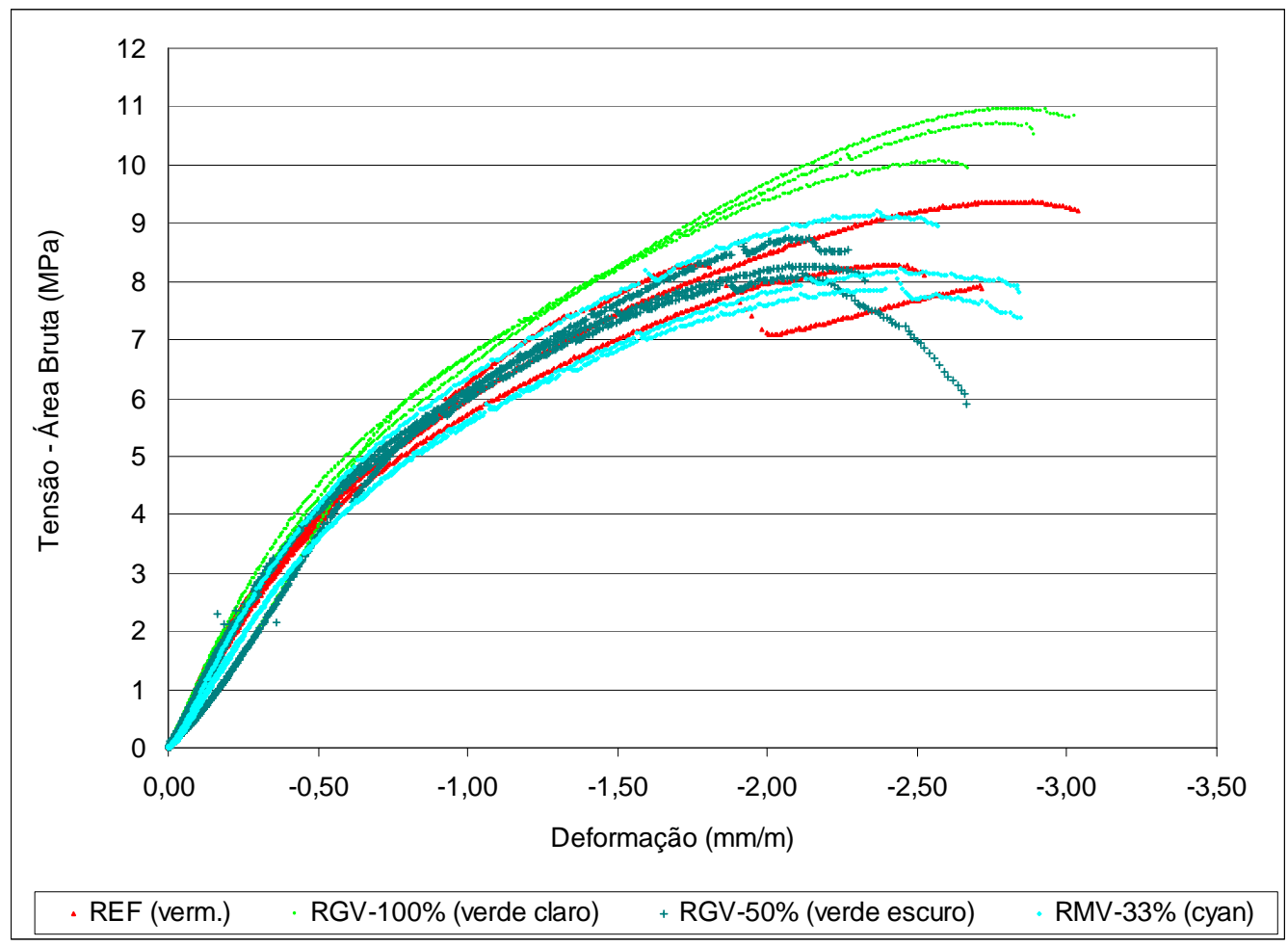

Figura 42 - Curva Tensão x Deformação dos prismas do Grupo 8,0 (REF, RGV-100\%, RGV$50 \%$ e RMV-33\%).

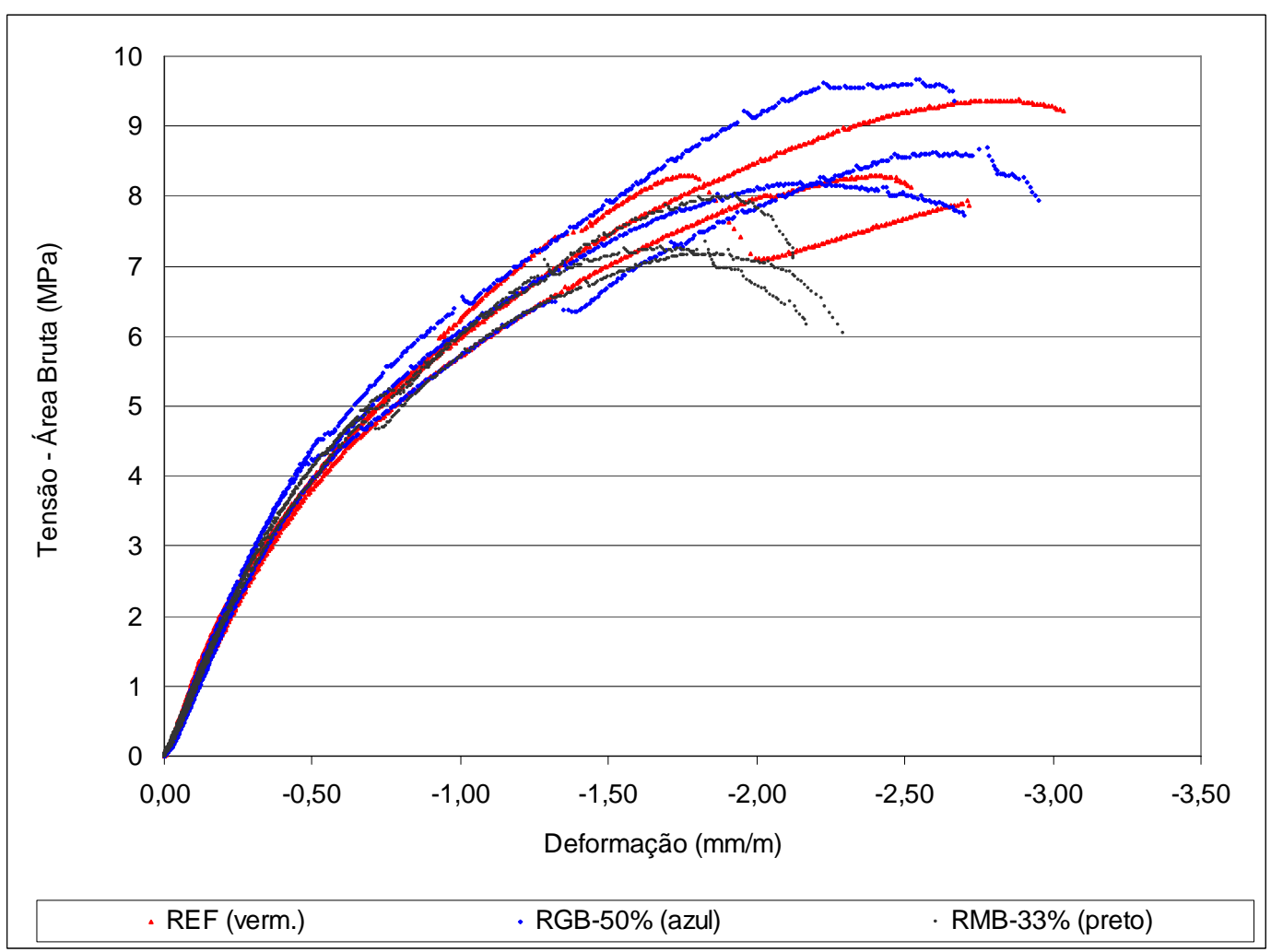

Figura 43 - Curva Tensão x Deformação dos prismas do Grupo 8,0 (REF, RGB-50\%, RMB$33 \%)$. 


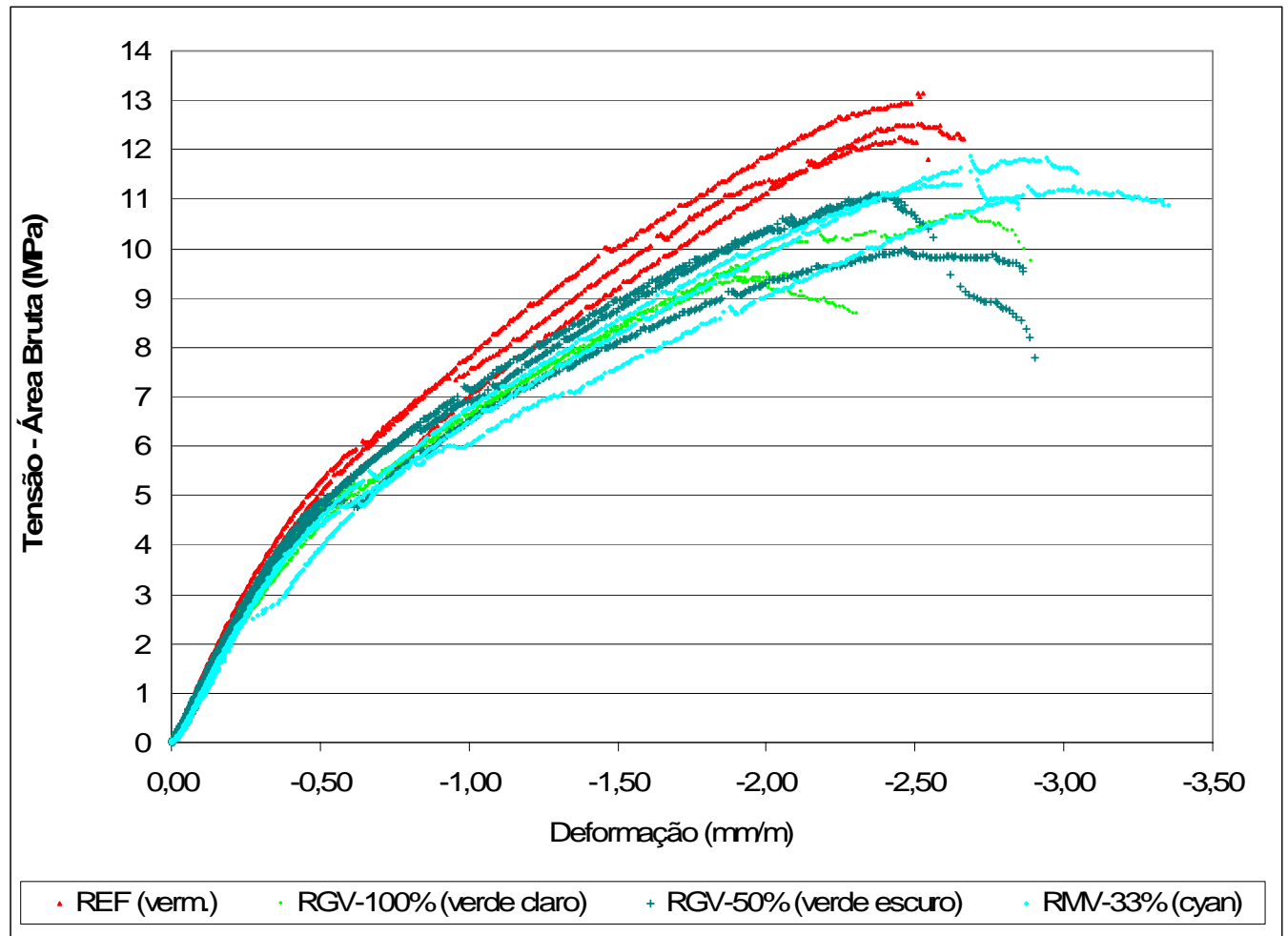

Figura 44 - Curva Tensão x Deformação dos prismas do Grupo 12,0 (REF, RGV100\%, RGV-50\% e RMV-33\%).

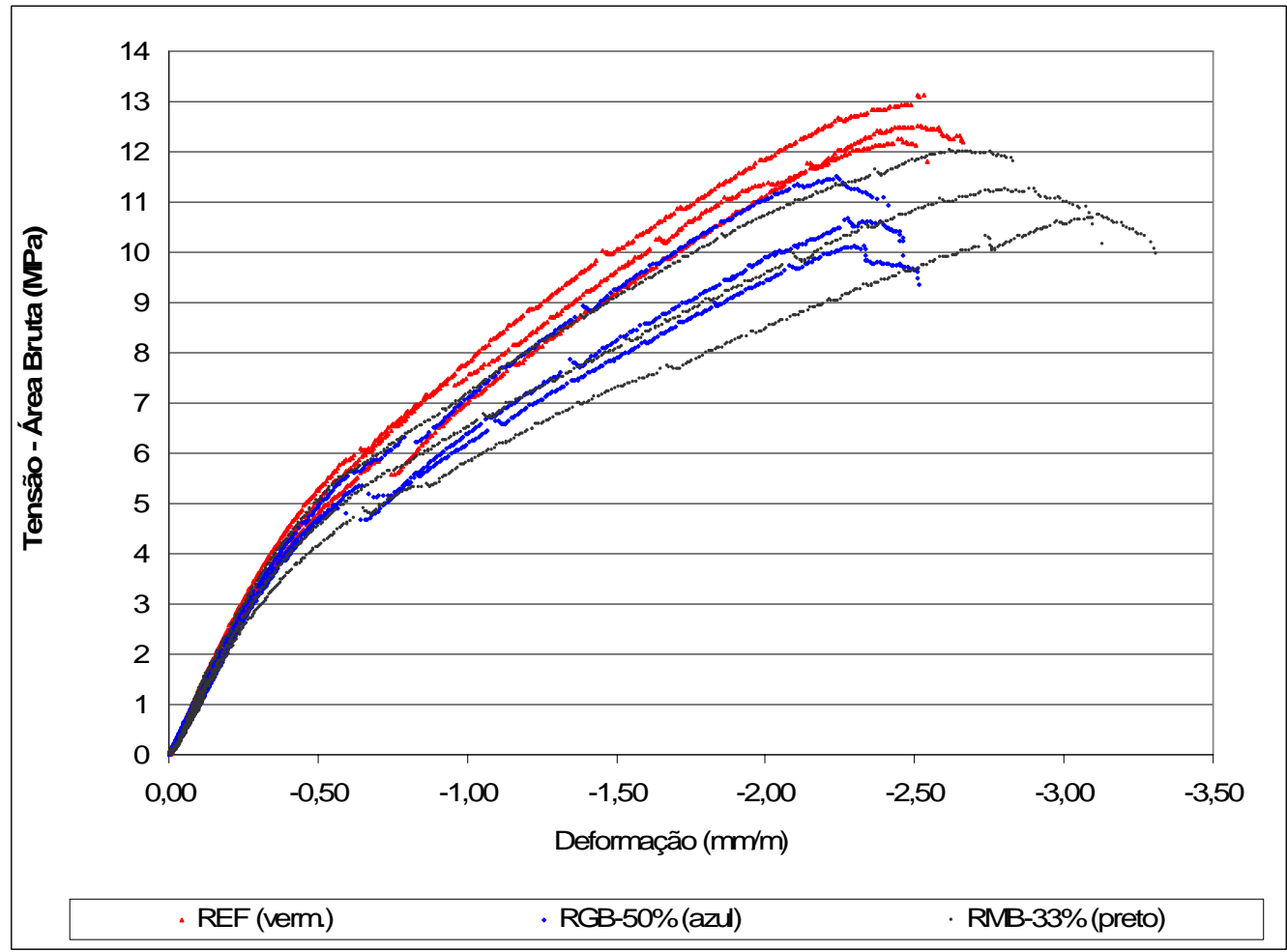

Figura 45 - Curva Tensão x Deformação dos prismas do Grupo 12,0 (REF, RGB-50\% e RMB-33\%). 


\section{APÊNDICE V - CURVAS TENSÃO x DEFORMAÇÃO DAS MINIPAREDES}

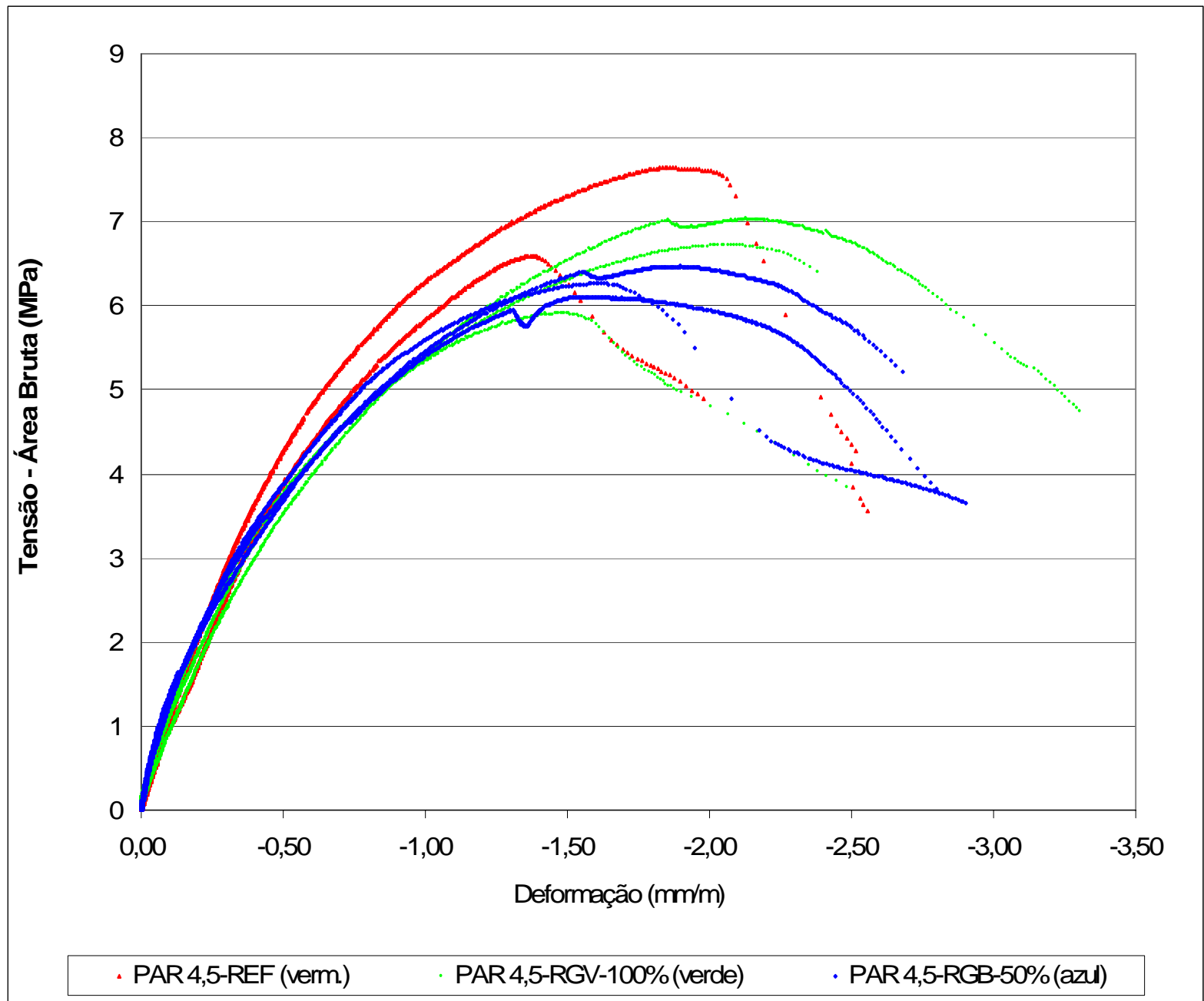

Figura 46 - Curva Tensão x Deformação das miniparedes do Grupo 4,5 (REF, RGV-100\% e RGB-50\%). 


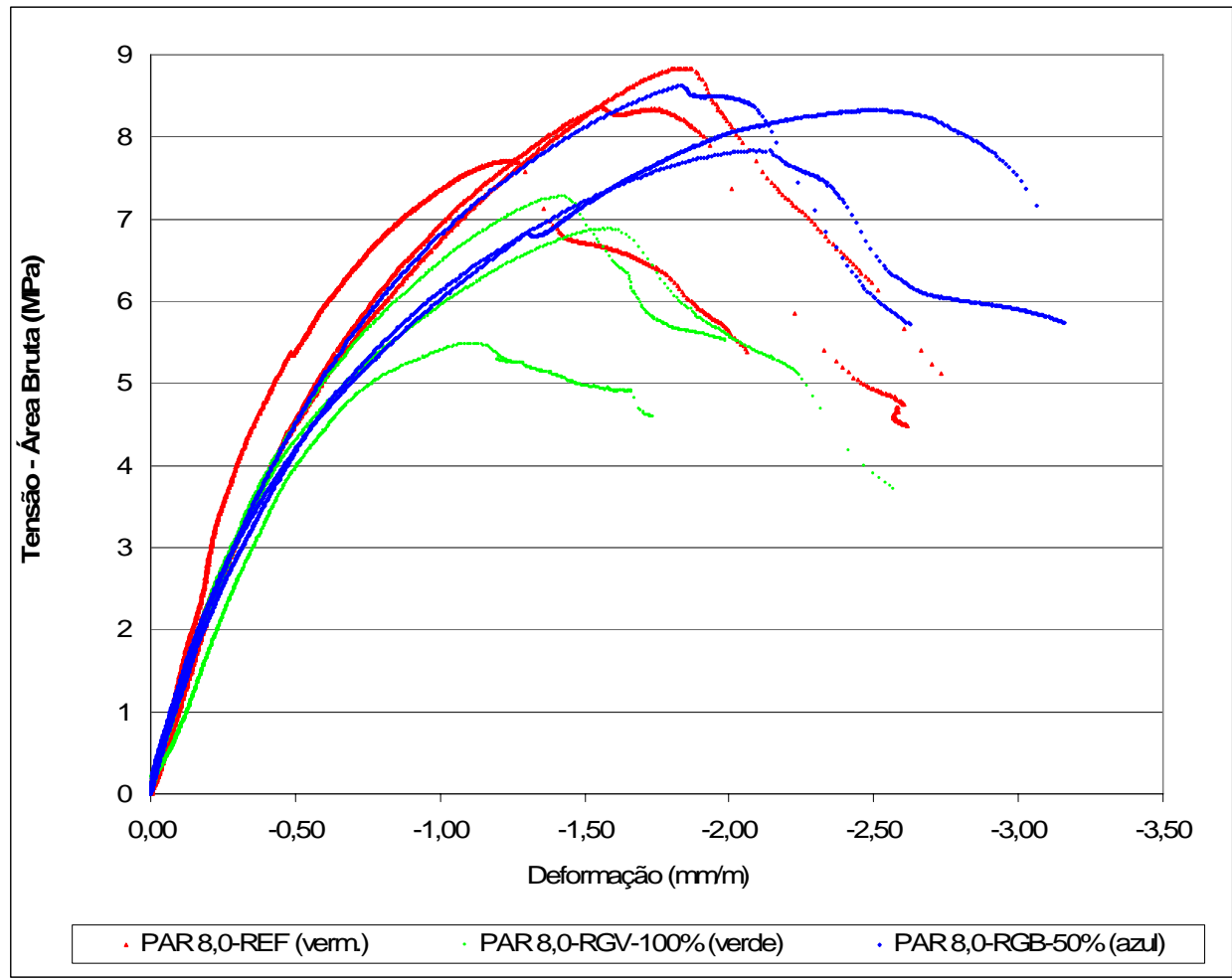

Figura 47 - Curva Tensão x Deformação das miniparedes do Grupo 8,0 (REF, RGV-100\% e RGB-50\%).

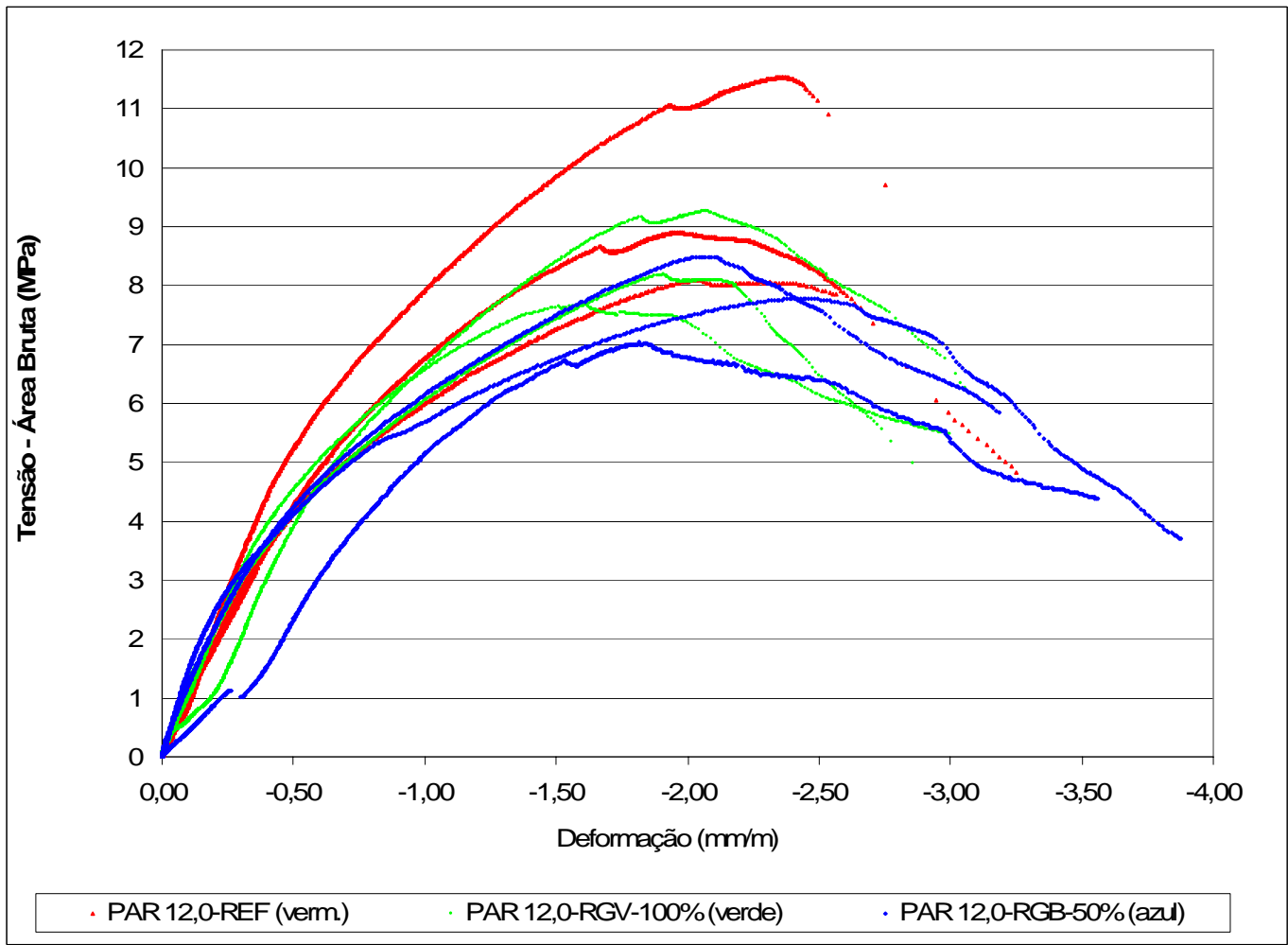

Figura 48 - Curva Tensão x Deformação das miniparedes do Grupo 12,0 (REF, RGV-100\% e RGB-50\%). 
ANEXOS 


\section{ANEXO A - FORMULAÇÃO DOS TESTES ESTATÍSTICOS E CONDIÇÕES EXIGIDAS}

\section{1 - ANÁLISE DE VARIÂNCIA}

Sejam A, B e C os parâmetros principais fixos da análise de variância; a, b e c, as variações desses parâmetros e $\mathbf{n}$ o número de réplicas. Em geral existirá abc...n combinações possíveis.

Caso todos os fatores do experimento forem fixados, pode-se facilmente formular o problema, obtendo resultados que indicam quais dos parâmetros analisados são importantes como também suas combinações. Para avaliar a influência de um determinado parâmetro principal fixo ou combinações entre os parâmetros principais, divide-se a média dos quadrados de cada fator principal ou combinação dos fatores principais pela média dos quadrados dos erros. A divisão entre a média dos quadrados de cada fator principal ou combinação dos fatores principais pela média dos erros é chamada de $\mathbf{F}_{\mathbf{0}}$.

A Tabela 1 apresenta uma análise de variância com três fatores, Delalibera (2006).

Tabela 1 - Equacionamento geral da análise de variância, Delalibera (2006).

\begin{tabular}{|c|c|c|c|c|}
\hline Parâmetros & $\begin{array}{l}\text { Soma dos } \\
\text { quadrados } \\
\end{array}$ & $\begin{array}{r}\text { Graus de } \\
\text { liberdade }\end{array}$ & Média dos quadrados & $F_{0}$ \\
\hline A & $\mathrm{SS}_{\mathrm{A}}$ & $a-1$ & $M S_{A}=S S_{A} /(a-1)$ & $\mathrm{F}_{0}=\mathrm{MS}_{\mathrm{A}} / \mathrm{MS}_{\mathrm{E}}$ \\
\hline B & $\mathrm{SS}_{\mathrm{B}}$ & $b-1$ & $\mathrm{MS}_{\mathrm{B}}=\mathrm{SS}_{\mathrm{B}} /(\mathrm{b}-1)$ & $\mathrm{F}_{0}=\mathrm{MS}_{\mathrm{B}} / \mathrm{MS}_{\mathrm{E}}$ \\
\hline C & $\mathrm{SS}_{\mathrm{C}}$ & $c-1$ & $\mathrm{MS}_{\mathrm{C}}=\mathrm{SS}_{\mathrm{C}} /(\mathrm{c}-1)$ & $\mathrm{F}_{0}=\mathrm{MS}_{\mathrm{C}} / \mathrm{MS}_{\mathrm{E}}$ \\
\hline$A \times B$ & $\mathrm{SS}_{\mathrm{AB}}$ & $(a-1)(b-1)$ & $\mathrm{MS}_{\mathrm{AB}}=\mathrm{SS}_{\mathrm{AB}} /[(\mathrm{a}-1)(\mathrm{b}-1)]$ & $\mathrm{F}_{0}=\mathrm{MS}_{\mathrm{AB}} / \mathrm{MS}_{\mathrm{E}}$ \\
\hline$A \times C$ & $\mathrm{SS}_{\mathrm{AC}}$ & $(a-1)(c-1)$ & $\mathrm{MS}_{\mathrm{Ac}}=\mathrm{SS}_{\mathrm{Ac}} /[(\mathrm{a}-1)(\mathrm{c}-1)]$ & $\mathrm{F}_{0}=\mathrm{MS}_{\mathrm{AC}} / \mathrm{MS}_{\mathrm{E}}$ \\
\hline $\mathrm{B} \times \mathrm{C}$ & $\mathrm{SS}_{\mathrm{BC}}$ & $(b-1)(c-1)$ & $\mathrm{MS}_{\mathrm{BC}}=\mathrm{SS}_{\mathrm{BC}} /[(\mathrm{b}-1)(\mathrm{c}-1)]$ & $\mathrm{F}_{0}=\mathrm{MS}_{\mathrm{BC}} / \mathrm{MS}_{\mathrm{E}}$ \\
\hline$A \times B \times C$ & $\mathrm{SS}_{\mathrm{ABC}}$ & $(a-1)(b-1)(c-1)$ & $\begin{array}{c}\mathrm{MS}_{\mathrm{ABC}}=\mathrm{SS}_{\mathrm{ABC}} /[(\mathrm{a}-1)(\mathrm{b}- \\
1)(\mathrm{c}-1)]\end{array}$ & $\mathrm{F}_{0}=\mathrm{MS}_{\mathrm{ABC}} / \mathrm{MS}_{\mathrm{E}}$ \\
\hline Erro & $\mathrm{SS}_{\mathrm{E}}$ & $a b c(n-1)$ & $\mathrm{MS}_{\mathrm{E}}=\mathrm{SS}_{\mathrm{E}} /[\mathrm{abc}(\mathrm{n}-1)]$ & \\
\hline Total & $\mathrm{SS}_{\mathrm{T}}$ & $a b c n-1$ & & \\
\hline
\end{tabular}

A soma total dos quadrados é calculada por meio da equação 1.

$$
S S_{T}=\sum_{i=1}^{a} \sum_{j=1}^{b} \sum_{k=1 /=1}^{c} \sum_{i=1}^{n} y_{i j k l}^{2}-\frac{y_{\ldots \ldots}^{2}}{a b c n}
$$

A soma dos quadrados de cada parâmetro principal são definidos por meio dos fatores $A\left(y_{i . . .}\right), B\left(y_{. j . .}\right)$ e $C\left(y_{. . . .}\right)$. 


$$
\begin{aligned}
& S S_{A}=\sum_{i=1}^{a} \frac{y_{i \ldots .}^{2}}{b c n}-\frac{y_{\ldots .}^{2}}{a b c n} \\
& S S_{B}=\sum_{i=1}^{a} \frac{y_{. j .}^{2}}{a c n}-\frac{y_{\ldots .}^{2}}{a b c n} \\
& S S_{C}=\sum_{i=1}^{a} \frac{y_{. . k .}^{2}}{a b n}-\frac{y_{\ldots .}^{2}}{a b c n}
\end{aligned}
$$

A soma dos quadrados das combinações $A \times B, A \times C$ e $B \times C$ são expressas através das equações 5,6 e 7 . A equação 8 define a soma dos quadrados da combinação de todos os parâmetros.

$$
\begin{gathered}
S S_{A B}=\sum_{i=1}^{a} \sum_{j=1}^{b} \frac{y_{i j . .}^{2}}{c n}-\frac{y_{\ldots .}^{2}}{a b c n}-S S_{A}-S S_{B} \\
S S_{A C}=\sum_{i=1}^{a} \sum_{k=1}^{c} \frac{y_{i . k .}^{2}}{b n}-\frac{y_{\ldots}^{2}}{a b c n}-S S_{A}-S S_{C} \\
S S_{B C}=\sum_{j=1}^{b} \sum_{k=1}^{c} \frac{y_{. j k .}^{2}}{a n}-\frac{y_{\ldots}^{2}}{a b c n}-S S_{B}-S S_{C} \\
S S_{A B C}=\sum_{i=1}^{a} \sum_{j=1}^{b} \sum_{k=1}^{c} \frac{y_{. j j k .}^{2}}{n}-\frac{y_{\ldots .}^{2}}{a b c n}-S S_{A}-S S_{B}-S S_{C}-S S_{A B}-S S_{A C}-S S_{B C}
\end{gathered}
$$

A soma dos quadrados do erro é definida pela equação 9 .

$$
S S_{E}=S S_{T}-\sum_{i=1}^{a} \sum_{j=1}^{b} \sum_{k=1}^{c} \frac{y_{. i j k .}^{2}}{n}-\frac{y_{\ldots}^{2}}{a b c n}
$$

Para verificação da relevância de um determinado parâmetro principal fixo ou combinada, aplica-se o teste $F$. Caso $F_{0}$ seja maior que $F_{\text {critico, }}$, pode-se afirmar que, com a confiabilidade adotada, que o parâmetro influi significativamente na propriedade analisada;

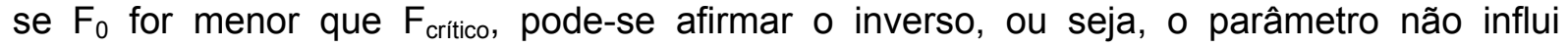
significativamente na propriedade avaliada. Quanto maior seja a diferença entre $F_{0}$ e $F_{\text {critico, }}$ 
maior será a influência do parâmetro analisado. $O$ valor de $F_{\text {critico }}$ depende do nível de significância adotado, sendo função do número de graus de liberdade de cada parâmetro e do número de graus de liberdade total.

\section{2 - CONDIÇÕES EXIGIDAS PARA A REALIZAÇÃO DO TESTE ANOVA}

De acordo com PRUDÊNCIO JÚNIOR (1999), a realização do teste ANOVA pressupõe o cumprimento de alguns requisitos:

- Os resíduos com relação às médias de cada grupo $\left(x_{\mathrm{ij}}-\bar{x}_{\mathrm{j}}\right)$ devem satisfazer a condição de normalidade que pode ser verificada pelo teste de Kolmogorov-Smirnov.

- A distribuição dos resíduos em relação a média $\bar{x}_{\text {.j }}$ deve ser uniforme, ou seja, não deve haver uma tendência de crescimento ou diminuição com a variação de $\mathrm{x} . \mathrm{j}$. Essa condição pode ser verificada através do teste de comparação de variâncias de K grupos.

\subsection{TESTE DE KOLMOGOROV-SMIRNOV}

Essa prova consiste na comparação das freqüências acumuladas observadas e as calculadas pela distribuição normal. A comparação é feita usando as freqüências acumuladas. Para cada "i", que é a ordem do valor $\mathrm{x}_{(\mathrm{i})}$, são calculados os seguintes parâmetros, Prudêncio Júnior (1999):

- A freqüência acumulada relativa observada para o valor ordenado $x_{i}$ a qual será dada por: $\mathrm{P}^{\prime} \mathrm{x}_{\mathrm{i}}=\mathrm{i} / \mathrm{n}$

- O valor $z_{i}$ na distribuição normal padronizada, correspondente a cada $x_{i}$

- A freqüência acumulada teórica, ou seja, a área da distribuição normal correspondente até o ponto $z_{i}$

- Determina-se a diferença, para cada i, entre as freqüências acumuladas relativas teórica e observada

- A maior diferença observada no passo anterior (DM) deve ser comparada com o valor de $D_{\alpha}(n)$, dado pela tabela extraída de Prudêncio Júnior (1999), que depende 
do nível de probabilidade e do tamanho da amostra. Caso $D M \leq D_{\alpha}(n)$, a hipótese da normalidade pode ser aceita.

Segundo Prudêncio Júnior (1999), o teste pode ser usado para valores pequenos de $n(n \geq 4)$. Alguns estudos realizados demonstram que a prova de Kolmogorov-Smirnov tem uma boa potência, isto é, não há uma probabilidade grande de aceitar a hipótese de normalidade quando esta não é verdadeira.

\subsection{COMPARAÇÃO DA VARIÂNCIA DE K GRUPOS COM DISTRIBUIÇÕES NORMAIS INDEPENDENTES}

De acordo com Prudêncio Júnior (1999), para comparar variância de K grupos utilizase o teste de Bartlett. A hipótese a ser testada é:

$$
\mathrm{H}_{0}: \sigma_{1}=\sigma_{2}=\sigma_{3}=\sigma_{4}=\ldots \ldots \ldots \sigma_{\mathrm{k}}
$$

Com a hipótese alternativa:

$$
H_{1}: \sigma_{i} \neq \sigma_{j} \text { para quaisquer }(i, j)
$$

Calcula-se a variância combinada:

$$
S_{c}^{2}=\sum_{1}^{k} \frac{\left(n_{j}-1\right) S_{j}^{2}}{(N-K)}
$$

E os valores de $\mathrm{B}$ e $\mathrm{K}_{1}$ dados por:

$$
\begin{gathered}
B=2,3026 \cdot\left[(N-K) \log S_{c}^{2}-\sum v_{j} \log S_{j}^{2}\right] \\
K_{1}=1+\sum \frac{1}{v_{i}}-\frac{1}{N-K}
\end{gathered}
$$

Onde $S_{j}^{2}$ e $v_{j}$ são as variâncias e o graus de liberdade de cada grupo, respectivamente. Segundo Prudêncio Júnior (1999), Barlett demonstrou que $B / K_{1}$ tem uma distribuição aproximada de $\chi^{2}$ com k-1 graus de liberdade. O procedimento para avaliar a hipótese $\mathrm{H}_{0}$ é pelo cálculo de $B / \mathrm{K}_{1}$. Caso:

$$
\frac{B}{K_{1}}>\chi_{\alpha}^{2}(k-1), \text { a hipótese } \mathrm{H}_{0} \text { é rejeitada }
$$




\section{3 - TESTE T DE STUDENT}

A comparação da variância de duas amostras foi realizada pelo teste $F$ e a comparação de médias pelo teste "t de student". Duas amostras podem ser consideradas semelhantes quando apresentam médias e variâncias iguais.

O valor de " $t$ " obtido deve ser comparado ao valor de $t_{\alpha(n-1)}$ obtido na tabela de distribuição de $t$ de Student. Considerando o teste de hipóteses, a hipótese nula $\left(\mathrm{H}_{0}\right)$ inclui a igualdade da média das amostras, enquanto a hipótese alternativa, que elas sejam diferentes, ou seja, que $\mathrm{m} 1>\mathrm{m} 2$ ou $\mathrm{m} 1<\mathrm{m} 2$, tabela 2 . Para este trabalho foi adotado o nível de significância $\alpha=0,05$. O valor de "t" é dado por:

$$
t=\frac{\left(\bar{x} c-\mu_{0}\right)}{\frac{s}{\sqrt{n}}}
$$

Tabela 2 - Teste de hipóteses.

\begin{tabular}{ccc}
\hline & Hipóteses & Rejeita-se $\mathrm{H}_{0}$ \\
\hline \multirow{3}{*}{ Testes unilaterais } & $\mathbf{H}_{0}: \mu=\mu_{0}$ & $\mathbf{t}>\mathbf{t}_{\alpha(\mathrm{n}-1)}$ \\
\cline { 2 - 3 } & $\mathbf{H}_{1}: \mu>\mu_{0}$ & $\mathbf{t}<\mathbf{t}_{\alpha(\mathbf{n}-1)}$ \\
& $\mathbf{H}_{0}: \mu=\mu_{0}$ & $\mathbf{t}>\mathbf{t}_{\alpha / 2(\mathrm{n}-1)}$ \\
\hline \multirow{2}{*}{ Testes bilaterais } & $\mathbf{H}_{1}: \mu<\mu_{0}$ & $\mathbf{H}_{0}: \mu=\mu_{0}$ \\
& $\mathbf{H}_{1}: \mu \neq \mu_{0}$ &
\end{tabular}

No caso de duas amostras com variâncias diferentes foi utilizada a aproximação t de Welch. 